\title{
Coral Reefs of the World
}

\section{Atlantic and Eastern Pacific Volume I}

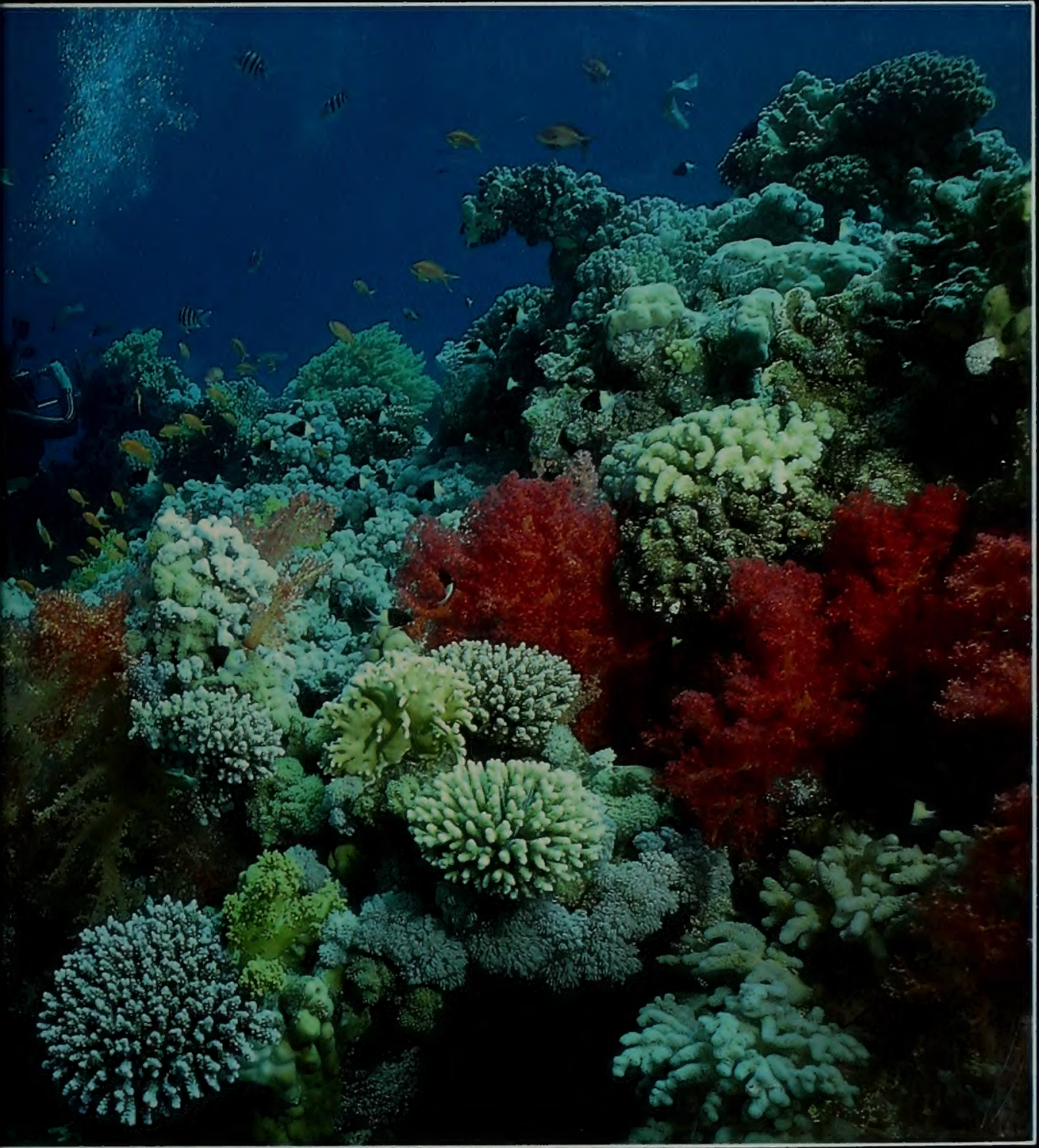

Compiled by The IUCN Conservation Monitoring Centre

(to 
Digitized by the Internet Archive in 2010 with funding from UNEP-WCMC, Cambridge 


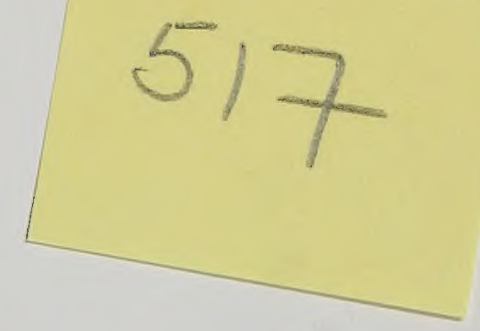





\title{
CORAL REEFS OF THE WORLD
}

\author{
Volume 1: Atlantic and Eastern Pacific
}


The United Nations Environment Programme (UNEP) is a Secretariat within the United Nations which has been charged with the responsibility of working with Governments to catalyze the most sound forms of development, and to co-ordinate global action for development without destruction.

The Regional Seas Programme was initiated by UNEP in 1974. Since then the Governing Council of UNEP has repeatedly endorsed a regional approach to the control of marine pollution and the management of marine and coastal resources and has requested the development of regional action plans.

The Regional Seas Programme at present includes ten regions* and has over 120 coastal States participating in it. Each regional action plan is formulated according to the needs of the region as perceived by the Governments concerned, and is designed to link assessment of the quality of the marine environment, and of the causes of its deterioration, with activities for the management and development of the marine and coastal environment. The action plans promote the parallel development of regional legal agreements and of action-oriented programme activities**.

\section{IUCN - THE WORLD CONSERVATION UNION}

Founded in 1948, IUCN - the World Conservation Union - is a membership organisation comprising governments, nongovernmental organisations (NGOs), research institutions, and conservation agencies in over 100 countries. The Union's mission is to provide leadership and promote a common approach for the world conservation movement in order to safeguard the integrity and diversity of the natural world, and to ensure that human use of natural resources is appropriate, sustainable and equitable.

Several thousand scientists and experts from all continents form part of a network supporting the work of its Commissions: threatened species, protected areas, ecology, environmental strategy and planning, environmental law, and education and communication. Its thematic programmes include forest conservation, wetlands, marine ecosystems, plants, the Sahel, Antarctica, population and natural resources, and Eastern Europe. The Union's work is also supported by 12 regional and country offices located principally in developing countries.

IUCN is referred to by its legal name, the International Union for Conservation of Nature and Natural Resources, in the text of this publication.

\section{WCMC - THE WORLD CONSERVATION MONITORING CENTRE}

The World Conservation Monitoring Centre (WCMC) - formerly the IUCN Conservation Monitoring Centre - is a joint venture between the three partners in the World Conservation Strategy, IUCN - the World Conservation Union, the World Wide Fund for Nature (WWF), and the United Nations Environment Programme (UNEP). Its mission is to support conservation and sustainable development by collecting and analysing global conservation data so that decisions affecting biological resources are based on the best available information.

WCMC has developed a global overview database of the world's biological diversity that includes threatened plant and animal species, habitats of conservation concern, critical sites, protected areas of the world, and the utilization and trade in wildlife species and products. Drawing on this database, WCMC provides an information service to the conservation and development communities, governments and United Nations agencies, scientific institutions, the business and commercial sector, and the media. WCMC produces a wide variety of specialist outputs and reports based on analyses of its data.

WCMC is referred to by its former name, the IUCN Conservation Monitoring Centre (CMC) in the text of this publication.

\section{THE IUCN COMMISSION ON ECOLOGY}

The IUCN Commission on Ecology (COE) serves as the Union's source of technical advice for translating knowledge of ecological processes into practical action for conservation, sustainable management and restoration, in particular of areas degraded by human action. The IUCN programmes on Forest Conservation, Marine Conservation, and Wetlands are under the umbrella of the Commission on Ecology. Commission members serve on advisory committees and in working groups associated with these programmes.

*Mediterranean Region, Kuwait Action Plan Region, West and Central African Region, Wider Caribbean Region, East Asian Seas Region, South-East Pacific Region, South Pacific Region, Red Sea and Gulf of Aden Region, Eastern African Region and South Asian Seas Region.

**UNEP: Achievements and planned development of UNEP's Regional Seas Programme and comparable programmes sponsored by other bodies. UNEP Regional Seas Reports and Studies No. 1 UNEP, 1982. 


\title{
CORAL REEFS OF THE WORLD
}

\section{Volume 1: Atlantic and Eastern Pacific}

\author{
Prepared by \\ The IUCN Conservation Monitoring Centre \\ Cambridge, U.K. \\ in collaboration with \\ The United Nations Environment Programme \\ with financial support from the World Wide Fund for Nature, \\ the United Nations Environment Stamp Conservation Fund, \\ and Exxon Corporation
}

\section{Editor}

Susan M. Wells

IUCN Conservation Monitoring Centre, Cambridge, U.K. 
Published jointly by UNEP, Nairobi, Kenya, and IUCN, Gland, Switzerland and Cambridge, U.K.

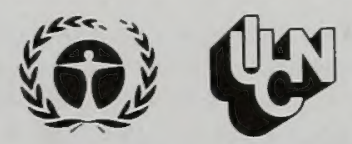

Copyright: 1988 United Nations Environment Programme

Reproduction of this publication for educational or other non-commercial purposes is authorized without prior permission from the copyright holder, provided the source is acknowledged.

Reproduction for resale or other commercial purposes is prohibited without the prior written permission of the copyright holder.

Citation: $\quad$ UNEP/IUCN (1988). Coral Reefs of the World. Volume 1: Atlantic and Eastern Pacific. UNEP Regional Seas Directories and Bibliographies. IUCN, Gland, Switzerland and Cambridge, U.K./UNEP, Nairobi, Kenya. xlvii + 373 pp., 38 maps.

ISBN: $\quad 2-88032-943-4$

Printed by: $\quad$ Page Bros, Norwich, U.K.

Cover design by: James Butler, Nagui Henein

Typeset by: IUCN Publications Services Unit

Cover photos: Reef scene with diver, Red Sea: David George

Available from: IUCN Publications Services,

219c Huntingdon Road, Cambridge CB3 0DL, U.K.

Reprinted 1991

The designations of geographical entities in this book, and the presentation of the material, do not imply the expression of any opinion whatsoever on the part of UNEP or IUCN concerning the legal status of any country, territory, or area, or of its authorities, or concerning the delimitation of its frontiers or boundaries.

\section{NO'TE}

This document is not an official publication but a compilation of information on coral reefs of international importance. It is a contribution to UNEP sponsored regional action plans for the protection and development of the marine environment and coastal areas in the Atlantic and Eastern Pacific oceans, specifically to the Caribbean, the South-East Pacific, and the West and Central African action plans. 
Page

\section{PREFACE}

\section{ACKNOWLEDGEMENTS}

\section{INTRODUCTION}

Methods and Format

Corals and Reef Distribution

Economic Importance of Reefs

Vulnerability of Reefs

Human Impact on Reefs

Reef Management

References

\section{TABLES}

1. Damage to reefs due to natural events

2. Known threats to reefs

3. Coral reef protected areas

4. National legislation relating to coral reefs

\section{ANGUILLA}

Introduction

Anguilla proposed Multiple Use Reserve

ANTIGUA and BARBUDA

Introduction

Palaster Reef Marine Park

Diamond Reef Marine Park

\section{BAHAMAS}

Introduction

Abaco Reef

Acklins Island Reefs

Andros Island Barrier Reef

Exuma Cays Land-and-Sea Park

Hogsty Reef

Inagua National Park

Pelican Cays Land-and-Sea Park

Peterson Cay National Park

San Salvador Fringing Reefs

\section{BARBADOS}

Introduction

Barbados Marine Reserve

\section{BELIZE}

Introduction

Ambergris Cay

Carrie Bow Cay

Columbus Cay to Tobacco Cay

Glover's Reef

Half Moon Cay Natural Monument and Lighthouse Reef

Turneffe Islands

\section{BERMUDA}

Introduction

North Shore Coral Reef Preserve

South Shore Coral Reef Preserve

BRAZIL

Introduction

Abrolhos, Parque Nacional Marinho dos xix

xx

xxii

xxvi

xxix

xxix

xxxii

xxxvii

xliii
Atol das Rocas, Reserva Biológica do

Tamandare Reef Complex

BRITISH VIRGIN ISLANDS 67

Introduction $\quad 67$

Anegada and Horseshoe Reef $\quad 71$

Baths, The 73

Cane Garden Bay $\quad 74$

Dogs, The $\quad 75$

Hans Creek Lagoon $\quad 76$

Little Jost Van Dyke $\quad 76$

Norman Island, Pelican Island and $\quad 78$ The Indians

North Sound $\quad 79$

Tobagos, The 81

Wreck of RMS "Rhone" Marine Park 82

CAYMAN ISLANDS $\quad 85$

Introduction $\quad 85$

Bloody Bay to Jackson's Point Marine Park 91

Cayman Dive Lodge and Radio Mast to 91 Sand Bluff Replenishment Zones

Mary's Bay to East Point Replenishment 91 Zone

North Sound Replenishment Zone, Little Sound Environmental Zone, Bowse Bluff to Rum Point Marine Park and Head of Barkers to Flats Replenishment Zone

South Sound Replenishment Zone 93

Spotter Bay to Anchors Point Replenishment 94 Zone

West Bay Marine Parks and Replenishment 94 Zone

\section{CHILE}

Introduction

Easter Island (Rapa-Nui)

\section{COLOMBLA}

101

Introduction

Albuquerque, Cayos

Corales del Rosario, Parque Nacional

E.S.E., Cayos del

Gorgona, Parque Nacional Natural Isla de

Malpelo, Isla del

Providencia, Isla de

Roncador, Banco

San Andrés, Isla de

Santa Marta, Bahía de

Serrana, Banco

Tayrona, Parque Nacional

Utría, Ensenada de

\section{COSTA RICA}

Introduction

Cahuita, Parque Nacional

Caño, Reserva Biológica Isla del 126

Coco, Parque Nacional Isla del $\quad 127$

Manuel Antonio, Parque Nacional 
CUBA

Introduction

Guacanayabo, Golfo

Juventud, Isla de la

\section{DOMINICA}

Introduction

Cabrits proposed National Park

DOMINICAN REPUBLIC

Introduction

Boca Chica, Bahía Andrés and Punta Caucedo

Este, Parque Nacional del

Jaragua, Parque Nacional

Montecristi, Parque Nacional

\section{ECUADOR}

Introduction

Galápagos, Parque Nacional

GRENADA

Introduction

\section{GUADELOUPE}

Introduction

Le Grand Cul de Sac Marin

L'Ilet Pigeon

\section{HAITI}

Introduction

\section{HONDURAS}

Introduction

Roatán Island

Swan Islands

JAMAICA

Introduction

Discovery Bay

Montego Bay Marine Park

Morant Cays

Negril

Ocho Rios Marine Park

Pedro Bank and Cays

Port Royal Cays

\section{MARTINIQUE}

Introduction

Caravelle, Reserve Naturelle de la

Fort-de-France, Baie de

South-east Coast Reefs

South Coast Reefs

\section{MEXICO}

Introduction

Alactán, Arrecife

Arcas, Cayos

Blanquilla, Parque Marino La

Chinchorro, Banco

Cozumel, Parque Submarino

Lobos, Isla de

North-east Yucatán Reefs

Puerto Morelos

Sian Ka'an, Reserva de la Biósfera

Verde, Isla
MONTSERRAT and ST KITTS-NEVIS

Introduction

NETHERLANDS ANTILLES 229 Introduction 229 Arasji Bay 234

Bonaire Marine Park 235

Colorado Point 237

Curaçao Underwater Park 238

NICARAGUA 241

Introduction 241

Big Corn Island 243

PANAMA 245

Introduction 245

Bocas del Toro, Archipiélago de 248

Chiriquí, Golfo de 249

Galeta, Reserva Biólogica Arrecife de 251

Perlas, Islas 252

Portobelo, Parque Nacional 253

San Blas, Archipiélago de $\quad 254$

PUERTO RICO 257

Introduction $\quad 257$

Cordillera, La 266

Jobos, Bahía de 268

Mona and Monito, Islas $\quad 269$

Muertos, Caja de 270

Parguera, La 271

Ratones, Cayo 273

Sergeant, Reef 274

Tourmaline and El Negro, Arrecife 274

Vieques, Isla 275

ST LUCIÄ 277

Introduction 277

Chastanet, Anse, to Pitons 280

Galet, Anse, to Pt La Ville $\quad 282$

Gallette, Anse 283

Maria Islands Reserve 283

ST MARTIN and ST BARTHELEMY 285 Introduction 285

ST VINCENT $\quad 289$

Introduction 289

Indian Bay and Dove Island 291

Johnson Point and Sharps Bay 292

Tobago Cays 292

TRINIDAD and TOBAGO 295

Introduction 295

Arnos Vale Bay 298

Buccoo Reef/Bon Accord Lagoon 298

Restricted Area
Culloden Bay

$\begin{array}{ll}\text { Culloden Bay } & 299 \\ \text { Eastern Tobago } & 300\end{array}$

Salybia Reef $\quad 302$

TURKS and CAICOS 303

Introduction 303

Turks Islands proposed Marine Park and $\quad 308$ Reserve

West Caicos 309

West Reef System, Grand Turk $\quad 310$ 


\section{Page}

U.S.A.

Introduction

Alligator Reef

Biscayne National Park

East and West Flower Garden Banks

Florida Middleground

Florida Oculina Banks

Fort Jefferson National Monument

Gray's Reef Marine Sanctuary

John Pennekamp Coral Reef State Park

John U. Lloyd State Park

Key Largo Coral Reef Marine Sanctuary

Looe Key National Marine Sanctuary

St Lucie Nearshore Reefs

\section{U.S. VIRGIN ISLANDS}

Introduction

Buck Island Reef National Monument

Saba Island and Perseverance Bay
Page

St Croix Coral Reef Area of Particular 352 Concern

Salt River Submarine Canyon 355

South-eastern St Thomas $\quad 356$

Virgin Islands National Park and 359 Biosphere Reserve

VENEZUELA

361

Introduction

361

Aves, Islas las

364

Mochima, Parque Nacional de 364

Morrocoy, Parque Nacional de $\quad 365$

Roques, Parque Nacional Archipiélago Los 367

$\begin{array}{ll}\text { WEST AFRICA } & 369\end{array}$

Introduction $\quad 369$

MAPS

\section{Country}

\section{ANGUILLA}

ANTIGUA and BARBUDA

BAHAMAS

BARBADOS

BELIZE

BERMUDA

BRAZIL

BRITISH VIRGIN ISLANDS

CAYMAN ISLANDS

CHILE

COLOMBIA

COSTA RICA

CUBA

DOMINICA

DOMINICAN REPUBLIC

ECUADOR

GRENADA

GUADELOUPE

HAITI

$\begin{aligned} \text { Page } & \text { Country } \\ 2 & \text { HONDURAS } \\ 8 & \text { JAMAICA } \\ 14 & \text { MARTINIQUE } \\ 30 & \text { MEXICO } \\ 36 & \text { MONSERRAT and ST KITTS-NEVIS } \\ 50 & \text { NETHERLANDS ANTILLES } \\ 60 & \text { NICARAGUA } \\ 68 & \text { PANAMA } \\ 86 & \text { PUERTO RICO } \\ 98 & \text { ST LUCIA } \\ 102 & \text { ST MARTIN and ST BARTHELEMY } \\ 122 & \text { ST VINCENT } \\ 132 & \text { TRINIDAD and TOBAGO } \\ 138 & \text { TURKS and CAICOS } \\ 142 & \text { U.S.A. } \\ 150 & \text { U.S. VIRGIN ISLANDS } \\ 156 & \text { VENEZUELA } \\ 160 & \text { WEST AFRICA } \\ 166 & \end{aligned}$

Page 

The last decade has seen growing concern for the future of coral reefs worldwide. Until comparatively recently, man used coral reefs for subsistence purposes only, as sources of food and craft materials. With the development of commercial fisheries, rapidly increasing populations still dependent on a subsistence lifestyle, growth of coastal ports and urban areas, increasing soil run-off due to deforestation and poor land use practices and most recently the exponential growth of coastal tourism, reefs have come under increasing pressure from both indirect and direct impacts. The theme "The Reef and Man" was chosen for both the 4th and 5th International Coral Reef Congresses (1981 and 1985) when numerous papers were presented documenting the deterioration of reefs around the world. Reef protection and management were major issues at the 3rd World National Parks Congress, Bali in 1982 and at the XV Pacific Science Congress, Dunedin, New Zealand in 1983, and are now integrated into many environmental programmes and projects at international, regional and national levels.

Associated with this concern, there has been growing demand for information about coral reefs and their status. In response to this, the Coral Reef Working Group of the IUCN Commission on Ecology carried out two projects, one to document threats to reefs (see below) and a second to compile an inventory of parks and reserves containing coral reefs. The latter resulted in a preliminary list of coral reef protected areas, published in the IUCN Coral Reef Newsletters (Salvat, 1978, 1979, 1981 and 1982) which forms the basis of this Directory.
The aims of the Coral Reef Directory are:

1. to provide a broad survey of the reefs of the world giving sufficient detail to enable priorities for reef conservation to be established at both national and international levels.

2. to identify those areas where further research and conservation action is required.

3. to establish to what extent those reefs currently receiving or recommended for some form of protection are representative of the full range of reef types.

4. to promote more effective management of coral reefs by making basic information widely available.

5. to facilitate comparison between areas, thereby providing a working tool for those concerned with reef management.

6. to stimulate increased interest in coral reefs on the part of the general public, government officials, planners, scientists and students.

Many of the sections in this directory are incomplete and much of the information included will inevitably become rapidly out of date. However, the coral reef database at the IUCN Conservation Monitoring Centre in Cambridge will be continuously updated. Information should be sent to:

IUCN Conservation Monitoring Centre, 219 c Huntingdon Road

Cambridge CB3 ODL, U.K. 

We are very grateful to the many people and institutions who have given generous assistance in the preparation of this volume.

Sections written by authors outside CMC are separately credited.

The staff of the IUCN Conservation Monitoring Centre gave invaluable support and assistance, in particular Patricia Almada-Villela, Diana Evans, Louise Henson, Martin Jenkins and Simon Nash, who helped with editing and proof-reading.

The maps were prepared by Reginald Piggot with the assistance of Graham Usher, Louise Henson and Barbara Lambert. The production to printing stages were handled by Barbara Lambert and Jo Taylor of the IUCN Publications Services Unit, with the assistance of Duncan Mackinder and Peter Rooney of the Computer Services Unit, IUCN Conservation Monitoring Centre.

We would particularly like to thank the following for reviewing the sections on, and providing information for, particular countries:

\section{ANGUILLA}

Dr A.D. Putney, ECNAMP, St Croix, U.S.V.I.

ANTIGUA and BARBUDA

Prof. H.G. Multer, Fairleigh Dickinson Univ., U.S.A.

Dr W.F. Raymond, Ocean Research and Survey Inc., Florida, U.S.A.

R. Wingrove, Peace Corps, Antigua

\section{BAHAMAS}

Dr R. Attrill, Nassau

Dr J.S. Bunt, AIMS, Queensland, Australia

Dr D.T. Gerace, Bahamian Field Station (College Center of the Finger Lakes, U.S.A.)

Dr C. Higgs, Dept. Fisheries, Nassau

S. Holowesko, Bahamas National Trust, Nassau

R. Palmer, Bristol, U.K.

Dr J.F. Storr, Buffalo, U.S.A.

J. Worsfold, Peterson Cay National Park, Bahamas National Trust

J. Yager, Freeport

\section{BARBADOS}

Dr G. Cambers, Coastal Conservation Project, St Michael

P. J. Cotter, U.S. Environmental Protection Agency, California, U.S.A.

Dr W. Hunt, Bellairs Research Inst. (McGill Univ., Canada)

\section{BELIZE}

J. Gibson, Wildlife Conservation International

C. Gibson, Belize

D. Griffith, Edinburgh, U.K.

Lt Col. M.G. Hodges, British Forces

J. Perkins, Concord, Massachusetts, U.S.A.

Dr K. Ruetzler, Smithsonian Institution, U.S.A.

D. Weyer, Belmopan

\section{BERMUDA}

Dr D.R. Dilen, Hydrologic, Environmental Research and Coastal Sciences, Georgia, U.S.A.

Dr A. Logan, Univ. New Brunswick, Canada

Dr B. Luckhurst, Dept. Agriculture and Fisheries

Dr S. Wyers, Bermuda Biological Station

Dr S.R. Smith, Univ. Georgia, U.S.A.

\section{BRAZIL}

Dr A. Edwards, Univ. Newcastle-upon-Tyne, U.K.

Dr J. Laborel, Univ. d'Aix-Marseille, France

Dr Z.M. Leão, Univ. Federal de Bahia

Dr Tommasi, Inst. Oceanog., Sao Paulo

Dr J. Vacelet, Marseille, France

\section{BRITISH VIRGIN ISLANDS}

Dr B.E. Brown, Univ. Newcastle-upon-Tyne, U.K.

Dr M.J. Canoy, College of the Virgin Islands, U.S.V.I.

Dr N.V. Clarke, National Parks Trust, Tortola

Dr E. Gladfelter, West Indies Laboratory (WIL), U.S.V.I.

Dr J. Ogden, WIL, St Croix, U.S.V.I.

L. Smith, Min. Natural Resources and Labour, Tortola

\section{CAYMAN ISLANDS}

E.J. Bergstrom, Director of Tourism, Grand Cayman

P.E. Bradley, Grand Cayman

M. Brunt, ODA, Surbiton, U.K.

Dr F.J. Burton, Mosquito Research and Control Unit, (MRCU), Grand Cayman

Dr J.E. Davis, MRCU, Grand Cayman

K.S. Gomez, Principal Secretary AL \& NR, Grand Cayman

Dr A. Logan, Univ. New Brunswick, Canada

Dr G.W. Potts, Marine Biological Association, Plymouth, U.K.

Dr S.H. Smith, MRCU, Grand Cayman

\section{CHILE}

Dr J.E. Randall, Bishop Museum, Hawaii

Dr L.H. Di Salvo, Coquimbo

Dr A. Cea Egaña, Chile

\section{COLOMBIA}

Dr R. Alvarez-León, INVEMAR, Santa Marta

Dr J. Geister, Univ. Bern, Switzerland

L. González, Fundación para la investigación y protección del medio ambiente, San Andrés

Dr J. Hernández C., INDERENA, Bogotá

Dr G. Márquez, Univ. Nac. Colombia, Bogotá

Dr J.E. Orejuela, La Planada Nature Reserve, Ricaute Nariño

Dr H. von Prahl, Univ. del Valle, Cali

Dr P. Ruíz, Univ. Nac. Colombia, Bogotá

J. M. Mow-Peters, San Andrés

\section{COSTA RICA}

Dr J. Cortés, Univ. Costa Rica, San Pedro

CUBA

Dr D. Kühlmann, Zoologisches Museum, Berlin, F.R.G.

S. Fenn, Diver Magazine, London, U.K.

Dr D. George, British Museum (NH), London, U.K.

D. Mercier, Spondyle Club, Antibes, France 
M. Rodrigues, Cuba Tourist Board, Toronto, Canada R. Saavedra, Inst. Nacional de Turismo, Habana Dr V. Zlatarski, CINVESTAV, Mérida, México

\section{DOMINICA}

Dr A.D. Putney, ECNAMP, St Croix, U.S.V.I.

Dr A. James, Min. Agriculture, Roseau

\section{DOMINICAN REPUBLIC}

Dr I. Bonnelly de Calventi, Centro de Investigaciones de Bología Marina de la Universidad Autónoma de Santo Domingo

Dr R. Briones, Museum of Natural History, Santo Domingo

Dr R. Galzin, Ecole Pratique des Hautes Etudes, France

Dr S. Peláez-Feucht, Dirección Nacional de Parques, Santo Domingo

Dr F.O. Ricart y Menéndez, Santo Domingo

\section{GUADELOUPE}

Dr C. Bouchon, Univ. Antilles-Guyane

Dr R. Galzin, Ecole Pratique des Hautes Etudes, France

Dr J. Laborel, Univ. d'Aix-Marseille, France

M. Vallance, Parc Naturel de Guadeloupe

F. Wencelius, Parc Naturel de Guadeloupe

\section{HAITI}

Dr P. Paryski, Institut de Sauvegarde du Patrimoine National, Port-au-Prince

Dr W.F. Raymond, Ocean Research and Survey Inc., Florida, U.S.A.

\section{HONDURAS}

Prof. J.C. Britton, Texas Christian Univ., U.S.A.

Dr W.C. Jaap, Florida Dept. of Natural Resources, U.S.A.

Dr A.C. Jensen, Southampton Univ., U.K.

\section{JAMAICA}

Dr SM. Head, Univ. West Indies, Kingston

Dr W.D. Liddell, Utah State Univ, U.S.A.

Dr S.L. Ohlhorst, Utah State Univ., U.S.A.

Dr J. Woodley, Discovery Bay Marine Lab.

\section{MARTINIQUE}

Dr C. Bouchon, Univ. Antilles-Guyane, Guadeloupe

Dr J. Laborel, Univ. d'Aix-Marseille, France

Dr M.J. Portecop, Univ. Antilles-Guyane, Guadeloupe

\section{MEXICO}

Dr A. Barcena Ibarra, Secretaría de Desarrolla Urbano y Ecología (SEDUE), México D.F.

Dr L. Castañares M., Subsecretaría de Ecología, SEDUE. Flora y Fauna Acuáticas, México, D.F.

Dr E. Chávez, Centro de Investigación y de Estudios Avanzados del IPN (CINVESTAV), Mérida, Yucatán

Dr T.M. Farrell, Oregon State Univ., U.S.A.

Dr A.R. Ferré-D'Amaré, Unidad Guaymas, Sonora

R. Giron Botello, SEDUE, México D.F.

Dr D. Gotshall, State of Califomia Dept. Fish and Game, U.S.A.

Dr E.S. Hobson, NOAA, Tiburon, California, U.S.A.

Dr E. Jordan, Univ. Nacional Autónoma de México, Puerto Morelos Marine Station, Quintana Roo

Dr A. Kerstitch, Sea of Cortez Enterprises, Arizona, U.S.A.

Dr D. Kühlmann, Zoologisches Museum, Berlin, F.R.G.

Dr A. López-Ornat, Centro de Investigaciones de Quintana Roo, Cancún
V. Santiago-Fandiño, Univ. Autónoma Metropolitana, México D.F.

Prof. J.W. Tunnell, CINVESTAV, Mérida, Yucatán

Dr V.N. Zlatarski, CINVESTAV, Mérida, Yucatán

\section{MONTSERRAT and ST KITTS-NEVIS}

Dr W.J. Arendt, USDA Forest Service, Puerto Rico

Dr A.D. Putney, ECNAMP, St Croix, U.S.V.I.

\section{NETHERLANDS ANTILLES}

Dr T. van't Hof, Curaçao

Dr R. Luxmoore, IUCN/CMC, Cambridge

\section{NICARAGUA}

Dr J. Geister, Univ. Bern, Switzerland

Dr A. López, Managua

Dr B. Nietschmann, Univ. Berkeley, U.S.A.

Dr H. Roberts, Louisiana State Univ., U.S.A.

PANAMA

Dr J. Cubit, Smithsonian Tropical Research Inst., Balboa Dr P.W. Glynn, Univ. Miami, U.S.A.

Dr L. D'Croz, Univ. Panamá

\section{PUERTO RICO}

Dr A. Antonius, King Abdulaziz Univ., Jeddah, Saudi Arabia

Dr R.A. Armstrong, Dept Marine Sciences, Univ. Puerto Rico, Mayaguiez

Dr H. Ferrer Hansen, Dept Natural Resources, San Juan Dr C. Goenaga, Univ. Puerto Rico, Mayaguiez

Dr M. Hernández-Avila, Univ. Puerto Rico, Mayagüez Dr J.M. Kubayrk, Univ. Puerto Rico, Mayagüez Dr M. del Llano, Dept Natural Resources, San Juan Dr J. Morelock, Univ. Puerto Rico, Mayagüez Dr W.F. Raymond, Ocean Research and Survey Inc., Florida, U.S.A.

\section{ST LUCIA}

C. Boatman, St Lucia

Dr R. Deveaux, St Lucia National Trust

Dr R. Earll, Marine Conservation Society, U.K.

Dr M.H. Goodwin, Environmental Research Projects, Rhode Island, U.S.A.

L. Holliday, York, UK.

K. Nichols, Fisheries Management Unit, St Lucia

Dr Y. Renard, ECNAMP, St Lucia

Dr A. Smith, ECNAMP, St Lucia

\section{ST MARTIN and ST BARTELEMY}

Dr T. van't Hof, Curaçao, Netherlands Antilles

\section{ST VINCENT and GRENADA}

Dr M.H. Goodwin, Environmental Research Projects, Rhode Island, U.S.A.

TRINIDAD and TOBAGO

Dr D. Hudson, Inst. of Marine Affairs

R.S. Laydoo, Inst. of Marine Affairs

\section{TURKS and CAICOS}

J. Brown, Turks and Caicos Development Trust

Dr C.H. Floyd, Min. of Commerce and Development, Grand Turk

Captain B. Gascoigne and the crew of the schooner "Cloudesley Shovell"

L. Holliday, York, U.K.

C. Lott, Florida, U.S.A. 
B. Mitchell, Massachusetts, U.S.A.

Dr T.W. Sherry, Dartmouth College, New Hampshire, U.S.A.

\section{U.S.A.}

Dr T.J. Bright, Texas A \& M Univ.

B. Brooks, Week of the Ocean Reef Committee, U.S.A.

Dr G. Davis, Channel Islands National Park, California, U.S.A.

Dr D. Gotshall, California Dept. of Fish and Game, U.S.A.

Dr W. Jaap, Florida Dept. of Natural Resources, U.S.A

Dr T. Leary, Gulf of Mexico Fishery Management Council, Florida, U.S.A.

Dr N. Nicholson, Georgia Dept. Nat. Resources, U.S.A. Dr W.F. Raymond, Ocean Research and Survey Inc., Florida, U.S.A.

Dr J.K. Reed, Fort Pierce, Florida

\section{VENEZUELA}

Dr C. de Blohm, FUDENA, Caracas

Dr F. Losada, Univ. Simón Bolívar, Caracas

Dr P.J. Salinas, Univ, de Los Andes, Mérida

\section{VIRGIN ISLANDS U.S}

Dr M.J. Canoy, College of the Virgin Islands, Dr M.L. Coulston, West Indies Laboratory (WIL), St Croix

Dr T. Geoghegan, ECNAMP, St Croix

Dr E. Gladfelter, WIL, St Croix

Dr J.C. Ogden, WIL, St Croix

Dr C. Rogers, VI National Park

WEST AFRICA

Dr J. Laborel, Univ. d'Aix-Marseille, France

The following institutions and individuals have provided valuable general assistance: Dr M. Carbonell, International Waterfowl Research Bureau; D. Elder, Marine Programme Officer, IUCN; D. Mack, WWF-U.S.; Dr A. Putney, ECNAMP, U.S.V.I.; Dr B. Salvat, Ecole Pratique des Hautes Etudes, Paris; M. Stafford-Smith, Tropical Marine Research Unit, York University, U.K.; J. Thorsell, CNPPA, IUCN. 



\section{METHODS AND FORMAT}

\section{Regional Coverage}

The Directory consists of three volumes covering 1) the Wider Caribbean, Atlantic and Eastern Pacific, 2) the Indian Ocean (up to and including South-east Asia), the Red Sea and the "Gulf" (i.e. the body of water between Saudi Arabia and Iran, commonly referred to as the Arabian or-Persian Gulf) and 3) the Pacific and Australasia. This volume (1) includes 39 countries within Central and Southern America (excluding the U.S. Pacific territories) and the Caribbean, and a brief description of the coral assemblages of tropical West Africa.

Four of the regions defined by the UNEP Regional Seas Programme are covered: the Wider Caribbean, the South-west Atlantic, the South-east Pacific and West and Central Africa. The Wider Caribbean Region includes all the 19 Caribbean islands, the U.S. Gulf States, Mexico, all Central American States (except EI Salvador which has no Caribbean coast), Colombia, Venezuela, Guyana, Suriname and French Guiana. The South-west Atlantic Region includes Brazil, with Uruguay and Argentina. The South-east Pacific Region covers the states of Colombia, Chile, Ecuador, Panamá and Peru.

All countries with coral reefs or assemblages within the Neotropical Realm (defined by Udvardy (1975) as the area extending from the southern subtropical U.S.A. to the southem tip of South America) are included, as in the IUCN directories for wetlands (Scott and Carbonell, 1986) and protected areas (IUCN, 1982).

The arrangement of the three volumes reflects conservation practicalities rather than the zoogeographical realities of coral distribution. The Wider Caribbean, South-west Atlantic and West and Central Africa Regions have similar coral faunas, although the latter two regions have faunas distinguished by several endemic species. The tropical Atlantic became isolated from the Indo-Malayan region, which is considered the centre of coral development, at an early stage and the faunas on either side of the isthmus of Panama have developed separately. The fauna of the Eastern Pacific is more closely related to that of the Indo-Pacific but is included in this volume for practical purposes since the countries involved have reefs on both their Caribbean and Pacific coasts.

\section{Sources of Information}

Information has been obtained from a wide variety of sources, including published and unpublished material, and from a worldwide correspondence with coral reef researchers, conservationists and government officials. However, there are many gaps, either because the information is not available or because it has not been possible to contact the person who could provide it.

Accounts for protected areas which are also in the IUCN Directory of Neotropical Protected Areas (IUCN, 1982) have been rewritten in the appropriate format and additional information included where relevant; data on terrestrial aspects have generally been reduced. A recent source of information on marine parks is Silva et al. (1986) which provides an update on the list compiled by Björklund (1974). A complete and accurate listing of marine parks of the world is not yet available, partly because there are numerous instances where it is not known whether the park legislation covers marine (or submarine) habitat.

In order to keep the volume to a manageable size, coral reefs have had to be considered in isolation from other closely associated marine habitats, such as seagrass beds and mangroves. The Directory of Neotropical Wetlands (Scott and Carbonell, 1986) provides a complementary volume, with its emphasis on other coastal and marine habitats.

Information on reef-related species has been taken mainly from the IUCN Red Data Books, including Groombridge (1982) for turtles and crocodiles, Thomback and Jenkins (1981) for dugong and other mammals and Wells et al. (1983) for marine invertebrates. Information on seabirds is largely from papers in Croxall et al. (1984).

Maps showing the distribution of reefs and of proposed and established protected areas have been compiled for each country using, where possible, material sent in by correspondents and, where this was unavailable, British Admiralty Charts. In many instances, it was possible to give only a very rough approximation of true reef distribution and the extent of reef coverage is probably greaily under-represented.

\section{Site Descriptions}

The format has been adapted from that used in other IUCN directories. For each country, an introductory section describes the distribution of reefs within the country, their status, relevant conservation issues and legislation. A comprehensive reference list, including scientific monographs and papers, popular books and articles, bibliographies, management plans and unpublished reports is included. This section is followed by detailed accounts for reefs already protected in national parks and reserves, reefs proposed for protection, and reefs recommended by qualified experts as requiring protection or management on the basis of their scientific interest or economic importance. These accounts have the following format:

1. Geographical Location province, region, geographical coordinates: where relevant the proximity to major towns, national borders, other protected areas and major features is noted.

2. Area, Depth and Altude in hectares and metres: areas of both protected and unprotected areas; minimum/maximum depth of reef; altitude of associated cay/atoll/terrestrial ecosystem. 
3. Land Tenure public (government-owned), freehold, private, etc., with percentages or hectarage where there is multiple ownership.

4. Physical Features topography, geology, climate, hydrology, and other physical features (e.g. salinity, water clarity, wave action, currents, water temperature), particularly as they affect management of the area; reef type e.g. barrier, fringing, atoll, patch.

5. Reef Structure and Corals reef zonation: coral morphology, diversity, per cent live cover and dominant species.

6. Noteworthy Fauna and Flora predominant algae and other vegetation; vertebrates and invertebrates which are of particular importance due to their dominance in the ecosystem, rarity, size of population, etc., in particular, species of possible economic importance (e.g. dugong, turtles, fish, molluscs, crustaceans, echinoderms, etc.) and those included in the IUCN Red Data Books.

7. Scientific Importance and Research importance of the reef in terms of the scientific interest of its coral formations and fauna; major research conducted in the area; details of current projects and scientific facilities.

8. Economic and Social Benefits use or potential use for fisheries (commercial or subsistence), tourism, recreation, mariculture, education, harbour protection.

9. Disturbance or Deficiencies siltation; pollution; damaging fishing methods (e.g. explosives, poisons, trawling); collection of corals for the curio trade, lime or building materials; over-collection of shells and other marine invertebrates; over-fishing of reef fish for food or the aquarium trade; anchor damage and boat groundings; damage from tourists (e.g. trampling) and SCUBA divers; dredging, filling and other forms of coastal development.

10. Legal Protecion degree of legal or special protection afforded to certain elements within the area.

11. Management local administrative entity for the area; presence of interpretative centres and wardens; degree of enforcement of legislation; system of zoning.

12. Recommendations legislation and management required; research priorities.

\section{CORALS AND REEF DISTRIBUTION}

\section{Structure of Coral Reefs}

Coral reefs are tropical, shallow water ecosystems, largely restricted to the area between the latitudes $30^{\circ} \mathrm{N}$ and $30^{\circ} \mathrm{S}$. The exact areal extent of coral reefs in the world is unknown and extremely difficult to estimate. However, Smith (1978) has produced a figure of $600000 \mathrm{sq} . \mathrm{km}$ for reefs to a depth of $30 \mathrm{~m}$. Under this analysis, about $14 \%$ occur in the Caribbean Sea, $1 \%$ in the South Atlantic and a further small percentage in the Eastern Pacific (Smith, 1978). They rank as among the most biologically productive and diverse of all natural ecosystems, their high productivity stemming from their efficient biological recycling, high retention of nutrients and their structure which provides habitat for a vast array of other organisms.

The true reef-building corals (hermatypic or stony corals) are animals (polyps) that collectively deposit calcium carbonate to build colonies. The coral polyps have symbiotic algae (zooxanthellae) within their tissues which process the polyp's waste products, thus retaining vital nutrients. The term "reef" is used in the directory for a population of stony corals which continues to build on products of its own making (Stoddart, 1969). Not all reefs are constructed predominantly of corals. In particular, several genera of red algae grow as heavily calcified encrustations which bind the reef framework together, forming structures such as algal ridges. In other cases, populations of corals exist, of ten in deeper, colder waters, which either do not build on themselves, or are formed of ahermatypic, non-symbiotic corals which do not build reefs. Many of these have been included in the directory (like true reefs they may also have a very high productivity) and have been termed coral assemblages or communities.

Present day reefs fall into two basic categories: shelf reefs, which form on the continental shelf of large land masses, and oceanic reefs, which develop in deeper waters, often in association with oceanic islands. Within these two categories are a number of different reef types; fringing reefs which grow close to shore (i.e. most shelf reefs, although some develop around oceanic islands); patch reefs which form on irregularities on shallow parts of the sea bed; bank reefs which occur deeper than patch reefs, both on the continental shelf and in oceanic waters; barrier reefs which develop along the edge of the continental shelf or through land subsidence in deeper water and are separated from the mainland or island by a relatively deep, wide lagoon; and atolls, which are roughly circular reefs around a central lagoon and are typically found in oceanic waters, probably corresponding to the fringing reefs of long since submerged islands. General descriptions of coral reefs, their ecology and environmental requirements are given in Wood (1983), Kaplan (1982), Salm and Clark (1984), Kenchington and Hudson (1984), Snedaker and Getter (1985) and Goodwin et al. (1986).

\section{The Wider Caribbean}

The majority of reefs described in this volume lie within the Wider Caribbean, a semi-enclosed body of water consisting of several deep basins, of which the two major are the Caribbean Sea and the Gulf of Mexico. These have a total surface area of about 4.31 million sq $\mathrm{km}$ and an average depth of approximately $2200 \mathrm{~m}$, the deepest point being $7100 \mathrm{~m}$ in the Cayman Trench (Rodriguez, 1981). The general oceanographic features of the Caribbean are fairly well understood and are reviewed in Unesco (1971) and Geoghegan (1985). Milliman (1973) reviews the geological history of Caribbean reefs.

Bayer (1969) and Munro (1983) summarize previous scientific investigations in the area. Biological investigations have been largely concentrated in the eastern Caribbean. Fewer studies have been made in the 
region lying south-west of Jamaica, which includes the wide shelf areas of Nicaragua and Honduras and the numerous oceanic banks of the Nicaragua-Jamaica Rise which separates the Colombian and Cayman Basins. General ecological surveys have been provided by a number of authors including Glynn (1973), Adey and Burke (1976) and Geister (1983).

The surface temperature in the tropical parts of the region averages about $27^{\circ} \mathrm{C}$ and does not vary much during the year, seasonal fluctuations not exceeding $3^{\circ} \mathrm{C}$. Temperatures in the southernmost part of the Gulf of Mexico are similar, but the northernmost part shows strong seasonal changes, from $16^{\circ} \mathrm{C}$ in winter to $28^{\circ} \mathrm{C}$ in summer. Salinity is relatively high between January and May and lower between June and December, owing to the inflow, in late autumn, of low salinity water from the south-east containing water discharged by the Orinoco and Amazon rivers or from the equatorial convergence (Rodriguez, 1981).

The Wider Caribbean lacks an extensive shallow continental shelf except off the Yucatán Peninsula and off parts of South America. Ideas on the development of coral reefs in this area changed dramatically in the 1970 s. It was originally thought that coral reef development was poor and algal ridge construction negligible compared with the Indo-Pacific. Adey and Burke (1976) showed that algal ridges are in fact common and it is now known that major coral reef formations of high species diversity and varying structure are widespread. Fringing and patch reefs are commonest; barrier reefs are rare although there are important examples off Belize and in the Bahamas; and bank or bank-barrier reefs are moderately common. Atoll-like structures are found in Belize (e.g. Glovers Reef), the Bahamas (e.g. Hogsty Reef) and in Colombian waters (e.g. Banco Roncador) but true atolls do not occur in the Caribbean. Small atoll-like reefs, more commonly known as basin or cup reefs are found in Puerto Rico, Bermuda and off México. General descriptions of Caribbean reefs are given in Glynn (1973), Adey and Burke (1976), Kaplan (1982), Glynn and Wellington (1983) and Goodwin et al. (1986).

The Antilles, which form an arc from Cuba in the north to the Netherlands Antilles in the south, have many of the most important reefs in the Region. There is an inner arc of high volcanic islands with a small marine shelf and an outer arc of low coralline islands with significant shelf areas. Reefs have developed around many of these islands, the extent and type of reef being influenced by aspect, substrate and hurricane incidence. Reef development is often greater on the smaller low islands with low rainfall and little sedimentary run-off (e.g. Anegada, Barbuda, Antigua, St Croix, Grande Terre and the southern Grenadines), although there are some islands of this type which lack reefs. In general reefs and algal ridges do not develop on recent, rapidly eroding volcanic shores as found on Saba, Montserrat, Dominica, northern Martinique and St Vincent, although there are some exceptions, such as Basse Terre. Caribbean shorelines are usually relatively sheltered and support extensive fringing reefs, while Atlantic shorelines are steeper and less luxuriant. The Greater Antilles (Cuba, Hispaniola and Puerto Rico) generally have more extensive reefs than the Lesser Antilles (apart from the Netherlands Aritiles) but the following reefs in the latter are considered particularly significant (Putney, 1982): Martinique ( $84 \mathrm{~km}$, south-eastern coast), Barbuda ( $77 \mathrm{~km}$, north, east and south reefs), British Virgin Islands (63 km, Anegada), Antigua ( $58 \mathrm{~km}$, north and east reefs), Barbados (44 km, east and south reefs), Guadeloupe (33 km, Grand Cul de Sac Marin), Sint Maarten $(25 \mathrm{~km}$, north-east reefs; $23 \mathrm{~km}$, south-west reefs), Anguilla (17 km, south coast).

The shelves and banks of the western-central and south-west Caribbean are characteristically flat with average depths of about $30 \mathrm{~m}$, the almost vertical edges dropping steeply to $400 \mathrm{~m}$ or more. Reefs are typically best developed on the shallow windward and up current edges and may be absent on the relatively deep leeward edges. The landward margins usually have well developed fringing reefs and the central portions of the banks tend to be flat, with algae, seagrasses and infrequent coral outcrops. Deep reefs may occur on the drop-offs and there are isolated patch reefs. Jamaica and the Cayman Islands lie in relatively deep water but are protected from the Atlantic swell, and fringing reefs are well developed especially on the north coasts (Glynn, 1973).

The Gulf of Mexico is basically an area of terrigenous sedimentation, but scattered reef growth is found off México and there are relict coral and algal mounds over much of the shelf. In the Bahamas and southern Florida, reef development is on eastern coasts, western shoal waters being inimical to coral growth. The Bahamas have innumerable and diverse reefs despite relatively low water temperatures; the Andros Barrier Reef is one of the longest in the region. There is no reef formation north of south Florida, but isolated hermatypic corals occur as far north as Cape Hatteras. The most northerly true reefs in the world are in Bermuda due to the warming influence of the Gulf Stream. Bermuda has a surprisingly large number of corals, but lacks some of the characteristic West Indian species such as Acropora palmata, and the reefs are only thin encrustations over Pleistocene rock.

Deep, cold-water "reefs" have been found in several areas, especially along the continental shelf of Europe, the Gulf of Mexico, South Carolina and West Africa. Formed of ahermatypic, branching corals such as Lophelia spp. and Oculina spp., they have been termed "banks" and generally form on rocky prominences at depths of $130-400 \mathrm{~m}$ in areas of upwelling with temperatures between $4^{\circ} \mathrm{C}$ and $10^{\circ} \mathrm{C}$ (Stetson et al., 1962; Reed, 1980). These attract high densities of many reef-associated species and are noted as good fishing grounds.

The coastal waters of Central and South America receive large influxes of fresh water from extensive mainland river systems. Reef development is therefore generally poor, although localized areas of significant reef are found on islands off Colombia, Honduras, Panamá and particularly Belize, which has the longest barrier reef in the Atlantic and several adjacent atolls. Coral reef development reaches its southern limit off Rio de Janeiro in Brazil, with biologically distinct communities which, as in Bermuda, lack many typical Caribbean species. This area forms a distinct subregion, separated by the Amazon-Orinoco River systems, with only half its coral fauna also occurring in the Caribbean. The narrow distribution of reefs in South America is thought to be due to the unfavourable conditions associated with proximity to a large continent. 
In general the region has a relatively homogenous faunal assemblage of about 70 hermatypic scleractian species, the only exception being southern Brazil where several endemic species are found. The Atlantic has less than half the number of coral genera found in the Indo-west Pacific and only eight genera are common to both areas (Acropora, Poriles, Montastraea, Siderastrea, Madracis, Leploseris, Cladocera, Favia). Until recently, $A$ palmata was the most abundant shallow water coral in the Caribbean, forming massive interlaced frameworks down to $6 \mathrm{~m}$, but this species is extremely vulnerable to wave action and has undergone widespread mortality from hurricanes. Ahermatypic corals show a slightly greater proportion of genera in common between the Pacific and Caribbean (20 out of 150). The hydrozoan corais Millepora and Stylaster are widespread. General descriptions of the coral fauna of the Atlantic are found in Walton Smith (1948) and Wood (1983).

\section{The Eastern Pacific}

Reef-building corals were originally considered to be rare in the Eastern Pacific but recent research has shown abundant coral populations despite the small size of the reefs (a few hectares or less in area), their discontinuous occurrence (absent from sand/mud coastal stretches) and their meagre development in areas experiencing upwelling and high river drainage (Dana, 1975; Glynn and Wellington, 1983). Reefs are found in the Gulf of California, and off the coasts of México, El Salvador, Costa Rica, Ecuador, Panamá, Colombia and most offshore islands. Coral assemblages are found around Easter Island. (In El Salvador a small patch of reef is known from off Acajutla (Gierloff-Emden, 1976), but since no further information has been obtained, a country section has not been compiled). The Gulf of California is the northernmost limit for hermatypic growth with the El Pulmo reef near the tip of Baja California probably being the northernmost reef. The southernmost limit for hermatypic corals is the Galápagos and some sites on the Ecuador coast.

Upwellings have an important influence on reef distribution along the mainland coast. Major upwellings in the Gulfs of Tehuantepec (México), Papagayo (Nicaragua/Costa Rica) and Panamá are caused by Atlantic winds that blow seasonally across the mountain gaps in these areas and move surface water off shore which in turn is replaced by cool subsurface water which inhibits reef growth. Oceanographic conditions in the area are described by Dana (1975). Despite a wide gap in terms of distance and water depth between the reefs of the Eastern Pacific and the Central Pacific, their faunas are essentially similar, although the Galápagos fauna exhibits a high degree of endemism.

\section{West Africa}

The West African coast has no true reefs, as a result of a combination of conditions associated with heavy river drainage and currents. However, coral assemblages are found at several sites in the archipelagos of the Gulf of Guinea and Cape Verde islands and along parts of the mainland coast. These are poorly known scientifically and their economic importance and conservation status merit further study.

\section{ECONOMIC IMPORTANCE OF REEFS}

The World Conservation Strategy (IUCN/UNEP/WWF, 1980) identifies coral reefs as one of the "essential ecological processes and life-support systems" necessary for food production, health and other aspects of human survival and sustainable development. Reefs protect the coastline against waves and storm surge, prevent erosion and contribute to the formation of sandy beaches and sheltered harbours. They are a source of raw materials such as corals and coral sand for building materials, black coral for jewellery, and stony coral and shells for ornamental objects. Increasing numbers of reef species are being found to contain compounds with medical properties.

In the Caribbean, the main area dealt with in this volume, the economies of most countries have traditionally been based on agriculture and fisheries. The Directory gives particular attention to the crucial role of reefs in fisheries and to their new role as a major focus of the tourist industry, owing to their aesthetic appeal and recreational value.

\section{Fisheries}

Reefs provide the fish, molluscs and crustaceans on which many coastal communities in developing countries depend. Reefs and other coastal habitats provide nutrients and breeding grounds for many commercial and subsistence food species, particularly in the Caribbean, where the lack of upwellings and the existence of a stable thermocline result in a generally low level of zooplankton in the food chain and in a comparatively small population of exploitable pelagic fish. Reef fish are generally the only immediate source of fresh fish on both the continental mainland and the islands, while major fishing countries such as the U.S.A, México, Venezuela and Cuba are less dependent on fish protein as a food source than small islands, such as those of the Lesser Antilles (UNEP/CEPAL, 1982). In these countries, with the development of tourism, recreational fishing has also become an important, if sometimes conflicting, activity.

Fishery yields of reefs appear to be very variable, according to the conditions under which they are measured, but it is thought that in general a sustainable yearly harvest of $15 \mathrm{t} / \mathrm{sq} . \mathrm{km}$ can be obtained from coralline areas in depths of less than $30 \mathrm{~m}$ (Munro and Williams, 1985). A UNDP/FAO Caribbean Fishery Development Project carried out between 1965 and 1975 provides a regional survey of catch rates (Munro, 1983) and Goodwin (1985) and Hunte (1985) describe the fishing industry in the Eastern Caribbean. Reefs and coral assemblages appear to be of less significance to fisheries in the Eastern Pacific and West Africa.

Caribbean fish are described by Randall (1968), Bohlke and Chaplin (1968), Wolf and Chislett (1974) and Munro (1983). About 180 of the known 350 species of reef or reef-associated fish are marketed. Spiny lobsters, particularly Panulirus argus and conch Strombus gigas, are also valuable resources forming the basis of major export industries (Dubois, 1985; Munro, 1983). The use of trawls or other nets for fishing is severely limited by the coralline habitat and in most areas techniques are restricted to individually buoyed traps or line fishing. 
Spearfishing is becoming an increasingly important method because of the low capital outlay required and high rates of unemployment (Munro, 1983; Hunte, 1985; Goodwin, 1985).

\section{Tourism}

The tourist industry in the Wider Caribbean has developed rapidly over the last 50 years, and since the 1960 s has become the leading economic sector in many island states. By 1981, there were about 100 million tourists annually. Over $90 \%$ visited the U.S. Gulf Coast and Central and South American countries, where, although the main attractions lie inland or on the Pacific coasts, marine tourism is developing rapidly in the Caribbean. Examples include the coast of Honduras, the San Blas Archipelago in Panamá, the Yucatán Peninsula in Mexico, and the offshore islands of South American countries (Beekhuis, 1981). Island countries receive most marine-related tourism. For example, the Bahamas received 96500 visitors in 1977, Puerto Rico 1376000 and the U.S. Virgin Islands 71800 (Beekhuis, 1981), most of whom concentrated their activities in the coastal zone where a favourable climate, beaches, clear water and the presence of reefs are the major attractions. In the Bahamas, tourism contributes $77 \%$ of the country's gross domestic product, in Antigua $40-50 \%$, in Barbados $20 \%$ and in Jamaica $6 \%$. In the Eastern Caribbean, most tourism is related to SCUBA diving, fishing, sailing and other marine sports. For example, in the British Virgin Islands, income from marine tourism has been estimated at US\$14 million, diving in the "Wreck of the Rhone" Marine Park accounting for US\$1 million alone (van't Hof, 1985).

\section{VULNERABILITY OF REEFS}

Biological research on reefs in the 1960 s and early 1970 s led to the view that reefs were fragile ecosystems, particularly vulnerable to human activities and slow to recover if damaged (Johannes, 1975). Subsequent work led to contrasting ideas, that reef communities are dynamic and unstable and that self-replacement and recovery from natural disturbance is normal and contributes to the maintenance of high diversity on the reef (Connell, 1978). These theories have been reviewed by Pearson (1981), Brown and Howard (1985), Brown (in press) and Grigg and Dollar (in press), the consensus being that reefs are perhaps not as fragile as was previously thought.

However, corals generally have very specific requirements for light, temperature, water clarity, salinity and oxygen. Their lack of mobility makes them vulnerable to siltation, through smothering and oxygen depletion. Coral growth tends to be slower where sediments are regularly disturbed and silted substrates inhibit larval settlement. Light penetration is decreased in turbid water, reducing photosynthesis by the symbiotic zooxanthellae; even in the clearest seas, reef-building corals are restricted to depths of less than $30 \mathrm{~m}$ and are generally found much shallower. Many stony corals have slow growth rates, which may be slowed further by adverse environmental conditions; Davies (1983) provides figures for reef growth in the range of $0.38-12 \mathrm{~m}$ per thousand years. Brown and Howard (1985) review the responses c: corals to stress, in terms of altered growth rate and metabolism (photosynthesis and respiration), loss of zooxanthellae, behavioural responses such as filament extrusion and mucus production, sediment shedding, altered reproductive biology and the appearance of disease.

Hurricanes, storms, diseases and sea level changes show that reefs are well adapted to recovery from a variety of sources of natural stress (Pearson, 1981), although the manner and speed with which this occurs may be immensely variable. Recovery rates have been estimated at from 20 to 50 years for complex reefs to only a few years for simpler reefs at a subclimax state of succession. Shallow water monospecific thickets of, for example, Acropora palmata may recover even more quickly (Grigg and Dollar, in press). There is some concern that such phenomena, particularly outbreaks of coral predators, are occurring at increasing frequencies, perhaps as a result of human activities, although at present there is no general consensus of opinion (Brown, in press). The observed increase in incidents may simply be an artefact of the rapid increase in reef studies over the last 20 years. Some of the more recent natural events in the Atlantic and Eastern Pacific are summarized in Table 1.

\section{Hurricanes and storms}

These can reduce large areas of reef to rubble through freshwater inundation and the breaking of branching corals. Hurricanes Frederic and David in 1979 and Hurricane Allen in 1980 (the strongest storm on record in the Caribbean) caused damage in numerous countries. The shallower reefs, dominated by $A$ palmata and $A$ cervicornis, tend to suffer the greatest mortality (Rogers, 1985b). Long-term monitoring studies of the impact of hurricanes on coral reefs have been carried out in Belize and on recovery rates in Jamaica (see country sections). Stoddart (1985) summarizes current thinking on the impact of hurricanes.

\section{El Niño and other Climatic Events}

Winter cold fronts periodically cause coral mortality in the more northerly parts of the region, such as México and the Florida Keys. Elevated temperatures may be equally damaging. The abnormally high sea-water temperatures which accompanied the severe 1982-83 El Niño event were probably responsible for the widespread "bleaching" (i.e. loss of symbiotic zooxanthellae) and death of corals which occurred in many localities in the tropical Pacific and western Atlantic (Glynn, 1984). It was estimated that by the end of 1983, eastern Pacific coral reefs had lost 70-95\% of their living coral cover to depths of $15-18 \mathrm{~m}$, some reefs having experienced drastic reductions and local extinctions of certain species. Coral reef recovery may take many years or decades. Coral mortality was also experienced in the Caribbean during the same period, to a lesser extent although the effects were more pronounced at shallow depths; the relation of this to El Niño is not clear.

\section{Coral Predators}

Coral predators may have a significant impact on reef structure and development. This is particularly evident in 
the Indo-Pacific, where outbreaks of the Crown-of-Thorns Starfish, Acanthaster planci, have affected many reefs. This species is absent from the Atlantic, but has a discontinuous distribution in the Eastern Pacific between northern México and Panamá. Although $A$ planci has not yet had a noticeable impact on these reefs, it is feared that it and other corallivores, such as the mollusc Jenneria pustulata and the pufferfish Arothron meleagris, will slow the process of recovery of reefs suffering from El Nin̄o (Glynn, 1984 and 1985; Glynn and Wellington, 1983). Since $A$ planci is separated from the Caribbean only by the narrow barrier of the Panama Canal, a potential threat is any major alteration of the canal which could permit the spread of this species across the isthmus. Such an event could have disastrous consequences for the reefs of the Caribbean (Glynn, 1974).

The sea urchin Diadema antillarum is normally abundant in reef, seagrass and sandy habitats. It probably removes more calcium carbonate from reefs than any other organism and plays a major role in determining algal cover and diversity. In the late 1970 s and early 1980 s it was reported in extremely high densities in the Caribbean (up to $50 / \mathrm{sq}$. m), particularly on overfished reefs (Hutchings, 1986). Fears of serious coral damage were allayed when a mass mortality of the species started on the Caribbean coast of Panamá in 1983 and spread to most of the Caribbean. The wide geographical spread and species-specificity of the mortality suggest a water-borne pathogen as the most likely causative agent. Recovery is likely to be slow as there are few, if any, unaffected populations to contribute larvae for the recolonization of depleted areas. Its absence is already being reflected in changes in reef communities, particularly in increased abundance of algae (Lessios et al., 1983; Lessios et al., 1984; Bak, 1985).

\section{Disease}

Two diseases, white band and black band, are widespread in the Caribbean region and others are occasionally reported (Antonius, 1981; Goodwin el al., 1986; Rogers, 1985b). Coral genera and species differ in their response but the general effect is a weakening of the reef framework. These diseases do not appear to be correlated with human activities and may be caused by bacteria (Peters, 1983; Gladfelter, 1982).

\section{HUMAN IMPACT ON REEFS}

Although reefs may be constantly experiencing change, there is increasing evidence that human impact, combined with natural disturbance, may significantly slow the recovery rate of a reef, particularly since man-induced damage is often chronic rather than temporary. Where reefs are of economic importance, their long recovery time may become an important issue. Kenchington and Hudson (1984), Salm and Clark (1984), Sorensen et al. (1984), Brown and Howard (1985), Salvat (in press) and Grigg and Dollar (in press) review the impact of human activities on coral reefs and Clark (1985) provides more detailed case studies.

Most threats to coral reefs are related to the fact that the adjacent coastal areas tend to be densely populated. Historically, human settlement in the Wider Caribbean has been away from the coast or, in Central America, on the Pacific coast, but recently Caribbean coastal populations have increased dramatically. Coastal cities significantly influencing shallow waters in this region include Santo Domingo (Dominican Republic), Miami (U.S.A.) and La Habana (Cuba). Others such as Maracaibo (Venezuela) and Barranquilla (Colombia) may have an indirect effect through river discharge. Many islands have very high population densities; for example, apart from Cuba and Dominica, the Antillean islands all have more than 100 inhabitants per sq. $\mathrm{km}$ (Barbados has over $550 / \mathrm{sq}$. $\mathrm{km}$ ). This, combined with very low per capita income (as in Haiti, Honduras, St Vincent, Grenada, Dominica), puts immense pressure on marine resources.

Rogers (1985b), in a survey of damage to Caribbean reefs, found that in most countries, portions of reefs have declined significantly in the last ten years. Fringing reefs, lying immediately off shore, are particularly vulnerable to pollutants and sediments washed off the land and may be affected by activities taking place many miles away, such as deforestation. They also suffer greatest damage from over-exploitation and recreational use owing to their accessibility. Atoll and barrier reefs are less vulnerable but may be affected by pollutants carried on oceanic currents or released from ships and, in areas which are important to fisheries, may be vulnerable to over-exploitation. The main impacts on reefs in the region covered by this volume are discussed below and are listed in Table 2.

\section{Run-off from Land Clearance}

Soil run-off is the most frequent source of increased sediment content in coastal waters, which is considered to be one of the most damaging impacts on corals. Deforestation has occurred throughout much of the Wider Caribbean region, nearly 1.8 million ha of forest disappearing each year (UNEP/CEPAL, 1980) and mangroves have been reduced in most countries. Logging and slash-and-burn agriculture, leading to erosion and increased soil run-off, has caused noticeable siltation on reefs in Brazil, Colombia, Costa Rica, French Antilles, Puerto Rico and Venezuela. This is often compounded by the input of fertilizers, pesticides and other pollutants. The responses of corals to sediment are very variable, many species being able to withstand low levels and others having behavioural or physiological responses to remove sediment (Grigg and Dollar, in press). Nevertheless, there are certainly many instances where damage is severe. Furthermore, siltation of this kind is often difficult to control since the source of sediment may be far from the site of damage and come under the control of different agencies and government authorities.

\section{Industrial, Domestic and Agricultural Pollution}

Although the Caribbean is reported to be cleaner than most semi-enclosed seas, various kinds of pollution are affecting many reefs (e.g. in Barbados, British Virgin Islands, Colombia, Dominican Republic, French Antilles, Jamaica, México, Netherlands Antilles, Puerto Rico and U.S.V.I.). Sewage pollution of reefs has been reported from 17 countries in the area (Table 2). Less than $10 \%$ of total domestic waste receives treatment before disposal and much reaches coastal waters, causing eutrophication 
and ensuing accelerated algal growth which smothers corals; oxygen depletion and toxic contamination compound these effects (Johannes, 1975; Brown and Howard, 1985; Pastorok and Bilyard, 1985). Recovery of the reef may take place rapidly once the source is removed, and increasing efforts are now being made to place outfalls in water deeper than optimal for coral growth and in sites exposed to strong currents and unrestricted water circulation.

Pollution from sugar industries and distilleries, characterized by high BOD, suspended solids and high $\mathrm{pH}$ values, is common in many Caribbean countries (UNEP/CEPAL, 1982) and may have an impact on reefs. Thermal pollution, from power plants and industrial complexes, affects reproduction and may cause expulsion of zooxanthellae (bleaching), a temperature rise of $4^{\circ} \mathrm{C}$ generally causing damage. Mining activities may have an impact on reefs; there are at least 56 large-scale operations in the Caribbean region, many of which are unregulated and discharge effluent which may cause pollution (UNEP/CEPAL, 1982). The long-term impact of heavy metals and other similar pollutants on coral reefs is still far from clear (Howard and Brown, 1984).

The impact of oil on coral reefs has been the subject of intensive research, particularly in the Wider Caribbean which is one of the world's largest oil producing areas. Of particular concern are oil terminals, tanker traffic, refineries and offshore oil reserves adjacent to reefs, all of which are potential sources of pollution. Crude oil production of Venezuela, México, Trinidad and Tobago, Colombia and Barbados was 3.6 million barrels a day in 1977 and production has increased rapidly. Offshore rigs are common and there are periodic spills and blow-outs (Rodriguez, 1981; Conliffe, 1985). Tanker routes often lie near reefs, and spills are known to have affected reefs in Panamá, the Florida Keys and Puerto Rico (Knapp et al., 1983; UNEP/CEPAL, 1982). No region-wide figures are available for refinery pollution but coastal refineries may account for a large proportion of petroleum hydrocarbons entering the ocean. Refined products tend to be more persistent and long-lived in the marine environment than crude oil and may pose a more serious long-term threat.

In fact it appears that there is little long-term effect of oil on corals, although short-term sublethal effects may be felt (Knapp et al., 1983). Single-event episodes, such as oil spills, rarely seem to have detrimental effects but chronic oil pollution may do so, particularly in the intertidal zone where the reef surface may be exposed to the air; there is no evidence that oil floating above the reef damages corals. Perhaps the greatest damage is from the clean-up operations which take place following spills, chemical detergents often being toxic.

\section{Coastal Development and Coral and Sand Mining}

Activities such as filling to provide sites for industry, housing, recreation, and airports, and dredging to create, deepen or improve harbours, ports and marinas have major impacts, through increased turbidity and altered water circulation. Large quantities of coral and sand are mined for use as lime, and for road and building materials, particularly on islands where terrestrial sources of such materials are limited. These activities, as well as the removal of coral and sand in the course of dredging and land-fill operations, have a major environmental impact. This includes beach erosion and transportation of sand to other sites as a result of altered water circulation, sedimentation and pollution from the introduction of toxic substances in the mining process, all of which may affect adjacent coral reefs. Dubois and Towle (1985) discuss these impacts with particular reference to the Caribbean region, where problems often arise on small islands such as Grenada, the Grenadines and St Lucia.

\section{Over-exploitation}

Exploitation of reef species is increasing in countries where cash economies have been introduced relatively recently, in those with high population growth rates, and where tourism has expanded rapidly. In most cases, the concern is not with species extinction but with lowered reef productivity. Spiny Lobsters, Queen Conch and a variety of fish and reef invertebrates (particularly black and stony corals and a variety of molluscs, collected for the marine curio trade) have been heavily over-exploited in the Caribbean, particularly where they are important to local people, are in demand by tourists and make up a major export trade (Hunte, 1985; Rogers, 1985b; Goodwin, 1985; Wells et al., 1983; Munro, 1983).

\section{Deleterious Fishing Methods}

A small proportion of fishing in the Caribbean is carried out using dynamite, fish poisons or intoxicants (Munro, 1983) although such methods are now illegal throughout most of the region. These can be extremely damaging, destroying the reef and wasting fish and killing invertebrates. Fish traps can cause damage by breaking corals. Spearfishing is a widespread and controversial fishing technique. In the context of commercial fisheries it may be economically attractive (for example $67 \%$ of the lobster catch in Belize is taken by spearfishing) since the older, larger, least productive members of the fish community tend to be caught (Munro, 1983). In marine parks, spearfishing by sports divers is generally considered unwise since large predators are removed which causes an imbalance in the ecosystem, and fish populations tend to be more timid, a distinct disadvantage for snorkellers and underwater photographers.

\section{Intensive Recreational Use}

At least 24 out of the 39 countries covered in this volume report recreational activities, mainly associated with tourism, as a factor in the deterioration of reefs. Anchoring, boat groundings, trampling, littering, and exploitation of marine resources causes localized reef damage and is reported regularly. The main impact, however, is probably not so much from these activities, as from the indirect effect of tourist-generated pollution and coastal development. Tourist facilities are usually concentrated along narrow coastal strips and in semi-enclosed bays. Breakwaters and jetties are often constructed to protect beach fronts and this leads to the alteration of water circulation and erosion of beaches elsewhere. A Caribbean Tourism Research Centre has been established in Barbados to study tourism and its impact in the Wider Caribbean region. 


\section{REEF MANAGEMENT}

\section{Protected Areas}

Reef management through a system of protected areas can help halt further degradation, facilitate the recovery of devastated areas, protect breeding stocks, improve recruitment in neighbouring areas and maintain the sustainable utilization of reef resources (Salm and Clark, 1984; Lien and Graham; 1985). In general the Neotropical Region has a poor representation of marine and coastal protected areas (Budowski and MacFarland, 1984) but the Caribbean area has seen major strides in the planning and implementation of such sites (Table 3).

The economic benefits of marine parks are being increasingly recognised (van't Hof, 1985; Salm and Clark, 1984; Lien and Graham, 1985) and the Caribbean provides good examples of economically successful coral reef protected areas. Income to a park accrues through entrance fees, concessions from commercial diving and boat operators, permits for particular activities, direct management of commercial activities by park staff, and the sale of souvenirs and educational materials. For example, Buck Island National Monument attracts some 50000 visitors a year, $90 \%$ of whom visit the snorkel trail, and the licensed charter boat operators who provide transport to the reserve give $1-3 \%$ of their income to the Parks Service. Against this income is balanced the cost of staffing a park, the maintenance of facilities, the management of the environment where necessary, the provision of educational and recreational activities and in some cases the purchase of the site. Studies carried out at the Virgin Islands National Park, which received over 566000 visitors in 1981, and at Cahuita National Park in Costa Rica showed a benefit/cost ratio of 10:1 (van't Hof, 1985). Further studies are required, but these figures may be widely applicable; for example, revenues from Buccoo Reef in Tobago are US\$510 000 a year and diving tourism at Bonaire in the Netherlands Antilles brings in US\$5 million a year.

Of the 39 countries included in this volume, 24 have a total of 80 protected areas which include coral reefs (see Table 3). This is extremely high compared with other parts of the world; for example, the 15 countries of the Red Sea and Gulf region have fewer than ten protected areas with reefs. Several countries such as the U.S.A., the British Virgin Islands, and the Netherlands Antilles now have comprehensive marine park programmes with a strong emphasis on the associated tourism and recreational benefits. Anguilla, Cuba, Dominica, the French Antilles, Haiti, Honduras, Montserrat, Nicaragua, Puerto Rico, St Vincent, St Kitts-Nevis, and the Turks and Caicos still have no coral reef protected areas, but several of these countries have projects under way. In addition to the established coral reef protected areas, a further 22 sites adjacent to terrestrial protected areas are recommended for inclusion or could be included, 113 other sites have been recommended for protection, and 27 have been identified as being of particular interest for their scientific or economic value.

The World Conservation Strategy emphasizes that any system of protected areas must aim to protect a representative selection of ecosystem types. This is still a problem as far as marine ecosystems are concerned, as there is no widely accepted classification. Problems in the classification of marine ecosystems are discussed by
Ray (1975) and Salm (1984). Hayden et al. (1984) produced a preliminary classification based on attributes of the physical environment combined with faunal assemblage data. The Caribbean is being investigated as a suitable region to develop a more detailed pilot classification, subregions having already been identified in the Caribbean Data Atlas (Ray et al., 1980).

Marine protected areas vary immensely in size (see Table 3), the area chosen often depending on practical rather than scientific considerations. Salm (1984) discusses optimum sizes for coral reef protected areas. The critical minimum core area is considered to be the smallest reef area in which all species found in the area have a $100 \%$ chance of being found on all reefs of the same size. For example, in the Chagos Archipelago, core areas correspond to at least 300 ha for each reef type (Salm, 1980); there are no known comparative studies for the Caribbean or Eastern Pacific. The remainder of the reserve (including reef-flats, land and intervening and surrounding waters) should function as a buffer and is zoned for different uses, permitting optimal use of the area by different interest groups with minimum conflict and maximum control. Reef flats and seagrass beds are often overlooked but are important in the recycling of nutrients in the reef ecosystem, and several fish have life cycles which involve two or more of these systems (Ogden and Gladfelter, 1983). The creation of protected areas around and including entire island systems, such as Buck Island off St Croix, and the extension of boundaries of terrestrial protected areas to include marine habitats are effective means of achieving protection of a group of interrelated ecosystems. Large multiple use areas are therefore generally more practical than small reserves although sanctuaries or strict reserves may still be required for critical habitat areas, such as nutrient sources, areas of high biological diversity and nesting, or to protect breeding stocks of important fish (Salm and Clark, 1984).

The Man and the Biosphere (MAB) programme, established in 1971 by Unesco, is of particular relevance in this context. One aim of the programme is the establishment of an international network of "Biosphere Reserves". These sites, selected to provide representative examples of the world's major ecosystems, encompass multiple zones including one or more highly protected core areas (to protect natural ecosystems and genetic diversity), traditional use areas (to study and document traditional use patterns), experimental areas (for manipulative research on resource utilisation) and rehabilitation areas (to study techniques for the restoration of degraded ecosystems). They must also offer possibilities for sharing personnel and educational research and training facilities and have the potential for involving local communities in research and educational programmes.

The 1984 Action Plan for Biosphere Reserves emphasizes the need to improve representation of coastal and aquatic ecosystems. Of the 252 listed Biosphere sites, less than a dozen include or are adjacent to reefs, and of these, only three (the Virgin Islands National Park (U.S.V.I.), the Galápagos and the Everglades, which includes Fort Jefferson National Monument), lie within the region covered by this volume. Biosphere Reserves are particularly appropriate for the coastal zone owing to their emphasis on linkages between conservation and development and because of the difficulty of including 
complete marine and coastal ecosystems within traditional forms of protected areas.

Consideration is now being given to establishing a multi-national reserve by including within the Virgin Islands Biosphere Reserve the adjoining land and waters in the British Virgin Islands. There are also plans for the establishment of a Lesser Antillean Biosphere Reserve, since there are few sites in the Eastern Caribbean large enough to contain the full range of zones usually found in biosphere reserves. Starting with the existing Virgin Islands Biosphere Reserve, a co-operative relationship would be established with protected areas on other islands to include examples of communities not currently represented, such as tropical rainforest. Outstanding examples of marine ecosystems have been identified, located where possible in areas where local support will encourage success, and with an emphasis on protecting and improving the potential for research and monitoring of over-exploited fisheries (Chakalall and Geoghegan, 1983; Wood, 1984; Goodwin, 1985; Rogers, 1985a). Potential marine sites, identified in the ECNAMP survey of conservation priorities for the Lesser Antilles (Putney, 1982) include Anegada and the surrounding waters of the British Virgin Islands (representing the largest reef complex in the Lesser Antilles), St Kitts-Nevis, St Lucia, Anguilla and St Vincent. Other priority areas identified by ECNAMP which include reefs are the proposed Parc National Guadeloupe and Barbuda. Areas identified as high priorities on account of multiple resouce values including coral reefs are: on Martinique, the west coast of Marie Galante, the east Caravelle Peninsula, the east Fort-de-France Bay, and the south peninsula; on Dominica, the north-east coast and Cabrits Peninsula; and in the Netherlands Antilles, the islets west of Barcadera, Aruba.

While biosphere reserves are aimed at protecting representative samples of ecosystems, the World Heritage Site system has been designed to conserve unique and outstanding examples of the world's natural heritage. These may be nominated by parties to the World Heritage Convention (Convention conceming the Protection of the World Cultural and Natural Heritage), concluded at Paris, 23 November 1972. Of the 62 listed natural sites, the following include or are adjacent to reefs: Aldabra, Great Barrier Reef (Australia), Sierra Nevada de Santa Marta (Colombia) and the Galápagos, of which the last two are described in this volume. There is clearly scope for listing other reefs on this convention. For example, Anegada in the British Virgin Islands has been nominated, and the Belize Barrier Reef would make an appropriate candidate if Belize were to become a party.

\section{Coastal Zone Management Planning}

The technology to avoid much human-induced damage to coral reefs is now available. For example, sewage outfalls can be placed below the level of coral growth, thermal effluent can be discharged in deep water and there are new methods for dispersing oil. Although this technology is not necessarily applied owing to lack of technical expertise, funding or co-ordination between the relevant government authorities, many countries are now developing integrated coastal management programmes. Examples in the Caribbean are Trinidad and Tobago, Jamaica and the U.S.V.I.. This relatively new field is discussed by Sorensen et al. (1984), Snedaker and Getter (1985) and Geoghegan (1985); guidelines are provided for the creation of national coastal resources management programmes; actions by international aid organizations; land use and coastal planning; and environmental impact assessment, many of which are specific to coral reefs. Furthermore, the International Affairs Office of the U.S. National Parks Service, in co-operation with the U.S. Agency for International Development and other organizations, has set up the C.A.M.P. (Coastal Area Management and Planning) Network to provide information and training opportunities.

The Unesco Coral Reef Management Handbook (Kenchington and Hudson, 1984), produced for dissemination in the Indo-Pacific but applicable to other regions, aims to provide political, administrative and technical decision-makers who have responsibility for coral reefs with the means to ensure that relevant issues are properly considered in the course of their work. Other management handbooks relating specifically to marine or coral reef ecosystems include Geoghegan (1983) and Goodwin et al. (1986). UNEP is currently preparing a set of Coral Reef Management Guidelines in collaboration with the Australian Great Barrier Reef Marine Park Authority.

\section{Reef Fisheries Management}

The World Conservation Strategy recommends that the maintenance of coral reef fisheries at sustainable levels be considered a requirement of global priority. Despite overfishing of many traditional resources such as conch and lobster, landings in much of the Wider Caribbean could probably be improved through stock enhancement, such as use of under-exploited non-reef species, artificial reefs and other fish aggregating devices. For example, in the Eastern Caribbean, artificial reefs are being studied as a method of improving small island fisheries and attracting fishermen away from depleted reefs (Goodwin and Cambers, 1983; Goodwin, 1985). Programmes are also under way to improve management of the spiny lobster and conch fisheries. The mariculture programme for Strombus gigas appears to have particular potential, providing a number of benefits including employment for local people and the possibility of reseeding depleted reef areas with hatchery-reared specimens. The omamental coral and shell trades need better control, both nationally and internationally (Wells and Alcala, in press). The shell trade can provides an important source of income and many molluscs can probably support fairly intense exploitation, but the trade needs improved management to prevent damage to the reef environment and local over-exploitation of the more popular species.

The Convention on International Trade in Endangered Species of Wild Fauna and Flora (CITES), concluded in Washington D.C., 1973, provides a mechanism for controlling international trade in threatened species. However, although many reef species are involved in international trade, few fit the strict criteria required for listing on the Appendices. All turtles Testudines and the dugong Dugong dugong (except Australian populations) are listed in Appendix I which prohibits international trade between parties. Black coral (Antipatharia), the Giant Clams Tridacnidae and a number of stony coral genera are listed in Appendix II, which means that an export permit is required from the country of origin. 
Most countries in the region covered by this volume have national legislation to regulate fisheries, including conch, lobster and sometimes corals (Table 4). This however, has generally been enacted on an ad hoc basis for particular species. For the Eastern Caribbean as a whole, a Fisheries Act has now been developed under the auspices of the Organization of Eastern Caribbean States (OECS) and FAO (Goodwin, 1985; Hunte, 1985). This provides for the preparation of fisheries management and development plans, appointment of national fisheries advisory committees, regional co-operation, establishment of marine reserves and conservation programmes and prohibition of certain gear and methods. It covers spiny lobsters, conch, turtles, coral and aquarium fish and particular attention will be paid to enforcement, especially in terms of voluntary co-operation. Appropriate legislation has now been passed in several countries (Hunte, 1985).

\section{Research, Training and Education}

Research into the coastal zone has increased dramatically in recent years, particularly in relation to the conflict between economic development and natural resource conservation. The Division of Marine Sciences of Unesco establishes research programmes in developing countries and trains specialists and technicians in marine sciences through the Major Inter-regional Project on Research and Training leading to Integrated Management of Coastal Systems (COMAR). Pilot projects are being drawn up to give each region the practical experience and background for decision-making in the field of coastal zone management (Unesco, 1986). These include projects on coastal and beach stability in the Lesser Antilles (Antigua, Dominica, Grenada, St Kitts, St Lucia and St Vincent); productivity and interactions between coral reefs, seagrasses and mangroves; and traditional knowledge and management of coastal and marine ecosystems, which has focused on the Asian and Pacific regions to date but will be extended to Latin America in 1987. In West Africa a seminar on coastal ecosystems was held at Dakar in 1979, in the course of which a COMAR project was defined to encourage the establishment of multidisciplinary research teams and training workshops in this area (Unesco, 1981).

The University of the West Indies, in collaboration with some of the organizations described below, is setting up a Centre for Resource Management and Environmental Studies (CERMES) in Barbados which will run training courses for resource managers, placing considerable emphasis on coastal and marine aspects. It already has research and training programmes on coastal zone management at its campuses in Jamaica and Trinidad. Training courses in Environmental Impact Assessment are currently being developed, many of which relate directly to coral reefs (Geoghegan, 1985). International seminars are held in the U.S.A. for administrators, managers and professional personnel involved in coastal and marine protected areas policy, planning, design, management and operations (Anon., 1986a). UNEP/FAO (1985) provide a list of marine environmental centres in the region, many of which are undertaking reef research and management programmes. A world list of coral reef research institutes is currently being prepared by Eldredge and Potter (in prep.); information on marine research institutes and scientists is also available in Unesco/FAO (1983).
Monitoring changes on reefs is a high priority (Brown and Howard, 1985). Simple, low-cost techniques for assessment have been designed for the Pacific (Dahl, 1981 ) and the Eastern Caribbean (Goodwin et al., 1986). Remote sensing of coral reefs, although costly, is becoming an increasingly useful technique, and a training course in Australia on the subject has recently been run under the auspices of the Unesco COMAR project.

Education programmes in schools and villages are also extremely important to help local people to understand the importance of reef resources and lead to improved enforcement of planning controls and regulations. A manual on coral reefs for students has been produced by the Caribbean Conservation Association (Griffith and Williams, 1985). Foreign visitors and tourists also need to understand the reef ecosystems, and marine parks are increasingly contributing to this through their provision of interpretative centres, underwater trails and guidebooks, such as Kaplan (1982) and Greenberg (1977).

\section{International and Regional Efforts}

Multinational collaboration and regional strategies are particularly important in the conservation and management of marine resources which are so often shared by several countries. Kenchington and Hudson (1984) summarize the international agencies and organizations which carry out activities relating to reef management. The following is a guide to those of particular relevance to the area covered by this volume.

\section{UNEP Regional Seas Programme}

The Regional Seas Programme was initiated by UNEP in 1974. Since then the Governing Council of UNEP has repeatedly endorsed a regional approach to the control of marine pollution and the management of marine and coastal resources and has requested the development of regional action plans.

The Regional Seas Programme at present includes ten regions and has over 120 coastal States participating in it. It is conceived as an action-orientated programme having concern not only for the consequences but also for the causes of environmental degradation and encompassing a comprehensive approach to combating environmental problems through the management of marine and coastal areas. Each regional action plan is formulated according to the needs of the region as perceived by the Governments concerned. It is designed to link assessment of the quality of the marine environment and the causes of its deterioration with activities for the management and development of the marine and coastal environment. The action plans promote the parallel development of regional legal agreements and of action-orientated programme activities.

An important UNEP contribution to the concept of promoting regional cooperation in assessing and combating marine pollution together with resource conservation and management in oceans and coastal areas has been the preparation and publication of a series of regional directories and bibliographies.

UNEP's recognition of the environmental importance of coral reefs, as well as the tremendous pressures on and 
global exploitation of these fragile ecosystems, has been demonstrated in the inclusion and encouragement of various measures to protect reefs in the regional action plans. The publication of the Pacific Coral Reef Researchers in UNEP's Regional Seas Directories and Bibliographies (UNEP/PSA/SPREP/UG, 1984) is also an indication of this concern. In order to give coral reefs and associated problems a deservedly much greater exposure it was decided to publish the three volumes of directories that would cover the coral reefs globally.

This volume covers three regions defined by the UNEP Regional Seas Programme: Wider Caribbean, South-East Pacific and West and Central Africa together with South-West Atlantic which currently is not covered by the UNEP's Regional Seas Programme.

The Wider Caribbean Region includes all the Caribbean islands, the US Gulf States, Mexico, all Central American States except El Salvador (which has no Caribbean Coast), Panamá, Colombia, Venezuela, Guyana, Suriname and French Guiana. The Caribbean Action Plan, (UNEP, 1983) adopted in 1981 at Montego Bay, Jamaica, included 66 specific environmental projects of which 25 were identified as "high priority" projects of interest to the whole region, including watershed management, pollution control, education, protection of coastal marine resources and environmental education. Immediate action was urged for eight areas: oil spill cooperation and contingency plans, guidelines for managing - watersheds, water pollution control improvements, better natural disaster risk assessments, study of the impact of tourism, protection of coastal marine resources, renewable energy production and environmental public education.

\section{IUCN and WWF}

The Caribbean was identified as a priority area under IUCN's Marine Programme of 1976 when a Caribbean Marine Programme was initiated in association with the Caribbean Conservation Association (CCA) (see below) and the UNEP Regional Seas Programme. In 1979, "A Strategy for the Conservation of Living Marine Resources and Processes in the Caribbean Region" was drawn up which included a Data Atlas (Ray et al., 1980) consisting of a set of 50 maps covering environmental parameters, habitats, species, socio-economic and jurisdictional data and other aspects of marine resources. A general project is now underway to promote and implement the World Conservation Strategy in the Caribbean through support to CCA and ECNAMP (see below) and through the development of a network of coastal and marine protected areas.

Current IUCN/WWF activities in the region include the development of marine parks in Jamaica, the Dominican Republic, Dominica, St Lucia and the Netherlands Antilles, and the general support of the national park services in several countries through assistance provided by the IUCN Commission on National Parks and Protected Areas (CNPPA). The Conservation Development Centre of IUCN is responsible for the development of National Conservation Strategies in Belize, Mexico, Panamá, Honduras, Venezuela and Costa Rica which will take reef ecosystems in these countries into account. WWF-US supports environmental education programmes and a conch resource management project.

\section{Unesco}

Unesco's main involvement in the region, as far as coral reefs are concerned, is in terms of its Man and the Biosphere Programme and research and training activities, both of which were described above.

\section{Caribbean Conservation Association (CCA)}

Based in Barbados, this is a regional non-governmental organization concerned with the management and conservation of the natural and cultural heritage of the Wider Caribbean. Activities include the coordination of natural resource management activities through the Eastern Caribbean Natural Area Management Program (ECNAMP) and Marine Resources Programme for the Eastern Caribbean (MRPEC).

\section{Eastern Caribbean Natural Area Management Programme (ECNAMP)}

Launched in 1976, ECNAMP operates in association with CCA and is funded by IUCN/WWF and the Rockefeller Brothers Fund. It runs a series of projects involving field action, training and research activities. A survey of conservation priorities in the Lesser Antilles led to the publication in 1980 of Data Atlases for the 25 islands and island groups of the Lesser Antilles, following a survey of conservation priorities, as a contribution to the UNEP Action Plan for the Caribbean Environment Programme (Putney, 1982; Putney et al., 1984; Towle, 1985).

\section{Commonwealth Science Council (CSC)}

The CSC has initiated a Coastal Zone Management Project in the small islands of the Eastern Caribbean with the aim of forming a co-operative network to complement other regional activities in the area. Its objectives are to: 1) enhance and encourage regional co-operation and sharing of resources in coastal management; 2) increase the level of expertise of local managers of coastal resources; 3 ) provide the basis for recommending environmental standards for coastal resource use; 4) establish an informal consultative network on coastal zone management in the region; 5) increase the database on coastal resources of the islands of the region; and 6) encourage governments to give high priority to sustained coastal zone development (Commonwealth Science Council, 1985).

\section{Island Resources Foundation}

Based in the U.S.V.I., this has extensive involvement in the region in coastal zone management with special reference to: 1) dredging and sand mining impact assessment, policy and technical requirements; 2) permitting, licencing and monitoring; and 3) solid and liquid waste disposal. 


\section{Environmental Research Projects (ERP)}

ERP is a non-profit organization which implements the CCA's Marine Resources Programme for the Eastern Caribbean. It focuses on the development of management strategies for conch and lobster, reef monitoring and artificial reefs, education, public awareness and indigenous capabilities for marine resource management and development.

\section{Virgin Islands Resource Management Co-operative (VIRMC)}

Established in 1982 through the initiative of the U.S. National Park Service, VIRMC aims to bring together local and regional expertise to solve resource management problems. Members include both private institutions and government agencies, concerned with conservation, research, resource management and economic development in the Virgin Islands region. The main emphasis has been on marine ecological studies and the establishment of the Virgin Islands Biosphere Reserve (Rogers, 1985a).

\section{International Conventions}

Most international wildlife conventions bear little relation to coral reefs. CITES and the World Heritage Convention were mentioned earlier. The following conventions also have, or could have, some bearing on reef management and conservation.

The Convention on the Prevention of Marine Pollution by Dumping of Wastes and Other Matter, 1972 and the International Convention for the Prevention of Marine Pollution from Ships (MARPOL 73/78) have been drawn up by the International Maritime Organization to prevent marine pollution from ships which may often have a direct impact on reefs. They are discussed by Kenchington and Hudson (1984).

The Convention on Wetlands of International Importance especially as Waterfowl Habitat, concluded at Ramsar, Iran, 2 February 1971, lists wetlands of international importance primarily to waterfowl, but sites may be selected on a variety of criteria. Wetlands are defined as areas of marsh, fen, peatland or water, fresh and marine, the depth of which at low tide does not exceed six metres, shallow coral reefs are therefore included. At present no coral reef sites are listed. It is generally felt that, in its present form, the Convention is not appropriate for reefs since (a) the emphasis is strongly on bird habita; (b) reefs generally extend to depths greater than $6 \mathrm{~m}$; and (c) reefs generally come under different national legislation from other wetland habitats which would complicate the implementation of the Convention within a country (Anon., 1986b; Wells, 1984). However, efforts are currently underway to revise the Convention to make it an important force for the protection of coastal wetlands essential for supporting fisheries.

\section{REFERENCES}

Adey, W.H. and Burke, R. (1976). Holocene bioherms (algal ridges and bank-barrier reefs) of the Eastern
Caribbean. Geol. Soc. Am. Bull. 87: 95-109.

Anon. (1986a). The Marine Connection. 1(1) (joint newsletter of the Oceanic Symposia of the 4th World Wilderness Congress and the International Marine Protected Areas Network).

Anon. (1986b). Is the Ramsar Convention appropriate for the Caribbean? Caribbean Wetlands Newsletter 5: 1-3. Antonius, A. (1981). The "band" diseases in coral reefs. Proc. 4th Int.Coral Reef Symp. 2: 7-14.

Bak, R.P.M. (1985). Recruitment patterns and mass mortalities in the sea urchin Diadema antillarum. Proc. Sth Int. Coral Reef Symp. 267-272.

Bayer, F. (1969). A review of research and exploration in the Caribbean Sea and adjacent regions. FAO Fish Rep. 71(1): 41-92.

Beekhuis, J. (1981). Tourism in the Caribbean: impacts on the economic, social and natural environments. Ambio 10(6): 325-331.

Bjorklund, M.I. (1974). Achievements in marine conservation. 1. Marine Parks. Env. Conserv. 1: 205-223.

Bohlke, J.E. and Chaplin, C.C.G. (1968). Fishes of the Bahamas and Adjacent Tropical Waters. Livingstone Publ. Co., Wynnewood, Penna. U.S.A.

Brown, B.E. (in press). Worldwide death of corals natural cyclical events or man-made pollution? Marine Pollution Bulletin.

Brown, B.E. and Howard, L.S. (1985). Assessing the effects of "stress" on reef corals. Adv. Mar. Biol. 22: 1-63.

Budowski, G. and MacFarland, C. (1984). Keynote Address: The Neotropical Realm. In: McNeeley, J.A. and Miller, K.R. (Eds). National Parks, Conservation and Development: The role of protected areas in sustaining society. Smithsonian Institution Press, Washington D.C.: 552-560.

Chakalall, B. and Geoghegan, T. (1983). Lesser Antillean Biosphere Reserve. Parks 8(2): 7-8.

Clark J.R. (Ed.) (1985). Coastal Resources Management: Development Case Studies. Renewable Resources Information Series, Coastal Management Publication 3. Research Planning Institute, Inc, Columbia.

Commonwealth Science Council (1985). Environmental Planning Programme: Coastal Zone Management of the Lesser Antilles Region. CSC Tech. Publ. Series 175: 42 pp. Conliffe, W.L.E. (1985). Environmental impacts of oil pollution in the Caribbean. In: Geoghegan (Ed.) (1985).

Connell, J. (1978). Diversity in tropical rainforests and coral reefs. Science 199: 1302-1310.

CPPS/UNEP, 1983: Action Plan for the protection of the marine environment and coastal areas of the South-east Pacific. UNEP Regional Seas Report and Studies No. 20.

Croxall, J.P., Evans, P.G.H. and Schreiber, R.W. (1984). Status and Conservation of the World's Seabirds. ICBP Technical Publication 2, ICBP, Cambridge, U.K.

Dahl, A.L. (1981). Coral Reef Monitoring Handbook. South Pacific Commission, Noumea, New Caledonia.

Dana, T.F. (1975). Development of contemporary eastern Pacific coral reefs. Mar. Biol. 33: 355-374.

Davies, PJ. (1983). Reef growth. In: Barnes, DJ. (Ed.). Perspectives on coral reefs. AIMS, Townsville: 69-106.

Dubois, R. and Towle, E.L. (1985). Coral harvesting and sand mining practices. Case Study 3. In: Clark, J.R. (Ed.): 203-289.

Dubois, R. (1985). Coastal fisheries management: Lessons leamed from the Caribbean. Case Study 4. In: Clarke, J.R. (Ed.): 292-361.

Eldredge, L.G. and Potter, T.S. (in prep.). Directory of Coral Reef Research Facilities of the World. University of Guam. 
Gelster, J. (1983). Holocene West Indian Coral Reefs: geomorphology, ecology and facies. Facies 9: 173-284.

Geoghegan, T. (1983). Guidelines for integrated marine resource management in the Eastern Caribbean. Caribbean Conservation Association, Eastern Caribbean Natural Area Management Programme (ECNAMP), St. Croix, U.S. Virgin Islands. Caribbean Environment Technical Paper 2.

Geoghegan, T. (Ed.) (1985). Proceedings of the Caribbean Seminar on Environmental Impact Assessment. Caribbean Conservation Association, Barbados. 287 pp.

Gierloff-Emden, H.G. (1976). La Costa de El Salvador Monografia Morfolç gica-Oceanogrífica (1st Spanish Ed.). Direcciçn de Publicaciones, Ministerio de Educaciçn, San Salvador. 286 pp.

Gladfelter, W. (1982). White-band disease in Acropora palmata: implications for the structure and growth of shallow reefs. Bull. Mar. Sci. 32: 639-643.

Glynn, P.W. (1973). Aspects of the ecology of coral reefs in the Western Atlantic region. Chap. 9. In: Jones, O.A. and Endean, R. (Eds) Biology and Geology of Coral Reefs Vol. 2. Academic Press, New York and London.

Glynn, P.W. (1974). The impact of Acanthaster on coral and coral reefs in the Eastern Pacific. Env. Conserv. 1(4): 295-304.

Glynn, P.W. (1984). Widespread coral mortality and the 1982-83 El Niño warming event. Env. Conserv. 11(2): 133-146.

Glynn, P.W. (1985). Corallivore population sizes and feeding effects following El Niño (1982-83) associated coral mortality in Panama. Proc. 5th Int. Coral Reef Cong., Tahiti, 4: 183-188.

Glynn, P.W. and Wellington, G.M. (1983). Corals and Coral Reefs of the Gallpagos Islands. University of California Press, Berkeley, L.A., London, 330 pp.

Goodwin, M.H. (1985). Characterization of Lesser Anillean Regional Fisheries. Island Resources Foundation, $48 \mathrm{pp}$.

Goodwin, M.H. and Cambers, G. (1983). Artificial Reefs. A handbook for the Eastern Caribbean. Prep. by Environmental Research Projects for Caribbean Conservation Association, Barbados, W.I.

Goodwin, M.H., Bannerot, S. and Rogers, C.S. (1986). Information for Coral Reef Management: $A$ Handbook for the Eastern Caribbean. South Carolina Sea Grant Consortium, Charleston, South Carolina.

Greenberg, I. (1977). Guide to Corals and Fishes of Florida, the Bahamas and the Caribbean. Seahawk Press, Miami.

Griffith, S.A. and Williams, E. (1985). Corals and Coral Reefs in the Caribbean: A manual for students. Caribbean Conservation Association, Barbados. 48 pp.

Grigg, R.W. and Dollar, S.J. (in press). Natural and anthropogenic disturbance on coral reefs. In: Coral Reef Ecosystems. Elsevier Press.

Groombridge, B. (1982). IUCN Amphibia-Reptilia Red Data Book Part 1, Testudines, Crocodilia and Rhynchoce phalia. IUCN, Gland, Switzerland.

Hayden, B.P., Ray, G.C. and Dolan, R. (1984).

Classification of coastal and marine environments. Env. Conserv. 11(3): 199-207.

Howard, L.S. and Brown, B.E. (1984). Heavy metals and reef corals. Oceanogr. Mar. Biol. Ann. Rev. 22: 195-210.

Hunte, W. (1985). Marine resources of the Caribbean. In: Geoghegan (1985).

Hutchings, P.A. (1986). Biological destruction of coral reefs. Coral Ree fs 4: 239-252.
IUCN (1982). IUCN Directory of Neotropical Protected Areas. Tycooly International Publishing Ltd, Dublin.

IUCN/UNEP/WWF (1980). World Conservation Strategy. IUCN, Gland Switzerland.

Johannes, R.E. (1975). Pollution and degradation of coral reef communities. In: Ferguson Wood, E.J. and Johannes, R.E. (Eds). Tropical Marine Pollution. Elsevier Scientific Publishing, Amsterdam: 13-50.

Kaplan, E.H. (1982). A Field Guide to Coral Reefs of the Caribbean and Florida. The Peterson Field Guide Series, Houghton Mifflin Co., Boston.

Kenchington, R.A. and Hudson, B.E.T. (1984). Coral Reef Management Handbook. Unesco Regional office of Science and Technology for South-East Asia, Jakarta: 281 pp.

Knapp, A.H., Sleeter, T.D., Dodge, R.E., Wyers, S.C., Frith, H.R. and Smith, S.R. (1983). The effects of oil spills and dispersant use on corals. In: Oil and Petrochemical Pollution 1(3): 157-169.

Lessios, H.A., Glynn, P.W. and Robertson, D.R. (1983). Mass mortalities of coral reef organisms. Science 222: 715. Lessios, H.A., Robertson, D.R. and Cubit, J.D. (1984). Spread of Diadema mass mortality through the Caribbean. Science 226: 335-337.

Lien, J. and Graham, R. (1985). Marine Parks and Conservation: Challenge and promise. Vols. 1 and 2. Henderson Park Book Series 10, The National Parks and Provincial Parks Association of Canada.

Milliman, J.D. (1973). Caribbean coral reefs. Chap. 1. In: Jones, O.A. and Endean, R. (Eds). Biology and Geology of Coral Reefs Vol. 1. Academic Press, New York \& London.

Munro, J.L. (Ed) (1983). Caribbean Coral Reef Fishery Resources. ICLARM Studies and Reviews 7, Manila, Philippines.

Munro, J.L. and Williams, D.McB. (1985). Assessment and Management of Coral Reef Fishes: biological, environmental and socio-economic aspects. Seminar C. Proc. 5th Int. Coral Reef Cong., Tahiti 4: 545-578.

Ogden, J.C. and Gladfelter, E.H. (Eds) (1983). Coral reefs, seagrass beds and mangroves: their interaction in the coastal zone of the Caribbean. Unesco Reports in Marine Science 23: $131 \mathrm{pp}$.

Pastorok, R.A. and Bilyard, G.R. (1985). Effects of sewage pollution on coral reef communities. Mar. Ecol. Prog. Ser. 21: 175-189.

Pearson, R. (1981). Recovery and recolonisation of coral reefs. Mar. Eco. Prog. Ser. 4: 105-122.

Peters, E. (1983). Possible casual agent of "white band" disease in Caribbean acroporid corals. J. Invert. Path. 41: 394-396.

Putney, A.D. (1982). Final Report. Survey of Conservation Priorities in the Lesser Antilles. Caribbean Conservation Association, Caribbean Environment Technical Report No. 1.

Putney, A.D., Jackson, I. and Renard, Y. (1984). The Eastern Caribbean Natural Area Management Programme: a regional approach to research and development for conservation action. In: McNeely, J.A. and Miller, K.R. (Eds). National Parks, Conservation and Development: The role of protected areas in sustaining society. Smithsonian Institution Press, Washington D.C.: 608-615.

Randall, J.E. (1968), Caribbean Reef Fishes. T.F.H. Publ., Neptune City, New Jersey.

Ray, G.C. (1975). A preliminary classification of coastal and marine environments. IUCN Occ. Pap. 14, Morges, Switzerland. 
Ray, G.C., McCormick-Ray, M.G., Salm, R.V., Campbell, D.G., Dobbin, J.A., Dobbin, N.E., and Smith, V.E. (1980). Data Atlas: Planning a Marine Conservation Strategy for the Caribbean Region. IUCN, Gland, Switzerland.

Reed, J. (1980). Distribution and structure of deep-water Oculina Varicosa coral reefs off central-eastern Florida. Bull. Mar. Sci. 30: 667-677.

Rodriguez, A. (1981). Marine and coastal environmental stress in the Wider Caribbean Region. Ambio 10(6): 283-294.

Rogers, C.S. (1985a). Towards a Lesser Antillean Biosphere Reserve. Parks. 10(3): 22-24.

Rogers, C.S. (1985b). Degradation of Caribbean and Western Atlantic coralreefs and decline of associated fisheries. Proc. 5th Int. Coral Reef Cong., Tahiti 6: 491496.

Salm, R.V. (1980). The genus-area relation of corals on reefs of the Chagos Archipelago, Indian Ocean. PhD dissertation, John Hopkins University, Baltimore, Maryland, U.S.A.

Salm, R.V. (1984). Ecological boundaries for coral-reef reserves: principles and guidelines. Environmental Conservation 11(3): 209-215.

Salm, R.V. and Clark, J.R. (1984). Marine and Coastal Protected Areas: A guide for planners and managers. IUCN, Gland, Switzerland.

Salvat, B. (Ed) $(1978,1979,1981,1982)$. Coral Reef Newsletters 1,2,3,4. EPHE, Paris.

Salvat, B. (Ed) (in press). Human activities causing damage to coral ree fs: Knowled ge and recommendations.

Scott, DA. and Carbonell, M. (1986). Directory of Neotropical Wetlands. IUCN, Cambridge, U.K. and IWRB, Slimbridge, U.K.

Silva, M.E., Gateley, E.M. and Desilvestre, I. (1986). A Bibliographical listing of Coastal and Marine Protected Areas: A global survey. Technical Report WHOI-86-11, Woods Hole Oceanographic Institution, Woods Hole, Massachusetts, U.S.A.

Smith, S.V. (1978). Coral reef area and contributions of reefs to processes and resources of the world's oceans. Nature 273(5659): 225.

Snedaker, S.C. and Getter, C.D. (1985), Coastal Resources Management Guidelines. Renewable Resources Information Series, Coastal Management Publication 2. Research Planning Institute Inc., Columbia, South Carolina. $205 \mathrm{pp}$.

Sorensen, J.C., McCreary, S.T. and Hershman, M.J. (1984). Institutional Arrangements for Management of Coastal Resources. Renewable Resources Information Series, Coastal Management Publication 1. Research Planning Institute Inc., Columbia, South Carolina. 165 pp. Stetson, T.R., Squires, D.F. and Pratt, R.M. (1962). Coral banks occurring in deep water on the Blake Plateau. Amer. Mus. Nov. 2114: 1-39.

Stoddart, D.R. (1969). Ecology and morphology of recent coral røefs. Biol. Rev. Camb. Phil. Soc. 44: 433-498. Stoddart, D.R. (1985). Hurricane effects on coral reefs. Conclusion to Symposium 3, Proc. 5th Int. Coral Reef Cong., Tahiti. 3: 349-350.

Towle, E.L. (1985). The island microcosm. Case study 8. In: Clark, J.R. (Ed): 589-749.
Thornback, J. and Jenkins, M. (1982). IUCN Mammal Red Data Book. Part 1. IUCN, Gland, Switzerland and Cambridge, U.K.

Udvardy, M.D.F. (1975). A Classification of the Biogeographical Provinces of the World. IUCN Occ. Pap. 18: $1-48$.

UNEP (1983a). Action Plan for the Caribbean environment programme. UNEP Regional Seas Reports and Studies 26.

UNEP (1983b). Action Plan for the Protection and Development of the Marine Environment and Coastal Areas of the West and Central African Region. UNEP Regional Seas Reports and Studies 27.

UNEP/CEPAL (1980). Overview of Natural Resources for Food and Agriculture in the Wider Caribbean Region. FAO, UNEP/CEPAL.

UNEP/CEPAL (1982). Development and environment in the Wider Caribbean Region: a synthesis. UNEP Regional Seas Reports and Studies 14.

UNEP/FAO (1985). Directory of Marine Environmental Centres in the Caribbean. UNEP Regional Seas Directories and Bibliographies, FAO, Rome. 214 pp.

UNEP/PSA/SPREP/UG (1984). Pacific Coral Reef Researchers. UNEP Regional Seas Reports and Studies 13. Unesco (1971). Symposium on Investigations and Resources of the Caribbean Sea and Adjacent Regions. Willemstad, Curacao, Netherlands Antilles, 18-26 November, 1968. Papers on physical and chemical oceanography, marine geology and geophysics and marine biology. Unesco, Paris, $545 \mathrm{pp}$.

Unesco (1981). The coastal ecosystems of West Africa: coastal lagoons, estuaries and mangroves. Unesco Reports in Marine Science $17.60 \mathrm{pp}$.

Unesco (1986). Research on coastal marine systems. Unesco Technical Papers in Marine Science 47. $27 \mathrm{pp}$.

Unesco/FAO (1983). International Directory of Marine Scientists. FAO/IOC/UN/OETB.

van't Hof, T. (1985). The economic benefits of marine parks and protected areas in the Caribbean region. Paper presented at 5 th Int. Coral Reef Cong., Tahiti (not published in proceedings).

Walton Smith, F.G. (1948). Atlantic Reef Corals. University of Miami Press, Florida. $112 \mathrm{pp}$.

Wells, S.M. (1984). Coral reefs and the Ramsar Convention. IUCN Bulletin 15(4-6): 56-57.

Wells, S.M. and Alcala, A.C. (in press). Collecting of corals and shells. In: Salvat, B. (Ed.) (in press).

Wells, S.M., Pyle, R.M. and Collins, N.M. (1983). The IUCN Invertebrate Red Data Book. IUCN, Gland, Switzerland and Cambridge, U.K.

Wolf, R.S. and Chislett, G.R. (1974). Exploratory fishing activities of the UNDP/FAO Caribbean Fishery Development Project 1965-1971: A summary. Mar. Fish. Rev. 36(9): 1-8.

Wood, E.M. (1983), Corals of the World. T.F.H. Publications, Inc. Ltd.

Wood, J. (Ed) (1984). Proceedings of the Workshop on Biosphere Reserves and Other Protected Areas for Sustainable Development of Small Caribbean Islands, May 10-12, 1893. Virgin Islands National Park, Caneel Bay, St John, U.S.V.I. U.S. Dept of the Interior, National Park Service, Atlanta, Georgia. 190 pp. 


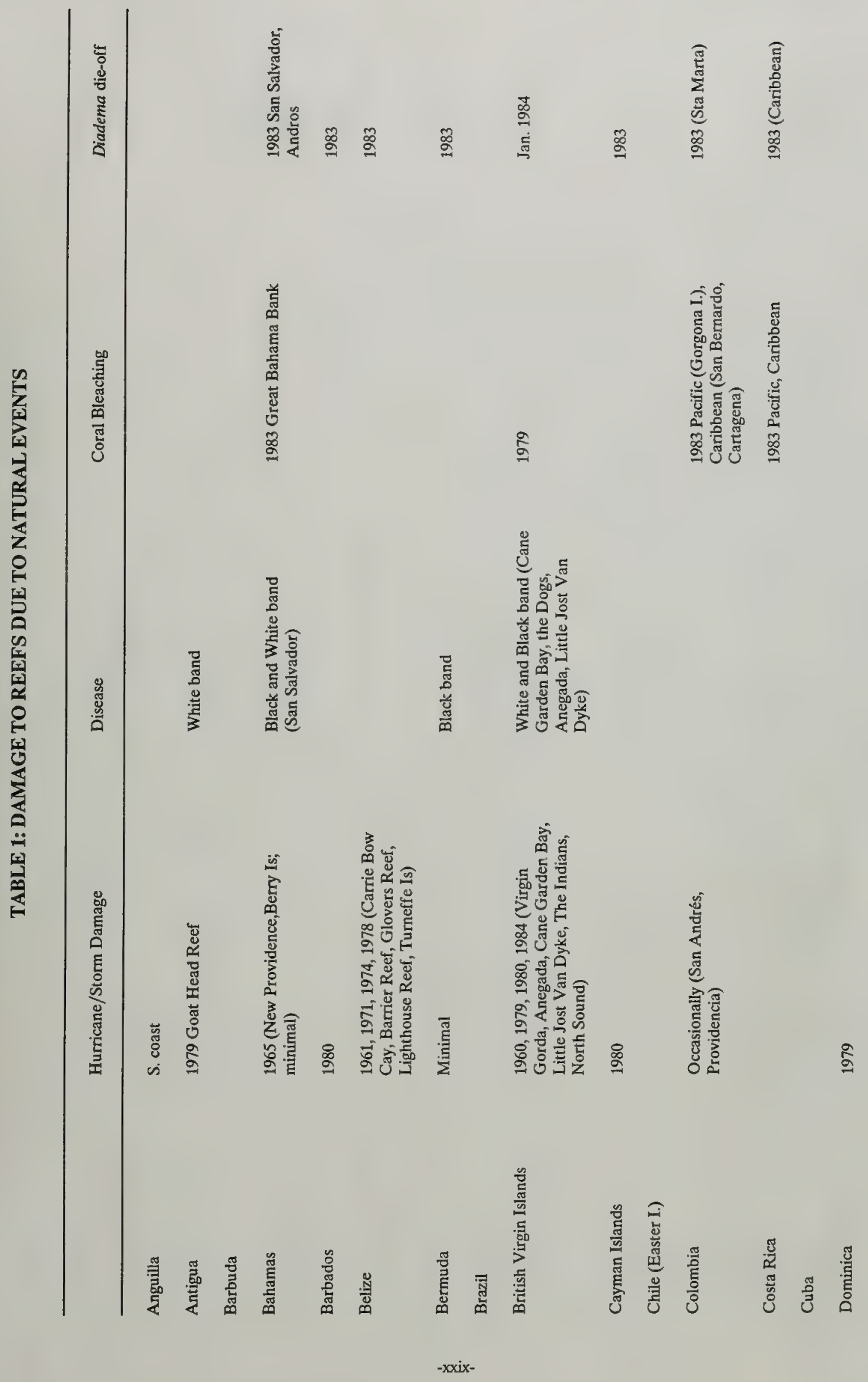




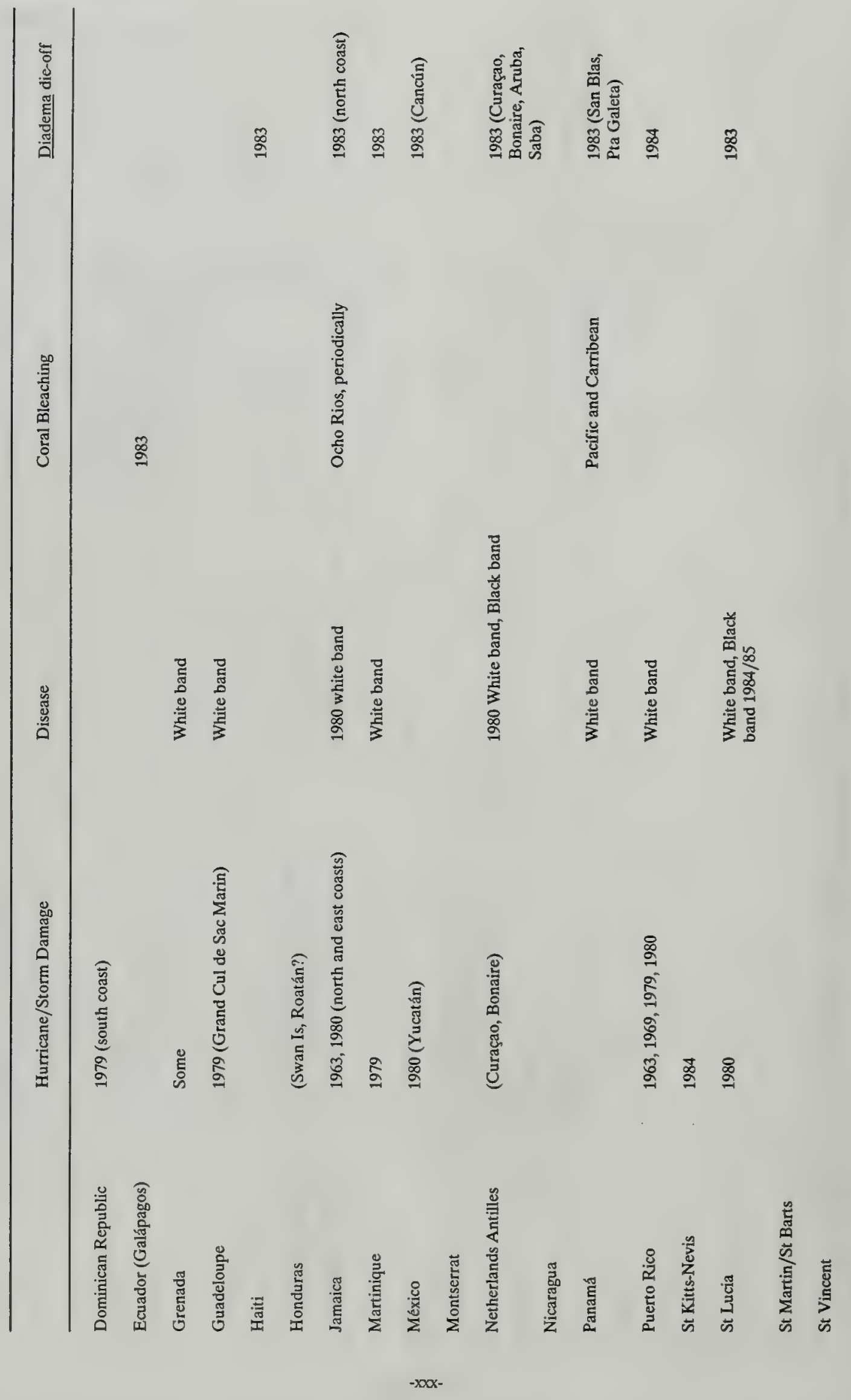




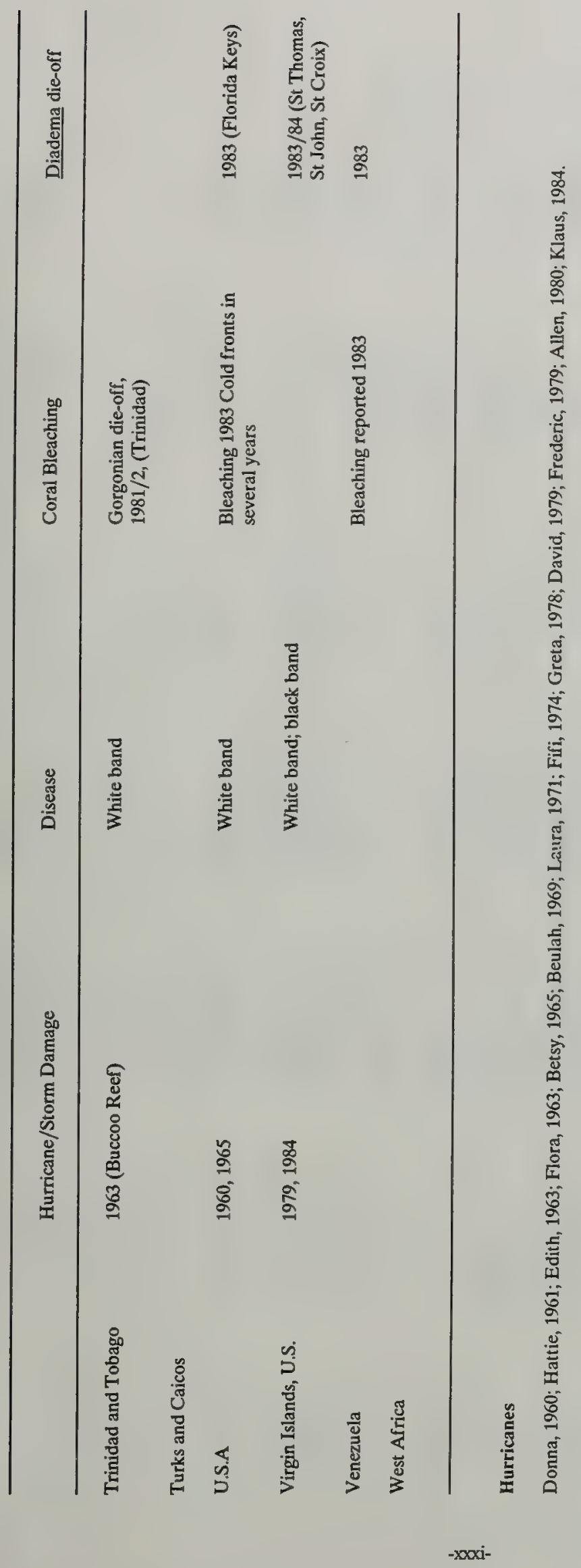




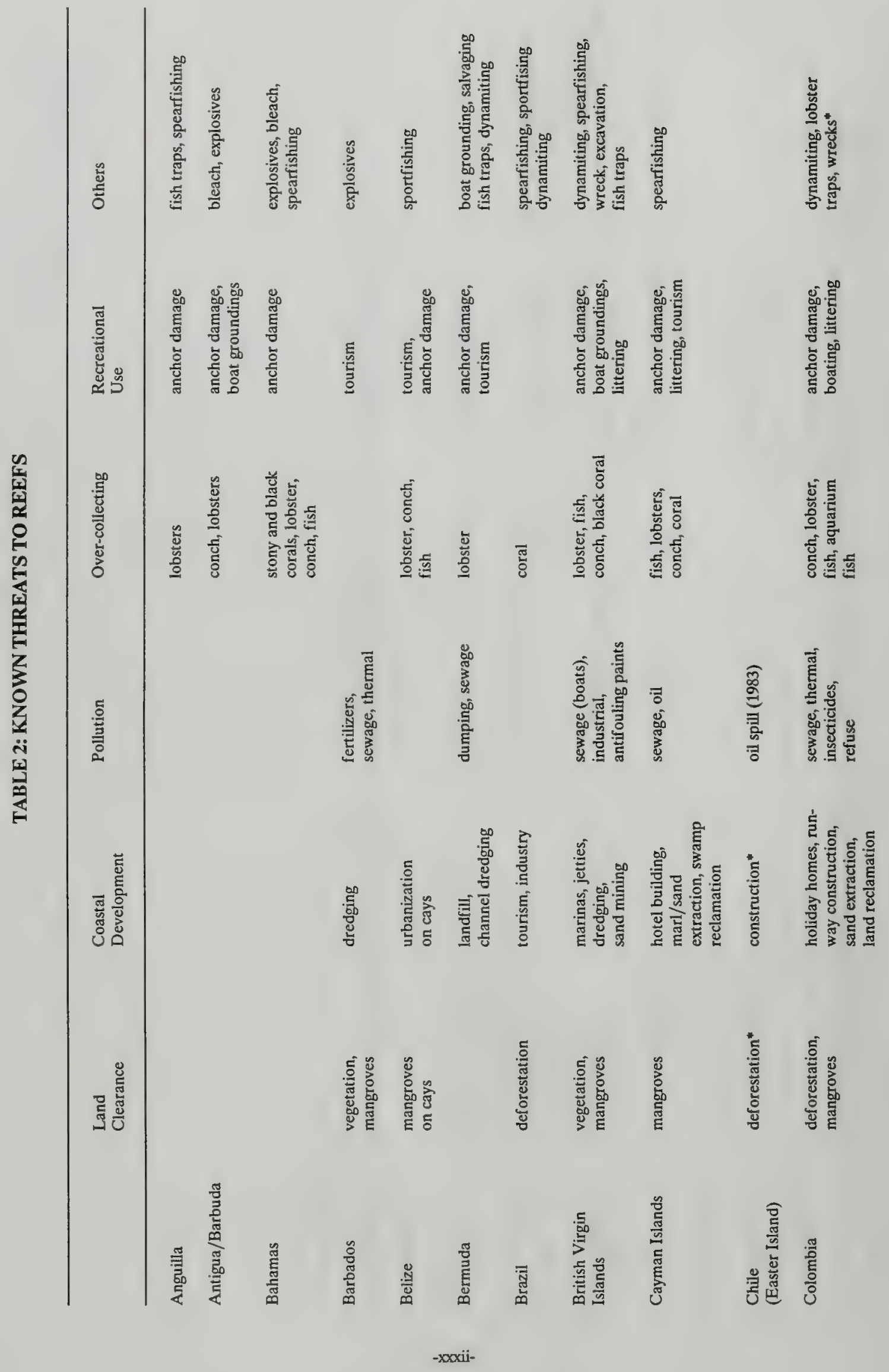




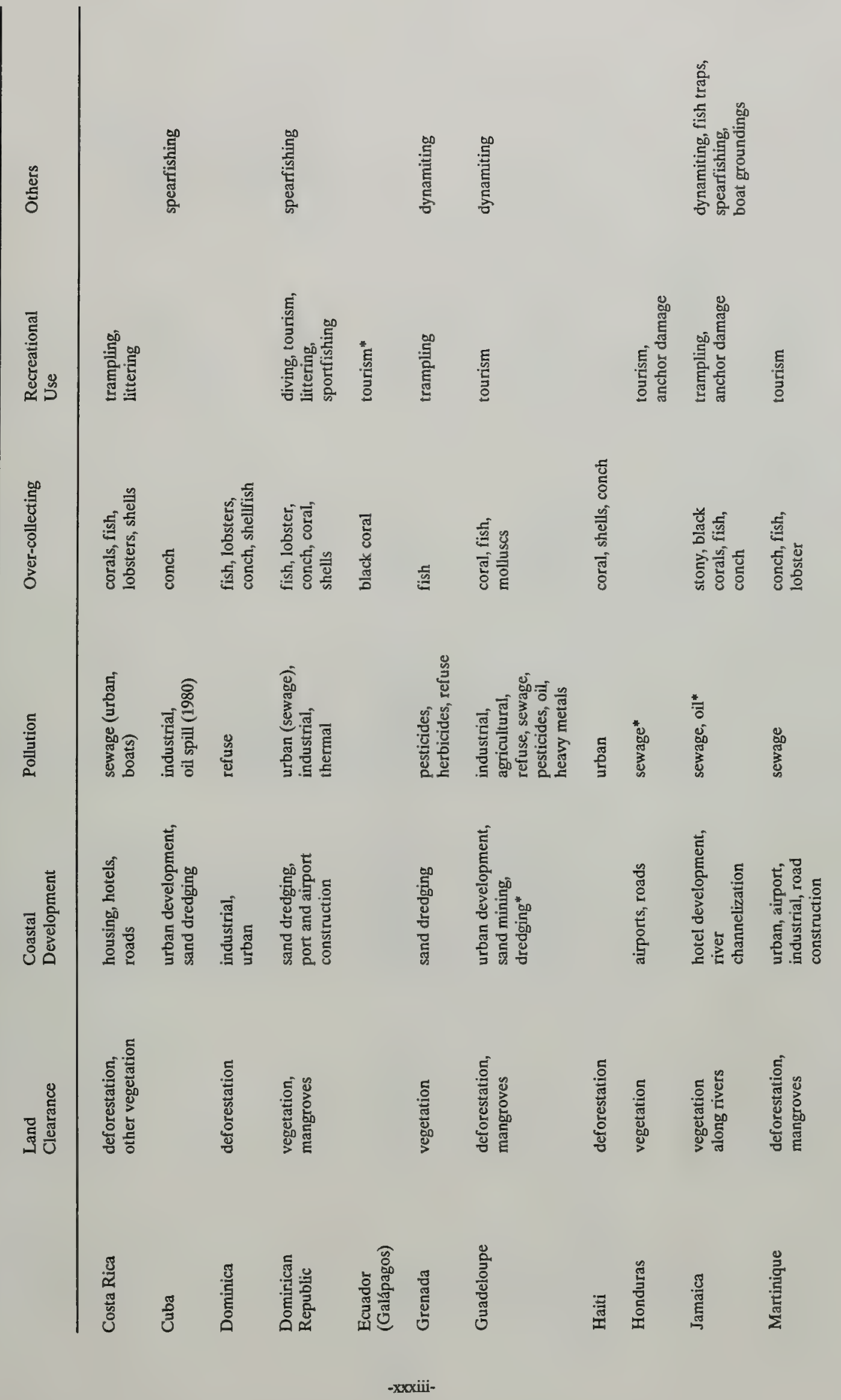




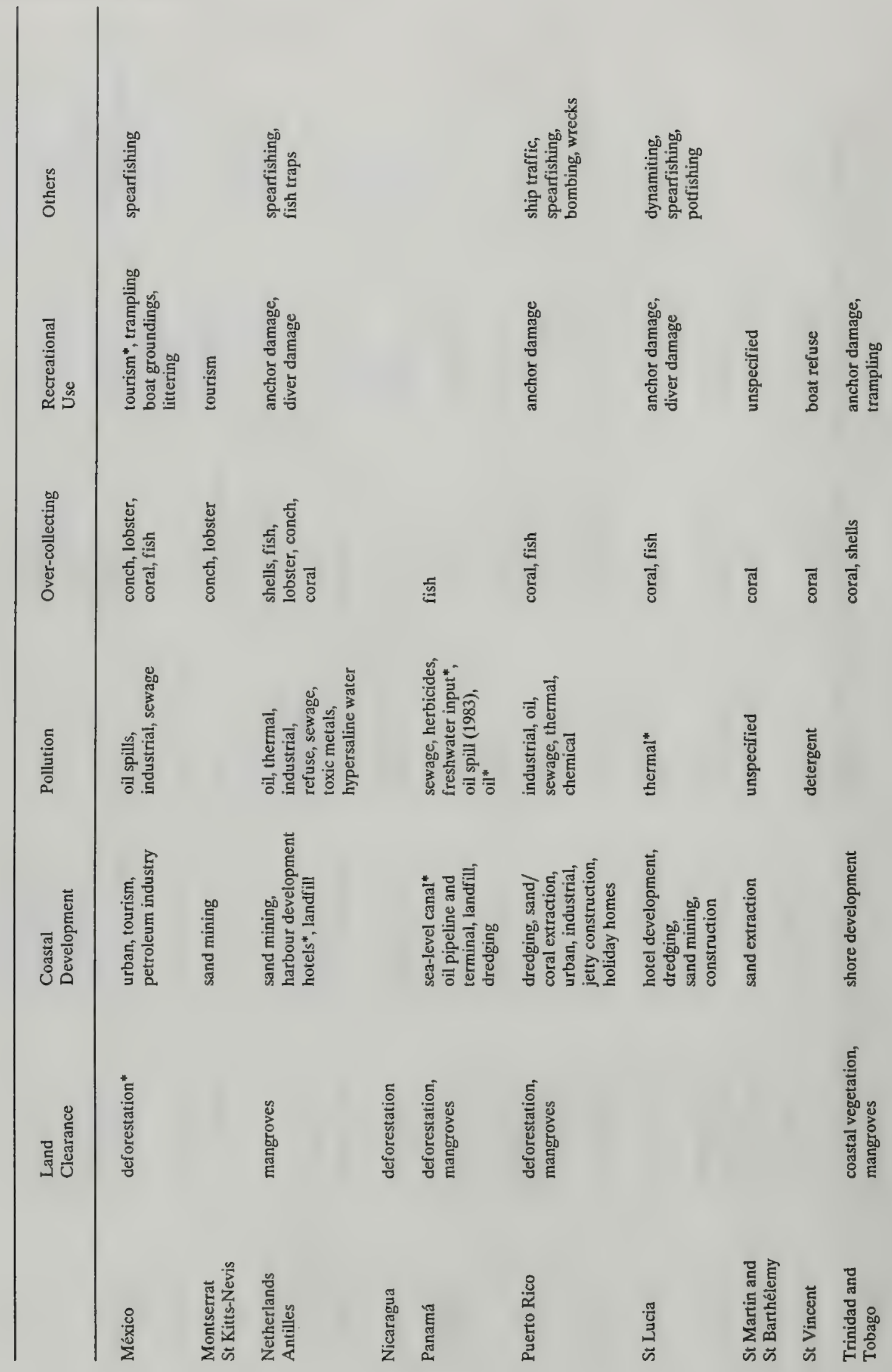




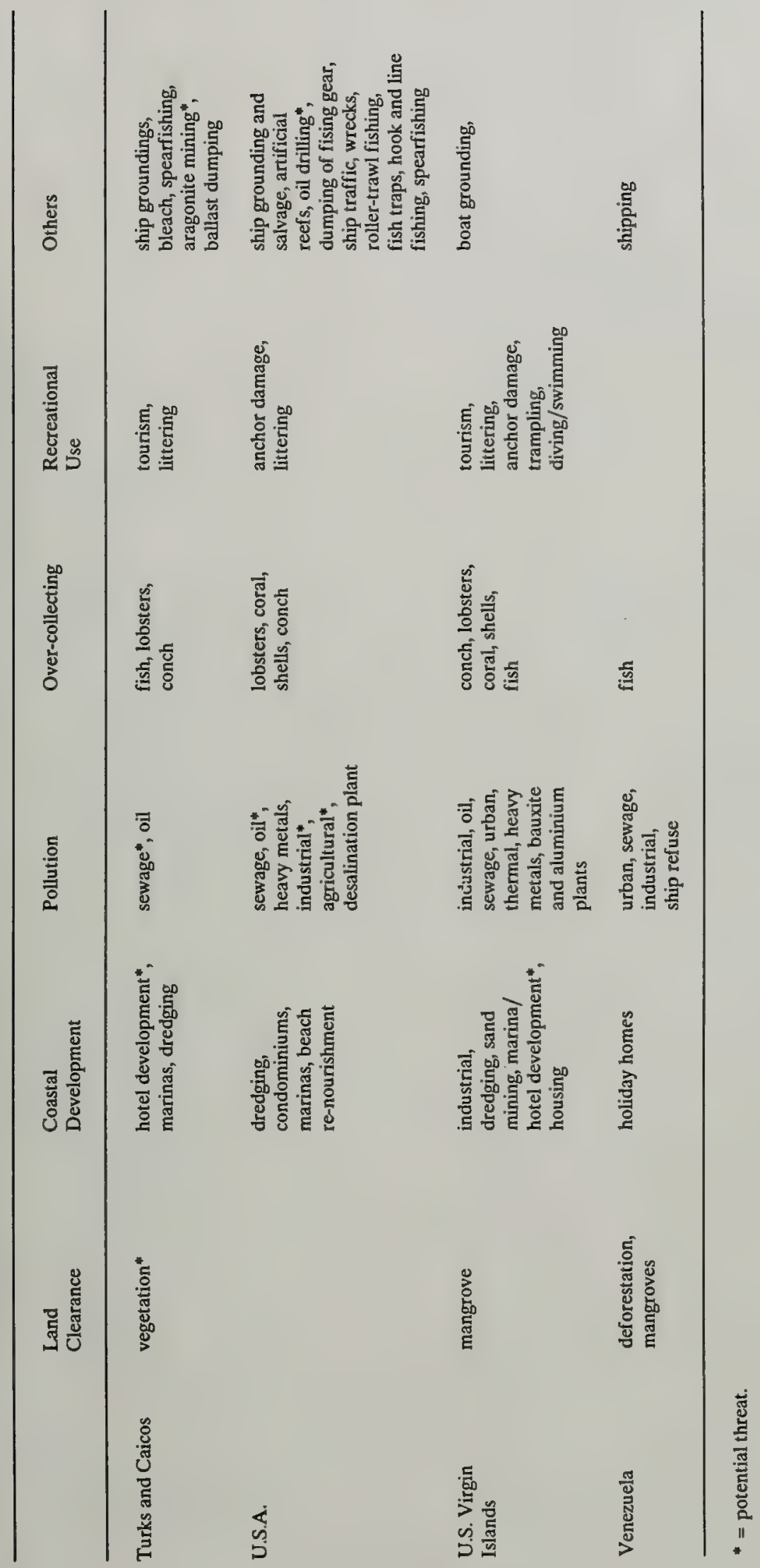



* party to World Heritage Convention

+ category not known

0 marine habitats not included within protected area

private reserve

For explanation of IUCN categories, see end of table.

$\begin{array}{cc}\text { Established } & \text { Proposed/ } \\ \text { Category } \quad \text { Area (ha) } & \text { Recommended }\end{array}$

ANGUILLA*

Multiple Use Reserve

VIII

ANTIGUA

Salt Fish Tail Reef Marine Park

Green Island

II $\quad 2,000$

Guana I. north to Bird I. reef

(IV)

Cades Reef

IV

IV

\section{BAHAMAS}

Inagua National Park

Peterson Cay National Park

Exuma Cays Land-and-Sea Park

Pelican Cays Land-and-Sea Park

Conception Island Land-and-Sea Park

Plana Cays

Colonial Beach, New Providence

Bimini Chain Reef

Andros Barrier Reef

Corrie Sound, north Eleuthera

Starve Creek, south Eleuthera

Elizabeth Harbour

San Salvador fringing reefs

Samana Cays

$\begin{array}{rrr}\text { II } & 74,333 & \\ \text { II } & 13,000 & \\ \text { II } & 45,584 & \\ \text { II } & 850 & \\ \text { II } & & \text { II } \\ & & \text { II } \\ & & \text { IV } \\ & & \text { IV } \\ & & \text { IV } \\ & & \text { IV } \\ & & \text { IV } \\ & & \text { IV } \\ & & \text { IV } \\ & & \text { IV }\end{array}$

26 other proposed protected areas (see text)

\section{BARBADOS}

Barbados Marine Reserve

II

BARBUDA

Palaster Reef Marine Park

II

BELIZE

Lighthouse Reef

Half-Moon Cay

Blue Hole

Man-o-War Cay

Carrie Bow Cay

Glover's Reef

South-west Cay

Hol Chan Reef

Mexico Rocks

Rocky Point

Sergeant's Cay to Goff's Cay

Tobacco Reef

III

4,144

IV/VI

(IV)

I $^{\circ}$

III

IV

III

IV

IV

IV

IV

BERMUDA

North Shore Coral Reef Preserve

South Shore Coral Reef Preserve

IV

12,000

"No fishing" marine reservoir

IV 


\section{Established}

Category
Proposed/

Recommended

\section{BRAZIL*}

Reserva Biológica do Atol das Rocas

Parque Nacional Marinho dos Abrolhos

36,249

Fernando do Noronha

$\begin{array}{rr}\text { I } & 36,249 \\ \text { II } & 91,200\end{array}$

Tamandare Reef Complex

II

$+$

\section{BRITISH VIRGIN ISLANDS*}

Wreck of the RMS Rhone Marine Park

II

Anegada

The Baths

North Sound

The Dogs

Little Jost van Dyke

The Tobagos

Norman I./Pelican I./The Indians

Hans Creek Lagoon

Cane Garden Bay

\section{CAYMAN ISLANDS}

$\mathrm{E}=$ Environmental Zone

$\mathbf{M}=$ Marine Park Zone

$\mathrm{R}=$ Replenishment Zone

Little Sound

Spanish Cove Resort - Jetty

North West Point - West Bay Cemetery

Victoria House - Sand Cay Apartments

Bowse Bluff - Rum Point

Scotts Anchorage - White Bay

Dick Sessinger's Bay - Beach Point

Jennifer Bay - Deep Well

Bloody Bay - Jackson Point

Preston Bay - Main Channel

Head of Barkers - Flats

West Bay Cemetery - Victoria House

North Sound

South Sound

Bats Cave Beach

Frank Sound

Cayman Dive Lodge

Radio Mast - Sand Bluff

Spotter Bay - Anchors Point

Spot Bay

Salt Water Point - Beach Point

Coral Isle Club

Mary's Bay - East Point

South Hole Sound

$\mathrm{E}$
$\mathrm{M}$
$\mathrm{M}$
$\mathrm{M}$
$\mathrm{M}$
$\mathrm{M}$
$\mathrm{M}$
$\mathrm{M}$
$\mathrm{M}$
$\mathrm{M}$
$\mathrm{R}$
$\mathrm{R}$
$\mathrm{R}$
$\mathrm{R}$
$\mathrm{R}$
$\mathrm{R}$
$\mathrm{R}$
$\mathrm{R}$
$\mathrm{R}$
$\mathrm{R}$
$\mathrm{R}$
$\mathrm{R}$
$\mathrm{R}$
$\mathrm{R}$

(II)

Easter Island

Anakena

Motu Nui/Iti
VI

I 
Established

Category Area (ba)
Proposed/

Recommended

Isla de Providencia

Ensenada de Utría

Banco Roncador

Cayos del E.S.E.

Cayos Albuquerque

Banco Serrana

Bahía de Sta Marta

Isla del Malpelo

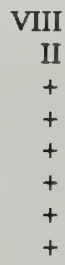

\section{COSTA RICA*}

Parque Nacional Cahuita

Parque Nacional Isla del Coco

Isla del Caño Reserva Biológica

Parque Nacional Manuel Antonio

Cabo Blanco Reserva Nacional

Reservas Biológicas Islas del Guayabo,

Pájaros and Negritos

Isla Uvita

Punta Uva

Manzanillo - Punta Mona

\section{CUBA*}

Isla de la Juventud

Golfo Guacanayabo

$\begin{array}{rr}\text { II } & \text { c 3,200 } \\ \text { (IV) } & 300 \\ \text { II } & 683 \\ \text { (IV) } & \\ \text { (1V) } & \end{array}$

\section{DOMINICA}

Cabrits National Park

II

DOMINICAN REPUBLIC*

Parque Nacional del Este

Parque Nacional Jaragua

Parque Nacional Montecristi

(II) $\quad 43,400$

II

Punta Caucedo

II $\quad 1,338$

II 53,000

ECUADOR*

Parque Nacional Galápagos

Parque Nacional Machalilla

II $/ \mathrm{X} \quad 691,200$

(II)

IV

Sandy I., Carriacou
Levera Pond and Bedford Point area

II

GUADELOUPE

Parc National de la Guadeloupe

Le Grand Cul de Sac Marin

L'Ilet Pigeon

\section{HAITI*}

Morne Rouge

Ile-a-Vache

\section{HONDURAS ${ }^{*}$}

Roatán

II

\section{JAMAICA*}

Montego Bay Marine Park

Ocho Rios Underwater Park

Morant Cays

Pedro Bank and Cays

Negril

Port Royal Cays

Discovery Bay 
Established

Category
Area (ha)
Proposed/ Recommended

\section{MARTINIQUE}

Reserve Naturelle de la Caravelle

Rocher du Diamant/Banc du Diamant

Escaliers de Trois-Rivieres

Mangrove du Cap Chevalier

Rocher de la Perle

South-east coast reefs

Baie de Fort-de-France

\section{MEXICO*}

Parque Marino La Blanquilla

Refugio Marino Punta Cancún and Nizuc

Parque Submarino Cozumel Chankanaab Lagoon

Reserva Ecológica Isla Contoy

El Garrafón Underwater Park

Tulum

Cabo San Lucas

Reserva de la Biósfera Sian Ka'an \#

(IV)

517
(II)

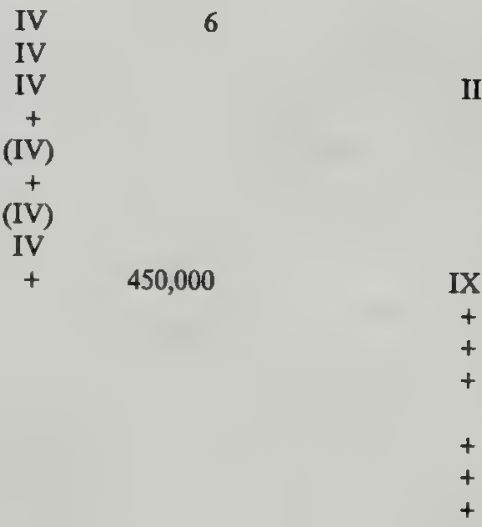

II

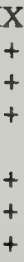

II $\quad 2,600$

II $\quad 1,036$

$+$

$$
+
$$

II

VI

$+$

X
+
+
+
+
+
+
+
+
II
II
II
+
(VII)

+
+
+
+
+
+
+

$+$

(+)

$+$

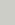

$+$

IV

+ ?

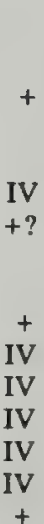

Puerto Morelos

Arrecife de la Anegada de Afuera

Isla de Enmedio, Arrecife el Rizo and

Punta Antón Lizardo

Isla Verde

Isla de Lobos

Cayos Arcas

\section{NETHERLANDS ANTILLES}

Bonaire Marine Park

Curacao Underwater Park

Jenkins Bay, Sint Eustatius

South coast, Sint Maarten

Saba Marine Park

Colorado Point, Aruba

Arasji Bay, Aruba

South-east coast, Sint Maarten

\section{NICARAGUA*}

Miskito Cays and Bank

\section{PANAMA*}

Parque Nacional Portobelo

Archipiélago de San Blas

Arrecife de Galeta, Isla Margarita, Isla Largo Remo, Bahía

las Minas

Bocas del Toro

Golfo de Chiriquí

$+$

\section{PUERTO RICO}

El Faro

La Parguera

Arrecife Guayama

Bahía de Jobos

Caja de Muertos

La Cordillera

Guanica Forest Reserve

\#The Reserva de la Biósfera Sian Ka'an has been declared as a protected area in México but is still awaiting formal designation as an international biosphere reserve. 
Established

Category Area (ha)
Proposed/

Recommended
Sergeant Reef, Maunabo

Cayo Ratones, Ponce

Arrecife Tourmaline and El Negro

Vieques Island

Islas Culebra and Culebrita

Islas Mona and Monito

\section{ST KITTS}

North coast

South-east Peninsula

\section{ST LUCIA}

Maria Islands Nature Reserve

Pigeon Island National Park

Pitons and Anse Chastanet

Savannes Bay

Anse Galette

\section{ST MARTIN}

South coast of Ile Tintamarre

\section{ST VINCENT}

Milligan Cay/Buccament Bay

Tobago Cays

Youngs Island

\section{TRINIDAD AND TOBAGO}

Buccoo Reef/Bon Accord Lagoon

Chaguaramas National Park

Eastern Tobago

Salybia Reef

Culloden Bay

Amos Vale Bay

TURKS and CAICOS ISLANDS

Northwest Reef to Pine Cay, Providenciales

Chalk Sound Cays, Providenciales

Bottle Creek Reef, N. Caicos

Three Marys Cays

Booby Rocks, Middle Caicos

Iguana Cay, E. Caicos

Joe Grant's Cay, E. Caicos

Admiral Cockburn and Long Cay, S. Caicos

White Cay, Bush Cay and French Cay, S. Caicos

West Caicos Reserve

Turks Islands Marine Park

North East Reef, Grand Turk
IV

IV

IV

IV

IV

IV

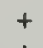

$+$

IV

(II)

11

+
IV
+
+

$+$

$+$

650

(II)

II

III

$+$

$+$

II

II

II

(IV)

II

(IV)

(IV)

(IV)

II

IV

II

II

U.S.A.*

Biscayne National Park

Fort Jefferson National Monument

Key Largo Marine Sanctuary

Looe Key National Marine Sanctuary

Gray's Reef Marine Sanctuary

John Pennekamp Coral Reef State Park

Florida Middleground HAPC

(IV) 


\section{Established \\ Proposed/
Category Area (ha)
Recommended}

Tennessee

Sombrero

American shoal

Eastern, Middle \& Western Sambo

Eastern Dry Rocks

Western Dry Rocks

Sand Key

Coalbin Rock

Rebecca Shoal

\section{VENEZUELA}

Parque Nacional Morrocoy

Parque Nacional Mochima

Parque Nacional Archipiélago Los Roques

$\begin{array}{lr}\text { II } & 32,090 \\ \text { II } & 94,935 \\ \text { II } & 225,153\end{array}$

VIRGIN ISLANDS, U.S.

Virgin Is National Park

Buck I. National Monument

II/IX

6,127

South-eastern St Thomas

St Croix Coral Reef APC

Salt River Submarine Canyon

Saba I./Perseverence Bay

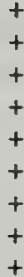

$+$

$+$

IV

I/II/IV

IV

\section{IUCN categories and management objectives of protected areas}

I Scientific Reserve/Strict Nature Reserve: To protect nature and maintain natural processes in an undisturbed state in order to have ecologically representative examples of the natural environment available for scientific study, environmental monitoring, education, and for the maintenance of genetic resources in a dynamic and evolutionary state.

II National Park: To protect natural and scenic areas of national or international significance for scientific, educational, and recreational use.

III Natural Monument/Natural Landmark: To protect and preserve nationally significant natural features because of their special interest or unique characteristics.

IV Managed Nature Reserve/Wildlife Sanctuary: To assure the natural conditions necessary to protect nationally significant species, groups of species, biotic communities, or physical features of the environment where these require specific human manipulation for their perpetuation.

V Protected Landscape or Seascape: To maintain nationally significant natural landscapes which are characteristic of the harmonious interaction of man and land while providing opportunities for public enjoyment through recreation and tourism within the normal life style and economic activity of these areas.

VI Resource Reserve: To protect the natural resources of the area for future use and prevent or contain development activities that could affect the resource pending the establishment of objectives which are based upon appropriate knowledge and planning.

VII Natural Biotic Area/Anthropological Reserve: To allow the way of life of societies living in harmony with the environment to continue undisturbed by modern technology.

VIII Multiple-Use Management Area/Managed Resource Area: To provide for the sustained production of water, timber, wildlife, pasture, and outdoor recreation, with the conservation of nature primarily oriented to the support of the economic activities (although specific zones may also be designated within these areas to achieve specific conservation objectives).

IX Biosphere Reserve: To conserve for present and future use the diversity and integrity of representative biotic communities of plants and animals within natural ecosystems, and to safeguard the genetic diversity of species on which their continuing evolution depends.

$\mathrm{X}$ World Heritage Site: To protect the natural features for which the area was considered to be of World Heritage quality, and to provide information for world-wide public enlightenment. 
This list is known to be incomplete but has been included as a guide to the types of legislation which exist for the management of coral reefs and reef fisheries. No information has been obtained for Brazil, Costa Rica, Nicaragua, Panamá, St Martin and St Barthélemy, Venezuela and West Africa. Corrections and additions should be sent to the compiler.

\section{ANGUILLA}

Fisheries Ordinance

- $\quad$ regulates take of spiny lobsters and turtles.

\section{ANTIGUA and BARBUDA}

Marine Areas (Preservation and Enhancement) Act No $5,1972$.

provides for protection of reefs, wrecks, fauna and flora, and creation of marine protected areas

Fisheries (Restriction on Methods of Salt-Water Fishing) Regulations of 1978 .

- regulates fishery methods

\section{BAHAMAS}

The Bahamas National Trust Act, 1959.

- regulates National Parks through bye-laws drawn up in 1986 which designates marine replenishment areas and nurseries; bans take of fish, turtle, crawfish, conch and welks; bans destruction or removal of any animals, including coral; bans removal of sand, and regulates scientific collecting.

The Fisheries Resources (Jurisdiction and Conservation) Regulations, 1986.

- bans use of bleach, poisons or explosives; prohibits export of marine products by non-Bahamians; regulates spearfishing; controls fishing gear; bans scuba gear, spearguns, and collecting of corals; controls take of spiny lobster, turtle, conch and stone crab; bans take of sponges.

\section{BARBADOS}

The Marine Areas (Preservation and Enhancement) Act, 1976.

- provides for establishment of marine parks and reserves; controls turtle collecting; bans spearfishing.

\section{BELIZE}

National Parks System Act, 1981.

- protects coral reefs within areas designated as National Parks.

The Fisheries Regulations, 1977.

- controls take of crawfish, lobsters, conch, bonefish and turtles.

The Fisheries Regulations (Amendment), 1982.

- provides for areas within $3 \mathrm{mi} .(4.8 \mathrm{~km})$ of Belize to be declared marine reserves.

\section{BERMUDA}

The Coral Reef Preserves Act, 1966.

- provides for creation of coral reef preserves; prohibits take of coral, flora and fauna.

The Fisheries Regulations, 1972.

- regulates take of spiny lobsters, fish, scallops, turtles, fishing methods, spearfishing (banned within $1 \mathrm{n} . \mathrm{mi}$. of shore); bans use of explosives.
The Fisheries (Use of Fish Pots) Orders, 1975, 1978 and 1981.

- regulates fishing with pots in Bermuda, and on the Argus and Challenger Banks.

The Fisheries (Protected Species) Order, 1978.

- prohibits take of turtles, mammals, corals and various molluscs within the exclusive fishing zone, and collecting with SCUBA gear; controls sales of marine products.

\section{BRITISH VIRGIN ISLANDS}

The Marine Parks and Protected Areas Ordinance, 1979.

- provides for protection of coral reefs.

The Fisheries Ordinance, 1979 and 1980.

- provides for protected areas where fishing is banned. Statutory rules No. 31, 1982, under the Ordinance.

- controls take of spiny lobsters and use of fish traps.

The Turtle Ordinance, 1969.

- bans collection of turtles (except Leatherback); controls egg collection.

\section{CAYMAN ISLANDS}

The Marine Conservation Law, 1978.

(Repeals the Fisheries Licensing Law and the Lobster (Restriction of Fishing) Law, 1964).

- protects lobsters except spiny lobsters; controls take of spiny lobsters, conch, coral and shells; bans spearfishing and take of fish and lobsters while SCUBA diving; controls spearfishing; protects corals from anchor damage; bans effluent discharge.

The Marine Conservation (Marine Parks) Regulations, 1986.

- provides for designation of Marine Parks, Environmental and Replenishment Zones on Grand Cayman.

The Marine Conservation (Marine Parks) (Amendment) Regulations, 1986.

- as above for Cayman Brac and Little Cayman.

\section{CHILE}

No legislaticn for marine parks or reef species.

\section{COLOMBIA}

Law 20, 1959.

- provides for the establishment of national parks.

Decreto 2811,1974 . Código de los Recursos Naturales y de la Protección del Medio Ambiente. protects natural resources.

Fishery Regulations.

- controls take of spiny lobsters.

\section{CUBA}

Ley de Protección del Medio Ambiente y del Uso Racional de los Recursos Naturales, 1980.

- provides for natural resource protection.

Legislation, 1977.

- controls take of conch.

(Spearfishing may be banned throughout).

\section{DOMINICA}

National Parks and Protected Areas Act, 1975. provides basis for park system.

Legislation controls take of turtles. 


\section{DOMINICAN REPUBLIC}

Law 1311, 1975.

- provides for establishment of national parks.

Ley $1728,1976$.

- controls take of coral.

Legislation

- controls spearfishing of lobsters.

\section{ECUADOR}

No legislation specific to coral reverves.

Spearfishing may be banned in Galápagos.

\section{GRENADA}

Legislation

- closed season for turtles.

\section{GUADELOUPE}

Legislation (No 79-6, AD/3/3), 1979.

- controls take of turtles, spiny lobsters and corals.

Local Decree for L'Ilet Pigeon.

- bans spearfishing.

\section{HAITI}

Decree, 1978 and Law, 1979.

- regulate fisheries and marine resources; prohibit cutting of mangroves.

Coral exports reportedly banned in 1976.

\section{HONDURAS}

Ley de Pescar, Decree 154, 29 May 1959.

- declares coral reefs as protected areas.

\section{JAMAICA}

The Wildlife Protection Law, 1945.

- protects black coral, turtles and other marine species; prohibits pollution of water-bodies containing fish and fishing with poison or explosives.

Beach Control Act, 1960.

- controls coastal development within one mile $(1.6 \mathrm{~km})$ of coast.

The Fishing Industry Regulations, 1975.

- controls take of spiny lobsters and fishing methods.

Spearfishing is banned in Montego Bay Marine Park.

\section{MARTTINIQUE}

Arreté Préfectoral No. 70/3 of 5 January 1970.

- controls take of lobsters.

\section{MEXICO}

Ley in Diario Oficial 20-07-56 and 15-04-81.

controls marine pollution.

Ley in Diario Oficial 23-03-71, 23-03-73 and 23-01-79.

- controls other forms of pollution.

Ley in Diario Oficial 9-10-57 and 24-05-72.

- controls various forms of fishing including lobsters.

Decree of 1974.

- prohibits collection of Plexaura homomalla

Spearfishing is banned in La Blanquilla Marine Park

\section{MONTSERRAT and ST KITTS-NEVIS}

Legislation

- controls take of turtles.

\section{NETHERLANDS ANTILLES}

Bonaire - The Marine Environment Ordinance, 1985.

- controls take of spiny lobster; bans spearfishing, take of turtle eggs and the collection or destruction of coelenterates and crustose coralline algae; regulates fisheries and activities affecting reefs and Lagoon Lac.

Curaçao - The Reef Management Ordinance, 1976.

- bans spearfishing and collection or destruction of Aruba. coelenterates and crustose coralline algae.

- ban on spearfishing and coral collection.

Permits for scientific and educational purposes are regulated in Bonaire and Curaçao.

PUERTO RICO

Coastal Zone Management Programme.

- details of legislation and regulations not known.

ST LUCLA

Fisheries Legislation.

- protects turtles and corals; controls take of conch collection; prohibits sale and export of aquarium fish.

Wildlife Protection Ordinance, 1980.

- bans dynamiting of coral reefs.

\section{ST VINCENT}

Legislation

- closed season for turtles.

TRINIDAD and TOBAGO

The Marine Areas (Preservation and Enhancement) Act, 1970.

- provides for creation of marine protected areas

Legislation

- controls take of fish, crustaceans and turtles; controls oil pollution.

Spearfishing banned at Bucco Reef Restricted Area.

\section{TURKS and CAICOS}

Fisheries Export Duty Ordinance, 1952. regulates take of conch and spiny lobsters.

The Fisheries Protection Regulations, 1976.

- bans collection of marine organisms with explosives or SCUBA, and fishing in Bell Sound; controls use of spearguns and take of lobsters, conch, turtles.

U.S.A.

The Marine Protection, Research and Sanctuaries Act, 1972.

- designates ocean waters as marine sanctuaries.

U.S. Endangered Species Act, 1973.

- bans turtic collection

Fishery Conservation and Management Act, 1977.

- regulates fisheries within $200 \mathrm{mi}$. territorial limit; provides for establishment of regional fishery management councils; regulates establishment of Habitat Areas of Particular Concern (HAPC); regulates take of coral; controls fishing; bans take of aquarium fish in protected areas.

Florida Statute 370.110.

- protects some stony corals and sea fans.

Ban on collection of Queen Conch in Florida State Parks. Monroe County bans use of spearguns.

\section{U.S. VIRGIN ISLANDS}

\section{Public Law 925.}

- provides for establishment of national parks; regulates fisheries and fishing methods; controls take of conch, lobster and whelks; bans spearfishing; bans take of marine life or features and water ski-ing within parks. 
Virgin Islands Law No. 4848.

- bans take of all corals from U.S.V.I. waters, and spearfishing within parks.

Virgin Islands Coastal Zone Management Act, 1978.

- provides for management of coastal areas and development of marine parks and reserve system.

U.S. Endangered Species Act, 1973.

- bans turtle collection.
The Organization of Eastern Caribbean States (OECS) has recently passed a moratorium on turtles, requiring that fishing for turtles and trade in turtle products be illegal. OECS has also developed legislation, which has been passed in most countries, for the regulation of conch and spiny lobster fisheries. This may supersede legislation described above in some OECS countries. 


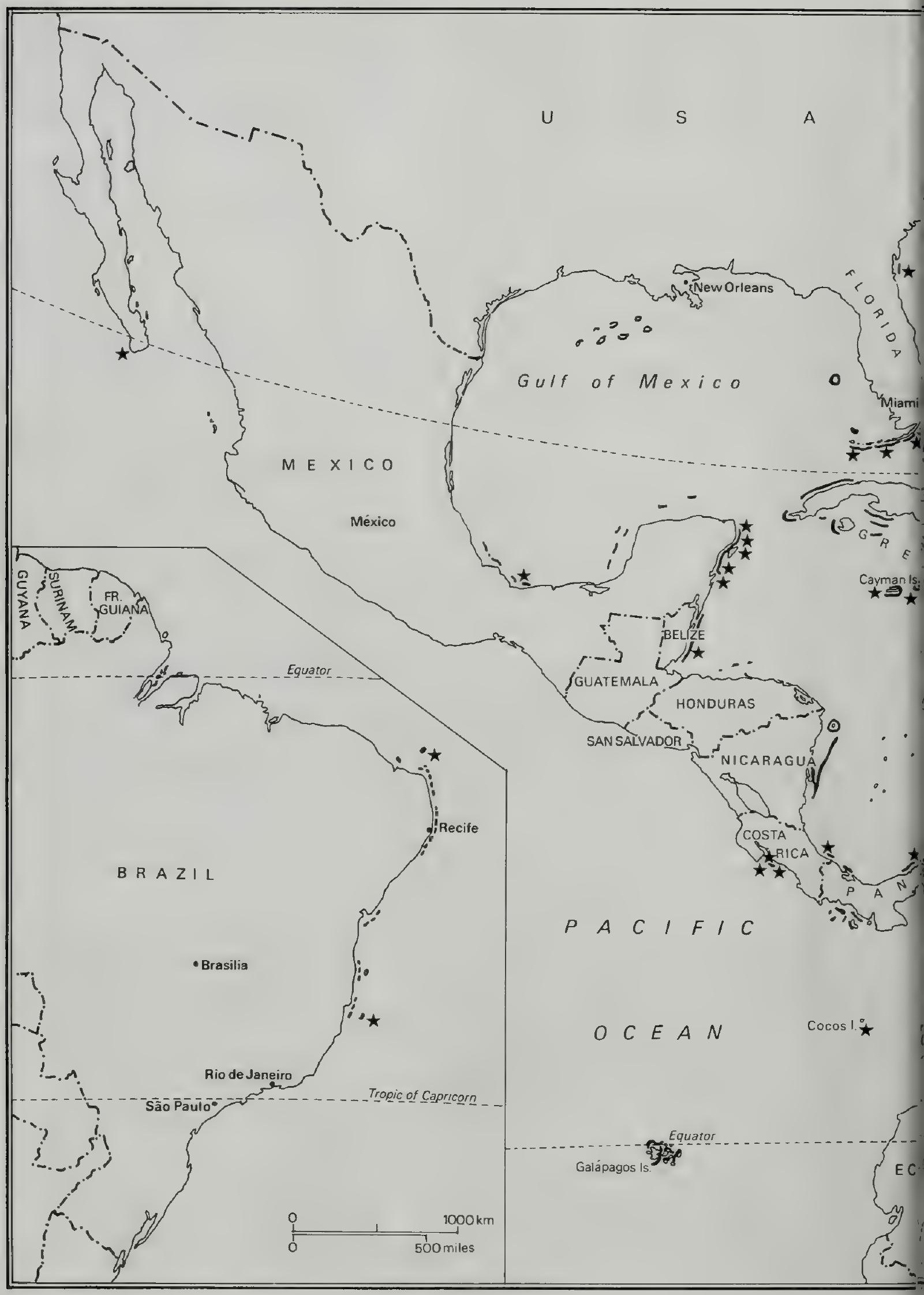





\section{INTRODUCTION}

\section{General Description}

Anguilla, the northernmost island in the Leewards chain, is a separate dependency of the United Kingdom (under the Anguilla Act, 1980), having formerly been part of the colony St Kitts-Nevis-Anguilla. It is a low island (maximum altitude $62 \mathrm{~m}$ ) of $9065 \mathrm{ha}$, formed from limestone and marls developed on old volcanic rocks. Hard cavernous weathered limestone is characteristic of much of the island. It shares a common submarine shelf with the islands of St Barthélemy (to France) and Saint Martin/Sint Maarten (part to France, part to the Netherlands), the Anguillan portion of the shelf covering 199700 ha (Jackson, 1981). There are several small, uninhabited cays: Dog Island, Prickly Pear Cays, Seal Island, Sandy Island and Sombrero Island, the last $48 \mathrm{~km}$ north-west of the main island. There are no surface streams but numerous salt ponds exist, most apparently resulting from the closure of former bays. The climate, geology and terrestrial environment are described in detail by Harris (1965). The island has a dry tropical marine climate with a mean monthly temperature of $80^{\circ} \mathrm{C}$. Average rainfall is about 40 in. $(1020 \mathrm{~mm})$ and surface run-off is negligible (Jackson, 1981). The dry season generally runs from January to April and the wet season from August to November but there is much annual variation. Strong, constant easterly trade winds predominate. Hurricanes occur on average once every 20 years and tropical storms are most frequent in August and September.

The marine environment is attractive with long stretches of white sand beaches, reasonably good reefs, clear water and a number of offshore cays and rocks. The north coast is characterized by high cliffs. Mangroves are found in a few enclosed bays (Harris, 1965). The Anguillan platform is relatively deep on the eastern side (40-65 m) and although there is some shallowing towards Anguilla, depths within $1 \mathrm{~km}$ of shore are still $23-45 \mathrm{~m}$ and there is no apparent bank-barrier development (Adey and Burke, 1976). Living reefs are found along the south coast of the island and an extensive reef system is found from the north-eastern point to Prickly Pear Cays (see account for "Multiple Use Reserve"). The $17 \mathrm{~km}$ long reef area along the south-east coast is considered one of the most important largely unbroken reef areas in the Eastern Caribbean (Putney, 1982).

A sixteen-day survey of the reefs was carried out in 1980; the results are described in Salm (1980) and maps are given in ECNAMP (1980). The relative exposure to hurricane-generated storm waves is the apparent cause of differences between the northern and southern reefs. The latter have a higher percentage of dead and broken coral, and the fore-reef slopes (and back-reef slopes in some instances) tend to be formed of Acropora palmata talus with little living coral. Certain reefs (e.g. those of Forest and Sandy Hill Bays) appear to be built entirely of more or less intact overturned dead $A$ palmata colonies. Coral diversity is generally lower on the southern reefs. The northern reefs support a high percentage cover of living coral and there are fields of intact $A$ palmata and $A$ cervicornis. They often have dramatic seascapes, providing superb snorkelling (Salm, 1980), and are described in the account for the proposed Multiple Use Reserve.

On the south-west coast at Shoal Bay (S) there is a small, west-trending reef off the rocky headland bordering the east end of the Bay. A palmata and Mille pora dominate the seaward crest. Below this is a slope with low coral cover but a variety of species, as well as zoanthids and gorgonaceans. Corals flourish in shallow, sheltered areas of the back-reef which is characterized by an assemblage of A palmata and Porites porites. The reef flat is dominated by Millepora. At Sandy Point, a small reef fringes and extends west from the point. The reef crest is Porolithonencrusted rock sparsely covered with $A$ palmata. Patch reefs are found inshore. Little Harbour consists largely of algal and seagrass beds with small, scattered coral colonies. A shallow reef separates the bay from the sea, with many dead Montastraea annularis colonies in the back-reef. A continuous fringing reef parallels the shoreline between Corito and Forest Bays. The lagoon has seagrass beds in shallower areas and patches of $A$ cervicornis and $M$. annularis in deeper areas. The lagoon floor in west Forest Bay has an unusual zonation of several algal and zoanthid zones with coral heads and bommies scattered throughout. The zoanthid zone is particularly unusual and attractive. On the reef, the fore-reef slope, once an area of vigorous $A$ cenvicornis and $A$ palmata growth, has been decimated by storms. At Sandy Hill Bay, a shallow reef projects across the bay mouth at both east and west headlands. The fore-reef at the western end has more living $A$ palmata than other south coast reefs. Sombrero Island is a desolate raised reef island, situated approximately $50 \mathrm{~km}$ to the north-west of Anguilla, which is surrounded by cliffs falling sheer into the sea to 13-20 $\mathrm{m}$ depth. The underwater cliffs are covered with encrusting organisms including small coral colonies (Porites astreoides, Agaricia, M. annularis and Millepora). The leeward coast is steatly embayed and there are pools and sheltered coves connected to the sea via tunnels or shallow channels. These areas have small colonies of Acropora palmata and Montastraea annularis.

There are a number of important sites for nesting sea birds, such as Anguillita Island, and turtles around the island. Nesting sea birds include the Red-billed Tropicbird Phaethon aethereus mesonauta, the Masked Booby Sula dactylatra, the Brown Booby S. leucogaster, the Brown Pelican Pelecanus occidentalis and possibly the Magnificent Frigatebird Fregata magnificens (Halewyn and Norton, 1984). The salt ponds are particularly attractive for waterfowl. Road Salt Pond is the only one currently used for commercial salt production, and this is likely to end shortly; sand dredging for construction purposes is permited at three ponds (Scott and Carbonell, 1986) and Maunday's Bay pond is being dredged and filled for a marina and related tourism facilities. Further information on the salt ponds is given in Jackson (1981). Important sites for seabird nesting, migratory species, wading birds and ducks are also given in ECNAMP (1980). Green Chelonia mydas, Loggerhead Caretta caretta, Hawksbill Eretmochelys imbricata and Leatherback Turtles Dermochelys coriacea 


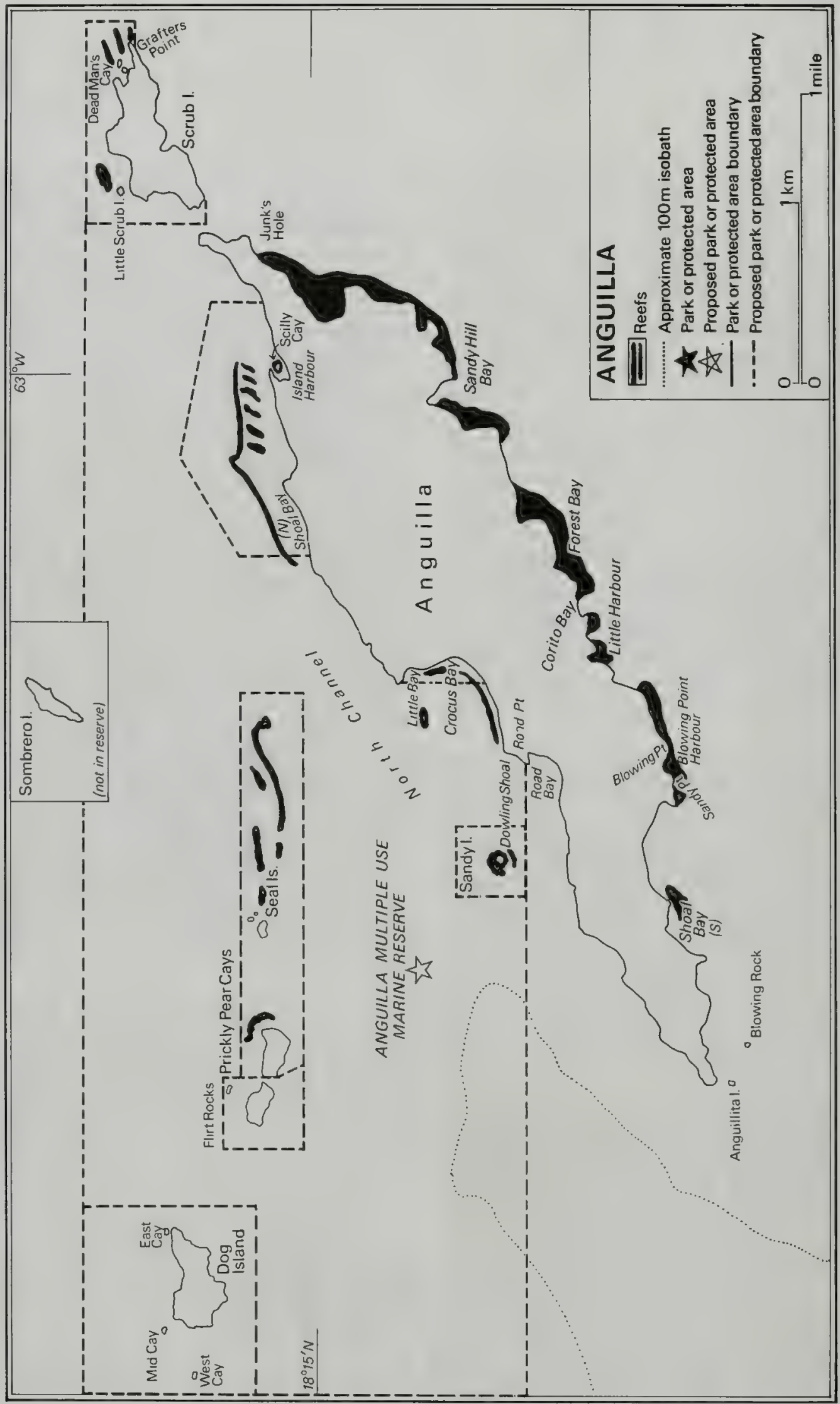


occur; their status is described in Meylan (1983) and Bacon et al. (19840).

Other than the 1980 survey by Salm, relatively little research appears to have been carried out on the reefs of Anguilla. The reefs of Anguilla, Saint Martin and St Barthélemy were surveyed by a French expedition (ECORECIF) in April 1986 (Bouchon in litt., 6.5.86).

\section{Reef Resources}

Tourism and fishing are the major industries on Anguilla and both are related to reefs. The fishing industry is described in detail by Olsen and Ogden (1980). Some $640000 \mathrm{lbs}(290000 \mathrm{~kg})$ of finfish, $980000 \mathrm{lbs}$ $(445000 \mathrm{~kg})$ of lobster and $52000 \mathrm{lbs}(23600 \mathrm{~kg})$ of conch are landed annually by commercial fishermen. An unknown quantity is taken by non-Anguillans. The coral reefs and submerged limestone edges on the south coast are critical habitats for juvenile fish populations and for lobster (Salm, 1980). The importance of areas off the north coast for fisheries is discussed in the account for the Multiple Use Reserve.

There is periodic rotation of fishery areas for lobster, finfish, conch and areas fished by seine. Finfish and conch resources are considered to be underexploited although further investigations are required. At Shoal Bay (S) on the south-west coast, many of the fish caught in traps are discarded and only the best are taken for sale in St. Maarten (Salm, 1980). Other areas with abundant fish life include Sombrero Island (numerous barracuda but groupers and other sought after species are rare), Forest Bay (especially lobsters) and Little Harbour (fish and lobsters). Whelks are also collected but there is no information on the impact of the harvest on populations.

In 1979 there were about 6000 visitors to the island. A major attraction is the strong cultural tradition, which shows its greatest expression in the traditional racing boats. The reefs around Anguilla are considered an under-exploited tourism resource holding great possibilities for development. There are a number of hotels on the coast and snorkelling and boating are important recreational activities; there is at least one SCUBA diving operation. The main localities for such activities are mapped in ECNAMP (1980). The best snorkelling and diving sites have been identified by Salm (1980) and include Sombrero Island, Corito Bay, Forest Bay, Sandy Hill Bay, Crocus-Little Bay, Shoal Bay (N), Outer Shoal Bay, Island Harbour, Scrub Island, Sandy Island, Dog Island, Prickly Pear Cays and Seal Island reefs. West Sandy Hill Bay offers the best opportunities for shallow, calm, reef-walking. New tourist facilities are being developed which will result in an increase in the demand for seafood, and much greater use of beaches, coral reefs, coastal waters and offshore cays for swimming, diving, snorkelling, cruising and other forms of marine recreation. This should promote an increase in jobs and new local enterprises and further growth in the underexploited segments of the fishing industry (Jackson, 1981). It is hoped that day tourists could be attracted from nearby Saint Martin/Sint Maarten.

\section{Disturbances and Deficiencies}

So far the reefs have suffered relatively little damage
(Rogers, 1985). However, unless efforts are made to establish guidelines for the development and control of visitor activities, they may soon suffer. Where extensive hurricane damage has occurred (this being particularly prevalent on the south coast), it is difficult to distinguish this from human-induced damage. However block anchors have caused damage in some areas and this problem may increase with the expansion of the tourist industry. The reef fish around Anguilla are small and timid, a result of spearfishing by Anguillan fishermen (Salm, 1980) and consideration should be given to banning this activity. Ciguatera outbreaks have been reported (Rogers, 1985).

\section{Legislation and Management}

At present there appears to be no legislation covering protection of marine habitats. Fisheries are controlled by a fisheries and turtle ordinance. Harvesting of lobsters with a carapace length of less than $3.5 \mathrm{in} .(8.9 \mathrm{~cm})$ is prohibited as is the collecting of turtle eggs and the taking of turtles below a given size and in the breeding season (Jackson, 1981).

The Anguilla Resources Development Project was set up in 1980 to: a) identify critical marine areas to be managed as Marine Parks or protected areas; b) develop a framework for managing commercial fishery resources; c) prepare a preliminary management document to integrate the management of critical marine resources. It is being carried out through ECNAMP.

\section{Recommendations}

The Government aims to further develop fisheries and tourism and to promote the development of marine parks or equivalent reserves as a way of conserving the resources critical to those industries. A three year tourist plan has been drawn up under the Anguilla Resources Development Project and policy statements have been drafted for fisheries development and the establishment of Marine Parks. Efforts are being made to avoid conflict between tourism, fisheries, recreation and commercial shipping. Jackson (1981) describes the preliminary results and recommendations, including the development of fisheries, the potential of salt ponds and problems associated with sand mining.

A minimum size of $1.5^{\prime \prime}(3.8 \mathrm{~cm})$ for the wire mesh used in fish trap construction is required. The lobster harvest is considered to be well above the maximum sustainable yield limit and enforcement of the minimum-size law is strongly advocated. For all fisheries, an improvement in the enforcement of legislation and in the monitoring of catches is necessary. Immature conchs should not be collected (Jackson, 1981; Olsen and Ogden, 1980).

A principal recommendation is the establishment of a Multiple Use Reserve which is described in a separate account. Additional recommendations have been made for areas outside the proposed reserve. These include the creation of administrative zones a) along the south-east coast (Junk's Hole and Blowing Point) for fishery management (especially Little Harbour and Forest Bay which should be managed as strict legal nursery reserves), recreation and tourism; b) at Road Bay commercial port; c) at Blowing Point Harbour commercial port; d) along 
the south-west coast for tourism management; e) at Anguillita Island for species management; f) on the remainder of the Anguilla shelf for sustainable fishery utilization (fin fish, lobster, conchs). The management of Little Harbour, Forest Bay and probably also Sandy Hill, Corito and Shoal Bay, for fish and lobster nurseries is considered particularly important. All activities (e.g. dredging, dumping and sewage disposal) that could degrade shallow habitats should be avoided. For example, Little Harbour is very vulnerable to disturbance of sediments on the bay floor; dredging or excessive boat anchoring would increase turbidity and disrupt the benthic and fish communities. It is important that the placing of fish traps or anchors directly on coral be discouraged, perhaps through preventative legislation backed by educational radio programmes and enforcements.

Goodwin (1985) recommends Anguilla as a potential marine site in a proposed Lesser Antillean Biosphere Reserve and places it on the short list for action.

\section{References}

Adey, W.H. and Burke, R. (1976). Holocene bioherms (algal ridges and bank-barrier reefs) of the eastern Caribbean. Geol. Soc. Am. Bull. 87: 95-109.

Bacon, P., Berry, F., Bjorndal, Hirth, H., Ogren, L. and Weber, M. (1984). The National Reports. Proceedings of the Western Atlantic Turtle Symposium, Costa Rica. Vol.3: University of Miami Press, Florida.

ECNAMIP (1980). Anguilla. Preliminary Draft Atlas Survey of Conservation Priorities in the Lesser Antilles. Eastern Caribbean Natural Area Management Program.

Goodwin, M.H. (1985). Characterization of Lesser Antillean Regional Fisheries. Island Resources Foundation. $48 \mathrm{pp}$.

Halewyn, R. van and Norton, R.L. (1984). The status and conservation of seabirds in the Carribbean. In: Croxall J.P., Evans, P.G.H. and Schreiber, R.W. (Eds) (1984). Status and Conservation of the World's Seabirds. ICBP Technical Publication No. 2, Cambridge.

Harris, D.R. (1965). Plants, animals and man in the Outer Leeward Islands, West Indies: an ecological study of Antigua, Barbuda and Anguilla. Univ. Calif. Publs Geog. 18: 1-164.

Jackson, I. (1981). A preliminary management strategy for the utilization of the critical marine resources of Anguilla. Report by ECNAMP as part of the Anguilla Resources Development Project.

Meylan, A.B. (1983). Marine turtles of the Leeward Islands, Lesser Antilles. Atoll Research Bulletin 278: $24 \mathrm{pp}$.

Olsen, D.A. and Ogden, J.C. (1980). Management planning for Anguilla's Fishery Industry. Draft Report to ECNAMP.

Putney, A.D. (1982). Survey of Conservation Priorities in the Lesser Antilles. Final Report. Caribbean Conservation Association, Caribbean Environment Technical Report 1.

Rogers, C.S. (1985). Degradation of Caribbean and Western Atlantic coral reefs and decline of associated fisheries. Proceedings of the Fifth International Coral Reef Congress, Tahiti, 1985 6: 491-496.

Salm, R.V. (1980). Anguilla. Coral reefs and the marine parks potential. Report commissioned by ECNAMP.

Scott, D.A. and Carbonell, M. (1986). A Directory of Neotre pical Wellands. IUCN, Gland and Cambridge.

\section{ANGUILLA PROPOSED MULTIPLE USE RESERVE}

Geographical Location North coast of Anguilla. $8^{\circ} 12^{\prime}-17^{\prime} \mathrm{N} ; 63^{\circ} 17^{\prime}-55^{\prime} \mathrm{W}$. To cover an area from Road Point on the main island to Grafters Point, Scrub Island, including Sandy Island, Dog Island, Prickly Pear Cays and all northern cays, rocks and reefs. The landward boundaries on Anguilla and Scrub Island would be the high tide marks (Jackson, 1981).

Area, Depth, Altitude No information.

Land Tenure Presumed to be Government.

Physical Features The offshore islands and cays are limestone and low-lying. Dog Island and Scrub Island have altitudes of $28 \mathrm{~m}$ and $24 \mathrm{~m}$ respectively.

Reef Structure and Corals An extensive reef ridge system runs east-west for about $15 \mathrm{~km}$ from the north-eastern tip of Anguilla to Prickly Pear Cays, broken by Northern Channel between Anguilla and Seal Island reefs. The reef is dominated by Acropora palmata although a few small algal lobes are present in the western section and a number of small algal ridge complexes are found in the eastern portion, against the north shore of Anguilla (Adey and Burke, 1976). Salm (1980) describes the marine communities in detail at several sites in the proposed Reserve.

Sandy Island is entirely encircled by reef, which is close to the shore except in the west where there is a sandy lagoon. To the south, the back-reef and part of the reef flat is dominated by $A$ palmata, Diploria clivosa, Porites astreoides and $P$. porites; in the surf zone an assemblage of Millepora and zoanthids is characteristic; the upper fore-reef and reef crest are dominated by $A$ palmata; a zone of Montnstraea annularis and $P$. porites occurs at 3-4 $\mathrm{m}$ depth. On the south-east this latter zone is lacking. The east side has a wide, gradually shelving limestone shelf, with zones progressing from an assemblage of Mille pora and zoanthids over the reef flat to an extended zone with $A$ palmata, $D$. strigosa, $P$. astreoides, Millepora and Gorgonia. The north-east is similar, although coral cover decreases. Along the north of the island, $A$ palmata forms a dense zone and slopes down to a zone with $P$. porites, Montastraea annularis and $A$ cervicornis at $4 \mathrm{~m}$ depth. An assemblage of Millepora and zoanthids characterises the reef flat. North-west of Sandy Island is a large shallow ridge with a small cay. The south side of the ridge has a diverse reef with an $A$ palmata dominated reef crest, and $A$ cervicornis, large Montastraea annularis heads and big patches of $P$. porites at 2-3 m depth.

On Dog Island, the west, north-west and north sides consist of a series of rock ledges and outcrops with caves and overhangs. Corals are sparse but typical of the reefs of the area. To the east of West Cay, there is a beautiful craggy, gullied reef. There is a sparse community of gorgonaceans, D. strigosa and $P$. astreoides, with $A$ palmata becoming more abundant in shallower water. On the west side of the cay there is a steep drop-off where Tubastrea coccinea is abundant.

North of Prickly Pear Cay East is a large, calm, sandy lagoon bordered to seaward by a reef. $A$ palmata dominates the crest, $A$ cervicornis grows along the reef base and the two zones are separated by a mixed coral 
zone. The reef deepens towards the north-west $(2-5 \mathrm{~m}$ depth) and becomes particularly attractive. Prickly Pear North is surrounded by $A$ palmata. From here to the bank barrier, reef coral cover is almost continuous and consists primarily of $A$ cervicornis, $M$. annularis and $P$. porites. The back-reef has an assemblage of $A$ cervicornis and $M$. annularis sloping up to $A$ palmata. Little Flirt Rock forms the western boundary of the bank barrier and is an area of caves and tunnels.

Seal Island Reef is a bank barrier reef extending about 4 miles $(6.4 \mathrm{~km})$ east from Prickly Pear Cays and Seal Island. At its eastern end, the reef curls south to form a knob-like projection, which is surrounded by a shelving grooved reef dominated by an assemblage of $A$ palmata, $P$. astreoides, $D$. strigosa and gorgonaceans, where $A$ palmata is particularly abundant. The central area of the knob consists of deeper undulating fields of $A$ cervicornis bordered by tiered turrets of $A$ palmata. Much of the Seal Island Reef has a well-defined central lagoon bounded on the seaward and landward sides by shallow reef. On the landward slope, $M$. annularis predominates at 3-8 $\mathrm{m}$ depth; at 2-3 m depth there is an assemblage of $A$ palmata, $D$. strigosa and $M$. annularis, and above $1 \mathrm{~m}$ depth the reef crest is dominated by an assemblage of $A$ palmata and Millepora. The lagoon has patch reefs and scattered coral colonies in deeper areas. A palmata dominates the fore reef crest and slope of the seaward reef down to $4 \mathrm{~m}$.

At Scrub Island, at the eastern end of Anguilla, a rock terrace dissected by gullies runs at $6 \mathrm{~m}$ depth from Coral Point to west Stoney Cove. This - is covered with $A$ palmata, zoanthids and a variety of coral species, coral coverage decreasing towards Stoney Cove. There are also fringing reefs in the two coves at the eastern end of the island which have not been examined.

On the north coast of Anguilla, some of the most interesting marine communities are found between Crocus Bay and Little Bay although there are no true reefs. Extensive seagrass beds are found off Crocus Bay. Sea fans are abundant in this area and, at the headland, large colonies of Porites are found, covered with a huge variety of invertebrates. More coral species were found here than in any other part of Anguilla investigated by Salm.

A fragmented fringing reef and series of patch reefs run from the west of Shoal Bay to the east of Island Harbour. Separated from this inner reef system by a deep channel is an outer bank barrier reef system which parallels the inner reefs. At the east end of Shoal Bay (N), the back-reef consists of algal-covered rock with small colonies of $A$ palmata and $P$. astreoides. The reef flat is formed of dead $A$ palmata. An assemblage of $P$. porites, $A$ cervicornis and gorgonians is characteristic from $1.5 \mathrm{~m}$ to $11-12 \mathrm{~m}$ depth. Westwards the reef deepens and widens, developing into a terrace bordering the channel. The seabed landward of the terrace is sandy with occasional patch reefs. At the western end of Shoal Bay $(\mathrm{N})$, the reef consists of an alternating series of shallow and deep patches, cut by numerous surge channels and showing little evidence of accretion in recent years. The patch reefs are surrounded by $P$. porites and dominated by an assemblage of $A$ palmata, $P$. astreoides and gorgonians. The back-reef zone of the fringing reef is mainly algal covered rock, with $A$ palmata dominant along a variety of corals. The wide, shallowly shelving fore-reef is dominated by $A$ palmata at $2-3 \mathrm{~m}$. The outer reef rises gradually from the channel floor. From $4-10 \mathrm{~m}$ there is a mixed coral zone; between 1.5 and $4 \mathrm{~m}$, an assemblage of $P$. porites, Montastraea annularis and $A$ palmata is characteristic. The central zone of the reef is characterized by pools with large colonies of corals including $D$. strigosa. The seaward slope of the reef is grooved with a variety of corals on the ridges.

Scilly Cay in Island Harbour is surrounded by a shallow rock terrace supporting an assemblage of phaeophytes, anemones and $P$. astreoides. The Island Harbour fringing reef is dominated by $A$ palmata on the back-reef, reef crest and fore-reef down to $3-4 \mathrm{~m}$, below which gorgonians predominate. The outer reef of the harbour, Sixty-Odd Reef, is similar to the outer Shoal Bay Reef although coral cover is less dense.

Noteworthy Fauna and Flora The Green Chelonia mydas and Hawksbill Turtle Eretmochelys imbricata nest on Dog Island and Prickly Pear Cays. Leatherbacks Dermochelys coriacea reportedly nest on Scrub Island; further details are given in Meylan (1983) and Bacon et al. (1984). Seabird colonies are largely restricted to offshore cays including Mid Cay, West Cay, East Cay (off Dog Island), West Prickly Pear Cay, and Seal Island (Jackson, 1981). The gastropod Cyphoma gibbosum is particularly abundant at Crocus Bay. Queen Conch Strombus gigas are found off Sandy Island (Salm, 1980).

Scientific Importance and Research No information, but the area has been surveyed by Salm (1980).

Economic Value and Social Benefits Seal Island barrier reef and the barrier reef off Shoal Bay $(\mathrm{N})$ are critical habitats for commercial fishery populations. Fish are also plentiful at Dog Island, West Cay, Scrub Island and Island Harbour. Sandy Island is highly valued for recreation and its aesthetic appeal.

Disturbance or Deficiencies Sandy Island and its surrounding reef are heavily used by visiting yachtsmen. Anchors and suspended sand particles have done extensive damage to corals, particularly on the north-west reef section where corals have died from siltation. The island itself is suffering erosion from a combination of heavy use and natural causes. Seal Island lagoonal communities are also very vulnerable to boat anchors. The reefs next to Shoal Bay and Island Harbour have been damaged by anchors, fish traps and hurricanes. The corals here are also severely affected by blackline disease, triggered possibly by the colonies being hit by fish traps or anchors. At the western end of Shoal Bay reef a high incidence of damaged Montastraea annularis and Diploria strigosa colonies was recorded (Salm, 1980). The creation of the Reserve, while attracting visitors to the area, may potentially threaten it through increased usage, unless strict management is applied (Jackson, 1981).

Legal Protection None specifically for the reserve area (see "Introduction" for general legislation).

Management None yet.

Recommendations Jackson (1981) gives detailed 
recommendations for the establishment of the Reserve. It would be divided into sub-zones, some of which would be legally established, and others which would be administrative units. It is hoped that they will be established in the following order:-

1. Sandy Island National Marine Park - to be established mainly for recreational purposes. The shallow ridge to the north-west of the island is considered to be particularly suitable for snorkelling.

2. Crocus Bay - Little Bay Underwater Education Trial - to be established as an area to promote education and environmental awareness. The strip of coast at this site is particularly suitable for a trail, with numerous gulleys and tunnels, a diverse invertebrate fauna and three small beaches.

3. Shoal Bay National Marine Park - for the maintenance of productive fishery habitats and for tourism [to be established at the same time as other fishery reserves (see Introduction)]. Island Harbour, with many tame fish, is particularly suitable for snorkelling.

4. Seal Island Coral Reef Reserve - for the same purpose as Shoal Bay National Marine Park. Some of the best snorkelling on Anguilla is found from the east end of the reef, through the lagoon reefs to Prickly Pear Cay East.

Dog Island, West Prickly Pear Island and Scrub Island would be administrative zones managed for tourism. SCUBA diving and snorkelling sites would be maintained; threatened and important species and cays and rocks protected, and caves would be protected for recreation. On Dog Island, beach recreation would be encouraged, suitable anchoring sites maintained and limited fishing allowed. The west, north and north-west sides of the island are suitable for shallow diving and deep snorkelling. West Cay has a particularly good dive site at the "wall" on the west side. Little Flirt Rock off Prickly Pear North is suitable for shallow diving and experienced snorkellers. Scrub Island has a good diving site at Deadman's Cay (Salm, 1980).

It is proposed that the Reserve should be administered by a special Fisheries and Marine Parks Division, created in the Ministery of Agriculture, Mineral Development and Fisheries. Staffing and equipment requirements are outlined in Jackson (1981). Management of dive sites, snorkelling sites, charter or pleasure boat anchorages and swimming areas should be improved. The need for licences and fees for marine activities is discussed in Jackson (1981).

All visitors to the Reserve should be required to obtain permits, but these must be readily available and inexpensive. Information on the Reserve and regulations should be issued with all permits. Spearfishing, recreational angling and collection of anything live or dead while snorkelling or diving should be prohibited anywhere around Sandy Island and Dowling Shoal, north and west of Dog Island and its Cays, north of Prickly Pear Cays and east to the end of Seal Island Reef, over the Shoal Bay - Island Harbour reef complex, around Little Scrub Island and Deadman's Cay, between Crocus Bay and Flat Cap Point to a distance of $50 \mathrm{~m}$ off shore and around the grottoes and caves at the western end of the island. Placement of fish traps, anchoring, standing, resting and walking on coral, breakage of coral and littering over reefs or on cays and beaches should be prohibited (Salm, 1980). 


\section{INTRODUCTION}

\section{General Description}

Antigua and Barbuda, with the uninhabited rocky islet of Redonda $\left(16^{\circ} 56^{\prime} \mathrm{N}, 62^{\circ} 20^{\prime} \mathrm{W}\right)$, form a two-state nation within the British Commonwealth. They are coral limestone islands, situated $35 \mathrm{~km}$ apart on a platform 50 miles $(80 \mathrm{~km})$ long and $13-20$ miles $(21-32 \mathrm{~km})$ wide which is bounded by the 100 fathom $(183 \mathrm{~m})$ isobath. They are described in detail by Harris (1965), with particular emphasis on geology, climate and terrestrial fauna and flora. Depths between the islands average $15-18$ fathoms $(27-33 \mathrm{~m})$. Antigua, to the south, covers $280 \mathrm{sq} . \mathrm{km}$ and is hilly, the eastern and northern parts consisting of low and undulating limestone hills less than $180 \mathrm{~m}$ high. To the south-west there are massive volcanic rocks averaging $300 \mathrm{~m}$ in altitude and reaching $402 \mathrm{~m}$ at Boggy Peak. The intricate coastline is deeply indented in most places and is fringed by reefs and shoals, apart from a few areas of the central western coast and the Falmouth and English Harbour areas on the south coast. The reefs are often formed on submerged limestone terraces or platforms (John and Price, 1979). Muddy lagoon systems largely colonized by mangrove vegetation have developed behind barriers of sand or coral debris in sheltered bays and inlets (Harris, 1965; Loveless, 1960). Barbuda is a low limestone (maximum altitude $147 \mathrm{ft}(45 \mathrm{~m})$ ) island of around $174 \mathrm{sq} . \mathrm{km}$ with no marked indentations in the coastline (Vaughan, 1919). To the north and west lies an area of lagoons, creeks and flashes separated by beach ridges and mangrove swamps. Codrington Lagoon, the largest area, extends southwards for practically the whole length of the island (Brasier, 1975a).

Easterly trade winds are strong and constant, with tropical storms occurring in August and September and hurricanes at an average interval of 20 years. The dry season runs from January to April, the wet season from August to November. Barbuda is one of the driest West Indian islands with a mean monthly rainfall of $8.2 \mathrm{~mm}$. Rainwater collects in sink holes so there is little run-off. The islands lie in the stream of the North Equatorial surface current which flows NWW. Tidal range is little more than $0.3 \mathrm{~m}$. Water clarity is high, visibility reaching $20 \mathrm{~m}$. The surface water temperature is fairly constant at $28^{\circ} \mathrm{C}$. Salinity is generally $35-36 \mathrm{ppt}$ but is much higher in the lagoons which rarely exceed $2 \mathrm{~m}$ in depth (Brasier, 1975a; Harris, 1965).

Bacon et al. (1984) provide an estimate of $25.45 \mathrm{sq.} \mathrm{km}$ reef coverage for both islands, most of which is fringing reef. On Antigua, the windward north, east and south coasts are shielded by an intermittent bank-barrier complex having a classic zonation of frame builders (seaward Acropora palmata, yielding to Montastraea species and other head corals and then Porites species). Reef crest zones include incipient algal ridges. A few flourishing reefs (including the leeward $A$ palmata reef complex of Sandy Island shoals) are found off the leeward west coast which is dominated by fine sediment and shelfward-migrating mud from open bays (Weiss and Multer, 1984).

In the north, a massive, predominantly $A$ palmata bank-barrier reef, about $20 \mathrm{~km}$ long, largely blocks the shore east from Belfast (or Mercer's Creek) Bay west to Diamond Bank. To the north-east, deeper structures (Three Fathoms Bank and Four Fathoms Bank) also appear to be developing. A similar, though shorter barrier, Cades Reef, occurs on the south-west corner of the island. In general, the $40 \mathrm{~m}$ curve is within a few hundred metres from shore and there is virtually no shallow-reef development (Adey and Burke, 1976). A few small reefs are present on the south shore where the Cades Reef shelf narrows and extends eastward. Morris Bay (S) has small coral hummocks about $8 \mathrm{~m}$ seaward of a seagrass bed (John and Price, 1979). Mamora Reef lies off Isaac Point, separated by a wide, seagrass-covered, sandy-floored lagoon. The crest of the reef begins as large coral growths in about $2-3 \mathrm{~m}$ of water which become more abundant as the reef flat is approached. At Half Moon Bay and Soldiers Point, there is a fringing coral reef seaward of a narrow, shallow lagoon. At Beggars Point (= Hodges $\mathrm{Pt}$ ) in the north, there is an intermittent belt of massive coral growths almost reaching the surface at low water, about $50 \mathrm{~m}$ from the shore and in 4-5 $\mathrm{m}$ of water (John and Price, 1979). Algal ridges occur on the east and south-east from Indian Town Point to Willoughby Bay.

A small ridge on the north side of Green Island is associated with a barrier reef blocking Nonsuch Bay. Most of the algal ridges are isolated and close against the shore. Generally they are not high, perhaps $10-30 \mathrm{~cm}$ above mean low water, and in many cases they are degenerating. Outside the ridges, an extensive but immature $A$ palmata reef system, at $1-4 \mathrm{~m}$ depth and lacking reef flats, is rapidly approaching the surface (Adey and Burke, 1976). The bank barrier reef about $1000 \mathrm{~m}$ wide at Nonsuch Bay is described by Macintyre et al. (1985). The shallow fore-reef is a poorly defined spur and groove system, largely covered with $A$ palmata, giving way seaward to an octocoral and coral-head pavement which marks the inner edge of the broad windward shelf. Shoreward of the spur and groove zone, the almost exposed reef crest is encrusted with coralline algae and has linearly oriented $A$ palmata and Millepora complanata colonies in troughs lying perpendicular to the reef. Shoreward of the reef crest there are numerous coral patches. In Nonsuch Bay itself, patch reefs rise up from $20 \mathrm{~m}$ depth.

Reefs are found around most of the coast of Barbuda, and are almost untouched by tourists and in excellent condition, particularly those at the south end, near Cocoa Point (see account for Palaster). A massive algal ridge, coralline-Millepora mound and spur about $35 \mathrm{~km}$ long with only a few small breaks, fringes the entire east side of the island from north-west of Goat Point to Gravenor Bay in the south. A large part of Goat Reef in the extreme north-west and Palaster Reef off the southern point are dominated by $A$ palmata. The $5 \mathrm{~km}$ long Cobb Reef in the north from Hog Point to Goat Point is not a contiguous reef system, but consists of several hundred single and sometimes double- or triple-cut reefs. These occupy an area of about $5 \mathrm{sq}$. $\mathrm{km}$ and are the most extensive group of cup reefs in the Caribbean (Adey and Burke, 1976). The foraminiferal fauna of the reefs and lagoons is described by Brasier (1975a and b). 


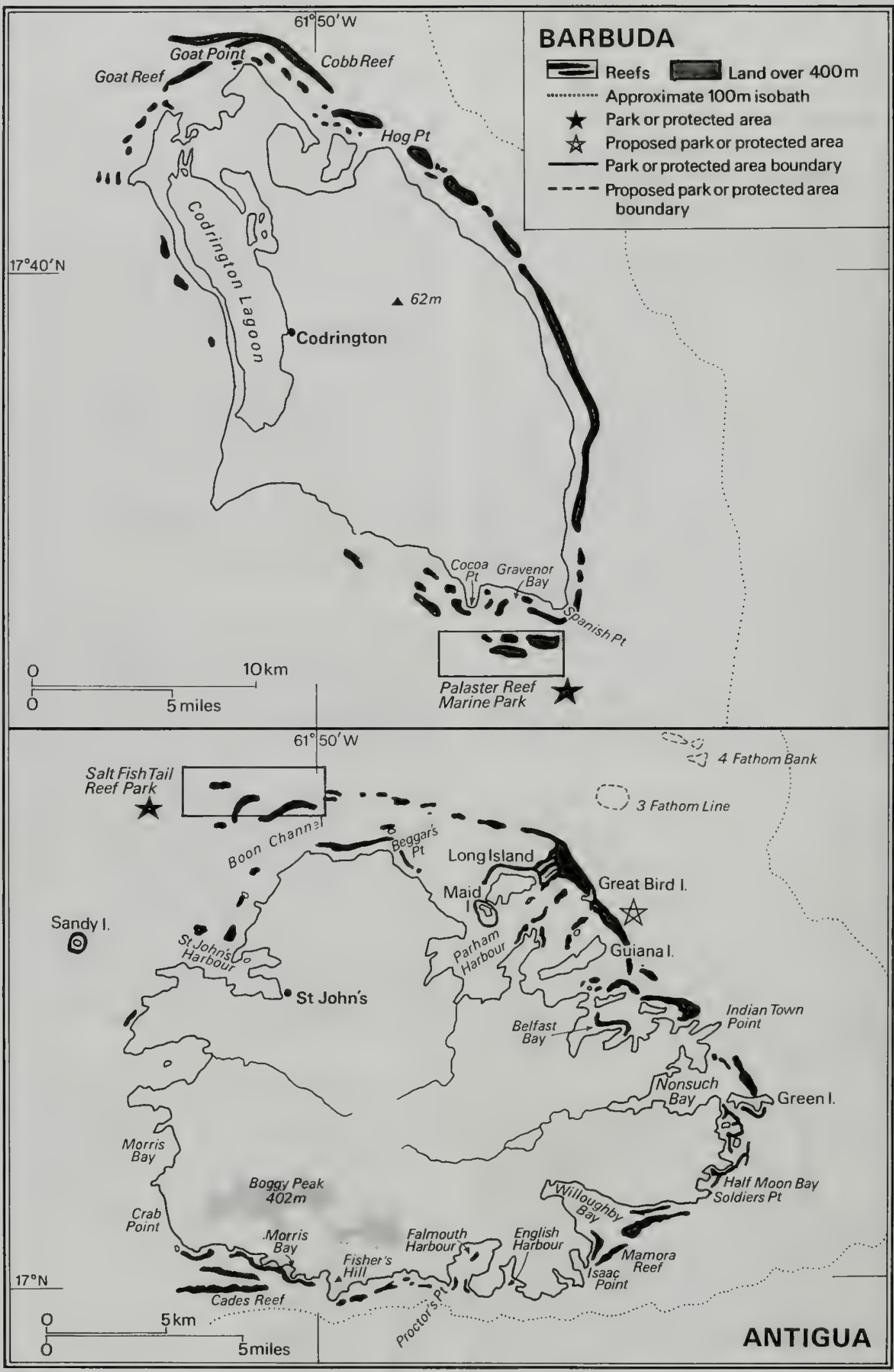


Scott and Carbonell (1986) discuss important mangrove areas including, on Antigua: the region of Parham Harbour and Guana Bay; Five Island Harbour on the west coast; salt ponds on the west coast from Runaway Bay south to Lignumvitae Bay; and on Barbuda: Codrington Lagoon, which has about 900 ha of mangroves, particularly in the north; the Bull Hole complex in south-central Barbuda, which is of particular botanical interest as the mangroves have no direct connection with the sea; the Flashes at the south-eastern tip of Barbuda. Halewyn and Norton (1984) list nine species of seabird nesting on Antigua and five species breeding on Barbuda, including two species of gull Larus spp., four species of tern Sterna spp. and the Brown Noddy Anous stolidus. The mangrove areas on Guana Island and at Bull Hole on Barbuda provide nesting areas for the threatened Antilles Wood Duck Dendrocygna arborea and those on Guana Island are the site of the only known West Indian Mockingbird Mimus gilvus nests in Antigua (Wingrove in litt., 1.2.85). Green Chelonia mydas, Hawksbills Eretmochelys imbricata, and Leatherback Dermochelys coriacea Turtles nest at a number of sites around both Antigua and Barbuda (Carr et al., 1982; Meylan, 1983; Bacon et al., 1984)).

Maps of the reefs of Antigua are currently being compiled, the result of several years research (Weiss and Multer, 1984). MacIntyre et al. (1985) describe the reef complex at Nonsuch Bay. John and Price (1979) describe the marine benthos from localities all around Antigua, to a depth of $10 \mathrm{~m}$, putting particular emphasis on marine algae. Reef accretion rates at Nonsuch Bay are described by Hubbard (1985). Previous surveys include those of Vaughan (1919) and Adey and Burke (1976)

\section{Reef Resources}

Both Antigua and Barbuda have important conch and lobster resources. DuBois (1985) reports that there are 800 full and part time fishermen, over half of whom depend on lobster and conch. Tourism grows, lobsters are being diverted from export to local markets. Turtles are exploited, particularly around tourist centres (Carr et al., 1982; Meylan, 1983; Bacon et al., 1984). Mangrove wood is used for charcoal, firewood and poles on both islands (Harris, 1965). Tourism in Antigua is mainly concentrated on the south and north coasts (e.g. Sandy Island) (ECNAMP, 1980b) and is actively encouraged by the Government (Harris, 1965). The only settlement on Barbuda is the village of Codrington situated on the east coast of the large lagoon and the island is still largely untouched by tourism (Robinson, 1979).

\section{Disturbances and Deficiencies}

Little information is available on the current status of the reefs and marine environment around Antigua and Barbuda, although Robinson (1979) thought them to be comparatively undisturbed and Rogers (1985) reported no reef deterioration. White band disease has been reported (Rogers, 1985). The brittle framework of Goat Head Reef was completely destroyed by Hurricane David in 1979 but less rigid members of the reef community survived in situ (Weiss and Multer, 1984). Harris (1965) describes the considerable impact that human activities have had on the native terrestrial fauna and flora, but there is little data on human impact on the marine environment. There is evidence of over-harvesting of conch and lobsters (Rogers, 1985; DuBois, 1985), partly due to the growth of the tourist industry. Fishing with bleach and explosives has been reported, and some damage has been caused by boat groundings and anchors (Rogers, 1985).

\section{Legislation and Management}

Fisheries are controlled under the Fisheries Regulations of 1978. There is a closed-season and minimum size limit for lobsters, but enforcement is reportedly not strong (DuBois, 1985). Turtle harvesting is controlled under the Turtle Ordinance of 1927 (Bacon et al., 1984). There are no regulations for the conch fishery.

A comprehensive, well-conceived Marine Parks Act, administered by the Fisheries Department of the Ministry of Agriculture, Lands and Fisheries (Marine Areas (Preservation and Enhancement) Act, No. 5 of 1972 and subsequent regulations and Schedule - SRO Nos 25 and 47 of 1973) has been in effect since 1972 (Nicholson, 1978; Peacock, 1974). Palaster Reef Marine Park (Barbuda) and Salt Fish Tail Reef Park (Antigua) (also known as Diamond Reef Marine Park) are decribed briefly in the following accounts. Green Island, one of Antigua's most important marine areas and tourist anchorages, is a privately owned Nature Reserve (Nicholson, 1977). Cades Reef off the south-west of Antigua is actively protected by dive shop owners who use it as a dive site and an area south-west of Mamora Reef is treated as a Park, also by local dive shops (Wingrove in litt., 18.2.85).

\section{Recommendations}

A UNDP/UNESCO project was proposed in 1979 to identify and develop a National Park system; this was to have a large marine component, and recommendations for the management of marine parks and marine resources were given in Robinson (1979). It was recommended that the two existing marine parks be developed. A Peace Corps volunteer has been taken on to follow up some of these suggestions.

On Antigua, it was recommended that special attention be paid to Great Bird Island, the associated islets to the south-west and the submerged reefs northward to Long Island and Bird Island Reef, which, with the entire section southward through Indian Town Point to Green Island, is an exceptionally fine natural area (Robinson, 1979). The entire reef section north of Guana Island, through Bird Island Reef, and including Exchange, Lobster, Rabbit, Red Head, Hells Gate, Gallery, Grey and Little Bird Islands (Bird Island is an important seabird site (Nicholson, 1977)) was recommended for Marine Park status. It was recommended that the islands should not be sold privately. Guana Island and Cades Reef have been proposed as a Marine Sanctuary (Wingrove in litt., 18.2.85). Antigua and Barbuda have been included on the preliminary list of potential marine sites for inclusion in a Lesser Antillean Biosphere Reserve (Goodwin, 1985). 
References

* = references not seen.

Adey, W.H. and Burke, R. (1976). Holocene bioherms (algal ridges and bank-barrier reefs) of the eastern Caribbean. Geol. Soc. Am. Bull. 87: 95-109.

Bacon, P., Berry, F., Bjorndal, Hirth, H., Ogren, L. and Weber, M. (1984). The National Reports. Proceedings of the Western Allantic Turtle Symposium, Costa Rica. Vol.3: University of Miami Press, Florida.

Brasier, M.D. (1975a). Ecology of recent sediment-dwelling and phytal foraminifera from the lagoons of Barbuda, West Indies. J. Foram. Res. 5: 42-62. Brasier, M.D. (1975b). The ecology and distribution of recent foraminifera from the reefs and shoals around Barbuda, West Indies. J. Foram. Res. 5: 193-210.

Carr, A., Meylan, A., Mortimer, J., Bjorndal, K. and Carr, T. (1982). Surveys of Sea Turtle Populations and Habitats in the Western Aslantic. NOAA Technical Memorandum NMFS-SEFC-91.

DuBois, R. (1985). Coastal fisheries management lessons learned from the Caribbean. Case Study 4 . In: Clark, J.R. (Ed.), Coastal Resources Management: Development Case Studies. Coastal Publications 3. Renewable Resource Information Series. Research Planning Inst. Inc, Columbia, S. Carolina.

ECNAMP (1980a). Barbuda. Preliminary Data Atlas. Survey of Conservation Priorities in the Lesser Antilles. Eastern Caribbean Natural Area Management Program.

ECNAMP (1980b). Antigua. Preliminary Data Atlas. Survey of conservation priorities in the Lesser Antilles. Eastern Caribbean Natural Area Management Program.

Goodwin, M.H. (1985). Characterization of Lesser Antillean Regional Fisheries. Island Resources Foundation. $48 \mathrm{pp}$.

Halewyn, R. van and Norton, R. L. (1984). The status and conservation of seabirds in the Caribbean. In: Croxall, J.P., Evans, P.G.H. and Schreiber, R.W. (Eds), Status and Conservation of the World's Seabirds. ICBP Technical Publication No. 2, Cambridge.

Harris, D.R. (1965). Plants, animals and man in the Outer Leeward Islands, West Indies: an ecological study of Antigua, Barbuda and Anguilla. Univ. Calif. Publs. Geog. 18: 164 pp.

Hubbard, D.K. (1985). What do we mean by reef growth? Proceedings of the Fifth International Coral Reef Congress, Tahiti, 1985 6: 433-438.

IUCN (1982). IUCN Directory of Neotropical Protected Areas. Tycooly International Publishing Ltd, Dublin.

-John, D.M. and Price, J.H. (1979). The marine benthos of Antigua (Lesser Antilles) 1. Environment, distribution and ecology. Botanica Marina 22: 313-326.

Loveless, A.R. (1980). The vegetation of Antigua, West Indies. J. Ecol. 48: 495-527.

MacIntyre, I.G., Multer, H.G., Zankl, H.L., Hubbard, D.K., Weiss, M.P. and Stuckenrath, R. (1985). Growth and depositional facies of a windward reef complex (Nonsuch Bay, Antigua, W.I.). Proceedings of the Fifth International Coral Reef Congress, Tahiti, 1985 6: 605-610.

Meylan, A.B. (1983). Marine turtles of the Leeward Islands, Lesser Antilles. Atoll Research Bulletin 278: 24 pp.

Nicholson, D.V. (1977). Some of the important wildlife areas of Antigua and Barbuda. Unpub. rep., Antigua Archaeological Soc.

*Nicholson, D. (1978). Presentation to Workshop on National Park Planning. Dominica.
-Peacock, N. (1974). A proposal for a marine parks scheme for Antigua and Barbuda. Min. Ag. Lands and Fisheries, Antigua.

Price, J.M. and John, D.M. (1979). The marine benthos of Antigua (Lesser Antilles) 2. An annotated list of algal species. Botanica Marina 22: 327-331

Robinson, A.H. (1979). Identification and development of a National Park System in Antigua and Barbuda. UNDP Project Document Draft. 1979.

Rogers, C.S. (1985). Degradation of Caribbean and Western Atlantic coral reefs and decline of associated fisheries. Proc. 5th Int. Coral Reef Congress, Tahiti, 6: 491-496.

Scott, D.A. and Carbonell, M. (1986). A Directory of Neotropical Wetlands. IUCN, Gland and Cambridge.

Vaughan, T.W. (1919). Fossil corals from Central America, Cuba and Porto Rico with an account of the American Tertiary, Pleistocene and Recent coral reefs. Bull. U.S. Nat. Mus. 103: 189-524.

Weiss, M.P. and Multer, H.G. (1984). Dynamic aspects of carbonate sediments, Antigua, W.I. (Abstract), Advances in Reef Science A Joint Meeting of the Atlantic Reef Committee and the International Society of Reef Studies (Oct. 1984). Miami, Florida.

\section{PALASTER REEF MARINE PARK}

Geographical Location A reef area lying about $3 \mathrm{~km}$ to the south-east of Cocoa Point, near Spanish Point, Barbuda; encompassed by a line drawn from $17^{\circ} 31^{\prime} 54^{\prime \prime} \mathrm{N}$ by $61^{\circ} 44^{\prime} 24^{\prime \prime} \mathrm{W}$ to $17^{\circ} 31^{\prime} 12^{\prime \prime} \mathrm{N}$ by $61^{\circ} 44^{\prime} 24^{\prime \prime} \mathrm{W}$, to $17^{\circ} 31^{\prime} 24^{\prime \prime} \mathrm{N}$ by $61^{\circ} 46^{\prime} 18^{\prime \prime} \mathrm{W}$, to $17^{\circ} 32^{\prime} 06^{\prime \prime} \mathrm{N}$ by $61^{\circ} 46^{\prime} 18^{\prime \prime} \mathrm{W}$ and back to the original point.

Area, Depth, Altitude -50 to $0 \mathrm{~m}$.

Land Tenure Government-owned.

Physical Features Shallow patch coral reefs.

Reef Structure and Corals Dominated by Acropora palmata (Adey and Burke, 1976).

Noteworthy Fauna and Flora Green Chelonia mydas, Hawksbill Eretmochelys imbricata and Leatherback Dermochelys coriacea Turtles occur in this area, limited nesting having been reported at Cocoa Point and Spanish Point (Bacon et al., 1984).

Scientific Importance and Research No information.

Economic Value and Social Benefits Palaster Reef and the adjacent reefs have a number of interesting wrecks (Nicholson, 1977). There is some fishing in the area.

Disturbance or Deficiencies Fishermen ignore the fact that the area is a park as it receives essentially no management by the authorities (Wingrove in litt., 18.2.85).

Legal Protection Park established 1973 under the Marine Areas Act (IUCN, 1982).

Management Administered by Fisheries Department, Ministry of Agriculture, Lands and Fisheries. The Park is undeveloped and unpatrolled, but the boundaries are 
delineated with red buoys.

Recommendations No information.

\section{DIAMOND REEF MARINE PARK}

Geographical Location A reef area lying about $5 \mathrm{~km}$ off the north-west coast of Antigua; $17^{\circ} 11^{\prime} 06^{\prime \prime} \mathrm{N}=17^{\circ} 12^{\prime} 18^{\prime \prime} \mathrm{N}$ and $61^{\circ} 49^{\prime} 30^{\prime \prime} \mathrm{W}=61^{\circ} 53^{\prime} 12^{\prime \prime} \mathrm{W}$.

Area, Depth, Altitude $2000 \mathrm{ha} ;-100$ to $0 \mathrm{~m}$.

Land Tenure Government ownership.

Physical Features Shallow calcium carbonate banks and extensive patch coral reefs. Includes Diamond Bank, Boon Reefs and Salt Fish Tail Reefs (Robinson, 1979).

Reef Structure and Corals The park includes Diamond Bank, Boon Reefs and Salt Fish Tail Reefs; there is no information on these.
Noteworthy Fauna and Flora Green Chelonia mydas, Hawksbill Eretmochelys imbricata and Leatherback Dermochelys coriacea Turtles almost certainly occur in the park area (Bacon et al., 1984).

Scientific Importance and Research No information.

Economic Value and Social Benefits There is some fishing.

Disturbance or Deficiencies Fishermen ignore the fact that the area is a Park as it receives essentially no management by the authorities (Wingrove in litt., 18.2.85).

Legal Protection Park established 1973.

Management Administered by Fisheries Department, Ministry of Agriculture, Lands and Fisheries. The Park is undeveloped and unpatrolled (Robinson, 1979) but the boundaries are delineated by red buoys.

Recommendations No information. 



\section{INTRODUCTION}

\section{General Description}

The Commonwealth of the Bahamas is an independent nation within the British Commonwealth. It comprises the only example of a large open ocean island system lying within the Atlantic Ocean tropics and consists of a $100000 \mathrm{sq}$. mi. (260 $000 \mathrm{sq} . \mathrm{km}$ ) archipelago that extends over $500 \mathrm{mi}$. $(800 \mathrm{~km})$ between south-east Florida and northern Hispaniola. The highest elevation is $206 \mathrm{ft}$ $(63 \mathrm{~m})$. The islands are believed to have once been an extension of the Florida Plateau and consist of the exposed tips of the Great and Little Bahamas Banks which are large submarine plateaux lying at an average depth of $5-20 \mathrm{~m}$. These are separated from the continental coast by a deep 50 mile $(80 \mathrm{~km})$ wide chasm, along which flows the Florida Current of the Gulf Stream. Each Bank is different but a common pattern exists: the central part is flat, with large islands lying along the north and east edges, and occasional low islands or rocks along the west and south edges. The outer shelf surrounding the flat part of the bank is usually less than one mile $(1.6 \mathrm{~km})$ wide and slopes seaward to $60-150 \mathrm{ft}$ $(18.3-45.7 \mathrm{~m})$ depth before plunging steeply; in some places depths of $12000 \mathrm{ft}(3658 \mathrm{~m})$ are found within two miles $(3.2 \mathrm{~km})$ of the shore (I.avett Smith, 1966). The Great Bahama Bank covers an area of $400 \times 200$ miles $(644 \times 322 \mathrm{~km})$ and is the southernmost and largest, split by two deep troughs, the Tongue of the-Ocean and Exuma Sound (Siegler, 1961). The Banks consist of vast deposits of nearly pure calcium carbonate mud and sand and the Bahamian shelf seas are considered to be exceptionally interesting and important as they provide examples of the warm, shallow, lime-depositing seas characteristic of the past but atypical of modern marine conditions (Newell et al., 1951).

The Bahamas are bathed by warm ocean currents and have a mild subtropical climate (Agassiz, 1894). Most rainfall occurs between May and October when subtropical breezes prevail and average annual rainfall is from 40 to $60 \mathrm{in}$. $(1020-1520 \mathrm{~mm})$, depending on the island. Easterly trade winds predominate for most of the year, and hurricanes occur occasionally (Newell and Rigby, 1957).

There are about 2750 islands, cays and rocks totalling 4400 square miles (11 $400 \mathrm{sq} . \mathrm{km}$ ) of exposed surface and seldom reaching more than about $30 \mathrm{~m}$ above sea level (Storr, 1964). The Little Bahama Bank supports the two main islands of Grand Bahama and Great Abaco. Andros, on the Great Bahama Bank, is the largest island $(176 \times 64 \mathrm{~km})$, and is predominantly low and marshy. The south-east Bahamas consist of a chain of islands and shallow-water reefs, separated by deep water, and extending from Crooked Island south-east to the Turks and Caicos Islands (Doran, 1955; Milliman, 1967a). The geology of the Bahamian reefs has been extensively studied by Illing (1954) and Newell et al. (1951). Extensive cavern systems have given rise to numerous Blue Holes, found both in the ocean and inland, particularly around Andros (see separate account) and Grand Bahama (Palmer, 1985a and c).
There are many areas with fine, extensive and virtually untouched coral reefs. A Shallow-water Fisheries Resources Survey found that reefs covered $1832 \mathrm{sq} \mathrm{km}$ (2.2\%) of the Great Bahama Bank and $324 \mathrm{sq} . \mathrm{km}(2.2 \%)$ of the Little Bahama Bank (Higgs in litt, 21.9.84). Living coral reefs fringe most of the windward northern and eastern coasts and the bank edges (Storr, 1964 and 1959) and hermatypic corals are widely distributed around the leeward edges and in areas sheltered from bank waters. Reef corals are generally absent from the shelf lagoon of the Great Bahama Bank on account of turbidity but the Banks support small patch reefs wherever a rocky substrate shows through the constantly forming oolitic sediments (Attrill, 1978).

The occasional low winter temperatures which occur in the Bahamas may affect coral growth and abundance (Walker et al., 1982) and it is thought that reef growth was probably more active in the Tertiary than it is now (Newell and Rigby, 1957). About 30 species have been recorded, of which the most important reef builders are Montastraea annularis, $M$. cavernosa, Siderastrea siderea, Diploria labyrinthiformis, Acropora palmata, A cervicornis and Porites porites (Newell et al., 1959).

The reef system along the south coast of Grand Bahama is considered one of the more important in the Bahamas. Reefs in Peterson Cay National Park are described in a separate account. Bunt et al. (1972) briefly describe reefs on this coast at the site selected for the installation of Hydro-Lab. Mushroom-shaped coral rock knolls, separated by sandy expanses, are found at $13.5-15 \mathrm{~m}$ depth about $2 \mathrm{~km}$ off shore, mainly covered with Halimeda, gorgonians and a little stony coral. Seaward, the knolls become more common, producing a series of ridges and channels, and the main reef is found at about $16 \mathrm{~m}$ depth. The outer face of the reef drops quite abruptly to $25-27 \mathrm{~m}$ depth, where there is a steep sand and rubble zone. Beyond $30-36 \mathrm{~m}$ depth, the bottom slopes steeply to the drop-off. A list of corals collected on the knolls is given in Bunt et al. (1972). The Atlantic Reef Committee has produced a map of the reefs of Little Bahama Bank (Macintyre pers, comm. 1984). Reefs off north-east Abaco are described in a separate account.

Bimini is a group of mainly low-lying mangrove covered islands on the north-west margin of the Great Bahama Bank, fronting the Florida Straits to the west. The best coral formations are found along the west margin of the cays south of Bimini in the clear ocean waters of the Florida Current and the area west of Rabbit Cay and Round Rock have communities closest to true reef formation (Squires, 1958). The islands of North, South and East Bimini enclose a shallow lagoon, the channels which connect this with the open sea providing a variety of habitats. A general description is given in Multer (1977); lagoonal communities and sediments are cescribed by Scoffin (1970) and Till (1970); reef profiles are given by Newell and Imbrie (1955) and corals and reef zonation have been described by Squires (1958). Collecting localities included: 1) the west side of Rabbit Cay, Round Rock and the tip of South Bimini; 2) Turtle Rocks; 3) areas round the Lerner Marine Laboratory; 


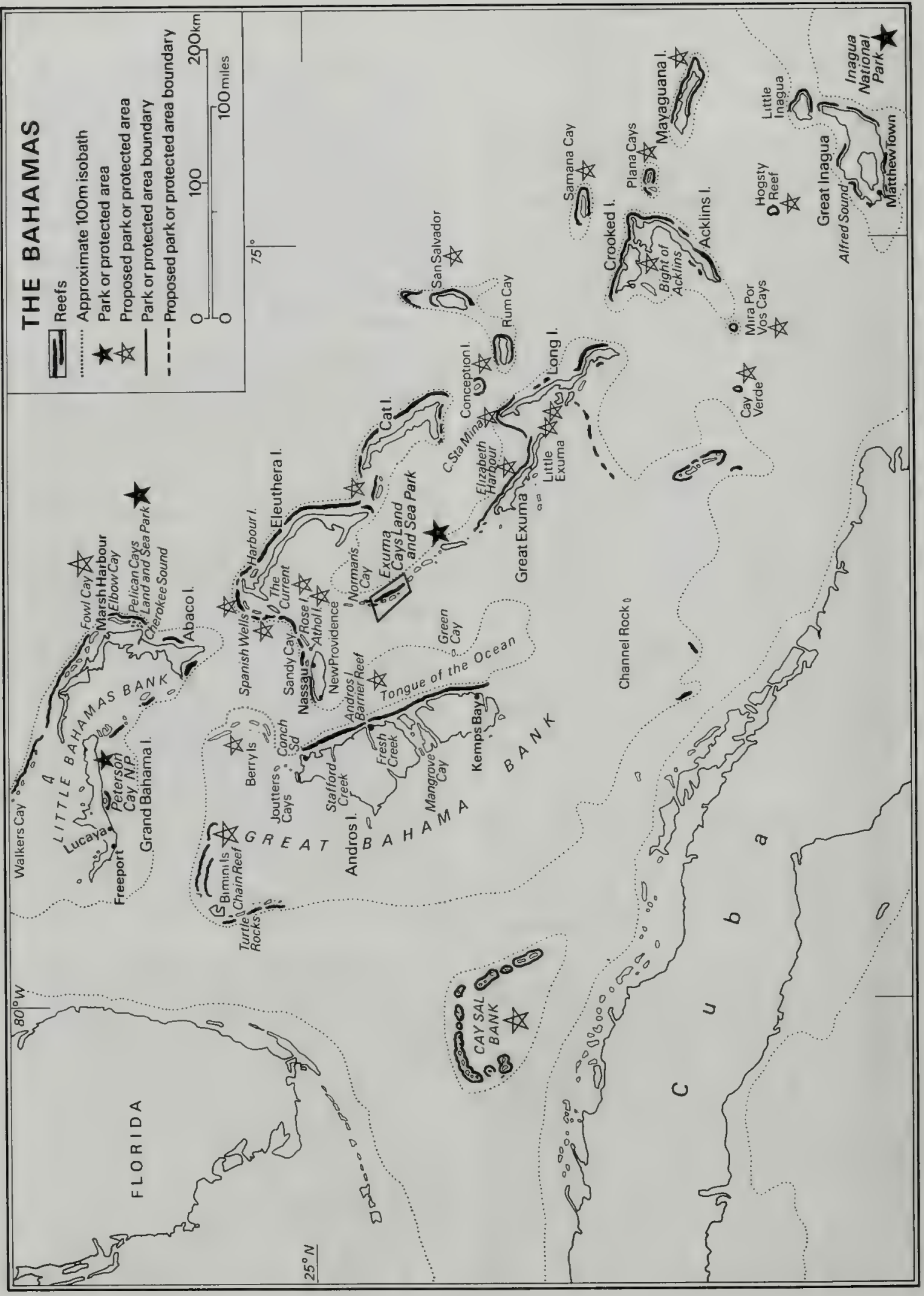


4) an area near Tocal Cay; 5) Grunt Drop; 6) the mouth of Upper Lagoon; 7) sites on the margin of the Great Bahama Bank. Although the fauna is not as luxuriant as that of the east Bahamas, most West Indian coral species were recorded but there are no extensive growths of $A$ palmata, and $A$ cervicornis is absent. This has been attributed to the large seasonal fluctuations in temperature of the shallow waters in the area combined with the regular flux of hypersaline turbid water which is swept across the bank by the persistent trade winds (Newell and Imbrie, 1955). Voss and Voss (1960) found that coral growth in shallow waters was mainly limited to Porites and Manicina.

A separate account describes the reefs of Andros. Englehardt (1915) described some of the reefs around New Providence following a collecting trip for the Brooklyn Museum. Most reefs occur in the north where the deep New Providence Channel runs close to the shore, the south coast having mainly sandy flats and old sponge beds with few reefs. The finest reefs at that time were said to be at Sandy Cay, almost due north of the eastern point and protected on the ocean side by a barrier reef, and at Goulding Cay near the western point. There were few stony corals in Nassau Harbour but gorgonians were abundant particularly at the "Narrows" at the eastern end. Reefs around Rose Island, Athol Island and Long Shoal, off north-east Nassau, are briefly mentioned by Haweis (1917) and Miner (1924, 1931 and 1933). The chain of reefs running from the eastern end of New Providence to Eleuthera (which are especially well developed to the north of Spanish Wells at the extensive and shallow reef called the Devil's Backbone) and those of Eleuthera and Cat Island are particularly important. Zankl and Schroeder (1972) describe geological aspects of Eleuthera reef.

Other major reef systems are found off Long Island, Crooked Island and Rum Cay (Attrill in litt., 9.10.84) and those around Inagua, Hogsty Atoll, Acklins Island, Exuma Cays and San Salvador are described in separate accounts.

Cay Sal Bank is a shallow, detached carbonate bank lying about $50 \mathrm{~km}$ west of the Great Bahama Bank, with an area of nearly $4000 \mathrm{sq} . \mathrm{km}(105 \times 66 \mathrm{~km})$. Like Hogsty Atoll (see separate account), it is unusual in resembling a drowned atoll with over $99 \%$ of the bank, including the southern flank and the entire centre, completely submerged to depths of $9-16 \mathrm{~m}$. The marine communities are described by Goldberg (1983) and four major zones were identified: 1) rubble - Lobophora; 2) Sargassum gorgonian-sponge; 3) Halodule and associates; 4) a patchy Thalassia zone. The lagoon is practically devoid of corals apart from occasional patch reefs. The rim is lined with a scattering of islands and rocks especially along the northern and eastern margins, the submerged, leeward bases of which present substrate for the development of corals although these do not appear to form a reef framework. Scleractinian development on the windward sides of the islands is negligible, and patch reefs and spur and groove systems are usually poorly developed on the outer bank slope to depths of about $30 \mathrm{~m}$. The best developed coral communities occur below this depth with the exception of the south-western sector where reefs are smothered in sediment. The biologicaloimpoverishment of the bank is considered to be due to wave and current-induced sediment stress, combined with an open and poorly developed rim. The cays and their terrestrial fauna are described by Buden and Schwartz (1968)

Extensive work on Bahamian reefs has been carried out. The Lerner Marine Laboratory at Bimini was an important base (Mathewson, 1963) but has now closed. Hydro-Lab submersible studies were carried out down to depths of $70 \mathrm{~m}$ or more off Lucaya, Grand Bahama Island (Bunt, 1971; Jaap, 1974) and in a number of localities inciuding Grand Bahama, Eleuthera, Cat Island, San Salvador, Crooked Island, Mayaguana Island, Great Inagua Island, Hogsty Atoll, Acklins, Norman's Cay and Long Island (Bunt et al., 1981; Pruna and Menuhin, 1972; Vittor, 1975). The deepest distribution of hermatypic corals known in the Atlantic has been found at San Salvador: Agaricia grahamae was observed to $119 \mathrm{~m}$ and Montastraea cavernosa to $113 \mathrm{~m}$ (Reed, 1985).

Reef fish are described by Bohlke and Chaplin (1968); Fowler (1944) gives an early account for the reefs off Great Abaco. Green Chelonia mydas, Hawksbill Eretmochelys imbricata and Loggerhead Caretta caretta Turtles nest and feed at several sites in the islands and the Leatherback Dermochelys coriacea occurs occasionally (Groombridge, 1982; Bacon et al., 1984). Sprunt (1984) gives a detailed survey of seabird colonies; fifteen species are established in the Bahamas. Important wetland sites are described in Scott and Carbonell (1986). Gillis et al. (1975) provide a comprehensive bibliography of the islands.

\section{Reef Resources}

The Government of the Bahamas, assisted by the United Nations Development Programme and FAO, has carried out a Shallow-water Fisheries Resources Survey of the Banks to assess the distribution of grouper, snapper, crawfish, conch and other Bahamian fishery resources. Preliminary findings provided estimates of standing stock and potential yield and suggested high potential yields of some species which are not commonly caught at the moment (Bahamas National Trust, 1984). Major fishing grounds inciude the Great and Little Bahama Banks, Cay Sal Bank and the Crooked Island-Acklins Island Bank, but full time fishermen number only about 560 . At present the industry is unable to meet the demands of the tourist industry or to supply fish at prices that are attractive to local consumers.

The Queen Conch Strombus gigas was found to be abundant on the north-western portion of the Little Bahama Bank, although it has been depleted throughout much of the country. Some 6-8 million pounds (2.7-3.6 million $\mathrm{kg}$ ) of spiny lobster Panulirus argus are taken in the commercial fishery each season, about $47 \%$ of the total cash value of landings and an unknown but considerable poundage is taken by local and foreign sportsfishermen, mainly by divers using spearfishing gear. A large proportion of the spiny lobster harvest is exported. There still exists the possibility of expanded fisheries production on the large shallow water shelf areas. Thompson (1978) describes the results of a major deep water fishery survey.

Although the population is growing rapidly, the Bahamas are unique among Caribbean islands in having a relatively low population density. However, with more than two 
million visitors a year, it is evident that reef-related activities are extremely important (Higgs in litt., 21.9.84). Tourism contributed over \$639 million to the economy in 1981 (Bahamas National Trust, 1984). The Research Unit, Bahamas Ministry of Tourism, conducted an Activities Survey during the second quarter of 1981 and found that in New Providence, the most populated island although one of the smallest, $27.6 \%$ of visitors participated in snorkelling activities and $5 \%$ in diving. In the Family Islands (i.e. islands other than New Providence), $80.7 \%$ participated in snorkelling and $12.7 \%$ in diving. Dive resorts are located in Nassau, Grand Bahama (Freeport, West End), Abaco (Marsh Harbour, Hope Town, Treasure Cay, Walker's Cay), Andros, Berry Islands, Bimini, Cat Island, Crooked Island, Eleuthera (Harbour Island, Spanish Wells), Exuma, Long Island and San Salvador.

\section{Disturbances and Deficiencies}

Hurricane Betsy in September 1965 caused considerable damage to reefs on the unprotected west side of New Providence and to those bordering the Berry Islands and slight damage to the more sheltered fringing and patch reefs on the north coast of New Providence (Easton, 1968). Coral bleaching was reported at the Gingerbread Grounds, Great Bahama Bank, in September 1983. About $90 \%$ of the Diploria strigosa colonies were bleached to $5-8 \mathrm{~m}$ depth. Other corals appeared normal and there was no apparent change in physical or biological conditions (Glynn, 1984). White band disease has been recorded in the Bahamas (Rogers, 1985) and black band disease has been reported from San Salvador (see separate account). Mass mortality of the sea urchin Diadema antillarum was recorded in 1983, from at least Andros and San Salvador, and was presumably related to the Caribbean-wide mortality of this species, possibly due to a water-borne pathogen (Lessios et al., 1984).

Bahamian reefs were considered to be deteriorating by the 1950s due to pollution, overfishing of conch, lobster, snapper and grouper and intensive spearfishing. Conch and large fish were reported to have become very scarce in the Rose Island, Athol Island and Long Shoal areas off New Providence (Ray, 1961). In the late 1970s, the main problems were the illegal use of chlorine bleach for catching spiny lobsters (Campbell, 1977) (this may have caused the deterioration of reefs at Yellow Banks, the Exuma Cay chain, the northern island chain and areas near New Providence), the use of dynamite for fishing, and the collection of coral (Attrill, 1978); coral collecting was particularly prevalent on the reef north of Rose Island, and Americans on day trips from the Florida Keys commonly and illegally removed stony and black corals from Cay Sal Bank for sale in Florida (Attrill, 1978). Overfishing of reef resources, such as conch, spiny lobster and grouper is still a major problem, although Rogers (1985) reports that there is little evidence of reef deterioration overall. Increasing pressure from visitors, particularly snorkellers and divers, may become serious and intensive spearfishing may still be having an effect (Higgs in litt., 21.9.84); there is already some evidence of damage from boat groundings. Scott and Carbonell (1986) note that very little is known of the effects of pollution in Bahamian waters; no major oil spills have occurred, but major shipping lanes, some heavily used, pass through the area.

\section{Legislation and Management}

The Fisheries Act 1969, the Fisheries (Amendment) Act 1974 and the Marine Products (Fisheries) Rules provided the legislation controlling exploitation of marine resources until 3 March 1986, when the Fisheries Resources (Jurisdiction and Conservation) Regulations, 1986 came into effect. The use of bleach, any toxic product or explosives for fishing is illegal and bleach may not be carried on fishing vessels. Collection and export of any marine products by non-Bahamians is prohibited. Spearfishing is prohibited within one mile $(1.6 \mathrm{~km})$ of the coast of New Providence, the southern coast of Freeport, Grand Bahama and within 200 yds $(183 \mathrm{~m})$ of the coast of the other Family Islands. Net mesh size and the design of fish traps is controlled. Spearfishing by individuals is permitted, but spearfishing for commercial purposes and the organisation of competitions is illegal (Higgs in litt. 21.9.84; Holowesko in litt., 18.10.84). The uprooting, destruction or sale of hard or soft corals without the written permission of the Minister responsible for the regulations is prohibited. There is a closed season from 1 April to 31 July for the collection of spiny lobsters, a minimum size limit and regulations for trap fishing. Berried females may not be taken and SCUBA gear and spearguns may not be used. There are controls on the taking of turtles (the taking and possession of Hawksbills is prohibited); conch may only be taken if they have a well formed lip; sponges may not be collected and stone crab may not be collected within two miles of the coasts of Bimini or Grand Bahama Island. The regulations also cover aspects of sportfishing, quality control of fishery products and aquaculture.

All National Parks come under the jurisdiction of the Bahamas National Trust. Under the Trust Act of 1959 , bye-laws can be made to manage the Parks and enforcement officers may be appointed. New bye-laws for all Land-and-Sea Parks, drawn up by the Trust, came into force on 13 February 1986. Originally designed primarily for recreational purposes, these Parks have been designated "marine replenishment areas and nurseries" and a moratorium has been placed on all types of fishing by commercial and sport fishermen within the park boundaries (Anon, 1986). Hunting, trapping, netting, the capture and removal of any fish turtle, crawfish, conch or whelk is prohibited, the destruction or removal of any animals, including coral is prohibited, sand may not be removed and collection for scientific purposes requires a permit from the Bahamas National Trust. Exuma and Pelican are described in separate accounts. Conception Island Land-and-Sea Park, 2100 acres (850 ha) and lying between Rum Cay and Cat Island, was established in July 1971 with a lease renewable every two years. Uninhabited, it is one of the three islands on which Christopher Columbus is known to have landed and is important for migratory and nesting birds and green turtles and there are good diving sites. The two National Parks which include reefs, Inagua and Peterson, are described in separate accounts. The Lucayan National Park is situated on the south coast of Grand Bahama and was created in 1982 to protect the Lucayan Cavern, the most extensive underwater cave system in the world; the Park boundaries do not extend to include the adjacent marine environment. At the eastem end of Nassau Harbour is an area known as the Sea Gardens which for many years has been promoted as a "reserve" by the operators of dive boats and glass-bottom boats (Holowesko in litt., 18.10.84); its only official 
protection is under the Fisheries Act Rules and Regulations which prohibits fishing within Nassau Harbour.

\section{Recommendations}

There have been numerous proposals for the protection and management of additional areas of reef. Ray (1961) recommended protection of the area around Rose Island, Athol Island and Long Shoal on account of its easy access and the fact that in the 1950 s it was still relatively pristine and considered to have some of the finest reefs in the Bahamas. Under the Strategic Assessment Project for the Caribbean Region carried out by IUCN (Ray and Miller, 1979), the Little Bahamas Bank was chosen as a study site in a project to develop a strategy for the conservation of living marine resources and processes; the Bahamas was subsequently recognised as one of the highest priority areas of the region. In 1983, the Bahamas National Trust submitted a proposal to the Government, entitled "The Development of a National Park System for the Commonwealth of the Bahamas', which called for the setting aside of a number of marine areas for designation as Parks, Reserves and Protected Areas. This was followed, in 1984, by a National Conservation Strategy which also recommends development of a representative system of protected areas, a management plan for sustainable use of economically important living resources, appropriate development and maintenance of environmental conditions and a fully developed programme of public education (Bahamas National Trust, 1984). An initial total of 52 sites have been identified (Bahamas National Trust, 1984). The following sites include reefs:

\section{Proposed National Parks}

Conception Island extension

Plana Cays, east of Crooked Island

\section{Proposed National Reserves}

Colonial Beach, New Providence, near Nassau

Bimini Chain Reef

Andros Barrier Reef (see separate account)

Corrie Sound, north Eleuthera

Starve Creek, south Eleuthera

Elizabeth Harbour, east coast of Great Exuma

San Salvador fringing reefs

Samana Cays, north of Crooked Island

\section{Proposed Protected Areas}

Athol Island and environs, New Providence

Rose Island rocks to Pimlico Cays, New Providence

Theo's Wreck, south coast Grand Bahama (not on map;

W of Peterson Cay N.P.)

Treasure Reef, south coast Grand Bahama (not on map;

W of Peterson Cay N.P.)

Fowl Cay Preserve (see account for Abaco reef)

Mamma Rhoda Reef, Berry Islands

Blue Holes on North Andros: Uncle Charlie's, Stalactite,

Cousteau's, Church's

(see account for Andros Barrier Reef)

Stafford Creek Reef

(see account for Andros Barrier Reef)

Small Hope Bay Reef

(see account for Andros Barrier Reef)
Andros Beach Hotel reef

(see account for Andros Barrier Reef)

Big Wood Cay Reef

(see account for Andros Barrier Reef)

Las Palmas Hotel Reef

(see account for Andros Barrier Reef)

Preacher's cave/Devil's Backbone, north of Spanish

Wells, Eleuthera

Current Cut, North Eleuthera

White Cay, south of Little Exuma

Allen Cays, north of Norman's Cay

Norman's Pond Cay environs

"Thunderball" Grotto, Exuma Cays area

Pigeon Cay, south of Great Exuma

Goat Cay/Tee Cay, north-west of Cat Island

Cape Santa Maria, north tip of Long Island

Bight of Acklins Cays

(see account for north-east Acklins coast)

Mira Por Vos Cays, south-west of Crooked Island

Cay Verde, south of Long Island

Booby Cay, Mayaguana Island

Hogsty Reef (see separate account)

Cay Sal Bank

\section{References}

* = cited but not consulted.

Adams, R.W. (1983). General guide to the geological features of San Salvador. In: Gerace, D.T. (Ed.). Field Guide to the Geology of San Salvador. 3rd Edition, CCFL Bahamian Field Station; 1-66.

*Agassiz, A. (1894). A reconnaissance of the Bahamas and of the elevated reefs in Cuba. Mus. Comp. Zool. Bull. 26: 1-203.

Anon. (1965). News and comments. Atoll Res. Bull. 112.

Anon. (1966). New National Parks for flamingos. Oryx 8(5): 276 .

Anon. (1986). New bye-laws ensure conservation. Currents (The Bahamas National Trust) 4(1): 1.

Attrill, R. (1978). Diver conservation. Caribbean Conservation News 1(4): 81-12.

Bacon, P., Berry, F., B jorndal, Hirth, H., Ogren, L. and Weber, M. (1984). The National Reports. Proceedings of the Western Atlantic Turtle Symposium, Costa Rica. Vol.3: University of Miami Press, Florida.

Bahamas National Trust (1984). A National Conservation Strategy for the Bahamas. Project Proposal. Benjamin, G.J. (1970). Diving into the blue holes of the Bahamas. Natl. Geog. Mag. 138: 347-363.

*Bohlke, J.E. and Chaplin, C.C.G. (1968). Fishes of the Bahamas and adjacent tropical waters. Livingstone Publ. Co., Wynnewood, Penna, U.S.A.

Buden, D.W. and Schwartz, A. (1968). Reptiles and birds of Cay Sal Bank, Bahama Islands. Quart. J. Florida Acad. Sci. 31: 290-320.

Bunt, J.S. (1971). New lab beneath the Bahamian Sea. Sea Frontiers 17: 171-174.

Bunt, J.S., Lee, C.C and Heeb, M.A. (1972). The site off Freeport intended for Hydro-Lab. Hydro-Lab Journal 1:3-6.

Bunt, J.S., Williams, W.T. and Chalker, B.E. (1981).

Coral associations at depths of 45 to 125 feet in the Bahamian region. Proc. 4th Int. Coral Reef Symp., Manila 1: 707-714.

Campbell, D.G. (1977). Bahamian chlorine bleach fishing: a survey, Proc. 3rd Int. Coral Reef Symposium. 
Carr, A., Meylan, A., Mortimer, J., Bjorndal, K. and Carr, T. (1982). Surveys of sea turtle populations and habitats in the Western Atlantic. NOAA Technical Memorandum NMFS-SEFC-91, U.S. Dept. of Commerce. Chambers, L.W. and Curran, H.A. (1986). Field guide to Snapshot Reef, Fernandez Bay, San Salvador Island, Bahamas, with observations on the ecology of the reef. CCFL Bahamian Field Station: Occasional Paper.

Chaplin (1962). The Hogsty Reef. Sea Frontiers.

Dahl, A.L., Macintyre, I.G. and Antonius, A. (1974). A comparative survey of coral reef research sites. Atoll Res. Bull. 172: 37-120.

Diehl, F., Garrett, R., Mellon, M., Cohen, G. and Elliott, N. (1986). Field guide to the invertebrates of San Salvador Island, Bahamas. CCFL Bahamian Field Station.

-Doran, E. (1955). Land forms of the south-east Bahamas. Univ. Texas Pub. 5509: 1-38.

Easton, W.H. (1968), Underwater effect of hurricane Betsy on some Bahamian reefs. (Abstract) Geol. Soc. Am. Spec. Pap. 101: 59,301.

Englehardt, G.P. (1915). The Bahamas, coral reefs and coral islands. Brooklyn Mus. Quart. 1: 202-215.

Fowler, H.W. (1944). Results of the Fifth George Vanderbilt Expedition (1944). The fishes. Monograph 6, Acad. nat. Sci., Philade phia: 69-93.

Gillis, W.T., Byrne, R. and Harrison, W. (1975).

Bibliography of the natural history of the Bahama Islands. Atoll Res. Bull. 191.

Glynn, P.W. (1984). Widespread coral mortality and the 1982-83 El Niño warming event. Environmental Conservation 11(2): 133-146.

Goldberg, W.M. (1983). Cay Sal Bank, Bahamas: a biologically impoverished physically controlled environment. Atoll Res. Bull. 271: 17 pp.

Groombridge, B. (1982). IUCN Amphibia-Reptilia Red Data Book, Part 1: Testudines, Crocodylia, Rhynchocephalia. IUCN, Gland, Switzerland.

- Haweis, S. (1917). The Book about the Sea Gardens of Nassau, Bahamas. P.F. Collie and Son, New York, 78 pp.

Hinman, E. (1983). Recent sedimentary lithotopes and ancient facies analogs. In: Gerace, D.T. (Ed.) Field guide to the geology of San Salvador. 3rd Edition. CCFL Bahamian Field Station: 117-145.

Illing, L.V. (1954). Bahamian calcareous sands. Am. Assoc. Petroleum Geologists Bull. 38: 1-95.

IUCN (1982). IUCN Directory of Neotropical Protected Areas. Tycooly International Publishing Ltd, Dublin.

-Jaap, W.C. (1974). Coral studies conducted at Hydro-Lab, Lucaya, Grand Bahama. Proc. Fla. Keys Coral Reef Workshop. State of Fla. Dept Nat. Res. St Petersburg: 19 pp.

Kissling, D. and Bray, R. (1980). Recent carbonates field study, San Salvador, Bahamas: a field study guide for participating personnel of Consolidated Gas Supply Corporation. Binghamton, N.Y. State University of New York, 43 pp.

Klingel, G.C. (1932). Shipwrecked on Inagua. Nat. Hist. 32: 42-55.

Klingel, G.C. (1940). The edge of the edge of the world. Nat. Hist. 45: 68-73.

Klingel, G.C. (1959). Wonders of Inagua, which is the name of a very lonely and nearly forgotten island. Robert Hale Lid, London.

*Klingel, G.C. (1961). The Ocean Island (Inagua). Anchor Books: Doubleday and Co., Garden City, N.Y.

Lavett Smith, C. (1966). Descending the Andros Reef. Nat. Hist. 75(8): 38-43.
Lessios, H.A., Robertson, D.R. and Cubit, J.D. (1984). Spread of Diadema mass mortality through the Caribbean. Science 35: 335-337.

Lighty, R.G. (1981). Fleshy-algal domination of a modern Bahamian barrier reef: example of an alternative climax reef community. (Abstract) Proc. 4th Int. Coral Reef Symp., Manila 1: 722.

-Long, EJ. (1958). An underwater Park. Nature Magazine 51(9): 486-488, 498.

Mathewson, R.F. (1963). The Lerner Marine Laboratory. Am. Zool. 3: 288.

Milliman, J.D. (1967a). The geomorphology and history of Hogsty Reef, a Bahamian atoll. Bull. Mar. Sci. 17(3): 519-543.

Milliman, J.D. (1967b). Carbonate sedimentation on Hogsty Reef, a Bahamian atoll. J. Sed. Petrology 37(2): 658-676.

Miner, R.W. (1924). Hunting corals in the Bahamas. Nat. Hist. 24: 594-601.

Miner, R.W. (1931). Forty tons of coral. Nat. Hist. 31: 374-387.

Miner, R.W. (1933). Diving in coral gardens. Nat. Hist. 33: $461-476$.

*Multer, H.G. (1977). Field guide to some carbonate rock environments: Florida Keys and western Bahamas. Dubuque, Iowa: Kendall/Hunt Publishing Co., 415 pp. (Bimini lagoon 62-67)

Nelson, B. (1984). Exploring Exuma's Land and Sea Park. The Bahamas Handbook. Etienne Dupuch, Nassau: 88-99.

Newell, N.D. and Imbrie, J. (1955). Biogeographical reconnaissance in the Bimini area, Great Bahama Bank. Trans. New York Acad. Sci. (Ser. 2) 18(1): 3-14.

Newell, N.D., Imbrie, P., Purdy, E.G. and Thurber, D.C. (1959). Organism communities and bottom facies, Great Bahamas Bank. Bull. Am. Mus. Nat. Hist. 117(4): 177-228.

Newell, N.D. and Rigby, J.K. (1957). Geologic Studies on the Great Bahama Bank. In: Regional aspects of carbonate deposition. Spec. Publ. Soc. Econ. Palaeout. and Min., Tulsa 5: 15-79.

Newell, N.D., Rigby, J.K., Whiteman, A.J. and Bradley, J.S. (1951). Shoal-water geology and environs, eastern Andros Island, Bahamas. Bull. Am. Mus. Nat. Hist. 97: 1-30.

Palmer, R. (1982). Report of the 1982 British Blue Holes Expedition. J. Soc. Underwater Tech. (Winter): 15-21.

Palmer, R. (1985a). The Blue Holes of the Bahamas. Jonathan Cape, London.

Palmer, R. (1985b). Peterson Cay National Park: observations on structure. Report to Bahamas National Trust.

Palmer, RJ. (1985c). The Blue Holes of Eastern Grand Bahama. Cave Science 12(3): 85-109.

Pierce, P.A. and Curran, H.A. (1986). Field guide to Telephone Pole (A cervicornis) Reef, Fernandez Bay, San Salvador Island, Bahamas. CCFL Bahamian Field Station: Occasional Paper.

- Pruna, A. and Menuhin, K. (1972). Seafloor panorama. Hydro-Lab Journal 1: 53-56.

Randall, J.E. and Ray, G.C. (1958). Bahamian Land-and-Sea Park. Sea Frontiers 4(2): 72-80.

-Ray, G.C. (1959). A survey of the Exuma Cays Land-and-Sea Park. Unpub. paper, Int. Game Fish Conference, Univ. of Miami, Florida.

Ray, G.C. (Ed.) (1961). Report of the Exuma Cays Park Project. Revised edition, Bahamas National Trust, pp. 1-39. 
Ray, G.C. and Miller, K.R. (1979). Final Report: A strategy for the conservation of living marine resources and processes in the Caribbean region. IUCN, Gland, Switzerland, $44 \mathrm{pp}$.

Reed, J.K. (1985). Deepest distribution of Atlantic hermatypic corals discovered in the Bahamas. Proc. 5th Int. Coral Reef Cong., Tahiti, 1985 6: 249-254.

-Rigg, H.K. (1969). A Park in the sea. The Skipper January, pp. 26-27.

Rogers, C.S. (1985). Degradation of Caribbean and Western Atlantic coral reefs and decline of associated fisheries. Proc. 5th Int. Coral Reef Congress, Tahiti Vol.6: 491-496.

Scoffin, T.P. (1970). The trapping and binding of subtidal carbonate sediments by marine vegetation in Bimini lagoon, Bahamas. J. Sed. Petrol. 40: 249-273.

Scott, D.A. and Carbonell, M. (1986). A Directory of Neotropical Wetlands. IUCN, Gland and Cambridge.

-Siegler, V.B. (1961). Bathymetric reconnaissance of Exuma Sound. Univ. Miami Inst. Mar. Sci. Rept. 61-64: 1-9.

Sprunt IV, A. (1984). The status and conservation of seabirds of the Bahama Islands. In: Croxall, J.P., Evans, P.G.H. and Schreiber, R.W. (Eds), Status and Conservation of the World's Seabirds. ICBP Technical Publication No. 2, Cambridge.

Squires, D.F. (1958). Stony corals from the vicinity of Bimini, Bahamas, British West Indies. Bull. Am. Mus. Nat. Hist. 115(4): 215-262.

Storr, J.F. (1964). Ecology and oceanography of the coral reef tract, Abaco I., Bahamas. Spec. Pap. Geol. Soc. Am. 79: 1-98.

Teeter, J.W. (Ed.) (1984). Proceedings of the 2nd Symposium on the Geology of the Bahamas, June 16-20, 1984. CCFL Bahamian Field Station. 296 pp.

Teeter, J.W. (1985). Pigeon Creek Lagoon, a modern analogue of the Pleistocene granny Lake Basin, In: Curran, H.A. (Ed.), Pleistocene and Holocene Carbonate Environments on San Salvador Island, Bahamas. Guidebook for Field Trip 2, The Geological Society of America 1985 Annual Meeting and Exposition in Orlando: $147-160$

Thompson, R.W. (1978). Results of the UNDP/FAO Bahamas deep water fishery survey 1972-75. Proc. Gulf Caribb. Fish. Inst. 30: 44-70.

Till, R. (1970). The relationship between environment and sediment composition (geochemistry and petrology) in the Bimini lagoon, Bahamas. J. Sed. Petrol. 40(1): 367-385.

Vaughan, T.W. (1919), Fossil corals from Central America, Cuba and Porto Rico with an account of the American Tertiary, Pleistocene and Recent coral reefs. Bull. U.S. Nat. Mus. 103: 189-524.

-Vittor, B.A. (1975). Coral reef infaunal populations at Hydro-Lab, Grand Bahama. Hydro-Lab Journal 3(1): 76-79.

Voss, G.L. and Voss, N.A. (1960). An ecological survey of the marine invertebrates of Bimini, Bahamas, with a consideration of the zoogeographical relationships. Bull. Mar. Sci. Gulf Carib. 10:96-116.

Walker, N.D., Roberts, H.H., Rouse, L.J. and Huh, O.K. (1982). Thermal history of reef-associated environments during a record cold-air outbreak event. Coral Reefs 1: $83-87$.

-Zankl, H. and Schroeder, J.H. (1972). Interaction of genetic processes in Holocene reefs off North Eleuthera Island, Bahamas. Geol. Rundschau 61: 520-541.

\section{ABACO REEF (INCLUDING FOWL CAY REEF PROPOSED PROTECTED AREA)}

Geographical Location Eastern coast of Great and Little Abaco Islands. Fowl Cay is situated off the south-east point of Scotland Cay, almost $10 \mathrm{~km}$ due north of Marsh Harbour, between Man o" War Cay and Great Guana Cay (this section excludes Pelican Cays - see separate account).

Area, Depth, Altitude The Abaco barrier reef extends for $175 \mathrm{~km}$. The lagoon area between this formation and the main island is $3-7$ miles $(4.8-11.3 \mathrm{~km})$ wide and $2-4 \mathrm{~m}$ deep.

\section{Land Tenure No information.}

Physical Features The north-east coast of Great Abaco Island is paralleled by a line of cays and a submarine ridge. Off Elbow Cay and Man o" War Cay, the reef extends one mile $(1.6 \mathrm{~km})$ seaward from the ridge, at a general depth of $4 \mathrm{~m}$ and is unbroken for almost 1.5 miles $(2.4 \mathrm{~km})$. Water temperatures for the area range from $23.2^{\circ} \mathrm{C}$ to $28.5^{\circ} \mathrm{C}$. Salinity averages $35.98 \mathrm{ppt}$. Storm damage is sometimes heavy. The predominant winds are north-east. The Antilles Current moves north-westward along the Abaco coast and is weak and fairly deep but effective in sustaining higher water temperatures during the winter.

Reef Structure and Corals The continuous reef barrier, one mile $(1.6 \mathrm{~km})$ from the cays, has large scattered coral mounds seaward and irregularly aligned patch reefs shoreward. The main reef barrier is built on the edge of the $4 \mathrm{~m}$ terrace and is $70-100 \mathrm{~m}$ wide, its outer edge dropping off to a depth of $8-16 \mathrm{~m}$. Beyond this, coral mounds develop in water depths of less than $16 \mathrm{~m}$, forming large, irregularly rounded structures with active coral growth covering not much more than $20-30 \%$ of their sides and tops. Those closest to the reef barrier rise to within $2 \mathrm{~m}$ of the surface. Generally they have a basal overhanging ledge, an internal cavern and a basal cavern.

The reef barrier has either a rough talus seaward slope or a slope heavily covered by Acropora palmata and an irregular and abrupt shoreward slope. The barrier is honeycombed with caverns. The first line of inner patch reefs is very irregular but similar in form to the barrier reef. Subsequent lines of patch reefs have almost vertical slopes as a result of heavy coral growth and protection from wave action by the outer reefs. The inner line of patch reefs is scant and almost bare of corals (Storr, 1964).

Coral growth is generally more vigorous in the mound area than in the reef barrier area. $A$. palmata is plentiful and is the dominant species of the reef barrier. Montastraea annularis is abundant only in deeper water. Several zones are described in detail by Storr (1964). The sea fan surf zone includes the outer $30 \mathrm{~m}$ of the main reef platform and the surfaces of reef structures seaward of this. Gorgonia flabellum is dominant, with alcyonarians, Millepora, Diploria clivosa and $T$. turbinata. The Montastraea zone is also exposed to wave action but is found in deep water and is characterized by $M$. annularis and $A$ palmata. The $A$ palmataActive-Wave-Action zone extends landward to the fourth line of patch reefs from the seaward margin of the reef barrier. In the outer area it is profusely covered with $A$ palmata, interspersed with a 
few massive corals such as $D$. strigosa and $D$. labyrinthiformis. Further shoreward, other corals such as Millepora alcicornis, D. clivosa and Porites astreoides become abundant. The Porites Moderate-Wave-Action Zone is characterized mainly by abundant colonies of $P$. astreoides and $M$. alcicornis.

The barrier reef is currently characterized by a lack of reef framework construction although there is a morphologically well-developed reef complex. It is currently dominated by a luxuriant fleshy-algal community of mainly Turbinaria, Stypopodium and Dictyota with few scleractinian corals and some Millepora. There is a dense cover of Sargassum in high-energy reef crest and reef flat environments. Abundant octocorals occur in shallow, somewhat protected fore-reef and back-reef areas (Lighty, 1981). The decline of the barrier reef is thought to be due to periodic offshore transport of cold water masses (Walker et al., 1982).

Noteworthy Fauna and Flora Mangroves occur in the lagoon shoreward of the reef. Fish are described by Storr (1964). Hawksbill Turtles Eretmochelys imbricata, Green Turtles Chelonia mydas and Loggerheads Caretta caretta are reported to nest on the east coast of Abaco (Groombridge, 1982; Carr et al., 1982).

Scientific Importance and Research A detailed study was made of the reef area between Elbow Cay and Man o' War Cay by Storr (1964) and the Abaco reef was surveyed more recently by Lighty (1981). The reef at Abaco is the only extensive reef development in the Bahamas found seaward of the submarine ridge and the line of cays. It contains, particularly at Hopetown on Elbow Cay, the sequence of zones expected in an ideal coral reef area, and may be the only example in the Bahamas of a typical self-built reef. Fowl Cay Reef has been surveyed by Storr (in litt., 6.12.84).

Economic Value and Social Benefits There are a number of dive centres on Abaco, including those at Marsh Harbour, Hopetown, Treasure Cay and Walker's Cay and recreational use of the area for boating has increased.

Disturbance or Deficiencies In late 1982 local fishermen were illegally using surface supply air lines (hookas) to supply crawfish divers who were illegally using breathing apparatus underwater for fishing and spearfishing on a commercial basis. This was partly due to the need to fish in deeper waters, shallower areas having been over-fished (Holowesko in litt., 18.10.84). Coral is no longer collected for sale as it was 30 years ago and there is a reduction in the littering of the water. However, the increase in use of power boats in the area has led to constant pressure waves being created, which lift up fine sediments, gradually killing small corals and other benthic life (Storr in litt., 6.12.84).

\section{Legal Protection None as yet.}

Management Local supporters of the Bahamas National Trust and Abaco dive operators already consider Fowl Cay a protected area and the Abaco Chamber of Commerce in Marsh Harbour is involved in this local conservation effort (Holowesko in litt., 18.10.84).

Recommendations Fowl Cay Preserve, to include Fowl
Cay reef and a portion of the Abaco Reef, has been proposed as a protected area and the area of the Marls, west of Abaco, has been recommended as a protected area for birds by the Bahamas National Trust (1984). Both areas are described in Scott and Carbonell (1986).

\section{ACKLINS ISLAND REEFS}

Geographical Location $22^{\circ} 30^{\prime} \mathrm{N}, 74^{\circ} 00^{\prime} \mathrm{W}$. The island is part of the Crooked Island District, but is separated from Crooked Island by a tidal channel, "The Going Through".

Area, Depth, Altitude Reef depth to $55 \mathrm{ft}(16.8 \mathrm{~m})$.

Land Tenure The north-east corner of Acklins Islands is Crown Land.

Physical Features Acklins Island is composed of Pleistocene calcarenite and is relatively flat apart from a series of striking "fossil dune ridges" (up to $30 \mathrm{~m}$ relief) parallel to the present coastline.

Reef Structure and Corals The reefs at Atwood Harbour on the north-east coast were described by Dahl et al. (1974). On the west side of the harbour there is patch reef $15 \mathrm{~m}$ from shore. Much of the reef surface was covered with crustose coralline algae (especially Porolithon and Neogoniolithon) but large colonies of Montastraea annularis, Acropora palmata, Millepora, Porites astreoides and $P$. porites were also present. The sandy bottom of the harbour had well developed Thalassia beds. The main reef area consists of a back-reef, which was characterized by small patch reefs with relatively dense coral growth, the reef crest, an upper fore-reef slope consisting of a barren zone $(1.5-6 \mathrm{~m})$ and a grooved zone $(6-18 \mathrm{~m})$, and the lower fore-reef slope.

On the east coast, off Pinefield Point, on the inner edge of the bank barrier reef there was a zone of abundant Montastraea annularis and Diploria coral heads leading to the turbulent inner edge of the reef flats where there were large overturned colonies of $A$ palmata and large colonies of Millepora. At $20 \mathrm{~m}$ there is a distinct sand flat, and below this depth coral assemblages are found on linear ridges which are separated by sand and gravel-filled grooves generally $3 \mathrm{~m}$ wide and $1 \mathrm{~m}$ deep. Near Golden Grove, midway down the east coast, there are abundant patch reefs shoreward of the bank barrier reef; a high percentage of their surfaces were covered with Porolithon, Neogoniolithon and other corallines. Large colonies of $A$ palmata and Millepora were observed along with abundant but small colonies of Agaricia agaricites. Other sites were briefly studied during surveys in 1970 and 1971 (Dahl et al., 1974).

Noteworthy Fauna and Flora Mangrove swamps are well developed on the northern end of the Bight of Acklins and are described in Scott and Carbonell (1986). Most of the vegetation is a heavy growth of low brush but there are also a few scattered trees. The Laughing Gull Larus atricilla has an established nesting colony on South Cay in the Bight of Acklins and the Least Tern Sterna albifrons antillarum has a colony site at Salina Point, the south-west tip of Acklins (Sprunt, 
1984). Fish are abundant on the patch reef on the west side of Atwood Harbour and Hawksbill Turtles Eretmochelys imbricata have been recorded there. Fish are also abundant off Pinefield Point.

Scientific Importance and Research The reefs were surveyed in 1970 and 1971 as part of the Smithsonian CITRE project (Comparative Investigations of Tropical Reef Ecosystems). Local facilities for research were poor at that time, but Atwood Harbour was considered an excellent location for a base station. It was suggested that the north-east coast of Acklins Island might be set aside as a research site. Bunt et al. (1981) have surveyed a site at $22^{\circ} 11^{\prime} \mathrm{N}, 74^{\circ} 17^{\prime} \mathrm{W}$.

Economic Value and Social Benefits Fishing is a minor occupation carried out in a primitive fashion on an occasional basis. There is a dive centre on Crooked Island which may take visitors to Acklins Reef.

Disturbance or Deficiencies The reefs have been relatively unaffected by human activity.

Legal Protection None.

Management No information.

Recommendations The reefs around Acklins are not specified in the proposal by the Bahamas National Trust for a National Parks System at this time but may be included on subsequent lists at a later date (Holowesko in litt., 18.10.84). The wetland area within the Bight of Acklins has been proposed as a protected area (Bahamas National Trust, 1984).

\section{ANDROS ISLAND BARRIER REEF PROPOSED NATIONAL RESERVE}

Geographical Location Off the east coasts of North and South Andros Islands.

Area, Depth, Altitude The barrier reef lies 1-3 miles $(1.6-4.8 \mathrm{~km})$ from the shore separated by a shallow lagoon, $1-2.5$ fathoms $(1.8-4.6 \mathrm{~m})$ deep at low tide.

\section{Land Tenure No information.}

Physical Features The east coast of Andros is bounded by a shallow rock platform about one mile $(1.6 \mathrm{~km})$ wide and two fathoms $(3.7 \mathrm{~m})$ deep. A line of low cays runs parallel to the shore in some areas, where the platform breaks the surface. To the south and north, where the platform is washed by Bank waters, the barrier reef (technically a fringing reef, Attrill in litt., 9.10.84) breaks down to patch reefs and scattered massive corals (Newell et al., 1959; Newell and Rigby, 1957). In some areas the barrier forms a flourishing reef more than half a mile wide. The outer edge drops to the rim of the Tongue of the Ocean at 16 fathoms $(29.3 \mathrm{~m})$ and from the rim drops abruptly to the bottom at $4000 \mathrm{ft}(1220 \mathrm{~m})$ depth. Vigorous currents flow through gaps in the barrier, across the lagoon and through the estuaries on the coast, but there is almost no soil run-off from the shore. Much of the floor of the lagoon is bare rock perforated by openings varying from small solution pits to Blue Holes (Newell et al., 1951), some of the latter of which have been surveyed (Benjamin, 1970; Palmer, 1982; Palmer, 1985a).

Reef Structure and Corals The lagoon has isolated heads of Siderastrea radians, and gorgonians are abundant in some areas. Immediately behind the barrier reef are numerous patch reefs which are generally oval or annular, with a diameter of $30-100 \mathrm{~m}$. They are characteristically fringed with blue sea fans and sea pens, and have scattered corals (Acropora cervicornis, Manicina areolata, Porites porites, P. furcata, Diploria labyrinthiformis and S. radians)

Extensive bank reefs are found on the barrier in the north-east. Further south, Fresh Creek causes a discontinuity in the barrier reef, but well developed reefs are found between High Cay and North Bight and between Goat Cay and Staniard Creek. Early studies by Newell et al. (1951) and Newell and Rigby (1957) showed that the reef crest consisted of Lithothamnion and Millepora alcicornis, was usually less than 75 yds $(69 \mathrm{~m})$ wide, and submerged at low tide. On the seaward side, $A$ palmata was dominant from sea-level to $25-30 \mathrm{ft}$ (7.6-9.1 m) and might reach a height of $10 \mathrm{ft}(3 \mathrm{~m})$. At greater depths it was replaced by $A$ cervicornis and $P$. porites. Closely spaced, anastomosing surge channels were aligned normal to the reef front. From 3 to $6-7$ fathoms $(5.5$ to $11-12.8 \mathrm{~m})$ the massive corals Montastraea annularis, $D$. strigosa, D. labyrinthiformis, S. siderea and Dendrogyra cylindrus were found, interspersed with Agaricia agaricites, $P$. porites and Acropora cervicomis. The most vigorous growth was at $4-7$ fathoms $(7.3-12.8 \mathrm{~m})$ beyond which corals became sparse. The outer edge of the reef was usually at $35-40 \mathrm{ft}(10.7-12.2 \mathrm{~m})$ depth. Seaward of this at $60 \mathrm{ft}(18.3 \mathrm{~m})$ depth, a rock pavement was found with scattered massive corals (Newell et al., 1959). A early popular description of the reef zonation is given in Lavett Smith (1966).

During the 1982 British Blue Holes Expedition, surveys were carried out around some of the Blue Holes (Palmer, 1982). At Conch Sound in the north, the barrier reef is $1-3 \mathrm{~km}$ off shore, with extensive coral head communities inshore; within the bay the water is shallow with limited coral growth. At Mangrove Cay, the reef lies approximately $1.5 \mathrm{~km}$ off shore and showed signs of recent devastation with a much reduced species diversity. Inshore and around the hole areas the shallow waters cover a sandy bed with few coral heads and a limited fauna except in the immediate area of the holes. The Doughnut Holes, $1-3 \mathrm{~km}$ off shore near Kemps Bay on South Andros, are surrounded by extensive growths of $A$ palmata and $A$ cervicornis; the surrounding water is 2-3 $\mathrm{m}$ deep and there are numerous coral heads supporting a diverse fauna. More recent descriptions of the barrier reef and patch reefs were made in the course of the 1985 and 1986 expeditions and data should shortly be available (Wells pers. obs., 1986).

Noteworthy Fauna and Flora Conchs Strombus gigas and Helmet Shells Cassis tuberosa were found in the lagoon (Newell et al., 1951); $S$. gigas still occurs (Wells pers. obs., 1986). Loggerheads Caretta caretta, Green Turtles Chelonia mydas and Hawksbill Turtles Eretmochelys imbricata all nest, if somewhat sparsely, along Andros's beaches (Groombridge, 1982). The cays off the east coast are the sites of established 
colonies of various seabirds, including the White-tailed Tropicbird Phaethon lepturus catesbyi, the Sooty Tern Sterna fuscata, the Bridled Tern Sterna anaethetus recognita and the Brown Noddy Anous stolidus (Sprunt, 1984). Green Cay, east of Andros is an important White-crowned Pigeon Columba leucocephala rookery although the population has undergone a considerable decline.

Scientific Importance and Research Regarded as one of the finest barrier reefs in the Caribbean with a spectacular vertical cliff face (Lavett Smith, 1966; Newell et al., 1951). The reef was visited several times in the 1920 s in order to collect corals and reef life to exhibit in the Natural History Museum in Washington D.C., U.S.A., and a popular account of the reefs around Mangrove and Little Golding Cay is given in Miner (1924 and 1931). Newell $e t a l$. (1951) studied the reef off the north-east coast from Fresh Creek and the Andros reefs were mapped by Newell and Rigby (1957). The Blue Holes have generated considerable scientific and popular interest since the beginning of the century (Vaughan, 1919; Benjamin, 1970; Palmer, 1982; Palmer, 1985a). There have reportedly been other recent reef studies, chiefly by scientists associated with Capital University of Columbus, Ohio, using the Forfar Field Centre at Stafford Creek, North Andros.

Economic Value and Social Benefits The Andros Reef is important to the local tourist trade, reefs off Stafford Creek Settlement, Small Hope Bay Lodge (Coakley Town), Big Wood Cay, Las Palmas Hotel Reef, South Driggs Hill Settlement and Andros Beach Hotel (Nicholls Town) being used by tourist SCUBA divers (Holowesko in litt., 18.10.84). Tourism on South Andros however, is still at a very early stage of development. The reefs and surrounding waters play a very important role in the fishing industry, as a source of grouper, snapper and other commercial fish, spiny lobsters and conch for both local consumption and export to Nassau (Wells, pers. obs., 1986).

Disturbance or Deficiencies The reefs suffered from the mass mortality of the sea urchin Diadema antillarum which was recorded throughout the Caribean in 1983/1984 (Lessios et al., 1984) and in some areas algal cover has increased noticeably. Each year pressure on the reef from tourist activities on North Andros increases, although the impact at present is small as most diving operators are conservation minded (Attrill in litt., 9.10.84). Pressure on South Andros will increase when the proposed electricity mains supply is installed, and a number of local plans for tourist developments materialize. Demands from commercial fisheries are growing; illegal (commercial) fishing by foreign poachers occurs more frequently in the extreme south (Cuban fishermen) and in the extreme north (American fishermen) (Holowesko in litt., 18.10.84). The reefs have also been threatened by the use of toxic substances such as bleach to collect crawfish (Panulirus argus) (Attrill in litt., 9.10.84).

\section{Legal Protection None.}

\section{Management None.}

Recommendations The Bahamas National Trust (1984) has proposed the entire reef off North Andros, from north of Joulter Cays to North Bight in South Andros, as a National Reserve. In addition, the five popular diving spots (Stafford Creek Reef, Small Hope Bay Lodge Reef, Big Wood Cay Reef, Las Palmas Hotel Reef and Andros Beach Hotel Reef) within the barrier reef boundaries and the Blue Holes on North Andros (Uncle Charlie's, Stalactite, Cousteau's and Church's) have been proposed for additional protection (Bahamas National Trust, 1984). The southern part of South Andros has been proposed as a National Reserve and it might be expedient to include coastal and marine areas within this. Further survey work and a study of the importance of the reef to the local economy is required before these proposed areas are designated.

\section{EXUMA CAYS LAND-AND-SEA PARK}

Geographical Location South central Bahamas, $50 \mathrm{mi}$. $(80 \mathrm{~km})$ south-east of Nassau, between Shroud Cay in the north and Bell Island in the south; $24^{\circ} 34^{\prime}-2 T \mathrm{~N}$, $76^{\circ} 33^{\prime}-45^{\prime} \mathrm{W}$.

Area, Depth, Altitude 45584 ha, of which some 8.75 sq. mi. ( $22.7 \mathrm{ha})$ is land; below sea level to several tens of metres above sea level.

Land Tenure 99 year Crown Lease, with the exceptions of Soldier Cay, O'Briens Cay, Bell Island, Little Bell Cay, Cistern Cay and Hall's Pond Cay, which are privately owned or leased.

Physical Features The Exuma Cays comprise about forty low lying aeolian limestone islands of Pleistocene origin, with numerous solution holes, and many smaller islets and rocks extending over 130 miles $(209 \mathrm{~km})$ along the edge of the Grand Bahama Bank from Beacon Cay in the north to the islands of Great and Little Exuma in the south. There are vast shoals to the west and the deep Exuma Sound to the east. Deep tidal channels cut between the cays, linking the bank with Exuma Sound. The eastern side of the cays is drier than the western side.

The Park itself is 22 miles $(35.4 \mathrm{~km})$ long and includes ten islands with a length of more than one mile $(1.6 \mathrm{~km})$ (Shroud, Hawksbill, Cistern, Warderick Wells, Hall's Pond, O'Brien's, Bell Island and Little Bell) (Randall and Ray, 1958). Hawksbill Cay has a series of rocky hills on the west, up to $30 \mathrm{~m}$ high and fronting directly onto the sea, interspersed with small beaches. On the east side there are extensive beaches. The northern coast is sandy with flats extending out to the channel separating this cay from Shroud Cay. Shroud Cay is an example of a pseudo-atoll island; beaches on the west side are smaller and there are more extensive shoals than on the east. The centre of the cay has extensive mangroves and a salt flat. Warderick Wells Cay is the most scenic, consisting of three detached islands enclosing a moderately deep lagoon with good anchorage. There is a wider variety of habitat than on the other cays with mangrove, cliffs and narrow beaches (Ray, 1961). There is a Blue Hole ("Sea Dragon Hole") near a small cay in Wide Opening (Nelson, 1984). Popular descriptions of the Park are given by Long (1958) and Rigg (1969).

Reef Structure and Corals The best reefs are found in the north and along the eastern side of the Park. Those 
on the east side of Shroud Cay and off Hawksbill Cay are probably similar to the better known Andros and Abaco Reefs (Ray, 1961). To the west there are large sandy shoals with infrequent coral knolls. On the east side of Wax Cay at the northern edge of the park, at about $15 \mathrm{ft}$ $(4.6 \mathrm{~m})$ there are large patch reefs with good coral growth, mainly Acropora cervicornis and numerous sea fans. At $50-60 \mathrm{ft}(15-18 \mathrm{~m})$, the bottom consists of $60 \%$ sand and $40 \%$ low coral rock with sparse living coral and gorgonian growth. Depth increases gradually to $80 \mathrm{ft}$ $(24.4 \mathrm{~m})$ where there is a zone of large mounds of coral rock with many crevices, after which the bottom drops away rapidly. The east side of Shroud Cay has patch reefs at 4-12 ft $(1.2-3.7 \mathrm{~m})$, some with stands of A cervicornis. Off the eastern side of Cistern Cay, patches of small corals and gorgonians are found at $50 \mathrm{ft}$ $(15.2 \mathrm{~m})$ from shore. Coral growth is poor on the windward side of Warderick Wells. Corals collected at Wax, Shroud and Cistern Cays are listed in Ray (1961).

Noteworthy Fauna and Flora The eastern sides of the cays are characterized by low canopy scrub dominated by Bumelia, Coccolobis spp. and Rachicallis; the western (leeward) sides of the islands have single canopied $(5 \mathrm{~m}$ ) forest dominated by Thrinax, Sabal and Bursera, high densities of epiphytic orchids such as Epidendrum spp., bromeliads such as Tillandsia spp. and typical North Bahamas strand communities characterized by Uniola, Strumfia and Scaveola. Sargent's Palm Pseudophoenix sargentii is noteworthy. Shroud Cay ( $3 \times 2$ miles $(4.8 \times$ $3.2 \mathrm{~km}$ )) is particularly interesting, being interlaced with channels lined with red mangroves. In 1973 the threatened Allen's Cay Rock Iguana Cyclura cyclura inornata was introduced to Bush Hill Cay in the far north of the Park and the rare Bahamian Hutia Geocapromys ingrahami was introduced to nearby Little Wax Cay (Nelson, 1984). Both species appear to be thriving (Nelson, 1984). The Hawksbill Turtle Eretmochelys imbricata has been recorded (Randall and Ray, 1958) and young Loggerheads Caretta caretta raised at Nassau's Seafloor Aquarium have been released off Shroud Cay (Nelson, 1984). In 1958 there were numerous fish, including large groupers and snappers, and Queen Conch Strombus gigas and lobsters were relatively abundant (Randall and Ray, 1958). Species lists for molluscs, reptiles, plants and other terrestrial fauna and flora are given in Ray (1961). Four species of seabird are known to have long established colonies on the cays: the White-tailed Tropicbird Phaethon lepturus catesbyi, the Roseate Tern Sterna dougallii, the Sooty Tern $S$. fuscata and the Least Tern S. albifrons antillarum (Sprunt, 1984).

Scientific Importance and Research A survey of the area including Norman's and Wax Cay to the north of the Park and Compass Cay to the south was carried out in 1958 (Ray, 1959 and 1961). A U.S. based research project on the reefs will be starting up shortly (P. Hall, pers. comm., 1986).

Economic Value and Social Benefits The Cays have long provided good anchorages and beaches for visitors from Nassau. There are dive centres at George Town and Staniel Cay (Great Exuma), and the area's proximity to Nassau makes it of major importance for tourism and recreation. The greatest number of visitors are cruising U.S. yachtsmen (Nelson, 1984).

Disturbance or Deficiencies In the 1970 s there was illegal commercial fishing by Bahamians, including the use of chlorine bleach in spearfishing for spiny lobsters Panulirus argus (Campbell, 1977). There is may be some coral damage due to diving (IUCN, 1982) although the actual removal of corals is minimal (Holowesko in litt., 18.10.84). The most evident impact of tourists on the Park is rubbish found on some of the beaches.

Legal Protection The Park was established July 1958, under the National Trust Act and revised under the Statute Law, Revised Edition 1965, Chapter 18. New bye-laws were passed in 1986 and are described in the introduction. Dumping of rubbish and liquid wastes is prohibited.

Management Administered by the Bahamas National Trust. Since 1982 there has been a full-time warden, the current warden patrolling the park permanently from a boat. Guide booklets dealing with the fauna and flora of the area have been produced and signs and information boxes have been installed. Two areas near Pasture Cay where all fishing is prohibited have been set aside in an attempt to establish sites where the fish are not afraid of divers (Nelson, 1984).

Recommendations Norman's Cay, just north of Shroud, was recommended for inclusion in the Park as a Park Headquarters, having the best anchorage in the area and being very attractive (Ray, 1961). This and the adjoining cays were privately owned or under lease in the $1960 \mathrm{~s}$. It was also recommended that only traditional sailing vessels should be used in the Park. These recommendations are perhaps now superfluous.

\section{HOGSTY REEF PROPOSED PROTECTED AREA}

Geographical Location $21^{\circ} 40^{\prime} \mathrm{N}, 74^{\circ} 20^{\prime} \mathrm{W}$, in the south-east Bahamas, nearly equidistant from Acklins, Great Inagua and Little Inagua Islands; 40 miles $(64.4 \mathrm{~km})$ from nearest land.

Area, Depth, Altitude $5 \times 9 \mathrm{~km} ; 12$ miles $(19.3 \mathrm{~km}$ ) perimeter; lagoon depth $2-8 \mathrm{~m}$; surrounding water more than $1800 \mathrm{~m}$.

\section{Land Tenure No information.}

Physical Features Hogsty is one of the most exposed and isolated places in the Bahamas. It resembles an atoll, is horse-shoe shaped, and has a distinct peripheral reef and shallow $(6-8 \mathrm{~m}$ depth) lagoon with a pronounced leeward pass on the west side. Depths around the atoll exceed $1800 \mathrm{~m}$ and the surrounding waters are very rough at most times of year (Chaplin, 1962). Wind driven currents move rapidly through the lagoon so there is little difference in water temperature and salinity between the lagoon and the open sea. The climate is dry with an annual rainfall averaging $7.3 \mathrm{~cm}$, most of which occurs between September and December. Tidal range is about $0.6 \mathrm{~m}$. Hurricanes are rare but can have severe effects (Milliman, 1967b).

The atoll supports two small sand cays. South-east Cay $(150 \times 150 \mathrm{~m})$ has a maximum elevation of $2 \mathrm{~m}$ and consists of a sand spit with scattered plant cover. 
North-west Cay $(270 \times 65 \mathrm{~m}), 2$ miles $(3.2 \mathrm{~km})$ to the north, has a maximum elevation of $4 \mathrm{~m}$ and is also vegetated. Geomorphology and bathymetry are discussed in Milliman (1967a) and sediments are described in detail in Milliman (1967b). The eastern lagoon has grass beds near the back-reefs, the rest of the bottom being thinly covered with Thalassia testudinum and Syringodium filiforme. The western lagoon has occasional patch reefs and few grasses or green algae; benthic fauna is less abundant (Milliman, 1967b). There are several wrecks on the atoll including the liberty freighter wrecked in 1963 (Milliman, 1967a).

Reef Structure and Corals Flourishing living reefs occur in some places. About 35 patch reefs are found in the western lagoon (2-8 $\mathrm{m}$ depth), some of which are low-lying coral mounds, others of which are $2-5 \mathrm{~m}$ in height. In the $1960 \mathrm{~s}$, some consisted mainly of one species of coral, such as Montastraea annularis, Agaricia or Diploria, while others had additional genera (Dendrogyra, Favia, Acropora). Alcyonarians, sponges and encrusting red algae were prominent (Milliman, 1967b).

The bank reef is generally flat with a few coral colonies. Behind the windward reef flat it is up to $1 \mathrm{~km}$ wide, whereas behind the leeward peripheral reef it is only a few tens of metres in width. Coral composition was similar in the 1960 s to the inner reef flat, and there were patches of Halimeda, Pennicilus, Udotea and seagrass. The reef flat was largely barren with dead Acropora palmata and abundant algal cover. Coral heads were distributed randomly over it, decreasing in abundance towards the lagoon. The reef flat was delineated by Millepora alcicornis, which was often exposed at low water, and there was no aigal ridge. Abundant coral patches behind the $M$. alcicornis consisted mainly of A palmata, Montastraea annularis, Porites and Agaricia. Encrusting red algae covered much of the bottom; there was abundant brown algae and some green algae. The inner reef flat had more Halimeda and less red algae and the corals there include $P$. porites, Manicina areolata, Montastraea annularis, Siderastrea siderea, Diploria and Dichocoenia (Milliman, 1967b).

On the seaward reef margin, the bottom shoals quickly towards the reef flat. There was almost complete cover of strongly orientated growths of Acropora palmata, with a few Diploria, Montastraea, Porites and Millepora alcicornis. On the leeward seaward margins, the bottom was mainly populated with alcyonarians and Diploria, Siderastrea, $A$ palmata, $P$. astreoides and $M$. alcicornis. There is no evidence of a spur and groove system although there are a few ridges and valleys which are not orientated in any particular direction. The reef front had a gently sloping bottom with scattered heads and encrustations of $A$ cervicornis, $A$ palmata, Porites, Siderastrea, Montastraea and Colpophylia, with abundant encrusting red algae and noncalcareous brown algae (Milliman, 1967b). A steep drop-off occurs at $60 \mathrm{ft}$ (18 m) on the west (Chaplin, 1962).

Noteworthy Fauna and Flora South-east Cay has scattered vegetation including Tourne fortia gna phalodes, Euphorbia mesembrianthemifolia, Portulaca deracea, I pomea of. ruba. North-west Cay has low-lying shrubs and Coconut Palms Cocos nucifera. Strombus gigas, the starfish Oreaster and various pelcypods were common in the eastern lagoon, and $S$. gigas was common on the back reef in the 1960s (Milliman, 1967b).

Sprunt (1984) lists the Sandwich Tern Sterna sandvicensis acuflavidus as the only seabird occupying a colony site since 1960. Chaplin (1962) describes the following additional birds on North-west Cay: a few pairs of Royal Terns $S$. maxima, a single pair of Sooty Terns $S$. fuscata and some Least Terns $S$, albifrons antillarum. Brown Boobies Sula leucogaster nested on South-west Cay and Brown Noddys Anous stolidus and Audubon's Shearwaters Puffinus Iherminieri were seen in the vicinity (Chaplin, 1962). These may nest occasionally but do not maintain long term colonies.

Scientific Importance and Research Hogsty Reef has been considered as one of the few true atolls in the Western Atlantic (another may be Cay Sal Bank) (Higgs in litt., 21.9.84) although this has been disputed. It was visited in the course of a deep water survey of Bahamian reefs with Hydro-Lab (Bunt et al.. 1981) at a site at $22^{\circ} 41^{\prime} \mathrm{N}, 73^{\circ} 51^{\prime} \mathrm{W}$. The area has not otherwise been visited by scientists in almost twenty years (Holowesko in litt., 18.10.84).

Economic Value and Social Benefits An automatic flashing light and an old tower with a rain catchment are situated on North-west Cay (Chaplin, 1962).

Disturbance or Deficiencies The major conservation problem is overfishing by Dominicans who fish there illegally (Attrill in litt. 9.10.84).

Legal Protection None.

Management No information.

Recommendations The area has been recommended as a protected area by the Bahamas National Trust (1984).

\section{INAGUA NATIONAL PARK}

Geographical Location Great Inagua Island; $20^{\circ} 55^{\prime}-21^{\circ} 15^{\prime} \mathrm{N}, 73^{\circ} 37^{\prime}-73^{\circ} 10^{\prime} \mathrm{W}$.

\section{Area, Depth, Altitude $74333 \mathrm{ha} ;-1 \mathrm{~m}$ to $28 \mathrm{~m}$.}

Land Tenure Leased from Crown until 2062 A.D.

Physical Features One of the largest islands in the Bahamas, Great Inagua is rocky, flat, windswept and barren, consisting primarily of saline marsh and seasonally flooded salinas with a few small hills with stunted xerophytic coppice (IUCN, 1982). Sheep Cay lies off the north coast. Coral reefs and mangroves are found to the north-west. Popular descriptions of the island are given by Klingel (1932, 1940, 1959 and 1961).

Reef Structure and Corals Reef development is greatest in the north-west of the island, including the area of Alfred Sound which is included within the Park boundary (Attrill in litt., 9.10.84). A popular description of the reef is given in Klingel (1959). The reefs off Union Creek are reportedly beautiful and do not appear to be threatened 
by human activity (Holowesko in litt., 18.10.84). A submarine cliff, half a mile $(\mathrm{O} .8 \mathrm{~km})$ from shore has been reported (Klingel, 1940). Milliman visited Inagua in 1965 and reported a "Lithothamnion"-type ridge on the eastern side (Anon., 1965). A deep reef study was carried out in the course of Hydro-Lab studies in the Bahamian region (Bunt et al., 1981).

Noteworthy Fauna and Flora Terrestrial vegetation is mainly Button Wood Conocarpus erectus and Black Mangrove Avicennia germinans in flooded areas. Higher ground has mixed broad leaf coppice, Inagua Oak Buceda buceras, Poisonwood Metopium toxiferum, Lignum Vitae Guaiacum sanctum and Gumbo Limbo Bursera simaruba.

$\begin{array}{llrr}\text { There are about } 50,000 \text { Roseate } & \end{array}$ Spoonbills Platalea leucorodia, 200 pairs of Reddish Egrets Dichromanassa rufescens, and approximately 300-400 pairs of parrots Amazona leucocephala bahamensis. Sprunt (1984) describes the seabird colonies of Great Inagua that have been occupied since 1960 . The species known to nest include: the White-tailed Tropicbird Phaethon lepturus catesbyi, Brown Pelican Pelecanus occidentalis, Gull-billed Tern Gelochelidon nilotica aranea, Roseate Tern Sterna dougallii, Least Tern $S$. albifrons antillarum which also nests on Little Inagua, Royal Tern $S$. maxima and the Sandwich Tern S. sandvicensis acuflavidus. The Inagua Island Turtle Pseudemys malonei is endemic to the island, inhabiting the freshwater ponds on the north-west point, outside the Park boundary (Groombridge, 1982; Carr et al., 1982). Hummingbirds are abundant and there is a wide variety of lizards (Klingel, 1932). Wetlands within the Park are described by Scott and Carbonell (1986).

Manta rays, turtles and abundant fish were found on the reefs in the 1930s (Klingel, 1940). The fish fauna is described in Bohlke et al. (1968). Loggerheads Caretta caretta, Green Chelonia mydas and Hawksbill Turtles Eretmachelys imbricata nest on Great and Little Inagua Islands. Green Turtles are most common on Great Inagua and Hawksbills are more frequently found at Little Inagua. Loggerheads have only minor nesting on the islands (Groombridge, 1982).

Scientific Importance and Research No detailed reef surveys have been carried out in the waters off Inagua (Attrill in litt, 9.10.84). Extensive work has been carried out on the flamingos from the base of the Arthur Vernay Camp (IUCN, 1982). Green Turtles Chelonia mydas have been raised experimentally at Union Creek (Anon., 1966) and the colony is still maintained for research purposes.

Economic Value and Social Benefits The protected area is remote and difficult to reach with few facilities for visitors (Anon., 1966). Tourism is not important and Matthew Town is the only settlement on the island which has a population of just over 900 .

Disturbance or Deficiencies Although turtles are totally protected within the Park boundaries, the eggs and adults of all species are taken whenever encountered (Groombridge, 1982). The illegal poaching of flamingos has been virtually eliminated, although there is a problem in the rookeries with introduced wild boars (Sus scrofa) causing damage to the rookeries and great loss of new-born flamingos. Overfishing by the local population occurs because the area of Alfred Sound is the only extensive area of shallow water close to Inagua. Since there is almost no tourism or diving, there are probably few other threats to the reefs (Attrill in litt. 9.10.84).

Legal Protection The Park was established in April 1965 under the National Trust Act. Plants (living or dead), sand, corals, sea fans and gorgonians may not be removed from the Park, and no animals, marine or terrestrial may be harmed or killed. Sport fishing with hook and line is permitted; spearfishing is permitted with a hand held spear or Hawailan sling and there are bag limits for lobster, conch and grouper, rock fish, mutton fish and hog fish. Dumping of rubbish and liquid wastes is prohibited.

Management Administered by the Bahamas National Trust. There are two wardens resident at Matthew Town (IUCN, 1982) who are keeping poaching of Green Turtles and illegal hunting of bird species to a minimum (Holowesko in litt., 18.10.84).

Recommendations The National Parks System proposal recommends the extension of the existing Park boundaries to include the habitats of the endemic Inagua Island Turtle Pseudemys malonei at North-west Point (Holowesko in litt., 18.10.84).

\section{PELICAN CAYS LAND-AND-SEA PARK}

Geographical Location Several small cays off Great Abaco Island, 8 miles $(13 \mathrm{~km})$ north of Cherokee Sound and 10 miles $(16 \mathrm{~km})$ south of Hope Town; includes Pelican Cays, Channel Rock, Gaulding Cay and the southern part of Sandy Cay (between Lynyard Cay and Tilloo Cay).

Area, Depth, Altitude 2100 acres (850 ha).

Land Tenure Crown land, leased to Bahamas National Trust.

Physical Features The area is part of the windward chain reef in the Abaco Cays (see also account for Abaco Reef). The reef at Sandy Cay is small and very beautiful, $12-8 \mathrm{ft}(3.7-2.4 \mathrm{~m})$ deep inside and $30 \mathrm{ft}(9.1 \mathrm{~m})$ deep outside (Stort in litt., 6.12.84).

Reef Structure and Corals The reefs are probably similar to Abaco Reef (Higgs in litt., 21.9.84).

Noteworthy Fauna and Flora The cays are noted for their plant and bird life, underwater caves and fish. Loggerhead Caretta caretta, Green Chelonia mydas and Hawksbill Turtles Eretmochelys imbricata nest sparsely throughout the Abaco archipelago and may occur within the park (Groombridge, 1982). The Sooty Tern Sterna fuscata has maintained a nesting colony since 1960 (Sprunt, 1984).

Scientific Importance and Research No information.

Economic Value and Social Benefits The Shallow-water Fisheries Resources Survey of the Great and Little 
Bahama Banks included a station within the boundaries of the Park which was found to have a high density of fishery resources, including Strombus gigas; this is the only place off the eastern shore of Abaco with high conch densities (Higgs in litt., 21.9.84). The park is one of the most popular diving spots in the Bahamas (Bahamas National Trust, 1984).

\section{Disturbance or Deficiencies No information.}

Legal Protection Established as a Park 26th August 1981, under the National Trust Act. Plants (living or dead), sand, corals, seafans and gorgonians may not be removed from the Park. Animals (marine or terrestrial) may not be injured or killed. Harpoon guns are prohibited. New bye-laws were passed in 1986 and are decribed in the introduction.

Management Administered by the Bahamas National Trust. There is no effective enforcement of the bye-laws but the high density of fishery resources within the Park suggests that residents and visitors respect them (Higgs in litt., 21.9.84).

Recommendations None at present.

\section{PETERSON CAY NATIONAL PARK}

Geographical Location Peterson Cay is $1 \mathrm{~km}$ off Barbary Beach on the south shore of Grand Bahama Island and about $10 \mathrm{~km}$ east of Freeport; $26^{\circ} 33^{\prime} \mathrm{N}$, $78^{\circ} 31^{\prime} \mathrm{W}$.

Area, Depth, Altitude The new boundaries give it a total area of approximately 13000 ha (from H.W.M., Barbary Beach, $2 \mathrm{~km}$ to the "drop-off" and from Grand Lucayan Waterway entrance in the south-west, $6.5 \mathrm{~km}$ to Sharp Rocks Pt in the north-east). The cay is about $8800 \mathrm{sq}$. $\mathrm{m}$; maximum altitude is less than $5 \mathrm{~m}$ above sea level; maximum depth about $50 \mathrm{~m}$ below sea level. The park originally included the cay and the surrounding marine area to within a quarter of a mile.

\section{Land Tenure 99 year crown lease which started in 1968.}

Physical Features Peterson Cay is a low lying aeolian cay of Pleistocene origin and appears to be the heavily eroded remnant of a fossil dune ridge (Palmer, 1985b). The upper intertidal zone, on the main Grand Bahama shoreline, is normally a sloping sand beach but there is an exposed rocky headland at Sharp Rocks Pt. The shore is bordered by casuarina/broadleaf scrub. The lower intertidal habitats are mainly rock platforms separated by sand flats sometimes colonized by algae or marine grasses. Palmer (1985b) gives a brief description of the geology of the area. There is a small Blue Hole near the end of the Lucayan Waterway. Rainfall averages 57 in. (1450 $\mathrm{mm}$ ) a year, with most falling in the summer. Prevailing winds are from the south-east but cold north-east winds may occur in winter. Hurricanes occur rarely, mostly from July to October. Offshore salinity is about $36 \mathrm{ppt}$. Average sea temperatures are about $28^{\circ} \mathrm{C}$ in July and $23^{\circ} \mathrm{C}$ in February. Tides are semidiumal with a vertical range averaging about $1 \mathrm{~m}$ and the dominant off shore current is to the WSW.
Reef Structure and Corals The lagoon (back-reef) has been insufficiently studied but there are many intergrading communities. The sediment substrate has sparse plant cover of Thalassia, Halodule, or Syringodium with algae such as Penicillus and Rhipocephalus. The most conspicuous animal is Oreaster reticulatus and the abundant burrowing fauna includes actiniarians, annelids, molluscs, crustaceans and echinoids (Meoma, Mellita). In areas of dense plant cover (where the sediment is fixed by rhizomes) there are Thalassia beds with some Syringodium and algae such as Penicillus, Rhipocephalus, Halimeda, Udotea, Avrainvillea. Conspicuous epifauna includes the molluscs Pinna carnea, Strombus spp., Cassis spp., echinoderms Oreaster, Tripneustes, Clypeaster and occasional small sponges and corals. Rock substrate is mostly dominated by algal mat (Lawrencia sp?, Cladophora sp, and others) and gorgonians (Plexaura, Eunicea, Plexaurella, Muricea, Pseudopterogorgia, and Pterogorgia). The dominant epifauna includes Oreaster, Clypeaster, and a sponge (Spheciospongia?). In shallow areas (less than $3 \mathrm{~m}$ ), the bivalve Brachidontes modiolus and the actiniarians Bunodosoma and Stichadactyla are conspicuous.

Submerged coral reefs occur $1-2 \mathrm{~km}$ offshore. The $1 \mathrm{~km}$ wide back-reef lagoon is less than $5 \mathrm{~m}$ deep. Four main reef zones can be recognized: a) Shallow $(1-5 \mathrm{~m})$ reef is well-developed between the Lucayan Waterway and Peterson Cay and is dominated by Mille pora complanata, Acropora palmata, and A cervicornis, though Diploria, Montastraea, and Agaricia are also abundant; sand-floored scour channels cut the reef at irregular intervals. This type of reef is unusually and attractively developed about $200 \mathrm{~m}$ west of the cay. b) Medium depth $(10-15 \mathrm{~m})$ reef consists of isolated coral heads up to $4 \mathrm{~m}$ high, separated by wide areas of sand platform. c) Deep (15-25 m) reef is 3-6 $\mathrm{m}$ high with sand-floored caves and canyons running perpendicular to the shore. d) "Edge-of-ledge" $(30-50 \mathrm{~m})$ reef is less than $2 \mathrm{~m}$ high, and also has sand-floored valleys running perpendicular to shore. Between (a) and (b) is an alga/gorgonian-dominated rock platform; between (c) and (d) is an alga/sponge-dominated sand platform.

Noteworthy Fauna and Flora Most of the shoreline of Barbary Beach and a tiny area of Peterson Cay have dune vegetation dominated by Casuarina equisetifolia, Uniola paniculata, Hymenocallis arenicola and Coccoloba uvifera. Rocky shores are characterized by Rhachicallis americana, Borrichia arborescens, Conocarpus erectus and Sesuvium portulacastrum. Sheltered corners of bays along Barbary Beach have some mangrove development with Avicennia germinans, Laguncularia racemosa and Conocar pus erectus.

Commercial species occurring in the Park include Nassau Grouper Epinephelus striatus, Spiny Lobster Panulirus argus and Queen Conch Strombus gigas. Sharp Rocks is the type locality of Epitonium sp. nov., a gastropod which feeds on anemones (Robertson, citation unknown). Two other species of Epitonium also occur on anemones here. Peterson Cay is a nesting site for terns and other sea birds. A decomposed Caribbean Manatee Trichechus manatus was found on Barbary beach (citation unknown), and a live one was reliably reported in the Lucayan Waterway about 1976. 
Scientific Importance and Research The Park has a rich and diverse marine fauna and flora and is ideally located for scientific research, particularly on coastal plant communities and adaptations. A geographical and biological survey of the area was carried out in 1985 by members of the Bahamas National Trust and volunteers on Operation Raleigh, using aerial photographs, which will culminate in the production of an accurate large-scale map. A pioneer mariculture operation (Tilapia), located in the Lucayan Waterway near the Western boundary of the Park, has existed since 1984 and may be expanded.

Economic Value and Social Benefits The park supports populations of commercially important Grouper, Spiny Lobster, Conch. Tourists and locals visit the area to snorkel, SCUBA dive, and picnic on Peterson Cay and Barbary Beach. There is considerable educational value as the Park is less than $\mathbf{3 0}$ minutes from Freeport by car or boat.

Disturbance or Deficiencies Fishing has depleted populations of grouper, Hogfish, and Spiny Lobster. Conch have become rare due to overfishing and "Whelks" (Cittarium) have reportedly disappeared from the Cay. Helmet Shells (Cassis) have been over-collected which may affect the populations of Tripneustes and other echinoids on which they feed. Oreaster are commonly collected for souvenirs. The area of Thalassia cover is reported to have greatly decreased. The reefs show signs of anchor and other damage. Sand has been removed for construction purposes from dune areas along Barbary Beach. Silting from the dredged Lucayan Waterway appears to have had minimal effect (dominant currents flow East to West).

Legal Protection Designated the Peterson Cay Land-and-Sea Park in 1968, the area was reclassified as a National Park in 1985. Bye-laws prohibit all fishing and collecting within Park Boundaries without written permission from the Bahamas National Trust.

Management A programme was initiated in January 1985 to properly establish the National Park which is administered by the Bahamas National Trust. Signs have been erected on the cay and others are to be installed at various localities at the boundary. A publicity campaign has been initiated and information displays are being placed on the cay and others will be placed at an access point on Barbary Beach. Picnic facilities and a nature trail are under construction on the Cay.

Recommendations The bye-laws need updating to incorporate proposed boundary extensions. A permanent, fully equipped warden should be housed nearby. Strong enforcement of bye-laws is required. A complete scientific inventory and continuous assessent of impact is necessary. An underwater trail will be created west of the Cay. Mooring buoys will be placed on the shallow reef immediately west of Peterson Cay to mark the locations of underwater nature trails and to reduce damage to coral from anchors. The publicity campaign is to be continued and an educational package for schools will be prepared. There are plans to plant coconut palms along the beach.

We are very grateful to J. Worsfold, coordinator at the Peterson Cay National Park, for compiling this account.
SAN SALVADOR FRINGING REEFS PROPOSED NATIONAL RESERVE

Geographical Location The proposed reserve includes the shelf, seaward to the wall, from Riding Rock Inn south, around French Bay, and then east and north to include the mouth of Pigeon Creek and Hinchinbroke Rocks. The area includes High and Low Cay located opposite the mouth of Pigeon Creek in the southern part of Snow Bay on the south-east end of San Salvador. A second section includes the outer perimeter of Grahams Harbor, including Green Cay, White Cay, Catto Cay, and Gaulin Cay, with their adjacent fringing reefs.

Area, Depth, Altitude The area and elevation of the cays on the perimeter of Grahams Harbor are as follows: Green Cay - 60 ha, $7.7 \mathrm{~m}$ above sea-level; White Cay 45 ha, $13 \mathrm{~m}$ above sea-level; Gaulin Cay -20 h, $3.04 \mathrm{~m}$ above sea-level; Catto Cay - $15.6 \mathrm{ha}, 7.5 \mathrm{~m}$ above sea-level. The area and elevation of the cays surrounding Snow Bay are as follows: Low Cay - $100 \mathrm{ha}, 5.9 \mathrm{~m}$ above sea-level; Middle Cay - 22.5 ha, $6 \mathrm{~m}$ above sea-level; High Cay - 137 ha, $18.2 \mathrm{~m}$ above sea-level. The entire reserve, including the $4 \mathrm{sq} . \mathrm{km}$ in Grahams Harbor, is $34 \mathrm{sq.} \mathrm{km}$.

\section{Land Tenure Unknown.}

Physical Features The offshore cays at Snow Bay and Grahams Harbor represent erosional remnants from the Pleistocene which were formerly extensive aeolian ridges (Teeter, 1984 and 1985). Gaulin Cay has erosional features such as palmetto stumps, and rhizocretions are found on other cays (Adams, 1983). The back-reef and reef crest are accessible for most of the year because of their location in the lee of the island. French Bay is accessible during calm periods only, since certain wave length patterns can bend around the island into the Bay causing rough seas and high turbidity. The fringing reef arcund Grahams Harbor is probably the least accessible as it is exposed during normal trade winds and is also affected by north and north-west winds which generally occur during the passage of cold fronts. Ambient temperatures range from $19^{\circ} \mathrm{C}$ in winter to $25^{\circ} \mathrm{C}$ in summer. Annual rainfall varies from $508 \mathrm{~mm}$ to $1524 \mathrm{~mm}$. The rainy season is usually between May and October.

Reef Structure and Corals Reef development falls into two categories: massive, linear wave-resistant features which have developed in the breaker zone at the edge of the shelf extending around the island; and structures of varied configuration and height which have developed in the zone between the reef barrier and the strandline (Hinman, 1983).

The Fernandez Bay shelf, from $400 \mathrm{~m}$ to $1500 \mathrm{~m}$ wide, slopes gradually from the shoreline to $14 \mathrm{~m}$ depth at the abrupt drop-off that descends at a $60^{\circ}$ angle. Kissling and Bray (1980) describe the innermost platform of this bay as being relatively barren rock encrusted with scattered, low colonies of Siderastrea radians, Favia fragum, Millepora complanata and a few sponges at depths usually less than two metres. Continuing outward to five metres depth, many small patch reefs are encountered with Montastraea annularis and Porites astreoides. Agaricia agaricites, Millepora complanata, P. porites, Dichocoenia stokesii, Eusmilia fastigiata, Diploria spp., and Siderastrea spp. are also found. Two 
patch reefs have been described in detail. Telephone Pole Reef is dominated by Acropora cervicornis; isolated fronds of $A$ palmata, small mounds of $P$. asteroides, $S$. radians, Montastraea annularis and Diploria spp. and non-coralline reef inhabitants are also present (Hinman, 1983). Approximately 100 yds $(90 \mathrm{~m})$ north of Telephone Pole Reef is Snapshot Reef, consisting of dome-shaped colonies of $M$. annularis. This is one of the few communities of the crinoids Nemaster rubiginosa and $N$. discoidea. $100 \mathrm{~m}$ seaward of the patch reefs there are assemblages of octocorals, sponges, corals and anemones. The remaining $50 \mathrm{~m}$ slopes gently to the top of the terrace and appears barren, although it supports a community of sea cucumbers, garden eels and sand dollars. The escarpment begins in $14 \mathrm{~m}$ of water, at the edge of the platform, and descends with terraces to $50 \mathrm{~m}$, after which the vertical wall is visible. The escarpment is dominated by $M$. annularis, $M$. cavernosa, Agaricia undata, A agaricites, A lamarcki, Helioceras cucullata, Mussa angulosa, Eusmilia fastigiata, Millepora alcicornis and species of Mycetophyllia and Madracis (Kissling and Bray, 1980).

Unlike Fernandez Bay, French Bay has extensive protected seagrass beds located behind the fringing reef. The fringing reef crest consists mainly of Acropara palmasa, Montastraea annularis and $A$ cervicornis. This reef is difficult to visit because of prevailing winds, and is accessible only during calm weather and moderate north-west winds.

Grahams Harbor reefs, and specifically those adjacent and north of Gaulin Cay, are some of the most spectacular on the island. One-hundred and twenty metres behind the reef crest there are lenticular reefs largely of $A$ palmata filled in with $A$ cervicornis, $P$. porites, $D$. clivosa and Agaricia agaricites. The reef crest has $A$ palmata, with narrow channels extending into the seaward slope, forming a sea fan surf zone with Gorgonia ventalina oriented to the current swells and low, flattened $D$. clivosa pressed against the substrate (Dustan, pers. comm., 1985)

Noteworthy Fauna and Flora The Rock Iguana, Cyclura rileyi, is rarely sighted on San Salvador proper, but is abundant on Gaulin Cay in Grahams Harbor and on High Cay in Snow Bay (Diehl et al., 1986). The cays in Grahams Harbor and those in Snow Bay are rookeries for several sea birds; Sooty Terns, Sterna fuscata, Bridled Terns S. anaethetus, Noddy Terns Anous sp., and Tricoloured Herons (Hydranassa tricolor) breed on Gaulin Cay; Brown Boobies (Sula leucogaster) and Magnificent Frigatebirds (Fregata magnificens) nest on White Cay, and High Cay is a nesting area for Noddy Terns (Miller pers. comm., 1985).

In Fernandez Bay the groupers in both the back-reef and reef crest areas seem almost tame, probably due to past feeding by divers.
Scientific Importance and Research Surveys have been carried out in Fernandez Bay by Kissling and Bray (1980), Pierce and Curran (1986) and Chambers and Curran (1986). Recent studies of the reefs north of Gaulin Cay by Dustan (pers. comm., 1985) have dealt with reef vitality, bio-optics, hydrogenetics of coral reefs, and bacteriology of reef corals and these reefs are used by students from the College Center of the Finger Lakes (CCFL) Bahamian Field Station situated on San Salvador. Ornithologists at the Field Station are studying the nesting behaviour of various birds on the cays.

Economic Value and Social Benefits The reefs around San Salvador, particularly Fernandez Bay, French Bay and Grahams Harbor, are dive localities for guests at the Riding Rock Inn and for students and researchers from the CCFL Bahamian Field Station. Telephone Pole Reef and Snapshot Reef in Fernandez Bay are visited regularly.

Disturbance or Deficiencies The $A$ cervicornis corals which form a major part of Telephone Pole Reef have died over the past five years (Pierce and Curran, 1986). Dustan (pers. comm., 1985) found a variety of diseased corals with Black and White Band Diseases among others; $M$. annularis, $D$. strigosa and $P$. asteroides had the former and $A$ palmata and $A$ cenvicornis the latter. Many coral colonies have undergone a reduction in their living tissue surface area as a result of sediment damage, with subsequent algal overgrowth.

The sea urchin Diadema antillarum has been absent from the reefs since $1983 ; 50-100$ have been found in the shallow rocky subtidal environment in French Bay in 0.5-7.0 $\mathrm{m}$ of water (Adams, pers. comm.). As suggested by Dustan (pers. comm.) there could be a correlation between the absence of this herbivore and the algal-sediment problem on the reefs, but this phenomenon could also be related to the mass mortality which took place over much of the Caribbean in 1983 (Lessios et al., 1984).

\section{Legal Protection None.}

Management The CCFL Bahamian Field Station and the Riding Rock Inn's dive shop have co-operated to eliminate the collecting of specimens by sport divers and students in an endeavour to protect the reefs from the impact of divers.

Recommendations The area has been proposed as a National Reserve by the Bahamas National Trust (1984). It is recommended that permanent moorings be placed off the reefs in Fernandez Bay so that divers entering the water from boats do not land directly on the reefs. Further studies should be made on the impact of divers and their effects, if any, on the health of the reefs.

We are extremely grateful to Dr D.T. Gerace for compiling this account. 


\section{BARBADOS}

\section{INTRODUCTION}

\section{General Description}

Barbados, an independent nation within the British Commonwealth, is situated $150 \mathrm{~km}$ east of the Lesser Antilles, and has an area of approximately $430 \mathrm{sq} . \mathrm{km}$ (ca $30 \times 14 \mathrm{~km}$ ) and an elevation of $339 \mathrm{~m}$. It is covered mainly by Pleistocene limestone, and has a regular coastline with no deep indentations or offshore islands. The coast consists largely of long stretches of sand beach except in the north and south where cliffs rise straight from the sea. The north-east trade winds predominate and blow almost constantly, the windward and leeward sides of the island showing marked differences in wave action and exposure. The period September to December is marked by increased cloud and rainfall. The island is in the hurricane belt. Average annual precipitation varies from $1100-1250 \mathrm{~mm}$ in the coastal regions to $1750-2120 \mathrm{~mm}$ in the higher, interior parts (James et al., 1977). Seawater temperatures off the west coast range from $29.5^{\circ} \mathrm{C}$ in the autumn to $26.0^{\circ} \mathrm{C}$ in February (Sanders and Stevens, 1973). The island is situated in the North Equatorial Current. Salinity is variable and ranges from 32 to $36 \mathrm{ppt}$; low salinity water masses drifting northward around Barbados are believed to come from the Amazon and Orinoco River systems. Tides are of the mixed semidiurnal type with two highs and two lows per day. Mean tidal range has been measured at $0.7 \mathrm{~m}$; diumal range is $1.1 \mathrm{~m}$. The geology of the island and reefs is described by James et al. (1977). Groundwater discharge along the west coast is described by Lewis (1985).

Actively growing reefs are restricted to the west, or leeward coast, between Bridgetown in the south and Shermans, 10 miles $(16 \mathrm{~km})$ to the north. A gently sloping shelf extends about $300 \mathrm{~m}$ seaward of the west coast to a depth of $10 \mathrm{~m}$. Fringing reefs form on this, mainly round headlands, as narrow segments, semi-circles or curved strips and are found intermittently between Freshwater Bay and Smitons Bay, just north of Shermans. They are generally poorly developed, consisting of reef rock and coral debris covered with Lithothamnion and sparse colonial growths of Porites porites, $\boldsymbol{P}$. astreoides, Siderastrea siderea and Millepora alcicornis. Colonies are more abundant towards the reef front which generally terminates in a series of spurs constructed almost entirely of $P$. porites, $P$. astreoides and $M$. alcicomis. An area of more prolific coral growth is found where the sea floor slopes more (e.g. between Speightstown and Lower Carlton $(3 \mathrm{~km}$ to the south) and between Alleynes Bay and Sandy Bay). Lewis (1960) noted two coral communities in such areas: Madracis asperula mixed with $P$. porites in shallower water and a mixed community of over 20 species in deeper water. Between Payne's Bay and Batts Rock Bay ( $3 \mathrm{~km}$ to the south), and north of Six Men's Bay, fragile branching corals decrease and coral heads predominate (notably Montastraea annularis, $M$. cavernosa and $S$. siderea). Despite prolific growth there is no indication of reef formation except possibly for massive colonial developments of $\boldsymbol{M}$. annularis opposite Freshwater Bay (MacIntyre, 1968). Although Acropora palmata was common on the fringing reefs in the Pleistocene and large tracts were even reported on the south coast in 1918 (Nuttings, 1919), this species has virtually disappeared as a reef builder (Lewis, 1984). Possible causes include successional processes, hurricane damage and land erosion.

At the edge of the shelf, the sea-bed falls regularly to about $20 \mathrm{~m}$ depth into a narrow trough paralleling the shore (Stearn et al., 1977). Seaward, a submerged barrier reef, $12-20 \mathrm{~m}$ deep and up to $100 \mathrm{~m}$ wide, runs parallel to the coast, $600-800 \mathrm{~m}$ off shore, extending from north to south and possibly connecting with a barrier reef along the south coast. This is the only submerged barrier in the Caribbean known to sustain prolific coral growth (Ott, 1975). Near river mouths the barrier is interrupted by roughly circular hollows, up to $100 \mathrm{~m}$ in diameter and $34 \mathrm{~m}$ deep (Steam et al., 1977). A second fossil submarine ridge runs parallel with this on the seaward side at 65-70 m depth (MacIntyre, 1967). Zonation and species composition of the barrier reef are described by Lewis (1960) and Macintyre (1968) and the zonation of north Bellairs Reef has been described by Stearn et al. (1977); these are summarized in the account on the Barbados Marine Reserve.

On the south coast, rubble banks and calcareous rock support only widely scattered coral patches. The reefs along the eastern and northern coasts are composed of dead coral rock supporting only secondary growths of coral. On the east coast, dead reefs extend several hundreds of metres from the shore and drop sharply to a sand and rubble bottom at 50-60 ft (15-18 m) depth. Reef flats $100-200 \mathrm{~m}$ wide fronting sandy beaches are composed of calcareous rock, one foot $(30 \mathrm{~cm})$ deep at low tide and exposed to heavy wave action. A few living corals are found on the flats ( $P$. divaricata, $P$. astreoides, $S$ radians and $F$ avia fragum). On the drop-off, less than $50 \%$ of the surface area is covered with living coral. Millepora forms stoutly branching colonies; on vertical sides facing the prevailing winds encrusting and flattened corals of Montastraea, Siderastraeo and Diploria are found (Lewis, 1960).

Lewis (1961) lists 33 hermatypic corals from Barbados, the dominant reef-builder being $M$. annularis; Sander (1973) mentions that 36 scleractinians have been recorded. A brief summary of work carried out by the Bellairs Research Institute of McGill University is given by Sander (1973) and a summary is given in the account for the Barbados Marine Reserve.

According to Halewyn and Norton (1984), Audubon's Shearwater Puffinus Iherminieri is the only seabird known to have nested on Barbados in recent times; breeding records for this species date from the nineteenth century, when it was being actively exploited, and it is thought likely to be now extinct. Small numbers of Hawksbill Turtles Eretmochelys imbricata are known to nest and Green Chelonia mydas and Loggerhead Turtles Caretta caretta have been recorded, most nesting occuring on the east coast (Bacon et al., 1984). Wetlands are discussed in Scott and Carbonell (1986) who note that there are several small permanent and seasonal brackish to saline coastal lagoons and three patches of mangroves. 


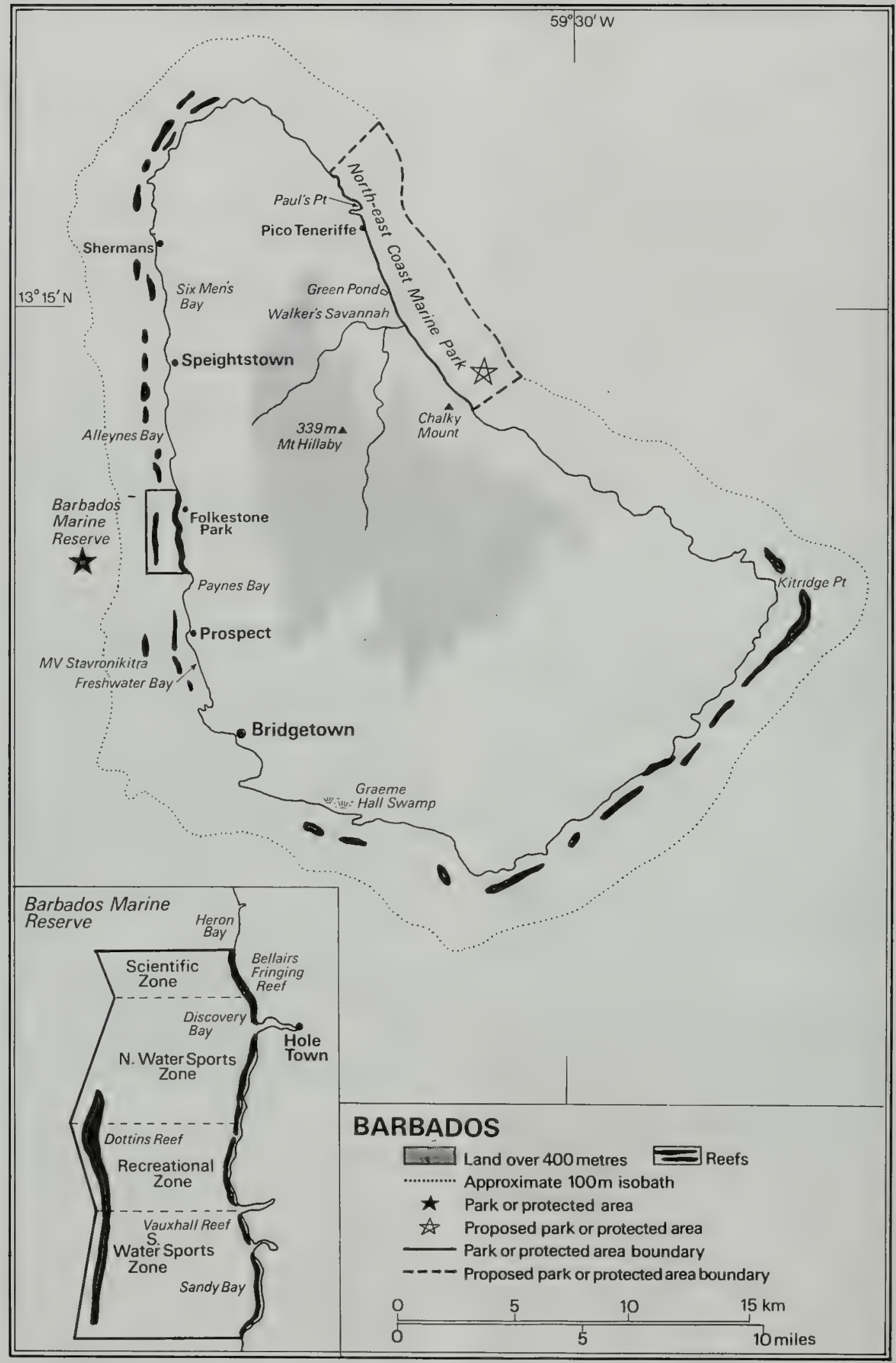




\section{Reef Resources}

The main marine resources are sea urchins, Queen Conch Strombus gigas, spiny lobster Panulirus argus, black coral and flying fish and there is a small seasonal fishing industry which is growing in importance. The sandy beaches are a major tourist attraction and there are popular diving sites on the west coast (Wood, 1984). Black corals are collected for the souvenir industry (Rogers, 1985). The recreational value of the Barbados Marine Reserve is discussed in the following account. A summary (in map form) of the important marine resources of Barbados is given in ECNAMP (1980).

\section{Disturbances and Deficiencies}

Hurricane Allen had a major impact on the northern Bellairs Fringing Reef in 1980. A year later, recolonization was taking place and Agaricia agaricites had become the dominant coral (Mah and Steam, 1985). The sea urchin Diadema antillarum suffered heavy mortality, averaging $93.2 \%$, in 1983 , the cause of which (probably a water borne pathogen) is discussed by Hunte et al. (1986).

With a population approaching 300000 , Barbados is one of the most densely populated islands in the world and as a result human impact on coastal and marine habitats has been noticeable. Prior to European settlement in the 17th century, the west coast was covered with deciduous and semi-deciduous tropical forest which reached the sea, with mangrove forest in the lagoon areas. Now mangrove is only found on the south coast at Graeme Hall Swamp. Rapid coastal development has been taking place recently, especially south of Speightstown. Combined with the increase in tourism, this could have a long term effect on the reefs and beaches (Bird, 1977). Rogers (1985) reports reef stress from sewage, thermal effluent, dredging, fishing with explosives and an increase in suspended matter nitrates and phosphates. Tomascik and Sander (1985) describe increased nutrient enrichment in coastal waters and suggest that this is due to the addition of fertilizers to the soil and to pollution accompanying urban development; Lewis (1985) discusses the role that groundwater seepage may play in this. The coastline of Barbados has been subject to much erosion (Bird, 1977), mainly due to sea level rise and winter storms, although pollution leading to coral reef deterioration may be a contributory factor.

\section{Legislation and Management}

The National Conservation Commission, formerly the Parks and Beaches Commission, is responsible for parks and reserves. The Marine Areas (Preservation and Enhancement) Act of 1976 provides the legal basis for the establishment of coastal and marine parks and reserves. The Barbados Marine Reserve is described in the following account. The collection of turtles is subject to a number of controls (Bacon et al., 1984).

A Coastal Conservation Project was started by the Government in 1983, with a diagnostic/pre-feasibility study being carried out by a team of Canadian consultants, funded by the Inter-American Development Bank (IADB) (Proctor and Redfern International Ltd, 1984). Since then, a Coastal Conservation Conservation
Project Unit has been maintained, whose major functions are to monitor coastal change and to advise on any new development in the coastal zone, and on sea defence measures. In 1986 a quantitative survey of the fringing reefs on the west and south coasts will be carried out with a view to establishing baseline monitoring data to be used for future comparisons. Following a further study in 1987, a planned approach to effective sea defence structures will be executed (Cambers in litt., 9.12.85).

\section{Recommendations}

A Park has been proposed for the north-east coastline, to stretch from Archers Bay, St Lucy, on the north coast, to Ragged Point, St Philip, on the east coast. This would cover 5000 ha and stretch $2 \mathrm{~km}$ inland, but would not include the marine environment; this coast however does not have living reefs (Wood, 1984). Additional areas on the west and south coasts have been proposed for protection (Sander, 1972) but have not been followed up. Improved legislation is required for all wrecks round Barbados, and spearfishing around the island should be monitored (Cotter, 1982). Barbados has been included on the preliminary list of potential marine sites for inclusion in a Lesser Antillean Biosphere Reserve (Goodwin, 1985).

\section{References}

- cited but not consulted

Anon. (1983). Minutes of the XVII AGM Caribbean Conservation Association (Business Meeting 1st Sept. 1983), Kingston, Jamaica.

Bacon, P., Berry, F., Bjorndal, K., Hirth, H., Ogren, L. and Weber, M. (Eds) (1984). Proceedings of the Western Atlantic Turtle Symposium, 17-22 July, 1983, San Jose, Cosia Rica, Vol 3. University of Miami Press, Florida.

Bird, J.B. (1977). Beach changes and recreation planning on the west coast of Barbados, W.I. Geographica Polonica 36: 31-41.

Bird, J.B., Richards, A. and Wong, P.P. (1979). Coastal subsystems of western Barbados, West Indies. Geografiska Annaler 61(3-4): 221-236.

Bray, R.D. (1981). Size variation of the rubble-dwelling ophiuroid Ophiocoma echinata of Barbados, West Indies. Proc. 4th Int. Coral Reef Symp., Manila 2: 619-621.

Cotter, P.J. (1981). The establishment of the Barbados Marine Reserve. Proc. 4th Int. Coral Reef Symp., Manila 1: 332 (abstract of 25 page manuscript).

Cotter, P.J. (1982). Barbados New Marine Reserve. Parks 7(1): 8-11.

ECNAMP (1980). Barbados. Preliminary Data Atlas. Survey of conservation priorities in the Lesser Antilles. Eastern Caribbean Natural Area Management Program.

Emery, A.R. (1972). Eddy formation from an oceanic island: ecological effects. Caribb. J. Sci. 12: 121-128.

Goodwin, M.H. (1985). Characterization of Lesser Antillean Regional Fisheries. Island Resources Foundation. $48 \mathrm{pp}$.

James, N.P., Stearn, C.W. and Harrison, R.S. (1977). Field Guide Book to Modern and Pleistocene Reef Carbonates, Barbados W.I. 3rd International Symposium on Coral Reefs, The Atlantic Reef Committee, University of Miami, Fisher Island. 
Halewyn, R. van, and Norton, R.L. (1984). The status and conservation of seabirds in the Caribbean. In: In: Croxall, J.P., Evans, P.G.H. and Schreiber, R.W. (Eds), Status and Conservation of the World's Seabirds. ICBP Technical Publication No. 2, Cambridge.

Hunte, W., Côté, I. and Tomascik, T. (1986). On the dynamics of the mass mortality of Diadema antillarum in Barbados. Coral Reefs 4(3): 135-139.

Lewis, J.B. (1960). The coral reefs and coral communities of Barbados, West Indies. Can. J. Zool. 38: 1133-1145.

Lewis, J.B. (1961). Scleractinia of Barbados. J. Barbados Mus. \& Hist. Soc. 28: 11-12.

Lewis, J.B. (1964/65). A preliminary description of some marine benthic communities from Barbados, West Indies. Can. J. Zool. 43: 1049-1074.

Lewis, J.B. (1978). An annotated bibliography of research on contemporary and fossil reefs in Barbados, West Indies. McGill University Marine Sciences Dept., Rep. No. 30, 63 pp.

Lewis, J.B. (1984). The Acropora inheritance: a reinterpretation of the development of fringing reefs in Barbados, West Indies. Coral Reefs 3(3): 117-122.

Lewis, J.B. (1985). Groundwater discharge onto coral reefs, Barbados. Proceedings of the Fifth International Coral Reef Congress, Tahiti, 1985 6: 477-481.

MacIntyre, I.C. (1967). Submerged coral reefs, west coast of Barbados, West Indies. Can. J. Earth Sci. 4(3): 461-474.

MacIntyre, I.G. (1968). Preliminary mapping of the insular shelf off the west coast of Barbados, W.I. Carib. J. Sci. 8: 95-100.

Mah, A.J. and Stearn, C.W. (1985). Changes produced by a hurricane on a fringing reef (Barbados). Proceedings of the Fifth International Coral Reef Congress, Tahiti, 1985 2: 232.

Nuttings, C.C. (1919). Barbados-Antigua expedition. Univ. Iowa Stud. Nat. Hist. 8: 1-274.

Ott, B. (1975). Community patterns on a submerged barrier reef at Barbados, West Indies. Int. Rev. der ges. Hydrobiologie 60(6): 719-736.

Proctor and Redfern International Ltd (1984). Coastal Conservation Project, Diagnostic and Pre-feasability Reports. Prepared for the Government of Barbados, Ministry of Housing and Lands.

-Sander, F. (1972). Suggestions for marine parks in Barbados. Proc. CCA Ann. Gen. Meet. St. Kitts.

Sander, F. (1973). Canadian tropical research in the West Indies. Nature 244: 201-202.

Sander, F. and Stevens, D.M. (1973). Organic productivity of inshore and offshore waters of Barbados: a study of the island mass effect. Bulletin of Marine Science 23: 771-792.

Scott, D.A. and Carbonell, M. (1986). A Directory of Neotropical Wetlands. IUCN, Gland and Cambridge.

Stearn, C.W., Scoffin, T.P. and Martindale, W. (1977).

Calcium carbonate budget of a fringing reef on the west coast of Barbados. Bull. Mar. Sci. 27(3): 479-510.

Tomascik, T. and Sander, F. (1985). Effects of eutrophication on reef building corals. Part 1. Growth rates of a reef building coral Montastraea annularis Ellis and Solander. Mar. Biol. in press.

Wood, J. (1984). Proceedings of the Workshop on Biosphere Reserves and Other Protected Areas for Sustainable Development of Small Caribbean Islands, May 10-12. Virgin Islands National Park, Caneel Bay, St. John, U.S. Virgin Islands. U.S. Dept of Interior, National Park Service, Southeast Regional Office, Atlanta, Georgia: 190 pp.

\section{BARBADOS MARINE RESERVE}

Geographical Location West coast of Barbados between Sandy Bay and Heron Bay, extending $1 \mathrm{~km}$ off shore; $13^{\circ} 10^{\prime} \mathrm{N}, 59^{\circ} 40^{\prime} \mathrm{W}$. Twelve $\mathrm{km}$ north of Bridgetown, near the village of Holetown.

Area, Depth, Altitude $250 \mathrm{ha} ;-50$ to $0 \mathrm{~m}$.

\section{Land Tenure Government owned}

Physical Features The Reserve includes two spur and groove fringing reefs, the Bellairs Fringing Reef and Vauxhall Reef, contained within a "beach cell" which is a limestone headland bounded by two sandy bays, Discovery Bay in the north and Sandy Bay in the south (Bird et al., 1979). The headland is a submerged Pleistocene deposit usually detectable to a depth of $12 \mathrm{~m}$. The reefs extend approximately $300 \mathrm{~m}$ from shore. A gently sloping prolific coral terrace extends to a depth of $25 \mathrm{~m}$ and then drops rapidly to a silty trough at $40-45 \mathrm{~m}$. Further from shore there is a nearly continuous bank reef, Dottins Reef, with a minimum depth of $12 \mathrm{~m}$ and average width of $75 \mathrm{~m}$; the seaward slope drops to a sandy plain at $50 \mathrm{~m}$ depth. The northern extension of the bank ends abruptly where an old stream bed cuts through the structure. On the barrier reef, sediment varies considerably at any depth, probably determined by microhabitat rather than depth. Currents are strongest on the ridge top and weakest on the inner slope, often showing large variations in any one day, but generally flowing in a southerly direction (Emery, 1972). Salinity varies from 33 to $36 \mathrm{ppt}$; oxygen from 4.2 to $5.0 \mathrm{ml} /$ litre and temperature from 26 to $29^{\circ} \mathrm{C}$ (Ott, 1975).

An artificial reef, the $118 \mathrm{~m}$ long $M . V$. Stavronikitra, lies $6 \mathrm{~km}$ south of the main Reserve, $1 \mathrm{~km}$ off shore near the village of Prospect. It is resting in $40-43 \mathrm{~m}$ of water with the upper decks $20-25 \mathrm{~m}$ below the surface. Another small boat has been sunk just seaward of the Vauxhall Reef as a shallower wreck dive site at $10 \mathrm{~m}$ depth.

Reef Structure and Corals The general structure of the west coast fringing reefs has been described by Lewis (1960), Macintyre (1968) and Stearn et al. (1977) and a useful summary is given in James et al. (1977). Thirty-five coral species have been found in the nearshore waters. Nine distinct zones have been identified. The sandy rubble zone is composed of coral fragments from the fringing reef and the more seaward zones. Seaward of the rubble zone is a $M$. mirabilis zone followed by monospecific stands of $A$ cervicornis. Beyond this, the mushroom coral zone has a great diversity of coral species, mainly from the genera Diploria, Agaricia, Siderastrea, Montastraea, Meandrina, Mycetophyllia, Colpophyllia and Manicina. Dominant colonial species of high energy areas include Palythoa mammilosa and Diploria strigosa in the swash zone, Favia fragum and Porites astreoides on the crest zone, and $P$. astreoides, $P$. porites, Agaricia agaricites, Siderastrea siderea, Millepora squamosa and $M$. complanata on the coalesced-spurs zone. The deeper spur and groove zone is more diverse, with the addition of Montastraea annularis, $M$. cavernosa, Madracis mirabilis and massive colonies of D. strigosa, D. labyrinthiformis and Dendrogyra cylindrus to the above community. Acropora palmata, once the main component of the nearshore reefs, is quite scarce today. 
The leading edges of the buttress generally contain large stands of $P$. porites on the southern sides of the reef.

The bank reef has a two sided zonation pattern reflecting seaward exposure and is described by Ott (1975) and Stearn et al. (1977). The inner slope or leeward side of the bank has a zonation pattern dominated from $40-45 \mathrm{~m}$ by $S$. siderea, from $25-40 \mathrm{~m}$ by Montastraea annularis and in the top ten metres by $\boldsymbol{M}$. cavernosa. The ridge top is an extremely diverse area with large Demospongiae, Xestospongia and Verongia, tall colonies of several species of Octocorailia and massive coral heads of Montastraea, Diploria and Siderastrea. The outer slope has a mixture of large colonies of $M$. annularis, $M$. cavernosa and $S$. siderea from the ridge top to a depth of $20 \mathrm{~m}$. Below this zone shingle-like plates of A lamarcki are quite common. The base of the outer slope, between 40 and $50 \mathrm{~m}$, is dominated by Demospongiae, Antipatharia and Octocorallia and a number of corals including $M$. cavernosa, Dichocoenia stokesii and Stephanocoenia michelinii.

Noteworthy Fauna and Flora The Reserve covers a wide range of marine habitats including two distinct reef types, large sandy bays and deep silty environments, and consequently has a wide range of faunal forms. The fish fauna of the islands numbers some $400-500$ species, many of which are reef-dwellers. Small populations of the spiny lobster, Panulinus argus, and the Hawksbill Turtle Eretmochelys imbricata have been observed in the area. Green Turtle Chelonia mydas and Leatherback Dermochelys coriacea may also occur here. The original taxonomic descriptions of many Caribbean black corals, Antipatharia, were made from specimens collected in the late 1890 s from areas now within the Reserve. The ophiuroid fauna is described by Bray (1981). One of the two remaining red mangrove areas on the island is located on the terrestrial edge of the Reserve near the first English settlement of Holetown.

Scientific Importance and Research The Marine Reserve staff are responsible for a continuing reef monitoring programme. The Bellairs Research Institute of McGill University is located by the Reserve Headquarters and has carried out pioneer reef research since the late 1950 s, with some 300 publications listed by Lewis (1978). Nearly 100 advanced graduate projects have been conducted through research facilities on the west coast. Current research includes: an environmental assessment of corals, fish and water quality over the fringing reefs; holothurian energetics; reef plankton dynamics; sponge physiology; deep sinkhole sedimentation; hurricane damage to nearshore reefs; larval recruitment of reef fish. The marine life on the $M . V$. Stavronikita is being quantitatively monitored to investigate progress and succession of feral and faunal colonization. The north Bellairs reef off the Bellairs Research Institute is considered particularly good for research work as it is easily accessible, relatively small and discrete $(150 \mathrm{~m} \times 150 \mathrm{~m})$, isolated from neighbouring reefs, has relatively few species of framebuilders and calcareous reef dwellers and is not affected by land-derived detritus (Stearn et al., 1977).
Economic Value and Social Benefits The Reserve encourages recreational activities within its boundaries and certain zones have been designated for different uses (see "Management"). The park staff assist the public in marine environmental awareness programmes with tours of the museum and media promotions.

Disturbance or Deficiencies The Holetown River drains agricultural land and pumps large amounts of fine silt and chemicals into the Reserve each time a major rainfall occurs. High tourist pressure and disregard for existing regulations make enforcement a major problem.

Legal Protection The Reserve was officially established on 29 November 1980 and the relevant legislation is formulated in the following gazetted acts: The Marine Areas (Preservation and Enhancement) Act, 1976; The Marine Areas (Preservation and Enhancement) Designation of Restricted Areas Order, 1981, which defines the boundaries; The Marine Areas (Preservation and Enhancement) Barbados Marine Reserve Regulations, 1981 (29 sections), which establishes regulations for the use of zones and enforcement policies.

Management The Reserve is managed by the National Conservation Commission of the Ministry of Tourism and the Environment. Personnel consist of a supervisor/marine biologist, three naturalists, two life guards and a secretary. The Reserve is divided into four zones. In the Scientific Zone in the north, which includes the Bellairs Fringing Reef, educational projects and research work are permitted but tourism is kept to a minimum through permit requirements and boating restrictions. The Northern and Southem Water Sports Zones are the largest zones, in which watersports are promoted and managed in a controlled fashion, compatible with other park activities. The Recreational Zone, situated between the two sports zones, includes Vauxhall Reef and a large section of Dottins Reef. The inshore reefs are for use by snorkellers, divers and glassbottom boats and the offshore reef for divers only. A twenty marker snorkel trail has been laid out on the fringing reef, each marker giving information on points of biological or other interest. The Marine Museum at Folkestone Park, just north of Holetown, is operated by the National Conservation Commission and provides office space, displays of local fauna and marine aquaria, and slide shows and films are laid on for the purpose of environmental education.

Recommendations A number of recommendations have been made including stricter enforcement of existing laws, expansion of environmental education programmes, closer ties with the research facilities of Bellairs and the University of the West Indies, provision of outside funding for management assessment projects, increased publicity activities and education of personnel in advanced tropical marine ecology and coastal zone management.

We are very grateful to $\mathbf{P}$. Cotter for compiling this account. 



\section{INTRODUCTION}

\section{General Description}

Belize, formerly British Honduras, is a recently independent nation within the British Commonwealth. It has an area of $22963 \mathrm{sq} \mathrm{km}$ and is bounded to the north by México, to the west by Guatemala and to the east by the Caribbean sea. The coast is fringed by a submerged coastal shelf edged with a well-developed barrier reef which is almost continuous, stretching for about $257 \mathrm{~km}$ from the Sapodilla Cays in the south to the Mexican border in the north. Ruetzler and Macintyre (1982) have brought together a collection of papers reviewing scientific work on the reef and Perkins (1983) provides a comprehensive review of the resources, conservation status and management of this ecosystem. This section summarises these publications.

The mainland coastal strip is bordered by narrow sand beaches or mangrove swamps which are extensive in river delta areas. Sand cays and mangrove cays (of which there are more than 200), found throughout the lagoon and along the barrier reef, are described briefly in Perkins (1983), in detail in Belize Survey and Lands Dept (1976) and in many of Stoddart's papers. Stoddart et al. (1982b) map 25 islands on the reef and ten in the lagoon and describe a further four reef and 28 lagoon islands. Underwater caves or "blue holes" (karst eroded sink holes formed during periods of lowered sea level) are common along the Belize Shelf; those on Lighthouse Reef (see separate account) and west of Cay Corker have been explored recently.

Geophysical features and physical parameters such as climate are reviewed in Perkins (1983). Stoddart (1962) discusses the submarine topography of the Belize coast and gives details of climate, currents and tides. Other studies include Ginsberg and Choi (1983). The dry season runs from March to the end of May and can lead to severe water shortage on the cays; from June to October, the coast is liable to hurricanes coming from the Caribbean. On the atolls, annual rainfall probably does not exceed 70 in. $(1780 \mathrm{~mm})$ and winds are from the east for most of the year. Tides are less than $2 \mathrm{ft}(0.6 \mathrm{~m})$ throughout the area and on the atolls are probably little more than $1 \mathrm{ft}(0.3 \mathrm{~m})$. The characteristics of the water are relatively stable but may vary with seasonal salinity and temperature changes. In general, ecological conditions are ideal for coral growth: clear water and sunlight, water temperature $25-29^{\circ} \mathrm{C}$, salinity about $36 \mathrm{ppt}$, constant circulation of well oxygenated water and a firm substrate at less than $20 \mathrm{~m}$ depth (Wantland and Pusey, 1971).

Fringing reefs are restricted to the coastal area between Placentia and Punta Ycacos at the northern entrance to Port Honduras. Relatively few coral species are present and Porites and Siderastrea dominate, being able to tolerate variations in salinity and highly turbid conditions (Perkins, 1983). Patch reefs are widespread in the central lagoons of atolls and faroes (rhomboid-shaped, steep-sided continental shelf atolls), and on the barrier reef platform. They are virtually absent in the Northern Shelf Lagoon but contrastingly plentiful in the Southern
Shelf Lagoon, particularly south of Dangriga. The coral zonation of patch reefs and faroes is described briefly in Perkins (1983).

The continental shelf is narrow $(13-28 \mathrm{~km})$ and has two distinct bathymetric regions: a flat, shallow, karst surface north of the Belize River delta, and a rugged high relief profile south of the delta. Submarine ridges provide the supportive framework for the barrier reef and the three oceanic atolls (see separate accounts) immediately seaward.

The Northern Shelf extends from Bulkhead Shoal to the Belize River delta. It consists of the barrier platform (0.5-1.5 km wide) which contains segments of barrier reefs (ribbon reefs), broken by inlets with numerous patch reefs and coral heads. The linear chain of cays, including Cay Corker (Caulker), Cay Chapel and Long Cay, separates the back-reef lagoon from the shallow Northern Shelf Lagoon. The alignment of the reef, cays, atolls and rivers in this area is due to strike-slip faulting associated with tectonic movements of the Yucatan and Nicaragua-Honduras blocks.

The Southern Shelf runs roughly parallel to the coastline between the Belize River delta and the Sapodilla Cays at the southern end of the barrier reef. The barrier platform here forms a barrier reef and cay complex of variable width $(1-14 \mathrm{~km})$. The Southern Shelf lagoon has a smooth floor $(9-27 \mathrm{~m})$ as far south as Twin Cays but further south the lagoon widens and there is an abrupt transition to deeper water $(27-65 \mathrm{~m})$. The shelf floor becomes complicated by a maze of patch reefs, faroes and pinnacles. Faroes are confined to the area (about $32 \mathrm{~km}$ long) between Carrie Bow Cay and Round Cay where the lagoon is widest.

Burke (1983) describes the barrier reef ecosystem and in particular seven transects, with particular emphasis on Gallows Point Reef. Approximately $31 \%$ of the reef occurs in the northern province, $62 \%$ in the central province and $6 \%$ in the southern province. The reef is divided into linear segments or ribbon reefs and south of Gladden Entrance becomes very fragmented. The distribution of fore-reef structures, their associated communities and the distribution of shallow-water reef systems is correlated with the distribution of wave energy reaching the reef. The northern province, from Reef Point (Rocky Point) southwards for $78 \mathrm{~km}$ to the northern tip of Gallows Point Reef, includes approximately $46 \mathrm{~km}$ of reef and the muddy, shallow Chetumal Bay-lagoon complex. South of Ambergris Cay (see separate account), the reef is partially replaced by a broad apron of Halimeda sand and is distinguished by a line of mangrove cays set well inside the shelf edge, separated from the reef by wide, shallow passes. The reef crest and inner fore-reef zone generally has few living corals and is rounded and gently sloping. The shoals between Ambergris Cay and Gallows Point are mainly pavement covered by rubble, sand and only sparse corals. Biota along the shelf-edge break is luxuriant.

The central province extends south approximately $120 \mathrm{~km}$ from Gallows Point Reef to Gladden Spit, on the northern side of Gladden Entrance, with more than 


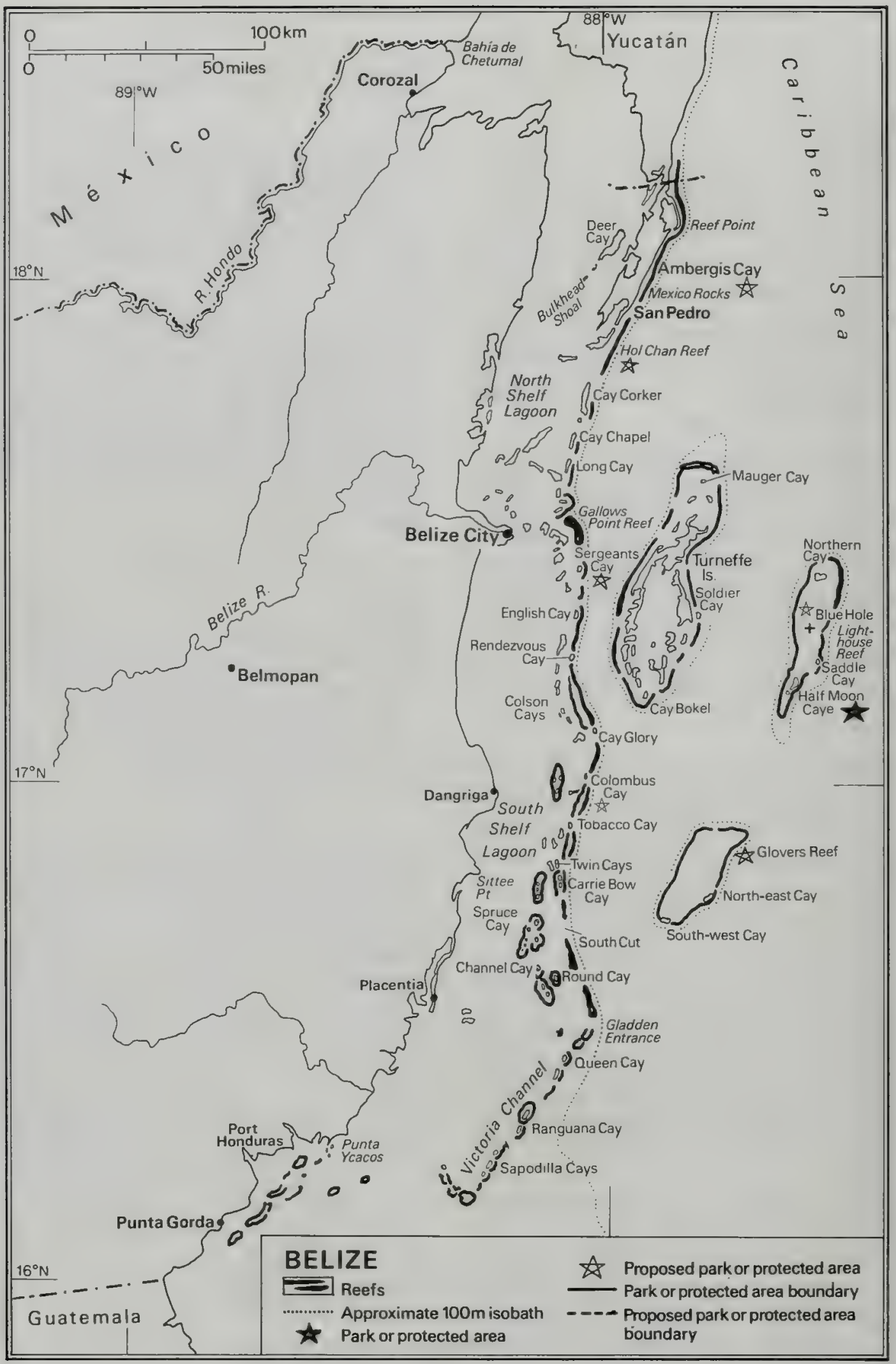


$91 \mathrm{~km}$ of shallow-water reef. It includes the central and southern lagoons with depths of less than $27 \mathrm{~m}$. Numerous mangrove cays occur near the center and landward side of the barrier platform and along the boundary of the southern lagoon. There are a few sand cays on the inner edge of the shallow-water reef, and the province includes the three atolls (see following accounts). Unlike other provinces, there are long, wide sections of uninterrupted reef, cut by only two major channels and scattered narrow passes. A high-relief spur and groove system occurs over $52 \mathrm{~km}$ of the reef and a double high-relief spur and groove system is found over $16 \mathrm{~km}$, separated from the reef crest by a channel containing boulder rubble. Shelf-edge coral ridges occur along $48 \mathrm{~km}$ and are capped by Acropora palmata at depths less than $20 \mathrm{~m}$. At greater depths the ridge is narrower, less continuous and platy corals dominate. Colombus Cay and Tobacco Cay reefs are described in a separate account. Burke (1983) describes transects at Rendezvous Cay, Colson Cay and South Cut. Rendezvous Cay, 18 miles ( $29 \mathrm{~km}$ ) south-east of Belize, was studied by the Cambridge Expedition in 1959-1960 and Thorpe and Bregazzi (1960) map the reefs and list the species recorded. Miller and MacIntyre (1977) describe a number of sites briefly, including the patch reef near Spruce Cay and the rhomboid shoal area near Channel Cay. The best developed sections in terms of unbroken reef zonation and coral luxuriance are adjacent to Columbus and Tobacco Cays, east of Dangriga (Perkins, 1983) (see separate account). Reefs at Carrie Bow Cay are also described in a separate account.

The southern province extends $59 \mathrm{~km}$ from Gladden Spit to Sapodilla Cays and has about $10 \mathrm{~km}$ of shallow-water reef and a deep lagoon, the Victoria Channel. A few small cays are found well inside the shelf edge. The reefs occur only as a fringe around islands and lagoon entrances. The reef crest is composed mainly of weakly coalesced Millepora - coralline mounds and rubble. Burke (1983) describes a transect at Queen Cay.

The barrier reef and atoll coral faunas are typically Caribbean. The scleractinian fauna totals 49 species of which 39 are hermatypic (Cairns, 1982; Wantland and Pusey, 1971; York, 1971). Stoddart (1962) compares the species compositions of the atolls.

Loggerhead Caretta caretta, Hawksbill Eretmochelys imbricata and Green Turtles Chelonia mydas nest on offshore cays and along the shoreline of southern Belize; Bacon et al. (1984) give details of nesting sites. Man's presence seems primarily responsible for the absence of turtles from suitable nesting beaches in northern Belize (Groombridge, 1982). The American Crocodile Crocodylus acutus and possibly Morelet's Crocodile $C$. moreletii occur on some parts of the coast and on offshore cays, especially in areas with protected lagoons. Despite legal protection, numbers are diminishing due to increased access by illegal hunters. The Caribbean Manatee Trichechus manatus is found along the shore and on offshore cays. Dolphins, Tursiops truncatus, Stenella plagiodon and Steno bredanensis have been recorded from coastal waters. Halewyn and Norton (1984) describe the status of seven species of seabird nesting in Belize, including the Magnificent Frigatebird Fregata magnificens, Red-footed Booby Sula sula, Brown Pelican Pelecanus occidentalis, Sooty Tern Sterna fuscata and Brown Noddy Anous stolidus. Fosberg et al. (1982) provide an annotated checklist of the plants of the cays, and Scott and Carbonell (1986) describe important wetland sites.

The barrier reef has received the concentrated attention of scientists only within the past two decades, although interest in the area dates back to the late nineteenth century as discussed by Ruetzler and Macintyre (1982). The first investigations focusing on the cays and reefs were undertaken by the "Cambridge Expedition to British Honduras 1959-1960" (Thorpe and Stoddart, 1962), when 40 cays were mapped and the reefs described (Stoddart, 1960). Subsequent studies treated a wide variety of subjects. In 1972 the Smithsonian established a field laboratory at Carrie Bow Cay (see separate account) and since then most work has concentrated on this area (Ruetzler and Macintyre, 1982). South Water Cay at the southern tip of Tobacco Reef, $2 \mathrm{~km}$ north of Carrie Bow Cay, is used for teaching and research by biologists from the Smithsonian Institution and elsewhere (Pringle, 1982). The fore-reef zone of the barrier reef was explored using the deep sea diving submersible NEKTON and the findings are discussed by Wantland and Pusey (1971). The effects of hurricanes on the reefs and cays have been extensively studied, providing comparable data for the study of rates of recovery of reefs (Stoddart, 1963, 1969 and 1974)

The Belize coral reef ecosystem is unique in the Western Hemisphere on account of its size, its array of reef types and the luxuriance of corals thriving in such a pristine condition (Dahl et al., 1974; Perkins, 1983). There are several unusual geophysical features (Perkins, 1983) including: the nearly continuous shelf-edge barrier reef (one of the largest in the world); the complex maze of patch reefs and faroes in a relatively deep shelf lagoon; the presence of faroes and the unusual diversity of reef types in a small geographical area; the assorted mixtures of terrigenous and carbonate shelf lagoon sediments; and the large offshore mangrove cays whose origins are marine. Several reef species have been found at very deep locations including scleractinian corals at $100 \mathrm{~m}$, the calcareous green algae Halimeda at $100 \mathrm{~m}$ and crustose red algae at $250 \mathrm{~m}$ (Stoddart, 1976).

\section{Reef Resources}

Fisheries, industrial development and socio-economic considerations are discussed in Perkins (1983). There is a long history of reef use by the people of Belize; Maya Indians used the cays between 300 B.C. and 900 A.D. and the cultural history of the area is reviewed by Perkins (1983). The barrier reef ecosystem is extremely important to the well-being of the fishing industry but the economic potential of reef resources has yet to be fully realized. Fishing is the only industry totally owned and managed by the Belizeans. A system of co-operatives was set up in the 1960 s and now employs 700 fishermen and has 450 boats (Gibson, 1978 and 1981; Dubois, 1985). Spiny lobster, conch, grouper and snapper are the main catches with lobster accounting for $60-70 \%$ of the value of all fisheries exports (Dress and Meyer, 1965). The Animal Research and Conservation Center, Bronx Zoo, New York has awarded a large grant for work on the reef, emphasizing the Nassau Grouper Epinephelus striatus (Carr, A. in litt. to M. Halle, 1984). There is one small-scale aquarium fish collector who operates in the mid-northern section of the barrier reef, under licence from the Fisheries Department (Gibson in litt., 13.11.85). 
The gorgonian Plexaura homomalla has been collected in Belize by a U.S. company for work on prostaglandins.

There is a small tourist industry based mainly on Ambergris Cay, catering for divers wishing to visit the atolls and barrier reefs which are major tourist attractions. Charter dive boats visit popular sites such as the Blue Hole, Lighthouse Reef, reefs around Glover's Reef and reefs between Colombus and Tobacco Cays (see separate accounts) as well as the Placentia Peninsula, Hol Chan and Mexico Rocks (near Ambergris Cay), Sergeant's Cay, Golf's Cay (north of English Cay), Cay Corker, St George's Cay (off Gallow's Point Reef), Southern Long Cay (off Cay Glory) and Cay Glory to South Water Cay. Sergeant's Cay used to have a hotel but this was damaged in Hurricane Hattie (Griffiths in litt., 31.10.84). The Blue Holes have potential for the specialized tourist market of underwater cave explorers. Belizeans use the cays along the southem part of the barrier reef, between Dangriga and Punta Gorda, such as Ranguana Cay, Pompion Cay (north-east of Ranguana Cay) and the Sapodilla Cays, mostly for fishing and recreation.

\section{Disturbances and Deficiencies}

Hurricanes are the principal factors affecting the reefs. Catastrophic ones occurred in 1931, 1955 and 1961 and less serious ones occur considerably more frequently (Gibson and Gibson in litt., 13.11.86). Hurricane Hattie (30-31 October, 1961) caused major topographic, sedimentological and ecological changes. The immediate effects were studied in detail (Stoddart, 1963) and the reefs and cay were resurveyed after three and ten years (Stoddart, 1969 and 1974). Up to $80 \%$ of the corals disappeared between Rendezvous and English Cays on the barrier reef, and heavy damage extended north to St George's Cay and south to Cay Glory; moderate damage was found as far south as Curlew Cay (Curlew Bank), south of Carrie Bow Cay (Stoddart, 1963). Subsequently Hurricanes Laura (1971), Fifi (1974) and Greta (1978) caused variable amounts of damage which is described in the following accounts.

Mass mortality of Diadema antillarum, possibly due to a water-borne pathogen, was observed in the Belize populations in mid July 1983 (Anon., 1984; Lessios et al., 1984) similar to that seen elsewhere in the Caribbean. Weyer (in litt., 1.10.84) reports that the damage is thought not to be too severe, although it is not known what the long-term effects will be.

New pressures on the reef ecosystem have arisen since independence, in 1981 (Perkins, 1983). Up until recently the small population of Belize has had little impact on the reefs; the barrier reef is far enough off shore, and the water currents are directed in such a way that the input of deleterious substances from the mainland is negligible at present but this may change. Although only about $15 \%$ of available arable land, including cattle ranches, is currently used, agriculture is the top-most national development priority. Siltation from soil erosion, and pollution from herbicides and fertilizers may, therefore, become increasingly serious threats to the reefs.

As stressed by Perkins (1983), while tourism is dependent on the health of the reefs, it is also a major threat through increased construction and development. At present, its impact is probably negligible but mangrove swamps and islands are already being cleared to provide more visually acceptable areas. Griffith (in litt., 31.10.84) reports that Cay Chapel has been radically altered in shape and sediment composition by clearing mangroves from beaches and dredging dense fringing Turtle grass Thalassia and Manatee grass Syringodium beds.

Shipping is still a small scale activity (Perkins, 1983). Oil companies are increasingly interested in the offshore area although oil has not yet been found (Perkins, 1983; Stoddart, 1962); there is considerable potential for damage to the reefs from oil production although at present there is a lack of baseline studies against which to measure such damage. A rig has now been established at a site on the southern plateau (Griffith in litt., 31.10.84).

Marine turtles (legal to harvest above certain weights) and manatees (protected) have been drastically reduced in recent years due to hunting (Bacon et al., 1984). There is some evidence that the commercial spiny lobster fishery is aiready at maximum sustainable yield levels (Gibson, 1978). Conch and grouper stocks are depleted and the development of the fishery industry on a larger scale with more sophisticated gear is imminent. Recreational fishing has already caused a decline in the abundance of particular species on popular fishing grounds. Sergeant's Cay and Goff's Cay suffer heavily from weekend fishing by the wealthier local population, most boats having outboards (Griffith in litt., 31.10.84).

\section{Legislation and Management}

Conservation legislation is described in Perkins (1983). Management of marine natural resources is vested in the Fisheries Administrator (Anon, 1979). The Fisheries Regulations (1977) set controls over the taking and trading of corals, set a minimum size limit for lobsters Panulirus argus, conch, bonefish and turtles, a quota of $600000 \mathrm{lbs}(272400 \mathrm{~kg}$ ) for lobsters, and establish closed seasons for lobsters from 15 March to 14 July, and for conch from July to September; they also prohibit the taking of breeding or moulting lobsters and the use of SCUBA gear for taking conch or lobster. Manatees are protected. The Fisheries Ordinance, by means of a new amendment (March, 1982), allows any area within the 3 mile $(4.8 \mathrm{~km})$ fishing limit of Belize to be declared a marine reserve if deemed necessary and to extend this to include the adjacent land (Miller, 1981).

Ten Crown Reserves and Bird Sanctuaries were established under the Crown Lands Ordinance, mainly for offshore mangrove cays and small islands with important bird nesting sites; these have reportedly remained as full legal entities following independence (Gibson and Gibson in litt., 13.11.85). The new National Parks System Act 1981 provides for the protection of wildlife and coral reefs within areas designated as a National Park, Nature Reserve, Wildlife Sanctuary or Natural Monument. The Belize Audubon Society, a non-governmental organisation, is involved with the planning and running of these reserves. To date only Half Moon Cay has been re-designated as a Natural Monument and is the only protected marine area with coral reefs. The New York Zoological Society and Belize Audubon Society are currently involved in the 
designation of $\mathrm{Hol}$ Chan Reef as a marine reserve and appropriate documentation is being prepared (Gibson in litt., 9.10.85).

The British Forces in Belize have set up a Reef Preservation Society in collaboration with the Belize Audubon Society and are contributing to increased public awareness of the significance of the reef (Hodges in litt., 22.10.85; Gibson in litt., 21.10.85)

\section{Recommendations}

Proposals for Marine National Reserves were drawn up by Deshler (1978) with the aim of controlling recreational fishing and diving, sites being chosen for their importance for commercial fish stocks and accessibility from Belize City (Perkins in litt., 24.7.84). The following include reefs:

Glovers Reef (see account), including South-west Cay.

Blue Hole, Lighthouse Reef (see account).

Hol Chan, Mexico Rocks and Rocky Point (see account for Ambergris Cay).

Sergeant's Cay to Goff's Cay.

Tobacco Reef (see account).

Perkins and Carr (1985) recommend a multi-disciplinary approach to management of the Barrier Reef, perhaps along the lines of the Australian Great Barrier Reef Marine Park. At present however, there are insufficient human and financial resources to initiate such a strategy and there is a clear need for greater international assistance. Consideration might be given for example to the listing of the Belize Barrier Reef on the World Heritage Convention. Education would need to be an important component of such a programme Recommendations have been submitted for the formation of a reef authority or coastal zone management committee and are under consideration by the Ministry responsible for reefs (Gibson and Gibson in litt., 13.11.85).

\section{References}

Anon. (1979). Establishment and planning, protection and management at Half Moon Caye NM, Belize. WWF/IUCN 1716, Feb. 121979.

Anon. (1984). Sea urchins: death in the Caribbean. Belize Audubon Society Bull. 16(5).

Bacon, P., Berry, Fo, Bjorndal, Hirth, Ho, Ogren, L. and Weber, M. (1984). The National Reports. Proceedings of the Western Atlantic Turtle Symposium, Costa Rica. Vol3: University of Miami Press, Florida.

Belize Survey and Lands Dept. (1976). Index to the Cays of Belize. Ministry of Lands and Agriculture

Burke, R.B. (1982). Reconnaissance study of the geomorphology and benthic communities of the outer barrier reef platform, Belize. In: Ruetzler and Macintyre (1982a).

Cairns, S.D. (1982). Stony corals (Cnidaria: Hydrozoa, Scleractinia) of Carrie Bow Cay, Belize. In: Ruetzler and Macintyre (1982a).

Dahl, A.L., Macintyre, I.G. and Antonius, A. (1974). A comparative study of coral reef research sites. Atoll. Res. Bull. 172: 37-120.

Deshler, W.O. (1978). Belize: proposals for wildlife protection and national parks system legislation and the establishment of national parks and reserves. UNDP/FAO. FAO/BZE/75/008. 41 pp.
Dress, J.K.W. and Meyer, J. (1965). Various aspects of the lobster and scale fishery in coastal waters (British Honduras). FAO/UNDP (Tech. Assist.). Rep. Fish. 2100. $16 \mathrm{pp}$.

Dubois, R. (1985). Coastal fisheries management lessons learned from the Caribbean. Case Study Four. In: Clark, J.R. (Ed.), Coastal Resources Management: Development Case Studies. Coastal Publication No.3, Renewable Resources Information Series, Research Planning Institute, Inc., Columbia, South Carolina.

Ebanks, WJ. (1975). Holocene carbonate sedimentation and diagenesis, Ambergris Cay, Belize. In: Wantland, K.F. and Pusey, W.C. (Eds), Belize Shelf - carbonate sediments, clastic sediments and ecology. Am. Ass. petrol. Geol. Stud. Geol. 2: 234-296.

Fosberg, F.R., Stoddart, D.R., Sachet, M.H. and Spellman, D.L. (1982). Plants of the Belize Cays. Atoll Res. Bull. 258: 77pp.

Gibson, J. (1978). The successes and failures of the fishing co-operatives of Belize. Proc. 31st Gulf Carib. Fish. Inst: 130-139

Gibson, J. (1981). Status of the lobster fishery in Belize. Fisheries Management Unit, Ministry of Health, Housing and Co-operatives, Belize.

-Ginsberg, R.N. and Cboi, D.R. (1983). Quaternary reefs of Belize, Central America. Proc. Inaugural Great Barrier Reef Conference, Townsville. JCU Press.

Godfrey, G.D. (1983). Ambergris Caye: Paradise with a Past. Cubola Productions, Belize.

Greer, J.E. and Kjerfve, B. (1982). Water currents adjacent to Carrie Bow Cay, Belize. In: Ruetzler and Macintyre (1982a).

Groombridge, B. (1982). The IUCN Amphibia-Reptilia Red Data Book. Part 1: Testudines, Crocodylia, Rhynchocephalia. IUCN, Gland, Switzerland.

IUCN (1982). IUCN Directory of Neotropical Protected Areas. Tycooly International Publishing Ltd., Dublin.

Halewyn, R. van and Norton, R.L. (1984). The status and conservation of seabirds in the Caribbean. In: Croxall, J.P., Evans, P.G.M. and Schreiber, R.W. (Eds). Status and Conservation of the World's Seabirds. ICBP Technical Publication No. 2, Cambridge.

James, N.P., Gainsburg, R.N., Marszalek, D.S. and Choquette, P.W. (1976). Facies and fabric specificity of early subsea cements in shallow Belize (British Honduras) reefs. J. Sed. Petrol. 46: 523-544.

Kjerfve, B. and Dinnel, S.P. (1983). Hindcast hurricane characteristics on the Belize Barrier Reef. Coral Reefs 1: 203-207.

K jerfve, B., Ruetzler, K, and Kierspe, G.H. (1982). Tides at Carrie Bow Cay, Belize. In: Ruetzler and Macintyre (1982a).

La Bastille, A. (1982). Paradise gained. Animal Kingdom 85(4): 18-23.

Lessios, H.A., Robertson, D.R. and Cubit, J.D. (1984).

Spread of Diadema mass mortality through the Caribbean. Science 226: 335-337.

Macintyre, I.G. and Graus, R.R. (1983). A back-reef sediment apron: Tobacco Reef, Belizean Barrier Reef. (Abstract). Biologie et Geologie des Recifs Coralliens. Colloque Annuel, Int. Soc. for Reef Studies, Nice, December 1983

Macintyre, I.G., Ruetzler, K., Norris, J.N. and Fanchald, K. (1982). A submarine cave near Columbus Cay, Belize a bizarre cryptic habitat. In: Ruetzler and Macintyre (1982a).

Miller, J.A. and Macintyre, I.G. (1977). Field Guide to the reefs of Belize. 3rd Int. Coral Reef Symp., Miami. $37 \mathrm{pp}$. 
Miller, W. (1981). Fisheries development plan, 1981-1983. Fisheries Management Unit, Ministry of Health, Housing and Co-operatives, Belize.

Perkins, J. (1983). The Belize Barrier Reef Ecosystem: an assessment of its resources, conservation status and management. New York Zoological Society.

Perkins, J.S. and Carr, III, A. (1985). The Belize Barrier Reef: status and prospects for conservation management. Biological Conservation 31: 291-301.

Pringle, J.S. (1982). Floristic observations on South Water and Carrie Bow Cays, Stann Creek District, Belize, in 1979-1980. Aloll Res. Bull. 259: 10 pp.

Putney, A. (1978). A strategy for marine conservation in the wider Caribbean. Results of IUCN Project 1462.

Ruetzler, K. and Ferraris, J.D. (1982). Terrestrial environment and climate, Carrie Bow Cay, Belize. In: Ruetzler and Macintyre (1982a).

Ruetzler, K. and Macintyre, I.G. (Eds) (1982a). The Allantic Barrier Reef Ecosystem at Carrie Bow Cay, Belize 1. Smithsonian Contribution to the Marine Sciences 12: 1-7.

Ruetzler, K. and Macintyre, I.G. (1982b). The habitat distribution and community structure of the barrier reef complex at Carrie Bow Cay, Belize. In: Ruetzler and Macintyre (1982a).

Ruetzler, K. and Macintyre, I.G. (1982c). Introduction. In: Ruetzler and Macintyre (1982a).

Scott, D.A. and Carbonell, M. (1986). A Directory of Neotropical Wetlands. IUCN, Gland and Cambridge.

Shinn, E.A., Hudson, J.H., Halley, R.B., Lidz, B., Robbin, D.M. and Macintyre, I.G. (1982). Geology and sediment accumulation rates at Carrie Bow Cay, Belize. In: Ruetzler and Macintyre (1982a).

Stoddart, D.R. (1960). The reefs and sand cays of British Honduras. In: Cambridge Expedition to British Honduras, 1959-1960, General Report. Cambridge, U.K.

Stoddart, D.R. (1962). Three Caribbean atolls: Turneffe Islands, Lighthouse Reef and Glover's Reef, British Honduras. Atoll. Res. Bull. 87: 1-151.

Stoddart, D.R. (1963). Effects of Hurricane Hattie on the British Honduras reefs and cays. October 30-31, 1961. Aroll. Res. Bull. 95: 1-142.

Stoddart, D.R. (1969), Post-hurricane changes on the British Honduras reefs and cays: re-survey of 1965 . Aroll. Res. Bull. 131: 1-25.

Stoddart, D.R. (1974). Post-hurricane changes on the British Honduras reefs: re-survey of 1972. Proc. 2nd Int. Coral Reef Symp. 2: 473-483.

Stoddart, D.R. (1976). Structure and ecology of Caribbean coral reefs. In: Symposium on progress in marine research in the Caribbean and adjacent regions. FAO Fisheries Rept. 200: 427-448.

Stoddart, D.R., Fosberg, F.R. and Sachet, M.-H. (1982a).

Ten years of change on the Glover's Reef Cays. Atoll. Res. Bull. 257.

Stoddart, D.R., Fosberg, F.R. and Spellman, D.L (1982b). Cays of the Belize Barrier Reef and lagoon. Atoll Res. Bull. 256.

Tebbutt, G.E. (1975). Paleoecology and diagenesis of Pleistocene limestone on Ambergris Cay, Belize. In: Wantland, K.F. and Pusey, W.C. (Eds), Belize Shelf carbonate sediments, clastic sediments and ecology. Am. Ass. petrol. Geol. Stud. geol. 2.

-Thorpe, J.E. and Bregazzi, P.K. (1960). Experiments and observationson the corals at Rendezvous Cay. Cambridge Expedition to British Honduras 1959-1960. General report: 22-28.

Thorpe, J.E. and Stoddart, D.R. (1962). Cambridge expedition to British Honduras. Geography Journal 128: $157-171$

Tsuda, R.T. and Dawes, C.J. (1974). Preliminary checklist of the marine benthic plants from Glover's Reef, British Honduras. Atoll Res. Bull. 173: 1-13.

Wallace, J. and Schafersman, S.D. (1977). Patch reef ecology and sedimentology of Glover's Reef Atoll, Belize. AAPG Studies in Geology 4: 37-52.

Wantland, K.F. and Pusey, W.C. (Eds) (1971). Guidebook for field trip to the Southern Shelf of British Honduras. Gulf Coast Assn of Geol. Soc. 21st Ann. Mtg. $87 \mathrm{pp}$.

Weyer, D. (1982). Half Moon Caye: Central America's first marine park. Parks 7(3): 5-7.

York, M.E. (1971). Patch reef communities of southern British Honduras and illustrated catalogue of common British Honduras corals. In: Wantland, K.F and Pusey, W.C. (Eds). Guidebook for field trips to the Southern Shelf of British Honduras. Gulf Coast. Assoc. Geol. Socs. 21st Arn. Mtg $87 \mathrm{pp}$.

AMBERGRIS CAY (INCLUDING HOL CHAN, MEXICO ROCKS AND ROCKY POINT PROPOSED RESERVES)

Geographical Location On the eastern side of Bahia de Chetumal, inside the barrier reef, south of Boca Bacalar Chico which forms the Belize-Mexico boundary.

Area, Depth, Altitude About $40 \mathrm{~km}$ long; $90 \mathrm{~m}-6.5 \mathrm{~km}$ wide.

Physical Features Ambergris Cay, the largest and northernmost of the Belize cays, is a spit formation extending southwards from the Mexican mainland. The dry season, with strong south-easterly winds, runs from March to May. The rest of the year has an average of 50 in. $(1270 \mathrm{~mm})$ rain, with easterly but variable winds. Violent winter storms blow between October and February and there are occasional hurricanes. Temperatures average $89-94^{\circ} \mathrm{F}\left(31.7-34.4^{\circ} \mathrm{C}\right)$ in summer, $70-85^{\circ} \mathrm{F}\left(21.1-29.4^{\circ} \mathrm{C}\right)$ in winter (Godfrey, 1983).

The cay is separated from the Yucatan Peninsula by Boca Bacalar Chico, a partly man-made channel, and consists of mangrove swamps, lagoons, a plateau in the north and sand ridges. There is a narrow, windward, sand and coral rubble beach ridge, with a broad expanse of supratidal flats and intra-island lagoons which are interspersed with outcrops of Pleistocene limestone that form the core of the island (Ebanks, 1975; Miller and Macintyre, 1977). There are twelve lagoons on the leeward side of the island, the largest of which is Laguna de San Pedro, situated to the west of the village of the same name. Wind, rain and tides combine to constantly alter the sandy windward shoreline and in the last two decades certain parts of San Pedro, the main town, have lost as much as $10 \mathrm{~m}$ to the encroaching sea. At the extreme southern end the sand gives way to numerous mangrove patches divided by navigable channels which connect the waters of the shoal reef area and those of the main lagoons (Godfrey, 1983). The cay is briefly described by Stoddart (1963 and 1969). Sediments and geology are described by Ebanks (1975) and Tebbutt (1975). 
Reef Structure and Corals The barrier reef almost merges with Ambergris Cay at Rocky Point (Reef Point) and then curves seaward and parallels the Mexican coastline. It is well developed, with excellent spur and groove on the inner fore-reef. At Rocky Point, the barrier reef zonation is unusual: the reef crest and fore-reef are constructed primarily of coral blocks where the hydrozoan Millepora and the brown algae Turbinaria are the most common organisms. An outcrop of Pleistocene limestone rocks on the shore provides evidence that the distribution of coral species has remained unchanged in that area (Longman and Wantland, 1978). Some areas have a reef crest of Millepora coralline mounds or coralline algae-encrusted corals (Burke, 1982). Coral is abundant behind the reef crest. The reef lagoon has large patch reefs of Montastraea, Siderastrea, Agaricia and Porites (Miller and Macintyre, 1977). Mexico Rocks is a region of reef approximately 6 miles $(9.6 \mathrm{~km})$ north of San Pedro, comprising both a deep gully/drop-off reef section and a shallow protected region behind the reef crest. Hol Chan is a cut in the reef to the south of San Pedro (Griffith in litt., 31.10.84).

Noteworthy Fauna and Flora Deer, peccary Tayassu sp., Paca Agouti paca and Ocelot Felis pardalis were once common but pressure from tourism has almost eliminated the larger mammals. There are a number of snakes and lizards including the Boa Constrictor Boa constrictor, Black-tailed Indigo Snake Drymarchon corais, Common Iguana Iguana iguana, Spiny-tailed Iguana (Wish Willy) Ctenosaura similis, Central American Basilisk Basiliscus basiliscus and the anole Anolis sagrei. Seabirds nesting in the area include the Brown Pelican Pelecanus occidentalis, Magnificent Frigatebird Fregata magnificens, Sooty Tern Sterna fuscata, Brown Booby Sula leucogaster, Redfooted Booby S. sula and cormorants. Many migrant passerines, particularly warblers, pass through in September and October. Waders, especially herons and egrets, are found on the smaller cays such as Cayo Rosario, Cayo Pajaros, Deer Cay and Cayo Cangrejo and Ospreys Pandion haliaetus breed (Godfrey, 1983). Cays to the west of Ambergris Cay are considered an important wetland site and are described in Scott and Carbonell (1986). Mangrove cays (Deer, Swab, Blackadore and Mosquito) are found in the lee of Ambergris Cay and there are additional small mangrove islands off the southern tip. Green Chelonia mydas and Loggerhead Caretta caretta Turtles nest on Ambergris Cay (Perkins, 1983; Bacon et al., 1984) and in the seventeenth century was an important source of turtles. Hol Chan cut is noted for its moray eel population (Griffith in litt., 31.10.84).

Scientific Importance and Research Very little scientific work has apparently been carried out in this area.

Economic Value and Social Benefits The history of the cay is described by Godfrey (1983). The main tourist resort area in Belize is San Pedro and as a result Ambergris Cay is now the most affluent cay in the country with more than twenty hotels and an airstrip. Recreational fishing and diving are major attractions with charter boats taking visitors to the offshore atolls (Godfrey, 1983). Mexico Rocks and Hol Chan Cut are important dive sites and attempts are being made to increase tourism by emphasising the attractions of the reef (Griffith in litt., 31.10.84).
The spiny lobster fishery has long been of major economic importance to the islanders. Before 1920 lobsters were abundant, but by the mid 1950s the island's resources were exhausted and the fishermen now travel to Turneffe and Lighthouse Reef. The industry is run by a fishing co-operative and attempts are being made to manage it. A joint Canadian-Belizean Conch Optimization Project is under way, conducted by two Canadian University Service Overseas volunteers (Perkins, 1983). Rocky Point is an important spawning area for the Nassau Grouper Epinephelus striatus and Yellowfin Grouper Mycteroperca interstitialis (Perkins, 1983).

Disturbance or Deficiencies Although damage from tourism is still low, recreational fishing and diving are having some effects on commercial fish populations near San Pedro (Perkins, 1983), there is some anchor damage to corals, and littering is more visible. Turtles now rarely nest on the beaches as these are popular tourist areas. The cay is being increasingly built-up and urbanised for tourism, and development plans for the interior include Cape Buffalo ranching and other schemes to boost the economy (Perkins in litt., 24.7.84). Manatee meat is reportedly on sale at some markets in Ambergris Cay (Deshler, 1978).

\section{Legal Protection None.}

\section{Management None.}

Recommendations Documentation on Hol Chan is being compiled in preparation for designation as a reserve (Gibson in litt., 9.10.85). Once this has been established, reserves for Mexico Rocks and Rocky Point are planned.

\section{CARRIE BOW CAY (PROTECTED PRIVATE RESEARCH SITE)}

Geographica! Location $16^{\circ} 48^{\prime} \mathrm{N}, 88^{\circ} 05^{\prime} \mathrm{W}$; on the barrier reef, $22 \mathrm{~km}$ south-east of Dangriga and $18 \mathrm{~km}$ east of Sittee Point (the nearest land); prior to 1944, known as Ellen or Bird Cay.

\section{Area, Depth, Altitude Maximum altitude $40 \mathrm{~cm}$.}

Land Tenure Carrie Bow Cay has been owned by Mr H.T.A. Bowman since 1943.

Physical Features Carrie Bow Cay is a small sand island with a surface area of $0.36 \mathrm{ha}$. It is protected from open ocean waves by a crescent-shaped reef crest to the east and a $100 \mathrm{~m}$ wide reef flat that extends from the crest to the islands seaward shore. The island was formerly double its present size but mangrove clearing in 1944 led to progressive erosion by storm tides. Currently it has an elliptical shape, aligned north-south, is $120 \mathrm{~m}$ long hetween mean tide level points, and has a maximum width of $36 \mathrm{~m}$. Under the influence of the predominant north-easterly trade winds, sand is deposited at the north point, north-west beach and around the south tip. Concrete block sea walls and rubble coral rock landfills have been built along the north-west and south-east 
shorelines to delay erosion. Conch shells abandoned by local fishermen have accumulated along the south-west coast (Ruetzler and Ferraris, 1982). The history of the cay is described in Stoddart ef al. (1982b).

The cay is separated from the mainland by a deep and wide lagoon, which grades into shallow seagrass bottoms, patch reefs and mangrove cays on the outer barrier platform. Shoreward, the eastern portion of the lagoon is less than $5 \mathrm{~m}$ deep, whereas the western part is as much as $20 \mathrm{~m}$ deep. The reef is separated from the main barrier reef by two channels, South Water Cut to the north $(0.4 \mathrm{~km}$ wide and $4 \mathrm{~m}$ deep) and Carrie Bow Cut to the south $(0.7 \mathrm{~km}$ wide and $5 \mathrm{~m}$ deep) (Ruetzler and Macintyre, 1982b). Mean tidal range is $15 \mathrm{~cm}$ and tides are described in detail by Kjerfve et al. (1982). Tidal currents are dominant in the major reef entrances but in the lagoon behind the reef crest, the water is primarily wind driven (Greer and Kjerfve, 1982). Highest temperatures on the cay occur during May and August $\left(33^{\circ} \mathrm{C}\right)$ and lowest during January and February $\left(21-22^{\circ} \mathrm{C}\right)$.

Reef Structure and Corals A distinct zonation is found from the lagoon (west) to the open ocean (east) that reflects primarily the water depth and prevailing wave and current regime. Five major units (lagoon, back-reef, reef crest, inner fore-reef and outer fore-reef) have been described along the barrier reef:

The lagoon (1.5-2.0 $\mathrm{m}$ depth) is marked by weak currents and a significant accumulation of fine sand and silt. A sand and seagrass Thalassia zone and a sand and rubble zone have been defined, extending for $50 \mathrm{~m}$.

The back-reef $(0.1-1.0 \mathrm{~m})$ is subjected to strong currents and the lagoonward transportation of sediments. It consists of a patch-reef zone and a rubble and pavement zone that extend out to about $245 \mathrm{~m}$. The patch reefs consist mainly of Montastraea annularis, with some Diploria labyrinthiformis and Agaricia agaricites. Approximately $50 \%$ of the surface, mainly on the tops of the patch reefs, is dead and overgrown by crustose coralline algae and algal turfs. Clusters of Acropora cervicornis and Porites astreoides and the octocoral Plexaura are dispersed throughout the sandy flat. The rubble pavement zone consists of gravel grading into a relatively smooth and undulating rock pavement adjacent to the reef crest which is described in detail by James et al. (1976). Rock surfaces are overgrown by isolated coral heads (Siderastrea siderea and Porites astreoides), scattered Dictyota spp., coralline crusts, and the boring sponge Cliona caribbaea.

The water over the reef crest $(0.2 \mathrm{~m}-0.1 \mathrm{~m})$ is in an almost constant state of agitation. Lagoonward there is a zone distinguished by a framework of dead $(60 \%)$ and living A palmata along with Agaricia agaricites and $P$. astreoides. Seaward of this, Acropora palmata, Millepora complanata and Palythoa caribaeorum dominate. The last zone of the reef crest consists of rubble and coral rock $(60 \%)$ covered by coralline crusts, $P$. caribaeorum, $M$. complanata, some Porites porites, Agaricia agaricites and the alcyonacean Erythropodium caribaeorum. At its limit, due south-east of Carrie Bow Cay, the reef crest zone grades into a coral-rubble storm ridge which actively accretes over the rubble and pavement zone during hurricanes. In lesser storms the rubble is stable due to platy growths of Acropora palmata.

The inner fore-reef (1-12 $\mathrm{m}$ deep) is also strongly affected by waves and begins with a transition zone of tall coral pinnacles on a sand and rubble bottom, the result of turbulent water movement. About $50 \%$ of these are formed by build-ups of dead $A$ palmata; the rest by live $M$. complanata, $A$ palmata and Agaricia tenuifolia. The well-defined spur and groove zone of high relief (3-10 $\mathrm{m})$ is described by James et al. (1978) and Wantland and Pusey (1971). The high-energy oscillating movement of water here has promoted coral growth on the spurs and erosion in the grooves (Shinn et al., 1982). The buttresses are characterized by foliate $A$ ienuifolia and $M$. complanata enclosing clusters of $P$. porites. The tops of many buttresses are dominated by stands of Acropora palmata and $A$. cervicornis and their flanks and the sand grooves in between by Agaricia agaricites, Diploria strigosa, various species of gorgonians and fleshy algae. The hydrozoans Stylaster roseus and $M$. alcicornis are characteristic. The low relief spur and groove system is dominated by a diverse population of gorgonians. The coral spurs are formed of Montastraea annularis, M. cavernosa, Acropora cervicornis and D. strigosa. Massive Demospongea become quantitatively important in the reduced agitation of deeper water.

The outer fore-reef is affected only by long-period storm waves. It begins with the inner reef slope which drops from $15 \mathrm{~m}$ to $22 \mathrm{~m}$. Most of the bottom is covered by a thicket of living and dead $A$ cervicornis that offers substrate to massive sponges such as Verongula gigantea and Callyspongia vaginalis. Columnar colonies of $M$. annularis at the top of the slope give way to large platy colonies at the base that are accompanied by $P$. astreoides, Siderastrea siderea and Agaricia tenuifolia. This slope is followed by a sand trough about $40 \mathrm{~m}$ wide and $23 \mathrm{~m}$ deep on which pieces of rubble support gorgonians and sponges, as well as some corals that form several small isolated patches predominantly of $M$. annularis and $M$. cavernosa. An outer ridge zone $(12-14 \mathrm{~m})$ runs parallel to the intertidal reef crest, delineating the continental shelf. It is formed either as a thicket of Acropora cervicornis or of $M$. annularis. The ridge supports a variety of corals, gorgonians and sponges among the dominant corals. The fore-reef slope drops from the ridge at $50-70^{\circ}$ down to $30-60 \mathrm{~m}$. At about $30 \mathrm{~m}$ depth there is an abundance of platy $M$. cavernosa and $M$. annularis, Agaricia fragilis, Leptoseris cucullata, Gorgonacea and Demospongea. Abundance of gorgonians decreases with depth whereas that of sponges increases.

The lagoon has low relief patch reefs to the west and south-west of Carrie Bow Cay, with a rich reef fauna and a particularly high diversity and biomass of sponges. The patch reefs are circular or oval, $5-60 \mathrm{~m}$ in diameter in depths of 3-6 m. Gorgonians are most abundant (20\%) followed by corals and milleporids (17\%) and sponges (9\%) (Ruetzler and Macintyre, 1972b).

Forty-two species of scleractinian corals and three species of hydrozoans have been described from Carrie Bow Cay (Cairns, 1982).

Noteworthy Fauna and Flora The seagrass beds and mangroves of the lagoon are described in Ruetzler and 
Macintyre (1982b). Terrestrial fauna and flora are limited due to the cay's small size, lack of freshwater and exposure to the open ocean. Details are given in Ruetzler and Ferraris (1982) and other papers in Ruetzler and Macintyre (1982). Coconut palms Cocos nucifera have been planted over the last 35 years and the vegetation is described by Pringle (1982). Hurricanes have caused regular damage to native vegetation. The main terrestrial animals are crabs Coenobita clypeatus, Ocypode quadrata, and Gecarcinus lateralis. The only resident vertebrate is the lizard Anolis sagrei (a widespread Caribbean species). Caretta caretta, the Loggerhead Turtle is known to nest and the Hawksbill Eretmochelys imbricata and Green Turtle Chelonia mydas may occur. A number of seabirds feed regularly around the island, and the Boat-tailed Grackle Cassidix mexicanus may breed. The Caribbean Manatee Trichechus manatus occurs in this area.

Scientific Importance and Research Reef zonation at the Carrie Bow Cay is generally typical of much of the reef platform (Ruetzler and Macintyre, 1982b). In 1970 the Smithsonian Institution Program "Investigations of Marine Shallow-Water Expeditions" (IMSWE) began as an interdisciplinary study of the coral reef ecosystem, and extensive research was carried out at Carrie Bow Cay. The Smithsonian field laboratory was established on the cay in 1972 and the many publications produced since then are listed in Ruetzler and Macintyre (1982). The Smithsonian project now includes work on the nearby mangrove areas of the Twin Cays (Gibson in litt. 13.11.85).

Economic Value and Social Benefits The Cay is not permanently inhabited, but is used regularly by researchers from the Smithsonian Institution. Conch fishing has been important in this area.

Disturbance or Deficiencies Until 1927, Carrie Bow Cay was a nesting ground for turtles and a roost for migratory birds and the reef abounded with conch, lobster, turtles and parrot fish. Subsequently much of the terrestrial and marine life was depleted through over-exploitation. This is now minimal, although considerable vegetation has been removed for the purpose of eliminating insects (Kjerfve and Dinnel, 1983).

Greatest damage now occurs from hurricanes. Over the last century, nine hurricanes and seven tropical storms have passed within a $50 \mathrm{~km}$ radius of Carrie Bow Cay, of which six occurred within the last twenty years. Damage to the cay is described in Stoddart (1963 and 1965) and summarised in Stoddart (1974). Hurricane Hattie in 1961 had a moderate impact on the reefs. By 1963, living coral on the shallower parts of spurs approached pre-hurricane luxuriance, but the deeper spurs and the southern sides of reef patches were still bare (Stoddart, 1965). By 1972 there was no obvious evidence of the 1961 storm although Hurricane Laura in 1971 had caused minor damage (Stoddart, 1974). Erosion of the cay has been concentrated at the north point and along the southern lee shore, and overall the island has lost $35 \mathrm{~m}$ in length since it was first mapped in 1960. The southern lee shore has been cut back by up to $17 \mathrm{~m}$ since Hattie. Hurricane Fifi (1974) resulted in a proliferation of Acropora cervicornis in the back-reef and lagoon zones during the subsequent four years. Hurricane Greta (1978) had a major impact on $A$ cervicornis, damaging the back-reef zone and causing coral debris to pile up against the patch reefs. By 1979, however, much of the debris had been carried out to the lagoon (Kjerfve and Dinnel, 1983; Ruetzler and Macintyre, 1982).

Legal Protection None, but the area is a protected research site by private agreement with H.T.A. Bowman (Ruetzler in litt., 22.2.84).

Management Under the control of private owner and presumably Smithsonian Institution.

Recommendations No information.

\section{COLUMBUS CAY TO TOBACCO CAY (INCLUDING MAN O' WAR CAYE CROWN RESERVE AND TOBACCO REEF PROPOSED PROTECTED AREA)}

Geographical Location $17^{\circ}-16^{\circ} \mathrm{N}, 88^{\circ} \mathrm{W}$; Colombus Cay lies due east of Stann Creek; Tobacco Cay lies at the southern end of a long unbroken section of the barrier reef; Man o' War Caye, $5 \mathrm{~km}$ to the south-west at the south entrance to the South Shelf Lagoon, is at the western extremity of the Tobacco Range.

Area, Depth, Altitude Tobacco Cay is a triangular island, $300 \mathrm{yds}(274 \mathrm{~m})$ long and up to $150 \mathrm{yds}(137 \mathrm{~m})$ wide in the south (Stoddart, 1964); area of 2.5 ha in 1975 (Stoddart, 1982b). Man o' War Caye covers 0.8 ha.

Land Tenure Columbus Cay is national land; Tobacco Cay is national and private land; other cays within this area are national and/or private land.

Physical Features Tobacco Range is an elliptical array of mangrove islands $(4.8 \mathrm{~km} \times 1.8 \mathrm{~km})$ with a shallow central lagoon, lying near the middle of the barrier platform at Tobacco Entrance. Tobacco Cay is vegetated and lies on the north side of one of the most important entrances in the central barrier reef and is described by Stoddart (1963) and Stoddart et al. (1982b)

Reef Structure and Corals The barrier reef zonation at Colombus Reef is particularly well-developed, with a reef crest, a zone of vigorous reef growth in the surf and a well developed spur and groove formation on the fore-reef (Miller and MacIntyre, 1977). The reefs off Tobacco Cay have well-formed spur and groove structures, similar to those at Glover's Reef. An area of shallow water corals is found at the inlet of the barrier reef (Perkins, 1983). The biological and sedimentological characteristics of the sediment apron extending shoreward of the reef crest of Tobacco Reef are described by Macintyre and Graus (1983). There is a patch reef at Man o' War Caye (IUCN, 1982).

Noteworthy Fauna and Flora Large and numerous Tarpon Megalops atlantica are found on the Tobacco Cay reefs. The Caribbean Manatee Trichechus manatus, Loggerhead Caretta caretta, Green Chelonia mydas and Hawksbill Turtles Eretmochelys imbricata may occur. Man o' War Caye is the only nesting site for the Brown Booby Sula leucogaster in Belize; White-crowned Pigeons Columba leucocephala and Magnificent Frigatebirds Fregata magnificens also nest there (IUCN, 1982). 
The vegetation of the Tobacco Range cays is described in Stoddart et al. (1982b). Man o' War Caye has mangroves, described in Stoddart et al. (1982b). The vegetation of Tobacco Cay has undergone extensive changes. In 1960 the cay was dominated by dense Stachyrarpheta up to $1 \mathrm{~m}$ tall, Wedelia trilobata, Hymenocallis and Ipomoea. In early 1962, after the effects of Hurricane Hattie, the dominant ground cover was Ipomoea and Hymenocallis, and Wedelia was much less widespread. Other changes are largely a function of clearing by the inhabitants (Stoddart, 1969; Stoddart et al., 1982b).

Scientific Importance and Research This area includes the best developed sections of the barrier reef in terms of unbroken reef, archetypal reef zonation and coral luxuriance (Perkins, 1983). Tobacco Cay was mapped in 1960, 1961 and 1962 (Stoddart, 1969). Just north of Columbus Cay, a submerged Pleistocene cave has been found in a Thalassiacovered lagoon of the barrier reef platform which is considered unique on account of the serpulid worms which have formed massive projections on the ceiling, superficially resembling stalactites, which are inclined at decreasing angles away from the entrance and oriented towards the cave entrance. This unusual feature is considered to be due to the restricted flow of water in the cave which is more favourable to the establishment of the worms than to other sessile biota (Macintyre et al., 1982).

Economic Value and Social Benefits Tobacco Cay is permanently inhabited (Stoddart, 1969), and is used for recreation and fishing by Belizeans. It is rarely visited by foreign tourists, although the reefs between Columbus and Tobacco Cays are popular dive-sites.

Disturbance or Deficiencies The reefs were damaged by Hurricane Hattie. By 1963, living coral was still absent or rare (Stoddart, 1965).

Legal Protection Man o' War Caye was established as a Crown Reserve, 6 September 1977, by government decree.

Management Man o' War Caye is run as a Bird Reserve by the Belize Audubon Society.

Recommendations Tobacco Reef is recommended for protected area status (Deshler, 1978).

\section{GLOVER'S REEF PROPOSED NATIONAL RESERVE}

Geographical Location $16^{\circ} 55^{\prime}-16^{\circ} 42^{\prime}, 87^{\circ} 41^{\prime}-87^{\circ} 52^{\prime} \mathrm{W}$. $25 \mathrm{~km}$ east of the barrier reef, $75 \mathrm{~km}$ south-east of Belize City and $45 \mathrm{~km}$ east of the nearest part of mainland (24 km SSE of Turneffe and $22 \mathrm{~km} \mathrm{SSW} \mathrm{of} \mathrm{Lighthouse}$ Reef).

Area, Depth, Altitude Approximate area 132 sq. km; $25.6 \times 10.4 \mathrm{~km}$; lagoon maximum depth $43 \mathrm{~m}$, average depth $27-37 \mathrm{~m}$.

Land Tenure Private and national ownership of cays.

Physical Features The atoll is elongated in the NNE-SSW direction, and surrounded by deep water (350-1000 m) within $1-2 \mathrm{~km}$ of the intertidal peripheral reef. The south-east of the atoll has a chain of six cays distributed over $10 \mathrm{~km}$, which vary between $150 \mathrm{~m}$ and $1 \mathrm{~km}$ in length and are more or less covered in coconut palms (Stoddart, 1962), including North-east Cay, Long Cay and South-west Cay. The well developed surface-breaking atoll reef flat is interrupted in the north-east and south-west by three openings. As in many atolls, the width of the reef flat varies with exposure to prevailing winds and is greatest on the eastern or windward side. The deep lagoon has some 700 patch reefs rising to the surface (Dahl et al., 1974), largely concentrated in the deep central area. Most of them are roughly circular with coral growth on the north and east sides; they are described by Wallace and Schafersman (1977). Water temperatures at the surface in open water vary between $25^{\circ} \mathrm{C}$ in winter and $31^{\circ} \mathrm{C}$ in summer. Winds blow steadily from the east for most of the year, although between November and February northern winds occur occasionally and last four or five days at a time (Dahl et al., 1974).

Reef Structure and Corals From the seaward margin of the peripheral reef, a gradually sloping reef front extends to the drop-off at a depth of $15-25 \mathrm{~m}$. The reef front varies in width from about $400 \mathrm{~m}$ (south-west cays) to $1.5 \mathrm{~km}$ (Long Cay) and is about $500 \mathrm{~m}$ wide on the leeward side. A system of deep parallel grooves runs perpendicular to the drop-off which is well developed on the windward (east) side of the atoll. Sediments produced in the breaker zone are transported down the grooves permitting undisturbed coral growth between them. There is a rich coral reef community including sponges and gorgonians, with most of the known Caribbean species. The leeward reefs are considerably more influenced by sediments which are driven out of the lagoon by wind-generated currents and has fewer scleractinians and less abundant reef fauna. Coral cover ends at around $45 \mathrm{~m}$ depth and gives way to a sand slope. The fore-reef slope is very steep at North-east Cay, almost vertical at Long Cay and vertical to overhanging at South-west Cay. A diverse community is found to a depth of at least $60 \mathrm{~m}$.

The patch reefs in the lagoon have a pronounced zonation which is described briefly by Dahl et al. (1974) and in more detail by Stoddart (1962). A transect on the east reef north of North-east Cay revealed six zones. The reef flat, 1-2 $\mathrm{m}$ deep, was covered with a low mat of yellow algae, Halimeda and Penicillus, with scattered colonies of brilliant blue Porites porites. The Porites zone, in about $1 \mathrm{~m}$ of water, was covered with broken $A$ cervicornis and scattered live colonies of $P$. divaricata. In the annularis zone, the reef flat deepens slightly and the dominant coral is Montastraea annularis in large colonies. Seaward of this is the crustose coralline algal zone which is covered with $A$ cervicornis rubble and abundant nodules of pink Lithothamnion. $P$. astreoides, in small colonies spaced about $2 \mathrm{~m}$ apart, is the only living coral. The reef crest zone is formed of blocks of $A$ palmata, encrusted with Lithothamnion and, near their upper surface, Agaricia agaricites. $P$. porites and Millepora are present in small amounts. Air reconnaisance indicated a sixth zone, seaward of the breakers, consisting of well-developed grooves and buttresses of Acropora palmata. A transect across the west reef revealed five zones: a reef flat of coarse white sand; a mixed cervicornis zone with $A$ cervicornis, $P$. astreoides, Montastraea annularis and Millepora alcicornis; a 
mixed palmata zone with sea whips and large but scattered $A$ palmata colonies rising from other corals to form the reef crest; an annularis zone falling seawards to 5-6 m, with a fairly continuous cover of low, small boulder-like colonies, mainly Montastraea annularis, and a downslope into deeper water with long buttresses of M. annularis and pillars of Dendrogyra cylindrus (Stoddart, 1962).

Noteworthy Fauna and Flora The atoll is a nesting site for Loggerhead Caretta caretta, Green Chelonia mydas and Hawksbill Eretmochelys imbricata Turtles (Bacon et al., 1984). South-west Cay is the only remaining nesting site in Belize for the Brown Noddy Anous stolidus. Other birds and reptiles are described in Stoddart (1962). The Caribbean Manatee Trichechus manarus occurs in the area. The species diversity of plants on the cays has been found to be higher, by a factor of two, than that of other Caribbean and Gulf of Mexico reef island groups (Stoddart et al., 1982a). Although many of the cays are now covered mainly by coconuts, North-east Cay has an important area of tall broadleaf littoral woodland on the south-east (Stoddart, 1962). A preliminary checklist of marine benthic plants is given in Tsuda and Dawes (1974)

Scientific Importance and Research In contrast to many other reefs in the Caribbean, the atoll has a great variety of reef types and optimum reef development in terms of density and species diversity of reef corals and associated organisms. It is well suited for direct comparison with Indo-Pacific atolls as there are no land influences, no pollution or other human disturbances, and the barrier reef and two comparable but physiographically different atolls are readily accessible. There are no research facilities on the atoll at present but several surveys of the reefs have been carried out and it was investigated as a site for the proposed CITRE (Comparative Investigations of Tropical Reef Ecosystems) programme (although this was never carried out). Education and research programmes are carried out regularly on two of the cays.

Economic Value and Social Benefits Long Cay and adjacent Little Cay are permanently inhabited and both islands are used as diving resorts for both Belizean and foreign tourists; North-east Cay also has a dive resort. There are numerous popular diving sites including the western side, Long Cay, the eastern side, South-west Cay and the north end (Perkins, 1983).

Disturbance or Deficiencies The remoteness of Glover's Reef means that it will probably remain relatively undisturbed, although there is now good accessibility and the atoll can be reached by boat in any weather. Although it is the only one of the three atolls which was not hit by Hurricane Hattie in 1961, there is potential for hurricane damage (Dahl et al., 1974) and the atoll was hit by Hurricanes Laura (1971) and Greta (1978); there is no information on the damage caused (Perkins in litt., 24.7.84). An exploratory oil well has been drilled on the atoll (Perkins, 1983). Most of the natural vegetation on the cays has already been replaced by coconuts (Stoddart, 1962).

\section{Legal Protection None.}

Management No information.

Recommendations Glover's Reef has been proposed as a National Reserve, and it is suggested that South-west Cay should be made a Marine Natural Area, with provision for fishing by hand only (Perkins, 1983).

\section{HALF MOON CAY NATURAL MONUMENT, LIGHTHOUSE REEF PROPOSED RESERVE and THE BLUE HOLE MARINE NATURAL AREA}

Geographical Location $17^{\circ} 28^{\prime}-17^{\circ} 07^{\prime} \mathrm{N}, 8^{\circ} 27^{\prime}-87^{\circ} 36^{\prime} \mathrm{W}$; $45 \mathrm{~km}$ east of the barrier reef; east of the Turneffe Islands from which it is separated by a channel $18-29 \mathrm{~km}$ wide.

Area, Depth, Altitude The atoll is $126 \mathrm{sq} . \mathrm{km}, 35 \times 8 \mathrm{~km}$; Half Moon Cay Natural Monument is 4144 ha; lagoon depth varies from about $2 \mathrm{~m}$ in the west to $4-6 \mathrm{~m}$ in the east.

\section{Land Tenure National and private land.}

Physical Features The smallest of the three Belize atolls, Lighthouse Reef lies along a NNE-SSW axis and has an irregular outline. The atoll is surrounded by a well-developed reef rim with three major inlets, one at the north end, one east of Half Moon Cay and one on the west. The south-west corner of the atoll consists of an arc-shaped reef segment about $13 \mathrm{~km}$ long and $3.2 \mathrm{~km}$ wide running south-west of Half Moon Cay. The eastem reefs are remarkable for the width of living reef (averaging $450 \mathrm{~m}$ ) and reef flat (averaging 1000-1400 m), which forms a broad shoal area. The reef is continuously pounded by surf and a strong current, estimated at 2-3 knots, flows across it under the influence of prevailing winds and waves. The western reefs are backed in the north by large accumulations of white sand up to $1000 \mathrm{~m}$ in width, the living reef forming an extremely narrow fringe. Further south there is no sand and the narrow reef fringes a shallow reef flat, 1-3 $\mathrm{m}$ deep, which merges almost imperceptibly with the lagoon floor. Patch reefs occur in the lagoon, but are less dense than in Glover's Reef lagoon. The most remarkable feature is the Blue Hole in the lagoon floor 4 miles $(6.4 \mathrm{~km})$ north of Saddle Cay which has Pleistocene stalactites and stalagmites and is considered to be a subaerially eroded sinkhole carved in the limestone by karst erosion during glacial low sea-levels.

There are six cays, varying greatly in size from Saddle Cay which is only a few metres in diameter to Northern Cay which covers over 2.25 sq. miles (5.8 sq. km). Northern Cay and Long Cay, which is also large, have considerable swampy areas. Half Moon Cay is a large sand and shingle cay and is described in detail in Stoddart (1962). Saddle and Hat Cays are smaller sandy cays with varied vegetation and Sandbore Cay, the most northerly, still had large areas covered by natural vegetation in 1961 .

Reef Structure and Corals Lighthouse Reef is surrounded on all sides by a well-defined reef flat; the reef plunges steeply to abyssal depths on the seaward sides, and there are living coral pinnacles on the lagoon floor. Six zones have been described in the Half Moon Cay area (Stoddart, 1962). The reef flat (1-2 m deep) deepens lagoonward and is covered with large patches of Thalassia over a sandy bottom, with very large 
specimens of Manicina areolata and occasional Favia fragum and Siderastrea radians. The Lithothamnion pavement (20-30 $\mathrm{m}$ wide) has a rocky bottom, 1-2 $\mathrm{m}$ deep, covered with both pink encrusting algae and numerous unattached nodules of calcareous algae, with occasional boulders of Porites astreoides, Diploria strigosa and Montastraea annularis. The palmata zone (1 $\mathrm{m}$ deep) has massive colonies of Acropora palmata and smaller colonies of Porites astreoides. The mixed reef zone is similar but more diverse with colonies of Porites porites and Agaricia agaricites as well as Acropora palmata and $P$. astreoides. The elevated reef-rock zone consists of dead, eroded reef-rock, the sides fringed with Millepora and algae, rising in small outcrops $20-40 \mathrm{~cm}$ above sea-level. The outer slope falls steeply to over $7 \mathrm{~m}$ depth where it levels out to form a deep platform, covered with large and very massively built $A$ palmata, 3-7 $\mathrm{m}$ tall. Between these enormous colonies, there is a carpet of open-branched $A$ cervicornis interrupted in places by large blocks of dead reef-rock topped with Agaricia agaricites and Millepora complanata.

Along the greater part of the west side of the atoll, there is a continuous rim of living reef at the surface, edging a wide sandy reef flat and falling fairly rapidly from the reef crest into deep water on the outer side. Five zones were recognised (Stoddart, 1962). The reef flat consists of a wide expanse of barren white sand, 1-2 $\mathrm{m}$ deep, lacking corals. A narrow ( $3 \mathrm{~m}$ wide) gorgonian zone is covered with sea fans and sea whips and sparsely scattered with small colonies of Montastraea annularis. Seaward of this is the cervicornis zone, covered with loose branched Acropora cervicornis. In the reef crest zone, the sea floor falls from about $2 \mathrm{~m}$ to over $3 \mathrm{~m}$, and $M$. annularis colonies dominate. Towards the outer edge are large wave-swept colonies of $A$ palmata interspersed with abundant encrusting and upright colonies of Mille pora complanata and $M$. alcicornis. This zone ends quite abruptly on the seaward side, commonly as an interrupted vertical wall of Montastraea with its base at about $3 \mathrm{~m}$ depth

The shallow lagoon includes a number of patch reefs on which $A$ palmata is dominant. The reef surrounding the Blue Hole consists mainly of $M$. annularis with one or two colonies of $A$ palmata on its inner edge, and a scattering of various other corals.

Noteworthy Fauna and Flora The eastern half of Half Moon Caye is covered with coconut palms and sparse ground level and littoral vegetation. The western half is covered in Siricote Cordia sebestena forest, the natural climax forest for sand cays in this region (Weyer, 1982). This is virtually the only remaining stand of its kind in Belize, others having been destroyed by hurricanes or human development (Perkins, 1983). Half Moon Cay is also the only nesting site of the Red-footed Booby Sula sula in Belize; the colony, currently estimated at 4000 individuals, has nested in the Siricote forest for over a hundred years and is unusual for the $98 \%$ predominance of the white adult phase. Magnificent Frigatebirds Fregata magnificens also nest in good numbers (Anon., 1979; IUCN, 1982; Perkins, 1983). Long Cay had a large nesting colony of White-crowned Pigeons Columba leucoce phala, but this may have been destroyed (Weyer in litt., 1.10.84). Several lizards have been recorded at Half Moon Cay including the Scaly-tailed Iguana Iguana iguana rhinolopha, the Wish
Willy Ctenosaura similis and an anole Anolis allisoni (Stoddart, 1962). Some of these species also occur on Northern Cay which is also notable for the large size of its land crabs. The American Crocodile Crocodylus acutus may occur here and possibly on Long Cay (Perkins, 1983; Weyer in litt., 1.10.84). Further details of the land fauna are given in Stoddart (1962). Green Turtles Chelonia mydas and Loggerheads Caretta caretta nest on Half Moon and Long Cays and Hawksbill Turtles Eretmochelys imbricata have been seen around Long Cay (Perkins, 1983; Bacon et al., 1984). The Caribbean Manatee Trichechus manatus may occur.

Scientific Importance and Research Half Moon Cay has been studied fairly extensively and is important for its bird fauna and natural vegetation. The atoll was visited in 1960 by the Cambridge Expedition to British Honduras (Stoddart, 1962).

Economic Value and Social Benefits Tourists visit Half Moon Cay in small numbers and Lighthouse Reef is popular with SCUBA enthusiasts. In particular, Northern Cay has a large and beautiful gorgonian forest on the north-west side; north of Long Cay there is an immense variety of corals including big branches of black coral; and south-east of Half Moon Cay there are attractive buttress formations (Perkins, 1983). The Blue Hole is popular with cave divers. There are no permanent inhabitants apart from the lighthouse keepers on Half Moon Cay and Sandbore Cay. Local fishermen take the Wish Willy and Iguana for food (Stoddart, 1962) and fish regularly although not very heavily. Long Cay is put to occasional military use and has the potential for an air-strip should tourism develop significantly (Deshler, 1978).

Disturbance or Deficiencies Hurricane Hattie had a major impact on Lighthouse Reef in 1961 although it lay entirely to the south of the storm track. On Half Moon Cay, the Siricote forest was flattened and most of the boobies were killed but the Cay has gradually recovered (Stoddart, 1963 and 1965; Weyer, 1982). Sandbore Cay, Northern Cay and Long Cay also underwent major changes (Stoddart, 1963 and 1965). The eastern reef suffered very little damage although minor damage occurred at the north end. Greatest damage seems to have occurred to the east-west section of reef between Half Moon Cay and Long Cay which was aligned transversely to the southerly winds and waves. Damage to the west reefs could not be assessed but the lagoon reefs suffered only slight damage (Stoddart, 1963). The atoll was hit by Hurricane Greta in 1978 but the damage was not assessed (Perkins in litt., 24.7.84).

On Half Moon Cay, young birds and eggs have been taken from the booby nesting colony by local fishermen and the introduced black rat Rattus ratrus (Weyer, 1982). Shooting of White-crowned Pigeons Columba leucocephala during the nesting season by Belizean hunters may have wiped out the large nesting colony on Long Cay (Weyer in litt., 1.10.84). There was uncontrolled collection of ornamental molluscs, conch, fish and lobsters (IUCN, 1982; La Bastille, 1982 and 1985). Large scale tourism could threaten Half Moon Cay and surrounding reefs (La Bastille, 1982) and there was considerable littering and beach oiling in 1982 (La Bastille, 1985). A certain amount of damage was reportedly caused to coral around the Blue Hole during the filming of a Cousteau film. 
Legal Protection Half Moon Cay was established as a Crown Reserve Bird Sanctuary in 1928 and 1978 by government decrees. It was declared officially as a Natural Monument in 1982 (IUCN, 1982). Fishing is prohibited within a four mile $(6.4 \mathrm{~km})$ radius around the Natural Monument.

Management Half Moon Cay Natural Monument is administered by the Fisheries Department and the Belize Audubon Society. A management plan is in preparation. The two lighthouse keepers will be appointed to act as wardens for both land and marine areas, under new government decrees. Weyer (in litt., 1.10.84) reports that the legal protection of the cay is not enforced but that the Belize Audubon Society is trying to correct this. The booby colony has a trail leading to it (IUCN, 1982), a new observation tower has been erected and signs (donated by New York Zoological Society) now proclaim the status of the cay as a Natural Monument and the laws concerning the area clearly for all visitors. A regular rat poisoning programme was started in 1970 (Weyer, 1982). The British Forces will assist with the placing of boundary marker buoys.

Recommendations It has been suggested that the entire reef should be considered for Reserve status and two other areas of the reef system have been specifically proposed as Reserves (Anon., 1979). The Blue Hole has been proposed for designation as a Marine Natural Area (Deshler, 1978).

\section{TURNEFFE ISLANDS}

\section{Geographical Location}

$17^{\circ} 38^{\prime}-17^{\circ} 09^{\prime} \mathrm{N}$

$87^{\circ} 44^{\prime}-87^{\circ} 57^{\prime} \mathrm{W}$. East of Belize City, separated from the barrier reef by a channel varying in width from 9 to $23 \mathrm{~km}$.

Area, Depth, Altitude Atoll is about $330 \mathrm{sq} . \mathrm{km}$; 30.5 miles $(49 \mathrm{~km}) \times 5-6$ miles $(8-9.6 \mathrm{~km}), 10$ miles $(16 \mathrm{~km})$ wide at Soldier Cay, the widest point.

\section{Land Tenure Private and national ownership.}

Physical Features The atoll is oriented NNE-SSW and is roughly lens- shaped. Large mangrove and sand cays are situated around the inner perimeter, possibly formed as a result of the shelter, provided by Lighthouse Reef, from the easterly trade winds. Temperature and salinity in the lagoon are subject to wide fluctuation but surface temperatures in the southern lagoon in June-July 1961 averaged $29^{\circ} \mathrm{C}$. Further information is given in Stoddart (1962).

On the east, windward side, there is a well-defined narrow reef which breaks the surface. The reef is highly segmented with about 23 gaps, generally less than $50 \mathrm{~m}$ wide and about $2-4 \mathrm{~m}$ deep. The reef crest zone is narrow and fringes the outer edge of a reef flat generally less than $1 / 4$ mile $(0.4 \mathrm{~km})$ wide. On the inner edge of the reef flat, which is usually submerged by $0.5 \mathrm{~m}$ of water, and intermittently covered with Thalnssia, algae and small corals, there are small sand cays, some with shingle ridges. Some of these are described in detail in Stoddart (1962). Most of the eastern side is fringed by a dry sand ridge, with a steep sandy shore colonized by Ipomoea and Sesuvium, a flat crest covered with coconut plantations and an undercarpet of the lily Hymenocallis littoralis. Westwards the coconuts give way to dense mangrove growth which bounds the interior lagoons. Southern Lagoon is about 17 miles $(27.4 \mathrm{~km})$ long, ranging in depth from 2 to $4 \mathrm{~m}$, and the bottom is composed of calcareous sand and silt covered with huge areas of Thalassia (Stoddart, 1962). The reef on the west side of the atoll is wider and more diffuse than the east reef and is generally submerged.

Reef Structure and Corals A transect at Calabash Cays, south-west of Soldier Cay, on the east of the atoll, revealed eight zones: the seaward shore of the cay; a sand and rubble platform adjacent to the cay; a reef flat; an inner reef zone with scattered colonies of Montastraea annularis, Porites astreoides and Dendrogyra cylindrus; a cervicomis zone where Acropora cervicornis predominates; an annularis zone (10-15 yds (9.1-13.7 m) wide) immediately landward of the breaker zone where the dominant colonies are large massive blocks of $M$. annularis, $P$. astreoides, D. cylindrus, and Siderastrea siderea, the larger colonies intersected by deep winding channels $6-8 \mathrm{ft}(1.8-2.4 \mathrm{~m})$ deep; a reef crest (agaricia) with massive blocks of largely dead coral, covered on the upper surface almost exclusively with Agaricia agaricites; and an outer slope which consists of a platform 10-15 ft (3-4.6 m) deep with small colonies of a variety of species including Montastraea, Porites and Siderastrea.

The west reef is separated from the mangrove fringe by a lagoon $3-4 \mathrm{~m}$ deep, several metres wide and floored with Thalassia. The main corals are $M$. annularis, Diploria labyrinthiformis and $D$. strigosa with $P$. porites, A agaricites, small colonies of Dendrogyra cylindrus, M. cavernosa, and occasionally Mycetophyllia lamarckana and Isophyllastrea rigida. Other zones are described in Stoddart (1962). There are no corals in the lagoons which are closed to the sea.

Noteworthy Fauna and Flora The endangered American Crocodile Crocodylus acurus is reported to occur, though its present status remains conjectural and there have been no recent reliable studies of the species at Tumeffe (Weyer in litt., 1.10.84). Perkins (1983) reported a large population (500-600) though this is extremely unlikely (see Groombridge, 1982). Previous estimates have usually been based on reports from local crocodile hunters who maintain that their illegal hunting has had no impact. It is possible that if the law is not enforced immediately, the crocodiles will soon disappear from this locality. Loggerhead Caretta caretta, Green Chelonia mydas, and Hawksbill Eretmochelys imbricata Turtles may occur here but do not nest (Bacon et al., 1984). The Caribbean Manatee Trichechus manatus has been reported from the lagoons. The Atlantic Bottlenose Dolphin Tursiops truncatus is sometimes found in the lagoon. Mauger Cay and Blackbird Cay, west of Soldier Cay, are sites for spawning aggregations of the commercially important fish, Nassau Grouper Epinephelus striatus and Yellowfin Grouper Mycteroperca interstitialis. Conchs Strombus gigas used to be abundant in the seagrass beds around the atoll and sponge beds thrived in the lagoon (see below). The land fauna is described in Stoddart (1962) and includes lizards, snakes and a number of birds. 
Scientific Importance and Research The atoll was visited in 1960 by the Cambridge Expedition to British Honduras.

Economic Value and Social Benefits Turneffe used to be the major coconut producing area in Belize before the plantations were damaged by hurricanes (Perkins, 1983; Stoddart, 1962). Many of the eastern cays are inhabited and there are lighthouses on Mauger Cay and Cay Bokel. Fishing is carried out in the lagoons. Conchs used to be collected in large numbers and the meat exported to Belize City. On Cay Bokel a resort has been developed specifically for anglers (Perkins, 1983). Other cays are used regularly by Belizean fishermen.

The seaweed Eucheuma sp. used to be grown sporadically in the lagoon and harvested (Perkins, 1983). The Southern Lagoon sponge beds supported a thriving industry in the late nineteenth and early twentieth centuries until 1919 when they were almost completely wiped out by a disease and possibly by over-collecting. The beds recovered but were decimated again in 1936 and 1939, and the industry subsequently declined. Hippospongia lachne (Sheepswool), $H$. gossypina (Velvet Sponge) and smaller quantities of Spongia barbara, $S$. dura and $S$. graminea were fished and, in 1939,700 000 cuttings were planted out in the lagoon. In 1960, one of the residents of Calabash Cays was still cultivating a few sponges and there was talk of reviving the industry although interest was slight (Stoddart, 1962). The sponge beds are reported still to be healthy.

Disturbance or Deficiencies Hurricane Hattie had a catastrophic impact on Turneffe Reef in 1961. It crossed the islands near Pelican Cay, causing extensive reef damage northwards to Mauger Cay. Southwards, damage was severe on south facing reefs, particularly near Cay Bokel (Stoddart 1963). A re-survey in 1965 revealed that living corals were still almost non-existent (Stoddart, 1969). It is not clear whether the eastern Turneffe reefs have recovered since then but it is probable that recovery has been minimal (Stoddart, 1974). Hurricane Greta hit the atoll in 1978; the damage it caused has not been investigated (Perkins in litt., 24.7.84). The impact of local people on the atoll is not known but many of them have domestic chickens, dogs and pigs; rats are a major pest in some areas. The natural vegetation of some of the cays has been destroyed completely and replaced with coconut plantations. Conchs have been over-collected and, as described above, the sponge industry has been virtually eliminated (Stoddart, 1962).

Legal Protection None.

Management No information.

Recommendations No information. 


\section{INTRODUCTION}

\section{General Description}

The British Crown Colony of Bermuda consists of about 130 oceanic islands situated in the Sargasso Sea, about $1200 \mathrm{~km}$ north-west of the Turks and Caicos Islands. The coral limestone islands lie on the Bermuda Seamount, a volcanic peak rising from the sea bed, the top of which forms the Bermuda Platform. There are two submerged volcanic peaks (or guyots) to the south-west: Challenger Bank is about 11 nautical miles $(20 \mathrm{~km})$ from Bermuda and Argus Bank is about 20 nautical miles ( $37 \mathrm{~km}$ ) away. Both banks are approximately $50 \mathrm{~m}$ deep on top. The total shelf area above the 100 fathom $(183 \mathrm{~m})$ isobath is $465 \mathrm{sq}$. miles (1204 sq. km) including a land area of only 55 sq. km. The Bermuda Platform is 775 sq. $\mathrm{km}$ in area; Challenger Bank is 27 sq. miles (70 sq. km) and Argus Bank is 24 sq. miles ( $62 \mathrm{sq}$. $\mathrm{km}$ ).

The physiography of the platform is suggestive of an atoll, in that carbonate islands, shoals and reefs surround a central shallow water lagoon. However, many of the shoals are not a result of active coral reef formation, but consist of eroded and submerged limestone deposits thinly veneered with encrusting organisms, particularly in the nearshore and inshore regions (Morris et al., 1977). The geology of the area has been summarized in several reports (James and Schenk, 1983; Land and Mackenzie, 1970; Mackenzie and Vacher, 1975; Upchurch, 1970). A brief overview is presented by Morris et al. (1977).

The islands form a narrow chain $35 \mathrm{~km}$ in length, with a land area of $56 \mathrm{sq} . \mathrm{km}$, and they enclose extensive inshore waters with a shoreline length of about $150 \mathrm{~km}$ (Sterrer and Wingate, 1981). The six main islands are now all linked by bridges and causeways and enclose four large water bodies: Great Sound, Harrington Sound, Castle Harbour and St George's Harbour. Great Sound is the largest and least enclosed, exchanging with North Lagoon through a large opening to the north-east. The two sub-units of Great Sound, Hamilton Harbour and Little Sound, have a more restricted water exchange (Morris et al., 1977). Harrington Sound is the most land-locked, with direct communication to North Lagoon through a narrow inlet plus subterranean exchange. Castle Harbour (10 sq. km) exchanges with North Lagoon through a narrow passage to the north-west and with the open ocean through a wider opening in the south-east between a series of small islands (Dryer and Logan, 1978). St George's Harbour is the smallest inshore basin and exchanges with the open ocean to the east via channels between large islands and also with North Lagoon by a narrow passage.

Bermuda is situated just south and east of the Gulf Stream drift but there is no dominant current and the water circulation forms irregular patterns. Southerly winds predominate in the summer, while west and north-westerly winds, including gales, are common in the winter. Annual rainfall averages $1470 \mathrm{~mm}$ and is evenly distributed throughout the year. Seawater temperature ranges from $16^{\circ}$ to $30^{\circ} \mathrm{C}$. Maximum tidal range is $1.2 \mathrm{~m}$. Salinity of North Lagoon varies little (36.0-36.5 ppt) but the inshore basins can become slightly fresher. There are no surface streams on Bermuda, although Mills Creek slowly drains the Pembroke Marsh area. Rainfall becomes either widespread direct runoff or groundwater that soaks through the porous limestone rock of the island. Extensive cave systems are found throughout the islands (Illiffe, 1979).

Bermuda's reefs have been described by several investigators (Atchison and Griggs 1967; Dodge et al., 1982; Fricke and Meischner, 1985; Garret and Scoffin, 1976 and 1977; Garret et al., 1971; Ginsberg and Schroeder 1969a, b and 1973; Ginsberg et al., 1967; Jordan, 1973; Laborel, 1966; Logan, in press; Logan et al., 1984; Meischner and Meischner, 1977; Prat, 1936; Rein, 1881; Smith and Musik, 1984; Stanley and Swift, 1967). The major reef area is around the shallow water platform to the north of the islands in North Lagoon which extends to the edge of the shallow reef platform, $11 \mathrm{~km}$ from the shore. The shallow southern reefs are essentially isolated boilers, the reef platform extending only $0.5 \mathrm{~km}$ from the shore; the majority of corals are in deeper water to seaward of these small boilers. Total reef area has been estimated at $177 \mathrm{sq} . \mathrm{km}$, of which $101 \mathrm{sq} . \mathrm{km}$ is offshore reef, $70 \mathrm{sq} . \mathrm{km}$ is patch reef and $17 \mathrm{sq} . \mathrm{km}$ is fringing reef (Bacon et al., 1984). Challenger and Argus Banks have good coral reef development but have been little studied.

Two classes of reefs have been identified: coral/algal reefs and algal/vermetid reefs. The former are the most extensive in area and relief and are produced primarily from the growth and accumulation of corals and encrusting calcareous algae. They may be divided into five major zones:

1. North Terrace These reefs, up to $1 \mathrm{~km}$ wide and from 10 to $18 \mathrm{~m}$ deep, have developed as a solid terrace, seaward of the northern shallow platform, and are the richest and most productive of the Bermudan system. The terrace has a distinctive ridge and groove topography, of about 2-4 m relief, oriented perpendicular to the platform margin. Hard coral coverage is very high $(40-60 \%)$ and the dominant species are Diploria strigosa, $D$. labyrinthiformis, Montastraea annularis, $M$. cavernosa and Porites astreoides. Many of these corals are massive hemispheres, greater than $1 \mathrm{~m}$ in diameter. Octocorals are common, particularly Pseudoplexaura spp., Pseudopterogorgia spp., Gorgonia ventalina and Plexaura flexuosa. Fleshy and calcareous algae and many invertebrate species are also abundant.

2. North Rim The North Rim reefs (or ledge flats) are located on the north, east and western margins of the Bermuda platform. At their outermost limit, adjacent to the North Terrace reefs, the Rim reefs are of high relief $(10 \mathrm{~m})$, rising up to $3-5 \mathrm{~m}$ depth, separated by sand channels. Moving lagoonward, the reefs fuse into a solid rim or ledge flat, about $0.4-0.8 \mathrm{~km}$ wide, with widely scattered sediment pockets and narrow sand channels. The sand channels become progressively larger towards the lagoon and the reefs less connected and ultimately isolated. Hard coral coverage ranges from 25 to $35 \%$ and the reefs are dominated by Diploria spp., Montastraea spp. and Porites spp., the colonies generally being smaller than those on the terrace. Soft corals are very numerous and often large (1 $\mathrm{m}$ in height). Pseudoplexaura 


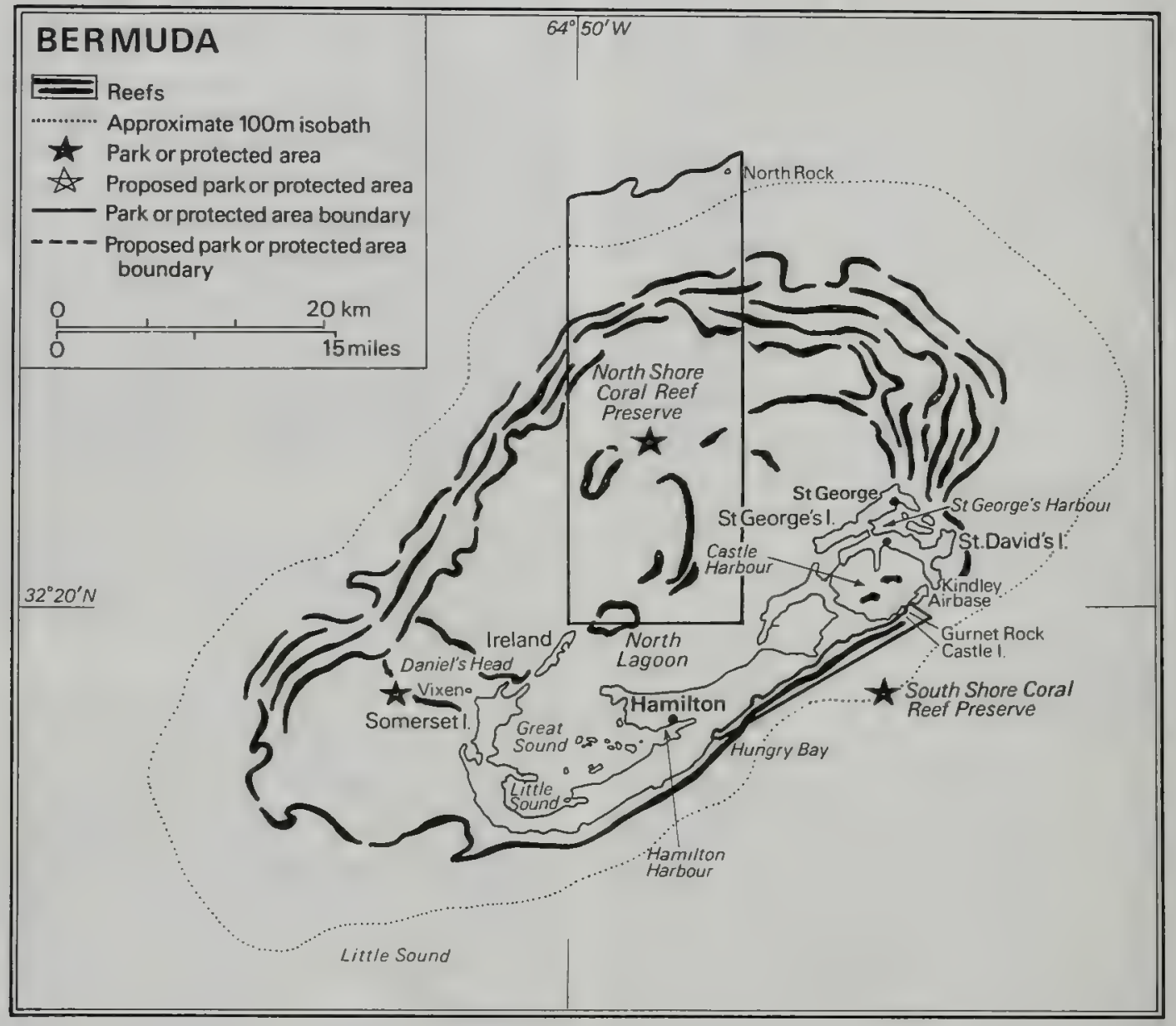


spp., Gorgonia ventalina, Pseudopterogorgia spp., Plexaura spp., Eunicea spp., fleshy and calcareous algae and many invertebrate species are abundant.

3. South Terrace These reefs are found seaward of the algal/vermetid reefs along the south shore of the island. They are a mixture of small and large (100-10 $000 \mathrm{sq} . \mathrm{m})$, high and low relief $(5-10 \mathrm{~m})$ reefs, scattered in a coarse sediment plateau or moat, $200-400 \mathrm{~m}$ wide and $15-20 \mathrm{~m}$ deep (Meischner and Meischner, 1977). Seaward of the moat is a solid reef terrace of about $6 \mathrm{~m}$ relief, $0.5-1 \mathrm{~km}$ wide. The reefs are topographically different from the North Terrace reefs, being characterized by a network of connected pillars, arches and over-hanging lips which create a complex system of channels and caves throughout the reef. The Diploria-Montastraea-Porites assemblage is dominant and hard coral coverage ranges from 45 to $60 \%$. Soft corals are abundant, dominated by Pseudoplexaura spp., Pseudopterogorgia spp., Plexaura flexuosa and Gorgonia ventalina. Fleshy and calcareous algae and many invertebrate species are common.

4. South Rim These reefs are found shoreward of the algal/vermetid reefs of the south shore, forming a narrow zone characterized by high turbulence and frequent sediment movement. The reefs are both large and small in extent (100-10 $000 \mathrm{sq}$. $\mathrm{m}$ ) with 3-4 $\mathrm{m}$ relief. They are separated by coarse sand channels that coalesce shorewards to form a wide $(100-300 \mathrm{~m})$ sand plain, about $4 \mathrm{~m}$ deep that emerges as beach sediment. Hard coral coverage varies from 20 to $35 \%$ and is dominated by the Diploria-Montastraea-Porites assemblage. Soft corals are not as common in this zone and the dominant species are Pseudoplexaura spp., Pseudopterogorgia spp. and Plexaura flexuosa. Algae and invertebrates are less abundant than in the previous zones.

5. Lagoon Reefs These are isolated reefs of varying size $(1000-100000$ sq. m) rising up from the lagoon floor (18 $\mathrm{m}$ depth) to about $2 \mathrm{~m}$ below sea level. The larger reefs have a coral-covered rim and sediment-filled pockets in the interior with scattered pinnacles of coral growth. Smaller reefs are less complex. The outer lagoonal reefs support a biological community very similar to the North Rim reefs but the inner, nearshore, reefs are often covered with fleshy algae and loose sediment. Hard coral coverage is low, $15-20 \%$, and the dominant species are Montastraea annularis, Madracis spp. and Oculina spp. Soft corals are not particularly abundant on these inner reefs and the dominant species are Pseudoplexaura spp., Plexaura flexaosa, Gorgonia ventalina and Eunicea spp. A great diversity of invertebrate species are found on all lagoonal reefs.

The algal/vermetid reefs or "boilers" are widely scattered on the North Rim. They are constructed from calcareous algae (e.g. Lithothamnion), the foraminifer Homotrema rubrum and the vermetid worms Dendropoma petraeum and Vermetus triquetrus (Safriel, 1974). They are emergent at low tide and form a nearly continuous structure along the length of the south shore, generally following the $8 \mathrm{~m}$ depth contour although isolated reefs are often found in shallower water. Typically, they have a narrow base and are expanded laterally at the top although massive buttress formations are sometimes found at their bases. The sides of these reefs are generally free of coral growth.
Depth distribution, zonation and growth morphology of corals from the outer reef slopes have recently been described by Fricke and Meischner (1985). Hermatypic coral growth occurs to a depth of $50-70 \mathrm{~m}$, with most deep water hermatypes growing on remnants of Pleistocene reefs down to about $60 \mathrm{~m}$. Major factors suggested to control depth limits of coral growth are the preponderence of unsuitable substrates, such as the extensive fields of rhodolith nodules below $50-60 \mathrm{~m}$ depth, and competition with algae (Wyers in litt., 26.11.85.)

Coral communities are also found in the inshore waters (8-24 $\mathrm{m}$ deep). Siderastrea radians and Isophyllia sinuosa are common throughout these basins and are vulnerable to human activities, particularly dredging in the harbours (Jickells et al., 1985; Meischner et al., 1981). The reefs of Castle Harbour, which were seriously damaged by the construction of the Kindley Air Force Base (see below), are described by Dryer and Logan (1978) and Frazier (1970). The branching corals Oculina spp., Madracis spp. and Agaricia fragilis predominate the vertical sides and bases of the reefs. The reef tops are most commonly colonized by Isophyllia sinuosa, Siderastrea radians, Madracis decactis and Oculina diffusa. A dense fleshy algal cover, with some calcareous algae, is now predominant. Living brain coral colonies of Diploria spp. are now uncommon within Castle Harbour, although numerous large dead colonies, up to $1.5 \mathrm{~m}$ high, may be found. Coral coverage is only $3-7 \%$, while algal coverage is $19-70 \%$ (Dilen in litt. 18.12.85).

Oculina valenciennesi, a mud-living coral, is strictly limited to the sheltered basins and may cover large areas. A major project was carried out by members of Kiel University in Harrington Sound, an almost totally enclosed lagoon with very restricted water exchange (residence time - 100 days) (Wefer et al., 1981). Neumann (1965) described a rocky zone, shallow sandy zone, Oculina zone and subthermocline zone in this sound, the Oculina zone being a unique feature. Oculina and the mussel Arca zebra cover extensive areas between $10 \mathrm{~m}$ and $18 \mathrm{~m}$ depth, perhaps due to the lack of dredging in this basin. Other results of the Harrington Sound Project are described in Wefer et al. (1981). Ecological accounts in Bodungen et al. (1982) and Wefer et al. (1981) focus mainly on calcium carbonate budgets, nutrient cycling and primary production in the Sound, and Alheit (1981) describes feeding interactions between reef fish and the zoobenthos.

Wetland habitats are described in Scott and Carbonell (1986), brief descriptions of a variety of coastal habitats being provided including shallow marine bays (approximately $1000 \mathrm{ha})$, rocky coastline $(140 \mathrm{~km})$, sandy beaches $(9 \mathrm{~km})$ and mangrove swamps $(16.7 \mathrm{ha})$. The Green Turtle Chelonia mydas occurs in Bermuda but breeding populations were destroyed by the early settlers. From 1967 onwards, eggs have been transferred from Costa Rica in order to re-establish a breeding population. Tagging studies to follow growth and movement patterns of the local population are continuing. Anecdotal evidence indicates that turtles are now more abundant than in 1978 as evidenced by the many reported sightings at sea (Luckhurst in litt., 31.10.84). The Loggerhead Caretta caretta also breeds and the Hawksbill Eretmochelys imbricata and 
Leatherback Dermochelys coriacea may be observed foraging (Bacon et al., 1984). Seabirds are described in Wingate (1973).

The Bermudan reefs are of considerable scientific interest, being the most northerly in the Atlantic. Corals and other species must withstand cool water temperatures $\left(16-19^{\circ} \mathrm{C}\right)$ during the winter months (Morris et al., 1977). Species diversity is low, only 26 of the 72 known Caribbean scleractinian coral species having been recorded, and the genus Acropora being notably absent. The most important genera are Diploria (two species), Montastraea (two species), Oculina (two or three species), Porites (two species), Siderastrea (two species), Isophyllia (one species), Favia (one species), Stephanocoenia (one species) and Madracis (two species). The hydrozoan Millepora alcicornis is common in most reef zones along with seventeen species of gorgonians and alcyonarians. The marine flora and fauna have recently been catalogued by Sterrer (1985) and a field guide has been produced by Cavaliere et al. (1983).

Research has been carried out on the Bermudan marine environment for about a century, much of the work being based at the Bermuda Biological Station, which maintains an extensive library collection of the scientific literature relating to Bermuda. Various aspects of the geology of reefs and biology of reef organisms have been investigated, although a number of studies concern specialized interests in individual species. With regard to corals, for example, recent research has included studies on growth (Dodge, 1978; Dodge and Vaisnys, 1977; Frazier, 1970; Iams, 1969), sources of nutrition (Johannes et al., 1970), interspecific aggression (Logan, 1984) and sexual reproduction (Wyers, 1985 and 1986). Logan (in press) cites further examples of work concerned with the ecology and systematics of other taxa, the morphology and diagenesis of reefs, and bioerosion processes.

In 1975 , the local government funded a five year multi-disciplinary environmental study of the inshore marine environment at the Bermuda Biological Station named the Bermuda Inshore Waters Investigations (BIWI). This involved measurements of fundamental oceanographic parameters, baseline surveys of the benthic communities, and a study of the proliferation of the mat-forming green alga Cladophora. The results of these investigations are presented in Bames and Bodungen (1978), Bodungen et al. (1982) and Morris et al. (1977). The study has been extended as the Marine and Atmospheric Program and further monitoring of nutrients, primary production (Jickells et al., 1985) and trace metal concentrations (Jickells and Knap, 1984) in the inshore and lagoon waters has been carried out. Inshore benthic surveys have continued as well as studies of the recolonization of damaged reefs (Smith, 1985).

Several major research programmes on the fate and biological effects of petroleum in the environment have been undertaken at the Biological Station. These include studies of hydrocarbons in sediments (Sleeter et al., 1980), tar deposition on beaches (Butler et al., 1973; Knap et al., 1980; Smith and Knap, 1985) and the effects of petroleum residues on intertidal organisms (Maynard, 1984). The effects of crude oil and chemically dispersed oil on the brain coral Diploria strigosa have been extensively studied in a three year multi-disciplinary project designed to simulate the range of conditions possible during a spill. Results are summarized by Knap et al. (1985) with further detail in Dodge et al. (1984, 1985), Knap et al. (1982, 1983) and Wyers et al. (1985) (see also below). Further studies are currently in progress to investigate the effects of chronic oil pollution on the reproduction of intertidal limpets.

Additional marine research has been carried out by the Bermuda Government's Division of Fisheries. Catch and effort statistics are collected on local fish and lobster populations, fish censuses have been carried out regularly and the recruitment patterns of Panulirus lobster larvae are being investigated. The fishery biology of two species of deep water crab (Geryon spp.) is being studied and the behavioural dynamics of fish in relation to fish traps is part of a long term study of fish trap management. The Government Aquarium conducts research on fish diseases and pathology.

\section{Reef Resources}

Bermuda has a typical coral reef fishery with Antillean fish traps providing approximately $50 \%$ of the total landings, which comprise $30-40$ reef species. Challenger Bank and Argus Bank are important fishing grounds. There is also an active line fishery for pelagic species taken principally by charter fishing vessels. Total finfish landings from 1975 to 1984 ranged from 350 to 515 metric tons. The landings of spiny lobsters for the same period were 35-60 metric tons (Luckhurst in litt., 31.10.84). There is no commercial trade in local shells.

A workshop in 1983 examined the potential for aquaculture in Bermuda (Sleeter, 1983); native species cited as having potential for mariculture were shellfish (conch, scallops, oyster and clams) and finfish (snappers, groupers and dolphin-fish or mahimahi). However, since very little is known of the biology of local species, it was recommended that basic research programmes began immediately and that preliminary market surveys for fisheries products should be initiated before any large-scale programme were considered. Sociological and political constraints should also be considered (Sleeter, 1983).

The tourist industry forms the basis of the island's economy and the reefs are well utilized by SCUBA diving, snorkelling and glass bottom boat operators. There are about five major diving operations and twelve boating operators around the island (Luckhurst in litt., 31.10.84). In 1980 there were an estimated 600000 visitors (Bodungen et al., 1982) and Bermudans also dive and snorkel on the reefs.

\section{Disturbances and Deficiencies}

Bermuda's reefs have been affected by a variety of coral diseases. Black Band disease is the commonest but occurs on a very small percentage of the reef corals, mainly Diploria spp. and Montastraea annularis. This infection, by blue green algae and bacteria, can destroy coral tissue at a rate of several sq. $\mathrm{cm}$ per month (Antonius, 1981; Garrett and Ducklow, 1975). In common with much of the Caribbean, Bermuda suffered mass mortality of the urchin Diadema antillarum in 1983, 
thought likely to have been caused by a water-borne pathogen (Lessios et al., 1983; Lessios et al., 1984). Bermuda lies outside the main Caribbean hurricane belt but experiences occasional hurricanes. There has been no hurricane for about 15 years (Morris et al., 1977; Sloan, 1982b) and damage to reefs is probably minimal.

With one of the highest population densities in the world $(57000$ in $55 \mathrm{sq} . \mathrm{km})$, the reefs are potentially under considerable threat, although damage due to human activities is at present not too serious. Smith and Knap (1985) report a decline in stranded beach tar which is attributed to a reduction in the operational discharges of oil tankers and a decrease in the occurrence of maritime oil spills since 1980 . There is however, a considerable threat from the grounding and stranding of vessels, about one major grounding occurring each year. Recently, large areas of the northern terrace and rim reefs have been severely damaged by groundings and subsequent salvage operations (Smith, 1985). The damage caused by the Mari Boeing, and subsequent rates of recovery of the reef, are described in the account for the North Shore Coral Reef Preserve. The oil tanker Tifoso grounded about two miles $(3.2 \mathrm{~km})$ east of North Rock on the edge of the platform in January 1983. She was successfully pulled off without any oil pollution but thousands of square metres of reef were destroyed. In September 1984, two ships (Sea Luck, a grain carrier, and Aguila Azteca, a fully laden oil tanker) grounded within a fortnight of each other about five miles $(8 \mathrm{~km})$ south-west of North Rock, on the edge of the platform. Both were successfully floated off without pollution occurring but there was extensive coral destruction along their paths over the reef. The recovery of these sites will be monitored over the next few years (Luckhurst in litt. 31.10.84). Research on the potential effect of oil spills (see above) has in fact shown that the main reef building coral in Bermuda, $D$. strigosa, is relatively tolerant of brief exposures to crude oil chemically dispersed in the water column, the effects being short-lived and recovery fairly rapid. Other reef invertebrates suffer mortality, and information in needed on the effect of oil spills on other marine environments.

Localized blasting for geological research has had an effect (Sterrer and Wingate, 1981) and the blasting and dredging of the eastern channel has destroyed some reefs. There are only two major navigable approaches to the islands; the eastem one used by all large ships and a southern one into Castle Harbour (there is also a western channel for vessels up to $2 \mathrm{~m}$ draught).

Castle Harbour historically had extensive coral reefs similar to the Southern Rim and Terrace Reefs and the area was a favourite collecting ground for naturalists, with clear water and abundant Diploria in shallow water. The size of the harbour was reduced by one-fifth and some important water exchange channels were closed as a result of the construction of Kindley Air Force Base from 1941 to 1944 . This involved dredging and landfill which severely perturbed the basin, killing most of the corals (Dryer and Logan, 1978; Dodge and Vaisnys, 1977; Dilen, 1984). The waters are now turbid, similar to other inshore basins, with visibility rarely exceeding $6 \mathrm{~m}$. Spoils from current dumping and outfalls are also found in the harbor (Sloan, 1982b; Sterrer and Wingate, 1981). It is considered unlikely that the reefs will ever recover to the pre-1941 conditions. Further siltation is still a potential threat.
The proliferation of the mat-forming green algae Cladophora spp. in sheltered bays has caused concern, and intensive studies have been carried out to determine the effects of sewage inputs in the inshore waters (Bodungen et al., 1982; Morris et al., 1977). It was concluded that there was no clear evidence of significant sewerage pollution, and that changes in the ecosystem, such as Cladophora growth and reductions in scallop populations, could not be shown to be related to sewage inputs. A decline in the local population of the Calico Clam Macrocallista maculata which is found only in Harrington Sound, was attributed to competition by Cladophora and over-collecting. The report emphasises possible future problems of sewerage discharge and the need for continued monitoring. The increasing nutrient enrichment of ground water is considered to be the major threat to wetlands, since as yet there is only one sewage system. As housing density has increased, eutrophication of groundwater from cesspits has also increased (Scott and Carbonell, 1986) which could ultimately affect the fringing reefs.

Other sources of disturbance in reef areas include anchor damage and pressures due to tourism (Sterrer and Wingate, 1981), although the effect of such activities has not been quantified. Commercial and recreational fishermen use the reefs extensively and may inflict damage on the reefs through poor anchoring practices although fish traps may be more damaging to corals than anchors due to their widespread use and large numbers (c. 3000 traps in 1985). There have been reports of over-fishing and a decline in the average size of lobsters (Rogers, 1985).

\section{Legislation and Management}

There are a number of legal provisions for the conservation of reefs and marine organisms, concerning both commercial and recreational use. The Fisheries Division of the Department of Agriculture and Fisheries is responsible for the management of marine habitats (Scott and Carbonell, 1986). Fisheries regulations (Anon., 1981a and b) include provisions for the licensing of fishing bcats, recording of catch and effort statistics, the use of fishing nets and traps (including types permitted and restricted areas), and closed seasons for certain locations. The use of fish traps is restricted to licensed fishermen and fishing and collecting by use of poisons or explosives is prohibited. Spearfishing is permitted only beyond one nautical mile from shore, only with a hand spear, and is limited to a catch of two fish of any one species per day. Spiny lobsters Panulirus argus can only be taken under licence, there is a closed season between April and August, and a minimum size limit of $9.2 \mathrm{~cm}$ carapace length. Size limits apply to hamlets, hogfish and rockfish. Additional fishing orders cover the use of fish pots. There are three fisheries wardens who are responsible for the enforcement of all fisheries regulations, both commercial and recreational.

The following species are protected within territorial waters under the Fisheries (Protected Species) Order 1978: marine turtles, marine mammals, stony corals, gorgonians, Queen Conch Strombus gigas, Harbour (Milk) Conch Strombus costatus, helmet and bonnet shells (Cassidae), Bermuda Cone Conus bermudensis, Netted Olive Oliva reticularis, Bermuda Scallop Pecten ziczac, Calico Scallop Argopecten gibbus and Atlantic 
Pearl Oyster Pinctada imbricata. Recently, the Calico Clam Macrocallista maculata was added to this list. SCUBA divers are prohibited from collecting or removing any marine animals and the sale of marine animals taken within the territorial waters is permitted only if they are for human or animal consumption (Wyers in litt., 26.11.85.).

A complete oil spill contingency plan has been developed, together with environmental sensitivity maps, a damage risk assessment and a scientific support coordination plan (Sleeter et al., 1983). There are some restrictions on construction work close to the coastline.

Two major zones constitute Coral Reef Preserves (see separate accounts), within which attached benthic organisms may not be collected by any means according to the Coral Reef Preserves Act 1966. The Preserves were designed to protect reef resources, rather than as educational facilities or for environmental monitoring. As such they are not marine parks or reserves, and there has been little attempt to describe comprehensively the biota and ecology of these areas as specific zones. The taking of any marine animal is prohibited within a third Protected Area (within a $300 \mathrm{ft}(91.4 \mathrm{~m})$ radius around the wreck Vixen, $900 \mathrm{ft}(274 \mathrm{~m})$ west of Daniel's Head). This is a popular tourist attraction and is frequently visited by commercial glass bottom boat operators, although rarely used by divers because of the boat traffic.

Legislation is now in place, as part of a new Fisheries Management Plan, to create a "no fishing" marine reservoir area of $35-40 \mathrm{sq}$. mi. (91-104 sq. km) on the Bermuda Platform. The location will be determined after a survey of potential sites and will extend from the shoreline to the edge of the platform (depth 35-40 fathoms $(64-73 \mathrm{~m}))$. The reservoir is intended to be a "no-stop" zone except for a small number of dive sites which will have permanent moorings. Fishing, spearfishing and recreational lobster diving will be prohibited. Troll fishing for pelagic species will be permitted along the edge of the reef platform. Permanent monitoring sites will be established within the reservoir for fish populations and benthic fauna, which can be compared with control sites outside (Luckhurst in litt., 27.11.85).

\section{References}

- = cited but not consulted.

Alheit, J. (1981). Feeding interactions between coral reef fishes and the zoobenthos. Proc. 4th Int. Coral Reef Symp., Manila 2: 545-552.

Anon. (1981a). Bermuda Division of Fisheries: coral reef preserves; protected areas; protected species; spearfishing; minimum sizes; closed season; general restrictions. Fisheries Office, Southampton, Bermuda.

Anon. (1981b). The Fisheries Regulations, 1972. Fisheries Office, Southampton, Bermuda.

Antonius, A. (1981). The "Band" diseases in coral reefs. Proc, 4th Int. Coral Reef Symp, Manila 2: 7-14.

Atchison, G.J. and Griggs, G.B. (1967). Bermuda Coral Distribution. Rept, Organism-Sediment Interrelationships Seminar, Bermuda Biol. Station. $17 \mathrm{pp}$. Bacon, P., Berry, F., Bjorndal, Hirth, H., Ogren, L. and Weber, M. (1984). The National Reports. Proceedings of the Western Atlantic Turtle Symposium, Costa Rica.
Vol3: University of Miami Press, Florida.

Bardach, J.E. (1959). The summer standing crop of fish on a shallow Bermuda reef. Limnol. Oceanogr. 4(1): 77-85.

Bardach, J.E., Smith, C.L and Menzel, D.W. (1958). Bermuda Fisheries Research Program Final Report. Bermuda Trade Development Board, Hamilton. 59 pp.

Barnes, J.A. and Bodungen, B.V. (Eds) (1978). The Bermuda Marine Environment II. Bermuda Biol. Stn Spec. Publ. 17.

Bodungen, B., Jickells, T.D, Robertson Smith, S. Ward, J.A.D., and Hillier, G.B. (Eds) (1982). The Bermuda Marine Environment III. Bermuda Biol. Stn Spec. Publ. 18.

Butler, J.N., Morris, B.F. and Sass, J. (1973). Pelagic tar from Bermuda and the Sargasso Sea. Bermuda Biol. Stn Spec. Publ. 10.

Cavaliere, A.R., Barnes, R.D. and Sterrer, W.E. (1983).

Field Guide to the Conspicuous Flora and Fauna of Bermuda. Bermuda Bial. Sin Spec. Publ. 26.

Dilen, D.R. (1984). Recent ecology of coral patch reefs in Castle Harbour Bermuda. Abstract. Advances in Reef Science. Joint meeting of the Atlantic Reef Committee and the International Society for Reef Studies, Miami.

Dodge, R.E. (1978). The natural growth records of reef-building corals. Ph.D Dissentation, Yale University. $237 \mathrm{pp}$.

Dodge, R.E., Knap, A.H., Wyers, S.C., Frith, H.R., Sleeter, T.D. and Smith, S.R. (1985). The effect of dispersed oil on the calcification rate of the reef-building coral Diploria strigosa. Proc. 5th Int. Coral Reef Congress, Tahiti 6: 453-457.

Dodge, R.E., Logan, A. and Antonius, A. (1982).

Quantitative reef assessment studies in Bermuda: a comparison of methods and preliminary results. Bull. Mar. Sci. 32(3): 745-760.

Dodge, R.E, and Vaisnys, J.R. (1977). Coral populations and growth pattern responses to sedimentation and turbidity associated with dredging. J. Mar. Res. 35: 715-730.

Dodge, R.E., Wyers, S.C., Frith, H.R., Knap, A.H. Smith, S.R. and Sleeter, T.D. (1984). The effects of oil and oil dispersants on the skeletal growth of the hermatypic coral Diploria strigosa. Coral Reefs 3(4): 191-198.

Dryer, S. and Logan, A. (1978). Holocene reefs and sediments of Castle Harbour, Bermuda. J. Mar. Res. 36: $399-425$.

Frazier, W.J. (1970). Description of reefs in Castle Harbour, Bermuda. Bermuda Biol. Stn Spec. Publ. 6: 53-72.

Fricke, H. and Meischner, D. (1985). Depth limits of Bermudan scleractinian corals: a submersible survey. Mar. Biol. 88: 175-187.

Garrett, P. and Ducklow, H. (1975). Coral diseases in Bermuda. Nature 253(5490): 349-350.

-Garrett, P. and Scoffin, T. (1976). Bermuda's north-west reefs colonize last interglacial storm modified barrier island features. Abstract, Bull. Am. Assoc. Petrol. Geol. 60: S673.

-Garrett, P. and Scoffin, T.P. (1977). Sedimentation on Bermuda's atoll rim. Proc. 3rd Int. Coral Reef Symp., Miami 2: 87-95.

- Garrett, P., Smith, D.L., Wilson, A.O. and Patriquin, D. (1971). Physiography, ecology and sediments of two Bermuda patch reefs. J. Geol. 79(6): 647-668.

-Ginsberg, R.N. and Schroeder, J.H. (1969a). Recent synsedimentary cementation in subtidal Bermuda reefs. In: Bricker, O.P., Ginsberg, R.N., Land, L.S. and 
Mackenzie, F.T. (Eds). Carbonate Cements. Bermuda Biol. Stn Spec. Publ. 3: 31-34.

-Ginsberg, RN. and Schroeder, J.H. (1969b).

Introduction to the growth and diagenesis of Bermuda reefs. Bermuda Conference on Carbonate Cements. September, 1969.

- Ginsberg, R.N. and Schroeder, J.H. (1973). Growth and submarine fossilization of algal cup reefs, Bermuda. Sedimentology 20: 575-614.

-Ginsberg, R.N., Shinn, E.A. and Schroeder, J.H. (1967). Submarine cementation and internal sedimentation within Bermuda reefs. Geol. Sac. Am. Spec. Pap. 115: 78-79.

Iams, WJ. (1969). New methods for studying the growth rates of reef-building corals. In: Ginsburg, R.N. and Garrett, P. (Eds), Reports of Research 1968 seminar on organism-sediment interrelationships. Bermuda Biol. Stn Spec. Publ. 2: 65-76.

Illiffe, T.M. (1979). Bermuda's caves: a non-renewable resource. Environmental Conservation 6: 181-186.

James, N.P. and Schenk, P.E. (1983): Field guide to Pleistocene and modern carbonates of Bermuda. Bermuda Biol. Sin Spec. Publ. 25.

Jickells, T.D. and Knap, A.H. (1984). The distribution and geochemistry of some trace metals in the Bermuda coastal environment. Est. Coast. Shelf Sci. 18: 245-262.

Jickells, T.D., Knap, A.H. and Smith, S.R. (1985). Trace metals and nutrient fluxes through the Bermuda inshore waters. Proceedings of the Contaminant Fluxes through the Coastal Zone Symposium. Nantes, France.

Johannes, R.E., Coles, S.L. and Kuenzel, N.T. (1970). The role of zooplankton in the nutrition of some scleractinian corals. Limnol. Oceanogr. 15: 579-586.

Jordan, C.F. (1973). Carbonate facies and sedimentation of patch reefs off Bermuda. Am. Assoc. Petrol. Geol. Bull. 57(1): 42-54.

Knap, A.H., Illiffe, T.M. and Butler, J.N. (1980). Has the amount of tar on the open ocean changed in the past decade? Mar. Pollut. Bull. 11: 161-164.

Knap, A.H., Sleeter, T.D., Dodge, R.E., Wyers, S.C. Frith, H.R. and Smith, S.R. (1983). The effects of oil spills and dispersant use on corals: a review and multidisciplinary approach. In: ???? (1983). Oil and Petrochemical Pollution. Graham and Trotman Ltd.

Knap, A.H., Solbakken, J.E., Dodge, R.E., Sleeter, T.D., Wyers, S.J. and Palmork K.H. (1982). Accumulation and elimination of $\left(9-{ }^{14} \mathrm{C}\right)$ Phenanthrene in the reef-building coral (Diploria strigosa). Bull. Environm. Contam. Toxicol. 28: 281-284.

Knap, A.H., Wyers, S., Dodge, R., Sleeter, T.D., Frith, H.R., Smith, S.R. and Cook, C.B. (1985). The effects of chemically and physically dispersed oil on the brain coral Diploria strigosa (Dana) - a summary review. Proc. 1985 Oil Spill Conf. (AP.I. Publ. No. 4385): 547-551.

Laborel, J. (1960). Contribution à l'étude des Madreporaires des Bermudes (systématique et repartition). Bull. Mus. Nat. Paris 38: 281-300.

Land, L. and Mackenzie, F.T. (1970). Field Guide to Bermuda Geology. Bermuda Biol. Stn Spec. Publ. 4.

Lessios, H.A., Glynn, P.W. and Robertson, D.R. (1983).

Mass mortalities of coral reef organisms. Science 222: 715.

Lessios, H.A, Robertson, D.R. and Cubit, J.D. (1984).

Spread of Diadema mass mortality through the Caribbean. Science 226: 335-337.

Logan, A. (1984). Interspecific aggression in hermatypic corals from Bermuda. Coral Reefs 3(3): 131-138.

Logan, A. (in press). Reefs. In: Sterrer, W. (Ed.), Bermuda: anatomy of an oceanic island. Wiley Interscience, New York.
Logan, A., Mathers, S.M. and Thomas, M.L.H. (1984). Sessile invertebrate coelobite communities from reefs of Bermuda: species composition and distribution. Coral Reefs 2(3): 205-213.

Mackenzie, F.T. and Vacher, H.L. (1975). Bermuda. In: Fairbridge, R. (Ed.). The Encyclopedia of World Regional Geology, Part 1. Dowden, Hutchinson and Ross, Inc. Pp. 117-121.

Maynard, N.G. (Ed.) (1984). Effects of petroleum residues on intertidal organisms of Bermuda. Bermuda Biol. Sin Spec. Publ. 21.

-Meischner, D. and Meischner, U. (1977). Bermuda south shore reef morphology - a preliminary report. Proc. 3rd Int. Coral Reef Symp., Miami 2: 243-250.

Meischner, D., Torunski, H. and Kuhn, G. (1981).

Significance of holocene Oculina coral growth, Bermuda Islands. Abstract. Proc. Fourth Int. Coral Reef Symp., Manila 1: 598.

Morris, B., Barnes, J., Brown, F. and Markham, J. (Eds) (1977). The Bermuda Marine Environment 1. Bermuda Biol. Stn Spec. Publ. 15: 120 pp.

Neumann, A.C. (1965). Processes of Recent carbonate sedimentation in Harrington Sound, Bermuda. Bull. Mar. Sci. 15: 987-1035.

Prat, H. (1936). Notes sur les atolls et les récifs coralliens des Bermudes. C.R Somm. Séances Soc. biogeogr. 3: 13-14.

Rein, JJ. (1881). Die Bermuda-Inseln und ihre Korallenriffe nebst einem Nachtrage gegen die Darwinische Senkungstheorie. Verh. dt. Geogr. Tag. 1: 29-46.

Rogers, C.S. (1985). Degradation of Caribbean and Western Atlantic coral reefs and decline of associated fisheries. Proc. Sth Int. Coral Reef Congr. Tahiti, 6: 491-496.

Safriel, U.N. (1974). Vermetid gastropods and intertidal reefs in Israel and Bermuda. Science 186: 1113-1115.

Scoffin, T.P. and Garrett, P. (1974). Processes in the formation and preservation of internal structure in Bermuda patch reefs. Proc. 2nd Int. Coral Reef Symp., Australia 2: 429-448.

Scott, D.A. and Carbonell, M. (1986). A Directory of Neotropical Wetlands. IUCN, Gland and Cambridge.

Sleeter, T.D. (Ed.) (1984). Assessment of the Potential for Aquaculture in Bermuda. Bermuda Biol. Stn Spec. Publ. 27.

Sleeter, T.D., Butler, J.N. and Barbash, J.E. (1980). Hydrocarbons in the sediments of the Bermuda region: lagoonal to abyssal depths. Advances in Chemistry Series 185: Petroleum in the Marine Environment: 267-288.

Sleeter, T.D., Knap, A.H. and Hughes, I.W. (1983). Oil spill contingency planning and scientific support coordination in Bermuda: a successful model. Proc. 1983 Oil Spill Conf. 149-153.

Sloan, N. (1982a). The Mari Boeing Site. Chap. 3. In: Bodungen et al, (1982): 101-102.

Sloan, N. (1982b). Threats to the corals of Bermuda. Chap. 3. In: Bodungen et al., (1982): 103-105.

Smith, S.R. (1985). Reef damage and recovery after ship groundings on Bermuda. Proc. 5th Int. Coral Reef Congress, Tahiti 6: 497-502.

Smith, S.R. and Knap, A.H. (1985). Significant decrease in the amount of tar stranding on Bermuda. Mar. Pollut. Bull. 16: 19-21.

Smith, S.R. and Musik, K.M. (1984). Aspects of the distribution and ecology of shallow water scleractinian and octocorallian species on Bermudian reefs. Abstract. Advances in Reef Science. Joint meeting of the 
Atlantic Reef Committee and the International Society for Reef Studies, Miami: 115.

Stanley, D.J. and Swift, DJ.P. (1967). Bermuda's southern aeolianite reef tract. Science 157: 677-681.

Sterrer, W.E. (1985). Marine Flora and Fauna of Bermuda. Wiley Interscience, New York.

Sterrer, W. and Wingate, D.B. (1981). Wetlands and marine environments. In: Hayward, S.J., Holt Gomez, V., and Sterrer, W. (Eds), Bermuda's Delicate Balance. The Bermuda National Trust. Chap. 11.

Upchurch, S.B. (1970). Sedimentation on the Bermuda platform. Ph.D. Dissertation, Northwestern University. 145 pp.

Wefer, G., Dawson, R. and Hempel, G. (Eds) (1981).

The Harrington Sound Project, Kiel University. Bermuda Biol. Sin Spec. Publ. 19.

Wilson, A.O. (1969). Three coral reefs of Bermuda's North Lagoon: physiography and distribution of corals and calcareous algae. Bermuda Biol. Sin Spec. Publ. 2: $51-64$.

Wingate, D.B. (1973). A Checklist and Guide to the Birds of Bermuda. Island Press, Bermuda.

Wyers, S.C. (1985). Sexual reproduction of the coral Diploria strigosa (Scleractinia, Faviidae) in Bermuda: research in progress. Proc. Sth Int. Coral Reef Congress, Tahiti 4: 301-306.

Wyers, S.C. (1986). Recent observations of spawning phenomena in Bermuda: does synchronous multi-species spawning occur in Western Atlantic coral communities? Paper given at 19th Meeting of the Association of Island Marine Laboratories of the Caribbean, St Croix, 20-23 May, 1986.

Wyers, S.C., Frith, H.R., Dodge, R.E., Smith, S.R., Knap, A.H., Sleeter, T.D. (in press). Behavioural effects of chemically dispersed oil and subsequent recovery in Diploria strigosa (Dana). Marine Ecology.

We are very grateful to S. Robertson Smith and S. Wyers for considerable help in compiling this account.

\section{NORTH SHORE CORAL REEF PRESERVE}

Geographical Location Bounded to south by a straight line due east from the most northerly extremity of the Commissioners House on Ireland Point; to west by a line from Gibbs Hill Lighthouse to the northem limit of breaking reefs $\left(64^{\circ} 50^{\prime} \mathrm{W}\right)$; to north by the northern limit of breaking reefs, including North Rock; and to east by a line from easternmost tower of Store Hill Wireless Station in Devonshire Parish to northern limit of breaking reef ( $\left.64^{\circ} 45^{\prime} \mathrm{W}\right)$ (Anon., 1981a).

Area, Depth, Altitude Approx. 12000 ha; maximum depth in lagoon about $20 \mathrm{~m}$, minimum depth over coral reefs about 1-2 m, although North Rock and a few breaker reefs are emergent on the north margin.

\section{Land Tenure Bermuda Government.}

Physical Features Rim reefs, lagoonal patch reefs, sandy bottom lagoon biotopes. Does not abut the coastline.

Reef Structure and Corals This area has mainly patch, pinnacle and table reefs. Boiler reefs are found to the north along the rim of the platform west of North Rock, with ledge flat reefs to the south (Morris et al., 1977). Coral cover on the patch reefs is generally $10-45 \%$ (Garrett et al., 1971). The dominant lagoonal reef-building corals are Diploria spp., Montastraea spp. and Porites astreoides (Scoffin and Garrett, 1974). An Oculina-Madracis assemblage characterizes the deeper lagoonal patch reefs and lower faces of the shallow patch reefs. Coral cover is high on the reefs immediately adjacent to North Rock, particularly on the reef-front terrace seaward of the Rock. The dominant species are D. strigosa, D. labyrinthiformis and $P$. astreoides (Dodge et al., 1982; Garrett and Scoffin, 1977; Logan, 1984; Smith and Musik, 1984).

Wilson (1969) studied the micro-atolls known as Make-do and Grid Reefs, and the deeper reef at Three Hill Shoals outside the eastern boundary of the Preserve. Grid Reef is nearly circular, $100 \mathrm{~m}$ in diameter, and rises from $15 \mathrm{~m}$ depth to within $1 \mathrm{~m}$ of the surface. The top is irregular with coral-algal knobs and sand channels. Make-do has a more elongated shape and its surface is at $4 \mathrm{~m}$ depth. The reef top has a broad sand flat with a few knobs. These reefs are considered to be expanding laterally by the growth of $M$. cavernosa and $M$. annularis, and vertically by the growth of Diploria spp., Montastraea spp., Porises spp. and lithothamnoids.

Bardach (1959) studied a reef within the Preserve which rises from the lagoon floor at $40-50 \mathrm{ft}(12.2-15.2 \mathrm{~m})$ almost to the surface. It is irregularly oval in shape, covers an area of 2.5 ha and is dotted with sand holes. The predominant corals are $P$. astreoides, D. labyrinthiformis, Millepora alcicornis and some Agaricia fragilis. Gorgonians are particularly abundant, especially Rhipidigorgia flabellum, Plexaura flexuosa and Eunicea grandis.

Noteworthy Fauna and Flora The area is representative of the reef and lagoon biota, but not unusual; a general description is given in Sterrer (1985). Turtles are sometimes seen and several species of seabirds (Wingate, 1973).

Scientific Importance and Research The reefs immediately adjacent to North Rock are considered to be the most flourishing on Bermuda. Some of the most intensively researched reef sites lie within the boundaries, although the preserve was not established as a focus for research and there has been little attempt to comprehensively describe its biota and ecology as a distinct area. The northern reefs, particularly in the vicinity of North Rock, are among those most frequently studied by intemational researchers and student groups. Aspects of research within the area include the geology of lagoon reefs, reef bioerosion, coral growth and various studies on the biology of reef organisms (see Introduction and Logan (in press) for review).

Economic Value and Social Benefits Benefits from fishing, tourism and recreation are not notably different from other reef areas. There are no special educational facilities associated with the preserves, although there are general exhibits for coral reef ecosystem interpretation at the Bermuda Aquarium and Zoo.

Disturbance or Deficiencies The grounding in December 1978 and salvage three months later of the Mari Boeing, just inside the western boundary $5.6 \mathrm{~km}$ 
west of North Rock, destroyed about $0.45 \mathrm{sq} . \mathrm{km}$ of shallow reef and left a zone of disturbed reef $25-50 \mathrm{~m}$ wide around this, which had a reduced population of surviving hard corals and very few other species (Sloan, 1982a; Smith, 1985). Recolonization of the most damaged area has been studied since 1980 and appears to be proceeding at the rate of $\mathrm{ca} 25 \mathrm{sq}$. $\mathrm{cm}$ of coral a year with Porites astreoides and Favia fragum the dominant recolonizing coral species; few other sessile macro-invertebrates have re-established on the damaged reefs (Smith, 1985). The North Channel and a small part of the South Channel cross the lagoon area, and ship traffic causes sediment resuspension in their vicinity.

Legal Protection Protected under the Coral Reef Preserves Act, 1966. It is an offence to remove, damage or be in possession of flora or fauna, whether alive or dead, which are attached to the coast, the sea-bed or any reef. Offenders are liable to a fine not exceeding $\$ 480$ or to imprisonment for a term not exceeding 6 months or to both (Anon., 1981a).

Management The aim of the preserve is to protect the reefs and there is no active management other than that carried out for reef resources throughout the island. Scientific research is conducted under special permit.

Recommendations None at present.

\section{SOUTH SHORE CORAL REEF PRESERVE}

Geographical Location Bounded by the mean high water mark of south shore; an imaginary straight line drawn between the most southerly extremity of the eastern arm of Hungry Bay and the most southern extremity of Gurnet Rock; and an imaginary line drawn from the most southerly extremity of Castle Island and extended to the south shore (Anon., 1981a).

Area, Depth, Altitude Approx. 530 ha; maximum depth about $16 \mathrm{~m}$, minimum depth is mean high water mark on shoreline and emergent tops of boiler reefs.

\section{Land Tenure Bermuda Government.}

Physical Features The Preserve includes the coastal rocky shores and sand beaches which are relatively exposed, particularly in the summer due to seasonality of prevailing winds. A narrow region of cup reefs borders the coastline and adjoins the seaward fore-reef slope.

Reef Structure and Corals The area includes mainly boiler reefs but some patch, pinnacle and table reefs are also found (Morris et al., 1977). Coral coverage is not as high as on the north shore and the dominant species are Diploria strigosa and Porites astreoides (Dodge et al., 1982; Smith and Musik, 1984).

Noteworthy Fauna and Flora The area is representative of the reef and lagoon biota described in Sterrer (1985). Turtles are sometimes seen and several species of seabird (Wingate, 1973). Nesting sites for birds, including Tropicbirds and the endangered, endemic Bermuda Petrel Pterodroma cahow, lie just outside the east boundary of the South Shore Preserve, on some islands which are formal Nature Reserves under a separate government provision, managed by the government conservation officer.

Scientific Importance and Research There has been little attempt to comprehensively describe the biota and ecology of the Preserve as a distinct area as it was not established as a focus for research. However, some of the most intensively researched sites on Bermuda's reefs happen to occur within the boundaries and sites within the Preserve are the most commonly studied examples of south shore reefs. The coral community structure of reefs near Natural Arches, for example, has been studied by Dodge et al. (1982) and Smith and Musik (1984). Particular interest has been shown in the geology and biology of the cup reefs, while the scope of other biological research within the area is similar to that indicated for the North Preserve (see Intrduction and Logan (in press))

Economic Value and Social Benefits Benefits, such as those from fishing, tourism and recreation, are not notably different from other reef areas. There are no special educational facilities associated with the preserve, although there are general exhibits for coral reef ecosystem interpretation at the Bermuda Aquarium and Zoo.

\section{Disturbance or Deficiencies Apparently none}

Legal Protection Protected under the Coral Reef Preserves Act, 1966. It is an offence to remove, damage or be in possession of flora or fauna, whether alive or dead, which are attached to the coast, the sea-bed or any reef. Offenders are liable to a fine not exceeding $\$ 480$ or to imprisonment for a term not exceeding 6 months or to both (Anon., 1981).

Management The aim of the Preserve is to protect the natural beauty of Bermuda's coral reefs and there is therefore no active management other than that carried out for reef resources throughout the island.

Recommendations None at present. 



\section{INTRODUCTION}

\section{General Description}

Brazil, the fifth largest country in the world (8 $511968 \mathrm{sq.} \mathrm{km}$ ), has a coastline which runs from $4^{\circ} 25^{\prime} \mathrm{N}$ to $33^{\circ} 45^{\prime} \mathrm{S}$. Geographical aspects of the coastline and the physical characteristics of the marine environment are reviewed in Laborel (1969). The coast is under the influence of trade winds from the north-east in the north and from the south-east in the south and lies outside the Caribbean hurricane belt. Some $3000 \mathrm{~km}$ of coast has reefs, although not all of these are true coral reefs. Laborel (1969) gives a detailed review based on extensive survey work using aerial reconnaissance as well as field work. The following description is a summary of this publication.

The north-west Amazonian coastline, from the border with French Guyana to São Luis do Maranhão is a vast marshy-alluvial plain, often bordered with mangroves. This area, where the continental platform is extremely broad (up to $100 \mathrm{~km}$ wide in front of Isla de Marajó) with no coral reefs and only scattered isolated coral growth, appears to act as a barrier to the dispersal of madreporians (see below). East of this, towards Cabo de São Roque, is a semi-arid region with high dunes along the coast, a narrow continental platform and high water turbidity caused by trade winds. Reefs are few in number and poorly developed but the area is little known, as roads and communications are poor and there are few accessible ports. Almost mono-specific coral formations, usually totally submerged, have been found in some sites, with Siderastrea stellata as the main reef builder, and Millepora alcicornis and Favia gravida as the secondmost important species. Some areas have still not been visited, such as the reef of João da Cunha, situated far from the coast in 1-8 $\mathrm{m}$ of water opposite the mouth of the Rio Mossoro; it is not even known whether is a coral assemblage. Reefs described by Laborel (1969) include Urca do Tubarão and Urca do Minhoto which are both relatively inaccessible and poorly known and Coroa das Lavadeiras, a large unexplored bank which is probably mainly sandy but which may have corals.

From Cabo de São Roque to Natal, an extensive line of reefs is found along the coast, bordered on the seaward side by the São Roque Channel. These reefs are generally narrow $(5-6 \mathrm{~m})$ without a definite reef flat and are formed from pinnacles composed of a small number of species dominated by $S$. stellata and Millepora. The pinnacles tend to be capped by a crust of Melobesiacae and vermetids, Dendropoma. Some of these "reefs" are simple banks on rocky emergent foundations. The reefs of Sioba, Fogo and Maracajaú are described in more detail in Laborel (1969).

Off Cabo de São Roque lie the islands of Fernando de Noronha and the Atol das Rocas, the latter of which is described in a separate account. Neither of these have true reef formations, but they have a rich coral fauna of about a dozen species forming dense unstructured populations between the surface and $15 \mathrm{~m}$ depth. At greater depths, in less agitated waters, pinnacles of Montastraea cavernosa are found. Fernando de
Noronha $\left(3^{\circ} 51^{\prime} \mathrm{S}, 32^{\circ} 26^{\prime} \mathrm{W}\right)$ is a volcanic archipelago, consisting of a principal island of $17 \mathrm{sq} . \mathrm{km}$, and eighteen islets of varying sizes. It is situated $350 \mathrm{~km}$ north-east of Cabo de São Roque and has a similar flora and fauna to the Atol das Rocas. Coral zonation is similar to that of the coastal coral formations with an algal crest of vermetids and Melobesiacae, and zones of Palythoa and Millepora alcicornis, Mussismilia and Montastraea cavernosa. Colonies of Mussismilia are small and only weakly attached to the substrate, possibly because of exposure to the trade winds. On the windward side, vermetid and algal growth is particularly luxuriant and extensive. The vermetid and algal reef in the creek Saco de Atalaiá, east of Morro do Espinhaço, is described by Kempf and Laborel (1968).

The islands of São Pedro and São Paulo (St Pauls Rocks), situated in the Atlantic about $500 \mathrm{~km}$ north-east of Fernando do Noronha, are less well known. An expedition from Cambridge University visited the latter in 1979 (Edwards and Lubbock, 1983) and found that both the fish (48 species) and coral faunas lacked diversity compared with Fernando de Noronha, but that there were a number of endemic fish. Only two hermatypic corals, Scolymia wellsi and Madracis decactis, and two ahermatypes, Polycyanthus sp. and Astrangia sp., were recorded, most growing at depths of more than $15 \mathrm{~m}$. Three of these were Brazilian species. From 1 to $5 \mathrm{~m}$ depth, the dominant invertebrate is a zoanthid, probably Palythoa sp.; at greater depth, a Caulerpa zone is found which grades into a zone of branching coralline red alga at $30-40 \mathrm{~m}$. Black coral, Antipathes thamnea and $A$ hirta, is found at greater depths. A variety of corals were dredged from $150-300 \mathrm{~m}$.

Along the $500 \mathrm{~km}$ stretch of mainland coast from Natal south to Rio São Francisco, the fauna becomes richer and reefs are frequent, long and linear, running parallel to the shore and based on stone reefs at $3 \mathrm{~m}$ depth. The coast is reasonably accessible and the presence of the Oceanographic Institute at Recife has led to detailed studies of this area. Some 140 miles $(225 \mathrm{~km})$ of coast have been surveyed by plane and 80 miles $(130 \mathrm{~km})$ have been studied on the ground. Reefs in the north of this area characteristically have an emergent reef flat with only two species of stony coral, F. gravida and Siderastrea stellata, and an algal ridge of Melobesiacea and Dendropoma. Three zones are found on the seaward slope: 1) Millepora alcicornis; 2) Mussismilia hartii and 3) at greatest depths, Montastraea cavernosa. Gorgonians are particularly abundant. Laborel (1969) describes the reefs at Cabedelo and Tambau in detail. From Pirangi to Camaratuba there are few reef formations. Reefs off Pitimbu, Pointe de Jaguaribe (Itamaracá Island) and Rio Doce are also described. Off Itamaracá Island, reefs consist of $90 \% \mathrm{~S}$. stellata which is of interest in that the colonies are not attached to the substrate. The reefs around Recife are considered to be depauperate although there is evidence to suggest that they were richer in the past.

Greatest reef development is found to the south between Maceió and Recife. Reefs from Olinda to Pedras Petras and Cabo Santo Agostinho have been well studied. 


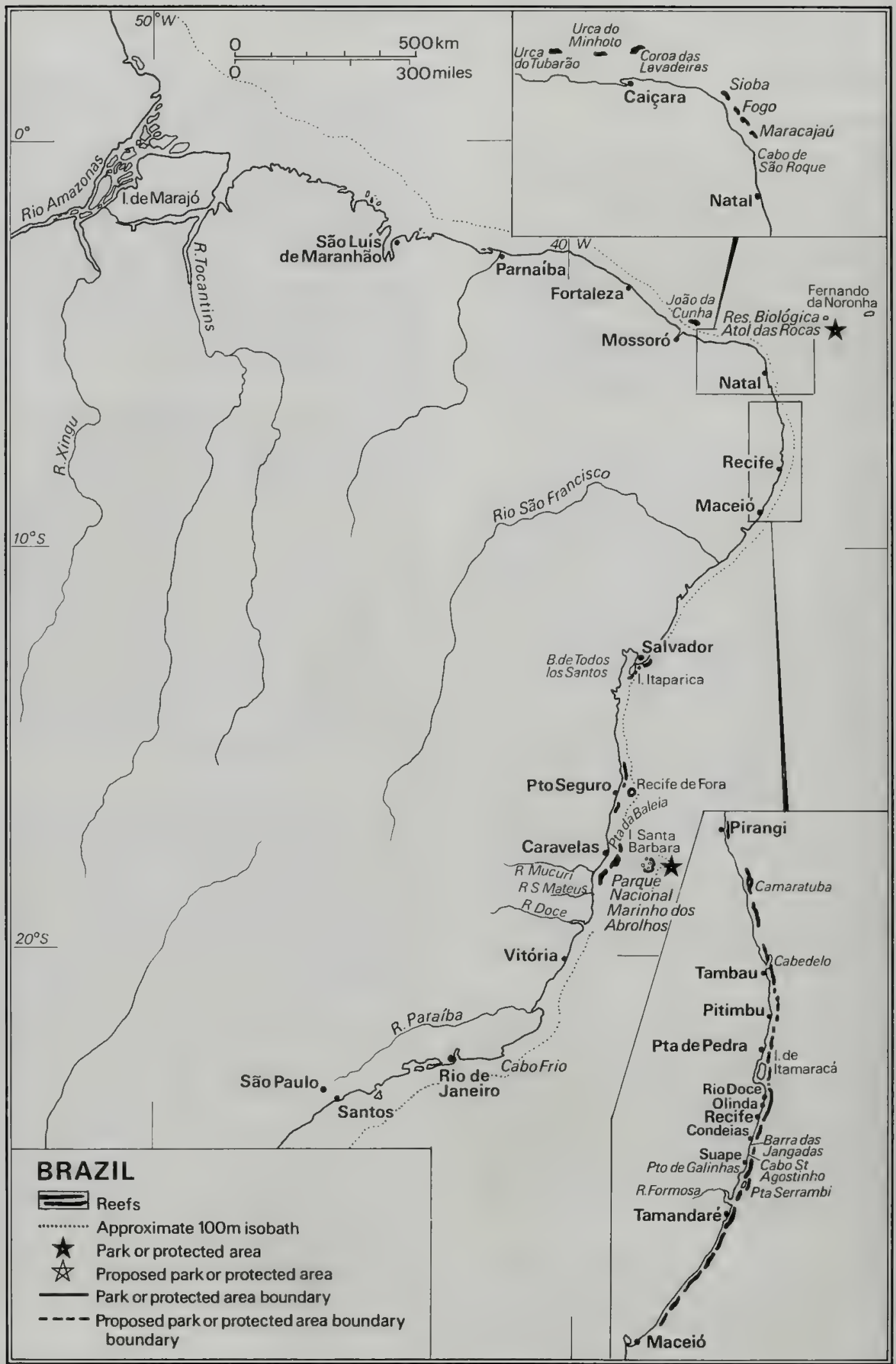


Laborel (1969) describes the reefs at Tacis, a reef off Recife that he names Banc de Base Aerienne, Candeias, Barra das Jangadas, Suape, Cupe (between Suape and Porto Galinhas), Porto Galinhas and Punta de Serrambi. Tamandaré reef is described in a separate account.

The mouth of the Rio São Francisco forms a major $100 \mathrm{~km}$ barrier between the reefs of the north and south. South of the river, reefs are found to the Bay of Salvador (Todos los Santos), down the coast of Bahia State and in the Abrolhos Archipelago, the most extensive and most southerly reef region in Brazil (see separate account). The endemic species Mussismilia braziliensis is the main reef builder in this region. Reefs in the Bay of Todos los Santos, off Itaparica Island and south of Punta da Baleia are described by Laborel (1969) and Leão et al. (1982a and b). Itaparica Island is $30 \mathrm{~km}$ long and much of its east coast is bordered with fringing reef, much of which is similar to the Abrolhos Reef and to the reef at Guarajuba, with a reef flat which is completely emergent at low tide, a Millepora alcicornis zone and abundant Mussismilia braziliensis. The latter however is less abundant at Guarajuba and Itaparica on account of turbid water, and is replaced by $M$. hartii. The Itaparica Reef is characterized by a back-reef zone consisting of shallow lagoons without the typical patch reefs found in the Caribbean.

Many of the reefs in this southern region have a characteristic formation of mushroom-shaped pinnacles, 1-25 $\mathrm{m}$ high and $2-50 \mathrm{~m}$ in diameter called "chapeiroes". Adjacent "chapeiroes" may coalesce at their tops to form bank or platform reefs $1-20 \mathrm{~km}$ long with varied shapes. Fringing reefs, in very shallow waters, lack spur and groove systems and the back-reef zone is represented by extremely shallow lagoons without patch reefs (Leão, 1982). South of Abrolhos, annual variations in water temperature are greater and there is a greater vertical temperature gradient. The southern limit of coral growth is at the border of the State of Espiritu Santo. A few extremely interesting coral "oases" are found scattered between the barriers formed by the cold upwelling of Cabo Frio and the mouths of the rivers Mucuri, São Mateus and Doce. These have clear waters and very interesting faunas, with in some places extensive fields of gorgonians.

The Brazilian coral fauna has long been considered of interest on account of its high proportion of endemic species which are discussed in Laborel (1969-70). Ten of the eighteen hermatypic coral species (56\%) known from Brazil are endemics (Laborel, 1969), but only five of seventeen species of gorgonians are exclusively Brazilian (Bayer, 1961). Excellent conditions for the survival of a West Indian reef fauna have been found on the continental shelf off the Guyanas and the Amazon, but the large volume of silt-laden freshwater from the Orinoco River in Venezuela and the Amazon in Brazil probably form a barrier some $2700 \mathrm{~km}$ wide. This was initially thought to cause disjunct distributions for most marine fauna but populations of typical West Indian reef fish are present over sponges on hard bottoms with oceanic salinity, from Cayenne, French Guyana, south to the Equator. More and better identified collections will probably show that this barrier interrupts gene flow only between populations of species directly associated with corals or occurring in reef habitats shallower than $50 \mathrm{~m}$ (Collette and Ruetzler, 1977).
The founding of the Oceanographic Institute at Recife in 1958 marked the start of extensive marine studies. Early reef studies by Hart (1870) and Branner (1904) were updated by Laborel (1969). The Brazilian reefs of the mainland coast have a number of unusual characteristics, many of them being partially elevated and dead, with living corals and algae on their outer and inner slopes only. This is partly due to their relatively recent evolution on top of a "mobile" littoral platform where sea-level variations have been quite strong and rapid (3-5 $\mathrm{m}$ amplitude). The effects of holocene sea level changes on the Brazilian reefs are described by Leão et al. (1985). Vermetid and algal reefs along the coast of Brazil are described by Kempf and Laborel (1968) and compared with those in Bermuda and the Mediterranean. Other reef and marine invertebrates besides corals show fairly high levels of endemism. Sponges from reef sites off Fernando de Noronha, Recife and the coast of Bahia are described by Hechtel (1976 and 1983).

The Caribbean and Amazonian Manatees Trichechus manatus and $T$. inunguis are found along the northern coast. The Loggerhead Caretta caretta, Olive Ridley Lepidochelys olivacea and Leatherback Dermochelys coriacea nest, apparently in small numbers in scattered localities from Maranhão State to Espirito Santo State. A large population of Green Turtles Chelonia mydas feeds in coastal waters and up to a few thousand may nest annually although this is unconfirmed (Groombridge, 1982; Bacon et al., 1984). Williams (1984) lists the seabirds nesting on the islands of Atol das Rocas, Fernando do Noronha and St Paul's Rocks. Important coastal wetland areas, including mangroves, are described in Scott and Carbonell (1986).

\section{Reef Resources}

Little information is available on the economic importance of Brazilian reefs. Reefs are undoubtedly important in coastal fisheries and, locally, for tourism, as at the Parque Nacional Marino dos Abrolhos (see separate account); however, large expanses of the Brazilian coastline, especially in the north, are relatively uninhabited and it is likely that reefs are not heavily used. Manatees and sea turtles are heavily exploited (Thornback and Jenkins, 1982; Groombridge, 1982; Bacon et al., 1984). Mangrove areas are exploited, notably in the north-east in the region of Salvador and Recife (Scott and Carbonell, 1986).

\section{Disturbances and Deficiencies}

Many of the Brazilian coastal reefs are currently severely stressed, largely due to the high sediment load of rivers caused by deforestation. Most of the coast has turbid water throughout the year, in sharp contrast to the waters of Atol das Rocas and Fernando do Noronha which are clear and living vermetid reefs appear to be disappearing in many areas, to be replaced by calcareous algae (Kempf and Laborel, 1968) The impact of coral extraction for lime and construction work on the Siderastrea stellata reefs at Itamaraca Island (north of Recife) and Recif de Fora (off Porto Seguro, Santa Cruz State) (Laborel, 1969), and the use of corals in southern Brazil to decorate houses (Tommasi in litt., 31.3.81) is not known. Sport 
fishing and spearfishing may be having a serious impact in some areas, particularly Fernando de Noronha (Laborel in litt. to B. Salvat, 20.7.81). Coastal developments are probably damaging reefs (Laborel, 1969), such as south of Abrolhos where the coast in the vicinity of Cabo Frio and Angra dos Reis, $100 \mathrm{~km}$ west of Rio de Janeiro, is being rapidly developed for the tourist industry. This, plus expanding industrial development, may threaten the coral "oases" in this area, some of which should perhaps be considered for Marine Park status.

\section{Legislation and Management}

No information is available on legislation controlling use of reef resources, although turtle collecting is controlled (Bacon et al., 1984). The Reserva Biológica do Atol das Rocas and the Parque Nacional Marinho dos Abrolhos are the only protected areas existing at present which contain coral reefs; these are described in separate accounts. The island of Fernando de Noronha is protected from abuse by visitors through its military status.

\section{Recommendations}

Robben (1985) discusses conservation of reefs in Brazil in relation to sea tenure. A group of conservationists forming a Committee for the National Park of Fernando de Noronha, would like the island of Fernando de Noronha to be declared a national marine park before tourist development begins in earnest (Anon., 1986). Tamandaré reef off Recife, described in a separate account, has potential as a protected area. Further information on this area is required.

\section{References}

* = cited but not consulted

-Andrade, G.O. de (1960). O recife anular de Rocs, um registro de recentes variações eustáticas no Atlantico equatorial. Anais hydrogr. D.H.N. Rio de Janeiro 18: 203-234.

Anon. (1979). Reserva Biologica do Atol das Rocas. Plano do Sistema de Unidades de Conservação do Brasil. M.A. Instituto Brasileiro de Desenvolvimento Florestal IBDF. Fundação Brasileira para Conservação de Naturez FBCN.

Anon. (1983). Brazil's first marine national park established. CNPPA Members Newsletter April/May 1983.

Anon. (1986). Plea for Brazilian marine park. Oryx 20: 195.

Bacon, P., Berry, F., Bjorndal, Hirth, H., Ogren, L. and Weber, M. (1984). The National Reports. Proceedings of the Western Ailantic Turtle Symposium, Costa Rica. Vol.3: University of Miami Press, Florida.

Barreira e Castro, C. (1981). Abrolhos, Santuário Ecológico na Costa da Bahia. Revista Geografica Universal Aug, 1981: 26-37.

Bayer, F.M. (1961). The Shallow-water Octocorallia of the West Indian Region. Martinus Nijhoff, The Hague. Pp 321-326.

Branner, J. (1904). The stone reefs of Brazil, their geological and geographical relations, with a chapter on the coral reefs. Bull. Mus. Comp. Zool. Cambridge (Geol.) 44(7): 1-285.

Collette, B.B. and Ruetzler, K. (1977). Reef fishes over sponge bottoms off the mouth of the Amazon River. Proc. 3rd Int. Coral Reef Symp, Miami : 305-310.

Edwards, A. and Lubbock, R (1983). The ecology of Saint Paul's Rocks (Equatorial Altantic). J. Zool., Lond. 200: 51-69.

Groombridge, B. (1982). The IUCN Amphibia-Reptilia Red Data Book. Part I: Testudines, Crocodylia, Rhynchocephalia. IUCN, Gland, Switzerland.

Hart, C.F. (1870). Geology and Physical Geography of Brazil. Boston.

Hechtel, G. (1976). Zoogeography of brazilian marine Demospongiae. In: Harrisson, F.W. and Cowden, R. (Eds), Aspects of Sponge Biology. Academic Press : 237-260.

Hechtel, G. (1983). New species of marine Demosponges from Brazil. Iheringia (Zoology), Porto Alegre 63: 59-89.

IUCN (1982). IUCN Directory of Neotropical Protected Areas. Tycooly International Publishing Ltd., Dublin.

Kempf, M. and Laborel, J. (1968). Formations de vermets et d'algues calcaires sur les côtes du Brésil. Rec. Trav. Stat. mar. Endoume 59: 43.

Laborel, J. (1969). Les peuplements de Madréporaires des côtes tropicales du Brésil. Ann. Univ. d'Abidjan, Serie E (Ecologie) II, 3. 260 pp.

Laborel, J. (1969-1970). Resultats scientifiques des Campagnes de la "Calypso". Ann. Inst. Ocean. 47: 15-227.

Leão, Z.M.A.N. (1982). Morphology, geology and development history of the southernmost coral reefs of western Atlantic, Abrolhos Bank, Brazil. Ph.D., Rosenstiel School of Marine and Atmospheric Science, Univ. of Miami.

Leâo, Z.M.A.N. (1983). Abrolhos - o refúgio pleistocênico de uma fauna terciária de corais. Ciências da Terra 8: 22-24.

Leāo, Z.M.A.N. (1985). Morphology, sedimentology and coral community of the Abrolhos reefs (Bahia, Brazil). Abstract. Proc. Sth Int. Coral Reef Congr., Tahiti 2: 100.

Leảo, Z.M.A.N. and Lima de Lima, O.A. (1982). Caracterização do substrato de recifes de corais holocênicos a partir de dados de sísmica de refração et de perfuração. Revista Brasileira de Geociências 12(4): 531-535.

Leāo, Z.M.A.N., Araujo, T.M.F. and Nolasco, M.C. (1982a). Recifes de Corais no estado da Bahia. Alos do IV Simpósio do Quaternário no Brasil : 225-258.

Leão, Z.M.A.N., Bittencourt, A.C.S.P., Dominguez, J.M.L., Martin, L. and Nolasco, M.C. (1985). The effects of holocene sea-level fluctuations on the morphology of the Brazilian coral reefs. Proc. 5th Int. Coral Reef Congr., Tahiti 3: 171.

Leão, Z.M.A.N., Ferreira, M.T.G.M. and Araujo, T.M.F. (1982b). Sedimentologia e estruturas biogênicas do recife de franja da Itha de Itaparica, Bahia. $X X X I I$ Congresso Brasileiro de Geologia, Salvador, Bahia : 263-299.

Ottman, F. (1963). L'Atol das Rocas dans l'Atlantique Sud tropical. Rev. Géogr. phys. géol. dyn. 2(5)2: 101-107.

* Robben, A.C.G.M. (1985). Sea tenure and conservation of coral reef resources in Brazil. Cultural Survival Quarterly 9: 45-47.

Scott, D.A. and Carbonell, M. (1986). A Directory of Neotropical Wetlands. IUCN, Gland and Cambridge. Thornback, J. and Jenkins, M. (1982). The IUCN Mammal Red Dara Book, Part 1. IUCN, Switzerland.

Williams, AJ. (1984). Breeding distribution, numbers and conservation of tropical seabirds on oceanic islands in 
the south Atlantic Ocean. In: Croxall, J.P., Evans, P.G.H and Schreiber, R.W. (Eds), Status and Conservation of the World's Seabirds. ICBP Technical Publication No. 2, Cambridge.

\section{PARQUE NACIONAL MARINHO DOS ABROLHOS}

Geographical Location In Bahia State, about $65 \mathrm{~km} \mathrm{~km}$ off shore opposite Caravelas; $17^{\circ} 58^{\prime} \mathrm{S}, 38^{\circ} 42^{\prime} \mathrm{W}$.

Area, Depth, Altitude The Park is subdivided into two areas covering a total of about 266 sq. naut. miles (912 sq. km); total area of reefs $6000 \mathrm{sq} \mathrm{km}$.

\section{Land Tenure Government.}

Physical Features The Abrolhos Archipelago is situated on the continental shelf which extends eastwards for up to $240 \mathrm{~km}$ on this part of the coast. It comprises four main islands (Santa Bárbara, the largest; Redonđa; Siriba; and Sueste) and an islet (Guarita) (Laborel, 1969) which are the remnants of a volcanic crater rim (Barreira e Castro, 1981). The Parcel dos Abrolhos to the east is an arc of reefs, reaching $20 \mathrm{~m}$ in height, separated from the archipelago by a narrow channel and based on cretaceous sedimentary rocks. An inner arc of reef extends from off Viçosa (25 km south of Caravelas) to off Prado in the north and includes the reefs of Prado, Guaratibas, Timbebás, Areia, Caboclas, Aranguera, Lixa, Parcel das Paredes, Sebastiāo Gomes, Coroa Vermelha and Viçosa. Parcel das Paredes is a vast area of reef covering some 200 sq. km, separated from the Arquipélago dos Abrolhos by the Abrolhos Channel, 7-8 miles (113-12.9 km) wide and $20-29 \mathrm{~m}$ deep. Coroa Vermelha Reef has a small carbonate islet ( $100 \mathrm{~m}$ wide, $1.5 \mathrm{~m}$ high) and much of the surrounding reef is exposed at low tide. Geological studies have been carried out here (Leão and Lima de Lima, 1982). The reefs at Prado and Lixa are elongated in shape; that at Timbebas is arc-shaped (Leão et al., 1982).

The Abrolhos has a tropical climate with high humidity and rainfall throughout the year. An easterly wind predominates from March to September, and a north-easterly from October to February when the water is clearest (Barreira e Castro, 1981).

Reef Structure and Corals The reefs of Parcel dos Abrolhos form an arc, $5 \mathrm{~km}$ wide and $20 \mathrm{~km} \mathrm{long,} \mathrm{and}$ remain submerged even at low tide. They are formed principally of massive corals and are described by Laborel (1969). Coral cover is variable but usually averages $50 \%$, the main reef builder being Mussismilia braziliensis. This has an unusual growth form unique to the Abrolhos, with vertical, mushroom-shaped pillars or pinnacles known as "chapeiroes" up to $2-3 \mathrm{~m}$ high which are abundant in depths of $5-10 \mathrm{~m}$. In the inner arc of reefs, the tops of adjacent chapeiroes coalesce to form bank or platform reefs, $1-20 \mathrm{~km}$ long with varied shapes, which do not display the well marked zones of Caribbean reefs. The outer arc, in waters $15-20 \mathrm{~m}$ deep, is formed by chapeiroes that do not coalesce. The reefs are typical of other reefs off the coast of Bahia in that they are completely emergent at low tide, forming a reef flat. This is covered by a diverse fauna and flora of soft corals, calcareous and non-calcareous algae and the corals Favia gravida and Siderastrea stellata which are resistant to high water temperatures and turbid water. An algal crest, with vermetid worms, is a major structural element. A Millepora alcicornis zone corresponds to the $A$ palmata zone in Caribbean reefs. At Recife de Areia, a spur and groove formation is found (Leão et al., 1982; Leão, 1985). Stony and rocky areas are found between the islands of the archipelago, where there is a depth of $8 \mathrm{~m}$ at low tide (Barreira e Castro, 1981). These reefs are also unique in Brazil in having Agaricia fragilis on the drop-off. The islands of the archipelago are fringed with coral and calcareous algal assemblages; profiles of some of these formations are given in Laborel (1969).

The reefs of Parcel das Paredes are almost all emergent at low tide. There is an extensive reef platform with a zone of anastomosing pinnacles extending seawards. The adjacent Recif do Lixa is the most well known as it is easily accessible from the port of Caravelas. Descriptions of zonation are given in Laborel (1969).

The coral fauna in this region is characterized by ten endemic species: Mussismilia braziliensis, $M$. hartii, M. hispida, Favia leptophylla, Millepora nitida, Siderastrea stellata, Porites branneri, F. gravida, Astrangia braziliensis, and Scolymia wellsi. Stephanocoenia michelini, Meandrina braziliensis and Madracis decactis are found here on the reefs, whereas in other areas they are only found at depths of $30-70 \mathrm{~m}$ below the reefs on the continental platform (Laborel, 1969 and 1969-70). Four species of endemic gorgonian are also found: Plexaurella grandiflora, Lophogorgia punicea, Pseudopterogorgia margravii and Phyllogorgia dilatata (Laborel in litt., 18.5.84). A total of about 20 coral species are known and there is a striking absence of branching acroporids. The low diversity (less than half the number found on Caribbean reefs) and high endemicity is considered to be the result of a) isolation of a late Tertiary community preserved during low stands of sea-level in the refugium provided by the seamounts off the Abrolhos Bank, and b) environmental conditions including periodic high turbidity particularly during winter storms, lack of disturbance favouring the endemic species and limited habitat diversity. The coral fauna is discussed in more detail in Leão (1983 and 1985).

Noteworthy Fauna and Flora The Loggerhead Caretta caretta, the Green Turtle Chelonia mydas and the Leatherback Dermochelys coriacea may occur here (Groombridge, 1982). At least sixteen sponges are endemic to the coasts of Bahia and Abrolhos (Hechtel, 1976 and 1983). Ninety five species of fish have been recorded in the Abrolhos and it is expected that more will be discovered. The Queen Conch Strombus gigas, which is rare along much of the Brazilian coast, is found in shallow stony and algal areas between the reefs. The Abrolhos Islands, particularly Santa Bárbara, are important nesting sites for a variety of seabirds including Anous stolidus, Sula dactylatra (the most abundant), S. leucogaster and Fregata magnificens; ten species have been recorded (Barreira e Castro, 1981).

Scientific Importance and Research The region has been visited a number of times, particularly in the $1960 \mathrm{~s}$ during the cruise of the Calypso, and includes the most interesting and important reefs on the Brazilian coast 
line. Unlike many other coral assemblages, there is still abundant marine life little disturbed by siltation from by deforestation and soil erosion (Laborel in litt. to B. Salvat, 20.7.81) although this is a potential problem (see below). It is the largest reef area in Brazil, the Parcel das Paredes alone covering $200 \mathrm{sq}$. $\mathrm{km}$, and has a particularly diverse structural formation with channels, platforms and pinnacles. All known Brazilian coral species are found in the area (21 madreporians and milleporians), as well as the species endemic to this region. In addition, there is a remarkably high density of corals and other marine invertebrates (Laborel, 1969 and 1969-70). It differs markedly from reefs further north in the lack of well marked zones and spurs and grooves, but there are well developed algal rims; the reefs are also unusual in being surrounded by sediments with appreciable amounts of muddy siliciclastic sediments (Leão, 1985). It is an important site for the study of speciation and faunal migration in the Atlantic, and its accessibility would make it an appropriate site for a marine research station (Laborel in litt. to B. Salvat, 20.7.81).

Economic Value and Social Benefits A lighthouse is situated on Santa Bárbara. There are wrecks on some of the reefs. Fishing, principally line fishing by local people, is the most important activity and takes place among the inner reefs and on the outer continental shelf. Diving and sport fishing are popular activities for visitors from the adjacent coastal cities in the summer. The majority use the inner reefs, but some make the 7.8 hour journey to the Parcel dos Abrolhos. Local fishing boats are chartered by divers (Barreira e Castro, 1981).

Disturbance or Deficiencies Although situated some 20 miles $(32 \mathrm{~km}$ ) from the coast, Parcel das Paredes has clear waters only during a few months of the year. This is probably due to the increasingly high sediment load of the rivers on the mainland opposite the archipelago, presumably caused by the extensive deforestation taking place in the interior (Laborel, 1969). Fishing with dynamite, although illegal, has taken place and coral blocks for building are mined in some areas. The seabirds have been disturbed on occasion by tourists who have taken eggs. Conch are collected by fishermen who sell the shells to tourists (Barreira e Castro, 1981).

Legal Protection Established as Brazil's first Marine National Park, 29 April, 1983 (Anon., 1983). Fishing with dynamite is prohibited.

Management A naval detachment is stationed on Santa Bárbara which provides a small degree of protection (Barreira e Castro, 1981).

Recommendations Further research is required in the area to produce recommendations for management.

\section{RESERVA BIOLOGICA DO ATOL DAS ROCAS}

Geographical Location $\quad 03^{\circ} 45^{\prime}-03^{\circ} 56^{\prime} \mathrm{S}, 33^{\circ} 37^{\prime}-33^{\circ} 56^{\prime} \mathrm{W}$. About 120 miles $(200 \mathrm{~km})$ north-east of the coast of the state of Rio Grande do Norte; 80 miles $(130 \mathrm{~km})$ west of Fernando de Noronha.

Area, Depth, Altitude $36249 \mathrm{ha}(2.5 \mathrm{~km} \times 3.5 \mathrm{~km}) ; 0-3 \mathrm{~m}$.
Land Tenure Transferred from the Navy to Instituto Brasileiro de Desenvolvimento Florestal (IBDF) ownership.

Physical Features Atol das Rocas is an almost circular, ring-shaped reef possibly lying on the same submarine shelf (the platform of the Rio Grande do Norte) as Fernando de Naronha. There is a single opening connecting the sea to an inner lagoon in the north. On the west of the atoll are two islands of coarse sand and broken coral: Farol has an area of 3.5 ha and Cemitério 3.2 ha. At low tide almost all the reef is exposed and the two islands are connected, the lagoon drying out to leave only a few small isolated ponds, the largest of which is on the east side and has a depth of 4-5 m (Laborel, 1960; Ottman, 1963). The reefs drop steeply on the outside of the atoll, the widest and best developed occurring on the south-east, exposed to the prevailing east winds. The average air temperature is $26.8^{\circ} \mathrm{C}$ and the surface water temperature is $25-26.7^{\circ} \mathrm{C}$. The hottest month is August; the driest month is October, and the rainy season is from March to July. The main current flows east-west. Water clarity is good throughout the year, due to the distance of the atoll from terrestrial influences from the mainland.

Reef Structure and Corals The reefs are considered depauperate and are based on calcareous algae and vermetids, rather than hermatypic corals. The north and east sides have large reef platforms of dead algae, exposed to the sea, with a fringe of calcareous algae at the mean level of low tide. To the south-east, there are algal reefs of Lithothamnion (Ottman, 1963). Favia gravida and Siderastrea stellata are known from shallow waters. It is likely that the fauna is richer at depths greater than 10-15 m, as occurs on Fernando de Noronha (Laborel, 1969). On the east side, numerous mushroom-shaped black rocks are found, 3-4 m above the reef table, with eroded bases, which are formed from dead calcareous algae (Ottman, 1963).

Noteworthy Fauna and Flora Ground vegetation consists of two grass species and Amarant/us which grows on guano (Laborel, 1969). There have been various unsuccessful attempts to introduce coconuts and fruit trees. The nine bird species recorded include four residents, three migrants and two occasional species. It is estimated that 100000 birds nest on Farol and Cemitério, including the Blue-faced Booby Sula dactylatra, the Brown Booby $S$. leucogaster, the Sooty Tern Sterna fuscata and the Brown Noddy Anous stolidus. Whales have been sighted off the atoll. The Green Turtle Chelonia mydas, Leatherback Dermochelys coriacea and the Loggerhead Caretta caretta may occur (Groombridge, 1982). Two species of shark are found and the area is rich in fish, several of which are listed in Anon. (1979).

Scientific Importance and Research Originally considered to be the only true Atlantic atoll, it is now recognised as an annular algal reef (Ottman, 1963).

Economic Value and Social Benefits The area is rich in commercial fish species as the shallow lagoonal waters provide optimum conditions for juveniles. Octopus, mussels, crabs and lobsters are also abundant (Anon., 1979). The islands are uninhabited and have no drinking water. A lighthouse was established on Farol in 1881; many wrecks are found around the island. 
Disturbance or Deficiencies Lack of permanent inhabitants means that the environment is undisturbed but this will create problems with wardening. The atoll lies in one of the main fishing zones of the western South Atlantic, heavily used by the Japanese (Laborel in litt. to B. Salvat, 20.7.81).

Legal Protection Reserve established 5 June 1979 by Federal Decree 83549 (IUCN, 1982).

Management Administered by the Depto de Parques Nacionais, Instituto Brasileiro de Desenvolvimento Florestal from Rua Alexandrino de Alencar, 1399, Caixa Postal 280, 59000 Natal, RN (IUCN, 1982).

Recommendations None at present.

\section{TAMANDARE REEF COMPLEX}

Geographical Location Off the coast of Pernambuco State, south of Recife and just south of the estuary of the Rio Formoso, off Punta do Lira.

Area, Depth, Altitude $0-10 \mathrm{~m}$ depth.

Land Tenure No information

Physical Features A thin (2-4 m) veneer of reef corals and calcareous algae has developed on parallel rows of beach rocks at depths of $0-10 \mathrm{~m}$. A brief description of the area is given in Laborel (1969).
Reef Structure and Corals Fauna includes at least four of the endemic Brazilian corals and interesting octocorals. The back-reef is composed of Millepora alcicornis and Mussismilia hartii, although there are few living corals. The majority of living cover consists of calcareous algae and Caulerpa. Scolymia wellsi is found on the steeper slopes of the ridges. The emergent reef flat has a dead crest of vermetids and Meliobesciacea. There are few scleractinions on the outer slope except for Siderastrea (Laborel, 1969).

Noteworthy Fauna and Flora The sponge fauna is of interest.

Scientific Importance and Research This formation is characteristic of the north-eastern Brazilian coast but is rare elsewhere. Its geological history is still completely unknown, but is linked to complex relative movements of the continental margin and the sea-level. The area is being studied by a research group from the University of Pernambuco (Laborel in litt., 18.5.84).

Economic Value and Social Benefits No information.

Disturbance or Deficiencies The area is in a zone of moderate urban and industrial development but, unlike many areas on the Brazilian, there is still the possibility of protecting it (Laborel in litt., 18.5.84).

Legal Protection None.

Management No information.

Recommendations Further information on the status of this area is required. 



\section{INTRODUCTION}

\section{General Description}

The British Virgin Islands (B.V.I.), a crown colony of Great Britain, consist of just over forty islands, small cays and rocks with a land area of 15281 ha; the marine area of the territory is well over five times the size of the land mass. The four largest islands are Tortola (the most heavily populated), Virgin Gorda, Anegada and Jost Van Dyke (Jackson, 1981). Geologically the islands belong to the Greater Antilles and, with the United States Virgin Islands (U.S.V.I.), rise from the Puerto Rican shelf, here lying about $65 \mathrm{~m}$ below sea-level. Most of the islands were uplifted from submerged volcanoes and are formed from volcanic debris and metamorphosed sediments (Dunne and Brown, 1980; Jackson, 1981). Their geological origin is described in Dunne and Brown (1980).

In spite of frequent small showers, the dry season is probably ten months or longer, the wettest months being October and November. Rainfall on the offshore cays probably does not exceed 30 in. $(760 \mathrm{~mm})$ a year. Surrounding waters drop off rapidly from the $200 \mathrm{~m}$ depth contour, although the areas selected for the marine parks and protected areas system are generally less than $24 \mathrm{~m}$ deep.

Little detailed information is available on the marine environments of Virgin Gorda and Tortola. On Virgin Gorda, South Sound, Taddy Bay and some of the coves on offshore islands have short but well developed bay-mouth reefs dominated by Acropora palmata. The majority of the south-east coast, however, has a narrow and steeply sloping shelf, $25-40 \mathrm{~m}$ deep, which prohibits reef formation (Adey and Burke, 1976; ECNAMP, 1980b). Reefs in North Sound and around Fallen Jerusalem in the south and the Dogs to the west are described in separate accounts. On Tortola, reefs occur along the south coast, in scattered areas along the north coast and off most off shore islands; mangroves are found on the south coast (ECNAMP, 1980a). Sites at Cane Garden Bay and Hans Creek Lagoon on Beef Island are described in separate accounts. Ogden (1982) describes sites around Norman Island including the proposed protected area (see separate account), the Santa Monica rocks to the south-west, which consist of several wave swept tall pinnacles dominated by encrusting Millepora and used by dive tour operators from the B.V.I. and U.S.V.I., and Money Bay on the south coast which has the only bank barrier reef on the island. Anegada, situated $19 \mathrm{~km}$ to the north and connected by a shallow shelf, is the most extensively studied of the islands and is described in a separate account.

Hawksbill Eretmochelys imbricata, Green Chelonia mydas and Leatherback Turtles Dermochelys coriacea all nest in the B.V.I., and detailed nesting data are given in Bacon et al. (1984). Wetlands are described in Scott and Carbonell (1986). Halewyn and Norton (1984) list fourteen species of seabird with established nesting colonies on the islands.

\section{Reef Resources}

Most development taking place currently in the British Virgin Islands is occurring on the coast and invoives marine resources. Towle et al. (1976) describe the natural resources of Virgin Gorda in relation to potential economic development and its impact. Income from tourism, which relies largely on marine resources, tripled in the period 1978-1982. The recreational boating industry has become particularly important, as described by Jackson (1981a, b and 1982) and Lund et al. (1985). Boating has become the most dynamic subsector of the British Virgin Islands economy with positive impacts on national income and in the provision of jobs. Charter and pleasure cruising boats accounted for about US\$14 million expenditure in 1978. The Virgin Islands are now the main centre for boat chartering in the eastern Caribbean, attracting many U.S. and European registered boats for the tourist season. Bareboat chartering showed a ten-fold increase in numbers of boats between 1969 and 1980. Crewed boat chartering and private pleasure cruising has grown simultaneously to such an extent that, in 1980, registration records showed 974 boats of all types licenced in the British Virgin Islands (Lund et al., 1985). This is paralleled by growth in vital support services ranging from repair and maintenance to berthing, storage, food provisioning and overnight accommodation for yachtsmen. In 1980 there were eleven marinas comprising 436 berths. Diving is a particularly important tourist activity, and yielded an estimated gross turnover of US\$1.0 million over 1981 and 1982. It is estimated that a minimum of 30000 SCUBA dives are made annually; five dive tour companies operate out of the B.V.I. and a large number of U.S.V.I. companies use the same dive sites.

About 150 full-time and part-time fishermen operate 90 fishing boats and approximately 1350 fish traps in British Virgin Island waters. The future of the industry is not clear as fishermen are increasingly being attracted to the tourist industry. There are few statistics available but the industry is receiving considerable attention from the government in order to increase the annual catch without causing over-exploitation (Wood, 1983).

\section{Disturbances and Deficiencies}

Hurricane David (August 1979) and Hurricane Allen (August 1980) passed close to the British Virgin Islands but their impact was limited (West Indies Laboratory, 1983). However Hurricane Frederic (September 1979), and Hurricane Donna (1960) damaged many reefs to the north of Virgin Gorda and at Anegada (Rogers et al., 1982) and Tropical Storm Klaus in 1984 damaged some reefs (Roger, 1985). White band disease of $A$ palmaia and $A$ cervicornis has been noted in Cane Garden Bay (Tortola), Great Dog and East Seal Dog (Anderson et al., 1985) and black band disease has been reported. Mass mortality of the sea urchin Diadema antillanum was reported from Virgin Gorda and Tortola in January 1984 and was related to the Caribbean wide mortality of this 


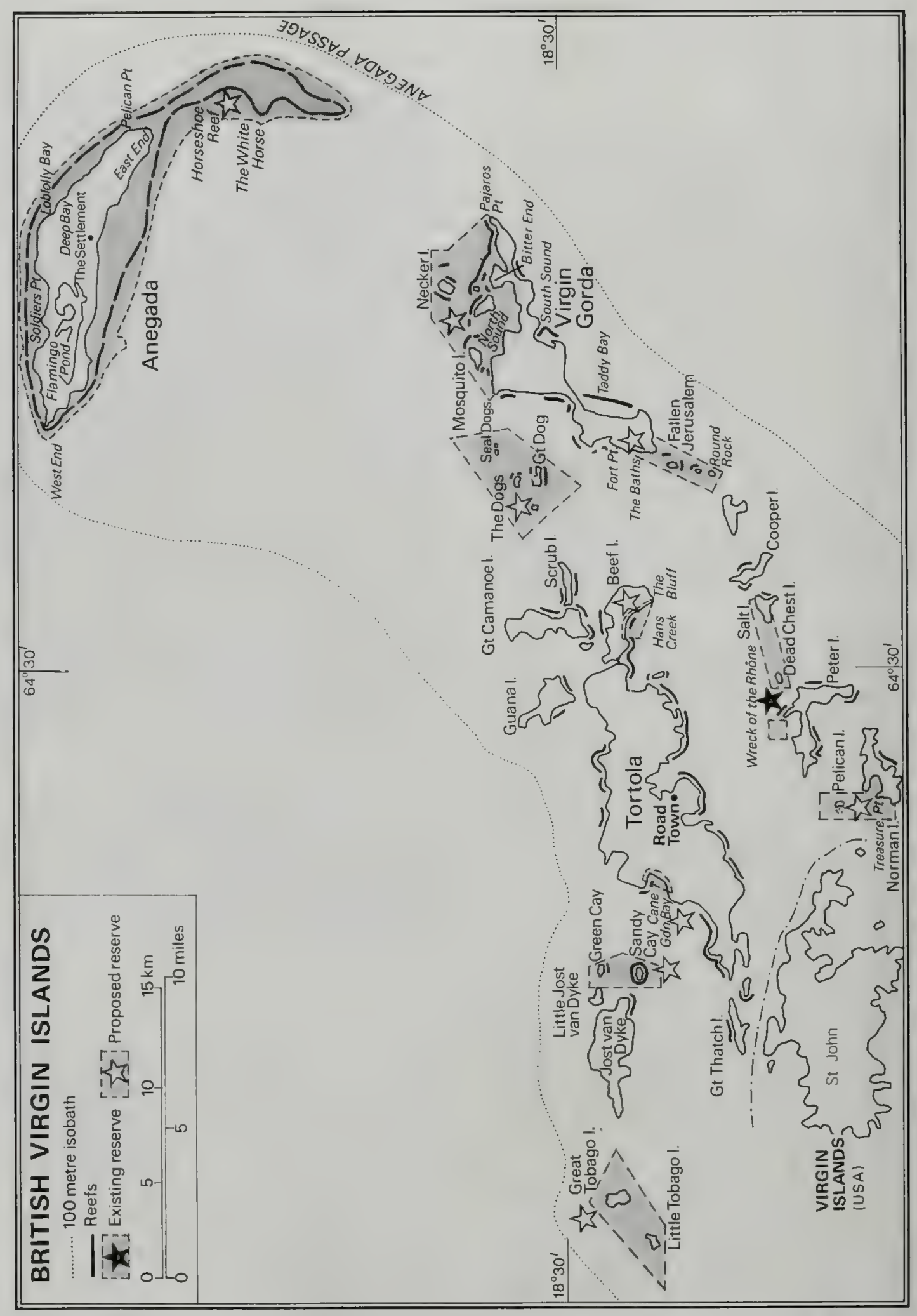


species which may have been the result of a water-borne pathogen (Lessios et al., 1984).

As a result of growth in marine habitat and coastal use, there has been increasing environmental damage, principally through physical habitat degradation and pollution. The construction of marinas and breakwaters to form new anchorage areas has considerably altered the coastline; alteration and clearing of land has resulted in sediment-laden runoff, and anchor damage and boat groundings have caused deterioration of reef and seagrass habitats. Pollution at anchorage sites, which by their very nature have low water exchange, is mainly due to waste discharge, the organic component of which may generate algal blooms. Even more potentially damaging pollution may result from industrial discharge and runoff, and chemical pollutants from antifouling paint (Lund et al., 1985; Rogers, 1985). Pollution is a problem at Road Town harbour on Tortola (ECNAMP, 1980a). Sand extraction has led to chronic erosion at Josiah's Bay beach on the north-eastern coast of Tortola, one of the most popular and heavily used beaches and a nesting site for the Leatherback Turtle, Dermochelys coriacea (Lettsome, 1985).

Thirteen of sixteen popular day-use anchorage sites in the British Virgin Islands are located within the boundaries of the proposed park sites. Many of these day-use areas are hard ground anchorages and are thus potential sites of significant coral community impact. Of the fourteen most popular overnight anchorages, the three falling within the boundaries of proposed marine park sites accommodate over $30 \%$ of the total overnight anchorage traffic (see separate accounts for North Sound, Norman I. and Cane Garden Bay).

Lobster and conch stocks are reported to have undergone some depletion (Rogers, 1985). Attention should be paid to the local black coral jewellery industry which may be leading to over-collection of black coral stocks. There are no estimates of the quantities taken each year and attempts to regulate the trade have proved unsuccessful (Canoy, 1981).

\section{Legislation and Management}

The Fisheries Ordinance $(18 / 1979,12 / 1980)$ makes provision for protected areas where fishing of any kind can be prohibited. All fishermen must obtain licences and Fisheries Officers are empowered to confiscate illegal fishing equipment and impose fines. Statutory rules $(1982$, No. 31) made under the ordinance include restrictions on spiny lobster (no females with eggs may be taken in any way; no spearing or hooking of lobster; no lobster less than $1 \mathrm{lb}(0.45 \mathrm{~kg})$ or $3.5 \mathrm{in} .(8.9 \mathrm{~cm})$ carapace may be taken) and there is a minimum mesh size of $1.5 \mathrm{in} .(3.8 \mathrm{~cm})$ for fish traps. Fish trap regulations and restrictions on conch shell size are in the process of being drafted. The Turtle Ordinance of 1969 prohibits catching all turtles, except Leatherback, and permits egg collection in July and August only, but is not enforced.

The Marine Parks and Protected Areas Ordinance, $(8 / 1979)$, makes provision for the complete protection of coral reefs, but patrolling and enforcing regulations are at an early stage (Clarke in litt., 19.3.84). The ECNAMP survey of conservation priorities of the Lesser Antilles identified the B.V.I., including the island of Anegada and surrounding reefs, as being of outstanding regional value (Geoghegan, 1983). The British Virgin Islands Parks and Protected Areas Project, a collaborative effort of the government of the British Virgin Islands, Ministry of Natural Resources and ECNAMP, was set up to identify and manage critical areas. In 1985 the B.V.I. Government provided an office for the National Parks Trust which is now a statutory body, but continues to receive support from ECNAMP (Clarke in litt., 19.3.85). Ten areas have been identified as marine parks or protected areas (see separate accounts):

\section{The Wreck of RMS Rhone Marine Park.}

Anegada, including Horseshoe Reef.

The Baths: south-west of Virgin Gorda.

Norman Island/Pelican Island and The Indians: east of St. John U.S.V.I.

North Sound: north coast of Virgin Gorda

- The Dogs: islands between Tortola and Virgin Gorda.

- Little Jost Van Dyke/Sandy Cay/Green Cay: east of Jost Van Dyke.

The Tobagos: west of Jost Van Dyke.

- Cane Garden Bay: north-west of Tortola.

Hans Creek Lagoon, Beef Island: east of Tortola.

The "Wreck of RMS Rhone National Park" has been established; eight areas have been accepted in principle by the Government and are awaiting further planning work before being legally declared (Jackson, 1981); and Hans Creek Lagoon is under consideration (Clarke in litt., 19.3.85). Anegada and The Baths have been placed on a tentative list for nomination as World Heritage Sites by the U.K. Government. The ten areas have been surveyed by the West Indies Laboratory, St Croix, and are to be managed by the National Parks Trust with different objectives in mind.

To monitor the impact of heavily used anchorage sites on biological communities, four long term monitoring sites have been set up, including the seagrass bed anchorage at Prickly Pear (North Sound) and the hard ground anchorage at The Baths (Virgin Gorda).

\section{Recommendations}

Although local fishermen are aware of over-fishing of lobster and reef fish, particularly with traps, a major educational campaign is necessary to make the fishery regulations acceptable in the community (Clarke in litt., 2.8 .84 and 16.8 .84 )

Co-operation with the U.S.V.I. is recognised as being necessary in the management of most marine resources and there are proposals to extend the Virgin Islands Biosphere Reserve (U.S.V.I.) to include marine areas around Norman Island. It has been recommended that SCUBA divers and other users of marine resources should be charged fees and that permanent mooring sites should be established. The B.V.I. have been identified as a potential marine site for inclusion in the proposed Lesser Antilles Biosphere Reserve on account of extensive marine resources, particularly around Anegada (Goodwin, 1985). 


\section{References}

* = cited but not seen

Adey, W.H. and Burke, R. (1976). Holocene bioherms (algal ridges and bank-barrier reefs) of the eastern Caribbean. Geol. Soc. Am. Bull. 87: 95-109.

Anderson, M., Lund, H., Gladfelter, E. and Davis, M. (1985). Ecological Community Type Maps and Biological Community Descriptions for Buck Island National Monument and Proposed Marine Park Sites in the British Virgin Islands. Technical reports of the Virgin Islands Resource Management Cooperative, Subtask 1.3., U.S. National Park Service.

Bacon, P., Berry, F., Bjorndal, Hirth, H., Ogren, L. and Weber, M. (1984). The National Reports. Proceedings of the Western Atlantic Turtle Symposium, Costa Rica. Vol.3: University of Miami Press, Florida.

Brown, B.E. and Dunne, R.P. (1980). Environmental controls of patch reef growth and development, Anegada, British Virgin Islands. Mar. Biol. 56: 85-96.

- Clarke, N.V. (1984). Rhone Marine Park - Draft Management Plan. Report prepared for the Government of the British Virgin Islands and ECNAMP, Tortola, British Virgin Islands.

-Cousteau, J. (1979). Unpub. report to B. Kilbride, Dive B.V.I., Virgin Gorda, B.V.I.

D'Arcy, W.G. (1975). Anegada Island: vegetation and flora. Aroll Res. Bull. 188.

Dunne, R.P. and Brown, B.E. (Eds) (1976). Anegada Marine Biological Survey. Unpub. report of the Cambridge Anegada Expedition 1975. 138 pp

Dunne, R.P. and Brown, B.E. (1980). Aspects of the ecology of coral reefs surrounding Anegada, British Virgin Islands. Atoll Res. Bull. 236: 1-83.

ECNAMP (1980a). Tortola; British Virgin Islands. Preliminary Data Allas. Eastern Caribbean Natural Area Management Program.

ECNAMP (1980b). Virgin Gorda; British Virgin Islands. Preliminary Data Allas. Eastern Caribbean Natural Area Management Program.

ECNAMP (1980c). Anegada; British Virgin Islands. Preliminary Data Allas. Eastern Caribbean Natural Area Management Program.

ECNAMIP (1985). Resource Management Planning Project for Anegada and the North Sound (Virgin Gorda). Project Proposal to WWF-UK.

Geoghegan, T. (1983). Eastern Caribbean Natural Area Management Programme. Caribbean Conservation News 3(7): 6-8.

Geoghegan, T. (1985). Public participation and managed areas in the Caribbean. Parks 10(1): 12-14.

Gladfelter, W.B., Ogden, J.C. and Gladfelter, E.H. (1980). Similarity and diversity among coral reef fish communities: a comparison between tropical western Atlantic (Virgin Islands) and tropical central Pacific (Marshall Is.) patch reefs. Ecology 61(5): 1156-1168.

Goodwin, M.H. (1985). Characterization of Lesser Antilles Regional Fisheries. Island Resources Foundation. $48 \mathrm{pp}$.

Groombridge, B. (1982). The IUCN Amplibia-Reptitia Red Data Book, Part 1: Testudines; Crocodylia; $R$ hynchoce phalia. IUCN, Gland, Switzerland.

Halewyn, R. van and Norton, R.L. (1984). The status and conservation of seabirds in the Caribbean. In: Croxall, J.P., Evans, P.G.H. and Schreiber, R.W. (Eds), Status and Conservation of the World's Seabirds. ICBP Technical Publication No. 2, Cambridge.
Howard, J. (1970). Reconnaissance geology of Anegada Island. Carib. Res. Inst. Spec. Geol. Publ. 1: 1-19.

IUCN (1982). IUCN Directory of Neotropical Protected Areas. Tycooly International Publishing Ltd., Dublin.

Jackson, 1.L. (1981a). A system of marine parks and protected areas for the British Virgin Islands. In: Conserving the Natural Heritage of Latin America and the Caribbean. Proc. 18th Working Session of IUCN/CNPPA, Lima, Peru, June 1981.

Jackson, I. (1981b). Study of the pleasure boat industry in the British Virgin Islands with emphasis on charter boats. World Tourism Organisation.

Jackson, I.L. (1982). Marine tourism, fisheries and the development of parks and protected areas in the British Virgin Islands. Paper presented at CCA/ECNAMP Workshop "Planning for Marine Resources Development", June, Anguilla.

Lessios, H.A., Robertson, D.R. and Cubit, J.D. (1984). Spread of Diadema mass mortality through the Caribbean. Science 226: 335-337.

Lettsome, B. (1981). Survey of mangroves and critical terrestrial areas. Unpub. report to ECNAMP, Tortola, B.V.I.

Lettsome, B. (1985). Josiah's Bay in grave condition. Resource October-December: 2,4.

Lund, H., Anderson, M., Gladfelter, E. and Davis, M. (1985). Development of a Monitoring Program for Safe Anchorages. Technical Report of the Virgin Islands Resource Management Cooperative, Subtask 1.4., U.S. National Park Service.

Ogden, J.C. (Ed.) (1982). The Bight at Norman Island: survey of a Potential Park Site. A report submitted to ECNAMP, West Indies Laboratory, Fairleigh Dickinson University.

Putney, A.D. (1982). Survey of Conservation Priorities in the Lesser Antilles. Final Report. Caribbean Environment Technical Report No. 1. Caribbean Conservation Association.

Rogers, C.S., Fitz, H.C. and Gilnack, M. (1982). Coral reefs, mangroves and seagrass beds of northern Virgin Gorda, British Virgin Islands. Unpub. rept. to ECNAMP, 65 pp.

Rogers, C.S. (1985). Degradation of Caribbean and Western Atlantic coral reefs and decline of associated fisheries. Proc. Sth Int. Coral Reef Congr. Tahiti 6: 491-496.

Scott, D.A. and Carbonell, M. (1986). A Directory of Neorropical Wetlands. IUCN, Gland and Cambridge.

Teytaud, A.R. (1983). Study of Management Alternatives for the Proposed Protected Areas of Sandy Cay and Norman Island, B.V.I. A report prepared for ECNAMP.

-Towle, E., Howell, C. and Rainey, W. (1976). Virgin Gorda Natural Resource Survey: economic development possibilities and environmental elements. Island Resources Foundation, St Thomas, U.S.V.I.

West Indies Laboratory (1983). The reefs of Anegada Island, British Virgin Islands: survey of Potential Marine Park Sites. Report submitted to ECNAMP and British Virgin Islands Government.

Wood, J. (Ed.) (1984). Proceedings of the Workshop on Biosphere Reserves and Other Protected Areas for Sustainable Development of Small Caribbean Islands, May 10-12, 1983. Virgin Islands National Park, Caneel Bay, St John, U.S.V.I. U.S. Dept of the Interior, National Park Service, Atlanta Georgia. 190 pp. 


\section{ANEGADA AND HORSESHOE REEF PROPOSED PROTECTED AREA}

Geographical Location $19 \mathrm{~km}$ north of Virgin Gorda.

Area, Depth, Altitude Anegada is $33 \mathrm{sq.} \mathrm{km;} \mathrm{maximum}$ altitude $8 \mathrm{~m}$; Horseshoe Reef is $17.5 \mathrm{~km}$ long and $8 \mathrm{~km}$ wide, covering nearly $30 \mathrm{sq}$. km; maximum depth $30 \mathrm{~m}$. Putney (1982) gives a length of $63 \mathrm{~km}$ for Horseshoe Reef, but this figure presumably includes the reefs to the north and south of Anegada.

\section{Land Tenure Government owned.}

Physical Features Anegada is a low, flat, limestone island formed by coral reef growth and limestone accumulation (an elevated coral reef) and is orientated parallel to the incoming wave trains. Its geology is described by Howard (1970) and is discussed by Dunne and Browne (1980). Solution pits and sinkholes are abundant with maximum diameters of $3 \mathrm{ft}(0.9 \mathrm{~m})$ and depths greater than $8 \mathrm{ft}(2.4 \mathrm{~m})$. Calcareous reef debris moves westwards with the Antillean stream along the north coast, and results in the formation of dunes up to $15 \mathrm{ft}(4.6 \mathrm{~m})$ high on the north coast and at West End (D'Arcy, 1975). The western third of the island consists of a sand plain, with a large salt pond area, Flamingo Pond. The island is exposed to the prevailing easterly to north-easterly winds due to its low altitude; water clarity on the windward reef can be poor because of exposure, but on the leeward side is generally better.

Reef Structure and Corals Anegada is surrounded on the north shore by a barrier reef which arises from coalescence of small (ca $10 \mathrm{~m}$ diameter) patch reefs north of East End. The windward shore reef is notable for its continuity, being broken at only a few points along the $11 \mathrm{mi}$. $(17.7 \mathrm{~km})$ shoreline by narrow channels, and absent altogether only at Deep Bay. The distance of the reef from the shore varies from several metres (Soldier Point) to $3 \mathrm{~km}$ (Pelican Point). The effect of wave action on the windward shore is noticeable, particularly at East End, and hurricanes may account for some apparent reef damage. Acropora palmata dominates the rear reef and reef flat in the north-eastern part. Surveys have been carried out at Loblolly Bay (Dunne and Brown, 1976; West Indies Laboratory, 1983) where the main reef consists of a mixture of coral and algal ridge systems, the dominant coralline algae being crustose species such as Lithophyllum spp., Porolithon spp. and Neogoniolithon spp. In the north-east, $A$ palmata is very patchy where it dominates the rear ridge, and much of it is dead and extensively bored and coated by crustose coralline algae. Beyond the buttress zone there is a coralline dominated spur and groove fore-reef but no drop-off. Maximum depths at the base of the spurs are approximately $10-15 \mathrm{~m}$, the bottom sloping away gently seawards.

A well-developed mixed coral reef and algal ridge system extends for more than $30 \mathrm{~km}$ from the easternmost corner of the island platform at "The White Horse" along Horseshoe Reef and along the north side of the island. Much of this consists of an A palmata back-reef and crest, with a coralline dominated spur and groove fore-reef. The $A$ palmata on the reef crest, especially in the middle to western sections, tends to be patchy with depths of perhaps several metres between each patch and 0-1 $\mathrm{m}$ on the patch (Adey and Burke, 1976).
The reefs at East End are described in some detail by Dunne and Brown (1980) and Anderson et al. (1985). The inshore zone consists of a fringing reef extending approximately $2 \mathrm{~km}$ east of Pelican Point around the eastern tip of the island and approximately $400 \mathrm{~m}$ to the west of the Point, its seaward extent being approximately $50-100 \mathrm{~m}$. It consists of three areas: 1) an inshore sand bottom, colonized by algae and spermatophytes; 2) a coralline algae dominated section; and 3) an outer living coral region. East of Pelican Point, and extending around the east end of the island, the outer rim of the reef consists of Porites porites var. divaricata, which then gives way to Acropora palmata in deeper water. West of Pelican Point, Porites is dominant.

There are caves and grottos among the patch reef formations south of East End. The patch reef crests have high habitat complexity with pore spaces extending into caves which open into caverns within the centre of many of the reefs. With an increase of depth (to $5 \mathrm{~m}$ ) between the patch reefs, grottos are formed which open seawards.

Horseshoe Reef is an extension of the continuous fringing reef surrounding Anegada and forms an arc approximately $12 \mathrm{~km}$ to the south-east into Anegada Passage towards Pajaros Point, Virgin Gorda. A number of sites on this reef are described in West Indies Laboratory (1983). The leeward (western) side of the reef represents a typical back-reef with reduced wave action and water movement. It is characterized by the presence of micro-atolls, up to $100 \mathrm{~m}$ in diameter, which have raised lips of living coral and shallow central sandy lagoons. $A$ palmata and Millepora are dominant; Tubastrea, A cervicornis and Agaricia are also found. At the base of the reef, at $10 \mathrm{~m}$ depth, abundant colonies of Montastraea annularis and Diploria occur. Large detached coral blocks are found in some places and coral cover averages $50 \%$. Gorgonians and soft corals are abundant, especially in deeper areas.

On the windward side, a shelf, $15-20 \mathrm{~m}$ deep, extends east for 2-4 miles $(3.2-6.4 \mathrm{~km})$. This is studded with patch reefs and "haystacks". The relatively shallow fore-reef is characterized by a complex arrangement of reef sections, mostly oriented perpendicular to the prevailing easterly wind and wave direction. The reef sections are frequently broken by channels through which heavy currents may flow. Acropora palmata and Millepora dominate shallow portions of the reef. The deeper areas generally consist of a rubble zone, an area of $A$ cervicornis and then scattered colonies of Montastraea. Gorgonians are abundant.

In contrast to the continuous fringing reef of the northern coast, the leeward side has a shallow $(2-8 \mathrm{~m})$ sandy shelf, about $5 \mathrm{~km}$ wide, dotted with numerous patch reefs. The large lagoon is bounded offshore by a contiguous series of reefs arising from the fusion of large (ca $100 \mathrm{~m}$ diameter) patch reefs at the north-west of Horseshoe Reef, west of East End (Anderson et al., 1985). The lagoon separates the main reef from the shore by more than $1.5 \mathrm{~km}$ and in some areas has well developed isolated patches of Diploria labyrinthiformis, Montastraea annularis, $A$ cervicornis and $A$ palmata. The non-hermatypic coral Tubastrea coccinea was recorded in several seaward facing overhangs of $M$. annularis. The rear reef extends $70-100 \mathrm{~m}$ beyond the lagoon to the reef top. There is marked patchiness where much of the substrate consists of dead coral, 
particularly $A$ cervicornis. Colonies of live coral are however well established and include $A$ palmata, $M$. annularis and $A$ cervicornis, which is particularly abundant. Large colonies of $D$. labyrinthiformis are also common and Tubastrea coccinea was recorded at the seaward limit of this zone. On the reef top, $A$ palmata is dominant, and there is a Millepora squamosa ridge. The spur and groove fore-reef is less marked than at the west end of the island (Dunne and Brown, 1980).

Patch reefs in the lee of the island showed a relatively good diversity of coral species and a greater abundance compared with the northern reef; they are described in detail by Brown and Dunne (1980) and Dunne and Brown (1980). The West Indies Laboratory surveyed the reefs outside the Anegada Reef Hotel (West Indies Laboratory, 1983). Particularly large colonies of $A$ cervicornis, A prolifera, Diploria labyrinthiformis and $D$. strigosa were found. The leeward reef environment is characterized by moderately strong, predominantly unidirectional trade winds (easterly to north-easterly), moderate oceanic currents, a relatively low amplitude, semi-diumal tide regime and a sheltered position with respect to the oceanic swell. The predominant currents cause a marked north-west/south-east orientation in the patch reefs.

Dunne and Brown (1980) list 31 species of coral from Anegada, down to a maximum depth of $10 \mathrm{~m}$; Madracis decactis was not recorded although it may occur at greater depth.

Noteworthy Fauna and Flora The flora and vegetation, now very disturbed and consisting mainly of cactus scrub and dry woodland, is described by D'Arcy (1975). Mangroves are found along the southern shore and seagrass beds lie offshore; a large seagrass bed is situated to the west of Horseshoe Reef (ECNAMP, 1980c). The Flamingo Pond Bird Sanctuary is the largest wetland in the B.V.I. and has been identified as one of the largest remaining saline lagoons in the Lesser Antilles (D'Arcy, 1975; ECNAMP, 1980c; IUCN, 1982; Scott and Carbonell, 1986). D'Arcy (1975) provides a checklist of the fauna and flora of the island. Horseshoe Reef is situated near the migration routes of Humpback Whales Megaptera novaeangliae and several shark species (Canoy, 1981; ECNAMP, 1980c). Hawksbill Eretmochelys imbricata and Green Chelonia mydas Turtles nest at a number of sites around the island, particularly on the north shore (Bacon et al., 1984; ECNAMP, 1985). The lagoon at East End contains abundant Strombus gigas and large specimens of Cassis tuberosa have been recorded close to the shore at Pelican Point (Dunne and Brown, 1980). Panulirus argus and $S$. gigas are found on the leeward side of Horseshoe Reef. The marine algal and fish populations of Horseshoe Reef are described in West Indies Laboratory (1983). Large numbers of herbivorous fish are found on the leeward part of the reef but the windward reef has a rather poor fish fauna, large predatory fish being noticeably lacking. The fish fauna has been studied by Gladfelter et al. (1980); 185 species of coral reef fish and some marine algae were described by Dunne and Brown (1980).

Scientific Importance and Research In the 1960s surveys were carried out as a result of proposals to build a jet port (Canoy, 1981). In 1975, the Cambridge Anegada Expedition (Dunne and Brown, 1976) spent eight weeks on the island mapping and surveying six sites on the north shore and several southern patch reefs. Brown and Dunne (1980) surveyed an area of patch reef off the southern leeward coast of Anegada, looking at the environmental controls of patch reef growth and development. Dunne and Brown (1980) outlined the reef structure of Anegada from four main study sites along the windward shore, and nine patch reefs along the leeward shore of the island. A more recent study (West Indies Laboratory, 1983) surveyed eight sites on the north and south coasts providing baseline data for coastal marine resource management. Anderson et al. (1985) surveyed seven sites on Horseshoe Reef (including the popular anchorage at The White Horse) of which only one site at East End overlapped with the study by Dunne and Brown (1976). Horseshoe Reef is considered to be one of the most extensive and diverse West Indian reefs (and possibly the third largest).

Economic Value and Social Benefits The history of the island is described by Dunne and Brown (1980). The population has remained low (about 200 people) for many years due to the lack of industrial development and poor potential for large scale fishing or agriculture. Fishing, however, used to be the main activity. The algal and seagrass beds of the lagoon south-east of East End contain commercially significant populations of Queen Conch Strombus gigas, Milk Conch Strombus costatus and King Helmets Cassis tuberosa. The beach at East End is littered with commercially harvested conch shells (Anderson et al., 1985).

In the 1960 s a variety of major tourism and industrial developments were proposed but these came to nothing. The island is famous among SCUBA divers for its wrecks, of which there are about 80 visible and probably many more completely covered by coral. The wreck of the Rocas, considered the most spectacular, is located at the end of Horseshoe Reef near The White Horse in a pass about $15 \mathrm{~m}$ deep (West Indies Laboratory, 1983). The island is visited by day trippers from North Sound, Virgin Gorda, but bareboat charters are not allowed to approach the island. Currently there is a single small hotel and restaurant in operation (the Anegada Reef Hotel). Most tourism ventures have failed because of high costs and difficult access to the reefs. There are plans to build an underwater hotel, to be entered by a surface hatch, at the southern end of Horseshoe Reef near Virgin Gorda. However, the exposure to oceanic sea conditions, complexity of the reef patterns and size of the reef area create serious navigational hazards.

A 1983 survey by the West Indies Laboratory concluded that there is potential for encouraging tourists and divers with an interest in conservation and natural history. The survey found that SCUBA diving conditions were not ideal (although the wrecks are popular) as many areas are subject to poor visibility as a result of intensive wave action, surge and sediment, are inaccessible (e.g. Horseshoe Reef), and are often restricted by wave conditions (e.g. Loblolly Bay). However, the high coral cover (usually more than $50 \%$ ) and spectacular reef formations provide good diving and snorkelling given suitable conditions (West Indies Laboratory, 1983). The size and complexity of Horseshoe Reef, combined with its previous relative inaccessibility, provides particular potential for increased use by divers and snorkellers, although the conditions are not ideal. Parts of the leeward side of the reef are particularly good for 
snorkelling, with good visibility. The micro-atolls on the leeward reef and the extensive cave systems, tunnels and complex channels on the windward reef provide interesting diving (Lund et al., 1985).

The most popular anchorage site is The White Horse (surveyed by Anderson et al., 1985). Although other areas offer unlimited and excellent anchorage on sand between patch reefs, the usage of these is low due to the high risk of running aground. Several anchorage sites occur in coves along the western end of Anegada, with low potential for anchor damage on the predominantly sand bottom lagoon (Lund et al., 1985). The low elevation of Anegada provides little shelter from wind even on the leeward side, and there are few supplies available for accommodation of the charter boater's needs.

Disturbance or Deficiencies Some areas on Horseshoe Reef suffered damage from Hurricane Frederic in September 1979 (West Indies Laboratory, 1983). Storm damage is particularly visible on the windward side of the reef. Caribbean-wide Diadema death, shown locally by reduced live populations and the presence of spines and tests littering the bottom, is probably the main factor behind excessive algal growth in the area. White band disease was noted among Acropora cervicornis colonies at the tip of Horseshoe Reef.

The area was initially threatened by British plans to turn Anegada into a jet superport and resort complex, involving the use of the reef as building material. Although this never happened, the reefs are now threatened by conch fishing, spiny lobster fishing, coral and shell collecting, dynamiting and misuse of fish traps (Canoy, 1981). A marine archaeological company has started excavation work on the wrecks in the south-eastern comer of Horseshoe Reef; the impact of this activity, which involves blasting sand off the tops of the wrecks with propeller-driven currents, on the reef is unknown (Clarke in litt., 16.8.84). Rogers (1985) reports that in 1985 the propeller of a ship anchored on the reef was being used to scour out holes while searching for gold from wrecks. Horseshoe Reef is highly susceptible to pollution, and even with the low frequency of anchoring, rubbish litters the bottom at The White Horse (Lund et al., 1985) and the vertical relief of the area is vulnerable to anchor damage.

The shallow reefs at Anegada show evidence of overfishing probably by spearfishermen and trap fishing. Large predatory fish and lobsters are uncommon in most areas, and the reefs no longer support a commercial fishery. Strombus gigas is common at Loblolly Bay but the southern sand flats have been extensively fished. All species of turtle are still caught including Leatherback Dermochelys coriacea with eggs. Island residents are now the main users of these resources for subsistence and make use of the southern patch reefs (West Indies Laboratory, 1983).

Legal Protection Flamingo Pond, 1147 acres (465 ha), was established as a bird sanctuary in 1977 (IUCN, 1982).

\section{Management None.}

Recommendations Anegada has been placed on the tentative list of potential sites for nomination as World Heritage Sites by the U.K. Government and has now been been proposed and accepted for protection under the British Virgin Islands National Parks and Protected Areas Project (Clarke in litt., 19.3.85). It is included with North Sound, Virgin Gorda, in a Resource Management Planning Project which would be carried out with the National Parks Trust and ECNAMP. This will take into consideration the traditional uses of resources, education of the community about relevant environmental issues and will review alternative management strategies (ECNAMP, 1985). The West Indies Laboratory survey (1983) at Anegada provides baseline data for the development of coastal marine resource management (Anderson et al., 1985); it recommends that the reefs should be made a marine reserve with fishing areas operating on a rotating closure system (West Indies Laboratory, 1983).

\section{THE BATHS PROPOSED PROTECTED AREA}

Geographical Location The area includes the waters and coast off the south-west tip of Virgin Gorda, the islands of Fallen Jerusalem and Round Rock and the scattered islets of Broken Jerusalem lying between them.

Area, Depth, Altitude about 810 acres (328 ha) marine; 152 acres (61.6 ha) terrestrial; shoreline to $60 \mathrm{ft}(18.3 \mathrm{~m})$; Round Rock is $220 \mathrm{ft}(67 \mathrm{~m})$, Fallen Jerusalem $140 \mathrm{ft}$ $(42.7 \mathrm{~km})$.

\section{Land Tenure Government owned.}

Physical Features The Baths are named after the subtidal bedrock which consists of large boulders ( $5 \mathrm{~m}$ diameter), lying on a sandy substrate and forming pools where they break the surface (Anderson et al, 1985). Fallen Jerusalem is scattered with huge boulders of volcanic origin which also surround the island to depths of $7 \mathrm{~m}$. Beyond these there is a flat expanse of pavement sloping to $17 \mathrm{~m}$. Reefs are found between Virgin Gorda and Fallen Jerusalem and between Fallen Jerusalem and Round Rock (ECNAMP, 1980b). The islands receive less than $30 \mathrm{in}$. (760 mm) rainfall annually, and are covered with cactus scrub.

Reef Structure and Corals Anderson et al. (1985) describe the reefs in this area. Off the Baths, coral and gorgonian cover is sparse (15-20\%) and occurs mainly on the sides of bedrock boulders. The sparsely populated reef pavement slopes from $7 \mathrm{~m}$ to $13 \mathrm{~m}$ depth. The lower fore-reef slopes to sand at $20 \mathrm{~m}$. Coral $(15 \%)$ and gorgonian $(15 \%)$ cover increases with vertical relief on the fore-reef; twelve species of coral have been identified on hard substrate. At Fallen Jerusalem, some of the larger boulders are capped by Acropora palmata stands which, with Montastraea annularis, is dominant. Coral cover decreases from $20 \%$ to $15 \%$ on the sloping reef pavement, and gorgonians are more abundant on the deeper pavement edge.

Noteworthy Fauna and Flora Turtles (possibly Hawksbill Eretmochelys imbricata and Green Chelonia mydas) nest on the small cay to the north of Round Rock (ECNAMP, 1980b) and on Fallen Jerusalem (IUCN, 1982); more recent details are given in Bacon et al. (1984). 
Scientific Importance and Research A long term monitoring photo-transect is sited at the hard ground anchorage used by most visitors to the Baths (Anderson et al., 1985).

Economic Value and Social Benefits The islands are uninhabited but the area is one of the most popular day use sites in the British Virgin Islands. The unusual rock formations of the Baths and white sand beaches are heavily frequented by visiting tourists, up to 33 boats having been reported in the area at one time (Lund et al., 1985). Popular dive sites are situated off the cays (ECNAMP, 1980b).

Disturbance or Deficiencies There is evidence of anchor damage, overtumed coral heads and rubbish dumping on the flat reef pavement at the Baths (Anderson et al., 1985). The marine community on the pavement where the boats anchor has almost disappeared; the anchorage area is obviously overcrowded as evidenced by anchored boats swinging into one another. The areas north and south of the Baths are increasingly being used as anchorages because of overcrowding in the area directly in front of The Baths. Shuttle boats from nearby Spanish Town in Taddy Bay, combined with dinghy traffic from day use boats, make it dangerous to swim or surface after a dive. Rubbish litters the seafloor where boats anchor, and caves and grottoes within The Baths are littered and polluted (Lund et al., 1985).

Legal Protection The Fallen Jerusalem Forestry Park (30 acres (12 ha)) established in 1974, is situated within the area (IUCN, 1982) and the National Park lands of Devil's Bay (58 acres (23.5 ha), 1969), Spring Bay (5.5 acres (2.2 ha), 1969) and Fort Point (36 acres (14.6 ha), 1978) on Virgin Gorda are to be included (Clarke in litt., 2.8.84).

\section{Management None.}

Recommendations The establishment of the region as a protected area, proposed under the British Virgin Islands Parks and Protected Areas Project, has been accepted in principle by the Government of the B.V.I. A management plan is being developed (Clarke in litt., 2.8.84). The Baths have been placed on a tentative list for nomination as a World Heritage Site by the U.K. Government. Management of this area is long overdue. In particular, the overcrowding of the anchorage at the Baths and the increasing use of areas to the north and south, require urgent attention (Lund et al., 1985).

\section{CANE GARDEN BAY PROPOSED PROTECTED AREA}

\section{Geographical Location North-west shore of Tortola.}

Area, Depth, Altitude Maximum depth $20 \mathrm{~m}$.

Land Tenure Many private owners.

Physical Features Cane Garden is a sheltered, west-facing bay with relatively low water motion. It has a sandy bottom, extends $300-400 \mathrm{~m}$ seawards with a maximum depth of $5 \mathrm{~m}$, and is bordered to the north by a rocky outcrop and to the south by bedrock outcrop. In the north, the cobble shore gives way seaward to bank pavement and then bank sand. The fringing reef adjacent to the southern shore line extends north across a major portion of the bay, broken by a channel at the northern tip. A pavement of boulders, sand and coral rubble borders the south side, rising from $5 \mathrm{~m}$ to $3 \mathrm{~m}$ depth (Anderson et al., 1985).

Reef Structure and Corals The back-reef slopes to the reef crest at $1 \mathrm{~m}$ depth and has a sparse covering of gorgonians (5\%) and live corals (5\%) which are small and widely spaced. Millepora sp. provides the main vertical relief and there are large Acropora palmata stands. These two species dominate the reef crest as well, increasing in abundance towards the fore-reef. Encrusting sponges are common. The reef crest drops vertically from $1 \mathrm{~m}$ to $3 \mathrm{~m}$ depth, to a spur and groove formation on the upper fore-reef, sand channels separating the walls which have $20 \%$ coral cover and $5 \%$ gorgonian cover; Millepora and $A$ palmata still dominate. A $75 \mathrm{~m}$-wide reef pavement, with $10 \%$ coral cover, slopes from $3 \mathrm{~m}$ to $7 \mathrm{~m}$, live coral cover and diversity increasing with depth. The lower fore-reef has $30 \%$ live coral cover, $10 \%$ gorgonian cover and a diverse community of large sponges. Montastraea cavernosa, M. annularis, A cervicornis, Agaricia, Diploria spp. and Millepora sp. are locally dominant. At $20 \mathrm{~m}$ depth the fore-reef interfaces with bank sand (Anderson et al., 1985).

Noteworthy Fauna and Flora Mangroves border a pond and provide important bird habitat (Lettsome, 1981). Marine turtles may nest here but this has not been confirmed (Bacon et al., 1984).

Scientific Importance and Research Surveyed by Anderson et al. (1985) and Lettsome (1981).

Economic Value and Social Benefits The bay provides a natural sandy anchorage; the channel is marked by navigational buoys, there is a restaurant in the harbour (Anderson et al., 1985), an attractive white beach lined with palm trees (Lund $e t$ al., 1985) and an historic site, the Callwood Distillery.

Disturbance or Deficiencies Much of the coral rubble may be a result of Hurricane Frederic in 1979 (Anderson et al., 1985). A palmata on the reef crest and fore-reef has a higher incidence of white-band disease than any other area visited in the British Virgin Islands. Lund et al. (1985) found the bay severely damaged, the entire central part, where anchoring is common, having no live cover and thin algal turf. The back-reef is covered with sediment and has no live coral. The reef reduces water exchange with the open ocean to a low level and one very stagnant water pond, beside Rhymer's Restaurant, flushes into the bay when significant rainfall occurs. More rubbish litters the sea floor here than in any other area surveyed in the B.V.I. The only healthy corals were on the far edges of the bay and on the lower fore-reef which is directly exposed to open ocean.

Legal Protection None.

Management None yet.

Recommendations The establishment of the region as a protected area, proposed under the British Virgin Islands Parks and Protected Areas Project, has been accepted in 
principle by the Government of the B.V.I. A management plan is being drawn up by the Town and Country Planning Office (Clarke in litt., 19.3.85).

\section{THE DOGS PROPOSED PROTECTED AREA}

Geographical Location West of Virgin Gorda; includes West Dog, Great Dog, George Dog and Cockroach Island (which form the Dogs), East Seal Dog, West Seal Dog and the surrounding waters.

Area, Depth, Altitude About 4000 acres (1620 ha) including ca 162 acres (65.6 ha) of land; shallow water surrounds the islands and depths of about $70 \mathrm{ft}(21 \mathrm{~m})$ occur between them; altitude of Great Dog is $270 \mathrm{ft}$ $(82.3 \mathrm{~m})$, of George Dog $250 \mathrm{ft}(76.2 \mathrm{~m})$ and West Dog $150 \mathrm{ft}(45.7 \mathrm{~m})$.

Land Tenure West Dog is government-owned; the other islands are privately owned.

Physical Features The cays receive less than 30 in. $(76 \mathrm{~cm})$ rainfall annually. Bedrock cliffs border most of each island but there are sand beaches on north Great Dog, south George Dog and south-east East Seal Dog. Seagrass beds occur off all the islands and are most extensive around West Dog, the Seal Dogs, Cockroach Island, north and west Great Dog and north George Dog; in deeper waters they give way to bank sand. Fringing reefs occur on the east coast of West Dog, north and south of Great Dog and south of George Dog and reef pavement is present south of Great Dog and west of George Dog (Anderson et al., 1985).

Reef Structure and Corals Anderson et al. (1985) surveyed nine sites around the islands of which only those at north and south Great Dog and south George Dog included reefs. Elsewhere, bedrock pavements and coral and gorgonian flats support live coral and gorgonian cover. Live coral cover is typically $10-30 \%$, locally dominated by Acropora palmata, Montastraea annularis and Millepora. Other common species include $A$. cervicornis which often predominates in coral rubble, Siderastrea siderea, blue, grey and bright green colonies of which dominate the coral flat from $8 \mathrm{~m}$ to $23 \mathrm{~m}$ depth off the north-west tip of George Dog, and Montastraea cavernosa which dominates the coral flat at $20 \mathrm{~m}$ depth north of Cockroach Island and the deepest (10-16 m depth) of the three bedrock zones north of West Seal Dog. Gorgonian cover typically varies from $5 \%$ to $20 \%$ although local abundance of Gorgonia on coral flats north of Cockroach Island increases the cover to $35 \%$.

South of Great Dog is a series of patch reefs paralleling the shore separated by a shallow ( $1.5 \mathrm{~m}$ depth) insular shelf of pavement and sand. The reef is composed of predominantly dead Porites porites and $A$ palmata. The reef crest of live $A$ palmata approaches $1 \mathrm{~m}$ of the surface and the patch reefs are separated by sand channels (average $7 \mathrm{~m}$ width) which are lined with dead $A$ palmata, $A$ cervicornis and a few live $M$. annularis recruits. The reef pavement has $45 \%$ live cora' cover and $10 \%$ gorgonian cover, both of which increase in density and diversity seawards. North of Great Dog, small dead reefs fringe the beach beyond which the substrate is colonized by a variety of corals (15-40\% live cover) equalled in number only by the reefs around Anegada. $M$. anmularis, capped by Millepora, is dominant and the reefs are within $1 \mathrm{~m}$ of $P$. porites thickets. Sand channels separate patch reefs in the area, and are colonized primarily by $A$ cervicornis, $P$. divaricata and small heads of Montastraea annularis. The health of the $A$ cervicornis thickets ranges from $90 \%$ alive to $90 \%$ dead, with white-band disease evident. A. palmata dominance increases with distance from the shore, but $M$. annularis and $P$. porites colonies are smaller than in the nearshore region; Tubastrea, Helioseris and Scolymia are present. $M$. annularis dominates the live corals on a pavement area, seaward of the patch reefs, much of which is composed of $A$ palmata fragments. Seaward of the pavement a sand bank slopes from 3-5 $m$ depth to a coral flat which descends gradually seaward and supports $15-20 \%$ live coral cover and equal gorgonian cover.

Off the south beaches of George Dog, the reef immediately adjacent to shore is composed largely of healthy stands of $A$ palmata. Live coral cover averages $50 \%$, with up to $80 \%$ locally, and $M$. annularis dominates at $2 \mathrm{~m}$ depth. At $3 \mathrm{~m}$ the reef gives way to a sparse gorgonian and coral flat with $M$. annularis still dominating the $15 \%$ live coral cover and Pseudopterogorgia dominating the 15\% gorgonian cover. A sand bank $10 \mathrm{~m}$ wide begins at $8 \mathrm{~m}$ and adjoins a seagrass bed at $10 \mathrm{~m}$ depth.

Noteworthy Fauna and Flora Most of the islands are covered with cactus scrub although Great Dog has dry woodland (ECNAMP, 1980b). Turtles (possibly Hawksbill Eretmochelys imbricata and Green Chelonia mydas) nest on Great Dog and have been sighted off the south of George Dog (ECNAMP, 1980b; Bacon et al., 1984). Seabirds nest on George Dog, West Dog and Seal Dogs; West Dog is important for Bridled Terns Sterna anaetherus (IUCN, 1982). Black Coral Stichopathes may occur at about $20 \mathrm{~m}$ depth off the subtidal bedrock zone north of Cockroach Island. Dense seagrass beds south of George Dog support populations of large conchs and helmet shells (Anderson et al., 1985).

Scientific Importance and Research Surveyed by the West Indies Laboratory. A station for the long term monitoring of white-band disease has been set up on the reef north of Great Dog (Anderson et al., 1985).

Economic Value and Social Benefits The islands include popular dive sites and anchorages (ECNAMP, 1980b), the latter being primarily suited for day use. The only overnight anchorages are on south-west George Dog and at South Bay on Great Dog. The former has both overnight and day visitors with up to six boats anchored at a time on the sandy bottom. The favoured anchorage is a sand strip on the outer edge of the reef which is an excellent fair weather anchorage accommodating no more than three boats at once (Lund et al., 1985). Visitors to north Great Dog anchor on the bank sand seaward of the reef. SCUBA diving tour operators frequent The Dogs, the north-west tip of George Dog being a popular location (Anderson et al., 1985). At north Great Dog there is a shallow garden of gorgonians and corals which is particularly popular. 
Disturbance or Deficiencies White-band disease has been noted on $A$ palmata north of East Seal Dog and $A$ cervicornis north of Great Dog (Anderson et al., 1985). The islands are uninhabited and the low frequency of usage has meant little boating damage. However, damage may easily occur from anchors and overuse, especially on the reef at north Great Dog which, at present, is protected by nature of its shallow position. The islands are small and subject to open ocean conditions which reduces the likelihood of chemical and liquid pollution (Lund et al., 1985).

Legal Protection West Dog Island Forestry Park, established in 1974, is within the area (IUCN, 1982).

Management None.

Recommendations Proposed for establishment as a protected area by the British Virgin Islands Parks and Protected Areas Project; a management plan is in preparation (Clarke in litt., 2.8.84).

\section{HANS CREEK LAGOON PROPOSED PROTECTED AREA}

Geographical Location Due east of Tortola, south-west shore of Beef Island, between the point of land south-east of Well Bay and The Bluff, the southernmost point of the island.

Area, Depth, Altitude The proposed area would extend $50 \mathrm{ft}(15 \mathrm{~m})$ inland and stretch $0.75 \mathrm{mi} .(1.2 \mathrm{~km})$ across the mouths of the bays; maximum depth $30 \mathrm{ft}(9 \mathrm{~m})$.

Land Tenure Single private owner.

Physical Features The area is a delicate system of mangroves, fringing Porites reefs and shallow bays and lagoons (Lettsome, 1981; Anderson et al., 1985). Hans Creek has a predominantly mangrove shoreline. The shallow lagoon contains several small (less than $70 \mathrm{~m}$ diameter) mangrove islands and a central fringing reef. The barrier reef, about $100 \mathrm{~m}$ offshore, is oriented east-west and is about $800 \mathrm{~m}$ in length. Seaward of this is a gorgonian bank which drops to bank sand.

Reef Structure and Corals The shallow (up to $1.5 \mathrm{~m}$ depth) quiet water of the west end has a sandy bottom with some algal covering, grading into Porites porites rubble to the east with less than $5 \%$ coral cover. A fringing reef, $15-25 \mathrm{~m}$ wide and $500 \mathrm{~m}$ long and composed of $P$. porites, borders the back of the lagoon, apparently growing seaward. The fore-reef, rising vertically from the lagoon, has virtually $100 \%$ live coral cover, but nearer the shore live coral cover reduces to zero with Thalassia seagrass dominating and mangrove recruits locally abundant. There are several patch reefs in the sandy lagoon composed of dead, bleached white $P$. porites. Bank pavement, bordering a $3 \mathrm{~m}$ deep channel, extends the length of the lagoon in an east-west direction, with a few small colonies of live coral. Most of the barrier reef crest is emergent, coral rubble having been hurled there during storms; the back-reef and fore-reef, composed of pavement, are largely algal covered and have less than $5 \%$ coral cover (Anderson et al., 1985).
Noteworthy Fauna and Flora Three species of mangrove are found around the lagoon (Rhizophora mangle, Laguncularia racemosa and Avicennia nitida) (Lettsome, 1981). The area is important bird habitat. There is no known turtle nesting (Bacon et al., 1984).

Scientific Importance and Research Surveyed by Lettsome (1981) and Anderson et al. (1985).

Economic Value and Social Benefits There is limited access to the lagoon via a dirt road on the westernmost point of land but no boat access. The lagoon is shallow, spectacularly turquoise and relatively unknown (Lund et al., 1985).

Disturbance or Deficiencies Of all the areas visited by Lund et al. (1985), Hans Creek showed least evidence of impact by man. The area is unusually delicate, due to its mangrove shoreline, and vulnerable to pollution as there is apparently no water exchange within the lagoon. Adverse impact would most likely result from foot traffic since it is shallow and accessible by land.

Legal Protection None.

Management None.

Recommendations Hans Creek is a pristine area which, with careful management, could be preserved in its original state (Lund et al., 1985). The area has been proposed for protected status by the British Virgin Islands Parks and Protected Areas Project, and is currently under consideration (Clarke in litt., 19.2.85).

\section{LITLE JOST VAN DYKE PROPOSED PROTECTED AREA}

Geographical Location The proposed protected area includes the south shore of Little Jost Van Dyke, Green Cay ( $200 \mathrm{~m}$ to the east), and Sandy Cay ( $2 \mathrm{~km}$ due south of Green Cay) and Sandy Spit (200 m south of Green Cay).

Area, Depth, Altitude 12 ha land; 267 ha marine; max depth $80 \mathrm{ft}(24.4 . \mathrm{m})$; maximum altitude of Green Cay $100 \mathrm{ft}(30 \mathrm{~m})$.

Land Tenure Sandy Cay, Green Cay and Sandy Spit are privately owned; the eastern end of Little Jost Van Dyke is government owned.

Physical Features The south-west waters of Little Jost Van Dyke have a sand bar which extends most of the way to Jost Van Dyke in the west. The southern coast shows a progression from small sheltered mangrove bays with fringing reefs in the west, to open coastline with bank reefs in the east. The eastern point is a rocky headland with steep cliffs and jumbles of large boulders. South of this is Manchineel Bay, surrounded by rocky cliffs and with pockets of sandy beach. Green Cay has a sandy spit on the south-western corner supporting dry evergreen littoral forest; to the west and south-east of this there are cobble beaches; there are reefs off the southern and south-eastern shores. The western part of Sandy Cay is a low flat sandy spit with a sandy beach which grades into 
cobbles and shingle to the north and south; the north-east and eastem point are rocky headlands. There are fringing reefs off the north and south sides of the Cay (Anderson et al., 1985). Sandy Spit is surrounded by a sandy beach and is low with a covering of beach vegetation (Teytaud, 1983).

Reef Structure and Corals Teytaud (1983) gives a brief description of the fringing reef off Manchineel Bay at Little Jost Van Dyke, the cut between Little Jost Van Dyke and Green Cay, the fringing reefs of the south of Sandy Spit (considered the best area for snorkelling and diving) and the reefs around Sandy Cay. Anderson et al. (1985) surveyed four sites in more detail: an overnight anchorage at south-west Little Jost Van Dyke; the south-east shore of Little Jost Van Dyke; the south-west shore at Green Cay; and the north-west coast of Sandy Cay.

At the overnight anchorage (3-7 $\mathrm{m}$ deep) in the mangrove bay in south-west Little Jost Van Dyke there is a seaward progression from mangrove on intertidal mud at $0.3 \mathrm{~m}$ depth to Thalassia seagrass beds at $1 \mathrm{~m}$ depth. Seagrass coverage decreases towards the fringing reef crest and there is an increase in dead Porites porites thickets; at the crest $(0.3 \mathrm{~m}$ depth), less than $1 \%$ of $P$. porites is living. The fringing reef has $20 \%$ live coral cover, composed mostly of Millepora with increasing live $P$. porites coverage $(5 \%)$ on the fore-reef. At the base of the reef $(1 \mathrm{~m})$ is a strip of clean sand which gives way to Syringodium seagrass at $2 \mathrm{~m}$.

The south-east shore of Little Jost Van Dyke is of bedrock and sand. Seaward of this is a sand bank which interfaces with bank pavement ( $2.5 \mathrm{~m}$ depth) on which live coral cover $(10 \%)$ and gorgonian cover $(10 \%)$ is greatest near the lower fore-reef edge of the pavement ( $4 \mathrm{~m}$ depth). The lower fore-reef slopes at $45^{\circ}$ from $4 \mathrm{~m}$ to a sand bank at $8-9 \mathrm{~m}$ depth. Montastraea annularis dominates the $40 \%$ live coral cover; gorgonian cover is $5 \%$. A back-reef rises from the bank sand at $9 \mathrm{~m}$ to $5.5 \mathrm{~m}$ depth. The back-reef and reef crest community composition is similar with $40 \%$ live coral cover and $10 \%$ gorgonian cover. The fore-reef of the bank shows a relative decrease in live coral cover $(30 \%)$, but an increase in gorgonians (15\%), and abundant sponges including large vase sponges. Platy $M$. annularis and the black corals Stichopathes and Antipathes are to be found on the fore-reef which interfaces with bank sand at $17 \mathrm{~m}$ depth.

The shore zone of south-west Green Cay is cobble beachrock to $0.3 \mathrm{~m}$ depth followed by consolidated Acropora palmata at $0.3-0.5 \mathrm{~m}$ depth. A narrow (4-5 $\mathrm{m}$ wide) fringing reef with $19 \%$ live coral cover and $3 \%$ gorgonian cover occurs between the shore and a bank pavement at $2 \mathrm{~m}$. The dominant live corals are $A$ palmata, Diploria strigosa and Millepora spp. The bank pavement of sand and partially consolidated coral rubble has $10 \%$ live coral cover, mostly $D$. strigosa, $A$ palmata, $A$ prolifera and $A$ cervicornis, and slopes from $2 \mathrm{~m}$ to a gorgonian and coral flat beginning at $3 \mathrm{~m}$ depth. The live coral cover of the flat $(15 \%)$ is dominated by $D$. strigosa and Montastraea anmularis; gorgonian cover is $5 \%$. In the immediate vicinity, another fringing reef forms an arc with its northern end adjacent to the shore. The back-reef is primarily dead consolidated $A$ palmata with high habitat complexity. Dead $A$ palmata colonized by Millepora dominates the reef crest $(0.5 \mathrm{~m})$. The fore-reef is composed mostly of live A. palmata (live coral cover is $35 \%$ ) and advanced consolidated $A$ palmata and is separated into patches by channels ca $2 \mathrm{~m}$ deep. White-band disease and gall formations are evident on some $A$ palmata.

The north shore bedrock of Sandy Cay borders a fringing reef composed of $15 \%$ live coral cover $(10 \%$ of the total accounted for by A. palmata). Large blocks of coral rubble are consolidated and encrusted with Millepora sp. Towards the seaward ledge at $5 \mathrm{~m}$, the live coral density decreases despite relatively high species diversity. The bank pavement from $5 \mathrm{~m}$ to $8 \mathrm{~m}$ has significant sand cover with live coral ( $5 \%$ cover) and gorgonians ( $5 \%$ cover) increasing towards the seaward edge which interfaces at $8 \mathrm{~m}$ with a gorgonian and coral flat which shows a conspicuous decrease in live coral diversity, but an increase in abundance with $10 \%$ live coral cover. Gorgonians increase in abundance ( $20 \%$ cover) and conspicuously increase in diversity. The majority (60\%) of the cover is consolidated coral rubble.

Noteworthy Fauna and Flora The vegetation of the islands is described by Teytaud (1983). The islands are mainly covered with cactus scrub. The south-west coast of Little Jost Van Dyke has some dense mangrove growth on intertidal mud; a swamp dominated by white mangrove Laguncularia racemosa is found on the west side of Sandy Cay. The Hawksbill Eretmochelys imbricata, the Green Chelonia mydas and possibly the Leatherback Dermochlys coriacea Turtle nest on Green Cay and the two former species nest on Sandy Cay and Sandy Spit (ECNAMP, 1980a; Bacon et al., 1984). Brown Pelicans Pelicanus occidentalus nest on Green Cay and the White-tailed Tropicbird Phaeton le pturus may nest on Sandy Cay (Teyteaud, 1983). Black corals, Stichopathes and Antipathes, are found on the lower forereef at south-east Little Jost Van Dyke (Anderson et al., 1985).

Scientific Importance and Research Surveyed by the West Indies Laboratory (1983) and briefly by Teytaud (1983).

Economic Value and Social Benefits The islands are uninhabited. The south-west coasts of the islands in the area provide popular day time and occasional overnight anchorages, particularly Little Jost Van Dyke (Anderson et al., 1985). West Green Cay is an attractive day and overnight anchorage. It is heavily used by boat traffic, being in the lee of the island with a secure sand/pavement anchorage. It provides access to Sand Spit Island, and is one of the prettiest cays in the B.V.I. with an outstanding gorgonian garden in its lee, commonly visited by snorkellers. There is a dive site to the north of Green Cay (ECNAMP, 1980a). There is no major fishing activity in the area.

Disturbance or Deficiencies Some of the coral rubble in the area, particularly on the north shore of Sandy Cay, may be a result of storm damage. White-band disease is evident off south-west Green Cay (Anderson et al., 1985). The anchorage site at Green Cay shows evidence of visitor disturbance; it is littered with garbage, little live coral is growing, and the few colonies present exhibit gall formations, perhaps as a result of environmental stress. Charter boats commonly use large Danforth anchors leaving long, deep gouges in the substrate. Gorgonians are equally scarce although areas not used for anchoring have spectacular and flourishing gorgonian gardens. The 
gorgonian garden at Sandy Spit shows anchor damage with recent coral breakage and coral heads upturned (Lund et al., 1985). Teytaud (1983) discusses possible impacts on the area of increased recreational development, sand mining and potential oil exploration in the vicinity.

\section{Legal Protection None.}

\section{Management None.}

Recommendations The establishment of Little Jost Van Dyke as a protected area, proposed under the British Virgin Islands Parks and Protected Areas Project, has been accepted in principle by the Government of the B.V.I. Teytaud (1983) gives an outline of suggested management alternatives and zonation. Two principle units are suggested: Green Cay Protected Landscape/Tourism Management Zone and Sandy Cay Managed Nature Reserve/Marine Wildlife Refuge.

\section{NORMAN ISLAND, PELICAN ISLAND AND THE INDLANS PROPOSED PROTECTED AREA}

Geographical Location The proposed reserve at Norman Island (south of Tortola) extends west from Water Point, the north-west extremity of the island, to the west end of the island, the Carval, and then one mile $(1.6 \mathrm{~km})$ north to include Pelican Island and the four rocks lying due west called the Indians.

Area, Depth, Altitude 4 ha land; 368 ha marine; maximum depth $100 \mathrm{ft}(30 \mathrm{~m})$; altitude of Pelican Island is $180 \mathrm{ft}(55 \mathrm{~m})$.

Land Tenure Norman Island privately owned; Pelican Island government owned.

Physical Features On Norman Island, Treasure Point, rising vertically from the sea and perforated by three underwater caves, separates two bays, The Bight and Privateer Bay. The latter has a cobble central shoreline with consolidated bedrock boulders extending subtidally to $2 \mathrm{~m}$ depth. The land surrounding the bays rises steeply to the summit of West Hill at $440 \mathrm{ft}(134 \mathrm{~m})$, the south-western portions of which are covered in deciduous forest dominated by turpentine trees Bursera simaruba. A sheer drop-off to $3 \mathrm{~m}$ depth parallels the shoreline and passes into pavement before interfacing with a dense Thalassia bed at $4 \mathrm{~m}$ depth. The Carvel, three large offshore rocks, to the south is extensively wave swept and virtually barren of any coral growth.

The Bight is bordered on the south by rocky clifs extending into an intertidal pavement which interfaces with a sand bottom at $10 \mathrm{~m}$ depth sloping to $16 \mathrm{~m}$ depth. To the north it is bordered by Water Point which ends in a submerged jumble of rocks; in the east there are two small sandy beaches. The slopes above the southern embayment of The Bight rise steeply. Pelican Island has a single hill with steep cliffs on the south-west. There is a shingle beach on the north-west side and a series of cobble terraces extending to a pavement at $3 \mathrm{~m}$ depth. The rest of the island has a rocky shore converging subtidally with a shallow reef; the lower fore-reef changes to bank sand at ca $20 \mathrm{~m}$ depth. The Indians are a small group of emergent bedrock pinnacles, rising $8 \mathrm{~m}$ to $10 \mathrm{~m}$ above sea level, ca $300 \mathrm{~m}$ west of Pelican Island to which they are joined by submarine bedrock (Anderson et al., 1985).

Reef Structure and Corals Ogden (1982) and Anderson et al. (1985) surveyed sites at Treasure Point and Water Point on Norman Island and at Pelican Island and the Indians; Teytaud (1983) provides additional comments. At Water Point the shallow bay pavement, extending seaward from $3 \mathrm{~m}$ to $10 \mathrm{~m}$ depth, has an unusually high proportion of Montastraea annularis contributing to the total live coral cover of $35 \%$. At $10 \mathrm{~m}$ the lower fore-reef slopes at $30^{\circ}$ to $15 \mathrm{~m}$ depth with increasing coral and gorgonian diversity, but decreasing live coral cover (to $20 \%$ ), still dominated by $M$. annularis but also with $M$. cavernosa. The fore-reef meets sand at $15 \mathrm{~m}$ depth. The bay to the south of Water Point and the Bight itself have seagrass and scattered coral communities dominated by $M$. annularis. Near the head of the Bight there is evidence of the reef being limited by natural sedimentation; the deeper areas are generally sandy.

At Treasure Point Millepora and Montastraea annularis dominate the live coral cover $(25 \%)$ of the pavement bedrock at $5-8 \mathrm{~m}$ depth. Beyond this, several large boulders, rising from $8 \mathrm{~m}$ to within $2 \mathrm{~m}$ of the surface, have $30 \%$ live coral cover including Mycetophyllia, Isophyllia and Dendrogyra, particularly towards the base of the boulders. The bank pavement seaward of this shows local dominance of Acropora cervicornis in the $10 \%$ live coral cover (Anderson et al., 1985). Moving into the Bight from the Point, there is a fringing reef with scattered colonies of Montastraea annularis dropping abruptly to a seagrass bed dominated by Thalassia. The walls of the caves are encrusted with coralline algae and sponges but little coral. Ring Dove Rock, opposite Treasure Point, is roughly circular in shape and rises to within $4 \mathrm{~m}$ of the surface in the west. It is cut by two channels running north/south. Dominant cover on the upper part of the rock is Millepora alcicornis, gorgonians, sea fans and sea whips which reach heights of $2 \mathrm{~m}$ at $10 \mathrm{~m}$ depth. Coral colonies are generally small and $A$ palmata is absent. At $15 \mathrm{~m}$ depth, $A$ cervicornis is found in small patches but appeared to be dying in 1982. The base of the rock grades into a flat plain of sand patches at $20 \mathrm{~m}$ with exposed outcrops of gorgonians and $A$ cervicornis.

At the Indians, Montastraea annularis and Millepora are dominant among the live coral cover $(30 \%)$ on the submarine vertical walls; the area is more diverse than Ring Dove Rock. Gorgonian cover is $10 \%$. Towards Pelican Island, the bedrock rises from ca $5 \mathrm{~m}$ to $0.5 \mathrm{~m}$ depth. Dominant corals among the $10 \%$ to $20 \%$ live coral cover include Montastraea annularis, Millepora and healthy stands of $A$ palmata. The remaining bank pavement to the east ranges from $2 \mathrm{~m}$ to $7 \mathrm{~m}$ depth with $25 \%$ live coral cover and $10 \%$ gorgonian cover. Some unconsolidated coral rubble (mostly $A$ cervicornis and $A$ palmata) is present. This pavement interfaces with bank sand rising towards the bedrock shoreline. In 1982 there was a healthy $A$ palmara reef on the eastern side of Pelican Island.

Noteworthy Fauna and Flora Conch are found off the south-west point of Norman Island (ECNAMP, 1980a). A list of fish recorded at Ring Dove Rock is given in Ogden (1982). The Hawksbill Eretmochelys imbricata 
and the Green Turtle Chelonia mydas nest on both Norman and Pelican Island (Bacon et al., 1984). Lund et al. (1985) report sighting several turtles feeding in the seagrass beds at Privateer Bay; grazing scars in the beds indicate an established turtle population. Teytaud (1983) describes the vegetation and fauna surrounding the Bight in some detail. There is a narrow fringe of white mangrove Laguncularia racemosa around two salt ponds bordering the eastern part and a number of threatened plants are found on the shoreline. Seabirds nest on Pelican Island, and Brown Boobies Sula leucogaster, Brown Pelicans Pelecanus occidentalis, Roseate Terns Sterna dougalli and a few Royal Terns $S$. maxima on the Indians. There is an important wader nesting and feeding area in the bay at the west end of Norman Island. The White-tailed Tropicbird Phaeton lepturus nests on the cliffs near Treasure Point caves; the Brown Pelican and possibly the Bridled Tern Sterna anaetherus nest on Norman Island as well.

Scientific Importance and Research Surveyed by Anderson et al. (1985) and Ogden (1982); other studies carried out in the context of the marine park programme at Norman Island are Teytaud (1983) and West Indies Laboratory (1982)

Economic Value and Social Benefits The islands are uninhabited, aesthetically pleasing and very popular because of their lack of development. The Bight is heavily used, accommodating over $11 \%$ of all overnight anchoring in the B.V.I., with excellent protection from prevailing seas and wind; in the tourist season there are often over 50 boats anchoring overnight. There are two sandy beaches and the caves at Privateer Bay are the major attraction for snorkellers and boaters but relatively few people go ashore. Norman Island has a day anchorage on the shallow bay pavement (ca $10 \mathrm{~m}$ depth). Boat activity at Pelican Island is low, although there is anchoring by day on the west coast of the island. There is some snorkelling, particularly at Water Point, and Ring Dove Rock. The Indians and Pelican Island are visited frequently by dive tours from both the British and U.S. Virgin Islands as well as by charter boats (Anderson et al., 1985; Lund et al., 1985; Teytaud, 1983) The conch population in the Bight is reported to have come under pressure from exploitation by tourists (Ogden, 1982).

Disturbance or Deficiencies Extensive coral damage was reported at the Indians following Hurricanes David and Frederick in 1979 but, although there was considerable $A$ cervicornis rubble at the base of the pinnacles, there was no obvious damage in 1982 (Ogden, 1982). The protected configuration of the Bight results in poor water circulation which makes it vulnerable to pollution from boats dumping waste. However, the general openness of the area suggests that pollution will probably not become a problem (Lund et al., 1985). Anchoring on the seagrass beds is potentially damaging, especially to the turtle population in Privateer Bay and the upright corals at the anchorage of Pelican Island. Although anchor scars have been seen in the seagrass beds in The Bight, recovery appears to be fairly rapid (Ogden, 1982). Rubbish is evident at the anchorage in the caves at Treasure Point and at the west coast of Pelican Island. Boaters and divers may iradvertently disturb the seabirds at the Indians (Teytaud, 1983). In 1983 Norman Island was up for sale and it was expected that the new owner would attempt to develop the area around the Bight; this would represent a considerable threat.

\section{Legal Protection None.}

\section{Management None.}

Recommendations The establishment of the region as a protected area, proposed under the British Virgin Islands Parks and Protected Areas Project, has been accepted in principle by the Government of the B.V.I. The boundary could be extended on agreement to meet the boundary of the existing St John National Park in the U.S. Virgin Islands (Jackson, 1981). Teytaud (1983) includes detailed information on socio-economic features and goals for management and recommended the inclusion of Carrot Rock $\left(18^{\circ} 19^{\prime} \mathrm{N}, 64^{\circ} 34^{\prime} \mathrm{W}\right)$ south of Peter Island in the proposed protected area. It is suggested that mooring buoys be installed at the Indians dive site and possibly outside the caves at Treasure Point. The West Indies Laboratory's study (1982) includes management strategy information complementing the biological survey of Anderson et al. (1985). Teytaud (1983) recommends further work be carried out on the caves at Treasure Point to determine an appropriate management strategy.

\section{NORTH SOUND PROPOSED PROTECTED AREA}

Geographical Location Waters off the north coast of Virgin Gorda to include Mosquito, Prickly Pear, Eustatia and Necker Islands, and Eustatia Reef, ending at Pajaros Point.

Area, Depth, Altitude 160 ha land; 3035 ha marine; maximum depth $70 \mathrm{ft}(21 \mathrm{~m})$; Mosquito Island is $290 \mathrm{ft}$ (88 m).

Land Tenure Mosquito and Necker Islands are privately owned; the rest of the area is government owned.

Physical Features The cays are largely covered with cactus scrub; dry woodland is found on Mosquito Island. Mangroves edge some of the bays on the Virgin Gorda coast and seagrass beds are scattered between the coast and the cays. The offshore cays receive less than 30 in. $(760 \mathrm{~m})$ rainfall a year. Water quality and currents are described in Rogers et al. (1982). Reefs occur off the north coast of the cays, effectively forming a barrier, and are present all round the coast of Necker Island, forming a lagoon system (ECNAMP, 1980b). The reefs include several partly protected short bank barriers up to $3 \mathrm{~km}$ long (Adey and Burke, 1976). The Invisibles, east of Necker Island, is a group of massive boulders with ledges and overhangs, sometimes forming small caves.

Reef Structure and Corals Anderson et al. (1985) and Rogers et al. (1982) describe the reefs around Necker Island. Off the south-eastern shore there is a lagoon with $15 \%$ patch reef cover. Seaward of this is a back-reef pavement which slopes from $5 \mathrm{~m}$ to $1 \mathrm{~m}$ depth and is composed of $90 \%$ coral rubble in a late stage of consolidation, making identification of species difficult. The size of the coral rubble fragments increases seawards. The reef crest includes a substantial sand bank and the seaward edge has large dead stands 
of $A$ palmata. The dominant coral of the shallow fore-reef is $A$. palmata and there is only $5 \%$ live coral cover; a significant portion of the $A$ palmata stands are infected by white-band disease. The fore-reef slopes gradually from $3 \mathrm{~m}$ to $17 \mathrm{~m}$ where it joins a sand bank extending seawards. Deeper areas have $10 \%$ coral cover and are dominated by Montastraea annularis; gorgonian cover reaches $5 \%$ with increased depth. Off the north-west shore, the reef consists of gorgonians, hard corals and sponges on a hard pavement which slopes very gradually to $11 \mathrm{~m}$ depth. The Invisibles, to the east, have corals on some of the boulders.

The eastern shore of Mosquito Island is bordered by Colquhoun Reef, which shelters a protected lagoon, Drake's Anchorage. The area is described by Rogers et al. (1982) and Anderson et al. (1985). The lagoon pavement has an irregular surface of live, dead and rubble coral (25\% cover). The north end of the lagoon has a Porites divaricata and $P$. porites fringing reef, $75 \%$ of which is dead; the area has a total dead coral cover of $20 \%$ and live cover of $10 \%$. The transition from pavement to back-reef is gradual, with an increase of $P$. porites thickets ( $10 \mathrm{~m}$ diameter) dominating the live coral cover of $18 \%$. The Colquhoun Reef crest is ca $30 \mathrm{~m}$ wide and $0.5-1.5 \mathrm{~m}$ deep with sparse live coral cover (5\%), and is dominated by $P$. porites thickets, interspersed with coral rubble and sand. Some upright colonies of mostly dead Acropora palmata are present near the fore-reef. The upper fore-reef has $25 \%$ average live coral cover with $100 \%$ of the $A$ palmata alive at 2-3 m. Millepora sp. is abundant throughout, with gorgonians providing $5 \%$ substrate cover. Despite an increase in species diversity, coral cover decreases from $3 \mathrm{~m}$ to $13 \mathrm{~m}$ depth where Montastraea annularis dominates the $10 \%$ coral cover, colonies being large and spaced 7-10 $\mathrm{m}$ apart, interspersed with sand (10\%) and gorgonians (25\%). The Colquhoun lower fore-reef has an impressive scleractinian community with significant density (55\% live cover), diversity and colony size. Gorgonians cover $20 \%$ of the substrate. The wall off the south-western side of Mosquito Island is a popular dive site; the drop-off begins in about $9 \mathrm{~m}$ and goes down to about $18 \mathrm{~m}$ with hard coral cover reaching $40 \%$ and a high coral diversity. North of this there is some spur and groove development.

The north coast of Virgin Gorda near Pajaros Point is bounded by Eustatia Reef, the emergent portions of which include $A$ palmata rubble probably as a result of the impact of Hurricane Frederic (Rogers et al., 1982). It is described by Anderson et al. (1985) and Rogers et al. (1982); the bank barriers were briefly studied by Adey and Burke (1976). The back-reef pavement is mostly structurally massive, $M$. annularis, with Diploria and Siderastrea being well represented. $A$ palmata accounts for a large portion of the $10 \%$ dead coral cover, and is the dominant branching coral in the $20 \%$ live coral cover. Much of the substrate is fragmented $A$ palmata, which is also prevalent in the shallower portions $(2 \mathrm{~m}$ depth) of Eustatia fore-reef. The $10 \%$ fore-reef live coral cover is mostly A palmata, Millepora and Palythoa, gorgonians making up less than $5 \%$. The fore-reef pavement of Eustatia Reef has $20 \%$ live coral cover, including structurally impressive mounds (ca $4 \mathrm{~m}$ by $10 \mathrm{~m}$ ) of Porites porites in a spur and groove formation with troughs $2 \mathrm{~m}$ deep. Gorgonians increase to $10 \%$ cover, up to the lower fore-reef at $6 \mathrm{~m}$ depth where there is a noticeable increase in size, density and diversity of corals and gorgonians. Live coral cover reaches $50 \%$ and there is a complex habitat down to $17 \mathrm{~m}$ depth, where the sloping fore-reef meets a sparse, flat, sand bank. The reef off the western shore of Eustatia Island is patchy but has impressive patch reefs with large Montastraea annularis colonies and dense $A$ prolifera and $A$ palmata thickets on the back reef.

Cactus Reef off the western side of Prickly Pear Island has abundant gorgonians and live coral cover of about $10 \%$ (Rogers et al., 1982).

Noteworthy Fauna and Flora Hawksbill Eretmochelys imbricata and Green Chelonia mydas Turtles nest on Prickly Pear and Mosquito Islands, at sites on the north coast of Virgin Gorda and possibly on Necker and Eustatia Islands (Bacon et al., 1984). Prickly Pear Island is important for wading birds (ECNAMP, 1980b). Rogers et al. (1982) provide a list of fish recorded during their survey and discuss distribution and diversity. Seagrass beds and mangroves are described in detail by Rogers et al. (1982). Mangroves fringe the northern shore of Virgin Gorda from Oil Nut Bay to Leverick Bay, with fairly dense stands in Biras Creek and Deep Bay. They are also found on the north-east shore of Mosquito Island and on the southern shore of Prickly Pear.

Scientific Importance and Research Eustatia and Colquhoun reefs are considered to be the only barrier reefs in the British Virgin Islands. There was once a marine laboratory at The Bitter End but this is no longer operating. The area was surveyed in 1982 by Rogers et al. (1982) and more recently by Anderson et al. (1985). There is a long term monitoring site on a seagrass bed anchorage at Prickly Pear Island (Anderson et al., 1985).

Economic Value and Social Benefits Traditionally a fishing community of about 400 people, this area has undergone major changes in the last fifteen years and is now the site of a number of luxury resort hotels. North Sound is one of the most popular anchorage areas in the British Virgin Islands, accounting for over $16 \%$ of boat nights in all anchorages, and is of particular importance as a hurricane refuge. Several anchoring and mooring sites are formally reserved for overnight use, including The Bitter End resort and Drake's Anchorage. The entire south-west coast of Prickly Pear Island, Gun Creek and Biras Creek are being increasingly used, especially overnight. SCUBA diving operations attract numerous pleasure boaters to Park sites, especially the lower fore-reef of the barrier reef from Pajaros Point to Eustatia Island (Lund et al., 1985). Other dive sites are situated off Necker (at the Invisibles) and Mosquito Islands (ECNAMP, 1980b). The lagoon off the eastern coast of Mosquito Island has an emergent sandy shoal much frequented by dinghies from boats in nearby Drake's Anchorage (Anderson et al., 1985).

Disturbance or Deficiencies Hurricane Frederic (1979) had a considerable impact on the North Sound reefs, particularly the upper fore-reef of Eustatia barrier reef and around Necker Island, and many now include a large component of coral rubble (Rogers et al., 1982). Human impact is also significant. Dredging in Deep Bay and Biras Creek in 1973 may have adversely affected some of the reefs and seagrass beds. The sea floor at The Bitter End anchorage has been dredged and considerable damage is apparent; over 60 boats may be moored here, 
with over 40 more present. Sewage effluent near the head of Biras Creek, where there is a marina and hotel, has altered the nearby benthic community. Mangrove cutting may increase sedimentation on the reefs. Further development in this and the Leverick Bay area may provide additional stress. Conch and lobster have reportedly been overfished but fish traps are not common; spearfishing may be a pressure. The reduced water exchange in Oil Nut Bay, $1 \mathrm{~km}$ west of Pajaros Pt, makes it particularly vulnerable to anchor damage although usage is currently low; the high aesthetic quality of this site makes it particularly vulnerable (Lund et al., 1985). There is still only a moderate amount of pressure from divers and snorkelers (Rogers et al., 1982).

Legal Protection None.

\section{Management None.}

Recommendations The establishment of the region as a protected area, proposed under the British Virgin Islands Parks and Protected Areas Project, has been accepted in principle by the Government of the B.V.I. North Sound is included in a Resource Management Planning Project with Anegada which would be carried out with the National Parks Trust and ECNAMP. This will take into consideration the traditional uses of resources, education of the community about relevant environmental issues and a review of alternative management strategies (ECNAMP, 1985). Rogers et al. (1982) make a number of recommendations including further assessment of the management required for different sites and for education of the local people as to environmental issues. It is recommended that spearfishing should be prohibited at the Invisibles and that they should receive some form of protection to maintain their attractiveness as a dive site.

\section{THE TOBAGOS PROPOSED PROTECTED AREA}

Geographical Location West of Jost Van Dyke; area to include Great Tobago, Little Tobago and Watson Rock (between Great Tobago and Jost van Dyke).

Area, Depth, Altitude 111 ha land; 287 ha marine; max. depth $150 \mathrm{ft}(45.7 \mathrm{~m})$; Great Tobago is $538 \mathrm{ft}(164 \mathrm{~m})$ high, Little Tobago is $279 \mathrm{ft}(85 \mathrm{~m})$.

Land Tenure Government owned.

Physical Features The bedrock cliffs bordering Little Tobago and Watson Rock Islands drop vertically to the sea and extend subtidally to great depths with near vertical slopes. There is a shallow coral reef on the south-east side of Little Tobago.

On Great Tobago there is a complex system of shallow reefs, bank pavement and sand channels off the south coast. On the east, pavement drops to an algal flat in deep water and there is a fringing reef in the centre of the coast. The south-west coast has bedrock cliffs bordering a rocky cove and extending subtidally to a depth of $5-7 \mathrm{~m}$. A cave mouthed with boulders passes through the south end of the island at the southern end of the cove. A healthy Acropora palmata fringing reef rises to $2.5 \mathrm{~m}$ depth at the back of the cove. The bottom is extremely scoured, and a gorgonian bank seaward of the reef supports live coral cover of about $15 \%$. Bedrock cliffs border most of the rocky north-west shore apart from one sand cove. Subtidal boulder and gravel talus extends from the cliffs to $\mathrm{ca} 7 \mathrm{~m}$ depth where a reef slopes at $30^{\circ}$ to $17 \mathrm{~m}$ depth and then at $60^{\circ}$ to an extensive offshore sandbank with a series of ledges running parallel to the shore at about $25 \mathrm{~m}$ depth (Anderson et al., 1985).

Reef Structure and Corals Anderson et al. (1985) surveyed the sandy cove on the north-west shore of Great Tobago Island and described six zones. The beach, of sand, gravel and bedrock boulders, gives way to a shallow sand bay with dead isolated coral heads ( $10 \%$ cover), at $3 \mathrm{~m}$ depth, projecting $0.75 \mathrm{~m}$ above the sand and partially colonized by corals ( $1 \%$ cover) and gorgonians $(1 \%$ cover). At $4 \mathrm{~m}$ depth a shallow reef rises sharply to $3 \mathrm{~m}$ depth and on either side of a central sand channel there is a shallow pavement which slopes gently to $6 \mathrm{~m}$ depth. The $1 \mathrm{~m}$ precipice at the sand/pavement interface is highly convoluted and is composed primarily of Montastraea annularis. Live coral cover is $10 \%$, and gorgonian cover is $5 \%$. Dominant corals include Diploria strigosa, $D$. clivosa and $M$. cavernosa. The reef zone begins at about $6 \mathrm{~m}$ depth with a conspicuous increase in gorgonian abundance and diversity. Gorgonian holdfast cover is only $10 \%$, but the crowns of the colonies provide $60-75 \%$ cover. Below about $7.5 \mathrm{~m}$ live coral cover $(25 \%)$ is dominated by $M$. annularis and Diploria and gorgonians become less abundant ( $10 \%$ cover). There are caverns and deep ledges resulting from bioerosion, and some incipient spur and groove formation. The lower fore-reef was probably once a massive Acropora cenvicornis reef, as much of the substrate is consolidated $A$ cervicornis. A spur and groove formation is created by plate-like $M$. annularis colonies and Diploria heads of about $1.5 \mathrm{~m}$ diameter. The slope descends at $45-60^{\circ}$ to $20 \mathrm{~m}$, with maximum habitat complexity in the grooves (up to $3 \mathrm{~m}$ deep). Live coral cover is $40 \%$ and, although gorgonian cover is low (5\% cover), colonies may measure $2 \mathrm{~m}$ across. Sponges here are large and diverse.

Noteworthy Fauna and Flora The islands are covered with cactus scrub. Seabirds nest at several sites (ECNAMP, 1980a) and this is the only recently recorded nest site in the B.V.I. for the Magnificent Frigatebird Fregata magnificens (Clarke in litt., 19.3.85). The Hawksbill Eretmochelys imbricata and perhaps the Green Turtle Chelonia mydas may nest on Great Tobago (Bacon et al., 1984). There is a spectacular gorgonian garden in the cove on the central west coast of Great Tobago (Lund et al., 1985).

Scientific Importance and Research Surveyed by the West Indies Laboratory (1983).

Economic Value and Social Benefits Great Tobago has a popular day anchorage in the cove on the central west coast, accommodating no more than three boats at once. The shallow sandy area of the cove is seldom used, boaters preferring to anchor over the gorgonian garden in 6-10 $\mathrm{m}$ depth (Lund et al., 1985).

Disturbance or Deficiencies The islands are uninhabited but there are feral goats on Great Tobago (Clarke in litt., 19.3.85). The gorgonian gardens in the cove on the central west coast of Great Tobago are at high risk from 
anchor damage and boating pollution (Lund et al., 1985).

Legal Protection None.

\section{Management None.}

Recommendations The establishment of the Tobagos as a protected area, proposed under the British Virgin Islands Parks and Protected Areas Project, has been accepted in principle by the Government of the B.V.I. Further planning work is awaited before the area is legally declared.

\section{THE WRECK OF RMS RHONE MARINE PARK}

Geographical Location Waters south of Tortola and east of Peter Island to include Dead Chest Island, the wreck of the RMS (Royal Mail Steamer) Rhone (18\%2'N; $64^{\circ} 33^{\prime} \mathrm{W}$ ) and the west and north coasts of Salt Island as far as Groupers Nest at the north-east tip; the anchor of the Rhone is in a small protected area apart from the main part of the park.

Area, Depth, Altitude 323 ha with 309 ha of sea and 34 acres (14 ha) of land on Dead Chest Island; altitude $60 \mathrm{~m}$.

\section{Land Tenure Government owned.}

Physical Features Dead Chest Island has a mostly rocky coastline with rocky intertidal areas, and cobble beaches on the north-west side. Subtidally, there are fringing reefs off the north coast supported by bedrock bank pavements. An emergent bedrock finger in the south, protecting the southern side from prevailing seas, is joined at its base with a fringing reef, thus forming a small lagoon. Sparse bank pavement surrounds the remainder of the south and west coasts.

On Salt Island, from Groupers Nest $1 \mathrm{~km}$ west to Man Head, the shore line is rocky and exposed to prevailing winds. Subtidally there is dense seagrass extending south-west to Salt Island Bay and Lee Bay. Salt Island Bay has a rocky shore which gives way to a palm tree-lined sandy beach in the southernmost part of the bay. To the south, Lee Bay has a cobble beach separating rocky headlands. A small fringing reef has developed off the rocky headland separating Lee Bay and Salt Island Bay. The wreck of the RMS Rhone is situated off the point on the south side of Lee Bay.

Reef Structure and Corals Anderson et al. (1985) surveyed sites at Dead Chest Island, Lee Bay and Salt Island Bay. The bank sand off the west coast of Dead Chest Island supports a few live coral species ( $5 \%$ cover) particularly Montastraea annularis, and slopes from the cobble interface of less than $1 \mathrm{~m}$ depth to the bank pavement at $3 \mathrm{~m}$ depth. The pavement extends seawards to $10 \mathrm{~m}$ depth and shows increasing coral density with distance from shore. The average live coral cover of $25 \%$ is dominated by $M$. annularis, Acropora palmata and Millepora spp. Gorgonians provide $5 \%$ of live cover. Off the north coast is a narrow (ca $3 \mathrm{~m}$ wide) fringing reef of predominantly $A$ palmata at $1 \mathrm{~m}$ depth. Beyond this is a pavement with live coral ( $20 \%$ cover) dominated by large stands of $A$ palmata, dead coral (15\%) and gorgonians (5\%). The pavement extends to $3 \mathrm{~m}$ depth where it drops abruptly to $5 \mathrm{~m}$ and is severely undercut. Seaward of this ledge (which extends around the east of the island), from $5 \mathrm{~m}$ to $14 \mathrm{~m}$ depth, is a fore-reef extending seawards for ca $50 \mathrm{~m}$. The live coral composition and health is impressive with relatively high species diversity, $80 \%$ live coral cover, $10 \%$ gorgonian cover and 5\% dead coral cover. Montastraea annularis dominates the area with uncommonly large mushroom colonies rising $5 \mathrm{~m}$ from the subtrate with $100 \%$ live coral cover. Colpophyllia heads, $1.5 \mathrm{~m} \times 3 \mathrm{~m}$, contribute to the high habitat complexity. Pavement abruptly borders the fore-reef at $14 \mathrm{~m}$ depth with characteristic gorgonian $(15 \%)$ and live coral $(15 \%)$ cover. Several caves are formed from ledges of eroded pavement.

To the north-east a bedrock outcrop rises from $14 \mathrm{~m}$ to ca $5 \mathrm{~m}$ depth and is fringed by a lower fore-reef from $14 \mathrm{~m}$ to $10 \mathrm{~m}$ depth. Live coral cover here is ca $20 \%$ and dominated by $M$. annularis with isolated $A$ palmata colonies. The capping pavement of the outcrop has $15 \%$ live coral cover and $10 \%$ gorgonian cover. $A$ palmata colonies in the shallowest parts rise nearly to the surface, with Diploria species also common. The fringing reef off the south of the island is primarily $A$ palmata with a healthy live coral cover of ca $25 \%$. The top of the reef is no deeper than $0.5 \mathrm{~m}$, is dominated by Millepora and is awash with $1 \mathrm{~m}$ waves.

Off Salt Island there is sparse coral cover. The pavement from $5 \mathrm{~m}$ to $8 \mathrm{~m}$ depth in Lee Bay has $15 \%$ live coral cover dominated by Millepora and 5\% gorgonian cover. The area around the wreck is extremely wave-scoured and there are very few coral colonies (Ogden, 1982). In Salt Island Bay, Millepora and Porites porites dominate the $5 \%$ live coral cover of the shallow (1.5 m depth) bedrock zone extending from the rocky shore. The shallow seagrass bed in the rest of the bay has occasional Acropora cervicornis and Manicina colonies. There are several patch reefs at $12 \mathrm{~m}$ depth, up to $10 \mathrm{~m}$ in diameter, surrounded by sand halos and almost entirely composed of dead $P$. porites with $1 \%$ live coral cover of Mille pora.

Noteworthy Fauna and Flora Cactus scrub is found on Dead Chest Island which is a seabird nesting site. Conch are found off Salt Island and Dead Chest. Leatherback Dermochelys coriacea, Hawksbill Eretmochelys imbricata and Green Turtles Chelonia mydas may occur here (ECNAMP, 1980a) but nesting is not recorded in Bacon et al. (1984).

Scientific Importance and Research Surveyed by Anderson et al. (1985) and briefly by Ogden (1982).

Economic Value and Social Benefits Several excellent dive sites are located off uninhabited Dead Chest Island and are increasingly frequently visited. Dead Chest Island has a single anchorage on the north-west coast and is rarely visited, even for day use (Lund et al., 1985). Salt Island Bay and Lee Bay are the most frequented areas on Salt Island and, although no formal overnight anchorages exist within the park boundaries, Salt Island Bay is occasionally used as such. Lee Bay is the anchorage for visitors to the wreck of RMS Rhone which is located on the south side of the bay. When the bedrock boulder area here fills up boats use the seagrass bed and Salt Island Bay. The wreck is visited by as many as seven 
charter dive boats and twenty charter and private yachts carrying up to 100 divers a day (Anderson et al., 1985; Geoghegan, 1985), its main attraction being its easy access and international fame. A small landing dock accommodates dinghy traffic in Salt Island Bay where there is a fishing village.

Disturbance or Deficiencies Pilfering from the wreck of the Rhone (IUCN, 1982) and damage to the wreck and marine life from boat anchors are common (Clarke, 1984). Anchor tracks are visible in the seagrass beds at both Salt Island Bay and Lee Bay and rubbish litters the bottom of the anchorage sites. The north-west anchorage of Dead Chest Island is sensitive to overuse (Lund et al., 1985). The openness of the Salt Island coastline permits excellent water exchange and pollution is unlikely to have a significant impact, excluding the diposal of solid waste.

Legal Protection Park established 1980 (IUCN, 1982).
Management Administered by the British Virgin Islands National Parks Trust. A draft management plan has been prepared in collaboration with commercial users of the park (Clarke, 1984). Moorings, funded by USAID, have been installed at Lee Bay for yachts; moorings for dive boats are soon to be installed by dive operators over the wreck itself. A permit system is to be set up with an annual fee charged to commercial users of the site and a single use fee for private yachts. The dive companies which install the moorings will be excused from paying the fees for the first five years (Geoghegan, 1985).

Recommendations Controls on spearfishing are required. Other recommendations are given in the draft management plan (Clark, 1984). Given the lack of personnel for effective wardening, the idea of deputizing dive tour operators as voluntary wardens is being considered, as well as the possibility of having a customs officer to act as part-time Chief Warden (Geoghegan, 1985). 



\section{INTRODUCTION}

\section{General Description}

The Cayman Islands $\left(1^{\circ} 15^{\prime} \mathrm{N}-19^{\circ} 45^{\prime} \mathrm{N}, 7^{\circ} 44^{\prime}-81^{\circ} 27^{\prime} \mathrm{W}\right)$, a dependent territory of Great Britain, consist of three limestone islands, Grand Cayman, Cayman Brac and Little Cayman. They are formed by the projecting peaks of a range of submarine mountains making up the Cayman Ridge which runs eastwards of the Sierra Maestra of Cuba. The ridge is bordered by the Cayman Trench to the south where depths exceed $5490 \mathrm{~m}$ and the Yucatan Basin to the north-west with depths of $4575 \mathrm{~m}$ (Roberts, 1974). The islands each have a central core of Bluff limestone of mid-Miocene to Oligocene origin, believed to be over $400 \mathrm{~m}$ thick and a low (3-4 m) coastal platform of Pleistocene ironshore, a marine consolidation of sand, lagoonal mud, coral and molluscs. The limestone shores are extensively eroded by the action of rain and sea and the grazing action of molluses and echinoderms (Potts, 1980; Spencer, 1985).

Tidal range is about $12-50 \mathrm{~cm}$ and tides are mixed diurnal or semidiumal (Bradley, 1986). Ocean currents are mainly from the south-east (Stoddart, 1980a). North-east trade winds predominate in winter and south-east trades in summer; north-westerly storms occur from December to April (Giglioli, 1976; Roberts, 1974). There is a hot summer season from May to November and the rest of the year is cooler and drier. Rainfall occurs principally in the summer months, commencing usually in May and rising to a maximum in October. The Grand Cayman annual average is about $13300 \mathrm{~mm}$; Cayman Brac has an annual average of about $12200 \mathrm{~mm}$ (Bradley, 1986). Climatic details are given in Giglioli (1976).

Grand Cayman is the largest island (197 sq. km) and rises steeply from the $305 \mathrm{~m}$ contour line (the Cayman Wall). The geology and geomorphology of the island have been described by Doran (1954) and Matley (1926). The island is limestone-capped and has extremely low relief (max. elevation $20 \mathrm{~m}$ ), with a dish-like configuration. The coastline, of limestone bedrock, storm berms and hurricane beaches, is 3 to $9 \mathrm{~m}$ high. The central area is lower with centripetal drainage through the mangrove swamps towards the low shores of North Sound. There are no terrestrial sediment-bearing streams or rivers causing soil run-off. The traditionally clear seas surrounding Grand Cayman are due to the physical and biological filtration of land surface water through the mangroves and the narrow insular shelf (Giglioli, 1976). Recent visibility measurements indicate an average horizontal visibility on the deep reefs of $41 \mathrm{~m}$, with a maximum of $60 \mathrm{~m}$; average visibilities around Cayman Brac and Little Cayman appear to be higher (Smith in litt., 6.6.86). Strong westerly directed currents exist along both the northern and southern flanks of the island.

Little Cayman is the smallest island ( $25 \mathrm{sq} . \mathrm{km}, 16 \mathrm{~km} x$ $2 \mathrm{~km}$ ) lying $117 \mathrm{~km}$ east-north-east of Grand Cayman and $11 \mathrm{~km}$ from Cayman Brac; it has a maximum altitude of $14 \mathrm{~m}$. Winds are dominated by the north-east trades, although south-easterlies prevail in summer. It is one of the least settled and least disturbed of all the Caribbean islands. This is due to its rugged topography on dissected limestone, its low and erratic rainfall, its brackish watertable, its tangled and impenetrable vegetation dominated by scrub woodland and, like Grand Cayman, its high level of infestation by the mosquito Aedes taeniorhynchus. Cayman Brac (32 sq. km, 12 x 1 mi. (19.2 $\mathrm{x} 1.6 \mathrm{~km})$ ) is situated 89 miles $(143 \mathrm{~km})$ east-north-east of Grand Cayman.

The shelf surrounding Grand Cayman is narrow, ranging in width from about 0.5 to $2.0 \mathrm{~km}$. Shallow water fringing reefs encircle most of the island and form numerous shallow-water lagoons. Seaward of these reefs are two distinctive submarine terraces. The seaward break in slope of the upper shallow terrace generally occurs at a depth of 8 to $10 \mathrm{~m}$. The lower terrace margin occurs at approximately $20 \mathrm{~m}$ depth where the fore-reef terrace is intersected by an extremely steep reef slope plunging off into very deep water (Rigby and Roberts, 1976; Roberts, 1971a, 1974 and 1983). Rich coral and calcareous algal growth occurs mainly at the seaward edge of both terraces and down to the limit of active reef growth at about $75 \mathrm{~m}$ depth (Rigby and Roberts, 1976). There are no fringing or barrier reefs on the west coast but there are continuous reefs on the upper shallow terrace and the fore-reef terrace except in the harbour area where they have been destroyed by anchoring (Smith in litt., 6.6.86).

Thirty-five reef sites were investigated in the course of the Cayman Islands Natural Resources Study (in the regions of North Sound, Little Sound, East End, South Sound, West Bay Beach and Twelve Mile Bank). Forty-three scleractinians were recorded and are listed in Raymont et al. (1976) and several new species have been recorded recently (Smith in litt., 6.6.86). In general, Grand Cayman reefs are similar to other Caribbean reefs. The only example of a massive reef structure due to algae is a patch reef within the back-reef area of West Bay Beach, about $1 \mathrm{~m}$ high, several metres in length and width and composed entirely of Peyssoniella with encrusting lithothamnioid algae. A general description of the zonation of Caymanian reefs is given in Raymont et al. (1976b) and Roberts (1974 and 1983) which is used as a basis for the following account.

In the back-reef zone, 19 scleractinians were described, the dominant species being Montastraea annularis and Acropora palmata. Other important corals are Agaricia agaricites, Diploria spp., Porites astreoides and Acropora cervicornis; the pharmaceutically important Plexaura homomalla occurs with a somewhat patchy distribution. Back-reef areas are generally healthy, as there are no extensive shallow reef flat areas which can be readily damaged by low tides or heavy rains. On the reef crest, the principal species is A palmata, intermingled with Millepora complanata. Along some sections of the south coast and at East End, the reef crest is comprised of coral rubble and other debris.

Most of the shallow terrace, extending $50-100 \mathrm{~m}$ from the reef crest, is hard ground surface often with significant sand cover. It is commonly dissected by shallow grooves and has a rich gorgonian and algal assemblage but relatively little coral; only 14 species have been 


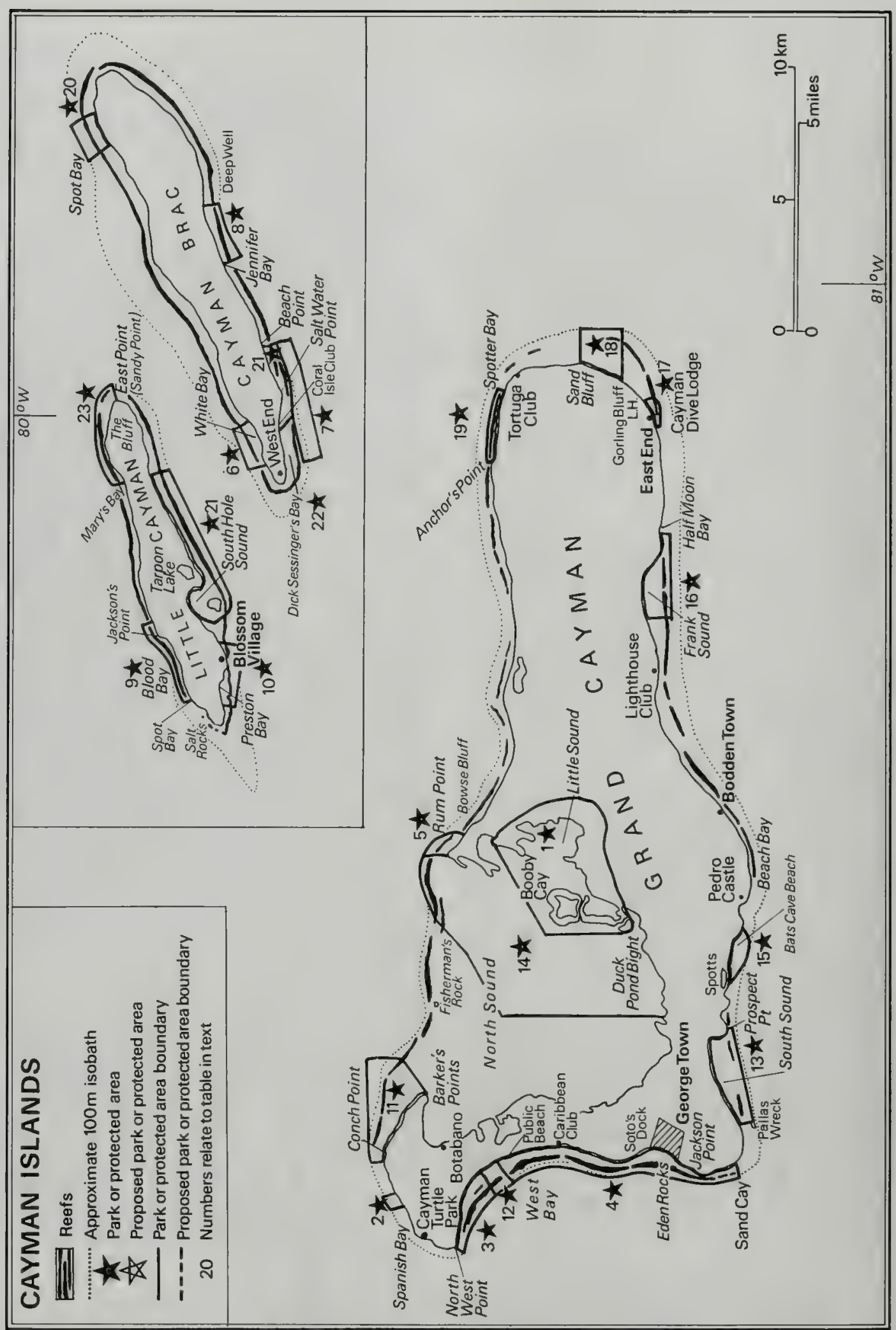


found. $A$ palmata predominates in shallow areas near the reef crest. Towards the seaward edge of the zone, coral growth becomes more pronounced and develops into a series of buttresses which project into deeper water. Thirty-five corals have been recorded from the upper buttress zone, the dominant species being Montastraed annularis, which forms colossal mushroom-shaped colonies on the upper parts of the buttresses and angled plates on the gulley walls, and Agaricia agaricites. Well defined ridges or spurs of living coral are prograding seaward and building toward the surface. The buttress system is variable around the island, and from North-west Point to North Sound there is a sheer bedrock cliff of $8-10 \mathrm{~m}$ with well developed coral growth in some areas.

The fore-reef slope has scattered corals exhibiting flattened plate formation and including Agaricia spp., Mycetophyllia reesii and Scolymia. The deep shelf terrace is $100-200 \mathrm{~m}$ wide and slopes down to $20-40 \mathrm{~m}$ depth with coral spurs running from the upper buttress for some distance. The landward portion is frequently an area of sediment accumulation; the shelf-margin reef varies from an unbroken ridge, through regularly spaced massive coral buttresses separated by narrow sediment-floored grooves, to irregularly spaced and widely separated coral buttresses. At the seaward edge, where there is an abrupt break in slope, Acropora cervicornis is common. The spurs terminate in a sand plain.

Off Pedro Castle, Jackson Point and Cayman Turtle Farm, spur formation is very restricted and there is a large expanse of sand. Low energy shelf-margin reefs, as at West Bay and Rum Point Channel (west of Rum Point), support thriving coral communities but display less exaggerated buttress formation and less steep offshelf profiles (Roberts, 1983). Montastraea annularis, Agaricia agaricites, Diploria strigosa, Colpophyllia natans and other massive corals dominate the shallow portions (Roberts, 1974). Along high energy sectors of the shelf, massive and regularly spaced living coral buttresses protrude into deeper water. These huge coral spurs occasionally coalesce, forming a wide variety of tunnel and cavern structures. A long-term study of sessile macro-invertebrate coelobite communities from a reef tunnel and gallery system off West Bay has been carried out by Logan (1981). The massive buttresses generally have a steep to overhanging seaward profile, with as much as $20-40 \mathrm{~m}$ of relief. There is a large and varied coral community of about 22 species, with $M$. annularis dominant and a luxuriant and varied growth of gorgonians and sponges. Some of the best examples can be found along the north central, east and south central sides of Grand Cayman, the south west side of Cayman Brac and the south-west and north-west sides of Little Cayman. Shallow areas which contained impressive buttress type formations used to occur in the George Town area off Soto's Dock where coral buttresses rose from about $11 \mathrm{~m}$ depth to within $2-3 \mathrm{~m}$ of the surface (Logan, 1981) and the Eden Rock Dive Center (Smith in litt., 6.6.86). Unfortunately these areas have suffered significant damage from boats, anchors and divers.

Twelve Mile Bank, $16 \mathrm{~km}$ west of Grand Cayman, is about $19 \mathrm{~km}$ long, 30 to $40 \mathrm{~m}$ deep and has coral heads rising to within $20 \mathrm{~m}$ of the water surface, including Manicina areolata, A tenuifoliata, Montastraea cavernosa, Porites porites and Madracis sp. There does not appear to be a well developed buttress formation but further investigations are required (Raymont et al., 1976b). Large barrel sponges Xestospongia sp. are particularly abundant and have very wide bases with thickened ramifications, an adaptation to the strong currents in this area (Smith in litt., 6.6.86).

With a few exceptions, the reefs of both Cayman Brac and Little Cayman are floristically, faunistically and structurally comparable to Grand Cayman. Shallow marine substrate maps of Little Cayman and Cayman Brac have recently been produced using aerial photographs (Logan, 1984)

The marine flora, particularly the seagrass communities, of the Cayman Islands is described by Raymont et al. (1976a). Mangroves cover 36\% of Grand Cayman, $40 \%$ of Little Cayman and $1 \%$ of Cayman Brac and are described, with other wetland types, in Bradley (1986). The terrestrial fauna of Little Cayman is described by Stoddart (1980b). A colony of an estimated 7100 Red-footed Boobies Sula sula (second only in size to the colony at Half Moon Caye, Belize) nests in mangroves on the north shore of Blossum Village salt pond with about 200 pairs of Magnificent Frigatebirds Fregata magnificens. Other important waterfowl sites are described in Bradley (1986). The Yellow-billed Tropicbird Phaethon lepturus, Brown Booby S. leucogaster and the Least Tern Sterna albifrons also have nesting colonies in the Cayman Islands (Bradley, 1985; Halewyn and Norton, 1984).

The marine fauna of the islands is described in Raymont et al. (1976a and b) and Stoddart (1980b). Reef-dwelling articulate brachiopods have been described by Logan (1977). The marine molluscs of Grand Cayman and the littoral molluscs of Little Cayman have been described by Abbot (1958) and Potts (1980) respectively. Marine turtles used to be common. Turtling began on a large scale in the Caymans in the second half of the seventeenth century and by the early nineteenth century populations had declined considerably (King, 1981). The Green Turtle Chelonia mydas was the most abundant (King, 1981) but the Loggerhead Caretta caretta, the Hawksbill Eretmochelys imbricata and the Leatherback Dermochelys coriacea were also present at least up to 1940 (Stoddart, 1980b). The Loggerhead still nests (at Bodden Bay, Grand Cayman) and Hawksbills and Greens forage in the area (Bacon et al., 1984). Green Turtles are raised commercially at the Government-owned Cayman Turtle Farm (CTF) north of West Bay (Rae and Stevens, 1976; Groombridge, 1982). Since 1980, CTF has released several thousand hatchlings and yearlings from the farm (from various geographic stocks) into local waters. The Caribbean Manatee Trichechus manatus is no longer found on Grand Cayman (Raymont et al., 1976a).

The Cayman Islands were visited in $\mathbf{1 9 3 8}$ by the Oxford University Expedition (Stoddart, 1980a). Since 1965, the main research unit on the islands has been the Mosquito Research and Control Unit which has carried out substantial work on wetlands (Bradley, 1986). In 1974 and 1975, the Cayman Islands Natural Resources Study was carried out, focusing on marine resources on account of the diminishing lobster and conch catches, the 
uncontrolled commercial harvesting of gorgonians and corals, the rapid destruction of beach ridges for sand for fill and construction and the increased impact of dredging (Raymont et al., 1976a and b; Wickstead, 1976). Studies on the marine environment of Grand Cayman included Rigby and Roberts (1976) and Roberts (1974, 1977 and 1983) (and see account for "North Sound"). Recommendations were made for future research on these subjects (Darbyshire et al., 1976; Giglioli, 1976). As part of the project, a Royal Society/Cayman Island Government Expedition visited Little Cayman to describe the major features of the terrestrial and marine environments and to provide background material for management decisions in the event of any proposals for major industrial and commercial development. Marine studies in the course of this expedition were concentrated around South Hole Sound in view of its tourist potential and susceptibility to change in the event of expanding settlement at Blossom Village (Stoddart, 1980b).

The Cayman Island Government Natural Resources Laboratory was revived in 1984. A marine biologist has been recruited and routine monitoring systems for the marine, lagoonal and swamp environments have been developed. Particular attention is being paid to the monitoring of long term changes in a) \% cover of benthic species, b) seagrass beds, c) sea urchin, conch and lobster populations, d) selected fin fish stocks and e) various water quality factors (Smith in litt., 6.6.86; Davies in litt., 10.9.84).

\section{Reef Resources}

Originally, the rocky terrain of the islands and the mosquito infested mangrove swamps meant that the islands were only suitable for subsistence farming. With the development of air services, the Caymans became a popular tourist resort and over 400000 tourists visited the islands in 1985 (Smith in litt., 6.6.86). About 30\% are divers, the Cayman Islands being one of the most popular dive destinations on the world (Bergstrom in litt., 6.7.84). Grand Cayman, with 326 recorded wrecks as well as attractive reef sites and spectacular drop-offs, has over 20 dive operations, but Cayman Brac and Little Cayman are equally popular with divers. The west and north-west coasts of Grand Cayman, near the main tourist centres, are most popular for diving (Davies in litt., 10.9.84), dive sites including George Town Harbour (Eden Rock), the North-west Point (and Spanish Bay), and North Sound Reef; other sites include East End, Cayman Dive Lodge (South Sound), the Tortuga Club in the north-east, Spotts, West End on Cayman Brac and Bloody Bay in Little Cayman (Bergstrom in litt., 6.7.84).

In 1976, fish populations were considered to be extensive (211 species recorded) (Raymont et al., 1976a), with large groupers and parrotfish (Rae and Stevens, 1976). The reef fishery was then considered to be underdeveloped although it was recognised that stocks would not support a large commercial fishery (Rae and Stevens, 1976). Twelve Mile Bank was of major importance for pelagic and demersal fish (Raymont et al., 1976a). Most fish stocks are now depleted (see below) although large fish are still common on Little Cayman. On Grand Cayman Strombus gigas is collected for food for both locals and tourists and is used as bait for trap and line fishing. The spiny lobster Panulirus argus was abundant in the early 1900 s but has been over-exploited and is rare; it is collected for consumption by islanders and tourists. There is a growing black coral industry but all the raw material is imported (Smith in litt., 6.6.86). In 1976, a limited amount of black coral was observed on the west and south coasts, and large concentrations were found on the north coast, very little coral occurring above $67 \mathrm{~m}$. The commercial potential of other species (Cushion Starfish Oreaster reticulatus, Sea Biscuit Clypeaster rosaceus, Calico Scallop Argopecten gibbus, Common Egg Cockle Laevicardium laevigatum, Tree Oyster Isognomon alatus and marine algae) is discussed in Raymont et al. (1976a).

\section{Disturbances and Deficiencies}

The reefs of the Cayman Islands are generally healthy since there is no river discharge to cause turbidity (Raymont et al., 1976b). However, the islands lie within the zone of catastrophic hurricanes, more than 40 having been recorded since 1751 (Stoddart, 1980a). Hurricanes of lesser magnitude occur at the rate of about four every ten years (Giglioli, 1976) and have had noticeable short-term effects on the reefs, such as Hurricane Allen in 1980 (Rogers, 1985). Flourishing fringing reef communities are commonly found only along segments of the north coast of Grand Cayman, generally in the North Sound area. Many of the areas which appear to have received the most severe hurricane damage have been colonized by Millepora alcicornis, Diploria clivosa and the zoanthid Palythoa. Reefs on the north side of Cayman Brac from Sarah's Turn, west past Billy Bodden's Store, appear to have suffered catastrophic damage 50 to 100 years ago, in the form of strong scouring; live coral colonies are very small and the beach which was sandy in the 1930s is now of ironshore and cobbles. It is possible that these changes were due to a hurricane (Smith in litt., 6.6.86). Diadema antillarum, the Long-spined Sea Urchin, underwent a dramatic population crash (Smith in litt., 6.6.86) during the 1983 Caribbean wide die-off, said to be due to a waterborne pathogen (Lessios et al., 1984), and populations are still very depressed particularly on the Lesser Caymans.

More recently, human activities have begun to have a noticeable impact on the environment. The Cayman "boom" and its impact on the islands is discussed by Giglioli (1976) and Wickstead (1976). The Lesser Caymans have not yet been affected on a large-scale, but Grand Cayman has suffered from rapid population growth, the hotel construction industry and associated environmental degradation. The marine environment is particularly vulnerable on account of the importance of local fisheries and the fact that the majority of tourists come for water-based recreational activities.

There are now very few large fish of kind and big groupers and parrot fish are rare compared with other Caribbean islands, presumably as a result of over-exploitation. Spiny lobsters and conch have been seriously over-exploited; the latter were already depleted in the 1970s (Rae and Stevens, 1976; Raymont et al., 1976a). Stocks of commonly eaten species (e.g. conch, snappers and groupers) are less depleted on Cayman Brac and Little Cayman than on Grand Cayman; the estimated biomass/hectare of jacks, groupers and barracuda on Little Cayman being five times the estimate for the west 
end of Grand Cayman. South Hole Sound on Little Cayman appears to contain the densest conch population remaining in the islands (Smith in litt., 6.6.86).

The problems of marl fill and dredging were studied in detail in the 1975 survey. Marl is an essential pre-requisite for almost all substantial building projects on the island due to the need for filling and levelling, particularly in swampy areas. Sand is another vital component in construction work on Cayman (Raymont et al., 1976 a and b). Water clarity around the island was very definitely reduced in 1971 and 1972 due to dredging in North and South Sounds. Filling mangroves and associated development ventures caused sediment plumes, in addition to natural plumes from swamps and ponds; effluent from the turtle farm was also cited. Clarity improved after 1973 when this type of dredging ceased, and the coral which, in many areas, looked as if it was dying, recovered (although no coral damage was reported by Raymont et al. (1976a)).

A considerable quantity of oil was found on most shores visited in the 1975 survey. Although levels were not considered serious at that time, it was pointed out than an increase could begin to have a severe and lasting ecological impact on both shore and reef life. The weather shores of all three islands continue to be polluted by tar, most of which is apparently derived from Arabian crude oil. A spill which affected some $6 \mathrm{~km}$ of coastline on Grand Cayman in 1982 was large enough to prompt an emergency clean-up operation by the Government. A number of vessels have been observed discharging oil slicks close to the shore (Davies in litt., 10.9.84). Litter was becoming a problem in 1976 (Raymont ct al., 1976a) and is still a problem in places but several big clean-up campaigns have been organised and some areas are much improved (Davies in litt., 10.9.84). Rose and Risk (1985) found a marked increase in the biomass of the sponge Cliona delitrix infesting Montastraea cavernosa on a portion of reef affected by the discharge of untreated fecal sewage from Cayman Turtle Farm.

There has been damage from the recreational use of the reefs such as coral collecting and boat anchoring, especially at Eden Rocks and at dive sites near the wreck of the Balboa (Rogers, 1985). It is often difficult to exert control because of the large numbers of snorkellers from cruise ships and the easy access of some sites from the shore (Bergstrom in litt., 6.7.84; Davies in litt., 10.9.84). Local diving operators are reported to be conservation conscious, which should help to minimise damage. Disturbance by man in the Lesser Caymans has been minimal. Reef fish faunas have not been disrupted by spearfishing and therefore are of considerable interest (Potts, 1980).

\section{Legislation and Management}

The Marine Conservation Law (1978) prohibits spearfishing and the taking, injuring, killing of any fish or lobster while SCUBA diving. The closed season for lobsters is 1 February-31 July, and the taking of berried females is prohibited at any time. Spearfishermen may only take three fish or three lobsters (in the open season) in any one day and only for consumption, although this is unenforced and largely ignored (Davies in litt., 10.9.84). Conch fishing is restricted (and there are now restricted areas to protect breeding stocks, see below), corals are protected from anchor damage and discharge of effluents is prohibited. Corals and shells may not be taken without permits; no permits (at least for black corals) have been granted for many years (Smith in litt., 6.6.86). Turtle collection is controlled under the Marine Conservation (Turtle Protection) Regulations of 1978 , by a closed season, minimum size limit, quotas and restrictions on capture methods. Oil spill contingency arrangements are under development (Burton in litt., July 1984).

A number of areas were recommended for protection by the Cayman Islands Natural Resource Study team in the 1970s (Raymont et al., 1976b). Based on some of these recommendations and on recent work, a marine parks scheme, involving a system of three types of zones, has been implemented. Marine parks were designated on Grand Cayman on 1st March 1986 under the Marine Conservation (Marine Parks) Regulations 1986 (published in Supplement 1, Extraordinary Gazette, 21st Feb, 1986, Cayman Islands Government) and on Cayman Brac and Little Cayman under the Marine Conservation (Marine Parks) (Amendment) Regulations, 1986 (Supplement No.1, Extraordinary Gazette, 15th May 1986).

In Environmental Zones, the taking of any form of marine life, the use of anchors and the entry of any person into the water is prohibited and there is a speed limit of five knots. In Marine Park Zones, the taking of all forms of marine life except fish (using certain methods only) and the anchoring of boats in certain areas and in certain ways are prohibited. In Replenishment Zones, the taking of conch and lobster and the use of spearguns, fish traps and most types of net are prohibited.

\section{Environmental Zones}

\section{Grand Cayman}

1. Little Sound, (see account for North Sound)

\section{Marine Park Zones}

Grand Cayman

2. Spanish Cove Resort - Jetty

3. North West Point - West Bay Cemetery (see account for West Bay)

4. Victoria House - Sand Cay Apartments (see account for West Bay)

5. Bowse Bluff - Rum Point (see account for North Sound)

Cayman Brac

6. Scotts Anchorage - White Bay

7. Dick Sessinger's Bay - Beach Point

8. Jennifer Bay - Deep Well

Little Cayman

9. Bloody Bay - Jackson Point (see separate account)

10. Preston Bay - Main Channel.

\section{Replenishment Zones}

\section{Grand Cayman}

11. Head of Barkers - Flats (see account for North Sound)

12. West Bay Cemetery - Victoria House (see account for West Bay)

13. South Sound (see separate account)

14. North Sound (see separate account) 
15. Bats Cave Beach

16. Frank Sound

17. Cayman Dive Lodge (see separate account)

18. Radio Mast - Sand Bluff (see separate account)

19. Spotter Bay - Anchors Point (see separate account)

Cayman Brac

20. Spot Bay

21. Salt Water Point - Beach Point

22. Coral Isle Club

Little Cayman

23. Mary's Bay - East Point (see separate account)

24. South Hole Sound

The zones will be marked by permanent signs on the shore and buoys where possible. Police and Fisheries Officers will be assigned to enforce the Marine Park Regulations, and it is hoped that the public will help in this effort (Anon., 1985).

\section{Recommendations}

Raymont et al. (1976a and b) gave a comprehensive set of recommendations for management of the marine resources of the islands. Many of these suggestions have since been put into operation. Other recommendations include improved litter prevention; rigid protection for the molluscs Cassis tuberosa, C. madagascariensis, Charonia variegata and Tonna galea; management of the black coral industry; improved management of conch stocks (such as a consumer survey to establish the requirements for imported conch; a catch limit of five conch/day/person; the use of Marine Park areas as conch reserves with appropriate controls (Replenishment Zones now in force), and fuller utilization of the resource by exploiting the tourist curio trade); further studies of spiny lobster stocks and their management; improved management of dredging activities (including the establishment seagrasses in areas of borrow pits, access channels and dredged harbours, particularly in the North Sound area); improved management of sand mining; and improved management of mangroves.

\section{References}

Abbot, R.T. (1958). The marine mollusks of Grand Cayman Island. British West Indies. Monogr. Acad. nat. Sci. Philadelphia 11: 138 pp.

Anon. (1985). Cayman Islands Government Marine Park Information. Issued $21.2 .85,4 \mathrm{pp}$.

Bacon, P., Berry, F., Bjorndal, Hirth, H., Ogren, L. and Weber, M. (1984). The National Reports. Proceedings of the Western Allantic Turtle Symposium, Costa Rica. Vol3: University of Miami Press, Florida.

Bradley, P. (1985). Birds of the Cayman Islands. Private Publication, Bradley, Cayman.

Bradley, P. (1986). The Cayman Islands. In: Scott, D.A. and Carbonell, M. (Eds). Directory of Neotropical Wetlands. IUCN, Cambridge and Gland.

Darbyshire, J., Bellamy, I. and Jones, B. (1976). Cayman Islands Natural Resoures Study. Part III. Results of the investigations into the physical oceanography. Ministry of Overseas Development, London.

Doran, E. (1954). Land forms of Grand Cayman Island, British West Indies. Texas Jour. Sci. 6: 360-377.

Giglioli, M.E.C. (1976). Cayman Islands Natural
Resources Study. Part II. The boom years, environmental deterioration and administration. Ministry of Overseas Development, London.

Groombridge, B. (1982). The IUCN Amphibia-Reptilia Red Data Book Part 1: Testudines, Crocodylia, Rhynchocephalia. IUCN, Gland, Switzerland.

Halewyn, R. van, and Norton, R.L. (1984). The status and conservation of seabirds in the Caribbean. In: Croxall, J.P., Evans, P.G.H. and Schreiber, R.W. (Eds), Status and Conservation of the World's Seabirds. ICBP Technical Publicatin No. 2, Cambridge.

King, F.W. (1981). Historical review of the decline of the Green Turtle and Hawksbill. In: Bjorndal, K. (Ed.), Biological Conservation of Sea Turtles. Smithsonian Institution Press, Washington D.C.

Lessios, H.A., Robertson, D.R. and Cubit, J.D. (1984).

Spread of Diadema mass mortality through the Caribbean. Science 35: 335-337.

Logan, A. (1977). Reef-dwelling articulate brachiopods from Grand Cayman, B.W.I. Proc. 3rd Int. Coral Reef Symp. 1: 87-93.

Logan, A. (1981). Sessile invertebrate coelobite communities from shallow reef tunnels, Grand Cayman, B.W.I. Proc. 4th Int. Coral Reef Symp. Vol. 2: 735-744.

Logan, A. (1984). Compilation of shallow marine substrate maps of the Lesser Caymans, British West Indies, using aerial photographs. (Abstract). Paper to be presented at the annual meeting of the International Society for Reef Studies, Miami.

Matley, C.A. (1926). The geology of the Cayman Islands (British West Indies). Quart. J. Geol. Soc. Lond. 82: 352-387.

Potts, G.W. (1975). Comments on the future development of Little Cayman. Unpub. typescript.

Potts, G.W. (1980). The zonation of rocky littoral areas around Little Cayman. Atoll. Res. Bull. 241: 23-42.

Rae, A.J. and Stevens, R.N. (1976). Cayman Islands Natural Resoures Study. Part V. Results of the investigations into commercial fishing potential. Ministry of Overseas Development, London.

Raymont, J.E.G., Lockwood, A.P.M., Hull, L.E. and Swain, G. (1976a). Cayman Islands Natural Resources Study. Part IVA. Results of the investigations into the marine biology. Ministry Overseas Development. London 130 pp.

Raymont, J.E.G. Lockwood, A.P.M., Hull, L.E. and Swain, G. (1976b). Cayman Islands Natural Resources Study. Part IV B. Results of the investigations into the coral reefs and marine parks. Ministry of Overseas Development, London. $25 \mathrm{pp}$.

Rigby, J.K. and Roberts, H.H. (1976), Grand Cayman Island: geology, sediments and marine communities. Brigham Young Univ. Geol. Stud. Spec. Publ. 4: 1-122.

Roberts, H.H. (1971a). Environments and organic communities of North Sound, Grand Cayman Island, B.W.I. Carib. J. Sci. 11(11-12): 67-79.

Roberts, H.H. (1971b). Mineralogical variation in lagoonal carbonates from North Sound, Grand Cayman Island (British West Indies). Sedimentary Geol. 6: 201-213.

Roberts, H.H. (1974). Variability of reefs with regard to changes in wave power around an island. Proc. 2 nd Int. Coral Reef Symp. 2: 497-512.

Roberts, H.H. (1977). Field Guidebook to the Reefs and Geology of Grand Cayman Island, B.W.I., 3rd Int. Symp. Coral Reefs, Atlantic Reef Committee, Univ. Miam., Fisher Island. Miami Beach, Florida.

Roberts, H.H. (1983). Shelf margin reef morphology: a 
clue to major off-shore sediment transport routes, Grand Cayman Islands, West Indies. Atoll Res. Bull. 263.

Rogers, C.S. (1985). Degradation of Caribbean and Western Atlantic coral reefs and decline of associated fisheries. Proc. 5th Int. Coral Reef Congr. Tahiti 6: 491-496.

Rose, C.S. and Risk, M.J. (1985). Increase in Cliona delitrix infestation of Montastrea cavernosa heads on an organically polluted portion of the Grand Cayman fringing reef. Marine Ecol. 6(4): 345-363.

Spencer, T. (1985). Marine erosion rates and coastal morphology of reef limestones on Grand Cayman Island, West Indies. Coral Reefs 4(2): 59-70.

Stoddart, D.R. (1980a). Scientific survey of Little Cayman. Atoll Res. Bull. 241: 1-10.

Stoddart, D.R. (1980b). Little Cayman: ecology and significance. Atoll Res. Bull. 241: 171-180.

Wickstead, J.H. (1976). Cayman Islands Natural Resoures Study. Part I. Final report and recommendations. Ministry of Overseas Development, London.

\section{BLOODY BAY TO JACKSON'S POINT MARINE PARK}

\section{Geographical Location North-east coast, Little Cayman.}

Physical Features From Bloody Bay to Jackson's Point the upper shore consists of a poorly developed storm beach of coral boulders and rubble, rising to a height of $2 \mathrm{~m}$ above mid-tide level. Below this, a sand or sand and rubble beach extends into the littoral region and in some areas onto the upper fore-reef terrace of the sublittoral region. The shore zonation is described in Potts (1980). Salt Rocks, lying to the west of the Marine Park, has an extensive limestone shore with an interesting intertidal and supratidal exposure of ironshore (Potts, 1980; Stoddart, 1980b).

Reef Structure and Corals Bloody Bay has a steep reef edge drop-off, known as the Cayman Wall, which plunges vertically from 10 to $200 \mathrm{~m}$ (Stoddart, 1980b).

Noteworthy Fauna and Flora No information.

Scientific Importance and Research No information.

Economic Value and Social Benefits The Cayman Wall in Bloody Bay is a popular dive site (Stoddart, 1980b).

Disturbance or Deficiencies In the late 1970 s proposals were put forward for a tanker transhipment facilities with shore installations at Salt Rocks and for docking facilities along the Bloody Bay drop-off (Stoddart, 1980b); however, nothing has come of these plans.

Legal Protection Declared a Marine Park in May 1986; previously recommended for protection by Potts (1975).

Management None.

Recommendations Information not yet available.

\section{CAYMAN DIVE LODGE AND RADIO MAST TO SAND BLUFF REPLENISHMENT ZONES}

Geographical Location Grand Cayman, east coast; the second Replenishment Zone extends from Radio Cayman's transmitter mast $1 \mathrm{~km}$ south to Goring Bluff Lighthouse and extends out to the reefs from South Channel to East End Channel.

Physical Features The lagoon in this area is bordered to seaward by a fringing reef and along the mainland by sand, ironshore and a small mangrove fringe. The waters are characteristically clear, there being a large influx of oceanic water over the reef and a corresponding loss of water through the two reef channels (Raymont et al., 1976a). Strong tidal currents and rough waters characterize the area (Raymont et al., 1976b).

Reef Structure and Corals The lagoon is perhaps the most varied on the island. There is a deep reef moat, extensive coral formations and a broad rubble reef crest (Raymont et al., 1976b). Zonation is similar to that described in the introduction. The pharmaceutically important gorgonian Plexaura homomalla has a patchy distribution on the back-reef. The reef crest is composed of coral rubble and other debris, with living Acropora palmata on the seaward edge in the breaker zone. The buttress zone is well developed with caves and deep gulleys (Raymont et al., 1976a; Roberts, 1974). In deeper parts, massive colonies of Montastraea annularis, up to $4 \mathrm{~m}$ high, are found.

Noteworthy Fauna and Flora The marine flora and fauna are described in Raymont et al. (1976a). There is a dense stand of Thalassia and Syringodium. Conch and lobster are present and were surveyed by Rae and Stevens (1976). The community structure is similar to that found in the northern half of North Sound.

Scientific Importance and Research No information.

Economic Value and Social Benefits The area is a popular dive site, the Cayman Dive Lodge being located at East End.

Disturbance or Deficiencies The area is relatively undisturbed due to its distance from the major development areas on the west coast (Raymont et al., 1976b). The entrance through the reef for small boats has recently been enlarged by the Government (Davies in litt., 10.9.84).

Legal Protection Both Replenishment Zones were declared in March 1986.

Management Information not available at present.

Recommendations None known.
MARY'S BAY TO EAST POINT REPLENISHMENT
ZONE

Geographical Location Eastern end of Little Cayman.

Physical Features The Bluff Limestone is a weathered 
and dissected rock outcrop in the littoral region with a storm beach of coral rubble behind the ironshore. The site is very exposed to south-east winds. Shore zonation is described in Potts (1980).

Reef Structure and Corals Well developed coral reefs (Stoddart, 1980b).

Noteworthy Fauna and Flora Once the main nesting area of the Green Turtle Chelonia mydas (Stoddart, 1980b).

Scientific Importance and Research No information.

Economic Value and Social Benefits No information.

Disturbance or Deficiencies No information.

Legal Protection Declared a Replenishment Zone in May 1986; previously recommended for protection by Potts (1975).

Management Information not yet available.

Recommendations None known.

NORTH SOUND REPLENISHMENT ZONE, LITTLE SOUND ENVIRONMENTAL ZONE, BOWSE BLUFF TO RUM POINT MARINE PARK AND HEAD OF BARKERS TO FLATS REPLENISHMENT ZONE

Geographical Location Grand Cayman, north coast, including the eastern outer reefs of North Sound.

Area, Depth, Altitude North and Little Sound cover an area of $80 \mathrm{sq} . \mathrm{km}$ (10 km diameter), with a perimeter of $45 \mathrm{~km}$ perimeter; depths rarely exceed $1.5 \mathrm{~m}$.

Physical Features North Sound and the adjacent Little Sound form the largest lagoon in the Cayman Islands, occupying about half of the northern side of Grand Cayman. The lagoon is a large dish-shaped embayment confined by a fringing reef to the north and surrounded by mangrove areas to the south, east and west. There are several islands of which the most prominent is Booby Cay on the south shore (Darbyshire et al., 1976, Roberts, 1971a). The fringing reef, $10.5 \mathrm{~km}$ long, runs south-east to north-west and consists of a submarine ridge intermittently broken by channels.

Oceanographic aspects are described in Darbyshire et al. (1976). The lagoon has a restricted water circulation and the deep fine muds associated with such calm environments. North Sound has a complex water transport system. Currents in the reef area are strong and flow in an east-west direction, with a strong flow in at Rum Point and out through the main channel. The remainder of the Sound has slow currents mainly driven by wind and waves. A further small channel is situated at Barker's Point. The prevailing easterly winds cause the eastern areas of the lagoon to be sheltered for most of the year whilst the west and south-western borders are subject to wind and wave action (Raymont et al., 1976b). Visibility in this area is good (Giglioli, 1976). Studies on carbonate sedimentation in the lagoon have been conducted by Roberts (1971b). An additional description of the area is given in Roberts (1977).

Reef Structure and Corals North Sound Reef is considered to be the best fringing reef on Grand Cayman (Roberts, 1971a). There are extensive and well-developed typical back-reef coral formations (see "Introduction"), described in detail in Raymont et al. (1976b). Roberts (1971a) describes a rubble flat sloping shoreward from the reef crest, formed almost exclusively of boulder- or cobble-sized pieces of Acropora palmata, extensively bored and encrusted by marine organisms. At the shoreward limit of the rubble flat, a channel-like depression, $2-4.5 \mathrm{~m}$ deep and of variable width, parallels the reef trend. No corals are found in the deeper sediments of the lagoon, but where bedrock shows through or where sediments are more consolidated as along the southern and western fringe, turbidity tolerant corals (Porites divaricata, $P$. asteroides, Siderastrea radians and Favia fragum) are found. Other corals include Isophyllia and Diploria and there are large stands of Plexaura homomalla.

The flat reef crest has flourishing coral growth and $A$ palmata is dominant. In deeper waters massive colonies of Montastraea annularis up to $4 \mathrm{~m}$ in height are found. The buttress zone consists of a gentle scarp with no pronounced coral development. The lower fore-reef terrace has a large number of spurs running the length of the zone with relatively little sediment between them. The lower buttress zone is moderately well developed and is typical of Caymanian reefs (Raymont et al., 1976a). A detailed description of the different organic communities of North Sound and the associated fore-reef shelf is given by Roberts (1977).

Noteworthy Fauna and Flora The Red Mangrove Rhizophora mangle borders much of North Sound, except the north-west and extreme north-east margins, and the whole perimeter of Little Sound (Giglioli, 1976; Roberts, 1977). Avicennia nitida, the Black Mangrove and Laguncularia sp., the White Mangrove, are found inland with the Red Mangrove, sometimes in pure stands but mostly mixed. $60 \%$ of the Sound is covered by a sea grass bed with lush growth of Thalassia testudinum (Roberts, 1977). Bradley (1986) describes the mangrove swamps and their avifauna on Booby Cay and on the east side of North Sound. Details of other marine flora are given in Raymont et al. (1976b).

The faunal communities of the Sound are described in detail in Raymont et al. (1976a). Tritons Trumpet Charonia variegata, King Helmet Cassis ruberosa and Queen Conch Strombus gigas are found in the back-reef zone but are rare. Rays are common. Conch and Spiny Lobster Panulirus argus were surveyed in North Sound by Rae and Stevens (1976). Both are found in the vicinity of Suckerfish Hole in the central lagoon. Hawksbills Eretmochelys imbricata and Green Turtles Chelonia mydas graze in the Thalassia beds in North Sound (Raymont et al., 1976a; Bacon et al., 1984).

Scientific Importance and Research North Sound is the main route through which drainage of Grand Cayman occurs. The Sound was the main study site for the Cayman Islands Natural Resources Study, which included experimental work to investigate the potential for planting algae and seagrasses in barren areas and the effects of grazing by $S$. gigas and the sea 
urchin Lytechinus variegatus (Raymont et al., 1976a). The area has been extensively studied, most publications dealing with the lagoon rather than the reef. Detailed descriptions are given in Roberts (1971a, 1971b and 1977).

Economic Value and Social Benefits The reefs, particularly the North Wall on the seaward side, are very popular on account of their suitability for shallow diving and snorkelling. They can be reached under most weather conditions, and are readily accessible to boats from West Bay, several marinas, Botabano and Rum Point (Raymont et al., 1976a). It is recommended that greater use of this area be made for diving and yachting activities (Wickstead, 1976). The Sound is an important nursery area for many commercial marine species (Giglioli, 1976).

Disturbance or Deficiencies The area is threatened by real estate development, marl and sand extraction and the extension of leisure activities (Raymont et al., 1976b). In the past most of the marl-fill used in major construction projects on Grand Cayman came from the southern and western shores of North Sound which were studied in the course of the Natural Resources Survey. However, no obvious lasting damage to the sediment community was observed. The greatest problem has been increased turbidity associated with swamp reclamation and mangrove drainage (Raymont et al., 1976a). In the early 1970 s, there were already seven real estate developments around North Sound with associated channels, access channels and borrow pits. Marl is now taken from the mangrove areas with draglines rather than dredges (Davies in litt., 10.9.84). If current development proposals are carried out, most of the mangrove habitat along the southern, western and north-western portions of North Sound will be lost within the next few years (Smith in litt., 6.6.86).

Legal Protection In March 1986, the coastline and water covering an area of about 5.5 sq. mi. in Little Sound, including Booby Cay and Duck Pond Bight, was declared an Environmental Zone; hunting and fishing are banned and boat traffic is restricted to protect the heron colony in Booby Cay. The area from Bowse Bluff on the north side to Rum Point was declared a Marine Park Zone. The area from Head of Barkers to Flats and a large area on the eastern side of North Sound were declared Replenishment Zones.

Management Information not yet available.

Recommendations Raymont et al. (1976a and b) recommended that sand extraction be limited to an area to the south of the reef where it would have only a minimal effect for a brief period of time and little effect on the reef. Recommendations for dredging management were given in Raymont et al. (1976b) and Darbyshire et al. (1976). In the 1970s, an artificial reef was established in North Sound to improve fish production in the area. Although initial results looked promising and recommendations for the continuation of the project were given in Raymont et al. (1976b), this was abandoned.

\section{SOUTH SOUND REPLENISHMENT ZONE}

Geographical Location South-west coast of Grand Cayman; the Replenishment Zone covers the area from the wreck of the Pallas east to Prospect Point, including the waters of South Sound.

Area, Depth, Altitude South Sound has an area of $7 \mathrm{sq} . \mathrm{km}$ and a depth of $3 \mathrm{~m}$.

Physical Features South Sound is a shallow lagoon with fringing reef on the southern edge and sandy beaches to the north and east. Sand Cay marks the western extremity of the reef (Darbyshire et al., 1976). At the western end of the Sound, there is a large channel through which a strong westerly current flows for most of the year (Raymont et al., 1976a); strong currents may occur on both sides of the reef (Raymont ef al., 1976b).

Reef Structure and Corals South Sound is bordered by fringing reef to the south. A large sand plain is found in the east of the Sound, to the west of which patch reefs and coral heads become common. The western part supports a large, varied and thriving gorgonian and stony coral assemblage. Typical back-reef development is present, with large colonies of Montastraea annularis and Acropora palmata predominant and considerable stands of Plexaura homomalla (Raymont et al., 1976a). The deep reef is one of the most impressive to be found on Grand Cayman and supports a large and varied fish population (Raymont et al., 1976b).

Noteworthy Fauna and Flora The marine flora and fauna of the Sound is described by Raymont et al. (1976a). There are substantial Thalassia beds towards the landward perimeter. At the eastern end, a large sand plain is populated by conch, rays and of ten large schools of jacks (Carangidae). Strombus gigas and lobster were fairly common in the early 1970 s despite regular fishing but are now rare (Davies in litt., 10.9.84). The mangrove swamp in South Sound and its avifauna are described in Bradley (1986).

\section{Scientific Importance and Research Not known.}

Economic Value and Social Benefits South Sound is well developed with residential accommodation on the northern edge (Darbyshire et al., 1976). It has been recommended that greater use of this area be made for diving and recreation. The area is close to the main tourist developments, the back-reef is readily accessible from the shore making it suitable for diving and snorkelling, although currents are too strong for the average swimmer, and the wreck of the Pallas lies in the south corner close to the reef. The deep reef is not always accessible due to weather conditions (Raymont et al., 1976b). Conch and lobster used to be fished in the Sound (Raymont et al., 1976a) but are rarely caught now. The entrance through the reef has been enlarged to improve the area as a harbour for small boats as it is one of the main shelters in north-westerly storms.

Disturbance or Deficiencies Threats to the reefs are not known. The area of mangroves in South Sound is under serious threat from proposals in the Cayman Island Development Plan for light industry and housing in this area; the entire swamp is likely to be filled in three to four years (Bradley, 1986). 
Legal Protection In March 1986, the area from the wreck of the Pallas east to Prospect Point, including the waters of South Sound was declared a Replenishment Zone.

Management Information not yet available.

Recommendations None known.

\section{SPOTTER BAY TO ANCHORS POINT REPLENISHMENT ZONE}

Geographical Location Grand Cayman; eastern end of north coast, off Great Bluff.

Physical Features Great Beach and Great Bluff above it form the shoreline between Spotter Bay and Anchors Point. There are sandy and cobble beaches with intermittent limestone cliffs of $7 \mathrm{~m}$ (Raymont et al., 1976a). The Bluff is wild and unspoilt (Raymont et al., 1976b).

Reef Structure and Corals The deep reef is well formed and the reef crest and back reef are fairly typical examples of Caymanian reef structures (Raymont et al., 1976b). The back-reef area is well represented by coralline algae, and Peysonniella forms reefs of several metres diameter (Raymont et al., 1976a).

Noteworthy Fauna and Flora The marine flora and fauna is described in Raymont et al. (1976a). Shallow waters along the shore have thick and often mixed stands of Thalassia and Syringodium. The coralline algae back-reef provides good habitat for lobster, grouper, snapper and other fish. The cliff supports a varied marine life including young lobster (Raymont et al., 1976b).

Scientific Importance and Research No information.

Economic Value and Social Benefits Access has been facilitated by the construction of a good unsurfaced road (Davies in litt., 10.9.84).

Disturbance or Deficiencies No development has taken place in the area yet. The deep reef used to have abundant black corals but these are no longer present (Smith in litt., 6.6.86).

Legal Protection Declared a Replenishment Zone in March 1986.

Management Information not yet available.

Recommendations None known.
WEST BAY MARINE PARKS AND REPLENISHMENT ZONE

Geographical Location West coast of Grand Cayman, from just north of Soto's Dock to south of Jackson Point, including Eden Rocks.

Physical Features Seven Mile Beach fronts the coast. There is no fringing reef but shallow fore-reef terraces are found at $10 \mathrm{~m}$ and a deeper one at $30 \mathrm{~m}$, which in places have well developed coral formations (Raymont et al., 1976b). Eden Rocks are situated off the ironshore coast of this area.

Reef Structure and Corals Zonation is similar to that described in the introduction. Despite the relatively low wave energy in West Bay, large buttresses of coral are found at the seaward edge of the shallow fore-reef terrace. These were studied at Soto's Dock to the north of George Town (Logan, 1981) and those at Eden Rocks are considered to be similar. Adjacent spurs often merge laterally with one another, either by roofing over of the groove with peripheral plate-like coral growth or by collapse and subsequent wedging of spur blocks in the groove. Reef tunnels so formed may be up to $25 \mathrm{~m}$ long, $5 \mathrm{~m}$ high and $5 \mathrm{~m}$ wide. A wide variety of tunnels exist, some open at both ends, others terminating in cul-de-sac reef galleries, each with varying degrees or roofing. Sessile invertebrate coelobitic communities attached to the walls and roofs are described by Logan (1981). Three main communities are recognised: a) an encrusting coralline algae community near the tunnel entrance; b) a demosponge-bryozoan community further in the tunnel, and c) a sclerosponge-brachiopod community in more deeply recessed parts or at the closed end where light is reduced.

Noteworthy Fauna and Flora Garden eels are found on the adjacent sand plain (Raymont et al., 1976a).

\section{Scientific Importance and Research No information.}

Economic Value and Social Benefits This is one of the main recreational areas on Grand Cayman and there are numerous hotels along the coast. Eden Rocks is one of the most popular diving sites on the island due to its sheltered position, proximity to the major tourist centres and harbour where cruise ships anchor, and presence of well developed, varied reef formations. There are two interesting shipwrecks to the north (Raymont et al., 1976a).

Disturbance or Deficiencies Eden Rocks are potentially threatened by their proximity to the enlarged harbour and urban centre. Excessive pressure by divers could also cause problems (Raymont et al., 1976a). Anchor damage is already a threat and there is evidence that the percentage of live coral is declining even where not damaged by anchors (Davies in litt., 10.9.84). Exploitation of sand in this area could result in decreased water clarity and should be discouraged (Raymont et al., 1976a). 
Legal Protection The whole of West Bay has been included under the 1986 Marine Parks legislation. A Marine Park Zone extends from North West Point to West Bay Cemetry, and a second one from Victoria House to Sand Cay Apartments at the southern end of the bay. A Replenishment Zone has been designated between West Bay Cemetery and Victoria House.
Management Information not yet available.

Recommendations There are plans to construct permanent anchorage sites for cruise ships so that they will not use their own anchors (Davies in litt., 10.9.84). 



\section{INTRODUCTION}

The mainland of Chile lies well outside the zone of coral reef development but Easter Island, $3568 \mathrm{~km}$ west of Chile in the Pacific, has significant coral communities. These are described in the following account.

The Corporación Nacional Forestal (CONAF) is responsible for national parks (Oltremari and Fahrenkrog, 1979). There are as yet no marine parks in Chile and the appropriate legislation is lacking. The need for marine protected areas and suggestions for their location are described in Castilla (1977). Most of this paper concerns the temperate regions of the country but there is a recommendation that the parks on Easter Island and Juan Fernández should be extended to include the marine environment. More recently, two marine reserves have been proposed for Easter Island (see separate account).

\section{References}

Abbott, I.A. and Santelices, B. (1985). The marine algae of Easter Island. Proc. Sth Int. Coral Reef Congr. Tahiti, 5:71-75.

Castilla, J.C. (1977). Marine National Parks in Chile: need for their establishment, probable locations and basic criteria. Collected Abstracts and Papers of the International Conference on Marine Parks and Reserves, Tokyo, Japan, 12-14 May, 1975. Bull. Marine Park Research Stations 1(2): 152-159.

Cea, A. and Di Salvo, L. (1982). Mass expulsion of zooxanthellae by Easter Island corals. Pacific Science 36: 61-63.

Corporación Nacional Forestal (1976). Plan de Manejo Parque Nacional Rapa Nui. Documento Técnico de Trabajo 20, FAO, Santiago.

Di Salvo, L.H. (1985). Ecological observations on the Easter Island sublittoral. Proc. Sth Int. Coral Reef Congr. Tahiti, 2: 106.

Etienne, M., Michea, G. and Diaz, E. (1982). Flora, vegetación y potencial pastoral de Isla de Pascua. Boletín Técnico 47. Universidad de Chile, Facultad de Ciencias Agrarias, Veterinarias y Forestales, Santiago.

Fell, F.J. (1974). The echinoids of Easter Island. Pacific Science 28: 147-158.

Garth, J. (1973). The Brachyuran crabs of Easter Island. Proc. Cal. Acad. Sci. Series 4, 39: 311-336.

Kohn, A. and Lloyd, M. (1973). Marine polychaete annelids of Easter Island. Int. Rev. Ges. Hid. und Hyd. 58: $661-672$.

Holthuis, L.B. (1972). The Crustacea Macrura of Easter I. Zool. Med., Rijksmuseum v Nat. Hist. Leiden 46: 29-54. Oltremari, J.V. and Fahrenkrog, E. (1979).

Institutionalization of National Parks in Chile. Parks 3(4): $1-4$.

Randall, J.E. (1970). Easter Island: an ichthyological expedition. Oceans 3: 48-59.

Randall, J.E. (1976). The endemic shorefishes of the Hawaiian Islands, Lord Howe Island and Easter Island. Travaux et Documents de l'O.RS.T.O.M. 47: 49-73.

Randall, J.E. and Cea Egañna, A. (1984). Native names of Easter Island fishes, with comments on the origin of the Rapanui people. Occ. Pap. Bernice Pauahi Bishop Museum 25(12): $16 \mathrm{pp}$.

Rehder, H.A. (1980). The marine mollusks of Easter Island and Sala y Gomez. Smithsonian Contrib. to Zoology 289.

Wells, J.W. (1972). Notes on Indo-Pacific Scleractinian corals, Part B. Scleractinian corals from Easter Island. Pacific Science 26: 184-190.

\section{EASTER ISLAND (RAPA-NUI)}

Geographical Location $27^{\circ} 10^{\prime} \mathrm{S}, 109^{\circ} 20^{\prime} \mathrm{W} ; 2230$ miles $(3568 \mathrm{~km})$ west of Chile; 1250 miles $(2011 \mathrm{~km})$ east of Ducie Atoll (Pitcairn Islands); the island of Sala y Gomez lies 250 miles $(402 \mathrm{~km})$ to the north-north-east.

Area, Depth, Altitude 106 sq. miles (274 sq. km); maximum altitude $500 \mathrm{~m}$; surrounded by deep ocean.

Land Tenure Partly privately owned by island families; partly owned by Chilean Government.

Physical Features The island is roughly triangular in shape, with a large volcanic cone at each apex. Steep cliffs occur at the apexes and eroded volcanic cones dot the island. A low rocky scarp borders the sea all around the island and there are three small beaches on the north shore only. Waves arrive from various directions all year, with least swell in summer. South-east trade winds dominate from October to April, and winds are mixed from March through September. Rainfall is about $1250 \mathrm{~mm}$ a year, with a rainy season in winter. There are no permanent freshwater streams. Yearly water temperatures range from a winter low of $19^{\circ} \mathrm{C}$ to a summer high of $24^{\circ} \mathrm{C}$; the water is unstratified to $30 \mathrm{~m}$. The underwater visibility is normally $20 \mathrm{~m}$ except after rains, and, in unusually good periods, may reach $50-60 \mathrm{~m}$.

Reef Structure and Corals There are no true reefs but three main species of hermatypic coral occur in profusion in certain areas and altogether there are probably 12 species, although most are rare in occurrence (Cea and Di Salvo, 1982; Di Salvo, 1985; Wells, 1972). Over most of the area accessible by SCUBA diving, Porites lobata, Pocillopora damicornis, and $P$. danae are seen scattered over the volcanic substrate with no obvious pattern of zonation. Coral coverage down to $60 \mathrm{~m}$ depth varies from very few per cent over most of the island to $80-100 \%$ in a few highly favourable areas with moderate depth and wave action. In shallow water there are algal turfs with the endemic Sargassum skottsbergi and Porolithonlike algae. At greater depth there is a mixed algal flora, often with pastures of Zonarialike algae and abundant Halimeda spp. Large expanses of the sea bottom are denuded by the grazing activities of Diadema savigny and Tripneustes spp. Other invertebrates include Holothuroidea, Porifera and various small and cryptic species.

Noteworthy Fauna and Flora . The marine fauna appears to be depauperate and highly endemic with 


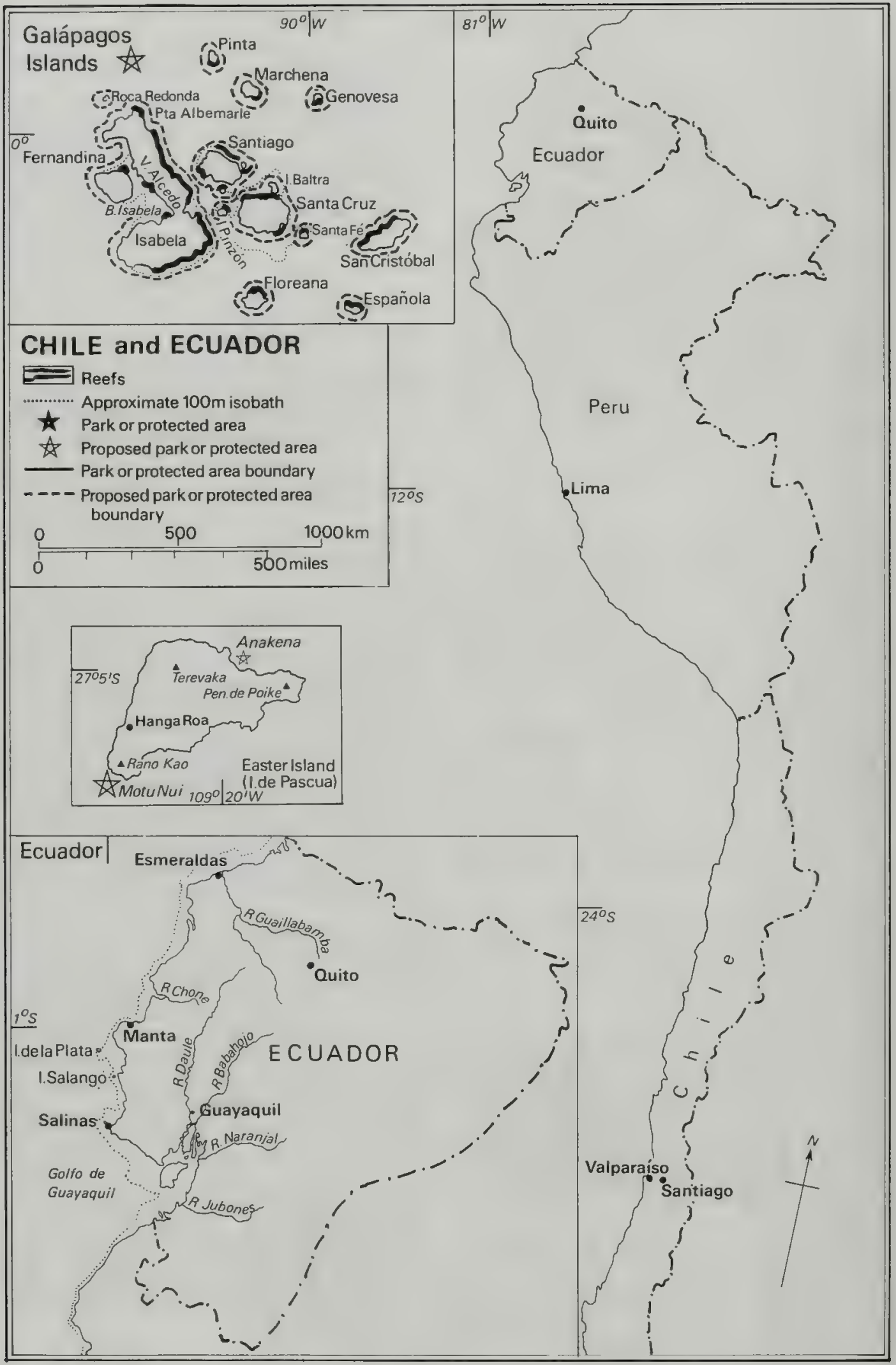


non-endemics of broad Indo-Pacific distribution. There are three species of lobster, of which Scyllarides roggeveeni and Parribacus perlatus have become uncommon apparently because of collection for food; Panulines pascuensis is still heavily fished. Crustaceans are described by Garth (1973) and Holthuis (1972) and molluscs by Rehder (1980). Three species of cowries occur, two of which are heavily collected for the shell trade, including the endemic Cypraea englerti and C. caputdraconis. A colourful and highly endemic fish fauna exists, 155 species having been described (Randall, 1970 and 1976; Randall and Cea Egaña, 1984). Discounting pelagic fish, $27.4 \%$ are endemic. There are few large predatory fish and encounters with sharks are rare. The marine algae are described by Abbott and Santelices (1985). Echinoids are described by Fell (1974) and polychaetes by Kohn and Lloyd (1973). The vegetation and flora of the island are described by Etienne et al. (1982). There are 13 species of seabird, and three species of marine turtle occasionally visit the island.

Scientific Importance and Research The unusual archeological remains on land have tended to draw interest away from marine research, and there have been only a few brief studies. However, Easter Island, with the small rocky satellite of Sala y Gomez, is the most isolated island in the Pacific Ocean, and is thus of great importance in the study of biogeographic dispersal and colonization by marine organisms. The fact that a great number of reef species live there, despite the lack of true reefs, makes it an interesting natural laboratory for the study of reef formation.

Economic Value and Social Benefits Tourism is very important on land on account of the rich cultural resources. To date, visitors have made little use of the marine environment; a dive facility has been installed, but diving is difficult and expensive. Islanders sell corals to dealers on the Chilean mainland and to tourists. Cowries are collected for shell jewellery. Lobsters are speared and trapped for sale in tourist restaurants. Pelagic fish resources are more valuable than those inshore and tuna fishing is a main source of income, but the endemic reef fish fauna is still heavily exploited by islanders.

Disturbance or Deficiencies Coral and shell collecting may have local effects in the areas suitable as marine parks, but overall do not cause any major conservation problems. A ship-grounding in 1983 caused a large oil spill all around the island which, according to the islanders, caused major changes to the algal flora. Some parts of the island are eroding rapidly due to the cutting of native forests and uncontrolled fires. This, combined with coastal construction projects, may lead to siltation of the nearshore environment. There are plans to extend and widen the existing runway for the NASA space shuttle but it is not known what impact this would have on the marine environment.

Legal Protection Lobsters are protected but the legislation is not enforced. The island in soto was designated as a national park in 1935, primarily for its archeological interest, and the park area does not extend below sea level.

Management The Corporación Nacional Forestal (CONAF) is responsible for the island and a management plan has been drawn up for the National Park (Corporación Nacional Forestal, 1976) but this does not extend to the marine environment. Islanders do not recognise the Chilean Government's authority to declare their lands a national park and respect few of its rules. Park Rangers protect and patrol land-based archeological sites. There is a museum but this is dedicated totally to archeological-anthropological materials and there is no interpretive material on the marine environment.

Recommendations Since Chile has as yet no marine parks, a new set of legislation is required. Two sites are appropriate for designation as marine protected areas on Easter Island. Anakena, on the north shore, would be suitable for a reserve designed primarily for tourism and recreation, perhaps along the lines of Hanauma Bay in Hawaii. There is easy access, a good beach and coral and fish viewing facilities could be established. Motu Nui/Iti, off the south-west point, is comparatively inaccessible but has a high diversity and abundance of corals and would make a very good scientific reserve. A marine-oriented wing of the existing museum should be established, in conjunction with an interpretive centre including a public aquarium of moderate size and a small laboratory for visiting scientists.

We are very grateful to Dr L.H. Di Salvo and Dr A. Cea Egaña for compiling this account. 



\section{INTRODUCTION}

\section{General Description}

The Pacific and Caribbean coastlines of Colombia are dominated by the estuaries of major river systems and conditions in many areas are suboptimal for coral growth. Nevertheless, on the offshore islands and in areas away from the influence of freshwater and siltation, there is extensive coral growth. The following is a summary of Prahl (in press), who describes the reefs in terms of seven reef zones, and Werding and Koster (1977) who briefly describe the reefs of the Caribbean coast. Prahl (in press) provides a checklist of corals recorded in Colombia.

On the Caribbean coast, coral diversity generally diminishes from west to east, due to the influence of rivers and the characteristics of the surrounding water. The most westerly reef zone is Uraba, where reefs are found at Zapzurro and Capurgana (north of Acandi). These are the least well-known reefs in Colombia but have been described by Werding and Manjarrés (1978). Banks of coral are found off Acandi but these are limited by sediment and freshwater discharge from the Rio Atrato. Submerged fossil reefs support small coral communities with Acropora palmata, Agaricia tenuifolia and some Mille pora squarrosa.

The Cartagena zone has the most extensive continental shelf reefs, extending from the island of Tierra Bomba, off Cartagena, $\left(10^{\circ} 23^{\prime}-10^{\circ} 20^{\prime} \mathrm{N}, 75^{\circ} 35^{\prime} \mathrm{W}\right)$ and Barú to Isla Fuerte $\left(9^{\circ} 23^{\prime} \mathrm{N}, 76^{\circ} 13^{\prime} \mathrm{W}\right)$. The reefs at Tierra Bomba are not well developed and have been described by Ramirez and De la Pava (1981). Off Boca Chica on Tierra Bomba there is a small, poorly developed fringing reef where Dendrogyra cylindris has been recorded; this is apparently the only specimen of this regionally restricted species to have been found on the mainland shore of Central or South America (Geister in litt., 25.11.84). Reefs off Punta Barú and Islas del Rosario are described by Pfaff (1969), Werding (1979) and Werding and Sánchez (1979). The Islas del Rosario group is described in a separate account. Reefs in the San Bernardo Archipelago are described by Prahl et al. (1977) and Erhardt and Meinel (1975), who recorded 42 scleractinians from Isla Ceycen. Those off Isla Fuerte are described by Prahl and Erhardt (1985).

The Santa Marta zone is influenced by sediments and discharge from Río Magdalena and Ciénaga Grande. Local upwellings and low temperatures may prevent the formation of well developed reefs (Márquez, 1982). The reefs around Santa Marta and in the Parque Nacional Tayrona are described in separate accounts.

The most eastern mainland reefs are at Bahía Portete and Puerto Lopez $\left(11^{\circ} 55^{\prime} \mathrm{S}, 71^{\circ} 17^{\prime} \mathrm{W}\right)$ in the Guajira Peninsula zone. These are exposed to river discharge and sediment run-off, siltation of nearshore waters (a natural, rather than human-induced characteristic) being a common phenomenon along the Guajira coast. At Portete there is a Pleistocene raised barrier reef. The bay itself, which is an important wetland site (Scott and Carbonell, 1986), has few corals apart from species adapted to turbid conditions (Prahl, in press). Puerto Lopez has a fringing reef easily accessible from shore which was visited by Geister (in litt, 25.11.84) in 1979. Despite the dry season, the water was turbid and the reef crest was only visible as a line of surf generated by the constant trade winds blowing across the Golfo de Venezuela. An impoverished scleractinian fauna was found consisting almost entirely of hardy species of Porites astreoides and Diploria clivosa. The breaker zone was colonized by low semi-encrusting colonies of Acropora palmata, indicating a reef of the strigosa-palmata type as defined by Geister (1977). Siltation stress appears to be a frequent if not permanent condition and may worsen during the rainy season. An ahermatypic deep water coral from the Guajira Peninsula is described by Erhardt (1976).

The San Andrés zone includes the offshore islands of San Andrés and Providencia and the four atoll-type structures (Roncador, Serrana, E.S.E. (Courtown)and Albuquerque) (see separate accounts). This part of the western Caribbean is characterized by stable thermal conditions (water temperatures $27-28^{\circ} \mathrm{C}$ ), free from the effects of continental terrigenous run-off. The reefs are exposed to high energy waves and trade winds. There is little information on the current status of the four atolls. They vary in size and configuration but have similar reef zonations to other Caribbean reefs and are reported to have a luxuriance reminiscent of Indo-Pacific reefs, but lacking the massive red algal encrustations of reef flats found in this area. Less than ten species contribute more than $95 \%$ of the reef corals, but this is balanced by the fact that several of the major species show different growth forms. A general description of all four atolls is given in Milliman (1969). Other atolls with bank reefs are Banco Serranilla, Bajo Nuevo and Banco Quita Sueño (Milliman, 1973).

The northern Pacific coast of Colombia, from the mouth of the Rio San Juan, is virtually inaccessible and is still little known but is considered to be one of the most interesting areas of the country, meriting further study (Anon, undated). Coral assemblages are found in the Utria region from Cabo Corrientes north to the Panamanian border. Important reef formations are found at Ensenada de Utría (see separate account) and at Caleta Tebada, opposite the beaches of Chicora in the extreme south of the Gulf of Cupica. Coral assemblages, but not reefs, are found at Bahía Cuevita, Bahía Octavia, Bahía Solano (to the Point of San Francisco), Bahia Limón and Punta Arditas. The coast in this area is dominated by the Cordillera del Baudo mountain range and consequently there is considerable freshwater and terrestrial sediment discharge from the rivers. Prahl (in press) distinguishes two further zones around the islands of Malpelo and Gorgona which are described in separate accounts.

Important wetland localities are described in Scott and Carbonell (1986). There is a severely depleted population of the American Crocodile Crocodylus acutus along the Caribbean mainland coast where the Caribbean Manatee Trichechus manatus is also found. The Loggerhead Caretta caretta has scattered nesting sites along the Caribbean coast and on offshore cays. The 


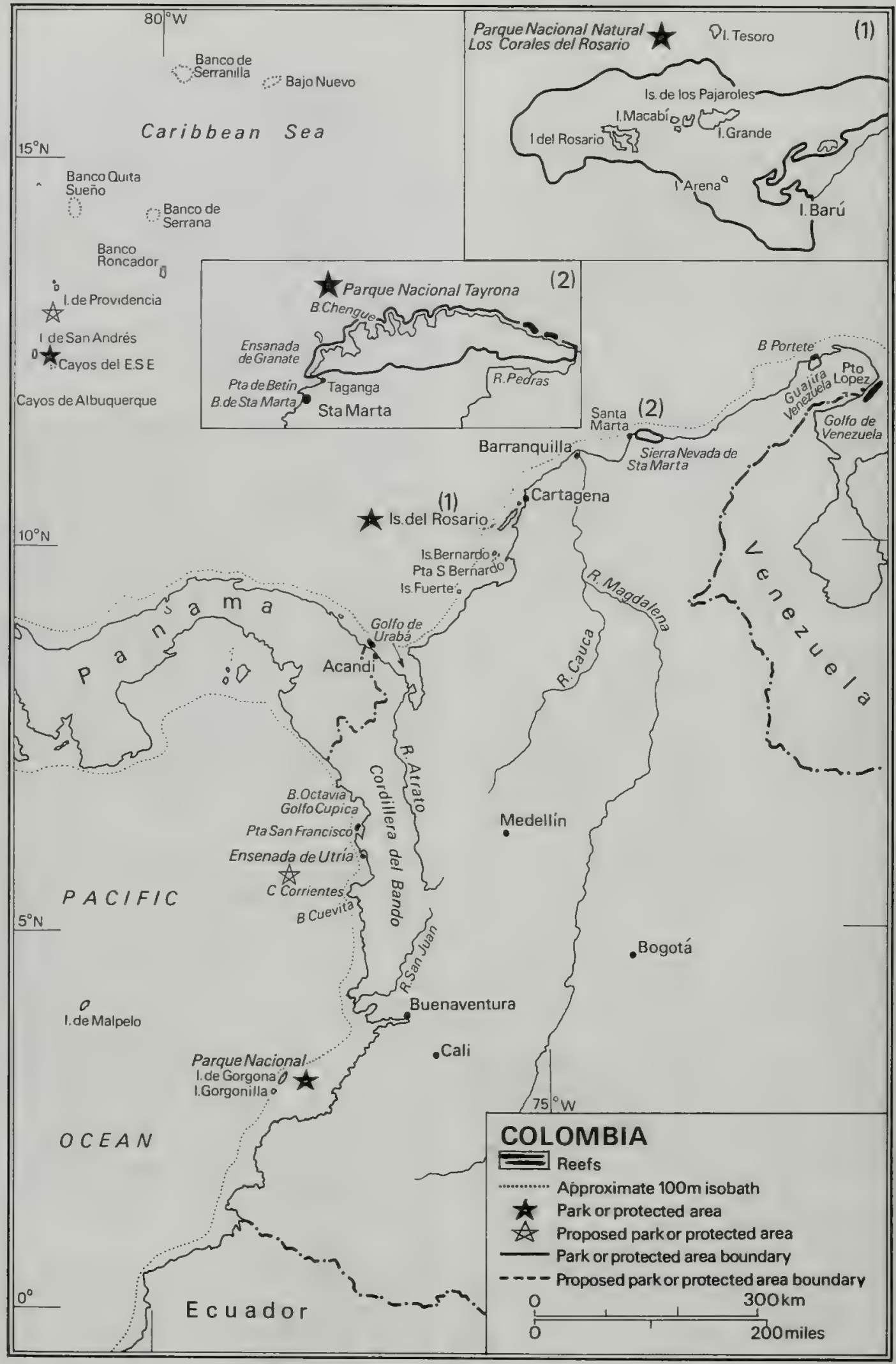


Green Turtle Chelonia mydas has been reported from the Pacific coast and nests on the Caribbean coast between Cartagena and Santa Marta and occasionally among the Islas del Rosario. The Hawksbill Turtle Eretmochelys imbricata nests on the mainland and in the Islas del Rosario. The Leatherback Dermochelys coriacea nests in the Gulf of Uraba and near Santa Marta (Carr et al., 1982; Bacon et al., 1984). Halewyn and Norton (1984) describe the status of seabirds nesting on the Caribbean coast and islands of Colombia.

Coral reef research is carried out at INVEMAR, the Instituto de Investigaciones Marinas de Punta de Betín at Santa Marta (see separate account), at the Facultad de Ciencias Marinas of the Universidad de Bogotá Jorge Tadeo Lozano and at the Centro de Investigaciones Pesqueras (Fishery Investigations Centre) of INDERENA at Cartagena. Prahl (in press) provides a brief history of reef research and Scott and Carbonell (1986) summarise research activities relating to wetlands, some of which may have a bearing on coral reefs. The four atolls were visited in 1966 by the Caribbean Reef and Atoll Program from the Institute of Marine Sciences, University of Miami. San Andrés and Providencia islands were visited by a number of expeditions early in the century and Providencia has recently been the subject of a major study by INVEMAR (see separate accounts). Further details on coral reef research are given in the following accounts.

\section{Reef Resources}

Reefs off the Caribbean coast are undoubtediy important for fisheries and tourism, but no general information has been obtained. Popular tourist sites include the Archipiélago del Rosario, the Santa Marta area, and the San Andrés and Providencia islands. Details for particular sites are given in the following accounts. All of the offshore islands, particularly the atoll type structures in the Caribbean, have extremely important fishery resources, especially spiny lobster Panulinus argus (Milliman, 1973). Information on the economic value of the Pacific reefs is not available.

\section{Disturbances and Deficiencies}

Bleaching and coral mortality, assumed to be associated with the 1982-1983 El Niño event, has been recorded at Isla de Gorgona on the Pacific coast and Islas San Bernardo in the Caribbean (Glynn, 1984) and smaller scale bleaching has been reported from the Cartagena area (Lessios et al., 1983). Mass mortality of the sea urchin Diadema antillarum was reported from the Santa Marta area in 1983 (Lessios et al., 1984). Human activities are having a noticeable impact in many areas and are described in the following accounts.

\section{Legislation and Management}

Decreto 2811 of 1974, Código de Los Recursos Naturales y de la Protección del Medio Ambiente, protects natural resources but has no particular application to reef resources, although matters relating to fishing and mariculture are covered. There are no specific regulations for the taking of turtles or other reef products, other than those promulgated under the
Ministry of Agriculture National Decree No. 1681 of 1978 which covers management of aquatic resources. There is a minimum size limit of $15 \mathrm{~cm}$ for the taking of spiny lobsters (Mow-Peter in litt., 15.11.84).

The basic principles concerning the establishment of National Parks were fixed in Decreto 20 of 1959. Decreto 2420 of 1968 created the Instituto de Desarollo de los Recursos Naturales Renovables y del Ambiente (INDERENA) and ascribed to it the function of declaring and administering national parks and reserves. National Parks and Reserves of Colombia are described in INDERENA (1984). Some of the most important reef areas fall within the following National Parks:

Parque Nacional Corales del Rosario

Parque Nacional Tayrona

Parque Nacional Natural Isla de Gorgona

\section{Recommendations}

Human activities potentially threaten many reefs, even those lying within National Parks, as outlined by Werding and Köster (1977), Werding and Sánchez (1979) and Prahl (in press). There is considerable need for improved management, particularly for the reefs of San Andrés, Santa Marta and Islas del Rosario. Management plans for coral reefs are reported to be in preparation (Hernández pers. comm. to J. Harrison, 1986). The following areas have been recommended for particular attention:

\section{Ensenada de Utria (proposed National Park)}

Isla de San Andrés (proposed management area)

Isla de Providencia (proposed management area)

Accounts are also given for the following areas which might be worthy of protection or management:

Isla del Malpelo

Bahía de Santa Marta

Four atolls or banks in the Caribbean: Roncador, Serrana, Cayos Albuquerque and Cayos del E.S.E.

\section{References}

\section{"cited but not consulted}

Abele, L.G. (1975). The macruran decapod crustacea of Malpelo Island. In: Graham J. (Ed.) (1975): 69-85.

Acero, A. (1978). Anotaciones ecológicas y sistemáticas sobre los peces de la familia Pomacentridae en el Caribe Colombiano. Mitt. Inst. Colombo-Alemán Invest. Cient. 10: 249-259.

Acero, A. (1979). Comentarios preliminares sobre los clinidos (Teleostei: Perciformes: Clinidae) del Caribe Colombiano. An. Inst. Invest. Mar. Punta de Betin 11: 59-70.

Albrecht, H. (1968). The reef at the doorsteps. Sea Frontiers 14: 300-306.

Albrecht, H. (1969). Behaviour of four species of Atlantic damselfishes from Colombia, South America (Abudefduf saxatilis, A taurus, Chromis multilineata, C. cyanea; Pisces Pomacentridae). Z. Tierpsychol. 26:662-676. 
Alvarez-León, R. and Salzwedel, H. (in press). Contribuciones Científicas del Instituto de Investigaciones Marinas de Punta de Betín "INVEMAR", publicadas entre 1966 y 1982. An. Inst. Invest. Mar. 13.

Anon. (undated). Zona de Utría. (account of reefs in Utría region).

Antonius, A. (1972). Occurrence and distribution of stony corals (Anthozoa and Hydrozoa) in the vicinity of Santa Marta, Colombia. Mitt. Inst. Colombo-Alemán Invest. Cient. 6: 89-103.

Bacon, P.R. (1981). The status of sea turtle stocks management in the Western Central Atlantic. Western Central Atlantic Fishery Commission (WECAFC), Study No. 7.

Bacon, P., Berry, F., Bjorndal, Hirth, H., Ogren, L. and Weber, M. (1984). The National Reports. Proceedings of the Western Atlantic Turle Symposium, Costa Rica. Vol.3: University of Miami Press, Florida.

Bakus, GJ. (1975). Marine zonation and ecology of Cocos Island, off Central America. Atoll Res. Bull. 179.

-Barriga-Bonilla, E., Hernández-Camacho, J., Jaramillo-T., I., Jaramillo-Mejía, R., Mora-Osejo, L.E., Pinto-Escobar, P. and Ruíz-Carranza, P. (1969). La Isla de San Andrés. Contribuciones al conocimiento de su ecología, flora, fauna y pesca. 152 S, Bogotá, Universidad Nacional, Dirección de Divulgación Cultural.

Beese, G. (1974). Results of trapfishery in the Ensenada de Chengue with special reference to Lutjanus synagris and $L$ analis. Divulgación Pesquera - INDERENA 3(5): 4-17.

Birkeland, C., Meyer, D.L.o, Stames, J.P. and Buford, C.L. (1975). Subtidal communities of Malpelo Island. In: Graham, J.B. (Ed.). The biological investigations of Malpelo. Smithsonian Contributions to Zoology 176.

Bock, W.D. and Moore, D.R. (1971). The foraminifera and micromollusks of Hogsty Reef and Serrana Bank and their paleoecological significance. Trans, 5th Caribb. Geol. Conf. Bull. 5, Queens College Press, May 1971: 143-146.

Bond, J. (1950). Results of the Catherwood-Chaplin West Indies Expedition, 1948. Part 2. Birds of Cayo Largo (Cuba), San Andrés and Providencia. Proc. Acad. natur. Sci. Philadel phia 102: 43-68.

Bond, J. and DeSchauensee, R. (1944). Results of the Fifth George Vanderbilt Expedition (1941): The birds. Acad. Nat. Sci. Phila. Monog. 6: 7-56.

Burgl, H. (1961). Contribución a la estratigrafía y litogénesis de la Isla de San Andrés. Bol. geol. 1(1-3): 5-25.

Cantera, J.R. (1983). Distribution des peuplements de Scleractiniaires sur un récif frangeant de l'île de Gorgona (côte pacifique de Colombie). Téthys 11(1): 25-31.

Carr, A., Meylan, A., Mortimer, J., Bjorndal, K. and Carr, T. (1982). Surveys of sea turtle populations and habitats in the Western Atlantic. NOAA Technical Memorandum NMFS-SEFC-91, U.S. Dept of Commerce. Caycedo, I.E. (1977). Fitopláncton de la Bahía de Neguange (Parque Nacional Tayrona) Mar Caribe de Colombia. An. Inst. Inv, Mar. - Punta Betin 9:17-44.

Caycedo, I.E. (1979). Observaciones de los equinodermos en las Islas del Rosario. An. Inst. Inv. Mar. - Punta Betín 11: $39-47$.

Corredor, L., Criales, M.M., Palacio, J., Sánchez, H. and Werding, B. (1979). Decápodos colectados en las Islas del Rosario. An. Inst. Inv. Mar. - Punta Betin 11: 31-34.

Coventry, G.A. (1944). Results of the Fifth George Vanderbilt Expedition (1941): the Crustacea. Acad. Nat. Sci. Phila. Monog. 6: 531-544.
Cuervo, A. (1979). Lista preliminar de las algas de las Islas del Rosario. An. Inst. Inv. Mar. - Punta Betin 11: 21-22.

Downey, M.E. (1975). Asteroidea from Malpelo Island with a description of a new species of the genus Tamaria. In: Graham, J. (Ed.): 86-90.

Duque Goodman, F. (1979). Malacofauna de aguas someras y substrato rocoso en la Bahía de Nenguange. Bol. Mus. Mar., Bogotá 9: 3-27.

Dunn, E.R. and Saxe, L.H. (1950). Results of the Catherwood-Chaplin West Indies Expedition, 1948. Part 5. Amphibians and reptiles of San Andrés and Providencia. Proc. Acad. natur. Sci. Philadelphia 102:141-165.

Erffa, A. von and Geister, J. (1976). Über ein holozånes Korallen-und Mangrovenvorkommen nahe Santa Marta, Kolumbien. Mitt. Inst. Colombo-Alemán Invest. Cient. 8: 165-186.

Erhardt, H. (1974). Liste der scleractinen Korallen der Bahia Concha bei Sta Marta, Atlantikkuste Kolumbien. Senckenbergiana Biologica 55(4-6): 399-407.

Erhardt, H. (1976). La existencia del coral Stephanocyathus nobilis (Moseley, 1881) en la costa de la peninsula Guajira. Una demostración primaria para la costa atlántica de Colombia. Mitt. Inst. Colombo-Alemán Invest. Cient. 8: 59-62.

Erhardt, H. and Meinel, W. (1975). Die scleractinen Korallen der Insel Ceycen, Islas San Bernardo, vor der kolumbianischen Atlantikkuste. Philippia 2(4): 236-247.

Erhardt, H. and Werding, B. (1973). Peces Chaetodontidae en las Bahias Orientales de Santa Marta. Bol. Museo del Mar 5: 8-17.

Erhardt, H. and Werding, B. (1975a). Los corales (Anthozoa e Hidrozoa) de la Ensenada Granate, pequeña bahía al este de Santa Marta, Colombia. Caldasia 11(53): 107-138.

Erhardt, H. and Werding, B. (1975b). Los litocorales de la Bahia de Santa Marta, Colombia. Bol. Museo del Mar. Bogotá 7.

Fowler, H.W. (1944). Results of the Fifth George Vanderbilt Expedition (1944). The fishes. Acad. nat. Sci. Phila. Monog. 6: 69-93.

Fowler, H.W. (1950). Results of the Catherwood-Chaplin West Indies Expedition, 1948. Part 3. The fishes. Proc. Acad. nat. Sci. Phila. 102: 69-93.

Gallego, H.C. (1978). Informe de la Comisión efectuada en San Andrés y Providencia: fauna silvestre. Unpub. rept.

Garzón, J.F. and Acero, A.P. (1983). Notas sobre la pesca y los pesces comerciales de la Isla de Providencia (Colombia), incluyendo nuevos registros para el Caribe occidental. Carib. J. Sci. 19(3-4): 9-19.

Geister, J. (1972). Zur Ökologie und Wuchsform der Säulenkoralle Dendrogyra cylindrus. Ehrenberg Beobachtungen in den Riffen der Insel San Andrés (Karibisches Meer, Kolumbien). Mitt. Inst. Colombo-Alemán Invest. Cient. 6: 77-87.

Geister, J. (1973a). Pleistozäne und rezente Mollusken von San Andrés (Karibisches Meer, Kolumbien) mit Bemerkungen zur geologischen Entwicklung der Insel. Mitt. Inst. Colombo-Alemán Invest, Cient. 7: 229-251.

Geister, J. (1973b). Los arrecifes de la Isla de San Andrés (Mar Caribe, Colombia). Mitt. Inst. Colombo-Alemán Invest. Cient. 7: 211-228.

Geister, J. (1975). Riffbau und geologische Entwicklungsgeschichte der Insel San Andrés (westliches Karibisches Meer, Kolumbien). Stuttgarter Beitr. Naturk. (Ser. B) 15: 203 pp. 
Geister, J. (1977). The influence of wave exposure on the ecological zonation of Caribbean coral reefs. Proc. 3rd Coral Reef Symp. Miami 1: 23-29.

Geister, J. (1980). Morphologie et distribution des coraux dans les récifs actuels de la mer des Caraibes. Ann. Univ. Ferrara 9 (Geol. and Paleo.) 7, Suppl. 28 pp.

Geister, J. (1983). Holocene West Indian Coral Reefs: geomorphology, ecology and facies. Facies 9: 173-284.

Geister, J. (1984). Géomorphologie, écologie et faciès des récifs actuels des Caraibes: conséquences pour l'interpretation des récifs fossiles. In: Geister, J. and Herb, R. (Eds), Géologie et paléoécologie des récifs. Institut de Géologie de l'Université de Berne. 1.1-1.14.

Geister, J. (in press). Recent coral reefs and geologic history of Providencia Island (Western Caribbean Sea, Colombia). Mem. segundo Congreso colombiano Geol., Bogotá, 1978.

Geyer, O.F. (1969). Vorläufige Liste der scleractinen Korallen der Bahía de Concha bei Santa Marta Kolumbien. Mitt. Inst. Colombo-Alemán Invest. Cient. 3: 25-28.

Glynn, P.W. (1984). Widespread coral mortality and the 1982-83 El Niño warming event. Environmental Conservation 11(2): 133-146.

Glynn, P.W., Prahl, H. von and Guhl, F (1982). Coral reefs of Gorgona Island, Colombia, with special reference to corallivores and their influence on community structure and reef development. An Inst. Invest. Mar. Punta de Betín 12: 185-214.

Graham, J.B. (Ed.)(1975). The biological investigations of Malpelo. Smithsonian Contributions to Zoology 176.

Guillot, G. and Márquez, G. (1978), Estudios en la vegetación bentónica marina del Parque Nacional Tayrona, Costa Caribe Colombiana. I: Relaciones vegetación - zonación - sustrato. An. Inst. Inv. Mar. Punta Betin 10: 133-148.

Halewyn, R. van and Norton, R.L. (1984). The status and conservation of seabirds in the Caribbean. In: Croxall, J.P., Evans, P.G.H. and Schreiber, R.W. (Eds), Status and Conservation of the World's Seabirds. ICBP Technical Publication No. 2, Cambridge.

* Hubach, E. (1956). Aspectos geográficos y geológicos y recursos de las Islas de San Andrés y Providencia. Cuadernos de Geografía de Colombia 12(395).

-INDERENA (1984), Colombia: Parques Nacionales. Bogotá.

IUCN (1982). Directory of Neotropical Protected Areas. Tycooly International Publishing Ltd., Dublin.

Kapraun, D.F. (1972). Notes on the benthic marine algae of San Andrés, Colombia. Carib. J. Sci. 12(3-4): 199-203.

Kaufmann, R. (1971). Beitrag zur subfossilen Molluskenfauna der Islas del Rosario, Kolumbien. Mitt. Inst. Colombo-Alemán. Invest. Cient. 5: 65-72.

Kocurko, M.J. (1977). Preliminary survey of modern marine environments of San Andrés Island, Colombia. Tulane Stud. Geol. Palaeont. 13(3): 111-134.

Koster, F. (1979). Observaciones de la Ictiofauna de las Islas del Rosario. An. Inst. Inv. Mar. - Punta Betin 11: 49-57.

Lessios, H.A., Glynn, P.W. and Robertson, D.R. (1983).

Mass mortalities of coral reef organisms. Science 222: 715.

Lessios, H.A., Robertson, D.R. and Cubit, J.D. (1984).

Spread of Diadema mass mortality through the Caribbean. Science 226: 335-337.

Loboguerrero, M.J. (1954). Sinopsis geográfica del Archipiélago de San Andrés y Providencia. Bol. Soc. geogr. Colombia 12(3,4): 193-209.
McCosker, J.E. and Rosenblatt, R.H. (1975). Fishes collected at Malpelo Island. In: Graham, J. (Ed.) (1975): 91-93.

Manjarrés, G.A. (1979a). Observaciones sobre los Anthozoa (excepto madreporaria) en las Islas del Rosario. An. Inst. Inv. Mar. - Punta Betín 11: 21-22.

Manjarrés, G.A. (1979b). Observaciones sobre los moluscos e inventario de las especies en las islas del Rosario. An. Inst. Inv. Mar. - Punta Betín 11: 35-38.

- Márquez, G. (1982). Los sistemas ecológicos marinos del sector adyacente a Santa Marta, Caribe Colombiano I: Generalidades. Revista Ecología Tropical 2(1): 5-23.

-Márquez, G. and Guillot, G. (1983). La vegetación marina del Parque Nacional Tayrona, Costa Caribe Colombiana II: tipos de vegetación. An. Inst. Inv. Mar.-Punta Betín 13: 17-51

Martínez, S.H. de and Vernette, G. (1980). Un complejo arrecifal cuaternario: Islas del Rosario. Primer Seminario sobre el Cuaternario de Colombia, Bogotá 1980.

Mergner, H. (1977). Hydroids as indicator species for ecological parameters in Caribbean and Red Sea coral reefs. Proc. 3rd Int. Coral Reef Symp., Miami. 1: 119-125. Meyer, D.L. and Macurda, D.B. (1976). Distribution of shallow-water crinoids near Santa Marta, Colombia. Mitt. Inst. Colombo-Alemán Invest. Cient. 8: 141-156.

Milliman, J.D. (1969). Four southwestern Caribbean atolls: Courtown Cays, Albuquerque Cays, Roncador Bank and Serrana Bank. Atoll Res. Bull. 129.

Milliman, J.D. (1973). Caribbean coral reefs. Chap. 1 in Jones, O.A. and Endean, R. (Eds) Biology and Geology of Coral Reefs. Vol.1, Academic Press, New York and London.

Milliman, J.D. and Supko, P.R. (1968), On the geology of San Andrés Island, western Caribbean. Geol. Mijn. 47: 102-105.

Mora-A, H. (1940). Archipiélago de San Andrés y Providencia. Bol. Soc. geogr. Colombia 6(4): 237-249.

Ortega-Ricuaurte, D. (1944). Los cayos colombianos del Caribe. Bol. Soc. geogr. Colombia 7(3): 279-291.

Pagnacco, P.F. and Radelli, L. (1962). Note on the geology of the isles of Providencia and Santa Catalina (Caribbean Sea, Colombia). Geol. Colomb. 3: 125-132.

- Parsons, JJ. (1956). San Andrés and Providencia, English-speaking islands in the western Caribbean. Univ. California Publ. in Geogr. 12: 84 pp.

Pfaff, R. (1969). La Scleractinia y Milleporina de las Islas del Rosario. Mitt. Inst. Colombo-Alemán Invest. Cient. 3: 17-24.

*Pinchot, G. (1930). To the South Seas: the cruise of the schooner Mary Pinchot to the Galapagos, the Marquesas, the Tuamotus and Tahiti. Philadelphia.

Prahl, H. von (1982). Notas sobre las formaciones de manglares y arrecifes coralinos en la isla de Providencia, Colombia. Mem. del Seminario Desarrollo y Planificacion Ambiental Islas de San Andrés y Providencia. FIPMA. Min. Ag.

Prahl, H. von (in press). Lista anotada de arrecifes coralinos y corales de Colombia.

Prahl, H. von and Erhardt, H. (1985). Colombia corales y arrecifes coralinos. Fondo para la Protección del Medio Ambiente "José Celestino Mutis", Bogotá. 295 pp.

Prahl, H. von, Guhl, F. and Grogl, M. (1977). Los arrecifes de la Isla de Tintipán y Múcura, Islas de San Bernardo. Comité de Investigaciones, Universidad de los Andes, Bogotá.

Prahl H. von, Guhl, F. and Grogl, M. (1978). Crustaceos decápodos comensales del coral Pocillopora damicornis 
L. en la Isla de Gorgona, Colombia. An. Inst. Inv. Mar.Punta Betín 10: 81-93.

Prahl H. von, Guhl, F. and Grogl, M. (1979). Gorgona. Universidad de los Andes. Com. Publ. - Futura Grupo Edit. Ltda. Bogota, D.E. 279 pp.

Prahl H. von, and Mejía, A. (in press). Primer reporte de un coral acropórido (Scleractinia: Acroporidae) para el Pacífico Americano. Revista de Biología Tropical.

Proctor, G.R. (1950). Results of the Catherwood-Chaplin West Indies Expedition, 1948. Part I. Plants of Cayo Largo (Cuba), San Andrés and Providencia. Proc. Acad. nat. Sci. Phil. 102:27-42.

Ramírez, A. and de la Pava, M (1981). Corales hermatipicos de la Isla de Tierra Bomba, Cartagena (Colombia). Estimación de algunos factores de incidencia en la sucesión vertical con anotaciones ecológicas. Tesis, Universidad Jorge Tadeo Lozano, Bogotá.

Ripper, A. von (1949). In the West Indies with the Catherwood-Chaplin Academy Expedition. Frontiers (Nat. Acad. Sci. Phila.) 13: 74-75.

Rodríguez, H. (1979). Poliquetos de aguas someras colectados en las Islas de Rosario. An. Inst. Inv. Mar. Punta Betín 11: 25-26.

Scott, D.A. and Carbonell, M. (1986). A Directory of Neotropical Wetlands. IUCN, Gland and Cambridge.

Stead, J.A. (1975). Field observations on the geology of Malpelo. In: Graham, J.E. (Ed.): 17-20.

Toro, R. (1929-1930). Una contribución a nuestro conocimiento de la flora silvestre y cultivada de San Andrés. Rev. Soc. Colombiana Sci. nat. 18(103): 201-207, 19(104): 56-58.

Valdivieso, and Tamsitt, (1963). A check list and key to the amphibians and reptiles of Providencia and San Andrés. Caribb. J. Sci. 3(2-3): 77-79.

-Vanderbilt, G. (1944), Results of the Fifth George Vanderbilt Expedition (1941): Introduction and itinerary. Acad. Nat. Sci. Phila. Mono. 6: 1-6.

Werding, B. (1979). Situación sistemática de algunos corales de las Islas del Rosario y nuevos reportes. An. Inst. Inv. Mar. - Punta Betín 11: 25-26.

Werding, B. (1982). Porcellanid crabs of the Islas del Rosario, Caribbean coast of Colombia, with a description of Petrolisthes rosariensis new species (Crustacea: Anomura). Bull. Mar. Sci. 32(1): 439-447.

Werding, B. and Erhardt, H. (1976). Los corales (Anthozoa e Hidrozoa) de la Bahia Chengue en el Parque Nacional "Tairona" (Colombia). Mitt. Inst. Colombo-Alemán Invest. Cient. 8: 45-57.

-Werding et al. (1976). Informe final sobre el estudio ecológico en la Bahía de Neguange Parque Nacional Tayrona. INVEMAR, Santa Marta, 63 pp.

Werding, B., Garzón, J. and Zea, S. (Eds) (1981).

Informe sobre los resultados de la expedición Providencia I a las Islas de Providencia y Santa Catalina (Colombia). Draft Report. Instituto de Investigaciones Marinas de Punta de Betín, INVEMAR.

Werding, B. and Köster, F. (1977). Las formaciones coralinas de la costa norte de Colombia. Un problema de conservación? An. Inst. Invest. Mar.-Punta Betin Suppl. $1: 67-74$.

Werding, B. and Manjarrés, G. (1978). Informe sobre las estructuras litorales y la flora y fauna marina en el noroccidente del Golfo de Uraba. Informe INVEMAR-COLCIENCIAS, $87 \mathrm{pp}$.

Werding, B. and Sánchez, H. (1979). Informe faunístico y florístico de las Islas del Rosario: Situación general y estructuras arrecifales. An. Inst. Inv. Mar.-Punta Betín 11: $7-20$.

\section{CAYOS ALBUQUERQUE}

Geographical Location $12^{\circ} 10^{\prime} \mathrm{N}, 81^{\circ} 50^{\prime} \mathrm{W}$; about $200 \mathrm{~km}$ east of Nicaragua, seaward of the continental shelf.

Area, Depth, Altitude About $6.5 \mathrm{~km}$ long east-west and $5 \mathrm{~km}$ wide north-south; lagoon depths average $10-15 \mathrm{~m}$, maximum $18 \mathrm{~m}$.

Land Tenure State owned within San Andrés jurisdiction.

Physical Features The atoll is nearly circular and lies on volcanic foundations. Two islands rise above the windward reef flat: North Cay $(350 \mathrm{~m} \times 125 \mathrm{~m})$ has an elevation of $2 \mathrm{~m}$; South Cay $(180 \mathrm{~m} \times 70 \mathrm{~m})$ is similar and lies $250 \mathrm{~m}$ to the south. Because of heavy, lush vegetation, the soils are richer and more loamy than on neighbouring atolls. A shallow, wide sand flat forms the lagoon sill and deepens from $3-5 \mathrm{~m}$ at the leeward reefs to $10-15 \mathrm{~m}, 3 \mathrm{~km}$ to the west; it is covered with small, low lying patch reefs. Two navigable channels on the south-west and north-west broach the flat into the lagoon. Patch reefs cover an estimated $20 \%$ of the lagoon bottom and are especially prominent in the northern half. Stands of Halodule and Syringodium are found on the northern and southern sides of North Cay. Salinity averaged $36.35 \mathrm{ppt}$, air temperature $28^{\circ} \mathrm{C}$ and water temperature $27.5^{\circ} \mathrm{C}$ in the 1960 s (Milliman, 1969).

Reef Structure and Corals A general description is given in Milliman (1969) (see "Introduction"), but there are no specific details for Cayos Albuquerque.

Noteworthy Fauna and Flora Coconut palms, Ficus trees and Scaevola shrubs are the prominent plants. The interior portions of both islands are heavily wooded, the trees on the windward side being lower. Nine species of birds have been reported from the cays, mainly migratory species and some boobies and terns, including breeding Red-footed Boobies Sula sula (Halewyn and Norton, 1984). The hummingbird Anthracothorax prevostii hendersoni used to be resident (Bond and DeSchauensee, 1944). The Loggerhead Turtle Caretta caretta and the Hawksbill Eretmochelys imbricata nest here and Green Turtles Chelonia mydas may also do so (Bacon, 1981; Carr et al., 1982)

\section{Scientific Importance and Research No information}

Economic Value and Social Benefits The atoll has been visited for many years by San Andrean and Providencian inhabitants for fish and turtles and in 1966 North Cay was inhabited by Providencian fishermen (Milliman, 1969; Mow-Peters in litt., 15.11.84). Because of over-fishing at San Andrés, the atoll is becoming increasingly important for its Strombus gigas, lobster and fish (especially Snappers and Haemulon album) stocks. There is a military presence and the cays are occasionally visited by tourists (Mow-Peters in lit., 15.11.84).

Disturbance or Deficiencies Intensification of the fisheries could damage the reefs.

Legal Protection None.

Management None. 
Recommendations The cays should be reserved for artisanal fishermen only, to prevent over-exploitation (Mow-Peters in litt., 15.11.84).

\section{PARQUE NACIONAL CORALES DEL ROSARIO}

Geographical Location $10^{\circ} 04^{\prime}-10^{\circ} 14^{\prime} \mathrm{N}, 75^{\circ} 37^{\prime}-75^{\circ} 53^{\prime} \mathrm{W}$; off the coast of the department of Bolivar, to the south of Cartagena; part of the Archipiélago del Rosario.

Area, Depth, Altitude $0-50 \mathrm{~m}$ depth; $17800 \mathrm{ha}$.

Land Tenure State owned.

Physical Features A shallow water coral platform extends from the north-east of Isla de Baru to the Archipiélago del Rosario. The park includes Isla del Rosario, Isla de los Pajarales, Isla Naval, Isla Grande, Isla Arena, Isla Tesoro, Isla Periquitos and the western coast of Isla Baru. The reefs are situated on subfossil reefs dating back 3000 years (Erffa and Geister, 1976; Geister, 1983; Martinez and Vernette, 1980; Pfaff, 1969). The islands are exposed to fairly constant north-easterly winds. Surface water temperatures range from 27 to $31^{\circ} \mathrm{C}$ and salinity fluctuates from 30 to $35 \mathrm{ppt}$ (Pfaff, 1969).

Reef Structure and Corals Fifty one species of coral from the Park are listed by Pfaff (1969). The zonation around the islands has been described by Werding and Sánchez (1979) who studied 24 sites around Isla Grande, Macabi, Pajarales, Isla del Rosario, Isla del Tesoro and Isla Arena. Geister (1977) described many of the more exposed reefs as of the strigosa-palmata type.

Much of the north coast of Isla Grande is bordered with extensive beds of Thalassia testudinum, which are replaced seaward by a reef flat of Porites porites. The back-reef consists of mixed corals, including abundant Acropora cervicornis. The reef crest is dominated by $A$ palmata. The fore-reef consists mainly of $A$ cervicornis down to $9-15 \mathrm{~m}$, and is followed by a mixed zone from 10 to $20 \mathrm{~m}$ with many species. Agaricia and Montastraea annularis become commoner at greater depths, the latter, which forms colonies $2 \mathrm{~m}$ high, being typical at $20-30 \mathrm{~m}$. On the south coast there is a large Thalassia bed with small amounts of $P$. porites, seaward of which are large beds of Acropora cervicornis. Down to $12-15 \mathrm{~m}$ there is a mixed zone with abundant Mille pora and also Agaricia tenuifolia. Below $15 \mathrm{~m} A$ lamarcki predominates and there are many sponges.

Isla Rosario is less exposed; from 0 to $2 \mathrm{~m}$ there are extensive beds of $P$. porites occasionally interrupted by lagoons with sand or seagrass. Below $2 \mathrm{~m}$ a diverse coral fauna including $P$. porites and $M$. alcicornis is found. At $6 \mathrm{~m}$, Agaricia tenuifolia becomes dominant, in some places mixed with Acropora palmata, $A$ cervicornis and other corals. At $12 \mathrm{~m}$ there is a drop-off to $32 \mathrm{~m}$ dominated by Agaricia lamarcki which ends at a sandy bottom. The west coast has large areas of Thalassia with coral patches. On the south side there is a dead Acropora cervicornis reef.
There is less coral surrounding Isla Arena, but on the south there is a rich area between 8 and $10 \mathrm{~m}$ with corals, octocorals and sponges, dominated by Montastraea annularis, Agaricia tenuifolia and Millepora alcicornis At $1 \mathrm{~km}$ from the island, a platform slopes to $32 \mathrm{~m}$ depth covered with corals dominated by Agaricia and Montastraea annularis. On the north coast there are $P$. porites reefs; the south and east have extensive Thalassia beds.

Isla del Tesoro has dense coral growth on the east side, with a reef crest of Acropora palmata. To the north, coral is found to depths of $40 \mathrm{~m}$, the dominant species being Montastraea annularis, with a reef crest of $A$ palmata. On the south side there is a plateas at 6-10 $\mathrm{m}$ with large colonies of $M$. annularis, $4 \mathrm{~m}$ high and $6 \mathrm{~m}$ in diameter (Werding and Sánchez, 1979).

Noteworthy Fauna and Flora The park is listed as an important wetland site (Scott and Carbonell, 1986). Seagrass beds of Thalassia testudinum and numerous green algae Cloroficeas, brown algae Feoficeas and red algae Rodoficeas are found, particularly around Isla Arena and Isla Rosario (Cuervo, 1979; Werding and Sánchez, 1979). Mangroves are found on most of the islands, particularly Los Pajarales and Isla del Tesoro. On Isla Grande, mangroves fringe the canals which penetrate the islands and are found particularly in the south-east around the lagoon which is an important nursery area for juvenile fish. On Los Pajarales, large Rhizophora mangle provide nesting sites for birds, particularly Magnificent Frigatebirds Fregata magnificens and Brown Pelicans Pelecanus occidentalis. Loggerhead Caretta caretta and Leatherback Dermochelys coriacea Turtles may occur here and the Green Turtle Chelonia mydas and Hawksbill Eretmochelys imbricata nest among the islands (Carr et al., 1982; Bacon et al., 1984). Anthozoans have been described by Manjarrés (1979a), corals by Pfaff (1969) and Werding (1979) and 26 species of polychaetes have been recorded by Rodriguez (1979). Decapod crustaceans, including a new species Petrolisthes rosariensis (Porcellanidae), are described by Corredor et al. (1979) and Werding (1982). Over 79 species of mollusc have been recorded (Manjarrés, 1979b) and 35 species of echinoderms have been described (Caycedo, 1979). Köster (1979) lists 106 species of fish but points out that this list is incomplete.

Scientific Importance and Research The area is considered to include the most important reefs on the Colombian coast. The Facultad de Ciencias Marinas de la Universidad de Bogotá Jorge Tadeo Lozano and the Centro de Investigaciones Pesqueras of INDERENA (Instituto de Desarrollo de los Recursos Naturales Renovables) are based at Cartagena. The Instituto de Investigaciones Marinas de Punta de Betín in collaboration with the Centro de Investigaciones Oceanográficas e Hidrografficas carried out a series of studies of the area for INDERENA to provide the information necessary for the implementation of the park and to make recommendations for future research and reef management (Werding and Sánchez, 1979).

Economic Value and Social Benefits Tourism and fisheries are important but no details have been obtained.

Disturbance or Deficiencies The main causes of damage 
are construction work (mainly for holiday homes) on the islands (often using fossil coral as well as living reef material), sewage pollution, illegal fishing by both visitors and local people (including spearfishing and the use of dynamite), anchor damage and the traffic of boats visiting the reefs. Strombus gigas, although reported to be abundant in some areas (IUCN, 1982) has in the past been overcollected (Kaufmann, 1971) as have lobster (Werding and Sánchez, 1979). The terrestrial environment is greatly disturbed by the cutting of wood for fuel and the trampling of livestock (Werding and Sánchez, 1979).

Legal Protection The Park was established May 1977, under Acuerdo 26 de 1977.

Management The Park is administered by the Jefe Parque Nacional Corales del Rosario, INDERENA, Cartagena. Staff include the director, a marine biologist, three wardens and three workmen. At present the park is not zoned but there are plans to identify certain areas to which entry will be prohibited and others for recreation. The park regulations are strictly enforced (IUCN, 1982).

Recommendations In 1979, the following recommendations were made by Werding and Sánchez (1979):

1. Prohibit further construction work, particularly on Pajarales where a land reclamation scheme, if it leads to further building, could have a serious impact on nesting birds.

2. Prohibit boat traffic within certain areas, particularly in the vicinity of nesting birds, and create special routes for boats.

3. Create a zone of full protection where fishing and boat traffic would be strictly controlled, possibly to a minimum distance of $1 \mathrm{~km}$ from the shore and/or to the $50 \mathrm{~m}$ isobath.

4. Consider the inclusion of additional areas within the national park, especially Isla Periquitos and part of Punta de Barú.

5. Improve protective legislation; all forms of fishing (spearfishing and conch and lobster harvesting) should be prohibited except for fishing by local people using traditional methods; there should be no coral extraction for commercial purposes; wood cutting and the introduction of livestock should be prohibited.

6. Create special protected areas for nesting birds and for the islands of Tesoro and Rosario on account of their particularly rich coral reefs and lack of permanent inhabitants.

\section{CAYOS DEL E.S.E. (COURTOWN CAYS AND CAYO BOLIVAR)}

Geographical Location $12^{\circ} 24^{\prime} \mathrm{N}, 81^{\circ} 25^{\prime} \mathrm{W} ; 200 \mathrm{~km}$ east of Nicaragua, seaward of the continental shelf; $33 \mathrm{~km}$ east-south-east of San Andrés.
Area, Depth, Altitude $8.5 \mathrm{~km}$ long (north-south) and $3.5 \mathrm{~km}$ wide; lagoon depths average $12 \mathrm{~m}$, locally reaching $16 \mathrm{~m}$.

Land Tenure State owned; under San Andrés jurisdiction.

Physical Features This lenticular atoll with volcanic foundations has five small cays and one rocky spit. Sandy Cay ( $200 \mathrm{~m} \times 25 \mathrm{~m}$; maximum height $1.5-2 \mathrm{~m}$ ) has windward beaches covered with encrusted reef rubble and a sand spit extending about $20 \mathrm{~m}$ south of the cay. East Cay $(300 \mathrm{~m} \times 100 \mathrm{~m})$ is the largest cay and has four bands of beach rock, paralleling the eastern shoreline, which extend windward on the reef flat. Three small cays, Middle Cay, West Cay and a sand spit on a patch reef collectively form the leeward peripheral reef which is poorly developed and broken by a $2 \mathrm{~km}$ gap in the north-west through to the lagoon. Most of Middle Cay is surrounded by emergent patch reefs. The windward reef flat is indented in two places giving the atoll an unusual bowed shape. Air temperatures average about $28^{\circ} \mathrm{C}$. Water temperatures average $27.5^{\circ} \mathrm{C}$ with small daily ranges. Salinities range from 36.1 to $36.4 \%$. North-east winds seldom drop below $7 \mathrm{~m} / \mathrm{sec}$ and there is a predominant north-east current (Milliman, 1969).

Reef Structure and Corals Surge channel lineations, with relief of $0.5-1 \mathrm{~m}$, are most conspicuous in the indented portions of the outer reef and extend into the reef front as a buttress-groove system. Patch reefs cover only about $10 \%$ of the lagoon bottom; coalescing patch reefs have nearly isolated the southern third of the lagoon (see "Introduction" for general description)

Noteworthy Fauna and Flora Tourne fortia shrubs and a low creeping vine grow on Sandy Cay with a few coconut palms. A large stand of coconut palms and large Scaevola bushes grow on the lagoon side of East Cay. The central vegetated portion of Middle Cay is bordered by Tournefortia and Scaevola bushes and West Cay probably has similar vegetation. A large patch of seagrass, Thalassia and Syringodium, extends some $100 \mathrm{~m}$ leeward of East Cay, on which the echinoid Tripneustes esculentus is particularly common. The Green Turtle Chelonia mydas may occur and the Loggerhead Caretta caretta and Hawksbill Eretmochelys imbricata nest (Carr et al., 1982). The Magnificent Frigatebird Fregata magnificens nests (Halewyn and Norton, 1984).

\section{Scientific Importance and Research No information.}

Economic Value and Social Benefits The atoll has been visited for many years by San Andrean and Providencian natives for fish and turtles. East Cay was inhabited in the 1960 s by a San Andrean fisherman and Middle Cay by several Providencian natives (Milliman, 1969). In the late 1960s, San Andrés fishermen visited the cays on an irregular basis for: a) hook-and-line fishing for silk snappers in deep water; b) fishing shallow reef areas for snapper, rock fish, jack and other fish with spearguns and taking lobster; c) collecting turtles and their eggs from the cay beaches, and d) collecting Strombus gigas (Geister in litt., 1984). Commercial lobster fishing is now important (Mow-Peters in litt., 15.11.84).

Disturbance or Deficiencies In 1944, there were reported to be abundant fish and lobsters (Fowler, 1944) 
but by 1966 fish populations seemed to be low and few lobsters were found, possibly a result of fishing by the natives. Commercial lobster fishing is still intensive however and the traps may damage corals (Mow-Peters in litt., 15.11.84). Turtle populations have declined due to intensive exploitation (Carr et al., 1982). Wrecks on the outer reefs are numerous, but the damage caused by the these and subsequent salvage efforts is not known (Geister in litt., 25.11.84).

\section{Legal Protection None.}

\section{Management None.}

Recommendations A status survey of the cays and reef resources is required.

\section{PARQUE NACIONAL NATURAL ISLA DE GORGONA}

Geographical Location $25^{\circ} 58^{\prime} \mathrm{N}, 78^{\circ} 11^{\prime} \mathrm{W}$; about $30 \mathrm{~km}$ off Departamento de Narino, on the Pacific coast.

Area, Depth, Altitude 4400 ha $(11 \mathrm{~km} \mathrm{x} 2.3 \mathrm{~km})$; maximum altitude $330 \mathrm{~m}$ (Cerro de la Trinidad).

Physical Features The island is a remnant of the Bolivar geosyncline which extends from the Gulf of Uraba in the north to the Gulf of Guayaquil off Ecuador. It is situated on the edge of the continental shelf; depths between the island and mainland are never more than $270 \mathrm{~m}$ but reach $3000 \mathrm{~m}$ rapidly on the west. The islet of Gorgonilla, at the south-west tip, is joined to Gorgona by the $700 \mathrm{~m}$ long isthmus of Tasca which is totally emergent at low tide. Punta del Horno and Punta del Vindo are isolated rocks at the northern and southern tips of the island (Prahl et al., 1979).

Temperatures vary from $24^{\circ}$ to $28^{\circ} \mathrm{C}$. Water temperatures on the east coast range from $27.2^{\circ}$ to $29^{\circ} \mathrm{C}$ and on the west coast from $18.7^{\circ}$ to $25.6^{\circ} \mathrm{C}$. Rainfall averages $4000-8000 \mathrm{~mm}$ a year and storms occur during all seasons. Winds are moderate, except in August when they are influenced by the southerly trade winds. Currents between the island and mainland are predominantly from the north-east, with an average speed of 0.3 knots. To the west, the flow is to the north-north-west as far as $79^{\circ} \mathrm{W}$. Tidal regime is typical of the Pacific coast of Colombia with two tides per day and alternate weeks of spring and neep tides. Further details are given in Prahl et al. (1979) and Glynn et al. (1982).

Reef Structure and Corals The reefs are described by Prahl et al. (1979) and Glynn et al. (1982). Fringing and patch reefs are found round Gorgona and are best developed on the east coast, notably at El Muelle (Pier Reef), Playa Blanca (1800 m long), Playa Pizarro and La Azufrada, the largest reef (c. $1 \mathrm{~km}$ ). There are a few isolated small assemblages in the Strait of Tasca, near Gorgonilla. Little coral is found on the west coast, presumably due to lack of suitable substrate, the steep drop-off, cold water temperatures and exposure to winds and ocean swell. The exception is on the rocky headland between the sand beach of La Camaronera and Puesto de
Gorgonilla in the south where coral reefs and numerous incipient reef formations are found. These are described in Glynn et al. (1982). The east coast also has little significant reef framework; coral diversity is low and growth is limited to $10-15 \mathrm{~m}$ depth, possibly due to the large number of rivers and streams causing freshwater inundation and sedimentation in some areas. Water is relatively calm on this coast and no spur and grcove formations have been found (Cantera, 1983; Prahl et al., 1979). All known reefs are composed predominantly of ramose Pocillopora species (Glynn et al., 1982).

Prahl et al. (1979) briefly describe the reef at La Azufrada. Pocillopora species comprise $87 \%$ of the corals, dominated by $P$. damicornis, followed by $P$. capitata and $P$. lacera. In deeper water $P$. robusta, Porites panamensis and Pavona varians are found, and the latter also occur on the edge of Pocillopora stands. Glynn et al. (1982) give further details.

Cantera (1983) studied a fringing reef $(500 \times 50 \mathrm{~m})$ near El Muelle, situated about $400 \mathrm{~m}$ from human habitation and therefore subject to human activities. The adjacent beach, $20 \mathrm{~m}$ wide, is formed of coral, volcanic sand and gravel, scattered with large volcanic boulders. The main characteristics of the recf are its low species diversity (10 coral species) and the dominance of Pocillopora damicornis. Five zones were defined:

1) The boat channel nearest shore (1-1.5 $\mathrm{m}$ deep at low tide, $2 \mathrm{~m}$ deep at high tide) has a few scattered coral colonies (maximum living coral cover is $10 \%$ ), mainly of $P$. damicornis and Psammocora stellata. Gorgonians and hydrozoans are more abundant. 2) The inner compact reef flat consists of dead Pocillopora corals bound with calcareous algae. Living coral cover may attain 20\%, the dominant species being Porites panamensis and Pavona varians. 3) a reef flat of largely living corals $(60 \%$ coral cover) scattered with non-coralline circular shaped areas of 1-2 m diameter. Pocillopora damicornis predominates and $P$. capitata is abundant. 4) The reef crest, never more than $1.5 \mathrm{~m}$ deep, is dominated by $P$. damicornis and has about $55 \%$ coral cover. 5) The outer slope is gradual down to $8 \mathrm{~m}$ depth from where it drops steeply to $15 \mathrm{~m}$ depth. From 1 to $4 \mathrm{~m}$ depth, massive colonies of Porites lobata and Pavona gigantea, 2-3 $\mathrm{m}$ in diameter, predominate and coral cover of up to $85 \%$ is reached. From 4 to $10 \mathrm{~m}$ depth, there is a gradual reduction in coral cover, with isolated colonies of Pocillopora damicornis, Pavona clivosa, P. gigantea and Porites lobata.

Glynn et al. (1982) describe El Muelle, Playa Blanca Reef, Paso de Tasca reefs and the reef build-ups south of $\mathrm{La}$ Camaronera; coral species found around the island are listed. In 1984 Acropora valida was recorded, the first time that a member of the family Acroporidae has been found in the Eastern Pacific (Prahl and Mejia, in press).

Noteworthy Fauna and Flora The island has approximately 2500 ha of lush tropical wet forest with mangroves Avicennia nitida and Laguncularia racemosa bordering parts of the coast. Prahl et al. (1979) provide a review of several taxonomic groups including mammals, birds, reptiles and amphibians, sharks and marine groups including polychaetes, littoral molluscs, decapod, crustaceans (in particular species commensal with Pocillopora damicornis, also described by 
Prahl et al., 1978)). The Loggerhead Caretta caretta and the Leatherback Turtles Dermochelys coriacea have been recorded. Penguins have recently been recorded and Fur Seals Arctocephalus australis, Humpback Whales Megaptera novaeangliae, Common Rorqual Balaenoptera physalus and Sperm Whales Physeter catodon macrocephalus are seen (Hernández pers. comm. 1986).

Scientific Importance and Research Isla de Gorgona has some of the most extensive and mature coral reef formations off the Pacific coast of Colombia and is of particular interest because of its location near the southernmost limit of coral reef development in the Eastern Pacific. Prahl et al. (1979) provide an overview of work carried out on the island. Glynn et al. (1982) discuss the influence of corallivores on the reef communities.

Economic Value and Social Benefits Since 1960 the island has functioned as a high security prison (the largest in Colombia) for about 800 inmates. Police, fishermen and occasional visitors make the total population up to about 1000 (Prahl et al., 1979).

Disturbance or Deficiencies Despite its distance from the coast, the island has suffered increasing environmental damage over the last few years. Much of this is due to the presence of the prison. There is considerable domestic pollution, massive deforestation, and destruction of the reefs through fishing and spearfishing (although this has recently stopped). The construction of a landing strip, near El Muelle, resulting in excessive soil run-off, threatens the reefs through siltation, and has already caused the death of an area of coral on the reef flat in La Azufrada bay (Cantera, 1983; Prahl et al., 1979). Coral bleaching and mortality, possibly associated with the abnormal 1983 El Niño, have been reported (Glynn, 1984). Some of the observed dead coral on reefs may be due to extreme low tides. Acanthaster planci is notably absent (Glynn et al., 1982).

Legal Protection In December 1983 the island was declared a National Park by INDERENA and in 1984 a presidential decree was to make the declaration official.

Management No information.

Recommendations The prison was scheduled to end by mid 1984 with a gradual relocation of prisoners.

\section{ISLA DEL MALPELO}

Geographical Location Pacific Ocean; $600 \mathrm{~km}$ east and slightly south of Isla del Coco, $500 \mathrm{~km}$ west of Buenaventura; $3^{\circ} 51$ 'N, $81^{\circ} 35^{\prime} \mathrm{W}$.

Area, Depth, Altitude Two peaks reach $1235 \mathrm{ft}(376 \mathrm{~m})$ and $1215 \mathrm{ft}(370 \mathrm{~m})$.

Physical Features Malpelo is a small, steep and barren basaltic rock, and is the only island on the Malpelo Ridge, a solitary volcanic submarine ridge extending NE-SW, $150 \times 50 \mathrm{mi} .(240 \times 80 \mathrm{~km})$, and separated from the mainland by depths of more than 1800 fathoms $(3290 \mathrm{~m})$. Its geology is described in Stead (1975). The surrounding waters have a strong thermocline between 6 and $35 \mathrm{~m}$ (Bakus, 1975); surface temperatures average $26.5^{\circ} \mathrm{C}$, and below the thermocline temperatures average $19.5^{\circ} \mathrm{C}$. Currents are described in Graham (1975); the island is in the path of El Niño. Visibility is very good. Rough waters and steep cliffs and caves all round the island make access difficult.

Reef Structure and Corals Although conditions for coral growth appear to be good, there is limited substrate. On steeply sloping rock walls corals are found as a veneer, interspersed with other organisms, or as shingled overhanging masses and on average there is only $10 \%$ coral cover. The smooth vertical subtidal walls are dominated by large sparsely distributed barnacles Balanus peninsularis. Permanent reefs are lacking except in the south-east, where the slope is more gradual and there is an extensive coral community to $30 \mathrm{~m}$ depth (Birkeland et al, 1975). Pocillopora robusta and two species of Porites predominate to $15 \mathrm{~m}$ depth but below about $18 \mathrm{~m}$ depth Porites is replaced by Pavona clivosa (Bakus, 1975). At depths of $28 \mathrm{~m}$, Agariciella planulata is dominant.

Noteworthy Fauna and Flora The majority of decapod crustaceans and fish are Central American mainland species, but there are also Indo-Pacific species, some known only from the Galápagos and from Isla del Coco, and some endemic to Isla del Malpelo. Forty-three species of decapod crustaceans have been described (Abele, 1975), and a number of starfish (Downey, 1975). The fish fauna is similar to that of Cocos Island (Bakus, 1975). McCosker and Rosenblatt (1975) recorded 70 species of fish, including many sharks; Fowler (1944) provides an early account of the fish. The Red-footed Booby Sula sula occurs on the island. The Green Turtle Chelonia mydas may occur. Information on the terrestrial fauna, including the endemic lizards Anolis agassiz, Diploglossus millepunctatus and one other, is given in Graham (1975).

Scientific Importance and Research Isla del Malpelo provides a natural laboratory for the study of evolution, as it has never been connected to the mainland, and it may serve as a stepping stone to the Galápagos and Isla del Coco. Animals and plants presumably arrive at the island on ocean currents. The island was visited briefly in 1972 by an expedition from the Smithsonian Tropical Research Institution, the U.S. Navy and other organisations. Dives were made at eight stations around the island and a concentrated study of zonation and population densities of benthic invertebrates was made (Birkeland et al., 1975; Graham, 1975). Further research is required, including, for example, studies on rainfall.

Economic Value and Social Benefits No information.

Disturbance or Deficiencies There is concern about the future of the island which might be developed as a naval base (Hernández, pers. comm. 1986).

Legal Protection No information.

Management No information.

Recommendations No information. 


\section{ISLA DE PROVIDENCIA PROPOSED MANAGEMENT AREA}

Geographical Location One of the islands in the San Andrés and Providencia Archipelago, originally called Old Providence Island. $13^{\circ} 19^{\prime}-13^{\circ} 24^{\prime} \mathrm{N}, 81^{\circ} 21^{\prime}-24^{\circ} \mathrm{W}$; $250 \mathrm{~km}$ from Nicaraguan coast; $90 \mathrm{~km}$ from San Andrés.

Area, Depth, Altitude Area of island is $15 \mathrm{sq} . \mathrm{km}$ ( $7 \mathrm{~km} \times 4 \mathrm{~km}$ ).

Land Tenure Private property apart from the small islets (Cayos Hermanos, Cayo Crangrejo, Cayo Basalto and Cayo Vaca) which are state owned.

Physical Features Isla de Providencia is situated with its sister island Santa Catalina on a shelf which stretches some $15 \mathrm{~km}$ NNE of the island. The island is elliptically shaped, with the longitudinal axis NNE-SSW, and is mountainous and very steep. It is of volcanic origin and its geological history is described by Geister (in press). General descriptions are given in Geister (in press), Loboguerrero (1954), Mora (1940), Ortega-Ricaurte (1944), Pagnacco and Radelli (1962) and Werding et al. (1981).

A $32 \mathrm{~km}$ long, 50-200 $\mathrm{m}$ wide barrier reef, about 1 mile $(1.6 \mathrm{~km})$ from the coast, surrounds the south, east and north sides of the island. It begins about $2 \mathrm{~km}$ off South Point, follows a NNE direction for $27 \mathrm{~km}$, turns westwards at a point known as "The Elbow" and ends about $1 \mathrm{~km}$ south of Low Cay at Table Rock, an isolated, circular, shallow cavernous rock formed of dead corals and overgrown by algae. This is $10-20 \mathrm{~m}$ in diameter and rises vertically from several metres depth. Low Cay is a spit of Acropora palmata shingle situated on the reef flat near the north-west end of the barrier where wave refraction results in heavy surf. South of this, strong surf has resulted in the formation of an algal ridge $(30 \mathrm{~cm}$ high) of encrusting red algae Melobesieae which is exposed at low tide. The northern part of the reef and lagoon resemble an incomplete atoll, both geomorphologically and ecologically. The southern half is more typical with a true barrier reef and lagoon. In the west, elongated patch reefs and submarine ridges suggest imperfect development or erosional remnants of the barrier reef. Two large deeper lagoons occur to the north of the island and two smaller ones to the east and south, all of which inter-connect via shallow-water areas.

The west of the island is characterized by sandy and rocky flats and sea grass beds at variable depths with no significant coral growth although there are abundant octocorals, sponges and some corals (Márquez in litt., 30.1.86). The north and south-west leeward sides of the island are thought to be similar. Providencia and the islet of Santa Catalina are separated by a shallow channel up to $5 \mathrm{~m}$ deep. The entrance to Catalina Harbour is partly obstructed by Lawrance Reef, a $700 \mathrm{~m}$ long coral shoal surrounded by a sandy flat about $8 \mathrm{~m}$ deep covered by seagrass. Cayo Crangrejo and Cayos Hermanos are volcanic islets partly surrounded by reefs, rising several $m$ above sea-ievel to the east.

Reef Structure and Corals The coral fauna and marine communities of Providencia resemble those of San Andrés. Werding et al. (1981) describe a variety of marine communities, studied at 24 sites, which include coral reefs. Prahl (1982) describes reef and mangrove communities. A survey of the reefs was carried out between 1969 and 1979 (Geister, 1983 and in press) and reef zonation is discussed in Geister (1977). The reef complex was subdivided into four units: the fore-reef terrace; the windward barrier reef; the lagoon with patch reef and fringing reefs; and the leeward shelf and outer slope.

The fore-reef terrace, one to several kilometres wide, consists of a rocky flat sloping gently seaward from the barrier reef to a depth of $20-30 \mathrm{~m}$, where the outer slope of the insular shelf starts. A ridge at $23-30 \mathrm{~m}$ depth may be a remnant of an ancient barrier reef and the wide depression in the fore-reef terrace towards the north-east may be an ancient Pleistocene lagoon. The fore-reef terrace has been surveyed to a depth of $15 \mathrm{~m}$ where scattered scleractinians and gorgonians were found. Above $10 \mathrm{~m}$ the terrace becomes more irregular with coral patches, mainly $A$ palmata, in shallower water. Isolated reef buttresses occur in some places, covered with a profuse growth of Millepora and Palythoa. In the Elbow area, the fore-reef terrace gradually shoals towards the reef flat. Reef growth, especially of Millepora, is rich only around the leeward margin of the flat, from where a slope leads down to the lagoonal terrace. Montastraea annularis and gorgonians cover the lower part of the slope.

In some areas, the barrier reef consists of continuous segments which rise steeply from the fore-reef terrace from a depth of $4-8 \mathrm{~m}$ to the reef flat near low tide level. At its leeward margin the reef flat either disintegrates into irregular coral shoals or ends at a break-off to the lagoonal terrace. Much of the flat may become emergent during spring low tides. Well developed spur and groove systems are found in several places, the spurs decreasing in height towards the fore-reef terrace and finally becoming discontinuous. The grooves are generally several metres wide, and lead down to the fore-reef terrace where some continue as shallow sandy channels. Mille pora is dominant in shallower parts of the barrier, commonly associated with coralline algae. Behind the reef flat, and in front of it in deeper water, patchy but luxuriant thickets of $A$ palmata may be seen, with large colonies of Diploria strigosa.

Where the barrier reef does not form a continuous reef, the fore-reef terrace merges with the lagoonal terrace in a transitional zone marked by numerous irregular coral pinnacles generally rising from $4-8 \mathrm{~m}$ depth to low tide level and separated from each other by a few metres to more than $20 \mathrm{~m}$. The tallest pillars have a reef flat near low tide level and reach several metres in diameter (Geister, 1983). All have a highly cavernous structure. The richest coral growth is generally restricted to the upper portions of the pillars, the lower parts being dominated by encrusting red algae Melobesieae and soft algae Turbinaria, Padina, and Dictyota. Millepora is the main hard coral down to $2-3 \mathrm{~m}$ depth and is found with Palythoa and thin crusts of coralline algae. Lower, thickets of A. palmata and Diploria spp. with loose patches of Montastraea annularis and octocorals are found.

The shallow, sandy lagoonal terrace, fringing the lee of the barrier and some of the larger patch reefs, may attain a width of $1.2 \mathrm{~km}$ and in places ends at a sand cliff which drops down to the bottom of the lagoon at $10 \mathrm{~m}$ or more depth. The lagoon floor is mainly covered with white 
sand and coral debris. Extensive carpets of $A$ cervicornis occur in certain shallow lagoonal areas north and east of the islands.

Numerous patch reefs of varying size are dotted over the floor of the lagoonal terrace and basin and, in certain areas of the eastern lagoon, there are shallow ribbon reefs, some more than $1 \mathrm{~km}$ long. In parts, a luxuriant growth of $A$ cervicornis is found. Four types of patch reefs were observed: a) shallow patch reefs of Palythoa - Millepora near the barrier, well exposed to swell or surf; b) patch reefs in shallow agitated water, generally on the lagoonal terrace where $D$. strigosa and $A$ palmata predominate; c) shallow patch reefs rimmed with rich $A$ cervicornis thickets such as White Shoal, and d) quiet-water patch reefs in deeper water or protected positions with gorgonians and several scleractinian species dominated by Montastraea annularis. Occasionally mixed stands of $M$. annularis and $A$ cervicornis form well-developed patch reefs in the shallow lagoon. Many coral patches in the deeper lagoon east of the island were found to be dead or almost dead, largely overgrown by soft algae, but this was not thought to be due to human disturbance.

The outer slope has only been visited at the Blue Hole site, to the north-west of Santa Catalina, where an almost vertical submarine cliff is covered by rich coral growth. The drop-off descends from a marginal shelf terrace at $18 \mathrm{~m}$ to a narrow sandy bench at $33 \mathrm{~m}$ from where a steep slope continues to greater depths. The coral fauna is characterized by $M$. annularis, Porites astreoides, $P$. clavaria, Siderastrea siderea and a few colonies of the pillar coral Dendrogyra cylindrus. Sea-fans and other octocorals are abundant. Along the deeper escarpment Eusmilia fastigiata, Colpophyllia natans, mussids, including Scolymia lacera and S. cubensis, and Meandrina meandrites become very conspicuous. Large plate-like agaricids such as Agaricia undata are locally dominant (Geister, 1978).

A shallow fringing reef lines the leeward shore of Santa Catalina Island, north and west of Cabeza Morgan, the western point of the island. Its shallow, narrow reef flat, overgrown by a carpet of $P$. porites, ends abruptly at a steep to vertical reef front, dropping down to a sandy lagoon floor at several metres depth. The coral fauna of the reef front reflects calm-water conditions with abundant Montastraea annularis and branching gorgonians such as Plexaura sp. Lawrance Reef has relatively steep flanks, rising in some places to $2 \mathrm{~m}$ below the surface. The reef crest is well developed in these shallower areas and is dominated by Acropora palmata. Patches of $A$ cervicornis and Porites porites var. furcata are common on shallow parts of the slopes. Deeper more mixed faunal associations of $M$. annularis, $P$. clavaria, Diploria sp., Siderastrea siderea, Stephanocoenia michelini, Dendrogyra cylindrus and branching gorgonians are found (Geister, 1978).

According to Geister's reef zonation scheme (Geister, 1977), the Providencia reefs can be classified as follows: a) the north-western segment of the barrier reef is a Melobesieae reef; b) the remaining barrier reef, a Palythoa-Millepora reef; c) Lawrance Reef, a strigosa-palmata reef, and d) the fringing reef at Santa Catalina, a porites reef. As a result of the great variation in wave exposure within the lagoon, patch reefs belong to the following types: Palythoa-Millepora, strigosa-palmata, cervicornis and annularis.

Noteworthy Fauna and Flora There are abundant stands of mangrove along the north-east and north-west coasts and small areas on the north and south coasts described in detail by Prahl (1982). Werding et al. (1981) provide species lists for anemones, sponges, polychaetes, molluscs, crustaceans (including those found in mangroves), echinoderems ( 23 species), fish (231 species) and birds. There is a high density of Strombus gigas in Bahía Agua Dulce on the west coast. The West Indian Top Shell Cittarium pica is found abundantly between rocks at low tide level at Low Cay, and is considered a great delicacy by many islanders. Spiny lobster Panulins argus is abundant in rocky areas especially on the east of the island; other crustacea are described by Coventry (1944). Fish are described by Fowler (1944 and 1950) and Garzón and Acero (1983). At Table Rock, swift currents, turbulence and numerous caves attract several species of large fish including sharks Carcharhinus sp. Manta Rays are occasionally seen in Bahía Catalina (Geister in litt., 22.5.84). The Loggerhead Turtle Caretta caretta nests in the area and the Green Turtle Chelonia mydas, the Hawksbill Eretmochelys imbricata and the Leatherback Dermochelys coriacea may nest in Bahia del Suroeste, $1 \mathrm{~km}$ south of Bahía Agua Dulce (Gallego, 1978; Carr et al., 1982). Terrestrial fauna and birds are described in Bond (1950), Bond and DeSchauensee (1944), Dunn and Saxe (1950) and Gallego (1978). Audubon's Shearwater Puffinus Iherminieri loyemilleri may nest on the island although it is reportedly close to extinction (Halewyn and Norton, 1984); Cayo Crangrejo may be its only nesting site in Colombia. The Boobies Sula sula, S. leucogaster and $S$. dactylatra, the Magnificent Frigatebird Fregata magnificens and a number of terns have been reported (Gallego, 1978). Migratory birds are listed by Gallego (1978).

Scientific Importance and Research The reef complex is unique in that it surrounds the only high altitude volcanic island situated off the Middle American shelf. The barrier reef is one of the largest in the western hemisphere, after the Belize Barrier Reef (Geister, 1978). The island has recently been the subject of a major study (Gallego, 1978; Prahl, 1982; Werding et al., 1981) by INVEMAR, supported by WWF, and was visited by a number of earlier expeditions including the Fifth George Vanderbilt Expedition and the Catherwood-Chaplin West Indies Expedition in the 1940s.

Economic Value and Social Benefits Bahía Catalina forms a natural harbour between Santa Catalina and Providencia, the latter of which can be reached by air and boat from San Andrés. The tourist industry is developing rapidly. The inhabitants make a living from fishing, agriculture and cattle breeding (Pagnacco and Radelli, 1962). The artisanal fishery at Bahia del Suroeste was studied by Garzón and Acero (1983) and Werding et al. (1981). Fish (groupers, snappers and porgies), conch (which are still relatively abundant) and lobsters are particularly important and turtles are caught. Nets are the main method of fishing but sometimes spearguns are used. A fish freezing plant has been established, the products being sent by air to San Andrés hotels (Geister in litt., 22.5.84).

Disturbance or Deficiencies Damage to the reefs has 
not been studied but the marine communities are considered to be little disturbed at present (Werding et al., 1981). Occasional hurricanes may affect the reefs (Pagnacco and Radelli, 1962). There are frequent shipwrecks. Rubbish and solid waste are discharged directly into the sea and potentially threaten the reefs through pollution. Sand is taken from the beaches for construction purposes and its removal may have damaging consequences in the future. An airport has been built close to the main mangrove area, which may alter the coastal environment (Mow-Peters in litt., 15.11.84; Werding et al. 1981). Turtle populations have declined due to over-exploitation and loss of nesting sites but the decline is not as serious as on San Andrés (Carr et al., 1982).

Legal Protection Under Resolución Ejecutiva Número 023 of 26 February 1971, the areas of Bahía de Agua Dulce, Cayo del Cangrejo and Bahia del Suroeste are declared protected areas for bathers.

Management The above areas are administered by the Corporación Nacional de Turismo de Colombia and fishing is controlled by INDERENA, but to date there has been little attempt at management (Mow-Peters in litt., 15.11.84).

Recommendations The local government will shortly be developing a programme which will lead to the declaration of the island as an "área de manejo especial", and improved management of the areas already declared as terrestrial reserves. Gallego (1978) lists recommendations for the terrestrial fauna which include preventing the introduction of further exotics into the island, protecting the remaining woodland and mangroves, and protecting turtle nesting beaches and sea bird rookeries; the need for an integral management plan is stressed.

Recommendations for the marine environment are given in Werding et al. (1981). The mangrove areas should be protected; the development of the fishery industry should be undertaken with care and traditional methods maintained; tourism should be controlled and waste disposal in the sea should be prohibited. Further management-oriented research is required on lobsters and Strombus gigas. The establishment of a marine station is recommended and suggestions for further research are made. It is recommended that sand dredging, the disposal of waste into the sea and coastal developments of a destructive nature be prohibited (Mow-Peters in litt., 15.11.84).

\section{BANCO RONCADOR}

Geographical Location $13^{\circ} 34^{\prime} \mathrm{N}, 80^{\circ} 04^{\prime} \mathrm{W} ; 200 \mathrm{~km}$ north-west of Cayos del E.S.E. and $140 \mathrm{~km}$ west of Providencia.

Area, Depth, Altitude $11 \mathrm{~km}$ long and $3.5 \mathrm{~km}$ wide at its widest part; lagoon depths average $10-12 \mathrm{~m}$, reaching $18 \mathrm{~m}$ in some places.

Land Tenure Claimed in the mid-19th century with Banco Serrana by the U.S. for guano (Milliman, 1969).
Since 1981 completely ceded to Colombia and now state-owned.

Physical Features The bank lies on volcanic foundations and resembles a fish-hook in shape. Cayo Roncador $(400 \times 150 \mathrm{~m})$ is covered mainly by coral rubble. A sand spit about $15 \mathrm{~m}$ in diameter lies on the inner reef flat of the north-eastern peripheral reef with beaches strown with coral debris and Strombus shells. A second sand spit (15 $\mathrm{m}$ in diameter) lies on the southern peripheral reef flat. Air temperatures averaged $27.9^{\circ} \mathrm{C}$ and water temperatures $28^{\circ}-28.4^{\circ} \mathrm{C}$ in 1969 (Milliman, 1969).

Reef Structure and Corals There is a well developed windward peripheral reef with a Millepora zone which extends up to $50 \mathrm{~cm}$ above water. The back-reef is shallow and often awash at low tide. Large boulders, standing up to $1.5 \mathrm{~m}$ above the reef flat, line extensive portions of the outer reef flat formed from lenticular blocks. Leeward peripheral reefs are poorly developed and, except for a few large but deep $(2-3 \mathrm{~m})$ patch reefs defining the peripheral reef to the south, the lagoon is open. Low-lying patch reefs cover at least a third of the lagoon, interspersed by sand patches (see "Introduction" for general description).

Noteworthy Fauna and Flora Vegetation is sparse; low-lying Tournefortia bushes and a creeping vine cover only small portions of the island. A hawk, boobies and terns have been recorded (Bond and DeSchauensee, 1944; Milliman, 1969) and seabirds migrate to Roncador to nest (Parsons, 1956). Halewyn and Norton (1984) report four nesting species of seabird including the Red-footed Booby Sula sula, Brown Booby S. leucogaster, Sooty Tern Sterna fuscata and the Brown Noddy Anous stolidus. The Loggerhead Caretta caretta, Hawksbill Eretmochelys imbricata and Green Turtle Chelonia mydas occur and the two former nest (Carr et al., 1982).

\section{Scientific Importance and Research Not known.}

Economic Value and Social Benefits During the last century the cay was inhabited by guano workers, remains of walls they constructed from coral still being visible (Milliman, 1969). The bank has long been visited by fishermen and the commercial lobster fishery is currently of major importance (Mow-Peters in litt., 15.11.84); boats from Cartagena frequently fish there (Carr et al., 1982).

Disturbance or Deficiencies In 1956 it was reported that an estimated 25000 seabird eggs were being removed annually by natives from San Andrés and Providencia (Parsons, 1956). Bird colonies are now being disturbed by soldiers and their dogs (Mow-Peters in litt., 15.11.84). The reefs may be affected by the lobster fishery and turtles have declined dramatically (Carr et al., 1982).

\section{Legal Protection None.}

\section{Management None.}

Recommendations A status survey of the bank and reef resources is required. 


\section{ISLA DE SAN ANDRES PROPOSED MANAGEMENT AREA AND HAINE CAY TO COTTON CAY ZONA DE RESERVA NATURAL}

Geographical Location $12^{\circ} 28^{\prime}-12^{\circ} 36^{\prime} \mathrm{N}, 81^{\circ} 40^{\prime}-81^{\circ} 44^{\prime} \mathrm{W}$; an oceanic island lying $200 \mathrm{~km}$ off the coast of Nicaragua, some $720 \mathrm{~km}$ WNW of the Colombian coast.

Area, Depth, Altitude The island is $12 \mathrm{~km}$ long (N-S) and $3 \mathrm{~km}$ wide with a maximum elevation of $100 \mathrm{~m}$.

Land Tenure Largely private land; some state owned such as the Naval Base and the small islets of Cayo Sucre (Johnny Cay), Cayo Coroloba (Haine Cay), Cotton Cay and Rocky Cay.

Physical Features The island, the largest in the San Andrés and Providencia Archipelago, rises steeply from the sea floor at a depth of about $2000 \mathrm{~m}$ and is situated some $80 \mathrm{~km}$ off the Middle American shelf. It is formed from uplifted reef and lagoonal limestone of Tertiary and Pleistocene age, as well as Holocene terrestrial and beach deposits and its geology is described by Milliman and Supko (1968) and Geister (1975). Early general descriptions of the island are found in Loboguerrero (1954), Mora (1940) and Ortega-Ricuarte (1944). The slopes around the coast are very steep, especially in the south and west where they exceed $25^{\circ}$ to depths greater than $800 \mathrm{~m}$. Although rather limited, there are some sandy beaches. In some areas such as Johnny Cay and on parts of the beach south of San Luis, on the east coast, the sands have been cemented to form beach rock (fig. 6 in Geister, 1975; Kocurko, 1977). The island is surrounded by a submarine terrace $200-500 \mathrm{~m}$ wide and about $20 \mathrm{~m}$ deep at its outer margin, which, in the east and north, lies outside the barrier reef. The north coast consists of coral limestone platforms undercut by a shelf and two beach areas. The west or leeward coast has two submarine terraces with marginal escarpments at 4 and $20 \mathrm{~m}$ depth (Geister, 1975).

The reef complex surrounding the island includes barrier, fringing and patch reefs, and lagoons and rocky flats. A large, living submerged barrier reef with lagoonal basin has been found east of the island, outside the modern barrier reef; the minimum depth at the reef crest is $20 \mathrm{~m}$ (Geister, 1975). A fringing reef ("Little Reef") flanks the north-east side and protects a shallow (less than $3 \mathrm{~m}$ deep) boat channel and calcareous sand beaches (Kapraun, 1972). A barrier reef is situated 2-3 km from the shore to the north and east, divided into two sections, Big Reef in the north and East Reef to the east. Within its northern arc is Johnny Cay, a small sandy island less than $300 \mathrm{~m}$ long. Nearby there are some extremely surf exposed coral algal platforms (the Blowing Rocks and Table Rocks) forming true algal ridges (figured in Geister $1973 \mathrm{~b}, 1975$ and 1983). The barrier reef lagoon is $2-3 \mathrm{~km}$ wide and up to $12 \mathrm{~m}$ deep with scattered patch reefs. Water depth across the top of the barrier reef is normally less than $30 \mathrm{~cm}$ on East Reef where corals are commonly exposed during spring tides, but up to $2 \mathrm{~m}$ on Big Reef. The immediate back-reef water depth is generally less than $2 \mathrm{~m}$ whereas the immediate fore-reef water depth may be $5-8 \mathrm{~m}$.

A fringing reef extends $5 \mathrm{~km}$ down the south-east coast from Bahía Sonora (South Bay) to South Point, less than $300 \mathrm{~m}$ from the shore with a boat channel up to $250 \mathrm{~m}$ wide, which is $4 \mathrm{~m}$ deep in the north and very shallow and narrow in the south. There are no distinct reefs along the west coast but a significant coral population is found there (Kocurko, 1977). There is a well developed leeward reef in the north-west ("Bar"), the northem tip of which ("Top Blowing Rock") is exposed to violent surf because of interference of different wave trains (Geister, 1975).

Rainfall averages $1750 \mathrm{~mm}$ a year, most occurring between July and December (Parsons, 1956). The prevailing winds and currents are easterly or north-easterly. Water temperatures range from 26 to $31^{\circ} \mathrm{C}$, averaging $27-28^{\circ} \mathrm{C}$, but occasionally rise above $40^{\circ} \mathrm{C}$ in shallow lagoons, and there is a tidal range of 30 to $60 \mathrm{~cm}$ (Geister 1973b and 1975).

Reef Structure and Corals The leeward coral communities are described by Geister (1975) and Kocurko (1977). This side of the island is characterized by a) well-developed cliffs, caves and wave-cut notches, b) encrusting red algal accumulations in the surf zone, c) accumulations of massive corals at the faces of some large submarine cliffs and d) extensive alcyonarian gardens. The shore zone is dominated by crustose coralline algae. Seaward of this is the upper platform zone, a narrow shelf ranging from 0.5 to $4 \mathrm{~m}$ in depth and from several metres to approximately $0.5 \mathrm{~km}$ in width which is dominated by alcyonarians, encrusting scleractinians and sponges. Below this, a cliff and cave zone is characterized by zoantharian corals with large massive faviid colonies locally concentrated on the face of drowned cliffs (Geister, 1975 and 1983). The caves support a rich community of Stylaster, sponges and bryozoans. The lower platform at $20 \mathrm{~m}$ depth is characterized by fine-grained, carbonate sediments dominated by scattered patches of alcyonarians along the drowned cliff towards its outer margin, and a dense coral carpet. This zone terminates seaward in a marginal escarpment or outer cliff (Geister 1975 and 1983).

The windward reefs on the east and north-east coasts are described in detail by Geister (1973b, 1975 and 1977) and the zonation is summarized by Kocurko (1977). These reefs are of the Palythoa-Millepora type, except for sectors with algal ridges that are Melobesieae reefs (Geister, 1975 and 1977). Seagrass beds are found seaward of the shore zone usually dominated by Thalassia testudinum and some Cymodocea manarorum. Small zoantharian corals are also found here including Diploria clivosa, Manicina areolata, Porites porites, $P$. astreoides and Siderastrea radians with the echinoid Lytechnicus variegatus. The immediate back-reef area is characterized by Acropora palmata and $D$. strigosa in the main reef zone and effective sediment binders in the turtle grass areas.

The back-reef lagoon consists of areas of barren sand and patch reefs. The lagoon has a flat bottom and is almost completely enclosed by shallow sandy platforms, locally of eroded limestone. The sandy areas are characterized by small, scattered patches of Halimeda, foraminifers, Strombus gigas, Pinna sp., scaphopods, burrowing worms, crustaceans and echinoids. Patch reefs are scattered throughout the lagoon and are round to oval in shape, domed, and $10-30 \mathrm{~m}$ or more in diameter. Water depth over the patch reefs ranges from 0 to $10 \mathrm{~m}$. The patch reef community is generally dominated by rich scleractinian growth with locally abundant gorgonians. M. annularis appears to dominate the deeper 
patch reefs and $A$ palmata the shallower ones. Gorgonians are found on both types but prefer intermediate depths of 3 to $7 \mathrm{~m}$. Other organisms occurring in the patch reef environment include encrusting algae, Millepora sp., numerous small zoantharian corals, gastropods, sponges and crustaceans. Geister (1975 and 1977) classifies the lagoonal fringing reefs and patch reefs as strigosa-palmata reefs, cervicornis reefs, porites reefs and annularis reefs.

The lagoonal terraces seem to be Pleistocene terraces covered by barren sand, rubble deposits and small patch reefs. In the sand areas, communities consist only of gastropods Strombus gigas, Vasum muricatum and Oliva sp., the echinoid Clypeaster subdepressus, burrowing crustaceans and corals adapted to the unstable bottom such as Manicina areolata, Sidereastrea radians, $P$. porites and locally $A$ cervicornis (Geister, 1980). The scattered patch reefs, usually less than $20 \mathrm{~m}$ in diameter and $2 \mathrm{~m}$ high are dominated by $A$ palmata, $P$. porites and $D$. strigosa. Other organisms include Diadema antillarum and Eucidaris tribuloides, sea anemones, gastropods Astraea sp. and Conus sp., Millepora sp., crustacears and sponges.

The northern part of the barrier reef, Big Reef, has a gentle slope on the seaward side with only a sparse community of corals and algae. At the crest is a well-developed community of $M$. complanata, Palythoa mammillosa and encrusting algae. Twenty-five species of zoantharian corals have been identified from the reef crest zone, although only about ten of them are frequent. There is a major spur and groove system at the rear of the reef crest (Geister 1975 and 1983). The fore-reef terrace is characterized by a hard, limestone bottom, covered by numerous small zoantharian corals and alcyonarians, which extends seaward for several $100 \mathrm{~m}$ and locally up to $2 \mathrm{~km}$. Narrow and very shallow sandy channels stretch seaward, probably representing a weakly developed spur and groove formation. The southern section of the northern reef, East Reef, and the southern reef, Half-a-Reef have a shallow reef flat at spring low tide level and well developed spur and groove systems in the fore-reef area. The spurs consist mainly of Mille pora and calcareous algae. Zoantharians, corals, gastropods, alcyonarians, isolated patches of $A$ palmata and $M$. annularis are also present. The Millepora spurs are up to $8 \mathrm{~m}$ high and $3+\mathrm{m}$ wide, rising to within a few $\mathrm{cm}$ of sea-level and are separated by narrow, vertical-walled grooves that are from less than $1 \mathrm{~m}$ to several metres wide.

The whole San Andrés reef complex has been mapped in detail and Geister (1975) provides numerous ecological profiles. Forty-nine species and subspecies of scleractinians and hydrocorals are listed by Geister (1975); an additional species Solenastrea hyades was found by Geister in 1977. The apparent absence of the common genera Oculina, Cladocera and Tubastrea is notable. The ecology and distribution of the pillar coral Dendrogyra cylindrus, which is found in quiet back-reef and leeward reef waters at $1-20 \mathrm{~m}$ depth, is described in Geister (1972).

Noteworthy Fauna and Flora Geister (1973a) recorded 121 species of marine molluscs from the reef complex, with some additional species in Burgl (1961); crustaceans are described in Coventry (1944). Kapraun (1972) recorded and described 47 species of benthic marine algae. The lagoon in the north-east has extensive areas covered with Thalassia testudinum mixed with a large number of siphonous green algae including Pencillus capitatus, Caulerpa racemosa, C. cupressoides and $C$. sertularioides. Sea turtles probably nest here rarely now although the Green Turtle Chelonia mydas, the Hawksbill Eretmochelys imbricata and the Loggerhead Caretta caretta occur (Carr et al., 1982). Birds of the island are described by Bond (1950) including 15 species endemic to San Andrés and Providencia. Audubon's Shearwater Puffinus Iherminieri loyemilleri may nest on the island although it is reportedly close to extinction (Halewyn and Norton, 1984). The Noddy Anous stolidus may nest on Johnny Cay and a number of terns have been recorded (Gallego, 1978). Reptiles, including an endemic snake Coniophanes andresensis, are described by Dunn and Saxe (1950) and Valdivieso and Tamsitt (1963), fish, including the endemic swamp-dwelling Gambusia aestiputens, by Fowler (1944 and 1950), and terrestrial plants by Proctor (1950) and Toro (1929 and 1930). Additional information is given in Barriga et al. (1969). There are no native mammals.

Scientific Importance and Research The breaker zone of the barrier reef differs from that of most other Caribbean reefs in that Millepora, rather than A palmata, is the dominant coral. Furthermore, an algal ridge is present in some places, possibly because the reef is exposed to the high swell of the western side of the Caribbean Sea. A scheme of ecological zonation based on coral distribution according to depth (light levels) and wave exposure, developed during work on the San Andrés reef complex (Geister, 1975), has subsequently been successfully applied to Caribbean reefs in general (Geister, 1977, 1983 and 1984). San Andrés and Providencia have been visited by several expeditions including the Pinchot South Sea Expedition (Pinchot, 1930), the Fifth George Vanderbilt Expedition (Vanderbilt, 1944), and the Catherwood-Chaplin West Indies Expedition (Ripper, 1949); these expeditions resulted in a number of publications.

Economic Value and Social Benefits San Andrés is a free port. Its strategic location, with Providencia, has made it the object of many historical colonial exploits (Milliman, 1969). There is a population of over 50000 , with tourism and commerce being the main activities in the north, where the capital is located, and subsistence farming, coconut plantations and fishing in the rest of the island (Geister in litt., 22.5.84). Cayo Roso (Rose Cay) is a tourist attraction; tourists are taken by launch to submerged beach rock formations, about $1.3 \mathrm{~m}$ deep, for snorkelling (Geister in litt., 25.11.84). The lobster industry is expanding rapidly (Mow-Peters in litt., 15.11.84).

Disturbance or Deficiencies Occasional hurricanes affect the reefs (Geister in litt., 25.11.84). The reefs, mangroves and lagoon on the east coast are threatened by the outflow of hot cooling water and waste oil from the power plant in town. Currents spread such disturbances southwards threatening the shallow-water biota such as seagrass beds, nearshore reefs and mangroves. On the west coast, refuse from hotels and residences is dumped into the sea south of Horn Landing. There are ship wrecks on East Reef, Half-a-Reef, in front of Rocky Cay and near Bocatora Hole (Geister in litt. 22.5.84; Mow-Peter in litt. 15.11.84). 
Sand has been dredged from the lagoonal areas, particularly Coco Plum Bay, and has been lost from beaches as a result of destruction of mangroves in the capital during land reclamation projects, the widening and deepening of the ship channel and harbour basin, and to provide building material. In Sound Bay and around the north coast there has been noticeable beach erosion due to the removal of sand from the upper parts of the beach. Mangrove destruction has contributed indirectly to the death of many coconut trees, due to the spread of a disease which can only be controlled by a beetle which inhabits the mangrove swamps (Geister in litt., 25.11.84; Mow-Peters in litt., 15.11.84).

In the late 1960 s, reef sharks Carcharhinus spp. were common around the Blowing Rock area but are now rare, possibly because of frequent disturbance by tourist divers (Geister in litt., 25.11.84). Turtle populations have declined through over-exploitation and loss of nesting habitat since most suitable beaches have been developed (Carr et al., 1982).

Legal Protection Resolución Ejecutiva No. 023 of 26 February 1971 declares an area of Bahía de San Andrés, between Haine Cay and Cotton Cay, as a Zona de Reserva Natural. Fishing is only permitted with an appropriate licence, and the reserve is considered primarily as a tourist attraction. Fishing has been banned since the 1960s at Cayo Roso ("El Acuario") within the reserve area. The three eastern segments of Little Reef, to the north-east of Hansa Point, are reported to have been protected since at least August 1979 and a signboard on the beach declares that spearfishing and collecting of marine organisms are prohibited (Geister in litt., 25.11.84).

Management The reserve around Haine Cay and Cotton Cay is administered by INDERENA and the Corporación Nacional de Turismo de Colombia, but to date there has been little attempt at management.

Recommendations The government will shortly be developing a programme which will lead to the declaration of "areas de manejo especial" and improved management of the existing reserves.

To reduce pollution in the lagoon and shallow water areas of the north-west coast, as no treatment plant has yet been built, sewage from the capital could be pumped directly into the sea north of German Point where a strong current would take it away from the insular shelf (Geister, 1975). Refuse on the island could be reduced by only importing drinks in bottles that are recycled and by buming all rubbish. As there is no appropriate area on the island for a proper refuse depot, because of potential ground water pollution, burned rubbish could be disposed of in deeper water beyond the leeward insular shelf, if no better solution can be found. The hot cooling water of the electricity plant should be pumped by pipeline to the deeper lagoon where it would cool faster and avoid damage to the rich communities of the immediate near shore. Sand dredging should not be permitted in the lagoonal areas to prevent siltation of the patch reefs but could be taken from the north and south points of the island where swift currents would carry suspended silt out to sea. If sand is to be taken from the beaches, areas at the bottom should be used rather than at the top (Geister in litt., 25.11.84; Mow-Peters in litt., 15.11.84). Traditional buildings, rather than cement constructions, should be put up to lessen the demand for sand. To avoid further damage to the coconut industry, the remaining mangrove stands should be managed or declared reserves, to provide a habitat for the beetle which can control the fungal disease. Artisanal fisheries should be considered a higher priority than commercial fisheries for development and management (Mow-Peters in litt., 15.11.84).

\section{BAHLA DE SANTA MARTA (INCLUDING PUNTA DE BETIN, MORRO GRANDE AND MORRITO)}

Geographical Location South-west of the Península de La Guajira, at the foot of the Sierra Nevada de Santa Marta, opposite the town of Santa Marta; $11^{\circ} 15^{\prime} \mathrm{N}$; $74^{\circ} 13^{\prime} \mathrm{W}$

Physical Features Punta de Betin is a high, narrow rocky cape forming the north-western end of the bay of Santa Marta. Its eastem shore is very sheltered with a shallow inner shelf of boulders scattered over a gravel and sand flat. Scattered coral growth is restricted to rocky surfaces. The western shore consists of steep rocky slopes which plunge to a depth of $20 \mathrm{~m}$ before flattening out to muddy sandy flats at $25 \mathrm{~m}$ depth. Morrito lies to the west of Punta de Betín, separated by a narrow channel and is little more than a rocky outcrop. Morro Grande, $1 \mathrm{~km}$ further west, is a high and narrow ridge about $500 \mathrm{~m}$ long (NE-SW axis). The marine environments of both islets are similar, with steep rocky slopes except on the landward side of Morrito, where there is a flat, coarse gravel area $4 \mathrm{~m}$ deep. The leeward sides of both islets are coral covered down to $25 \mathrm{~m}$ depth where the slopes are replaced by sand flats. At the western and northern side of Morrito, coral growth extends to $30 \mathrm{~m}$ depth (Antonius, 1972). Surface water temperatures in July in the Bahia de Santa Marta are $24^{\circ} \mathrm{C}$. The lack of reef construction in this area may be due to occasional cold upwellings (Antonius, 1972).

Reef Structure and Corals Corals in the vicinity of the Bahía de Santa Marta are described by Antonius (1972) and Erhardt and Werding (1975b). The scattered coral growth on the eastern shore of Punta de Betin is dominated by Millepora complanata. Only four scleractinians (Diploria strigosa, Manicina areolata, Siderastrea radians and Favia fragum) have been recorded. On the western coast coral abundance decreases with depth; Millepora complanata, $M$. squamosa and $F$. fragum are abundant down to a depth of $1 \mathrm{~m}$ and $M$. cavernosa predominates at greater depths $(20-25 \mathrm{~m})$. Colpophyllia natans and Diploria strigosa dominate at depths between 4 and $15 \mathrm{~m}$. In the deeper waters $(20-30 \mathrm{~m})$ around Morrito and Morro Grande, Montastraea cavernosa predominates and may comprise $50 \%$ of the living coral cover. A variety of other corals are also found, most colonies occurring as either encrusting or disc-shaped forms. Above depths of $20 \mathrm{~m}, C_{\text {a }}$ natans is dominant (Antonius, 1972). Gorgonians are also abundant, their distribution related to current intensity and water turbidity (Márquez in litt, 30.1.86).

Noteworthy Fauna and Flora The marine fauna and flora of this area are extremely well known. Reef fish were described by Albrecht (1968 and 1969) and Acero 
(1978 and 1979). The fauna of unstalked crinoids (seven species) at Santa Marta, described by Meyer and Macurda (1976), is considered to be unique in the tropical western Atlantic. The Caribbean Manatee Trichechus manatus, the Leatherback Dermochelys coriacea, Hawksbill Eretmochelys imbricata, Green Turtle Chelonia mydas and Loggerhead Turtle Caretta caretta occur here and the last three may nest (Carr et al., 1982; Bacon et al., 1984). The Ciénaga Grande de Santa Marta, a complex of wetland habitats near the mouth of the Rio Magdalena is the most important site for waterfowl on the Caribbean coast of Colombia (Scott and Carbonell, 1986).

Scientific Importance and Research INVEMAR, the Instituto de Investigaciones Marinas de Punta de Betín, is based at Santa Marta and runs courses and carries out a variety of research work in this area. Numerous papers on the marine environment and coral reef fauna and flora have been published in no. 1-10 of the Mitteilungen aus dem Instituto Colombo-Alemán de Investigaciones Cientificas de Punta de Betín, which, since 1979 (no. 11), has been continued under the name of the Anales del Instituto de Investigaciones Marinas de Punta de Betin; 59 publications relating to Santa Marta are listed in Alvarez-León and Salzwedel (in press). A popular account of the marine station is given in Albrecht (1968).

Economic Value and Social Benefits The aquarium at the marine station is open to the public.

Disturbance or Deficiencies Mass mortality of the sea urchin was reported in the Santa Marta area in 1983 (Lessios et al., 1984). Insecticides have contaminated the Bahia de Santa Marta, causing heavy mortality on the reef communities at Punta de Betín (Werding and Koster, 1977). Refuse from Santa Marta has been dumped by the truckload into the sea north-east of Punta Betín (Geister pers. obs. 1968-70).

\section{Legal Protection None.}

Management None.

Recommendations In view of the importance of this area for scientific research, it should be considered for management.

\section{BANCO SERRANA}

Geographical Location $14^{\circ} 16^{\prime} \mathrm{N}, 80^{\circ} 20^{\prime} \mathrm{W} ; 70 \mathrm{~km}$ NNW of Roncador.

Area, Depth, Altitude $32 \times 16 \mathrm{~km}$

Land Tenure Serrana and Roncador were claimed in the mid 19 th century by the U.S. for their guano deposits. Most of these have now been removed (Milliman, 1969) and in 1981 Serrana was ceded to Colombia.

Physical Features Banco Serrana is a large atoll on volcanic foundations with six cays. East Cay is a small islet covered with coral and molluse Astrea sp. rubble; Tourne fortia is the only plant present. South Cay (150 $\mathrm{m} \times 25 \mathrm{~m}$ ) is composed mainly of rubble and sand with beach rock lining the seaward beach and has a sparse covering of Tournefortia, Ipomoea and Euphorbia. Little Cay forms the apex of an equilateral triangle with South and Narrow Cays. It is less than $100 \mathrm{~m}$ in diameter and is composed mainly of fine sand with rubble lining the south and east seaward beaches, and beachrock on the south and west sides. Nartow Cay, west of South Cay, is composed of rubble, and the entire reef flat west of the cay is covered with beachrock and rubble. South-west Cay is the largest $(500 \mathrm{~m} \times 200 \mathrm{~m})$ and although most of the island is only a few metres high, sand dunes on the south and west reach heights greater than $10 \mathrm{~m}$. A creeper vine covers much of the low-lying part of the cay and several species of shrubs grow on the dunes. North Cay, on the northern edge of the peripheral reef, is composed of sand and rubble and has three species of plants, Tournefortia, I pomoea and a creeper (Milliman, 1969).

The peripheral reef is well developed on three sides but the western side is completely open. The reef flat, up to $100 \mathrm{~m}$ wide, is generally $1-2 \mathrm{~m}$ deep. By South-west Cay there is a hole $9 \mathrm{~m}$ deep with gradual sandy slopes and some Syringodium grass on the bottom. Two bands of patch reefs, one extending north from East Cay, the other extending south from the northern peripheral reef towards Little Cay, effectively divide the shallow lagoon in half, although water flows over these extensive reef complexes. East of the patch reef bands, depths reach $20 \mathrm{~m}$ but average $15 \mathrm{~m}$, and an estimated $30 \%$ of the bottom is covered with patch reefs which shoal rapidly. Leeward of the linear reef bands, is a broad shallow flat with depths generally less than $10 \mathrm{~m}$, only about $5 \%$ of which is covered with patch reefs. Air and water temperatures average $27.9^{\circ} \mathrm{C}$; salinities range from 35.93 to $36.04 \mathrm{ppt}$. (Milliman, 1969).

Reef Structure and Corals In the lagoon, alcyonarians and gorgonians, with Montastraea heads and scattered clumps of green algae, dominate the eastern coalescing patch reefs in deeper water. As the reef shoals, Acropora cervicornis and $M$. annularis increase in abundance. In depths shallower than $4 \mathrm{~m}, A$ palmata and Millepora alcicornis are prolific. The encrusting coral Porites astreoides is common and $A$ cervicornis exhibits three distinctive growth forms. The most common corals on the reef flat are Montastraea annularis, Liploria, $A$ palmata, $A$ cervicornis and alcyonarians. On the reef front, in depths of $5-10 \mathrm{~m}$, the colonies are small and fragile; at shallower depths $(1-3 \mathrm{~m})$ colonies are longer and thicker but with few branches, and on the reef flat colonies are smaller but with many thick branches. The nature of the bottom and the zonation of the corals on these coalescing patch reefs are similar to the windward peripheral reefs, and are subject to considerable surf. In contrast to the windward reefs however, alcyonarians are more common, red algae are common and the emergent Millepora zone and surge channels lineations are absent. The second, leeward coalescing patch reef has similar zonation (Milliman, 1969). (See "Introduction" for general description).

Noteworthy Fauna and Flora The Loggerhead Caretta caretta, Hawksbill Eretmochelys imbricata and Green Turtle Chelonia mydas occur and the atoll has the best foraging and nesting grounds in the region (Vanderbilt, 1944; Carr et al., 1982). Eight species of birds were recorded in 1941 (Bond and DeSchauensee, 1944) and some 100000 boobies and terns were nesting on 
South-west Cay in 1966 (Milliman, 1969). Halewyn and Norton (1984) list the Magnificent Frigatebird Fregata magnificens, Red-footed Booby Sula sula, Brown Booby S. leucogaster, Roseate Tern Sterna dougallii, Bridled Tern $S$. anaethetus, Sooty Tern $S$. fuscata and Brown Noddy Anous stolidus as breeding. Foraminifera and micromolluscs are described by Bock and Moore (1971).

\section{Scientific Importance and Research No information.}

Economic Value and Social Benefits The bank is very important for the spiny lobster fishery and turtling. There is a military garrison on South Cay (Carr et al., 1982).

Disturbance or Deficiencies In 1941, Cayman Brac natives lived on Banco Serrana most of the year, collecting guano and hunting turtles (Vanderbilt, 1944). In the $1950 \mathrm{~s}$, Jamaicans were reported to collect 300000 bird eggs annually from South-west Cay (Parsons, 1956). The current presence of soldiers and their dogs has had a negative impact on bird populations; turtles may also be taken. The current high intensity of lobster fishing in surrounding waters gives cause for concem as the traps may damage the reefs (Mow-Peters in litt., 15.11.84).

\section{Legal Protection None.}

Management None.

Recommendations A status survey of the bank and its resources is required.

\section{PARQUE NACIONAL TAYRONA}

Geographical Location $11^{\circ} 16^{\prime}-11^{\circ} 23^{\prime} \mathrm{N}, 73^{\circ} 53^{\prime}-74^{\circ} 12^{\prime} \mathrm{W}$; on the coast of the Departamento de Magdalena, to the east of Santa Marta, extending as far as the mouth of the Rio Piedras.

Area, Depth, Altitude $15000 \mathrm{ha}$; $0-900 \mathrm{~m}$ altitude.

Land Tenure Mainly state owned except for 30 properties in private hands totalling about $1500 \mathrm{ha}$.

Physical Features Clifs edge most of the coastline, interspersed with beaches and adjacent submarine terraces with seagrass beds, coral reefs and bays and coves protected by alluvial banks. Inland the topography is irregular. The foot hills of the Sierra Nevada de Santa Marta generally run north-south and have temporary watercourses. Bahía Chengue, $15 \mathrm{~km}$ east of Santa Marta, has been described by Werding and Erhardt (1976). Coral formations are found on the exposed western sides of the bay and on the south and east there are reefs backed by lagoons covered with Thalassia. Prevailing winds are north-easterly. Ensenada de Granate, $5 \mathrm{~km}$ from Santa Marta, is a small bay sheltered on the north and east by the Punta de la Aguja, a large rocky promontory. The bay reaches a depth of $25 \mathrm{~m}$ and the bottom is covered largely by coral formations (Erhardt and Werding, 1975). Bahía de Concha is a deep sheltered bay, $10 \mathrm{~km}$ north-east of Santa Marta, with a small fringing reef (Antonius, 1972; Mergner, 1977). Other bays with coral formations include Bahia Neguanje (east of Bahía Chengue), described by Werding et al. (1976), Bahía Gayraca (between Bahia Chengue and Bahia Neguanje) and Bahia Cinto (Márquez in litt. 30.1.86).

Reef Structure and Corals Zonation in Bahía Chengue is described by Werding and Erhardt (1976). The lagoon on the south-west of the bay is covered with Thalassia with scattered Manicina areolata and Siderastrea radians, and ranges in depth from $0.3-0.4 \mathrm{~m}$ near the beach to $1.5 \mathrm{~m}$ at its deepest point. A canal zone, with a maximum depth of $4 \mathrm{~m}$, separates the lagoon from the reef. The bottom is covered with coral rubble from the reef but also has a variety of live corals. The reef is dominated by Acropora palmata, particularly on the exposed reef crest. On the canal side, Agaricia tenuifolia and Millepora spp. may predominate. The reef slope is covered with diverse coral growth to $6 \mathrm{~m}$. Colpophyllia natans and $S$. siderea are particularly abundant. On the sheltered east side of the bay, large coral covered areas are found. Acropora palmata dominates to depths of $5 \mathrm{~m}$, followed by a zone where Agaricia tenuifolia is most abundant. From 6 to $10 \mathrm{~m}$, Madracis mirabilis predominates and below this, a zone of mixed corals is found. Coral growth in the southern part of the bay is limited by vigorous water movements and increased turbidity.

Thirty-six coral species were described from the Ensenada de Granate, including Tubastrea tenuilamellosa which covered large areas but has not been found in other bays within the park. The zonation in the bay is described by Erhardt and Werding (1975). The Tubastrea zone extends to a depth of $2.5 \mathrm{~m}$ and this species is found mainly in caverns undercut into the rocky slope. Two zones of mixed corals are found further seawards, separated by a bank of sand. The eastern side of the bay is exposed and has a much richer coral fauna.

Twenty species of corals have been described from the Bahía de Concha (Antonius, 1972; Erhardt, 1974; Geyer, 1969). The fringing reef, primarily a Porites reef (Geister, 1977), had a reef flat $10-30 \mathrm{~m}$ wide with a dense monospecific breaker zone of Porites porites, with its seaward edge $30 \mathrm{~cm}$ deep. From here a sandy flat extended down, becoming increasingly steep between 2 and $3 \mathrm{~m}$ and ending in a drop-off at $3 \mathrm{~m}$ depth, falling to $8 \mathrm{~m}$. Around $10 \mathrm{~m}$ depth the slope flattened to a mud flat. Dichocoenia stellaris and $D$. stokesii were dominant in deeper waters $(10-15 \mathrm{~m})$. No obvious zonation was seen between 2 and $10 \mathrm{~m}$ but a number of species were found. Some $20 \%$ of the coral colonies were found to be dead probably due to sedimentation. A poor overgrowth of Millepora squamosa and $M$. alcicornis was found at the reef edge (Antonius, 1972). A reef profile with zonation is given in Mergner (1977).

Noteworthy Fauna and Flora About $90 \%$ of the park is still covered by natural vegetation consisting of semi caducous shrubs and xerophytic scrubland grading to cloud and elfin forest inland. Mangroves are found locally and various endemic plants are found in the Santa Marta region such as Melocactus sp., Mimosa martensis, Caesalpinia ebano and Scheleamagdalenica. Over 100 mammal species are thought to occur in the park, including Jaguar Panthera onca, Paca Agouti paca, 
Crab-eating Fox Cerdocyon thous, Collared Peccary Tayassu tajacu, Red Howler Monkey Alouatta seniculus and other primates. Humpback Megaptera novaeangliae, Blue Balaenoptera musculus and Bryde's Rorqual B. edeni whales are seen in April/May with their young (Hernández pers. comm. 1986). There are 250 birds and 50 reptile species. Marine turtles including the Hawksbill Eretmochelys imbricata and probably the Loggerhead Caretta caretta, Green Turtle Chelonia mydas, and Leatherback Dermochelys coriacea nest there (Carr et al., 1982; Bacon et al., 1984). The Caribbean Manatee Trichechus manatus used to occur in the area but has not been seen recently. In Bahía de Nenguange, 173 species of mollusc have been found (Duque Goodman, 1979). Unstalked crinoids from Concha and Chengue are described by Meyer and Macurda (1976) and chaetodontid fish are described by Erhardt and Werding (1973). Benthic vegetation is described in Guillot and Márquez (1978) and in more detail in Márquez and Guillot (1983).

Scientific Importance and Research Archeological remains of the Tayrona culture are found in many parts of the park and have been studied. Survey and inventory work on a number of taxonomic groups has been carried out. Bahía de Neguange has been studied in detail and papers have been published on the phytoplankton (Caycedo, 1977), molluscs (Duque Goodman, 1979) and many other taxonomic groups. A marine biological field station is situated in the Bahia de Gayraca. Alvarez-León and Salzwedel (in press) list 83 publications concerning Tayrona, many of them carried out by INVEMAR.

Economic Value and Social Benefits Facilities have been provided for tourists and visitors including camp sites, observation posts, bathing areas, a restaurant, hides and observatories. The trap fishery for snappers in Ensenada de Chengue has been studied by Beese (1974).

Disturbance or Deficiencies Agricultural activities and coconut plantations are important on private properties and a paved road crosses the area which was initially proposed for strict protection. Visitors cause some damage especially by leaving rubbish (IUCN, 1982). Increasing sedimentation as a result of deforestation is a continuing threat to the reefs (Werding and Koster, 1977). The reef flat of the shallow Porites porites reef in the Bahia de Concha is being destroyed by people trampling over it. Dynamite fishing and the collection of fish for the aquarium trade has caused problems. Violent storms modify reef structure on occasions (Werding and Erhardt, 1976).

Legal Protection The Park was declared in 1964 and ratified by Acuerdo 04 de 1969.

Management The Park is administered by the Jefe Parque Nacional Tayrona, INDERENA, Santa Marta, Colombia. Staff include the chief forester, an agricultural assistant, a biologist, two technicians, 13 guards and 20 workers. Zonation provides for a strictly protected area, a zone of natural regeneration, one for general recreation, archeological zone and a buffer zone. A brochure has been produced for visitors (IUCN, 1982).

Recommendations The park requires further attention from the government to resolve problems created by existence of private properties within the boundaries and the growing pressure of tourism (Márquez in litt., 30.1.86).

\section{ENSENADA DE UTRIA PROPOSED NATIONAL PARK}

Geographical Location $6^{\circ} 00^{\prime} \mathrm{N}$; $77^{\circ} 21^{\prime} \mathrm{W}$; Central

Choco, Pacific coast of Colombia.

Area, Depth, Altitude The inlet is $7 \mathrm{~km}$ long.

Physical Features Ensenada de Utria is formed by a peninsula running southwards parallel to the coastline. The area is extremely diverse with small coral islands, lava rock formations, sandy beaches, mangrove swamps, several estuaries, abundant freshwater streams, extensive rain forest and coral reefs.

Reef Structure and Corals Two reef areas are found in the inlet. Riscal de la Chola is situated midway along the eastern side, separated from the Playa de la Aguara by a sandy lagoon. It has an extensive reef flat with a reef crest $300 \mathrm{~m}$ long and $150 \mathrm{~m}$ wide covered by dense, finely branching Pocillopora damicornis which is exposed during extreme low tides. There are also extensive patches of Psammocora stellata. The fore-reef slopes steeply to the bottom of the bay, with living coral down to about $10 \mathrm{~m}$ where it is limited by water turbidity.

The second reef is located off Playa Blanca on Isla Salomón at the tip of the peninsula. It is a typical fringing reef, $300 \times 120 \mathrm{~m}$, and due to its protection from ocean swell by the island and its location away from terrestrial run-off, it has greater diversity and more luxuriant coral growth than Riscal de la Chola (Anon., undated).

Noteworthy Fauna and Flora There are a magnificent relict mangrove community and well over 100000 ha of pristine tropical wet forest. The Green Turtle Chelonia mydas and Leatherback Dermochelys coriacea may occur.

Scientific Importance and Research The area is considered to have one of the most extensive and mature coral reef formations on the Pacific coast of Colombia. The area was visited by the Allan Hancock Pacific Expeditions between 1932 and 1941 and in 1949.

Economic Value and Social Benefits The few inhabitants in the area are mostly fishermen and Embera Indians whose presence constitute a cultural asset to the region.

Disturbance or Deficiencies Riscal de la Chola is affected by exposure to the ocean swell and sedimentation from river run-off; much of the eastern end of the reef is dead (Anon., undated).

Legal Protection None.

Management None.

Recommendations The Ensenada de Utría and the adjacent Baudo Range are recommended as a national park. 



\section{INTRODUCTION}

\section{General Description}

The Atlantic coast of Costa Rica, of some $200 \mathrm{~km}$, is not particularly suited for coral growth, being formed primarily from quatemary alluvial sediments, and having a number of large estuaries. However, where outcrops of fossil reefs are found, corals occur, and there are an estimated $10 \mathrm{sq} . \mathrm{km}$ of living reef. The three main reef zones on this coast are, from north to south: Moín-Limón (including Isla Uvita), Cahuita, and the reefs between Puerto Viejo and Punta Mona (Cortés and Guzmán, 1985).

The reefs between Moin and Puerto Limón are not well developed but include interesting biotopes. In very shallow waters, Siderastrea corals with dough-nut shaped heads, $1-2 \mathrm{~m}$ in diameter and $20 \mathrm{~cm}$ high, are found in extensive areas of zoanthids and Thalassia beds. Between Moin and Portete there is a platform that gradually deepens to more than $15 \mathrm{~m}$. In shallow water, seven species of coral and one hydrocoral have been found. Below six metres crinoids are extremely abundant, with hydroids and sponges. Around the rocky headlands (Portete, Punta Piuta and Limón) the bottom shelves steeply over $20 \mathrm{~m}$ from $1.5 \mathrm{~m}$ to $15 \mathrm{~m}$ depth. The deeper parts have abundant populations of ahermatypes, Stylaster roseus and a species of Hyalospongiae. The edges of the platform are covered with the barnacles Megabalanus antillensis and calcareous algae, and are heavily eroded by the sea urchin, Echinometra lucunter, gastropods and chitons. Mergner (1977) gives a profile of the reef and zoanthid reef plate, $500 \mathrm{~m}$ west of Punta Piuta. Isla Uvita is separated from Limón by a $3 \mathrm{~km}$ wide channel with a very strong current. It has well developed reefs. Octocoral and coral diversity and abundance are high on the west coast, the south has an extensive platform similar to the one described above, the east has very strong currents, a barren sea bottom and a small tidal platform with barnacles and calcareous algae, and the north has steep drop-offs with a rich ascidian, sponge and hydrozoan fauna.

The best developed coral reef in Costa Rica is in the Parque Nacional Cahuita, which is described in a separate account. From Puerto Viejo to Punta Mona (13 km to the east), there are extensive but isolated reefs at Puerto Viejo, Punta Cocles and Punta Uva, and a continuous reef from Manzanillo to Punta Mona. Reefs at Puerto Viejo have been badly damaged but Punta Cocles has a well developed reef with a rich coral fauna. Punta Uva has a more extensive reef with a rich coral fauna including Palythoa caribbea, Stylaster roseus and Solandaria gracilis. Cursory studies of the reef complex between Manzanillo and Punta Mona indicate well developed reefs.

On the Atlantic coast, octocorals are found from Moin to Punta Mona, and twenty-five species have been described by Guzmán and Cortés (in press). The highest diversity was found at Isla Uvita and Cahuita. Stony corals (35 species) of the Allantic coast are described by Cortés and Guzmán (in press). All species are found at Cahuita and ten or more species have been found at Portete, Isla Uvita, Punta Uva, Manzanillo and Punta Mona.

The Pacific coast of Costa Rica is approximately $1300 \mathrm{~km}$ long, with rocky outcrops, sandy beaches, mangroves and some forty-four known coral formations. Coral development is poor in the north because of seasonal cold upwellings in the Papagayo area (Glynn et al., 1983). Previously existing reefs on the north-west coast are thought to have died out over the period 1650 to 1800 A.D. through thermal stress. Live massive corals (Pavona gigantea and Porites lobata) occur but are relatively uncommon between Samara and Cabo Santa Elena in the Papagayo area (Glynn et al., 1983) and five out of six reefs found here were dead. South to Dominical only isolated colonies are found although there is a rich octocoral fauna. The following coral species have been recorded: $P$. lobata, Pocillopora damicornis, $P$. eydouxi, $P$. meandrina, Psammocora stellata, Pavona (two species) and the ahermatypes Astrangia sp., Tubastrea coccinea and Oulangia bradleyi.

The southem part of the Pacific coast is richer in corals and reefs as, since it is in the lee of the Talamanca and Central Mountains, there is no upwelling. Reef communities, however, are generally small (a few hectares at most), shallow (5-15 m) and have low coral diversity (three to nine species), resembling those on the Panamanian coast. The chief reef-building corals are Pocillopora damicornis, P. elegans and Porites lobata and most structural development is found at sites protected from direct wave assault (Glynn et al., 1983). Isla Negritos, in the Golfo de Nicoya, may be surrounded by coral reefs. Isolated corals and octocorals have been found around the island and rock headlands at the tip of the Peninsula de Nicoya. Corals off the Parque Nacional Manuel Antonio are described in a separate account. The best developed reef on this coast is Isla del Caño, also described in a separate account. Further south, in the Golfo Dulce, the reefs are dominated by massive colonies of $P$. lobata and form virtually monospecific stands. The larger reefs near the Rio Esquinas drainage are several hectares in area, with steep reef fronts and a poritid framework extending to $12-15 \mathrm{~m}$ depth. The best reefs off the Pacific coast of Costa Rica are at Isla del Coco, $500 \mathrm{~km}$ offshore, also described in a separate account.

The Costa Rican fish fauna is described by Phillips and Pérez-Crwet (1984). The largest Green Turtle Chelonia mydas rookery in the Carribean is situated at Tortuguero on the Atlantic coast; Hawksbill Eretmochelys imbricata and Leatherback Dermochelys coriacea also nest in low to moderate numbers on this coast. The Olive Ridley Lepidochelys olivacea has two mass nesting sites on the Pacific coast at Nancite and Ostional; numbers nesting here are probably higher that at any other site in the world. Leatherback, Hawksbill, Green and possibly Loggerhead Caretta caretta also nest on this coast. The American Crocodile Crocodylus acutus formerly occurred in wetlands along the Pacific and Atlantic coasts but is now severely depleted (Groombridge, 1982; Bacon et al., 1984). The Caribbean Manatee Trichechus manatus is found on the Atlantic coast. Scott and Carbonell (1986) 


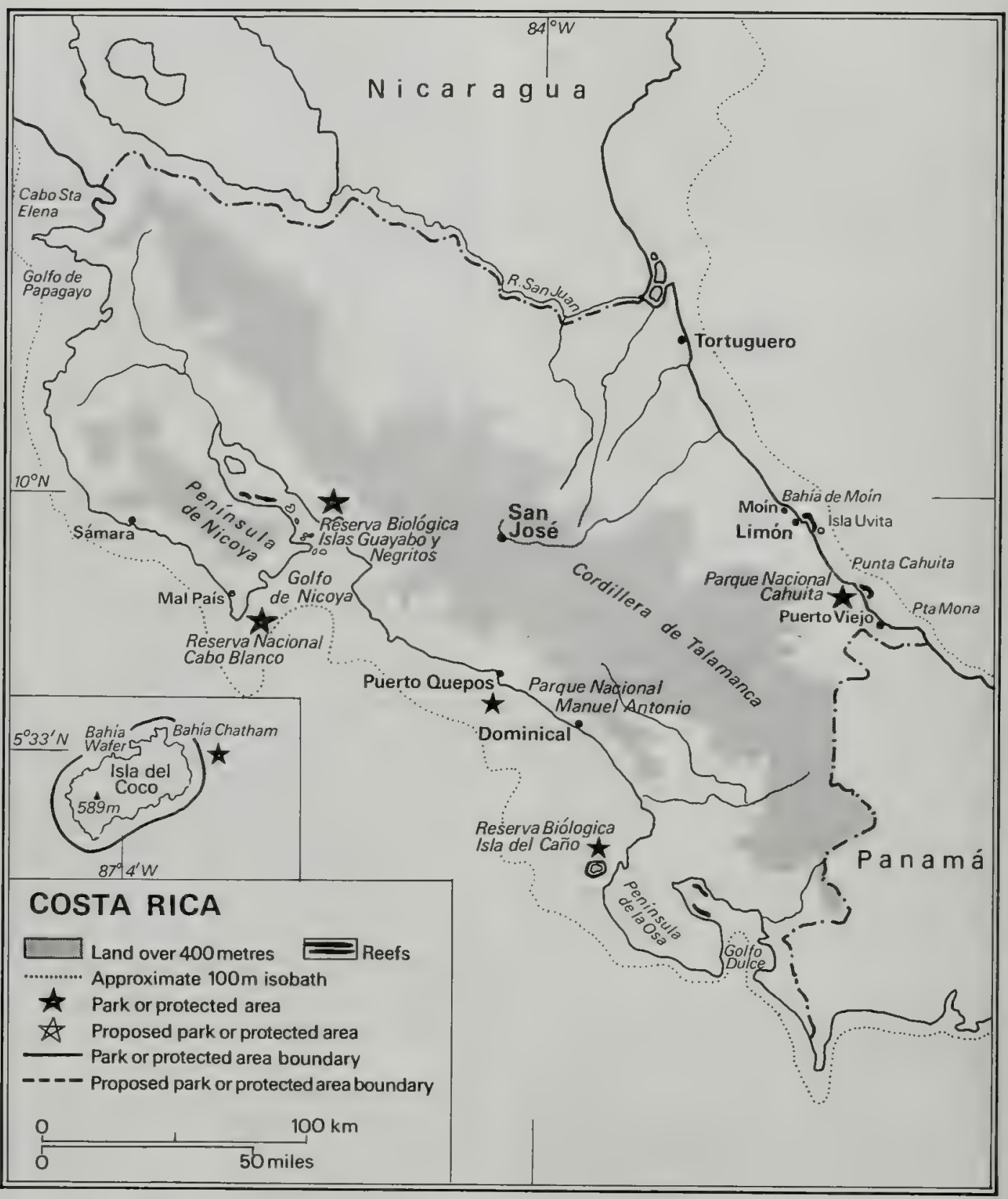


describe important wetland sites on the coast but these do not coincide with the reef sites discussed here.

\section{Reef Resources}

The reefs are important for fisheries and tourism but no general information on economic aspects has been obtained. Tourism is important in several National Parks (see separate accounts).

\section{Disturbances and Deficiencies}

Since June 1983, bleached and dying corals have been observed in several localities on both Atlantic (Cahuita, Punta Cocles, Manzanillo and Punta Mona) and Pacific coasts (Samara, Mal País, Manuel Antonio, Isla del Caño). This phenomenon is probably associated with elevated water temperatures caused by the 1983 El Niño (Cortés et al., 1984). The corals on one patch reef in Golfo Dulce have recently all died through unknown causes (Glynn et al., 1983). Mass mortality of the sea urchin Diadema antillarum was observed on the Caribbean coast in 1983, and is presumed to be associated with the Caribbean-wide mortality of this species, perhaps due to a water-borne pathogen (Lessios et al., 1984).

Human activities are having an increasing impact on the reefs. On the Atlantic coast, the reefs around Puerto Limón are under stress due to human pressure, removal of organisms and urban pollution. The reefs around Puerto Viejo have been seriously affected by siltation, urban wastes and collecting. At Isla Uvita, boat loads of corals, destined for the souvenir trade, are periodically removed. The reefs between Manzanillo and Punta Mona are relatively inaccessible but a road is being built to Manzanillo and the forest in this area will soon be exploited. There is therefore a potential threat from siltation, increasing numbers of visitors and reef exploitation. Stocks of reef fish and lobsters are reported to be declining (Rogers, 1985). Damage to the reefs at Cahuita is described in a separate account. There is little information on the effect of human activities on the Pacific reefs but it is considered that complete destruction of these sparse coral communities will be inevitable if there is no change of attitude.

\section{Legislation and Management}

At present collecting of marine specimens, other than commercial fish, is unrestricted. On the Atlantic coast only the reef at Cahuita is protected. On the Pacific coast four protected areas border coral reefs and give some, but not complete, protection (Boza and Mendoza, 1981; IUCN, 1982). The only activities permitted in the Reservas Biológicas Islas del Guayabo, Pajaros and Negritos, established in 1973 and enlarged in 1974, are biological monitoring and research; disturbances, such as tourism, are prohibited (Schultz, 1977). The Reserva Nacional Cabo Blanco comprises the island and tip of the Peninsula de Nicoya. The Parque Nacional Manuel Antonio and Reserva Biológica Isla del Caño are described in separate accounts. Isla del Coco, $500 \mathrm{~km}$ from the mainland, has National Park status (see separate account).

\section{Recommendations}

There is urgent need for laws to protect marine resources. Reefs on the Atlantic coast that should be considered for immediate protection are: Isla Uvita, Punta Uva and the reefs from Manzanillo to Punta Mona. The latter in particular need further study as they seem to be very healthy and little altered; few people live in the vicinity and the area is comparatively inaccessible (Cortés and Guzmán, 1985; Cortés and Murillo, 1985a). The terrestrial environment at Isla Uvita is partly protected by the Port Authorities but the reefs are unprotected. On the Pacific coast, the entire Península de la Osa, including Isla del Caño, has been suggested for Park status (Schultz, 1977).

\section{References}

\section{* = cited but not consulted}

Anon. (undated). Cocos Island National Park and its Natural Heritage (leaflet for visitors). National Park Service, Ministry of Agriculture and Livestock, Costa Rica.

Bacon, P., Berry, F., Bjorndal, Hirth, H., Ogren, L. and Weber, M. (1984). The National Reports. Proceedings of the Western Atlantic Turtle Symposium, Costa Rica. Vol.3: University of Miami Press, Florida.

Bakus, GJ. (1975). Marine zonation and ecology of Cocos Island, off Central America. Atoll Res. Bull. 179: $10 \mathrm{pp}$.

Boza, M.A. and Mendoza, R. (1981). The National Parks of Costa Rica. INCAFO, S.A. Madrid, España. 310 pp.

Bussing, W.A. (1983). A new tropical eastern Pacific labrid fish, Halichoeres discolor, endemic to Isla del Coco, Costa Rica. Rev. Biol. Trop. 31(1): 19-24.

Cañova, P. (1983). Cocos Island: verdant treasure. Sea Fiontiers 29(3): 158-165.

*Centro Científico Tropical (1982). El Parque Nacional "Manuel Antonio": Inventario Biologico, Terrestre y Marino, Estudio Oceanográfico y Diseño Paisajista. Report to National Parks Authority of the Ministry of Agriculture and the Office of National Planning and Economic Policy, San José.

Cortés, J. (1981). The Coral Reef at Cahuita, Costa Rica: A Reef Under Stress. M.Sc. Thesis, McMaster University, Hamilton, Ontario. 176 pp.

Cortés, J. (1983). Arrecifes coralinos y deforestación. VIII Simposio Latinoamericano sobre Oceanografla Biológica-Memorias, Montevideo, Uruguay.

Cortés, J. and Guzmán, H. (1985). Arrecifes coralinos de la Costa Atlántica de Costa Rica. Brenesia 23: 275-292.

Cortés, J. and Guzmán, H. (in press). Organismos de los arrecifes coralinos de Costa Rica: III. Descripción y distribución geográfica de corales escleractinios (Cnidaria: Anthozoa: Scleractinia) de la Costa Atlántica. Brenesia.

Cortés, J. and Murillo, M. (1985a). Marine Parks of Costa Rica, Central America. Symposium on Endangered Marine Animals and Marine Parks, Cochin, India. Paper 37. Marine Biological Association of India. 9 pp.

Cortés, J. and Murillo, M. (1985b). Reefs under mud. Symposium on Endangered Marine Animals and Marine Parks, Cochin, India. Paper 50. Marine Biological Association of India. 8 pp. 
Cortés, J., Murillo, M.M., Guzmán, H. and Acuña, J. (1984). Pérdida de zooxantelas y muerte de corales y otros organismos arrecifales en el Atlántico y Pacífico de Costa Rica. Rev. Biol. Trop. 32(2).

Cortés, J. and Risk, J.M. (1984). El arrecife coralino del Parque Nacional Cahuita, Costa Rica, Rev. Biol. Trop. 32(1): 109-121.

Cortés, J. and Risk, M.J. (1985). A reef under siltation stress: Cahuita, Costa Rica. Bull. Mar. Sci. 35(3):

Croxall, J.P., Evans, P.G.H. and Schreiber, R.W. (Eds) (1984). Status and Conservation of the World's Seabirds. ICBP Technical Publication No. 2, Cambridge.

Durham, J.W. (1962). Scientific results of the Galápagos Expedition 1953-54 of the International Institute for Submarine Research; corals from the Galápagos and Cocos Islands. Proc. Calif. Acad. Sci. 32(2): 41-56.

Durham, J.W. (1966). Coelenterates, especially stony corals, from the Galápagos and Cocos Islands. In: R.I. Bowman (Ed.). The Galapagos. University of California Press: 123-135.

Emerson, W.K. and Old, W.E. (1964). Additional records from Cocos Island. The Nautilus 77(3): 90-92.

Fosberg, F.R. and W.L. Klawe (1966). Preliminary list of plants from Cocos Island. In: Bowman, R.I. (Ed.). The Galapagos; Proceedings of the symposia of the Galapagos International Scientific Project. Univ. of Califomia Press, pp. 187-189.

Glynn, P.W. (1974). The impact of Acanthaster on corals and coral reefs in the Eastern Pacific. Env. Cons. 1(4): 295-304.

Glynn, P.W., Druffel, E.M. and Dunbar, R.B. (1983). A dead Central American coral reef tract: possible link with the Little Ice Age. J. Mar. Res. 41: 605-637.

Groombridge, B. (1982). The IUCN Amphibia-Reprilia Red Data Book. Part 1 IUCN, Gland and Cambridge.

Guzmán, H. and Cortés, J. (in press). Organismos de los arrecifes coralinos de Costa Rica: IV Descripción y distribución geográfica de Octocoralarios (Cnidaria: Anthozoa) de la costa Atlántica. Brenesia.

Hertlein, L.G. (1963). Contribution to the biogeography of Cocos Island, including a bibliography. Proc. Calif. Acad. Sci. 32(8): 219-289.

Hogue, C.L. and Miller, S.E. (1981). Entomofauna of Cocos Island, Costa Rica. Atoll Res. Bull. 250.

IUCN (1982). Directory of Neotropical Protected Areas. Tycooly International Publishing Ltd., Dublin.

Lessios, H.A., Robertson, D.R. and Cubit, J.D. (1984).

Spread of Diadema mass mortality through the Caribbean. Science 226: 335-337.

Lopez, A. (1984). The treasure of Cocos Island can't be removed. Hawaiian Shell News 32(10): 12.

Mergner, H. (1977). Hydroids as indicator species for ecological parameters in Caribbean and Red Sea coral reefs. Proc. 3rd Int. Coral Reef Symp., Miami. 1: 119-156. Montoya, M. (1983). Los moluscos marinos de la Isla del Coco, Costa Rica. I. Lista anotada de especies. Brenesia 21: 325-353.

Murillo, M.M. and Cortés, J. (1984). Alta mortalidad en la población del erizo de mar Diadema antillarum Phillippi (Echinodermata: Echinoidea) en el Parque Nacional Cahuita, Limón. Rev. Biol. Trop. 32(1): 167-169

National Parks Service (1977). National Parks of Costa Rica I. In: Collected Abstracts and Papers of the International Conference on Marine Parks and Reserves, Tokyo, May 1975. The Sabiura Marine Park Research Station, Kushimoto, Japan.

Phillips, P.C. and Pérez-Crwet, MJ. (1984). A comparative survey of reef fishes in Caribbean and Pacific Costa Rica. Rev. Biol. Trop. 32(1): 95-102.
Risk, M.J., Murillo, M.M. and Cortés, J. (1980). Observaciones biológicas preliminares sobre el arrecife coralino en el Parque Nacional de Cahuita, Costa Rica. Rev. Biol. Trop. 28(2): 361-382.

Rogers, C.S. (1985). Degradation of Caribbean and Western Atlantic coral reefs and decline of associated fisheries. Proc. 5th Int. Coral Reef Congr. Tahiti 6: $491-496$.

Schultz, R.L. (1977). National Parks of Costa Rica II. In: Collected Abstracts and Papers of the International Conference on Marine Parks and Reserves, Tokyo, May 1975. The Sabiura Marine Park Research Station, Kushimoto, Japan.

Scott, D.A. and Carbonell, M. (1986). A Directory of Neotropical Wetlands. IUCN, Gland and Cambridge.

Shasky, D.R. (1983). New records of Indo-Pacific mollusca from Cocos Island, Costa Rica. Nautilus 97(4): 144-145.

Slud, P. (1967). The birds of Cocos Island (Costa Rica). Bull. Am. Mus. Nat. Hist. 134(4): 263-295.

Soto-S., R. (1983). Nuevos informes para la flora bentónica marina de Costa Rica. Brenesia 21: 365-370.

Stegenga, H. and Kemperman, T.C.M. (1983).

Acrochaetiaceae (Rhodophyta) new to the Costa Rican Atlantic Flora. Brenesia 21: 67-91.

Valdez, M.F. and Villalobos, C.R. (1978). Distribución espacial, correlación con el substrato y grado de agregación en Diadema antillarum Philippi (Echinodermata: Echinoidea). Rev. Biol. Trop. 26: 237-245.

Wellington, G.M. (1973). Additions to the Atlantic benthic flora of Costa Rica. Brenesia 2: 17-20.

Wellington, G.M. (1974a). The benthic flora of Punta Cahuita: an annotated list of species with new additions to the Costa Rican Atlantic flora. Brenesia 3: 19-30.

Wellington, G.M. (1974b). An ecological description of the marine and associated environments at Monumento Nacional Cahuita. San José, Subdirección de Parques Nacionales. $81 \mathrm{pp}$.

\section{PARQUe NACIONAL CAHUITA}

Geographical Location $9^{\circ} 40^{\prime}-48^{\prime} \mathrm{N}, 82^{\circ} 45^{\prime}-50^{\prime} \mathrm{W}$. $40 \mathrm{~km}$ south of Puerto Limón, in south-eastern Limón province, Atlantic coast.

Area, Depth, Altitude Sea level to $10 \mathrm{~m}$; total 1700 ha (1100 ha land; 600 ha marine).

Land Tenure The terrestrial part is mostly under private ownership; the government is expropriating lands.

Physical Features The Park follows the low, Caribbean shoreline for approximately $10 \mathrm{~km}$. The bedrock of the terrestrial sector is Pleistocene alluvial sandstone and Punta Cahuita is formed on emergent ancient coral. A fringing reef extends $6.5 \mathrm{~km}$ along the coast, $100-1000 \mathrm{~m}$ from the beach, varying in depth from $1 \mathrm{~m}$ near the coast to $7 \mathrm{~m}$ in some lagoon channels and to $15 \mathrm{~m}$ on the reef front (Risk et al., 1980). The climate is hot and wet with annual rainfall close to $350 \mathrm{~cm}$, with a brief dry season in October and a second less rainy season between January and February. A detailed description is given in Wellington (1974b). 
Reef Structure and Corals The reefs are described by Cortés (1981) and Wellington (1974b) and Cahuita was one of several localities studied by Risk et al. (1980). Thalassia beds are situated close to shore, and are scattered with corals (Siderastrea siderea, Porites porites, Manicina areolata) and sponges. An inner reef, about $500 \mathrm{~m}$ long, lies less than $100 \mathrm{~m}$ from shore on the eastern side of Punta Cahuita. The lagoon has some Thalassia testudinum, Sargassum sp., holothurians and near the reef itself, a few corals (Diploria clivosa, $P$. astreoides and Millepora complanata). The reef crest is well developed with large colonies of Acropora palmata. The fore-reef is dominated by $P$. porites, (much eroded by Diadema antillarum), with small colonies of Diploria strigosa, Siderastrea radians, and $S$ siderea. Agaricia agaricites forms dense monospecific stands from 3.5 to $5.5 \mathrm{~m}$. From 5.5 to $7 \mathrm{~m}$ where the reef ends in sand and mud, huge heads (greater than $1.5 \mathrm{~m}$ in diameter) of Stephanocoenia michelinii, Siderastrea siderea, Colpophyllia natans and D. strigosa are found, as well as small colonies of a variety of other species.

An external reef runs north-west/south-east for $4 \mathrm{~km}$ before turning inshore towards Puerto Vargas, $3 \mathrm{~km}$ south of Punta Cahuita. It is separated from the shore by a large lagoon, $100-1000 \mathrm{~m}$ wide, which has several small patch reefs, dominated by Acropora palmata, $S$. siderea and $D$. strigosa (the latter two species form massive colonies more than $1 \mathrm{~m}$ in diameter) and several species of octocorals (Gorgonia flabellum, Plexaura flexuosa, Plexaurella spp. and Eunicea spp.). The western end of the lagoon is very shallow $(10-75 \mathrm{~cm})$ and about $100 \mathrm{~m}$ wide with dense growths of algae and scattered colonies of Porites porites, Manicinia areolata and S. radians. Highest live coral coverage occurs near Puerto Vargas at the eastern end where there is a platform $50-100 \mathrm{~m}$ wide at 6-9 $\mathrm{m}$ depth bordering a drop-off to $15 \mathrm{~m}$. The shallow part is very rich in sponges, with possibly twenty to twenty-five species (currently being studied), some Agaricia agaricites, Montastraea cavernosa and $S$. siderea. From 9 to $15 \mathrm{~m}$ there is a dense growth of a variety of corals. The northern and western ends of the reef have well developed buttresses but little live coral. In shallow parts (less than $20 \mathrm{~m}$ ), Millepora complanata and Stylaster roseus predominate, interspersed with Favia fragum. The walls and deeper areas down to $10 \mathrm{~m}$ have Agaricia fragilis, Madracis decactis and Siderastrea siderea. On the western side of Punta Cahuita is a small reef called Arrecife Don David. An extensive lagoon has Thalassia stands and patch reefs of $P$. porites. The reef crest is dominated by Acropora palmata and the fore-reef is covered by a wide variety of corals.

Thirty-five species of stony coral have been recorded, the majority of which are sediment tolerant species (Cortes and Guzmán, in press). Octocorals (twenty species) are described by Guzmán and Cortés (in press).

Noteworthy Fauna and Flora An almost undisturbed tropical moist forest association is found on the point itself. A pure stand of Swamp Palm Raphia taedigera occupies the south-west corner of the Park and coconut palms line the beach. Red mangroves are found near the headland on the northern side. A total of 120 species of marine algae have been identified. The marine flora of the Park and Atlantic coast is described by Wellington (1973 and 1974a), Stegenga and Kemperman (1983) and Soto (1985). Common mammals include the Howler
Monkey Alouatta palliata, Three-toed Sloth Bradypus tridactylus, Red Squirrel Sciurus granatensis and Margay Felis wiedii pirrensis. The bird fauna includes the Brown Pelican Pelecanus occidentalis, Green Ibis Mesembrinibis cayennensis, Great Skua Catharata skua, Bridled Tern Sterna anaethetus, Sooty Tern S. fuscata and Green Macaw Ara ambigua (see also IUCN, 1982). The Hawksbill Turtle Eretmochelys imbricata and the Leatherback Dermochelys coriacea nest in the area, and the Green Turtle Chelonia mydas and Caribbean Manatee Trichechus manatus are known to occur. The fish population is very diverse, and Wellington (1974b) provides checklists for several marine taxa.

Scientific Importance and Research The Park includes the only extensive coral reef in Costa Rica. This has been studied for many years by scientists from CIMAR of the Universidad de Costa Rica. Rustic, simple laboratory facilities and skiffs with outboard motors for marine research are available. A marine resources inventory has been completed.

Economic Value and Social Benefits Many fishermen depend on the reefs; hook and line fishing is the main method and nets are rarely used. Lobster is obtained by diving. Tourism is an important activity in the area and many people visit the inner reef area, including students. Recreational activities are permitted in the bay next to the reef; a wreck lies on the western end of the reef. A glass bottom boat takes visitors to the reef but there are no marinas or dive centres (Cortés in litt., 21.8.84).

Disturbance or Deficiencies The population biology of Diadema antillarum was studied by Valdez and Villalobos (1978) in the 1970 s but Costa Rican populations suffered widespread mortality in 1983 (Murillo and Cortés, 1984) as did many Caribbean populations. Recently bleached and dying corals were observed in the Park, possibly associated with the $1983 \mathrm{El}$ Niño; water temperatures of $33-35^{\circ} \mathrm{C}$ were recorded in June 1983 in the Park (Cortés et al., 1984).

The reefs however are mainly under stress from siltation, the amount of suspended and resuspended sediments being extremely high. Coral growth rates, diversity and live coral coverage are very low and large quantities of terrigenous material are found in massive corals. Geochemical analysis and long-shore current patterns suggest that Rio La Estrella (10 km north Cahuita) is the source of sediment. Sedimentation has increased over the last fifteen years due to deforestation inland (Cortés, 1981 and 1983; Cortes and Murillo, 1985b; Cortés and Risk, 1984 and 1985). As a result of this stress, the most abundant coral species are those that are most sediment-resistant. Some colonies show changes in their morphology in response to sedimentation, such as Agaricia agaricia which grows in vertical fronds, or in response to a reduction in light as a result of turbidity, such as Montastraea annularis which forms shingles in $5 \mathrm{~m}$ of water. Dead corals are particularly abundant on the north of the reefs, but coral growth increases towards the south.

Visitors walking on the reef may contribute to the low live coral coverage on the inner reef. Inland, clearing of vegetation for cocoa and banana plantations is no longer permitted and coconut harvesting along the beach presents no real problems. 
Legal Protection The Park was established on 24 September 1970 by Executive Decree 1236-A. Spearfishing is prohibited; hook and line fishing is permitted.

Management The staff include a superintendent, four guides, five guards and two labourers. A team composed of the personnel of the Costa Rican National Park Service and CATIE have developed a management plan which is under review. The headquarters of the Park are situated on the shore.

Recommendations A visitor centre and facilities such as additional glass bottomed boats should be installed. $A$ field station with laboratory facilities should be constructed (Cortés in litt., 28.11.84).

We are very grateful to J. Cortés for compiling this account.

\section{RESERVA BIOLOGICA ISLA DEL CANO}

Geographical Location $8^{\circ} 43^{\prime} \mathrm{N}, 83^{\circ} 52^{\prime} \mathrm{W}$; Pacific coast of southem Costa Rica, off the Peninsula de la Osa; situated $15 \mathrm{~km}$ off Parque Nacional Corcovado.

Area, Depth, Altitude The island measures 300 ha (protected area), has a maximum altitude of $90 \mathrm{~m}$ within the reserve and is surrounded by coral reefs of a maximum depth of $15 \mathrm{~m}$.

Land Tenure National Land (Servicio de Parques Nacionales).

Physical Features The island is mainly covered with natural forests that have suffered few alterations by man, apart from at the west end where some deforestation took place during preliminary work for an airstrip which was never built; the forest has not entirely recovered (Cortés in litt., 20.8.84). The centre of the island is a high plain crossed by several streams that are full throughout the year. Annual rainfall is about $5000 \mathrm{~mm}$; the top of the island can be swampy during the rainy season which is followed by conditions of complete drought in the dry season (November-April). The coast has high cliffs, very small beaches (less than $200 \mathrm{~m}$ long) and an extensive intertidal zone. The water surrounding the island is usually very clear. The average surface water temperature is $28^{\circ} \mathrm{C}$, with a marked thermocline at $20-24 \mathrm{~m}$ depth $\left(22-26^{\circ} \mathrm{C}\right)$. Salinity is about $32-34 \mathrm{ppt}$. Southerly trade winds predominate.

Reef Structure and Corals Most of the reefs surrounding the island are patch reefs. Coral growth is richest on the east side, where a reef flat about $200 \mathrm{~m}$ long extends to $15 \mathrm{~m}$ depth with discontinuous coral growth. From 0.15 to $2.0 \mathrm{~m}$ there is $60 \%$ living coral cover, dominated by Pocillopora damicornis. In deeper areas large specimens of Porites lobata and occasional patches of Pavona spp. and Pocillopora spp. are found. There is no clear zonation but massive species occur more commonly in deeper water than in shallow water. The north side has no platforms in shallow water, but coral growth occurs from 3 to $10 \mathrm{~m}$. There are well developed coral formations consisting mainly of Poriles lobata, as well as large patchy areas with Pocillopora spp. and non-massive colonies of Porites lobata from 2 to $6 \mathrm{~m}$. The south coast is exposed to strong wave and current action and the reefs are formed mainly from calcareous algae and isolated coral heads. There are many isolated rocky areas (like seamounts), $20 \mathrm{~m}$ deep, with a vigorous fauna of octocorals and sponges. At least ten octocoral species have been recorded here including Pacifigorgia sp., Lophogorgia sp. and Muricea sp. Twelve scleractinian corals have been recorded down to a depth of $15 \mathrm{~m}$ (Cortés and Murillo, 1985a). In general, coral growth around the island is restricted to water less than $20 \mathrm{~m}$ deep because of the thermocline and lack of suitable substrate in deeper waters.

Noteworthy Fauna and Flora The most important resource is the forest area which consists mainly of cowtree, spanish cedar, buccy tree, fig tree and others. The terrestrial wildlife of the island is poor apart from a few birds, the only large mammals being feral pigs. The reptile fauna includes the Red Frog Dendrobates granuliferous and snakes Boa spp. No seabirds nest on the island. Many fish such as groupers (Serranidae), bonefish (Albulidae), jacks (Carangidae), snappers (Lutjanidae) and sharks, and crustaceans such as lobsters, are of potential economic importance.

Scientific Importance and Research There are no scientific facilities but the vegetation and bird fauna have been documented and the reefs have been studied by the Universidad de Costa Rica since 1984. The island is one of the few between Baja California, México, and southern Panamá to have rich coral and fish faunas (National Parks Service, 1977; Cortés and Murillo, 1985). The island was an important native cemetery and archeological research has been carried out.

Economic Value and Social Benefits The island has great potential for commercial and sport fisheries. It is of value for tourism and recreation on account of its archeological interest and scenic value.

Disturbance or Deficiencies During the 1982-1983 El Niño, the reefs suffered damage from elevated sea water temperatures (Cortés el al., 1984). The damage is currently being evaluated. Feral pigs cause erosion, and the sediments that are carried to the sea have started to damage the reefs. There is no control of fishing around the island, and according to fishermen, stocks of lobsters, sharks and molluscs of commercial value have been considerably reduced. Guards and tourists also fish (Cortés in litt, 20.8.84). The archaeological sites have been looted.

Legal Protection Isla del Caño was declared a Biological Reserve under law No. 6215 on March 1978, and has been declared part of the Parque Nacional Corcovado. On 2 January 1985, a marine area $3 \mathrm{~km}$ wide around the island was protected under Executive Decree no. 16015-MAG. Spearfishing is not permitted.

Management The Servicio de Parques Nacionales has two guards.

Recommendations The marine environment needs improved supervision to prevent over-fishing. Boat anchoring should be limited to non-reef areas (Cortés in litt., 20.8.84). A programme to eradicate pigs should be started to avoid further erosion and siltation on 
the reefs. Better scientific facilities should be considered by the National Park Foundation to improve research conditions (Cortés and Murillo, 1985a).

We are very grateful to $H$. Guzman for compiling this account.

\section{PARQUE NACIONAL ISLA DEL COCO (COCOS ISLAND)}

\section{Geographical Location $\quad 5^{\circ} 30^{\prime}-34^{\prime} \mathrm{N}$; 87 $7^{\circ} 01^{\prime}-06^{\prime} \mathrm{W}$;} approximately midway between mainland Costa Rica (500 km north-east) and the Galápagos Islands $(630 \mathrm{~km}$ south-west).

Area, Depth, Altitude No accurate data seems to be available on the physical dimensions of the island. Area often quoted as 4660 ha and coastline length as $23 \mathrm{~km}$, but this is a physical impossibility. The island is roughly rectangular in shape; actual area calculated from maps appears to be 3200 ha. The maximum altitude, on Cerro Iglesias, is variously quoted from $589 \mathrm{~m}$ to $849 \mathrm{~m}$ depending on authority consulted; naval charts and Costa Rican topographical maps give the former figure.

\section{Land Tenure Government.}

Physical Features The Cocos Ridge extends in a south-westerly direction from Costa Rica almost to the Galápagos and has relatively deep trenches on the north and south sides, Isla del Coco being the only portion to appear above sea level. The irregular coastline is abrupt with towering (up to $180-190 \mathrm{~m}$ ) precipitous cliffs rising from a narrow shore shelf. There are two main bays (Bahia Wafer and Bahía Chatham) on the north coast which afford anchorage, small sandy beaches and ten islets off shore, the biggest being Manuelita near Bahía Chatham. Inland, the terrain is irregular and hilly, rising to Cerro Iglesias, the highest peak. The island is volcanic and subject to frequent land slides. There are numerous streams, many of which plunge over peripheral cliffs as picturesque waterfalls. There is heavy rainfall throughout the year (probably over $600 \mathrm{~cm}$ total) with a short, relatively dry season from January to March.

The island is situated in the eastward-flowing Equatorial Counter Current (Hertlein, 1963). Tidal amplitude is about $2 \mathrm{~m}$ and water temperatures range from 29 to $30^{\circ} \mathrm{C}$. A slight thermocline $\left(1.1-1.7^{\circ} \mathrm{C}\right.$ temperature change) occurs between depths of 13 and $22 \mathrm{~m}$ at the end of the tropical dry season. Underwater visibility is often $30 \mathrm{~m}$, especially below the thermocline. The underwater profile consists of stepwise shelves, almost no intertidal zone, a shallow submerged coral reef, and sand and rubble falling off abruptly to several hundred metres (Hertlein, 1963).

Reef Structure and Corals The only study of underwater zonation was made on the leeward side of the island near Bahía Chatham and Bahía Wafer (Bakus, 1975). The intertidal zone is described briefly. In deeper waters within the bays and in most waters outside the bays, the subtidal benthic fauna is dominated $(95 \%)$ by the mushroom-shaped hermatypic coral Porites californica. Virtually monotypic reefs of this species extend almost from the water surface down to depths of from 8 to at least $31 \mathrm{~m}$ where they give way to rippled sand containing numerous tubes of the polychaete Chaetopterus. Living Porites is intermixed with Porites rubble. Pocillopora robusta occurs in small scattered patches at depths of 1 to $8 \mathrm{~m}$ and Tubastrea aurea is common at various depths, particularly at Isla Manuelita (Bakus, 1975). Eighteen species of scleractinian corals, including fourteen hermatypic species have been reported from Isla del Coco (Durham, 1962 and 1966).

Noteworthy Fauna and Flora Brief details of terrestrial vegetation and fauna are given in Hogue and Miller (1981). The island is covered by lush tropical vegetation and is the only major island of the eastern Tropical Pacific area to support a very humid tropical rain forest, with cloud forest at high elevations (above $500 \mathrm{~m}$ ). There are 155 vascular and 48 nonvascular plants of which about $15 \%$ are endemic to the island (Fosberg and Klawe, 1966). There are numerous seabird nesting colonies including the Greater Frigatebird Fregata minor, Sooty Tern Sterna fuscata, Brown Noddy Anous stolidus, Black Noddy $A$ minutus, White Tern Gygis alba, Brown Booby Sula leucogaster and Red-footed Booby $S$. sula. The Magnificent Frigatebird $F$. magnificens is a rare visitor (Croxall et al., 1984). There are seven nesting species of land bird including the endemic Cocos Island Cuckoo Coccyzus terrugineus, Ridgeway Flycatcher Nesotriccus ridgwayi, and Cocos Island Finch Pinaroloxias inornata (Slud, 1967; Canova, 1983). There are two endemic lizards, Anolis townsendi and Sphaerodactylus pacificus, but no native mammals. A species list, including twenty-nine endemic species, is given by Hertlein (1963).

The overall diversity of marine life is moderate compared to the mainland, possibly due to the island's isolation. The coral formations are more highly developed however, probably as a result of the greater clarity of the water. The sea urchin Diadema mexicana and the starfish Linckia columbiae are common. The lobsters Panulirus gracilis and $P$. penicillatus are known from the island, as well as eleven species of ophiuroids. Sponges are relatively uncommon except as encrusting forms under coral rubble. The fish fauna is exceptionally rich in standing crop and is moderately diverse, 156 species having been recorded (Bakus, 1975; Bussing, 1983). The fauna is currently being reviewed. The molluscan fauna is described by Emerson and Old (1964), Montoya (1983) and Shasky (1983). Vast migrations of White-tip Triaenodon obesus and Hammerhead Sharks Sphyrna, mantas (Mobulidae), Bottle-nosed Dolphins Tursiops truncatus and fish pass close to the island. The Green Turtle Chelonia mydas may occur.

Scientific Importance and Research Early research is described by Hertlein (1963). The Janss Foundation's vessel R/V Searcher visited the island in 1972 to document the major nektonic groups, including crustaceans and fish, and to obtain data on holothurians toxic to fish (Bakus, 1975). The island is now regularly visited by scientists. Research currently in progress is based mostly on the terrestrial fauna and flora of the island, and incluces: studies of landbirds and Cocos Island geology, a survey of the island flora and a study of the biogeographic affinities of Cocos insects (Sherry and Werner in litt., 16.1.85). 
Economic Value and Social Benefits No permanent human settlement has survived on the island (Bakus, 1975) but there is now a garrison of Costa Rican National Guardsmen. The island has been known to mariners and cartographers since the first half of the sixteenth century and has been a stopping place for pirates, privateers and whaling vessels (IUCN, 1982). It now receives some $300-400$ visitors a year (Canova, 1983).

Disturbance or Deficiencies The Crown-of-thorns Starfish Acanthaster planci has been recorded from the reefs but not in plague proportions (Glynn, 1974). The island has long been visited more or less regularly by passing vessels and yachts, and littering and other minor disturbances have occured. IUCN (1982) reported these problems to be under control but Sherry and Werner (in litt., 16.1.85) report that increasing numbers of visitors, including treasure hunters, are beginning to have a measurable impact. Various expeditions and yacht crews, about one or more every week or so throughout the year, have an increasing effect in the Bahia Wafer and Bahia Chatham camping areas. There is as yet no adequate means to dispose of rubbish and human wastes. There are reports that lobsters and some fish are decreasing in abundance due to unrestricted fishing, especially by commercial boats. As prices of marine products go up, increasing numbers of fishing vessels visit the island for shark, fin fish and lobster.

The terrestrial environment is threatened by sizeable populations of introduced species including pigs, goats, rats, cats, white-tail deer and coffee plants brought by early settlers. Pigs have caused particular damage to the natural vegetation, resulting in soil erosion which may threaten the reefs. The soil is shallow and poor in nutrients, and this, combined with the high rate of rainfall makes the island very vulnerable to erosion (Canova, 1983; Sherry and Werner in litt., 16.1.85)

Legal Protection Established as a National Park on 11 July 1978 by Executive Decree no. 8448-A (also quoted as 22 June, no. 8748-A). Since 16 July 1984, the surrounding waters have been protected to a distance of $5 \mathrm{~km}$ from the shore by Executive Decree no. 15514-MAG. Collecting of terrestrial or marine organisms is not permitted except for recognised scientific purposes.

Management Administered by the Servicio de Parques Nacionales, Ministerio de Agricultura y Ganadería, San José, Costa Rica. Three National Guards are stationed on the island for about three months at a time, but they have little training in conservation (Sherry and Werner, in litt., 16.1.85). Due to the island's remoteness and its lack of adequate living facilities, funding is currently insufficient to maintain National Park guards. A leaflet has been produced for visitors to the island (Anon., undated). Trails have been cut and marked through the forest (Canova, 1983). Fernando Cortés, of the Servicio de Parques Nacionales de Costa Rica, is currently organising a group called "Friends of Cocos Island" to assist with fund raising, protection, conservation and future research on the island. There are no management programmes at present for any component of the flora and fauna.

Recommendations Funds are urgently needed to aid the National Park Service in wardening the island and to provide a small building for living quarters, a small lab, a generator (ideally water-powered) and a short-wave radio
(Sherry and Werner in litt, 16.1.85). Pigs need to be controlled and preferably destroyed (Canova, 1983). A proposal was submitted to list Isla del Coco as a World Heritage Site (Lopez, 1984) but this has not been accepted.

\section{PARQUE NACIONAL MANUEL ANTONIO}

Geographical Location $9^{\circ} 23^{\prime} \mathrm{N}, 84^{\circ} 09^{\prime} \mathrm{W}$; $62 \mathrm{~km}$ south of San José, $7 \mathrm{~km}$ south of Puerto Quepos in Puntarenas Province.

Area, Depth, Altitude 683 ha; sea level $100 \mathrm{~m}$.

Land Tenure Most of the land is privately owned, and much of it is being purchased by government expropriation.

Physical Features Most of the area consists of a string of wide, white sandy beaches (Espadillo Sur, Manuel Antonio, Puerto Escondido and Playa Playita) with high cliffs, 12 offshore islands and a background of lush tropical forest. The main rock types are of Cretaceous origin, with limestone cliffs and islands and some pillow lava. Tombolo Catedral is a rock connected to the mainland by a narrow sand spit. Annual rainfall is about $3900 \mathrm{~mm}$ and there is a three month dry season (IUCN, 1982).

Reef Structure and Corals Corals used to be abundant including Pocillopora damicornis, Psammocora stellata and Porites lobata, but there was extensive mortality in 1983, possibly associated with the unusual EI Niño of that year (Cortés et al., 1984; Cortés and Murillo, 1985a); the sea bottom is now covered with algae and scattered gorgonians Lophogorgia sp. and Pacifigorgia sp.

Noteworthy Fauna and Flora Coconuts and other palms, papaya, banana, manzanillo and mangroves grow in the Park. The northernmost population of the threatened Titi Monkey Saimiri oerstedii is found there, and White-faced Cebus capuccinus and Spider Ateles geoffroyi Monkeys, crabs and iguanas are common (IUCN, 1982). A variety of seabirds (including the Brown Pelican Pelecanus accidentalis) nest on the offshore islets. A biological inventory has been compiled by Centro Científico Tropical (1982).

Scientific Importance and Research Marine and terrestrial surveys were being carried out in the early 1980s (IUCN, 1982).

Economic Value and Social Benefits The park is popular with tourists and a sunken freighter is used by divers.

Disturbance or Deficiencies There has been extensive coral mortality associated with the 1983 El Niño (see above). There is said to be some disturbance from nearby hotels and housing, particularly as the area is rather small for effective protection.

Legal Protection The Park was set aside by Executive Decree in 1972, but protection does not seem to extend to the marine fauna. 
Management The 1981 management plan defines six use zones (intangible, primitive, extensive, intensive, recuperation and special) but these do not extend to the marine area. The plan calls for various buffer zones adjacent to the Park including a major one for controlled tourism-recreation development on an adjacent beach
(IUCN, 1982). There is a superintendent, four guides, five guards and some labourers. A leaflet for visitors has been produced.

Recommendations None known. 



\section{INTRODUCTION}

\section{General Description}

Cuba, covering an area of $110922 \mathrm{sq} . \mathrm{km}(1200 \mathrm{~km}$ from Cabo San Antonio to Cabo Maisí and $191 \mathrm{~km}$ maximum north-south width) has a coastline estimated at $3500 \mathrm{~km}$ by Kühlmann (1974a) and 5746 km by Jiménez (1982). The insular shelf varies in width from some $100 \mathrm{~m}$ on the coast south of the Sierra Maestra to more than $140 \mathrm{~km}$ off Havana in the north and around Isla de la Juventud in the south. Maximum depths on the shelf reach about $100 \mathrm{~m}$; depths immediately off the shelf range from 1000-7000 m (Kühlmann, 1974a). Sea temperatures average $20-28^{\circ} \mathrm{C}$; currents, bathymetry and salinity are described by Jiménez (1982). The rainy season runs from May to October and the dry season from November to April. Rainfall is abundant and well distributed and there are only occasional hurricanes.

Islets, cays and coral reefs border much of the insular platform, estimates of the total number of islets varying from 1600 (Kühlmann, 1974a) to 4195 (Jiménez, 1982). Total reef length in Cuba is estimated at $3966 \mathrm{~km}$ $(2150 \mathrm{~km}$ on the north coast and $1816 \mathrm{~km}$ on the south coast (Jiménez, 1984a). A detailed description of the coast and offshore islets is given in Jimenez (1984a) and a popular account is given in Jimenez (1984b). There are four main island groups: Los Colorados and Jardines del Rey (or Sabana-Camagiey) in the north, and Jardines de la Reina and Los Canarreos in the south.

Los Colorados stretches over a distance of $255 \mathrm{~km}$ and lies on the edge of the platform formed by the Golfo de Guanahacabibes. The islands, of which there are about 160 , are largely sedimentary in origin and the majority are covered with mangroves. The mangrove and brackish water swamps on the north coast of the Golfo de Guanahacabibes are described in Scott and Carbonell (1986). The barrier reef of Los Colorados extends up the north-west coast, joining the mainland coast at Punta Gobernadora. Corals are also found at some sites off the mainland in this area, such as around Cabo San Antonio and Península de Guanahacabibes (the north coast of which has numerous banks and reefs). A guyot partially covered with corals lies $16 \mathrm{~km}$ to the north-east of Cabo San Antonio. Fringing reef stretches $23 \mathrm{~km}$ from Punta Gobernadora to Bahia de Cabanas, and is fairly continuous from Bahía Honda to Cayo Piedras del Norte, near the Península de Hicacos.

Los Jardines del Rey or the Sabana-Camagüey group consists of about 990 cays and islands, many of which are mangrove covered, stretching over $465 \mathrm{~km}$ from Cayo Piedras to Bahia de Nuevitas and bordered to the north by a barrier reef, similar to that bordering Los Colorados. Jiménez (1984a) describes many of the cays and reefs. Scott and Carbonell (1986) describe the cays with respect to their important wetland habitats. Cays to the east of the Santa Maria group have particularly interesting submarine cave formations. Near Nuevitas the reef approaches the coast and follows it closely further east to Cabo Maisi on the eastern end of the mainland, interrupted only by major bays such as the mouth of the Río Sagua de Tanamo. The north coast reefs therefore extend almost continuously for $2150 \mathrm{~km}$.

Cabo Maisi is arid and isolated with reefs lying off the coast. Fringing reefs stretch along the south coast from Cabo Maisi to Cabo Cruz. The archipelago of Los Jardines de la Reina is $360 \mathrm{~km}$ long and consists of several groups of cays, bordered by a barrier reef of about $400 \mathrm{~km}$ which fringes the platform of the Golfo de Guacanayabo and Ana Maria. Many of the cays are mangrove covered and are mentioned by Scott and Carbonell (1986). Golfo de Guacanayabo is described in a separate account. The group of cays making up the Laberinto de Las Doce Leguas is situated on the edge of the insular platform and is bordered by a steep drop-off.

Los Canarreos consists of several groups totalling 672 cays bordered by a barrier reef. They are described in detail in Jiménez (1984a), with particular accounts for Cayo Piedras, $9 \mathrm{~km}$ south of Bahía de Cochinos; the Golfo de Cazones, in which there is a reef-covered structure resembling a submerged atoll; Cayos Blancos del Sur; and the mangrove area of Ensenada de la Broa. The archipelago is considered an important wetland site by Scott and Carbonell (1986). Los Jardines y Jardinillos, east of Isla de la Juventud, are sand barrier islands with magnificent beaches on the south coast, including one of oolitic sand at Cayo Largo, and are bordered by a barrier reef; many of the cays are coral fringed. West of Isla de la Juventud, a barrier reef with a steep drop-off is found along the cays of San Felipe and Los Indios. The Banco de los Jardines, north of the Archipiélago de Canarreos, is unusual for the white sand of the sea bottom.

Submarine caves are found in a number of places including Caverna del Ojo del Megano (15 km ENE of Cayo Bahía de Cádiz); off Playa Girón on the south coast; Cayo Palomo in Los Canarreos; Punta Caimán in west Cuba; Cueva de los Camarones and along much of the north coast. Cueva de los Camarones east of Havana is the type locality of the cave shrimp Barbouria cubensis but has been damaged by visitors.

Zlatarski and Estalella (1982) recognise three types of reef: fringing, "bank" and a reef type found on muddy substrates (described separately in the account for Golfo de Guacanayabo). Fringing reefs are found where the continental shelf is narrow, for example on the north-east and south-east coasts which border Pico Turquino, the highest mountain in Cuba. Bank reefs are found where the shelf is wider, particularly around the archipelagos, for example $100-1000 \mathrm{~m}$ off shore on the southern coast between Casilda and Cienfuegos, along the southern coast of Isla de la Juventud, on the south-west coast and on the north coast. Bank reefs are also found seaward of the archipelagos on both the north and south coasts. Off the northern coast of Pinar del Río, there are extensive bars on which particularly vast reefs have developed (Kühlmann, 1974a; Vaughan, 1919; Zlatarski and Estalella, 1982).

Kühlmann (1974a) describes a more complex system of reef types, based on substrate type and other environmental factors. Bank reefs run more or less 


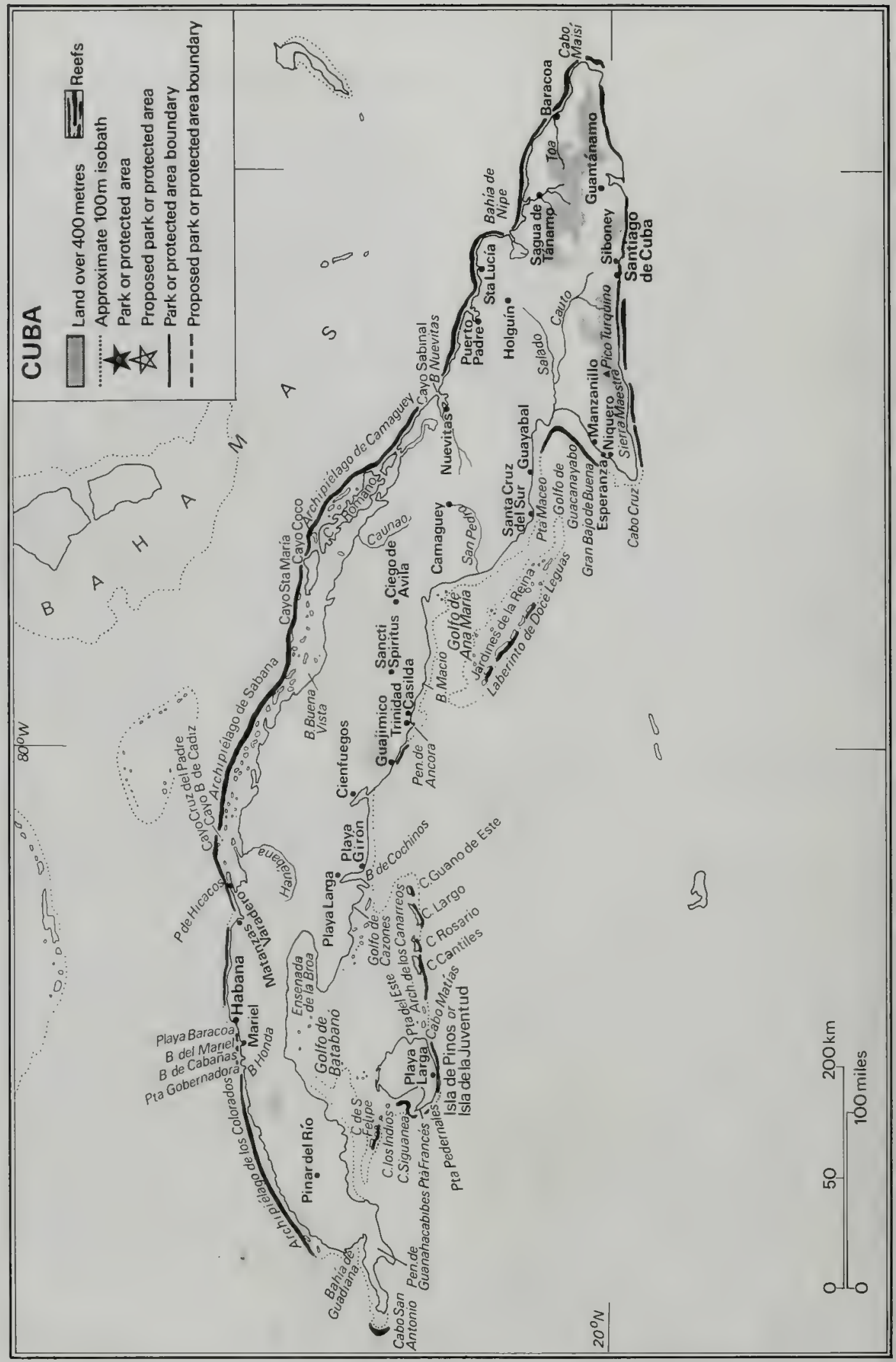


parallel with the shoreline following submarine terraces and are nearshore, shallow structures (Kühimann, 1971). Cross-bar reefs are similar to bank reefs, but extend in front of bays. If the edges of submarine terraces are covered by more than $10 \mathrm{~m}$ of water they are settled densely with corals but there is no reef formation. Cluster reefs, a form of patch reef, are found on small prominences on otherwise flat substrates and may eventually form miniature atolls. Extensive submarine limestone platforms support diffuse coral growth consisting. of several types of reef and are referred to as complex reefs. Other reef types include coral canyons, square or incision reefs, spur and tongue reefs and horst reefs.

The major reef building coral in Cuba is Acropora palmata; other important species are Montastraea annularis, Millepora complanata, A prolifera, Siderastrea siderea, Porites astreoides, Agaricia agaricites, Diploria strigosa and Montastraea cavernosa (in decreasing order of significance as reef builders). Zonation (or coral associations) is described by Kühlmann (1970, 1971 and 1974b). Lagoon environments typically have Cladocora arbuscula, $P$. divaricata, Manicina areolata and Siderastrea radians. Acropora prolifera grows on the lagoonward reef slope in quiet to moderately turbulent water, often with Diploria strigosa. The reef crest may have a variety of species, or, if it is extremely exposed, is devoid of corals and overgrown with Gorgonia flabellum. On the seaward edge of the reef at a depth of 1-3 m, A palmata and Millepora alcicornis predominate. $D$. strigosa, $P$. astreoides and Favia fragum may also be present. Deeper than $3 \mathrm{~m}$, the seaward reef slope $\left(30-60^{\circ}\right.$ inclination) is densely packed with a variety of corals with Montastraea annularis predominating (Kühlmann, 1974a).

Zlatarski and Estalella (1982) describe 44 reef profiles in schematic form, 20 along the north-west coast and western point, 12 on Isla de la Juventud and Los Canarreos and 12 on the south-east coast and cays of Los Jardines de la Reina. A number of additional smaller sites were studied in the same general areas. The bathymetric range and relative abundance of scleractinians is given and there is a general description of the zonation of fringing and barrier reefs. Coral abundance at some sites is described by Kühlmann (1971 and 1974a); the bank reef systems between Matanzas and Varadero ("km 14") on the north coast, Macao, Guajimico, Ancon and parts of Larga are particularly rich. Black corals seem to be comparatively abundant at shallow depths in many areas, presumably due to the lack of exploitation.

Early descriptions of the reefs include Agassiz (1894) and Vaughan (1919), and the history of marine research in Cuba is described by Jiménez (1984a). Cayo Largo in Los Canarreos was visited by the Catherwood - Chaplin Expedition and is described by Ripper (1949). Extensive studies of the submarine shelf started in 1963, including work on the numerous submarine caves around the coast (Jiménez, 1982 and 1984a). A series of volumes is in preparation which will detail the natural history, geography and socioeconomy of the country and will include geology, climate, renewable resources and aspects of the economy such as tourism with detailed accounts for the different regions. Volumes on geography and culture (Jiménez, 1982) and the coastal shelf (Jiménez, 1984a) have already been produced. Other recent works include Kühlmann (1970, 1971 and 1974a) and Zlatarski and Estalella (1982). Lists and descriptions of the corals of Cuba are available in Duarte-Bello (1961) (who describes species collected from reefs off the north coast of the Provinces of Pinar del Rio and Havana) and Zlatarski and Estallella (1982) who provide a monograph of the western Atlantic reef coral province.

The Instituto de Oceanologia of the Academia de Ciencias and the Departamento de Biologia in the university, Havana, have carried out extensive research on the marine environment. The bay in front of the institute has been particularly well studied although it does not support coral growth (Béhéty González, 1980; Herrera Moreno et al., 1981). Alcolado (1979) describes the sponge community at the entrance to Barlovento Harbour, near Havana on the north coast, and briefly mentions reef assemblages there. Fish communities of coral reefs and other marine communities have been studied by Mochek and Valdés-Muñoz (1983), on the north-west and south-west Cuban platform, near Havana and at Punta del Este on the Isla de la Juventud. Gorgonians were studied by Alcolado et al. (1980) at Playa Hollywood, to the north of Havana, and the reproductive cycle of Plexaura homomalla has been studied by Béhéty González and Guardiola (1979). Kusel (1972) describes the seaweeds of Cuba. Urchin grazing and erosion have also been studied (Jiménez, 1984a). There is a laboratory for speleological studies at Siboney.

The Caribbean Manatee Trichechus manatus occurs along both coasts of Cuba. The American Crocodile Crocodylus acutus was previously present throughout Cuba (Kühlmann, 1966) and adequate populations are still found in the chains of offshore islets along the north and south coasts. The endemic Cuban Crocodile C. rhombifer is mainly a freshwater species and is now found only in Matanzas Province and on the Isla de la Juventud (Groombridge, 1982). The Loggerhead Turtle Caretta caretta, Green Turtle Chelonia mydas and Hawksbill Eretmochelys imbricata nest and details of nesting beaches are given in Bacon et al. (1984). The iguanid lizard Cyclura nubila is found on offshore islets and rocky parts of the Cuban coast but is declining as it is hunted (Kühlmann in litt. 12.4.1984). Halewyn and Norton (1984) list the seabird species nesting on the mainland, north coast and south coast cays; Cayo Largo is reported to be an important site.

\section{Reef Resources}

On the archipelagos, the main traditional sources of income are charcoal production and livestock. Many of the cays are border posts and a number have hydrographic stations situated on them (Cayo Piedra del Norte, Cayo Cruz del Padre and Cayo Bahía de Cádiz). There is a meteorological station on Cayo Guano del Este. Fishing is important around much of the coast particularly at Golfo de Guacanayabo, Laberinto de las Doce Leguas, Isla de la Juventud, Cayo Romano and Los Colorados. Fishery yields in some areas are $6 \mathrm{~kg} / \mathrm{ha}$ (Munro, 1983). Lobsters Panulinus argus are a major product and are fished intensively in many areas (Buesa Mas, 1969). The Golfo de Batabano on the south coast between Isla de Juventud and the mainland is the most important lobster fishery area, on account of its abundant seagrass beds and the construction of artificial reefs specifically for lobsters. This area used to be an 
important sponge fishing centre and although wild stocks are no longer exploited there is now a sponge culture operation (Jiménez, 1984a). An artificial reef has been built near Havana to improve fish and crustacean production.

Tourism is becoming increasingly important; SCUBA diving is now a popular activity with Cubans and is being promoted on a large scale as a tourist attraction, although overseas divers are not numerous at present. Isla de la Juventud is one of the main diving centres (see separate account). Cayo Largo del Sur, also in Los Canarreos, has a white sand beach as its main attraction; a hotel was built in the early 1960 s but was converted to a fishing co-op with the subsequent failure of the tourist industry but there are now new plans for reviving tourism on this island (Jiménez, 1984a). The main SCUBA diving site here is at Cayo Rosario. The most popular beach in Cuba is Playa Varadero, a resort area $133 \mathrm{~km}$ east of Havana with shallow fringing reefs suitable for snorkelling and novice divers. From the western end of the Peninsula de Hicacos from Matanzas Bay eastwards 23 dive sites have been marked along the coast. Underwater scenery includes submarine caves and channels running out towards the drop-off; this area has become the island's main SCUBA training centre. In Los Jardines del Rey, the Santa Maria group of cays have good tourist potential with beaches on the north coast and mangroves to the south (Jiménez, 1982). Other diving areas include: the Blue Circuit beaches or Playa del Este, to the west of Havana along a $50 \mathrm{~km}$ stretch of the north coast including Jibacoa beach which has nine marked sites; Barlovento Marina, west of Havana; Guardalavaca, a resort on the north coast in the east near Holguin, including Playa de Santa Lucía and Club Mayanabo; Carbonera in Matanzas Province; Golfo de Ana María near Ciego de Avila; Casilda in Sancti Spiritus Province and the Jardines de la Reina Archipelago. Cave diving is being promoted as a tourist attraction and sites are open at Cepero Cave in Varadero and at Playa Girón (information from tourist brochures; Rodrigues in litt., 4.4.85). Playa Girón, at the mouth of Bahía de Cochinos west of Cienfuegos, is an important tourist centre as is Playa Larga at the head of the bay; Siboney (east of Santiago de Cuba), Playa de Cayo Esquivel and Isla de Sabinal are also resorts.

\section{Disturbances and Deficiencies}

There is no information on reef damage in Cuba due to natural events but human activities are having an increasing impact. The main industrial and urban centres of Cuba are on the coast (Havana, Mariel, Nuevitas and Cienfuegos) and there has been much alteration of the coastline in these areas. Sand is dredged for construction materials. The area around Havana Bay appears to be suffering greatest pollution (Herrera Moreno and Amador Pérez, 1983). Jiménez (1984a) reports that reefs off Playa Viriato on the north coast near Bahia de Mariel have suffered from pollution, particularly from Río de Quibo. The effect of pollution on gorgonians between Havana Harbour and Playa Baracoa has been studied by Herrera Moreno and Alcolado (1983). Pollution studies have been carried out by Herrera Moreno and Valle Garcia (1980) in the lagoon at Guayabal on the south-east coast, which receives the effluent from three industrial complexes. Oil pollution is very evident in the Havana region, the beaches of Santa Maria del Mar to the east of Havana being particularly badly affected. In 1980 an oil spill from a tanker caused some damage to marine life in a fishing area near Cabo San Antonio (Jiménez 1982). Oil drilling exploration has been undertaken on some of the cays such as Lucas and Francés. Spearfishing is reportedly heavy around Cabanas on the north west coast and conch stocks have been noticeably over-fished in the Santiago region (Jiménez, 1984a).

\section{Legislation and Management}

There is no information available on efforts being made to protect the reefs. The Dirección Nacional de Flora $y$ Fauna, created in 1984, is responsible for research on and conservation of flora, fauna and the environment. Jiménez (1982) discusses legislation relating to marine resources and pollution. The 1980 Ley de Proteccion del Medio Ambiente y del Uso Racional de los Recursos Naturales provides a framework for protection. Turtle collecting is controlled and collection of eggs is prohibited (Bacon et al., 1984). Legislation was introduced to control the over-exploitation of conch in 1977 (Jimener, 1984a). According to one tourist leaflet, spearfishing is prohibited throughout Cuba, and a "réserve a la plongée sous-marine" is said to exist on Isla de la Juventud.

\section{Recommendations}

Since marine aspects of the tourist industry are being promoted so heavily and pollution is already known to be a problem, there is clearly a need for action to be taken towards management of reef resources. The Instituto Nacional de Turismo is aware of degradation of coastal areas and has initiated a project to replace introduced Casuarina trees along the coast with native plants (Jiménez, 1984a). Scott and Carbonell (1986) report that all cays in Cuba will eventually be protected by a law in the process of being adopted. Currently all hunting and capture of wildlife is prohibited on the cays; it is presumed that this applies to terrestrial wildife only.

\section{References}

Agassiz, A. (1894). A reconnaissance of the Bahamas and of the elevated reefs of Cuba. Bull. Mus. Comp. Zool. 26: 1-203.

Alcolado, P.M. (1979). Estructura ecologica de la comunidad de esponjas en un perfil costero de Cuba. Ciencias Biológicas 3: 105-127.

Alcolado, P.M., Corvea, A. and González, A. (1980). Variaciones morfologicas internas y externas de los abanicos de mar (Gorgonia spp.) y su valor adaptativo. Ciencias Biológicas 5: 47-56.

Bacon, P., Berry, F., Bjorndal, Hirth, $\mathbf{H}_{n}$ Ogren, Lo and Weber, M. (1984). The National Reports. Proceedings of the Western Atlantic Turte Symposium, Costa Rica. Vol.3: University of Miami Press, Florida.

Béhéty González, P.A. (1980). Variaciones en la dieta de Cyphoma gibbosum Linnaeus en función de la profundidad. Ciencias Biológicas 5: 75-84.

Béhéty González, P.A. and Guardiola, M. (1979). Ciclo reproductivo de Plexaura homomalla (Esper, 1792) forma kuekenthali Moser, 1921 (Gorgonacea). Ciencias Biológicas 3: 99-104.

-Buesa Mas, RJ. (1969). Biology and fishing of spiny 
lobsters, Panulirus argus (Latreille). In: Bogdanov, A. (Ed.). Soviet-Cuban Fishery Research. Pub. for U.S. Dept. of Interior and N.S.F. by Isr. Prog. Sci. Transl., Jerusalem.

Duarte-Bello, P.P. (1961). Corales de los arrecifes Cubanos. Acuario Nacional (Educacional) 2: 85 pp. Mariano, Cuba.

Groombridge, B. (1982). The IUCN Amphibia-Reptilia Red Data Book Part 1: Testudines, Crocodylia, Rhynchcephalia. IUCN, Gland, Switzerland.

Halewyn, R. van and Norton, R.L. (1984). The status and conservation of seabirds in the Caribbean. In: Croxall, J.P., Evans, P.G.H. and Schreiber, R.W. (Eds), Starus and Conservation of the World's Seabirds. ICBP Technical Publication No.2, Cambridge.

Herrera Moreno, A. and Alcolado, P.M. (1983). Efectos de la contaminación sobre las comunidades de gorgonáceos al Oeste de la Bahía de la Habana. Ciencias Biolbgicas 10: 69-85.

Herrera Moreno, A. and Amador Peréz, S. (1983).

Efectos de la contaminación sobre el bentos de la Bahía. Ciencias Biologicas 10: 87-101.

Herrera Moreno, A. and Valle García, R. del (1980). Características de la meiofauna bentónica en la laguna y zona costera de Guayabal, en relación con el grado de contaminación. Ciencias Biologicas 5: 29-44.

Herrera Moreno, A., Valdés-Muñoz, E. and Ibarzábal Bombalier, D. (1981). Evaluación poblacional del erizo negro, Diadema antillarum Phillipi, mediante un diseño de muestreo aleatorio estratificado, y algunos aspectos de su biología. Ciencias Biolbgicas 6: 61-79.

Jiménez, A.N. (1982). Cuba: La Naturaleza y el Hombre

Vol. 1. El Archipiélago. Editorial Letras Cubanas, La Habana, Cuba.

Jiménez, A.N. (1984a). Cuba: La Naturaleza y el Hombre Vol. 2. Bojeo. Editorial Letras Cubanas, La Habana, Cuba.

Jiménez, A.N. (1984b). Cuba Jardln Coralino. Catey, Ediciones Turísticas de Cuba, Instituto Nacional de Turismo de Cuba, La Habana.

Kühlmann, D.H.H. (1966). Putzerfische sambern Krokodile. Z. Tierpsychol. 23: 853-854.

Kühlmann, D.H.H. (1970). Die Korallenriffe Kubas. 1. Genese und Evolution. Int. Rev. ges. Hydrobiol. 55: 729-756.

Kühlmann, D.H.H. (1971). Die Korallenriffe Kubas. II. Zur Okologie der Bankriffe und ihrer Korallen. Int. Rev. ges. Hydrobiol. 56: 145-199.

Kühlmann, D.H.H. (1974a). Die Korallenriffe Kubas. III. Riegelriff und Korallenterrasse, zwei verwandte Erscheinungen des Bankriffes. Int. Rev. ges. Hydrobiol. 59: 305-325.

Kühlmann, D.H.H. (1974b). The coral reefs of Cuba. Proc. 2nd Int. Coral Reef Symp. Vol. 2: 69-83.

Kusel, H. (1972). Contribution to the knowledge of the seaweeds of Cuba. Bot. Mar. 15(186-198).

Mochek, A.D. and Valdés-Muñoz, E. (1983). Acerca de la conducta de los peces de las comunidades costeras en la plataforma cubana. Ciencias Biológicas 9: 87-106.

Munro, J.L. (Ed.) (1983). Caribbean Coral Reef Fishery Resources. ICLARM Studies and Reviews 7, Manila, Philippines.

Ripper, A. von (1949). In the West Indies with the Catherwood - Chaplin Academy Expedition. Frontiers (Nat. Acad. Sci. Phila.) 13: 74-75.

Scott, DA. and Carbonell, M. (1986). A Directory of Neotropical Wetlands. IUCN, Gland and Cambridge.

Vaughan, T.W. (1919). Fossil corals from Central America, Cuba and Puerto Rico with an account of the
American Tertiary, Pleistocene and Recent coral reefs. Bull. U.S. Nat. Mus. 103: 189-524.

Zlatarski, V.N. and Estalella, N.M. (1982). Les Scléractiniaires de Cuba. Académie Bulgare des Sciences, Sofia.

\section{GOLFO GUACANAYABO}

Geographical Location South coast between Cabo Cruz and Santa Cruz del Sur; $77^{\circ}-78^{\circ} \mathrm{W}, 20^{\circ}-20^{\circ} 40^{\prime} \mathrm{N}$.

\section{Area, Depth, Altitude Area of Gulf $100 \mathrm{~km} \times 91 \mathrm{~km}$.}

Physical Features Río Cauto, the largest river in Cuba, flows into the Gulf and the waters are quiet and turbid, with a visibility of only about $20-30 \mathrm{~cm}$. The substrate is in general flat and muddy ('Zlatarski and Estalella, 1982). The coastline is largely marshy and mangrove lined. There are some 187 mangrove-covered sedimentary cays situated in several groups, formed as a result of the heavy soil run-off deposited by the river. Groups of cays include Cayos de Balandras, near Niquero; a group (Cayo Largo and Cayo Grande) off Manzanillo; others at the mouth of the Cauto (La Maya cays) and opposite Camagüey; and a group on the Gran Banco de Buena Esperanza.

Reef Structure and Corals Coral associations in the Gulf form on the muddy bottom and have relief of up to $20-25 \mathrm{~m}$. The vertical walls are covered with small, branching colonies of Oculina and Cladocora arbuscula with a luxuriant growth of sponges, giving the reefs a "gelatinous" appearance. Coral diversity is low on the main body of the reef and zonation is not readily apparent, although at depths of $2-5 \mathrm{~m}$ there is a zone dominated by Acropora cervicornis. The reef flat, varying in width from $10-50 \mathrm{~m}$, is often barren, with coral rubble of Oculina, A cervicornis and Porites, or a dense growth of Thalassia. Less frequently other corals are found, including Porites spp., Mille pora alcicornis, Mussa angulosa, Mycetophyllia lamarckiana, Madracis spp., Siderastrea radians and Eusmilia fastigiata forma guacanayabensis. Many of the corals growing in the Gulf have unusual morphologies due to their unusual habitat (Zlatarski and Estalella, 1982). Curious coral formations are found on the Banco de Chinchorro and Banco de Bueno Esperanza, with oval or ring-shaped depressions (Jiménez, 1984a).

Noteworthy Fauna and Flora The Caribbean Manatee Trichechus manatus probably occurs here. The Rio Cauto has an extensive estuarine system with large brackish lagoons and mangrove swamps. The flamingo Phoenico pterus ruber is reported to breed here and there is a brief description of the area in Scott and Carbonell (1986).

Scientific Importance and Research These reefs are unique in that they have formed in an environment not usually conducive to coral growth, and are constructed of corals not normally known as reef builders. They are of particular scientific interest as there are numerous fossil records of reefs on muddy substrates during the Palaeozoic, but only rarely have comparable reefs been described from the Recent (Zlatarski and Estalella, 1982). 
Economic Value and Social Benefits The Gulf is the centre of the shrimp fishing industry and there are a number of fishing towns around the shore and small fishing villages on the mangrove cays (Jiménez, 1982). The lobster fishery is also important and tyres have been sunk in some areas to make artificial reefs.

Disturbance or Deficiencies Hurricane Flora is thought to have had a major impact on these reefs in 1963 (Zlatarski and Estalella, 1982).

Legal Protection None.

Management None.

Recommendations Further research on these reefs is required.

\section{ISLA DE LA JUVENTUD (FORMERLY ISLA DE PINOS)}

Geographical Location South coast, part of Archipiélago de Los Canarreos; $47 \mathrm{~km}$ from the mainland.

Area, Depth, Altitude About $2200 \mathrm{sq} . \mathrm{km}$; south coast $81 \mathrm{~km}$ in length, total coastline $229 \mathrm{~km}$.

Physical Features A general description of the island is given in Jiménez (1984a). Geologically it is one of the oldest parts of Cuba. There are caves at Punta del Este and along the south coast. There are a number of beaches including the $28 \mathrm{~km}$ Playa Larga on the south coast and Playa de Arenas Negras on the north coast.

Reef Structure and Corals Reefs are found along the south coast. Zlatarski and Estalella (1982) describe 12 reef profiles at different sites around the island including Punta Francés, Carapachibey, Playa Larga, Cabo Matias, and Nueva Gerona. Jiménez (1984a) describes the reef $1.5 \mathrm{~km}$ off Punta del Este which is largely dominated by Acropora palmata and Agaricia spp.

Noteworthy Fauna and Flora The original pine forest has been largely destroyed but there are some remnants. Mangroves are found in a number of areas including the north-west, such as Punta de Buenavista. Scott and Carbonell (1986) give a brief description of the wetland area at Ciénaga de Lanier and Ensenada de La Siguanea in south-central and western Isla de la Juventud respectively. The endemic Cuban Crocodile Crocodylus rhombifer occurs here. Green Chelonia mydas, Hawksbill Eretmochelys imbricata and Loggerhead Caretta caretta Turtles nest on a number of beaches. Reef fish communities at Punta del Este have been described by Mochek et al. (1983). Black coral is unusually abundant in water as shallow as $20 \mathrm{~m}$.

Scientific Importance and Research The Academia de Ciencias de Cuba has a research station at Punta del Este.

Economic Value and Social Benefits The island has a rapidly growing population, although there are still numerous bays along the south coast which are little populated. Nueva Gerona in the north of the island, $2 \mathrm{~km}$ from the mouth of Río de Casas, is the capital and a fishing village. Fishing is important all round the island. Lobster fishing is important in Ensenada de la Siguanea. Jacksonville on the south coast is a fishing centre populated with Cayman islanders. Tourism has become increasingly popular and the island is now the main diving centre in Cuba, the drop-off at the island shelf on the south providing dramatic scenery. The $6 \mathrm{~km}$ long "Pirate Coast" from Cabo Francés to Punta Pedernales is particularly popular and has 16 marked diving sites, each with mooring buoys. There is a modern resort at Playa de Arenas Negras on the north coast as well.

Disturbance or Deficiencies In 1967 there were plans to link the island with the mainland by a viaduct which would have crossed the Golfo de Batabano, but this has never been undertaken. It has also been suggested that the island could be linked to the mainland at Cabo Francés actoss the cays and shallow channels of San Felipe and Los Indios (Jiménez, 1982). There are currently no signs of any obvious pollution or disturbance to the reefs in the diving area (George in litt., 11.12.85).

Legal Protection None, although tourist brochures mention a "réserve à la plongée sous-marine".

Management None known

Recommendations Jiménez (1984) recommends that spearfishing should be prohibited although tourist literature suggests that this activity is prohibited throughout Cuba in any case. This area may be appropriate for designation as a marine park. 


\section{INTRODUCTION}

\section{General Description}

Dominica, the most northerly of the Windward Islands and an independent nation in the British Commonwealth, is a steep, mountainous, volcanic island of $298 \mathrm{sq} \mathrm{mi}$ (772 sq km), with a coastline which consists largely of rocky cliffs with relatively few beaches. The coastal shelf is narrow and coral reef habitats are limited, with little shallow reef development (Adey and Burke, 1976; Goodwin, 1985). Reefs occur mainly on the west coast (ECNAMP, 1980; Goodwin, 1985) and on the northern side of promontories elsewhere.

Underwater surveys of the west coast, except for most of the area between Loubiere and St Joseph, were carried out by Goodwin (1985). The coastal shelf is generally narrow and depths exceeding $180 \mathrm{~m}$ within $1000 \mathrm{~m}$ of shore were recorded at all sites surveyed. The most extensive shelves were found in the vicinity of Pointe Ronde and the area between St Joseph and Grand Savanne. The shelf is typically irregular, probably due to boulders and rock formations, to a depth of ca $50 \mathrm{~m}$, often with a steep drop between 60 and $65 \mathrm{~m}$. Seagrass beds (mainly Syringodium sp., with occasional Thalassia $\mathrm{sp}$.) were found in the vicinity of Bioche, Dublanc, and Morne Espagnol and, to a lesser extent, in the vicinity of Coulibistri, Colihaut and the Cabrits (Goodwin, 1985). No true coral reefs were found, although extensive live coral coverage of rocks and boulders was found at Scotts Head, Soufriére, Pointe Guignard, Mero, Grand Savanne, Pointe Ronde, Petite Baie, Portsmouth, the Cabrits and Toucari. With the exception of Soufriere, Portsmouth and the Cabrits, detailed visual observations were made at these sites and at Pte Tarou between Loubiére and St Joseph (Goodwin, 1985). The richest coral assemblages were found at Petite Baie and Toucari, of which the latter is within the proposed Cabrits National Park (see separate account).

At Scotts Head the dominant living cover was algal turf with numerous sponges and some coral (Agarica spp, Siderastrea siderea and Meandrina meandrites were prevalent). At Point Guignard there were two rock outcrops sloping steeply to $20-25 \mathrm{~m}$, beyond which a sand slope continued. The surfaces of the outcrops facing each other had an extensive and diverse coral cover, with Montastraea annularis and Madracis mirabilis conspicuous. On the outer surfaces, sponges were the dominant cover and fine silt was noticeable; there was a considerable amount of dead coral covered with algal turf. At Pte Tarou the coral/rock area was not extensive and did not appear to be a major habitat. The reef at Mero began at about $10 \mathrm{~m}$; there was considerable coral variety and little sediment, but filamentous alga appeared to be overgrowing much of the reef. At Grand Savanne there were no extensive reef formations, but many small patches of boulders encrusted with corals scattered over a large expanse of shallow ground. At Pointe Ronde, the reef began at ca $12 \mathrm{~m}$ where there were numerous boulders encrusted with corals, interspersed with sponges and alcyonarians on a coarse sand substrate with very little silt evident; in several areas fire coral (Millepora sp.) encrusted the alcyonarians. Below $15 \mathrm{~m}$, algae became more abundant and corals more sparse. At Petite Baie there was a well-developed coral community (15 spp. recorded) covering large boulders at $17 \mathrm{~m}$, with Montastraea annularis the commonest species; algal overgrowth was less extensive than in other areas and grazing fishes were abundant (Goodwin, 1985).

Twenty-three species of coral in 14 genera were recorded during the west coast surveys (Goodwin, 1985) and at least 30 species of stony coral are present in the proposed Cabrits National Park (Putney et al., 1983). The west coast coral areas also contained invertebrate species typical of calm water coral reefs, including tube worms (Sabellidae and Hermodice sp.), medusa worms (Terebellidae), anemones (Condylactis gigantea and Bartholomea sp.), cleaner shrimp (Periclimenes pedersoni), arrow crabs (Stenorhynchus seticornis), black sea urchins (Diadema antillarum) and crinoids (Nemaster sp.) (Goodwin, 1985).

Juvenile and adult conch (Strombus gigas and $S$. costatus) have been recorded in seagrass areas between Bioche and Pointe Ronde and numerous large $S$. gigas were observed in the reef area at Pointe Ronde. Juvenile and near adult spiny lobsters (Panulirus argus and $P$. guttatus) have been recorded at several sites, although the extent of suitable habitat on the west coast appears to be small. Populations are reportedly greater on the east coast, probably because of greater harvest difficulties associated with rougher seas (Goodwin, 1985).

Leatherback

Dermochelys

coriacea Hawksbill Eretmochelys imbricata and Green Chelonia mydas Turtles nest on the island and details of the nesting / beaches are given in Bacon et al. (1984) and Groombridge (1982). Croxall et al. (1984) list seven species of seabirds with resident breeding populations including the White-tailed Tropicbird Phaeton lepturus, Roseate Tern Sterna dougallii, Bridled Tern $S$. anaethetus, Sooty Tern $S$. fuscals and Brown Noddy Anous stolidus. There are few wetlands and only four small stands of mangroves (Scott and Carbonell, 1986).

\section{Reef Resources}

The economy is largely based on agriculture, although artisanal fishing is important. Coral is collected on the north coast. There are several diving and snorkelling sites on the west coast but the tourist industry is only just beginning to recover from the effects of the damage caused by Hurricane David in 1979 (ECNAMP, 1980; Scott and Carbonell, 1986).

\section{Disturbances and Deficiencies}

Hurricane David devastated the island in 1979 but its impact on the reefs is not known. Most of the towns and villages are scattered along the coast and $95 \%$ of coastal lands are under private ownership. The area between Loubiére and St Joseph on the west coast is affected by intensive industrial/urban activity and river input resulting in large amounts of silt and other contaminants; 


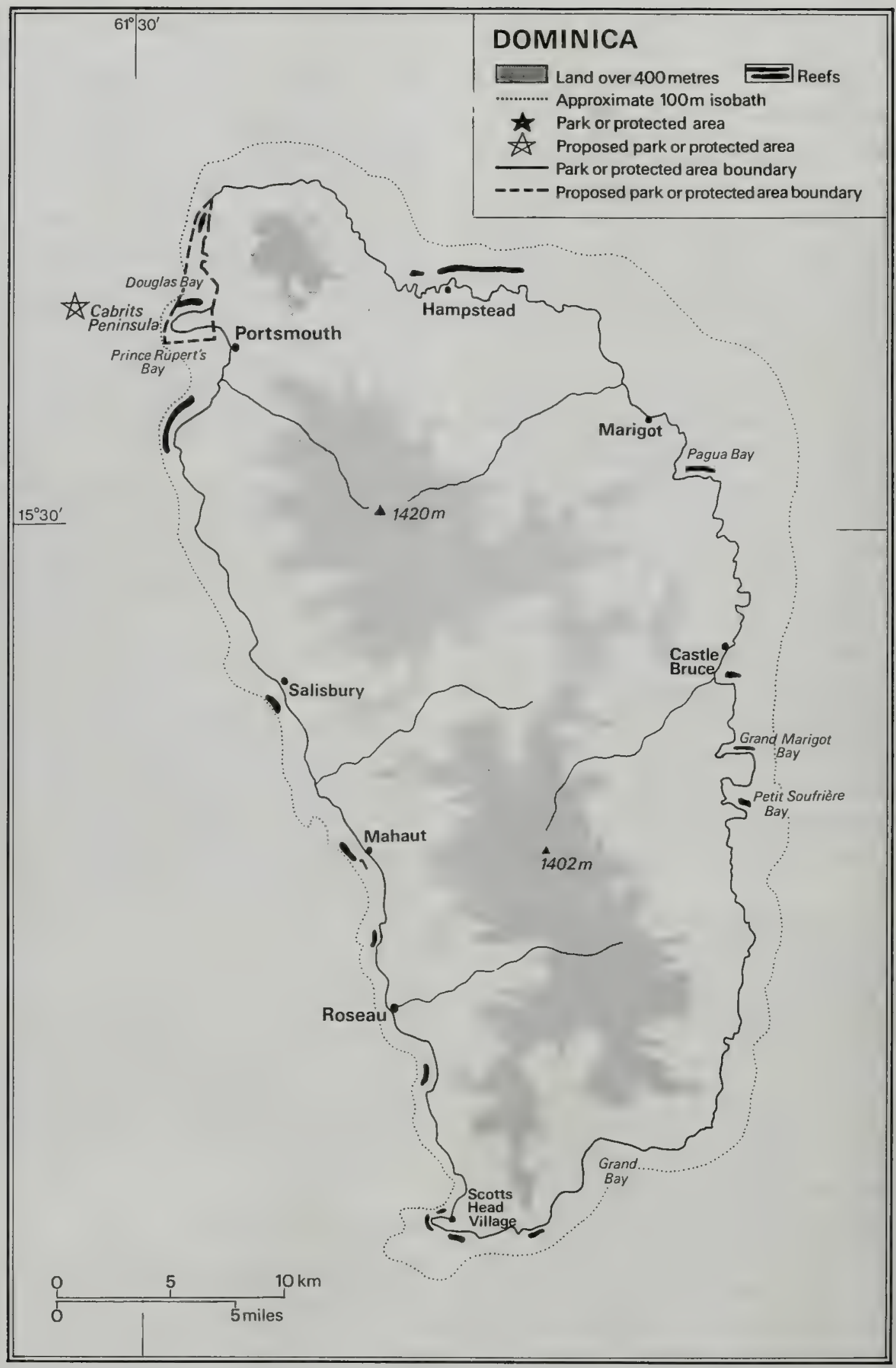


if reefs occur here (this area has not been surveyed), they may have been damaged. Considerable turbidity and bottom silt were observed between Layou and Pte Tarou and in the northern portions of Prince Rupert's Bay. There was also evidence of periodic sediment loading at Scotts Head. Rubbish was common in the bays immediately adjacent to villages, but no indications were seen of gross pollution or environmental degradation (Goodwin, 1985). The inshore fisheries are fully exploited by local fishermen and local demand for fish exceeds supply more than two-fold (Goodwin, 1985). A fatal outbreak of ciguatera, which followed Hurricane David, is described by Taylor (1984).

\section{Legislation and Management}

The Forestry Division is the government department responsible for conservation, the National Parks and Protected Areas Act of 1975 providing the legal basis for a park system. The proposed Cabrits National Park, which contains some reefs, is described in a separate account. Protective legislation for turtles includes minimum size limits, closed seasons and total protection for eggs and nesting turtles (Carr et al., 1982; Bacon et al., 1984).

\section{Recommendations}

Recommendations for management of the reefs in the proposed Cabrits National Park are given in the following account. Goodwin (1985) recommends the establishment of artificial reef areas in appropriate areas around the coast to improve fisheries productivity and yields, the Mero - Grand Savanne and Bioche - Dublanc areas being considered the most suitable sites.

\section{References}

Adey, W.H. and Burke, R. (1976). Holocene bioherms (algal ridges and bank-barrier reefs) of the eastern Caribbean. Geol. Soc. Am. Bull. 87: 95-109.

Anon. (1977). Plan for the management and development of the proposed Cabrits National Park. Team Report. Eastern Caribbean Workshop on National Park Planning. Min. of Ag., Roseau, Dominica.

Anon. (1983). Cabrits Project Annual Report, 1982.

Anon. (undated). Report to IUCN/WWF. Project 1973.

Bacon, P., Berry, F., Bjorndal, Hirth, H., Ogren, L. and Weber, M. (1984). The National Reports. Proceedings of the Western Atlantic Turtle Symposium, Costa Rica. Vol.3: University of Miami Press, Florida.

Carr, A., Meylan, A., Mortimer, J., Bjorndal, K. and Carr, T. (1982). Surveys of sea turtle populations and habitats in the Western Allantic. NOAA Technical Memorandum NHFS-SEFC-91, US Dept. of Commerce.

Croxall, J.P., Evans, P.G.H. and Schreiber, R.W. (Eds) (1984). Status and Conservation of the World's Seabirds. ICBP Technical Publication No. 2, Cambridge.

ECNAMP (1980). Dominica. Preliminary Data Atlas. Survey of Conservation Priorities in the Lesser Antilles. Eastern Caribbean Natural Area Management Program.

Goodwin, M.H. (1985). TCP/DMI/4402 - Feasibility study on the establishment of artificial reefs. FAO Draft Technical Report.

Groombridge, B. (1982). The IUCN Amphibia-Reptilia Red Data Book, Part 1: Testudines, Crocodylia,
Rhynchocephalia. IUCN, Gland, Switzerland.

James, A.A. (1985). Flora and Fauna of the Cabrits Peninsula. Forestery and Wildlife Division, Ministry of Agriculture, Commonwealth of Dominica.

Lynch, R. (1971). Report to ECNAMP on marine resources of St Kitts, Nevis, Montserrat and Dominica.

Putney, A.D., Butler, G., Edwards, S. \& James, A. (1983). Background information on the proposed Cabrits National Park. Draft Report.

Scott, D.A. and Carbonell, M. (1986). A Directory of Neotropical Wetlands. IUCN, Gland and Cambridge.

Taylor, FJ.R. (1970). Marine algae of Dominica. Smithsonian Contr. Botany 3: 1-16.

Taylor, FJ.R. (1984). Human and domestic animal fatalities as well as skin reactions associated with the rough triggerfish Canthidermis maculatus (Bloch) in Dominica, West Indies, following Hurricane David. Rev. Int. Oceanogr. Med. 73/74: 35-40.

\section{CABRITS PROPOSED NATIONAL PARK}

Geographical Location A peninsula (formerly known as Prince Rupert's Head) on the north-west coast, $1.5 \mathrm{~km}$ north of Portsmouth; 15 $34^{\prime}-15^{\circ} 38 \mathrm{~N}, 61^{\circ} 27^{\prime}-61^{\circ} 30^{\prime} \mathrm{W}$. Includes a portion of Prince Rupert's Bay to the south and Douglas and Toucari Bays to the north.

Area, Depth, Altitude Terrestrial area to cover 105 ha, maximum altitude $179 \mathrm{~m}$; marine area to cover about $426 \mathrm{ha}$, to a depth of $160 \mathrm{~m}$.

Land Tenure State-owned apart from 16 ha of the swamp area which is in private hands (Anon,, 1977; James in litt., 19.12.85).

Physical Features Dominated by two steep volcanic hills (the Inner and Outer Cabrits) separated by a narrow valley. The site reportedly contains the most impressive area of dry scrub forest and the most extensive area of wetlands on the island. At least 53 tree species have been identified, although the forest is thought to be largely or entirely regrowth, as most, if not all, of the original vegetation appears to have been cleared in the 18 th and 19th centuries (James, 1985). The peninsula is joined to the mainland by a wetland area of some 35 ha, largely marsh with Cyperus, Achrosticum aureum and Eleocharis, but also some swamp forest (mostly Annona glabra with some Laguncularia racemosa and Pterocarpus of ficinalis). The vegetation is described in Anon. (1977) and James (1985). There are cliffs to the north of Douglas Bay and beaches line the inner portions of this bay, Toucari Bay and Prince Rupert's Bay. The marine area of greatest importance lies in Douglas and Toucari Bays.

There is a definite dry season from February to mid-June and a wetter season the rest of the year. Average rainfall is $60-70 \mathrm{in}$. (ca 170-180 cm) (James, 1985). Mean annual temperature is $28^{\circ} \mathrm{C}$, with moderate trade winds cooling the land most of the year. The currents circulate in a southerly direction. Tidal range, except during storms, rarely exceeds $30 \mathrm{~cm}$.

Reef Structure and Corals The fringing reefs in Douglas and Toucari Bays are considered the finest in 
Dominica. Goodwin (1985) noted that reefs in the Toucari area had the greatest species diversity and development of living cover of those surveyed on the west coast. Between 12 and $25 \mathrm{~m}$ depth in the Bay, 18 species were recorded and Montastraea annularis was most abundant. Some algal overgrowth was observed, particularly on Siderastrea siderea, and algal turfs (Halimeda, Codium and Dictyota) were conspicuous between the corals; very little silt was observed. Sponges were present in shallow areas of the reef and became more abundant below $17 \mathrm{~m}$ depth where $M$. annularis became less abundant. Below $25 \mathrm{~m}$, coarse sand and sponges were the dominant features and there was little coral cover. At about $8 \mathrm{~m}$ the reef is interrupted by a sandy shelf with little coral growth. Patch reefs of isolated coral are found in Douglas Bay. Thirty coral species have been recorded within the Park (Putney et al., 1983).

Noteworthy Fauna and Flora Seagrass beds are found in Douglas and Toucari Bays and there are some mangroves. The interest of the area as a wetland site is described in Scott and Carbonell (1986). More than fifty species of fish have been recorded in the Park. Goodwin (1985) noted that the fish fauna at Toucari Bay was particularly diverse, with over 20 species recorded. Lobsters and conch Strombus gigas are scarce but present. The Green Turtle Chelonia mydas and the Hawksbill Eretmochelys imbricata have been reported nesting in Douglas and Toucari Bays and the Leatherback Dermochelys coriacea may nests (Bacon et al., 1984). The terrestrial vertebrate fauna includes one amphibian, three snakes, and six lizard species of which the largest is an iguana, Iguana delicatissima; it is edible and becoming increasingly rare. Five bat species have been recorded, and over sixty species of birds, including residents and migratory species from the continent. Additional information and lists of species are given in Anon. (1977), James (1985), and Putney et al. (1983).

Scientific Importance and Research The marine areas of the Park have been surveyed. The marine ecosystem has been found to be outstanding in the number of species of fish existing there compared with other marine areas in Dominica (Anon., 1977). Goodwin (1985) considered reefs in Toucari Bay to be unique amongst those surveyed in terms of diversity of species and extent of living cover.

Economic Value and Social Benefits The region has long been important because of its good harbours and abundant resources of wood, water, game and fruit. The Cabrits Peninsula was an important military fortification from 1750-1850. Increasing numbers of tourists visit it, mainly because of the relatively calm and safe anchorage in Prince Rupert's and Douglas Bays. The latter is an important recreational beach due to its proximity to Portsmouth, south of the Peninsula, which is the second major town on Dominica. A German investor has purchased a portion of the swamp area from the
Government for the development of a hotel, restaurant and marina. School parties and other organized groups currently constitute the highest proportion of visitors. Harvesting for fish, shellfish and lobsters is a major year round activity in Prince Rupert's Bay, Douglas Bay and Toucari Bay (Anon., 1977; Putney et al., 1983).

Disturbance or Deficiencies Human impact on the terrestrial environment is described in Anon. (1977). The marine environment has suffered from overfishing of lobsters (now scarce and small), conch, finfish, shellfish and turtles; the latter are caught whenever seen. Sea fans and Black Coral are occasionally collected from the reefs and rock communities (James in litt., 19.12.85).

Legal Protection Legislation for the creation of the Cabrits National Park has been drafted, and in February 1986 it was reported that formal creation of the Park by the national legislature was expected shortly (Putney in litt., 18.2.86). At present, the Cabrits area is protected under the laws of Dominica (Chapter 80: Forest Laws). Terrestrial wildlife and marine turtles are protected under the Forestry and Wildlife Act (No. 12 of 1976) (James in litt., 19.12.85).

Management The Cabrits Project is a multi-institutional effort aimed at the conservation and development of the Cabrits National Park and is partially funded by WWF-US (Anon., undated). Most of the project activities are executed by the Dominican Park Service with assistance from other government departments, the non-governmental Dominica Conservation Association (DCA) and ECNAMP. A draft management plan was drawn up by participants of the 1977 Caribbean Conservation Association/Eastern Caribbean Wildlands Programme/Dominica Government sponsored National Park Planning Workshop (Anon., 1977) which included proposals for the development of the area in terms of the local economy, and the zoning of the Park. After extensive review by the community of Portsmouth and the relevant government departments, the development concepts for the proposed Park were prepared in a document entitled "Cabrits 2000" which was endorsed by the Government of Dominica in 1984. A boundary survey has been carried out, two underwater trails have been laid and promotional materials (a booklet, a brochure, a poster and postcards) have been prepared (James in litt., 19.12.85). A Guard House of historic interest has been renovated to serve as a field museum. Local guides have been licensed to conduct tours of the area. Talks have been given to local schools and the media has provided the Park with some publicity.

Recommendations It is hoped that local fishermen will conduct tours of some of the reef areas which will enable them to improve their income. Artifical reefs could be installed to enhance the value of Douglas and Toucari Bays as breeding reserves once the park is established (Goodwin, 1985), and these sites could also be used for experimental work on artificial reefs. 


\section{DOMINICAN REPUBLIC}

\section{INTRODUCTION}

\section{General Description}

The Dominican Republic has $1576 \mathrm{~km}$ of coast (including the islands of Saona, Catalina, Beata and the Cayos Siete Hermanos) which is characterized by a combination of coralline cliffs and escarpments, river estuaries, and beaches and marshlands often associated with lagoons. About $166 \mathrm{~km}$ of the coast is bordered by reefs and $268 \mathrm{~km}$ by mangrove (Geraldes, 1983). Geraldes (1983) gives a general description of the coastline, based mainly on aerial surveys and Bonnelly de Calventi (1978) and Hartshorn et al. (1981) discuss marine and coastal resources.

The climate is tropical with much regional variation. Rainfall is high, most falling between May and November. Currents are dominated by the Northern Equatorial Current, which flows westwards and divides in two at the Paso Mona, forming northern and southern branches; countercurrents, usually associated with tides, are common near the coast. Tides are semi-diurnal, with a mean spring tidal range of $90 \mathrm{~cm}$ on the north coast and $30 \mathrm{~cm}$ on the south coast (Hartshom et al., 1981).

The continental shelf is generally narrow, with a mean width of $7.5 \mathrm{~km}$, and covers an area of ca $8130 \mathrm{sq}$. km. More than half this total is concentrated in five areas: the Banco Montecristi, the Bahía de Samaná, the Cabo Engaño, San Pedro de Marcoris and the region of Bani-Barahona. Two submerged banks, Navidad and de La Plata, lie $70 \mathrm{~km}$ north and $150 \mathrm{~km}$ south-west respectively of Cabo Samaná (Hartshorn et al., 1981).

The largest expanse of reef along the north coast is in the Montecristi region in the north-west (see separate account). Further east, reefs are widespread, and are found in the area berween Cabo Isabela and Puerto Plata, in the regions of Río Camú and Río San Juan, on the northern and eastern (Bahía Rincón) sides of Península de Samaná, in the Bahía de la Jina, at Miches and along much of the coast from here as far as Cabo Engaño, the easternmost part of the country. Most of these are patch reefs, but in some areas they extend to form fringing or barrier reefs. For example, there are fringing reefs between Cabo Isabela and Puerto Plata, and east of Río San Juan, small barrier reefs in Bahia de la Jina and a large barrier reef in the Macao region between Nisibón and Charca de Bavaro (Geraldes, 1983).

On the south coast, barrier type reefs are found at Boca Chica and Puerto Viejo, the latter being larger and more diverse than the former. Fringing and patch reefs are common. Geraldes (1976) describes the reefs at Puerto Viejo, Bahía de Andrés (see separate account) and Los Bajos in Bahía Ocoa. Bahía de las Calderas (Peravia province) and Punta Magdalena (La Malena) to the east of Bahia de Andrés (San Pedro de Macoris province) were also visited briefly.

CIBIMA, the Centro de Investigaciones de Biología Marina established at Guibia, near Santo Domingo, in 1975 , has surveyed the reefs of the south coast (Geraldes and Bonnelly de Calventi, 1978) with the aim of looking at areas particularly important for fisheries or tourism. A survey of the reefs around Alta Vela, on the south coast, and at Banco de la Plata (ZEE) has been carried out (Geraldes, unpub.). Geraldes (1976) provides an annotated list of scleractinians recorded from the Dominican Republic; 46 species have been described (Geraldes and Bonnelly de Calventi, 1978).

Major wetland sites are described in Scott and Carbonell (1986). Mangroves are found at many sites on both the north and south coasts. The largest expanse in the country is found in Bahía de Samaná and has Rhizophora mangle, Avicenia and Conocarpus spp (Hartshorn et al., 1981). This area, which contains the mouths of Río Yuna and Río Barracote, reportedly forms the largest estuary in the Caribbean. An extensive mangrove area is also found east of Morro in the Montecristi region (see separate account). Sea-grass beds are also widespread. Their distribution is poorly known, although Hartshorn et al. (1981) note the following: Bahía de Montecristi; Bahía de Icaquitos; Bahía Catalinita; Bahía Las Calderas; Bahía Este de Ocoa; Puerto Viejo. They are noted as an important habitat for the Caribbean Manatee (Trichechus manatus) and the Queen Conch (Strombus gigas).

A malacological survey has been carried out on seventeen beaches (Diaz Carela et al., 1978). The American Crocodile Crocodylus acutus is found although in diminished numbers, in suitable habitat, such as mangroves, around the coast. The Leatherback Turtle Dermochelys coriacea occasionally nests in low densities on suitable beaches; the Green Turtle Chelonia mydas occasionally nests on the south coast and nesting Hawksbill Eretmochelys imbricata and Loggerhead Caretta caretta are also found (Bacon et al., 1984). The area extending roughly from the Laguna Limón to the Cabo Engaño is said to be an important turtle-nesting area (Hartshorn et al. 1981). The Caribbean Manatee Trichechus manatus occurs mainly on the north and south-west coasts and has been reported from the Thalassia beds in Puerto Viejo (Geraldes, 1976). Halewyn and Norton (1984) list up to twelve species of seabird which have nesting colonies on the Dominican Republic and its surrounding islands. Terrero (1980) provides a list of fish reported from the waters of the Dominican Republic. The Bahía de las Calderas on the south coast is interesting for its bioluminescence (Almonte, 1976).

\section{Reef Resources}

The reefs play a major role in supporting the artisanal fisheries of the country and are playing an increasingly important role in the development of the tourist industry. Los Bajos, in Bahía Ocoa, is a particularly important site for fisheries. The deep reef here $(21-30 \mathrm{~m})$ with its large colonies of Acropora cervicornis supports abundant fish, lobster Panulinus argus and crab populations (Geraldes, 1976). Tourism is now a major industry on the south coast, particularly at Isla Catalina and Bahia de Andrés. 


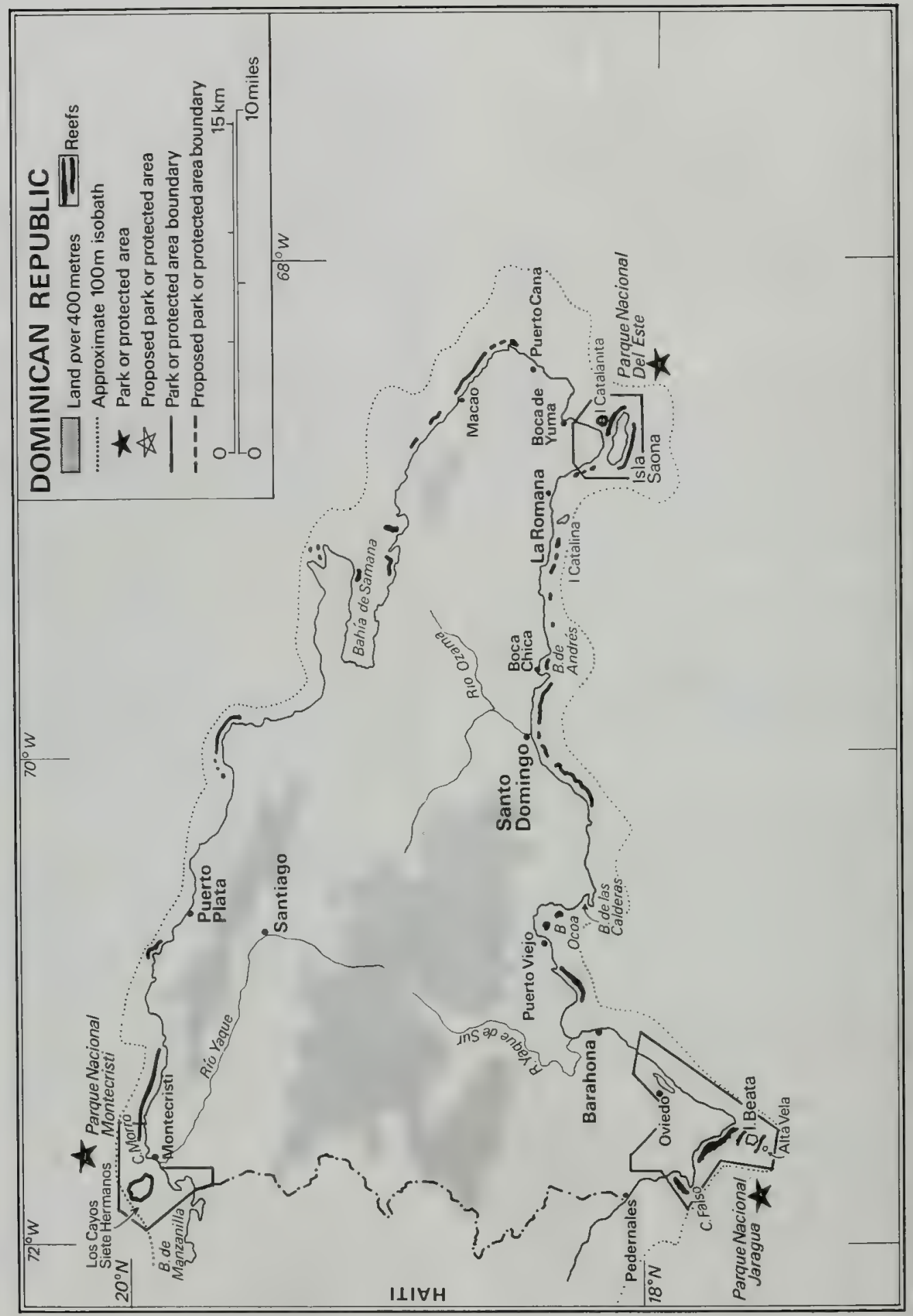




\section{Disturbances and Deficiencies}

Hurricanes Frederic and David damaged reefs in 1979 (Rogers, 1985), particularly in the Boca Chica area (Geraldes, 1982). The sea urchin Diadema antillarum was affected by the Caribbean-wide mass mortality of this species in 1983 (Lessios et al., 1984).

Human activities have been having a noticeable impact on the coastline. Many of the low-lying coastal regions have been converted to coconut plantations, paddy fields and livestock areas. Poor coastal management in some areas, such as Miches, has led to erosion and subsequent severe damage to the adjacent reefs through high sediment run-off (Geraldes, 1983). Dredging for coralline sand has been carried out recently at Puerto Viejo (west of Santo Domingo) and at Boca Chica in Bahía de Andrés (see separate account). The popular recreational beach at Guibia near Santo Domingo has deteriorated, largely due to dredging and pollution of Río Ozama which has its outfall near here (Rivas et al., 1980). At Puerto Viejo, dredging activities have taken place in the vicinity of the reefs for the expansion of the harbour. There is no information on whether this has caused damage to the reefs, but mangroves have been destroyed (Geraldes and Bonnelly de Calventi, 1978). On the south coast, tourism, diving and sport fishing have resulted in damage to the reefs. Briones (in litt., 29.1.86) notes that spearfishing has become increasingly popular recently and has apparently severely affected some sites, for example at the Banco de la Plata, an area once renowned for its abundant fauna; in 1984 there was a conspicuous scarcity of commercial sized fish here and much evidence of damage to coral.

Mangroves have been exploited for tanin, charcoal and construction wood; it has been estimated that $50 \%$ of the mangroves at Puerto Viejo and on adjacent islets were destroyed between 1919 and 1962 (Hartshom et al., 1981). Mangroves in Bahía de Samaná are reportedly threatened by increasing rice cultivation in the region (Hartshorn et al., 1981).

Lobster and conch stocks are reported to have declined (Rogers, 1985). All turtle populations are subject to heavy exploitation of adults and eggs (Groombridge, 1982; Bacon et al., 1984). Corals are collected, mainly for sale as ornaments, but also for lime-making. Most extraction of coral (both soft and stony) is carried out near the cities of Montecristi, Puerto Plata and Samaná on the north coast, at Boca Chica and Isla Catalina on the south coast, and possibly at other sites (Briones in litt. 29.1.86). The commonest species on sale are Acropora palmata, A cervicornis, Agaricia tenuifolia and Diploria spp. Jewelry from Antipatharia and, recently, from the horny skeletons of some gorgonians (Octocorallians), is also very popular. Shells of Strombus gigas and Cassis spp. and dried starfish Oreaster reticulatus are commonly on sale. The latter, used as lures in arrowhead traps, were reportedly collected in large numbers at Pedernales in the south-west of the country which caused a marked decrease in population (Briones in litt., 29.1.86).

\section{Legislation and Management}

Collection of corals requires a licence (Ley 1728, 1976) issued by the Department of Game and Fisheries but few licences have been issued in recent years and most coral extraction is carried out without the requisite authorisation (Briones in litt., 29.1.86). Exports reportedly dropped from $6626 \mathrm{~kg}$ over ten months in 1975 to nil in 1979 (Hartshorn et al., 1981). Legislation exists to control spearfishing for lobsters and to the exploitation of turtles (Bacon et al., 1984). Mangrove and wetland conservation is discussed by Alvares et al. (1978) and Scott and Carbonell (1986).

Scott and Carbonell (1986) describe the main agencies concerned with environmental issues. The Departamento de Recursos Pesqueros is responsible for carrying out research on marine flora and fauna from the point of view of commercial development but with regard for conservation. The Dirección Nacional de Parques is responsible for national parks. Two national parks, Montecristi and Jaragua, contain reefs and are described in the following accounts.

\section{Recommendations}

There are proposals for the extension of the boundaries of the Parque Nacional del Este (see separate account) to include reefs. The establishment of a Marine Park at Punta Caucedo on the south coast has been recommended (see account for Boca Chica area).

\section{References}

* = cited but not consulted

-Almonte, N. (1976). Bahía de Las Calderas, flora y fauna. Observaciones bio-ecológicas y comportamiento dinámico de sus aguas. Departamento Hidrográfico de la Marina de Guerra Dominicana, Santo Domingo, R.D.

Alvares, V. and Bonnelly de Calventi, 1. (1978). Los mànglares del sur y su conservación. Conservación y Ecodesarrollo Ciencia y Tecnología 8: 147-192.

-Anon. (1978). Los algas marinas de la Bahía de Andrés. Rapport Interne, CIBIMA-UASD. 17 pp.

Bacon, P., Berry, F., Bjorndal, Hirth, H., Ogren, L. and Weber, M. (1984). The National Reports. Proceedings of the Western Atlantic Tunle Symposium, Costa Rica. Vol.3: University of Miami Press, Florida.

Barnwell, F.H. (1977). Phase synchrony of skeletal rhythms within populations of corals (Millepora and Acropora) at Boca Chica, Dominican Republic. Am. Zool. 17: 869 .

Bonnelly de Calventi, I. (1978). Los recursos marinos y el medio ambiente en la República Dominicana. Conservación y Ecodesarrollo, Ciencia y Tecnologia 8: 13-50.

-Borrell, (1981). (reference to Jaragua not known).

Diaz Carela, C. and Bonnelly de Calventi, I. (1978).

Estudio malacológico en 17 playas de la República Dominicana. Conservación y Ecodesarrollo, Ciencia y Tecnologia 8: 107-145.

Dirección Nacional de Parques (undated). Plan de Manejo del Parque Nacional del Este.

Galzin, R., Renaud-Mornant, Jo, Jakowska, S. and Bnnnelly de Calventi, I. (in press). La laguna de la Bahía de Andrés en Santo Domingo y su eventual desequilibrio (extracción de sedimento, contaminación). Contribuciones del Centro de Investigaciones de Biología Marina (CIBIMA) de la Universidad Autónoma de Santo Domingo. No. 37. 
* Geraldes, F. (1976). Ecología y taxonómica de los arrecifes de coral dominicanos. 1. Costa Sur. Tesis, Universidad Autónoma de Santo Domingo, República Dominica.

- Geraldes, F.X. (1983). Descripción biológica de los ecosistemas costeros Dominicanos (estudio aéreo). Suplemento del Listín Diario, 26.11.83.

Geraldes, F.X. (1984). El mar alrededor de Beata y Alto Velo, Prov. Pedernales. Unpublished.

Geraldes, F. and Bonnelly de Calventi, I. (1978). Los arrecifes de coral de la costa sur de la República Dominicana. Conservación y Ecodesarrollo, Ciencia y Tecnologia 8: 107-145.

Geraldes, F. (1982). Los efectos del huracán David y la tormenta Federico en el arrecife de coral de Boca Chica. Contribuciones del Centro de Investigaciones de Biología Marina (CIBIMA), Universidad Autónoma de Santo Domingo: 27: 10pp.

Groombridge, B. (1982). The IUCN Amphibia-Reprilia Red Data Book. Part 1: Testudines; Crocodylia; Rhynchocephalia. IUCN, Gland, Switzerland.

Halewyn, R. Van and Norton, R.L. (1984). The status and conservation of seabirds in the Caribbean. In: Croxall, J.P., Evans, P.G.H. and Schreiber, R.W. (Eds) Status and Conservation of the World's Seabirds. ICBP Technical Publication No. 2, Cambridge.

Hartshorn, G., Antonini, G., DuBois, R., Harcharik, D., Heckadon, S., Newton, H., Quesada, C., Shores, J. and Staples, G. (1981). La República Dominicana - Perfil ambiental del Pais - Un Estudio de Campo. AID Contract No. AID/SOD/PDC-C-0247. JRB Associates, Virginia.

-Indotec, (1984). (reference to Jaragua not known).

IUCN (1982). Directory of Neotropical Protected Areas. Tycooly International Publishing Ltd, Dublin.

Katx, A.D. (1981). Marine areas of the Parque Nacional del Este. Report of visits to Parque Nacional del Este and surrounding marine areas.

Lessios, H.A., Robertson, D.R. and Cubit, J.D. (1984).

Spread of Diadema mortality through the Caribbean. Science 226:335-337.

-Osiris de Leon, (1983). (reference to Jaragua not known).

Peláez Feucht, S. (1985). Propuesta técnica para la elaboración del plan de manejo y conservación del Parque Nacional Jaragua. Dirección Nacional de Parques, Santo Domingo. (available as English translation as project proposal to WWF-US).

-Pérez de I. (1975). (Pollution at Boca Chica; reference not known).

Rivas, V., Ruíz, N. and Bonnelly de Calventi, I. (1980).

Guibia: una playa urbana. Sus aguas, flora y fauna. Estudios Hidrobiológicos de Guibia y Zonas Aledanas. Notas científicas, Contribuciones 1, Centro de Investigaciones de Biología Marina, Universidad Autónoma de Santo Domingo.

Rogers, C. (1985). Degradation of Caribbean and Western Atlantic coral reefs and decline of associated fisheries. Proc. 5th Int. Coral Reef Congress, Tahiti, 6: 491-496.

Secretaría de Estado de Agricultura, Subsecretaría de Recursos Naturales, Departamento de Vida Silvestre, Sección de Estudios y Manejo de Areas Silvestres (1983). Estudios en las areas silvestres de la Península de Barahona e Isla Beata.

Terrero, N. (1980). Peces reportados para la Hispaniola. Contribuciones del Centro de Investigaciones de Biologia Marina, Universidad Autbnoma de Santo Domingo, 2.

\section{BOCA CHICA, BAHIA DE ANDRES AND PUNTA CAUCEDO}

Geographical Location $18^{\circ} 17^{\prime} \mathrm{N}, 69^{\circ} 37^{\prime} \mathrm{W}$; in the Distrito Nacional, east of Santo Domingo, central south coast.

Physical Features Bahía de Andrés is bordered to the west by Punta Caucedo and to the east by Punta Malena. The coastal region is largely humid subtropical forest, with extensive subtropical waters coming from the Rio Brujuelas. A calm lagoon, over $1 \mathrm{~km}$ wide, is separated from the open sea by a barrier reef. The lagoon connects with the sea at each end, in the east by a shallow sandy channel and at the western end by a deeper passage (15-20 $\mathrm{m}$ deep) through which boats can pass, protected from the surf. There are two islands in the lagoon. La Matica $(200 \times 150 \mathrm{~m})$ is a coralline island lying $500 \mathrm{~m}$ off Boca Chica. La Piedra (Los Pinos) was artificially constructed from the dredging spoil resulting from the channel and wharf, built at the entrance to the port of Andrés. There is a white sand beach along the coast. Most of the lagoon has an average depth of $0.5 \mathrm{~m}$, with a sand bottom and stands of seagrass (Thalassia and Syringodium). To the north and west of La Piedra the lagoon has been artificially deepened and has a bottom of muddy sand with a faunal community typical of disturbed bottom strata.(Galzin et al., in press; Geraldes, 1976; Geraldes and Bonnelly de Calventi, 1978).

Reef Structure and Corals The barrier reef extends across the bay from north-east to south-west where it becomes a $10 \mathrm{~m}$ wide fringing reef extending to Punta Caucedo. Parch reefs and coral communities are found in the east of the bay but corals are absent from the lagoon (Galzin et al., in press).

Geraldes (1976) and Geraldes and Bonnelly de Calventi (1978) give detailed descriptions of the reef. The inner slope is composed largely, and in some places exclusively, of Porites porites. The reef flat is $0.2-0.4 \mathrm{~m}$ deep and $50-100 \mathrm{~m}$ wide and is largely covered with dead Porites and scattered sea grass Thalassia. Occasional living coral colonies are found in deeper areas. Towards the breaker zone, large coral rocks and boulders are found with scattered corals growing on them, including Helioseris cucullata, Siderastrea siderea, S. radians, Diploria strigosa, $P$. asteroides, Millepora alcicornis and $M$. complanata. Zoanthids, especially Zoanthus sociatus, are common at the base of rocks. The breaker zone is interrupted in some areas by small channels 0.5-1.5 $\mathrm{m}$ deep; towards the open sea these are dominated by $D$. strigosa, $D$. clivosa and Acropora palmata. In the deeper and more exposed parts of the crest, $A$ palmata dominates, the crest merging with a palmata zone at $4-5 \mathrm{~m}$ depth. At $6 \mathrm{~m}$ a variety of other species are found including increasing numbers of gorgonians, octocorals, sponges and echinoderms.

Below this is a buttress zone which has a rich growth of corals. A palmata predominates, forming large colonies up to $5 \mathrm{~m}$ in height, with other coral species and abundant octocorals and gorgonians scattered between. A sandy channel runs parallel to the reef at $15 \mathrm{~m}$; in the past large colonies of $A$ cervicornis could be found at the bases of the buttresses but now there are only small scattered colonies. At $17 \mathrm{~m}$, beyond the channel, there is a rocky promontory, $3-8 \mathrm{~m}$ high, which is abundantly covered with corals (Geraldes, 1976; Geraldes and Bonnelly de Calventi, 1978). 
Noteworthy Fauna and Flora Marine algae of Bahía de Andres have been described (Anon., 1978). La Matica is covered with mangroves, predominantly Rhizophora mangle. Other plants were introduced in the 1940 s when the island was the site of a small aquarium and marine zoo. There are some mangroves around La Piedra. Fish, crustaceans and other invertebrates found on the reef are described by Geraldes (1976) and Geraldes and Bonnelly de Calventi (1978).

Scientific Importance and Research No information, beyond survey work described in this account.

Economic Value and Social Benefits Andrés is an important sugar producing port. Boca Chica is now one of the major tourist resorts in the country, the local people gaining their main source of income from this instead of fishing, as in the past (Geraldes, 1976).

Disturbance or Deficiencies Geraldes (1982) describes the effects of Hurricane David and Tropical Storm Federico in 1978. These two events caused major changes to the beach and reefs in this area. East of $\mathrm{La}$ Piedra, the inner reef was largely destroyed and the breaker zone and palmata zones were badly damaged.

Pollution studies were carried out at the mouth of Rio Brujuelas and coliform bacteria were found to be present (Perez de I., 1975). There are signs of pollution in the lagoon and agents responsible for ciguatera outbreaks have been identified (Geraldes and Bonnelly de Calventi, 1978). Fishing is moderately heavy in the Bay (Geraldes, 1976).

Major dredging projects were carried out in Bahia de Andrés in 1954 for materials for construction of the international airport, in 1955 for the construction of a fishery port at Boca Chica and the building of La Piedra Island, and in 1977 for the construction of the Marina. Galzin et al. (in press) studied the impact of this activity as part of an IUCN/WWF project. Fourteen stations in the lagoon were sampled and one on the reef. The fauna of the western part of the lagoon has been noticeably influenced by increased sedimentation and turbidity as a result of dredging and the creation of an artificial beach. A sugar cane processing factory is also affecting this area through the discharge of acidic, warm water. The reef has not yet been affected by these activities due to the direction of current flow, but there is a potential danger in the long-term (Geraldes, 1976).

Certain corals are now noticeably scarce on the outer reef, including $A$ cervicornis and $A$ palmata. This is considered to be due to the massive commercial exploitation, in the 1970 s, of stony corals by commercial divers at depths of $1-20 \mathrm{~m}$. From January to October $1975,6626 \mathrm{~kg}$ of corals were collected at Boca Chica, primarily young colonies of $A$ palmata, $A$ cervicomis, Agaricia and Montastraea. The habitat has been noticeably damaged and the fish fauna impoverished (Geraldes, 1976; Geraldes and Bonnelly de Calventi, 1978).

\section{Legal Protection None.}

Management None known.

Recommendations There has been a recommendation that Punta Caucedo should be made a marine park
(Peláez Feucht in litt., 29.6.84). In view of the importance of this area for tourism, there is a clear need for the management and restoration of the lagoon and reef habitat as stressed by Geraldes (1976) and Geraldes and Bonnelly de Calventi (1978).

\section{PARQUE NACIONAL DEL ESTE}

Geographical Location $18^{\circ} 15^{\prime} \mathrm{N}, 68^{\circ} 45^{\prime} \mathrm{W}$ in the province of Altagracia, south-east tip of Dominican Republic, including the peninsula to the south-east of $\mathrm{La}$ Romana and Isla Saona.

Area, Depth, Altitude Sea-level to $50 \mathrm{~m} ; 43400$ ha (does not include marine area): mainland peninsula 31000 ha, Isla Saona 11000 ha.

Land Tenure Mainly government land but some private ownership, particularly on Isla Saona.

Physical Features The Park consists of low coastal limestone substrate including several cave systems. The west coast of the peninsula, from Guaraguao on the northern boundary to Palma Seca near the south-west tip of the mainland, has sandy beaches interspersed with rocks and shallow waters. Within a few hundred metres of the shore, the bottom is mostly sand gradually dropping off and blending into seagrass beds. The sediment thins seaward with increasing scattered gorgonians, soft corals and small stony coral heads to a small drop $(2-3 \mathrm{ft}(0.6-0.9 \mathrm{~m}))$ onto a barren unconsolidated sediment. At about $70 \mathrm{ft}(21 \mathrm{~m})$ there is an increase in slope and a well developed reef continues down to $120 \mathrm{ft}(37 \mathrm{~m}), 2 \mathrm{~km}$ from shore (Katz, 1981). The south coast from Palma Seca to El Aljibe is swampy with mangroves, the sea bottom being covered by sediment from Bahia Catalinita, the bay formed betwen the mainland and Isla Saona, passing through the Paso de Catuan, the narrow western entrance to the bay. Around Peñón Gordo and Las Tres Hermanas, midway down the west coast of the peninsula, there is some scattered coral growth $100-200 \mathrm{~m}$ offshore in 8-12 ft $(2.4-3.6 \mathrm{~m})$ of water (Katz, 1981). The exposed east coast is rocky with small beaches.

The offshore island of Saona, separated from the peninsula by the Paso de Catuán, is also flat except for the north-east coast which has cliffs. At Punta Canto de la Playa on the south coast has an attractive beach, but the sea bottom between the beach and the breakers is covered with seagrass, and the sea is extremely turbid. Approximately $3 \mathrm{~km}$ from shore the reef outcrop, Bajos de Caballo, has live coral and abundant fish on the north-west side although most of the rest of the coral is dead (Katz, 1981). Beaches are found between Punta Catuano in the north-west and Punta de Cruz in the south-east and in some areas in the south. Rainfall averages $100-200 \mathrm{~cm}$ a year and there are two rainy seasons (December to April and May to November). The Park is extremely arid, with no rivers or streams. A brief description of the geology of the area is given in the management plan (Dirección Nacional de Parques, undated).

Reef Structure and Corals Fringing reefs, dominated 
by Acropora palmata, are found along the south coast of Isla Saona. Coral patches, comprised mainly of Diploria, Porites and Montastraea annularis, occur along the west coast of the peninsula and in some areas off the east coast. There is a lot of coral off the south coast of Isla Saona, but most of this is dead and barren. The limestone pavement around the reef has loose coral rubble or large dead Acropora spp. colonies, with occasional living colonies of $A$ palmata or small heads of Montastraea and Diploria. There are a few interesting sites with living coral and abundant small fish in areas protected from strong easterly and southerly wave action. The best sites around Isla Saona are from Punta Cacon to Punta Catuano, a sheltered area in the west, and have mostly hard coral (Acropora and Porites). Seaward, there is a hard limestone bottom with increasing soft coral growth until sand cover is reached. Coral on the deep reef $(70 \mathrm{ft}-120 \mathrm{ft}(21-37 \mathrm{~m}))$ off the west peninsula forms narrow $(5 \mathrm{ft}-10 \mathrm{ft}(1.5-3 \mathrm{~m})$ ) rows perpendicular to the shore, separated by sand channels (Katz, 1981).

Noteworthy Fauna and Flora Much of the Park is covered with scrubby woodland and cacti, described in the management plan. Coconut plantations occur in the western part and mangroves, the four common Caribbean species: Rhizophora mangle, Conocarpus erectus, Laguncularia racemose and Avicennia germinans, are found along the coast, particularly in the south. Seagrass beds of Thalassia testudinum and Cymodocea manatorum occur in some areas. The importance of the area as a wetland site is described in Scott and Carbonell (1986). There are a remarkable number of large rays on the west coast of the peninsula. North-east of Catalina Island outside the Park to the north-east, black coral is found (Katz, 1981). Large numbers of starfish Oreaster reticulatus and sea cucumbers occur in the seagrass beds of Isla Saona.

The Caribbean Manatee Trichechus manatus occurs occasionally off the coast, particularly in the bay of Las Calderas, which is entered through a narrow channel near the south-west tip of the mainland. Dolphins Tursiops truncatus and whales have been recorded off shore. Leatherback Turtles Dermochelys coriacea nest on the beaches and the Green Turtle Chelonia mydas, the Hawksbill Eretmochelys imbricata and the Loggerhead Turtle Caretta caretta have been recorded within the Park (Bacon et al., 1984). Preliminary studies have resulted in records for thirty-seven fish, nine corals, eight marine plants and algae and 124 other invertebrates. The iguana Cyclura cornuta is found in the east of the peninsula and on Isla Saona. Eight endemic birds, out of a total of 112 species, have been recorded, woodland and mangroves being their most important habitats. The rocky coastline is important for nesting seabirds. There are a number of mammals including the Solenodon Solenodon paradoxus and the Hutia Plagiodontia hylaeum. Terrestrial fauna are listed in IUCN (1982) and in the management plan.

Scientific Importance and Research Inventories of the fauna and flora have been compiled (Dirección Nacional de Parques, undated). A survey of the western part of the Park was carried out as a cooperative project between the Museo Nacional de Historia Natural and the Dirección Nacional de Parques, to determine new boundaries for this part of the Park (Katz, 1981).
Economic Value and Social Benefits About twelve families live within the Park at La Gran Chorra on the eastern coast of the mainland and a further 370 live on Isla Saona. Subsistence agriculture, artisanal fishing and the coconut plantations are the main sources of income. There are a small number of foreign tourists, although the lack of freshwater and abundance of mosquitos are a deterrent. However, there is potential for increased recreational use and the area has considerable archaeological, anthropological and historical interest in addition to its wildife attractions. A tourist centre, Dominicus Americanus, has recently been built to the north of the Park. Casa de Campo, west of the Park, has a marina and runs day trips and snorkelling/SCUBA boats to various sites and beaches on and around Isla Catalina. If included within the boundary extension, they could build up the boating/snorkelling trips as visits to a "National Park". There are good fishing and probably SCUBA sites in deep areas (more than ten fathoms $(18 \mathrm{~m})$ ) off the south of Isla Saona (Katz, 1981). The entire $12 \mathrm{~km}$ offshore reef paralleling the western coast of the peninsula is good for SCUBA diving.

Disturbance or Deficiencies Hurricanes and sedimentation from Catalinita Bay may have caused the disappearance of coral off Palma Seca, last mapped twenty years ago by the U.S. Army Corps of Engineers. Lobster and conch have been depleted by overfishing and the manatee by hunting. Slash and burn cultivation is a problem in the terrestrial area, particularly on Isla Saona. Litter and pollution are more prevalent at Mano Juan on the south coast than elsewhere in the area since this is where most of the population of Isla Saona live (Katz, 1981).

Legal Protection The Park was established on 16 September 1975 by law \# 1311, but the adjacent marine area is not protected. The rules of the Park are outlined in the management plan.

Management Administered by the Direccion Nacional de Parques, Boca de Yuma, Provincia Altagracia. The management plan designates strict natural zones (e.g. La Caldera in the south, for mangroves and the endemic Columba leucocephala), managed natural zones, wilderness zones, protected anthropological zones and tourist/administrative zones. There is a staff of fifteen. Casa de Campo pays some of the personnel at the military base on Isla Catalina to keep the beach area clean (Katz, 1981). The navy exert some control on fishing activities. Navigation is difficult in the vicinity of the Canal de Catuano and to the north of Isla Catalinita (Peláez Feucht in litt., 25.10.84).

Recommendations The management plan gives proposals for the management of the different zones and suggestions for visitor facilities, such as interpretive centres, and for research to be carried out within the Park. There are plans to include the Canal de Catuano within the boundaries as well as to extend the coastal boundary to a distance of $500 \mathrm{~m}$ into the sea to provide protection for the reefs and marine habitat. Katz (1981) recommends that the boundary be extended further, to at least $2 \mathrm{~km}$ offshore or, preferably, to the 100 fathom $(183 \mathrm{~m})$ line and that it should include Isla Catalina, Catalinita Bay and certain shallow areas off Isla Saona. Some of the SCUBA sites may need protection such as the deep waters off west and south Isla Saona, eastern 
Catalinita Bay, the waters off Playas Guanabano and the Larga, on the east coast of the Park (possible spectacular drop-off), and the area around Isla Catalina (south-west coast and north-east sea cliff). These sites should be investigated to determine which should have restricted access and which can be open to the public. The marine extension of the Park, although protected, should still be used by local fishermen and use of the area for education and recreation should be increased.

\section{PAROUE NACIONAL JARAGUA}

Geographical Location $17^{\circ} 40^{\prime} \mathrm{N}, 71^{\circ} 30^{\prime} \mathrm{W}$; extreme south-west of the Dominican Republic, around the south coast of the Península de Barahona, including the islands of Beata and Alto Velo, the Laguna de Oviedo and adjacent marine waters. The northern boundary is marked by the Oviedo-Pedernales road.

Area, Depth, Altitude $1338 \mathrm{sq}$. km of which about $758 \mathrm{sq} . \mathrm{km}$ is marine; maximum altitude (Punta del Cerro) is $334 \mathrm{~m}$.

\section{Land Tenure Government owned.}

Physical Features The Park includes a wide variety of terrestrial and marine ecosystems, with the coastal lagoon, Laguna de Oviedo, on the east coast of the peninsula. The coast is bordered by coral reefs interspersed with sand banks. The insular shelf varies in width from one $\mathrm{km}$ to $35 \mathrm{~km}$ south of Cabo Beata. The geology of the region is described by Osiris de Leon (1983). The Peninsula consists largely of a low coralline rock platform surrounded at sea level by an area of coastal lagoons. At Cabo Falso on the west coast, the platform drops rapidly into the sea forming cliffs of $30 \mathrm{~m}$. On the south-west, the major lagoons are Puerto en Medio, Manuel Matos, Salada and Salado de Bucan de Base; other lagoons are of a temporary nature. The Oviedo (about $28 \mathrm{sq} \mathrm{km}$ in area) and Robiza lagoons lie along the south-east coast. Some of the lagoons are brackish; Oviedo is saline. There are a number of rocky headlands. There are no rivers or streams. Isla Beata has a similar calcareous formation with small saline lagoons on the north-east coast while Alto Velo consists of a combination of calcareous and volcanic rocks. The climate is semi-arid with an average annual rainfall of $500-700 \mathrm{~mm}$, more rain falling in the east due to northerly trade and local winds. There is a dry season in the first part of the year (Peláez Feucht, 1985). Further details are given in Secretaría de Estado de Agricultura et al. (1973).

Reef Structure and Corals There have been no detailed studies of the reefs but common corals include Porites asteroides, Solenastrea bournoni, Acropora cervicornis, Millepora squarrosa and various gorgonians (Peláez Feucht, 1985). Off parts of Alto Velo there is often a sheer drop from the tidal zone to up to $8 \mathrm{~m}$ depth which is covered with sponges, hydrozoans and calcareous algae (including Halimeda and Penicillium). From $8 \mathrm{~m}$ to around $15 \mathrm{~m}$ depth, there are colonies of Madracis, Porites, Montastraea, Millepora, Diploria, Dichocoenia and Agaricia which increase in size and number with increasing depth and form large patches which Geraldes
(1984) considered could be developing into a fringing reef. Below this the bottom becomes sandy with gorgonians and other benthic organisms.

Noteworthy Fauna and Flora The terrestrial vegetation is largely xerophytic (Czerwenka, 1983) and is described by Secretaría de Estado de Agricultura et al. (1973) and summarised by Pelaez Feucht (1985). There are many endemic plants and animals including a large population of flamingoes Phoenicopterus ruber and many migratory birds. Peláez Feucht (1985) gives details of some of the terrestrial fauna. The importance of Laguna Salada and Laguna Oviedo as wetland sites is described in Scott and Carbonell (1986). The marine turtles Dermochelys coriacea, Eretmochelys imbricata, Caretta caretta and Chelonia mydas nest in the Park (Bacon et al., 1984). The Queen Conch Strombus gigas used to be abundant but is so no longer. Geraldes (1984) considered the fish fauna here to be the finest and most abundant he had encountered in the Dominican Republic.

Scientific Importance and Research The Parque Nacional Jaragua is the largest national park in the Dominican Republic and is one of the most pristine and diverse. A survey of the Península de Barahona, primarily of the terrestrial ecosystems, was carried out as part of a programme carried out by the Departamento de Vida Silvestre de la Secretaria de Estado de Agricultura to inventory and evaluate the ecosystems of the Dominican Republic. The study was undertaken with the co-operation of the Dirección Nacional de Parques and the Museo Nacional de Historia Natural. The area has considerable archaeological interest.

Economic Value and Social Benefits The socioeconomy of the region is described briefly by Peláez Feucht (1985). Artisanal fishing is an important and growing activity, some 30 fishermen now using the Laguna de Oviedo. A fishing village is situated near Cabo Rojo in the extreme west of the Park and there are temporary fishing encampments on the south coast of the Park and on Isla Beata. The wide insular shelf to the south of Beata has been identified as the most productive fishing area in the country, with a production of 3.4 tonnes/sq. km (Indotec, 1984). There are anchorages at Cabo Rojo, Las Cuervas and Isla Beata but currents around Cabo Falso can be dangerous. It is hoped that the tourism potential of the Park will be developed. Some of the most attractive marine scenery in the Dominican Republic is found off Punta Lanza on the west coast of Isla Beata (Borrell, 1981).

Disturbance or Deficiencies The area is largely pristine at present. However there are fears that overfishing could become a problem, particularly in Laguna de Oviedo, and human activities are beginning to have an impact on the terrestrial portion of the Park (Peláez Feucht, 1985).

Legal Protection Established by presidential decree no. 1315, 11 August 1983.

Management A management plan is being developed with the financial assistance of WWF-US.

Recommendations The management plan will give detailed recommendations for the development of the Park, taking into account the need for management of the fishing industry and the integration of the Park into the 
local economy (Peláez Feucht, 1985). There is a proposal for a detailed study of the marine environments within the Park.

\section{PARQUE NACIONAL MONTECRISTI}

Geographical Location $19^{\circ} 52^{\prime} \mathrm{N}, 71^{\circ} 42^{\prime} \mathrm{W}$ in the extreme north-west of the Dominican Republic, bordering Haiti.

Area, Depth, Altitude Approximately $530 \mathrm{sq.} \mathrm{km;} 30 \mathrm{~m}$ depth to $200 \mathrm{~m}$ altitude.

Land Tenure Estate lands are leased to agriculture and salt workers' co-operative.

Physical Features The area includes the mouths of Rio Artibonito and the delta of Río Yaque de Norte, which drain the largest watershed in the country. Soils in the Park are alluvial (Peláez Feucht in litt., 25.10.84) and there are large areas of marshland, mangrove and Thalassia seagrass beds. The sea is generally calm with a swell of 1 or $2 \mathrm{ft}(0.31$ or $0.61 \mathrm{~m})$. Seven coral cays, known as "Cayos Siete Hermanos", lie near the mouth of the Rio Yaque and are surrounded by poor coral communities; some of the cays are completely covered at high tide (Geraldes, 1983). East of Morro de Montecristi is a large expanse of mangrove, to the east of which begins the largest coral reef on the north of the island, stretching from Montecristi to Punta Ricia, much of this lying outside the park boundaries (Geraldes, 1983).

Reef Structure and Corals The coral fauna is comparatively poor around the Cayos Siete Hermanos due to the proximity of the mouth of the Rio Yaque which brings down sediment. Porites porites is dominant, surrounded by dead remains of a dense coral community. Most of the reef east of Morro is outside the Park. At its eastern end it consists of patches and shoals; at the level of Punta Fragata a true barrier reef begins with an extensive lagoon and beds of Thalassia and other forms of marine vegetation (Geraldes, 1983). There are also areas of mangrove. The reef is reportedly rich (Geraldes, 1983), with Acropora palmata dominant (Peláez Feucht in litt., 25.10.84).
Noteworthy Fauna and Flora The Hawksbill Turtle Eretmochelys imbricata nests in the cays and the Leatherback Turtle Dermochelys coriacea has been taken in the area. The Caribbean Manatee Trichechus manatus is found on the reef in the north of the Park and also among the reefs of the surrounding areas. A protected population of the American Crocodile Crocodylus actutus is found in another area of the Park. Mangroves are extensive in the Bahia de Manzanillo and around El Morro (Peláez Feucht in litt., 25.10.84). The importance of the Cayos Siete Hermanos as a wetland site is described in Scott and Carbonell (1986).

Scientific Importance and Research A large proportion of the population of Caribbean Manatee T. manatus lives in the area but has been little studied. The fringing reef east of Morro de Montecristi is the most extensive on the north coast but has not been studied (Palaez Feucht in litt., 25.10.84).

Economic Value and Social Benefits According to the Instituto Dominicano de Tecnología Industrial (INDOTEC), the bank off Montecristi is potentially a major fishing ground. Subsistence fishing is traditionally carried out in the area.

Disturbance or Deficiencies Artisanal fishing with fine meshed haul nets (trawlers) are a threat; further potential threats include the installation of large farm and shrimp plants within the limits of the Park. The estuarine communities have been affected by the extensive use of river waters in irrigation and by dams constructed in the upper reaches of the Valle del Cibao, leading to decreasing freshwater in the estuary and increasing penetration of sea water upstream. Aquaculture and tourist development are reportedly planned for the region (Geraldes, 1983). The reef to the east of the park is said to be little disturbed although there is a tourist beach near Punta Ricia.

Legal Protection Presidential Decree 1315 declared the area as a National Park on 11 August 1983.

Management To date, there is no management of the area, but a management plan will be prepared as soon as financial support becomes available.

Recommendations Financial support is required. 


\section{INTRODUCTION}

Small coral formations are present along the mainland coast of Ecuador (Dana, 1975; Glynn and Wellington, 1983), for example at Machalilla $\left(1^{\circ} 28^{\prime} \mathrm{S}, 80^{\circ} 47^{\prime} \mathrm{W}\right.$, south of Manta) but the only detailed information is for the Galápagos Islands (see separate account).

Coastal wetlands are described in Scott and Carbonell (1986). The American Crocodile Crocodylus acutus was formerly abundant in coastal wetlands and inland waters but is now severely depleted. The Green Turtle, the Hawksbill, the Olive Ridley and the Leatherback (Chelonia mydas, Eretmochelys imbricata, Lepidochelys olivacea and Demochelys coriacea occur along the coast. The Green, Hawksbill and Leatherback nest in small numbers on the mainland; the Green Turtle nests in good numbers in the Galápagos (Groombridge, 1982).

No information has been obtained on the economic value of the mainland coral resources or on their conservation status. The situation in the Galápagos is described in the following account.

The National Parks and wildlife legislation of Ecuador are briefly summarized in IUCN (1982) and Scott and Carbonell (1986). A marine extension to the Parque Nacional Galapagos was declared in 1986 (see separate account). Machalilla National Park on the coast of Manabi Province includes Islas de la Plata and Salango and two miles of coastline and is described in IUCN (1982); there is no information on corals.

\section{References}

* cited but not consulted

-Abbott, D.P. (1966). Factors influencing the zoogeographic affinities of Galápagos inshore marine fauna. In: Bowman, R.I. (Ed.) The Galapagos. Proceedings of the Symposium of the Galápagos International Scientific Project. University of Califomia Press, Berkeley and Los Angeles: 108-122.

Agassiz, A. (1892). General sketch of the expedition of the Albatross, from February to May, 1981. Bull. Mus. Comp. Zool. Harv. College 23(1): 1-89.

Anon. (1986). Galapagos declared marine reserve. WWF News 42: 6.

-Briggs, J.C. (1974). Marine Zoogeography. McGraw-Hill, New York.

Broadus, J.M. (1985). A special marine reserve for the Galápagos Islands. Coastal Zone '85, Baltimore, MD, August 1985.

Coulter, M.C. (1984). Seabird conservation in the Galápagos Islands, Ecuador. In: Croxall, J.P., Evans, P.G.H. and Schreiber, R.W. (Eds), Status and Conservation of the World's Seabirds. ICBP Technical Publication No. 2, Cambridge.

Crossland, C. (1927). Marine ecology and coral formations in the Panama region. the Galápagos and Marquesas Islands and the Atoll of Napuka. The expedition to the South Pacific of the S.Y. St
George. Trans Roy. Soc. Edinburgh 55(2): 531-554.

Dana, T.F. (1975). Development of contemporary Eastern Pacific coral reefs. Mar. Biol. 33: 355-374.

Durham, J.W. (1962). Scientific results of the Galápagos Expedition 1953-1954 of the International Institute for Submarine Research; corals from the Galápagos and Cocos Islands. Proc. Calif. Acad. Sci. 32(2): 41-56.

Durham, J.W. (1966). Coelenterates, especially stony corals, from the Galápagos and Cocos Islands. In: Bowman, R.I. (Ed.) The Galapagos. Proceedings of the Symposium of the Galápagos International Scientific Project. University of California Press, Berkeley and Los Angeles.

Fowler, H.W. (1944). Results of the Fifth George Vanderbilt Expedition (1944). The Fishes. Acad. nat. Sci. Philadel phia Monogr, 6: 69-93.

Glynn, P.W. (1983). Widespread coral bleaching and death in Panama (1983). Reef Encounter 1: 4.

Glynn, P.W. (1985). Corallivore population sizes and feeding effects following El Niño (1982-983) associated coral mortality in Panama. Proc. Sth Int. Coral Reef Congress, Tahiti 4:183-188.

Glynn, P.W. and Wellington, G.M. (1983). Corals and Coral Reefs of the Galapagos Islands. University of California Press, Berkeley.

Glynn, P.W., Wellington, G.M. and Birkeland, C. (1979). Coral reef growth in the Galápagos: limitation by sea urchins. Science 203(4375): 47-49.

Groombridge, B. (1982). IUCN Amphibia-Reptilia Red Data Book, Part 1: Testudines, Crocodylia, Rhyncocephalia. IUCN, Gland, Switzerland.

IUCN (1982). IUCN Directory of Neotropical Protected Areas. Tycooly International Publishing Ltd, Dublin.

Joubin, L. (1912). Bancs et récifs de coraux (Madrépores). Ann. Inst. Océanogr. 4:1-7.

McCosker, J.E. and Rosenblatt, R.H. (1984). The inshore fish fauna of the Galápagos Islands. Chapter 9 in: Perry (1984): 133-144.

-McCreary, S. (1985). The Recruitment and Application of Scientific Information in Coastal and Marine Resources Management: Analogs to the Galápagos Islands. Woods Hole Oceanogr. Inst. Tech. Rept. WHOI-85-14.

Perry, R. (Ed.) (1984). Key Environments: Galapagos. Pergamon Press Ltd., Oxford.

Robinson, G. (1983). A marine park in the Galápagos. Noticias de Galápagos 37: 9-13.

Robinson, G. (1982). Antipatharian corals (Black corals) of the Galápagos Islands: biology, distribution and abundance. Project proposal.

Scott, D.A. and Carbonell, M. (1986). A Directory of Neotropical Wetlands. IUCN, Gland and Cambridge.

Villa, J.L. (1981). Project for the establishment of a marine park in the Galápagos Islands. In: Conserving the Natural Heritage of Latin America and the Caribbean. Proc. 18th Working Session CNPPA, Lima : 301-304.

Wellington, G.M. (1975). The Galápagos Coastal Marine Environments. A resource report to Dept of Nat. Parks and Wildlife, Quito, Ecuador. 353 pp.

-Wellington, G.M. (1976). Suggestions for the management of a Galápagos Marine Park. Noticias de Galápagos 25: 5-12. 


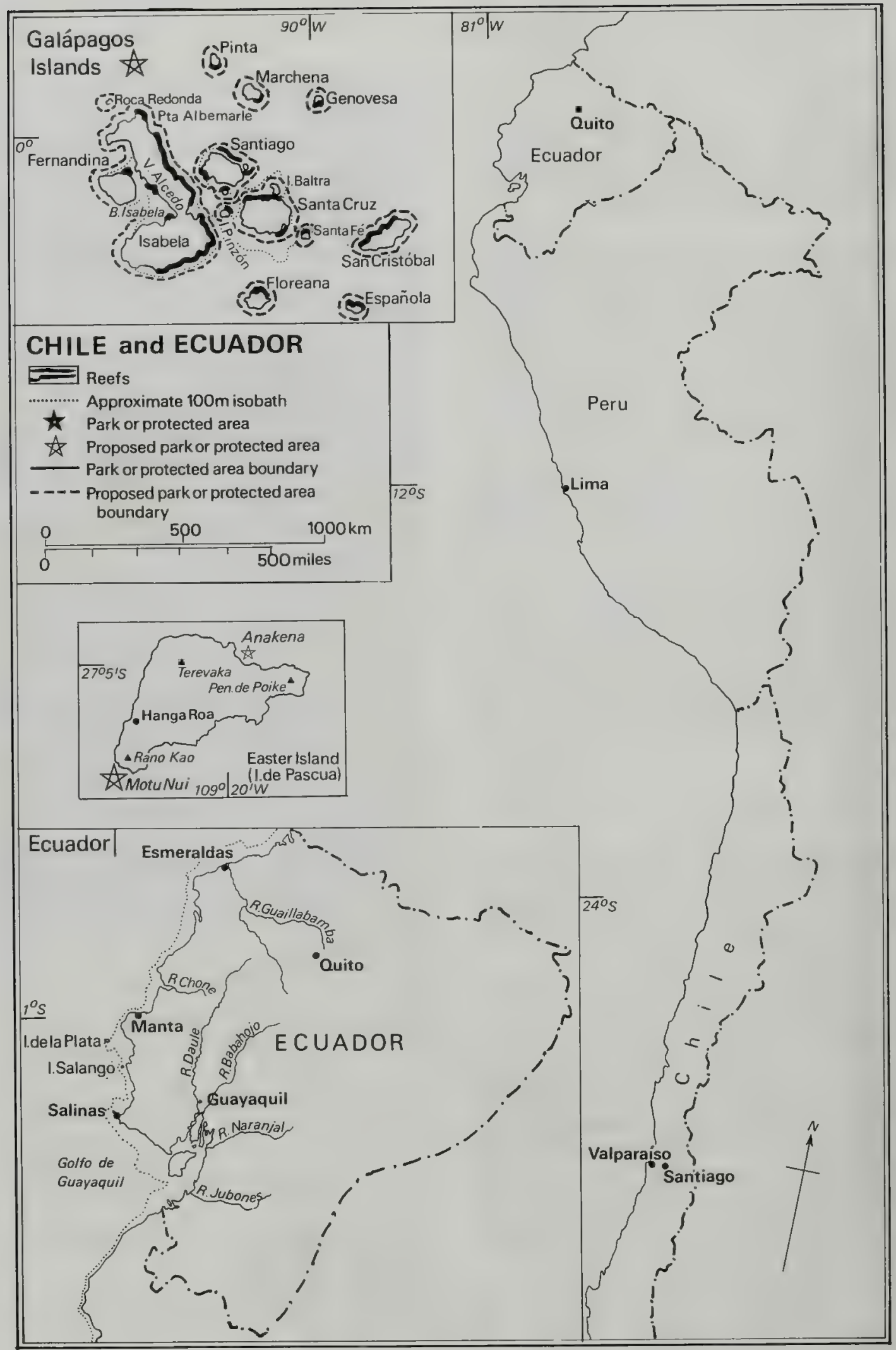


Wellington, G.M. (1984), Marine environment and protection. Chapter 17 in: Perry (1984): 247-264.

Wells, J.W. (1983a). New coral species from the Galápagos Islands. Pac. Sci. 36.

Wells, J.W. (1983b). Annotated list of the scleractinian corals of the Galapagos. In: Glynn, P.W. and Wellington, G.M. (1983). Corals and Coral Reefs of the Galapagos Islands. University of California Press, Berkeley.

\section{PARQUE NACIONAL GALAPAGOS}

Geographical Location $1^{\circ} 50^{\prime} \mathrm{N}-1^{\circ} 30^{\prime} \mathrm{S}, 8^{\circ} 20^{\prime}-91^{\circ} 50^{\prime} \mathrm{W}$; $1000 \mathrm{~km}$ from the coast of Ecuador.

Area, Depth, Altitude The terrestrial area of the park comprises 691200 ha ( $88 \%$ of the total land area of the archipelago); the archipelago, including the marine area, covers $45600 \mathrm{sq} . \mathrm{km}$ and has a maximum altitude of $1700 \mathrm{~m}$.

\section{Land Tenure Government owned.}

Physical Features The archipelago consists of 13 major islands and at least 68 islets and rocks, all of which, except the two most northerly islands, are situated on a shallow marine platform. The oldest islands are low and flat or undulating; the majority are younger and volcanic, flanked with lava. Most of the larger islands are surrounded by a relatively broad $(100-200 \mathrm{~m})$ gently sloping shelf that is well illuminated to $20-30 \mathrm{~m}$ depth. The shallow shelves surrounding Pinta, Marchena, Wolf and Darwin, which are all relatively isolated bathymetrically, are much narrower. Further information on the islands is given in Perry (1984).

The marine environments are highly varied and are associated with water temperature regimes reflecting differences in nutrient and light levels, ranging from warm temperate conditions brought on by vigorous upwelling (Equatorial Undercurrent) and a moderately cool, warm temperate-subtropical influence (Peru Current) to seasonally tropical conditions (Panama Flow). These currents are described in detail by Glynn and Wellington (1983). The seasonally fluctuating North Equatorial Front, which separates tropical and subtropical water masses, lies just south of the northern islands of Darwin and Wolf for much of the year, and these islands are most tropical in their marine biota, with extensive fringing reefs. In the western sector, defined as western Isabela and Fernandina, upwelling of cool nutrient-laden water via the Equatorial Undercurrent is often intense, particularly between the months of June and December. Temperatures as low as $14^{\circ} \mathrm{C}$ have been recorded. Upwelling of the Equatorial Undercurrent may also influence the southern islands of Floreana and Española, especially along their western shores. The central zones, comprising the east coast of Isabela, Santa Cruz, Santiago and perhaps Marchena and Pinta, undergo moderate seasonal temperature fluctuations (c. $10^{\circ} \mathrm{C}$ ) (Wellington, 1984).

Compared with continental shelf waters, water transparency is generally not very variable seasonally and turbidity from river run-off is neglible. Upwelling west of
Isabela, due to the shoaling of the Equatorial Current, supports high levels of plankton productivity that reduce water clarity in that sector. Where corals are abundant, visibility is usually about $15 \mathrm{~m}$ except at Cartago Bay (Isabela) and Darwin Bay (Genovesa) where it is lower. Glynn and Wellington (1983) provide a detailed description of sea temperatures and cloud cover. Tides are semidiurnal or unequal diurnal with slight irregularities occurring between successive highs and lows. The range of spring tides varies from west to east between islands, from $1.5 \mathrm{~m}$ at Isabela to $2.0 \mathrm{~m}$ at Genovesa.

There are two distinct seasons: a wet season from January to April and a dry season with persistent fog drip for the remainder of the year. Mean annual rainfall is $760 \mathrm{~mm}$ or less. Wave action is generally strong on the south and south-eastern island shores and, due to the steep bathymetry of the islands, waves strike the shore with their full force. During the greater part of the year, sea and swell direction are from the south-south-east and are generated by the prevailing Trades which are strongest in August and September.

Reef Structure and Corals Between 1973 and 1976, the reefs of all of the major islands and a number of the small islets and rocks were surveyed by Glynn and Wellington (1983) and Wellington (1984) (who commented on the fact that their findings do not agree with early work by Joubin (1912)). Large subtidal areas still remain to be surveyed. Volcanism and upwelling appear to be the physical factors having the greatest effect on present-day coral distribution with water turbulence, tectonic movements and landslides important in certain locations.

The southern islands (San Christóbal, Española and Floreana) are influenced by the warm South Equatorial Current; they are bathed by relatively cool water and there is no upwelling. Coral communities, rather than reefs, are mainly found along their northern coasts, framework construction being limited to the north-eastern corners. The reefs on the north-west coast of San Christóbal were surveyed at Wreck Bay, Bassa Point, Finger Point, Hobbs Bay and Pitt Point. Surveys on Española were confined to the Gardner Bay area in the north-east and the Suarez Point area in the west. The shallow shelf and satellite islands of Floreana were surveyed in detail along the north-west sector, from Black Beach to Point Cormorant, where reef corals were absent or rare. Coral communities and reefs were generally best developed around the north coast, particularly in the Cormorant Bay area where at Onslow, a small islet off Point Cormorant, Pocillopora once formed a dense monotypic stand over an area of approximately one hectare before it was killed by the EI Niño event of 1983 (see below). To the east, at Champion Island, a Pavona reef extended $0.5 \mathrm{~km}$ along the western side of the island and was estimated to have a maximum vertical growth of $10 \mathrm{~m}$. Robinson (1982) described sites at Champion in the course of work on black coral. A strong current site had a bottom topography consisting of a shallow barnacle - Pocillopora shelf dropping abruptly to $10 \mathrm{~m}$ depth with a wall with abundant $A$ panamensis colonies, and from 10 to $30 \mathrm{~m}$, a steeply sloping bottom with numerous outcrops of rock or coral. In a more sheltered site, there was a shallow Pocillopora bed, followed by a gradual sandy slope to $20 \mathrm{~m}$ depth with several large beds of massive corals Pavona and Porites, $2 \mathrm{~m}$ high. 
The central islands (Santa Fé, Santa Cruz, Pinzón, Rabida, east side of Isabela and Santiago) are thermally intermediate or seasonally cool. The reefs at the anchorage on the north-eastern corner of Santa Fé were surveyed, the most significant coral development occurring on the lee side of two rock reefs between which flowed a strong tidal current which conforms with the pattern observed in the southern islands. The other central islands showed no obvious distributional pattern in their coral community development. Reef building corals occur around much of Santa Cruz and early brief surveys were made by Agassiz (1892), Crossland (1927) and Durham (1962). Additional work was carried out by Glynn and Wellington (1983) who surveyed Pinzón at a site on the north-east coast and Rabida on the north end of the island, where coral communities were generally well developed. The eastern sector of Isabela has the greatest area of shallow shelf. Glynn and Wellington (1983) surveyed sites at Point Albemarie, Cape Marshall and Cartago Bay. Reef formations occur at Punta Boquerizo on the western point of Santiago. The east coast of Bartolome Island was also briefly surveyed.

The western sector is characterized by very cool waters. On Isabela, sites were examined on the open coast in the south-west at the Iguana Cove area, further north at Black Cove and Cape Berkeley, and east along the north side of Banks Bay. More sheltered sites were surveyed at Elizabeth Bay (Bahia Isabela), the coastal stretch to the north-west including the Urvina uplift, and Tagus Cove. Fernandina Island was surveyed just south of Mangle Point, at Cape Hammond, Cape Douglas and about half way between the two capes, and at Espinosa Point, due west of Tagus Cove. The western islands were noticeable for the sparse occurrence of hermatypic coral communities, presumably due to the Equatorial Undercurrent upwelling which brings temperatures well below the limits tolerated by reef corals. Reef building corals were largely confined to the inner reaches of Elizabeth Bay and the shore of Isabela on the leeward side of Fernandina (Urvina Bay), both of which are possibly not subject to the full effect of the upwelling, and to the lava rock pools at Punta Espinosa on Fernandina, which are appreciably warmer than the water offshore. At the latter, Pocillopora colonies were found thriving in protected mangrove areas (Wellington, 1984). The prominence of ahermatypic corals at shallow depth in Tagus Cove is probably due in part to the cool nutrient-rich and turbid waters in this area. Exposed sites harbour species-rich and abundant macrophytic algal communities, reflecting the easterly moving streams of the Equatorial Undercurrent.

The northern islands (Genovesa, Marchena, Pinta, Wolf and Darwin) are subtropical/tropical. On Genovesa, survey work was restricted to the Darwin Bay area on the south coast. On Marchena, the north coast anchorage at Montalvo Point and the south-eastern coast near Espejo Point were visited. Pinta Island was surveyed at a sheltered site west of Cape Ibbetson. The northern half of Wolf (good coral was found at eastem areas) and the south side of Darwin (substantial coral growth at the southem tip) were surveyed. Coral development in these islands seems to extend deeper and to be confined chiefly to the southem exposures of the islands. The paucity of coral communities on the eastern side of Darwin Bay and around Wolf and Darwin Islands can be correlated with slides and slumping on the steep shores.
The major reef-building species are Pocillopora robusta and three massive species: Pavona clavus, $P$. gigantea and Porites lobata. Incipient reef building is widespread throughout the archipelago, occurring along most shorelines except where upwelling is intense (i.e. western Isabela and Fernandina). Reef framework construction was recorded at 17 sites throughout the islands (Glynn and Wellington, 1983). Pocilloporid build-ups are the most common and reach modest proportions (up to one metre thick and several hundred square metres in area) in the southern, western and northern island groups. Four Pavona clavus build-ups were found in the southern, central and northern islands, the largest being at Champion Island (Floreana) and at the south side of Bartolomé Island (Santiago). A single build-up dominated by Porites was found at Bartolomé.

Many of the small islets and rocks in the archipelago are bordered by steep escarpments which drop vertically to a depth of $100 \mathrm{~m}$ or more, interrupted occasionally by ledges. Such walls are restricted to offshore islands and constitute a unique insular habitat. Vertical wall communities are found at Roca Redonda, Punta Vicente Roca, Tagus Cove, Punta Morena, Cape Bucanero (west Santiago), Islas Beagle (between Santiago and Santa Cruz) and Rocas Bainbridge (off south-east Santiago) (Robinson, 1983). Stony corals predominate in this habitat but ahermatypic corals Tubastraea and black corals are common (Wellington, 1984). Two species of black coral are found in coastal waters and are abundant in crevices and holes (Robinson, 1982). Antipathes panamensis is rare compared to the endemic $A$ galapagensis but both are found throughout the archipelago on steep, vertical rocky walls from of 3 to $50 \mathrm{~m}$ depth. Preliminary studies of their ecology were carried out at Isla Champion (Robinson, 1982).

A comprehensive study of Galapagan corals has recently been undertaken which describes thirteen hermatypic and 32 ahermatypic species (Wells, 1983 a and b). The hermatypic fauna is largely west Pacific in origin. The ahermatypic fauna has $30 \%$ endemism, its richness directly related to high productivity in the westem sector of the archipelago. At Tagus Cove, for example, six species are very common and these are endemic. Due to the presence of temperate conditions, the Galapagan biota contains a significant nontropical element (Abbott, 1966; Briggs, 1974; Durham, 1966) and lacks or supports low numbers of certain species that are abundant in coral communities elsewhere. The coral-eating mollusc Jenneria and the Crown of Thorns Starfish Acanthaster planci are absent but the sea urchin Eucidaris, which has little effect on corals elsewhere in the Eastern Pacific is locally abundant.

Noteworthy Fauna and Flora The biogeographic distributions and affinities of marine taxonomic groups are discussed in Glynn and Wellington (1983) and Wellington (1984). The area contains a mixture of central and eastern Pacific faunas with a distinct Galápagos endemic component. Marine algae ( $36 \%$ endemic), Brachyura ( $22 \%$ endemic), Mollusca (35\% endemic) and Echinodermata (several endemics) are described by Wellington (1984). The Giant Sea Star Luida superba, the largest five-armed sea star ever known, has been found at Tagus Cave (Robinson, 1983; Wellington, 1984).

Of the 57 resident bird species, 27 depend for food on the 
surrounding ocean or on the physical interaction between the ocean and terrestrial environment. Flightless Cormorants Nannopterum harrisi and Galapagos Penguins Spheniscus mendiculus are virtually confined to the western islands where the upwelling enriches ocean productivity. With the exception of a few individuals nesting on Plata Island, the Waved Albatross Diomedea irrorata nests only on Española. The status of seabirds nesting in the Galápagos Archipelago is reviewed by Coulter (1984) and in Perry (1984).

The endemic sea lion subspecies, Zalophus californianus wollebaecki and the endemic furseal, Arctocephalus galapagoensis are found on most islands (Perry, 1984). Baleen whales (Fin Balaenoptera physalus, Sei $B$. borealis, Minke B. acutorostrata, and the Humpback Megaptera novaeangliae), toothed whales (Pilot Globicephala maerorhynchus, Killer Orca orca and False Killer Pseudorca crassidens) and Sperm Whales Physeteridae are regularly encountered in the surrounding waters as well as Bottlenose Dolphins Tursiops truncatus, dolpin fish, wahoo, sailfish, the Sunfish Mola mola and many sharks. The marine iguana Amblyrhynchus cristatus is found in the intertidal zone feeding on the marine algae encrusting rocks (Perry, 1984). The Green Turtle Chelonia mydas is abundant, nesting on most islands; the Hawksbill Turtle Eretmochelys imbricata occurs occasionally but does not nest there. The marine fish fauna is described by McCosker and Rosenblatt (1984); an early account is provided by Fowler (1944). Important wetland sites are described by Scott and Carbonell (1986).

Scientific Importance and Research The scientific importance of the marine environment is summarized by Villa (1981) and Wellington (1984): a unique benthic and demersal community with about $20 \%$ endemism; special oceanographic conditions due to the presence of cool currents; upwelling areas and water masses of different origins; a high primary production that maintains a high diversity of pelagic and coastal life; a variety of geomorphological characteristics that offer a high density of marine environments completely isolated from the continent, and the relatively pristine nature of these environments.

Early visitors to the Galapagos concluded that coral reefs were absent but it is now known that the islands comprise the southernmost limit of hermatypic corals in the eastern Pacific (Glynn and Wellington, 1983). Early publications on the reefs include Agassiz (1892), Crossland (1927), Joubin (1912) and Durham (1962). The Charles Darwin Research Station has a department of Marine Biology and Oceanography. Studies have been initiated on lobsters, white fish, marine turtles and black coral. A comprehensive survey of the marine environment was carried out by Wellington (1975) to assess marine resources in preparation for the extension of the National Park boundaries to include part of the sea. A monitoring programme is underway in Puerto Ayora Bay on the south coast of Santa Cruz (Villa, 1981). Glynn and Wellington (1983) describe the results of an examination of coral growth rates on different islands. Linear growth in massive Pavona species appears to be accelerated during the periodic occurrence of El Niño events.

Economic Value and Social Benefits A large proportion of the 5000 residents live mainly by fishing (Villa, 1981) and the bacalao fishery is a traditional source of livelihood (Robinson, 1983). The black coral Antipathes panamensis is used for making jewellery (Robinson, 1982). Tourist SCUBA diving is increasing (Robinson, 1982; Wellington, 1984) and major dive sites include Roca Redonda, Punta Vicente Roca (Isabela), Tagus Cove, Isla Albany (Santiago); Sombrero Chino is popular for snorkelling (Robinson, 1983).

Disturbance or Deficiencies Glynn and Wellington (1983) discuss a variety of biological interactions on Galapagan reefs which influence the distribution and abundance of corals. Acanthaster planci has not been recorded from the Galapagos but coral growth appears to be limited by other naturally occurring predators. The echinoderm Eucidaris thouarsii has a major influence on pocilloporid species and Pavona clavus, decreasing coral growth by $30 \%$ at a patch reef at Onslow (Glynn et al., 1979). It is found throughout the archipelago, often in large numbers, but is less common and sometimes absent in the western sector (Iguana Cove, Tagus Cove, Point Espinosa lava pools). Its abundance is possibly due to lower fish predation on the urchins in the Galápagos than on mainland coasts. Damselfish may influence the zonation of corals and enchance growth through their grazing activities (Wellington, 1984). A potential, possibly unique form of disturbance is the tendency for the Galapagos Sea Lion to occasionally rub its belly against the branch tips of Pocillopora corals.

Three pocilloporid patch reefs were killed in the 1970s. As a result of volcanism and subsequent tectonic uplift, the reef at Punta Espinosa (Fernandina) underwent a gradual exposure and the one at Urvina Bay was suddenly elevated. The third reef, at Pinzón Island, was buried by sand. Tectonic events may aiso influence coral growth; at Urvina Bay there are emergent coral communities, probably resulting from the eruption of Volcán Alcedo on Isabela in 1953. Although outside the range of tropical storms, the reefs may suffer damage from high seas. The most serious damage that the reefs have undergone is extensive bleaching and death linked to the 1982/83 El Niño, which caused an anomalous warming of the surface waters (Glynn, 1983). Some $95 \%$ of the reef corals are considered to have died and the Pocillopora reef at Onslow has been completely killed. Echinoid predators have not been affected and are feeding on the dead coral framework. Although it is thought that Porites lobata communities may regenerate, many others may not (Glynn, 1985).

The reefs are coming under increasing pressure from human activities, especially exploitation of marine resources. There are fears that black coral could be overexploited with the increase in the tourist industry and demand for souvenirs (Robinson, 1982). The National Fisheries Institute in recognition of possible over-exploitation of bacalao stocks, has proposed that production of salted-dry fish be held to a limit of $200 \mathrm{t}$ a year. A programme has been initiated to locate new fishing areas within the islands and to experiment with new fishing methods, including the use of longlines and wired fish traps with the aim of spreading the pressure out among several other fish species. There is no current legal power to stipulate that certain fishing methods be banned from sensitive areas such as the breeding range of cormorants or penguins and sea lion rookeries and these methods may present a possible threat. However, it is thought that the National Fisheries Institute will consult with the park service over these issues (Robinson, 1983). 
Legal Protection The marine extension to the National Park was designated in 1986 (Anon., 1986).

\section{Management To be implemented.}

Recommendations The masterplan for the National Park, published in 1974, recommended the extension of the park boundary 2 miles $(3.2 \mathrm{~km})$ seaward of the coastline around all islands (Robinson, 1983; Wellington, 1976). The new plan, under which the marine extension has been declared, has recommended that it should extend to a distance of $5 \mathrm{~km}$ from shore, roughly excompassing the $200 \mathrm{~m}$ depth contour and increasing the protected marine area to nearly 500000 ha. This includes over $90 \%$ of the biota characteristic to the islands and provides protection for pelagic species such as cetaceans (Wellington, 1984).

A zonation scheme for the marine section is decribed in Robinson (1983). In Zone 1, covering $90 \%$ of the coastal area, artisanal fishermen would be permitted to continue their activities at current levels. Subsistence harvesting of intertidal and subtidal organisms would be permitted and rights of anchorage would not be regulated although commercial or semi-commercial activities would be prohibited. In Zone 2, collection of all marine species would be prohibited except by specific permit, which would be granted by the park authority only upon submission and approval of scientific projects. Areas within this would be delimited on the basis of identifiable landmarks and their seaward extension would be determined on a site-by-site basis, possibly to the $50 \mathrm{~m}$ isobath. This zone would be similar in concept to the "intensive use" zone in the terrestrial areas of the park, but visits would be allowed after sunset to permit night diving. The areas included would be those of particular value to science, tourism and education, and some of the potential sites are listed by Robinson (1983): Roca Redonda, Punta Espinosa (Fernandina), Punta Vicente
Roca, Tagus Cove, Punta Morena and Caleta Iguana (all on Isabela), Islas Marielas, Cape Bucanero, James Bay and Punta Boquerizo (all on Santiago), Isla Albany, Rabida, Islas Beagle, Sombrero Chino and Rocas Bainbridge.

Zone 3 would consist of all coastal areas and bays adjacent to ports and would provide the Park with the authority to control marine pollution and inconsistent recreational activities such as water skiing. Right of innocent passage through this zone would be granted. Zone 4 would include certain areas representative of each of the major marine habitats which would be given complete protection and would serve as control areas for environmental monitoring and assessment of tourist impact. Examples of mangroves, sandy beaches, coral reefs, back lagoons and vertical rock walls would be included. Zone 5 would delineate areas as refuges for the repopulation or recuperation of exploited marine species and responsibility for their identification would lie with the National Fisheries Institute. They would remain under Zone 5 status for whatever period of time the National Fisheries Institute decided and the exploitation of specified marine species would be prohibited. The marine park plan should provide for a mechanism to review the zone status of any area and a process for changing its classification from one zone to another.

Management of the marine environement is discussed most recently in Broadus (1985) and McCreary (1985). At the time of going to press, it is not known exactly which strategies are a being used. Improvements in the facilities for carrying out marine research have been recommended (Villa, 1981), including the establishment of a small laboratory close to the existing facilities on Santa Cruz to provide training in fisheries and marine biology, serve as a field station and improve conditions for visiting marine scientists. 


\section{INTRODUCTION}

\section{General Description}

Grenada, an independent nation within the Commonwealth, is the southernmost island of the Lesser Antilles chain, lying on the Grenadines Shelf. This is in general $15-20 \mathrm{~km}$ wide and extends over $180 \mathrm{~km}$ on the southern portion of the Lesser Antilles Ridge. The dependencies of Grenada in the Grenadines include some twenty low lying islands extending north to and including Carriacou and Little Martinique (see St Vincent account for other islands in this group). The total area is $344 \mathrm{sq}$. km. The geological composition is mainly volcanic. The terrain on Grenada is mountainous, reaching $840 \mathrm{~m}$ on $\mathrm{Mt}$ St Catherine, with very little flat or gently sloping land. Carriacou is less rugged but more seriously eroded. Rainfall ranges from $1300 \mathrm{~mm}$ to $4000 \mathrm{~mm}$ a year. Hurricanes are infrequent but rainstorms may cause severe damage.

Three quarters of the Grenadines platform is $36-40 \mathrm{~m}$ deep and has no shallow reef systems. To the east the shelf forms a broad carbonate platform terminating in a steep slope extending into the Tobago Trough. At its margin is a ridge, formed presumably by extinct barrier reefs, extending nearly continuously for over $45 \mathrm{~km}$, which is covered with algal nodules and coral debris. Living forms include Halimeda, some corals, sponges and crustose coralline algae but this system has yet to be studied in detail (D'Anglejean and Mountjoy, 1973).

The north-east coast of Grenada is mainly low lying and straight, whereas the south-east is higher, rising to $840 \mathrm{~m}$, and much embayed. Living reefs are found patchily around all coasts, except the west (ECNAMP, 1980a); total reef cover has been estimated at $250 \mathrm{sq}$. $\mathrm{km}$ (Bacon et al., 1984). Adey and Burke (1976) describe small fringing Acropora palmata reefs, mostly in bays in the south, and several inshore, apparent bank-barrier structures, with well developed fleshy algal pavements, on a shelf at $10-20 \mathrm{~m}$ depth on the south-east coast from Marquis Point to Telescope Point. There are no algal ridges.

Goodwin et al. (undated) describe the marine environment of the north-east coast, around Levera, Green and Sandy Islands. There are no well developed reefs, coral growth appearing to be limited by turbulence and the scouring action of tidal currents and wind driven surge, despite the availability of hard substrate. The islands are particularly exposed on their north and east sides. On the south and west coasts of Levera, there is scattered coral, Porites furcata being the commonest species in shallow waters. Live coral is virtually absent below $6 \mathrm{~m}$. There is a small patch reef of Acropora palmata and Millepora sp. off the north-west coast, which is the best developed reef in this area. There are no corals off the north-east coast and only a scattering off the south-east. Green I. has scattered patches of well-developed coral colonies on the south-west coast, dominated by $A$ palmata in shallow water and Montastraea annularis below $3 \mathrm{~m}$. Corals are not found below $12-15 \mathrm{~m}$. Sporadic coral cover is found on the north and east coasts. Sandy I. has very little reef cover.

Large bank barrier reef complexes have developed on the windward side of Carriacou and the adjacent smaller islands and there are two small bench algal ridges on the south side of Carriacou (Adey and Burke, 1976). Many of the shallower parts of these reefs, especially the more protected north- and south-facing structures, are strongly $A$ palmatadominated and have well developed deeper fore-reef head coral zones. In the more exposed east-facing sections, the $A$ palmata tends to be replaced by crustose coralline-Millepora pavements. Some reef crests and upper fore-reefs are characterized by more or less smooth pavements with a thin algal turf.

Species density and coral associations have been studied on reefs at Saline Island and Jack Adam Island, volcanic islands situated to the south and west respectively of Carriacou (Goodwin et al., 1976). Saline Island is directly exposed to the Atlantic on the north-eastern shore. On the western shore a shallow fringing reef connects with White Island. A small fringing reef borders the southern shore, sloping from $0.5 \mathrm{~m}$ to $12 \mathrm{~m}$ depth where the coral gives way to a sand and rubble bottom. Jack Adam Island is protected from the Atlantic by Carriacou and is surrounded by coral growth which forms a fringing spur on the north-east end of the island. To the south of the spur, coral growth extends $180 \mathrm{~m}$ from the shore in a gradual slope to $11 \mathrm{~m}$ depth. On the reefs at both sites Porites porites, Montastraea annularis, Agaricia agaricia, $P$. astreoides and Siderastrea siderea account for more than $90 \%$ of total coral cover.

The northernmost and southernmost Grenadines generally lack large bench or shallow bank-barrier reefs, although some small reefs occur in coves or between small islands. The $11-13 \mathrm{~m}$ deep shelf on which the massive southern reefs are formed is quite narrow or absent, especially at Ronde to the south of Carriacou, where the $40 \mathrm{~m}$ contour closely approaches the east sides of the islands (Adey and Burke, 1976).

Leatherbacks Dermochelys coriacea, Hawksbills Eretmochelys imbricata and Green Turtles Chelonia mydas nest on many beaches on Grenada and in the Grenadines (Bacon et al., 1984; Carr et al., 1982; Groombridge, 1982). Three species of breeding seabird have been recorded from Grenada and twelve from the Grenadines (Halewyn and Norton, 1984). Important wetland areas, including mangroves are described in Scott and Carbonell (1976).

\section{Reef Resources}

Tourism is concentrated on part of the southern coast of Grenada, west of Bacolet, and there is considerable potential for further expansion (ECNAMP, 1980a; Wood, 1984). Diving is a popular activity in the north (Bedford Point, Sauteurs), off the east coast (south of Grenville) and at a few sites on the south coast (ECNAMP, 1980a). In the Grenadines, where only Carriacou, Petit Martinique and Ronde are inhabited, tourism is 


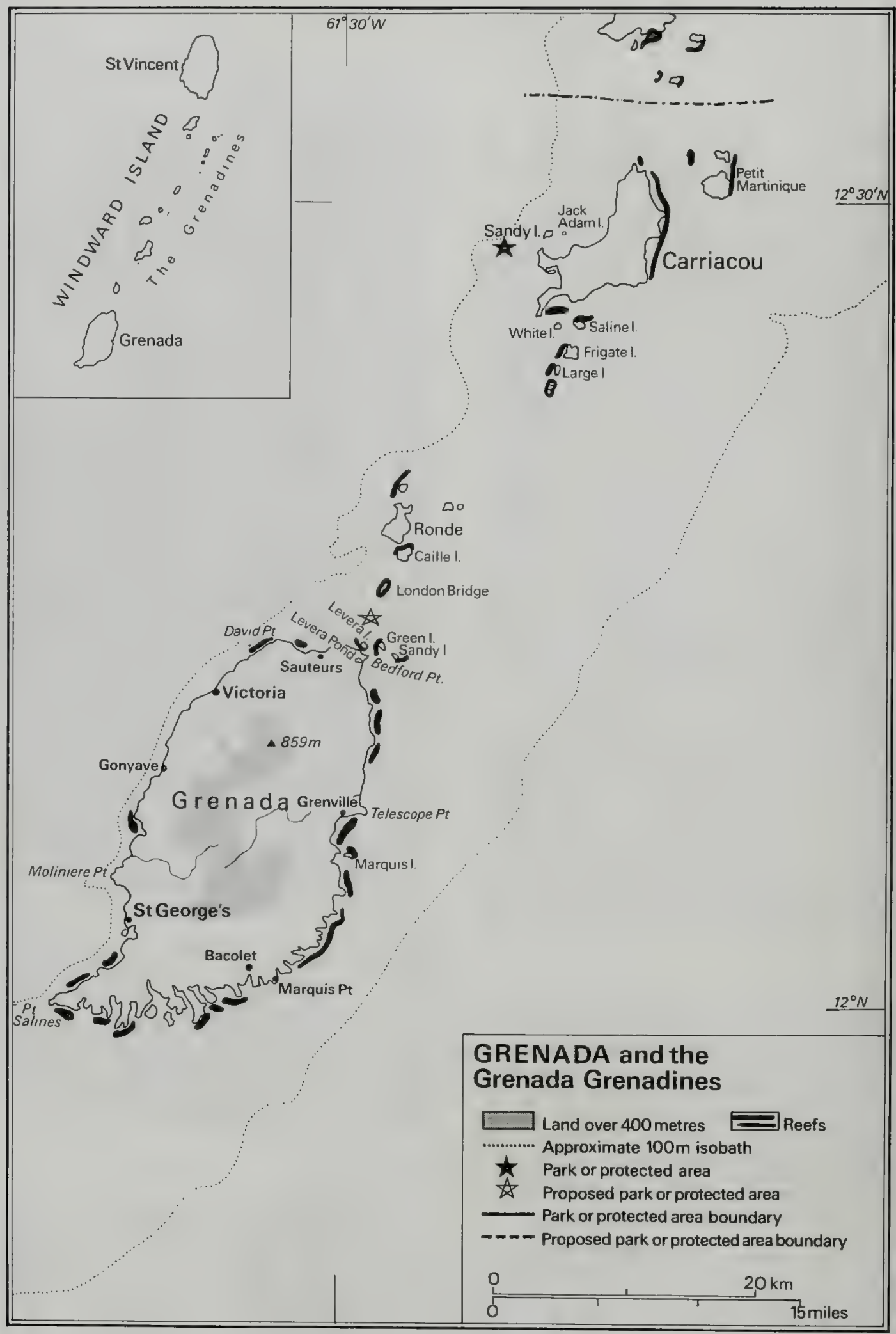


potentially important around Carriacou, particularly on the east coast. Reef fish, conch and lobster fishing are important along much of the north and south coasts of Grenada (Goodwin et al., undated) and in the Grenadines.

\section{Disturbances and Deficiencies}

White band disease has been recorded in Grenada and the Grenadines and storm damage has been found on some reefs throughout this area. In Grenada, run-off, dredging, agricultural pesticides and fishing with explosives are reported to have had an impact and at least one reef is suspected to have been killed by run-off containing pesticides and herbicides (Goodwin and Bannerot, 1985). Wood (1984) mentions other potential threats to the coastal and marine environment including beach pollution, disposal of wastes, removal of sand for construction purposes and poorly planned coastal development. No significant reef deterioration has been reported from the Grenadines apart from some impact from visitors walking on the reefs and some fishing with explosives although there has been a significant decline in reef fisheries (Rogers, 1985).

\section{Legislation and Management}

A Beach Protection Ordinance was passed in 1955. The Environmental Conservation Council was launched in 1983 as a national conservation organization, to advise on the management of natural resources (Wood, 1984). The U.S. based consultancy group Environmental Research Projects are experimentally rearing lobsters un Grenada (Dubois, 1985). There is a closed season for turtle harvesting on Grenada and a Hawksbill Turtle project is underway on Carriacou (Bacon et al., 1984; Carr et al., 1982).

\section{Recommendations}

On Grenada, a national park has been proposed at Bedford Point to include Levera, Green and Sandy Islands and the important wetland, Levera Pond (ECNAMP, 1980a; Goodwin et al., undated; Meylan, 1984; Wood, 1984). If this proposal goes ahead, it is recommended that the boundary should extend to the 15 fathom $(27.5 \mathrm{~m})$ contour. Fishing should be allowed to continue at current levels but catch statistics should be monitored so that a management strategy can be developed for fishery stocks in this area (Goodwin et al., undated). It is suggested that attention should be directed towards other marine areas with richer marine resources for development as marine parks. Much of the coast around Carriacou, Petit Martinique and London Bridge (an island south of Ronde) is considered important marine habitat (ECNAMP, 1980b). Sandy Island, a low sandbank with a covering of scrub and palm trees, off the west coast of Carriacou, is reported to be a reserve. It has well developed and varied reefs and is accessible for diving and other recreational activities. It is also popular with yachts and requires some form of protection from damage caused by anchors, littering and thoughtless divers.

\section{References}

Adey, W.H. and Burke, R. (1976). Holocene bioherms (algal ridges and bank-barrier reefs) of the eastern Caribbean. Geol. Soc. Am. Bull. 87: 95-109.

Bacon, P., Berry, F., Bjorndal, Hirth, H., Ogren, L. and Weber, M. (1984). The National Reports. Proceedings of the Western Atlantic Turtle Symposium, Costa Rica. Vol.3: University of Miami Press, Florida.

Carr, A., Meylan, A., Mortimer, J., Bjorndal, K. and Carr, T. (1982). Surveys of sea turtle populations and habitats in the Western Atlantic. NOAA Technical Memorandum NMFS-SEFC-91, U.S. Dept of Commerce.

D'Anglejean, B.F. and Mountjoy, E.W. (1973).

Submerged reefs of the eastern Grenadines shelf margin. Bull. geol. Soc. Am. 84: 2445-2454.

Dubois, R. (1985). Coastal fisheries management lessons learned from the Caribbean. Case Study 4. In: Clark, J.R. (Ed.) Coastal Resources Management: Development Case Studies. Coastal Publication No. 3. Renewable Resources Information Series, Research Planning Institute, Inc, Columbia, South Carolina.

ECNAMP (1980a). Grenada. Preliminary Data Atlas. Survey of Conservation Priorities in the Lesser Antilles. Eastern Caribbean Natural Area Management Program.

ECNAMP (1980b). Grenada Grenadines. Preliminary Data Allas. Survey of Conservation Priorities in the Lesser Antilles. Eastern Caribbean Natural Area Management Program.

Goodwin, M.H. and Bannerot, S. (in prep.). Information for Coral Reef Management: a handbook for the Eastern Caribbean.

Goodwin, M.H., Cole, M.J.C., Stewart, W.E. and Zimmerman, B.L. (1976). Species density and associations in Caribbean reef corals. J. exp. mar. Biol. Ecol. 24: 19-31.

Goodwin, M.H., Goodwin, S.T. and Putnam, K.D. (undated). Preliminary Marine Survey of the Proposed Levera National Park, Grenada. Report to the Government of Grenada and CCA/ECNAMP, Environmental Research Projects, Narragansett, R.I., U.S.A.

Groombridge, B. (1982). The IUCN Amphibia-Reptilia Red Data Book, Part 1: Testudines, Crocodylia, Rhynchocephalia. IUCN, Gland, Switzerland.

Halewyn, R. van and Norton, R.L. (1984). The status and conservation of seabirds in the Caribbean. In: Croxall, J.P., Evans, P.G.H. and Schreiber, R.W. (Eds). Status and Conservation of the World's Seabirds. ICBP Technical Publication No. 2, Cambridge.

Lewis, J.B. (1975). A preliminary description of the coral reefs of the Tobago Cays, Grenadines, West Indies. Atoll Res. Bull. 178: 9 pp.

Meylan, A. (1984). The ecology and conservation of the Caribbean Hawskbill (Eretmochelys imbricata). Final report WWF Project 1499.

Rogers, C.S. (1985). Degradation of Caribbean and Western Atlantic coral reefs and decline of associated fisheries. Proc. 5th Int. Coral Reef Cong., Tahiti. 6: 491-496.

Scott, D.A. and Carbonell, M. (1976). A Directory of Neotropical Wellands. IUCN, Gland and Cambridge.

Wood, J. (Ed.) (1984). Proceedings of the Workshop on Biosphere Reserves and Other Protected Areas for Sustainable Development of Small Caribbean Islands, May 10-12, 1983. Virgin Islands National Park, Caneel Bay, St John, U.S. Virgin Islands. U.S. Dept of Interior, National Park Service, Atlanta, Georgia. 190 pp. 



\section{INTRODUCTION}

\section{General Description}

Guadeloupe, with St Martin and St Barthélemy, forms an overseas department of France. The archipelago, covering an area of $703 \mathrm{sq} . \mathrm{mi}$. (1821 sq. km), consists of two principal islands, Grande Terre (585 sq. $\mathrm{km}$ ) and Guadeloupe or Basse Terre (943 sq. km), which are separated by the Rivière Salée, and three smaller neighbouring islands to the south-east: Marie Galante (149 sq. km), La Désirade (27 sq. km) and the Saintes Archipelago (14 sq. $\mathrm{km}$ ). Prevailing winds are from the north-east, east and south-east. Rainfall varies from 800 to $1500 \mathrm{~mm}$ on Grande Terre to over $7500 \mathrm{~mm}$ on Basse Terre.

Basse Terre is mountainous and volcanic, its high rainfall supporting fairly extensive rainforest. True reefs are generally absent on the leeward coast, although coral diversity is high. Rich coral formations are found below $15 \mathrm{~m}$ from Bouillante to Deshayes, but periodic storms prevent reef formation in shallower waters. One of the richest sites is the fringing reef around Ilet Pigeon (see separate account). The south-west and south coasts have poorly developed reefs as the area is subject to volcanic discharge from Mt Soufrière (1484 m) (Laborel, 1982). On the eastern side of the southern part of Basse Terre, there is a weak barrier system, the southern part of which has little live Acropora palmata (Adey and Burke, 1976); fleshy algae are prominent. Other reefs are dominated by Sargassum. The best developed reefs are in the sheltered areas of the Grand and Petit Culs de Sac Marin (see below) and off Goyave and Petit Bourg.

Grande Terre has a maximum altitude of $110 \mathrm{~m}$ and is a limestone island with vegetation dominated by dry woodland and cactus scrub. Living reefs are mainly found around ancient coral constructions 4-5 $\mathrm{m}$ deep and are rich in Diploria. The east coast has extensive calcareous algal reefs, particularly in the regions of Anse Maurice, Moule, Anse à l'Eau and la Gourde. These form barriers, interrupted at intervals by grooves or channels, and have a diverse coral fauna, including Porites astreoides, Favia, Diploria, Montastraea, Siderastrea and occasionally Acropora. In contrast, the south coast from Pte des Chateaux to Gosier has narrow and sometimes localized reefs of the fringing type. There is an extensive shelf at $20-30 \mathrm{~m}$ lying off this coast and bank barriers may be developing in several places (Adey and Burke, 1976; Battistini and Petit, 1979). The reef-flat, at most several metres wide, is composed of large fragments of $A$ palmata and debris of $P$. porites covered with living coral, particularly $A$ palmata. Coralline- Millepora areas are also abundant, especially in the west, and vermetids are abundant in the east. Emergent rubble mounds and more or less smooth pavements are found on or near the reef crests. As on the east coast, there is no drop-off but there is a sharp zonation from an almost completely coral-free zone at $10-40 \mathrm{~m}$ depth and a deeper zone with dense populations of gorgonians and non-calcareous algae (Laborel, 1982). The west coast resembles the south, with fringing reefs stretching from Anse Laborde, $1 \mathrm{~km}$ north-east of Anse Bertrand, in the north to Port Louis. There is a large proportion of dead coral and low species diversity, $A$ palmata and $P$. porites dominating, but living corals are more abundant than on the south coast, particularly A palmata, Diploria strigosa and D. clivosa.

Between Grande Terre and Basse Terre there is a double system of bays, the "Culs de Sac". The Grand Cul de Sac Marin, situated to the north, is described separately. The Petit Cul de Sac Marin, to the south, differs markedly, having a series of emergent reef flats, mainly on the western side of the bay, and rich coral growth from the surface to $45-50 \mathrm{~m}$ depth (Laborel, 1982). The commonest species are Siderastrea, Madracis mirabilis, Stephanocoenia intercepta, Agaricia agaricites, Colpophyllia, Acropora cervicornis, Dendrogyra cylindrus and Meandrina meandrites (Battistini and Petit, 1979).

La Désirade has small reefs on the south coast in Anse de Baie Mahault, Anse Petite Rivière ( $500 \mathrm{~m}$ to the west) and Grande Anse. The coast resembles the east coast of Grande Terre with discontinuous algal reefs and is described in more detail in Battistini and Petit (1979). The north side of Désirade has numerous well-developed coralline lips or terraces directly on the largely cliff shore (Adey and Burke, 1976). On Marie Galante, fringing reefs are found only on the west, south-west and south sides of the island from l'Anse Piton to Grand-Bourg and are described in Battistini and Petit (1979). Iles des Saintes, just to the south of Basse Terre, lacks any extensive shelf and well-developed reefs are lacking (Adey and Burke, 1976). The north and eastern side of Grande Terre and the south-eastern sides of Marie Galante and $\mathrm{La}$ Désirade have the most extensive and massive Caribbean algal ridge systems known in the Caribbean. In many places, these are well over $1 \mathrm{~m}$ high with well-developed back-ridge terraces, blow holes and pillar-and-room structure (Adey and Burke, 1976).

Gruner and Delplanque (1973) give a general review of marine fauna. Some 260 species of marine mollusc have been described. Mangrove fish communities are described by Louis (1983 and 1985), Louis and Lasserre (1982) and Louis and Guyard (1982). The Green Turtle Chelonia mydas, Hawksbill Eretmochelys imbricata, Leatherback Dermochelys coriacea, and possibly Loggerhead Caretta caretta occur in Guadeloupe waters; the three former species nest (Bacon et al., 1984). Halewyn and Norton (1984) list nine species of seabird known to breed on Guadeloupe and its surrounding islands. There are about 9668 ha of mangrove which provide habitat for a variety of waterfowl as described by Scott and Carbonell (1986) and Louis and Guyard (1982). Seagrass beds of Thalassia testudinum are found in sheltered areas to $10 \mathrm{~m}$ depth in clear water, but in turbid areas as at Pointe-à-Pitre, they are found only to $2 \mathrm{~m}$ depth. There is very little seagrass on the rocky leeward coast but it is abundant on the windward coast in the shelter of the reefs, at Saint-Anne, Gosier, Petit Bourg, Goyave and most importantly in the Grand Cul de Sac Marin (Bouchon, 1986).

Comparatively little research has been carried cut on the reefs of Guadeloupe. Early studies included a brief comment on corals by Dollfus (1936). Chassaing et al. 


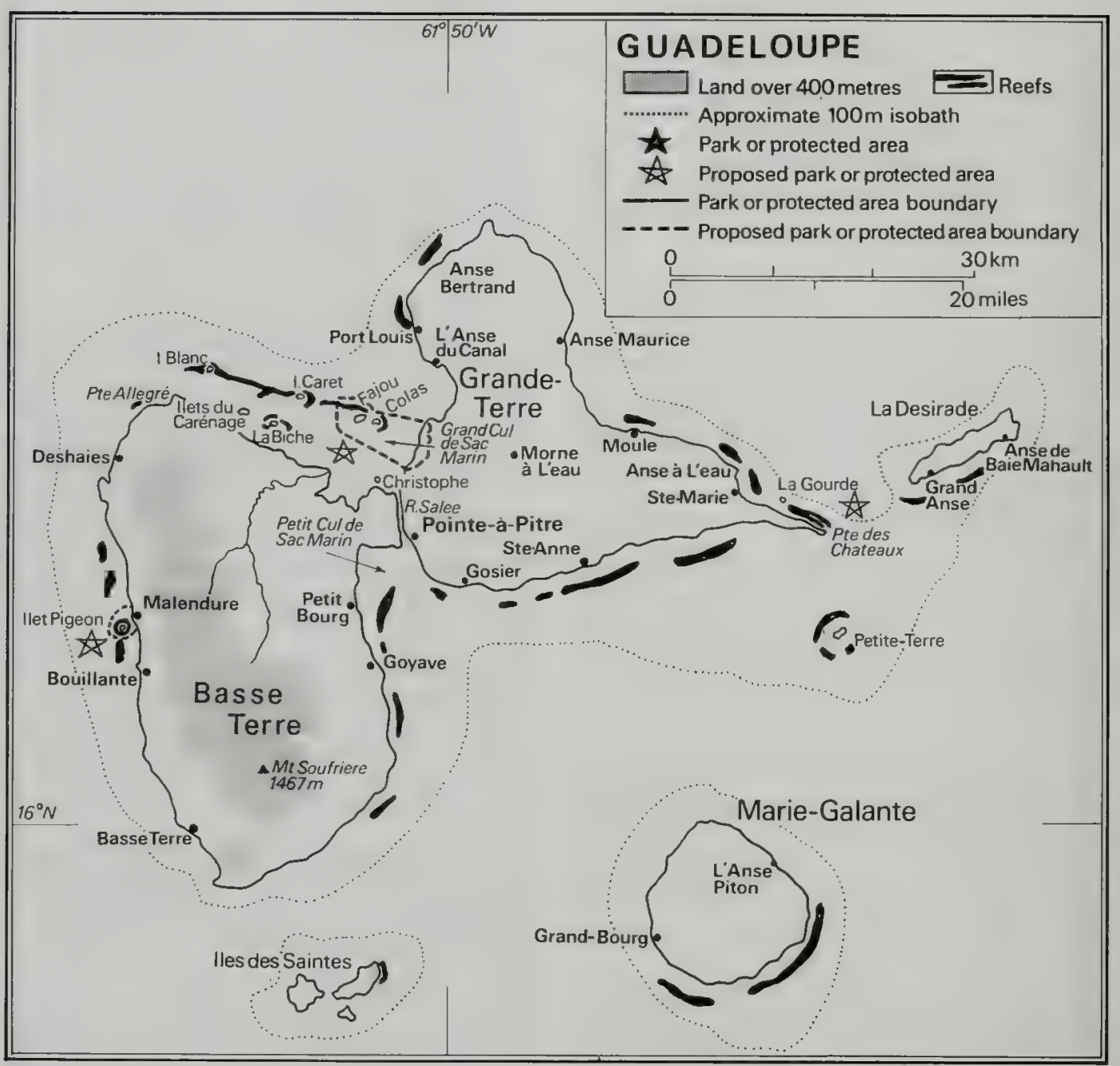


(1978) provided a popular guide to the corals of the French Antilles. The Parc National de la Guadeloupe has produced various publications on marine life including Chassaing (1982). Currently the EPHE (Ecole Pratique des Hautes Etudes, Paris) is carrying out a major interdisciplinary coastal zone programme, the CORANTILLES project, supported by the Federation Française d'Etudes et de Sports Sous-marins, in collaboration with the Centre Universitaire Antilles-Guyane and local diving clubs. The mangrove and coastal zone sections have been completed but surveys of coral communities at llet Pigeon and Grand Cul de Sac Marin, and a more detailed survey of the entire marine environment and its fish communities are still underway (Bouchon in litt., 26.1.86). The results of this survey work will contribute to the rational exploitation and management of marine resources (Laborel, 1982).

\section{Reef Resources}

Marine resources are mapped in ECNAMP (1980). Tourism is becoming increasingly important, particularly on the west coast of Basse Terre (Meylan, 1983). Subsistence fishing using traps is heavy (Bouchon in litt., 26.1.86). Brief details of the fishing and tourist industries are given in Wood (1984). Despite the high yields of the reef fisheries (Munro, 1983), large quantities are reef fish products are imported (Goodwin, 1985).

\section{Disturbances and Deficiencies}

Hurricanes have periodically damaged "the reef. Hurricane David caused considerable damage in 1979 to the reef off Sainte Anne on the south coast of Grande Terre and in the Grand Cul de Sac Marin. White band disease has been reported (Rogers, 1985).

Human activities are an increasing threat to the reefs. Bouchon (1986), Gruner and Delplanque (1973) and Chassaing et al. (1978) mention urban development, industrial and agricultural pollution, fishing using traps and collection of corals by tourists. The reefs in the Petit $\mathrm{Cul}$ de Sac Marin are probably under greatest threat. The shallow, northern part is turbid and subject to urban and industrial pollution, sedimentation and pesticides from banana cultivation (Laborel, 1982). Waste from distilleries may be affecting marine life at Marie-Galante, and litter accumulating in the two Culs de Sac Marin is posing problems (Gruner and Delplanque, 1973). Heavy metal pollution, such as vanadium in waste oils, as well as nitrates, phosphates and organochlorides in pesticides and the waste from sugar factories are all toxic to the marine environment. Siltation resulting from soil erosion, coastal development and dredging are cited by Bouchon (1986) as potential threats although further work is required to determine the exact impact of these on the reefs.

Rapid population growth has caused depletion of some reef resources. Subsistence fishing has resulted in over-exploitation (Bouchon in litt., 26.1.86); the mollusc Lambis has been over-collected in seagrass beds. The marine curio trade has been increasing since the 1970 s and could become a problem (Gruner and Delplanque, 1973). Marine turtle populations have declined markedly, partly due to the massive trade in turtle products (primarily various tourist souvenirs) (Bacon et al., 1984; Meylan, 1983). This is now declining due to improved law enforcement (Renard/Putney in litt., 18.2.86). Sand mining takes place illegally on some beaches (Scott and Carbonell, 1986) and could ultimately damage reefs. Mangroves have been destroyed in many areas, especially around urban areas such as Pointe-à-Pitre, Raizet (where the airport has been extended), Pte Jary and Pont de la Gabarre.

\section{Legislation and Management}

Leatherback Turtles, turtle eggs, berried lobsters, spiny lobsters under $14 \mathrm{~cm}$ and corals are protected in coastal waters under legislation (No. 79-6, $\mathrm{AD} / 3 / 3$ ) of April 1979; there are closed seasons and minimum size limits for Hawksbills and Green Turtles.

The proposed Parc National de la Guadeloupe is described in IUCN (1982) and will include the marine areas of Ilet Pigeon and the Grand Cul de Sac Marin (Laborel, 1982), the latter of which will be designated a Réserve Naturelle (see separate accounts).

\section{Recommendations}

The entire peninsula at Pointe de Chateaux (eastern tip of Grande Terre), which includes reefs, shallow saline lagoons important for migratory shorebirds and turtle nesting sites has been proposed as a protected area (Scott and Carbonell, 1986). Gruner and Delplanque (1973) recommend the protection of an area on La Désirade although access would be difficult for tourists. Guadeloupe is included on the preliminary list of potential marine sites for inclusion in a Lesser Antillean Biosphere Reserve (Goodwin, 1985).

\section{References}

* = cited but not consulted

Adey, W.H. and Burke, R. (1976). Holocene bioherms (algal ridges and bank-barrier reefs) of the eastern Caribbean. Geol. Soc. Am. Bull. 87: 95-109.

Anon. (1979). Le Parc naturel de la Guadeloupe. Presentation Sommaire, Assoc. Caraibe pour l'Environment, 13 ème Assemblée Generale Annuelle, Guadeloupe 26-29, September 1979.

Bacon, P., Berry, F., Bjorndal, Hirth, H., Ogren, L. and Weber, M. (1984). The National Reports. Proceedings of the Western Atlantic Turtle Symposium, Costa Rica. Vol.3: University of Miami Press, Florida.

Battistini, R. and Petit, M. (1979). Récifs coralliens, constructions alguaires et arrecifes à la Guadeloupe, Marie Galante et la Désirade. Atoll Res. Bull. 234: 8 pp.

Bernard, P., Galzin, R. and Salvat, B. (1981). Note sur les nuisances liées au prelevement de sable corallien dans le lagon du Grand Cul-de-Sac Marin en Guadeloupe. Rev. Int. Océanogr. Med. 63-64: 199-123.

Bouchon, C. (1986). Le Grand-Cul-de-Sac-Marin. Rapport ecrit pour constituer le dossier de creation de la réserve du Grand-Cul-de-Sac (draft).

Bouchon, C. and Laborel, J. (1986). Les formations coralliennes du Grand Cul de Sac Marin de Guadeloupe. 
Resultats préliminaires. Rapport préliminaire Projet CORDET (Etude ecosystèmes cotiers du Grand Cul de Sac Marin de Guadeloupe).

Chassaing, J.P. (1982). Les Fonds Marins. Parc Naturel de Guadeloupe, Office National des Forêts, Basse-Terre, Guadeloupe.

Chassaing, J.P., Delplanque, A. and Laborel, J. (1978).

Coraux des Antilles françaises. Rev. franc. d'aquariol. 3: 57-83.

Dolifus, R.P. (1936). Polypiers (Hexacoralliaires et Hydrocoralliaires) recoltés à la Guadeloupe par la mission cryptogamique du Muséum en 1936. Bull. Mus. Hist. nat. Paris 8: 514-515.

ECNAMP (1980). Guadeloupe. Preliminary Data Atlas. Survey of conservation priorities in the Lesser Antilles. Eastern Caribbean Natural Area Management Program.

ECNAMP (1982). Final Report. Survey of conservation priorities in the Lesser Antilles. Caribbean Conservation Association, Caribbean Environment Technical Report, No. 1.

Galzin, R. (1979). Les extractions de sable corallien en Guadeloupe et leurs conséquences sur la faune ichtyologique. C.R. Acad. Sci. Paris 289 Serie D : 853-856. Galzin, R. (1981). Effects of coral sand dredging on fish fauna in the lagoon of "The Grand Cul de Sac Marin", Guadeloupe, French West Indies. Proc. 4th Int. Coral Reef Symp. Vol. 1: 115-121.

Galzin, R., Toffart, J.L., Louis, M. and Guyard, A. (1982). Contribution à la connaissance de la faune ichtyologique du Grand Cul de Sac Marin en Guadeloupe. Cybium 6(1): 85-99.

Goodwin, M.H. (1985). Characterization of Lesser Antillean Regional Fisheries. Island Resources Foundation. $48 \mathrm{pp}$.

Gruner, L. and Delplanque, A. (1973). Les Fonds Sous Marins. Inventaire des ressources naturelles de la Guadeloupe. I.N.R.A., Station de Zoologie, Domaine Duclos, Petit Bourg, Guadeloupe.

Guilcher, A. and Marec, A. (1978). Le récif barrière et le lagon du Grand Cul de Sac Marin (Guadeloupe, Antilles Francaise)

Geormorphologie

sediments. Oceanologica Acta 1(4): 435-444.

Halewyn, R. van and Norton, R.L. (1984). The status and conservation of seabirds in the Caribbean. In: Croxall, J.P., Evans, P.G.H. and Schreiber, R.W. (Eds), Status and Conservation of the World's Seabirds. ICBP Technical Publication No. 2, Cambridge.

IUCN (1982). IUCN Directory of Neotropical Protected Areas. Tycooly International Publishing Ltd., Dublin.

Kermarrec, A. and Chassaing, J.P. (1976). Nuisances liées au prélèvement de sable marin en Guadeloupe. Nouv. Agron. Antilles-Guyane 2(2): 109-133.

Laborel, J. (1982). Formations coralliennes des Antilles françaises. Oceanis 8(4): 339-354.

Louis, M. (1983). Biologie, écologie et dynamique des populations de poisson dans les mangroves de Guadeloupe (Antilles françaises). Thèse d'etat, U.S.T.L. (Universitaire des Sciences et Techniques du Languedoc), Montpellier. 275 pp.

Louis, M. (1985). Reproduction et croissance de Bairdiella ronchus (Poisson Scianidae) dans les mangroves de Guadeloupe (Antilles françaises). Rev. Hydrobiol. trop. 18(1): 61-72.

Louis, M. and Guyard, A. (1982). Contribution a l'étude des peuplements ichtyologiques dans les mangroves de Guadeloupe (Antilles françaises). Bull. Ecol. 13(1): 9-24.

Louis, M. and Lasserre, G. (1982). Etude du peuplement de poissons dans les lagunes des mangroves de Guadeloupe (Antilles françaises). Oceanologica Acta No. SP: 333-338.

Meylan, A.B. (1983). Marine turtles in the the Leeward Islands, Lesser Antilles. Atoll Res. Bull. No 278.

Munro, J.L. (Ed.) (1983). Caribbean Coral Reef Fishery Resources. ICLARM Studies and Reviews 7, Manila, Philippines.

-Portecop, J. and Benito-Espinal, E. (1984). Etude de la flore et de la faune aviare des îlets du Grand $\mathrm{Cul}$ de Sac Marin. Unpub.

Rogers, C.S. (1985), Degradation of Caribbean and Western Atlantic coral reefs and decline of associated fisheries. Proc. 5th Int. Coral Reef Cong., Tahiti. 6: 491-496.

Scott, D.A. and Carbonell, M. (1986). Directory of Neotropical Wetlands. IUCN, Gland and Cambridge.

Wood, J. (Ed.) (1984). Proceedings of the Workshop on Biosphere Reserves and Other Protected Areas for Sustainable Development of Small Caribbean Islands, May 10-12, 1983. Virgin Islands National Park, Caneel Bay, St John, U.S. Virgin Islands. U.S. Dept of Interior, National Park Service, Atlanta, Georgia. $190 \mathrm{pp}$.

\section{LE GRAND CUL DE SAC MARIN (PROPOSED RESERVE NATURELLE)}

Geographical Location $16^{\circ} 20^{\prime} \mathrm{N}, 61^{\circ} 33^{\prime} \mathrm{W}$; between northern Basse Terre and the west coast of Grand Terre, from l'Anse du Canal to Allègre Point.

Area, Depth, Altitude Total area of lagoon about 11 000 ha; area of "wetland" $7000 \mathrm{ha}$; lagoon $10 \mathrm{~km}$ wide at centre and $35 \mathrm{~km}$ long; maximum depth $20 \mathrm{~m}$; proposed reserve about 4700 ha.

\section{Land Tenure Almost entirely state-owned.}

Physical Features A large shallow north-facing bay, into which flows the Rivière Salée, the channel separating Basse Terre and Grande Terre. It is enclosed to the north by a bank-barrier reef $29 \mathrm{~km}$ in length, extending from Ilet Fajou in the north to Sainte Marie in the south (near the Petit Cul de Sac Marin) and reaching a width of $200-300 \mathrm{~m}$ over $15 \mathrm{~km}$. It is broken by four passes (Bouchon, 1986). The Passe de la Grande Coulée marks the west limit of the lagoon and is responsible for most of the water exchange with the open sea. Passe a Caret, to the west of Ilet Caret is $20 \mathrm{~m}$ deep. Passe a Fajou is a simple depression a few metres deep and Passe à Colas, at $35 \mathrm{~m}$, is the deepest. The three main passes are considered to be a drowned river valley. Sedimentology and hydrography are described in detail by Guilcher and Marec (1978) and Bouchon (1986) provides a brief geological history of the barrier reef and describes the sediments of the lagoon. The waters in the bay are generally turbid nearshore but are clearer and less brackish seaward. The islets of La Biche, Carénage and Christophe lie in the lagoon (Guilcher and Marec, 1978) and the reef flat supports a number of cays or "îlets": Colas and Caret (very small and sandy), Fajou (with mangroves) and Ilot Blanc (on the east end of the reef). The bay is surrounded by mangroves and contains seagrass beds and small patches of coral. 
Reel Structure and Corals About 50 coral species have been recorded from the reefs in the Grand Cul de Sac Marin. Scattered corals are found in the shallow seagrass beds in the lagoon, mainly branched Porites spp., Mille pora alcicornis and in less sandy areas Oculina diffusa, Cladocora arbuscula, Manicina areolata, Siderastrea radians and Solenastrea bournoni. Patch reefs are abundant near Ilet Fajou, Passe à Colas and to the west of La Biche, south-west of Passe à Caret, but many have been damaged by cyclones (Bouchon and Laborel, 1986; Guilcher and Marec, 1978). The patches are formed mainly of $P$. furcata, large colonies of which may reach a diameter of several metres, sometimes covered with Acropora cervicornis and a few other massive forms. The edges of the patches may slope gently with a covering of seagrass, or more steeply in which case a dense halo of coral is found between 5 and $10 \mathrm{~m}$ depth, formed of large colonies dominated by Montastraea annularis, $M$. cavernosa, Colpophyllia amaranthus, Meandrina meandrites, Diploria spp. and some branching forms particularly Madracis mirabilis. Certain species normally found at greater depths also occur because of the turbidity of the water, such as Agaricia spp., Scolymia spp. and some antipatharians.

Seaward there is a flat sand area with abundant $A$ palmata, followed by the barrier reef proper (Battistini and Petit, 1979). Bouchon and Laborel (1986) describe the barrier reef at three sites: 1) opposite Ilet Fajou, 2) an area in the west which has been mined for sand and 3 ) in the east at Passe a Colas. Behind the reef crest, the reef flat is often bare of corals although Diploria spp. and Millepora spp. may be abundant. The reef crest is formed of massive corals with calcareous algae, rarely more than $2-3 \mathrm{~m}$ in width. The central section has a well developed coralline-Millepora spur and groove formation and a few incipient algal ridges (Adey and Burke, 1976). The grooves are colonized by Agaricia agaricites followed by the main spur constructors, $A$ palmata and $M$. complanata which dominate to a depth of several metres.

The external slope, to a depth of $55 \mathrm{~m}$ at which point coral growth ceased, was studied by Bouchon and Laborel (1986) at a site opposite Ilet Fajou. Three zones were identified. The upper zone, to $10 \mathrm{~m}$, has only a limited covering of corals, mainly of small encrusting colonies of Favia fragum and Porites astreoides, with abundant gorgonians and colonial zoanthids. The middle zone from 10 to $25-30 \mathrm{~m}$ has maximum coral development, with a relief resembling a spur and groove formation but not corresponding to that of the reef crest. The elongated mounds are formed mainly of Montastraea annularis but there is also a high diversity of other corals including Dendrogyra cylindrus. The depressions between the mounds now have largely dead colonies of $A$ cervicornis. The deepest zone from 30 to $55 \mathrm{~m}$ has an increasingly poor coral fauna, although some deep water species occur.

Bouchon and Laborel (1986) describe the coral communities in the passes. The sides of Passe a Colas are populated with Montastraea spp. and Diploria spp. near the surface, with occasional stands of $A$ cenvicornis now largely dead. Below $5 \mathrm{~m}$, the sides drop steeply to another slope between 15 and $25 \mathrm{~m}$, largely silted but with pinnacles of massive colonies of Montastraea spp. and a variety of deepwater invertebrates. The upper walls of Passe a Caret are similar; below $10 \mathrm{~m}$ there is a rich coral zone dominated by $\boldsymbol{M}$. annularis, possibly due to the greater clarity of the water in this pass.

Noteworthy Fauna and Flora The lagoon has extensive mangrove swamps, brackish to saline coastal lagoons with associated marshes and swampy Pterocarpus forest. Mangroves border the lagoon and are found on the offshore islets; covering 6068 ha, they comprise $80 \%$ of all mangroves on Guadeloupe and are described by Scott and Carbonell (1986). Seagrass covers about 6700 ha of the lagoon at depths to $5 \mathrm{~m}$ (Bouchon, 1986) and the seagrass community is described briefly by Bouchon and Laborel (1986). The flora and avifauna of the islands in the lagoon are described by Portecop and Benito-Espinal (1984). The islets are important nesting sites for the Magnificent Frigatebird Fregata magnificens, the White-tailed Tropicbird Phaethon lepturus and the Cattle Egret Bubulcus ibis. A number of important waterfowl are also found in the area (ECNAMP, 1980; Scott and Carbonell, 1986). Galzin et al. (1982) have recorded 109 fish species from the bay; the fish fauna of the mangroves, particularly that in the lagoons of Manche-à-Eau and Belle-Plaine, is described by Louis (1985), Louis and Lasserre (1982) and Louis and Guyard (1982). Molluscs, echinoids and other invertebrates are listed by Kermarrec and Chassaing (1976) and include a number of commercially important species such as Strombus gigas, Panulirus argus and Tripneustes esculentus (Bouchon, 1986). Green Turtles Chelonia mydas and Hawksbills Eretmochelys imbricata nest on Fajou and Caret (Bacon et al., 1984; Meylan, 1983) and Leatherback Turtles Dermochelys coriacea may occasionally nest on Fajou.

Scientific Importance and Research The reefs of the Grand Cul de Sac Marin are considered among the best in the Lesser Antilles. A study of the problems associated with sand dredging (Galzin, 1981) was funded by IUCN/WWF as part of the "Action Concertee" Committee of Renewable Natural Resources Management Mangroves and Coastal Zones in the Lesser Antilles. The lagoon, which appears to be silting up, is currently being studied. The mangrove fringe has been extensively studied (Laborel, 1982) and a C.O.R.D.E.T. programme is still underway.

Economic Value and Social Benefits Fin fishing, conch and lobsters are important fishery resources in the bay (ECNAMP, 1980), fishermen from Ste Rose, Lamentin, Baie-Mahaut, Vieux Bourg and Morne à l'eau using the area intensively (Gruner and Delplanque, 1973). The area is important for tourism and there are at least two popular dive sites in the bay (ECNAMP, 1980).

Disturbance or Deficiencies The reefs have been badly damaged by the hurricanes of 1979 and 1980. Many of the lagoonal patch reefs appear to have been affected and are now covered with dead corals. Acropora cervicornis and Porites spp. which were previously abundant behind the reef crest are now largely dead; the algal crest was also seriously damaged. Three years after these events there was still little sign of recovery in some areas, although $A$ palmata and Madracis mirabilis colonies have shown considerable re growth (Bouchon and Laborel, 1986).

In 1971, a ten year sand mining concession to exploit a 1600 ha area of coral sand surrounded by live corals in the lagoon near Passe à Caret was granted. This led to a 
strong suspension of fine particles and an increase in bacterial density, the impact of which was described by Bernard et al. (1981) and Galzin (1979 and 1981). At the western end of the barrier reef at Passe à Caret, $80 \%$ of the corals consisted of four species (Acropora cervicornis, A palmata, Porites astreoides and Agaricia agaricites) which are particularly sensitive to sedimentation (Kermarrec and Chassaing, 1976). A palmata in this area is now largely dead, and unlike areas where this species was affected by hurricanes, there is little sign of recovery. The colonial zoanthid Zoanthus sociatus has colonized large areas behind the reef crest and there is high coral mortality. Siltation is clearly visible in this area and obviously comes from the lagoon (Bouchon and Laborel, 1986). A study revealed that within the dredged area mollusc diversity was greatly reduced and several species, such as Pinna carnea and Polinices hepaticus, had totally disappeared. Several corals had died and were covered with algae, the echinoderm Meoma ventricosa had proliferated and Diadema antillarum populations had diminished in neighbouring seagrass beds (Kermarrec and Chassaing, 1976). The fish fauna was also severely disturbed (Galzin, 1981).

Solid waste disposal is considered a problem and pollution may be occurring as a result of run-off from agricultural activities on the surrounding land. Corals are collected within the bay and besides the "legal" sand mining described above, sand is taken illegally off the west coast of the bay (ECNAMP, 1980). There are still some traces of illegal fish dynamiting, for example, near Ilet Caret. Fish are now very wary in the lagoon. In the 1970 s there was an increase in the Diadema population which may have been associated with over-fishing of their predators (Gruner and Delplanque, 1973).

Legal Protection None at present although legislation is currently in preparation.

\section{Management None known.}

Recommendations Part of the Grand Cul de Sac Marin, including the Lambi mangroves, Ilet à Fajou (originally proposed as a sanctuary (Anon, 1979)) and extensive seagrass beds, is proposed as a Réserve Naturelle to form part of the proposed Parc National de la Guadeloupe. This part of the park is currently in preparation. The are is listed as a priority marine habitat for conservation (ECNAMP, 1982). Kermarrec and Chassaing (1976) provide recommendations for ensuring minimum damage during sand extraction.

\section{L'ILET PIGEON (PART OF PROPOSED PARC NATIONAL DE LA GUADELOUPE)}

Geographical Location $16^{\circ} 10^{\prime} \mathrm{N}, 61^{\circ} 48^{\prime} \mathrm{W}$; west coast of Basse Terre opposite Malendure, $1 \mathrm{~km}$ from the shore.

Physical Features L'Ilet Pigeon is a twin volcanic rock, about $500 \mathrm{~m}$ in diameter, separated from the mainland leeward coast by a sandy channel $\mathbf{4 5} \mathrm{m}$ deep. There is a small beach and the islands have steep slopes. There is a hot underwater spring $25 \mathrm{~m}$ deep on the north coast which has limited coral growth. Surrounding waters are generally crystal clear and calm as the islands are very sheltered (Laborel in litt., 18.5.84).

Reef Structure and Corals There is a small fringing reef with living coral down to $48 \mathrm{~m}$ (Anon., 1979; Laborel, 1982). The sloping volcanic seabed is covered by a thin veneer of encrusting Millepora, gorgonians and sponges to a depth of $10-15 \mathrm{~m}$. From 15 to $45 \mathrm{~m}$ there is an actively growing dense, lush zone of coral. Thirty-eight coral species have been recorded (Laborel in litt. 18.5.84).

Noteworthy Fauna and Flora The Green Turtle Chelonia mydas and the Hawksbill Eretmochelys imbricata are found in this area. There are abundant fish, including large Jolthead Porgies Calamus bajonado, many of which are tame (Laborel in litt., 18.5.84). The islands are covered with xerophytic vegetation and have large populations of iguanas and crabs (Gruner and Delplanque, 1973).

Scientific Importance and Research The most popular diving centre in Guadeloupe (Laborel in litt. 18.5.84).

Economic Value and Social Benefits The islands are uninhabited and are visited by few fishermen. They are easily accessible from the nearby centre of Malendure (Gruner and Delplanque, 1973). Tourism is presumed to be important in this area.

Disturbance or Deficiencies Hurricanes have periodically damaged the reefs (Laborel, 1982).

Legal Protection A local decree prohibits spearfishing (Anon., 1979).

Management An interpretative centre, la Maison de la Mer is being built on the mainland coast, and an aquarium and swimming trails have been planned. Dive tour operators are promoting the area as the "Colt Cousteau Réserve" to attract tourists (Bouchon in litt., 6.5.86).

Recommendations Proposed as part of the proposed Pare National de la Guadeloupe. 


\section{INTRODUCTION}

\section{General Description}

The Republic of Haiti, with a coastline of $1500 \mathrm{~km}$, includes several large offshore islands ( $\mathrm{La}$ Gonave, La Tortue, Ile-à-Vache and the Cayemites) as well as a number of smaller cays and islets. The topography is extremely rugged, reaching an altitude of $2674 \mathrm{~m}$. The climate is tropical. Annual rainfall ranges from less than $300 \mathrm{~mm}$ in the north-west to over $4000 \mathrm{~mm}$ in the mountainous south-west, most rain falling in the summer. The north coast is extremely exposed, and is bordered by a barrier reef separated from the mainland by a $30 \mathrm{~m}$ deep channel. The reefs are possibly the least well known in the Caribbean, but the major areas are as follows:

1. North coast of Ile-à-Vache: $18^{\circ} 07^{\prime} \mathrm{N}, 73^{\circ} 36^{\prime} \mathrm{W}$

2. Les Iles Cayemites and the Baie des Baradères: $18^{\circ} 37^{\prime} \mathrm{N}, 73^{\circ} 40^{\prime} \mathrm{W}$

3. La Gonave, particularly the south-east tip: $18^{\circ} 45^{\prime} \mathrm{N}$, $72^{\circ} 50^{\prime} \mathrm{W}$

4. The bay of Port-au-Prince (Sand Key and Les Irois): $18^{\circ} 37^{\prime} \mathrm{N}, 72^{\circ} 22^{\prime} \mathrm{W}$

5. Les Arcadins, off the coast near Pointe Pathron: $18^{\circ} 49^{\prime} \mathrm{N}, 72^{\circ} 37^{\prime} \mathrm{W}$

6. North-west of Gonaives: $19^{\circ} 30^{\prime} \mathrm{N}, 72^{\circ} 55^{\prime} \mathrm{W}$

7. The north coast, to the east and west of Cap-Haitien (30/40 $\mathrm{km}$ in each direction): $19^{\circ} 48^{\prime} \mathrm{W}, 72^{\circ} 17^{\prime} \mathrm{W}$

There appear to have been no ecological or general research studies on the reefs of Haiti. A survey using Hydro Lab included transects on deep water reefs at La Gonave and Rochelois Bank ( $\left.18^{\circ} 38^{\prime} \mathrm{N}, 7^{\circ} 13^{\prime} \mathrm{W}\right)$ (Bunt et al., 1981). The Santa María Expedition visited Cap Haitien in 1977 to collect core borings at the site of the Santa Maria Foundation's "Wreck Site No. 5" which was thought to be the possible location of the remains of the flagship of Colombus which was wrecked on a reef off Cap Haitien in 1492. Wreck Site 5 is a ship-shaped mound of Porites porites with a few stands of Acropora cervicornis on top, in $3 \mathrm{~m}$ of water; excavations revealed that it is not a wreck (Raymond, 1977).

Major wetland areas are described in Scott and Carbonell (1986). Haiti and its surrounding islets support breeding populations of up to twelve species of seabird as detailed by Halewyn and Norton (1984). Green Chelonia mydas, Loggerhead Caretta caretta and Hawksbill Eretmochelys imbricata Turtles nest on a number of beaches (Bacon et al., 1984; Carr et al., 1982).

\section{Reef Resources}

The fishing industry is poorly developed and predominantly artisanal. The Queen Conch Strombus gigas is an important resource. Tourism, which was being developed, has recently declined as a result of the economic problems in the country.

\section{Disturbances and Deficiencies}

There is very little information on the status of the reef of Haiti. As in most Caribbean countries, the sea urchin Diadema antillarum underwent a mass mortality in 1983 (Lessios et al., 1984). Human activities are probably also having a certain impact, although one of the few benefits of the decline in tourism is that there is less damage to the reefs and mangrove areas than might be expected. However, reefs near Port-au-Prince are being affected by pollution and sedimentation as a result of increasing deforestation, and top soil erosion is becoming a problem, particularly in the north (Paryski in litt., 20.6.84).

Haiti has for some years been an important source of corals and shells for the international marine curio trade. The main collecting areas for corals are the Bay of Gonave, Leogane and the vicinity of Port-au-Prince, but coral is brought from all round the coast to Port-au-Prince for export (Rudloe, 1979/80). The U.S. imported $11.5 \mathrm{mt}$ coral from Haiti in 1978 but exports dropped to $905 \mathrm{~kg}$ in 1984 . The coral trade was reported to be causing noticeable damage to reefs in the Bay of Gonave (Wells, 1981). Severe over-fishing of the Queen Conch has been reported (Brownell and Stevely, 1981). Hawksbill shells are often used locally as ornaments and the large amounts of tortoiseshell on sale at Port-au-Prince airport are claimed to be from locally caught turtles, which is probably contributing to the decline of this species (Bacon et al., 1984; Carr et al., 1982).

\section{Legislation and Management}

Scott and Carbonell (1986) summarise current environmental legislation. The Service des Ressources en Pêches of the Ministère de l'Agriculture, des Ressources Naturelles et du Developpement Rural (MARNDR) is responsible for fisheries. A decree of 1978 and a law of 1979 cover fisheries and marine resources and prohibit the cutting of mangroves. Coral exports were reportedly banned in 1976 but there is no evidence of this being enforced (Wells, 1981). The Service Protection Environnement et Faune (Direction des Ressources Naturelles) is responsible for national parks and preservation of the environment. Coral reefs are not included in any of the national parks so far gazetted.

\section{Recommendations}

It is hoped that as soon as the terrestrial parks are well established, other areas including mangrove swamps and coral reefs can be protected (Scott and Carbonell, 1986; Paryski in litt., 20.6.84). A Country Environmental Profile carried out by US-AID in 1985 stressed the importance of marine resources and recommended sites at Morne Rouge and Ile-à-Vache as marine parks (Paryski in litt., March 1985). It has been reported that 


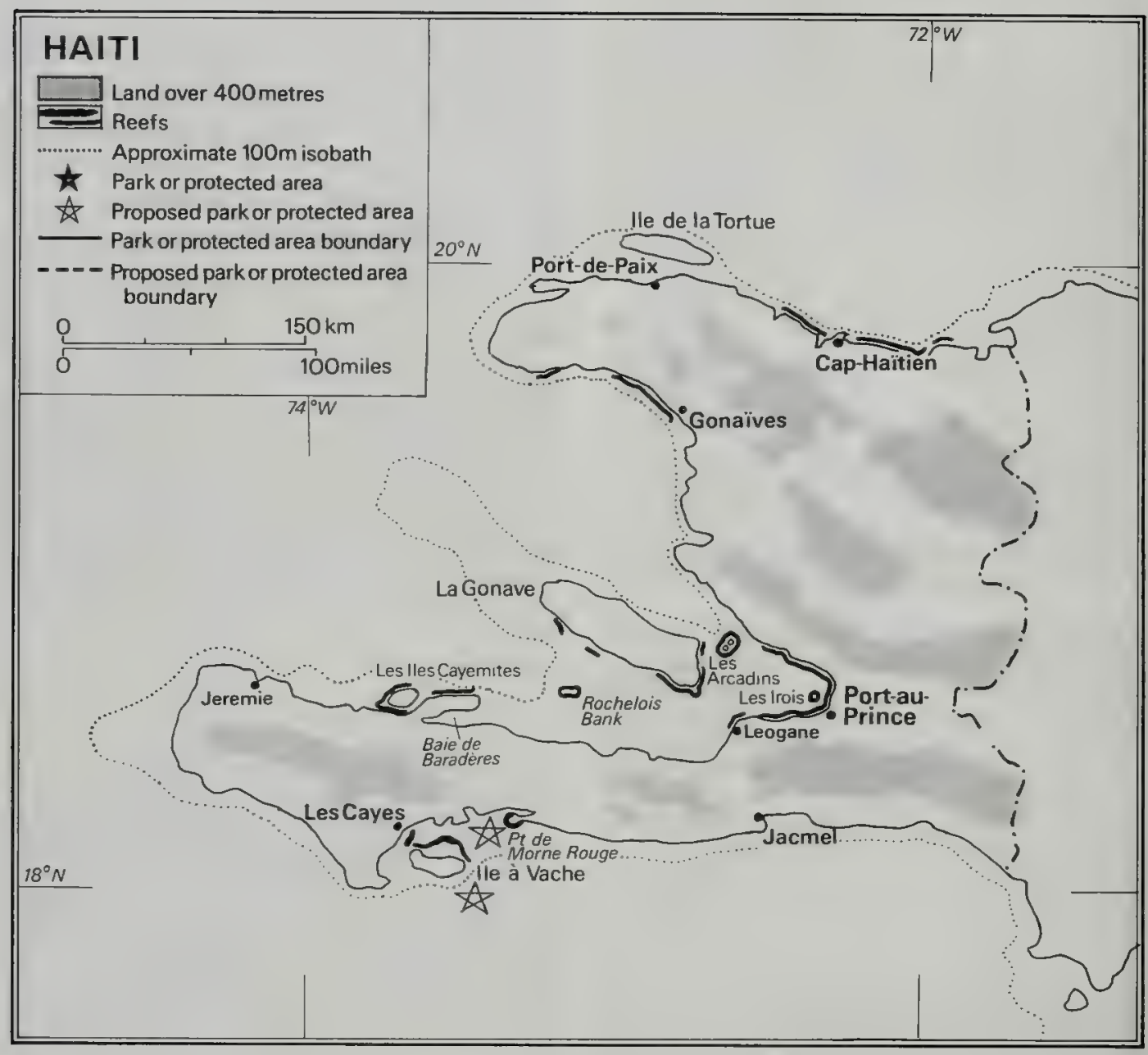


there is interest in creating an area at Les Arcadins as a marine reserve, the local people in the area being particularly concerned to take this action.

\section{References}

Bacon, P., Berry, F., Bjorndal, Hirth, H., Ogren, L. and Weber, M. (1984). The National Reports. Proceedings of the Western Atlantic Turtle Symposium, Costa Rica. Vol.3: University of Miami Press, Florida.

Brownell, W.N. and Stevely, J.M. (1981). The biology, fisheries and management of the queen conch Strombus gigas. Marine Fisheries Review 43(7): 1-12.

Bunt, J.S., Williams, W.T. and Chalker, B.E. (1981).

Coral associations at depths of 45 to $125 \mathrm{feet}$ in the Bahamian region. Proc. 4th Int. Coral Reef Symp. Manila, Vol. 1: 707-714.

Carr, A. et al. (1982). Surveys of sea turtle populations and habitats in the Western Atlantic. NOAA Technical Memorandum NMFS-SEFC-91.
Halewyn, R. van and Norton, R.L. (1984). The status and conservation of seabirds in the Caribbean. In: Croxall, J.P., Evans, P.G.H. and Schreiber, R.W. (Eds), Status and Conservation of the World's Seabirds. ICBP Technical Publication No. 2, Cambridge.

Lessios, H.A., Robertson, D.R. and Cubit, J.D. (1984). Spread of Diadema mortality through the Caribbean. Science 226: 335-337.

Raymond, B. (1977). The Santa María Expedition of August 1977. Unpub. rept. for Ocean Research and Survey Inc., Fort Lauderdale, Florida.

Rudloe, J. (1979/80). Notes on a trip to Haiti to investigate the coral trade.

Scott, D.A. and Carbonell, M. (1986). A Directory of Neotropical Wetlands. IUCN, Gland and Cambridge.

Wells, S.M. (1981). International trade in omamental corals and shells. Proc. 4th Int. Coral Reef Symp. Manila, Vol. 1: 323-330. 



\section{INTRODUCTION}

There is no information available on the reefs of mainland Honduras. Collin (1978) reports that the Bay Islands (Islas de Bahía) have well developed reefs that have never been described but more recent studies on Roatán have been made by Britton and Fergusson (1981), Rix (1972), Jaap and Halas (1982) and Jensen (1985). Reefs around Roatán and Great Swan Island are described in separate accounts. There appears to be some fringing and patch reef development around the Cayos Cochinos about $35 \mathrm{~km}$ north east of $\mathrm{La}$ Ceiba.

Mangroves occur widely on both coasts and important wetland sites are described in Scott and Carbonell (1986). The status of breeding seabirds is given in Halewyn and Norton (1984). Leatherback, Green, Loggerhead and Hawksbill Turtles (Dermochelys coriacea, Chelonia mydas, Caretta caretta and Eretmochelys imbricata nest in Honduras, apparently in low to moderate numbers (Groombridge, 1982) although Bacon et al. (1984) report nesting by only the two former species. The region provides good foraging habitat. Exploitation is heavy and populations appear to be depleted (Groombridge, 1982).

DIGERENARE has a marine biology laboratory on the north coast of Honduras at $\mathrm{La}$ Ceiba, which conducts research mainly on economically important marine fish and arthropods (IUCN, 1982) Information on the value of Honduran reef resources has not been obtained, apart from that given in the following accounts. In particular, Roatán is becoming increasingly important for reef related tourism.

The "Ley de Pescar", decree 154 of 29 May 1959, declares coral reefs as "protected areas" but there are no marine parks or reserves (IUCN, 1982). The Asociación Honduréña de Ecología is currently drawing up a proposal for four networks of protected areas, one of which will cover marine and coastal ecosystems (Halle in litt., 18.6.86). Protection of the Roatán reefs has been under consideration since the 1970s, and some form of management is urgently required.

\section{References}

* cited but not consulted

Bacon, P., Berry, F., Bjorndal, Hirth, H., Ogren, L. and Weber, M. (1984). The National Reports. Proceedings of the Western Atlantic Turtle Symposium, Costa Rica. Vol.3: University of Miami Press, Florida.

Britton, J. and Fergusson, G. (1981). Roatán. A Guide to the Western Caribbean Island. 4th Ed. Dept of Biol., Texas Christian University.

Champagne, L.F. (1979). A comparison of shallow water molluscan fauna inhabiting ThalassiaGoniolithonPorites zones from Lime Key, Roatán, Honduras and Rodriguez Key, Florida. Masters thesis, Texas Christian University, $111 \mathrm{pp}$.

-Collin, (1978). (reference not known).
Davidson, W. (1979). Historical Geography of the Bay Islands, Honduras. 2nd Ed., Southern Univ. Press, Birmingham, Alabama. 199 pp.

Groombridge, B. (1982)。 IUCN Amphibia-Reptilia Red Data Book Part 1. Testudines, Crocodylia, Rhynocephalia. IUCN, Gland and Cambridge.

Halewyn, R. van and Norton, R.Lo (1984). The status and conservation of seabirds in the Caribbean. In: Croxall, J.P., Evans, P.G.H. and Schreiber, R.W. (Eds), Status and Conservation of the World's Seabirds. ICBP Technical Publication No. 2., Cambridge.

Holliday, Lo (1985). Road to Roatán. Diver Magazine, February 1985: 28-29.

IUCN (1982). IUCN Directory of Neotropical Areas. Tycooly International Publishing Ltd, Dublin.

Ivey, M.L., Breyer, J.A. and Britton, J.C. (1980).

Sedimentary facies and depositional history of the Swan Islands, Honduras. Sedim. Geol. 27: 195-212.

Jaap, W.C. and Halas, J. (1982). Roatán, Honduras Reef Evaluation Study, 7-22 September 1982. Memo to Dr. E.J. Gissendammer, with unpub. rept on "The Marine Environment of Roatán".

Jensen, A.C. (1985). Biology Report. Roatán 1984 Operation Raleigh Reconnaissance.

-McBirney, A. and Bass, M. (1969). Geology of Bay Islands, Gulf of Honduras. In: McBirney, A. (Ed.) Tectonic relations of Northern Central America and the Western Caribbean. The Bonacca Expedition. Am. Assn Petrol. Geol. Mem. 11, Menasha, Wis.: 229-243.

-Nathano, R.R. and Associates, et al. (1975). A Technical and Economic Feasibility Study of the Tornasal-Copan-Roatán Project. Presented to the Instituto Hondureño de Turismo. Tegucigalpa, Honduras. Nunley, R.E. (1979). A level-bottom molluscan fauna from Calabash Bight, Isla de Roatán, Honduras. Masters Thesis, Texas Christian University, $82 \mathrm{pp}$.

- Oliver, S.R. (1977). Informe de la Misión de PNUMA/PNUD. FONDETUR, Tegucigalpa, D.C. Honduras.

Rix, C.F. (1972). A preliminary study on the north reef of Roatán. M.Sc., North-eastern Illinois Univ.

Rogers, C.S. (1985). Degradation of Caribbean and Western Atlantic coral reefs and decline of associated fisheries. Proc. 5th Int. Coral Reef Cong., Tahiti. 6: $491-496$

Scott, D.A. and Carbonell, M. (1986). A Directory of Neotropical Wetlands. IUCN, Gland and Cambridge.

Stewart, H.B. (1962). Oceanographic Cruise Report of the USC and GS Ship Explorer - 1960. U.S. Dept of Commerce, Coast and Geodetic Survey.

Tortora, L.R. (1975). The coral assemblages of the Swan Islands, Honduras. M.Sc. Thesis, Texas Christian University.

Tortora, L.R. and Keith, D.E. (1980a). Octocorals of the Swan Islands, Honduras. Caribb. J. Sci. 15(3-4): 87-93.

Tortora, L.R. and Keith, D.E. (1980b). Scleractinian corals of the Swan Islands, Honduras. Caribb. J. Sci. 16(1-4): 65-72.

U.S. Geol. Surv. (1967). Geological Survey research, 1967, oceanic islands, geology of Swan Island. U.S. Geol. Survey Prof. Pap. 575A: 127. 


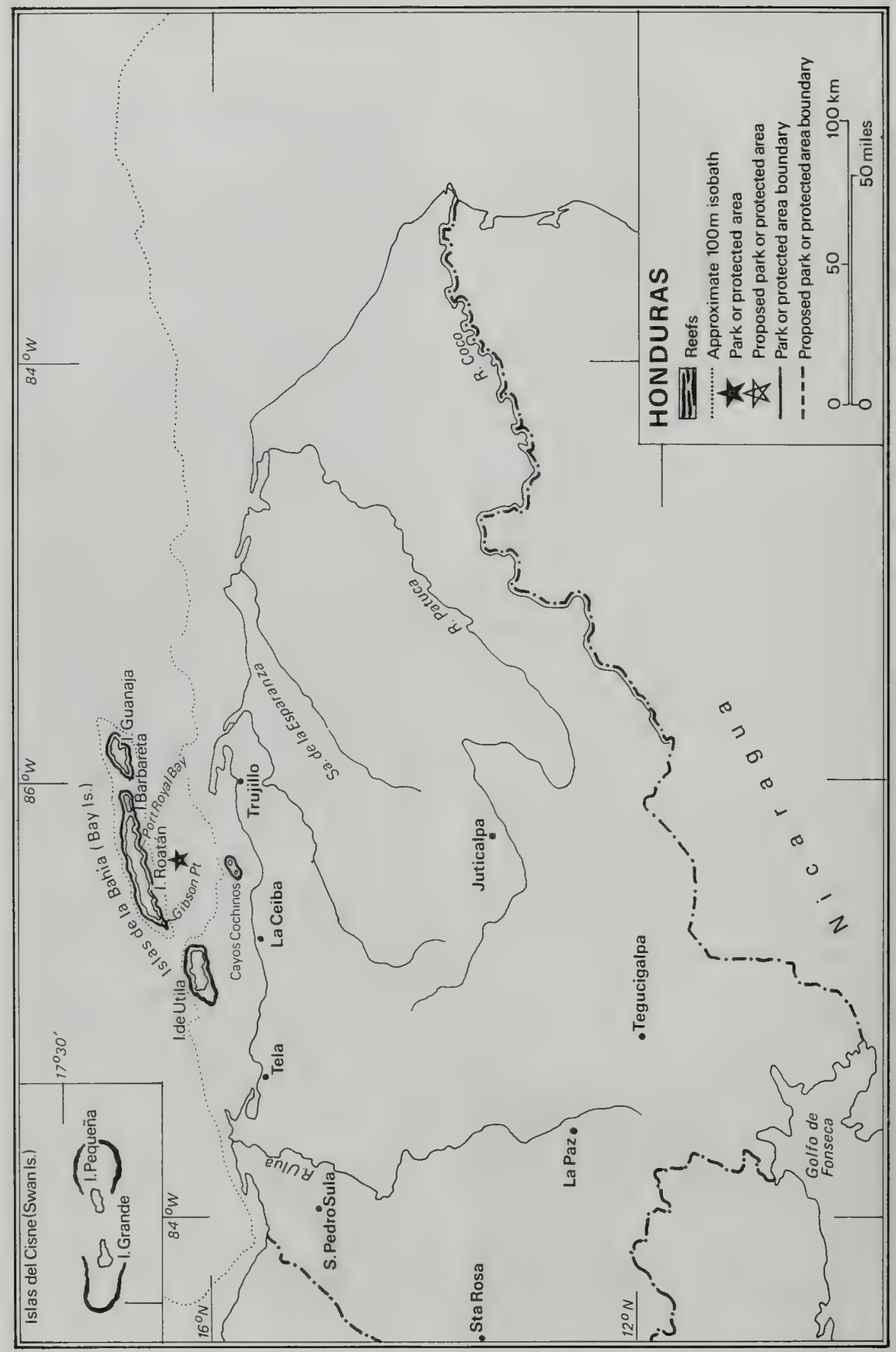




\section{ROATAN ISLAND PROPOSED MARINE PARK}

Geographical Location $16^{\circ} 15^{\prime}-16^{\prime} 25^{\circ} \mathrm{N}, 86^{\circ} 22^{\prime}-86^{\circ} 37^{\prime} \mathrm{W}$; within the Bay Island Archipelago, 60 miles (96.6 km) from the Honduras coast.

Area, Depth, Altitude Roatán covers 12740 ha (48 x $4 \mathrm{~km}$ ); maximum altitude $300 \mathrm{~m}$.

Land Tenure The marine area is Government owned, the terrestrial area is privately owned.

Physical Features The Bay Islands (Utila, Roatán and Guanaja) are situated on the Bonacca ridge, a crest which parallels a deep ocean trench, oriented east-west. McBirney and Bass (1969) discussed the geology of the area, and Davidson (1979) the historical geography. Roatán is hilly, only $2.2 \%$ of the land area being considered flat, and the island is tilted to the south due to uplifting. The strata are metamorphic and sedimentary with reefal facies. It is surrounded by deep water, the $200 \mathrm{~m}$ contour lying $7-10 \mathrm{~km}$ offshore on the north and south sides. There are 23 coastal cays, including Santa Elena, Morat and Barbareta off the eastern tip.

Little data is available on the marine physical environment but general features may resemble those of the Belize Barrier Reef (Britton and Fergusson, 1981). Several coastal habitat types are found including mangroves, ironshore, coral reefs, seagrasses, mud and sand. A nearly continuous barrier and fringing reef dominates the north coast. Channels up to $126 \mathrm{ft}$ (38.4 m) deep, formed by erosion during glacial times, cut through the reef platform and are correlated with streams and bays. They are maintained by fresh water and turbidity associated with terrestrial run-off. Shallow reefs appear to have been impacted by the phenomenon of sheet flow run-off during the rainy season maintaining its integrity as a surface lens. The south coast has a discontinuous fringing reef and escarpment reefs. Shallow barrier reef platforms are found off George (Fort) Cay and the "Reef House", in the centre of the south coast. Fringing shoreline and escarpment margin reefs are more common, with a $30-40 \mathrm{ft}(9.1-12.2 \mathrm{~m})$ deep horizontal reef platform continuing seaward to a sharp vertical escarpment that may continue to a depth of $250 \mathrm{ft}$ $(76.2 \mathrm{~m})$ or greater.

Port Royal Bay is an extensive stretch of water, delineated to the south by a fringing reef and backed by steep conical hills with a very narrow coastal strip (Jensen, 1985). The lagoon is about 5-10 $\mathrm{m}$ deep, sedimentary and well carpeted with sea grass except in shallow water. The bay is fed by numerous small streams, each separated from the Bay proper by a sandy bar during the dry season. There are three deep $(24 \mathrm{~m})$ channels through the reef. George Cay and Cusack Cay lie at the east and west ends of the bay and two smaller islands lie to the north-east of Cusack.

The climate is mild with a rainy season from October to January; mean precipitation is $85 \mathrm{in}$. (2160 mm), the rainy season providing $59 \%$ of annual precipitation. Temperature ranges from 25.4 to $28.9^{\circ} \mathrm{C}$. Trade winds from the east or south-east are relatively constant. During the winter, northerly winds associated with cold fronts occasionally cause a change in local meteorologic conditions (Jaap and Halas, 1982).
Reef Structure and Corals The biota is typically West Indian-Caribbean. Jaap and Halas (1982) recorded 52 species of stony corals although Britton and Fergusson (1981) recorded only 38 from the south coast. Dominant corals in the shallower areas are Agaricia tenuifoliata, Montastraea annularis, Acropora palmata, Diploria clivosa. In vertical situations, Agaricia lamarcki dominates and there is greater species diversity. At 2-9 m depth, coral cover ranges from 30 to $70 \%$ and coral density from two to seven species per sq. $m$ and 7 to 46 colonies per sq. $\mathbf{m}$.

Jensen (1985) describes the reefs at Port Royal Bay. The lagoon has about 50 patch reefs, the greatest concentration being south of Jennings Point and east of Cusacks Island. The majority are dominated by sponges, particularly Iricinia strobilina. Coral dominated reefs are found in areas of low siltation and relatively rapid water movement. The Amphora Wreck and a reef of boulders at the base of Jennings Point, the site of an old British Garrison Fort, provide additional hard substrates for corals. The fringing reef across the Bay has well established spur and groove formations, many grooves being covered with plate corals. The reef entrances are high energy zones populated predominantly by gorgonians and stony corals capable of withstanding considerable wave movement. The coral is replaced at $10 \mathrm{~m}$ by a sedimentary channel which prohibits coral growth. The reef proper slopes gently to $10 \mathrm{~m}$ where a vertical drop-off occurs, flattening into a sandy slope between $15 \mathrm{~m}$ and $50+\mathrm{m}$. This terracing is repeated at intervals out into deeper water. The drop-off is dominated by plate corals, Agaricia sp., large sponges, gorgonians and Halimeda.

On the north coast, the shallow reef parts are dominated by $M$. annularis and the platform tops are most often covered with $A$ tenuifoliata. Where the reef crest is less than $0.5 \mathrm{~m}$ deep, dead coral predominates. Seaward, a spur and groove formation is found, with tunnels running from behind the reef to the deeper seaward areas which are a focal point for diving. Near the western end, the shallow barrier is less developed, and the reef ceases west of Gibson Point (Jaap and Halas, 1982).

Noteworthy Fauna and Flora The island is densely vegetated. Invertebrates, plants and 96 species of fish recorded during the 1982 survey are listed in Jaap and Halas (1982). Conch Strombus gigas occur at a number of sites but in Port Royal Bay are restricted to deep water. Britton and Fergusson (1981) provide a checklist of marine molluscs of south-east Roatán. The molluses from Lime Key are described by Champagne (1979) and those from Calabash Bight by Nunley (1979). Jensen (1985) gives species lists for the reef crest, fringing reef and mangroves at Port Royal Bay. Careening Cay, George Cay and Cusacks Island have stands of black mangrove and further extensive stands are reported to occur to the east of the Bay. Crocodiles may occur here. Hawksbill Eretmochelys imbricata, Loggerhead Caretta caretta, Leatherback Dermochelys coriacea and Green Turtles Chelonia mydas are found in the good foraging habitat around the Bay Islands (IUCN, 1982; Jensen, 1985 ), but there is no confirmed nesting and numbers appear to be badly depleted (Groombridge, 1982). Endemic species of opossum Marmosa ruatanica ruatanica and agouti Dasyprocta ruatanica occur on the island and there are several endemic birds. 
Scientific Importance and Research In 1982 a multidisciplinary study was carried out for the World Bank and the Honduras Government in response to the economic potential of increased tourism on the island and the need to ensure that poorly planned development projects do not adversely affect the environment. Sixteen reef sites were studied briefly, eight on the north coast and eight on the south, and their tourist carrying capacity was evaluated (Jaap and Halas, 1982). A study of the natural resources of the Bay Islands has recently been carried out by the Honduran planning secretariat CONSUPLANE with funding from the Organization of American States. Roatán is often visited by university coral reef study groups from the U.S.A but little of their research is published or widely disseminated. Operation Raleigh carried out a marine archeological survey in the Port Royal area in 1984 (Holliday, 1985).

Economic Value and Social Benefits Diving tourism is of major importance to Roatán's economy. It is estimated that between 3000 and 3500 divers visit Roatán annually, but the resorts are still considered under utilized. Current diving activities probably generate between $\$ 1700000$ and $\$ 2100000$ annually and it is thought that this could be increased to $\$ 3500 \quad 000-\$ 7300000$, the reefs being capable of sustaining some 20 000-25 000 divers annually (Jaap and Halas, 1982). The Reef House is a major resort and is the base of the Caribbean Institute which provides educational holidays. Port Royal at the remote western end of the island is relatively unspoilt and tourism is low key. There is one dive resort, the reef across the Bay being a popular dive site, and the industry is expected to expand in the future (Jensen, 1985). The small patch reefs in the lagoon are probably important sanctuaries for commercial fish as the fish fauna was diverse and abundant and the reefs did not appear to be subject to heavy fishing pressure (Jensen, 1985). The fringing reef across the Bay is, in contrast, heavily exploited by local people for food, most fish being caught by free diving with spearguns. There is a limited amount of trap fishing.

Disturbance or Deficiencies Hurricanes may have a periodic impact on the reefs and white band disease has been reported (Rogers, 1985). With the exception of one site, all reef areas visited in the 1982 survey were healthy, although regularly used by tourists from the resorts. Human waste and refuse is dumped in the sea, and although not a problem at the moment, this could threaten the reef as the population increases with development of the tourist industry. There are already stagnant water areas in some of the bays near population centres. The expansion of the tourist industry in Port Royal Bay could affect the reef if there are no controls on sewage disposal. There is minor damage in some areas from anchoring, for example in Port Royal Bay, caused partly by dive boats and partly by chartered yachts used by tourists not knowledgeable of the local waters, as there are few aids to navigation around the island. Damage caused by divers and collection of marine curios is currently minimal (Jaap and Halas, 1982).

The greatest potential threat to the Roatán reefs is probably sedimentation from run-off and airbom dust particles caused by vegetation clearance on land. This is illustrated by the reefs off the eastern end of the airport runway where there has been chronic turbidity to about 4-5 $\mathrm{m}$ depth and reduced coral density. From $4-5 \mathrm{~m}$ down to $20 \mathrm{~m}$, sediments smothered a large proportion of the colonies of Montastraea annularis, Colopophyllia natans and Agaricia lamarcki. In sediment channels on the slope there was as much as $4-6 \mathrm{in} .(10.2-15.2 \mathrm{~cm})$ of accumulated land sediment. Fish populations declined in this area. Adjacent reefs were affected by infilling of the sea to expand the airport. Clay roads which produce large amounts of sediment during the rainy season may also have an impact (Jaap and Halas, 1982).

Legal Protection Legislation establishing the wildlands and coral reefs of the Bay Islands as a National Park was to be submitted in 1979 (IUCN, 1982) but it is not clear whether this has taken place.

Management Most dive masters appear to be aware of the need for conservation and most of the dive resorts discourage or prohibit souvenir collection (Jaap and Halas, 1982).

Recommendations Zoning plans were designed for the Bay Islands by Nathano et al. (1975) and Oliver (1977) and COHDEFOR was considering the establishment of a watershed management programme on Roatán with an initial staff of two (IUCN, 1982). Jaap and Halas (1982) give detailed recommendations for the management of the reefs. Four minimum statutes are proposed prohibiting a) the taking of hard and soft corals by tourist divers, b) souvenir collecting by tourist divers, c) spearfishing and enforcing d) the monitoring trap fishing. The potential for black coral collection for local purposes might be investigated, and limited collection of marine invertebrates by local people should be permitted. Moderate spearfishing by the local population for local consumption should be continued. Although the establishment of a Marine Park is not considered essential at present, it should be considered for the future and implementation of the statutes should be a high priority. It is suggested that dive masters and local law enforcement agents could provide the basis for an effective enforcement system. New tourist developments should focus on diving activities and the requirements of tourist divers. Safety precautions during diving trips should be improved. Jensen (1985) recommends the establishment of permanent anchorages at prime dive sites at Port Royal Bay and emphasizes the need for further scientific work in the area.

\section{SWAN ISLANDS}

Geographical Location $150 \mathrm{~km}$ north-east of Honduras; including Isla Grande (Great Swan), Isla Pequeña (Little Swan) and Booby Cay.

Area, Depth, Altitude The total area of the islands is less than 2 sq. miles ( $5.2 \mathrm{sq} . \mathrm{km}$ ).

Physical Features Isla Grande is the largest of the three islands and is just over 2 miles $(3.2 \mathrm{~km})$ long and about 0.5 miles $(0.8 \mathrm{~km})$ wide; Isla Pequeña is 1.5 miles $(2.4 \mathrm{~km})$ long and less than 0.5 miles $(0.8 \mathrm{~km})$ wide. Booby Cay is a small limestone islet. The islands lie along the Swan Islands-Jamaica-South Haiti Fault zone on the south-eastern side of the Cayman Trench. Their geology is described in Ivey et al. (1980), Stewart (1962) and U.S. Geol. Surv. (1967). Isla Grande is characterized by a 
prominent upraised reef of coralline limestone forming cliffs, $50-60 \mathrm{ft}(15.2-18.3 \mathrm{~m})$ high along all but one small portion of the southern coast. Along the north-east coast from the northem end of Jacobsons Bay west to Fowler Point, the upraised reef is lower and interrupted by occasional small bays with pocket beaches. The southern coast of Isla Pequeña consists of a continuous limestone cliff, $50-60 \mathrm{ft}(15.2-18.3 \mathrm{~m})$ high. The northern coast rises equally steeply for $15-20 \mathrm{ft}(4.6-6.1 \mathrm{~m})$ and then less steeply to the top of the island. The islands are surrounded by fringing reefs (Tortora and Keith 1980a and $b$ ).

Reef Structure and Corals The reefs were briefly studied during the visit of the Explorer (Stewart, 1962) Coral growth was considerably less abundant and less varied than on the reefs of Panama. The main constituents were Acropora, Porites, gorgonians and the calcareous algae Halimeda. Coral assemblages on shallow-water, nearshore patch reefs along the western and northern leeward sides of Isla Grande are described by Tortora (1975). Octocorals and scleractinians (16 species) are described by Tortora and Keith (1980a and b).

Noteworthy Fauna and Flora The flora of the islands is described briefly in Stewart (1962). Isla Pequeña is dominated by cactus, "sea grape", and a succulent, locally known as "sea lettuce". On Isla Grande, a thick covering of sea lettuce along the edge of the cliffs gives way to low sea grape inland. The central flat area is dominated by grasses, large trees and luxuriant underbush. The Hutia Geocapromys thoractus used to be abundant on Isla Pequeña but is now apparently extinct. A large iguana was abundant on Isla Pequeña and common on Isla Grande and a number of other reptiles have been recorded. Green Turtles Chelonia mydas, Hawksbills Eretmochelys imbricata and
Loggerheads Caretta caretta were common in the 1950 s and nested on the islands. Halewyn and Norton (1984) list three species of birds, the Red-footed Booby Sula sula, the Brown Booby S. leucogaster and possibly the Magnificent Frigatebird Fregata magnificens as having breeding colonies on Swan Island; Isla Pequeña had large colonies in the $1950 \mathrm{~s}$.

Scientific Importance and Research The U.S. research vessel, Explorer, visited the island briefly in 1960 and carried out studies on tides, currents, geology and the natural history of the islands (Stewart, 1962). The islands are now used as a field station by the Texas Christian University (Britton in litt., 1984).

Economic Value and Social Benefits A U.S. weather station is situated on Isla Grande. Isla Pequeña and Booby Cay are uninhabited (Tortora and Keith, 1980a and b). There is a good landing for small boats at the western end of Isla Grande. Landing on Isla Pequeña is difficult on account of the precipitous cliffs surrounding most of the island (Stewart, 1962). Guano used to be mined on this island. Freshwater is in short supply on Isla Grande and none is available on Isla Pequeña

Disturbance or Deficiencies The islands were damaged by a severe hurricane in 1955 . Goats were introduced to Isla Pequeña in the 1950 s but had died off by 1960 . Introduced cats were present but were few in number (Stewart, 1962). There is no information on the status of the reefs.

Legal Protection No information.

Management No information.

Recommendations No information. 



\section{INTRODUCTION}

\section{General Description}

Jamaica, an independent nation within the British Commonwealth, lies some $150 \mathrm{~km}$ south of Cuba from which it is separated by the $7000 \mathrm{~m}$ deep Cayman Trench. With an area of $10962 \mathrm{sq} . \mathrm{km}(235 \times 80 \mathrm{~km})$, it is the third largest island in the Caribbean. It is orientated ESE-WNW, the smaller eastern end of the island being dominated by the Blue Mountains, whose main ridge rises over $2000 \mathrm{~m}$, and the central/western part consisting of a faulted eroded plateau of Tertiary limestones, barely reaching $900 \mathrm{~m}$. The climate is sub-tropical with two wet seasons (October and May) and two dry seasons, the driest months being February and March. Rainfall is variable in different parts of the island. North-easterly trade winds predominate and the region is exposed to hurricanes between July and October. The surface temperature of the coastal waters varies between $24^{\circ} \mathrm{C}$ in January and $29.8^{\circ} \mathrm{C}$ in July, although higher temperatures are often encountered in harbours and lagoons where circulation is restricted. Tides vary in height from $20-36 \mathrm{~cm}$ and are irregular, tending to double up so that they occur only once a day. There is a well defined westward current on both coasts which becomes more pronounced during the trade wind season between April and December (Goreau, 1959). A weather monitoring programme is underway at Discovery Bay (Porter, 1985).

In general, the north and east coasts have a narrow $(1 \mathrm{~km}$ or less) insular shelf and a similarly narrow coastal plain, backed by uplands exceeding $200-300 \mathrm{~m}$ in altitude. The north coast is fringed by a narrow system of well-developed, spectacular and diverse reefs extending with some gaps along the seaward edge of the insular shelf from Morant Point in the east to Negril in the west. The presence or absence of a continuous, well developed reef crest is governed mainly by the shape and elevation of the underlying platform. The Discovery Bay reefs (see separate account) are most well known due to the presence of the Discovery Bay Marine Laboratory and the classic series of studies carried out by Goreau (see below). Reefs at Montego Bay, Ocho Rios and Negril are also described in separate accounts.

Other reef localities on the north coast are less well known but have been briefly described by Goreau (1959), Goreau and Goreau (1973), Liddell et al. (1984a) and Woodley and Robinson (1977). About $8 \mathrm{~km}$ east of Discovery Bay, at Runaway Bay and Pear Tree Bottom, the fore-reef escarpment is a massive perpendicular sill, largely covered by sediments, but with interesting cryptic fauna in tunnels formed by roofed-over sediment channels. Pear Tree Bottom has long reef mounds on the fore-reef terrace in the Acropora cervicornis and mixed zones, and an inshore zone of well developed buttresses and surge channels. In both localities, the outer face of the escarpment is a $20 \mathrm{~m}$ high vertical wall with a rich biota of algae, sponges, gorgonians, corals, hydroids and antipatharians (Woodley and Robinson, 1977). Rio Bueno, $5 \mathrm{~km}$ west of Discovery Bay, has a deep bay with precipitous reefs on either side. On the west, the submarine shelf is shallow and narrow, and reef zonation is greatly compressed. A very mature system of buttresses covered with a diverse coral assemblage lies immediately in front of the breaker zone, the spurs terminating in a vertical wall which drops sheer from 5-10 $\mathrm{m}$ to $200 \mathrm{~m}$ (Liddell et al., 1984b; Woodley and Robinson, 1977).

Chalet Caribe, just to the west of Montego Bay, is a good example of a fractured vertical fore-reef escarpment with crevices and caves with cryptic fauna. Near shore, there is a sand-covered hard ground with mostly massive corals. Seaward of this is a mixed zone, with incipient buttress development between sand channels in about $6 \mathrm{~m}$ of water, which merges with a continuous sill along the edge of the terrace at about $10 \mathrm{~m}$ depth, large sections of which have separated from the seaward face of the escarpment. Canyons and caves between the fractured blocks provide cryptic habitats for a number of species.

The south coast, between Kingston and Savanna-la-Mar, is characterized by a broad insular shelf up to $20 \mathrm{~km}$ wide and extensive alluvial plains between limestone hills, drained by many rivers. Reef development is not continuous but is more diverse than on the north coast. Early descriptions (e.g. Goreau, 1959) suggesting poor reefal development on the south coast relative to the north, may have been due to contemporary hurricane damage. For example, since Hurricane Allen devastated north coast reefs in 1980 , shallow water reefal habitats are now better preserved on the south coast than on the north. Reefs are best developed on the island shelf between Port Royal and Portland Point, and include sill reefs, pseudo barrier reefs, patch and fringing reefs, the latter along the coast of Hellshire.

Substantial reefs are found from Morant Point to Morant Bay in the east, and sporadically along the south coast to Kingston but river outflow and low water clarity may locally inhibit reef growth in this region. West of Portland Bight, well-developed reefs are found off Alligator Pond, Black River and Savanna-la-Mar. Elsewhere along the south coast, corals often occur where suitable hard substrates are present, but do not form significant reefs. Large-scale emergent algal/vermetid reefs have been described off Pedro Bluff in south-west Jamaica (Hendry and Head, 1985).

Two large and important shallow banks lie off the south coast: the Pedro Bank to the south-west and Morant Cays to the south-east (see separate accounts). These small isolated oceanic islands are poorly known biologically, but are important fishing and bird breeding areas, with impressive and healthy reef development. Other banks which may support coral growth include Mackerel Bank, Alice Shoal, Salmon Bank, Decca Ridge, Silver Bank and Navidad Bank. California Bank (8.6 sq. km) lies 22 km south of Kingston at a depth of 35-45 m and appears to have sparse coral cover and poorly developed sill reefs (Munro, 1983).

By 1959,41 scleractinian species in 25 genera and three families had been described from Jamaica (Goreau, 1959). First revised by Goreau and Wells (1967), the full list now contains 64 species (including ahermatypes) (Wells and Lang, 1973). Kinzie (1973) recorded 38 


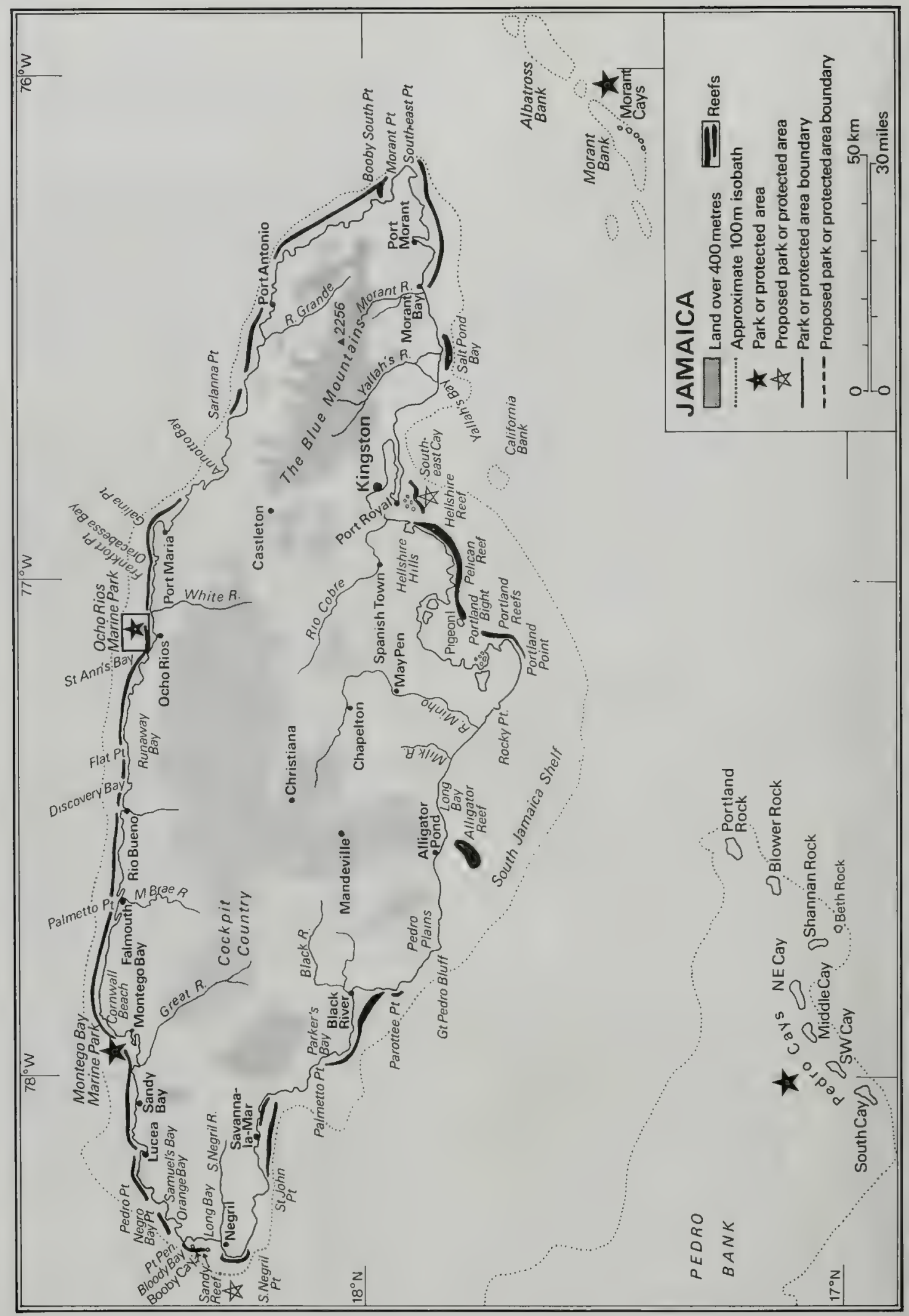


species of gorgonians. Studies underway on south coast communities suggest that one more scleractinian and several more gorgonian species may be present (Head, S.M., unpublished data). Montastraea annularis forms the broad basis of Jamaican reefs and is the single most important framework coral. Colonies grow to a very large size on the seaward slope, notably in the buttress zone. In shallower water, Acropora palmata becomes dominant, and the relative ease with which it breaks up in heavy seas provides the material for the reef flat and ramparts (Goreau, 1959).

Major coastal wetlands are described by Scott and Carbonell (1986). The Hawksbill Eretmochelys imbricata, Loggerhead Caretta caretta and Green Turtle Chelonia mydas nest at a number of sites around the island (Bacon et al., 1984; Groombridge, 1982). The American Crocodile Crocodylus acutus is found along the south coast. The mainland and surrounding islets support nine, and possibly eleven, breeding species of seabird; Morant Cays support five, and possibly seven, species; and Pedro Cays support between three and eleven species (Halewyn and Norton, 1984).

A classic series of studies at Discovery Bay by Goreau cover coral reef communities (Goreau, 1959 and 1965; Goreau and Goreau, 1973), coral growth (Goreau, 1963), coral nutrition (Goreau et al., 1971), coral reef fauna (Hartmann and Goreau, 1970), the geological history of coral reefs (Goreau, 1965; Goreau and Burke, 1966) and contemporary geological processes in coral reefs (Goreau and Hartmann, 1963; Goreau and Land, 1974; Land and Goreau, 1970). Fringing reef sediments of the north coast are described by Boss and Liddell (in press). Other recent studies include Liddell et al. (1984a) and several cited in the separate account for Discovery Bay.

Compared with the north coast, the south coast reefs have received relatively little study. Descriptions of reefs and corals in the Kingston area (see separate account) include Goreau (1959 and 1964), Goreau and Goreau (1959), Head and Hendry (1985) and Mergner (1972 and 1977). Several studies on cay geomorphology and vegetation resulted from the 1939 Cambridge Expedition (Chapman, 1944; Steers, 1940a and 1940b; Steers et al., 1940). Little Pelican Cay (Portland Bight) was described from the botanical viewpoint by Adams (1969). The reefs of the Hellshire coast and the Port Royal Cays are currently being studied in the course of the Caribbean Coastal Management Study (CCMS) (see below).

\section{Reef Resources}

The developing economy of Jamaica depends largely on tourism and fisheries. Coral reefs are a major element in the attractiveness of the country to holiday makers. The north coast has a long history as a recreational area and the south coast is becoming increasingly important. For example, since the installation of a road along the Hellshire coast, this area has become very popular with day trippers, some 4000 people visiting Half Moon Bay at weekends (Head and Hendry, 1985).

Reef fisheries are of major importance and the Jamaican industry is described in detail by Munro (1983), a compilation of papers resulting from an ODA/University of West Indies Fisheries Ecology Research Project which took place from 1969 to 1973 . This investigated the main characteristics of the offshore line fishery and the impact of trap fishing on reef fish communities. Fishing is important on much of the north coast where no point in the fringing reef system is more than 5 miles $(8 \mathrm{~km})$ from a fishing beach. Other major fishing grounds include Pedro Bank, Navidad Bank and other offshore banks. Yields of $15 \mathrm{~kg} / \mathrm{ha}$ have been calculated for the Jamaican reef fisheries.

\section{Disturbances and Deficiencies}

Hurricanes have periodically inflicted considerable damage on Jamaican coral reefs. Studies after Hurricane Flora in 1963 revealed that some corals survived but were bleached through the loss of their zooxanthellae (Goreau, 1964). Hurricane Allen had a major impact on the reefs in August 1980 (Liddell et al., 1984b; Ohlhorst and Liddell, 1981; Woodley, 1980; Woodley et al., 1981), destroying many of the shallow and some of the deep reefs of the north and east, and flattening whole fields of $A$ cervicornis (95\% mortality) (Knowlton et al., 1981). Initial research on the reefs around Discovery Bay suggested that recovery was taking place more rapidly than was previously expected (Woodley, 1980), but Knowiton et al. (1981) and Rosesmyth (1984) recorded delayed mortality in coral fragments. Mass mortalities of Diadema antillarum populations took place on the north coast in summer 1983 with maximum mortality in the Discovery Bay area (Hughes et al., 1985; Liddell and Ohthorst, 1986; Morrison, 1984). White band disease has been recorded (Rogers, 1985).

Human activities are having an increasing impact. The reefs are heavily over-fished (Munro, 1974 and 1983), individual fish are small, illegal explosives have often been used and the fishery is no longer very productive. The reef fish community has been altered and it is likely that the relative abundance of certain predators, herbivores and other grazers has been changed. It is also possible that the relative abundance of grazing echinoids, algae and corals may be changing (Woodley, 1979; Woodley and Robinson, 1977). Marine curios are collected commercially and casually. In the 1970 s, stony and black corals were collected in large quantities as souvenirs and the former for construction; this is reportedly still occurring (Rogers, 1985). Reefs in popular recreational areas are subject to damage from trampling and boat anchors.

Since the 1960 s there has been considerable construction and engineering work at many localities on the north coast which has often generated high temporary sediment loads in the sea. Large hotels used to discharge relatively untreated sewage into the sea, often onto the reef, causing pollution problems. Studies on the effects of sewage pollution carried out in 1973 (Bames, 1973) revealed that detergents were particularly damaging to corals and marine life.

Kingston Harbour had become seriously polluted by the early 1970s (Wade, 1976; Wade et al., 1972) and effluent may be causing major reef degradation through eutrophication along the north-east part of the Hellshire coast, to the west of the harbour entrance (Head and Hendry, 1985) where the fringing reefs, seagrass beds and beaches appear to be already substantially degraded. Head and Hendry (1985) compared the reef at Lime Cay, one of the offshore Port Royal Cays (see separate 
account), with fringing reefs, such as Half Moon Bay, on the mainland. Coral cover on the latter was found to be very low, with much dead coral and algal overgrowth, indicating that coral mortality had been fairly recent. The deterioration of the reefs may also have contributed to beach erosion. This is of considerable concern since the area is scheduled for development on the basis of the attractiveness of the environment.

\section{Legislation and Management}

The Wildlife Protection Law (1945) gives legal protection to black coral, all marine turtles, the Iguana Cyclura collei, Crocodile Crocodylus acutus and Caribbean Manatee Trichechus manasus and prohibits the discharge of effluents into any enclosed body of water containing fish, or to fish with poison or explosives. The Fisheries Division of the Ministry of Agriculture has the legal power through the Fishing Industry Act to designate Fish Sanctuaries; the Fishing Industry Regulations 1975 provide partial protection for spiny lobsters. Additional legislation for the protection of black coral was in preparation in 1978. Munro (1983) gives recommendations for improvement of the fishing industry. The Beach Control Act (1960) requires the licensing of any construction, enclosure, drainage works, etc. within a mile $(1.6 \mathrm{~km})$ of the coast and of any construction on, or interference with, the sea-bed. With the expansion of the tourist industry, the Beach Control Authority and the Ministry of Health set standards for sewage treatment but these are not always adhered to.

The Natural Resource Conservation Department (NRGC) is responsible for National Parks and reserves. The following areas (described in separate accounts) have been designated:

\section{- Montego Bay Marine Park \\ - Ocho Rios Marine Park \\ - Pedro Bank and Cays: closed to fishing, turtling and the taking of birds \\ - Morant Cays: closed to fishing, turtling and the taking of birds}

Other areas which have been proposed for protection and management are:

\section{- Negril proposed National Park \\ - Port Royal proposed National Park}

\section{Recommendations}

Discovery Bay has never been formally, proposed for protection but should perhaps be considered, given its importance as a scientific research site.

A multidisciplinary Caribbean Coastal Management Study (CCMS) is currently underway involving the University of the West Indies and Dalhousie University, funded by the International Development Research Centre of the Canadian Government. This aims to provide baseline data for the coastal environment of Hellshire, an area of once virgin, low lying karst country, which has been designated through the Urban Development Corporation for residential, industrial and amenity development. The area will eventually house some 175000 people and will provide a major recreational resource for the 1.2 million inhabitants of the Kingston and Spanish Town areas. An additional aim of this project is the creation of a Marine Environment Analyis Unit at the University of the West Indies (Head and Hendry, 1985).

\section{References}

Adams, C.D. (1969). A botanical description of Big Pelican Cay, a little known island off the south coast of Jamaica. Aroll Res. Bull. 130.

Aller, R.C. and Dodge, R.E. (1974). Animal-sediment relations in a tropical lagoon, Discovery Bay, Jamaica. J. Mar. Res. 32: 209-232.

Anon. (1978). Proposal for Development of Marine Reserves in Jamaica. Proposal to WWF/IUCN, Project 1801.

Anon. (?Woodley) (1981). Environmental Feasibility Study of the Jamaica Peat Resources Utilization Project. Vol. 2, Technical Report. Natural Resources Conservation Dept and the Traverse Group Inc.

Asprey, G.F. and Robbins, R.G. (1953). The vegetation of Jamaica. Ecol. Monogr. 23: 359-412.

Bacon, P., Berry, Fo, Bjorndal, Hirth, H., Ogren, L. and Weber, M. (1984). The National Reports. Proceedings of the Western Allantic Turtle Symposium, Costa Rica. Vol.3: University of Miami Press, Florida.

Barnes, E.S. (1973). Sewage pollution from tourist hotels in Jamaica. Mar. Poll. Bulletin 4: 102-105.

Bonem, R.A. (1984). Sedimentologic development of lagoonal patch reefs. Advances in Reef Sciences. Abstracts of Papers, Joint Meeting of the Atlantic Reef Committee and the International Society for Reef Studies, Miami, October: 12-13.

Bonem, R.M. and Stanley, G.D. (1977). Zonation of a lagoonal patch reef: analysis, comparison and implications for fossil biohermal assemblages. Proc. 3rd Int. Coral Reef Symp. Miami 2: 175-181.

Boss, S.K. and Liddell, W.D. (in press). Patterns of sediment composition of Jamaican fringing reef facies. Sedimentology.

Chapman, V.J. (1944). The 1939 Cambridge University Expedition to Jamaica. Part 1. A study of the botanical processes concemed in the development of the Jamaican shore-line. J. Linn. Soc. Lond. 52: 407-447.

Chapman, VJ. (1961). The marine algae of Jamaica. Part 1. Myxophyceae and Chlorophyceae. Bull. Institute of Jamaica Science Series 12.

Chapman, VJ. (1963). The marine algae of Jamaica. Part 2. Phaeophyceae and Rhodophyceae. Bull. Institute of Jamaica Science Series 12.

Cotterell, C. (1980). A proposal for the development of the Palisadoes/Port Royal National Park. Natural Resources Conservation Department, Kingston. Unpublished report.

Dahl, A.Loo, Macintyre, I.C. and Antonius, A. (1974). A comparative survey of coral reef sites. Atoll Res. Bull. 172: $37-120$.

D'Elia, C.F., Webb, K.L. and Porter, J.W. (1981). Nitrate-rich groundwater inputs to Discovery Bay, Jamaica: a significant source of $\mathbf{N}$ to local coral reefs? Bull. Mar. Sci. 31: 903-910.

Dodge, R.E, Aller, R.C. and Thompson, J. (1974). Coral growth related to resuspension of bottom sediments. Nature 247: 574-577.

Goreau, T.F. (1959). The ecology of Jamaican coral reefs: 1. Species composition and zonation. Ecology 40: $67-90$. 
Goreau, T.F. (1963). Calcium carbonate deposited by coralline algae and hermatypic corals in relation to their roles as reef builders. Ann. New York Acad. Sci. 109: 127-167.

Goreau, T.F. (1964). Mass expulsion of zooxanthellae from Jamaican reef communities after Hurricane Flora. Science 145: 383-386.

Goreau, T.F. (1965). The regulation of form in reef building corals as a function of depth and light intensity. Abs. Symposium on Growth, UWI, Mona, 1965. Goreau, T.F. and Burke, K. (1966). Pleistocene and Holocene geology of the island shelf near Kingston, Jamaica. Mar. Geol. 4: 207-225.

Goreau, T.F. and Goreau, N.I. (1959). The physiology of skeleton formation in corals. II. Calcium deposition by hermatypic coals under various conditions in the reef. Biol. Bull. 117: 239-250.

Goreau, T.F. and Goreau, N.I. (1973). The ecology of Jamaican coral reefs: II. Geomorphology, zonation and sedimentary phases. Bull. Mar. Sci. 23: 399-464.

Goreau, T.F., Goreau, N.I. and Yonge, C.M. (1971). Reef corals: autotrophs or heterotrophs. Biol. Bull. 141: 247-260.

Goreau, T.F. and Hartman, W.D. (1963). Boring sponges as controlling factors in the formation and maintenance of coral reefs. Amer. Assoc. Adv. Sci. Publ. 75: 25-54.

Goreau, T.F. and Land, L.S. (1974). Fore-reef morphology and depositional processes, North Jamaica. Bull. Mar. Sci. 23: 77-85.

Goreau, T.F. and Wells, J.W. (1967). The shallow water Scleractinia of Jamaica: revised list of species and their vertical distribution range. Bull. Mar. Sci. 178: 442-453.

Graus, R.R., Macintyre, I.G. and Herchenroder, B.E. (1984). Computer simulation of the reef zonation at Discovery Bay, Jamaica: hurricane disruption and long-term physical oceanographic controls. Coral Reefs 3: $59-68$.

Groombridge, B. (1982) The IUCN Amphibia-Reptilia Red Data Book, Part I. Testudines, Crocodylia, Rhyncocephalia. IUCN, Gland, Switzerland.

Halewyn, R. van and Norton, R.L. (1984). The status and conservation of seabirds in the Caribbean. In: Croxall, J.P., Evans, P.G.H. and Schreiber, R.W. (Eds), Status and Conservation of the World's Seabirds. ICBP Technical Publication No. 2, Cambridge.

Hanley, F. (1984). Time-budgeting and foraging strategy of the stoplight parrotfish Sparisoma viride Bonnaterre, in Jamaica. J. exp. mar. Biol. Ecol. 83: 159-177.

Hartman, W.D. and Goreau, T.F. (1970). Jamaican coralline sponges. Zool. Soc. Lond. Symp. 25: 20 pp.

Head, S.M. and Hendry, M.D. (1985). Development of the Hellshire Hills, Jamaica: implications for management strategy of reefs and related ecosystems. Proc. 5th Int. Coral Reef Congress, Tahiti 6: 519-524.

Hechtel, G.J. (1965). A systematic study of the Demospongiae of Port Royal, Jamaica. Bull. Peabody Mus. Nat. Hist. 20: 1-103.

Hendry, M.D. (1982). The structure, evolution and sedimentology of the reef, beach and morass complex at Negril, Western Jamaica. Report to Petroieum Corporation of Jamaica, P.O. Box 579, Kingston 10, Jamaica.

Hendry, M.D. and Head, S.M. (1985). Late quaternary sea-level changes and the development of the raised reef/dune sequence at Great Pedro Bluff, south-west Jamaica. Proc. Sth Int. Coral Reef Congress, Tahiti 6: 119-124.

Hughes, T.P. Keller, B.D., Jackson, J.B.C. and Boyle,
M.J. (1985). Mass mortality of the echinoid Diadema antillarum Philippi in Jamaica. Bulletin of Marine Science 36: 377-384.

Itzkowitz, M. (1977). Spatial organisation of the Jamaican damselfish community. J. exp. mar. Biol. Ecol. 28: 217-241.

Kinzie, R.A. III (1973). Coral Reef project - papers in memory of Dr. Thomas F. Goreau. 5. The zonation of West Indian gorgonians. Bull. Mar. Sci. 23: 93-155.

Knowlton, N., Lang, J.C., Rooney, C.M. and Clifford, P. (1981). When hurricanes kill corals: evidence for delayed mortality in Jamaican staghorns. Nature 294: 251-252.

Land, L.S. and Goreau, T.F. (1970). Submarine lithification of Jamaican reefs. Jour. Sed. Petrol. 40: $457-462$.

Lang, J.C. (1974). Biological zonation at the base of a reef. Am. Sci. 62: 272-281.

Lewis, C.B. (1940a). Report on the decline in the yield of booby eggs on Pedro and Morant Cays with recommendations for conservation. Unpublished report, Kingston, Jamaica.

Lewis, C.B. (1940b). Observations on marine turtles of the Pedro and Morant waters with recommendations for conservation. Unpublished report, Kingston, Jamaica.

Lewis, C.B. (1947). A trip to the Morant and Pedro Cays. Natural History Notes of the Natural History Society of Jamaica 3: 105-108.

Liddell, W.D. and Ohlhorst, S.L. (1981).

Geomorphology and community composition of two adjacent reef areas, Discovery Bay, Jamaica. J. Mar. Res. 39: 791-804.

Liddell, W.D. and Ohlhorst, S.L. (1986). Changes in benthic community composition following the mass mortality of Diadema at Jamaica. J. Exp. Mar. Biol. Ecol. 95: 271-278.

Liddell, W.D. and Ohlhorst, S.L. (in press). Patterns of reef community structure, North Jamaica. Bull. Mar. Sci.

Liddell, W.D., Ohlhorst, S.L. and Coates, A.G. (1984a). Modern and Ancient Carbonate Environments of Jamaica. Sedimenta $X$. The Comparative Sedimentology Laboratory, University of Miami: 101 pp. Liddell, W.D., Ohlhorst, S.L. and Boss, S.K. (1984b). Community patterns on the Jamaican fore-reef (15-56 m). Palaeontographica Americana 54: 385-389.

Mailer, S.R. (1982). The development and management of a marine park system in Jamaica. 1. Montego Bay Marine Park, Survey and Management Plan. Unpub. Report, Discovery Bay Marine Laboratory.

Mailer, S.R. (1984). The development and management of a marine park system in Jamaica. 2. Ocho Rios Underwater Park, Survey and Management Plan. Discovery Bay Marine Laboratory.

Mergner, H. (1972). The influences of several ecological factors on the hydroid growth of some Jamaican coral cays. Proc. Symp. Corals and Coral Reefs, Mar. biol. Ass. India 275-290.

Mergner, H. (1977). Hydroids as indicator species for ecological parameters in Caribbean and Red Sea coral reefs. Proc. 3rd Int. Coral Reef Symp., Miami 1: 119-126. Moore, E. and Sander, F. (1976). Quantitative and qualitative aspects of the zooplankton and breeding patterns of copepods at two Caribbean coral reef stations. Est. Coastal Mar. Sci. 4: 589-607.

Moore, E. and Sander, F. (1979). A comparative study of zooplankton from oceanic, shelf and harbour waters of Jamaica. Biotropica 11: 196-206.

Morrison, D. (1984). Mass mortality of Diadema antillarum on a Jamaican coral reef: effect on the aigal 
community. (Abstracts) Advances in Reef Science. Joint Meeting of the Atlantic Reef Committee and the International Society for Reef Studies, (Oct.1984) Miami, Florida : 85-86.

Munro, J.L. (1974). The biology, exploitation and management of Caribbean reef fishes. Pt. VI. Assessment of potential productivity of Jamaican fisheries. Res. Rept, Zool. Dept, U.W.I. 3: 56 pp.

Munro, J.L. (Ed.) (1983). Caribbean Coral Reef Fishery Resources. ICLARM Studies and Reviews 7.

Ohlhorst, S.L. (1980). Jamaican coral reefs: important biological and physical parameters. Ph.D. Thesis, Yale University, $147 \mathrm{pp}$.

Ohlhorst, S.L. and Liddell, W.D. (1981). Hurricane damage to Jamaican coral reefs. Geol. Soc. Am., Abstracts with Programme 13: 522.

Porter, J.W. (1985). The maritime weather of Jamaica: its effect on coral productivity. Proc. Sth Int. Coral Reef Congress, Tahiti, Vol. 6: 363-367.

Porter, F.W., Woodley, J.D., and Battery, (1977). The establishment of a long-term monitoring survey on a Jamaican coral reef. Paper read to 3rd Int. Symp. Coral Reefs, Miami.

Porter, F.W., Woodley, J.D., Smith, G.J., Neigel, J.E., Battey, J.F. and Dallmeyer, D.G. (1981). Population trends among Jamaican reef corals. Nature 294: 249-250.

Robinson, C.J. (1980). Cambridge Coral Microstructure Project. Jamaica 1980. Expedition report.

Rogers, CS. (1985). Degradation of Caribbean and Western Atlantic coral reefs and decline of associated fisheries. Proc. 5th Int. Coral Reef Cong., Tahiti. 6: 491-496.

Rosesmyth, M.C. (1984). Growth and survival of sexually produced Acropora recruits: a post-hurricane study at Discovery Bay. (Abstract) Advances in Reef Science. Joint Meeting of the Atlantic Reef Committee and the International Society for Reef Studies, (Oct. 1984), Miami, Florida : 105-106.

Rosesmyth, M.C. and Woodley, J.D. (1984). The submersible research programme at the Discovery Bay Marine Laboratory: deep diving for all! (Abstract) Advances in Reef Science. Joint Meeting of the Atlantic Reef Committee and the International Society for Reef Studies, (Oct. 1984), Miami, Florida : 107-108.

Ross, C.E. (1985). Proposed Royal Palm Forest Park in the Negril Great Morass, Jamaica. Caribbean Wetlands Newsletter 4: 4-5.

Scott, D.A. and Carbonell, M. (1986s). A Directory of Neotropical Wetlands. IUCN, Gland and Cambridge.

Steers, J.A. (1940a). The coral cays of Jamaica. Geogr. Journ. 95: 30-42.

Steers, J.A. (1940b). The Cays and Palisadoes, Port Royal, Jamaica. Geogr. Rev. 30: 279-296.

Steers, J.A., Chapman, V.J., Colman, J. and Lofthouse, J.A. (1940). Sand cays and mangroves in Jamaica. Geogr. Journ. 96: 305-328.

Steven, D.M. (1965). Productivity of inshore waters off Jamaica: a comparative study at four stations. Office of Naval Research Washington D.C. Contract NONR 1135905. Final report.

Tunnicliffe, V. (1983). Caribbean staghom coral populations: pre-Hurricane Allen conditions in Discovery Bay, Jamaica. Bull. Mar. Sci. 33(1): 132-151.

Wade, B.A. (1976). The pollution ecology of Kingston Harbour, Jamaica. Vol. 2(4). Benthic Ecology. Research Report 5. Dept Zool., U.W.I., Mona.

Wade, B.A., Antonio, L. and Mahon, R. (1972).

Increasing organic pollution in Kingston Harbour,
Jamaica. Mar. Poll. Bull. 3(7): 106-111.

Wells, J.W. and Lang, J.C. (1973). Systematic list of Jamaican shallow water Scleractinia. Bull. Mar. Sci. 23: 55-58.

Woodley, J.D. (1979). The effects of trap-fishing on reef communities in Jamaica. Proc. Is. Mar. Labs. Carib. 13: 27.

Woodley, J.D. (1980). Hurricane Allen destroys Jamaican coral reefs. Narure 287: 387.

Woodley, J.D. and Robinson, E. (1977). Field guidebook to the modern and ancient reefs of Jamaica. Atlantic Reef Committee, Miami: 39 pp.

Woodley, J.D. et al. (1981). Hurricane Allen's impact on Jamaican coral reefs. Science 214: 749-755.

Zans, V.A. (1955). The West Indian Chank Shells from Pedro Cays. Natural History Notes of the Natural History Society of Jamaica. 74: 41-43.

Zans, V.A. (1958). The Pedro Cays and Pedro Bank. Report on the survey of the Cays, 1955-1957. Geological Survey Dept. Jamaica Bulletin 3: 47.

\section{DISCOVERY BAY}

Geographical Location $18^{\circ} 13^{\prime} \mathrm{N}, 77^{\circ} 25^{\prime} \mathrm{W}$; mid-way along north coast.

Area, Depth, Altitude 1.25 sq. km; maximum depth of central basin $53 \mathrm{~m}$.

Physical Features The Bay forms a sharp indentation in the coast. The near perfect concentric bathymetric contours suggest that it is a karst feature (Liddell et al., 1984a), although it has also been suggested that it represents a drowned river valley. It is partly cut off from the sea by the fringing reef which extends between the two headlands, broken by a channel which was dredged to $12 \mathrm{~m}$ in 1966 to allow the traffic of ore-carrying ships to the Kaiser Bauxite terminal. In the lagoon zone behind the fringing reef in the west of the Bay are several submarine springs (Woodley and Robinson, 1977) and a $10 \mathrm{~m}$ deep Blue Hole. A deep basin within the Bay occupies most of the west and centre. Fine sediment accummulates in this and low illumination prevails. Tidal amplitude is low $(20-35 \mathrm{~cm})$. Porter (1985) describes the surface weather patterns.

Reef Structure and Corals Within the Bay, the lagoon zone has scattered coral heads and gorgonians, corals and reef rubble becoming more abundant seaward. Mound corals dominate, and there is high turbidity. The bottom slopes into the deep lagoonal basin which has no corals (Tunnicliffe, 1983). There are well developed and diverse reefs along the walls at Colombus Park, outside the Marine Laboratory in the west (Ohlhorst, 1980), and at Red Buoy Reef in the east (Bonem and Stanley, 1977; Bonem, 1984). Extensive patches of algae, Porites porites and Madracis mirabilis are found to $10 \mathrm{~m}$ depth. From 10-20 $\mathrm{m}$ depth there is a high diversity of corals with Montastraea annularis, Colpophyllia natans, Agaricia lamarcki, Helioseris cucullata, Stephanocoenia michelinii, Siderastrea siderea and Mycetophyllia aliciae accounting for $82 \%$ of the colonies. Coral cover however is low (18\%) while sponges are diverse and abundant. Sediment resuspension is very high causing low light levels. 
The West Fore-reef, first described by Goreau (1959) and Goreau and Goreau (1973), exhibited the structural and ecological zones which characterize most Jamaican north coast reefs. Pre-hurricane conditions were also described by Dahl et al. (1974), Kinzie (1973), Goreau and Land (1974), Lang (1974), Liddell and Ohlhorst (1981), Moore and Sander (1976), Tunnicliffe (1983) and Woodley and Robinson (1977). Recent data from pre-hurricane and relatively undisturbed post-hurricane sites indicate that coral diversity increases from the shallow fore-reef terrace to the fore-reef escarpment, decreases on the upper fore-reef slope and then increases at a depth of $45 \mathrm{~m}$. Coral cover decreases from $60 \%$ at $5 \mathrm{~m}$ to $35.0 \%$ at $15 \mathrm{~m}$ and $27.9 \%$ at $22 \mathrm{~m}$ (due to the unstable nature of the steeply sloping fore-reef escarpment) and then increases to $58.9 \%$ at $30 \mathrm{~m}$ before declining to $38.5 \%$ at $56 \mathrm{~m}$. Coral diversity and cover are highly variable on the back-reef, depending on the degree of turbidity and nature of the substratum. Total living cover (all corals, algae and sponges) is high between $0-5$ and $56 \mathrm{~m}$ depth, typically reaching $80-90 \%$; total reef diversity is lowest but relatively constant on the fore-reef terrace and nearly double at the deeper sites $(22-56 \mathrm{~m})$ (Liddell and Ohlhorst, in press).

Liddell and Ohlhorst (1981 and in press) and Liddell $e t$ al. (1984a) provide recent descriptions of the West Fore-reef, according to the following zones: reef crest, fore-reef terrace, fore-reef escarpment, fore-reef slope and deep fore-reef. The reef crest $(0-7 \mathrm{~m}$ depth) has an upper zone dominated by Acropora palmata. Behind it there is a highly variable zone, generally shallow and sometimes emergent, with abundant living coral. Reduced salinity and high turbidity caused by severe rainstorms or sedimentation may be responsible for the high mortality of corals in this area. The reef flat is a reticulate, ridge-like structure $5-20 \mathrm{~m}$ wide, exposed at low tide, and composed of dead colonies and broken slabs of Acropora palmata with abundant calcareous algae. A slightly deeper, well developed mixed zone, dominated by Montastraea annularis and $A$ cervicornis, merges with the fore-reef terrace (7-15 $\mathrm{m}$ depth). This consists of large parallel lobes or buttresses orientated perpendicular to the reef crest and extending seaward at a moderate slope for approximately $200 \mathrm{~m}$. The lobes are interrupted by large sand patches and channels forming spur and groove topography with as much as $5 \mathrm{~m}$ relief. The spurs terminate in a steep escarpment at $15-25 \mathrm{~m}$ depth. The terrace is dominated by $A$ cervicornis with scattered heads of other corals, predominantly $M$. annularis and Colpophyllia natans. The escarpment has less $A$ cervicornis and a more even distribution of other species. The fore-reef slope which begins at $25-30 \mathrm{~m}$ depth has a sand "moat" containing scattered coral heads followed by increasing coral cover at 30-35 $\mathrm{m}$ depth. The coral often forms parallel fingers and occasional pinnacles with $10 \mathrm{~m}$ relief. At about $35 \mathrm{~m}$ the slope steepens and below this the reef is dominated by various sponges and plating Agaricia spp. Liddell et al. (1984b) give a detailed description of the zones between 15 and $56 \mathrm{~m}$ depth at the site called "Zingorro". A slope break at 45-65 m depth marks the beginning of the deep fore-reef wall which ends at a depth of about $122 \mathrm{~m}$ on the more gentle island slope. Corals cease to be important below $75 \mathrm{~m}$. The upper part of the deep fore-reef supports a rich fauna of demosponges, gorgonians, sclerosponges, antipatharians and algae.
The East Fore-reef is less well known but is briefly described by Woodley and Robinson (1977) and in more detail by Liddell and Ohlhorst (1981). Unlike the West Fore-reef, the reef crest is not exposed, is poorly developed and has a reduced $A$ palmasa zone. The platform behind is $3-5 \mathrm{~m}$ deep and the rear zone has more living coral, including numerous patch reefs, than is found on the west. Seaward of the crest is a barren zone of pavement, wider and more developed than the equivalent zone on the West Fore-reef, with scattered colonies mainly of Siderastrea radians and Diploria clivasa. The mixed zone merges with a very broad (ca $800 \mathrm{~m}$ ) fore-reef terrace which extends from 7 to $28 \mathrm{~m}$ depth with a very shallow slope. $A$ cervicornis and $M$. annularis predominate although coral diversity is high. Unlike the West Fore-reef, there are no pronounced coral buttresses rising above the sand, but rather extensive low-relief fields of coral and sand. $A$ cervicornis is generally less abundant and algae are more abundant, particularly below $20 \mathrm{~m}$, than on the West Fore-reef. Between 15 and $28 \mathrm{~m}$ depth, the plain is broken by shallow sand channels and at $28 \mathrm{~m}$ depth the slope steepens forming an escarpment which descends to $38 \mathrm{~m}$. Seaward of this, morphological features are very similar to the West Fore-Reef, but are lowered by $10 \mathrm{~m}$.

Further east, a shallow extensive hard-ground platform is bounded by another gentle escarpment sloping from 12 to $16 \mathrm{~m}$ depth, covered by a coral and gorgonian garden dominated by $M$. annularis. About $1 \mathrm{~km}$ further east at a site called the West Bull, the shelves become narrow again and the bottom slopes steeply from the shore. A barren zone about $40 \mathrm{~m}$ wide is followed by an area of weak buttress development, zoned successively by $A$ cervicornis, $M$. annularis and Agaricia spp. (Woodley and Robinson, 1977).

Early descriptions of the deep reefs near Discovery Bay are given in Lang (1974) and they are now being studied with the aid of a submersible. A near-vertical submarine cliff between 55 and $130 \mathrm{~m}$ depth is covered with reef growth. An Agariciadominated coral reef near the top gives way to a sclerosponge reef by $90 \mathrm{~m}$ depth. At the foot of the cliff, the island slope begins. Rosesmyth and Woodley (1984) list some of the research projects carried out on the deep reef.

Noteworthy Fauna and Flora The Caribbean Manatee Trichechus manatus, the Hawksbill Eretmochelys imbricasa and the Green Turtle Chelonia mydas may occur here. There are large beds of Thalassia testudinum in the lagoon area.

Scientific Importance and Research The Discovery Bay Marine Laboratory is a major research and teaching centre for scientists from all over the world as well as from the University of the West Indies, and over 300 papers have been published since it was established. The reefs are probably some of the most extensively studied in the world. They are rich and well developed both in shallow and deep water, with an extensive depth range of coral development over a steep gradient (Lang, 1974) and a relative lack of freshwater input (D'Elia et al., 1981). Their proximity to the coast facilitates close monitoring of various parameters. Furthermore, the relatively narrow horizontal extent of the reef biotope is advantageous in instrument monitoring as well as in on-site investigations. 
A number of reef-mapping projects have been undertaken. Patterns of community composition, bottom cover and species diversity have been determined by line transects for a number of sites over the period 1976-1983 (Bonem, 1984; Liddell and Ohlhorst, 1981; Liddell $e t$ al., 1984b). The Cambridge Coral Microstructure Project studied growth rates and coral microstructure in 1980 , following Hurricane Allen (Robinson, 1980). Aller and Dodge (1974) and Dodge et al. (1974) studied the effects of resuspension of sediment on coral growth. A long-term monitoring programme (Porter et al., 1977) and a long-term submersible programme (Rosesmyth and Woodley, 1984) have been initiated. Further research is required particularly to provide an inventory of the reefs in the area and data on patterns of water movement and changes in the reefs over time.

Economic Value and Social Benefits Columbus Park, on the west side of the bay, is a popular tourist spot which claims to mark where Christopher Columbus first landed on "Xamaica". The Kaiser Bauxite terminal supports local businesses and provides a medical clinic for the community. There is a public beach on the south-east side of the bay, and several private houses on the east of the bay are owned as week-end retreats by Montego Bay families (Nash, pers. obs., 1982). Local fishermen use fish traps throughout the area.

Disturbance or Deficiencies The eye of Hurricane Allen passed within $65 \mathrm{~km}$ of Discovery Bay in August 1980 and caused considerable damage to the reefs. Its impact has been well documented ( Liddell et al., 1984a; Ohlhorst and Liddell, 1981; Porter et al., 1981; Woodley, 1980; Woodley et al., 1981). Graus et al. (1984) have carried out a computer simulation of the damage caused. The intensity of the storm damage was inversely correlated with depth, although the effects at any one depth were spatially patchy due to variation in reef morphology and shoreline geometry. Shallow sites, less than $10 \mathrm{~m}$ deep, were severely affected. On the shallow terrace only a few large massive corals, such as Montastraea annularis, were left standing and the Acropora palmata zone was reduced to overlapping plates of dead $A$ palmata rubble. Areas below $30 \mathrm{~m}$ were little affected, although storm rubble transported from shallower sites was apparent. At intermediate depths $A$ cervicornis, which previously accounted for $16.3 \%$ of the bottom cover, almost totally disappeared. A study to determine the patterns of recovery of these reefs, which were almost completely obliterated, is currently underway. Initial research suggested that recovery would be rapid (Woodley, 1980) but further studies (e.g. Rosesmyth, 1984) are revealing that recruitment of new colonies is slow, due to mortality and competition with other reef invertebrates.

Mass mortality of Diadema antillarum, due to a water-borne pathogen, took place on the north coast of Jamaica in summer 1983, with maximum mortality in the area of Discovery Bay in August. The effect of this on the algal community is described by Liddell $e t$ al. (1984b), Liddell and Ohlhorst (1986), Hughes et al. (1985) and Morrison (1984). Between 0 and $15 \mathrm{~m}$, the population was reduced to less than $1 \%$ of premortality density. Filamentous and fleshy algae which had previously not been abundant, quadrupled and nearly tripled, respectively, within three months. The disturbance, however, had little effect on the deeper reef community.
The Kaiser Bauxite Co. dock has a very slight influence on the reefs, through the presence of bauxite or iron oxide in sediments. The dredging of the ship channel into Discovery Bay to permit docking of large ocean-going vessels had minimum impact on the reef. D'Elia et al. (1981) discuss the input of nitrate-rich groundwater into the Bay. Large reef fish are scarce in Discovery Bay as fish traps are still used extensively (Dahl et al., 1974).

Legal Protection None known.

Management None known.

Recommendations The scientific importance of these reefs would seem to be good reason for affording them some kind of protection, perhaps as a scientific reserve.

\section{MONTEGO BAY MARINE PARK}

Geographical Location Between Cornwall Beach and the west end of Montego Bay Airport runway, on the north coast.

Area, Depth, Altitude 50 ha; from less than $5 \mathrm{~m}$ deep to over $60 \mathrm{~m}$.

Physical Features The reef forms part of a nearly continuous system of fringing reefs stretching along the north coast (Mailer, 1982). The bottom topography of the north coast reefs is largely created by a descending series of Pleistocene land surfaces, cliffs and terraces formed during past "ice-ages" when sea-level was lower than it is today (Goreau and Goreau, 1973). About 39\% of the Park is less than $5 \mathrm{~m}$ deep and is a continuation of a shallow shelf extending from the shore. At the edge of the shelf, the first cliff drops to a fore-reef terrace which slopes seaward from $5 \mathrm{~m}$ to $15 \mathrm{~m}$ depth. Another steep escarpment then drops to a muddy slope at $30 \mathrm{~m}$ depth which becomes precipitous beyond $60 \mathrm{~m}$. About $57 \%$ of the Park lies between 5 and $60 \mathrm{~m}$ depth, and the remaining $4 \%$ lies in deeper water and is inaccessible to divers (Mailer, 1982).

Reef Structure and Corals The Montego Bay Reef is generally similar in structure to other north coast reefs. However, the reef crest is simpler and less well developed and there is no emergent reef-flat. Four principal zones can be distinguished. The lagoon zone includes the reef areas closest to shore and has a number of scattered crest-type areas. Live coral cover may reach $70 \%$. The rear-zone areas of the lagoon are less structurally developed, consisting of fairly shallow coral platforms extending shoreward from the buttress zone and gradually grading into hard grounds or sandy areas. A buttress zone lies along the outer edge of the shallowest Pleistocene platform where a sharp change in depth occurs. This change is exaggerated by prolific coral growth, resulting in impressive drops of as much as $5 \mathrm{~m}$. The buttress wall is intersected by narrow, steep sided canyons and tunnels with sandy floors. The buttress line acts as a breakwater, resulting in a noticeable change in community structure between the front and back slopes although both have high live coral cover, averaging over 
70\%. In the fore-reef zone, coral growth is less prolific, rarely producing more than $2-5 \mathrm{~m}$ of relief. The coral tends to be confined to distinct lobes with intervening sand channels. Live coral coverage is $30-48 \%$. At about $15 \mathrm{~m}$ depth the fore-reef terrace ends abruptly in a steep wall which drops to a silty slope at about $30 \mathrm{~m}$. Reef growth is considerable along the wall and on scattered blocks. Live coral cover averages $66 \%$.

Dominant corals in the patch-crest areas of the lagoon zone are Agaricia agaricites, Montastraea annularis and Acropora palmata. On the rear-zone, $M$. annularis and Agaricia agaricites are also common but Acropora palmata is replaced by $A$ cervicornis. In the back buttress zone the dominant organisms are $M$. annularis and the zoanthid Zoanthus sociatus which forms dense green mats. On the front buttress, Porites astreoides and Agaricia agaricites are dominant. Millepora complanata is more common on the front than the back. On the shallow fore-reef terrace, Montastraea annularis is dominant, whereas in deeper areas Madracis mirabilis dominates. A agaricites and Acropora cervicornis are also common. Fleshy and calcareous algae, including Lobaphora variegata, Dictyota sp., Halimeda copiosa and $H$. goreaui become increasingly abundant with increased depth. $L$ variegata and $H$. copiosa dominate the fore-reef escarpment, $M$. mirabilis is the dominant coral in shallower areas and plate-like forms of Agaricia spp. and Montastraea annularis become more important with depth. Bryozoans, antipatharians, gorgonians and many varieties of sponge are also common.

Noteworthy Fauna and Flora Although the area is small, diverse plant and animal assemblages are found, the terraced bottom profile contributing to the zonation of communities. Coral reefs are by far the most extensive and diverse communities, but hard grounds, grass beds and sand communities are also found. Several commercially important species of fish occur, including snappers Lutjanidae, grunts Haemulidae, parrotfish Scaridae, jacks Carangidae, barracuda Sphyraenidae and mackerel Scombridae. Spiny lobsters Panulirus argus are found in small numbers. Queen Conch Strombus gigas is moderately abundant on fore-reef seagrass areas. In the deeper waters of the fore-reef escarpment and the deep slump-blocks, the black corals Antipathes salix and $A$ pennacea are common (Mailer, 1982). The Caribbean Manatee Trichechus manatus, the Green Turtle Chelonia mydas and the Hawksbill Turtle Eretmochelys imbricata may occur here. The nearby mangrove lagoon is described by Scott and Carbonell (1986).

Scientific Importance and Research The reef is unique as a north coast reef undamaged by Hurricane Allen, which destroyed many other Jamaican reefs in August 1980 (Woodley et al., 1981). A survey was carried out in 1973 by a University of West Indies team. A second detailed survey was carried out in 1982, supported by IUCN/WWF (Project 1801), the Inter-University Council for Higher Education Overseas (UK), the University of West Indies and the Natural Resource Conservation Department.

Economic Value and Social Benefits This area is located at the largest tourist centre in Jamaica and represents a huge potential attraction. The Park is used by snorkellers who are generally taken out by guides; at least three commercial dive operators use the Park and divers also come on their own. Glass bottom boats are the most popular way of visiting the Park and the present number of operators could easily cater for a twenty-fold increase in business. The buttress zone of the reef, with its combination of walls, canyons and tunnels, together with a rich fauna of corals and fish, provides particularly exciting snorkelling and shallow scuba-diving. The fore-reef escarpment with its precipitous drop-offs forms an ideal dive site for experienced divers (Mailer, 1982).

Disturbance or Deficiencies Montego Bay Marine Park is listed on the IUCN Commission on National Parks and Protected areas list of "threatened protected areas of the world" on account of the lack of management. The fish population is depleted, presumably through over-fishing. Numerous fish traps are placed in the Park by local fishermen. Spearfishing is common and even small fish are taken; wounded fish are a common sight and all fish tend to be wary and difficult to approach. Considerable damage is probably being caused by anchors and badly placed fish traps; boat groundings and propeller damage seem to have affected corals in some place especially very shallow heads of $A$ palmata.

Large colonies of black coral are rare as a result of previous collection. Snorkellers and divers may take coral and guides have also been observed to do so; few colonies of the pillar coral Dendogyra cylindrus remain undamaged. Acropora palmata and $A$ cervicornis also suffer severe damage but their comparatively high growth rate means that they recover fairly rapidly. If the rate of damage increases however, serious degradation may occur.

The Park may, in the long-run, be affected by pollution and sediment from the Airport swamp drainage channel to the north of the Park, which carries dirty water and oil in considerable quantities after heavy rain. Two storm gullies which pass through Montego Bay and enter the sea to the south of the Park often carry pollutants, and the Montego River carries the outflow of a major sewage treatment plant. The Park may have been affected by dredge and fill activities in the development of the water front at Montego Bay but this has proved difficult to assess. Montego Bay is the largest town on the north coast and urban development and heavy population pressure may be expected to affect the reefs (Mailer, 1982).

Legal Protection On the inititiative of the Jamaican Tourist Board the Park was declared a "Protected Area" by the Beach Control (Protected Area) (Montego Bay) Order, 1974 under the Beach Control Law, 1955 (Law 63 of 1955). Collection of black coral is prohibited under the Park (Protected Area) regulations; in addition black coral will eventually be protected under the Wildlife Protection Act. All forms of fishing are banned but there is no attempt to enforce this law (Mailer, 1982). A nearby mangrove lagoon is protected as a fish sanctuary (Scott and Carbonell, 1986).

Management As yet, there is still no real control over the Park area, due in part to lack of appreciation of its importance and potential function (Mailer, 1982).

Recommendations It is suggested that a buffer zone should be created around the Park to expand the area covered to approximately 225 ha. Details of the proposed 
boundaries are given in Mailer (1982). Within the buffer zone, limited fishing by means of trap and line, but not net or speargun, would be permitted. Pot fishermen would need a permit to use the area and would be restricted in the number of pots and mesh size used. Boat use in this area would not be restricted and sand anchoring, whilst being encouraged, would not be enforced. Other Park regulations would apply. Initial management steps for the Park should be:

1. Placement of responsibility for early development of the Park and appointment of a Marine Park Advisory Committee.

2. Allocation of funds and creation of a budget.

3. Appointment of an on-site manager, who would also be responsible for Ocho Rios Underwater Park.

4. Hiring of suitable wardens.

5. Review of existing legislation protecting the Park including consideration of proposed buffer area. In particular fishing should either be totally prohibited by making the possession of fishing gear or fish an offence or it should be controlled by restricting the numbers of fish traps and mesh size used. Spearfishing should be prohibited and legislation, and its enforcement, for the taking of marine organisms should be improved. Further restrictions on boat use are needed; anchoring should be controlled and mooring buoys installed.

6. Development of recreation facilities, public education and advertisement.

7. Development of research and monitoring programmes.

\section{MORANT CAYS MANAGED AREA}

Geographical Location Approximately $17^{\circ} 24^{\prime} \mathrm{N}$, $75^{\circ} 58^{\prime} \mathrm{W}$; about $60 \mathrm{~km}$ SSE of Morant Point, east Jamaica.

Area, Depth, Altitude Area less than $20 \mathrm{~m}$ deep is about $20 \mathrm{sq}$. $\mathrm{km}$; bank area less than $100 \mathrm{~m}$ deep is about 100 sq. $\mathrm{km}$. Four small cays are developed in an arcuate string of reefs some $7 \mathrm{~km}$ in length. Cays maximum $2-5 \mathrm{~m}$ elevation.

Land Tenure The Cays are deemed to be within a part of the parish of Kingston and are public land. Persons or organizations may be appointed lessees.

Physical Features Four small islands with sparse vegetation, two of which comprise North East Cay, then Middle Cay and South West Cay, are found, with associated reefs and shoals, on a ridge rising from the sea bed at $1000-1500 \mathrm{~m}$ depth. The ridge is continuous with Decca Ridge and Albatross Bank which have minimum depths of 20-30 m. The geography and vegetation of the Cays have been described by Chapman (1944), Steers (1940) and Steers et al. (1940). No published data exist for the underwater reef zonation or structures. Bathymetric charts show the topography to windward of the main reefs to be steep, while large shallow shoal areas are found to leeward. No published data exist for the oceanographic conditions, but the reefs are highly exposed with heavy wave action and strong currents over reef and back-reef.
Reef Structure and Corals No proper surveys have been made to date. A reconnaissance visit to North East Cay in December 1982 included a traverse swim from the northern "lagoon" over the reef flat to the windward fore-reef (S.M. Head, unpublished data). The upper fore-reef had relatively low live coral cover, with many Cliona covered tossed Acropora palmata blocks and abundant zoanthids. The uppermost fore-reef and crest had a substantial live $A$ palmata growth, the coral in the form of thick cylinders strongly wave aligned. Leeward of this was a well developed zone of $A$ prolifera, giving way to a rich back-reef assemblage with abundant Porites astreoides, $P$. porites, Siderastrea siderea, $S$. radians, Diploria strigosa and $D$. clivosa. Over much of the windward side of the cay, a deep (3-5 m) lagoon intervenes between reef and shore, and very rich coral growth was found on knolls in this region, with a high diversity of hard corals and gorgonians. This impression of good coral growth was confirmed by observation from a helicopter, and contrasts strongly with the statement "in no sense of the word a coral reef" given of the area by Steers et al. (1940).

Noteworthy Fauna and Flora There are no accurate data on reef organisms, but the area is much less intensively fished than any other part of Jamaica, and on the 1982 visit far more large fish, especially of groups like the triggers and snappers, were seen than would be expected on any inshore reef. Numbers of spiny lobster and Queen Conch were also high. The vegetation on all three main cays was mapped and described by Chapman (1944).

The most important fauna is the nesting bird population. Steers et al. (1940) recorded Brown Noddy Anous stolidus and Sooty Tern Sterna fuscata in "large numbers" and referred to the presence earlier in the year of "myriads of boobies". The booby eggs ("several hundred thousand annually") were taken and sold in Kingston for thirty shillings per thousand. The bird populations of the Morant Cays are being studied by the Natural Resource Conservation Department, Kingston. Annually about 27000 pairs of Sooty Tern and 1500 pairs of Brown Noddy nest on Middle Cay; the totals for the whole island group are estimated at 35000 and 2000 respectively. Small numbers of Bridled Terns $S$. anaethetus, Royal Terns $S$. maxima, Laughing Gulls Larus atricilla and Frigatebirds Fregata spp. also nest. There is good evidence for Hawksbill Turtle Eretmochelys imbricata nesting, and the presence of Leatherback Turtles Dermochelys coriacea has been reported by fishermen (Ann Haynes pers. comm.).

Scientific Importance and Research The area is not yet evaluated, but the low level of disturbance of marine life suggests it could be an important conservation site and a useful control to the depleted and overfished inshore reefs. The terrestrial vegetation, described from studies in 1939 (Chapman, 1944), should be resurveyed. The only current research on the area is that described above on the nesting birds.

Economic Value and Social Benefits The cays provide fishing and temporary residence for small numbers (up to 100) of fishermen, and seasonal egg collectors, both licensed and unlicensed.

Disturbance or Deficiencies At present there is minimal underwater disturbance and fishery pressure is not yet as 
high as on the mainland or the Pedro Bank. Terrestrial disturbance is high on North East Cay, where resident fishermen are based. The other cays are unoccupied but are visited for egg collection.

Legal Protection In theory fully protected under the Morant and Pedro Cays Law of 1907 (amended 1953), which prohibits unlicensed trespass, killing or disturbance of birds, egg collecting and fishing or turtle hunting within three miles $(4.8 \mathrm{~km})$ of the Cays. Licences are issued for fishing and egg collection.

Management Under the aegis of the Land Commission and Fisheries Department, Ministry of Agriculture. The Morant and Pedro Cays Law is in complete abeyance due to the impossibility of policing and enforcement, but the isolation of the Cays prevents serious misuse except for egg collection. In recent years the Natural Resource Conservation Department has maintained a presence on Middle Cay during the nesting season, and has prevented egg collection on this cay, but not on the others.

Recommendations Prohibition of access and egg collection on Middle Cay should be enforced during the nesting season. Encouraging healthy stocks of breeding birds on Middle Cay would tend to increase the numbers of laying birds on the other cays and lead to a viable egg collecting industry. Studies should be undertaken of the marine communities of the Morant Cays with a view to declaration of the area as a marine park or conservation area.

We are very grateful to Dr S. Head for compiling this account

\section{NEGRIL PROPOSED NATIONAL PARK}

Geographical Location West point of island.

Area, Depth, Altitude $0-20 \mathrm{~m}$ depth.

Land Tenure Negril Morass, north-east of Negril, is owned partly by the state and partly by the Petroleum Corporation of Jamaica.

Physical Features This area is described in Anon.(1981). The rocky shores of the South Negril Headland, Point Pen, Ireland Pen and South-west Point are separated by the sandy shores, set well back, of Long Bay, Bloody Bay, Orange Bay and Samuel's Bay. The bays are shallow to a depth of $12 \mathrm{~m}$, level with the major headlands, where a submarine cliff occurs, which drops to a sandy plain at $20 \mathrm{~m}$ depth. The southern limit seems to be due west of the South Negril River and the northern limit is between Orange and Samuel's Bay. Within the bays, the limestone shelves generally slope gently seaward although in Long Bay there are some shallow eminences 1-1.5 km off the beach; Booby Cay, composed of Pleistocene reef limestones, seems to be part of the series, other eminences being crowned with modern patch reefs. Sandy Cay ( $800 \mathrm{~m}$ long), just north of the centre of the Long Bay lies $1.5 \mathrm{~km}$ off shore.

At the southern and northern end of Ireland Pen, the outer shelf is less than $200 \mathrm{~m}$ wide, but widens off shore from the outlet of the North Negril Canal. To the north of Orange Bay, the shelf widens to $0.5 \mathrm{~km}$ and is dissected by a drowned river valley running south-north. A drowned cliff-line and sea-level notch divide the shelf from the slope areas, running almost continuously from the southern end of Long Bay around to the drowned river valley north of Orange Bay. The cliff, with many caves, slopes steeply from $10 \mathrm{~m}$ depth to about $18 \mathrm{~m}$ where the notch is located and is dissected by steep sided grooves particularly in Long Bay.

Reef Structure and Corals True reefs, as distinguished from coral assemblages, are rare in shallow shelf waters at Negril. Scattered coral communities are found on the shelf in shallow water notably around Booby Cay, Samuel's Bay, just outside the western side of Orange Bay and at two localities in Long Bay. Shallow reef growth is best developed in Samuel's Bay, probably because it is more exposed to northerly weather. A group of rather low diversity patch reefs are scattered $1 \mathrm{~km}$ off shore near the northern end of the Bay over an area of $200 \mathrm{sq}$. $\mathrm{m}$. At the southern end of Long Bay, some small reefs have grown up on rocky headlands around the shore. Reefs occur on shallow eminences of the offshore shelf where basal limestone reaches close to sea-level (Sandy Cay and the adjacent cay), and around exposed sides of rocky headlands or emerged reefs (western and northern coastline of Booby Cay, Point Pen, Pelican Cay and the shoreline of Ireland Pen); the latter have Acropora palmata in shallower waters and Montastraea annularis, M. cavernosa, Diploria strigosa and D. clivosa in deeper water.

The rock platforms and submarine cliffs of Long Bay are remarkable for their relatively low cover and low constructive reef development compared with equivalent structures on the north coast, possibly due to the calm and sheltered aspect of Negril. The possible reasons for this are discussed in Anon.(1981), and include the greater susceptibility of this area to hurricanes. Negril suffered a direct hit in 1912 and there is an almost total absence of Acropora cervicornis, a species particularly susceptible to hurricanes.

The coral community of the outer shelf is very similar throughout its length. On the shallower landward sections, scattered coral heads and sponges cover 5-15\% of the rock surface. Diadema antillarum was abundant here in 1981 (but may have declined now, see below). Coral cover becomes higher on the outer parts of the shelf and as it slopes into deep water a linear organization of coral colonies becomes apparent down-slope, with small buttresses about $1 \mathrm{~m}$ high developing. Hendry (1982) lists the commoner corals; the most common growth form is massive or nobby. In some places this grades into a system of spurs and grooves, particularly in Samuel's Bay where the platform slopes without a break to $16 \mathrm{~m}$ depth. The buttresses achieve several metres of coral reef construction above the basement. Similar formations occur in Orange Bay and Bloody Bay, but not in Long Bay, where a large proportion of basement rock is still exposed on the submarine shelf. At the shelf edge, however, there is an increase in abundance of corals and, although there is much evidence of contemporary bio-erosion, the escarpment supports various degrees of reef growth, especially on the lower part of the rocky slope at about $20 \mathrm{~m}$ depth. 
Reefs on the north-east side of Orange Bay and in Samuel's Bay have the following zonation: a) shallow back-reef lagoon floored by Thalassia; b) coral heads; c) patch reef; d) sand; e) main reef crest with $A$ palmata; f) narrow rocky plain with small coral heads; g) narrow sandy belt; h) rock platform with corals forming buttresses $4 \mathrm{~m}$ high at seaward end; i) sand; and j) second rock platform coral community, also organized linearly, terminating in $6 \mathrm{~m}$ high buttresses at $16 \mathrm{~m}$ depth.

The western wall of the drowned river valley to the north of Orange Bay is steep and has a rich and varied coral assemblage. The eastern valley wall becomes obscured by coral growth to the north-east, and the valley floor is relatively shallow and appears to be slowly filling with carbonate sediment. Coral cover on the drowned cliff face between Long Bay and north of Orange Bay is variable; dense thickets of Madracis mirabilis are found on the cliff edge north of the North Negril Canal and at Sand Clubs Reef, on the cliff in Long Bay; elsewhere coral cover varies from $20-70 \%$. Sponges and gorgonians are common nearly everywhere. Between the cliff-line and deeper reef, at about $18 \mathrm{~m}$ depth is a moat-like feature. A discontinuous sill reef has developed at the top of the deep reef at $22 \mathrm{~m}$ and extends down to a steep scarp-like front. Coral morphology is platy or encrusting and Hendry (1982) lists common species. Acropora cervicornis is notably scarce. The deeper reef areas have been extensively overgrown by algae.

The sand plain at the foot of the escarpment slopes gently seaward with increasing steepness with a series of broad reefs, $3-4 \mathrm{~m}$ in relief, extending to at least $35 \mathrm{~m}$ depth. These correspond to the pinnacle reefs at the top of the fore-reef slope on the north coast. Beyond them, at about $55 \mathrm{~m}$, there is a final reef above a vertical wall. The pinnacle reefs and lower part of the escarpment reef are remarkable for being heavily overgrown with calcareous and fleshy algae. Corals and even sponges have been overgrown and many of the former are dead.

Hendry (1982) describes other marine benthic communities in the area.

Noteworthy Fauna and Flora Seagrass beds of Thalassia testudinum are common in Orange Bay, Bloody Bay and the northem part of Long Bay and are described by Anon.(1981) and Hendry (1982). Healthy beds support large numbers of Queen Conch Strombus gigas, wrasse Labridae, parrotfish Scaridae and the edible sea urchin Tripneustes ventricosus. The abundance of seagrass beds at Negril is a reflection of the low prevailing wave energies. Caribbean Manatee Trichechus manatus, Green Turtle Chelonia mydas and Hawksbill Eretmochelys imbricata may occur. The 2300 ha wetland area of Negril Morass is described in Scott and Carbonell (1986). This includes mangroves, tidal marshes and extensive peat formations and there are several species of waterfowl.

Scientific Importance and Research The Negril reefs have played an important role in contributing to the sediment which now retains the Morass (Anon., 1981).

Economic Value and Social Benefits The shallow reef around Booby Cay is attractive for snorkelling, and reefs in Long Bay are also popular with tourists. The patch reefs near the northern end, in clear shallow water $(2 \mathrm{~m})$ are good for snorkelling and glass bottom boats, and a cannon and anchor provide additional attractions (Anon., 1981).

Disturbance or Deficiencies Since the 1960s, there has been considerable construction work and development in the region of Negril which could affect the reefs. The patch reefs at the southern end of Long Bay near to the South River have suffered heavily from sedimentation which appears to have increased in recent years; mortality is $75 \%$ in some places, and some algal overgrowth is also apparent on remaining live coral surfaces. Reasons for the poor condition of these reefs need to be identified but increasing turbidity as a result of the canalization of the South Negril River, which may also have killed the seagrass bed, may be involved (Anon., 1981; Hendry, 1982). The overgrowth of the deep reefs by algae is a sign of severe disturbance and could be due to sewage pollution or decreased predation by herbivores such as Diadema.

The area at the southern end of Long Bay, flanked by the rocky shore towards South Negril Point, is markedly affected by the South Negril River, the outflow of which deposits a layer of peat-like material on the sea bottom, inhibiting the development of the benthic community. A Thalassia bed has been killed and there are few corals near the river mouth although Acropora palmata occurs only $100 \mathrm{~m}$ off shore. The corals Solenastrea bournoni and Siderastrea radians are found in the polluted area (the former is very rare in Jamaica but used to occur in Kingston Harbour). On rocky pavements to the south and around the headland towards South Negril Point, the coral community becomes similar to that found elsewhere in the Bay (Anon., 1981). Threats to the Negril Morass wetland, in the form of peat mining, are described by Scott and Carbonell (1986).

Legal-Protection The reefs are not protected but Negril Morass is a designated Conservation Area.

\section{Management None.}

Recommendations In 1978, plans were in preparation by the NRDC for the establishment of a National Park at Negril which would have a marine component. This was part of a training programme sponsored by the Canadian International Development Agency. Currently there are plans to create a Royal Palm Recreational Park to encompass one of the largest stands of swamp forest in the Negril Morass; this will not include any reef habitat (Ross, 1985).

\section{OCHO RIOS MARINE PARK}

Geographical Location North coast, between Ocho Rios Bay in the west and Bentley Point in the east; the nearshore boundary runs just behind the reef flat and the offshore boundary runs in an east-west straight line.

Area, Depth, Altitude 265 ha; about $25 \%$ lies between $0-5 \mathrm{~m}$ depth, $54 \%$ between $5-40 \mathrm{~m}$ and $21 \%$ in depths greater than $40 \mathrm{~m}$.

Physical Features The reef is described in detail by Goreau (1959) and is typical of the large fringing reefs 
found on the north coast. It runs in an east-west direction $10-600 \mathrm{~m}$ from shore and extends across part of the mouth of Ochos Rios Bay. It interrupts the trade wind seas tangentially so that wave action is moderate except from January to March when there are northerly gales. Visibility is variable, depending on wind-generated turbulence and the amount of sediment carried by the rivers. Surface salinity is sometimes noticeably decreased by freshwater welling into the sea from the base of the limestone cliffs.

Reef Structure and Corals An almost continuous reef crest, with an emergent reef flat, runs the length of the Park. Near White River, the crest gives way to a broad sandy bottom with no coral, and there are several smaller passages through the reef flat at various points. At the western end of the Park, the crest sweeps in a gentle arc to the south, terminating off Ocho Rios Bay, and there is an extensive reef terrace which becomes narrower to the east. Behind the crest is a shallow, sheltered lagoon, which is widest at each end of the Park. Seaward of the reef flat, the bottom slopes gradually into deeper waters. In the eastern part of the Park, the reef drops sharply to a sandy plain which is broadest off White River. Over 75 species of coral have been recorded and coral reefs account for over $55 \%$ of the Park area.

Mailer (1984) describes the distribution of reef communities in the Park, and Goreau (1959) gives the detailed classical description of zonation in this area. Three back-reef inshore communities are included within the Park (off the Americana Hotel, off Carib Ocho Rios and around Bentley Point) which have a rocky shoreline dropping into $1-2 \mathrm{~m}$ of water with a variety of corals and other invertebrates (Mailer, 1984). According to Goreau (1959), the most numerous species of coral on the shore zone were Acropora palmata, Montastraea annularis, M. cavernosa, Diploria strigosa, Porites astreoides, $P$. porites, Siderastrea siderea and Manicina areolata. Encrusting Lithothamnion was usually abundant on exposed wave-swept rocks. The lagoon varies in depth from $1-5 \mathrm{~m}$ and has a sandy bottom largely covered with seagrasses Thalassia testudinum and Syringodium filiforme, and a few isolated heads of coral in deeper water. Gorgonians, molluscs and echinoderms are abundant. Patch reefs occur in the lagoon outside the Park boundaries, particularly along the south-western shore of Ocho Rios Bay near Reynolds Pier.

The rear zone of the reef crest is very variable and is particularly well developed towards the end of the Park. It has a rich and varied coral population with massive species predominating of which Montastraea annularis, $M$. cavernosa, $D$. strigosa, $S$. siderea and $P$. astreoides are most important. Branching species such as Acropora palmata, $A$ cervicornis, $A$ prolifera, $P$. porites and $P$. furcata are also common but less important in terms of biomass. The reef flat is mainly composed of dead $A$ palmata forming a broad expanse about $40 \mathrm{~m}$ wide and $0.5 \mathrm{~m}$ deep except in channels and pools. Dead coral on the reef flat is usually overgrown with a thick mat of the green colonial zoanthid, Zoanthus sociatus, giving it a characteristic appearance. Except for a few encrusting colonies of $D$. clivosa, corals are scarce but Millepora, Gorgonia, Lithothamnion and Halimeda are fairly abundant. A rich coral fauna resembling that of the rear zone is found in many of the shallow channels. The 1980 hurricane produced a number of storm islands along the seaward edge of the reef flat, sheltering the latter from wave action.

The surf zone along the seaward edge of the reef flat is dominated by $A$ palmata arranged in blocks oriented in the direction of the prevailing seas. It is populated almost exclusively by huge tree-like colonies of $A$ palmata, except on the sides of surge channels where other species may be found. The deeper parts of the zone have a more diverse coral fauna and foraminifera, Halimeda and other calcareous algae form more than $60 \%$ of the bulk of the finer sediments. Mailer (1984) discusses the influence of the hurricane on it. The barren zone, a trough of reduced coral growth directly seaward of the breaker zone, was dominated by $A$ palmasa up until the hurricane and now has a varible composition of coral rubble and a variety of living corats.

A buttress zone is found along most of the reef, forming an almost continuous barrier along the reef flat between White River and the shoreward end of Double Reef Canyon. It consists of huge spurs of living coral which project outward into much deeper water separated by narrow canyons, the walls of which are perpendicular or overhanging. Along the eastern end, the buttresses slope to a sandy bottom, marking the seaward limit of reef development. Towards the west the gently sloping fore-reef terrace, supporting a prolific growth of coral, extends seawards in front of the buttresses. The crests of the buttresses now average $5 \mathrm{~m}$ depth, the large colonies of $A$ palmata, described by Goreau (1959) as capping the ridges, having been moved during the hurricane. In the extreme east of the Park, off Bentley Point, massive buttresses rise from a sandy terrace at $15 \mathrm{~m}$ depth and, despite the hurricane, still have high coral cover, averaging $63 \%$. Agaricia agaricites is still abundant on many of the buttress, its extreme hardness and toughness probably accounting to some extent for the resistance of the buttresses to storm damage. Also abundant on the spur crests are large tree-like growths of Acropora palmata, heads of Montastraea annularis, Millepora, $P$. porites and $P$. furcata. The buttress sides are built up mainly of gigantic colonies of Montastraea annularis; $P$. porites and $P$. furcata are also abundant.

The fore-reef terrace is characterized by broad, coral-covered lobes separated by meandering sand channels. Goreau (1959) described two zones: an upper cervicornis zone, 8-15 m deep, which was destroyed in the hurricane and has been replaced by a zone of high coral diversity but moderately low abundance; and an annularis zone in deeper water which has also been considerably altered and is now dominated by Agaricia agaricites.

Mailer (1984) describes the hardground communities, seagrass communities and sediment areas.

Noteworthy Fauna and Flora The Caribbean Manatee Trichechus manatus and the Green Turtle Chelonia mydas may occur in this area. The Hawksbill Eretmochelys imbricata is fairly numerous and the sandy beach adjacent to White River is a nesting site. Commercially important fish such as snappers Lutjanidae, jacks Carangidae, grunts Haemulidae and groupers Serranidae are found in all parts of the Park, but are most abundant towards the eastern end among the buttress 
caves near White River and along the fore-reef escarpment. Lobsters are found on the reef flat and rear zone and may be seasonally abundant but large adults are exceedingly rare. The Queen Conch Strombus gigas is found in sandy and seagrass areas. Black coral, Antipathes sp. and $A$ pennacea, is found on steep drop-offs and in caves and overhangs but is rare.

Scientific Importance and Research The site of extensive reef studies including the pioneering study of typical West Indian reefs (Goreau, 1959).

Economic Value and Social Benefits The proximity of the Park to the town of Ocho Rios provides great potential for developing the reefs as a visitor attraction, providing additional employment and an inflow of foreign currency and increasing public awareness of the marine environment. Use of the area by visitors, commercial operators and fishermen has increased considerably since 1966 although few people are awareof its designation as a Park. There are four watersport operations which provide a variety of activities including diving, snorkelling, windsurfing, glass bottom boat tours and jet skiing. "The Mountain" is a popular dive site within the Park, off the Shaw Park Hotel. One operation estimates that they deal with 10000 visitors a year (Mailer, 1984).

Disturbance or Deficiencies Hurricane Allen in 1980 caused considerable damage, particularly in the breaker zone. Towards the western end of the Park destruction was total, and it is unlikely that this part will fully recover. However, overall the hurricane did not seriously affect the attractiveness of the reefs. Mailer (1984) gives details of damage to the different reef zones.

Channelization and alteration of river-courses in the course of hotel development is probably responsible for patches of dead coral through increased fresh water levels and areas of pollution in the lagoon and just off shore. Mailer (1984) lists a variety of other sources of pollution, including a sewage treatment plant. There has been considerable overfishing in the area and few large fish are seen anywhere. Fishing with traps, nets and spearfishing within the Park occurs regularly although it is illegal; it is estimated that about 180 fishermen use this area. Spearfishing is less of a problem than in Montego Bay but the proximity of the reef to the shore makes control of this activity difficult. There is a scarcity of adult Strombus gigas and black coral due to heavy collecting pressure. Young hatchling Hawksbills are often harassed by the public at White River (Mailer, 1984). There is a potential threat to the reef fish from the growing demand for ornamental fish, although currently there is no collection within the Park. There is considerable collection of corals, echinoids and shells by divers and snorkellers, some boatmen organizing special collecting trips. In some areas, such as the lagoon channel between Carib Ocho Rios and Mallards Bay and "Double Reef" passage, boat groundings have damaged coral mounds.

Legal Protection Declared a Marine Park in 1966 under the Beach Control (Protected Area) (Ocho Rios) Order 1966 (Mailer, 1984). Turtles are protected under the Protected Species Act and Black Coral Antipatharia is shortly to receive protection. Fishing within the Park is prohibited.
Management The area has never been properly managed. The Ocho Rios Chamber of Co merce has been considering the need for a management and development plan and methods of financing the supervision and policing of the Park (Anon., 1978). A few of the commercial diving operations prohibit spearfishing and coral collecting.

Recommendations Mailer (1984) provides detailed recommendations for the management of the Park which are summarized as follows:

1. Contact must be made with interested organizations to discuss the future of the Park and placement of responsibility for its management.

2. An Underwater Park Advisory Committee should be appointed.

3. Policies on purpose and direction of the Park must be decided; fishing restrictions, boundaries and other legal aspects should be reviewed.

4. An onsite manager must be appointed, who would also be responsible for the Montego Bay Marine Park.

5. Operational details such as facilities, budget and equipment must be planned.

6. Park Wardens must be appointed and police co-operation sought.

7. Research and monitoring programmes should be developed.

8. Recreational facilities, mooring, signposts, publicity and education programmes should be developed and an entry or permit system arranged.

The original study site of Goreau is of particular scientific interest and should be protected from any interference. It is recommended that lagoon and shore areas including the turtle nesting beach near White River, be included within the Park. A system of zonation for the Park, if these additional areas could be included, is given by (Mailer, 1984).

\section{PEDRO BANK AND CAYS MANAGED AREA}

Geographical Location A large shallow water bank to the south-east of Jamaica; $17^{\circ} 37^{\prime}-16^{\circ} 42^{\prime} \mathrm{N}, 77^{\circ} 20^{\prime}-79^{\circ} 4^{\prime} \mathrm{W}$, the Cays lying about $100 \mathrm{~km}$ from the mainland.

Area, Depth, Altitude The total shelf area less than $50 \mathrm{~m}$ deep is about $8000 \mathrm{sq} . \mathrm{km}$, that less than $20 \mathrm{~m}$ deep is about 2400 sq. km. The Pedro Cays have a maximum elevation of about $2-5 \mathrm{~m}$; total land area is approximately 27 ha.

Land Tenure The Cays are deemed to be within and a part of the parish of Kingston, and are public land. Persons or organizations may be appointed lessees of the Cays.

Physical Features The Pedro Bank is roughly triangular in outline, $70 \mathrm{~km}$ in its long axis (east-west) and about $43 \mathrm{~km}$ in width at the western end. Most of the bank has water depths between 5 and $40 \mathrm{~m}$, and rises from the sea bed at $800 \mathrm{~m}$ or more. The submarine topography is fairly flat, the bottom covered with coral rubble, sand and 
silt, with patches of scattered corals and algae increasing to the south-east where the cays and reefs and shoals are situated. Good bathymetric data are available from a British Naval Hydrographic survey conducted in 1970, but practically nothing is known of the physical oceanography of the area, which is very exposed and has strong currents.

There are four cays on the south-east end of the Bank, in an arc curving to the south-west, named North East Cay ( $7.5 \mathrm{ha}$ ), which is permanently inhabited by fishermen, Middle Cay (4 ha), South West Cay (15.2 ha) and South Cay (0.2 ha). All were mapped and the geomorphology described by Zans (1958). The island arc is extended at both ends by reefs and shoals which come close to the water surface, and over which strong seas break heavily. Portland and Blower Rocks are two small outcrops of oolitic limestone which break water to the east of the Pedro Cays.

Reef Structure and Corals The submarine ecology of the Pedro Bank is poorly known because of its inaccessibility, the strong seas and current action and because of the extraordinary abundance of large sharks. The only ecological description of the reefs is that of Zans (1958) who published a section across the reef encircling North East Cay and a brief description, apparently still valid from observations made in 1982 (S.M. Head, unpublished data). The reefs are simple in form, arising from a sandy platform at about $6 \mathrm{~m}$ depth on both fore- and back-reef. The reef crest seems to be a Millepora-Palythoa association with abundant encrusting coralline algae indicative of high exposure conditions. A well developed Acropora palmata zone is found on both sides of the reef crest in fore-reef and back-reef environments. A cervicornis is abundant in the deeper fore-reef, with Diploria spp., Montastraea spp., Porites spp. and Colpophyllia natans. Echo sounder evidence suggests the presence of sill reefs on southern and south-eastern parts of the bank, but these have never been investigated by divers. According to Munro (1983) and Zans (1958), coral cover becomes progressively more patchy and sparse to the north and north-east of the bank.

Noteworthy Fauna and Flora Little is known of the marine fauna of the Pedro Bank, although the fish fauna is prolific (Munro 1983), and there is or was evidence of nesting Green Chelonia mydas, Hawksbill Eretmochelys imbricata and Loggerhead Caretta caretta Turtle (Lewis, 1940b). The Pedro Bank is the only known habitat in Jamaican waters of the West Indian Chank Shell Xancus angulatus where it is common (Zans, 1955).

The terrestrial flora is low and sparse with only six indigenous species of land plant (Lewis 1947, supplemented by Zans (1958)), and a few introduced Cordia bushes and coconut palms. The principal interest lies in the avifauna, lists of which were published by Lewis (1940a) and Zans (1958). White Sula dactylatra and Brown S. leucogaster Boobies, Frigatebirds Fregata spp., Brown Noddies Anous stolidus, Sooty Sterna fuscata, and Bridled S. anaethetus Terns are described as common, with six other species less common or rare. The White Booby colony of 500 birds (Zans, 1958) was on Middle Cay but no recent data are available on its present status, although it is thought that up to 200 pairs of Brown Boobies and some Frigatebirds still nest within the Cays (Ann Haynes pers. comm.).
Scientific Importance and Research This cannot be assessed without extensive surveys, although as the largest offshore bank, the Pedro Bank is likely to be of considerable research and conservation importance. To date, the only studies on the area are those listed above, but attempts are being made to re-evaluate the breeding bird stocks of the Cays. The bank was studied as part of the ODA/UWI Fisheries Ecology Research Project (Munro, 1983).

Economic Value and Social Benefits The Pedro Bank is a very important fishing ground. In 1974, 72 canoes were employed and the annual catch was about 750 tonnes (Munro, 1983). 1984 estimates suggest the Cays now support some 350 fishermen, serviced by nine carrier vessels (K. Aiken pers. comm.) The collection of seabird eggs on the Cays was once very profitable, but by 1958 the yield had drastically declined. At present production for sale on the mainland is probably zero, but it is assumed that fishermen based on the Cays continue to supplement their diet with any eggs available.

Disturbance or Deficiencies There is now a high degree of terrestrial disturbance by the large numbers of resident fishermen who are having serious effects on the bird populations. Although the human population is confined to North East Cay, it is assumed that they visit and disturb the other cays as well. Although the fishing pressure on the Bank is increasing, the area is unlikely to be overfished at present, judging by yield estimates in Munro (1984).

Legal Protection In theory Pedro Bank and Cays are fully protected under the Morant and Pedro Cays Law of 1907 (amended 1953), which prohibits unlicensed trespass, killing or disturbance of birds, egg collecting and fishing or turtle hunting within three miles $(4.8 \mathrm{~km})$ of the Cays. Licences are issued for fishing and egg collection.

Management Under the aegis of the Land Commission and Fisheries Department, Ministry of Agriculture. The Morant and Pedro Cays Law is in complete abeyance due to the impossibility of policing and enforcement.

Recommendations There is an urgent need for evaluation of nesting bird numbers and species, and investigation of the possibility of creating one or more reserves on the uninhabited cays. Study of the reef and bank ecology and resources is also necessary in case of further increase in fishery pressure.

We are very grateful to Dr S. Head for compiling this account.

\section{PORT ROYAL CAYS (PART OF PROPOSED PORT ROYAL NATIONAL PARK)}

Geographical Location South and east of Port Royal and the entrance to Kingston Harbour, on the south coast; $17^{\circ} 55^{\prime} \mathrm{N}, 76^{\circ} 49^{\prime} \mathrm{W}$.

Area, Depth, Altitude Total area of cays, reefs and enclosed shallow water communities approximately 
2500 ha. Depths range from intertidal to $30 \mathrm{~m}$, both within the system and seawards of the "barrier". Cays are all low, maximum elevation ca $2 \mathrm{~m}$, but may be heavily vegetated to a height of $\mathrm{ca} 10 \mathrm{~m}$.

Land Tenure Under public ownership; the jurisdiction over the terrestrial component is vested in the Commissioner of Lands, Lands Department. Practical control over the underwater component would appear to be with the Fisheries Department, Ministry of Agriculture.

Physical Features The Port Royal Cays are bounded by a roughly triangular outline. The northern boundary is the Palisadoes, a narrow gravel spit (incorporating several limestone islands) running west from the coast and terminating at Port Royal. The southern boundary is the pseudo-barrier reef which runs from South Cay, about $5.6 \mathrm{~km}$ south of Port Royal, towards the north-east, terminating in East Middle Ground, about $7 \mathrm{~km}$ from South Cay and $1.7 \mathrm{~km}$ off shore from the Palisadoes.

Eight cays break water and have variable vegetation cover. Rackham's Cay and Maiden Cay are at present mere sand bars on top of patch reefs. The twin South Cays and South-east Cay are small islets, about $100 \mathrm{~m}$ in maximum dimension, situated on the pseudo-barrier reef. Gun and Drunkenman's Cay are similar in size, but situated on patch reefs. The largest, Lime Cay $(380 \mathrm{~m} \mathrm{x}$ $100 \mathrm{~m}$ ), is about 2.6 ha in area.

The geology of the area was described by Goreau and Burke (1966), and the Port Royal Cays are interpreted as karst relicts arising from an erosional basement approximately $40 \mathrm{~m}$ below present sea-level. This surface is partly buried beneath gravel originating from the Hope River; nowadays this same source supplies the Palisadoes. During an earlier low sea-level stand, a similar gravel strip was deposited further seawards, and this formed the base for the modern pseudo-barrier reef. Still further south, a drowned sill reef is found along the shelf edge about $12 \mathrm{~km}$ south of Port Royal. This rises to within $20 \mathrm{~m}$ of the surface, and has strongly dissected relief.

Salinity and temperature off Lime Cay vary from ca 34.56 to $36.25 \mathrm{ppt}$ and 27.2 to $30.6^{\circ} \mathrm{C}$; secchi disc readings average about $16 \mathrm{~m}$ (Moore and Sander, 1979). Low salinity crises associated with hurricane rainfall may affect the Port Royal Cays, especially Gun and Rackham's Cays near the harbour mouth, causing coral bleaching or death (Goreau, 1964). Prevailing winds blow from the south-east, and the barrier system provides substantial protection, from wave action, to the smaller reefs in its lee, especially Maiden City, Lime and Drunkenman's Cays and their associated reefs. Even these show conspicuous geomorphological and community differences between the eastern (exposed) and western (sheltered) slopes. Nothing is known of current patterns in the area, except a general slow drift to the west.

Reef Structure and Corals Local differences in topography, slope and exposure combine to make the zonation of Port Royal Cays and reefs complex and interesting. Unfortunately, few descriptions have been published. Goreau (1959) described zonation of the pseudo-barrier reef, emphasizing the amount of dead Acropora rubble on the fore-reef which he attributed to hurricane damage in 1951. Recent visual surveys (Head, S.M., unpublished data) demonstrate impressive $A$ palmata regrowth in the shallow fore-reef off both South-east and South Cays. Contrary to Goreau (1959), some development of a buttress or spur and groove zone is present, especially off South Cays. The shallow fore-reef is dominated by $A$ palmata and Diploria strigosa, with Porites astreoides, Montastraea annularis and Millepora complanata. A prolifera and A cervicornis are common in slightly deeper water. The fore-reef is visually less diverse than that of the more sheltered cays, and gorgonians are scarce. The back-reef contains extensive seagrass beds, with knolls of Montastraea annularis, $P$. porites, $P$. astreoides, Siderastrea siderea and $S$. radians. In the deeper back-reef, $A$ cervicornis forms large patches, and gorgonians are abundant.

Patch reefs are rather better known, and profiles can be found in Mergner (1972 and 1977), and Head and Hendry (1985). The moderately exposed eastern fore-reef usually has abundant Diploria clivosa and $D$. strigosa in shallow water, alternating with stands of $A$ palmata. In deeper water (ca $8 \mathrm{~m}$ ) diverse communities are found, patchily dominated by $P$. porites and $A$ cervicornis beds where cover can approach $100 \%$. Many gorgonians are found, especially Gorgonia ventalina, Pseudopterogorgia acerosa and $P$. americana. The western leeward reef slopes generally have high sand and Thalassia cover, and corals may be confined to knolls, often founded on huge colonies of $D$. strigosa or $M$. annularis, heavily eroded by Diadema antillarum. Further off shore in deeper water, $A$ cervicornis beds may be developed. Coral diversity on the east and south faces of Lime Cay is high; to date 40 scleractinian species have been collected in waters less than $25 \mathrm{~m}$ deep. The varied habitats support a high gorgonian diversity (Head, S.M., unpublished data).

Noteworthy Fauna and Flors Port Royal Cays and reefs support an extensive and diverse fish and invertebrate fauna, but fishing pressure is high and stocks of commercial species are rather low on the reefs closer to Kingston. Hawksbill Turtles Eretmochelys imbricata are quite often sighted in the area and definitely nest on the beach of the Palisadoes and probably also on some of the further cays (Haynes, A, pers. comm.). The barrier cays support important nesting colonies of pelicans, and the significance of the cays for other birds is under investigation. The vegetation pattem of the cays has been followed over several years. Extensive mangrove (Rhizophora and Avicennia) stands are found on some cays, especially Drunkenman's. Lime Cay contains at least 32 plant species (Asprey and Robbins, 1953) with, in particular, species of Sporobolus, Sesuvium, Scaevola, Acacia, Caesalpinia, Conocarpus, Pithecellobium, Thespesia and Coccoloba.

Scientific Importance and Research The Port Royal Cays and reefs are important scientifically because of their high habitat diversity, their rich fauna and flora, and comparatively unspoilt nature. They are also conveniently sited for rapid boat access from the Port Royal Marine Laboratory of the University of the West Indies. Studies on the reefs and their corals include Goreau (1959 and 1964), Goreau and Burke (1966), Goreau and Goreau (1959), Head and Hendry (1985) and Mergner (1972 and 1977). The marine algae of the area 
are described in Chapman (1961 and 1963), the sponges by Hechtel (1965) and aspects of fish behaviour by Hanley (1984) and Itzkowitz (1977). The results of a major fishery study programme are published in Munro (1983). Aspects of nutrient chemistry and plankton ecology are described by Moore and Sander (1976 and 1979) and Steven (1965). Terrestrial botany was described by Chapman (1944) (who also provided useful maps of the cays), Steers (1940b) and Steers et al. (1940).

Currently, studies are underway by U.W.I workers to investigate the reef ecology of the Port Royal Cays, their scleractinian and gorgonian fauna, and their algae and seagrasses. The Cays are also being studied as a "control" side in a major programme based at the Port Royal Marine Laboratory from 1984 to 1987 , aimed at studying the environments and management problems of the Hellshire coastline, immediately to the west of the Cays. This study is funded by the International Development Research Centre, Ottawa, and is a joint co-operative programme between the University of the West Indies and Dalhousie University. Data are being collected on chemical and physical oceanography, plankton productivity, sedimentology, benthic ecology and coastal communities, providing the first integrated ecosystem study for a Jamaican coastal area.

Economic Value and Social Benefits The Port Royal Cays are extensively used by artisanal fishermen, operating from small canoes, and mainly using fish pots. Munro (1983) records experimental catch rates of 1.17 to $3.81 \mathrm{~kg} /$ trap/night, a yield substantially less than on underfished offshore banks, but much greater than on the heavily overfished north coast of the island. From Munro's figures, the potential yield of the Port Royal Cays area is of the order of $30-40$ tonnes per year, and could probably sustain some 16 canoes and 40 fishermen. The Port Royal Cays are extensively used for weekend recreation, the favoured sites being Lime and Maiden Cays. Fishermen supplement their earnings by providing a taxi service to Lime Cay. Provision of proper facilities on Lime Cay could allow a substantially heavier use than it receives at present. The weekend visitors are exclusively Jamaican residents and the considerable tourist potential of the Cays and the Port Royal area in general has yet to be realized. Educationally, the value of the area is considerable given its proximity to the capital, and use by schools could be encouraged by some elementary guides and publicity. The reefs and cays are used by marine biology classes of U.W.I..

Disturbance or Deficiencies The overfishing of the area has already been mentioned, although the problem at Port Royal is not as severe as on the north coast, and decreases with increasing distance from Port Royal.
Fishing is almost entirely for commercial species; in the absence of heavy tourist usage, shell and coral collection is negligible. The major problem for reefs in the Kingston area appears to be eutrophication from the highly polluted Kingston harbour, the ecology of which has been severely stressed (Wade, 1976; Wade et al., 1972). Little is known of the details of water movement out of the harbour and along the coast, but several indirect lines of evidence suggest the principal flow is south and to the west, away from the Port Royal Cays and towards the degrading ecosystem of the Hellshire coast. Water clarity and community structure data suggest that some influence of harbour water is experienced at Gun, Rackhams and Drunkenman's Cays. The impact is very much reduced at Lime Cay, and may be negligible further south and east. The pattern of eutrophication spread is currently under investigation within the IDRC funded coastal management study. There is some evidence of reef damage by dynamite fishing, but currently this practice seems to be more common in the harbour than on the offshore reefs.

\section{Legal Protection None at present.}

\section{Management None at present.}

Recommendations The Port Royal Cays and reefs are recognised as being of considerable national importance and have been proposed as part of a Palisadoes/Port Royal National Park. An outine development plan has been published (Cotterell, 1980). Investigations of the ecology of the area with a view to drawing up zoning recommendations, are underway at the U.W.I. in collaboration with the Natural Resource Conservation Department. Considering its national importance, there is an urgent need for a full resource evaluation and management study. Planned development of the area could provide a significant source of employment and provide a major amenity and educational resource. The research and conservation importance of the area could easily be safeguarded by a system of zoning. This would be easy to apply, because human recreational usage is already localized to the cays with attractive sandy beaches. This could be further encouraged by installation of shelters and sanitary facilities on Lime and perhaps Maiden Cay. Collection of corals and shells on all reefs should be prohibited, and restriction of access to South Cays considered during bird nesting seasons. In the absence of adequate policing of the area, the conservation interest is perhaps best served by concentrating human use to certain areas by provision of simple recreational facilities.

We are very grateful to Dr S.M. Head for compiling this account. 



\section{MARTINIQUE}

\section{INTRODUCTION}

\section{General Description}

Martinique, an Overseas Department of France, is a volcanic island of $1079 \mathrm{sq} . \mathrm{km}$, with a semi-arid area in the south (including Mt du Vauclin, $504 \mathrm{~m}$ ) and a wetter, geologically younger area to the north (Montagne Pelee (1397 m), Massif du Morne Jacob and Massif du Carbet). Annual rainfall in the south averages $500 \mathrm{~mm}$ (at Ste Anne) and there are only temporary rivers. From Vauclin northwards, rain increases to $7000 \mathrm{~mm}$ a year on the slopes of Carbet and Mome Jacob, where rain forest is found. There is a fairly well defined dry season in the winter months. Easterly trade winds predominate and the east coast is subject to storms, especially between December and July. The island is within the hurricane belt. Tidal range averages $70 \mathrm{~cm}$. Water visibility varies from 3 to $8 \mathrm{~m}$ in the Baie de Fort-de-France to up to $15 \mathrm{~m}$ or more in the south at Ste Anne and Pte du Diamant. On the windward side, turbidity depends on conditions but in the lagoon visibility generally ranges from 4 to $10 \mathrm{~m}$ (Battistini, 1978).

The insular shelf on the leeward west coast is narrow, dropping off rapidly to $4000 \mathrm{~m}$. Reefs are almost completely absent in the north-west, geologically younger part of the island as a result of hurricanes, the almost vertical submarine slopes and volcanic sedimentation (Montagne Pelée having erupted as recently as 1928). Rocher de la Perle off the north-west point, is a volcanic "piton" several hundred metres off shore which is covered with encrusting Millepora to a depth of about $15 \mathrm{~m}$; below this there are spectacular large sponges, antipatharians and gorgonians. Further south at Bas Baudy there is a thin scattering of corals on sandy slopes, 14 species having been recorded (Bouchon and Laborel, in prep.). Isolated coral formations are found along the coast of the Massif du Carbet, between St Pierre and Fort-de-France. Although not forming true reefs, these formations are dense and diverse below $10 \mathrm{~m}$ depth (below the influence of hurricanes), 35 species having been recorded (Bouchon and Laborel, in prep.). Baie de Fort-de-France has considerable reef development in shallow water (see separate account). Further south to Rocher du Diamant there are no true reefs, but scattered coral formations, rich in sponges and antipatharians adapted to strong currents, are found particularly at Cap Salomon. The south coast from Le Diamant to Pointe des Salines has the richest coral formations, those in the region around Ste Luce being the best developed (see separate account).

The windward or Atlantic coast has virtually no reefs north of the Presqu'ile de la Caravelle, and is characterized by steep cliffs cut in volcanic sediments and a narrow steeply sloping shelf. A fringing reef from Pte Lahoussaye to south of Ste Marie is dominated by fleshy algae, with scattered coralline-Millepora mounds. Reef formations occur opposite Petite Salée, to the west of Pte de la Batterie, and around Anse Cosmy and la Trinité The reefs around the Presqu'ile de la Caravelle are described in a separate account; they are less than $400 \mathrm{~m}$ wide with a well-developed crest of coral debris. South of the islet of Saint-Aubin is a small isolated patch reef (Battistini, 1978).

Further south, the insular shelf forms a wide shallow plateau extending seawards for up to 20 miles $(32 \mathrm{~km})$. The coastline has a series of deeply indented bays, protected by a line of rich coral-algal reefs and very exposed, inaccessible cays. The bays are biologically diverse with well developed and almost pristine mangroves and seagrass beds. The major interest of this area is the extensive bank barrier reef system, with fleshy algal stands on the crests. This extends to the north of the Presqu'ile for $10 \mathrm{~km}$ where it is separated from the coast by depths of $20-35 \mathrm{~m}$; reefs here are about $1 \mathrm{~km}$ wide and $5-10 \mathrm{~m}$ deep. South of the peninsula, the reefs extend for about $25 \mathrm{~km}, 3-8 \mathrm{~km}$ from the coast, separated by lagoonal areas up to $30 \mathrm{~m}$ deep in the north and $12-25 \mathrm{~m}$ in the south. They are described in a separate account.

A general review of reef distribution is provided by Battistini (1978), who concentrated on the east coast barrier reef south of the Presquille de la Caravelle and the Baie de Fort-de-France; Laborel (1982) provides a summary of this paper. Adey and Burke (1976) and Laborel and Laborel-Deguen (1979) also provide reef descriptions and the reefs off the south-east coast have been studied by Adey et al. (1977). Bouchon et al. (1985) and Bouchon and Laborel (in prep.) provide the most detailed account of reef distribution and ecology and identify three main coral communities as follows:

From 0 to $3 \mathrm{~m}$ depth, the shallow-water species Acropora palmata, Siderastrea radians, Favia fragum and Diploria strigosa predominate. This zone is vulnerable to wave action, particularly hurricanes, and $A$ palmata has been noticeably absent since the 1979 hurricanes (see below). In deeper water to $15 \mathrm{~m}$, the community is dominated by Stephanocoenia michelinii, Agaricia agaricites, Porites astreoides, $P$. porites, D. labyrinthiformis, D. strigosa, Colpophyllia natans, Montastraea annularis, Dichocoenia stokesi, Millepora alcicornis and M. squarrosa. From 15 to $40 \mathrm{~m}$, the community is dominated by Madracis decactis, M. mirabilis, Agaricia lamarcki, Helioseris cucullata, Siderastrea siderea, Montastraea cavernosa, Meandrina meandrites, Mycetophyllia aliciae and Eusmilia fastigiata. A small group of species is found in the seagrass beds including Porites divaricata, $P$. furcata, Manicina areolata, Solenastrea bournoni, Oculina diffusa and Mille pora alcicornis.

Thirty coral species were reported by Battistini (1978). Chassaing et al. (1978) provide a popular account of corals. More recently, Bouchon and Laborel (in prep.) have recorded 44 species of scleractinians and four hydrocorallians down to a depth of $40 \mathrm{~m}$; at present there is no information on populations below this depth. Even taking into account the fact that the fauna is not fully known, it appears that the corals of Guadeloupe and Martinique are less diverse than those of other parts of the Caribbean for reasons that at present are unknown. For example, Tubastraea occulina, Agaricia tenuifolia and Solenastrea hyades have never been recorded from Martinique and Cladocora arbuscula, once abundant in 


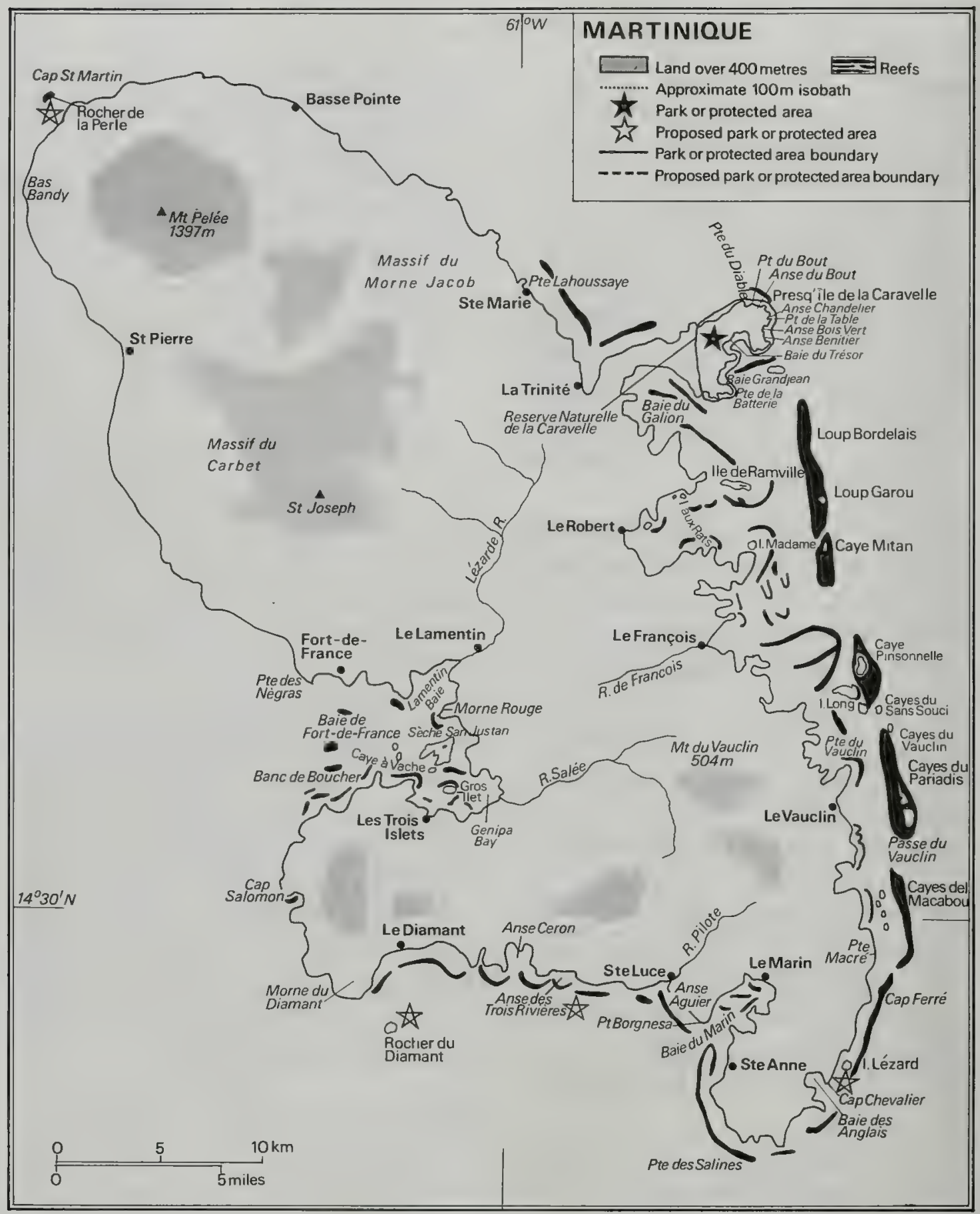


the seagrass beds, was not found during the CORANTILLES II mission. Philippot (in prep.) describes the gorgonian fauna down to $35 \mathrm{~m}$ depth, 35 species having been recorded. The richest areas for gorgonians are the south coast reefs.

There is an estimated total area of about 10000 ha of seagrass beds, the main areas being described in Laborel-Deguen (in prep.), and some 2200 ha of mangrove. Major wetland areas are described by Scott and Carbonell (1986). The sponge fauna (70 recorded species) is described by Vacelet (in prep.) and the mollusc fauna (331 recorded species) by Lamy (in prep.). Farrugio and Saint-Felix (1975) and Bouchon-Navaro and Louis (in prep.) describe the 182 species of fish that have been recorded. Halewyn and Norton (1984) describe the status of nine species of seabirds known to breed on Martinique. The extensive reefs and sheltered waters along much of the east coast provide important feeding and nursery habitat for Green Turtles Chelonia mydas and Hawksbills Eretmochelys imbricata. The former is most common but does not nest locally in significant numbers, the main nesting species being Hawksbills and Leatherbacks Dermochelys coriacea (Bacon et al., 1984; Carr et al., 1982).

The reefs have been studied in the course of various projects on the marine environment of the French Antilles by the Centre Universitaire Antilles-Guyane. From 1983 to 1984 a major survey was carried out during the CORANTILLES II programme (see introduction for Guadeloupe), under the auspices of the Comite Régional Martinique (COREMA) de la Fédération Française d'Etudes et de Sports Sous Marins (Laborel, in prep.). About 50 sites around the island were visited and a summary of the results is provided by Bouchon et al. (1985). Parts of this programme are still underway.

\section{Reef Resources}

There is little published information on the reef resources of Martinique although both fisheries and tourism are important elements of the economy (Wood, 1984). Yields of reef fish are potentially high but do not meet demand (Munro, 1983) and large quantities are imported from other Caribbean countries (Goodwin, 1985). Clairouin (1980) and Marfin (1978) describe the spiny lobster fishery (Panulirus argus and $P$. guttatus). SCUBA diving is popular at certain localities.

\section{Disturbances and Deficiencies}

The south coast reefs are vulnerable to hurricanes, Hurricanes David and Allen having caused localized damage, mainly in shallow areas around Ste Luce. There has been a fairly rapid recovery of some species, particularly gorgonians and the stony coral Madracis mirabilis, but only poor recovery of Acropora palmata and $A$ cervicornis. Mass mortality of the sea urchin Diadema antillarum around the whole coast occurred in 1983, presumably due to the water-borne pathogen which affected many Caribbean populations (Laborel, in prep.; Lessios et al., 1984). Possibly associated with this die-off, with the hurricane damage or with increased siltation, the CORANTILLES II mission recorded unusual proliferations of the zoanthid Zoanthus sociarus in certain areas of Baie de Fort-de-France and the south coast (Laborel, in prep.). There are fears that this could outcompete corals.

There has been a noticeable decline in lobster stocks due to heavy demands from the tourist industry and a dramatic decline in populations of the Queen Conch Strombus gigas, only four individuals having been found during the entire CORANTILLES II survey (Laborel, in prep.). There is some concern that large edible fish species of Lutjanidae and Pomadasyidae are being over-exploited (Bouchon-Navaro and Louis in prep.; Laborel, in prep.; Wood, 1984). Exploitation of marine turtles is very heavy and is apparently more intense than elsewhere in the Lesser Antilles. Turtles and eggs are consumed locally and there is a massive tourist trade in shell, stuffed turtles and jewellery. Stuffed juvenile Hawksbills were on sale by the boxful in Fort-de-France in the early 1980s (Carr et al., 1982).

One of the main conclusions of the Mission CORANTILLES II was that certain reefs are now under serious threat from siltation. Twenty to thirty years ago, the shores of the main bays were surrounded by mangroves, contained flourishing seagrass beds and coral reefs and the waters were relatively clear. Several human activities are implicated including deforestation, loss of mangroves, agriculture and coastal development (Laborel, in prep.). The Baie de Fort-de-France, the Baie du Marin and areas surrounding Ste Luce are particularly threatened, heavy sedimentation having occurred here for several years. In both areas there is a noticeable drop in coral diversity below $10-15 \mathrm{~m}$ due to the turbidity of the water. It is thought that the interesting marine communities around Cap Salomon may be affected by pollution spreading south from Baie de Fort-de-France. Gorgonians were found to be rare in areas of heavy sedimentation, the only species surviving in the worst affected parts of Baie de Fort-de-France being the encrusting species Erythropodium caribaeorum (Philippot, in prep.). Siltation appears to have had little impact on fish diversity at present but has caused a significant drop in abundance (Bouchon-Navaro and Louis, in prep.). Sponges are one of the few taxonomic groups which do not appear to have been affected in areas of high siltation (Vacelet, in prep.). Seaborne pollution has been reported from some localities (ECNAMP, 1980).

\section{Legislation and Management}

Environmental legislation, covering the creation of national parks and protection of natural resources, is described in Wood (1984). There is little legislation directly related to the marine environment. Lobster fishing is prohibited between October and March and there is a minimum size limit of $22 \mathrm{~cm}$, established under Arreté Préfectoral No. $70 / 3$ of 5 January 1970. Collection of turtle eggs is prohibited but is never enforced. A Prefectoral decree of 19 March 1983 regulates fishing and the turtle trade (Wood, 1984).

The Parc Naturel Régional de la Martinique was established under a decree of 24 October 1975 and a Ministry Act of 24 August 1976 (Wood, 1984). It consists of a number of separate zoned areas, totalling $70143 \mathrm{ha}$, including forested areas in the north, areas around Baie de Fort-de-France and small areas on the south-east and east coasts including the Reserve Naturelle de la 
Caravelle (see separate account) which has been particularly well developed. However, protection does not extend to the marine environment in any of these areas. The CORANTILLES II mission took the opportunity to increase public awareness of the importance and vulnerability of coral reefs through lectures, slideshows, exhibitions and the involvement of the Association des Professurs de Biologie et Geologie de la Martinique and local diving clubs in the programme. It is hoped that they will be involved in future reef management programmes. A film has been produced (Laborel, in prep.).

\section{Recommendations}

The results of the CORANTILLES II program will form the basis of a firm set of recommendations for the protection and management of the reefs of Martinique. Bouchon and Laborel (in prep.) have recommended that the following areas be considered for protected area status, the type of protection to be decided according to the requirements of users of the area:

\section{Rocher du Diamant and Banc du Diamant (south coast) \\ 2. Escaliers de Trois-Rivières (south coast) \\ 3. Mangrove du Cap Chevalier (south-east coast) \\ 4. Rocher de la Perle (north-west coast) \\ 5. One of the Atlantic coast bays e.g. Baie du Trésor, Presqu'ile de la Caravelle.}

Laborel-Deguen (in prep.) stresses the need to include seagrass beds in protected areas as these are likely to be affected by the increasing pollution and siltation problems. Other marine areas which require particular attention are Baie de Fort-de-France and the south-east coast algal reefs. Descriptions of some of these areas are given in the following accounts.

Laborel (in prep.) makes a number of recommendations for future work on the reefs. Studies of the siltation problems in Baie de Fort-de-France and Baie du Marin are urgently required. Bouchon-Navaro and Louis (in prep.) recommend the establishment of monitoring sites in areas important to fisheries which appear to be threatened by siltation. The effects of Diadema mortality and the proliferation of Zoanthus sociatus should also be monitored. Work is required on the edible urchin Tripneustes esculentus whose distribution appears to be very variable around the island. The apparently disastrous decline of Strombus gigas and possible deterioration of fish populations should be investigated.

\section{References}

* = cited but not consulted

Adey, W.H., Adey, PJ., Burke, R. and Kaufmann, L. (1977). The Holocene reef systems of Eastern Martinique, French West Indies. Aioll Res. Bull. 218.

*Adey, W. and Burke, R. (1976). Holocene bioherms of Lesser Antilles. Geologic control of development. Studies in Geology 4: 67-81.

Bacon, P., Berry, F. Bjorndal, Hirth, H., Ogren, L. and Weber, M. (1984). The National Reports. Proceedings of the Western Aslantic Tunle Symposium, Costa Rica. Vol.3: University of Miami Press, Florida.
Battistini, R. (1978), Les récifs coralliens de la Martinique. Cahiers ORSTOM, sér. Oceanogr. 16(2): 155-177.

Bouchon, C. and Laborel, J. (in prep.). Les récifs et communautés coralliennes des côtes de la Martinique. Mission CORANTILLES II.

Bouchon, / C., Bouchon-Navaro, Y., Louis, M. and Laborel, J. (1985). Influence of the degradation of the coral assemblages on the fish communities of Martinique (French West-Indies). 38th GCFI Congress, November 1985, Fort-de-France, Martinique.

Bouchon-Navaro, Y. and Louis, M. (in prep.). Les poissons des formations coralliennes de la Martinique. Mission CORANTILLES II.

Carr, A., Meylan, A., Mortimer, J., Bjorndal, K. and Carr, T. (1982). Surveys of sea turtle populations and habilats in the Western Allantic. NOAA Technical Memorandum NMFS-SEFC-91, U.S. Dept of Commerce.

Chassaing, J.P., Delplanque, A. and Laborel, J. (1978).

Coraux des Antilles françaises. Rev. franc. d'aquariol. 3: $57-83$.

Clairouin, N. (1980). Contribution à l'étude du stock de langouste Panuliris argus en Martinique. Science et Pêche, Bull. Inst. Pêches marit. 300: 7-18.

ECNAMP (1980). Martinique. Preliminary Data Atlas. Survey of Conservation Priorities in the Lesser Antilles. Eastem Caribbean Natural Area Management Program.

-Farrugio, H. and Saint-Felix, C. (1975). Etude des fonds de pêche du littoral atlantique martiniquais. Ressources, exploitation, prespectives. Science et Pêche, Bull. Inst. Pêches Mart. 251: 1-20.

Goodwin, M.H. (1985). Characterization of Lesser Antillean Regional Fisheries. Island Resources Foundation. $48 \mathrm{pp}$.

Halewyn, R, van and Norton, R.L. (1984). The status and conservation of the seabirds in the Caribbean. In: Croxall, J.P., Evans, P.G.H. and Schreiber, R.W. (Eds), Status and Conservation of the World's Seabirds.

ICBP Technical Publication No. 2, Cambridge.

IUCN (1982). IUCN Directory of Neotropical Protected Areas. Tycooly International Publishing Ltd., Dublin.

Laborel, J. (1982). Formations coralliennes des Antilles Francaises. Oceanis 8(4): 339-354.

Laborel, J. (in prep.). Presentation. Mission CORANTILLES II.

-Laborel, J. and Laborel-Deguen, F. (1979). Aperçu sur les récifs coralliennes de la Martinique. Courrier du parc regional de la Martinique 30: 24-31.

Laborel-Deguen, F. (in prep). Les herbiers de phanérogames marines de la Martinique. Mission CORANTILLES II.

Lamy, D. (in prep). Les coquillages de la Martinique. Mission CORANTILLES II.

Lessios, H.A., Cubit, J.D., Robertson, D.R., Shulman, M.J., Parker, M.R., Garrity, S.D. and Levings, S.C. (1984). Mass mortality of Diadema antillarum on the Caribbean coast of Panama. Coral Reefs 3(4): 173-182.

Marfin, J.P. (1978). Biologie et pêche de la langouste Panulirus guttatus en Martinique. Science et Pêche Bull. Inst. Pêches marit. 247: 11-20.

Munro, J.L. (Ed.) (1983). Caribbean Coral Reef Fishery Resources. ICLARM Studies and Reviews 7.

Philippot, V. (in prep.). Les gorgonaires des côtes de la Martinique. Mission CORANTILLES II.

Portecop, J. (undated). Parc Naturel Régional de la Martinique: Presqu'tle de la Caravelle. Editions Delroisse, Paris. $48 \mathrm{pp}$.

Scott, D.A. and Carbonell, M. (1986). Directory of Neotropical Wetlands. IUCN, Gland and Cambridge. 
Vacelet, J. (in prep.). Etude préliminaire des Spongiaires de la Martinique. Mission CORANTILLES II.

Wood, J. (Ed.) (1984). Proceedings of the Workshop on Biosphere Reserves and Other Protected Areas for Sustainable Development of Small Caribbean Islands, May 10-12, 1983. Virgin Islands National Park, Caneel Bay, St John, U.S.V.I. U.S. Dept of Interior, National Park Service, Atlanta, Georgia. 190 pp.

\section{RESERVE NATURELLE DE LA CARAVELLE}

Geographical Location $14^{\circ} 40^{\prime} \mathrm{N}, 60^{\circ} 58^{\prime} \mathrm{W}$; half of the Presqu'île de la "Caravelle", north-east coast.

Area, Depth, Altitude 517 ha (within the larger Parc Naturel Régional de la Martinique); 0-200 m.

Land Tenure Predominately public land.

Physical Features The peninsula is highly dissected with cliffs, beaches and reefs, and is formed of calcareous sediments of coral origin, with a volcanic substratum (labradorite and basalt, partly in hexagonal columns). The geology is described by Portecop (undated). The soils erode easily in deforested areas and on steep slopes; sediment accumulates along the coast in the mangroves and forms large sandy beaches. The Baie du Galion on the south of the peninsula is sheltered with clear waters and is probably deep in some areas. The sheltered bays of Grandjean and Trésor and the creeks Benitier, Bois Vert and Chandelier lie to the east. On the north coast, the hills drop steeply into a number of bays with offshore islets. The peninsula is arid, rainfall barely exceeding $100 \mathrm{~mm}$ a year, with a dry season from November to March. Trade winds prevail and moderate the temperature which reaches $30-32^{\circ} \mathrm{C}$ in calm periods (IUCN, 1982).

Reef Structure and Corals The reefs surrounding the park are poorly known. There are narrow fringing reefs around much of the coast except off the steep cliffs at Pte du Diable and Pte de la Table at the tip (Battistini, 1978). The coastal zone at Anse du Bout, a creek on the east coast with an emergent reef flat, is described in Portecop (undated). Bouchon and Laborel (in prep.) briefly describe the Baie du Trésor, which has a large Thalassia seagrass bed scattered with the following corals: Siderastrea radians, $S$. siderea, Porites astreoides, $P$. divaricata, Manicina areolata, Solenastrea bournoni and Millepora alcicornis. The south-east coast barrier reef (see separate account) extends north-west from the Presqu'ile.

Noteworthy Fauna and Flora The fauna and flora of the peninsula is described in Portecop (undated). Mangroves Rhizophora mangle and Avicennia nitida border the south coast. Magnificent Frigatebirds Fregata magnificens, Sooty Terns Sterna fuscata and Brown Noddies Anous stolidus are among the resident seabirds (ECNAMP, 1980; Portecop, undated). The Green Turtle Chelonia mydas and the Hawksbill Eretmochelys imbricata occur in the area. The fish fauna has been described in the Baie du Trésor (Bouchon-Navaro, in prep.).
Scientific Importance and Research No information.

Economic Value and Social Benefits Tourism is important. A lighthouse is situated on the peninsula.

Disturbance or Deficiencies There is little evidence of any major disturbance to the marine environment in this area.

Legal Protection The Reserve was established on 2 March 1976 and covers the terrestrial part only (although Bouchon and Laborel (in prep.) consider the surrounding reefs to be protected).

Management No very active management. The Reserve is administered by the Parc Naturel Régional de la Martinique and there is one gamekeeper (IUCN, 1982). An illustrated brochure for visitors has been produced (Portecop, undated).

Recommendations It has been proposed that a marine extension should be added to the Reserve. Bouchon and Laborel (in prep.) recommend additional protection for Baie du Trésor.

\section{BAIE DE FORT-DE-FRANCE}

Geographical Location West coast, extends to south of Fort-de-France and west of Le Lamentin; $14^{\circ} 34^{\prime} \mathrm{N}, 61^{\circ} 01^{\prime}$.

Area, Depth, Altitude About 2200 ha.

Land Tenure The surrounding land is mainly privately owned.

Physical Features The bay is large and shallow, sheltered from the east trade winds, but subject to some winds from the west (Battistini, 1978). The tidal range is very small. Two major rivers, the Lézarde and the Salée, drain into the bays of Lamentin and Genipa respectively, resulting in high turbidity. Visibility rarely exceeds 3-4 m. Sedimentological studies have been carried out by Battistini (1978).

Reef Structure and Corals Despite the poor conditions for reef growth, there are abundant coral formations to depths greater than $20 \mathrm{~m}$, particularly in the southern part near Pointe-du-Bout and Les Trois Ilets, and considerable reef development in shallow water. The bottom of the bay is covered with large coral patches, several metres in diameter and less than two metres high, with a diverse coral fauna. Reefs in the region between Pointe Desgras, Lamentin Airport, Pointe-du-Bout, Gros Ilet and Baie de Genipa are described by Battistini (1978), particularly those at Sèche San Justan, Caye à Vache, Gros Ilet and Banc du Boucher. These are at $10-15 \mathrm{~m}$ depth and are generally not emergent, although some parts may only be covered by $30-40 \mathrm{~cm}$ water. Behind the reefs there are large expanses of shallow reef flat mainly covered by seagrass. Living corals, predominantly massive species, are found only on the seaward, west facing slopes of the reefs which are in the form of projecting spurs interspersed with coral knolls. There is a noticeable lack of branching corals. Micro-lagoons, small deeper areas of water enclosed within the reef flat, are characteristic of 
these reefs (Battistini, 1978). During the CORANTILLES II mission 38 species of coral were described, a surprisingly high diversity considering the heavy siltation of the area, but perhaps due to the variety of available habitats (Bouchon and Laborel, in prep)

Bouchon and Laborel (in prep.) identified three main coral communities: a) one found in a number of places with a fairly diverse fauna b) another associated with the seagrass beds and c) a community found in all heavily silted areas of the bay (Blanc de l'Ilet a Ramier, Gros Ilet and Pointe des Nègres) with low specific diversity and coral cover. Sites were described at Pointe des Nègres, Banc Mitan, Banc du Fort Saint-Louis, La Grande Sèche, Le Blanc de l'Ilet a Ramier, Banc de la Pointe du Bout, Banc Boucher Caye à Vache and la Seche San Justan, Gros Ilet, Trois Ilet and adjacent areas and the "Cimetière à Bateaux"; most of these had been significantly affected by siltation and turbidity.

Noteworthy Fauna and Flora The bay is bordered by mangroves and has large areas of seagrass beds, $0.5 \mathrm{~cm}-1 \mathrm{~m}$ deep, on the reef flats, particularly to the south of Morne Rouge. Thalassia restudinum predominates (Battistini, 1978; Laborel-Deguen, in prep.). The adjacent shoreline is important for waterfowl and is identified as a wetland of international importance (ECNAMP, 1980; Scott and Carbonell, 1986). Lamy (in prep.) describes 178 species of mollusc from the area, the Pointe des Nègres being especially rich. Only 20 species of fish were recorded in the bay (Bouchon-Navaro and Louis, in prep.). The gorgonian fauna also had a very low species diversity (Philippot, in prep.), only Erythropodium caribbaeorum occurring in abundance, presumably as a result of the heavy siltation in the area. Despite siltation, the sponge fauna is still rich (Vacelet, in prep.).

Scientific Importance and Research The area was surveyed briefly by Battistini (1978) and in more detail during the CORANTILLES II mission when it was considered a focal area of interest (Laborel, in prep.). Historically, the reefs were probably well developed but they have declined as a result of increasing siltation from the rivers (some of which may have been natural), the growth of seagrass beds and the spread of mangroves (Battistini, 1978).

Economic Value and Social Benefits This is economically the most important area of Martinique with the greatest concentration of agricultural, industrial and urban development. Despite the increasingly poor condition of the reefs, the Baie holds great potential for tourism and recreation and it is considered important that efforts should be made to save it (Laborel, 1982). Dive sites are located in the southern part of the bay and there are anchorages and a marina (ECNAMP, 1980).

Disturbance or Deficiencies Hurricanes in 1979 had some effect, particularly at Pointe des Negres, where stands of Madracis mirabilis and Porites porites were badly damaged, and at Banc Mitan, where $75 \%$ of branching corals, particularly Madracis mirabilis, had been damaged and all colonies of Diploria, Colpophyllia and Meandrina had disappeared (Bouchon and Laborel, in prep.). The reefs have been extensively damaged by a variety of human activities in recent years including extension of the runways at Lamentin Airport, destruction of mangroves, poor agricultural soil management and road and building construction. There is extensive cultivation, urban and industrial development and some solid waste disposal in the south. Sewage pollution appears to have acted synergistically with terrigenous sedimentation causing heavy siltation on the bottom of the bay (Bouchon and Laborel, in prep.; Laborel, 1982; Scott and Carbonell, 1986).

The CORANTILLES II mission identified the area as of major concern because of siltation. All the sites where molluses were collected were affected by siltation. Blanc Ilet Ramier at the exit of the bay was least affected but even here there were signs of silt deposition in deep water (Lamy, in prep.). Several areas have been particularly affected by siltation and pollution from effluents. At Pointe des Nègres there is increased turbidity, algal overgrowth and lack of regrowth of damaged corals, the continued presence of species characteristic of clear waters, such as Dendrogyra cylindricus, Dichocoenia stokesi and Meandrina meandrites, indicating that conditions have only recently deteriorated. At Banc Mitan, coral cover is only $1 \%$ and many colonies already show signs of necrosis. At Banc du Fort Saint-Louis, corals are largely destroyed although 19 species were recorded indicating the previous richness of this site. At $\mathrm{La}$ Grande Sèche a large stand of Acropora cenvicornis is showing signs of necrosis. Le Blanc de l'Ilet a Ramier is one of the areas worst affected by siltation, overgrowth of algae indicating pollution as well. Banc de la Pointe du Bout still has a rich coral fauna with $80 \%$ live cover, but there are some large dead colonies covered with a fine layer of silt and others with a dead "halo", particularly of Agaricia. Banc Boucher now has only skeletal remains of a stand of Acropora cervicornis although a variety of other species are still present. At Caye à Vache and Sèche San Justan there are many recently dead corals, at Gros Ilet, Trois llets and adjacent areas little living coral remains and at "Cimetière à Bateaux", near the refinery and main sewage effluent, colonies are noticeably small and limited to $2 \mathbf{m}$ depth although 28 species have been recorded.

Legal Protection The marine environment receives no protection but 250 ha of wetland in the south-east are included within the Reserve de Chasse Maritime established in 1976 (within the Parc Naturel Regional de la Martinique?) in which hunting is prohibited (Scott and Carbonell, 1986).

\section{Management None.}

Recommendations Conservation action is urgently required and a large part of the area has been proposed for protection (Bouchon and Laborel, in prep; Laborel, 1982; Scott and Carbonell, 1986; Laborel, in prep.). Pointe des Nègres is in particularly urgent need of action.

\section{SOUTH-EAST COAST REEFS}

Geographical Location $14^{\circ} 45^{\circ} \mathrm{N}, 60^{\circ} 55^{\prime} \mathrm{W}$; east coast, from the Presqu'ile de la Caravelle south to Pte des Salines.

Area, Depth, Altitude About $25 \mathrm{~km}$ from the Presqu'ile to Le Vauclin. 
Physical Features From the Presqu'ile to Vauclin, the segmented barrier reef lies $3-8 \mathrm{~km}$ from the coast, separated by depths of up to $30 \mathrm{~m}$ in the north and 12 to $25 \mathrm{~m}$ in the south. The reef of Macabou merges with the fringing reef on the mainland at the south-east point, south of Vauclin (Battistini, 1978). The average depth is 5-10 $\mathrm{m}$ except at the cays, some of which are submerged, such as Cayes du Sans Souci, and others of which are locally emergent by a few centimetres such as Pinsonnelle, Pariadis, Vauclin and Mitan. Only Loup Garou in the north is a true sand and coral debris cay, covered with low bushes. The cays of Pariadis, Pinsonnelle, Vauclin and Loup Garou are described by Battistini (1978). The geological formation of the reefs is described in Adey et al. (1977). The lagoon has isolated patch reefs and fringing reefs surrounding islets and headlands. The waters tend to be turbid with visibilities of 3-12 $\mathrm{m}$ depending on wave activity.

Reef Structure and Corals Adey et al. (1977) give a general description of the bank reefs. From Passe du Vauclin north to the Presqu'ile de la Caravelle there is a double bank-barrier system whereas south of Cap Ferre - a single bench ridge system is predominant. Coral growth is restricted ( 33 stony coral species have been recorded) and is commonly replaced on the crest by carbonate pavement covered with a heavy diverse growth of fleshy algae (fleshy algal pavement). The reef crest is locally dominated by Millepora complanata and $M$. squarrosa. The back, upper fore-reefs and crest are characterized by large standing crops of fleshy algae, especially the genera Sargassum and Gracilaria, and generally only a few scattered corals (Adey et al., 1977).

The area of coral dominance on the inner reef system is restricted to the fore-reef and extends from just beneath the zone of heavy algal growth ( $3-4 \mathrm{~m}$ depth) to sand (10-15 $\mathrm{m}$ depth). Because of the turbid water and consequently reduced light penetration, corals within this zone represent a community usually found within a much wider depth range. Many colonies have assumed the plate-like form usually associated with deep water species, but are generally of a less fragile construction. Below the algal zone, the abundance of various species of Faviidae increases with depth and then decreases again near the base of the deep fore-reef. Favia fragum, Diploria clivosa, $D$. strigosa, D. labyrinthiformis and Colpophyllia natans are common over the entire reef although the latter two species are more common on the fore-reef. Montastraea annularis and $M$. cavernosa are generally more common near the break in the fore-reef slope and $M$. annularis and Porites astreoides are more common on the deep fore-reef.

On the outer reef system, scleractinian corals are concentrated along the deep fore-reef and locally in reef flat areas behind the algal ridge. Where the slope steepens markedly, there is a sharp decrease in fleshy algae and a corresponding increase in coral frequency. Millepora squarrosa, three Diploria spp., and occasionally Acropora palmata dominate the transition across the slope break. A gradual increase in Montrastraea annularis, Colpophyllia spp., $M$. cavernosa and Siderastrea siderea then occurs down the reef face. The back-reef areas behind the algal ridges are much more complex with locally abundant large patches of less energy tolerant species such as $A$ palmata and $P$. porites. The back-reef slope is mostly occupied by seagrass communities.
The reef from Passe du Vauclin south to Cap Ferre was not explored by Adey et al. (1977), but aerial reconnaissance indicated that it is dominated by fleshy algal pavement, with coralline-Millepora mounds on the crest in the north and a high algal ridge in the south, north-east of Point Macré. Battistini (1978) describes Macabou reef, which is considered to be one of the most diverse and luxuriant coral communities, and the fringing reef in the extreme south-east. Bouchon and Laborel (in prep.) briefly looked at the reefs at Cap Chevalier and found them to be in a very pristine state. Particularly noteworthy are the enormous colonies of Solenastrea bournoni more than five metres in diameter and three metres high.

Inside the inner reef system, circulation and turbulence are restricted, creating conditions suitable for well-developed lagoonal communities but with low coral productivity. More or less continuous fringing reefs are found along this coast except in the most northerly and southerly points. Bouchon and Laborel (in prep.) describe sites at Loup Garou, off Baie du Robert (Le Rocher du Petit Piton, Ile aux Rats, Ilet Madame) and Cap Chevalier. Fringing reefs in the vicinity of Ilet Ramville, Ilet Long and Pte du Vauclin are described by Battistini (1978). The primary corals are Manicina areolata, Porites astreoides, $\boldsymbol{P}$. divaricata, $\boldsymbol{P}$. furcata and $P$. porites. Siderastrea radians and $S$. siderea are associated but are less common and occasional scattered colonies of Diploria clivosa, D. strigosa and Oculina valenciennesi (near shore) are found. An extremely delicate form of Millepora alcicornis is abundant in the shallow seagrass zone adjacent to the immediate back-reef. This area is characterized by a considerable current, but with low turbulence, and is also a common location for the formation of free nodules of Siderastrea.

Noteworthy Fauna and Flora The crustose coralline algae, which are the main builders of the algal ridge caps and form a thin crust over much of the surface of the algal pavements, and the fleshy algae dominating the crests are described in Adey et al. (1977). The fleshy algal pavements are heavily populated with typical seagrass species, listed in Adey et al. (1977). In the lagoon area immediately behind the inner reefs, extensive beds of Thalassia testudinum and Syringodium filiforme and complementary benthic algal populations are found. Laborel-Deguen (in prep.) studied those in several of the bays between Baie du Robert and Cap Chevalier. Many of the inner bays have extensive mangrove populations.

Vacelet (in prep.) describes the sponge fauna in the Baie du Robert and around Loup Garou. Lamy (in prep.) found a rich mollusc fauna within the Baie du Robert. A rich fish fauna was found at Loup Garou by Bouchon-Navaro and Louis (in prep.) and 49 species were described. The fish assemblages of the algal-dominated inner reef system differ markedly from those of typical $A$ palmata and mixed $A$ palmata. coralline - Millepora reefs of the eastern Caribbean (Adey et al., 1977). The south-eastern coast has a number of seabird colonies (ECNAMP, 1980). The Hawksbill Eretmochelys imbricata and Leatherback Dermochelys coriacea nest in small numbers, particularly on Loup Garou and Macabou (Bacon et al., 1984) and the Green Turtle Chelonia mydas is frequently observed although nesting has not been recorded. 
Scientific Importance and Research The reefs were surveyed in 1975 by Adey et al. (1977) when three aerial reconnaissance flights were carried out and detailed SCUBA diving and snorkelling observations made at Vauclin Point reef, Cayes de Pinsonnelle algal ridge, Ilet de Ramville reef and Islet Lezard algal ridge. Additional survey work was carried out by the CORANTILLES II mission in 1985. Although other double bank-barrier systems are known in the Caribbean, at Worlds End and Horseshoe Reef in the Grenadines, the Martinique system is the most extensive. Despite their unusual morphology, these reef systems may be among the most productive in the West Indies. The large coral colonies at Cap Chevalier on the south-east coast are thought to have great potential for coring studies.

Economic Value and Social Benefits This area supports conch, lobster and turtle fisheries (ECNAMP, 1980). There are a number of popular dive sites and Cap Chevalier is a popular recreational area (Bouchon and Laborel, in prep.).

Disturbance or Deficiencies The area seems to be one of the least disturbed in Martinique. The CORANTILLES II mission found little evidence of siltation or other forms of reef deterioration. However, at Cap Chevalier, several of the islets are being spoilt by litter and rubbish left by visitors.

Legal Protection None for the marine communities but to the north of Cap Chevalier there is a Reserve de Chasse Maritime in which hunting is prohibited (Scott and Carbonell, 1986).

\section{Management None.}

Recommendations Areas for protection and management should be identified. Bouchon and Laborel (in prep.) recommend the creation of a protected area for the mangroves at Cap Chevalier. The Baie des Anglais has been identified as an area of multiple resource value.

\section{SOUTH COAST REEFS}

Geographical Location South coast from Morne du Diamant to Pte des Salines, including Rocher du Diamant.

Physical Features Although reasonably accessible, this coast is nevertheless fairly exposed and subject to strong currents in some areas (Laborel, in prep.). Reefs, locally emergent, form a continuous line, extending $1 \mathrm{~km}$ offshore and reaching depths of $40-45 \mathrm{~m}$, and are interrupted by only a few moderately deep passes, relics of former drowned valleys (Battistini, 1979). The Baie (or Cul-de-Sac) du Marin is the main indentation. Now significantly altered by sedimentation, it has large areas of seagrass, sand banks and some coral communities. A cay, $100 \times 50 \mathrm{~m}$, lies off Ste Luce.

Reef Structure and Corals The reef shows characteristic zonation, with a lagoon containing seagrass beds and patch reefs of Porites, a barely emergent reef crest dominated by Acropora palmata and an external slope dominated by Madracis mirabilis to $10-15 \mathrm{~m}$ depth, followed by a zone of high relief with Montastraea anmularis which is replaced at about $30-35 \mathrm{~m}$ depth by Agaricia (Laborel, 1982).

Bouchon and Laborel (in prep.) describe sites at Rocher du Diamant, around Trois-Rivières and in the region of Ste Luce, Pte Borgnèse and Baie du Marin. Rocher du Diamant is a volcanic "piton" with a comparatively poor fauna influenced by the strong currents in this region. At Trois-Rivières there is a rich fauna on the outer terraces, dominated by Siderastrea radians, Montastrea cavernosa and Meandrina meandrites. At Ste Luce, large coral colonies are found behind the offshore cay. Eighteen species have been recorded and Porites porites, Diploria strigosa and Montastraea annularis are dominant. The cay was once surrounded by large stands of Acropora palmata to $3 \mathrm{~m}$ depth which were destroyed by the hurricanes; a few colonies of $A$ palmata, $P$. porites and Millepora complanata are growing on the dead remains. Pte Borgnèse is bordered by a large submarine platform, 5-6 m deep, covered by a rich coral community dominated by Montastraea annularis which provides $90 \%$ coral cover. Off Ste Anne, the reefs which were not affected by hurricanes have active growth of Madracis mirabilis. Coral communities on the outer slope here may rival those at Trois-Rivières and Ste Luce in richness. Baie du Marin must once have had rich coral communities, 28 species having been recorded recently, but these are now largely dead, the skeletons overlain with a layer of silt. Siderastrea radians is dominant down to $20 \mathrm{~m}$ and seems to be able to resist siltation. At about $15 \mathrm{~m}$, there must have recently been an almost monospecific population of Agaricia lamarcki but only a few living colonies remain.

Noteworthy Fauna and Flora The line of reefs and cays shelters a large area of seagrass and mangroves. Between Anse Ceron and Ste Anne a band of seagrass $0.5-1.5 \mathrm{~km}$ wide between the shore and the coral reefs is cut by deep passes. The Baie du Marin and Anse Figuier also have large seagrass areas (Laborel-Deguen, in prep.). There is a major mangrove area, still largely pristine, at Anse des Trois-Rivières (Bouchon and Laborel, in prep.). Fish were described at Rocher du Diamant, Ste Luce and Baie du Marin (Bouchon-Navaro, in prep.). Reefs south of Anse Figuier and the outer reef slopes off Ste Luce have rich fish faunas. Philippot (in prep.) describes the gorgonian fauna, this coast having the greatest abundance and diversity, apart from Baie du Marin which is heavily silted. Sponges are described by Vacelet (in prep.), Anse Figuier having a particularly rich fauna. Lamy (in prep.) described molluscs from Rocher du Diamant, Ste Luce, Anse Figuier, Pte Borgnèse and Baie du Marin. The richest sites were between Le Diamant and Cap Salomon and at Anse Figuier; the poorest sites were those affected by hurricanes or siltation.

Scientific Interest and Research A number of sites were surveyed by the CORANTILLES II mission in 1985 and the Trois-Rivières region was identified as being of particular ecological interest. Reefs around Ste Luce are considered to be the best developed on Martinique (Bouchon and Laborel, in prep.).

Economic Value and Social Benefits The shallow lagoonal areas are important to local fisheries. This is considered to be one of the most attractive reef areas (Laborel, 1982) and tourism is important. It could be 
further developed, for example at Trois-Rivières. Popular diving sites include Rocher du Diamant and "la Grande Savane" off Ste Anne (Bouchon and Laborel, in prep.).

Disturbance or Deficiencies Shallow coral communities on the outer slope were seriously damaged to a depth of $1 \mathrm{~m}$ by Hurricane David in 1979 and have still not recovered.

The Baie du Marin has been seriously damaged by sedimentation, its waters being very turbid with visibility reduced to $2 \mathrm{~m}$. The coral communities are largely dead, the skeletons overlain with silt and only those species which are silt resistant surviving. At Trois-Rivières there are already signs of siltation, the sediment possibly originating from the Ste Luce region. Many of the large coral colonies behind the Ste Luce cay are now being invaded by zoanthids (Palythoa caribaeorum and Zoanthus sociatus) which may also be due to increasing turbidity and pollution of the waters. The construction of a new main road near the Trou du Diable has resulted in large amounts of soil run-off which may be responsible for much of the coral mortality (Bouchon and Laborel, in prep.).

Legal Protection None.

Management None.

Recommendations The region of Trois-Rivières has been identified as of particular potential for marine park or reserve status on account of its scientific and economic importance. In the short term, it is imperative to find a solution to the problem of siltation. The Rocher du Diamant and Banc du Diamant are also recommended for reserve status; the Rocher du Diamant should be open to divers but all collection of marine organisms should be prohibited. The Banc du Diamant would make a good sanctuary-type reserve apart from the problems of enforcement (Bouchon and Laborel, in prep.). 



\section{MEXICO}

\section{INTRODUCTION}

\section{General Description}

México, with a coastline of $6760 \mathrm{~km}$ on the Pacific and one of $2900 \mathrm{~km}$ on the Gulf of Mexico, is distinguished by the presence of three very different areas with coral reefs and communities: the coast of Veracruz, the Yucatan Peninsula and the Pacific coast (including Baja Califomia). Almost equally distributed on either side of the Tropic of Cancer, the fauna and flora incorporates both temperate and tropical elements. In the lowlands below $750 \mathrm{~m}$, the climate is tropical, with high humidity and rainfall in the Gulf of Mexico but a drier climate along the Pacific coast. Annual rainfall is $1100-2000 \mathrm{~mm}$ in eastern and south-western Yucatán and from Veracruz to Tampico and may reach $5000 \mathrm{~mm}$ in some places. Rainfall in northem Yucatán does not exceed $700 \mathrm{~mm}$ a year. The rainy season is from June to October. The Gulf of Mexico is subject to north-easterly trade winds for most of the year although during the winter months winds may shift to the south-east. Winds are stronger from October to March when speeds of $30-35 \mathrm{~km} / \mathrm{hr}$ are common. These are often associated with cold fronts or "nortes" which usually last for about six days; there are 15-20 each year. Hurricanes may occur between August and October.

Ferré-D'Amare (1985) provides a summary of the hydrology of the Gulf of Mexico waters. Mean surface water temperatures are lowest in February and highest in August. Annual mean water temperatures range from $26.1^{\circ} \mathrm{C}$ at Veracruz to $27.6^{\circ} \mathrm{C}$ in Cozumel. Limited cold-water upwelling with bottom temperatures of $17-18^{\circ} \mathrm{C}$ occur along the eastern side of the Yucatan shelf and the southernmost section of the Campeche Bank. During the rainy season, salinities may drop significantly and values as low as $18.3 \mathrm{ppt}$ have been recorded near Veracruz. Tides are semidiurnal in the eastern Yucatán and diurnal in the Gulf of Mexico; tidal amplitude does not exceed 0.5-1.0 m.

Reefs off Tuxpan and Veracruz in the Gulf of Mexico are affected by the winter "nortes" and by heavy rain causing run-off (Tunnell in litt., 9.10.85; Santiago-Fandiño in litt., 1984). The northernmost true reefs are Blanquilla, Medio and Isla de Lobos, situated between Tampico and Tuxpan (Glynn, 1973; Rigby and McIntyre 1966; Smith, 1954; Flores, 1955). These are semi-lunar in shape, oriented north-south and usually less than 10 ha in size with a flat top at depths of less than $1 \mathrm{~m}$. Maximum reef development occurs in the south-east sections, suggesting a strong influence from the dominant south-east currents and from periodic destructive storms from the north. Blanquilla (about $750 \mathrm{~m} \times 500 \mathrm{~m}$ ), at the tip of Cabo Rojo, is the most northerly and is described by Moore (1958). Live coral is rare on the seaward side, but is more abundant on the west side, particularly along the edge of a small, $10 \mathrm{ft}$ (3 m) drop-off. Moore (1958) lists corals and other marine invertebrates found there. Rigby and McIntyre (1966) give brief descriptions of Arrecife Blanquilla and Arrecife Medio, both of which have been affected by dredging and construction in the course of oil exploration. The damage caused has never been assessed and the reefs may have suffered even more recently from the Ixtoc-1 oil spill. Huerta and Garza (1965) describe the marine algae from Blanquilla and Lobos. Isla de Lobos, to the south-east of the other two, is described in a separate account. Reefs are found at Tanhuijo and Tuxpan, 19.5 and $24.8 \mathrm{mi}$. ( 31.4 and $39.9 \mathrm{~km}$ ) respectively, south of Lobos on either side of Arrecife Enmedio (Chávez in litt., 1984).

The geology of the Veracruz area has been described by Langford (19??), Edwards (1969), Freeland (1971) and Morelock and Koenig (1967) and the topography and sediments of the reefs are described by Emery (1963). These are very similar to each other, oval in shape, oriented NW-SE, with elevated ridges and shallow lagoons, and are built on banks of calcareous bioclastic debris. Like the Tuxpan reefs, these platform or table type reefs have a windward reef flat littered with storm-tossed boulders and encrusting coralline algae in $0.5-1.0 \mathrm{~m}$ of water, a nearly level lagoon generally covered with Thalassia testudinum and scattered coral heads of Diploria clivosu in $1.0-1.5 \mathrm{~m}$ of water and a leeward lagoon margin of moderate coral cover, mainly $D$. clivosa, surrounded by finer sediments in $1.5-2.0 \mathrm{~m}$ of water. There are small, often vegetated, sandy cays within the lagoons of some reefs, usually located on the south-western corner of the platform. The reefs arise from a range of depths across the continental shelf from $1.5 \mathrm{~m}$ near shore to some $40 \mathrm{~m}$ off shore. As with the Tuxpan reefs, maximum reef development occurs in the south-east sections, suggesting a strong influence from the dominant currents from the south-east and from periodic destructive storms from the north.

Kühlmann (1975) described the reefs of La Blanquilla, Pájaros, Isla Verde and Anegada de Adentro. La Blanquilla and Isla Verde are described in separate accounts. Other reefs in the group immediately off Veracuz include Galleguilla, Gallega, Sacrificios and Hornos, which is connected to the mainland by a causeway and is largely dead (Emery, 1963). Another group is found further south, off Punta Antón Lizardo, including the fringing reef $\mathrm{El}$ Giote, a nearshore group comprising Blanca, Chopas (and the associated island of Salmedina), Rizo, Enmedio and Cabeza reefs and an offshore group comprising Anegada de Afuera, Santiaguillo, Topatillo and Anegadilla. The stony corals of Arrecife Enmedio were studied by Rannefeld (1972) and 291 species of molluscs were described from the reef by Tunnell (1974). Nearshore turbid water conditions may contribute to the low coral diversity on reefs in this area. Minimum winter temperatures may be close to the lower limits at which extensive reef growth occurs, especially near the coast where occasional upwelling is believed to occur. Seasonal temperature lows probably exclude less tolerant species (Farrell et al., 1983).

The coral fauna is impoverished compared with other reefs in the West Indies but over 30 species have been recorded (Tunnell in litt., 9.10.85). Acropora, massive Porites and large brain corals dominate and in the 1950 s more than $90 \%$ of the outer reef edge consisted of living coral. The reefs off Tampico and Veracruz are all very similar and Ferré-D'Amaré (1985) provides a general description. Coral diversity and cover are high at about $6 \mathrm{~m}$ depth on the windward side of the reefs 


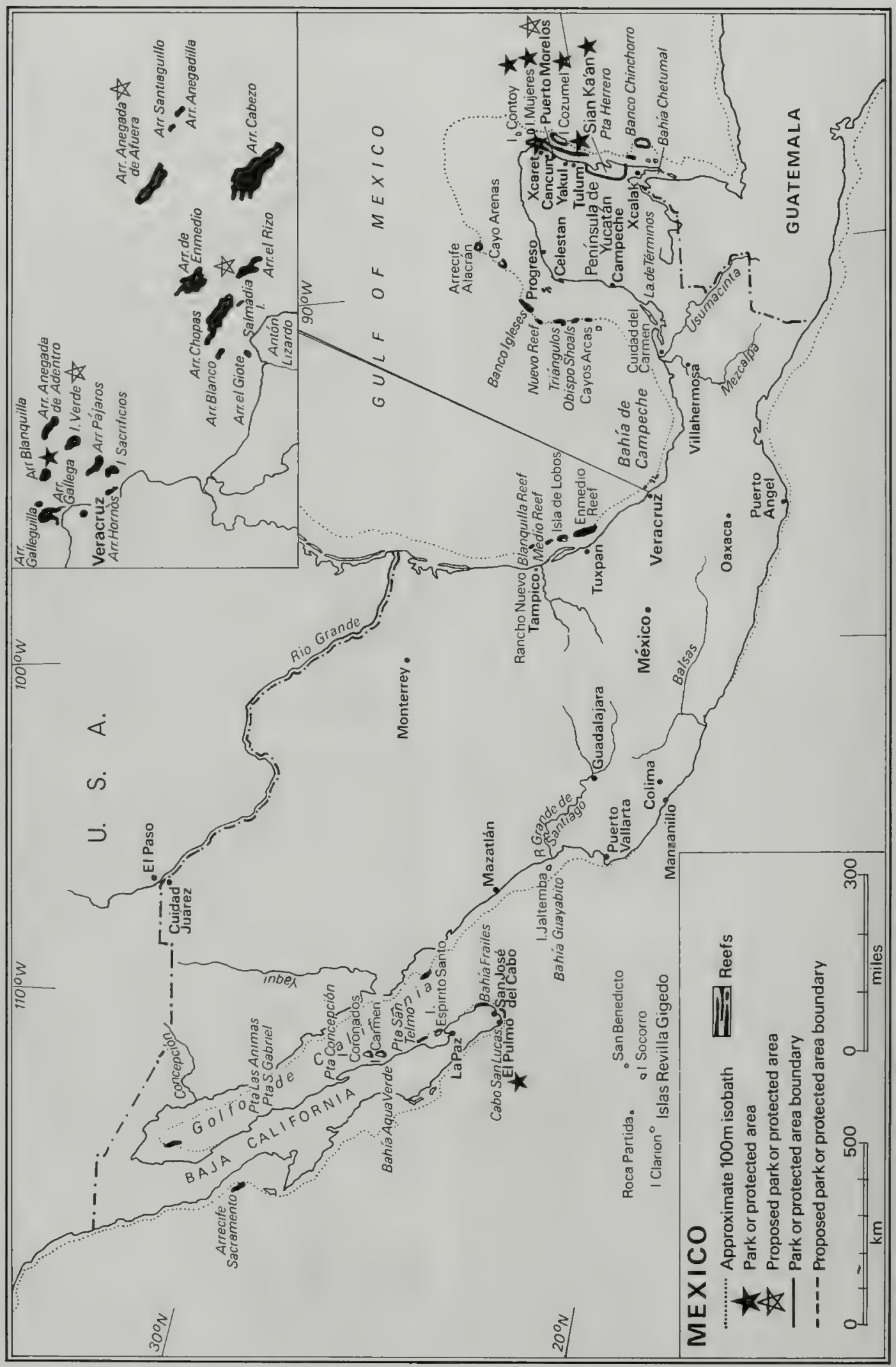


(Chávez, 1973; Berges et al., 1980). The windward crests, which are occasionally emergent, usually consist of a barren pavement, less than $50 \mathrm{~m}$ wide, composed mainly of unconsolidated coralline debris and some Lithothamium. Acropora palmata dominates in shallow water and is most abundant on the windward side of the reefs. Spur and groove formations are usually absent. Between 5 and $15 \mathrm{~m}$ there is a diverse community dominated by Diploria strigosa on the reefs near Tampico and by Montastraea cavernosa and Siderastrea spp. near Veracruz. On the leeward sides of the reefs, $M$. annularis dominates at this depth. From 15 to $25 \mathrm{~m}$ where coral growth ceases, a community dominated by $M$. cavernosa and Agaricia spp. is found.

The second important reef area in México is the Campeche Bank, an underwater extension of the Yucatán Peninsula, which slopes gradually northwards for about 125 miles $(200 \mathrm{~km})$ and then descends abruptly into the waters of Sigsby Deep. Submerged rocky limestone mounds along the western margin rim the upper surface of the submerged terrace at $50-60 \mathrm{~m}$ depth and rise to 20-35 m, forming loci for coral growth. The reefs reflect the dominant north-east and subordinate south-east. directions of wave approach with a) crescentic reefs with large north-east facing limbs and a lesser arm facing south-east and b) linear patch reefs aligned subparallel to the north-east (Logan, 1961). Zlatarski (1984 and 1985) found that the reefs reach a maximum height of $40 \mathrm{~m}$ above the continental shelf.

The zonation pattern of the windward side is basically the same for all Campeche Bank reefs, and 20-25 hermatypic species have been recorded from this area. If hard substrate is available, a moderate to low density encrusting community, composed chiefly of Agaricia agaricites, Montastraea spp. and Solenastrea spp. with some Lithothamnium, is found from 20 to $25 \mathrm{~m}$. From 10 to $20 \mathrm{~m}$, reef communities are dominated by Diploria spp., Montastraea spp. and Porites astreoides. A palmata and Montastraea annularis, with Millepora spp. are the main reef builders in shallower waters, the former forming monospecific communities in "shoals" of maximum depth $15 \mathrm{~m}$. On most reefs, a spur and groove structure of up to $6 \mathrm{~m}$ relief is found in the $A$ palmata zone. The reef crest of unconsolidated coralline debris is bordered by a zoanthid dominated zone with Palythoa caribaeorum and Zoanthus sociatus. The strong winds which blow for at least half the year prevent the formation of Acropora cervicornis zones, but this species appears to have played a relatively important role in the development of the Campeche Bank reefs (Farrell et al., 1983; Macintyre et al., 1977).

The thermal climate of the reefs on the margin of the Bank is probably more favourable than it is closer to shore (Glynn, 1973) and the absence of coral reefs on the eastern sector of the shelf is possibly due to periodic upwelling of cold water (Logan et al., 1969). On the western side, there are six well-developed emergent structures, of which the largest and most northerly is Arrecife Alacrán and the most southerly is Cayos Arcas. The others (Banco Obispo, Triángulos, Bancos Ingleses, Nuevo Reef and Cayo Arenas) are less well known but have been described to some extent and some have been surveyed by CINVESTAV (Logan 1961; Logan et al., 1969; Chávez et al., 1985). The Ingleses, Obispo and Triángulos groups are small knolls or simple reef walls with very steep sides and small reef flats, oriented to the north-east, the longest wall measuring less than $3 \mathrm{~km}$. A Nurse Shark Ginglymostoma cirratum breeding site has been recorded at Triángulos (Rodriguez pers. comm. 1984). The Arenas and Arcas groups are each formed by three crescent-shaped reef walls with wide reef flats and in some cases sandy, vegetated cays. The reefs are less than $3 \mathrm{~km}$ long and there is no noticeable leeward coralline growth. Cayos Arcas and Arrecife Alacrán are described in separate accounts; the latter is often termed an atoll because of its central lagoon.

On the east coast of the Yucatán Peninsula, reefs border the state of Quintana Roo for about $350 \mathrm{~km}$ from the tip south to Tulum, including the offshore islands, and are predominantly barrier-cum-fringing reefs (Jordan et al., 1981). The coastline is notable for its lack of rivers, but numerous limestone sink holes or cenotes, particularly in the south, result in an outflow of freshwater at various points. Coral growth is restricted by the slight bottom slope, sand accumulation and resuspension of sediment by wave action. Major reef building species are absent, with low population densities in the fore-reef zone. There are no spur and groove systems and the reefs are dominated by gorgonians. However, unlike most typical reef zonations, rich coral communities are present in the rear zone. The lagoon has no coral formations except in a few isolated sites. Jordan (1979) described 38 species of Scleractinia and 23 alcyonarians from this area.

The northernmost reefs from Cancuin south to Puerto Morelos are best developed, with continuous reef structures up to $10 \mathrm{~km}$ long and $3 \mathrm{~km}$ wide. Some of these reefs are described in separate accounts, and a generalized account of the barrier reef is given in the Cancún account. Castañares and Soto (1982), Jordan (1979b and 1980) and Jordan et al. (1981) describe reefs off Punta Nizuc, Punta Petempich, Punta Tanchancté, Bajo Finduvet, Puerto Morelos, Punta Maroma, Punta Brava, Akumal and Tulum. Other sites in this area which lack true reefs but have small banks of coral include the bays at Xcaret, Panul, Yukul, Chemuyil and Xelha. Huerta and Garza (1980) have described marine algae along this coast, particularly in the south at Chetumal and Xcalak.

From Puerto Morelos to Punta Maroma (18 km south) the barrier reef is broken and the sea bottom is sandy with seagrass beds. Punta Maroma has fine reefs in clear water with strong currents which have been the subject of a number of studies (Jordan, 1979; Jordan et al., 1981; Martin, 1982; Moreno et al., 1982). There are extensive banks of Porites furcata and a zone of sponges is found in front of the reef; Thalassia is abundant in the lagoon. From Playa del Carmen to Tulum the barrier reef disappears over a distance of about $35 \mathrm{~km}$, probably because this part of the coast is sheltered by Isla Cozumel. There are no true reefs, although corals are found encrusting rocks, and octocorals may be abundant. There are several cenotes, good examples occurring at Xcaret, Panul, Yakul, Akumal, Xelha and Chemuyil. These small bays have rocky shores and a marked halocline with usually only $10-20 \%$ coral reef cover on account of the freshwater inflow, although $A$ palmata may be abundant (Anon., undated). Akumal is unusual in having a true reef, $20-30 \mathrm{~m}$ from the beach and $200 \mathrm{~m}$ wide. There is a clear zonation, with $M$. annularis near the shore, and Plexaura homomalla and patches of Dendrogyra cylindrus further seaward. Such coastal inlets tend to be very vulnerable as they provide marginal 
conditions for coral growth, and many of them are popular tourist attractions such as Xelha, which receives large numbers of visitors each day. At Tulum, the barrier reef reappears but is considerably deeper than in the north. Coral diversity is poor and $A$ palmata is dominant. Turbidity is comparatively high in the lagoon.

Further south the reef extends off Sian Ka'an and Xcalak, a fishing port, to the Chinchorro Bank (see separate accounts). There are no reefs in Bahia Chetumal.

Coral assemblages on the Pacific coast of México are poorly known and are reviewed in Glynn and Wellington (1983). Compared to the Atlantic coast, coral assemblages are found on the shore rather than off shore and around islands and do not form true reefs. They are generally found in rocky areas; for example Astrangia and Porites are often found encrusting caves. Patches of Pocillopora may occur in small bays. A dense patch of corals, mainiy Pocillopora, occurs on the landward side of Isla Jaltemba in the bay of Guayabitos about $60 \mathrm{~km}$ north of Puerto Vallarta (Greenfield et al., 1970; Chávez in litt., 1984) which appears to be similar to the coral communities found at Islas Perlas in Panamá (Ferré-D'Amaré, in litt., 9.1.86). Near Escondido Bay, in an inlet called Puerto Angelita, an approximation to a reef is found, consisting mainly of Pocillopora capitata. Palmer (1928) briefly described some areas in the south on the coast of Oaxaca. Further south, the Golfo de Tehuantepec is an area of cold upwellings which prevents the formation of reefs (Glynn et al., 1983).

The Gulf of Califomia represents a northward extension of the subtropical coral fauna, surface water temperatures ranging from 15 to $28^{\circ} \mathrm{C}$ and for a period of several months each year temperatures drop too low for the survival of many species. Coral communities have received relatively little scientific attention. Squires (1959) describes the Puritan-American Museum Expedition to the Gulf to collect and study corals. Other early references include Durham (1947) and Steinbeck and Ricketts (1941). Details of the marine life in this area may be found in Gotshall (1982). Stony corals are prominent features of the benthos only from $\mathrm{La} \mathrm{Paz}$ to Cabo San Lucas. The El Pulmo reef tract, described by Brusca and Thompson (1977), is found near the southern tip of Baja California $\left(23^{\circ} 26^{\prime} \mathrm{N}, 109^{\circ} 25^{\prime} \mathrm{W}\right)$ between two prominent rocky headlands, Cabo Pulmo to the north and Los Frailes to the south. The reefs project off shore in a north-easterly direction and consist of a series of rocky ridges covered with algae and encrusting Porites, with occasional growths of Pavona clivosa, $P$. gigantea and Pocillopora. Coral growth is richest on the ridge margins where large colonies of Pavona up to $3 \mathrm{~m}$ in diameter predominate. Between the ridges a similar coral fauna is found dominated by Poriles. The two commonest corals are $P$. californica and Pocillopora elegans (Gotshall in litt., 4.10.84). Other coral assemblages in this area are found at Punta Pescadero in Bahía de Palmas, Los Frailes, San José del Cabo and Cabo San Lucas (Glynn and Wellington, 1983). Punta Pescadero supports relatively rich coral and gorgonian populations, and all these areas have very rich fish communities, described by Hobson (1968).

Slightly further north, coral communities are found at San Gabriel Bay on the south-east side of Isla Espiritu Santo. Dense growths of Porites are found on the sandy bottom of this gently sloping, sheltered, horseshoe-shaped embayment. An extensive growth of Pocillora elegans, forming a series of coral heads up to $40 \mathrm{ft}(12 \mathrm{~m})$ in diameter aligned to form a barrier approximately $300 \mathrm{ft}$ $(91 \mathrm{~m})$ long, was found in the centre of the bay. The upper surfaces of the colonies were largely dead and covered with algae. Porites californica occurred in some parts of the bay, and the area was rich in fish. The reef here plays an important role in water circulation in the bay, protects the coastline and is a unique habitat within the region. A small Pocillopora reef community is found off the west coast of the island.

Further north there is a steady diminution of the coral fauna. The San Telmo reefs are situated north of San Carlos Bay, just south of San Telmo Point. Scattered colonies of Porites are found on isolated rock patches at Marquer Bay on Carmen Island. Coral formations composed predominantly of $P$. californica are found in the inner harbour of Puerto Escondido, Coronadas Island, and in the bays of Agua Verde and Salinas. $P$. panamensis is considered to be the only common reef coral present north of Concepción Bay (Glynn and Wellington, 1983). Coral assemblages may also occur off Isla Las Animas and at San Diego Reef off Isla San Diego.

The high, barren, inaccessible, volcanic Revilla Gigedo Islands support many diverse fish and coral communities including Porites californica, Pocillopora elegans, cup coral Tubastraea and Bathycyatus, and gorgonians Muricea, Eugorgia, Lophogorgia, Pacifigorgia, Gorgonia and Filigella (Gotshall in litt., 4.10.84). The reef at Isla Socorro is particularly rich and was studied by Villalobos (19??). Fowler (1944) describes some of the fish found around these islands.

Scott and Carbonell (1986) describe important wetland and mangrove sites in the country. The coast and islands of the Gulf of Mexico have between seven and eleven species of nesting seabird; the Caribbean coast and adjacent islands have five to eight species (Halewyn and Norton, 1984). Six species of sea turtle nest in Mexico. The Loggerhead Turtle Caretta caretta has important nesting sites in Quintana Roo and on the north-east coast of Yucatán; minor nesting sites are found in Veracruz from Tampachichi to Barra de Corazones and in Campeche from Tabasco to Laguna de Términos. One third of the entire mainland breeding population of Green Turtles Chelonia mydas in the east Pacific is found on the Michoacan coast, and this species also nests in small numbers in most states on the Caribbean coast. The Hawksbill Eretmochelys imbricata is extremely rare on the Pacific coast but it nests sparsely on the Caribbean coast. Kemp's Ridley Lepidochelys kempii has a major feeding ground in the Gulf of Mexico and the only known nesting site in the world is on a $20 \mathrm{~km}$ beach near Rancho Nuevo in southem Tamaulipas; sporadic nesting may occur further south in Veracruz and Tabasco. The Olive Ridley Lepidochelys olivacea nests only on the Pacific coast, with large scale nesting in Oaxaca, especially at La Escobilla. The Pacific coast of México is an important nesting site for the Leatherback Dermochelys coriacea, particularly at south-east Guerrero, Bahía de Chacahua, Michoacán, Jalisco, Colima, Oaxaca and Baja California. The Caribbean coast supports only sparse nesting (Groombridge, 1982). A detailed description of nesting beaches in the Caribbean and Gulf of Mexico is given in Bacon et al. (1984). 
Currently, extensive research work is underway on coral reefs in México. SEDUE (Secretaría de Desarrollo Urbano y Ecología) is carrying out a research programme on the Veracruz reefs (see below). The Yucatán reefs are being studied by CINVESTAV for the Government of the State of Quintana Roo and a catalogue of corals is being produced. Other studies are being carried out at the Puerto Morelos Marine Station (Univ. Nal. Autón. México), as part of a long term study to provide information for the management of the reefs, and at CIQRO (Centro de Investigaciones de Quintana Roo) in the course of management of the Sian Ka'an area. Growth rates and population biology of the commercially important gorgonian Plexaura homomalla have been studied along the coast between Nizuc and Tulum in the course of a research project supported by CONACYT (Consejo Nacional de Ciencia y Tecnología) (Jordan and Nugent, 1978; Martin, 1982; Moreno et al., 1982). Scott and Carbonell (1986) list the organisations and agencies involved in wetland and marine research.

\section{Reef Resources}

The three most important economic activities in the Mexican Atlantic are tourism, fisheries and oil extraction. Oil has become the major industry since the discovery of the highly productive Campeche Bank oil field (Ferré-D'Amaré, 1985). Tourism has grown rapidly in north-east Yucatán since the 1970s when a government-supervised project was launched to create a large resort complex at Cancún, a previously almost uninhabited region. Fisheries are also expanding rapidly, the catch from this area, at 0.25 million tons annually, amounting to about $20 \%$ of the national catch. Quintana Roo and Baja California Norte are the main spiny lobster producing areas. Panulirus argus, $P$. guttatus and $P$. laevicauda are found in Quintana Roo but only the former is exploited commercially (Lozano and Briones, undated). The reefs and coral communities of the Pacific coast have less economic importance and there is no information about their role in either fisheries or tourism. The El Pulmo and San Gabriel reefs in the Gulf of California were both once important pearl fishery sites for Pinctada mazatlantica, El Pulmo being the centre of the Gulf of California industry until the 1940s when the pearl oysters ceased to mature and the fishery died out (Squires, 1959).

\section{Disturbances and Deficiencies}

Mexican reefs are under threat from a variety of sources. Natural events which affect the reefs include "nortes" during the winter months and freshwater inflows from mainland drainage systems. The Caribbean-wide mass mortality of the sea urchin Diadema antillarum extended to the north-east coast of the Yucatan Peninsula (Lessios et al., 1984).

Human impact is even greater. The reefs off Veracruz are under stress from intense fishing and oil spills (Tunnell, 1985) (see accounts for "La Blanquilla", "Isla Verde" and "Isla de Lobos"). Long term impacts of the petroleum industry, from petrochemical effluents and drilling muds, have not been investigated (Ferré-D'Amaré, 1985). The Ixtoc-1 oil spill of June 1979, which dumped 3100000 barrels of crude oil into the Gulf of Mexico over a ten month period, may have been responsible for the appearance, in several places in the Veracruz area, such as Isla Verde, of dense mats of green algae covering corals and rocks (Jernelov and Linden, 1981). Villalobos-Figueroa (1981) studied the impact of the oil spill at La Blanquilla, Isla Verde and Anegada de Adentro and concluded that none of these islands suffered serious effects. Tunnell and Dokken (1980) and Baca et al. (1982) monitored the impact on Arrecife Enmedio for six consecutive summers and found that although the beaches and nearshore lagoon areas of Isla Enmedio and Isla Solmedina were heavily affected, the reefs were largely spared. By 1985, oil on the windward sides had almost disappeared but some mats on the south-east and leeward sides in the lagoon have not changed. These mats are covered with sparse populations of algae (Caulerpa sertularioides and Cympolia barbata) and the invertebrates Echinometra lucunter and Cerithium litteratum.

Reefs off the Yucatán Peninsula are coming under increasing threat from tourism, particularly the indirect effects of the industry such as coastal development. Until 1970 , the State of Quintana Roo was practically inaccessible and covered by semi-humid tropical forest. Recently the construction of roads, coastal development and immigration from other states have caused rapid population growth (17\% p.a.) although the current population is still low. Sixty per cent of the land is now cleared and covered by secondary vegetation of no commercial value (Anon., 1983). Deforestation may lead to increased soil run-off which could threaten the reefs. The large-scale tourist development at Cancun is discussed in a separate account. The reefs off Veracruz receive heavy usage by Mexican SCUBA divers and students from American and Mexican universities; the impact of these activites is not known but may be adverse in some of the more popular areas.

Over-exploitation of reef resources may become an increasing problem. Strombus gigas has already become depleted although it is still collected in large quantities and there are fears of spiny lobster over-collection. Marine turtles are heavily exploited and stocks appear to be more or less depleted throughout the area. The Green Turtle suffers heavy mortality from egg collection and entrapment in shrimp nets on the Pacific coast and is also heavily exploited on the Caribbean coast. The Olive Ridley is heavily exploited (Bacon et al., 1984; Groombridge, 1982). There is no information on-the conservation status of coral communities on the Pacific coast.

\section{Legislation and Management}

There is now considerable awareness within the country of the need to protect and manage the reefs of México. A number of laws exist for the control of marine pollution (hydrocarbon pollution: Diario oficial 20-07-56 and 15-04-81; other forms of pollution: Diario oficial $23-03-71,29-03-73,23-01-79$ ). There is legislation to control various forms of fishing including lobster (Diario oficial 9-10-57, Diario oficial 24-05-72). A 1974 decree declared Plexaura homomalla a natural resource, on account of its potential value in medical research, and its collection is prohibited (Nugent et al., 1978).

Coastal zone management in Mexico is described by Ibarra (1985). The Dirección General de Parques, 
Reservas y Areas Ecológicas Protegidas is responsible for protected areas. Within this, SEDUE, the Subsecretaria de Ecología y Desarrollo Urbano, is supporting two projects concerned with reef management. One is specifically designed to look at management strategies for the reefs of the Veracruz area; the second is to draw up a catalogue and general management plan for all Mexican reefs (Giron in litt., 20.10.84). The former is progressing well and the Management Plan will include a description of the area and impacts on the reefs, proposed zoning, and plans for an interpretive centre (on the mainland) and mooring buoys. The original reserve area of $\mathrm{La}$ Blanquilla will be maintained as a sanctuary zone; other zones will be identified for diving and snorkelling and for spearfishing. A marine laboratory and facilities for research are also being considered.

A number of reef areas in México are nominally protected, but there is much confusion over the exact areas concerned, the legislation needs revision, and enforcement and management require improvement. The following areas including or adjacent to reefs are protected:-

\section{* = described in a separate account}

1. La Blanquilla, Veracruz. 28 July $1975 . *$

2. Reserva Ecológica Isla Contoy, Quintana Roo. 8 July 1981 (terrestrial reserve for birds; see account for north-east Yucatán reefs).

3. Reefs at Punta Cancún and Nizuc, Quintana Roo. 7 February 1973.*

4. El Garrafón Underwater Park, Isla Mujeres, Quintana Roo.*

5. East coast of Isla Cozumel, Quintana Roo. 2 June 1980.*

6. Tulum, Quintana Roo. 23 April 1981 (primarily a cultural site).

7. Reserva de la Biósfera Sian Ka'an. 20 January 1986.*

8. Cabo San Lucas, Baja California. 29 November 1973 (primarily for whales).

\section{Recommendations}

A number of additional areas have been recommended for protection including:

1. Puerto Morelos*

2. Arrecife de la Anegada de Afuera, off Veracruz, proposed by CONOPAN and by SAHOP in 1981.

3. Isla de Enmedio, Arrecife el Rizo and Punta Antón Lizardo, off Veractuz, proposed by SAHOP in 1981.

4. Isla Verde, proposed by $\mathbf{M}$. Costello and $\mathbf{M}$. Arendaño in 1971.*

There is a urgent need for improvement in the enforcement of existing legislation, for further legislation to control collection of marine organisms and spearfishing and for improved educational programmes. The Quintana Roo coastline must be considered a high priority, given the speed with which the tourist industry is developing in that area. Jordan and Moreno (undated) stress the need for management of this coast, for controls on collecting of marine organisms, spearfishing, pollution, and for the establishment of educational programmes.

\section{References}

" = cited but not consulted

-Allen, R.L. (1982). The reptant decapods of Enmedio and Lobos coral reefs, southwestern Gulf of Mexico. M.S. Thesis, Corpus Christi State Univ., Corpus Christi, Texas, 65 pp.

Anon. (1983). CIQRO's Request to WWF for the support of the Ziyan-Caan Biosphere Reserve. Project proposal to WWF-US.

Anon. (undated a). Chart of the Reefs of Cozumel, México.

Anon. (undated b). Reserva Ecológica Isla Contoy. SEDUE leaflet.

Anon. (undated c). Arrecifes del Caribe, (paper provided by E. Jordan).

-Arenas, (1966). (reference to Isla Verde; not located).

-Baca, B.J., Schmidt, T.M. and Tunnell, J.W. (1982).

Ixtoc oil in the seagrass beds surrounding Isla de Media. Paper presented at Simposio Internacional IXTOC-1 México, June 1982, México City.

Bacon, P., Berry, F., Bjorndal, Hirth, H., Ogren, L. and Weber, M. (1984). The National Reports. Proceedings of the Western Atlantic Turtle Symposium, Costa Rica. Vol3: University of Miami Press, Florida.

Bautista-Gil, M.L. and Chávez, Ea. (1977).

Contribución al conocimiento de los foraminíferos del Arrecife de Lobos, Veracruz. Mem. 5th Congr. Nac. de Ocean., Esc. Cienc. Mar y Ali., Sonora, México (Ed. Manrique, F.).

Beekhuis, J.V. (1981). Tourism in the Caribbean; impacts on the economic, social and natural environments. Ambio 10(6): 325-331.

-Berges, G.O., Calvario, O., Campos, G., Domínguez, E. and Espejel, J. (1980). La comunidad coralina de Isla de Sacrificios, Veracruz, México. Unpub. report to Facultad de Ciencias, Univ. Nal. Autón. Méx.

Bonet, F. (1967). Biogeología subsuperficial del Arrecife Alacranes, Yucatán. Univ. Nac. Autón. Méxaco, Inst. de Geología 80: 1-92.

Bonet, F and Rzedewski, J. (1962). La vegetacion de las Islas del Arrecife Alacranes, Yucatán (México). An. Esc. Nac. Cienc. Biol. México 11(1-4): 15-50.

Boyd, D.W., Kornicker, L.S. and Rezak, R. (1963).

Coralline algae microatolls near Cozumel Island, México. Contrib. to Geol., Dept Geology, Wyoming Univ. 2: 105-108.

Brusca, R.C. and Thompson, D.A. (1977). Pulmo Reef: the only "coral reef" in the Gulf of California. Ciencias Marinas 1(3): 37-53.

Cabrera, E., Sousa, M. and Durán García, R. (1983).

Listado florístico preliminar. In: Sian Ka'an: Estudios Preliminares de una zona en Quintana Roo propuesta como Reserva de la Biósfera. CIQRO-SEDUE, México.

Carr, A., Meylan, A., Mortimer, J., Bjorndal, K. and Carr, T. (1982). Surveys of sea turtle populations and habitats in the Western Allantic. NOAA Technical Memorandum NMFS-SEFC-91.

Castańares, L.G. and Soto, L.A. (1982). Estudios sobre los corales escleractinios hermatípicos de la costa noreste de la península de Yucatán, México. Parte 1. Sinópsis taxonómica de 38 especies (Cnidaria, Anthozoa, Scleractinia). An. Inst. Cienc. del Mar y Limnol. Univ. Nal. Aurón. México 9(1): 295-344.

Castello, J.M. (1971). Maravillas del primer parque nacional submarino de México. Contenido 101: 18-25.

Castorena, V. and Metaca, M. (1979). El coral negro, una riqueza en peligro. Técnica Pesquera 141: 22-27. 
Castro, del R. (1976). Inscripción de las arenas carbonatadas y de su ámbito submarino al noreste de la península de Yucatán, México. Tesis profesional, Esc. Sup. Ingeniería, I.P.N., 74 pp.

Castro-Aguirre, J.L. and Márquez-Espinoza, A. (1981). Contribución al Conocimiento de la Ictio fauna de la Isla de Lobos y Zonas adyacentes, Veracruz, Méxaco. Departamento de Pesca, Serie Científica 22, Dirección General del Instituto Nacional de Pesca.

César Dachary, A. and López Ornat, A. (1983). Economía, población y dinámica en el uso del suelo en la reserva de la biósfera y su zona periférica. In: Sian Ka'an: Estudios Preliminares de una zona en Quintana Roo propuesta como Reserva de la Biósfera. CIQRO-SEDUE, México.

Chamberlain, C.K. (1966). Some octocorals of Isla de Lobos, Veracruz, México. Brigham Young Univ. Geol. Stud. 13: 47-53.

Chávez, E.A. (1973). Observaciones generales sobre las communidades del arrecife de Lobos, Veracruz. An. Escuela nac. Cienc. biol. (México) 20: 13-21.

Chávez, E.A. and Hidalgo, E. (1984). Spatial structure of benthic communities of Banco Chinchorro, México. Advances in Reef Science. Abstracts of Papers, joint meeting of the Atlantic Reef Committee and the International Society for Reef Studies.

Chávez, E.A., Hidalgo, E. and Sevilla, M.L. (1970).

Datos acerca de las comunidades bentónicas del Arrecife de Lobos, Veracruz. Revista de la Sociedad Mexicana de Historia Natural 31: 211-280.

Chávez, E.A., Hidalgo, E. and Izaguirre, M.A. (1985). A comparative analysis of Yucatán coral reefs. Proc. 5th Int. Coral Reef Cong., Tahiti, Vol.6: 355-361.

De la Torre, A.R. (1978). Coral negro: un recurso o una especie en peligro. In: Higuian, J.B. (Ed.), Proc. Annual Gulf and Caribbean Fisheries Institute 31: 158-163.

Durham, J.W. (1947). Corals from the Gulf of California on the North Pacific coast of America. Geol. Soc. Am. Mem. 20: 68 pp.

-Edwards, G.S. (1969). Distribution of shelf sediments, offshore from Antón Lizardo and the Port of Veracruz, México. Texas A \& M Univ., Dept Oceanog. Report 69-10-T: 74 pp.

Ekdale, A.A. (1972). Ecology and paleoecology of marine invertebrate communities in calcareous substrates, north-east Quintana Roo, México. M.Sc. Thesis, Rice University, $159 \mathrm{pp}$.

*Emery, K.O. (1963). Coral reefs off Veracruz, México. Geofísica International 3(1): 11-17.

Espejel Carbajal, I. (1983). La vegetación de las dunas costeras. In: Sian Ka'an: Estudios Preliminares de una zona en Quintana Roo propuesta como Reserva de la Biósfera. CIQRO-SEDUE, México.

Espejel, JJ. (1983). Biología acuática descripción general de los recursos bióticos y económicos. In: Sian Ka'an: Estudios Preliminares de una zona propuesta como Reserva de la Biósfera. CIQRO-SEDUE, México.

Farrell, T.M., D'Elia, C.F., Lubbers, L. and Pastor, L.J. (1983). Hermatypic coral diversity and reef zonation at Cayos Arcas, Campeche, Gulf of Mexico. Atoll Res. Bull. 270:1-7.

Ferré-D'Amaré, A.R. (1985). Coral reefs of the Mexican Atlantic: a review. Proc. 5th Int. Coral Reef Cong., Tahiti, Vol. 6:349-354.

*Flores, RJ. (1955). Los arrecifes de la cuenca de Tampico-Tuxpan. Bol. Assoc. Mex, Geol. Petrol. 11/12: 397-500.

Folk, R.L. (1967a). Sand cays of Alacrán Reef, Yucatán, México. Morphology. J. Geol. 75: 412-437.
Folk, R.L. (1967b). Carbonate sediments of Isla Mujeres. Quintana Roo, México and vicinity. New Orleans Geol. Soc. Guidebook, Field trip to Península of Yucatán, Mtg. Geol. Soc. Am. 100-123.

Folk, R.L. and Cotera, A.S. (1971). Carbonate sand cays of Alacrán Reef, Yucatán, México: sediments. Atoll Res. Bull. 137.

Folk, R.L. and Robles, R. (1964). Carbonate sands of Isla Pérez, Alacrán Reef complex, Yucatán. Jour. Geol. 72: $255-292$.

Fosberg, F.R. (1962). A brief study of the cays of Arrecife Alacrán, a Mexican atoll. Atoll Res. Bull. 93: $25 \mathrm{pp}$.

Fowler, H.W. (1944). Results of the Fifth George Vanderbilt Expedition (1944). The fishes. Acad. nat. Sci. Phila. Monog. 6: 69-93.

*Freeland, G.L. (1971). Carbonate sediments in a terrigenous province: the reefs of Veracruz, México. Ph.D. Dissertation, Rice Univ., 253 pp.

García Salazar, M. (1983). Fauna Silvestre. In: Sian Ka'an: Estudios Preliminares de una zona en Quintana Roo propuesta como Reserva de la Biósfera. CIQRO-SEDUE, México.

Garduno, M.A. (1984). Chankanaab Park, a project to protect the ecosystem of Cozumel, Quintana Roo, México. Advances in Reef Science. Abstracts of papers, Joint Meeting of the Atlantic Reef Committee and the International Society for Reef Studies, Miami. October 26-28, 1984.

Glynn, P.W. (1973). Aspects of the ecology of coral reefs in the Western Atlantic Region. Chap. 9 in: Endean, R. and Jones, O.A. (Eds), Biology and Geology of Coral Reefs Vol.2(1), Academic Press, New York.

Glynn, P.W., Druffel, E.M. and Dunbar, R.B. (1983). A dead Central American coral reef tract: possible link with the Little Ice Age. J. Mar. Res. 41: 605-637.

Glynn, P.W. and Wellington, G.M. (1983). Corals and Coral Reefs of the Galapagos. University of California Press, Berkeley, Los Angeles, London.

Gotshall, D. (1982), Marine Animals of Baja California: a guide to the common fish and invertebrates. Sea Challengers, Monterrey, California, $112 \mathrm{pp}$.

Green, G. (1977). Sinópsis taxonómica de trece especies de esponjas del arrecife la Blanquilla, Veracruz, México. An. Centro. Cienc. del Mar y Limnol. Univ. Nal. Autón. México 4(1): 79-98.

*Greenfield, D.W., Hensley, D., Wiley, J.W. and Ross, S.T. (1970). The Isla Jaltemba coral formation and its zoogeographical significance. Copeia 1: 180-181.

Groombridge, B. (1982). The IUCN Amphibia-Reptilia Red Data Book, Part 1: Testudines, Crocodylia, Rhynchocephalia. IUCN, Gland, Switzerland.

Halewyn, R. van and Norton, R.L. (1984). The status and conservation of seabirds in the Caribbean. In: Croxall, J.P., Evans, P.G.H. and Schreiber, R.W. (Eds), Status and Conservation of the World's Seabirds. ICBP Technical Publication No. 2, Cambridge.

Hidalgo, E. and Chávez, E.A. (1967). Prospección ecológica en el arrecife de Lobos, Veracruz. Contr. Inst. Nal. Invest. Biol. Pesq. México. III. Congr. Nal. Ocean: 1-21 (unpub. report).

-Hildebrand, H.H., Chávez, H. and Compton, A. (1964). Aporte al conocimiento de los peces del arrecife Alacranes, Yucatán, México. Ciencia, Mex. 23(3): 107-134.

Hobson, E.S. (1968). Predatory behaviour of some shore fishes in the Gulf of California. USDI Fish and Wildlife Service, Bureau of Sport Fisheries and Wildlife, Research Report 73: 92 pp. 
"Hoskin, C.M. (1963). Recent carbonate sedimentation on Alacrán Reef, Yucatán, México. Nat. Acad. Sci. National Research Council, Foreign Field Research Program, Publ. 19. 160 pp.

-Hoskin, C.M. (1967). Coral pinnacle sediments, Alacrán reef lagoon, México. J. Sed. Petrol. 36(4): 1055-1074.

Hoskin, C.M. (1968). Magnesium and strontium in mud fractions of recent carbonate sediment, Alacrán reef, México. Am. Assoc. Petr. Geol. Bull. 52: 2170-2177.

-Huerta, L. (1958). Contribución al conocimiento de las algas de los bajos de la sonda de Campeche, Cozumel e Isla Mujeres. An. Esc. Nal. Cienc. Biol. 9(1-4): 115-123.

- Huerta, L. (1961). Flora marina de los alrededores de Isla Pérez, Arrecife Alacranes, Sonda de Campeche, México. An. Esc. Nal. Cienc. Biol. 10(1-4): 11-22.

- Huerta, L. and Garza, A. (1965). Algas marinas de la Barra de Tuxpan y de los arrecifes Blanquilla y Lobos. An. Esc. Nal. Cienc. Biol. 13: 5-21.

*Huerta, L. and Garza, A. (1980). Contribución al conocimiento de la flora marina de la zona sur del litoral de Quintana Roo, México. An. Esc. Nal. Cienc. Biol. 23: $25-44$.

-Ibarra, M.M. (1986). Coastal Management in Mexico. Coastal Zone Management Journal. (full citation not known).

Jernelov, A. and Linden, O. (1981). Ixtoc 1: a case study of the world's largest oil spill. Ambio 10(6): 299-306.

Jordan, E. (1979a). An analysis of a gorgonian community in a reef calcareous platform on the Caribbean coast of México. An. Centro Cienc. del Mar y Limnol., Univ. Nal. Autón. México 6(1): 87-96.

Jordan, E. (1979b). Estructura y composición de arrecifes coralinos en la región noroeste de la Península de Yucatán, México. An. Centro Cienc. del Mar y Limnol., Univ. Nal. Autón. México 6(1): 69-86.

-Jordan, E. (1980). Arrecifes coralinos del Noreste de la Península de Yucatán: Estructura comunitaria, un estimador del Desarrollo Arrecifal. Tesis. Centro Cienc. del Mar y Limnol. Univ. Nal. Autón. México. 148 pp.

Jordan, E., Angot, M. and de la Torre, R. (1978).

Prospección biológica de la Laguna de Nichupte (Cancú n), Q. Roo, México. Nota Científica, An. Centro Cienc. del Mar y Limnol., Univ. Nal. Autón. México 5(1): 179-188.

Jordan, E., Merino, M., Moreno, O. and Martin, E. (1981). Community structure of coral reefs in the Mexican Caribbean. Proc. 4th Int. Coral Reef Symp., Manila, Vol. 2: 303-308.

Jordan, E., Moreno, O., Martin, E. and Merino, M. (19??). Ecología y preservación: el uso y manejo de los arrecifes coralinos de Quintana Roo. Simposio Quintana Roo: Problemática y Perspectivas. Cancún October 1980, CIQRO and UNAM.

Jordan, E. and Nugent, R.S. (1978). Evaluación poblacional de Plexaura homomalla (Esper) en la costa noreste de la Península de Yucatán (Octocorallia). An. Centro Cienc. del Mar y Limnol. Univ. Nal. Autón. México 5(1): 189-200.

Kenyon, J. (1984). Black coral off Cozumel. Sea Frontiers 30(5): 267-277.

"Kornicker, L.S., Bonet, F., Cann, R. and Hoskin, C.M. (1959). Alacrán reef, Campeche Bank, México. Publ. Inst. Mar. Sci. Univ. Texas, Port Arkansas 6: 1-22, 171-185.

Kornicker, L.S. and Boyd, D.W. (1962). Shallow-water geology and environments of Alacrán Reef complex, Campeche Bank, México. AAPG Bull. 46: 640-673.

Kühlmann, H.H. (1975). Characterization of the coral reefs off Veracruz, México. Int. Revue ges. Hydrobiol. 60(4): 495-521.

Langford, R. (19??). (Geology of Veracruz reefs). Thesis.

Lessios, H.A., Robertson, D.R. and Cubit, J.D. (1984), Spread of Diadema mass mortality through the Caribbean. Science 226: 335-337.

Logan, B.W. (1961). Coral reef and bank communities of the Campeche shelf, Yucatán, México. Geol. Soc. Am. Spec. Pap. 68: 218 (Abs.)

-Logan, B.W., Harding, J.L., Aur, W.M., Williams, J.D. and Snead, R.G. (1969). Carbonate sediments on reefs, Yucatán shelf, México. Part I. Late Quatemary sediments. Mem. Am. Assoc. Petrol. Geol. 11: 1-128.

Lot-Helgueras, A. (1968). Estudios sobre fanerógamas marinas en las cercarías de Veracruz. Ver. Tesis Profesional, UNAM, Facultad de Ciencias, 66 pp.

López-Ornat, A. (1983). Localización y Medio Físico. In: Sian Ka'an: Estudios Preliminares de una Zona en Quintana Roo propuesta como Reserva de la Biósfera. CIQRO-SEDUE, México.

Lozano, E. and Briones, P. (19??). Projecto biologia y dinámica poblacional de las langostas del Caribe Mexicano. Internal Report. Instituto de Ciencias del Mar y Limnología, Estación Puerto Morelos.

*MacIntyre, I.G., Burke, R.B. and Stuckenrath, R. (1977). Thickest recorded Holocene reef section, Isla Pérez core hole, Alacrán Reef, México. Geology 5: 749-754.

Martin, E. (1982). Ciclo reproductivo, proporción sexual y fecundidad del coral blando Plexaura homomalla (Esper.) en el mar Caribe Mexicano (Octocoralla: Plexauridae). An. Inst. Cienc. del Mar y Limnol. Univ. Nal. Autón. México 9(1): 359-380.

*Moore, D.R. (1958). Notes on Blanquilla, the most northerly coral formation in the western Gulf of Mexico. Publ. Inst. Mar. Sci. 5: 151-155.

*Morelock, J. and Koenig, KJ. (1967). Terrigenous sedimentation in a shallow-water coral reef environment. J. Sed. Petrol. 37(4): 1001-1005.

Moreno, O., Merino, M. and Jordan, E. (1982).

Estimación de la edad en un organismo colonial Plexaura homomalla (Esper.) (Octocorallia: Plexauridae). An. Inst. Cienc. del Mar y Limmnol. Univ. Nal. Autón. México 9(1): 345-358.

Nugent, R.S., Jordan, E. and de la Torre, R. (1978). Investigaciones preliminares de la biomasa de Thalassia testudinum Konig, en la costa del Caribe Méxicano: nota cientifica. An. Centro Cienc. del Mar y Limnol. Univ. Nal. Autón. México 5(1): 247-254.

Olmsted, I.C., Lopéz-Ornat, A. and Durán García, R. (1983). Vegetación de Sian Ka'an; reporte preliminar. In: Sian Ka'an: Estudios Preliminares de una zona en Quintana Roo propuesta como Reserva de la Biósfera. CIQRO-SEDUE, México.

Orme, W.A. (1982). Cayos Arcas: new oil port 70 miles off shore. $R$ and $D$ Mexico $2(11): 22-25$.

Palencia, A.L. (1983). Isla Verde: un laboratorio natural. Técnica Pesquera Enero 1983: 20-24.

Palmer, R.H. (1928). Fossil and recent corals and coral reefs of western México. Three new species. Proc. Am. Philos. Soc, 67: 21-31.

-Rannefeld, J.W. (1972). The stony corals of Enmedio Reef off Veracruz, México. M.Sc. Thesis, Texas A and M. Univ. 103 pp.

Rice, W.H. and Kornicker, L.S. (1962). Mollusks of Alacrán Reef, Campeche Bank, México. Univ. Texas, Pub. Inst. Mar. Sci. 8: 366-403. 
Rigby, J.K. and McIntyre, W.G. (1966). The Isla de Lobos and associated reefs, Veracruz, México. Brigham Young Univ. Geol. Stud. 13: 3-46.

Roberts, K.A. (1981). Polychaetes of Lobos reef, Veracruz, México. M.S. Thesis. Corpus Christi State Univ., Corpus Christi, Texas, 40 pp.

Santiago-Fandin̄o, V. (1977). Estudio taxonómico y algunos aspectos ecológicos sobre las madréporas (Coelenterata, Hexacorallia) del Arrecife "La Blanquilla", Veracruz, México. Tesis para optar por el Título de Biólogo (B.Sc. Biology Thesis). Universidad Nacional Autónoma de México, Facultad de Ciencias. 101 pp.

Scott, D.A. and Carbonell, M. (1986). A Directory of Neotropical Wetlands. IUCN, Gland and Cambridge.

-Smith, G.W. (1954). Gulf of Mexico Madreporaria. U.S. Dept. Fish and Wildlife Serv. Fish. Bull. 89: 291-295.

Steinbeck, J. and Ricketts, E.F. (1941). Sea of Cortez. New York, Viking Press. 598 pp.

Squires, D.F. (1959). Results of the Puritan-American Museum of Natural History expedition to western México. Corals and coral reefs in the Gulf of California. Bull. Am. Mus. Nat. Hist. 118: 371-431.

Thornback, J. and Jenkins, M. (1981). The IUCN Mammal Red Data Book Part 1. IUCN, Gland, Switzerland.

Tunnell, J.W. (1974). Ecological and geographical distribution of Mollusca of Lobos and Enmedio coral reefs, south-western Gulf of Mexico. Ph.D. dissertation, Texas $\mathbf{A}$ and $\mathbf{M}$ University.

Tunnell, J.W. (1985). Environmental stresses of the Veracruz coral reefs (Southwestern Gulf of Mexico). Paper presented at 5th Int. Coral Reef Cong., Tahiti (not published in proceedings).

Tunnell, J.W. amd Dokken, Q.R. (1980). Observations on IXTOC-1 oil impact on southwestern Gulf of Mexico coral reefs. Paper presented at Congreso sobre Problemas Ambientales de México, December 1980, México City.

-Villalobos, A. (19??). (reference to Isla Socorro study not located).

-Villalobos-Figueroa, A. (1971). Estudios ecológicos en un arrecife coralino en Veracruz, México. In: Coloquio sobre investigaciones y Recursos del Mar Caribe y Regiones Adjacentes. UNESCO: 531-545.

Villalobos-Figueroa, A. (1981). Evaluación de los efectos del derrame del Ixtoc 1 sobre la comunidad arrecifal de Veracruz y Campeche. Segundo informe. Programa Coordinado de Estudios Ecológicos en la Sonda de Campeche, Universidad Autónoma Metropolitana.

Zlatarski, V.N. (1984). Preliminary notes on the scleractinians and reefs of south-eastern México. Advances in Reef Science. Abstracts of Papers, Joint meeting of the Atlantic Reef Committee and the International Society for Reef Studies, Miami, December 1984.

Zlatarski, V.N. (1985). Scleractinians and reefs of south-eastern México. Paper presented at 5th Int. Coral Reef Cong., Tahiti (not published in proceedings).

\section{ARRECIFE ALACRAN}

Geographical Location $22^{\circ} 23^{\prime} \mathrm{N}, 89^{\circ} 41^{\prime} \mathrm{W}$; $135 \mathrm{~km}$ north of the port of Progreso on the Yucatán shelf.
Area, Depth, Altitude $25 \times 13 \mathrm{~km}, 185 \mathrm{sq} . \mathrm{km}$; maximum depth in lagoon is $23 \mathrm{~m}$.

Physical Features The general morphology of the atoll is described by Folk (1967a) and Hoskin (1963). Sediment composition is described by Bonet (1967), mineralogy of the muds by Hoskin (1968) and geology by Komicker et al. (1959). The north-west trend and general form of the atoll are due in part to the prevailing north-east trade winds and strong westerly currents. Its sub-oval pattern of outer reefs, enclosed shallow lagoon and relationship to the Campeche Bank characterize it as a shallow lagoon shelf atoll. The surrounding waters are $170 \mathrm{ft}(52 \mathrm{~m})$ deep. The atoll is subject to occasional hurricanes. Tidal range is about $2 \mathrm{ft}(0.6 \mathrm{~m})$. Lagoonal salinity ranges from about 30 to $34 \mathrm{ppt}$ and temperatures from 27 to $35^{\circ} \mathrm{C}$. Rainfall is extremely low other than during storms.

There are seven sand cays on the leeward rim of the reef, situated mainly to the north and south and together comprising less than $0.5 \mathrm{sq} . \mathrm{km}$. Despite several severe storms, the total land area of the cays for which data are available has quadrupled since 1899. All the cays are very low, with maximum heights of $3.4 \mathrm{~m}$, and consist largely of sand, with dune and beach ridges accounting for heights over 1 or $2 \mathrm{~m}$. They are described by Folk (1967a) and Fosberg (1962). Isla Pérez is the largest $(2850 \times 500-600 \mathrm{ft}(869 \times 152-183 \mathrm{~m}))$ and most complex. It is crescent-shaped and the main part is heavily vegetated with Suriana shrubs and a few Casuarina trees. Isla Pájaros $(2150 \times 60 \mathrm{ft}(655 \times 18 \mathrm{~m}))$ and Isla Chica $(650 \times 400 \mathrm{ft}(198 \times 122 \mathrm{~m}))$ are saucer-shaped and situated to the south-east near the south end of the reef. The central areas of both these islets are covered with grass; mangroves grow at the tip of Pajaros. Isla Desertora $(2300 \times 1000 \mathrm{ft}(700 \times 305 \mathrm{~m}))$ is situated one third of the way up the reef and is also saucer-shaped with a grassy central area and Portulaca and cactus. East $(2700 \times 300 \mathrm{ft}(823 \times 91 \mathrm{~m}))$ and West $(2900 \times 500 \mathrm{ft}$ $(884 \times 152 \mathrm{~m}))$ Desterrada Cays are situated to the north and were once a single island which was divided in the course of a hurricane in 1946. Both cays are very low and surrounded by large sand flats; West Desterrada has dunes covered with Tournefortia brush. Sediments of Isla Pérez, the most complex cay, are discussed by Folk and Robles (1964) and sedimentation composition of the other cays by Folk and Cotera (1971) and Hoskin (1967).

Reef Structure and Corals Arrecife Alacrán has a semi-circular well-developed windward reef on the eastern side, a less sharply defined belt of reef growth along the leeward margin and a central lagoon heavily choked with a maze of coral (Folk and Cotera, 1971). The windward reef forms a continuous barrier along the north, east and south-east which is emergent at low tide and is formed predominantly of Montastraea, Diploria and Acropora with coralline algae on the windward slopes. The western and south-western sides are much more irregular and without any marked line of emergent coral heads, leaving the lagoon open to the sea. This lee side is characterized by small patch reefs and submerged sand bars. The lagoon is filled with microatolls and ailastomosing north-trending chains of coral, giving a cellular pattern to the lagoon and making navigation difficult (Folk, 1967).

Reefs around Isla Pérez, located in the south-western part of the lagoon, are described by Kornicker and Boyd 
(1962) and MacIntyre et al. (1977). The reef on the north-east side of the island faces windward into the lagoon and has several zones. Acropora cervicornis dominates the reef crest and top of the reef slope; Montastraea anmularis dominates the west zone, and is followed by a Porites porites and a Lithothamnion zone. The reef on the south side has a $M$. annularis zone and an $A$ palmata zone. Two microatolls about $2 \mathrm{mi}$. (3.2 km) north of Isla Pérez were also examined. They rise from about $40 \mathrm{ft}(12 \mathrm{~m})$ depth to within a few feet of the surface and are $200-300 \mathrm{~m}$ in diameter. Acropora is scarce and $M$. annularis dominates on the upper slopes of the microatolls with scattered colonies of $P$. porites.

The windward reef was studied near the wreck known as the "boilers", to a depth of $40 \mathrm{ft}(12 \mathrm{~m})$. The leeward reef was studied in the vicinity of Isla Desertora and Desaparecida Bar. Detailed descriptions of zonation are given by Kornicker and Boyd (1962). The outer slope of the leeward reef shelves gently. Alcyonarians and Plexaura homomalla are abundant on the reefs. At least 18 coral species have been recorded (Chávez et al., 1985).

Noteworthy Fauna and Flora Bonet and Rzedowski (1962) and Fosberg (1962) discuss cay vegetation and fauna. The atoll is an important site for nesting seabirds and there are about 13 resident species. Blue-faced Boobies Sula dacılylatra nest on Pájaros, Desertora (large numbers) and Chica. Magnificent Frigatebirds Fregata magnificens nest on Chica, Desertora, both Desterradas and in huge numbers on Isla Pérez. Sooty Terns Sterna fuscata nest on East Desterrada and in huge numbers on Isla Pérez. The West Indian Monk Seal Monachus tropicalis used to be abundant, but may now be extinct at Alacrán, not having been seen since 1948. Green Turtles Chelonia mydas nest on Pérez, Pájaros and Desertora. Sharks are abundant, particularly in the shallow waters off Isla Pájaros (Folk, 1967). Hildebrand et al. (1964) recorded 142 species of fish. A list of insects was given by Fosberg (1962) and molluscs were described by Rice and Komicker (1962); Strombus gigas was considered abundant. In 1962, Thalassia beds were abundant (Fosberg, 1962); marine algae were described by Huerta (1961).

Scientific Importance and Research Arrecife Alacrán is the largest and most complex of the series of reefs lying along the edge of the Campeche Bank and is the only one with a central lagoon. The atoll has been extensively studied and is one of the best known in the Caribbean. In the early $1960 \mathrm{~s}$ it was investigated jointly by the Instituto de Geologia of the Universidad Nacional Autónoma de México and the University of Texas. Folk (1967) gave a summary of publications. CINVESTAV is currently giving priority to the study of the south-east Mexican reefs and Alcrán was surveyed by Chávez et al. (1985).

Economic Value and Social Benefits Isla Pérez is inhabited and has a lighthouse and weather station and West Desterrada has an automatic light. Altogether there are about 6-10 inhabitants, of whom about half are transient fishermen. There are at least two wrecks. The atoll was visited by traders from Jamaica in search of the West Indian Monk Seal which was killed for its oil (Fosberg, 1962). It is currently visited by fishermen who collect $S$. gigas for bait. The shells are piled up in mounds 1-1.5 m high on the beach, as at Pájaros, Chica and Pérez. Panulirus argus and fish, especially the Red Grouper Ephinephelus morio, are also taken, mainly by skin diving and spear gun. There is little likelihood that Alacrán will be developed for tourism, on account of its inaccessibility (Chávez, in litt., 1984; Santiago-Fandiño pers. comm.).

Disturbance or Deficiencies There is some evidence of disturbance by humans (Chávez in litt., 1984).

Legal Protection None.

Management None.

Recommendations None known.

\section{CAYOS ARCAS}

Geographical Location The most southerly cays on the Campeche Bank, west of the Yucátan Peninsula. $91^{\circ} 58^{\prime} \mathrm{E}, 20^{\circ} 12 \mathrm{~N}$; about $300 \mathrm{~km}$ south-west of Arrecife Alacrán.

Area, Depth, Altitude Shallow water platform has area of $3-4 \mathrm{sq} . \mathrm{km}$; water depth around the cays is about $40 \mathrm{~m}$.

Physical Features Cayos Arcas consists of three coral and sand cays enveloping a small protected lagoon on a shallow water platform which rises above the Campeche Bank. Easterly to north-easterly trade winds prevail and probably account for the typical north-west trend of the arcuate windward reef margin characterizing Cayo del Centro, the largest of the cays. Winds in this area are lighter and more variable ( $20-30 \mathrm{~km} / \mathrm{hour})$ from April to September than from October to March when speeds of $30-35 \mathrm{~km} / \mathrm{hr}$ are common. Hurricanes occur occasionally. The tidal range is small (about $1.0 \mathrm{~m}$ ) and the mean minimum water temperature is probably between 20 and $22^{\circ} \mathrm{C}$ (Farrell et al., 1983).

Reef Structure and Corals Over 20 species of coral have been recorded from the reefs but more species will probably be found if deeper parts are investigated. The most developed reef in terms of physical structure and coral coverage is a $3 \mathrm{~km}$ long, arcuate structure to the north-west of the central cay. An extensive reef flat, over $100 \mathrm{~m}$ wide, was almost completely covered by a dense monospecific stand of Acropora cervicornis when Farrell et al. (1983) visited the area. The zone from 1 to $3 \mathrm{~m}$ is now dominated by the zoanthids Palythoa caribaeorum and Zoanthus sociatus. From 3 to $7 \mathrm{~m}$, A palmata is dominant (Chávez et al, 1985). To the lee of this, the bottom gradually slopes from 7 to $18 \mathrm{~m}$ with a more diverse assemblage of corals, predominantly Acropora, Montastraea annularis and Diploria strigosa, with substratum coverage ranging from 20 to $60 \%$ and decreasing with distance from the reef flat. This back-reef area gives way to sandy substrata in the lagoon which has numerous patch reefs.

To the windward side of the reef flat there is a small non-emergent reef crest composed of unconsolidated coral rubble encrusted with calcareous red algae. No true algal ridge is present. On the fore-reef, the zoanthids Palythoa caribbea and Zoanthus sociatus are 
the dominant epibenthic fauna between 1 and $3 \mathrm{~m}$. From 3 to $7 \mathrm{~m}, A$ palmata is dominant, covering $75 \%$ of the substratum. Massive corals, particularly Montastraea and Diploria, and gorgonians are abundant below $7 \mathrm{~m}$ in a diverse community extending to approximately $350 \mathrm{~m}$ from the crest, and to a depth of $18 \mathrm{~m}$ where sand appears. At the more protected southern end of the reef, the Montastraea-Diploria community occurs in shallower water. The distribution of major reef zones on the reef is mapped by Farrell et al. (1983). High wave energy levels may account for some of the species distributions. The depth to which the fore-reef Palythoa and $A$ palmata dominated zones extends and the lack of $A$ cervicornis and Agaricia on the fore-reef is probably a result of intense wave action during storms. In back-reef areas with lower wave intensities the zonation is compressed and the coral head communities exist closer to the surface.

Noteworthy Fauna and Flora The cays are covered with various plants, the largest of which are chest-high shrubs and a few introduced Casuarina trees and cactus. Several hundred Blue-faced Boobies Sula dactylatra and about 20 pairs of Magnificent Frigatebirds Fregata magnificens nest on the island (Farrell in litt., 1984). A Nurse Shark (Orectolobidae) breeding site has recently been recorded (Rodriguez pers. comm., 1984). Waters off the west coast of the Yucatan Peninsula include excellent foraging areas for Loggerhead Caretta caretta, Hawksbill Eretmochelys imbricata and Green Chelonia mydas Turtles (Carr et al., 1982); the Loggerhead and Hawksbill may nest on the island.

Scientific Importance and Research Coral diversity appear to be greater here than elsewhere on the western Yucatán shelf (Farrell et al., 1973). The absence of Halimeda, the calcareous green alga which is the dominant producer of carbonate sediments on the Alacrán reef, is notable. A continuing environmental monitoring programme was instituted before the construction of the oil terminal (Farrell et al., 1983). The Mexican Government and the national oil company PEMEX are thought to be interested in studying the fauna and the flora of the cays (Farrell in litt., 1984). Farrell et al. (1973) and CINVESTAV have briefly surveyed the area (Chávez et al., 1985); the latter consider that this site offers potential for monitoring reefs affected by human activities.

Economic Value and Social Benefits There is a lighthouse and several small buildings on the island; PEMEX employees live there from time to time. The lagoon is a popular refuge for local shrimp and shark fishermen (Farrell et al., 1983). Tourism is unlikely to develop on the Cayos Arcas as they are not easily accessible and are too small to build both an airstrip and tourist facilities (Farrell, 1983).

Disturbance or Deficiencies The Cayos Arcas are at the northern boundary of Mexico's offshore petroleum resources. A deepwater oil terminal has been built in the sheltered waters south of the cays with a daily loading capacity exceeding half the total daily national export flow of more than 2 million barrels (Orme, 1982; Chávez et al., 1985). This has caused significant stress to the reef biota (Chávez et al., 1985), the dense covering of $A$ cervicornis in shallow water having largely disappeared.

Legal Protection None.
Management None.

Recommendations The results of the current environmental project must be considered and a monitoring programme should be established to follow the community structure through time (Chávez et al. 1985).

\section{PARQUE MARINO LA BLANQUILLA}

Geographical Location $19^{\circ} 13^{\prime}-19^{\circ} 14^{\prime} \mathrm{N}, 96^{\circ} 30^{\prime}-96^{\circ} 60^{\prime} \mathrm{W}$; about $4.6 \mathrm{~km}$ from port of Veracruz, State of Veracruz.

Area, Depth, Altitude 668680 sq. m; lagoon average depth $1.25 \mathrm{~m}$; maximum depth of drop-off $37 \mathrm{~m}$; maximum elevation $1.80 \mathrm{~m}$.

\section{Land Tenure Public (Government managed).}

Physical Features La Blanquilla Reef is part of the northernmost part of the Veracruz coastal reef complex influenced by the waters of the rivers Atoyac and Jamapa. It is oval in shape, oriented NW-SE with a lagoon surrounded by a circular reef which is rarely exposed. On the south-west leeward side there is a small cay (El Peyote), 2000 sq. $m$, formed of sand and coral rubble with little vegetation. The lagoon bottom is mainly sandy with a depth of $0.35-1.25 \mathrm{~m}$. It is very sheltered. Visibility is about 3-10 $\mathrm{m}$ dropping to $2.5 \mathrm{~m}$ on the western side. Two depressions run either side of the cay; the western one is sandy and about $200 \mathrm{~m}$ in length with a maximum depth of $2 \mathrm{~m}$; the eastern one is $50 \mathrm{~m}$ long with increasing depth and a more acute slope (Kühlmann, 1975; Santiago-Fandiño, 1977; Villalobos-Figueroa, 1971).

The climate is sub-humid and hot with a rainy season in the summer (mean maximum annual precipitation: $350 \mathrm{~mm}$ ) and a dry season in the autumn (mean minimum annual precipitation: $25 \mathrm{~mm}$ ). The mean maximum annual temperature is $28^{\circ} \mathrm{C}$ and the minimum $21^{\circ} \mathrm{C}$. The water temperature varies with depth, from 28 to $29^{\circ} \mathrm{C}$ at the surface to $13.5^{\circ} \mathrm{C}$ at $10 \mathrm{~m}$ in the winter. The lagoon temperature decreases towards the north-east, as a result of the influence of oceanic water. Salinity is between 36.0 and 36.7 ppt but may drop to $32 \mathrm{ppt}$ in the lagoon. The reef is under the influence of the monsoons in the autumn and winter during which winds up to $120 \mathrm{~km} / \mathrm{h}$ occur. The area is also affected by hurricanes, with windspeeds up to $200 \mathrm{~km} / \mathrm{h}$. Water clarity varies seasonally from 1.5 to $15 \mathrm{~m}$ visibility. The reef has three different types of waters: oceanic, mixed and coastal and the prevailing currents are from the N-NE (Santiago-Fandiño, 1977; Villalobos-Figueroa, 1971). Prevailing winds are from the south-east and north-east, and in the winter occasionally from the north.

Reef Structure and Corals The La Blanquilla Reef is generally similar to the other reefs of the complex. The lagoon, with $7 \%$ coral cover, is dominated in the centre by colonies of Diploria strigosa and $D$. clivosa up to $1 \mathrm{~m}$ in diameter. Siderastrea radians and Porites astreoides are also abundant, but living Acropora palmata is scarce, with many dead colonies and little new growth. The west side of the lagoon is an area of sand 
deposition. Millepora alcicornis is abundant around the edge, forming part of the reef barrier, but $D$. strigosa and $D$. clivosa are dominant. $P$. porites becomes abundant in the north-east part of the lagoon, where oceanic waters circulate. In the south-east, there is a large turtle grass bed of Thalassia testudinum; in the north-east Zoantharia covers large areas.

The windward or eastem side of the outer reef slope has been poorly studied because of the surf. The reef crest has few stony corals but abundant Zoantharia. The slope consists of a mixture of terraces and cliffs with abundant growths of $A$ palmata, the colonies of which are small and oriented to the south-west. The leeward or western outer slope is steep and dissected and has many large colonies of Montastraea annularis, often conical in form and up to $3 \mathrm{~m}$ in height. Patches of healthy $A$ prolifera cover $10 \%$ of the substratum. $A$ palmata covers $2 \%$ of this area, the colonies being greatly branched. D. clivosa, $D$. strigosa, Siderastrea siderea and $S$. radians are also found as well as patches of $A$ cervicornis and $M$. cavernosa.

From the west to the north, the outer slope of the reef has diverse corals. A palmata is dominant with large colonies and covers $25 \%$ of the substratum up to $3 \mathrm{~m}$ depth. From $6 \mathrm{~m}$ downwards, $D$. strigosa is dominant in a community including $M$. annularis, D. clivosa and Colpophylia natans. In some areas there are small buttress-like zones. Towards the north, depth increases and cliffs and terraces appear, the zonation becoming increasingly less obvious. Twenty-seven corals have been recorded from La Blanquilla and are listed by Santiago-Fandiño (1977); this is a poorer fauna than Caribbean reefs further east. A popular account of the reef is given in Castello (1971).

Noteworthy Fauna and Flora The cay is covered with vegetation, including Tournefortia guaphalodes (Borraginaceae), Ipomea litoralis (Convolvulaceae) and Sesuvium postulacastrum (Aizoaceae). It is an important nesting site for a variety of birds including Least Stema albifrons antillarum, Bridled S. anaethetus and Black Chlidonias niger Terns, Franklin's Gulls Larus pipixcan, Ruddy Turnstones Arenaria inter pres morinella and Brown Pelicans Pelecanus occidentalis; it is also frequented by Magnificent Frigatebirds Fregata magnificens (Villalobos-Figueroa, 1971). The Caribbean Manatee Trichechus manatus, Loggerhead Turtle Caretta caretta, Kemp's Ridley Turtle Lepidochelys kempii and Leatherback Turtle Dermochelys coriacea may occur here (Groombridge, 1982). The Green Turtle Chelonia mydas and Hawksbill Turtle Eretmochelys imbricata definitely occur (Santiago-Fandiño pers. comm., 1984). Sea turtles in Veracruz are heavily exploited and are generally depleted. Several important commercial fish species are found: snappers Lutjanus sp., grunts Haemulon sp. parrotfish Scarus sp., jacks Seriola sp., pompano Trachinotus sp., mackerel Decapterus sp., grouper Epinephelus sp., tarpon Megalops sp. and octopus Octopus sp. The sponge fauna is described by Green (1977).

Scientific Importance and Research The Sección de Hidrobiología del Instituto de Biología de la UNAM initiated a hydrobiological study here in 1963, which has resulted in many publications listed by Villalobos-Figueroa (1971) and Santiago-Fandiño (1977).
La Blanquilla is a particularly good research site on account of its diversity and the changes due to storms and winds, and its proximity (about two miles $(3.2 \mathrm{~km})$ ) to pollution sources makes it suitable for pollution monitoring studies. The many studies (Kühlmann, 1975; Santiago-Fandiño, 1977; Villalobos-Figueroa, 1971) carried out here make it one of the classic reef sites.

Economic Value and Social Benefits In the past, the inhabitants of Veracruz used corals as a building material (Villalobos-Figueroa, 1971); the port of Veracruz fortress was built by the Spaniards in $16 / 17$ th century using colonies of Diploria sp. and oyster shells (Santiago-Fandiño in litt., 2.3.85). There are two automatic lighthouses. The reef is used by fishermen, and is visited by SCUBA divers, snorkellers, other recreational visitors and groups of students. There is potential for further use of the area for fisheries, recreation (diving) and education.

Disturbance or Deficiencies Corals were taken by snorkellers and divers for souvenirs and major damage was done by collectors who removed coral for the commercial curio trade, but such activities have almost ceased. Anchors and boat propellers have caused damage, particularly to colonies of $A$ palmata, $A$ cervicornis and Diploria sp. Ninety per cent of the $A$ palmata colonies in the lagoon are dead, perhaps as a result of low tides exposing the colonies coinciding with heavy rainfall, a combination of factors observed several years ago (Santiago-Fandiño in litt., 1984). It is also possible that human activities were involved. Fish and octopus populations have been over-fished, and the spiny lobster Panulirus is extremely scarce although it is not clear if this is due to over-collection.

The reef is very vulnerable to pollution from the port of Veracruz, both domestic and industrial, and to oil pollution from the passage of petroleum tankers close to the reef (Santiago-Fandiño, 1977). Urban sewage causing high organic matter levels and turbidities is considered a particularly serious problem (Chávez in litt., 1984). However, the Ixtoc-1 oil spill does not seem to have had any lasting effect in this region (Villalobos-Figueroa, 1981).

Legal Protection The first Marine Park in the Gulf of Mexico, La Blanquilla was proclaimed 28 July 1975. Commercial fishing and sport fishing including spearfishing are forbidden. It is also forbidden to leave fish waste on the beaches. Legal protection covers $100 \%$ of the reef.

Management Administered by the Secretaria de Desarrollo Urbano y Ecología (SEDUE), Dirección de Fauna y Flora Acuática, México D.F., but as yet there is no enforcement of the legislation. In the past, a dive shop proprietor kept a degree of control over activities on the reef (Santiago-Fandiño in litt., 1984). The Navy now maintains fairly strict control and permission is required to visit the reef.

Recommendations SEDUE is carrying out a project on the Veracruz reefs which will lead to improved management at La Blanquilla. Recommendations for $\mathrm{La}$ Blanquilla include: 1) improved enforcement of the legislation; 2) monitoring of the reef; 3) improved recreation facilities; 4) prohibiting collection by schools 
and universities; 5) education of locals and tourists as to the importance of the coral reef and park; 6) further research.

We are very grateful to Vicente Santiago-Fandiño for compiling this account.

\section{BANCO CHINCHORRO}

Geographical Location $\quad 18^{\circ} 47^{\prime}-18^{\circ} 23^{\prime} \mathrm{N}, 87^{\circ} 14^{\prime}-87^{\circ} 27^{\prime} \mathrm{W}$; 15 miles $(24 \mathrm{~km})$ off coast of south-eastem Quintana Roo, between Xcalak and El Ubero.

Area, Depth, Altitude $46 \mathrm{~km} \mathrm{x} 14 \mathrm{~km}$; lagoon maximum depth $11 \mathrm{~m}$ in the south, becoming shallower to $3-4 \mathrm{~m}$ near Cayo Centro, and $2 \mathrm{~m}$ in the north.

Physical Features Part of the Great Atlantic Reef Belt, the bank is egg-shaped and is separated from the mainland by a $1000 \mathrm{~m}$ deep channel. The outer reef surrounds an interior lagoon. The western slope is particularly steep. In the Yucatán Strait, the current is strong (often over 2 knots) and northerly; on top of the Bank there is a steady slower SE-NW current. There are four cays. Cayo Norte consists of two mangrove covered islands; Cayo Centro, the largest, is a mangrove island in the lagoon and Cayo Lobos, the smallest, is an elliptical sandy bank $300 \mathrm{~m}$ long at the southern end of the reef with no mangroves (Chávez and Hidalgo, 1984). Salinity is 36.6-36.94 ppt; other hydrographic features are described by Chávez et al. (1985).

Reef Structure and Corals Chávez and Hidalgo (1984) recognise five main zones: the fore slope, the rear slope, the fore ridge, the rear ridge and the lagoon. Gorgonia flabellum is the most abundant alcyonarian on the bank and 15 scleractimans and 14 alcyonarians have been recorded (Chávez et al., 1985).

The fore slope consists of alternate steeply sloping coral ridges and grooves, extending from near sea-level to 15-25 $\mathrm{m}$ deep with abundant corals. From 15 to $25 \mathrm{~m}$ an almost flat terrace of sand extends seaward with corals and soft corals. Acropora palmata is abundant in shallow water and is replaced by $A$ cervicornis but Gorgonia flabellum is dominant on the ridges. Agaricia agaricites and Millepora are also common on top of the ridges.

The rear slope has a sandy subzone extending from 2 to $60 \mathrm{~m}$ depth, and an inner subzone $200-300 \mathrm{~m}$ wide which is often difficult to separate from the rear surf zone; it is composed of reef patches $3-4 \mathrm{~m}$ high covered with massive corals, dominated by Montastraea annularis, Diploria strigosa and Colpophyllia natans, and alcyonarians and loggerhead sponges.

The fore ridge is a continuous ridge of Acropora palmata rising to $2-3 \mathrm{~m}$ below the surface. The $500 \mathrm{~m}$ wide inner slope of hard substrate is covered with encrusting algae and small colonies of D. strigosa, Porites porites and Siderastrea radians, with soft corals and algae. The western side of the bank has a surf ridge of $A$ palmata and massive corals, although the dominant elements are $G$. flabellum and Briareum asbestinum.
The lagoon is being actively filled by sediment from the windward side. In the south there are patch reefs which become less common and disappear in the north. Millepora alcicomis and $P$. astreoides are dominant in the south, $G$. flabellum in the centre and Sphesiospongia vesparium in the north.

Noteworthy Fauna and Flora Garden eels, sometimcs at high densities, are found on the sandy part of the rear slope, as well as the Queen Conch Strombus gigas. There are abundant large fish. Mangroves are found on the islands. A Thalassia seagrass bed is found in the shallower northern part of the lagoon (Chávez and Hidalgo, 1984). The marine algae of the Bank are described by Huerta and Garza (1980). Cayo Centro is an important breeding site for Frigatebirds Fregata magnificens and the Olivaceous Cormorant Phalacrocorax olivaceus (López-Ornat in litt., 21.9.84). Dugongs and turtles probably occur there.

Economic Value and Social Benefits The area is fished for Strombus gigas and Panulirus argus by fishermen from Xcalak, (López-Ornat in litt., 21.9.84). There are two lighthouses and many wrecks. The bank is gradually becoming popular with SCUBA divers who make 4-6 day trips from Cancún.

Disturbance or Deficiencies In the $1950 \mathrm{~s}$ and $1960 \mathrm{~s}$ spiny lobsters were being taken illegally from the bank by Belize fishermen. However, the fishing potential is considerable and current disturbance is probably small (López-Ornat in litt., 21.9.84).

\section{Legal Protection None.}

Management The bank is the exclusive fishing ground of the Co-operativa de Pescadores de Xcalak and is managed by the fishermen (López-Ornat in litt., 21.9.84).

Recommendations None known.

\section{PARQUE SUBMARINO COZUMEL}

Geographical Location $20^{\circ} 16^{\prime}-20^{\circ} 36^{\prime} \mathrm{N}, 86^{\circ} 44^{\prime}-86^{\circ} 03^{\prime} \mathrm{W}$; east coast of Isla Cozumel, 8 miles $(12.9 \mathrm{~km})$ off north-east tip of Yucatán Peninsula, State of Quintana Roo.

Area, Depth, Altitude Cozumel is $30 \times 10$ miles $(48 \times 16 \mathrm{~km})$.

Physical Features Isla Cozumel is separated from the mainland by a deep water channel and is surrounded by exceptionally clear water with strong currents in some areas. About 20 reefs have been identified and charted for diving. Most of the best reefs are located off the south-west coast. They form on ridges on the edges of submarine terraces and are influenced by the strong currents in the area (Zlatarski, 1984).

Chankanaab Lagoon, within the refuge and $10 \mathrm{~km}$ south of the town of San Miguel, is a rare example of a cenote or sink hole containing coral life, connected to the sea by an underground channel (54 $\mathrm{m}$ long) with two entrances 
into the lagoon and one into the sea (Garduno, 1984). There is a series of underwater caves along the shore line, into which freshwater flows, creating a halocline. Nearshore, the bottom is shallow and sandy, largely due to the presence of an artificial reef.

Reef Structure and Corals Recent algal bioherms near Cozumel are described by Boyd et al. (1963). The reefs are basin or cup reefs, with a principal framework of coral and an algal rim outlining the periphery. A brief diving guide to Cozumel (Anon., undated) describes some of the more popular diving sites. Paraíso Reef consists of a series of three inshore reefs lying just north of the International Pier, 200 yds $(183 \mathrm{~m})$ offshore, and a reef south of the Pier, which is divided into sections, each one about 500 yds $(457 \mathrm{~m}$ ) long, slightly further offshore.

Further south, in the Chankanaab Lagoon, coral life flourished in the recent geological past and there are two small fossil reefs. The lagoon is now heavily filled with sediment (see below) and natural coral growth is limited to Montastraea annularis, Agaricia agaricites, Siderastrea radians, Porites porites and $P$. astreoides (Garduno, 1984). Off shore there are several large coral heads at $28 \mathrm{ft}(8.5 \mathrm{~m})$ depth, reaching to within $14 \mathrm{ft}(4.2 \mathrm{~m})$ of the surface with abundant marine life

Tormentos Reef is situated off Punta Tormentos, south of Chankanaab, and consists of more than 60 coral heads on a sandy bottom at $25-35 \mathrm{ft}(7.6-10.7 \mathrm{~m})$. Yocab Reef is about 400 yds ( $366 \mathrm{~m}$ ) long, fairly shallow and lies a mile $(1.6 \mathrm{~km})$ south of Punta Tormentos. Tunich Reef is slightly deeper and has stronger currents; it lies off Punta Tunich, about half a mile $(0.8 \mathrm{~km})$ south of Yocab. San Francisco Reef runs parallel to San Francisco beach, half a mile $(0.8 \mathrm{~km})$ from shore. The Santa Rosa Wall is the second most popular drop-off for diving; it begins at $70 \mathrm{ft}$ $(21 \mathrm{~m})$ and has strong currents.

Palancar Reef, the most well known diving site, is a conglomeration of many different coral formations stretching for three miles $(4.8 \mathrm{~km})$, lying one mile $(1.6 \mathrm{~km}$ ) off shore in a region of strong currents (up to 4 knots). The north is shallower, the drop-off starting at $50 \mathrm{ft}(15 \mathrm{~m})$; in the south it starts at $90 \mathrm{ft}(27 \mathrm{~m})$ and there are coral pinnacles up to $60-70 \mathrm{ft}(18-21 \mathrm{~m})$ tall. At a spot called Horseshoe, a series of coral heads at the top of the drop-off form a natural horseshoe shape. It is the most diverse reef and a number of new species have recently been described there (López-Ornat in litt., 21.9.84). Colombia Reef is a few miles south of Palancar; the drop-off starts at $70-90 \mathrm{ft}(21-27 \mathrm{~m})$ and is similar to Palancar. At Maracaibo Reef, off the southern tip of Cozumel, the drop-off starts at $120 \mathrm{ft}(36 \mathrm{~m})$; there are usually strong currents, and large coral formations, caves and crevices are found.

Noteworthy Fauna and Flora Loggerhead Caretta caretta, Hawksbill Eretmochelys imbricata, Leatherback Dermochelys coriacea and Green Chelonia mydas Turtles nest on Cozumel (Bacon et al., 1984). The Caribbean Manatee Trichechus manatus may occur. Fish are abundant particularly at Tunich Reef (large fish including Manta Rays, barracuda and moray eels), Chankanaab Lagoon (tarpon and barracuda), Santa Rosa Wall (jack, eagle rays, shark and many others), Palancar and Colombia drop-offs (large groupers, jacks and occasionally turtles). Algae are described by Huerta (1961).
Scientific Importance and Research Detailed studies of the reefs, particularly Palancar, are being carried out by CINVESTAV (López-Omat in litt., 1984). Cozumel still has many unspoilt reefs and provides an ideal area for the study of reef management in relation to the development of tourism. The Instituto de Ciencias del Mar y Limnologia, UNAM, has recently started a research programme in the area. One project is concerned with shallow and deep reef formations and another with recovery and management of corals in Chankanaab Lagoon.

Economic Value and Social Benefits Tourism is rapidly expanding in this area and the Cozumel reefs attract many visitors including SCUBA divers, cruise ships and package tour holidays. In 1973 Chankanaab Park was developed as a tourist centre, with dive and snorkel gear rental shops, a restaurant and other facilities (Garduno, 1984). The park receives up to $400-500$ visitors a day, particularly at the height of the season when parties of 200 or more visit from cruise ships. A fishery co-operative exploits various commercial fish species. The area is used for SCUBA training because of its easy access, shallowness and visitor facilities. A botanical garden has been planted around the lagoon.

Wall diving at Palancar Reef is a particularly popular activity for SCUBA enthusiasts. Other popular dive sites include Paraiso Reef (north and south), Plane Wreck (the wreck of an airliner at the north end of Paraiso Reef), La Ceiba Reef, Chankanaab Caves, Tormentos Reef, Yocab Reef, Tunich Reef, San Francisco Reef, Cardona Reef, La Francesca Reef, Herradura Reef, Barracuda Reef, Ladrillas Reef (Anon., undated).

Black coral is collected on Palancar Reef (Castorena and Metaca, 1979) and probably on other reefs, and is the basis of an important industry on the island. There are about 500 black coral carvers but only a few divers. Collecting is prohibited above $150 \mathrm{ft}(46 \mathrm{~m})$, but coral colonies of commercial quality are found mainly below $240 \mathrm{ft}$ (73 m) (Kenyon, 1984).

Disturbance or Deficiencies There is very little freshwater run-off, no heavy industry or extensive land development and still considerable areas of forest on the island. Most of the population of 20000 inhabitants and visitors are concentrated in the 10 mile $(16 \mathrm{~km})$ stretch of hotels and urban housing along the west coast, centred on San Miguel. However, tourism may be having an impact on the reefs (Anon., undated). There is said to be unavoidable damage through trampling (Chávez in litt., 1984) and there have been reports of excessive spearfishing and collecting of marine curios, leading to depletion of fish. Black coral has been over-collected in many areas (Castorena and Metaca, 1979). Small dive boats do not anchor on the offshore reefs, but some of the larger ones do and may cause damage.

Before it was established as a Park, Chankanaab Lagoon was a popular picnic site and suffered extensive damage from littering and trampling. In the past few years, storms and cyclones, such as Cyclone Beulah in 1967, have deposited sediment into the lagoon, covering much of the coral life. Recreational use of the lagoon has almost destroyed the remaining natural coral growth. An artificial beach adjacent to the lagoon, a poorly treated sewage system (developments associated with the tourist centre) and the use of fertilizers in the Park botanical 
gardens have increased sand deposition and algal growth (Garduno, 1984). The reef itself has also been severely damaged by trampling, littering and heavy pressure from visitors.

Legal Protection A 20 mile $(32 \mathrm{~km})$ stretch of reefs was designated a Marine Refuge by decree on 11 June 1980 . This extends from the International Pier south to Punta Celerain at the southern tip of the island between the high-tide mark and the $50 \mathrm{~m}$ isobath. Spearfishing, black coral diving, shell collecting and the removal of any form of marine life are prohibited within this area (Anon., undated). Chankanaab Park was established within the refuge in 1973, specifically for tourists. The regulations for the rest of the marine refuge apply here and in addition, boats are prohibited from entering the Park area.

Management No action has been taken to implement the legislation, but boat operators and dive guides are considered responsible for enforcing regulations within the park. Local people such as boatmen and people working in the tourist industry are concerned about the health of the reefs. Mexican dive guides are reported to be setting up fish feeding stations. A 120 yd $(110 \mathrm{~m})$ long underwater trail has been installed on $\mathrm{La}$ Ceiba Reef, sponsored by the La Ceiba Hotel.

In creating Chankanaab Park, the coast road was rerouted to the other side of the lagoon and the old road covered with sand to create a beach. A project is now under way to try and restore the coral communities in the lagoon. Dredging of sediment from the channel and lagoon will hopefully increase seawater input, improve circulation and clear bedrock surfaces in the lagoon, providing improved conditions for coral growth (Garduno, 1984).

Recommendations It has been recommended that the Cozumel Reefs be proclaimed as a National Park and that the entire east coast be included within such an area. This suggestion has already been put before the relevant authorities in Mexico City. Mooring buoys should be placed at the most frequently dived reefs, particularly Palancar. In the future it may be necessary to close reefs to divers on a rotational basis to allow the corals time to recover. Although Palancar is the most well known and popular reef, others are equally good.

Garduno (1984) makes a number of recommendations for future management of Chankanaab Park. A natural barrier of plants and shrubs is to be built to prevent sedimentation from the beach into the lagoon. A new treatment system for sewage is required to stop algal growth in the lagoon, and fertilizers should not be used in such large quantities in the gardens. An information and interpretive centre should be established, with exhibitions, slide shows, films and an aquarium so that tourists benefit educationally from their visit. There are long term plans for the establishment of a coral reef research centre to be based in Cozumel. Long term monitoring studies of the reefs are urgently required.

\section{ISLA DE LOBOS}

Geographical Location $21^{\circ} 28^{\prime}, 97^{\circ} 13^{\prime} \mathrm{W}$; state of Veracruz, 35 miles $(56 \mathrm{~km})$ north-east of Tuxpan, $100 \mathrm{~km}$ south-east of Tampico, 7 miles $(11.3 \mathrm{~km})$ from the coast.

Area, Depth, Altitude Reef area is $8000 \times 3500 \mathrm{ft}$ $(2440 \times 1067 \mathrm{~m})$ at low tide; maximum depth in lagoon is $8 \mathrm{ft}(2.4 \mathrm{~m})$; average depth $2 \mathrm{ft}(0.6 \mathrm{~m})$.

Physical Features Isla de Lobos is the southernmost reef and cay of a group of three structures (including Arrecife Blanquilla and Arrecife Medio) lying on a broad, shallow, detrital-blanketed shelf. The sand cay $(2000 \times 1000 \mathrm{ft}(610 \times 305 \mathrm{~m}))$ has a maximum elevation of 11-12 ft (3.3-3.6 m), is crescent-shaped and situated in the south-western part of the lagoon. The reef around the island is slightly crescent-shaped and is situated on a gently eastward dipping platform off the main coast of Mexico. It rises from a gently sloping surface, approximately $120 \mathrm{ft}(36 \mathrm{~m})$ deep, to a relatively uniform flat-topped lagoon, now virtually at low-tide level. The shallow, saucer-shaped lagoon is reef-rimmed, with the margin well defined on the windward side as an algal ridge which reaches low tide. Most of the shallow areas are covered by Thalassia which is exposed at maximum low tide. A broad apron of sand extends south of the reef and two well-defined ridges of sand stretch from the north-west and south-west tips of the reefs.

Prevailing winds are south-easterly, interrupted periodically by strong north-westerlies. Two channels into the lagoon at the southern end of the island have strong currents through them. Water circulation within the lagoon has been altered by the construction of a causeway and ship channel and is described by Rigby and MacIntyre (1966). Outside the lagoon, circulation around the reef is mainly from east or south-east towards the west. Occasional storms from the north-west have a considerable impact on the island. Visibility is normally about $20 \mathrm{ft}(6 \mathrm{~m})$ in the lagoon, except during storms and in the ship channel. On the windward reef, visibility is normally $60-80 \mathrm{ft}(18.3-24.4 \mathrm{~m})$ and up to $150 \mathrm{ft}(45.7 \mathrm{~m})$ on occasions; on the leeward reef it is less, due to the westward drift of sediments across and off the platform (Tunnell in litt., 9.10.85). There is a single tidal cycle a day with a small tiđal fluctuation (Chávez et al., 1970; Rigby and McIntyre, 1966).

Reef Structure and Corals Detailed descriptions of reef habitats and communities are given by Hidalgo and Chávez (1967) and Rigby and Macintyre (1966), as well as descriptions of rocky and sandy shore habitats. The leeward reef is characterized by deep steep-walled, broad grooves separated by flat-topped spurs. The windward reef has numerous radiating, V-shaped grooves separated by sharp-crested spurs, and extends north of the lagoon for nearly half a mile $(0.8 \mathrm{~km})$ in the form of two parallel ridges. Thalassia testudinum blankets much of the interior of the shallow lagoon. A Thalassia-Porites community is found along the western margin of the lagoon and a Thalassia-Diploria community along the eastern margin behind the reef crest. Lithothamnium is abundant in the lee of the windward reef at the margin of the lagoon particularly to the north.

On the reef itself, there is a broad zone of Diploria clivosa at the edge of the lagoon behind 
the Lithothamnion ridge, where this is well-developed, or at the reef crest. D. clivosa is particularly abundant at the north end of the leeward reef and along the western margin of the lagoon where it may cover $70-80 \%$ of the area with heads up to $2-3 \mathrm{~m}$ in diameter although only a few $\mathrm{cm}$ high. The Lithothamnium ridge on the reef crest is best developed in the north on both the windward and leeward reefs, where it may reach $1 \mathrm{~m}$ in height and is constantly awash with strong surf. It is less well-defined in the south-east where corals may cover $40-50 \%$ of the surface. In the south-west the ridge is not pronounced and the western edge of the lagoon slopes gently seaward, although Lithothamnium is still dominant, covering $60-70 \%$ of the surface.

The upper part of the windward and leeward reefs is dominated by an Acropora palmata community down to $5 \mathrm{~m}$ depth. This is followed on the leeward reef by a Montastraea annularis zone and on the windward side by a $D$. strigosa zone. At depths greater than $18 \mathrm{~m}$, particularly at the southern end of the reefs, a $M$. cavernosa zone is found. Further details are given in Rigby and MacIntyre (1966). Octocorals are described by Chamberlain (1966). The reef has also been described in detail by Chávez (1973) and Chávez et al. (1970).

Noteworthy Fauna and Flora The island is largely covered with palms; a list of terrestrial plants is given in Hidalgo and Chávez (1967). A detailed study of the Thalassia community was carried out by Chávez et al. (1970) and marine algae are listed by Huerta and Garza (1965). The foraminifera of the reef are described by Bautista-Gil and Chávez (1977), polychaetes by Roberts (1981) and decapods by Allen (1982). Tunnell (1974) recorded 220 mollusc species from the reef and a detailed study of the 130 fish recorded there has been made by Castro-Aquirre and Marquez-Espinoza (1981). The Caribbean Manatee Trichechus manatus may occur. The area was formerly a good nesting and foraging zone for the Hawksbill Turtle Eretmochelys imbricata but numbers are now badly depleted (Carr et al., 1982). The Kemp's Ridley Lepidochelys kempii, Leatherback Dermochelys coriacea and Green Turtle Chelonia mydas may occur here; the Loggerhead Caretta caretta nests in the region of Tuxpan.

Scientific Importance and Research Isla de Lobos is a suitable site for research as most of the lagoonal and upper reef regions are readily available without using a boat. Development of dock facilities by the Pemex petroleum company has improved access to the surrounding deeper water, and the petroleum company makes regular trips between the island and the mainland (Rigby and MacIntyre, 1966). Studies of the reef have been carried out by Hidalgo and Chávez (1967) and Rigby and MacIntyre (1966).

Economic Value and Social Benefits Oil is extracted from within the lagoon. A light house is situated on the cay (Rigby and MacIntyre, 1966). There are about ten permanent inhabitants and occasional tourists. Fishing is an important activity (Chávez in litt., 1984).

Disturbance or Deficiencies A petroleum well platform is situated on the reef flat, immediately behind the windward reef crest, and there are seven producing oil wells. A ship channel and associated spoil pile, topped by a road, has been dredged through the western (leeward) lagoon to the north-west point of the island where dock facilities have been established, bisecting the lagoon. This has caused a certain amount of damage. It appears that the area between the island and the spoil piles may now be becoming filled with fine sediment and abnormal lagoonal communities have already developed. Coral development is now poor west of the island and south of the ship channel. A detailed description of this area is given by Rigby and MacIntyre (1966).

Legal Protection No information.

Management No information.

Recommendations Fishing should be controlled and quotas established; there should be no further increase in the resident population and no introductions of exotic species (Chávez in litt., 1984).

\section{NORTH-EAST YUCATAN REEFS (INCLUDING REFUGIO MARINO PUNTA CANCUN-NIZUC AND RESERVA ECOLOGICA ISLA CONTOY)}

Geographical Location State of Quintana Roo; north-east tip of Yucatán Peninsula including Isla Contoy, Isla Mujeres, Cancín, Punta Nizuc, Finduvet and areas south to Puerto Morelos.

Physical Features Isla Contoy (176 ha; $6 \mathrm{~km} \times 20-700 \mathrm{~m}$ ) is at the extreme north-east of the Yucatán Peninsula, $30 \mathrm{~km}$ north of Isla Mujeres and $12.5 \mathrm{~km}$ from the coast. It has a mainly rocky coastline with small sandy beaches and three interior lagoons (Anon., undated b), and has the most northerly reefs in this area including a small patch reef, Isla Che between Contoy and Isla Mujeres. No studies have been carried out on these reefs and although they are popular with snorkellers they are probably not as rich as the reefs further south.

Isla Mujeres, to the south of Isla Contoy, is $8 \mathrm{~km}$ long. There is a patch reef one $\mathrm{km}$ off the south-west shore called Los Manchones; it measures $700 \mathrm{m \times 1} \mathbf{k m}$ and is in $30-40 \mathrm{ft}$ ( $9-12 \mathrm{~m}$ ) of water. At El Garrafón, opposite Los Manchones, there is a shallow fringing reef; on the northern tip of the island is another rather poor fringing reef. Folk (1967) described carbonate sediments off the island.

Isla Cancún is a sandy island $21 \mathrm{~km} \times 400 \mathrm{~m}$, separated from the mainland by Nichupte Lagoon which is connected to the sea by two canals. Punta Cancun is the most northerly point and Punta Nizuc is the southern point; white sandy beaches are found the length of the island and the water is very clear. Nichupte Lagoon is about 1.5-2.0 $\mathrm{m}$ deep, with a maximum depth of $3.5 \mathrm{~m}$ and is covered mainly with seagrass Thalassia testudinum. Jordan et al. (1978) describe the benthic communities of Nichupte Lagoon at Cancún and Castro (1976) describes benthic communities between Carmen and Isla Mujeres.

There is an almost continuous reef along the coastline of Quintana Roo resembling in part barrier and in part fringing reef (Jordan, 1979b). From Punta Nizuc to Punta Caracol the shoreline is formed from calcareous rock; much of the rest of the coast to Puerto Morelos has 
sandy beaches. Immediately seaward of the beach is a zone with patches of Syringodium and Halodule, and in some areas small Thalassia beds. The lagoon is variable in width, ranging from $50-60 \mathrm{~m}$ at Punta Nizuc to $3 \mathrm{~km}$ at Bajo Finduvet, and in general is wider in the north than in the south. The average depth is $5-7 \mathrm{~m}$, although in the north, depths of 6-10 $\mathrm{m}$ are reached. The bottom is largely covered with Thalassia, often with scattered Manicina areolata colonies, although in some places bedrock is visible, in which case large sponges may be abundant with scattered octocorals. At Punta Nizuc in the north there is a triple barrier reef, each barrier separated by channels about $10 \mathrm{~m}$ deep covered with Thalassia testudinum. The interior barrier is about 3-4 $\mathrm{m}$ deep, the next is 7-8 $\mathrm{m}$ deep and the seaward one reaches $20-25 \mathrm{~m}$. The exterior barrier reef has very dense coral cover, Porites porites and Acropora palmata playing important roles. Seaward of these reefs is an area dominated by sponges. This area is described in detail by Jordan (1979b).

To the south of Punta Nizuc there are numerous reef patches, and the reef forms a series of sections separated by channels, $200-300 \mathrm{~m}$ wide. At Finduvet there is a sandy bottom with large patches of $A$ cervicornis, some with branches more than $2 \mathrm{~m}$ long; there is also a zone of $P$. porites and alga Turbinaria turbinata. From Bajo Finduvet to Punta Petempich the barrier reef is not as evident and there are a series of small bays. From Punta Petempich to Puerto Morelos, the barrier reef is particularly evident. Between Punta Petempich and Punta Tanchacté the lagoon is $3-4 \mathrm{~m}$ deep and has banks of $A$ palmata, some of which is dead. Further south at Punta Tanchacté there is a reef front to $20 \mathrm{~m}$ with caves and eroded rock with large fish (Anon., undated c).

Reef Structure and Corals Jordan (1979b) and Jordan et al. (1981) surveyed localities at a number of sites in this area including Punta Nizuc, Bajo Finduvet and Punta Petempich, and give a generalized description of the reefs along the coast (see also "Introduction"). The main characteristics of the fore-reef are: a) the existence of a basal substratum with a slight slope, b) the absence of buttresses particularly in the northern sections and c) the presence of sand patches starting at a depth of about $10 \mathrm{~m}$ (Jordan et al,, 1981). The reefs of Quintana Roo are notable for their abundant gorgonian populations.

The fore-reef slopes from $8^{\circ}$ to $15^{\circ}$ to a sandy platform at a depth of about $20-25 \mathrm{~m}$ in the north, and during periods of south and south to easterly winds the slope may become covered with the algae Sargassum and Turbinaria. Coral colonies are small $(20-30 \mathrm{~cm}$ in diameter) and not very numerous, resulting in a very low living coral coverage and there is no true reef formation except in some places at depths of $15-20 \mathrm{~m}$. There is a clear dominance of Siderastrea siderea, Montastraea cavernosa and Diploria strigosa, which are particularly resistant to high rates of sedimentation. A palmata and $M$. annularis, the typical reef builders of the West Indies, are intolerant of heavy sedimentation and are poorly represented, possibly because the slight slope encourages movement and redeposition of sediment. There is a significantly smaller number of species than in the rear zone, but a relatively higher diversity. However, a high abundance and diversity of alcyonarians (up to 19 species) have been recorded. Towards the breaker zone there is a barren zone with only a few colonies of Mille pora complanata.

The breaker zone consists of a shallower subzone (0.6-1.8 $\mathrm{m}$ deep) characterized by a relatively high coverage of living corals, dominated by $A$ palmata and $M$. complanata, a relatively small number of species, small, flat very solid colonies and relatively abundant small gorgonians; and a deeper subzone (down to $3.5 \mathrm{~m}$ ) practically devoid of stony corals and gorgonians. The relative richness of coral populations in the shallower subzone is an unusual feature for West Indian reefs.

The back-reef is shallow $(1.0-3.0 \mathrm{~m})$ and has the greatest live coral cover, but there is often no very clear zonation. There is usually a high total number of species with a relatively low species diversity. Environmental conditions appear to be very favourable for coral growth (Jordan, 1979b; Jordan et al., 1981). A palmata and $M$. complanata dominate near the breaker zone followed by a zone of $A$ palmata and then a mixed zone of $D$. strigosa, Agaricia agaricia and $A$ tenuifoliata; Acropora palmata and Montastraea annularis may dominate near the lagoon. Banks of $P$. porites are also found. At Bajo Finduvet and Tanchacté, large banks of $A$ cervicornis are found on a sandy bottom near the lagoon. Throughout the back-reef, gorgonians are aiso abundant and show a distinct zonation described in Jordan (1979a).

Noteworthy Fauna and Flora Mangroves are found in several areas including Cancún and are particularly abundant on Isla Contoy (Anon., undated b). Algae of Isla Mujeres are described by Huerta (1958). Loggerhead Caretta caretta, Green Chelonia mydas and Hawksbill Eretmochelys imbricata Turtles nest on the coast of Quintana Roo where the fringing reefs provide extensive foraging habitat (Groombridge, 1982) and the Leatherback Dermochelys coriacea may occur. All four species nest on the beaches of Isla Contoy and Isla Mujeres (Bacon et al., 1984). Crocodylus acutus may also occur. The Caribbean Manatee Trichechus manatus occurs off the Yucatán Peninsula (Thomback and Jenkins, 1982). Isla Contoy is one of the most important seabird nesting areas on the Mexican Caribbean coast, with Magnificent Frigatebirds Fregata magnificens, Brown Pelicans Pelecanus occidentalis, Black Skimmers Rynchops nigra, White Ibis Eudocimus albus, egrets and herons (Ardeidae) and cormorants Phalacrocorax spp. (Anon., undated b; Scott and Carbonell, 1986). The area is rich in commercial fish species including sharks, barracuda, snappers, grunts, jacks and parrotfish. There is an underwater cave to the north of Isla Mujeres which is famous for its sleeping sharks. Spiny lobster Panulirus argus are abundant and there are smaller numbers of $P$. guttatus. Ekdale (1972) describes the molluscs in the area of Cancún Lagoon. The Queen Conch Strombus gigas occurs; it used to be abundant at Punta Nizuc and in other parts of the coastal lagoon but populations of this, lobsters and fish have been greatly depleted (Anon., 19??). Cassis tuberosa and Fasciolaria tulipa are still relatively abundant.

Scientific Importance and Research A number of studies have been carried out in the area, particularly around Cancún where baseline studies of Nichupte Lagoon were carried out prior to the development of the resort (Jordan et al., 1981). Seagrass biomass 
determinations have been carried out at Punta Nizuc and between Cancún and Isla Mujeres (Nugent et al., 1978). There are small research stations on Isla Contoy (Anon., undated b) and Isla Mujeres.

Economic Value and Social Benefits Black coral is collected commercially off the coast of Quintana Roo (De la Torre, 1978). Plexaura homomalla, an octocoral with valuable medicinal properties, has been found to be relatively abundant in the north and a study has been carried out to determine the possibility of exploiting it (Jordan and Nugent, 1978); study sites included Punta Nizuc (Martin, 1982) and Punta Petempich (Jordan and Nugent, 1978).

Tourism has developed rapidly in the region and is probably the most important source of income, the reefs attracting many snorkellers and divers. The main resort area is at Cancin and was established by the Mexican Government. It is expected to grow to 10000 rooms by 1995 (Beekhuis, 1981); most of the hotels have been built on the narrow stretch of sand separating Nichupte Lagoon from the sea. Sailing, windsurfing, fishing, diving and yachting are popular activities, and there is a marine museum. Punta Nizuc, the southemmost point of the sand spit, is a particularly scenic spot and is the site of a Club Mediterranée development.

Isla Mujeres is a popular resort, less sophisticated than either Cancún or Cozumel. Although there are several hotels on the island, many visitors are day trippers from Cancún who come by boat; several hundred tourists a day may visit the El Garrafón Underwater Park for snorkelling and the aquarium. There are dive equipment rental shops, a restaurant, a jetty for boats and a museum. SCUBA diving is popular on Los Manchones Reef. Isla Contoy is visited by tourists on day trips from Cancún and Isla Mujeres; recreational activities include birdwatching, barracuda fishing and snorkelling; there is also a photographic museum by the harbour.

Disturbance or Deficiencies Hurricane Allen, in August 1980 , caused extensive destruction of corals in the fore-reef zone, particularly of branching forms, but there was little damage in the rear zone. Other hurricanes have caused little damage (Jordan et al., 1981). Mass mortality of the sea urchin Diadema antillarum has been reported at Cancún (Lessios et al., 1984).

Tourism and, in particular, the Cancún development could present a threat to the reefs (Jordan et al., 1981; Jordan et al., 1980). Over the last ten years, the reefs at Isla Mujeres have been spoiled by the large numbers of tourists visiting them (López-Omat in litt., 21.9.84). The shallow fringing reef at El Garrafón has been almost totally destroyed by trampling and litter, and considerable damage has already occurred on the small offshore reef patch Los Manchones (Chávez in litt., 1984). The reef at the northern tip of the island is also in poor condition and covered with litter. Black coral has been over-collected in several areas (De la Torre, 1978). There is some disturbance of the birds at Isla Contoy by tourists (Scott and Carbonell, 1986).

Legal Protection A marine refuge area was declared by a decree of 7 February 1973 for the area including the reefs of Punta Cancún and Punta Nizuc, but the exact boundaries have not been defined and no efforts have been taken to implement the decree. Regulations exist to control the exploitation of spiny lobsters, black coral and conch. The Reserva Ecológica Isla Contoy was established on 8 January 1981 to protect the avifauna of the island (Anon., undated b). The El Garrafón Underwater Park was set up on Isla Mujeres in about 1980 , primarily for recreational purposes; the area was already the most popular swimming and snorkelling bay. Spearfishing and collection of marine curios is not permitted but there is little enforcement, and the Park is a commercial enterprise rather than a conservation effort.

Management Legislation has not been implemented for most areas. Isla Contoy is administered by the SEDUE who have provided facilities for visitors (Anon. undated b). Some of the hotels and dive operators at Cancuin try to encourage visitors to be aware of the need for reef conservation; for example, at Punta Nizuc tourists are encouraged not to spearfish or collect curios (Anon., undated c). Although a vast number of guide books and information brochures are produced for tourists, few of these have any conservation information.

Recommendations There is an urgent need to set up a programme for the reefs of Isla Mujeres similar to the one being established on Cozumel for Chankanaab Lagoon and reefs. This could be based at El Garrafón. Hotels could be persuaded to encourage visitors not to spearfish or collect marine curios.

References have been cited in this account where possible but much of it is based on personal observations by S.M. Wells (November 1984) and conversations with local dive guides and biologists working in the area.

\section{PL'ERTO MORELOS PROPOSED PROTECTED AREA}

Geographical Location East coast of Yucatán Peninsula, state of Quintana Roo, $34 \mathrm{~km}$ south of Cancún.

Area, Depth, Altitude The lagoon is $700 \mathrm{~m}$ wide and has a maximum depth of $6 \mathrm{~m}$; the fringing reef is $2 \mathrm{~km}$ in length.

Physical Features The coastline is bordered by a sandy beach. A fringing reef stretches north from the town for $2 \mathrm{~km}$ and is one of the most accessible reefs on this coast. Offshore, the barrier reef, a continuation of the reef running from Punta Nizuc south to Belize, runs relatively close to the beach.

Reef Structure and Corals The zonation and ecology of the fringing reef is described by Castanares and Soto (1982). The following zones were identified: lagoon, back-reef, fore-reef or reef slope, and sandy bottom. The lagoon bottom is covered mainly with seagrasses, Thalassia testudinum being the most abundant, with Halimeda, sponges and a few coral colonies such as Manicina areolata and Porites divaricata scattered among it. Opposite the town of Puerto Morelos there is a patch reef in the lagoon, $50 \times 120 \mathrm{~m}$, formed of large colonies of Montastraea annularis, other scleractinians and octocorals.

The gorgonian community in the reef lagoon is described by Jordan (1979a). About $400 \mathrm{~m}$ shoreward of the reef 
barrier, a calcareous platform is found on the lagoon bottom, about $400 \mathrm{~m}$ long and $40-45 \mathrm{~m}$ wide, parallel to the reef and slightly elevated above the lagoon bottom. A relatively abundant scleractinian and gorgonian fauna is found on the platform. At the south end, $M$. annularis has formed large coral heads, some of which are dead at the surface. Elsewhere on the platform are smaller colonies; the dominant species are Dichocoenia stokesii and Siderastrea siderea. Jordan (1979a) describes the gorgonians on the platform.

The back-reef, lying between the lagoon and the reef crest, is $50-100 \mathrm{~m}$ wide. The first zone of the back-reef is dominated by $M$. annularis which forms large colonies 1-2 $\mathrm{m}$ in diameter, with small colonies of other species around the base; Colpophyllia natans and Dendrogyra cylindrus may also reach large sizes. Among the octocorals, Plexaura homomalla and $P$. flexuosa predominate. Behind this zone in depths of less than $1.4 \mathrm{~m}$ there is a mixed zone of a variety of species which are listed by Castañares and Soto (1982). In some places, this zone is followed by a well defined zone of Acropora palmara and also zones of octocorals and hexacorals. In other areas, channels $5-10 \mathrm{~m}$ wide cross the back reef, filled with a variety of corals.

Beyond this the reef crest is found in depths of $1-5 \mathrm{~m}$. This is largely made up of dead $A$ palmata colonies encrusted with calcareous algae and occasional small living corals of different species. The reef slope has abundant and diverse corals but there are no buttresses and the base of the reef is sloping calcareous rock which drops gently to a sandy platform at $20-25 \mathrm{~m}$ depth. Between 15 and $25 \mathrm{~m}$, systems of spurs and grooves are found in some areas. The zonation of the reef slope is influenced by the movement of sediment. Between 4 and $8 \mathrm{~m}$ depth, sediment action is considerable and the dominant species are algae, the octocoral Gorgonia flabellum and occasional stony corals. From 8 to $10 \mathrm{~m}$, octocorals are abundant in small robust colonies. From 10 to $15 \mathrm{~m}$ some 19 species of octocorals are found. Stony corals increase in diversity between 7 and $10 \mathrm{~m}$, the main species being Siderastrea radians, Diploria clivosa and Porites astreoides. At $10 \mathrm{~m}$, large colonies $(1-3 \mathrm{~m}$ in diameter) of $M$. annularis, $C$. natans and $M$. cavernosa are found, as well as a variety of species forming smaller colonies. Thirty-eight species of scleractinians were found at Puerto Morelos and are described by Castañares and Soto (1982).

Noteworthy Fauna and Flora Hawksbill Eretmochelys imbricata, Green Chelonia mydas and Loggerhead Turtles Caretta caretta nest in the area (Bacon et al., 1984).

Scientific Importance and Research The Centro de Ciencias del Mar y Limnología de la Universidad nacional Autónoma de México (UNAM) was established at Puerto Morelos in $1982,3 \mathrm{~km}$ to the north of the town. Much of the research work on reefs is aimed at providing baseline data for reef management (Jordan et al., 19??). There are well-equipped laboratories, living accommodation and a boat. Research programmes under way include studies of scleractinian and gorgonian reef community structure, population biology of Plexaura homomalla, plankton, rcef bacterial ecology and reef structure in relation to environmental factors. Students from the graduate programme in Marine Science at the UNAM take part in these projects.
The reproductive biology and growth rates of the spiny lobsters Panulins argus and $P$. guttatus are being studied to provide baseline data for their management (Lozano and Briones, undated). The reef at Puerto Morelos has been used as a study site in many of the projects on Plexaura homomalla including growth rates (Moreno et al., 1982), fecundity (Martin, 1982) and transplant experiments (Jordan and Nugent, 1978).

The neighbouring aquaculture station of the Instituto Nacional de Pesca (National Institute of Fisheries) is carrying out a government sponsored project on Strombus gigas mariculture. CIQRO, the Centro de Investigaciones de Quintana Roo also has a base at Puerto Morelos.

Economic Value and Social Benefits The inhabitants of Puerto Morelos make their living largely from fishing and there is a small amount of tourism. The town is a cargo port for Cozumel.

Disturbance or Deficiencies The coral patch in the lagoon to the north of the jetty is reported to have deteriorated as a result of collecting (Anon., undated).

Legal Protection None.

Management None.

Recommendations There is a local movement of fishermen and researchers to protect the reef (prohibit fishing, taking of corals for souvenirs and anchoring of boats) (López-Ornat in litt., 21.9.84).

\section{RESERVA DE LA BIOSFERA SIAN KA'AN}

Geographical Location East coast of Yucatán Peninsula, State of Quintana Roo, south of Tulum, including Bays of Espiritu Santo and Ascensión.

Area, Depth, Altitude 450000 ha total, 120000 ha marine; maximum altitude $10 \mathrm{~m}$.

Land Tenure $99.8 \%$ Government owned; $0.2 \%$ privately owned (mainly along coast); details of coastal land tenure are given in César Dachary and López-Omat (1983).

Physical Features The area includes 100000 ha of forest, 180000 ha of swamps and mangroves, 100000 ha of marshes, islands and lakes and a $90 \mathrm{~km}$ barrier reef. There are no rivers. Coastal dunes stretch from the northern limit of the reserve, $42 \mathrm{~km}$ south to Punta Allen, and are found on the peninsula separating the two bays. The marshes are characterized by "petenes" or hammocks, which are islands of bushy vegetation and are described by Olmsted et al. (1983). The geology, climate, soils and hydrology of the area are described by López-Omat (1983). There is a rainy season from May to October, most rain falling in June and September. Seventy-five per cent of the reserve is flooded between September and December (Anon., 1983). Temperature ranges from $22^{\circ} \mathrm{C}$ in January and February to $27.8^{\circ} \mathrm{C}$ in May. Easterly trade winds predominate from March to November; from November to March the predominant winds are the cold wet north/north-easterly "nortes". 
Hurricanes occur on average once every eight years, usually between June and October. Marine tornados have also been recorded.

The bays of Ascensión and Espiritu Santo cover an area of $105000 \mathrm{ha}$, representing $80 \%$ of the aquatic area within the proposed reserve. Bahiá de la Ascención is $12.5 \mathrm{~km}$ wide at its mouth (from Punta Allen to Punta Hualastok). Cayo Culebras $(0.75 \times 4.5 \mathrm{~km})$ is situated in the centre of the mouth, but does not noticeably impede currents. Bahía del Espiritu Santo, to the south, opens to the sea through a $2.5 \mathrm{~km}$ wide channel between Punta Niluc and the northern tip of Isla Elchal, and through a second channel $100 \mathrm{~m}$ wide between the south of this island and Punta Herrero. Espejel (1983) gives brief descriptions of the bays and mangroves surrounding them.

Reef Structure and Corals A barrier reef about $1 \mathrm{~km}$ long, part of the Yucatán - Belize reef system, is found off the bays of Ascensión and Espiritu Santo. This has a frontal zone approximately $1 \mathrm{~km}$ wide dominated by gorgonians and a reef crest, usually $0.25-0.5 \mathrm{~km}$ wide but is wider in front of the major bays.

Noteworthy Fauna and Flora The vegetation and plants of the reserve are described by Cabrera et al. (1983) and Olmsted et al. (1983). Mangroves Rhizophora mangle, Avicennia germinans and Laguncularia racemosa are found along the shores of the creeks and bays and there is a small area $(3 \mathrm{~km})$ of original dune vegetation on the northern peninsula. The importance of the area as a wetland habitat is described in Scott and Carbonell (1986). This is described in detail by Espejel Carbajal (1983). The terrestrial part of the reserve has a diverse mammal fauna including tapir, five cat species, two monkey species, two deer species and peccary. Terrestrial fauna is listed in García Salazar (1983). There are an estimated 300 bird species, including four species of vulture and 15 herons. Major Brown Pelican Pelecanus occidentalis, Frigatebird (Fregatidae) and heron (Ardeidae) roosts are situated within the reserve. Boobies (Sulidae) visit the area in May.

In the coastal zone, the Caribbean Manatee Trichechus manatus, two crocodile species Crocodylus acutus and $C$. moreletii and three marine turtle species nest in the reserve. Loggerheads Caretta caretia and Green Turtles Chelonia mydas are the most important species and there are a few Hawksbills Eretmochelys imbricata. Conch Strombus gigas is abundant, partly because the fishery concentrates on spiny lobsters. Fish are abundant, over 52 species having been recorded, including many commercial species (Espejel, 1983).

Scientific Importance and Research The Centro de Investigaciones de Quintana Roo (CIQRO) has been co-ordinating extensive work in the area since the reserve was proposed and numerous surveys have been carried out. Nine research workers have been employed to work on a variety of projects including seabirds and turtles. The reef is diverse and in good condition, forming the basis of the fisheries in the area and protecting the bays of Ascensión and Espíritu Santo from erosion and hurricanes. Sedimentation patterns are of scientific interest (Anon., 1983). A team from CINVESTAV have looked at some of the reef areas (Zlatarski pers. comm., 1984).
Economic Value and Social Benefits The area was a Mayan domain during pre-Columbian times and there are numerous archaeological remains. The area is easily accessible from Tulum, an archaeological site which is becoming an increasingly popular tourist site. Currently there are about 500 Mayan descendants living in the area as farmers or fishermen. The socio-economy of the area and its exploitation by man is described by César Dachary and López-Ornat (1983), and details of chicle exploitation, copra plantations and fishing co-operatives are given. The copra plantations are not economically viable at the moment. The two bays are important nursery areas for Panulirus argus and a co-operative fishery successfully exploits this species based at Punta Allen (Espejel, 1983). Local people catch fish by skin diving and spearfishing. There is great potential for the development of tourism in the littoral area (Anon., 1983; César Dachary and López-Ornat, 1983), but there are very few visitors at present, apart from those in the few luxury exclusive hotels along the northern peninsula who come mainly for big game fishing.

Disturbance or Deficiencies The reefs are relatively healthy apart from large thickets of dead Acropora palmata and $A$ cervicornis in the breaker zone. It is not clear whether this is a result of hurricane damage, salinity changes or some other cause (Wells pers. obs., 1984). Massive corals appeared to be healthy and the outer reef is also reported to be healthy with high coral cover (Zlatarski pers. comm., 1984). Much of the original coastal vegetation has been replaced by coconut plantations but inland the forest has been little disturbed and most of the mangroves are intact. The impact of current fishing pressure is not known. The great economic potential for tourism means that strict control and planning will be required in the future to ensure that increased visitor numbers do not damage the reefs.

Legal Protection The Reserva de la Biósfera Sian Ka'an was declared on 20 January 1986 under Mexican legislation.

Management WWF-US have approved first-year funding to support protection of the area and some construction costs to facilitate researchers. A three-year project was started in 1982 to review the preliminary results and management requirements. A management plan is currently in preparation. There are plans to establish field stations and interpretative centres, and the local inhabitants will be involved at all stages. Tourism will be encouraged but will be concentrated in the coastal area and there will be strict controls on the minimum sizes of property developments to keep buildings to a minimum. Seven zones are to be established within the reserve: a protected core area inland; a buffer zone comprising the inhabited area and borders of roads; an inland harvesting zone for the exclusive use of the Mayan inhabitants; a tourism-archaeological zone for educational and interpretive purposes; a littoral zone; a marine buffer zone for the use of local fishermen, and an area of 35000 ha situated between the two bays which will form a Natural Sanctuary (Anon., 1983). A project to improve turtle nest protection is under way along part of the coast.

Recommendations Consideration will now be given to listing this area as an International Biosphere Reserve under the Unesco MAB programme. A survey of the marine environment should be considered a high priority. 


\section{ISLA VERDE PROPOSED PROTECTED AREA}

Geographical Location Lies $7 \mathrm{~km}$ off the coast near Veracruz.

Area, Depth, Altitude Island $300 \mathrm{~m}$ long; widest part of reef $1450 \mathrm{~m}$.

Physical Features Villalobos-Figueroa (1981) describes the physical features of the cay which is larger and more vegetated than La Blanquilla. The reef is elliptical with an emergent zone on the south coast and a small enclosed lagoon. Surface water temperatures vary from $23.25^{\circ} \mathrm{C}$ from November to March, to $32^{\circ} \mathrm{C}$ in July and August, although temperatures in shallow parts of the lagoon may reach $35^{\circ} \mathrm{C}$. Salinity ranges from $35-36 \mathrm{ppt}$ to $38 \mathrm{ppt}$; it is stable in some areas but elsewhere it decreases in June and July due to fresh water input from the rivers San Carlos and Jamapa. From December to April, turbidity and turbulence increase due to the prevailing winds, the "nortes".

Reef Structure and Corals Villalobos-Figueroa (1981) gives a short description of the reef community and describes a number of zones: 1) an emergent rim, dominated by the alga Padina; 2) a number of Thalassia dominated communities; 3) a zone on the west, dominated by Diploria clivosa and Porites furcata with some Montastraea cavernosa and M. annularis and 4) a zone on the north and north-west of the island, exposed to the prevailing currents and with abundant and diverse corals and octocorals, including Acropora palmasa, A prolifera, A. cervicornis and D. clivosa.
Noteworthy Fauna and Flora Seagrass beds of Thalassia occur in the lagoon. Green Chelonia mydas, Hawksbill Eretmochelys imbricata and Loggerhead Caretta caretta Turtles occur in the area (Carr et al., 1982).

Scientific Importance and Research Isla Verde has been studied by Arenas (1966) and Lot-Helgueras (1968), pollution studies were carried out by Villalobos-Figueroa (1981) and Palencia (1983) provides a popular account of the reefs.

Economic Value and Social Benefits For over 20 years, the island has been regularly visited by students from the Universidad Nacional Autónoma de México and plays a very important role in education (Palencia, 1983).

Disturbance or Deficiencies Isla Verde is considered to be seriously threatened by pollution. Following the Ixtoc-1 spill, there was considerable pollution of the beaches by hydrocarbons and dense mats of green algae covered corals and rocks (Jernelov and Linden, 1981). However, the reefs appeared to be comparatively unaffected (Villalobos-Figueroa, 1981).

\section{Legal Protection None.}

Management None.

Recommendations Was recommended for protection by M. Costello and M. Arendaño in 1971. 



\section{MONTSERRAT and ST KITTS-NEVIS}

\section{INTRODUCTION}

\section{General Description}

The British colony of Montserrat lies in the southern Leewards, $43 \mathrm{~km}$ south-west of Antigua. It is a forested, rugged, volcanic island, approximately $100 \mathrm{sq} . \mathrm{km}$ in area. Much of the $49 \mathrm{~km}$ shoreline consists of steep cliffs or boulders, with a single permanent beach on the eastern windward coast at Farm Bay and nine beaches on the western side. The coastal shelf off the southern end of the island is extremely narrow, the $90 \mathrm{~m}$ bathymeter line lying only $0.6 \mathrm{~km}$ offshore (Meylan, 1983). Small scattered patches of reef are present along all but the windward coast (ECNAMP, 1980c). Seagrass beds are located off the northern and southern extremities of the island, around Bransby Point and off Blackburne Airport. There are two patches of coastal mangroves, one of which (Fox's Bay Bird Sanctuary) is described by Scott and Carbonell (1986).

The independent islands of St Kitts ( $65 \mathrm{sq} . \mathrm{km}$ ) and Nevis ( $36 \mathrm{sq} . \mathrm{km}$ ) are situated on the same submerged bank as St Eustatius (Netherlands Antilles), some $100 \mathrm{~km}$ to the south-west. St Kitts, $168 \mathrm{sq} . \mathrm{km}$ in area, is of volcanic origin and reaches $1315 \mathrm{~m}$ in altitude. It is separated from Nevis, a volcanic cone $93 \mathrm{sq} . \mathrm{km}$ in area and rising to $985 \mathrm{~m}$, by a strait $3.2 \mathrm{~km}$ wide. The narrow shelf on the north-east side of both islands has inshore depths of 18-22 $\mathrm{m}$ and several small bank barrier reefs with associated fringe or bench reefs. Most of these have Acropora palmata caps, although coralline - Millepora spur and groove formations are also important (Adey and Burke, 1976). The reefs are mapped by ECNAMP (1980a and b) and occur along much of the coast of both islands.

A coastal inventory of St Kitts, compiled by Environmental Research Projects has revealed considerably more reef than was anticipated (Goodwin in litt., 3.12.85). Reefs are particularly numerous on the east coast between Canada Estate and North Frigate Bay and at Dieppe (Meylan, 1983). There are fairly extensive coral reef areas off Frigate Bay which have not been studied in detail although a brief description is given in Towle et al. (1985). On the Caribbean side the inshore reef communities are depauperate, with about $20 \%$ coral cover, mainly of low encrusting forms. Reefs with more extensive coral are located further offshore. On the Atlantic coast, there is a patch reef offshore with $10 \%$ living hard and soft coral cover.

On Nevis, the small system on the north-east appears to be a degenerate $A$ palmata reef which, except for scattered patches of $A$ palmata and Millepora, has been coated in recent times by fleshy algae. A few small algal ridges are scattered through this system on the sides of channels through the reef (Adey and Burke, 1976). Extensive seagrass beds lie off the north-west and southern shores (ECNAMP, 1980b).

Marine turtles, primarily Green Chelonia mydas and Hawksbill Eretmochelys imbricata with small numbers of
Leatherback Dermochelys coriacea and Loggerhead Caretta caretta, are found in the region. Green and Hawksbill Turtles may have nested on all three islands but there is little confirmed nesting at present, probably because of habitat loss and exploitation, although good numbers are found in foraging habitats. The south-eastern end of St Kitts, where seagrass beds cover $1200 \mathrm{ha}$, is a nesting area for the Leatherback and there is sporadic nesting of Hawkbills and Green. Turtles are reported to nest in small numbers in the Frigate Bay area (Towle et al., 1985). Small beaches on the south-east coast of Nevis may still be used for nesting and there is some nesting on Montserrat of Hawksbills and Leatherbacks (Bacon et al., 1984). Halewyn and Norton (1984) give the status of seabirds nesting on the three islands.

\section{Reef Resources}

There is little information on the extent of usage of the reefs of these islands, although the marine resources of St Kitts and Nevis are known to be rich (Lynch, 1979; UNDP 1974 and 1976). Conch and lobster fishing are important around the south-east of St Kitts and around much of Nevis (Wood, 1984). Pinney's Beach, close to Charlestown on Nevis (population 10000 in 1980), is one of the main recreational areas for residents and tourists. Snorkelling is possible at a site on the south-east coast (ECNAMP, 1980b).

Most of the population of St Kitts (35 000 in 1980) is concentrated along the coastline but the long south-eastern peninsula is virtually uninhabited (Meylan, 1983). The tourist industry has only recently become important (Scott and Carbonell, 1986) but, with government support, is expanding rapidly; visitors to the island numbered nearly 40000 in 1984 . Frigate Bay, an 85 acre site lying between the Caribbean and Atlantic coasts at the top of the south-east peninsula holds $67 \%$ of the hotel rooms on St Kitts. The Frigate Bay Development Corporation, founded in 1973, has been responsible for development of the area and the beaches and reefs, such as the fringing reef at Half Moon Bay north of Muddy Point, are used intensively by locals and tourists. The south-east peninsula is of potential importance for tourism and the surrounding reefs are considered suitable for snorkelling and diving. An environmental assessment and tourism focused land use planning effort is already underway, since although the area is currently largely inaccessible, a road is to be built shortly (Towle et al., 1985).

Montserrat has a population of about 12000 with an economy based on holiday villa tourism and some agriculture (Scott and Carbonell, 1986). The deep marine environment and lack of coastal resources has limited the development of artisanal fisheries, although they are an important source of food and demand constantly outstrips supply (Wood, 1984). There are dive sites and good snorkelling reefs on the west coast (ECNAMP, 1980c) where Little Bay is to be developed into a large resort. 


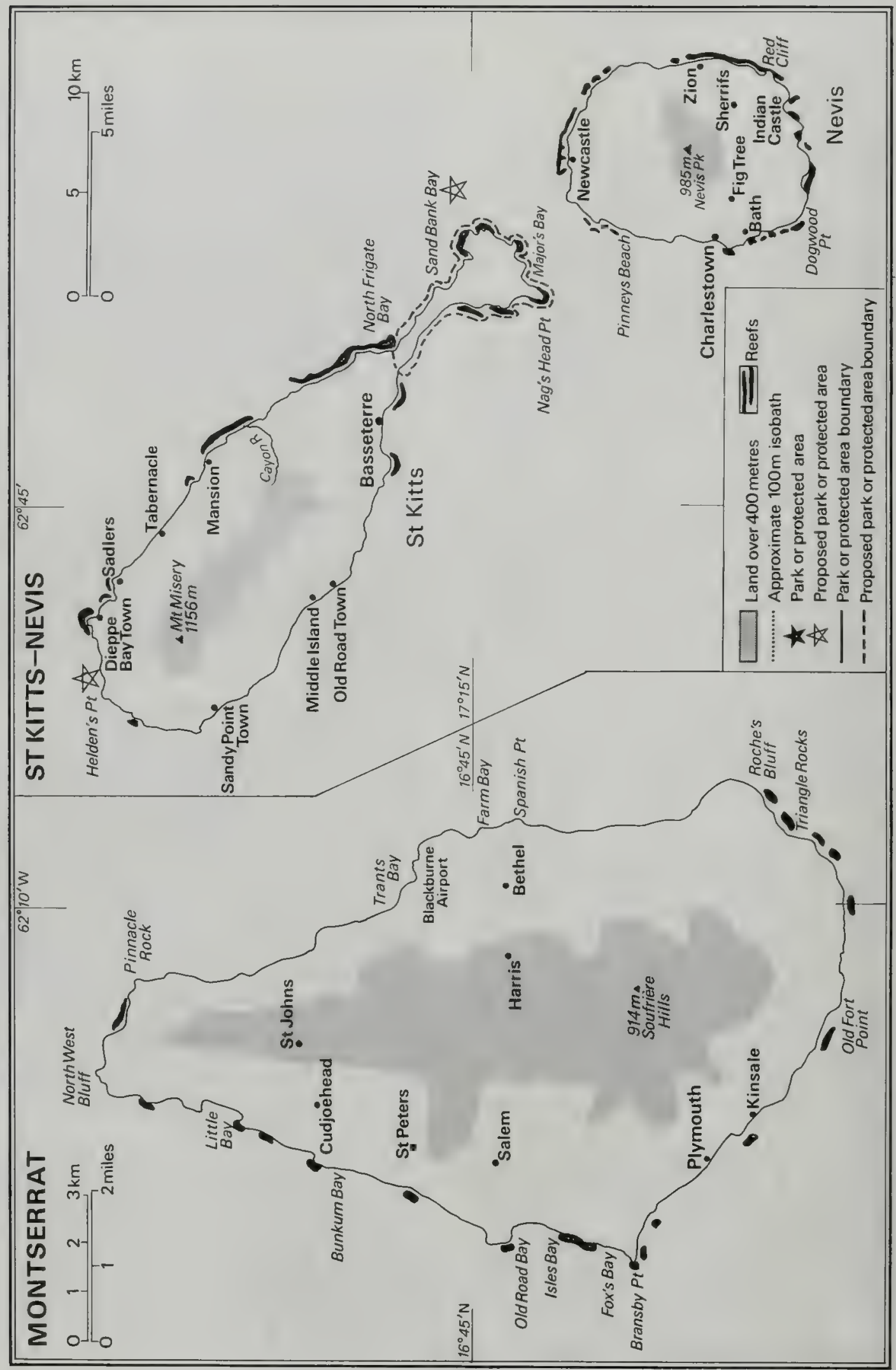




\section{Disturbances and Deficiencies}

There is only scattered information on the conservation status of the reefs around the three islands. No significant reef deterioration has been reported for Montserrat (Rogers, 1985). However, sand mining for construction purposes is being practiced at several beaches including Fox's Bay and Farm Bay, and the beach profile at the latter has already been radically altered (Meylan, 1983). On St Kitts and Nevis, preliminary observations suggest that the inshore reefs are being over-fished, particularly conch and lobster stocks (Wood, 1984). On St Kitts, there is some seaborne pollution on the north coast of the south-east peninsula (Scott and Carbonell, 1986). Sand mining still occurs illegally, for example at Sandy Point and near Frigate Bay. There is some concern that heavy recreational use of the Frigate Bay area is causing a decline in wildlife in the area. Although no major ecological disaster is forecast, further development will probably lead to continued deterioration of the marine and terrestrial resources. At present there is little indication of damage to reef communities in this area, other than that due to Tropical Storm Klaus in 1984, but elsewhere there has been extensive growth of algae which could be due to nutrient enrichment of the water from soil run-off and sewage effluent (Towle et al., 1985). On Nevis, the dunes behind Indian Castle Beach are being mined for sand and the beach north of Red Cliff was fouled by seaborne tar in 1983 (Meylan, 1983). On all three islands, the tortoiseshell trade is heavy, both in raw shell and in tourist souvenirs, and turtle meat is eaten; turtle populations are generally considered to be declining (Meylan, 1983).

\section{Legislation and Management}

All islands have legislation for turtles, including closed seasons and minimum size limits. Artificial reef studies have been carried out on Montserrat and St Kitts for the purpose of enhancing lobster stocks (Goodwin, 1985b) and an artificial reef was built between Isles Bay and Fox's Bay on Montserrat in 1983 (Goodwin and Cambers, 1983). On St Kitts, a local fisherman is assisting with tagging studies of local lobster populations and is monitoring post-larvae collectors installed in several bays (Goodwin, 1985). At present there are no marine protected areas on these islands.

\section{Recommendations}

Towle et al. (1985) make recommendations for improved environmental management of the Frigate Bay area on $\mathrm{St}$ Kitts, including the formation of a formal waste disposal and litter control plan, the initiation of data collection, the encouragement of non-consumptive uses of nearshore marine resources, the elimination of speargun rental facilities, and the provision of information and educational materials for visitors.

An area on the north coast of St Kitts, extending into the sea, and the entire south-east peninsula, with its major wetland site, have been proposed as reserves (ECNAMP, 1980a; Scott and Carbonell, 1986). The Island Resources Foundation has recently carried out an environmental study of the latter area (Putney in litt., 18.2.86) and the
Fisheries Division is preparing a proposal to earmark certain fish habitats in this region as protected areas (Wood, 1984). Local fishermen are to be involved in monitoring projects on reef fisheries (Goodwin, 1985). There are no plans for marine reserves on Montserrat or Nevis (ECNAMP, 1980b and c). St Kitts-Nevis has been included on a preliminary list of potential marine sites for inclusion in a Lesser Antillean Biosphere Reserve and is suggested for the short list (Goodwin, 1985a).

\section{References}

* cited but not consulted

Adey, W.H. and Burke, R. (1976). Holocene bioherms (algal ridges and bank-barrier reefs) of the eastem Caribbean. Geol. Soc. Am. Bull. 87: 95-109.

Bacon, P., Berry, F., Bjorndal, K., Hirth, H., Ogren, L., Weber, M. (1984). The National Reports. Proceedings of the Western Allantic Turtle Symposium, Vol. 3. University of Miami Press, Florida.

ECNAMP (1980a). St Kitts. Preliminary Data Atlas. Survey of Conservation Priorities in the Lesser Antilles. Eastern Caribbean Natural Area Management Program.

ECNAMP (1980b). Nevis. Preliminary Data Atlas. Survey of Conservation Priorities in the Lesser Antilles. Eastern Caribbean Natural Area Management Program.

ECNAMP (1980c). Montserrat. Preliminary Data Atlas. Survey of Conservation Priorities in the Lesser Antilles. Eastern Caribbean Natural Area Management Program.

Goodwin, M.H. (1985a). Characterization of Lesser Antillean Regional Fisheries. Island Resources Foundation, $48 \mathrm{pp}$.

Goodwin, M.H. (1985b). Feasibility study on the establishment of artificial reefs. Draft Technical Report TCP/DM1/4402.

Goodwin, M.H. and Cambers, G. (1983). Artificial reefs: a handbook for the Eastern Caribbean. Environmental Research Projects and Caribbean Conservation Association. 83 pp.

Halewyn R. van, and Norton, R.L. (1984). The status and conservation of seabirds in the Caribbean. In: Croxall, J.P., Evans, P.G.H. and Schreiber, R.W. (Eds), Status and Conservation of the World's Seabirds. ICBP Technical Publication No. 2, Cambridge.

-Lynch, R. (1979). Report to ECNAMP on marine resources of St Kitts, Nevis, Montserrat and Dominica.

Meylan, A.B. (1983). Marine turtles of the Leeward Islanđs, Lesser Antilles. Atoll Research Bull. 278: 24 pp.

Rogers, C.S. (1985). Degradation of Caribbean and Western Atlantic coral reefs and decline of associated fisheries. Proc. Sth Int. Coral Reef Congress, Tahiti. Vol.6: 491-496.

Scott, D.A. and Carbonell, M. (1986). A Directory of Neotropical Wetlands. IUCN, Gland and Cambridge.

Towle, E., Rainey, W., Skerritt, R. and Williams, V. (1985). Tourism and the environment: a case study of Frigate Bay, St Kitts. Island Resources Foundation, $65 \mathrm{pp}$.

-UNDP (1974). Environmental status report and guidelines for development. Antigua, Barbados, British Virgin Islands, Cayman Islands, Dominica, Montserrat, St Kitts and Nevis, St Lucia, St Vincent and Turks and Caicos. Island Resources Foundation.

*UNDP (1976). St Christopher/Nevis National Physical Development Plan. UNDP Physical Planning Project St Lucia. 
Wood, J. (Ed.) (1984). Proceedings of the Workshop on Biosphere Reserves and Other Protected Areas for Sustainable Development of Small Caribbean Islands,
May 10-12, 1983. Virgin Islands National Park, Caneel Bay, St John, U.S. Virgin Islands. U.S. Dept of Interior, National Park Service, Atlanta, Georgia. 190 pp. 


\section{INTRODUCTION}

\section{General Description}

The Netherlands Antilles, an integral part of the Netherlands, comprise two groups of islands: the Leeward Islands and the Windward Islands. The Leeward group (situated confusingly within the Windward Islands of the Lesser Antilles) consists of the islands of Curaçao, Aruba and Bonaire. Curaçao and Bonaire are both oceanic islands, surrounded by deep water, whereas Aruba is situated on the coastal shelf of the South American mainland, $27 \mathrm{~km}$ north of Venezuela. Curaçao is the largest island $(63 \mathrm{~km} \mathrm{x} \mathrm{4-8} \mathrm{km}$; $420 \mathrm{sq} . \mathrm{km}$ ) and is situated some $66 \mathrm{~km}$ north of Venezuela. Sandy beaches are rare around Curaço and Bonaire but Aruba has vast sandy beaches on the west coast and smaller ones along the windward north-east coast.

The longitudinal axis of the islands runs north-east/south-west, and the eastern trade winds, with an average velocity of $7.2 \mathrm{~m} / \mathrm{sec}$ and a persistency of over $96 \%$, cause considerable differences between the exposed north-east coasts and the sheltered south-west coasts. Hurricanes passing north of the Leeward group occasionally cause heavy damage to shallow reefs on the south-west coasts. Annual precipitation averages $500 \mathrm{~mm}$, with generally a main rainy season from October to January and a drier season in May, although rainfall is often very erratic. Most rainwater flows directly seawards through river beds which only then contain water (Roos, 1971). Periods of turbidity may result from bad weather on the Venezuelan coast (Roos, 1964). The mean tidal range is about $30 \mathrm{~cm}$ (Bak, 1977). The salinity varies between 34.4 and $36 \mathrm{ppt}$ and temperatures average $26-28^{\circ} \mathrm{C}$.

The north coast of Curaçao has rough seas and surf, apart from short infrequent calmer periods between August and December. The south coast, sheltered from the trade winds, is calmer (Hoogerwerf, 1977) and has no rivers, rain water running off through narrow gullies. Coral limestone cliffs are interrupted by landlocked bays which may extend far inland, several of which are decribed in Roos (1964). The south-west coast of Curaçao usually has a north-west current with a velocity rarely exceeding 1 knot. The currents on the north-east coast and around the tip of the island can be much stronger.

The Windward Group, consisting of Sint Maarten, Sint Eustatius and Saba, is $900 \mathrm{~km}$ north-east of the Leeward group and is part of the arc of the Lesser Antilles. Annual precipitation averages $1000 \mathrm{~mm}$, there is a rainy season in November and the islands lie in the hurricane belt. They are mainly surrounded by shallow, flat, sandy bottoms that slope to considerable depths. Sint Maarten (the northern part of the island including St Martin) is situated on the Anguilla Bank with Anguilla and St Barthélemy. Detailed descriptions of the shoreline are given in Vroman (1968). Sint Eustatius (Statia) ( $30 \mathrm{sq} . \mathrm{km}$ ), on a relatively shallow bank with St Kitts and Nevis, has a volcano, active in late Pleistocene or early Holocene time, at the southern end. Much of the shoreline is rocky and steep with few sandy beaches. A large seagrass bed lies north of Orangebaai (Oranjestad). Saba $(13 \mathrm{sq} . \mathrm{km})$ is also an inactive volcano and rises steeply from $650 \mathrm{~m}$ with a nearly continuous steeply sloping, eroding shore. Depths of more than $60 \mathrm{~m}$ occur irregularly quite close to shore. There are few sheltered bays around the rocky coastline and no permanent beaches. There are only small, scattered patches of seagrass, the most extensive lying off Flat Point and Old Booby Hill. The Saba Bank is a sandy area of approximately $2000 \mathrm{sq} . \mathrm{km}$ to the south of Saba, $7-20 \mathrm{~m}$ deep, and is described by van der Land (1977).

Reefs in the Leeward Islands are mapped in ECNAMP (1980 a, b and c). The reefs off the south-west coasts of Bonaire and Curaçao generally have a common profile. The main features are a submarine terrace extending 50-100 $\mathrm{m}$ from the coast to a 8-12 $\mathrm{m}$ deep drop-off and a steep slope from the drop-off to a depth of $50-60 \mathrm{~m}$. The most prolific coral growth is found over this terrace and slope, although individual corals penetrate deeper and are found on a second drop-cff at $80 \mathrm{~m}$ which is separated from the steep slope by a sediment-covered terrace. Variations of this general model occur according to differences in the geomorphology of the nearby shore, the width of the terrace and the steepness of the submarine slope (Bak, 1975).

The north-east coasts of the Leeward Islands are surrounded by steep shore cliffs and very rough seas, making access difficult but the general submarine morphology appears to be similar to the leeward coasts. However, heavy surge and strong currents produce a different reef community. Large parts of the reef terrace are densely covered with Sargassum platycarpum, which in places stretches over the drop-off to a depth of $40 \mathrm{~m}$. Generally, hermatypic corals and Millepora species cover the terrace and drop-off. The growth form of the colonies is flattened and encrusting, an adaption to the strong wave action and currents (Bak, 1975). Species such as Acropora palmata and Porites branneri occur at much greater depths than on the sheltered south-west coasts.

Curaçao is surrounded by fringing reefs about $50-100 \mathrm{~m}$ wide, which slope down to a sand bottom at about $50-60 \mathrm{~m}$ depth. Roos (1971) describes corals found at 20 localities around Curaçao, the majority on the south-east and the south-west coast. Descriptions of the area included within the Curaçao Underwater Park and of the reefs of Bonaire are given in separate accounts.

Being on the continental shelf, the south coast of Aruba lacks the drop-off found on the south coast of Bonaire and Curaçao, but has a partly emerged reef with tiny islands (which are described by Scott and Carbonell (1986)), partly covered with mangroves and separated from the main island by a long, narrow lagoon (Roos, 1971). Coral growth on the south-west coast is limited due to the sandy bottom at maximum depths of $20-30 \mathrm{~m}$ (Bak, 1975), but is more extensive towards the exposed south-east coast which resembles the south-east point of Curaçao. Reefs off Colorado Point are described separately. In some places, (e.g. Arasji on the north-west point - see separate account), a shingle bottom is found about $1 \mathrm{~km}$ offshore at $20 \mathrm{~m}$ depth, with many small coral 


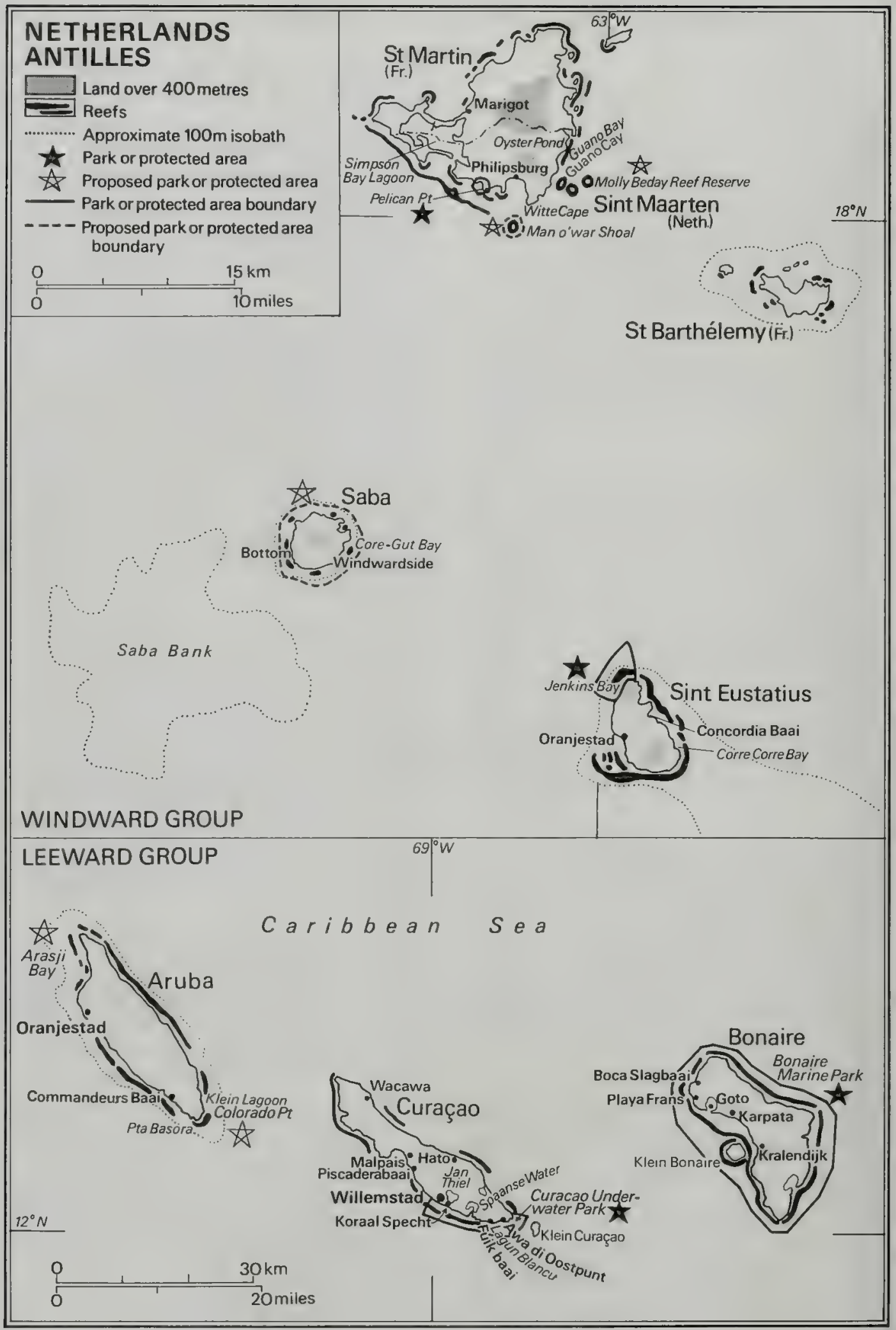


colonies. Where there is a steeper slope, dense Montastraea annularis reefs sometimes develop. Millepora spp., Agaricia agaricites and gorgonians may be common at $10 \mathrm{~m}$, in response to the strong water movement. The colonies are oriented parallel to the wave front and most are encrusting or flattened although Millepora spp. forms large ridges extending seawards (Bak, 1975). Some reefs are unusual in their lack of Agaricia spp. Roos (1971) describes corals at 14 localities around the island. Ormond (198?) described a number of sites including the barrier reef along the south coast and the fringing reef between the eastern end of the barrier reef and Commandeursbaai.

No major reefs are known in the Windward group. In exposed areas, Acropora palmata forms shallow reefs, colonies generally occurring scattered on the bottom or on large boulders if present. On steep slopes, corals are more densely packed but never attain the status of a coral reef community (Bak, 1977). Hurricanes may contribute to poor reef development. Roos (1971) described a number of sites around these islands but the most exposed coasts are still virtually unexplored. The Saba Bank has coral reefs on the southern and eastern margins (Bak, 1977) but these are poorly developed (Macintyre et al., 1975).

The flat sandy plateau around Sint Eustatius is unfavourable to coral growth which is restricted to sheltered cliffs, cobbly bottoms and the leeside of boulders. A quite narrow but distinct $22-30 \mathrm{~m}$ shelf extends around much of the island but is relatively deep and there are no extensive $A$ palmata reefs. Off the south-eastern point of the island, a continuous and very well developed algal ridge, the Corre Corre ridge, extends for about $1 \mathrm{~km}$ along the eastern shore of the island. This extends over $1 \mathrm{~m}$ above low water, with a front edge which drops nearly vertically to depths of about $6 \mathrm{~m}$ and a strongly terraced back ridge. A smaller and lower ridge also occurs off the south-eastern point of Concordia Bay (Adey and Burke, 1976). (Living reef is mapped by ECNAMP (1980e) as occurring all around the island but this may refer to the algal ridge). Roos (1971) describes corals at six localities around the island.

Saba has a steeper slope around it as it is not situated on a bank, but the surf-swept rocky shores are equally unsuitable for coral growth (Adey and Burke, 1976). However, isolated coral formations occur around the coast (ECNAMP, 1980d), and Roos (1971) describes corals at three localities. A brief survey was carried out in 1984 at the request of the Island Government, in connection with the establishment of a marine park (van't Hof in litt., 7.9.94). Off the south coast, there is a well developed reef at $80 \mathrm{ft}$ depth $(24 \mathrm{~m})$, separated from the shore by a wide sand channel and dropping off at the seaward edge. The reef runs parallel to shore for at least one kilometre. Coral cover is over $90 \%$, with large flattened colonies of Montastraea annularis, Colpophyllia natans and Porites astreoides. There are also some seamounts, the surface of which have good reef development at $100-110 \mathrm{ft}$ depth $(30-33 \mathrm{~m})$. The dominant scleractinians are $C$. natans, Agaricia spp. and $M$. annularis, coral cover reaches $100 \%$ and the fish fauna is spectacular. Shallow Acropora palmata stands occur along the south-west coast and at Core Gut Bay. As a result of erosion, large boulders are found all along Saba's coast, most of which have been colonized by scleractinians and gorgonians. The larger the boulders, the better protected they are from sedimentation due to coastal run-off. This is particularly well demonstrated at Core Gut Bay where boulders $3-4 \mathrm{~m}$ high and $3-4 \mathrm{~m}$ in diameter, covered with predominantly live $M$. annularis, $C$. natans and $P$. astreoides, are found in sediment rivers that have scoured the corals from the base of the boulders; the boulders look like huge coral mushrooms (van't Hof in litt., 7.9.84).

Several small bench algal ridges are found on the east coast of Sint Maarten off Guano Bay, the largest of which, about $1 \mathrm{~km}$ south of Oyster Pond, was examined by snorkelling by Adey and Burke (1976). The reefs on the south-west coast form an apparently continuous barrier (ECNAMP, 1980f) and are considered to be among the more important marine habitats of the Lesser Antilles, extending more or less continuously for $23 \mathrm{~km}$ (ECNAMP, 1982).

The Windward and Leeward groups have a similar number of coral genera (about 23) but the Windwards have fewer coral species ( 33 hermatypic corals compared with 50 in the Leewards). This is largely because deep water species are lacking from the Windwards. The Windwards also differ from the Leewards in the abundance of Isophyllia and Isophyllastrea which are rare in the Leewards (Bak, 1977). The coral fauna of Curaçao is not considered to be especially rich, but is similar to that of Barbados (Roos, 1964). The reefs of the Netherlands Antilles are compared with others in the Caribbean in Bak (1977).

The fish fauna of Curaçao is described by Nagelkerken (1974), the distribution of groupers (Serranidae) and snappers (Lutjanidae) throughout the Netherlands Antilles is described by Nagelkerken (1981), and a comparative study of carnivorous fish has been carried out in Curaça Underwater Park and Bonaire. In the latter, where spearfishing pressure is very low, groupers were found to be far more abundant (van't Hof, 1983c).

Bacon et al. (1984) and Meylan (1983) describe the status of marine turtles. In the Windward group, the Green Turtle Chelonia mydas and the Hawksbill Eretmochelys imbricata are fairly common around all three islands and nest on Sint Eustatius; the latter nests on Saba. In the Leeward group, the Hawksbill is particularly common and nests and the Green and Loggerhead Caretta caretta also occur. The seabird colonies of the Netherlands Antilles are described by Halewyn and Norton (1984). In the Windward Islands, Sint Maarten and St Martin have at least nine and possibly eleven breeding species; Saba has four and possibly seven breeding species; Sint Eustatius has three breeding species. In the Leeward Islands, Bonaire supports between six and eight breeding species; Curaçao has one and maybe three species breeding; Aruba has seven or eight breeding species. Important wetland sites in the Netherlands Antilles are described in Scott and Carbonell (1986).

The Caribbean Marine Biological Institute (CARMABI) at Piscaderabaai in Curaçao has been engaged in coral reef research since the late $1950 \mathrm{~s}$ and more than 250 papers have been produced. Roos (1971) described the shallow water stony corals of the Netherlands Antilles, and ecological aspects were described by Bak (1975). Most research has been done on Curaçao, with some on 
Aruba and Bonaire. A reef mapping project using aerial surveys has been carried out in the Leeward group (van Duyl, 1985). The marine habitats of the Windward group, particularly on the most exposed coasts, are relatively unstudied, but from what is known it appears that the Leeward group is considerably richer in terms of reef development and species diversity (Bak, 1975). In 1970, CARMABI embarked on a coral reef research programme aimed at the establishment and management of marine parks and most research carried out in the islands is linked to this (van't Hof, 1982a).

\section{Reef Resources}

Fishing, although artisanal, is an important activity in the islands. In the Leeward group, there are three main types: bottom fishing, using hand lines and small boats, which is reef-based; limited trap fishing on the shallow reef terrace; and nearshore trolling, which is of moderate importance, and involves the use of larger boats for pelagic and semi-pelagic species such as tuna (Scombridae), wahoo, marlin Makaira spp., dolphin fish Coryphaena spp. and barracuda Sphyraena spp. Five ornamental fish traders operate out of Curaçao. There are one full time and five part time collectors of black coral, whose catches are monitored, and small quantities of manufactured items are exported. On Saba, there is occasional spearfishing by some 10-20 local fishermen but there appears to be no over-exploitation (van't Hof in litt., 7.8.84).

Tourism, based on reef-related activities, is becoming increasingly important in the Leeward group. Bonaire (see separate account) has limited resources and is the least populated island. Since 1974 it has depended heavily on tourism, its popularity being largely due to the lack of industrial development and the fact that it is relatively unspoiled. Diving is an essential part of the tourist industry (Anon., undated; van't Hof, 1982a). In Curaçao, the most populated island of this group, tourism is centred on the south-west coast near the Underwater Park (ECNAMP, 1980c). Diving and snorkelling are also popular activities on Aruba, particularly on the barrier reef on the south coast, near Commandeursbaai, and at Arasji on the west coast (Ormond, 198?). Tourism is also being developed in the Windward group. On Sint Maarten, the most populated island, it is concentrated around Philipsburg on the south coast; there are dive sites off the south-east point and three SCUBA operations take diving groups to Anguilla (ECNAMP, 1980f). There are 35 dive sites on Saba and some of the south-west coral formations have been identified as potential attractions for snorkelling and diving (ECNAMP, 1980d). The unusual coral formations around Saba, including seamounts, coral-covered, mushroom-shaped boulders and pinnacles encrusted with algae, sponges, gorgonians and other invertebrates provide considerable potential for the development of tourism and for further research (van't Hof in litt., 7.9.84).

\section{Disturbances and Deficiencies}

White-band disease, which spread throughout the Leeward Islands between 1980 and 1982, caused the death of more than $90 \%$ of the complete standing stock of $A$ cervicornis. Regeneration started in March 1982 and has been studied experimentally on Agaricia agaricites and Montastraea annularis on the south-west coast of Curaçao (Baket al., 1977; Bak and Criens, 1981). Mass mortalities of Diadema antillarum have recently been reported from around Curaçao, Bonaire, Aruba and Saba (Bak, 1985), probably due to the water-borne pathogen considered to be responsible for the Caribbean-wide death of this species. The long term significance of this is not known. Storm damage was also reported from the north-east coast of Curaçao and at Bonaire (Rogers, 1985).

Disturbances on the Bonairean reefs due to human activities are discussed in the account for the Bonaire Underwater Park. Occasional storms, water turbidity, oil pollution, thermal pollution, eutrophication of the surface water and pier construction have been considered responsible for the local absence of living colonies of $A$ palmata and $A$ cervicornis along the coast of Curaçao and Bonaire (van Duyl, 1982). Reefs around Curaçao have been affected to varying degrees by over-fishing, collecting and industrial pollution (van't Hof, 1982b). The previously abundant reef life was seriously affected by spearfishing and shell and tropical fish collection, to the point where groupers, turtles, Spiny Lobsters Panulirus argus and, on Bonaire, Strombus gigas, became rare. The north coast of Curaço was affected by heavy pollution, particularly in the area from Hato to Wacawa (Hoogerwerf, 1977). A sanitary land fill at Koraal Specht is now full; a new land fill at Malpais has been constructed and dumping of waste at Hato is now illegal (van't Hof in litt., 53.86). An environmental impact study is currently underway in the Caracasbaai area, which is leased to the Isla Oil Refinery (Sybesma, 1986).

Ormond (198?) described severe damage to the reefs on the south coast of Aruba mainly as a result of pollution from the following sources: nitrates and phosphates from sewage effluent, the waste dump, rum factory, Lago Esso Refinery and oil spills from the tanker terminal; phenols from the waste dump, rum factory, refinery and oil spills; and toxic metals from a paint factory and the refinery. Furthermore, high concentrations of sewage bacteria were found in the sea along this coast. The barrier reef was considered to be largely dead, with a maximum of $20 \%$ live coral cover in only a few places. Much of the damage was caused by the eroding activities of the urchin D. antillarum which increased in numbers (prior to its more recent disappearance) as a result of increased algal growth caused by the pollution and possibly a decrease in the predatory triggerfish (Balistidae) population through spearfishing. More recently, CARMABI has prepared a report for the Government of Aruba on the impact of the Lago Oil Refinery on the marine environment and it is reported that action may be taken against the company concerned (Sybesma, 1986). The refinery was reported to have closed down in 1985 (Scott and Carbonell, 1986).

There is little information on the conservation status of the reefs of the Windward group. Following the development of tourism in the 1960s, the Spiny Lobster has declined so seriously on Sint Maarten that local consumption has had to be met by imports (Dubois, 1985). There are several sand mining sites around the coast of Sint Maarten (ECNAMP, 1980f) and extensive commercial development on the south coast (Meylan, 1983) which may be having an impact. 


\section{Legislation and Management}

The Bonaire Island Government passed several ordinances dealing with marine resource management and conservation including a minimum size requirement for catching spiny lobster and bans on spearfishing, the collection of turtle eggs and the collection or destruction of coelenterates and crustose coralline algae (Timmers, 1979). In 1985, the Marine Environment Ordinance was passed which incorporates existing marine environmental legislation and provides for comprehensive management regulations with regard to fisheries, coral reefs and the vulnerable Lagoon Lac (see separate account). The Island Government of Curaçao passed similar legislation, the Reef Management Ordinance, in 1976 (Hoogerwerf, 1977), which prohibits spearfishing and collecting or destroying of coelenterates and crustose algae in all island waters. On Aruba, spearfishing and the collection of corals are banned, although there is evidence that enforcement is not very good (Ormond, 198?). Permits may be issued on Bonaire and Curaçao for the collection of corals for scientific and educational purposes only; permits on Aruba do not specify the purpose of collecting. Attempts are currently being made to change the legislation on spearfishing in order to permit this activity under licence (Sybesma, 1985a and b).

The private Netherlands Antilles National Parks Foundation (Stichting Nationale Parken Nederlandse Antillen - STINAPA) is responsible for administration of Parks. The Bonaire and Curaçao Underwater Parks are described in separate accounts. A marine park is situated on the north-west coast of Sint Eustatius near Jenkins Bay (ECNAMP, 1980e) and one has been established on the south coast of Sint Maarten to the west of Philipsburg (ECNAMP, 1980f). No information is available on these areas.

\section{Recommendations}

A survey of the reefs on the western part of Curaçao was planned for 1984, with a view to establishing a second park on the island. There are no formal proposals for marine parks on Aruba (ECNAMP, 1980a and d), but recommendations have been made for two areas (see separate accounts). A proposal for the establishment of a marine park on Saba has been prepared, to include all island water zones for different types of use (van't Hof, 1985c). Reserves have been proposed for the reefs off the southern tip of Sint Maarten and for the islands to the south-east (Man O'War Shoal, Pelican Cay and Molly Beday) which have important seabird rookeries.

\section{References}

Adey, W.H. and Burke, R. (1976). Holocene bioherms (algal ridges and bank-barrier reefs) of the eastern Caribbean. Geol. Soc. Am. Bull. 87:95-109.

Anon. (undated). Project Bonaire Marine Park. IUCN files.

Bacon, P., Berry, F., Bjorndal, K., Hirth, H., Ogren, L., Weber, M. (1984). The National Reports. Proceedings of the Western Atlantic Turtle Symposium, Vol. 3. University of Miami Press, Florida.

Bak, R.P.M. (1975). Ecological aspects of the distribution of reef corals in the Netherlands Antilles. Bijdr. Dierk. 45: $181-190$.
Bak, R.P.M. (1977). Coral reefs and their zonation in the Netherlands Antilles. AAPG Studies in Geology 4: 3-16.

Bak, R.P.M. (1985). Recruitment pattems and mass mortalities in the sea urchin Diadema antillarum. Proc. 5th Int. Coral Reef Congr., Tahiti, Vol.5: 267-272.

Bak, R.P.M., Brouns, J.J.W.M. and Heys, F.M.L。 (1977). Regeneration and aspects of spatial competition in the scleractinian corals Agaricia agaricites and Montastraea annularis. Proc. 3rd Int. Coral Reef Symp., Miami, Florida 1977: 143. Abstract.

Bak, R.P.M. and Criens, S.R. (1981). Survival after fragmentation of colonies of Madracis mirabilis, Acropora palmata and A cervicornis (Scleractinia) and the subsequent impact of a coral disease. Proc. 4th Int. Coral Reef Symp., Manila, Vol. 2:221-227.

Bak, R.P.M. and van Moorsel, G.W.N.M. (1979). De invloed van het water en Energie Bedrijf (Bonaire) op het Koraalrif. CARMABI, Curaçao, Internal Report.

Dubois, R. (1985). Coastal fisheries management lessons learned from the Caribbean. Case Study 4. In: Clarke, J.R. (Ed.). Coastal Resources Management: Development Case Studies. Coastal Publication 3, Renewable Resources Information Series, Research Planning Institute Inc., Columbia, South Carolina.

ECNAMP (1980a). Aruba. Preliminary Data Atlas. Survey of Conservation Priorities in the Lesser Antilles. Eastern Caribbean Natural Area Management Program.

ECNAMP (1980b). Bonaire. Preliminary Data Ailas. Survey of Conservation Priorities in the Lesser Antilles. Eastem Caribbean Natural Area Management Program.

ECNAMP (1980c). Curaçao. Preliminary Data Allas. Survey of Conservation Priorities in the Lesser Antilles. Eastern Caribbean Natural Area Management Program.

ECNAMP (1980d). Saba. Preliminary Data Atlas. Survey of Conservation Priorities in the Lesser Antilles. Eastem Caribbean Natural Area Management Program.

ECNAMP (1980e). St Eustatius. Preliminary Data Atlas. Survey of Conservation Priorities in the Lesser Antilles. Eastern Caribbean Natural Area Management Program.

ECNAMP (1980f). Saint Martin/Sint Maarten. Preliminary Data Allas. Survey of Conservation Priorities in the Lesser Antilles. Eastern Caribbean Natural Area Management Program.

ECNAMP (1982). Final Report. Survey of Conservation Priorities in the Lesser Antilles. Eastern Caribbean Natural Area Management Program.

Gorissen, M.W. and Meyer, GJ. (1981). Het belang van de zeegrasvelden en de mangrovebossen in de lagune Lac voor de vissen in Lac en voor de vissen op het rond Bonaire gelegen koraalrif. Verslag no. 157, Laboratorium voor Aquatische Oecologie, Nijmegen.

Halewyn R. van and Norton, R.L. (1984). The status and conservation of seabirds in the Caribbean. In: Croxall, J.P., Evans, P.G.H. and Schreiber, R.W. (Eds), Status and Conservation of the World's Seabirds. ICBP Technical Publication No. 2, Cambridge.

Hoogerwerf, D. (1977). Curaçao (Netherlands Antilles). Participant presentation at Workshop on Nature Conservation, Dominica. 16 November - 4 December 1977.

IUCN (1982). IUCN Directory of Neotropical Protected Areas. Tycooly International Publishing Ltd, Dublin.

MacIntyre, I.G., Kinsman, DJJ. and German, R.C. (1975). Geological reconnaisance survey of Saba Bank, Caribbean Sea. Caribb. J. Sci. 15(1-2): 11-15.

Meylan, A.B. (1983). Marine turtles of the Leeward Islands, Lesser Antilles. Atoll Res. Bull. 278:24.

Nagelkerken, W.P. (1974). On the occurrence of fishes in 
relation to corals in Curaçao. Stud. Fauna Curaçao 45: 118-141.

Nagelkerken, W.P. (1981), Distribution of the groupers and snappers of the Netherlands Antilles. Proc. 4th Int. Coral Reef Symp., Manila Vol.2: 479-484.

Newton, E. (1982). Annual Report. Project 1496. Bonaire Marine Park.

Newton, E. and van't Hof, T. (1982). The distribution of black corals around Bonaire. Proc. Ass. Is. Mar. Labs Carib. 16.

Ormond, R. (198?). Final report to the Aruba Beach Club on aspects of the marine environment of Aruba (Unpub, rept.).

Rogers, C.S. (1985). Degradation of Caribbean and Western Atlantic coral reefs and decline of associated fisheries. Proc. 5th Int. Coral Reef Cong., Tahiti 6: 491-496.

Roos, P.J. (1964). The distribution of reef corals in Curaçao. Stud. Fauna Curaçao 20: 1-51.

Roos, P.J. (1971). The shallow-water stony corals of the Netherlands Antilles. Studies fauna Curaçao and other Car. Isl. 37: 1-108.

Scatterday, J.W. (1974). Reefs and associated coral assemblages off Bonaire, Netherlands Antilles, and their bearing on Pleistocene and recent reef models. In: Cameron, A.M., Campbell, B.M., Cribb, A.B., Endean, R., Jell, J.S., Jones, O.A., Mather, P. and Talbot, F.H. (Eds). Proc. 2nd Int. Coral Reef Symp., The Great Barrier Reef Committee, Brisbane, Australia : 85-106.

Scott, D.A. and Carbonell, M. (1986). A Directory of Neotropical Wetlands. IUCN, Gland and Cambridge.

Sybesma, J. (1985a). Curaçao Underwater Park. Progress report July-September 1985. Netherland Antilles National Parks Foundation. 6 pp.

Sybesma, J. (1985b), Curaçao Underwater Park. Progress report October-September 1985, Netherland Antilles National Parks Foundation. 4 pp.

Sybesma, J. (1986). Curaçao Underwater Park. Progress report April-June 1986, Netherlands Antilles National Parks Foundation. 8 pp.

Timmers, W.W. (1979). Wet geving Natuurbeheerop de Nederlandse Antillen in 1978. STINAPA Doc. Ser. no. 6. $304 \mathrm{pp}$.

van den Hoek, C., Colyn, F., Cortel-Breeman, A.M. and Wanders, J.B.W. (1972). Algal vegetation types along the shores of inner bays and lagoons of Curaçao and of the Lagoon Lac (Bonaire), Netherlands Antilles. Verh. Kon. Ned. Akad. Wet. Afd. Natuurkunde 2, 61(2): 1-72.

van der Knaap, M. (1982). Kanastervisserijonderzoek op Bonaire. Nederlandse Antillen Subfaculteit Biologie, R.U. Leiden.

-van der Land, J. (1977). The Saba Bank - a large atoll. FAO Fish Rept, 200: 469-481.

van Duyl, F.C. (1982). The distribution of Acropora palmata and Acropora cervicornis along the coasts of Curaçao and Bonaire, Netherlands. Abstract of paper given at meeting of the International Society for Reef Studies, Leiden.

van Duyl, F.C. (1985), Allas of the Living Reefs of Curaçao and Bonaire (Netherlands Antilles). Publ. 17, Foundation for Scientific Research in Surinam and the Netherlands Antilles.

van't Hof, T. (1981). Progress Report. May-August, 1981, Bonaire Marine Park.

van't Hof, T. (1982a). Bonaire Marine Park: an approach to coral reef management in small islands. Paper presented at Third World National Parks Congress, Bali, Indonesia. October 1982. van't Hof, T. (1982b). WWF/IUCN Project 3065: Curaçao Underwater Park, Annual Report 1982.

van't Hof, T. (1982c). Curaçao Underwater Park (WWF/IUCN project 3065). Progress Report. September-December 1982.

van't Hof, T. (1983a). Curaçao Underwater Park (WWF/IUCN Project 3065). Progress Report. January-March 1983.

van't Hor, T. (1983b). Guide to the Bonaire Marine Park. STINAPA Doc. Ser. No. 11, STINAPA, Curaçao, $153 \mathrm{pp}$.

van't Hof, T. (1983c). Curaçao Underwater Park. Progress Report Oct-Dec. 1983, IUCN/WWF Project No. 3065, Netheriands Antilles National Parks Foundation.

van't Hof, T. (1983d). The influence of dredging on a coral reef in Bonaire, Netherlands Antilles. Proc. Ass. Is. Mar. Labs Carib. 17.

van't Hof, T. (1985a). Curaçao Underwater Park Management Plan. Netherlands Antilles Foundation, Curaçao.

van't Hof, T. (1985b). The economic benefits of marine parks and protected areas in the Caribbean region. Paper presented at 5th International Coral Reef Congress, Tahiti (unpub.).

van't Hof, T. (1985c). Saba Marine Park. A proposal for integrated marine resource management in Saba. Netherlands Antilles National Parks Foundation, Curaçao. van't Hof, T. and Cornet, H. (1983). Guide to the Curaçao Underwater Park. STINAPA Doc. Ser. No. 12, STINAPA, Curaçao.

van't Hof, T. and Kristensen, I. (1981). Interim report on the previous history, the present status and the future requirements of the Bonaire Marine Park (IUCN/WWF Project 1496).

Vroman, M. (1968). The marine algal vegetation of $\mathrm{St}$ Martin, St Eustatius and Saba (Netherlands Antilles). Stud. Flora Curaçao and Other Carib. Is. 2: 1-120.

\section{ARASJI BAY}

Geographical Location $12^{\circ} 17^{\prime} \mathrm{N}, 70^{\circ} 02^{\prime} \mathrm{W}$; north-west point of Aruba.

Physical Features Arasji is a small bay situated just below a rocky headland and is moderately exposed to waves deflected around the point. A small cliff is situated $1 \mathrm{~km}$ back from the shore which has a sandy beach. The bay slopes very gradually out to sea. Visibility is poor (up to $25 \mathrm{ft}(8 \mathrm{~m})$ ) on account of wave action and the sand bottom (Ormond, 198?).

Reef Structure and Corals Despite sandy conditions and moderate wave action, there is abundant coral in the northern part of the bay at 5-15 ft (1.5-4.6 m) depth, with average live coral cover of $30 \%$. Acropora palmata predominates close to shore and $A$ cervicornis further out, with a variety of other corals and gorgonians scattered among it (Ormond, 198?).

Noteworthy Fauna and Flora The headland is covered with scrubby vegetation and cacti (Ormond, 198?).

Scientific Interest and Research Not known. 
Economic Value and Social Benefits There is a lighthouse on the cliff. A few visitors snorkel in the bay, and there is considerable potential for tourism (Ormond, 198?).

Disturbance or Deficiencies Although coral cover and visibility are poorer than in south-east Aruba, there is no particular evidence of pollution or damage to the corals. Corals were being collected here on a semi-commercial basis in the late 1970s for sale in the U.S.A. and South America (Ormond, 198?).

Legal Protection None.

\section{Management None.}

Recommendations Arasji is considered the most suitable site on Aruba for the development of a commercially operated marine park on account of its comparative lack of exposure, its reasonably good corals and its attractive adjacent coastal area. Ormond (198?) makes a number of suggestions for the implementation of such a park.

\section{BONAIRE MARINE PARK}

Geographical Location The Park consists of the marine area, from high water tidemark to $60 \mathrm{~m}$ depth, around the islands of Bonaire and Klein Bonaire; $12^{\circ} 02^{\prime}-12^{\circ} 18^{\prime} \mathrm{N}$, $68^{\circ} 12^{\prime}-68^{\circ} 25^{\prime} \mathrm{W}$.

Area, Depth, Altitude About 2600 ha (Park includes the Lac Lagoon); Bonaire has a coastline of $104 \mathrm{~km}$; depths are from sea-level down to $60 \mathrm{~m}$.

Land Tenure Territorial waters owned by the Government. Approximately $60 \%$ of the coastal land is also Government owned; Klein Bonaire is privately owned.

Physical Features Physical conditions are very stable. Temperatures range from $26^{\circ} \mathrm{C}$ in February to $28^{\circ} \mathrm{C}$ in September. The water is extremely clear, low in nutrients and poor in plankton with a salinity of $36 \mathrm{ppt}$. Torrential rains may bring freshwater and mud from the land into the sea, but this occurs rarely. The north and east coasts are exposed to trade winds, the east coast having considerable wave action; the leeward coast is protected except in the south-west and has very calm water (IUCN, 1982). Bonaire lies outside the hurricane belt.

The north of Bonaire is hilly with basaltic and limestone rocks and steep cliffs occur along most of the coast. The south is flat with lagoonal areas and a low coast with coral rubble beaches or beach rock and carbonate sand. Lac is a shallow lagoon on the east coast with a surface area of $8 \mathrm{sq} . \mathrm{km}$, one third of which consists of mangroves and mudflats (van't Hof, 1982a; Scott and Carbonell, 1986). It is protected by a reef barrier but connected to the sea by a narrow opening. The algal vegetation has been described by van den Hoek et al. (1972).

The island is surrounded by deep water and continuous fringing reefs. A gradual sloping submarine terrace, varying in width from 20 to $160 \mathrm{~m}$, extends down to a drop-off at about $10 \mathrm{~m}$ and is followed by a slope varying in angle from $30^{\circ}$ to vertical, down to a depth of $50-60 \mathrm{~m}$. There is no true drop-off along parts of the windward coast where the submarine terrace continues to slope down at a low angle with only a slight increase in inclination between 15 and $20 \mathrm{~m}$ depth (van't Hof, 1982a).

Reef Structure and Corals Reef zonation has been described by Bak (1977) and Scatterday (1974), and van't Hof (1982a) proposes the following zonation, slightly modified after Bak (1977), for the leeward coast. The shore zone ( 0 to $1 \mathrm{~m}$ depth) is characterized by encrusting Diploria clivosa. An Acropora palmataMille pora spp. zone occurs from 1 to $4 \mathrm{~m}$ depth and an $A$ cervicornis zone from 4 to $7 \mathrm{~m}$ depth. $\mathrm{A}$ drop-off zone from 7 to $12 \mathrm{~m}$ is characterized by Gorgonacea just above the drop-off and Montastraea annularis at the drop-off; the effects of biodegradation are visible and dead surfaces of $M$. annularis are often colonized by Madracis mirabilis. On the north-west coast, the shallow terrace is often densely covered with exeptionally large heads of Montastraea annularis and $M$. cavernosa. On the windward side the terrace extends $100-200 \mathrm{~m}$ from shore at $12 \mathrm{~m}$ depth and is covered mainly with crustose coralline algae and Sargassum. The upper reef slope (from 12 to $25 \mathrm{~m}$ ) on the leeward side is dominated by $M$. annularis and Agaricia agaricites. The lower slope (from $25 \mathrm{~m}$ downwards) is often characterized by a $M$. annularisAgaricia spp. reef shingle community. With increasing depth, $A$ lamarcki, $A$ grahamae, Stephanocoenia michelini and Montastraea cavernosa become more important. About 55 species of stony coral have been described from Bonaire. Antipathes $c f$. dichotoma and $A$ pennacea are the principal species of black coral on the reef. Both are most abundant on the leeward side of the island, but $A$ dichotoma is often absent on the windward side (Newton and van't Hof, 1982).

Noteworthy Fauna and Flora The seagrass beds and mangroves of Lac function as a nursery for at least nine species of commercially important reef fish (Gorissen and Meyer, 1981). Strombus gigas, the Queen Conch used to be common in the seagrass beds, which are also characterized by the sea star Oreaster reticulatus and the urchin Tripneustes ventricosus. Hawksbills Eretmochelys imbricata and possibly Leatherbacks Caretta caretia and Green Turtles Chelonia mydas nest on Bonaire (Bacon et al., 1984). Breeding birds at Lac and other important wetland sites within the Bonaire Marine Park are described in Scott and Carbonell (1986).

Scientific Importance and Research The Bonaire reefs offer a wide array of reef structures and a rich reef fish population, lacking signs of over-exploitation or other serious human interference. The Park is unique in comprising all the reefs around Bonaire rather than a specific area and can be regarded as a resource management programme for an island reef complex. The Karpata Ecological Centre has wet and dry laboratories, basic equipment and residential facilities. Research is carried out to provide answers to management problems such as visitor impact, the possible need for a schedule of temporarily closed areas, the impact of resource exploitation in the Park and the impact of coastal zone development. Research needs are determined in co-operation with CARMABI; Park staff work on problems relating to immediate Park management and CARMABI focuses on more fundamental studies of coral 
reef ecology, providing baseline data for reef management (van't Hof, 1982a). Many of the papers published by CARMABI deal with the Bonaire marine environment. Current research projects include surveys, monitoring, status and distribution of black corals, reef mapping, the nursery function of Lac and dive statistics. A project to rear conch was set up on Bonaire in 1981 (Dubois, 1985).

Economic Value and Social Benefits The island has six villages, the main one being Kralendijk (Playa), but most of the land is uninhabited. The reefs are easily accessible, and their main uses are fishing and recteation. There was a $46 \%$ increase in diving tourism on Bonaire from 1980 to 1981 (van't Hof, 1982a) which now brings in about US\$5 000000 a year. There are four commercial diving operations. Over 50000 dives were logged off Bonaire in 1981 (van't Hof, 1981), the majority off Klein Bonaire, the second most popular site being in front of the Flamingo Beach Hotel (van't Hof, 1981). Dive sites and tourist facilities are mapped in ECNAMP (1980b) and described in van't Hof (1983b). Black coral is collected by the Bonairean Handicrafts Foundation, under a strict system of control: about 300 colonies, $90-250 \mathrm{~cm}$ high, are collected annually (Anon., undated; van't Hof, 1981). A survey has been carried out to provide a scientific basis for the management of commercial harvesting (van't Hof, 1981).

Disturbance or Deficiencies van't Hof (1982a) outlines actual and potential disturbances to the reefs. The Water and Electricity Company (Water en Energie Bedrijf, WEB) discharges hypersaline, hot cooling water into the sea and a study revealed the destruction of approximately 15000 sq. $m$ of living reef in the 1970s (Bak and van Moorsel, 1979). This impact was considered local but expansion of the plant could have further adverse effects on adjacent reefs. Saline cooling water from the power station generating electricity for the Dutch World Broadcasting Station (Radio Nederland Wereld Omroep (RNWO)) is discharged into the sea and has had a minor, local effect on corals through increased temperature. The crude transhipment facility of the Bonaire Petroleum Corporation (BOPEC) discharges treated ballast water and bilge from carriers into the sea. This currently has no known effects on the reefs but its possible long-term effects should be studied. The risk of a major oil spill is present, though unlikely, and small spills have so far had only minimal effects. BOPEC is a member of the Clean Caribbean Co-operative (CCC), an organization that helps its members to act quickly in the case of a major spill. Shipping activity has so far had little effect on the reefs, but as it increases, port and pier construction may cause major local damage to the reefs. Tar sampling on the beaches is carried out in connection with the Caribbean Marine Pollution (Petroleum) Monitoring Program (CARIPOL) (van't Hof, 1981).

Current fishing effort does not seem to be having an impact on reef fish populations, but fish traps, when used, cause damage to corals (van der Knaap, 1982; van't Hof, 1983a). The impact of the occasional collection of turtles by fishermen, and of spiny lobster collecting and spearfishing is unknown but probably minimal (van't Hof, 1982a). Fish collection for the aquarium trade has been almost totally abandoned, as has collection of corals and shells for the souvenir trade. Collection of black coral in the past may have caused a decline in the population in some parts of the island; the impact of current collecting practices is not known. Violations of current legislation are infrequent and generally involve spearfishing and black coral collection.

Yachting and boating may have an increasingly serious effect, particularly on the leeward coast where boats are anchored on the narrow terrace of the fringing reef since there are no sheltered shallow bays. Quadrats established to investigate anchor damage showed little change over-a year, but storm damage quadrats at Karpata demonstrated significant regrowth of Acropora palmata. Increasing numbers of inexperienced snorkellers and SCUBA divers may also damage reefs. Permanent quadrats have been established to photographically monitor the stability of the reef components in areas of high diving pressure (Anon., undated).

Several development projects for hotels and resorts pose a threat, particularly in the absence of a long-term plan for tourist development. The construction of one marina is in progress and another one is planned without the necessary safeguards for control of pollution and sedimentation. The Flamingo Paradise project to develop a canal system, marina and water front building was never completed, but impact assessment studies (Newton, 1982; van't Hof, 1983d) showed that it would have caused heavy sedimentation.

The topography and water circulation of Lac could be affected by expansion of the solar salt works of the Antilles International Salt Company (AISCO). Lac is also potentially threatened by plans to mine sand which would affect the habitat of juvenile Queen Conch Strombas gigas, this species having already been heavily over-fished. There are indications of over-collection of the sea star Oreaster reticulatus by souvenir hunters. The mangroves are showing signs of damage, due partly to natural causes but probably also because of the construction of a dam further inland which has reduced freshwater run-off in the bay. Further threats to wetland areas are described in Scott and Carbonell (1986). Private ownership of Klein Bonaire leaves the future of its coast and coral reefs insecure. However, the 6000 ha Washington-Slagbaai National Park ensures that no development will take place in the north-western part of Bonaire.

Legal Protection The Bonaire Marine Park was established in 1979, under an IUCN/WWF project with WWF-Netherlands funding (van't Hof and Kristensen, 1981). Under early island ordinances, turtle eggs could not be disturbed or taken and there was a minimum size of $25 \mathrm{~cm}$ from eye to tail for lobsters. An export licence was required for exports of coral reef products. Spearfishing was prohibited in 1971, the use of seine nets was controlled and collection of reef organisms forbidden (Anon., undated; van't Hof and Kristensen, 1981). In 1985, the Marine Environment Ordinance was passed by the Island Council. This incorporates the above legislation and covers five major topics (van't Hof, 1982a):

1. An advisory committee which is to advise the Government on all matters regarding the marine environment;

2. The Bonaire Marine Park, its boundaries and regulations: all activities that may cause damage are prohibited (details given in van't Hof, 1982a), but traditional fishing is permitted; 
3. Fishery regulations which cover spearfishing, fish traps, conch fishing, turtle eggs, spiny lobsters and seine nets;

4. Regulations for Lac Bay which cover boat use, digging of canals, building of dams, removal of sand, and mangrove destruction;

5. Sanctions which include a maximum fine of US $\$ 2800$ or maximum imprisonment of one month.

The ordinance allows for additional measures to be taken by the Island Government, such as the temporary closure of areas suffering from high recreational pressure, control of the trap fishery and management of conch resources.

The Park includes a number of important wetland sites on the coast such as the Washington-Slagbaai National Park and Lac (Scott and Carbonell, 1986).

Management To facilitate control, the Park is not zoned as it is small and there are few areas of conflicting use. However, there are two "strict reserves", Karpata to Goto and Playa Frans to Boca Slagbaai, on the west coast where SCUBA diving and snorkelling are prohibited although traditional fishing other than trap fishing is permitted (van't Hof, 1982a). At the dive site named "Hands Off", only experienced non-camera carrying divers are allowed access, which permits the monitoring of the effects of novice divers and underwater photographers on the reef (van't Hof, 1981). A system of permanent moorings has been developed to prevent anchor damage, and 30 moorings have been put down. The Bonairean Handicrafts Foundation is allowed to collect black coral in an area where little recreational diving takes place, with a maximum of 24 collecting dives by two divers annually. A park staft member accompanies each collecting trip and records length and weight of the specimens collected.

The newly built Karpata Ecological Centre, based on an old plantation house facing the reefs, functions as headquarters, offering a variety of facilities for visitors and researchers. Park staff include a manager (director of Karpata Ecological Centre) and a ranger/diver/boatman. There are two boats, two vehicles, diving equipment, underwater photographic equipment and communication equipment. The Island Government is expected to provide funds for managing the Park; additional funds should become available through the tourist trade.

A number of brochures, a detailed guidebook and a film providing information on the Park have been produced for visitors and divers. Lectures and slide presentations have been given to tourist divers, and a divers' guide has been published (van't Hof, 1983b). A two-day course on environmental management was organized for school teachers.

Recommendations It is thought that in the future a full-time senior park ranger with law enforcement authority will be necessary. Environmental education of the local population is still required and it may be necessary to employ a full-time environmental education officer who could carry out a number of tasks, including the training of dive guides. To help ensure future funding of the Park, a proposal has been submitted to the Island Government to levy a tax per air fill, although grants will continue to be necessary for some time (van't Hof, 1982a). Legal measures are needed for the conch fishery (Anon, undated) and the black coral industry needs further investigation. Trap fishing in the drop-off zone and on the reef-slope should be prohibited because of the irreversible damage it causes to corals and other reef invertebrates, and the heavy impact it has on groupers and non-food reef fish. In the shallow Acropora cervicornis zone, regeneration of damaged corals is more rapid and there does not appear to be over-fishing. In Lac Bay, it is recommended that traps are used in the seagrass beds only and a minimum mesh size has been determined (van't Hof, 1983a); the Bay should be left undisturbed because of its nursery function for reef fish.

\section{COLORADO POINT}

Geographical Location $12^{\circ} 11^{\prime} \mathrm{N}, 69^{\circ} 50^{\prime} \mathrm{W}$. South-east point of Aruba.

Physical Features Water is clear with visibility up to and sometimes greater than $80 \mathrm{ft}(24 \mathrm{~m})$. The Point is exposed to prevailing easterly winds and waves (Ormond, 198?).

Reef Structure and Corals A rich well-developed fringing reef extends from west of the entrance of Klein Lagoon to just east of Punta Basora. The reef slopes gently from shallow water down to a partly sandy bottom at $40 \mathrm{ft}(12 \mathrm{~m})$. The slope is covered with a dense growth of a variety of corals with about $90 \%$ live coral coverage. Four zones were clearly identified: a) Acropora palmata in shallow water, b) Montastraea and other corals, c) A cervicornis and d) a mixed zone of Montastraea and gorgonians (Ormond, 198?).

Noteworthy Fauna and Flora Compared with other reefs on Aruba, the Queen Triggerfish Balistes vetula was moderately abundant and the urchin Diadema antillarum was scarce when surveyed by Ormond (198?).

Scientific Importance and Research This site is considered to have the best coral on Auba and was surveyed briefly by Ormond (198?).

Economic Value and Social Benefits The site's exposure to waves does not make it suitable for development as a major tourist attraction (Ormond, 198?).

Disturbance or Deficiencies The reef is situated upstream of sources of pollution on the south coast, and on the tip of the island where any pollutants may quickly be dispersed in the surrounding waters. The impact of the Lago Oil Refinery on the marine environment of the south coast of Aruba has been studied by CARMABI (Sybesma, 1986) (details not available at time of going to press). Fishing pressure is light due to the exposed nature of this part of the coast (Ormond, 198?).

Legal Protection None.

Management None.

Recommendations This was considered the highest priority area on Aruba for the creation of a marine park. The adjacent land was part of the social club of the Lago 
Esso Refinery and it was suggested that part of this might be donated by the refinery as a shore base for the park (Ormond, 198?). The refinery is reported to have closed in 1985 (Scott and Carbonell, 1986). Sybesma (1986) reports that a lawsuit is being carried out against the activities of the refinery in relation to the marine environment; it is not known, at the time of going to press, to what extent these affected this area.

\section{CURACAO UNDERWATER PARK}

Geographical Location Leeward coast of Curacao, from eastem tip of island extending $20 \mathrm{~km}$ westwards; $12^{\circ} 06^{\prime} \mathrm{N}$, $68^{\circ} 42^{\prime}-68^{\circ} 54^{\prime} \mathrm{W}$.

Area, Depth, Altitude 600 ha reefs and 436 ha inner bays; from highwater tidemark down to $60 \mathrm{~m}$ depth.

\section{Land Tenure $75 \%$ of the Park borders private land.}

Physical Features Physical conditions are very stable, with a salinity of $36 \mathrm{ppt}$ and temperatures ranging from $26^{\circ} \mathrm{C}$ in February to $28^{\circ} \mathrm{C}$ in September. Nutrient levels are low and the water is extremely clear. The eastern part is fairly heavily exposed to wave action, but this decreases westwards. The coast is largely of coral rubble beaches and/or beachrock, with steep cliffs in the Jan Thiel/Caracasbaai area. A submarine terrace, from 16 to $230 \mathrm{~m}$ wide, drops to $10 \mathrm{~m}$, followed by a steep reef slope $\left(40^{\circ}\right)$ with a lower limit at $50-60 \mathrm{~m}$ depth. Three inner bays, Spaanse Water, Fuikbaai and Awa di Oostpunt, are connected by relatively narrow openings to the sea. Spaanse Water is the largest and shallowest (maximum depth $12 \mathrm{~m}$ ) and has no clear water; Fuikbaai and Awa di Oostpunt both reach more than $20 \mathrm{~m}$ depth and have clear water in some areas. All three inner bays have seagrass areas. The bottom fauna of the inner bays has not been well studied although algal vegetation has been described by van den Hoek et al. (1972).

Reef Structure and Corals There is a diverse array of fringing reef types, both biological and geological, with different types of reef communities in various stages of development. Reefs further west in the vicinity of Piscaderabaai have been described in detail and are similar in many respects to those of the Park (Bak, 1977). A brief description of the Park reefs is given in the management plan (van't Hof, 1985a) and some areas are briefly mentioned in Roos (1964).

The shore zone is characterized by Diploria, including the encrusting $D$. clivosa which is limited to this zone. The Acropora palmata zone is dominated by dense stands of this species, but Millepora spp. and crustose coralline algae, especially Porolithon pachydermum, are also found. Seaward, in the barren zone, the sea floor consists largely of unconsolidated coral, algal fragments and gorgonians, such as Pseudopterogorgia acerosa and $P$. americana which are common. In the lower terrace zone, species abundance and coral cover increases; Madracis mirabilis is particularly common, often growing in monospecific fields. East of Spaanse Water, an A cervicornis zone is frequently found on the lower terrace. East of Lagun Blancu, on the shallower submarine terrace, an $A$ palmatahead coral-gorgonian community is dominant.

In the drop-off zone, coral cover and species diversity is higher. Montastraea annularis, $M$. cavernosa and Siderastrea siderea cover significant parts of the bottom and Agaracia agaricites becomes abundant. The upper-slope zone (from 15 to $30 \mathrm{~m}$ ) is vertical or near-vertical over about $22 \%$ of the reef length and has low coral cover but abundant sponges and antipatharians; along the upper edge gorgonians are very abundant and $M$. cavernosa is the most prominant scleractinian. Elsewhere in this zone, $A$ lamarcki predominates among a highly diverse coral community of deep and shallower water species. In the lower-slope zone, both species diversity and coral cover decline, and $A$ agaricites is almost completely replaced by $A$ lamarcki and $A$ grahamae. Deep water species such as Madracis formosa and Mycetophyllia reesi appear and most corals are flat, encrusting and small, although some, such as $A$ lamarcki, grow to large sizes. Coral cover decreases with depth while sediment increases, the main component being coral debris. The second terrace, at $60 \mathrm{~m}$ depth, is covered with fine sediment which limits coral growth to a few rocky outcrops; hermatypic corals may grow on these to depths of at least $80 \mathrm{~m}$ (Bak, 1975 and 1977).

Noteworthy Fauna and Flora Mangroves are found round Spaanse Water and Fuikbaai. van't Hof (1985a) describes work carried out on the fish fauna and briefly describes the invertebrate fauna of the reef and inner bays. The spiny lobster Panulirus argus is found in low densities. Antipatharians are present throughout the Park, becoming more abundant towards the east (notably Antipathes cf. dichotoma). The Hawksbill Eretmochelys imbricata is the only turtle species seen regularly.

Scientific Importance and Research The Park area was chosen on the basis that it includes the reefs on Curaçao least affected by human interference (van't Hof, 1982b) The reefs have been surveyed and mapped (van Duyl, 1985; van't Hof, 1983a) and a comparative study of reef fish communities in this Park and the Bonaire Park has been carried out (van't Hof, 1983a).

Economic Value and Social Benefits Recreational diving, tourism and fisheries are important. The local fishery is described by van't Hof (1985a). A hotel is located at the western park boundary which offers docking facilities for the Park's boat and caters for divers and snorkellers. Of the inner bays, Spaanse Water is the most developed, with marinas, housing and recreational facilities; part of Fuikbaai serves as a deep water port facility for sand and gravel transport. Until recently, the full potential of the reefs as a tourist attraction had not been realized but efforts are being made to rectify this. From January to August 1985, 1200 divers logged a mean of 1.4 dives per diver, compared with 5000 divers logging a mean of 8 dives per diver on Bonaire.

Disturbance or Deficiencies Overfishing, especially illegal spearfishing, is a problem, partly due to lack of wardening. Awa di Oostpunt used to support a substantial conch population but this has been depleted. There is illegal collection of corals and black coral. Coastal development may become a potential threat but phosphate mining has now ceased. Caracasbaai is a 
centre for oil shipment and transhipment and there are frequent small oil spills at the docks; to date, this has had no impact on the reefs. Dredging in the course of the construction of a marina adjacent to the aquarium may lead to damage through sedimentation and turbidity.

Legal Protection The Park was officially opened on December 14, 1983. Legal protection is based on the Reef Management Ordinance of 1976, which bans spearfishing. The export of tropical fish is subject to licence by the Government. Additional legislation has been submitted to the Island Government which covers anchoring on coral, construction of piers and jetties, placement of buoys, collecting of reef invertebrates and plants, possession of spearguns inside the Park, concessions to tour operators and permits for scientific or educational collecting.

Management The Park is administered by the Netherlands Antilles National Park Foundation. The Park was funded by WWF-Netherlands and the Netherlands Government for two years (van't Hof, 1982b) and the Curaçao Government is now subsidizing it for five years until it is self-sufficient from diving tourists. The Reef Management Ordinance has been poorly enforced but since July 1983, the park staff, consisting of a Park manager and a local counterpart, has had law enforcement authority and patrols the Park. A detailed management plan outlines current and proposed management practices (van't Hof, 1985a). The Park owns a boat, a pick-up truck and diving, photographic and communications equipment. Mooring buoys have been placed to prevent anchor damage and there is a snorkel trail under construction. Folders for visitors have been produced and a guide published (van't Hof and Cornet, 1983). On-site interpretation is provided by park staff and audi-visual presentations are taken to schools. Awa di Oostpunt and Fuikbaai have recently been stocked with juvenile conch from Bonaire's conch farm.

Recommendations The management plan (van't Hof, 1985a) lists recommendations for the final establishment and continued management of the Park.

We are very grateful to Tom van't Hof for compiling the preliminary draft of this account. 



\section{INTRODUCTION}

\section{General Description}

Reef development along the $352 \mathrm{~km}$ Pacific coastline of Nicaragua is inhibited by the influence of the cold upwelling in the Gulf of Papagayo, off Costa Rica, extending northwards (Glynn et al, 1983). However, the Caribbean coastline of $541 \mathrm{~km}$, described by Nietschmann (1973 and 1979), has a large area of reef. Until recently, this was very poorly known, although Vaughan (1919) briefly described some areas. Currently, a comprehensive investigation of the meteorology, physical oceanography, marine geology and coastal geomorphology of the Caribbean eastem shelf is underway by the Coastal Studies Institute, Louisiana State University (Murray et al., 1982; Owens and Roberts, 1978).

The shelf, which is $250 \mathrm{~km}$ wide in the north and narrows to $20 \mathrm{~km}$ in the south, deepens quickly to $20-40 \mathrm{~m}$ and maintains this general depth to the abrupt shelf edge. Heavy rainfall (4000-5000 $\mathrm{mm}$ a year) and rapid erosion of the volcanic highlands which flank the coast, result in the transport of large volumes of fresh water and sediment to the nearshore shelf. Persistent momentum provided by north-east trade winds and density gradients set up by riverine effluents interfacing with saline shelf waters, produce a strong (over $70 \mathrm{~cm} / \mathrm{s}$ ) north-south flowing coastal boundary current. This creates a zone, approximately $10 \mathrm{~km}$ wide, with a ramp of terrigenous sediments forming an interface between the shelf and shoreline where high turbidity and shifting substrate prevent reef formation. Outside this zone, reef growth is essentially uninhibited, as if the terrigenous coast and its abundant sources of noncarbonate sediment did not exist. Reefs flourish here even when occasionally affected by turbid water (Roberts and Murray, 1983).

Reefs vary from small patches and pinnacles to large (tens of metres in diameter), complicated platforms (kilometres wide) and well-defined belts and, apart from the narrow zone occupied by the coastal boundary current, are distributed across virtually the entire shelf. Only a few are close enough to sea level to be observed from the surface (Roberts and Murray, 1983). There are six major areas: Miskito Bank, north-east of Puerto Cabezas; Man O'War Cays, Crawl Cay and Taira (Tahira) Cay, east-north-east of Little Sandy Bay and Rio Grande Bar; the Pearl Cays, including King's Cay and Asking Cay (east of Tasbapauni), and Set Net Cays (east of Set Net); the Little Corn Island area; and the Big Corn Island area (Nietschmann in litt., 25.11.85).

The Pearl Cays complex of shallow reefs lie close to shore on the edge of the turbid coastal boundary and migration of turbid water into the complex is not uncommon, according to local fishermen. In spite of this however, the cays support a thriving community of Acropora palmata colonies on their windward eastern sides. Only Maroon Cay, in the coastal boundary current zone, has a poorly developed coral community at the reef crest. Coralline algae are abundant at the shallow margins of the reef and reconnaissance field work suggests that this increase is at the expense of typical
Caribbean reef-building corals. Mangroves occupy the cay interiors which consist of flooded storm rubble and other sediments. The remaining part of the Pearl Cays platform, especially the eastern section, is complicated by numerous carbonate build ups, many of which do not reach the surface (Roberts and Murray, 1983).

Reefs elsewhere vary from isolated build-ups surrounded by vast areas of relatively flat bottom, mantled with carbonate sediments rich in Halimeda, to mid-shelf carbonate platforms and island flanks that are veneered with a complex of living reefs of various sizes and dimensions such as those around Big and Little Corn Islands. Seaward of the Corn Islands, the sea floor deepens to about $60 \mathrm{~m}$ and extends to the abrupt break in slope that marks the shelf edge. At this point open ocean water is constantly moving on-shelf, promoting reef growth. Rugged reef topography characteristic of a belt several kilometres wide parallels the shelf edge. Some reefs are linear and tend to form a submerged barrier at the shelf margin, and others are isolated pinnacles rising over $20 \mathrm{~m}$ from the sea floor (Roberts and Murray, 1983). Big Corn Island (Isla del Maiz Grande) is described in a separate account. Aerial photos suggest that the reefs of Little Corn Island (Isla del Maiz Pequeña) have similar general patterns of topography and ecological structure to those of Big Corn Island.

Important wetland areas on the Nicaraguan coast are described in Scott and Carbonell (1986). Extensive work has been carried out on the five sea turtles found in Nicaragua (Groombridge, 1982; Nietschmann, 1975, 1977 and 1981; Bacon et al., 1984). Loggerheads Caretta caretta have scattered nesting sites along Caribbean coasts and offshore cays, but are sparse on the Pacific coast. Extensive areas of sea grass exist on continental shelf waters and provide grazing pasture for Green Turtles Chelonia mydas, which nest on the Caribbean coast and sporadically on the Pacific coast. Hawksbills Eretmochelys imbricata nest sparsely on both coasts, and are found on many of the Caribbean cays and reefs; Nicaragua is probably the last refuge for this species in the Caribbean. The Olive Ridley Lepidochelys olivacea, occurs only on the Pacific coasts where it is the commonest species. The Leatherback Dermochelys coriacea has sparse nesting on both coasts. Halewyn and Norton (1984) list three species of seabirds, the Brown Booby Sula leucogaster, Black Noddy Anous minutus and Brown Noddy $A$ stolidus, which may nest on the Caribbean coast and offshore islets of Nicaragua.

\section{Reef Resources}

Spiny lobsters are abundant on many of the reefs, which are important fishing areas for the coastal Miskito and Corn Island communities (Chislett and Yesaki, 1974). Most of the Nicaraguan coral cays are used as campsites by turtlemen, lobstermen and, more recently, Jamaican fishermen but due to the recent war in eastern Nicaragua, fishing pressure has been considerably reduced (Nietschmann in litt., 25.11.85) 


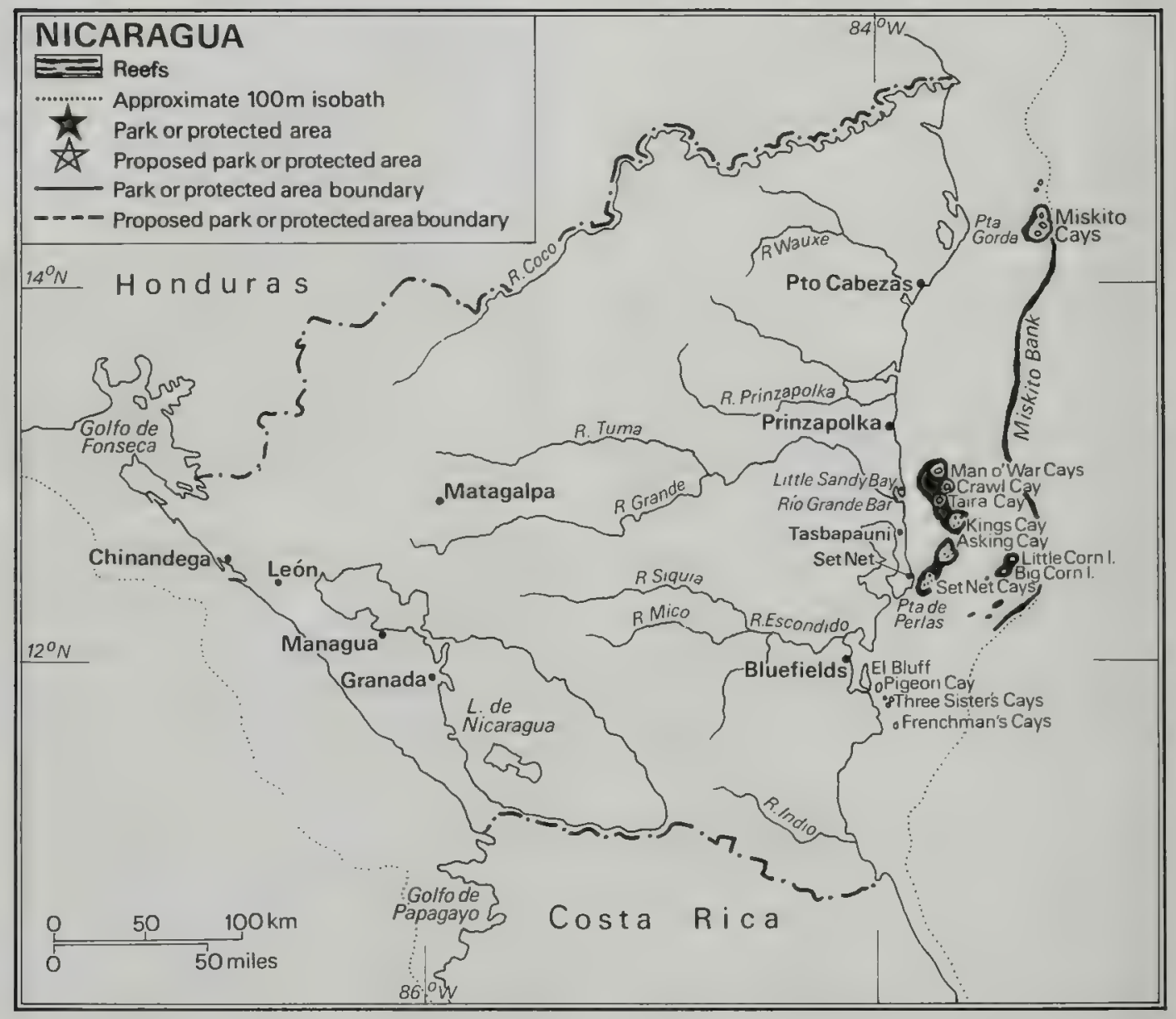




\section{Disturbances and Deficiencies}

Current research suggests that coastal waters are subject to considerable sedimentation under natural conditions (see above). However, it has also been suggested that reefs close to the mainland and prevailing coastal boundary current have been affected by heavy siltation caused by distant deforestation and erosion along the Ladino (non-Indian) agricultural front.

\section{Legislation and Management}

The reefs on the continental shelf are claimed by the Nicaraguan State, but all reefs, cays and intervening waters, other than around the Corn Islands, are also claimed by the Miskito people and nation. Ownership of these areas and resources were issues discussed during peace negotiations between the Indian resistance organization and the Government in 1984 and 1985. Conflict had broken out in the early 1970 s between the Miskito and Jamaicans who had leased fishing rights from Managua but not from the Miskito. The Miskito currently aim to defend their collective ownership over Indian land and sea territories.

The Instituto Nicaraguense de Recursos Naturales y del Ambiente (IRENA) is the governmental organisation responsible for conservation and wildlife research (IUCN, 1982). There are no protected marine areas (although Ray and McCormick (1976) list the coastal lagoons of Miskito and Golfo de Fonseca as marine reserves).

\section{Recommendations}

The projected management plan for coral reefs and resources under an acceptable autonomy agreement between the Nicaraguan State and the Miskito, Sumo and Rama people would include strong conservation efforts to insure recovery of sea turtle populations, protection against intrusion of "resource pirates" from coastal cities or from other countries and a sustainable management plan based on village by village control of reefs and inshore waters (traditional sea tenure). A plan presented to the Nicaraguan Government in 1980 for a marine park centred around the Miskito Cays and Miskito Bank area has been postponed.

\section{References}

* = cited but not consulted.

Bacon, P., Berry, F., Bjorndal, K., Hirth, H., Ogren, L., Weber, M. (1984). The National Reports. Proceedings of the Western Ailantic Turtle Symposium, Vol. 3. University of Miami Press, Florida.

Chislett, G.R. and Yesaki, M. (1974). Spiny lobster fishing explorations in the Caribbean. Mar. Fish. Rev. 36(9): 43-49.

Conzenius, E. (1929). Les îles Corn du Nicaragua. La Géographie, Paris 52: 346-362.

Geister, J. (1977). The influence of wave exposure on the ecological zonation of Caribbean coral reefs. Proc. 3rd Coral Reef Symp. Miami, 1: 23-29.

Geister, J. (1983). Holocene West Indian Coral Reefs: geomorphology, ecology and facies. Facies 9: 173-284.
Glynn, P., Druffel, E.M. and Dunbar, R.B. (1983). A dead Central American coral reef tract: possible link with the Little Ice Age. J. Mar. Res. 41: 605-637.

Groombridge, B (1982). The IUCN Amphibia-Reptilia Red Data Book, Part 1: Testudines, Crocodylia, Rhynchocephalia. IUCN, Gland, Switzerland.

Halewyn, R. van and Norton, R.L. (1984). The status and conservation of seabirds in the Caribbean. In: Croxall, J.P., Evans, P.G.H. and Schreiber, R.W. (Eds), Status and Conservation of the World's Seabirds. ICBP Technical Publication No. 2, Cambridge.

IUCN (1982). IUCN Directory of Neotropical Protected Areas. Tycooly International Publishing Ltd, Dublin.

McBirney, A.R. and Williams, H. (1965). Volcanic history of Nicaragua, Publ. Geol. Sci., Univ, California. 55: $1-75$.

-Murray, S.P., Hsu, S.A., Roberts, H.H., Owens, E.H. and Crout, R.L. (1982). Physical processes and sedimentation on a broad, shallow bank. Estuarine Coastal Shelf Science 14: 135-157.

-Nietschmann, B. (1973). Between Land and Water

Seminar Press, New York.

-Nietschmann, B. (1975). Of turtles, arribadas and people. Chelonia 2(6): 6-9.

-Nietschmann, B. (1977). Memorias de Arrecife Tortuga: Historia y Economica de las Tortugas en el Caribe de America Central. Banco de América, Managua. -Nietschmann, B. (1979). Caribbean Edge. Bobbs-Merrill Co., New York.

Nietschmann, B. (1981). Following the underwater trail of a vanishing species - the Hawksbill Turtle. National Geographic Society Research Reports 13: 459-480.

Owens, E.H. and Roberts, H.H. (1978). Variations of wave-energy levels and coastal sedimentation, eastern Nicaragua. Proc. 16th Coastal Engr. Conf., Hamburg, West Germany: 1195-1214.

Peters, J.L., Allen, G.M., Bardour, T. and Loveridge, A. (1929). Vertebrates from the Corn Islands. Bull. Mus. Comparative Zool., Harvard 69: 126-146.

Ray, C. and McCormick, G. (1976). Critical Marine Habitats; list of areas. Report to IUCN, IUCN/WWF project 39/4-1037.

Roberts, H. and Suhayda, J.N. (1983). Wave-current interactions on a shallow reef (Nicaragua, Central America). Coral Reefs 1: 209-214.

Roberts, H.H. and Murray S.P. (1983). Controls on reef development and the terrigenous-carbonate interface on a shallow shelf, Nicaragua (Central America). Coral Reefs 2: 71-80.

Scott, D.A. and Carbonell, M. (1986). A Directory of Neotropical Wetlands. IUCN, Gland and Cambridge.

Vaughan, T.W. (1919). Fossil corals from Central America, Cuba and Porto Rico with an account of the American Tertiary, Pleistocene and Recent coral reefs. Bull. U.S. Nat. Mus. 103: 189-524.

\section{BIG CORN ISLAND (ISLA DEL MAIZ GRANDE)}

Geographical Location Off the Caribbean coast, east of Bluefields; $12^{\circ} 10^{\prime} \mathrm{N}, 83^{\circ} \mathrm{W}$.

Area, Depth, Altitude Maximum altitude of island $100 \mathrm{~m}$.

Land Tenure Mostly private; reefs owned by the Corn Island people. 
Physical Features The island is volcanic with low coastal areas and numerous beaches between rocky headlands. The vegetation is primarily coconut groves and mangroves. Conzenius (1929) gave a general account of the island and more recently, McBirney and Williams (1965) described its geology. There is a discontinuous but linear shallow reef around the north and north-east coast (Roberts and Suhayda, 1983). The north coast has a triple fringing reef (Geister, 1983).

Reef Structure and Corals Geister (1983) describes the windward fringing reefs. The first reef fringes the coastline with no separating channel. It is best developed in the east and west but disappears in the centre, apart from some isolated coral assemblages. It has a very shallow sandy reef flat overgrown by Thalassia and Halimeda. The vertical outer slope is a drop-off to 2-3 $\mathrm{m}$ depth and consists of a dense framework of Agaricia tenuifolia which tends to form wide overhanging colonies with extensive labyrinths underneath. An inner channel, 5-10 m deep, separates this from the second reef, and contains several patch reefs, with overhanging margins of $A$ tenuifolia.

The second fringing reef, almost a small barrier reef, is a Palythoa-Mille pora reef type (Geister, 1977). It has partly disintegrated into patch reefs and merges with the first reef at either end. It is $100-200 \mathrm{~m}$ broad, $3 \mathrm{~km}$ long and broken into 14 main sections by channels. The rear slope is steep to vertical and formed by $A$ tenuifolia. The reef flat, $0.5-1 \mathrm{~m}$ deep, is overgrown by Acropora palmata, Millepora and Porites astreoides. The fore-reef slope is steep to vertical in the east but slopes more gradually in the west where it is overgrown by a poor fauna of scleractinians and octocorals in the shallows. The outer channel is about $600 \mathrm{~m}$ wide and over $10 \mathrm{~m}$ deep. It is covered by sand in the east but forms a carbonate hardground to the west where it is partly overgrown by corals.

The third fringing reef, over $250 \mathrm{~m}$ wide and more than $3 \mathrm{~km}$ long, is irregular in outline and lies in $7 \mathrm{~m}$ of water, reaching the surface in only a few places. From the reef base up to $3 \mathrm{~m}$ depth Montastraea annularis predominates; above $3 \mathrm{~m}$ Acropora palmata is dominant. The slopes on both sides of this reefs are ill defined.

Roberts and Suhayda (1983) describe part of the northern reef. A palmata and Montastraea annularis are the dominant frame-building corals of the reef crest. The landward limit is characterized by abundant corals and a rather abrupt change in topography, at $2-3 \mathrm{~m}$ depth, to the back-reef lagoon floor. The fore-reef slopes uniformly to $12-15 \mathrm{~m}$ where it merges with a zone of sediment accumulation and deep patch reef development. The slope is characterized by isolated colonies of $A$. palmata, heads of $M$. annularis, Porites astreoides, Diploria strigosa and $D$. clivosa, and abundant coralline algae in both encrusting and rhodolith forms. The lagoon is floored by coral sand and rubble, colonized by Thalassia testudinum and a variety of small coral heads.

Noteworthy Fauna and Flora Peters et al. (1929) described the vertebrate fauna on the island.

Scientific Importance and Research Wave current interactions have been studied on a portion of the northern coast (Roberts and Suhayda, 1983).

Economic Value and Social Benefits The island is largely dependent on copra production. Lobster fishing is a major source of income (Geister pers. obs.; Nietschmann in litt. 25.11.85). Traps are put out on the surrounding Miskito Bank, and there is a freezer-plant for lobster tails which are exported to the U.S.A. There are regular flights from Managua, via Bluefields and Puerto Cabezas, to the islands and scheduled boat connections with Bluefields.

Disturbance or Deficiencies A freighter grounded on top of the third fringing reef in 1969/70 and may have caused damage (Geister in litt., 1984).

Legal Protection No information.

Management No information.

Recommendations None known. 


\section{PANAMA}

\section{INTRODUCTION}

\section{General Description}

Panama has $1169 \mathrm{~km}$ of coastline on the Caribbean and $1697 \mathrm{~km}$ on the Pacific, the two coasts being only $65 \mathrm{~km}$ apart at the narrowest point. The Caribbean coast has about $250 \mathrm{~km}$ of fringing reef, most of which is now at a post-climax stage, having passed through its most active period of coral growth more than 2000 years ago. The general structure of these reefs is similar to that described in the separate account for Arrecife de Galeta (Cubit and Williams, 1983; Macintyre and Glynn, 1976), the richest reef areas being between Isla Margarita and Bahia las Minas (including Punta Galeta), at Bocas del Toro and in the Archipiélago de San Blas (see separate accounts). Many of the reefs east of the Panama canal are influenced by strong north and north-east trade winds from December to April (Macintyre and Glynn, 1976). The reef flats here are of interest for the density of zoanthid colonies and for their distinct zonation pattem (Sebens, 1982). Forty-nine hermatypic corals, 16 ahermatypic corals and four species of Millepora have been recorded from this side of the isthmus. Dendrogyra cylindrus is absent although it is present on nearby Caribbean islands (Porter, 1972b). The Smithsonian Tropical Research Institution has a marine laboratory at Punta Galeta and a field station in the Archipielago de San Blas and the reefs and marine habitats of these two areas have been the subject of long-term studics.

Fewer reefs are found on the Pacific coast than on the Caribbean coast, since sea temperatures are lower $\left(26.6^{\circ} \mathrm{C}\right.$ at Balboa cf. $27.9^{\circ} \mathrm{C}$ at Cristóbal) and subject to greater fluctuations $\left(15-33^{\circ} \mathrm{C}\right.$ cf. $\left.24-31^{\circ} \mathrm{C}\right)$, and tidal ranges are greater $(6.5 \mathrm{~m} \mathrm{cf.} 0.7 \mathrm{~m})$. Salinities of enclosed coastal areas near freshwater sources are generally higher (22 ppt cf. $18 \mathrm{ppt}$ on the Caribbean side) due to less river run-off (Glynn, 1972). The coast experiences fewer strong winds, has lower rainfall and less seasonal variation in cloud cover. Sedimentation is higher and corals are found in shallower water, but whereas reefs on the Caribbean side are often exposed at low water, those on the Pacific side are usually subtidal. They generally consist of shallow (less than $10 \mathrm{~m}$ ) Pocillopora banks, usually with few species, bound together by calcareous red algae (Porter, 1972b). Pocilloporid corals appear to be able to tolerate seasonally cool conditions, but it is noticeable that most reef development occurs on island shores away from the full effects of upwelling (Glynn, 1977; Glynn and Stewart, 1973). Coral diversity on the Pacific side is much lower than on the Caribbean side, only 21 species having been recorded, the highest diversity occurring at Isla Uva in the Islas Contreras. Coral cover, however, tends to be much higher and $90 \%$ coverage is common, a coverage rarely found on the Caribbean side (Porter, 1972b). In general, the reefs are considered to have an impoverished Indo-Pacific coral, fish and associated invertebrate fauna. The reefs around the islands in the Golfo de Chiriqui, considered to be the best on this coast (Glynn et al., 1972) and in the Golfo de Panamá are have been studied in some detail and are described in separate accounts.

Major wetland sites on the coast are described by Scott and Carbonell (1986) and seabird colonies are described by Halewyn and Norton (1984). The Loggerhead Caretta caretta is the most abundant sea turtle on the Pacific coast and subadults are found off the Caribbean coast; the second most abundant turtle on the Pacific coast is the Olive Ridley Lepidochelys olivacea. The Green Turtle Chelonia mydas is heavily exploited on the Caribbean coast but nests in several sites; there is very little nesting on the Pacific coast. The Hawksbill Eretmochelys imbricata has low numbers on the Pacific coast and is more common on the Caribbean coast. The Leatherback Dermochelys coriacea nests sparsely on the Pacific coast and in several sites on the Caribbean coast (Bacon et al., 1984; Groombridge, 1982). The American Crocodile Crocodylus acutus was formerly abundant along both coasts but populations are now severely depleted; the Caribbean Manatee Trichechus manarus may still occur.

\section{Reef Resources}

There is little general information on the marine resources of Panamá, but the reefs are certainly important for artisanal fishing, particularly on the Caribbean coast, for example at Punta Galeta. The Golfo de Chiriqui on the Pacific side is an important area for shrimp fishing. Tourism is not yet a major industry, but the San Blas islands are being developed as a resort area, the reefs being a major attraction.

\section{Disturbances and Deficiencies}

Glynn (1983, 1984b and 1985) describes the extensive coral mortality suffered by Panamanian reefs in 1983, apparently correlated with the abnormal E1 Niño of that year. Reef recovery on the Pacific coast could take many years as the chief frame building corals produce few planulae, certain species have been severely reduced in numbers or jocally exterminated, corallivores are still abundant and bioerosion is high. Lessios et al. (1984) describe mass mortality of Diadema antillarum populations on the Caribbean coast in 1983 when populations were reduced to $1-5 \%$ of their previous levels. Observations on the Pacific coast at Taboguilla, where there had been coral bleaching, showed no urchin mortality. It has been suggested that a water-borne pathogen was the causal agent and it is thought that the absence of $D$. antillarum will probably be reflected by changes in the algal, coral and echinoid communities and by altered patterns of bioerosion. White band disease was reported by Rogers (1985).

There is little information on the effect of human activities on the reefs, but threats to specific sites, mainly in the form of industrial development, are described in the following accounts. The creation of a sea-level canal across the isthmus, a project that has been discussed on several occasions, would constitute a major threat, the full implications being discussed by Glynn (1972 and 1974a) and Porter (1972b). For example, Acanthaster planci occurs on the Pacific side where it is an important predator, although populations have not reached outbreak proportions (Glynn, 1973a and 1974) possibly 


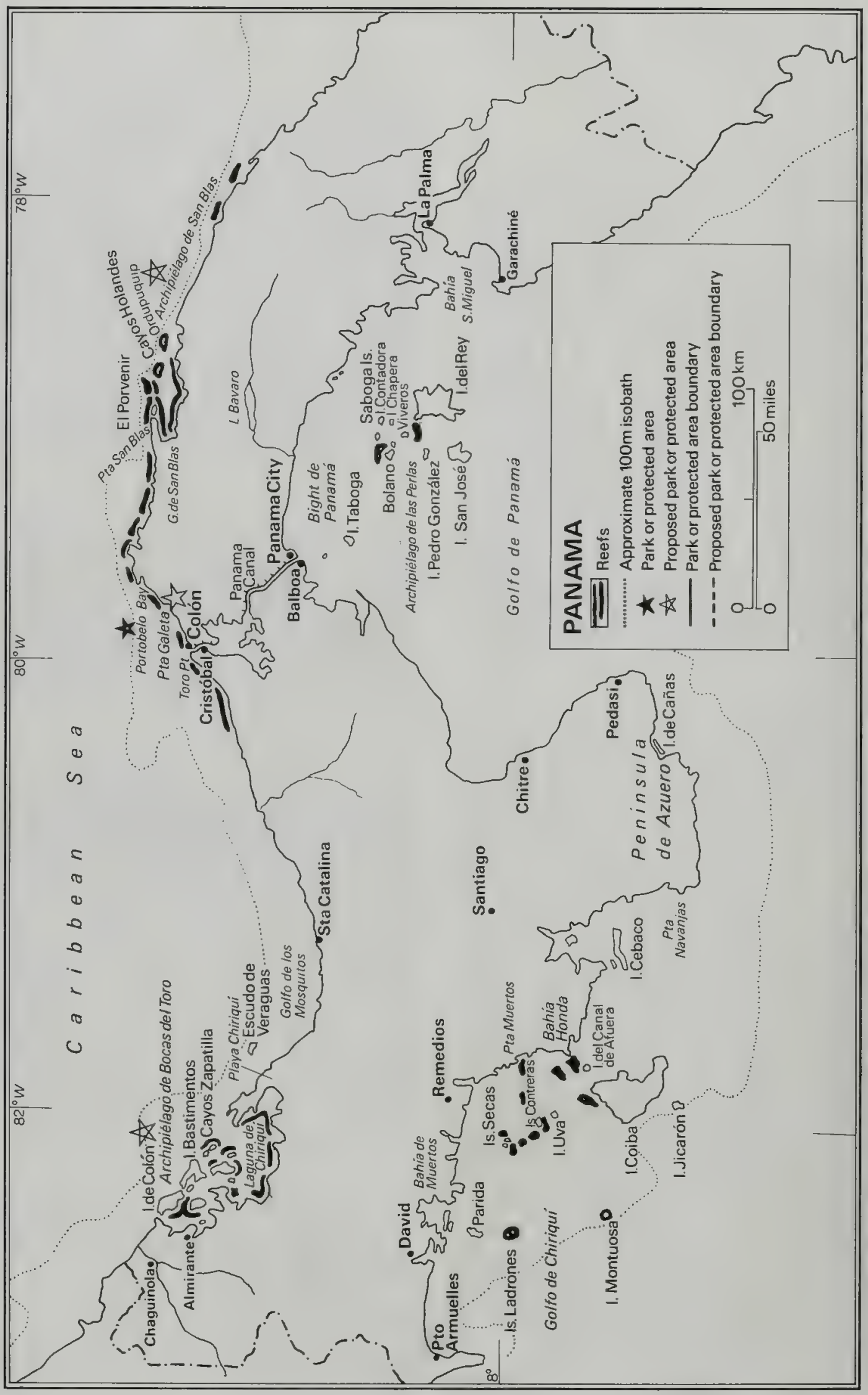


due to high levels of predation by invertebrate corallivores (Glynn, 1984a). A sea-level canal would permit the spread of this species to the Caribbean, possibly with very severe consequences.

\section{Legislation and Management}

Information on legislation pertaining to coral reefs has not been obtained, although there are regulations to control turtle collection (Bacon et al., 1984). The Dirección General de Recursos Naturales Renovables (RENARE) is responsible for managing and protecting wildlife. There are no state owned marine parks in Panamá, but Parque Nacional Portobelo borders coral reefs and Punta Galeta is maintained as a private scientific reserve by the Smithsonian Tropical Research Institute (see separate accounts). Reserves at Isla de Cañas (Los Santos Province) and Playas de Barquete (Chiriquí Province) on the Pacific coast protect turtle nesting beaches, but not coral reefs (Cornelius, 1981)

\section{Recommendations}

Certain areas clearly require management to prevent deterioration of the coral reefs. The following accounts describe Bocas del Toro, Archipiélago de San Blas and the area surrounding Punta Galeta (Isla Margarita and Isla Largo Remo to the west and Bahia las Mina to the east) on the Caribbean coast, where conservation activities area proposed or underway. Golfo de Chiriquí and Islas Perlas on the Pacific coast are also described; although there are no formal proposals, these areas should perhaps be considered for protected area status.

\section{References}

* = cited but not consulted

Anon. (1985a). New protected areas in Central America. CNPPA Newsletter 31: 5-6.

Anon. (1985b). A regional conservation strategy for Panamá. World Conservation Strategy in Action. IUCN Bulletin Supplement 4: 5.

Bacon, P., Berry, F. Bjorndal, K., Hirth, H., Ogren, L., Weber, M. (1984). The National Reports. Proceedings of the Western Atlantic Turtle Symposium, Vol. 3. University of Miami Press, Florida.

Birkeland, C., Reimer, A.A. and Young, J.R. (1973).

Effects of oil on tropical shore natural communities in Panamá. Final report to Federal Water Quality Administration, Environmental Protection Agency, Project 18050EFV, $221 \mathrm{pp}$.

Cornelius, S. (1981). Status of sea turtles along the Pacific coast of Middle America. In: Bjorndal, K. A. (Ed.). Biology and Conservation of Sea Turtles. Smithsonian Institution Press, Washington D.C.

Cubit, J.D. (1985). Possible effects of recent changes in sea level on the biota of a Caribbean reef flat and predicted effects of rising sea levels. Proc. 5th Int. Coral Reef Congress, Tahiti, 3: 111-118.

Cubit, J., Batista de Yee, G., Roman A., and Batista, V. (1984). El valor de los manglares y de los arrecifes de franja como recurso natural en la provincia de Colón. Revista Médica de Panamá 9: 56-67.

Cubit, J. and Williams, S. (1983). The invertebrates of
Galeta Reef (Caribbean Panama): a species list and bibliography. Atoll Res. Bull. 269: 45 pp.

Dahl, A.L., Macintyre, I.G. and Antonius, A. (1974). A comparative survey of coral reef research sites. Atoll Res. Bull. 1972: 37-77.

-Dalfelt, A., Thelen, K., Tovar, D., Guerra, C. and Sanjur, A. (1975). Plan de Manejo y Desarrollo para el propuesto Parque Nacional Portobelo, Panamá. FAO/PNUD/IPAT/RENARE. 83 pp.

Dana, T.F. (1975). Development of contemporary eastern Pacific coral reefs. Mar. Biol. 33: 355-374.

Forsbergh, E.D. (1969). On the climatology, oceanography and fisheries of the Panamá Bight. Inter-Amer. Trop. Tuna Comm. Bull. 14: 49-385.

Fowler, H.W. (1944). Results of the Fifth George Vanderbilt Expedition (1944). The fishes. Acad. nat. Sci. Philadel phia Monog. 6: 69-93.

Glynn, P.W. (1972). Observations on the ecology of the Caribbean and Pacific coasts of Panamá. Washington Biol. Soc. Bull. 2: 13-30.

Glynn, P.W. (1973a). Acanthaster effects on coral reef growth in Panamá. Science 180: 504-506.

Glynn, P.W. (1973b). Aspects of the ecology of coral reefs in the western Atlantic region. In: Endean, $R$. and Jones, O.A. (Eds), Biology and Geology of Coral Reefs. Academic Press, New York.

Glynn, P.W. (1974a). The impact of Acanthaster on corals and coral reefs in the eastern Pacific. Env. Cons. 1: 295-304.

Glynn, P.W. (1974b). Rolling stones among the Scleractinia: mobile coralliths in the Gulf of Panama. Proc. 2nd Int. Coral Reef Symp. 2: 183-198.

Glynn, P.W. (1976). Some physical and biological determinants of coral community structure in the eastern Pacific. Ecol. Monogr. 46: 431-456.

Glynn, P.W. (1977). Coral growth in upwelling and non-upwelling areas off the Pacific coast of Panamá. $J$. Mar. Res. 35: 567-585.

Glynn, P.W. (1981). Acanthaster population regulation by a shrimp and a worm. Proc. 4th Int. Coral Reef Symp. Vol. 2: 608-612.

Glynn, P.W. (1983). Extensive bleaching and death of reef corals on the Pacific coast of Panamá (1983). Env. Cons. 10(2): 149-154.

Glynn, P.W. (1984a). An amphinomid worm predator of the Crown-of-Thorns Sea Star and general predation on asteroids in Eastem and Western Pacific coral reefs. Bull. Mar. Sci. 35(1): 54-71.

Glynn, P.W. (1984b). Widespread coral mortality and the 1982-83 El Niño warming event. Env. Cons. 11(2): 133-146.

Glynn, P.W., Howard, L.S., Corcoran, E. and Freay, A.D. (1984). The occurrence and toxicity of herbicides in reef-building corals. Mar. Poll. Bull. 15: 370.

Glynn, P.W. (1985). Corallivore population sizes and feeding effects following El Niño (1982-1983); associated coral mortality in Panamá. Proc. Sth Int. Coral Reef Congr., Tahiti, 4: 183-188.

Glynn, P.W. and Macintyre, I.G. (1977). Growth rate and age of coral reefs on the Pacific coast of Panamá. Proc. 3rd Int. Coral Reef Symp. 2: 252-259.

Glynn, P.W. and Stewart, R.H. (1973). Distribution of coral reefs in the Pearl Islands (Gulf of Panama) in relation to thermal conditions. Limnol. Oceanogr. 18: 367-379.

Glynn, P.W., Stewart, R.H. and McCosker, J.E. (1972). Pacific coral reefs of Panamá: structure, distribution and predators. Geol. Rundsch. 61: 483-519. 
Groombridge, B. (1982). The IUCN Amphibia-Reprilia Red Data Book, Part 1: Testudines, Crocodylia, Rhynchocephalia. IUCN, Gland, Switzerland.

Halewyn, R. van, and Norton, R.L. (1984). The status and conservation of seabirds in the Caribbean. In: Croxall, J.P., Evans, P.G.H. and Schreiber, R.W. (Eds), Status and Conservation of the World's Seabirds. ICBP Technical Publications, No. 2, Cambridge.

- Hendler, G.L. (1976). Marine studies. In: Windsor, D.M. (Ed.). Environmental monitoring and baseline data 1975. Smithsonian Institution, Washington D.C.

-Hendler, G.L. (1977). Marine studies. In: Windsor, D.M. (Ed.). Environmental monitoring and baseline data 1976. Smithsonian Institution, Washington D.C.

IUCN (1982). IUCN Directory of Neotropical Protected Areas. Tycooly International Publishing Ltd., Dublin.

Lasker, H.R. and Coffroth, M.A. (1985). Vegetative reproduction, clonal spread and histocompatibility in a Caribbean gorgonian. Proc. Sth Int. Coral Reef Congr., Tahit, 4: 331-336.

Lasker, H.R., Peters, E.C. and Coffroth, M.A. (1984).

Bleaching of reef coelenterates in the San Blas Islands, Panamá. Coral Reefs 3: 183-190.

Lessios, H.A., Cubit, J.D., Robertson, D.R., Shulman, M.J., Parker, M.R. Garrity, S.D. and Levings, S.C. (1984). Mass mortality of Diadema antillanum on the Caribbean coast of Panamá. Coral Reefs 3: 173-182.

MacIntyre, I.G. and Glynn, P.W. (1976). Evolution of a modern Caribbean fringing reef, Galeta Point, Panamá. Am. Assoc. Petrol. Geol. Bull. 60(7): 1054-1072.

Meylan, A. (1984). The Ecology and Conservation of the Caribbean Hawksbill (Eretmochelys imbricata). Final Report WWF, Project 1499.

- Meyer, D.L. and Birkeland, C. (1974). Marine studies. In: Rubinoff, R.W. (Ed.) Environmental monitoring and baseline data 1973. Smithsonian Institution, Washington D.C.

*Meyer, D.L., Birkeland, C. and Hendler, G.L. (1975). Marine studies. In: Windsor, D.M. (Ed.). Environmental monitoring and baseline dasa 1974. Smithsonian Institution, Washington D.C.

Moore, A.W. (1985). Una propuesta: Un plan para la conservación y el desarrollo de la Provincia de Bocas del Toro. WWF/IUCN Project No. 3629: 68 pp.

Morales, R., Barborak, J.R. and MacFarlane, C. (1984). Planning and managing a multi-component, multi-category international biosphere reserve: the case of the La Amistad/Talamanca Range/Bocas de Toro wildlands complex of Costa Rica and Panamá. Conservation, Science and Society. Contribution to the First International Biosphere Reserve Congress, Minsk, Byelorussia/USSR, UNESCO/UNEP.

Ogden, J.C. (1977). Carbonate-sediment production by parrot fish and sea urchins on Caribbean reefs. Stud. in Geol. (Am. Assoc. Petrol. Geol.) : 281-288.

Porter, J.W. (1972a). Predation by Acanthaster and its effects on coral species diversity. Am. Nat. 106: 487-492.

Porter, J.W. (1972b). Ecology and species diversity of coral reefs on opposite sides of the isthmus of Panamá. Washington Biol. Soc. Bull. 2: 89-116.

Ray, C. and McCormick, G. (1976). Critical Marine Habitats; list of areas. Report to IUCN, IUCN/WWF project 39/4-1037.

Robertson, D.R. and Glynn, P.W., (1977). Field Guidebook to the Reefs of San Blas Islands, Panama. 3rd Int. Symp. Coral Reefs, Atlantic Reef Committee, Miami.

Rogers, C.S. (1985). Degradation of Caribbean and Western Atlantic coral reefs and decline of associated fisheries. Proc. 5th Int. Coral Reef Cong., Tahiti 6: $491-496$.

*Rosa, G.C. de la and Varela, C.E. (1977).

Características socio-económicas de la comunidad de Nuevo Tonosí (Portobelo). RENARE, Panamá. 91 pp.

Scott, D.A. and Carbonell, M. (1986). A Directory of Neotropical Wetlands. IUCN Gland and Cambridge.

Sebens, K.P. (1982). Intertidal distribution of zoanthids on the Caribbean coast of Panamá effects of predation and desiccation. Bull. Mar. Sci.32(1): 316-335.

* Tovar, D. (1972). Estudio preliminar para el Plan de Manejo del Propuesto Parque Nacional Portobelo, RENARE. Panamá.

\section{ARCHIPIELAGO DE BOCAS DEL TORO}

Geographical Location $\quad 9^{\circ} 15^{\prime} \mathrm{N}, 82^{\circ} 10^{\prime} \mathrm{W}$; east of Almirante, Bocas del Toro Province, Caribbean Sea.

Area, Depth, Altitude Over 2000 sq. $\mathrm{km}$.

Land Tenure mangrove areas are state-owned; there is some private land.

Physical Features The Bocas del Toro area is dominated by two large (1000 sq. $\mathrm{km})$, shallow, almost enclosed bays, Laguna Chiriquí and Bahía de Almirante. It has a tropical climate with a mean annual temperature of $25^{\circ} \mathrm{C}$ at sea level and a mean annual precipitation between 2500 and $7000 \mathrm{~mm}$. There are clear waters, abundant marine life, sand beaches, bays, islands, seagrass beds and diverse coral formations (Moore, 1985).

\section{Reef Structure and Corals No information.}

Noteworthy Fauna and Flora Mangroves dominate in areas of calm water, such as along the shores of Laguna de Chiriqui which is described in Scott and Carbonell (1986). The area is of major importance as a rookery for Hawksbill Eretmochelys imbricata. Leatherback Dermochelys coriacea and Green Chelonia mydas Turtles, Long Beach being one of the main nesting beaches (Bacon et al., 1984; Meylan, 1984). Seabirds, lobsters (Panulirus argus and $P$. guttatus) and fish are abundant. Laguna de Chiriquí has breeding populations of Audubon's Shearwater Puffinus iherinieri and Redbilled Tropicbirds Phaethon aethereus (Halewyn and Norton, 1984). The Caribbean Manatee Trichechus manatus, Baird's Tapir Tapins bairdi, peccaries Tayassu spp. and pacas Agouti paca are found in the area. The Puma Felis concolor and the Jaguar $P$. onca may still be found in more isolated areas inland Moore (1985) describes the terrestrial fauna of the interior. Endemic frogs are found on Isla Bastimentos, Cayo Nancy and Cayos Zapatilla and an endemic snake is found on the Escudo de Veraguas (Moore, 1985).

Scientific Importance and Research A three-day study of the area was carried out by the Smithsonian Tropical Research Institute in 1971, but there has been little other research work although sea turtles have been surveyed.

Economic Value and Social Benefits About half of the population of the province of Bocas del Toro are indians (the Guaymies, the Teribes and the Bokotás). The 
archipelago is important for artisanal fisheries exploiting lobsters and fish including Snappers Lutjanus cyanopterus, Mackerel Scomberomorus maculatus and Jacks Caranx chrysos. These are mainly consumed locally although part of the catch is sent to Panama City (Moore, 1985). Lobsters are heavily exploited but are still relatively abundant. Sea turtles, particularly the Green and the Hawksbill, are traditionally hunted but are still fairly common during the nesting season. Other abundant resources such as shrimp and other fish are seldom or never exploited (Moore, 1985; Anon, 1985b). Bocas del Toro has considerable potential for tourism (Moore, 1985).

Disturbance or Deficiencies The area is threatened by the transisthmus oil pipeline, completed in September 1982, which terminates in Laguna de Chiriqui. A small oil spill in 1983 led to major action to persuade the oil companies to implement some form of pollution control but to date this has been unsuccessful. Tanker accidents, de-ballasting by tankers and low-level chronic spillage at terminals pose additional threats (Meylan, 1984, Moore, 1985). Further oil exploration and exploitation are planned in the Laguna de Chiriquí for a period of 27 years (Moore, 1985). In connection with the pipeline, a road has been built linking the province to the rest of Panamá which may well have a long term impact. Local people are concerned that misuse of land in other provinces will lead to migration of people to Bocas del Toro with consequent deforestation, erosion, sedimentation and increased social problems, as has occurred in other provinces (Anon., 1985b).

Several hydrological projects are planned to take advantage of the enormous potential of the Changuinola and Teribe rivers. These projects may significantly affect the ecology and socio-economy of the region if carried out as planned. In particular, the Chinguinola hydro-electric project could result in heavy freshwater and sediment inflow into the Bahia de Almirante (Moore, 1985). Threats to the terrestrial ecosystems are described in Moore (1985), and include a potential tin mining operation, the intensive banana industry and hunting.

The traditional indian way of life is threatened by modernization, and artisanal fishing may be developed or replaced by modern gear and equipment. In Laguna de Chiriqui, boats from Nicaragua and other parts of Panamá, apparently with government licenses, have started to exploit the shrimp resources of the region. The local people are concerned by the large numbers of dead fish that result from the use of nets with very small size meshes, which could lead to widespread general over-exploitation of marine resources (Moore, 1985).

Legal Protection The area borders the proposed biosphere reserve of La Amistad in Costa Rica and the Talamanca Range in Panamá (Morales et al., 1984). There are no marine reserves but Long Beach on Isla Bastimentos is a turtle sanctuary.

Management There is little enforcement of regulations in the turtle sanctuary.

Recommendations IUCN has identified the province of Bocas del Toro as a potential area for designing a regional conservation strategy. A preliminary study, carried out with RENARE, has identified the issues critical to natural resource conservation and the socio-economic welfare of the people. These include the need to survey, compile an inventory of and manage marine resources. Tourism should be carefully controlled. A planning project for the province has been drawn up, based on the World Conservation Strategy, and has been presented to the relevant authorities; official approval is expected shortly. A four-man team is to be based in the province for two years (Anon., 1985). A government plan for a national parks system in Panama has already recommended the establishment of a national park to include Isla Bastimentos (with Long Beach and other turtle nesting beaches), the adjacent Cayos Zapatilla, and the surrounding reefs and seagrass beds (Moore, 1985). Chiriquí Beach should be given particular protection for turtles (Meylan, 1984). An independent long-term monitoring programme to study the effects of the pipeline and associated activities should be set up.

\section{GOLFO DE CHIRIQUí REEFS}

Geographical Location East Pacific, off west Panamá. The islands in the Gulf include Islas Secas $\left(7^{\circ} 57^{\prime} \mathrm{N}\right.$, $82^{\circ} 00^{\prime} \mathrm{W}$, including Cavada $7^{\circ} 58^{\prime} \mathrm{N}, 82^{\circ} 01^{\prime} \mathrm{W}$ ), Islas Contreras $\left(7^{\circ} 49^{\prime} \mathrm{N}, 81^{\circ} 45^{\prime} \mathrm{W}\right)$, Uva $\left(7^{\circ} 48^{\prime} \mathrm{N}, 81^{\circ} 45^{\prime} \mathrm{W}\right)$ and Coiba $\left(7^{\circ} 24^{\prime} \mathrm{N}, 81^{\circ} 40^{\prime} \mathrm{W}\right)$.

Physical Features Most of the island groups are of volcanic origin. The Islas Secas and Islas Contreras are $15-20 \mathrm{~km}$ from the mainland; no island is more than 5 sq. $\mathrm{km}$, and there is no freshwater run-off (Porter, 1972a).

Oceanographic conditions in the Golfo de Chiriquí are described by Dana (1975). The median rainy season (May-November) surface temperature is $28^{\circ} \mathrm{C}$; the dry season median is $28.9^{\circ} \mathrm{C}$. The bay has noticeably better conditions for coral growth than the Golfo de Panamá, which has cold upwellings, greater cloud cover and poorer water clarity (Glynn and Macintyre, 1977). Unlike the Golfo de Panamá which has strong north-easterly trade winds in the dry season, there are only light breezes and no upwelling at this time of year. During the rainy season, stronger southerly (onshore) winds are more prevalent, causing the cooler subsurface water to be mixed upward to the surface. There are significant seasonal differences in the observed median depths of the $25^{\circ} \mathrm{C}, 20^{\circ} \mathrm{C}$ and $18^{\circ} \mathrm{C}$ isotherms: the first is shallowest during the rainy season; the latter two are shallowest during the dry season. Fluctuations of these thermoclines subject benthic organisms at the appropriate depths to temperature changes as great as $7^{\circ} \mathrm{C}$ but thermal conditions appropriate for coral reef growth exist to depths near $20 \mathrm{~m}$.. Surface salinities are significantly higher in the dry season (31.2 ppt) than in the rainy season $(30.5 \mathrm{ppt})$, this dilution extending over $50 \mathrm{~km}$ out to sea and to depths in excess of $20 \mathrm{~m}$. The water in the Gulf was noticeably more turbid in the rainy season than in the dry season. There is a mean tidal range of $2.5 \mathrm{~m}$ (Dana, 1975).

Reef Structure and Corals Several reef studies have been carried out in this area including those by Dana (1975), Glynn et al. (1972), Glynn (1973b) and Porter (1972a). Dana (1975) visited the islands of Naranjas, 
Coiba, Jicarón, Cebaco, Montuosa, Canal de Afuera and Parida, the island groups of Contreras, Secas and Ladrones and the mouth of Bahía Honda.

Structural reefs are few and scattered but occasional patches of coral growth of varying sizes were found at all locations visited. Reefs vary from ones of highly irregular outline in sheltered embayments to more or less exposed fringing reefs. No reef visited exceeded about 2 ha and they are usually subtidal, but are not found at depths greater than $10 \mathrm{~m}$. The majority have a minimum framework height of $3 \mathrm{~m}$ and appear to be undergoing vigorous accretion in protected coves as well as on the seaward sides of the island. They generally have relatively flat tops reaching to the height of spring-tide low-water levels, but lack consolidated reef flats. Live coral coverage on the reef flat is highly variable, annual variations being controlled largely by the periodic occurrence of deleterious low water exposure. At Isla Secas, the reef flat is completely exposed at low water; Pocillopora damicornis predominates, followed by Porites panamensis and Psammocora stellata. Sand patches, filamentous algae and crustose coralline algae also contribute significantly to reef flat surfaces. The seaward edges of the reefs are slightly lower than the central portions; the low seaward drop-offs to fine silty sand bottoms are irregular. Water depth at the reef base does not exceed about $10 \mathrm{~m}$ at low tide (Dana, 1975; Glynn, 1976).

The reefs consist primarily of interlocking Pocillopora damicornis branches encrusted and cemented together by coralline algae, particularly in the upper portions and reef crest. Reefs tend to have $70-80 \%$ cover of this species, although other pocilloporids may be present. Colonies grow contigously and most rapidly in a vertical direction to form an interlocking wave-resistent framework of high porosity (Glynn, 1973b; Glynn and Macintyre, 1977). Higher growth rates of this species are found in the Golfo de Chiriquí than in the Golfo de Panamá. In the Islas Secas, a minimal horizontal growth rate of $21.4 \%$ per annum was calculated (Glynn, 1973b); growth rate studies were also carried out on one of the unnamed islands in the southernmost sector of these islands (Glynn, 1977). A patch reef, $100 \mathrm{~m}$ off the shore of Isla Uva in the Islas Contreras was described by Glynn (1976). The entire reef periphery was found to be growing rapidly, especially on the upper seaward slope where Pocillo pora coral coverage is near $80 \%$. In contrast, the Secas fringing reef was prograding along the reef crest only. Below the predominantly Pocillopora zone, there was increasingly high coral diversity, with massive corals such as Agariciella planulata, Porites spp., Pavona spp. and Mille pora intricata appearing.

Small colonies of the genera Porites, Psammocora (Stephanaria) and Millepora are found widely scattered among the Pocillopora. In deeper zones, on the lower slope and at the base of the reef, other species are found with $P$. damicornis, including $P$. robusta, Pavona, Agariciella and Porites (Glynn, 1973b; Glynn and Macintyre, 1977). Massive colonies of Porites, Pavona and Agariciella, of about $1 \mathrm{~m}$ maximum diameter, are found at the bases of the seaward periphery of some reefs, as well as moderate amounts of coral debris in the form of broken Pocillopora branches. On the fairly steeply sloping silty sand bottoms, isolated colonies of Psammocora, Porites, Pavona and Millepora are found at widely spaced intervals to a depth of about
$15 \mathrm{~m}$. By $20 \mathrm{~m}$ depth, colonies are extremely rare and none are found at greater depths; Psammocora may be the deepest living species (Dana, 1975).

Coral cover on the Secas reefs reaches $90 \%$, the reefs being particularly healthy. On Isla Uva, coral cover is about 40\% (Porter, 1972a). A pocilloporid patch reef on Uva, 1.38 ha in size, has been the subject of a Crown-of-thorns Starfish Acanthaster planci study (Glynn, 1973a and 1981). Total coral coverage amounted to 6200 sq. $m$ and at least eleven scleractinian species and three species of Millepora were present in this area; one of the Millepora species found at Coiba, Contreras and Secas is considered to be endemic (Glynn, 1972).

Noteworthy Fauna and Flora Reef associated invertebrates and fish are discussed in Glynn et al. (1972) in the context of coral predation.

Scientific Importance and Research The best developed fringing and patch reefs on the Pacific coast of Panamá are found in the Golfo de Chiriqui, particularly in the Contreras and Secas island groups (Dana, 1975; Glynn, 1972; Glynn et al., 1972). Isla Coiba and Islas Secas have been visited by an expedition from the Smithsonian Tropical Research Institution.

Economic Value and Social Benefits The Golfo de Chiriqui is an important centre for the shrimp fishing industry (d'Croz in litt., 14.10.85).

Disturbance or Deficiencies Acanthaster planci occurs in the Golfo de Chiriqui and the effect of its predation on corals has been studied at Islas Secas and Isla Uva (Glynn, 1973a; Porter, 1972a). Some of the Islas Secas group were found to have no Acanthaster present but in other areas there were relatively stable populations. Numbers may be limited by a predatory Painted Shrimp Hymenocera picta and a scavenging worm Pherecardia striata (Glynn, 1981). Excessively low tides with two hour exposures of the reef can have devastating effects, and occur irregularly. Midday and seasonal summer exposures are generally more damaging because of the sun. Colonies bleach within a few days of exposure, and after 2 or 3 weeks are covered with algae (Glynn, 1976).

The Golfo de Chiriqui reefs have been extensively damaged recently (Glynn, 1983 and 1984b). The El Niño of 1982/83 which caused an anomalous warming of surface waters in the tropical Pacific Ocean, has been implicated. At least $10000 \mathrm{sq}$. $\mathrm{km}$, including the mainland nearshore and offshore islands, have been affected. All Millepora hydrocorals and scleractinian corals ( 5 genera) have been affected to some degree, resulting in either bleaching or death. The most susceptible corals were Millepora, followed by Pocillopora and then the massive corals Porites, Pavona and Gardineroseris. P. gigantea and Psammocora stellata were the least affected species. No living colonies of Millepora, including the endemic species, could be found, suggesting that this genus may be locally extinct. Other recurrent natural events which have occurred include a strong earthquake centred near the gulf.

Man's activities have also increased dramatically in the Chiriquí area in recent years including a copper mine project, dam construction, transhipment of oil and 
pesticide use (Glynn, 1983). However, activities involving excavation (the Cerro Colorado copper mine, the construction of La Fortuna Dam and an oil pipeline) do not appear to have caused significant increases in sedimentation, and the copper mine project has essentially been discontinued since 1979. No persistent oil or detergent contamination has been observed and although pesticide levels are increasing they are unlikely to have affected the reefs in the dry season when there is minimal run-off. High herbicide levels were found in bleached corals, however, and these may be partially responsible for some of the high mortalities (Glynn et al., 1984).

\section{Legal Protection None.}

\section{Management None.}

Recommendations The severity of the bleaching phenomenon on these reefs warrants the most urgent and close attention. A major study is currently underway to investigate this (Glynn, 1984b).

\section{RESERVA BIOLOGICA ARRECIFE DE GALETA, AND ISLA MARGARTTA AND BAHIA LAS MINAS PROPOSED PROTECTED AREAS}

Geographical Location Off Punta Galeta, province of Colón, south-western Caribbean Sea; 924'N, 79051'W, $6 \mathrm{~km}$ east of the Panamá Canal.

Land Tenure Most of Punta Galeta is within a U.S. Navy reservation.

Physical Features The area is south of the Caribbean "hurricane belt" and is subject to relatively little disturbance. The mean seawater temperature is approximately $29^{\circ} \mathrm{C}$ with the range of variation confined to plus or minus a few degrees (except during extreme low tides when temperatures in shallow pools of standing water on the reef platform may reach $35-40^{\circ} \mathrm{C}$ ). Salinities average about $33 \mathrm{ppt}$, also with little variation (Cubit and Williams, 1983). Turbidity and wave action increase during the dry season (December to May) (Sebens, 1982). The annual tidal range for the reef flat is $0.38 \mathrm{~m}$. Current flow is predominantly from west to east.

Core studies have shown that Galeta Reef was initially a typical shallow-shelf Caribbean fringing reef dominated by Acropora palmata with a mixed coral-head community on its seaward slope. Subsequently, its development was restricted both vertically and laterally so that it became an emergent reef with a well-cemented shallow fore-reef pavement and extensive coral-boulder reef flat on which mangroves have now encroached (Macintyre and Glynn, 1976).

The fringing reef consists of a broad platform, bordered on the landward side by mangroves and enclosing a lagoon. On the seaward side, the platform slopes into 3-10 $\mathrm{m}$ of water before reaching a sand bottom (MacIntyre and Glynn, 1976). The surface of the reef platform is at the lower level of the intertidal zone, and is never deeply under water. Tidal range is only about $30 \mathrm{~cm}$. Wave action tends to maintain water over the reef even during the lowest low tides, but during calm weather the reef platform may be exposed above water level for long periods of the day, subjecting the biota of the platform to extremes of desiccation, solar radiation, high temperatures, rainfall and predation by shore birds. There are approximately $30-40$ such instances of reef exposure each year, varying in duration from 1 to 14 hours (Cubit and Williams, 1983).

Reef Structure and Corals The plant-dominated character of Galeta reef flat is evident from its five distinct biotic zones: Acanthophora, Thalassia, Zoanthus, Laurencia and coralline algae. Detailed descriptions of these zones are given in Birkeland et al. (1973) and Sebens (1982). Most of the hard substrata of the reef platform are covered with algae, primarily the two red algae $A$ spicifera and Laurencia papillosa. The seagrass $T$. testudinum occupies much of the area of loose sediment. The main sources of calcium carbonate are crustose coralline algae and Halimeda opuntia. Over half of the areas in the two inshore zones, Acanthophora and Thalassia, have a rocky, or rubble and sand substrate. Some large central and inshore parts of the reef flat also have a dominantly rubble and sand bottom containing significant but patchy coral communities of Porites furcata, $P$. astreoides and Siderastrea radians. The biota of the subtidal reef slope consists of various species of foliose and crustose coralline algae, some fleshy algae and live corals (Macintyre and Glynn, 1976).

Seaward of the reef flat, the coralline zone extends down the gently sloping fore-reef and Millepora complanata is dominant to a depth of $1 \mathrm{~m}$ below mean low-water level. Beyond this depth, until a distinct drop-off ( $3-4 \mathrm{~m}$ depth), heads of $M$. complanata, $S$. siderea, $P$. astreoides, P. furcata, Diploria sp., Favia fragum, Agaricia agaricites, Montastraea annularis and Acropora palmata are scattered over the crustose coralline algal bottom. A zone of Gorgonia flabellum is present between about $2 \mathrm{~m}$ and the drop-off. The rich coral cover at and directly below the drop-off comprises mainly $P$. furcata, Agaricia agaricites, $S$. siderea, Diploria sp. and Isophyllia sinuosa. Below the drop-off at about $6 \mathrm{~m}$ depth, the abundance of corals decreases sharply and platy colonies of Agaricia sp. and $S$. siderea are scattered over the unconsolidated mud-sand and coral-rubble bottom. The lower depth limit for corals is approximately $12 \mathrm{~m}$ where fleshy algae become more abundant on the soft bottom, which levels off at a depth of $14 \mathrm{~m}$.

Active accumulation of interlocking reef framework is not evident on Galeta Reef except at the eastern edge where large thriving corals of $S$. siderea, Agaricia agaricites, $P$. furcata and Diploria strigosa are common, as well as dead and encrusted colonies of Acropora palmata (Macintyre and Glynn, 1976). Thirty-six species of hermatypic corals have been recorded in this area (Porter, 1972b).

Noteworthy Fauna and Flora Extensive mangrove stands are found along the shoreline (Cubit et al., 1984; Macintyre and Glynn, 1976). Approximately 775 species of macro-invertebrates have been documented, gastropods, polychaetes, and certain groups of decapods having been more thoroughly studied than sponges, ascidians, bryozoans and smaller crustaceans. There is also more information on those invertebrates that are major occupiers of primary substratum on the shallow reef platform slope and sand bottom. Cubit and Williams 
(1983) provide an inventory of invertebrates known from the reef, particularly from the reef platform, as well as a comprehensive bibliography. The Caribbean Manatee Trichechus manatus and the Leatherback Dermochelys coriacea may occur here. The Hawksbill Eretmochelys imbricata and the Green Tutle Chelonia mydas occur around Isla Grande and are taken by local people for food. Crocodylus acutus and Caiman crocodilus fuscus are found in the mangroves (Cubit et al., 1984). The mangrove and coconut groves shelter a number of terrestrial species considered threatened in Panamá, including Tamandua Tamandua spp., White-tailed Deer Odocoileus virginianus, Jaguarundi Felis yagouaroundi, Ocelot $F$. pardalis, Otter Lutra longicaudis, Common Procyon lotor and Crab-eating $P$. cancrivorus Racoons, Chestnut-winged Chachalaca Ortalis garrula, Pale-vented Pigeon Columba cayennensis, Wood Ibis Mycteria americana, Central American Boa Boa spp. and Common Iguana Iguana iguana (Cubit in litt. 8.11.84).

Scientific Importance and Research The Smithsonian Tropical Research Marine Laboratory, situated directly on the reef platform at Punta Galeta, is the southernmost marine laboratory in the Caribbean. Intensive monitoring of the reef biota began in 1970 with a three year Environmental Sciences Program supported by the U.S. Environmental Protection Agency (Hendler, 1976 and 1977; Meyer et al., 1975; Meyer and Birkeland, 1974). Most of the reef studies have been monitoring surveys designed to determine the physical parameters and species composition of the reef and to document temporal changes in the distribution and abundance of the biota of the reef. For example, populations of echinoids on the intertidal reef flat have been censused for ten years. More recently, the monitoring was expanded to include physical factors in a set of projects supported by the Smithsonian Institution Environmental Sciences Program. These include studies of recent changes in sea level (Cubit, 1985). The rate of sea level change is expected to increase rapidly and may exceed accretion rates, raising water levels over the reef flat. The reef has also been studied by a number of visiting investigators (Cubit and Williams, 1983). The contiguous areas of Isla Margarita (to the west), Punta Galeta and Bahia Las Minas (to the east) constitute the most extensive reefs and mangroves on the Caribbean coast of Panamá between Bocas del Toro and the San Blas Archipelago (Cubit in litt., 8.11.84)

Economic Value and Social Benefits A wide variety of organisms including Strombus gigas, Panulirus argus, $P$. guttarus and many fish are taken from the mangroves and reefs for food. A survey of the economic value of these habitats has been carried out and the results are given in Cubit et al. (1984).

\footnotetext{
Disturbance or Deficiencies Extreme low tides coinciding with midday sun or heavy rain occur occasionally in spring and summer and may cause massive death of corals and zoanthids on the reef flat and even in parts of the subtidal coralline zone (Sebens, 1982). Mass mortality of the urchin Diadema antillarum occurred in 1983 , possibly due to a water-borne pathogen. Densities dropped from an estimated 14000 per ha in June 1982 to 0.5 per ha in May 1983, but by February 1984 had risen to 38 per ha (Lessios et al., 1984).
}

Between 1910 and 1953, parts of certain reefs were dredged to obtain landfill (Cubit in litt., 8.11.84). Over the last 100 years, the reef and mangrove complex between Punta Toro to the east and María Chiquita to the west has been reduced by about $25-30 \%$. Mangrove removal and the dredging of reefs has caused increased siltation which may be damaging the reefs further. There is a petroleum refinery which may discharge effluents into the Bahia Las Minas (Cubit et al., 1984).

Legal Protection Galeta Reef was established as a private scientific biological reserve in the late 1960 s (Cubitt and Williams, 1983). Access is mainly limited to scientists conducting investigations and the area is closed to fishermen and, apart from one zone, to tourists (Cubit in litt., 8.11.84).

Management The reserve and laboratory are maintained by the Smithsonian Tropical Reseach Institute (STRI) in co-operation with the U.S. Navy. There are four "zones": a) a reef for observation only, b) a reef where experimental manipulation and collection of voucher specimens are strictly regulated by the Scientist-in-charge at the Laboratory, c) reefs open to limited numbers of tourists but where collecting and fishing are prohibited, d) reefs closed to tourists. Access to the latter two is controlled by the U.S. Navy (Cubit in litt., 8.11.84).

Recommendations STRI is working with local conservation groups and the municipal government of Colón to establish the area around Isla Margarita and Isla Largo Remo, adjacent to and west of Galeta as a nature and recreation park to protect the reefs and mangroves from real estate development. So far, this area has been little affected by man, and its location is such that currents carry pollution away from it (Cubit et al., 1984). The project has widespread support. STRI is also recommending that the local and national governments protect the reefs and mangroves in Bahía Las Minas. This is contiguous and to the east of Punta Galeta and includes a variety of small coral islands surrounded by reefs and partially covered with mangroves and coconut groves (Cubit et al., 1984).

\section{ISLAS PERLAS}

Geographical Location Situated in the Golfo de Panamá, about $70 \mathrm{~km}$ south-east of Panama City. The group includes the following islands: San José, Del Rey, Pacheca, Contadora, Saboga (northern sector, $31 \mathrm{~km}$ from coast), Chapera, Pedro González, Mogo Mogo and Bolano.

Area, Depth, Altitude Saboga has a maximum altitude of $68 \mathrm{~m}$.

Physical Features The $20 \mathrm{~m}$ isobath lies close to most islands and the $50 \mathrm{~m}$ isobath approaches the westem perimeter of the archipelago. The islands are subject to a wide range of contrasting physical conditions. From January to April, when the Intertropical Convergence Zone is at its most southerly position, northerly winds from the trade winds system predominate over the 
Panamá Bight, and there is a dry season over the Golfo de Panama, with decreased run-off and increased incident radiation. Strong offshore winds produce a mass transport divergence which causes a lowering of sea-level and upwelling of relatively cold water rich in micronutrients. Mean primary production increases by a factor of two (Forsbergh, 1969). In the wet season, wind movement is often slight and sea surface temperatures may vary considerably. Surface salinity varies from 30 to $33 \mathrm{ppt}$ in the dry season to $28 \mathrm{ppt}$ at the end of the wet season. There is evidence that a major influx of cold water occurs to the west of the islands, and that some upwelling may also occur to the east. This cold water causes an increase in phytoplankton levels and an influx of anchovies and other fish (Glynn, 1972 and 1977 ).

Reef Structure and Corals The chief frame-building coral is Pocillopora damicornis with massive species of Pavona and Porites commonly contributing to the reef structure. Reef development is shallow, usually from extreme low water to a depth of $4 \mathrm{~m}$ below MLW. Maximum reef thickness is usually $1-2 \mathrm{~m}$ but occasionally approaches $3 \mathrm{~m}$. Coralline algae, present as gravel and cobble-sized nodules, often occur as thin deposits at slightly greater depth.

Coral reefs are more abundant and attain greater dimensions on the northern and eastern sides of the islands, apart from Mogo Mogo and Bolano which show greatest reef development on their north-west and south-west sides respectively. Isla Saboga and Isla Contadora have particularly large areas of reef. Pedro Gonzalez has very few reefs. Several reefs are found on the relatively broad shelf off the north-west corner of Del Rey, one of these located at the north-west corner of Isla Viveros. Reefs are sparse around Del Rey itself and are concentrated on the north-east shelf (Glynn and Stewart, 1973).

Coral growth rates have been studied and were observed to be greater on the sides of the islands showing greatest reef development i.e. north and east. Sedimentation rates were significantly greater on the south and west, but the principal limiting factor is temperature. Pocillopora damicornis growth rate declines markedly on shores exposed to temperatures of $20-21^{\circ} \mathrm{C}$ (Glynn and Stewart, 1973). Detailed growth studies have been carried out at fringing reefs on Saboga (Glynn, 1976 and 1977).

Large areas of the sea bottom around the Islas Perlas are covered by coral colonies are apparently mobile; five species are involved: Pavona gigantea, $P$. clivosa, P. varians, Agariciella planulata and Porites panamensis. The rest of this unusual community consists of crustose coralline algae and the thamnasterid coral, Psammocora stellata (Glynn, 1974b).

Noteworthy Fauna and Flora The fish fauna was described by Fowler (1944).

Scientific Importance and Research Several comparative studies on the reefs around the Islas Perlas and in the Golfo de Chiriquí (see separate account) have been carried out (Glynn, 1976 and 1977).

Economic Value and Social Benefits No information.

Disturbance or Deficiencies Acanthaster planci seems to be generally absent from the Golfo de Panamá although there is a single record of it from Isla Taboga (Glynn, 1974a). Coral bleaching and death occurred on many of the reefs in late 1983, the extent of bleaching ranging from $22.7 \%$ at Contadora to $80 \%$ at Chapera. This was equal to the bleaching observed earlier in the year in Golfo de Chiriquí (Glynn, 1984b). The impoundment of Río Bayano, located $50 \mathrm{~km}$ east of the canal entrance may lead to modification of the coastal environment of Golfo de Panamá through diminishing sedimentation and organic matter input and alterations in the salinity regime (Glynn, 1984).

Legal Protection According to Ray (1976) this area is a National Park but it is not listed in IUCN (1982). Islas Taboga and Uraba, near the coast (but not in the Islas Perlas) are designated wildlife refuges for seabirds (Anon, 1985a).

\section{Management None.}

Recommendations No information.

\section{PAROUE NACIONAL PORTOBELO}

Geographical Location $\quad 9^{\circ} 47^{\prime}-9^{\circ} 39^{\prime} \mathrm{N}, 7^{\circ} 47^{\prime}-79^{\circ} 30^{\prime} \mathrm{W}$; on the Caribbean coast in the Portobelo District, Province of Colón, east of the Panamá Canal.

Area, Depth, Altitude 17364 ha; sea-level to 979 m.

Land Tenure $73 \%$ national land, $20 \%$ private land, $7 \%$ government farms.

Physical Features The area has about $70 \mathrm{~km}$ of coastline with many bays, islands, mangroves and swampy areas. Annual precipitation is $4800 \mathrm{~mm}$ and the mean temperature is $25.9^{\circ} \mathrm{C}$ Historically, Portobelo Bay is the most important feature of the Park as the site selected by the Spaniards to build a fortification to defend the port from where gold brought from Perú by land was shipped to Spain. Some of the ruins of the complex (houses, church, customs, buildings, canons, military fortifications) are well preserved (IUCN, 1982).

Reef Structure and Corals There are several coral formations along the coast indicating a rich marine fauna but no details are available.

Noteworthy Fauna and Flora There is a dense and heterogenous forest on the mainland and large swampy areas of mangroves. Because of the existence of different ecosystems inside the Park, a high diversity of species is expected. The Hawksbill Turtle Eretmochelys imbricata periodically uses the beaches of the Park to nest. The Leatherback Turtle Dermochelys coriacea and the Caribbean Manatee Trichechus manatus may occur (IUCN, 1982).

Scientific Importance and Research General surveys of the flora, vegetation, fauna and natural resources of the Park have been carried out (IUCN, 1982) but have not been published.

Economic Value and Social Benefits The economic importance of the area is described by de la Rosa and 
Varela (1977). About 5000 people live within the Park boundaries. Sir Francis Drake was buried there.

Disturbance or Deficiencies The Park is subject to severe disturbance from activities such as agriculture, hunting and pollution as a result of the people living in it. Portobelo town lies within the ruins, many of which have been damaged (IUCN, 1982).

Legal Protection The Park was established on 22 December 1976, by Legislative Decree No. 91 (IUCN, 1982).

Management The zoning recommended in the Management and Development Plan (Dalfelt et al., 1975; Tovar, 1972) has not been implemented yet. It includes proposals for different zones for primitive use, extensive use, intensive use, historical-cultural and special use. The Park is administered by the Instituto Panameño de Turismo (IPAT), Panama City, Panama; RENARE, Apartado 2016, Panama City, Panamá. IPAT and RENARE have approximately five guards and one social worker in the area.

Recommendations None known.

\section{ARCHIPIELAGO DE SAN BLAS}

Geographical Location $\quad 9^{\circ} 26^{\prime}-9^{\circ} 39^{\prime} \mathrm{N}, 78^{\circ} 30^{\prime}-78^{\circ} 45^{\prime} \mathrm{W}$; off the Caribbean coast between Punta San Blas and Cabo Tiburón, about $100 \mathrm{~km}$ east of Colon, extending to within $48 \mathrm{~km}$ of the Colombian border.

Land Tenure The Cuna Indians have title to over 365 islands and a strip of land along the adjacent coast. They have jurisdiction over agreements to buy, settle or establish any forms of business on their islands (Dahl et al., 1974).

Physical Features The archipelago stretches for a distance of $175 \mathrm{~km}$, parallel with the coast at a distance of not more than $15 \mathrm{~km}$ from it (Porter, 1972b). The chain of islands includes Picofeo, Korbiski, Nalu Nega, Smithsoniantupu and Porvenir. Large rivers empty into the Gulf of San Blas (Ogden, 1977).

Reef Structure and Corals On the seaward side, many of the islands are protected by a well-developed algal ridge of crustose coralline algae and vermetid gastropods, bordering a barren zone. On the leeward side of the islands, steep drop-offs and strong currents favour reef growth. Species diversity increases between 5 and $20 \mathrm{~m}$. At $30-50 \mathrm{~m}$ there is a sand bottom supporting isolated patches of Agaricia, Montastraea and other corals which extends down to a maximum depth of $70 \mathrm{~m}$ (Porter, 1972b).

Ten reef locations were visited in the course of a survey for the CITRE program (Comparative Investigations of Tropical Reef Ecosystems), some of which are also briefly described by Robertson and Glynn (1977). Sail Rock is an exposed rock marking an isolated reef not far from Isla Porvenir. The water was very turbid (less than $2 \mathrm{~m}$ visibility at $20 \mathrm{~m} \mathrm{depth)}$ and there was a marked thermocline at about $3 \mathrm{~m}$. The zonation is given schematically in Dahl et al. (1974). Agaricia sp. dominates at the edge of the shallow platform and there is no coral below about $20 \mathrm{~m}$ where sediment prevents the growth of species other than A tenuifolia. At the north end of Picofeo, there are typical back-reef coral communities dominated by Porites porites, with a rich Agaricia sp. coral community at the outer edge of the platform. The reef terminates in a shallow sand flat at about $6 \mathrm{~m}$. Off Punta Sardingan, on the mainland near Punta San Blas, the reef drops steeply to about $30 \mathrm{~m}$. Agaricia spp. tend to dominate at all depths except in very shallow water where $P$. porites is most abundant. Vigorous coral growth is found around the group of islands at Salar, among the inner San Blas islands north of Punta Macolla. There are spectacular drop-offs and overhangs, and profiles of some of these are given in Dahl et al. (1974).

Cayos Holandés include an area on the southern side at Isla Ordupuquip which has the greatest diversity of coral species at any site visited in the archipelago. The northern reef around Cayos Holandés is characterized by an emergent algal ridge along the seaward front formed by actively accreting crustose coralline algae and vermetid gastropods and described in Glynn (1973b). The algal ridge has its greatest elevation where wave action is strongest, and is terraced, descending in step-like fashion to a shallow moat. The ridge has a mean width of about $15 \mathrm{~m}$, but may extend up to $30-40 \mathrm{~m}$ seaward as spurs. Crustose coralline algae, particularly members of the Mastophoroideae, form a veneer of pavement on exposed surfaces or frequently assume an erect, arborescent growth form in sheltered situations. Shallow pools are common on the terraced ridge and contain a variety of large fleshy algae. Blow holes, which spout in rhythm with the advancing breaker line, suggest the presence of subsurface room and pillar structures. A sinuous limestone parapet separates the moat from the broad, leeward reef flat and is formed of a lithified conglomerate of corals and bioclastic detritus. On the submerged seaward slope of the algal ridge, filamentous and encrusting algae predominate, although limited coral growth occurs in some areas, $P$. astreoides and Agaricia agaricites being the main species. Acropora palmata has not been observed in the breaker zone but occurs further seaward at 4-6 m depth. Montastraea occurs at 6-15 m depth. In general, corals occur at a low density and are poorly developed in the seaward spur and groove zone. In contrast, vigorous coral growth is taking place on the leeward reef shelf and slope with nearly complete coverage and high species diversity from MLW to depths of $45 \mathrm{~m}$. Beyond the algal ridge at the east end, there is a broad rock platform with a drop-off, a profile of which is given in Dahl et al. (1974). The reef area at Picofeo covers 5300 sq. m (Ogden, 1977).

Noteworthy Fauna and Flora Hawksbills Erefmochelys imbricata and juvenile Green Turtles Chelonia mydas are common; the Leatherback Dermochelys coriacea has a major nesting site at Bahia Aglatomate (Groombridge, 1982). The Caribbean Manatee Trichechus manatus may occur.

Scientific Importance and Research The Smithsonian Tropical Research Institution has a field station in the archipelago. Ten sites were surveyed in the course of the proposed CITRE program and the well developed algal ridge off Cayos Holandés was identified as being of particular interest. Both this and the predominance 
of Agaricia corals at all depths are typical of most Caribbean reefs (Dahl et al., 1974). Rates of coral erosion caused by the striped parrotfish Scarus croicensis have been studied at Picofeo by Ogden (1977). Lasker and Coffroth (1985) have studied reproductive strategies of the gorgonian Plexaura at sites on Korbiski and Macaroon reefs. Studies of the mass mortality of the urchin Diadema antillarum were carried out on the reefs close to Punta San Blas (Nalunega, Korbiski, Tiantupu, Makerel, House) and at Cayos Limones (the reefs of Open Coconut, East End, Panama Flag and Chichime) (Lessios et al., 1984).

Economic Value and Social Benefits Tourist resorts are being developed in the San Blas Islands. In 1977, there were hotels at the western end of the Archipelago in the vicinity of Porvenir (Robertson and Glynn, 1977).

Disturbance or Deficiencies Stony corais, gorgonians, sea anemones and zoanthids were affected by the phenomenon of bleaching and mortality in June 1983, probably due to the elevated sea temperatures observed at the time and associated with the abnormal El Niño (see "Introduction"). Living coral cover at Sail Rock decreased by $20 \%$ and at House Reef by $35 \%$ (Lasker et al., 1984). Many had recovered by September although the problem was still present (Glynn, 1984b; Lasker et al., 1984). Shallow reef communities may have suffered only $5 \%$ reduction in living cover although Agaricia tenuifolia may have suffered much higher mortalities on some reefs. Mass mortality of the sea urchin Diadema antillarum was observed in 1983, a reduction of over $90 \%$ occurring in the populations on some reefs (Lessios et al., 1984).

The islands were relatively undisturbed by human activities in the early 1970s (Dahl et al., 1974) but there is extensive deforestation which may lead to erosion and subsequent siltation on the reefs.

Legal Protection Comarca San Blas is an anthropological reserve which includes the islands and part of the mainland (IUCN, 1982).

\section{Management None knowr.}

Recommendations The Comarca San Blas may eventually include some coastal areas. 



\section{INTRODUCTION}

\section{General Description}

The Commonwealth of Puerto Rico, an outlying territory of the U.S.A., is almost rectangular in shape with a surface area of $8897 \mathrm{sq} . \mathrm{km}$, and a rugged topography. It is the easternmost island in the Greater Antilles and lies on a submarine platform including the islands of Vieques, Culebra and Culebrita to the east and Mona and Monito to the west. The geology is described by Monroe (1980). The insular shelf is $1-2$ miles $(1.6-3.2 \mathrm{~km})$ wide on the north coast where it is bordered by the Puerto Rican Trench, narrowing io less than a mile wide in the north-west. In the south the shelf is about 2.8 miles $(3.2-12.9 \mathrm{~km})$ wide and drops from $70 \mathrm{ft}(21.3 \mathrm{~m})$ to $1800 \mathrm{ft}(549 \mathrm{~m})$ at the seaward edge; in the south-west it extends seaward for $6-11$ miles $(9.7-17.7 \mathrm{~km})$. It is widest in the east.

Oceanic currents flow from east to west on both coasts, although there is a periodic reversal on the north coast. The north and east coasts are exposed to winds and waves from the Atlantic striking the island from the east and north-east. The Cordillera Central, oriented east-west across the island, causes a considerable reduction in rainfall from north-east to south-west. Average annual rainfall varies from over $5000 \mathrm{~mm}$ in the Sierra de Luquillo to less than $1000 \mathrm{~mm}$ on the south coast. There are two rainy seasons, one between July and November (the hurricane season) and one in May. Tropical storms and hurricanes develop with easterly air streams and are accompanied by torrential rain and high seas. Occasional cold fronts during the winter months bring torrential rain for several days and cause extensive flooding. Average temperatures vary very little from $28.1^{\circ} \mathrm{C}$ in September to $25.5^{\circ} \mathrm{C}$ in February. Tidal range is slight $(0.18-0.34 \mathrm{~m})$ and tides are normally semidiumal except on the south coast where they are diumal. Velazco-Domínguez et al. (1985) give a detailed account of coastal currents.

Although corals grow around much of Puerto Rico, physical conditions result in only localized reef formation. On the north coast, reef development is almost non-existent along the western two thirds possibly as a result of one or more of the following factors: high rainfall; high run-off rates causing erosion and silt-laden river waters; intense wave action which removes suitable substrate for coral growth; and long shore currents moving material westward along the coast. This coast is steep, with most of the island's land area draining through it. Reef growth increases towards the east. On the wide insular shelf of the south coast, small reefs are found in abundance where rainfall is low and river influx is small, greatest development and diversity occuring in the south-west where waves and currents are strong. There are also a number of submerged reefs fringing a large proportion of the shelf edge in the south and west with high coral cover and diversity; these appear to have been emergent reef $8000-9000$ years ago which failed to keep pace with rising sea levels (Goenaga in litt., 7.3.86). Reefs on the west coast are limited to small patch reefs or offshore bank reefs and may be dying due to increased sediment influx, water turbidity and lack of strong wave action (Almy and Carrión-Torres, 1963; Kaye, 1959). Goenaga and Cintrón (1979) provide an inventory of mainland Puerto Rican coral reefs and the following is a brief summary of their findings.

There is little reef development on the north coast except for patchy coral growth and narrow linear "reefs" consisting of coral communities covering fossil sand dunes formed during lower sea levels. North of Isla Verde and in several other places these ridges are exposed as small rocky islets. There are several minor coral assemblages at Arecibo and submerged patch reefs off Camuy and Puerto de Tortuguero. An extensive but highly stressed reef fringes the shore at Dorado. The reef flat (1-3 $\mathrm{m}$ deep) has abundant gorgonians, and the predominant corals are Diploria strigosa and $D$. clivosa. The reef front has many dead corals overgrown by algae and other corals; seaward of this reef are small patch reefs at $25 \mathrm{~m}$ with abundant fish life. East of San Juan, there is a poorly developed and heavily stressed discontinuous chain of rock reefs trending in an east-west direction and extending $1.5 \mathrm{~km}$ off shore. These consist of a thin coral veneer over a shallow platform which, in some cases, such as Isla Piedra, east of San Juan, and Isla Cancora, rise above water (Kaye, 1959). Patch reefs are found off Punta Las Marias which are typically mound-like and rise to within a couple of metres of the surface. The tops are covered with head corals bordered by Acropora palmata; the lower slopes are covered with gorgonians.

A well developed reef system used to lie in clear waters north-west of Boca de Cangrejos with extensive coral growth from the surface to $10 \mathrm{~m}$ depth. This has been virtually destroyed by sedimentation due to extensive dredging and organic pollution from sewage treatment plants in Torrecilla Lagoon. Currently, almost no living coral is found deeper than $1.5 \mathrm{~m}$. The reefs in the region of Punta Vacia Talega are described in detail in Goenaga and Cintrón (1979). Stony corals are present on rock reefs and beach rock platform as encrusting forms and are most abundant along the northern side of the inner reef. Millepora complanata is the most abundant species near the surface, and Diploria and Isophyllia are common in deeper areas. Soft corals are present in sheltered areas. Scattered patch reefs breaking the surface are found between Punta Iglesias and Punta San Agustín, east of Punta Vacia Tallega; although these do not form a continuous barrier, they provide an effective wave energy absorbing structure. Water quality is characterized by high levels of suspended particles and low visibility, and reef patches adjacent to the shore are dead, probably as a result of siltation. Water quality and coral health improves off shore but corals are only present in depths of $1-3 \mathrm{~m}$ on the outermost reefs.

Reef development improves east of the easternmost major river, Espiritu Santo. Fringing reefs, about $0.5 \mathrm{~km}$ wide, border the north and west sides of Punta Miquillo and the north and east sides of Punta Picua. Both headlands were probably once sand cays, but are now connected to the mainland by a broad marsh and narrow sand tombolos. The reefs have poor coral development, especially at Punto Miquillo where there may be damage from the dredging of a channel parallel to the shoreline. 


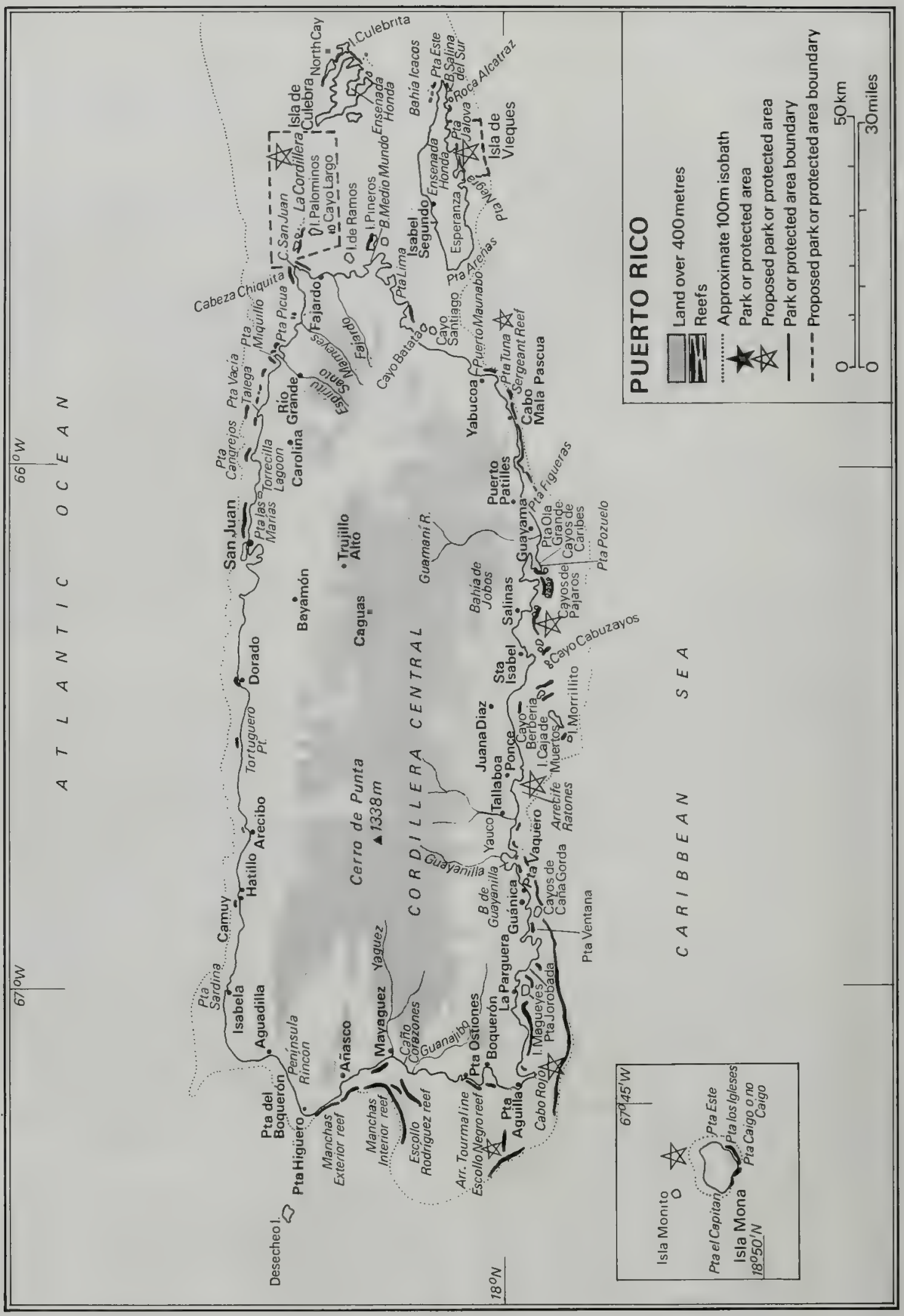


Punta Percha, to the west, forming part of the same system, has similar reefs but slightly higher living coral cover. Ensenada Comezón, between Punta Miquillo and Punta Picua, has numerous patch reefs, more than $2 \mathrm{~m}$ high, which lack distinct zonation. Algae are dominant and the surrounding waters are generally very turbid but a number of corals occur. Two large, roughly circular (300-500 $\mathrm{m}$ diameter) patch reefs occur off the mouth of Rio Mameyes, each with an exposed shoal of coarse sand. Coral diversity is low, probably due to siltation from the river.

To the east is a complex of barrier, fringing and patch reefs which are responsible for the formation of Luquillo Beach at Punta Percha. The fringing reefs surrounding the northern and eastern end of the beach have deteriorated on the seaward edge where growth is limited to the upper $3 \mathrm{~m}$. East of Luquillo, water transparency increases gradually and the reefs have slightly higher living coral cover. East of Rio Juan Martin, there is a series of patch and fringing reefs with low coral diversity, which have been described by Torres (1973). Siltation appears to be the main factor limiting coral growth. West of Cabeza Chiquita to Cabo San Juan, there is a fringing reef system, also in a poor state of health.

Conditions on the shallow platform east of Puerto Rico are ideal for coral development. The best reef development on the north-east coast is the fringing reef system around the La Cordillera islets and the islets of Isla Ramos, Isleta Marina and Cayo Ahogado between the mainland and La Cordillera. These have reefs on their eastern shores, the degree of reef development apparently related to distance from the mouth of Rio Fajardo. The islands are susceptible to occasional drastic wave erosion (Goenaga and Cintrón, 1979). The reefs at Cordillera, Culebra and Vieques are upstream of east coast river discharge and generally still have high coral diversity and cover (see separate accounts).

On the mainland, nearshore waters are affected by persistent high levels of turbidity. An extensive, but dying, fringing reef is found from north-east Cabo San Juan to the north end of Punta Sardinera, protecting the entrance to Bahia Las Croabas. There are no coral reefs from Playa Sardinera to Punta Barrancas, presumably because of the influence of Río Fajardo although narrow reefs project eastward about $450 \mathrm{~m}$ from Punta Barrancas and Mata Redonda. Between these two headlands, there is a shallow but small reef in the north of Bahia Demajagua (McKenzie and Benton, 1972).

Further south on the east coast, Isla Pineros off Medio Mundo, Ceiba, has moderate coral growth on its north and east coasts. Cabeza de Perro, an islet to the south, was used by the U.S. Navy for bombing practice and lacks marine benthic life. South to Punta Lima, the coast is mainly bordered by Thalassia sea rass beds with occasional small fringing and patch reefs. Most of the latter lie on a 6-7 m deep platform, many patch reefs not reaching intertidal level. Some probably lie on sand or mud formations, judging from their location at the edge of tidal swamps (Kaye, 1959).

South-west of Punta Lima, turbidity increases due to sediment-laden rivers and creeks. Several islets such as Cayo Santiago and Cayo Batata have coral growth in shallow waters and south facing areas open to the sea, with surprisingly dense $90 \%$ living $A$ palmata stands intermingled with gorgonian and head corals close to the surface. Submerged shoals with sparse coral growth occur occasionally off Humacao, as at Bajo Parse which has numerous gorgonians, small head corals and extensive patches of the encrusting sponge Anthosigmella varians. Further south, there is little coral growth in Yabucoa Bay (apart from an annular reef in the southern part of the bay with a few living corals) presumably because of river outflow (Diaz-Piferrer, 1969; Seiglie, 1969). About 5.5 nautical miles $(10.2 \mathrm{~km})$ east of Yabucoa Bay, La Conga reef is probably part of the submerged barrier reef bordering most of the southern shelf of Puerto Rico.

At Maunabo, the insular shelf is only $1 \mathrm{~km}$ wide; the associated high energy wave conditions and reversing tides flush Sergeant Reef, south-east of Punta Tuna, clean of river sediments (see separate account). A fringing reef extends almost continuously for four miles $(6.4 \mathrm{~km})$ between Cabo Mala Pascua to Puerto Patillas; this is exposed at low tide and protects a low sandy apron at the foot of the Sierra de Guardarraya. Arrecife Guayama, lying $0.6-0.9 \mathrm{~km}$ off Punta Figueras and nearly $5 \mathrm{~km}$ in length, is well developed but is now affected by siltation; the Acropora palmata zone has low coral cover and many dead colonies. West of this reef, off Arroyo, are the Corona and Algarrobo patch reefs which appear relatively healthy and little affected by siltation. Arrecife Las Mareas, south of Las Mareas, Guayama, is almost devoid of living coral.

South-west of Punta Pozuelo, a fringing barrier reef, Cayos Caribes, extends for about $2.5 \mathrm{~km}$ forming an arc with Cayos de Barca and Cayos de Pajaros and protecting the entrance of Bahia de Jobos. Living coral cover is moderate and increases westward. On the lee side of the reefs are a number of narrow sand cays fringed by mangrove vegetation. The Ponce basin contains very turbid water, with a bottom of silt and clay. About $2.5 \mathrm{~km}$ south of Ponce, reefs are found at Baja Tasmanian, on a two-tiered platform, the northern level 6-12 $\mathrm{m}$ deep, and the southern level 18-24 $\mathrm{m}$ deep. A cervicornis is particularly abundant at the lower level with large shingle-like growths of various massive corals at the shelf edge (Beach, 1975). Numerous offshore cays with healthy coral cover occur off Salinas, Santa Isabel and Ponce (see separate accounts for Bahía de Jobos and Caja de Muertos).

Off Tallaboa and Bahía de Guayanilla, living coral cover is neglible, due to industrial development, although some isolated heads of $A$ palmata and $M$. complanata still survive on the seaward side. Over the last four years, coral cover has declined from $10-20 \%$ to less than $1 \%$. A few areas of high coral cover and diversity still occur, for example, on the walls of the Guayanilla submarine canyon (Goenaga in litt., 7.3.86). The reef off Punta Verraco, on the west of Guayanilla Bay, has an extensive Thalassia and Syringodium bed on its reef flat. Stony coral cover on the shallow front reef is very reduced but the deeper fore-reef has an extensive and quite healthy community of soft corals and gorgonians. An extensive submerged reef extends from Punta Vaquero to Punta Ventana, where it breaks the surface first as a fringing reef and later as a barrier reef protecting Playa Tamarindo, Bahía de la Ballena and Playa de Cana Gorda just west of Guánica. This reef is almost totally devoid of living coral and has huge carpets of the fast-growing colonial anemones Zoanthus and Palythoa lying over the dead coral framework. 
Quinn (1972) has described surge channels on the south-west coast.

West of Punta Jorobado, reefs become more prolific and complex, due to limited rainfall, minimal soil run-off and low wave action, and are described in the account for $\mathrm{La}$ Parguera (Goenaga and Cintrón, 1979). Around Cabo Rojo, the reefs are small and often do not break water although coral growth is fairly abundant. In the small bay west of Cabo Rojo lighthouse, patches of coral alternate with Thalassia grass beds, and are described in Almy and Carri6n-Torres (1963). Bajo Gallardo is a well developed, relatively untouched reef about $13 \mathrm{~km}$ west of Punta Aguila, Cabo Rojo, with luxuriant $A$ palmata growth and abundant fish life. Roca Ola, a patch reef in Bahía Sucia, Cabo Rojo, has large colonies (more than $3 \mathrm{~m}$ diameter) of Montastraea annularis (Goenaga in litt., 7.3.86)

Between Cabo Rojo and Mayagüez, there is high water turbidity near shore, unusually slight wave action and heavy land drainage. The broad bank that lies immediately off shore minimizes wave action, limiting water circulation and the removal of land drainage pollution. The coral patches and assemblages generally have few stony corals, often covered by mats of macro-algae, but there are spectacular, dense stands of gorgonians (Kolehmainen, 1974). Bahía de Boquerón is very turbid, its reefs surrounded by mud, but nevertheless there is a dense covering of corals, particularly gorgonians.

Reefs to the north include Escollo Negro and Arrecife Tourmaline (see separate account), Las Coronas, Escollo Rodriguez, Cayo Fanduco, Manchas Interiores, Manchas Exteriores, Arrecife Peregrina and Gallardo. Las Coronas is a shallow $(2-4 \mathrm{~m})$ sand shoal colonized principally by large-sized gorgonians and occasional massive corals, extending east to Cayo Fanduco. Manchas Interiores, Manchas Exteriores and Arrecife Peregrina have low relief spur and groove systems sloping more or less abruptly westward giving way to a dense black coral dominated fauna. Encrusting coral growth with large pillar corals and gorgonians dominate the shallow depths. Escollo Rodriguez, situated about $1.6 \mathrm{~km}$ west of Cayo Corazones, consists of a series of elongated patch reefs which lack the distinct zonation found in the other reefs. There is abundant fish life but the reefs appear to be affected by siltation from the Guanajibo River (Morelock et al.,1983; Schneidermann and Morelock, 1973).

A study of reef fish was carried out on a $25 \mathrm{sq} . \mathrm{km}$ reef tract about $9.5 \mathrm{~km}$ off the coast on the west coast from an underwater habitat (Parrish, 1982; Parrish and Zimmerman, 1977). This area consisted of a shallow bank, 3-6 $\mathrm{m}$ deep with a steeply sloping face of living coral on the seaward side to $16.5 \mathrm{~m}$ depth. The reef has a variety of living hexacorals and octocorals growing on an open porous structural framework of dead coral with a diverse assemblage of other sessile invertebrates and low, encrusting filamentous algae.

North of Arrecife Peregrina to Punta Higuero, the insular shelf is less than $1 \mathrm{~km}$ wide and has well developed reefs at its outer edge where the bottom slopes steeply. Stony corals, unusual gorgonians and black corals are abundant at depths of $15-40 \mathrm{~m}$ but water transparency is quite variable, being influenced by river discharge. Poorly developed fringing reefs, consisting mainly of partially dead $A$ palmata and scattered gorgonians occur on the north side of the Rincón Peninsula from Punta Higuero to Punta del Boquerón. North of this point, only scattered, undeveloped coral growth occurs. There is an underwater cave system off Bajura, Isabela, with dense coral growth, especially Agaricia, on the outer walls and ledges.

Numerous fringing, patch and offshore bank barrier reefs are found around the coast of Vieques. Reefs on the south coast are discussed in the separate account for the proposed Vieques marine sanctuary. Those off the eastern end are well known as a result of a series of studies carried out for the U.S. Navy in 1978. The area is used as a practice range for air-dropped bombs and ships gunnery, but includes reefs at Punta Este on the eastern point, Peñasco Fosil, Punto Gato, Gato Afuera, Isla Yallis and Punta Icacos around Bahía Icacos on the north coast, Cerro Indio, Pena Roja, Bahía Salinas, Punta Salinas, Cerro Matias, and Roca Alcatraz on the south coast (Antonius and Weiner, 1982; Dodge, 1981; MacIntyre et al., 1983). Brief descriptions of these reefs are given in Antonius and Weiner (1982).

In the late 1970 s, it was alleged that they were threatened by excessive run-off and sedimentation as a result of bombing and bulldozing and were being directly damaged by stray bombs and shells (Antonius, 1981; Antonius and Weiner, 1982; Dodge, 1981; Raymond, 1978; Rogers et al., 1978). Field investigations were concentrated within Bahía Icacos and Bahía Salina del Sur, the areas believed to be suffering the greatest military impact. The sediments of these two areas are described by Morelock (1978) and Raymond (1978). Raymond (1978) also carried out an ecological survey of the shallow reefs fringing the promontories on the eastern, western and northern shores of Bahia Salina del Sur. Two extensive sand beaches border the north-eastern and north-western corners. The fringing reef off the west side of the bay consists of a well-developed Acropora palmata communit and banks and mounds of Porites porites occur around two distinct promontories on the north coast (Macintyre et al., 1983). The fringing reef on the eastern side of the bay consists of Montastraea, Siderastrea and Diploria coral heads. Another reef juts out from the promontory and has zonation typical of shallow water Caribbean reefs: a reef crest and shallow fore-reef dominated by $A$ palmata and a mixed coral community at depths greater than $4 \mathrm{~m}$, including $M$. annularis, $D$. strigosa and $S$. siderea. The seaward slope levels off at a depth of $8 \mathrm{~m}$, grading into the sediment floor of the bay. The back-reef shoreward of the reef crest is composed of large colonies of $M$. annularis on rubble and pavement. MacIntyre et al. (1983) describe the results of core drilling and give estimates of accumulation rates for this reef. Roca Alcatraz, an island $\mathbf{1 ~ k m}$ south of the bay is surrounded by an $A$. palmata reef.

Reefs outside the range area include Mosquito Reef, some distance off the north-west coast and Ensenada Honda off the south coast (Dodge, 1981) which falls within the proposed marine sanctuary area (see separate account). There is no information readily available for the reefs of Culebra and Culebrita Islands. The shallow-water sublittoral benthos is described by Cerame-Vivas et al. (1971); communities of $P$. furcata are 
found along the south-east coast of Culebra (Glynn, 1973) and Ensenada Honda is described by Cintrón et al. (1974).

Extensive research has been carried out on the reefs and associated marine environments of Puerto Rico, particularly by the Department of Marine Sciences at the University of Puerto Rico at Mayaguez and within the Departamento de Recursos Naturales. Canals (1980) provides a bibliography of publications on reefs and Lugo (1978) provides a general description. Loya (1976) considered species diversity to be low; Pressick (1970) recorded 18 coral species at Icacos Island and Szmant-Froelich (1973) recorded 13 at Bahia de Jobos. More recent discoveries suggest that the fauna is comparable with other Western Atlantic areas. Weinberg (1981) recorded 38 species from shelf edge reefs. Armstrong (1980) and Morelock (in litt., 1984) have recorded 54 species from the $\mathrm{La}$ Parguera reefs. Octocorals, of which about 54 species have been recorded in Puerto Rico are described by Bayer (1961), González-Brito (1970) and Rees (1973). Remote sensing techniques are being used to map the reefs of Puerto Rica and assess fishery resources (Armstrong 1984 a and b). Almodovar (1979) and González-Liboy and Santiago (1980) provide bibliographies on marine botany and seagrass beds respectively.

The Caribbean Manatee Trichechus manatus was once fairly common around Puerto Rico and small groups are still frequently sighted on the south and around the mouth of the Fajardo River. The Green Turtle Chelonia mydas, the Hawksbill Turtle Eretmochelys imbricata and the Leatherback Dermochelys coriacea nest around Puerto Rico and on the offshore islands (Bacon et al., 1984) and the Loggerhead Turtle Caretta caretta is reported to nest on Culebra (Groombridge, 1982). Seven species of seabird breed on the mainland (Halewyn and Norton, 1984); Cordillera has six breeding species; Desecheo Island has four breeding species; Culebra has twelve species and the seabirds of Vieques, Mona and Monito Islands are mentioned in separate accounts. Important wetland areas, particularly mangroves, are described in Scott and Carbonell (1986) and U.S. Dept of Commerce (1978). The latter also provides descriptions of dunes, beaches and coastal forests.

\section{Reef Resources}

Few publications are available on the economic importance of the Puerto Rican reefs, but tourism and fishing are major activities (see separate accounts). Most fishing is artisanal. In the 1970 s there was an annual production of $3000 \mathrm{lbs}(1350 \mathrm{~kg})$ per fisherman, and about 2000 fishermen (U.S. Dept of Commerce, 1978). Stevenson (1978) describes the Puerto Rican trap fishery; Fast and Pagán-Font (1973 and 1974) describe other aspects of the fisheries. Fishery stocks are most abundant in the south-west. The tourist industry and local interest in water-related recreation grew rapidly in the 1960 s and 1970 s and increasing numbers of condominiums and marinas have been built in formerly rural coastal areas. The most important areas for tourism are in the north-east and south-west (U.S. Dept of Commerce, 1978). On Vieques, where about $65-75 \%$ of the land area is owned by the U.S. Navy, the population is low and is restricted to Isabel Segunda on the north side of the island. Marine resources of the island are described by
Torres and Pearl (1972). There is a large artisanal, commercial fishing fleet, but industry and tourism are virtually non-existant (Anon., 1982) although a new marina and charter boat operation has been established at Esperanza (Morelock pers. comm., 1984).

\section{Disturbances and Deficiencies}

Damage to Puerto Rican coral reefs due to natural phenomena has been documented on several occasions. Mass mortality of Millepora complanata was observed during heavy rains on the east coast (Goenaga and Canals, 1979) and a heavy mortality of echinoids and other reef flat organisms was found to be related to extreme low water exposure at midday (Glynn, 1968). However, these effects are negligible compared to catastrophic events such as hurricanes. Hurricane Edith caused extensive destruction of branching corals in 1963 (Glynn et al., 1964; see account for "La Parguera"). Two tropical storms in 1979 (David and Frederic) caused extensive damage on the outer east coast and southern coastal reefs. This was most obvious in the shallow $A$ palmata zone where colonies were ripped off and overturned causing damage to adjacent massive corals (Goenaga and Cintrón, 1979). The hurricanes also caused damage to the reefs off the eastern point of Vieques (Raymond and Dodge, 1980) and particularly to the more exposed south coast reefs where all $A$ palmata stands were destroyed and Porites beds severely affected. On the north coast, $A$ palmata was badly damaged in the fore-reef area and some Porites beds were crushed by broken $A$ palmata branches, Long Reef experiencing greatest damage. A palmata, once the main reef building coral on Vieques, is now considered a minor component. Mass mortality of the sea urchin Diadema antillarum was reported in January 1984 and was presumably related to the Caribbean-wide mortality of this species, possibly due to a water-borne pathogen (Lessios et al., 1984). White band disease has been recorded (Rogers, 1985).

Many of the mainland reefs in Puerto Rico have suffered considerable damage recently from human activities. The south-west and north-east, as well as being the richest areas in terms of marine resources are also under greatest pressure from development (U.S. Dept of Commerce, 1978). Extensive coral reef degradation has been observed at the following sites: 1) all reefs from San Juan to Las Cabezas de San Juan; 2) inshore Fajardo reefs; 3) Humacao reefs; 4) annular reef off Puerto Yabucoa; 5) inshore Ponce reefs; 6 ) all reefs off Bahía Guayanilla and Bahia de Tallaboa; 7) all reefs off and fringing Guánica; 8) all west coast inshore reefs from Boquerón to Rincón; 9) reefs off Arecibo; and 10) reefs off Dorado (Goenaga and Cintrón, 1979).

The most important damaging factor appears to be siltation due to upland vegetation clearing, periodic inshore dredging and alterations in sediment dynamics. Sedimentation as a control factor in the distribution of coral reefs in Puerto Rico is discussed by Cintrón et al. (1973), Kolehmainen (1974), Loya (1976), Rogers (1977) and Schneidemann et al. (1976) and a detailed review is given by Velazco-Dominguez et al. (1985). The rugged topography and warm moist climate are conducive to high rates of erosion and sedimentation. Once largely forested, Puerto Rico had lost $66 \%$ of its forest cover by 1978. Lugo et al. (1980) estimate that erosion problems of a severe and moderate nature exist in $48 \%$ and $22 \%$ 
respectively of the total area of the island. Dredging and construction in the coastal zone has led to the loss of about $75 \%$ of the mangrove and other wetland areas.

The north and east coast reefs are strongly stressed by terrigenous input from major river systems and benthic communities are subjected to heavy doses of sediment after periods of heavy rain. Intensive upland deforestation in the last 30 years has probably increased run-off and may contribute to the paucity of reef growth along the north coast. East of Rio Juan Martin, reefs have probably been affected by water pumping activities in sand extraction pits. Damming of the Rio Grande at Arecibo, construction of a breakwater and dredging until 1975 caused high turbidity and alteration of the shoreline and sedimentary processes in Arecibo Bay (Delgado, 1976). Reefs from Cabo San Juan to La Cordillera have undergone rapid degradation due to sittation and coral extraction. Reefs at Isla Verde have deteriorated because of dredging and associated sedimentation at Boca de Cangrejos. The east coast has persistent high levels of turbidity since silt discharged by the rivers is pushed back against the coast by winds, waves and currents (Velazco-Dominguez et al., 1985). The inshore Fajardo reefs have also been affected by siltation which may have accounted for high Diadema populations (in the 1970s) on reefs such as Ahogado compared with offshore reefs such as Cayo Largo (Goenaga and Cintrón, 1979). Goenaga and Canals (1980) reported salinities of less than 25 ppt and high turbidity near Rio Fajardo on a reef which suffered massive mortality of Millepora complanata. Siltation has also affected many of the reefs west of Punta Lima. Río Antón Ruiz is occasionally dredged and pumped; a further source of siltation is the recent development of Palmas del Marat Humacao which resulted in vegetation clearance of extensive areas of steep slopes.

On the south and south-east coasts, currents and waves drive discharged river sediment back against the coast to the nearshore stands, contributing to the development of mangroves which play an important role in the trapping of silt. Offshore reefs are affected more by the resuspension of biochemically generated sediment deposited throughout the Holocene. Arrecife Las Mareas, Guayama, has been killed probably as a result of siltation from the Guamani River east of Punta Ola Grande (Torres, 1978). A rock-jetty protecting the entrance to Puerto Las Mareas blocks the westward movement of silted waters and extensive dredging for the construction of an artificial harbour may have contributed to high sediment levels and coral mortality.

The south-west coast, with its sheltered waters, is particularly threatened by the development of industrial port complexes. Industrial development of Bahia Guayanilla and Tallaboa has significantly altered the reefs in this area. Reefs off Tallaboa, which has a large petro-chemical complex, are under stress from siltation caused by periodic dredging of ships channels, propeller stirring, the discharge of bilge water containing oily wastes, and industrial effluents and increased sediment load in the Guayanilla and Tallaboa Rivers (Morelock et al., 1979; Morelock et al., 19??; Velazco-Domínguez et al., 1985). In shallow waters there is almost no living coral. Reefs off Guánica are heavily stressed, with low diversity and sometimes $100 \%$ cover of Zoanthus or Palythoa, similar to the Guayanilla reefs. This may be due to sedimentation, although these reefs border the Guánica State Forest Reserve (IUCN, 1982), which should ensure that excessive soil run-off does not occur.

On the west coast, siltation as a result of sugar plantations, increasing industrial and housing developments, and low salinities caused by the discharge of Rio Guanajibo are threatening the reefs between Cabo Rojo and Mayaguiez (Kolehmainen and Biaggi, 1975; Morelock et al., 1983), as described in the account for Escollo Negro. Reefs off Boquerón have suffered from resuspension of silt trapped in the bay. Escollo Rodríguez and Algorrobo reefs are stressed by industrial contamination from Mayagüez and discharge from the Yaguez River and the reefs appear to be being silted over.

Pollution is the second most damaging factor. Studies by the Puerto Rico Nuclear Center in Mayagüez, Anasco and Jobos Bays found that organic and trace element pollution was present in all three areas (Seiglie, 1971). About 150 oil spills were recorded around the coast in 1975 , but there appear to have been no long term effects on the reefs as a result of major oil spills in 1969 off San Juan and in 1974 on the south coast (U.S. Dept of Commerce, 1978). The effects of oil spills near Cabo Rojo and near Guanica are described by Nadeau and Bergquist (1977) and Diaz-Piferrer (1962) respectively. The islets off the mouth of Rio Mameyes were heavily impregnated with bunker oil during an oil spill in 1978.

Discharge of untreated or partially treated sewage and boat anchoring may also cause problems. Urban and industrial development has had a noticeable impact on reefs near the ports of Arecibo, San Juan (the largest urban area and port), Yabucoa (a large man-made harbour), Ponce (second largest urban area and heavily industrialized), Guánica and Bahía de Guayanilla. In Yabucoa Bay, heavy ship traffic may contribute to the paucity of coral formations. Bahía de Guayanilla is seriously affected by chemical and thermal effluents. It has been calculated that $15.8 \%$ of the sewage generated in the country goes into the sea with no treatment, raw sewage discharge takes place at Arroyo, Ponce, Guayana, Mayaguiez and Aguadilla (Velazco-Dominguez et al., 1985).

In the north-east, La Cordillera and the mainiand coast have come under considerable pressure from the construction of tourist complexes and summer residences. Coral extraction for the marine curio trade is a localized problem on the reefs from Cabeza Chiquita west to Cabo San Juan in Fajardo, in La Cordillera and in Culebra. It was reported that many fishermen were abandoning fishing in order to collect corals (Torres, 1975; U.S. Dept of Commerce, 1978; Lugo, 1978; Goenaga and Cintrón, 1979). Ballantine et al. (1985) have monitored levels of Gambierdiscus toxicus on Caracoles Reef in the south-west and Escalona de Motta and De la Noceda (1985) described incidences of ciguatera poisoning.

On Vieques Island litigation was brought against the U.S. Navy in 1977 and 1978, by the Commonwealth of Puerto Rico and others claiming that range usage in the east of the island was promoting excessive sedimentation and turbidity on nearby offshore coral reefs (Antonius, 1981; Antonius and Weiner, 1982; Dodge, 1981; Rogers et al., 1978). Studies by the Florida Reef Foundation concluded that military impact was negible compared to natural 
storm damage and that the reefs of the bombing range were in better condition in terms of diseased and/or dead corals than control reefs studied in the Virgin Islands. A study of the growth characteristics of Montastraea annularis within and external to the Vieques range area revealed no significant differences due to high sedimentation (Dodge, 1981). The possible decrease in coral reproductive output, as a result of increased energy put into maintenance, was not assessed. It was suggested that absolute protection, through military restrictions, of the reefs on Vieques outweighed the disadvantages of occasional bomb explosions (Antonius, 1981 and 1982). There is considerable disagreement over this issue. Bombing and construction activities associated with military activities have undoubtedly altered both the marine and terrestrial environment at Bahia Salina del Sur and destroyed or damaged many of the fringing reefs (Antonius and Weiner, 1982; Raymond, 1978). Whereas hurricanes cause selective damage to shallow fast growing organisms, bombing causes unselective damage affecting deeper slow growing corals as well as the fast growing ones. Recently dead corals lying on discrete bomb-made craters have spread homogenously over large reef areas as a result of the two hurricanes (Goenaga in litt., 1983). These fragments can move around the bottom with wave action which may be less intense than that produced by storms, causing abrasion of healthy corals. Environmental reports have also been prepared for Culebra in the context of U.S. Navy activities (Commonwealth of Puerto Rico, 1970; U.S. Fish and Wildife Service, 1979) and Rogers et al. (1978) describe the impact of military activities on the reefs.

\section{Legislation and Management}

The Departamento de Recursos Naturales is responsible for wildlife, territorial waters and the management and protection of natural resources. The Environmental Quality Board prepares Environmental Impact Assessments prior to the initiation of developments affecting the environment and is responsible for pollution control. The U.S. Soil Conservation Service operates several programmes to respond to problems of sedimentation and soil run-off and provides technical assistance to land owners and others who wish to carry out locally adapted soil and water conservation programmes. Regulations for erosion control have been drafted (U.S. Dept of Commerce, 1978). The Caribbean Fishery Management Council is responsible for the preparation of fishery managment plans; in 1978 plans were in preparation for reef fish and spiny lobsters. U.S. Dept of Commerce (1978) lists other agencies with jurisdiction over or having an impact on the coast. An Oil Spill Contingency Plan is in operation.

In 1974, the Departamento de Recursos Naturales de Puerto Rico, the governmental organization concerned with conservation, and the Planning Board jointly established a program to prepare a coastal management programme for Puerto Rico, funded by the U.S. Department of Commerce through the Office of Coastal Zone Management. The Culebra segment of the programme was approved in 1977 and the final programme in 1978 (U.S. Dept of Commerce, 1978). This activity had been partly stimulated by the formation in 1972 of a committee on "Puerto Rico and the Sea" by a group of concerned citizens. The coastal management programme includes a variety of activities outlined in
U.S. Dept of Commerce (1978) and proposals for a system of Natural Reserves, which includes the following areas with reefs:

1. El Faro Reserve. A headland in the north-east, about 440 ha in area, which is already protected and is owned by the Conservation Trust and other private bodies. It has varied topographical features including mangroves, coral reefs, a bioluminescent lagoon and important populations of birds and fish.

2. La Cordillera (also proposed as a Marine Sanctuary; see separate account).

3. Arrecife Guayama, Off Arroyo, south-east coast Reefs have high living coral cover (50-84\%) and considerable recreational potential; currently there are serious siltation problems in this area.

4. Bahia de Jobos (see separate account).

5. Caja de Muertos (see separate account).*

6. Guánica Forest and Biosphere Reserve. This would include the Guánica State Forest $(30 \mathrm{~km}$ west of Ponce and described in IUCN (1982)) and the adjoining cays and reefs of the Bahía de la Ballena area. The forest is important for its bird fauna and endemic plants. Reefs and mangroves are currently threatened by siltation and are vulnerable to pollution from adjacent industrial complexes.

7. La Parguera (also proposed as a Marine National Sanctuary; see separate account).

8. Tourmaline and El Negro reef complex (see separate account).

9. Islas Mona and Monito (see separate account).

Areas considered to be of particular importance by Goenaga and Cintrón (1979) are:

10. Sergeant Reef, Maunabo (see separate accolint).

11. Cayo Ratones, Ponce (see separate account).

12. Vieques proposed Marine Sanctuary (see separate account).

13. Underwater caves off Bajura, Isabela (as a tourist attraction).

14. Reefs around Culebra and Culebrita Islands; proposed for protection under the Culebra segment of the Coastal Management

Program. The Culebra National Wildlife Refuge which includes all the islands surrounding the main island of Culebra except Cayo Norte, is described in IUCN (1982).

Special Planning Areas have been proposed under the Coastal Zone Management Programme (U.S. Dept of Commerce, 1978). These are important resource areas subject to serious present or potential use conflicts. They include:

- All mangrove wetlands

- Boca de Cangrejos

- Bahía de Jobos

- South-west Puerto Rico, including Guánica, La Parguera and Boquerón

- Isabela Dunes

- Laguna Tortuguero

- Vieques

\section{Recommendations}

The following is a summary of the recommendations given by U.S. Dept of Commerce (1978), Goenaga and Cintrón (1979) and Velazco-Domínguez et al. (1985): 
1. Prepare televised educational programmes on reefs and booklets for divers and yachtsmen on anchoring, sitting and standing on coral, shell collecting and spearfishing by the Coastal Zone Management Division. Several information booklets have already been prepared for the public by the Division.

2. Reduce siltation due to inland vegetation removal. The new erosion regulations being prepared by the Coastal Zone Management Division should include the control of upland deforestation, reforestation of river banks with vegetation or bamboo, development of reforestation programs in upland areas, protection and restoration of wetland areas and discouragement or prevention of alterations to fresh and brackish wetlands, use of agricultural practices which reduce or minimize soil loss such as terracing, contouring etc., discouragement of monocultures which lead to soil depletion and erosion, avoidance of clear felling, control of the use of heavy equipment on fragile soils, analysis of effects of earthmoving activities before any development, and avoidance of removal of adjacent vegetation unless essential.

3. Control run-off and erosion from construction and mining activities.

4. Prohibit toxic waste outfall and solid waste disposal into coastal waters, locate sewage outfall pipes beyond nearshore habitats and away from reefs, monitor water quality regularly around industrial plants, sewage outfall, marinas and tourist centres. Pollution research should be promoted and sponsored by the Dept of Natural Resources in co-ordination with the Environmental Quality Board and the University of Puerto Rico, and if necessary should lead to the modification of laws and regulations.

5. Discourage seafloor dredging in inshore waters, carry out environmental assessments prior to offshore dredging, use ecologically sound dredging methods, monitor dredging sites and develop contingency plans for dredged materials found to be high in toxins. Dredging guidelines are given in U.S. Dept of Commerce (1978).

6. Prohibit the uses of explosives in or near reefs and seagrass beds, and the firing of targets in reefs and bays.

7. Establish protected areas around the most important reef ecosystems and provide appropriate legislation and enforcement; place permanent mooring buoys and prohibit anchoring in reef and sea grass areas that are popular anchorages.

8. Amend the Fisheries Act of $\mathbf{1 9 3 6}$ to include corals and to prohibit collection without a permit from the Dept of Natural Resources.

\section{References}

- cited but not consulted.

Acevedo, R. (in prep.). Ms Thesis (Ponce reefs) (reference not known).

Almodovar, L.R. (1979). Bibliografía sobre botánica marina en Puerto Rico. Science-Ciencia 6(3): 126-129.

Almy, C.C. and Carrion-Torres, C. (1963). Shallow water stony corals of Puerto Rico. Carib. J. Sci. 3(2,3): 133-162.
-Anon. (1968). The bioluminescent bays of Puerto Rico. U.S. Nat. Park Service, Washington D.C.: 48 pp.

Anon. (1982). Preliminary candidate Marine Sanctuary Site Evaluation. U.S.A.

Anon. (undated). Las Islas de Mona y Monito. Una Evaluación de sus recursos naturales e históricos. Vol. I and II. Estado Libre Asociado de Puerto Rico, Oficina del Gobernador, Junta de Calidad Ambiental.

Antonius, A. (1981). Coral reefs under fire. Proc. 4th Int. Coral Reef Symp. Vol. 1: 216 (abstract).

Antonius, A. and Weiner, A. (1982). Coral reefs under fire. Mar. Ecol. 3(3):255-277.

Appeldoorn, R.S. and Lindeman, K.C. (1985).

Multispecies assessment in coral reef fisheries using higher taxonomic categories as unit stocks with an analysis of an artisanal haemulid fishery. Proc. 5th Int. Coral Reef Cong., Tahiti 5: 507-514.

Armstrong, R.A. (1980). New records of scleractinian corals from Puerto Rico. Proc. Assoc. Is. Mar. Labs Carib. 15: 3

Armstrong, R.A. (1981). Changes in a Puerto Rican coral reef from 1936-1979 using aerial photo analysis. Proc. 4th Int. Coral Reef Symp. 1: 309-315.

Armstrong, R.A. (1984a). Computer classification of coral reefs using thematic mapper simulator data. Advances in Reef Science. Proc. Joint Meeting of Atlantic Reef Committee and International Society for Reef Studies, Miami Oct. 1984: 9.

Armstrong, RA. (1984b). Assessment of shallow water demersal and pelagic fish resources of the Eastern Caribbean using remote sensing technology. Remote Sensing Technology and its Application to Fisheries. Proc. 34th Gulf Marine Fisheries Commission Meeting, Biloxi, Mississippi.

Bacon, P., Berry, F, Bjorndal, K., Hirth, H., Ogren, L., Weber, M. (1984). The National Reports. Proceedings of the Western Alantic Turtle Symposium, Vol. 3. University of Miami Press, Florida.

Ballantine, D.L., Bardales, A.T., Tosteson, T.R. and Dupont-Durst, H. (1985). Seasonal abundance of Gambierdiscus toxicus and Ostreopsis sp. in coastal waters of south-west Puerto Rico. Proc. 5th Int. Coral Reef Cong., Tahiti 4: 417-422.

Bayer, F.M. (1961). The shallow-water octocorallia of the West Indian region. Stud. Fauna Curaçaco 13: 1-373.

-Beach, D. (1975). Sedimentation on the western Isla Caja de Muertos insular shelf. Puerto Rico. Masters Thesis, Univ. of Puerto Rico.

-Beach, D.K. and Trumbull, J.V.A. (1980). Marine Geological Map of the Puerto Rico Insular Shelf, Isla Caja de Muertos Area. U.S. Geological Survey, Report 80-366, 17 pp.

Canals, M. (1980). Bibliografía sobre los arrecifes de coral. Departamento de Recursos Naturales, San Juan, Puerto Rico.

-Canals, M., Ferrer, H. and González, J. (1980). El arrecife coralino de Caja de Muertos, Puerto Rico. Rept to Dept Nat. Resources, Commonwealth of Puerto Rico.

"Cerame-Vivas, M.J., Hendrick, W.F. and Prentice, J.R. (1971). Observations on the shallow water sublittoral benthos of Culebra and Culebrita Islands. An ecological overview. Mimeo, Dept Mar. Sci., Univ. of Puerto Rico, Mayaguiez.

-Cintrón, G., McKenzie, F. and Olagasti, R. (1973). Studies at PRINUL site. Final report of missions 3 and 5. Puerto Rico International Underwater Laboratory.

"Cintrón, G., Perl, H. Benton, M., Cham, C. and Cintrón, B. (1974). Ensenada Honda (Culebra, Puerto 
Rico): biology and gross oceanographic description. I Simposio del Departamento de Recursos Naturales.

- Cintrón, G. and Thurston, J. (1975). Caracteristicas de la plataforma insular de Isla de Mona. II Simposio del Departamento de Recursos Naturales.

Coker, R.E. and González, J.G. (1960). Limnetic copepod populations of Bahia Fosforescente and adjacent waters, Puerto Rico. J. Elisha Mitchell Sci. Soc. 76: 8-28.

Commonwealth of Puerto Rico (1970). An island in transition Culebra 1970: a staff report on the environment to the Governor's special committee on Culebra, Office of the Governor, Environmental Quality Board. 104 pp.

-Dahl, A.L. (1973). Benthic algal ecology in deep reef and sand habitat off Puerto Rico. Bot. Mar. 16: 171-175.

-Delgado, R. (1976). Sedimentación en la Bahía de Arecibo - Intervención de obras humanas y recursos naturales. III Simposio del Departamento de Recursos Naturales, 1976: 134-140.

Díaz, C.A., del Llano, M., Canals, M.A., Cintrón, B. and Toro, JA. (1983). Suplemento Tecnico para el plan de manejo de la Reserva Natural de Bahía de Jobos. Departamento de Recursos Naturales, Puerto Rico.

-Diaz-Piferrer, M. (1962). The effects of an oil spill on the shore of Guanica, Puerto Rico. Proc. 4th Meeting Assoc. Island Marine Labs Caribbean. Univ. Puerto Rico, Mayaguez: 12-13.

Diaz-Piferrer, M. (1969). Report on the benthic algae of Yabucoa Bay. Unpub. Rept.

Dodge, R.E. (1981). Growth characteristics of reef-building corals within and external to a naval ordinance range: Vieques, Puerto Rico. Proc. 4th Int. Coral Reef Symp. 2: 241-248.

Escalona de Motta, G. and De la Noceda, G.G. (1985). Epidemiological, clinical and experimental aspects of ciguatera in Puerto Rico. Proc. 5th Int. Coral Reef Cong., Tahiti 4: 415.

-Fast, D.E. and Pagan-Font, F_A. (1973). Puerto Rico's coastal fisheries, 1972. 10th Meeting Assn Island Marine Labs. of the Caribb. (Abs): p 57.

-Fast, D.E. and Pagán-Font, F.A. (1974). Comparative observations on an artificial tire reef and natural patch reefs off southwestern Puerto Rico. In: Colugna, L. and Stone, R. (Eds), Proc. Int. Conf. Artificial Reefs. Center Mar. Res., Texas A \& M Univ., Texas: 49-55.

Glynn, P.W. (1968). Mass mortalities of echinoids and other reef flat organisms coincident with midday low-water exposures in Puerto Rico. Mar. Biol. 1(3): 226-243.

Glynn, P.W. (1973). Ecology of a Caribbean coral reef the Porites reef-flat biotope. Part 1. Meteorology and hydrography. Mar. Biol. 20: 297-318.

Glynn, P.W., Almodovar, L.R. and González, J.G. (1964).

Effects of Hurricane Edith on marine life in La Parguera, Puerto Rico. Carib. J. Sci. 4: 335-345.

Goenaga, C. (1982a). Nota sobre las modificaciones de las poblaciones de coral de los arrecifes de la costa sur a consecuencia del Huracán David. Mem. del 3 Simp. sobre la Fauna de Puento Rico, Univ. Puerto Rico, Humacao.

- Goenaga, C. (1982b). The marine communities of Isla de Mona, a proposed National Marine Sanctuary. Rept to NOAA, U.S. Dept Interior.

-Goenaga, C. and Canals, M. (1979). Relacion de mortandad massiva de Millepora complanata con alta pluviosidad y escorrentia de Río Fajardo en Cayo Ahogado, Fajardo. Abs. for VI Symp., Dept Nat. Res., Puerto Rico.
Goenaga, C. and Cintrón, G. (1979). Inventory of the Puerto Rican Coral Reefs. Report submitted to the Coastal Zone Management Programme of the Dept of Natural Resources, Commonwealth of Puerto Rico.

González-Brito, P. (1970). Una lista de los octocorales de Puerto Rico. Carib. J. Sci. 10: 63-69.

González-Liboy, J. and Santiago, D. (1980). Bibliografia sobre las praderas submarinas de Puerto Rico. Departamento de Recursos Naturales, San Juan, Puerto Rico.

Groombridge, B. (1982). The IUCN Amphibia-Reptilia Red Data Book Part 1: Testudines; Crocodylia; Rhynchocephalia. IUCN, Gland, Switzerland.

Halewyn R. van and Norton, R.L. (1984). The status and conservation of seabirds in the Caribbean. In: Croxall, J.P., Evans, P.G.H and Schreiber, R.W. (Eds), Status and Conservation of the World's Seabirds. ICBP Technical Publication No. 2, Cambridge.

IUCN (1982). IUCN Directory of Neotropical Protected Areas. Tycooly International Publishing Ltd, Dublin.

Kaye, C. (1959). Shoreline features and quaternary shoreline changes, Puerto Rico. U.S. Geol. Surv. Prof. Pap. 317-B.

* Kolehmainen, S. (1974). Siltation experiments on corals in situ. In: Puerto Rico Nuclear Center Annual Report: $77-80$.

-Kolehmainen, S. and Biaggi, J. (1975). Ecological Status of a Puerto Rican coral reef. Rept to Dept Nat. Res., Commonwealth of Puerto Rico.

Lessios, H.A., Robertson, D.R., and Cubit, J.D. (1984).

Spread of Diadema mass mortality through the Caribbean. Science 226: 335-337.

Loya, Y. (1976). Effects of water turbidity and sedimentation on the community structure of Puerto Rican corals. Bull. Mar. Sci. 26(4): 450-466.

Lugo, A. (1978). Los Arrecifes de Coral en Puerto Rico. Departamento de Recursos Naturales, Programa de la Zona Costanera, Puerto Rico.

*Lugo, A.E., Quinones Marques, F, and Weaver, P.L. (1980). La erosión y sedimentación en Puerto Rico. Carib. J. Sci. 16(1-4): 143-165.

Maclntyre, I.G., Raymond, B, and Stuckenrath, R. (1983). Recent history of a fringing reef, Bahia Salina de Sur, Vieques Island, Puerto Rico. Atoll Res. Bull. 268.

-McKenzie, F. and Benton, M. (1972). Vacia Talega: a report on the marine environment. Report submitted to P.F.Z. Properties Inc., Puerto Rico.

Monroe, W.H. (1980). Some tropical landforms of Puerto Rico. Geological Survey Professional Paper 1159.

-Morelock, J. (1978). (reference not known).

Morelock, Jo, Boulton, K. and Galler, G. (1979).

Sediment stress and coral reefs. In: Lopez, J.M. (Ed.), Proceedings of the Symposium on Energy Industry and the Marine Environment in Guayanilla Bay (Mayagüez, Puerto Rico, 12 July 1979), Mayagüez Center for Energy and Environmental Research, University of Puerto Rico: 46-58.

Morelock, J., Grove, K. and Hernández, M.L. (1983).

Oceanography and patterns of shelf sediments Mayagüez, Puerto Rico. Journal of Sedimentary Petrology 53(2): 371-381.

Morelock, J., Grove, K. and Trumbull, J.V.A. (19??). Sediments and recent geological history of the Guayanilla submarine canyon system, Puerto Rico. (reference not known).

-Morelock, J., Schneidermann, N. and Bryant, W.R. (1977). Shelf reefs, south-western Puerto Rico. Studies in Geology 4: 17-25. 
-Nadeau, RJ. and Bergquist, E.T. (1977). Effects of the March 18, 1973 oil spill near Cabo Rojo, Puerto Rico, on tropical marine communities. Proc. 1977 Oil Spill Conf. Amer. Petrol. Inst., Washington D.C.: 535-538.

- Navarro, N.R. (1974). Estudio ecológico y taxonómico de los organismos marinos comunes en la isla Caja de Muertos. Science-Ciencia 1(2).

Odum, H.T., Burkholder, P.R. and Rivero, J. (1959).

Measurements of productivity of turtle grass flats, reefs and the Bahia Fosforescente of southern Puerto Rico. Publ. Inst. Mar. Sci. Univ. Texas 6: 159-170.

Olson, M.H. (1985). Population characteristics of Hawksbill sea turtles (Eretmochelys imbricata): a case study of the Endangered Species Act. Proc. Sth Int. Coral Reef Cong., Tahiti 5: 475-480.

Pagán-Font, F.A. (undated). Preliminary assessment of the marine resources of Mona Island. Appendix F., Vol. 2. In: Anon. (undated).

Parrish, J.D. (1982). Fishes at a Puerto Rican coral reef: distribution, behaviour and response to passive fishing gear. Carib. J. Sci. 18(1-4): 9-20.

Parrish, J.D. and Zimmerman, RJ. (1977). Utilization by fishes of space and food resources on an offshore Puerto Rican coral reef and its surroundings. Proc. 3rd Int. Coral Reef Symp., Miami : 297-303.

Praded, J. (1980). Shipwreck remains in turtle habitat. Animals (119)2.

Pressick, M.L. (1970). Zonation of stony coral of a fringe reef south-east of Icacos Island, Puerto Rico. Carib. J. Sci. 10: 137-139.

-Quinn, A. (1972). Study of surge channels on south-west coast of Puerto Rico. M.Sc. Dissertation, Univ. of R.I.

Raymond, B. (1978). The marine sediments of a naval bombing range, Vieques, Puerto Rico. Unpub. rept., Ocean Research Survey Inc.

Raymond, W.F. and Dodge, R.E. (1980), 1979 hurricane damage to coral reefs of Vieques. Report to Naval Facilities Engineering Command, Virginia.

Rees, J.T. (1973). Shallow-water octocorals of Puerto Rico: species account and corresponding depth records. Carib. J. Sci. 13: 57-59.

-Rogers, C. (1977). The response of a coral reef to sedimentation. Ph.D. Dissertation, Univ, of Puerto Rico.

Rogers, C. (1979a). The productivity of San Cristobal reef, Puerto Rico. Limnol. Oceanogr. 24:342-349.

Rogers, C. (1979b). The effect of shading on coral reef structure and function. J. exp. mar. Biol. Ecol. 41: 269-288.

Rogers, C.S. (1983). Sublethal and lethal effects of sediments applied to common Caribbean reef corals in the field. Mar. Poll. Bull. 14(10): 378-382.

-Rogers, C. Cintrón, G. and Goenaga, C. (1978). The impact of military operations on the coral reefs of Vieques and Culebra. Rept submitted to Dept Nat. Res., San Juan, Puerto Rico.

Rolle, F. ., Heatwole, H., Levins, R. and Torres, F. (1964). Faunal notes on Monito Island, Puerto Rico. Carib. J. Sci. 4(1): 321-322.

Schneidermann, N. Pilkey, H.O. and Saunders, C. (1976). Sedimentation on the Puerto Rico insular shelf. J. Sed. Petrology 46(1): 167-173.

-Schneidermann, N. and Morelock, J. (1973).

Sedimentation around Escollo Rodriques. Report, Dept Marine Sciences, U.P.R., Mayagüez, Puerto Rico.

Scott, D.A. and Carbonell, M. (1986). A Directory of Neotropical Wetlands. IUCN, Gland and Cambridge.

Seiglie, G. (1969). Report on the foraminifers of Yabucoa Bay. Unpub. Rept.
Seiglie, G.A. (1971). A preliminary note on the relationships between foraminifers and pollution in two Puerto Rican bays. Carib. J. Sci. 11(1-2): 93-98.

Stevenson, D.K. (1978). Management of a tropical pot fishery for maximum sustainable yield. Proc. Gulf Caribb. Fish Inst. 30: 95-115.

Szmant-Froelich, A. (1973). The zonation and ecology of the Jobos Bay coral reefs. Ann. Rept., PRNC - 162 (Puerto Rico Nuclear Center). Aguirre Power Project, Environmental Studies 1972.50 pp.

-Torres, F. (1973). Ecological study and evaluation of coral reef system for "Playas de Luquillo Development". Unpub. Report.

*Torres, F. (1975). Report on coral extraction. Mimeo, 9 pp.

Torres, F. (1978). The benthic communities of Guayama. Report submitted to Puerto Rican Aqueduct and Sewer Authority

-Torres, F. and Pearl, W. (1972), Vieques marine resources. In: Vieques 1972: survey of natural resources. Environmental Quality Board, Commonwealth of Puerto Rico.

*U.S. Fish and Wildlife Service (1979). Draft environmental statement: proposed disposition and administration of lands declared excess by the U.S. Navy on the islands of Culebra and Culebrita in Puerto Rico. U.S. Fish and Wildlife Service.

US. Department of Commerce (1978). Puerto Rico Coastal Management Program and Final Environmental Impact Statement. Prep. by OCZM, NOAA and the Dept. of Natural Resources, Commonwealth of Puerto Rico. 194 pp.

U.S. Department of Commerce (1984). Final environmental impact statement and management plan for the proposed La Parguera National Marine Sanctuary. NOAA and Department of Natural Resources, Puerto Rico.

Velazco-Domínguez, A.T., Webb, R.M., Cintrón, G. and Martínez, R.F. (1985). Sedimentation and Puerto Rican coral reefs. Report prepared for Coastal Zone Management Program, Task 3.7. Division of Marine Resources, Dept of Natural Resources, Commonwealth of Puerto Rico.

Villamil, J. and Canals, M. (Eds) (1981). Suplemento Técnico para el plan de manejo de la Reserva Natural de Bahía de Jobos. Departmento de Recursos Naturales, San Juan, Puerto Rico.

Villamil, J., Canals, M., Silander, S., del Llano, M., Martínez, R., García, A., Molinares, A., González, J., Questell, E., Pérez, M. and Rivera, M. (1980). Suplemento Técnico para la Reserva Natural Caja de Muertos. Departamento de Recursos Naturales, Puerto Rico: 246 pp.

Wadsworth, F.H. (undated). The historical resources of Mona Island. Appendix N. In: Anon. (undated).

Weinberg, (1981) (coral species list; reference not known).

\section{LA CORDILLERA PROPOSED NATURAL RESERVE}

Geographical Location North-east coast extending from tip towards Culebra; $18^{\circ} 22^{\prime} \mathrm{N}, 65^{\circ} 32^{\prime} \mathrm{W}$.

Area, Depth, Altitude Covers an area of approximately $160 \mathrm{sq} . \mathrm{km}$. 
Land Tenure Puerto Rico territorial waters.

Physical Features La Cordillera is a shallow, narrow submarine ridge approximately 18 miles ( $29 \mathrm{~km}$ ) long, trending east-south-east and supporting a number of islets with high quality fringing reefs. The islets, especially Icacos, the westernmost and largest, are composed of oolitic eolianite, deposited and partially submerged some time previous to the development of the reefs (Kaye, 1959). Most of the islands are high and vegetated. On Icacos, rock reef fringes two thirds of the north shore (Goenaga and Cintrón, 1979); in the north-west the beaches consist of loose, white, calcite sand whereas in the south-east they are formed of consolidated beach rock. Island vegetation changes from low scrub in the north-west to sea grapes and white mangrove in the south-east (Almy and Carrion-Torres, 1963). The Palominos complex and Cayo Largo are situated on the same platform, south of the main line of La Cordillera reefs. Palominos, the top of a submerged hill, has ridges which continue south and east as large submerged banks. Palominitos was formed by wave-deposited sand and coral fragments on the reef platform and has a maximum altitude of less than $3 \mathrm{~m}$ (Goenaga and Cintrón, 1979). The waters in this area are affected by severe storms, tsunamis and water spouts, and the region is seismically active (Anon., 1982). The tidal range in Bahia de Fajardo is $0.34 \mathrm{~m}$ (Velazco-Domínguez et al., 1985).

Reef Structure and Corals Fringing reefs surround most of the islands in this area. Many of the reefs around Icacos and Palominitos have a similar formation which is probably typical of the north-east coast (Pressick, 1970). Reefs along the east, north and north-east sides of Cayo Icacos are most well known (Almy and Carrión-Torres, 1963). In the north, corals cover less than $50 \%$ of the available surface area (McKenzie and Benton, 1972), and very little growth is observed behind the north-west reef (Almy and Carrión-Torres, 1963). The south-western shore is more protected and has higher coral cover, particularly to the north and south where the currents pass round the ends of the island. Almy and Carrion-Torres (1963) discussed general aspects of the reefs on this coastline and listed 21 coral species collected from the reef.

The zonation of a $420 \mathrm{~m}$ long reef in the south-east, between Icacos and Audry Rock is described by Pressick (1970). The shore zone extends in a gradual slope to about $1.6 \mathrm{~m}$, and scattered living corals are found at about $20 \mathrm{~m}$ from the shore line. The lagoon extends out about $195 \mathrm{~m}$ from the shore zone. The sandy slope has patches of coral, with Thalassia testudinum gradually becoming more abundant. Manicina areolata is common among the seagrass. The bottom of the lagoon is sandy with sparsely scattered Acropora cervicornis and $A$ palmata. Gorgonians are abundant. The rear zone (seaward slope of the lagoon) rises sharply to form the reef flat and has a rich coral covering including massive colonies of Montastraea annularis, Diploria and Porites astreoides. The reef flat is about $50 \mathrm{~m}$ wide and is generally exposed at low tide. A palmata and Millepora complanata predominate, and Astrangia solitaria forms attractive tiny red colonies throughout the zone. At the edge of the reef flat there is a $3 \mathrm{~m}$ drop-off with massive heads of Montastraea annuiaris and abundant Agaricia agaricites. This zone gives way to an Acropora palmata zone. Colonies of this species spread to diameters of 3-5 $\mathrm{m}$ and are interspersed with small, scattered Diploria heads. A Diploria zone extends down to depths greater than $4 \mathrm{~m}$.

The south coast reef on Palominitos is described in Goenaga and Cintron (1979). The reef crest and $A$ palmata zones intermix and are dominated by $A$ palmata. Mille pora complanata is common as well as $D$. clivosa, Favia fragum, Dichocoenia stokesii, A cervicornis and $P$. asteroides. Coral cover is high although many colonies are broken. The mixed zone descends to about $6 \mathrm{~m}$ and is dominated by gorgonians and Montastraea annularis; $P$. porites and $A$ cervicornis are also common. This zone is very diverse and has a small spur and groove system of about $2.5 \mathrm{~m}$ in relief. At $6 \mathrm{~m}$, large colonies of $A$ palmata are abundant. The steep reef slope is dominated by Agaricia agaricites and has several other species in abundance.

Cayo Largo is a relatively untouched reef and needs further study (Goenaga and Cintrón, 1979). The reef crest has abundant Acropora palmata with occasional colonies of Millepora complanata. In the palmata zone, cover is slightly reduced. It gives way abruptly to the mixed zone which is an area of medium relief with high coral diversity; Montastraea annularis, $A$ palmata, $P$. porites and Millepora complanata are common. The reef slope is dominated by $A$ cervicornis on the upper slope and gorgonians at greater depths; $P$. porites is also very common. The reef flat is dominated by $P$. porites and there is a notable absence of Diadema and other urchins. The reef terminates eastwards with a bare sand "halo" about $8 \mathrm{~m}$ wide, after which there is a healthy Thalassia bed.

Noteworthy Fauna and Flora Hawksbill Turtles Eretmochelys imbricata may nest here (but are not recorded by Bacon et al. (1984)) and the Caribbean Manatee Trichechus manatus and Leatherback Turtle Dermochelys coriacea use the area. The area is inhabited by spiny lobster, octopus, helmet shells, and a variety of reef fish. Numerous Queen Conch Strombus gigas occur in the Thalassia bed adjacent to Cayo Largo (Goenaga and Cintrón, 1979). Five hundred Sooty Terns Sterna fuscata, several hundred Brown Boobies Sula leucogaster, a few Laughing Gulls Larus atricilla, between 1000 and 2000 Bridled Terns Sterna anaethetus, 500 Roseate Terns $S$. dougallii, and between 1000 and 2000 Brown noddies Anous stolidus nest in the area (U.S. Dept of Commerce, 1978; Anon., 1982; Halewyn and Norton, 1984).

Scientific Importance and Research These are considered the best developed reefs on the north-east coast, with high diversity and extensive living coral cover (Goenaga and Cintrón, 1979), but further study is required.

Economic Value and Social Benefits The area is a popular holiday resort and snorkelling, SCUBA diving, fishing and pleasure boating are popular pastimes; divers are attracted by several shipwrecks. There are extensive well-developed coral formations and associated fish and shellfish resources (Anon., 1982).

Disturbance or Deficiencies The area was formerly used as a military ordnance testing ground (Anon., 1982). The urban industrial centre of Fajardo with its commercial port and marina is less than $5 \mathrm{~km}$ from the area which is 
heavily fished by artisanal fishermen and holiday makers. Spearfishing is frequent and divers remove shellfish and coral. The fore-reef of Palominitos is damaged by what appears to be boats anchoring (Goenaga and Cintrón, 1979). There is increasing pressure from tourist development and the building of summer residences (U.S. Dept of Commerce, 1978).

\section{Legal Protection None.}

Management None specifically for the reefs but the area lies within the South-west Special Planning Area (U.S. Dept of Commerce, 1978).

Recommendations The Puerto Rico Coastal Zone Management Program has recommended that a Natural Reserve be established at La Cordillera and a marine sanctuary has been proposed by NOAA (U.S. Dept of Commerce, 1978) and the Chelsea International Co-operation (Anon., 1982). It would be a particularly suitable area because of its accessibility and popularity.

\section{BAHIA DE JOBOS PROPOSED NATURAL RESERVE}

Geographical Location An area on the south coast, in the municipalities of Salinas and Guayama, including Cayos de Pájaros $\left(17^{\circ} 55^{\prime} \mathrm{N}, 66^{\circ} 15^{\prime} \mathrm{W}\right)$, Cayo Morrillitos $\left.\left(17^{\circ} 55^{\prime} \mathrm{N}, 66^{\circ} 15^{\prime} \mathrm{W}\right), 66^{\circ} 17^{\prime} \mathrm{W}\right)$, Cayos de Ratones (1756', $66^{\circ} 17^{\prime} \mathrm{W}$ - not to be confused with Cayo Ratones described in separate account), Arrecife Media Luna, Cayo Alfenique, Cayos de Caracoles, Cayo Cabuzazos and Cayos de Barca.

\section{Land Tenure State owned}

Physical Features The surrounding land is largely flat with a few hills rising only to $50 \mathrm{~m}$. The climate is arid and characterized by short periods of heavy rain which may produce flash floods, most of which discharge into the sea. Annual rainfall averages $1086 \mathrm{~mm}$. Temperatures range from 22 to $31^{\circ} \mathrm{C}$ with an annual average of $26.5^{\circ} \mathrm{C}$. The dry season extends from January to April and the wet season from June to November. The area includes a wide variety of habitats such as estuaries, mangroves, salt marshes, coral reefs and sea grass beds and has been described by Beach (1975) and Díaz et al. (1983).

Reef Structure and Corals Szmant-Froelich (1973) studied the zonation and ecology of the Bahia de Jobos reefs and found 13 coral species. Profiles for some of these areas are given in Goenaga and Cintron (1979). Cayos de Pajaros had a Mille pora complanata dominated reef crest fragmented into buttresses about $3 \mathrm{~m}$ high, a well developed $A$ palmata zone and a mixed zone and slope typical of other reefs in the area. Cayo Morrillos had a very wide $M$. complanata reef crest with $2 \mathrm{~m}$ high buttresses and much coralline algae; the palmata zone and slope was similar to Cayos de Pájaros.

On Cayos de Ratones, $A$ palmata was common on the $M$. complanata dominated reef crest. Seaward of this, there was an abrupt slope leading to a bare sand area with scattered isolated small head corals. Beyond this, depth increased rapidly to an area where mounds topped with $M$. complanata were found. The $A$ palmata zone was found at greater depth followed by a mixed zone with gorgonians dominant on the upper part and massive corals dominant near the reef base. Myceto phyllia and Oculina were also common.

Cayo Alfenique was crescent-shaped with the same three zones, although these were less well defined on the east side of the reef and the $A$ palmata zone was not nearly as well developed as on other nearby reefs. A spur and groove system was found east of the reef slope, with north-south orientation (parallel to the reef crest). Gorgonians dominated the spurs and bare sand was found on the bottoms of the channels. The lagoon had sparse Thalassia and dead Porites.

On Cayo Cabuzazos, small Diploria clivosa and $D$. strigosa formed an important component of the $M$. complanata dominated reef crest. Calcareous algae and Palythoa were common. Beyond the $A$ palmata zone the mixed zone consisted of $A$ cervicornis, gorgonians and other corals. The reef slope was dominated by Agaricia agaricites and gorgonians, with other corals and sponges. The reef flat was a well developed Porites biotope, with a Thalassia bed mixed with Porites on the shoreward side.

More recent studies have shown that the reefs have significantly changed since 1973. Diaz et al. (1983) describe the current status of reefs at Arrecife Las Mareas-Guayama, Cayos Caribe, Cayos de Barca, Cayos de Pájaros, Cayo Morrillos, Cayos Ratones, Punta Colchones and Punta Puerca, and Cayo Media Luna. Szmant-Froelich (1973) found that reef diversity increased towards the east, but currently reef diversity is highest in the west at Cayos de Pájaros and Cayo Morrillos; these changes are probably due to hurricane damage (see below).

Noteworthy Fauna and Flora Bahia de Jobos is an important wetland site with the second largest mangrove swamp in the country, brackish lagoons and saline lagoons and is one of the best areas in Puerto Rico for migratory shorebirds (Diaz et al., 1983; Scott and Carbonell, 1986). All the cays, except Media Luna, have mangroves in various stages of development (Goenaga and Cintrón, 1979). Bahia de Jobos is the most important area in Puerto Rico for the Caribbean Manatee Trichechus manatus and is a feeding area for the Hawksbill Eretmochelys imbricata and Green Turtle Chelonia mydas (Groombridge, 1982; Scott and Carbonell, 1986). The fish fauna has been well documented, over 260 species having been recorded in the bay and among the cays, including many commercially important species (Diaz et al., 1983). The rich invertebrate fauna includes large populations of spiny lobsters Panulirus sp. and the molluscs Crassostrea rhizophorae, Isognomon alatus and Brachiodontes exustus (Scott and Carbonell, 1986). Díaz et al. (1983) describe the mammal, bird, reptile and amphibian faunas.

Scientific Importance and Research In the 1970s, the offshore reefs in this area were considered to be in good condition, with high living coral cover diversity and rich benthic and nekton populations (Goenaga and Cintrón, 1979). The reefs play a major role in the ecology of the area as described by Diaz et al. (1983). Scientific work on the area, carried out largely by the Dept of Natural Resources, is described in Diaz et al. (1983). 
Economic Value and Social Benefits The main activities in the region are agriculture and fishing. The reefs play an important role in the latter, the main aspects of which are described by Díaz et al. (1983). Bahía de Jobos forms a well protected natural harbour and is popular for recreational activities such as boating and picnicking (U.S. Dept of Commerce, 1978).

Disturbance or Deficiencies Recent studies have shown major changes in reef composition and structure since the study by Szmant-Froelich (1973), live coral reef biomass having been reduced by $50 \%$. The changes are partly due to natural damage, the reefs having been seriously damaged by Hurricanes Frederic and Allen in 1979, but human activities have also had a major impact, a chronological list of these events being provided by Diaz et al. (1983). Scott and Carbonell (1986) list threats to the wetland area, many of which may also affect the reefs. A large petrochemical development encircles the mangrove swamp and the entire area is under consideration for industrial expansion (U.S. Dept of Commerce, 1978). Industrial development and poorly sorted fill used at El Tuque, west of Ponce, contribute to turbidity in the water, and Diaz et al. (1983) document a number of dredging activities which have caused sedimentation. The area is potentially threatened by thermal discharge from the Aguirre power plant; Szmant-Froelich (1973) discussed the possible effects of this but suggested that waste chemicals and increased productivity would do greater damage.

Legal Protection The reefs have no protection but Bahía de Jobos was designated as a Special Planning Area by the Coastal Zone Management Program in 1978. There is a National Estuarine Sanctuary at Mar Negro, the mangroves at Punta Arenas are protected by a Commonwealth Law and most of the mangroves at Punta Pozuelo are included in the Aguirre State Forest (Scott and Carbonell, 1986).

Management The Department of Natural Resources has prepared a management plan for the area (Villamil and Canals, 1981) which was updated by Diaz et al., 1983; it is not known whether any of these recommendations have been put into operation. A management plan has also been produced for the National Estuarine Sanctuary.

Recommendations Recommended as a Natural Reserve to incorporate the existing National Estuarine Sanctuary. The technical supplement of the management plan (Diaz et al., 1983) makes a number of recommendations including a reduction in the use of inorganic fertilisers, the implementation of erosion control measures, the curtailment of heavy industry development and the initiation of research on the hydrology of the aquifer.

\section{ISLAS MONA AND MONITO PROPOSED NATURAL RESERVE}

Geographical Location $67^{\circ} 57^{\prime} \mathrm{W}, 18^{\circ} 10^{\prime} \mathrm{N}$; the islands are about 3 miles $(4.8 \mathrm{~m})$ apart, about 50 miles $(80 \mathrm{~km})$ west of Puerto Rico, half way between Puerto Rico and the Dominican Republic, in the middle of Mona Passage.

Area, Depth, Altitude Monito $=500 \mathrm{~m}$ x $300 \mathrm{~m}$; maximum altitude $60 \mathrm{~m}$; Mona $=14000$ cuerda (5486 ha); maximum altitude $90 \mathrm{~m}$.

\section{Land Tenure No information.}

Physical Features Both islands are surrounded by high vertical cliffs which drop to $100 \mathrm{ft}(30 \mathrm{~m})$ below sea-level and are undercut by caves at sea-level. They are the furthest offshore islands in Puerto Rico and are surrounded by clear seas with visibility up to $200 \mathrm{ft}$ $(60 \mathrm{~m})$. The current in Mona Passage, where depths reach 500 fathoms $(915 \mathrm{~m})$, is generally to the south-west, but sometimes to the north-east. Winds are mainly from the north-east and south-east, and high seas often make access difficult; there are occasional hurricanes. The climate is semi-arid with a mean temperature of $79^{\circ} \mathrm{F}$ $\left(26.1^{\circ} \mathrm{C}\right)$ and mean annual rainfall of $32 \mathrm{in.}(813 \mathrm{~mm})$. There is no water supply other than rain. Monito is roughly rectangular and covered with xeric scrub vegetation. Mona is a carbonate island with a very flat, gently sloping upland surface, composed mainly of pitted limestone and dolomite, with caves which contain phosphorite deposit. The upland area is bordered by a narrow coastal lowland plain around the southern edge of the island from Punta Este to Punta los Ingleses and from just west of Punta Caigo o no Caigo almost to Punta el Capitán on the west. The north has high sheer sea cliffs. Sandy beaches extend for five miles ( $8 \mathrm{~km})$ on the south. Vegetation consists of low cacti and shrubs or is absent (Anon., undated).

Reef Structure and Corals The marine communities of Mona are described by Goenaga (1982b) and Cintrón and Thurston (1975). Reefs are found on the less exposed south-east, south and west sides of the islands and are considered to be in good condition. The north coast of Mona descends vertically as a wall to $90-100 \mathrm{ft}(27-30 \mathrm{~m})$ depth with abundant soft corals, fish and turtles. The south-west coast is fringed by reef. Black coral is present. A barrier reef south of Cabo Barrio Nuevo protects a shallow lagoon with coral (Pagán-Font, undated).

Noteworthy Fauna and Flora Terrestrial fauna and flora are described by Rolle et al. (1964) and Anon. (undated). There are many endemic species (58 on Mona) including the Mona Ground Iguana Cyclura stejnegeri, Mona Coqui Eleutherodactylus monensis (a frog), Mona Blind Snake Typhlos monensis, Mona Boa Epicrates monensis monensis, several lizards, snakes, land snails, birds and a freshwater cave shrimp. The islands are also a refuge for a number of rare Puerto Rican species. The Green Turtle Chelonia mydas, Leatherback Dermochelys coriacea and Hawksbill Turtle Eretmochelys imbricata are known to nest on Mona Island (Bacon et al., 1984; Groombridge, 1982; Olson, 1985). Surrounding waters are visited by Humpback Whales Megaptera novaeangliae, Pilot Whales Globicephala macrorhynchus, large fish such as tuna, shark and Blue Marlin, and seabirds not found elsewhere in Puerto Rico. Nine species of seabird breed on the two islands (Halewyn and Norton, 1984): the White-tailed Tropicbird Phaethon leprurus, Magnificent Frigatebird Fregata magnificens, Red-footed Booby Sula sula, Brown Booby S. leucogaster, Bridled Tern Stema anaethetus, Sooty Tern S. fuscata, Brown Noddy Aious stolidus, possibly the Laughing Gull Larus atricilla and the Masked Booby Sula dactylatra. A total of 270 fish species have been recorded. Ghost and Hermit Crabs are 
common on the Mona beaches. There are important but potentially threatened populations of Spiny Lobster Panulirus argus, Queen Conch Strombus gigas and West Indian Top Shell Cittarium pica (Pagán-Font, undated). There is a small area of mangrove. Turtle grass is not extensive (Anon., undated).

Scientific Importance and Research The Environmental Quality Board of Puerto Rico assessed the resources of Mona and Monito in 1972 (Anon., undated). Both islands are visited by research scientists and students from the Marine Sciences Laboratory on Isla Magueyes, La Parguera.

Economic Value and Social Benefits There is no protected harbour and the anchorage at Playa de Pájaros is only suitable in fine weather. There is an automatic lighthouse on Mona and the island has been uninhabited for $\mathbf{4 0 0}$ years; Monito has never been inhabited. From 1880 to 1920 the islands were an important source of guano but this has all been removed (Anon., undated). There is a small amount of commercial fishing in the area but this could support only a limited amount of expansion. The islands receive a growing number of visitors, about 2500 a year, including students, scientists and people who come for recreational purposes such as swimming and snorkelling.

Disturbance or Deficiencies Although comparatively undisturbed at present, the islands are extremely vulnerable to any form of development and current visitor use is already having adverse impacts. There has been a decline in the abundance of edible marine resoures, turtles, White-crowned Pigeons Columba leucoce phala and Zenaida Doves Zenaida aurita. Large numbers of sea turtles, particularly the Hawksbill, continue to be poached in defiance of the U.S. Endangered Species Act (Olson, 1985). There is no control over spearfishing which is reported to have had a deleterious effect on fish populations and oil pollution has been reported on Mona beaches (Anon., undated). A ship which was wrecked on a reef off Mona in 1985 is still there, with fuel leaking onto the reef and beach (Praded, 1986). Introduced animals including cats and rabbits have caused problems on land although the mongoose has not yet been introduced. Goat and pig populations have been allowed to increase for hunting and rubbish has favoured the rat population. The natural lignum vitae Guaiacum spp. vegetation was collected in the past and is now disturbed by pigs and goats, but it is not known how seriously.

\section{Legal Protection None.}

Management In 1962, administrative control was passed to the Division of Fisheries and Wildlife in the Department of Agriculture. Biologists were assigned to the island to study and protect the wildlife but there has been little effective management (Wadsworth, undated).

Recommendations Recommended for protection under the proposed coastal management programme (U.S. Dept of Commerce, 1978). Recommendations in Pagán-Font (undated) include the setting up of a detailed study of marine resources, the establishment of a research base and the creation of scientific reserves, both marine and terrestrial.

\section{CAJA DE MUERTOS PROPOSED NATURAL RESERVE}

Geographical Location South coast; the proposed reserve includes Caja de Muertos $\left(17^{\circ} 55^{\circ}-17^{\circ} 54^{\prime} \mathrm{N}\right.$, $66^{\circ} 33^{\prime} \mathrm{W}, 8.5 \mathrm{~km}$ off the coast and west of Santa Isabel), Cayo Berberia $\left(17^{\circ} 55^{\prime} \mathrm{N}, 66^{\circ} 27^{\prime} \mathrm{W}, 5.5 \mathrm{~km}\right.$ to the north-east) and Cayo Morrillitos at the tip of Caja de Muertos.

Area, Depth, Altitude Caja de Muertos is $2.75 \times 1.85 \mathrm{~km}$; Cayo Berbería is $1.5 \mathrm{~km} \times 200 \mathrm{~m}$. The two cays are separated by a channel $5.42 \mathrm{~m}$ deep. The proposed reserve will cover an area of 18836 ha.

\section{Land Tenure State-owned.}

Physical Features Villamil et al. (1980) gave a detailed description of the area, including climate (data from Santa Isabel airport), geology and physico-chemical characteristics of the water. Aspects of marine geology are described by Beach and Trumbull (1980) and sedimentation by Beach (1975). Both cays are vegetated. Villamil ef al. (1980) mapped the marine communities of the proposed reserve; seagrass beds cover 1110 ha and coral reefs cover 519 ha, a variety of other types making up the remaining area.

Reef Structure and Corals Cayo Berberia had an extensive $(3 \mathrm{~km})$ fringing reef on the eastern and southern shores. Coral development reached a maximum on the southern shore where the $A$ palmata zone reached 95\% cover prior to Hurricanes David and Frederick. The reef was described in more detail by Villamil et al. (1980) who considered it to be richer and more diverse than the reef at Caja de Muertos. The reef crest was a low relief zone which, with the exception of some Millepora complanata and small Agaricia agaricites and Favia fragum colonies, was devoid of coral growth and dominated by algae, with much coral rubble. The $A$ palmata zone now appears as a low relief barren platform with sand filled depressions and only a few small colonies of $A$ palmata and other hermatypic corals. Porites astreoides is the most abundant species and coral cover is $11.6 \%$. Beyond this zone, the reef slopes down to a depth of $12 \mathrm{~m}$ at an average angle of $35^{\circ}$. Coral cover and diversity increase considerably on the fore-reef slope. The dominant coral is Montastraea annularis and coral cover averages $21.7 \%$ (Ferrer Hansen, in litt. 12.5.86). South-east of Berberia is a small submerged reef called Las Cervezas which had extensive $A$ palmata coverage and dense gorgonian stands. Fish life was especially abundant.

On Caja de Muertos, greatest reef development was found on the north-eastern shore. This reef was particularly noticeable for its complex high relief lagoon which supported a variety of benthic and nektonic fauna (Goenaga and Cintrón, 1979). It was described by Canals et al. (1980) and Villamils et al. (1980). Four zones were identified: a) a lagoonal zone, b) a reef crest, dominated by Millepora spp. and zoanthids, c) an Acropora palmata dominated zone and d) a fore-reef (4-7 $\mathrm{m}$ deep), where gorgonians and octocorals predominated. Twenty six species of coral were recorded. Coral cover was highest $(34-37 \%)$ on the fore-reef and only $2-11 \%$ in the palmata zone. 
Noteworthy Fauna and Flora Villamil et al. (1980) gave a detailed description of flora and vegetation of the cays. Mangroves are found on the two major cays and there is a large expanse of seagrass. The terrestrial fauna is described by Villamil et al. (1980), including insects, reptiles (14 species), birds (there is a colony of about 150 Brown Booby Sula leucogaster on Cayo Morrillito) and mammals. Caja de Muertos has an interesting herpetofauna. Cayo Berberia is characterized by its completely undisturbed vegetation which provides an important nesting area for pigeons and doves. Navarro (1974) and Villamil et al. (1980) describe the marine fauna of the area. Villamil et al. (1980) provide species lists for echinoderms, crustaceans, molluscs and fish (69 species). The reef at Cayo Berberia has a higher diversity of fish than that at Caja de Muertos. Juvenile spiny lobsters Panulinus argus and the Queen Conch Strombus gigas have been recorded. Large numbers of marine turtles may nest on the beaches of Caja de Muertos, although not recorded in Bacon et al. (1984), and the area is visited by the Caribbean Manatee Trichechus manatus.

Scientific Importance and Research Villamil et al. (1980) describe scientific research on the cays, which includes a study by the Departamento de Recursos Naturales in September 1980.

Economic Value and Social Benefits Fishing is important in the area.

Disturbance or Deficiencies Hurricanes David and Frederick caused greater damage at Caja de Muertos than at Cayo Berbería and affected the $A$ palmata zone, resulting in increased algal cover in this area. Caja de Muertos reefs appear to be more intensively fished than those around Cayo Berberia (Villamil et al., 1980).

Legal Protection None at present.

Management Caja de Muertos is currently leased to the Club Nautico de Ponce by the Departamento de Transportación y Obras Públicas. Cayo Berberia forms part of the Aguirre State Forest and comes under the jurisdiction of the Departamento de Recursos Naturales.

Recommendations The proposed boundaries of the reserve and recommendations for its management are given in Villamil et al. (1980). It is suggested that the mangroves on Caja de Muertos should be made a restricted zone; zones for recreational activities should be established; collection of marine organisms should be prohibited; tracks and buildings on the island should be appropriately managed and facilities for research should be provided. Cayo Morrillito should be protected as a bird sanctuary and a rat extermination programme should be initiated. Anchoring should be limited to certain sites, spearfishing prohibited, and an underwater trail established. It is not known whether any of these recommendations have been carried out.

N.B. Data for this account were received during final preparation of the manuscript and it was not possible to compile a full account although material is available.

\section{LA PARGUERA PROPOSED NATIONAL MARINE SANCTUARY}

Geographical Location South-west coast, $28 \mathrm{~km}$ south east of Mayaguiez; $17^{\circ} 58^{\prime} \mathrm{N}, 67^{\circ} 04^{\prime} \mathrm{W}$; the area includes the following islands and cays: Cayo San Cristóbal, Cayo Laurel, Cayo Media Luna, Cayo Mario, Cayo Enrique, Cayo Turrumote, Cayo Corral, Isla la Gata, Cayo Caracoles, Cayo Majimo and Cayo Caballo Ahogado. Bahía Fosforescente, a mangrove-bordered bay on the mainland is situated to the east of La Parguera, and Isla Magueyes is situated just south of the town. Details of the boundaries are given in U.S. Dept of Commerce (1984).

Area, Depth, Altitude Wetland area covers 400 ha.

Land Tenure Coastline and wetland area largely state-owned; the Conservation Trust owns about 300 ha of land surrounding the bay.

Physical Features The coast forms a broad landward indentation at the fishing village of $\mathrm{La}$ Parguera and is fringed with mangroves, intertidal mudflats, natural salt flats and shallow saline lagoons. The insular shelf is about five miles $(8 \mathrm{~km})$ wide at this point, and supports two elongated reef systems aligned approximately east-west. Goenaga and Cintron (1979) discuss their possible origin. The outer line of reefs (Turrumote, Media Luna and Laurel) is situated about $3 \mathrm{~km}$ off shore, each reef facing the incoming waves from the east-south-east. The inner reefs (Enrique, La Gata complex, Caracoles, Majimo) are closer (1 km) to shore, forming an arc which is convex to the south. Most of the reefs are small but they increase in length westwards, and Arrecife Margarita reaches a length of two miles $(3.2 \mathrm{~km})$. They are considered to be poorly formed barrier or ribbon reefs. Channels between the reefs are $50-70 \mathrm{ft}(15.2-21.3 \mathrm{~m})$ in depth and have sandy bottoms. Between the inner reef line and shore are small patch reefs; their rapid growth combined with the spread of mangroves is causing the shelf in this part to become shallower.

Hydrographic conditions in the waters off La Parguera are described by Coker and Gonzáles (1960) and summarized by Almy and Carrión-Torres (1963). The climate is semi-arid with an average rainfall of 30 in. (762 $\mathrm{mm}$ ) and an annual evaporation rate of $80 \mathrm{in.}$ $(2030 \mathrm{~mm})$. Salinity averages $35.4 \mathrm{ppt}$ and surface temperatures range from 25.5 to $32.0^{\circ} \mathrm{C}$. The temperature-salinity characteristics are indicative of a mild hydrographic climate (Glynn, 1973). Winds are from the south-east or east-south-east and tend to freshen in the forenoon. Currents are from east to west and flow parallel to the coast. A continuous surface current flow over the reef, and a maximum daily tidal range of only $40 \mathrm{~cm}$ prevents marked temperature and salinity differences. A detailed description of this area is given by U.S. Dept of Commerce (1984).

Reef Structure and Corals The majority of the larger reefs typically have a broad (up to $50 \mathrm{~m}$ wide) shallow reef flat. Of the outer reefs, Cayo Turrumote has the greatest variety of species although it is comparatively short. It is formed from large coral boulders thrown up by waves to an average height of about $1 \mathrm{~m}$, but reaching 2-3 $\mathrm{m}$ on the eastem end. The exposed part of the reef 
has maximum dimensions of $100 \times 1000 \mathrm{ft}(30 \times 300 \mathrm{~m})$ and is topped with white mangroves. Seaward of the exposed part, the shallow fore-reef flat is covered with a Porites porites pavement, scattered with Millepora complanata, Acropora palmata and $A$ prolifera. The pavement is unusually narrow, about $60 \mathrm{ft}(18.3 \mathrm{~m})$ wide, and at a depth of $2 \mathrm{ft}(0.6 \mathrm{~m})$ gives way to a dense growth of Acropora palmata in the surf zone. At 5-10 ft (1.5-3 m) $M$. complanata is found intermixed with $A$ palmata, with large massive boulders of Montrastraea annularis. Beyond $30 \mathrm{ft}(9.1 \mathrm{~m})$, coral density decreases although diversity increases. Coarse sand patches occur among the gorgonian patches.

On the shoreward side of Cayo Turrumote, an open lagoon extends to a steep slope along the north edge of the reef. $P$. porites, Favia fragum and Siderastrea radians floor the shallow parts of the lagoon and give way to sand and widely spaced coral colonies in water deeper than $2 \mathrm{ft}(0.6 \mathrm{~m})$. At the north edge of the reef, the gently sloping lagoon floor drops from $15 \mathrm{ft}(4.6 \mathrm{~m})$ to a sand covered bank at $35 \mathrm{ft}(10.7 \mathrm{~m})$ depth. A palmata is abundant along the edge of the drop-off and a variety of corals are found on the slope (Almy and Carrión-Torres, 1963). A buttress zone of very high relief, "The Pinnacles", so-called because of the large, platy colonies of $M$. annularis which have grown in pyramid-like form (Nash pers. obs., 1983), has an abundant fish fauna (Goenaga and Cintrón, 1979).

Cayo Laurel is described by Glynn (1973). The reef flat has a high population density of $P$. furcata, usually oriented in patches parallel to the longitudinal axis of the reef. Six zones were identified down to $3 \mathrm{~m}$ depth. The shoaling seaward slope, with no spur and groove structure, is dominated by $A$. palmata and gives way to a rigid framework of Millepora complanata which forms a sill on the seaward edge of the reef-flat. This has abundant dead coral colonies and is often exposed at extreme low water. On the leeward side, $P$. furcata and coral rubble predominate, the former appearing in dense stands in depths of $1.5 \mathrm{~m}$. The deep edge of this $P$. furcata belt grades abruptly into a smooth sandy bottom, beyond which Thalassia testudinum is abundant.

The other outer reefs are similar, built of coral boulders with $P$. porites dominating the fore-reef flat and parts of the lagoon, and abundant $A$ palmata in the surf zone. A steep slope usually borders the seaward edge of each reef, beginning at 15-20 $\mathrm{ft}(4.6-6.1 \mathrm{~m})$ and dropping to a trough at $65 \mathrm{ft}(20 \mathrm{~m})$ which tends to be particularly well developed along the fronts and east ends of the longer reefs. Where the trough is less evident on long reefs, a buttress formation may be present. There seems to be a slight variation in the faunal assemblages of each reef (Almy and Carrión-Torres, 1963).

Cayo Enrique is the best known of the inner reefs and is described by Almy and Carrion-Torres (1963), Armstrong (1981) and Morelock et al. (1977). It is located $1.5 \mathrm{~km}$ south of La Parguera and is approximately $1.4 \mathrm{~km}$ long and $0.4 \mathrm{~km}$ wide at its widest point, aligned almost parallel to the shore (Armstrong, 1981), but oriented to the incoming waves and currents. It forms an apron reef with a shallow $(0.5-3 \mathrm{~m})$ area of sand deposition leeward of the reef flat. T. testudinum areas occur at both ends of the sandy lagoon and on the reef flat, and patch reefs are found in the middle and western parts of the lagoon. The reef flat is composed mainly of living Thalassia, Zoanthus, Porites and occasionally Halimeda clumps (Armstrong, 1981). The reef crest is dominated by Millepora complanata, and the zoanthid Palythoa caribbea is found encrusting dead corals near the reef crest.

At the eastern end, the fore-reef of Cayo Enrique is relatively broad and gradually slopes to a depth of $20 \mathrm{~m}$. It gets narrower and steeper towards the west. The reef lacks a spur and groove formation but has a well defined coral zonation. A palmata occurs seaward of the crest to a depth of $3 \mathrm{~m}$ followed by $A$ cervicornis to $5 \mathrm{~m}$. A zone of massive corals occurs from 5 to $15 \mathrm{~m}$ and is composed mainly of Montastraea, Diploria and Agaricia. The lagoon patch reefs are dominated by $M$. annularis in addition to numerous sponges and gorgonians. Other corals present include Acropora cervicornis, $S$. siderea and Diploria labyrinthi formis. Dead coral heads covered with algae are common in this area (Armstrong, 1981).

The reef flat at La Gata reef complex has been divided into seven zones: a) a latticework of Millepora complanata and encrusting calcareous red algae; b) a pool with dead coral debris; c) an emergent reef flat; d) a mixed Thalassia - coral rubble zone; e) sand; $f$ massive clumps of the alga Acanthophora spicifera, and g) a sandy leeward lagoon (Glynn, 1968).

Goenaga and Cintrón (1979) give brief descriptions of reef zonation at San Cristóbal, Cayo Enrique, Cayo Laurel, Turrumote, Isla La Gata, Margarita, Las Pelotas, Cayo Ahogado, Cayo Media Luna, La Conserva, and Collado. San Cristóbal, a small reef $45 \mathrm{~km}$ south-west of La Parguera, has a high relief Acropora palmata zone with an abundant fish fauna. Cayo Laurel is a large, well-developed reef. Cayo Caballo Ahogado is situated shoreward of Cayo Enrique and is described briefly by Almy and Carrión-Torres (1963) and Morelock et al. (1977).

The main differences between the inner and outer reefs are the extensive Red Mangroves Rhizophora mangle on the former, mainly on the east and west ends, and the well developed mud flats and Thalassia beds in the lagoons (Almy and Carrión-Torres, 1963). The patch reefs north of the inner line of reefs, have mangrove thickets in various stages of development and a restricted coral fauna compared with the other reefs. $P$. porites is abundant in shallow areas and there is a poorly developed $A$ palmata zone on the seaward side. $P$. porites is the main constituent of the coral assemblages fringing the coastline and also around the non-coral island Isla Magueyes. Almy and Carrión-Torres (1963) and Armstrong (198) provide a checklists of coral species found in the $\mathrm{La}$ Parguera area which has the greatest recorded number (54) in Puerto Rico. The productivity of the reefs is described in Odum et al. (1959); Rogers (1979a and 1983) studied productivity and sedimentation on San Cristóbal Reef.

Noteworthy Fauna and Flora Mangroves Rhizophora mangle, Laguncularia racemosa and Avicennia nitida are found on the cays and along the shoreline throughout the area (Almy and Carrión-Torres, 1963; Armstrong, 1981; Glynn et al., 1964; Odum et al., 1959). The importance of the area as a wetland is described by Scott and Carbonell (1986). A Cattle Egret Bubulcus ibis colony existed on 
Cayo Caballo Blanco in the 1960s (Glynn et al., 1964) and Brown Pelicans Pelecanus occidentalis still occur in the area. The Caribbean Manatee Trichechus manatus, the Green Turtle Chelonia mydas, the Hawksbill Turtle Eretmochelys imbricata and the Leatherback Turtle Dermochelys coriacea are found within the proposed sanctuary (U.S. Dept. of Commerce, 1984). Before being taken over by the Department of Marine Sciences, University of Puerto Rico, Isla Magueyes was a zoo. A population of Cuban Iguanas Cyclura nubila from the old zoo is now resident and breeding on the island. A smaller green iguana Iguana sp. also occurs. A population of monkeys (possibly Green Monkeys Cercopithecus aethiops) was maintained on Isla Guayacan by an American medical institute and some reportedly still survive (Nash pers. obs., 1983).

Scientific Importance and Research The marine laboratory of the Department of Marine Sciences is situated on Isla Magueyes. As a result the reefs and marine environment of $\mathrm{La}$ Parguera have been extensively studied and are the subject of numerous publications. The reefs are considered to be some of the best developed in Puerto Rico. The high productivity of the area is attributed to the limited rainfall, minimal soil run-off and large quantities of organic matter contributed by the mangrove communities (Goenaga and Cintrón, 1979). The Bahía Fosforescente is of considerable scientific interest and has been studied on account of its luminescence which is caused by the dinoflagellate Pyrodinium bahamense (Glynn et al., 1964; Odum et al., 1959; Anon, 1968).

Economic Value and Social Benefits The economy of the area is described in U.S. Dept. of Commerce (1984). La Parguera is a fishing village (Almy and Carrión-Torres, 1963) and local people collect octopus and molluses off the reef flat. The haemulid (grunt) fishery is described by Appeldoom and Lindeman (1985). The area is a popular recreation site; Cayo Enrique is visited frequently by pleasure boats that stay up to 3-4 days anchored in the calm, sandy lagoon (Armstrong, 1981). La Parguera is being used increasingly as a weekend resort by families from further inland and increasing numbers of "casetas", houses on stilts, are being built over the waters bordering the mangroves (Nash pers. obs., 1983). The iguanas resident on Isla Magueyes are a popular tourist attraction with special boat trips to the island to "feed the iguanas" and Bahía Fosforescente is a further attraction.

Disturbance or Deficiencies Hurricanes are the main destructive agents. The effects of Hurricane Edith in 1963 were documented by Glynn et al. (1964). Although extensive coral destruction on the outer reefs was observed, Cayo Enrique and other inner reefs suffered only 10 to $50 \%$ Acropora destruction, and there was slight damage to the mangroves. The topography of many of the outer cayos was considerably altered. Hurricane Beulah had a major impact in 1969. Hurricane David in 1979 passed $160 \mathrm{~km}$ to the south of Ponce and caused significant damage with boulder rampart accumulation on the reef flat at Cayo Enrique. The impact of this hurricane is described by Goenaga (1982a).

Changes on Cayo Enrique from 1936 to 1979 were studied using aerial photo-analysis (Armstrong, 1981). A two-fold increase in lagoonal seagrass areas occurred over this period. Mangrove areas increased fifteen times between 1936 and 1978 but an area of 1560 sq. $\mathrm{m}$ was destroyed by Hurricane David. Mass destruction of reef biota was recorded in 1965 as a result of extreme midday low tides. The impact was felt most strongly by echinoids and is discussed by Glynn (1968).

The La Parguera reefs have been subjected to comparatively little pressure from industry or development but the potential threats are considerable (Scott and Carbonell, 1986). Increased deforestation inland on the La Parguera limestone hills, proposed resort development, domestic waste discharge and proximity to major industrial areas give cause for concern (Goenaga and Cintrón, 1979; Rogers, 1979b). Oil pollution, in the form of tar balls, was observed on the boulder ramparts at Cayo Enrique in 1979 and 1980. If this continues it could represent a major source of pollution. The effects of collecting by local fishermen and anchoring of pleasure boats are considered negligible at present by Armstrong (1981) but Appeldoom and Lindeman (1985) consider the grunt fishery to be heavily over-exploited.

Legal Protection The reefs are currently not protected but part of the coastline lies within the Boquerón State Forest (Scott and Carbonell, 1986).

Management None but the area lies within the South-west Special Planning Area (U.S. Dept of Commerce, 1978).

Recommendations The area is proposed as a National Marine Sanctuary and a Final Environmental Impact Statement and Management Plan has been drawn up (U.S. Dept. of Commerce, 1984). This contains recommendations for future management, proposed legislation, long-term monitoring studies and interpretive facilities.

\section{CAYO RATONES PROPOSED PROTECTED AREA}

Geographical Location South coast, about 1.1 naut. mi. $(2.03 \mathrm{~km})$ south of Ponce; $17^{\circ} 57^{\prime} \mathrm{N}, 66^{\circ} 40^{\prime} \mathrm{W}$.

Physical Features One of the numerous mangrove islets fringed by coral reefs which lie off Ponce (other islets include Isla de Frío, Isla de Cardona, and Cayo Cardona). Waters are moderately silt-laden (Goenaga and Cintrón, 1979). Tidal range at Ponce is $0.18 \mathrm{~m}$ (Velazco-Domínguez et al., 1985)

Reef Structure and Corals A fringing reef borders the south coast of the island. Its zonation was described by Goenaga and Cintrón (1979). The reef crest was dominated by Millepora complanata, with occasional colonies of $A$ palmata and abundant Palythoa. In the $A$. palmata zone living cover increased seaward; many dead colonies were found shoreward. Large buttresses, abcut $3 \mathrm{~m}$ in relief were topped with $A$ palmata, scattered gorgonians and Montastraea annularis colonies. A palmata cover decreased towards the mixed zone which was dominated by gorgonians, for a width of about $100 \mathrm{~m}$. M. annularis, $M$. cavernosa and Siderastrea were also common, as well as dead $A$ cervicornis colonies. On the reef flat Thalassia and Syringodium 
were found but the Porites biotope was not well developed. The reefs are now being described by Acevedo (in prep.). Ferrer Hansen (in litt., 12.5.86) reports that the fore-reef is now dominated by $M$. cavernosa and that the encrusting gorgonian Erythropodium caribaeorum is the most dominant species.

Noteworthy Fauna and Flora Mangroves grow on the reef flat (Goenaga and Cintrón, 1979). The Caribbean Manatee Trichechus manatus, Hawksbill Turtle Eretmochelys imbricata and Leatherback Turtle Dermochelys coriacea may occur in this area.

\section{Scientific Importance and Research No information.}

Economic Value and Social Benefits No information.

Disturbance or Deficiencies The reef at Cayo Ratones is considered to be deteriorating as evidenced by the abundance of $E$. caribaeorum. This is probably due to the high sedimentation rates and turbidity which have been recorded in this area, possibly because Cayo Ratones lies 2.6 . naut. mi. $(4.8 \mathrm{~km})$ downstream of a sewage treatment plant and 4.6 naut. mi. $(8.5 \mathrm{~km})$ downstream of the industrial harbour at Ponce (Ferrer Hansen in litt., 12.5.86; Acecevedo, in prep.).

Legal Protection None.

Management None.

Recommendations Recommended as a protected area by Goenaga and Cintrón (1979).

\section{SERGEANT REEF PROPOSED PROTECTED AREA}

Geographical Location South-east coast, $0.3 \mathrm{~km}$ south-east of Punta Tuna.

Area, Depth, Altitude $1.08 \mathrm{~km}$ long; $0.1 \mathrm{~km}$ wide at widest point.

\section{Land Tenure No information.}

Physical Features No information.

Reef Structure and Corals The reef flat has abundant Acropora cervicornis thickets. Further seaward there is an area of reduced $A$ palmata growth with high encrusting algal cover; this zone gives way to one of dense Porites growth, with patches larger than 100 sq. m in some places, alternating with $A$ palmata colonies. Seaward of this is a zone of dense $100 \% A$ palmata, which thins out with depth until gorgonians predominate (Goenaga and Cintrón, 1979).

Noteworthy Fauna and Flora No information but the Caribbean Manatee Trichechus manatus and the Hawksbill Eretmochelys imbricasa and Leatherback Dermochelys coriacea Turtles may occur in this area (Groombridge, 1982).

Scientific Importance and Research No information.
Economic Value and Social Benefits Protects the shoreline in the vicinity of Punta Tuna from the south-east swell (Goenaga and Cintrón, 1979).

Disturbance or Deficiencies No information.

Legal Protection None.

Management None.

Recommendations Recommended as a protected area by Goenaga and Cintrón (1979).

\section{ARRECIFE TOURMALINE AND EL NEGRO (ESCOLLO NEGRO) PROPOSED NATURAL RESERVE}

Geographical Location West coast, approximately $10 \mathrm{~km}$ west of Punta Ostiones; $18^{\circ} 5^{\prime}-180^{\circ} 10^{\prime} \mathrm{N}, 67^{\circ} 17^{\prime}-67^{\circ} 19^{\prime} \mathrm{W}$.

Area, Depth, Altitude El Negro (Negro Bank) covers $25 \mathrm{sq} . \mathrm{km}$.

Physical Features Two of the offshore reef areas on the west coast north of Boquerón. Currents flow mainly north-south or south-north, the northerly flow predominating (Loya, 1976). Visibility at EI Negro is poor according to Loya (1976) although Goenaga and Cintrón (1979) mention high water transparency. East and West Reefs rise vertically on Escollo Negro from an average depth of $20 \mathrm{~m}$ to about $7 \mathrm{~m}$; West Reef is a flat patch reef.

Reef Structure and Corals Escollo Negro is characterized by a low relief spur and groove system with high living coral cover and diverse encrusting coral growth. The system diminishes shorewards and gorgonian cover increases (Goenaga and Cintrón, 1979). East Reef has a reef flat at 6-8 $\mathrm{m}$ depth dominated by Acropora cervicornis which provides $45 \%$ coverage, Montastraea annularis accounting for $28 \%$. The upper fore-reef is at $9-17 \mathrm{~m}$ depth and the lower fore-reef at $18-20 \mathrm{~m}$ depth. At greatest depths, $M$. cavernosa is the main reef builder. At West Reef, the four commonest species, $M$. cavernosa, Siderastrea radians, $S$. siderea and Diploria strigosa, cover $73 \%$. At East Reef, the four commonest species, M. cavernosa, M. annularis, Agaricia agaricites and $S$. siderea, cover $62 \%$. Twenty-one coral species have been recorded at El Negro (Loya, 1976).

Noteworthy Fauna and Flora No information, but the Caribbean Manatee Trichechus manarus, the Hawksbill Turtle Eretmochelys imbricata and the Leatherback Turtle Dermochelys coriacea may occur (Groombridge, 1982). Dahl (1973) studied algae in deep reef and sand habitats.

Scientific Importance and Research Nine missions were carried out at the El Negro Bank in 1972 and 1973 by the Puerto Rico International Undersea Laboratory (PRINUL) to study the effects of sedimentation on reefs. The area was chosen because of its proximity to river run-off from Rio Guanajibo and the smaller Rio Yaguez (Loya, 1976). 
Economic Value and Social Benefits No information.

Disturbance or Deficiencies Turbidity and sedimentation produced by resuspension of local fine calcareous sediments during heavy, long-period ground swells originating in the Atlantic Ocean mainly during winter months are the most important factors affecting reef growth in this area (Cintrón et al., 1973; Kolehmainen, 1974; Loya, 1976). Terrigenous suspended sediments and domestic pollution from Río Guanajibo and the presence of seston and plankton in the water column also affect turbidity. $M$. cavernosa is the dominant coral in areas most seriously affected by sedimentation, Siderastrea siderea suffering high mortalities.

\section{Legal Protection None.}

Management None.

Recommendations Recommended as a Natural Reserve (U.S. Dept of Commerce, 1978; Goenaga and Cintrón, 1979).

\section{VIEQUES ISLAND PROPOSED MARINE SANCTUARY}

Geographical Location $18^{\circ} 06^{\prime} \mathrm{N}, 65^{\circ} 24^{\prime} \mathrm{W} ; 18 \mathrm{~km}$ east of Puerto Rico. The proposed marine sanctuary is situated on the southern coast of the island between Punta Negra and Punta Jalova. The seaward boundary is delineated by the $50 \mathrm{~m}$ isobath, which is the edge of the island's coral shelf and is situated $2.6-4.5 \mathrm{~km}$ from shore (Anon. 1982).

Area, Depth, Altitude The marine sanctuary site covers $48 \mathrm{sq}$. km.

Land Tenure The island lies within Puerto Rico's territorial waters, but portions of this site are restricted by the U.S. Navy (Anon., 1982).

Physical Features The seabed within the proposed sanctuary is a gradually sloping limestone and coral shelf, sheared off at the edge by volcanic activity. Beyond $50 \mathrm{~m}$ depth, the bottom plunges sharply to $900 \mathrm{~m}$ within the $4.8 \mathrm{~m}$ territorial water boundary, finally reaching a depth of $4 \mathrm{~km}$, at $24 \mathrm{~km}$ from shore. Fine-grained sands overlay the hard coral bottom. The shoreward boundary is fringed by mangroves and sandy beaches. The clarity of the water contributes to the luxuriousness of the reefs. Several phosphorescent bays occur in the western portion of the proposed area outside Federally restricted water (Anon., 1982).

Reef Structure and Corals No detailed information although there is a reef at Ensenada Honda. The reefs are probably similar to those of Culebra, and almost certainly similar to those at the eastern end of Vieques which have been intensively studied (see "Introduction", Macintyre et al., 1983).

Noteworthy Fauna and Flora Mangroves fringe the coast. Halewyn and Norton (1984) list six species of seabird which breed on Vieques and its surrounding islets: Red-billed Phaethon aethereus and White-tailed $P$. lepturus Tropicbirds, Brown Pelicans Pelecanus occidentalis, Roseate Sterna dougallii, Bridled $S$. anaethetus and Least $S$. albifrons Terns. The Caribbean Manatee Trichechus manatus may be found here occasionally. Green Chelonia mydas, Hawksbill Eretmochelys imbricata and Leatherback Dermochelys coriacea Turtles nest sparsely on Vieques (Bacon et al., 1984; Groombridge, 1982).

Scientific Importance and Research The area's relative isolation makes it an ideal site for research, particularly into the nature and ecological relationships of phosphorescent bay habitats (Anon., 1982). Despite the intensive work carried out at the eastern end of Vieques, particularly at Bahia Salina del Sur, the reefs of the proposed sanctuary do not seem to have been surveyed.

Economic Value and Social Benefits Currently the area is primarily used by the U.S. Navy. A small artisanal commercial fishing fleet operates in the area (Anon., 1982).

Disturbance or Deficiencies No information, but the reefs may be affected by military activities (see "Introduction").

\section{Legal Protection None.}

Management The area has been designated an Area of Particular Concern (APC) by the Commonwealth of Puerto Rico. Currently not managed actively as a marine sanctuary, it is indirectly protected, since the U.S. Navy restricts access to the south coast because of defence training activities (Anon., 1982).

Recommendations Proposed as a National Marine Sanctuary site by NOAA (U.S. Dept of Commerce) and the Chelsea International Corporation (Anon., 1982). The island of Vieques was proposed as a Special Planning Area under the Coastal Zone Management Programme (U.S. Dept of Commerce, 1978). 



\section{ST LUCIA}

\section{INTRODUCTION}

\section{General Description}

St Lucia, an independent nation in the British Commonwealth, is one of the northern Windward Islands, separated from Martinique to the north and St Vincent to the south by channels about $30 \mathrm{~km}$ wide. The island is mainly volcanic with minor outcroppings of limestone on the leeward side and is rugged and lush with steep mountains, a small plain in the south and eroded hills in the north. The windward, eastern shoreline is very irregular with numerous islets of volcanic rock formed by erosion. The west coast has several deep harbours and bays in the central area. The submerged insular shelf is very narrow along the mid-west coast (about $100 \mathrm{~m}$ ) and wider $(5 \mathrm{~km})$ to the east, north and south. There are several coastal islets, the most notable of which are the Maria Islands in the south and Pigeon Island, opposite Gros Islet, on the north-west coast. The prevailing winds are easterly and north-easterly and about half average 11-21 knots. There is a dry season from February to May and a rainy season from June to November; annual rainfall varies around the island from $1500 \mathrm{~mm}$ to $3500 \mathrm{~mm}$. Tidal range near Vieux Fort is approximately $34 \mathrm{~cm}$.

Reefs are found on all coasts (ECNAMP, 1980) but in general are small and appear to be in an early stage of development. They are most numerous around the islands to the east and south, particularly at Laborie Bay, Anse Galette and the region between Savannes Bay and the Maria Islands, areas which are relatively free of the direct influence of sediment laden streams (Roberts, 1972). The Maria Islands and Anse Galette reefs are described in separate accounts. Savannes Bay $\left(13^{\circ} 46^{\prime} \mathrm{N}\right.$, $60^{\circ} 56^{\prime} \mathrm{W}$ ), between Saltibus and Burgot Points, has small patch reefs fringing the entrance to the bay and a small island (Scorpion Islet) in the north-east portion of the Bay. It is described in some detail by Goodwin (1984). A reef at Vieux Fort is briefly described in Anon. (1980). Twenty four scleractinians and one hydrocoral have been reported from the south-east coast (Price, 1982).

Reefs in the region of Grand Cul de Sac Bay, south of Castries were surveyed in the course of an impact assessment of the Hess oil transhipment facility. Reefs adjacent to the facility were affected by sediment and fishing catches had been affected (Price in litt., 1985).

Larger reefs are found on the south-west coast in the region of Anse Cochon, the Pitons and Anse Chastanet, north and south of Soufrière. The area around Anse Chastanet and the Pitons is described in a separate account. Strong north-flowing currents contribute to the rich coral communities found on the steep submarine slopes of the extinct volcano Gros Piton (Anon., 1980). An exposed reef at Atlantic Beach is mentioned in Anon. (1980).

Scott and Carbonell (1986) list important mangrove areas, including Esperance, Marigot Bay, Marquis, Praslin, Savannes Bay, Trougascon and Volet, and a survey of mangrove resources has recently been carried out (Anon., 1985b). Hawksbill Eretmochelys imbricata,
Green Chelonia mydas and Leatherback Turtles Dermochelys coriacea nest around the island (Bacon et al., 1984; Groombridge, 1982; Meylan, 1984). Seabirds nesting on St Lucia include Red-billed Phaeton aetherus and White-tailed $P$. lepturus Tropicbirds, Magnificent Frigatebirds Fregata magnificens, Roseate Sterna dougallii and Bridled $S$. anaethetus Terns and the Brown Noddy Anous stolidus (Halewyn and Norton, 1984).

\section{Reef Resources}

Over $30 \%$ of the revenue of St Lucia is derived from the marine sector, including sand mining, fishing, transport and tourism (Mitchell and Gold, 1982). There are about 2000 fishermen, including part-timers, and 400 fishing boats. Artisanal fishing villages are common along the leeward and southern protected coastlines and most of the catch is consumed locally (Towle, 1985); there has been little development of a commercial fishing industry (Wood, 1984) although reef fishery yields are considered high (Munro, 1983). Conch and lobster fishing are carried out on the north-east and west coasts and coral is collected at a number of localities (ECNAMP, 1980; Rogers, 1985). Conch fishing is concentrated primarily in the Gros Islet area and increasingly around Vieux Fort (Goodwin in litt., 6.10.84); once collected mainly for export to Martinique, it is now mainly used locally (Goodwin, 1985). A study of the fishery along the south-east coast has recently been carried out (Anon., 1985b).

Tourism has increased with the construction of a new international airport at Vieux Fort, and now represents $18 \%$ of the GNP. The Pitons, Anse Chastanet and the Maria Islands are becoming increasingly popular for recreational diving and there are SCUBA concessions based in Anse Chastanet and Castries. Savannes Bay has not yet become important for recreational diving. Snorkelling and diving are also popular at a number of reefs on the north-west coast (ECNAMP, 1980).

\section{Disturbances and Deficiencies}

Hurricane Allen damaged the St Lucia reefs in 1980 (Rogers, 1985). There was a high mortality of the urchin Diadema antillanum in 1983 which resulted in rapid growth of algae on many reefs (Smith in litt., 23.10.84). This was probably due to the water-borne pathogen, thought to have been responsible for the Caribbean-wide mortality of this species. Urchin numbers on St Lucia are now increasing (Smith, in litt. 20.1.86). White band disease has been recorded (Rogers, 1985).

Sedimentation associated with construction and dredging is becoming a major problem. Sand mining, now illegal but originally a traditional activity at Vigie Beach, a popular recreational area on the north-west coast near Castries, caused serious beach erosion and damage to the offshore coral and algal communities (Dubois and Towle, 1985; Boatman in litt., 2.5.86). Similar problems arose in Rodney Bay (Gros Islet Bay) which was selected for 


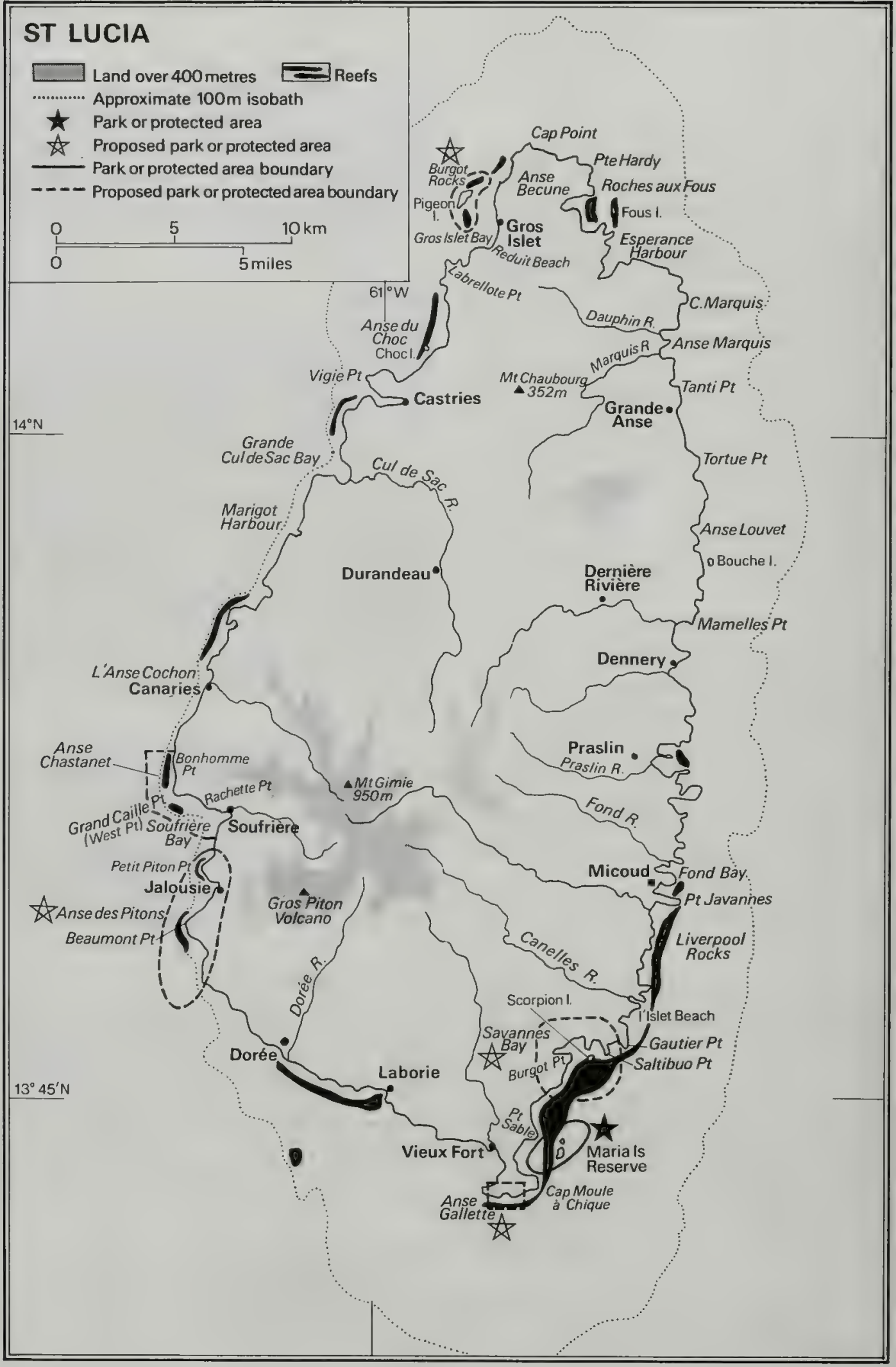


development as a resort in the early 1970s. At the northern end of the Bay, Pigeon Island and a shallow reef formed a semi-enclosed, protected anchorage with high ecological diversity, historical significance and value for the net, lobster and conch fisheries. Considerable dredging took place during the 1940s in this area, and in the $1970 \mathrm{~s}, 2.5$ million $\mathrm{cu}$. yds of coral sand were dredged to construct a causeway to link Pigeon Island with the mainland where a hotel complex was scheduled for development. This caused serious beach erosion, Pigeon Island losing much of its beach. Attempts at restoration by the St Lucia National Trust have been only partially successful. The local fishery, seagrass beds and coral reefs have been destroyed through increased sedimentation and alteration of the currents by the causeway. The reefs are badly degraded although there are still good stands of Acropora cervicomis. The local fishermen have lost the additional income they used to obtain from taking tourists to see the reef at Pigeon Island passage which is now largely buried beneath the causeway (Towle, 1985). Other areas where there is significant sand mining include Anse Lavoutte and Grande Anse (Meylan, 1984). Other threats to the reefs include recreational divers, particularly in the Anse Chastanet and Pitons area (see separate account), anchor damage, fishing with explosives and coral collection (Rogers, 1985).

\section{Legislation and Management}

A Parks and Beaches Commission has been set up to manage the beaches (Anon., 1983). Fisheries legislation protects turtles, controls conch collection, prohibits the collection of coral and the import, export or sale of aquarium fish without permission from the Chief Fisheries Officer (Goodwin in litt., 6.10.84).

Extensive work on coral reef management has been undertaken in St Lucia through ECNAMP, the Fisheries Management Unit and local initiative. A coral reef management project, funded by WWF-US, has been carried out by Environmental Research Projects, co-ordinated through the St Lucia Fisheries Management Unit (Goodwin, 1984 and 1986). A training program was undertaken to acquaint staff of the St Lucia Fisheries Management Unit and volunteer divers from the St Lucia British Sub Aqua Club with basic coral reef monitoring techniques. A system for undertaking monitoring surveys has been established, an information leaflet on coral reefs has been published, and there have been numerous educational activities. A systematic inventory of coastal resources is being conducted and support will be given to locally initiated public information and education activities.

In 1981, ECNAMP and the Government of St Lucia initiated, under the auspices of the Central Planning Unit, a study of the conservation and development requirements for the south-east coast, from I'Islet beach in the north to Moule à Chique in the south, including the reefs and mangrove area of Savannes Bay and the Maria Islands. The project aims to find solutions to conflicts among the various users of the area and to the stresses on critical resources which are emerging or already exist, while promoting healthy and sustainable development, through a multi-disciplinary approach. Recommendations for further work have been made (Geoghagen, 1983; Goodwin, 1984b). The project has been used as a case study of integrated coastal zone management for a variety of workshops, training schemes and pilot regional management projects (e.g. Anon, 1985a; see Introduction to this volume) as it has a heavy emphasis on research and training.

Currently there is a marine reserve at the Maria Islands (see separate account). Legislation is now in place for the Pitons-Anse Chastanet reefs and the area should soon be delineated by the Fisheries Management Unit (Smith in litt. 20.1.86). Pigeon Island National Park was established in 1979 as a historical monument (Devaux, 1979) and the St Lucia National Trust would like to declare a marine reserve in this area. However, the region is not currently considered threatened and is not considered a priority (Devaux in litt., 24.2.86). Anse Galette and Savannes Bay are being developed as a coastal zone management area; there is already a protected Mangrove Area at the latter (Wood, 1984).

\section{Recommendations}

Plans for wetland and mangrove reserves are described in Scott and Carbonell (1986). St Lucia has been identified as a potential marine site for inclusion in the proposed Lesser Antilles Biosphere Reserve (Goodwin, 1985). Further coral reef management work has been proposed (Goodwin, 1986).

\section{References}

* = cited but not consulted

Anon. (1980). St Lucia Marine Biological Survey. Report of the York B.S.A.C. Project.

Anon. (1983). Minutes of XVII AGM (Business Meeting 1st September 1983), Caribbean Conservation Association, Kingston, Jamaica.

Anon. (1985a). Environmental Planning Programme: coastal zone management of tropical islands. Proc. Workshop/Planning Meeting on Coastal Zone Management of the Lesser Antilles Region. CSC Technical Publications Series No. 175 CSC (85)EPP-2, Commonwealth Science Council, London.

Anon. (1985b). Annual Report 1985. ECNAMP - St Lucia Office.

Bacon, P., Berry, F., Bjorndal, K., Hirth, H., Ogren, L., Weber, M. (1984). The National Reports. Proceedings of the Western Atlantic Turtle Symposium, Vol. 3. University of Miami Press, Florida.

*Clifton, K.E. and Clifton, T.R. (1984). The marine life of Anse Chastanet Bay, St Lucia. Report prepared for the Anse Chastanet Hotel. 38 pp.

Corke, D. (1983). The reptiles of the Maria Islands, St Lucia. A report to the Eastern Caribbean Natural Area Management Program (ECNAMP) and the World Wildlife Fund.

Devaux, R.J. (1979). Pigeon Island National Park: a brief history and guide. St Lucia.

Dubois, R. and Towle, E.L. (1985). Coral harvesting and sand mining practices. Case Study 3. Coastal Resources Management: Development Case Studies. Coastal Pubication 3. Renewable Information Series, Research Planning Institute Inc., Columbia, S. Carolina: 203-289.

ECNAMP (1980). St Lucia Preliminary Data Allas. Survey of Conservation Priorities in the Lesser Antilles. Eastern Caribbean Natural Area Management Program. 
Geoghegan, T. (1983). Eastern Caribbean Natural Area Management Programme. Caribbean Conservation News 3(7): 6-8.

Goodwin, M. (1984a). Continuation of coral reef management activities in St Lucia, West Indies. Project Proposal to WWF-US.

Goodwin, M.H. (1984b). A survey of coral habitats associated with the Maria Islands, St Lucia. Report to Fisheries Management Unit, St Lucia and ECNAMP.

Goodwin, M.H. (1985). Characterization of Lesser Antillean Regional Fisheries. Island Resources Foundation: $48 \mathrm{pp}$.

Goodwin, M.H. (1986). Report on Coral Reef Management Activities in St Lucia, West Indies.

Groombridge, B. (1982). The IUCN Amphibia-Reprilia Red Data Book, Part 1: Testudines, Crocodylia, Rhynchocephalia. IUCN, Gland, Switzerland.

Halewyn, R. van and Norton, R.L. (1984). The status and conservation of seabirds in the Caribbean. In: Croxall, J.P., Evans, P.G.H. and Schreiber, R.W. (Eds), Status and Conservation of the World's Seabirds ICBP Technical Publication No. 2, Cambridge.

Hayes, M. and Lawrence, N. (1982). A survey of the Maria Island Marine Environments (Vieux-Fort, Saint Lucia). Fisheries Management Unit, St Lucia.

Lessios, H.A., Robertson, D.R. and Cubit, J.D. (1984).

Spread of Diadema mass mortality through the Caribbean. Science 226: 335-337.

Meylan, A. (1984). The ecology and conservation of the Caribbean Hawksbill (Eretmochelys imbricata). Final Report, WWF Project 1499.

Mitchell, C. and Gold, E. (1982). The integration of marine space in national development strategies of small island states: the case of the Caribbean states of Grenada and St Lucia. Dalhousie Ocean Studies Program, Halifax, Nova Scotia.

Munro, J.L. (Ed.) (1983). Caribbean Coral Reef Fishery Resources. ICLARM Studies and Reviews 7, Manila, Philippines.

Price, W.S. (1982). A preliminary list of reef corals and hydrocorals from the south-east coast of St Lucia. Report to ECNAMP.

Renard, Y. (1983a). Conservation and development of the Maria Islands Nature Reserve. First Progress Report for the period ending February 28th, 1983. Submitted to WWF-US. Eastem Carribbean Natural Area Management Program.

Renard, Y. (1983b). Maria Islands Nature Reserve, St Lucia. WWF Monthly Report, August 1983, Project 3075: 597-598.

Renard, Y. (1983c). Conservation and development of the Maria Islands Nature Reserve. Progress Report covering the first year of activity (Nov. 1st 1982 - Oct. 31st 1983). Report to WWF-US

Roberts, H.H. (1972). Coral reefs of St Lucia, West Indies. Caribb. J. Sci. 12: 179-190.

Rogers, C.S. (1985). Degradation of Caribbean and Western Atlantic coral reefs and decline of associated fisheries. Proc. Sth Int. Coral Reef Cong, Tahiti 6: $491-496$.

Scott, D.A. and Carbonell, M. (1986). A Directory of Neotropical Wellands. IUCN, Gland and Cambridge.

Smith, A. (1983). Observations on the marine plants and hermatypic corals of Maria Island, St Lucia. Report to ECNAMP.

St Lucia National Trust (1985). Maria Islands Nature Reserve Interpretive Guide. ECNAMP, Vieux Fort.

Towle, E.L. (1985). The Island Microcosm. Case Study
8. Coastal Resources Management: Development Case Studies. Coastal Pubication 3. Renewable Information Series, Research Planning Institute Inc., Columbia, S. Carolina: 203-289.

Wood, J. (Ed.) (1983). Proceedings of the Workshop on Biosphere Reserves and Other Protected Areas for Sustainable Development of Small Caribbean Islands, May 10-12, 1983. Virgin Islands National Park, Caneel Bay, St John, U.S. Virgin Islands. U.S. Dept of the Interior, National Park Service, Atlanta, Georgia. 190 pp.

\section{ANSE CHASTANET - PITONS PROPOSED PROTECTED AREA}

Geographical Location Anse Chastanet Bay is approximately $0.3 \mathrm{~km}$ north of Grand Caille Point (13 $\left.51^{\prime} \mathrm{N}, 61^{\circ} 04^{\prime} \mathrm{W}\right)$ (known locally as West Point); the area includes Rachette Point, Soufrière Bay and the promontory around Petit Piton to Gros Piton Point $\left(13^{\circ} 48^{\prime} \mathrm{N}, 61^{\circ} 04^{\prime} \mathrm{W}\right)$.

Area, Depth, Altitude Petit Piton is $2438 \mathrm{ft}(732 \mathrm{~m})$ at its summit; coastline of area is $9.4 \mathrm{~km}$.

Physical Features Anse Chastanet Bay is bordered by a small, $300 \mathrm{~m}$ long, sandy beach at the end of a valley. From Grand Caille Point, rocky cliffs (up to $300 \mathrm{~m}$ high) extend past Rachette Point to Soufrière Bay. The town of Soufrière lies on the coast at the end of a river valley. The coastline is comparatively gently sloping as far as the hospital site, north of Petit Piton. From here the steep slopes of Petit Piton, on the coast, dominate the coastal scenery. There is a sandy beach at Jalousie and the coastline is comparatively uniform from here to Gros Piton Point.

The steep landward slopes continue underwater along most of the coast. There is no detailed chart but a bathymetric survey of Soufriere Bay has recently been completed. Over most of the area, the $60 \mathrm{~m}$ bathymetric contour lies within $200 \mathrm{~m}$ of the coast; depths of $300 \mathrm{~m}$ are reported to lie within $1 \mathrm{~km}$ of the coast. In certain areas, for example off Petit Piton, the seabed profile is very steep, often with substantial cliff faces. There are several sea level caves at Grand Caille Point. Anse Chastanet Bay has a rather unusual seabed topography, perhaps due to the hydrodynamic regime created by Grand Caille Point. Although the shallow sandy plateau extends some $100-150 \mathrm{~m}$ from the beach at Anse Chastanet, there is a large, amphitheatre-like pit at the southern comer of the bay, which comes to within $30 \mathrm{~m}$ of the shore and cliff.

Anse Chastanet is subject to heavy wave swells on occasion. There are strong tidal streams near shore off Grand Caille Point which may make SCUBA diving very difficult at times but otherwise the area is a popular diving site.

Reef Structure and Corals Reefs extend north to $300 \mathrm{~m}$ beyond Grand Caille Point, but as far as Bonhomme Point, they are only found in localized small patches associated with shallow nearshore rock outcrops. To the south, reefs extend to the northern end of Soufrière Bay 
(Hummingbird) and then start again in the vicinity of the hospital to the north of Petit Piton, and extend around the Piton as far as Jalousie Beach and Anse L'Ivrogne. There is no reef development directly out from the Jalousie Beach. Smaller scattered patches of reef are found below the Gros Piton and extend along the coast to Gros Piton Point. The extent of reefs in this section of coast is as follows:- Anse Chastanet (Turtle Reef) Soufrière (Hummingbird): $2.3 \mathrm{~km}$; Petit Piton Reef: $2.0 \mathrm{~km}$; Gros Piton Reef: $2.8 \mathrm{~km}$ (reef extending to depths of $30 \mathrm{~m}$ ).

A shallow plateau, usually not exceeding $10 \mathrm{~m}$ in depth, extends along much of the coast, varying in width from $150 \mathrm{~m}$ at Anse Chastanet Bay to $10-20 \mathrm{~m}$ at the. Petit Piton. There is usually a distinct reef edge with characteristic coral species, beyond which the slope steepens. From Grand Caille Point to Rachette Point, especially at Rachette Point, large blocks of rock lie on the plateau as a result of cliff erosion, and lead to an increased species diversity in this area. The plateau around Petit Piton is narrow and the drop-offs relatively steep probably due to periodic land slides from the steep slopes of the mountain. At Grand Caille Point there is a distinct "upwelling" effect due to strengthening of the water current as it moves over the submerged seaward extension of the point which lies at a right angle to the current. This results in a particularly interesting and diverse assemblage of corals and sponge species and to large shoals of bait and predatory fish which are unrivalled in abundance on this section of coast.

Coral reefs flank the northern and southern seaward boundaries of the amphitheatre-like pit in the Anse Chastanet Bay. The central (eastern) slope of the pit is predominantly sandy with small patches of coral and sponge and extends to $50 \mathrm{~m}$. The bay has been mapped by Clifton and Clifton (1984). There is a luxuriant patch reef on the southern border of the bay on a steep slope which drops to more than $40 \mathrm{~m}$ within $200 \mathrm{~m}$ of the shore. Coral growth is reported to at least $40 \mathrm{~m}$ depth. A brief survey by Goodwin (1984) revealed that living cover and coral density was higher than at the Maria Islands.

There is a characteristic zonation of corals associated with the shallow plateau, reef edge and reef slope. Although there are some similarities with the zonation described by Roberts (1972) for Anse Gallete, there are also major differences, notably the absence of any well developed Acropora palmata or A cervicornis zones. In the 0-5 $\mathrm{m}$ depth range, the Millepora (a flat encrusting species) and $M$. squarrosa and Gorgonia zones (Roberts, 1972) are present; Porites porites is often dominant. A palmata was recorded as individual colonies at several sites around the island, and young solitary colonies were present in Anse Chastanet Bay. Bedrock, large boulders and block slabs interspersed with sandy areas characterize the shallow plateau and a wide variety of other coral species commonly occur overlying the rock (i.e. not forming reef as such) including $P$. asteroides, Montastraea annularis, Meandrina meandrites, Dichocoenia stokesi, Stephanocoenia michelinii, Diploria strigosa, Siderastrea radians, $S$. siderea and Colpophyllia natans. There are also a few isolated large colonies of the Pillar Coral, Dendrogyra cylindricus.

It would appear that it is only at the reef edge $(8-11 \mathrm{~m})$ that any thickness of coral occurs and there is a notable shallowing of the reef edge at some sites. The principle reef edge species include $P$. porites, Montastraea annularis, Madracis mirabilis and $P$. asteroides. $M$. annularis colonies often grow in a columnar form of up to $2 \mathrm{~m}$ in length, the spaces between the heads being filled characteristically by the grey zoanthid Palythoa caribbea.

The reef slope varies in steepness and many of the species already mentioned figure prominently. There are varying degrees of coral cover with some of the shallower slopes having a markedly low cover of corals (less than $50 \%$ ) than the steeper slopes. Species which are found mainly on the reef slopes include $A$ cervicornis (rare to occasional), Agaricia sp. (probably $A$ agaricites which is particularly dominant in the vicinity of Anse Chastanet but was not recorded elsewhere as abundantly at 20-40 m), Helioseris cuculata, Madracis mirabilis, Montastraea cavernosa, Mussa angulosa, Scolymia lacera, Mycetophyllia spp., Eusmilia fastigiata, and Isophyllia spp.

Some 40 species of coral (including Millepores) have been recorded from the south-east and west coasts of $\mathrm{St}$ Lucia (Clifton and Clifton, 1984; Roberts, 1972; Price, 1982; Goodwin, 1984), and virtually all the species mentioned occur within the section of coast described here.

Noteworthy Fauna and Flora An extremely diverse and visually dominant assemblage of sponges are found here often dominating large sections of the reef. The massive sponge Xestospongia muta is extremely common and is often more visually dominant than coral in all reef zones, apparently acting as a nucleus around which other species, including corals, settle. The large sea fan Iciligorgia schrammi is very common on the reef slopes especially on block walls and cliffs where tidal streams are stronger. Clifton and Clifton (1984) completed a species listing from Anse Chastanet Bay of all the larger flora and fauna; their fish list for the bay (149 species) illustrates the richness of this small area. There is a large colony of garden eels Nystactitchthys halis on the sandy slopes of the pit in Anse Chastanet Bay. The upwelling area off Grand Caille Point is rich in bait species, Chromis spp., creole wrasse, sergeant majors, boga herring, and a variety of silversides, and predatory species like king fish, bar jacks, black jacks and snappers. Turtles are often seen on the aptly named "Turtle Reef"; Green Chelonia mydas and Hawksbill Turtles Eretmochelys imbricata nest on the beach at Anse Chastanet (Bacon et al., 1984).

Scientific Importance and Research The peculiar submarine topography and hydrodynamic regime of the Anse Chastanet area result in a remarkably diverse assemblage of species and habitats. There have been a number of surveys of the area (see above) and monitoring has been continued as a joint project between the Fisheries Management Unit and the local BSAC branch.

Economic Value and Social Benefits Anse Chastanet is a popular tourist resort and caters for watersports, particularly diving. There is some fishing by local people. The region is widely recognised by the St Lucia diving club and diving schools as one of the most 
interesting diving sites on the Island. An assessment of the existing (tourism, fishing) and potential human uses of the area, is being undertaken by the OAS.

Disturbance or Deficiencies The sea urchin Diadema suffered extensive mortality over two weeks in November 1983 (Smith, pers. comm.) but urchins were in evidence on all the reefs visited ( $\max .5 /$ dive) in April 1985. There was clear evidence of algal growth, especially at some reef edge areas at Anse Chastanet, mainly involving Montastraea. There are a large number of dead sea fans (Iciligorgia) on the southern side of Anse Chastenet Bay. Lange coconut trunks in the pit at Anse Chastanet must have caused considerable damage to corals before they came to rest and may still move in strong storms. There are some signs of coral bleaching at Anse Chastanet but this is not widespread and the frequency is low ( 5 examples/30 minute dive).

There appears to be some disturbance of the reefs from recreational use. Anse Chastanet Bay is a popular yacht anchorage and whilst the the sandy area near the shore is generally used, anchor damage clearly causes some problems especially in the seagrass bed. Large numbers of divers use the area but diving school instructors try to give good training in buoyancy control to minimise trampling effects. The columnar Montastraea heads at the reef edge have collapsed in several areas which may be a normal feature of the biology of this growth form but is likely to be exacerbated by stray anchors or diver trampling.

There are probably low levels of spearfishing (for domestic consumption) and coral collecting; both these practices are discouraged by the diving schools. Seine nets and fish pots are widely used throughout the region by local fishermen and undoubtedly catch some of the more attractive reef fish, such as butterfly and angel fish. They probably also cause physical damage as they are dragged up from the seabed.

There are proposed developments to the Jalousie estate which could affect the Gros Piton and Petit Piton reef (Goodwin, 1984a and in litt., 6.10.84). No work had begun on this in April 1985 but plans are imminent (Boatman in litt., 29.10.85). A geothermal project which would heat the Soufrière river poses a potential threat to reefs nearby, although it is planned to pump the water back into the springs. Work is due to start in 1986. Whether the effects of the heat will cause any greater problems than the freshwater input of the Soufrière river at present is debatable.

Legal Protection Legislation is now in place for the creation of a protected area which should soon be delineated by the Fisheries Management Unit (Smith in litt., 20.1.86). Fisheries legislation will include a complete ban on coral harvesting, spearfishing, fishing boats within the area, all fishing activities and fines for anchor misuse (Boatman in litt., 29.10.85).

Management A management plan is being developed by the Fisheries Management Unit in collaboration with consultants from Environmental Research Projects.

Recommendations Recommendations were made for a management regime which would maximise resource use but minimise existing and potential threats; these are now largely underway including 1) a systematic survey of the nearshore coastal communities and important species of this region which is being undertaken by the dive club and Fisheries Managment Unit; 2) the development of a management plan should be drawn up which should seek to resolve existing and potential conflicting uses; the potential of any marine reserve designation should be resolved and zoned use of the nearshore coastal strip should be evaluated; and 3) a monitoring programme, recommended by Goodwin (1984), will be developed from the current survey work.

Additional projects identified include 1) an assessment of the Gros Piton area; 2) census studies of Diadema on night dives on precisely located reefs to establish recolonisation rates; and 3 ) aerial photographs for a broader perspective of the Anse Chastanet Bay/West Point area and precise mapping.

We are very grateful to Dr. R. Earll for providing the original draft of this account.

\section{ANSE GALET TO PT LA VILLE}

Geographical Location $1 \mathrm{~km}$ west of Anse La Raye on west coast, north of Anse Cochon; $13^{\circ} 56^{\prime} \mathrm{N}, 61^{\circ} 03^{\prime} \mathrm{W}$.

Physical Features The bay is surrounded by hills. A fringing reef, about $700 \mathrm{~m}$ in length, borders the coast from Anse Galet Beach to Pt La Ville and slopes steeply from $3 \mathrm{~m}$ to $40 \mathrm{~m}$ depth. Prevailing winds are from the north-east and the bay is very sheltered, although offshore swells may reach the beach. Westerly currents of up to 2 knots may occur at times (Boatman in litt., 2.5.86).

Reef Structure and Corals The reef includes a variety of coral species. Acropora palmata is found only at the eastern end of the reef where there is high wave action. Dendrogyra cylindricus is also present. An unpublished list of corals recently recorded in the bay is available (Boatman in litt, 2.5.86).

Noteworthy Fauna and Flora The Green Turtle Chelonia mydas occurs and the Hawksbill Eretmochelys imbricata may be found here. Information on molluses and fish is available (Boatman in litt., 2.5.86).

Scientific Importance and Research Not known, although some survey work has been carried out (Boatman in litt., 2.5.86).

Economic Value and Social Benefits The site is easily accessible from nearby tourist centres and can be reached by boat and road. Fishing is important.

Disturbance or Deficiencies Due to its proximity to Anse La Raye, the area has been heavily fished and fish abundance and diversity have been reduced. Seine netting, spearfishing, pots and handlines are frequently used and dynamiting took place in the past. There are signs of coral damage from boat anchors (Boatman in litt., 2.5.86).

Legal Protection None. 
Management Under the control of the Fisheries Management Unit.

Recommendations None known.

Information for this account was kindly provided by $\mathrm{C}$. Boatman.

\section{ANSE GALETTE PROPOSED PROTECTED AREA}

Geographical Location Southern point of St Lucia, $13^{\circ} 42 \mathrm{~N}, 60^{\circ} 57 \mathrm{~W}$.

Physical Features The reef has formed on a substrate of volcanic boulders, eroded from the cliff faces of the adjacent mountain, Moule à Chique, which extend from low-tide level to the sand-covered bay floor ( $8 \mathrm{~m}$ deep), a distance of 15-45 m (Roberts, 1972).

Reef Structure and Corals Five zones were identified by Roberts (1972). The landward extremity of the reef had a substrate of volcanic rubble and coral cobbles covered with Millepora and Gorgonia flabellum. At low tide, the landward portions were at sea-level. The Acropora palmata zone (1-5 m deep) was of irregular relief, with coral colonies intermittently grouped, sometimes up to $2 \mathrm{~m}$ tall. Other corals, Diploria and Montastraea, and boulders encrusted with coralline algae were dispersed throughout this zone. In the Porites zone (3-7 $\mathrm{m}$ deep), $P$. porites and $P$. astreoides were abundant, $P$. porites sometimes forming a blanket. Secondary corals included $M$. annularis, $D$. strigosa, Colpophyllia, and Agaricia agaricites. The Acropora cervicornis zone (6-8 m deep) had a variety of corals including $D$. strigosa, $D$. labyrinthiformis, Colpophyllia, Siderastrea siderea and $M$. annularis. The dominant $A$ cervicornis is locally abundant, reaching 1-1.5 $\mathrm{m}$ in relief. The alcyonarian-Diploria zone extended on rocky protrusions through the lagoon sediments, and included the sea feather Pseudopterogorgia sp., D. strigosa and D. labyrinthiformis (Roberts, 1972).

Noteworthy Fauna and Flora The Green Turtle Chelonia mydas and Hawksbill Eretmochelys imbricata may be found here.

\section{Scientific Importance and Research Not known.}

Economic Value and Social Benefits Not known.

Disturbance or Deficiencies Not known.

Legal Protection None.

Management Under the control of the Fisheries Management Unit.

Recommendations Management of this area is being considered in relation to proposals for the Savannes Bay area and the Maria Islands.

\section{MARIA ISLANDS RESERVE}

Geographical Location $13^{\circ} 43^{\prime} \mathrm{N}, 60^{\circ} 56^{\prime} \mathrm{W}$; less than one mile $(1.6 \mathrm{~km})$ off the south-eastern coast.

Area, Depth, Altitude 27.5 acres (11.1 ha); altitude c. $329 \mathrm{ft}(100 \mathrm{~m})$. (Maria Major is about 23 acres $(9.3 \mathrm{ha})$ in area; Maria Minor is 4.5 acres (1.8 ha).).

\section{Land Tenure Public/Saint Lucia National Trust.}

Physical Features The Maria Islands consist of two main islands with vegetation and an area of sand beach, and several large rocks. To the south and east the sea bottom drops sharply to about $20 \mathrm{~m}$. In the north and west the bottom is shallow for a much greater distance, with extensive seagrass beds and occasional sand flats. In the west, depths generally range from $2-6 \mathrm{~m}$ although there are some deeper areas $(12 \mathrm{~m})$. Off this coast four distinct patch reefs are found, referred to as A, B, C, and $D$ ( $A$ being the northernmost reef) (Hayes and Lawrence, 1982), interspersed with occasional large coral boulders on the sandflats and seagrass beds. Reef $A$ is approximately $13 \mathrm{~m} \mathrm{x} 17 \mathrm{~m}$ in size, very close to shore and partly exposed at low tide. Reef $B$, situated between the two Maria Islands, is larger and is swept by a continuous current from the channel. Reef $C$ is the largest, measuring about $50 \mathrm{~m} \mathrm{x} 42 \mathrm{~m}$, is subject to considerable wave action, and parts of it are occasionally exposed. Reef $D$ is directly off the rocky south-west tip of the southern island within several feet of the shore and is generally subject to strong wave action. It measures approximately $20 \mathrm{~m} \times 7 \mathrm{~m}$ and drops off sharply to a sand bottom at $20 \mathrm{~m}$ on the south and west.

Easterly winds predominate and the north and east sides of the islands are subject to high waves. Information from local fishermen indicates that on the seaward side of the islands strong currents move in a northerly direction for part of the year and in a southerly direction during the remaining months. A strong westerly current flows between the islands. On the west side currents generally flow south and west. A detailed description of the area is given in Goodwin (1984). Hurricanes occur, the most recent being Allen in 1980 . There is less than 40 in. $(1016 \mathrm{~mm})$ rain a year (St Lucia National Trust, 1985).

Reef Structure and Corals The reefs are typical high-energy shallow-water structures, the hermatypic corals mainly occurring as a thin layer conforming to the underlying rock and boulders. The dominant species is Acropora palmata. The two northern reefs are in shallow water with much of the coral growing at a depth of 1-2 m (Smith, 1983). A palmata, Millepora complanata, Diploria labyrinthiformis, Colpophyllia natans, Palythoa sp., and Dichocoenia stokesii are fairly abundant. Large central portions of reefs $\mathrm{B}$ and $\mathrm{C}$ consist of dead coral covered with algae. A palmata covers $35 \%$ of reef $\mathrm{C}$, and a further $12 \%$ is covered with $C$. natans and Diploria labyrinthiformis. Sea fans, Gorgonia flabellum and $G$. ventalina, are also common (Hayes and Lawrence, 1982). Reef D at the southern end of Maria Island meets a gently sloping sand bottom at a maximum depth of $16 \mathrm{~m}$. There is mainly dead $A$ palmata below $5.0 \mathrm{~m}$ on the steep southern face of the reef, the rubble colonized by an algal felt and corals such as Montastraea annularis, $M$. cavernosa, Siderastrea siderea, Agaricia spp., Porites spp., the hydrozoan Millepora squarrosa and occasional zoanthid colonies. There were 
also numerous young colonies of Acropora palmata (Smith, 1983). A general account of the reefs in the Maria Islands - Savannes Bay area is given in Roberts (1972) and further details are given in Goodwin (1984); there have been noticeable changes in the composition of the reefs in the period between these two studies.

Noteworthy Fauna and Flora The reefs have a rich and diverse fish fauna, including commercially valuable species such as the spiny lobster Panulirus argus. Reefs $A$ and $D$ had particularly abundant and large fish. The algae and spermatophytes of the area are described by Smith (1983) and a brief description of the seagrass beds is given in Hayes and Lawrence (1982). A species list is given in Hayes and Lawrence (1982). The islands, which are mainly covered with bushy scrub and some trees, have an endemic ground lizard Cnemidophorus vanzoi, an endemic snake Dromicus ornatus (Corke, 1983) and are important for a variety of birds including the Magnificent Frigatebird Fregata magnificens, the Common Tern Sterna hirundo, the White-tailed Tropicbird Phaethon lepturus and the Ground Dove Columbina passerina. They are one of the few remaining undisturbed seabird nesting sites in St Lucia (Renard, 1983b) due to the absence of predators such as rats and the mongoose Herpestes javanicus. The Green Turtle Chelonia mydas and the Hawksbill Eretmochelys imbricata occur in these waters. A popular account of the fauna and flora is given in St Lucia National Trust (1985).

Scientific Importance and Research The development of $A$ palmata reefs is limited to very few areas around $\mathrm{St}$ Lucia, the most extensive reefs occurring in Laborie Bay and around Maria Island. The large reef off Maria Island is considered the best example on account of its size, accessibility and wealth of coral. All four Maria Island reefs are considered important in reducing erosion of the leeward shoreline of the islands (Smith, 1983). Surveys of the Maria Islands marine environment were carried out in 1982 by marine biologists attached to the Fisheries Management Unit (Hayes and Lawrence, 1982) and in 1984 by Goodwin (1984b). The marine environment is now being monitored by the Fisheries Management Unit as a joint project with a local dive club, and additional research is underway or in preparation for the terrestrial environments (Renard, 1983a and c). The reefs offer an excellent opportunity for research because of their accessibility (Smith, 1983).

Economic Value and Social Benefits Fishermen set pots, collect whelks, and fish with nets and lines. The area supports and provides food for commercial fish caught off the Vieux-Fort area and other areas in the south. The Maria Islands are important to tourism, being close to one of St Lucia's largest hotels (Hayes and Lawrence, 1982). The largest reef (C) in the south is considered to be most suitable for snorkelling as it can be easily reached from the Maria Islands beach (Smith, 1983).

Disturbance or Deficiencies although illegal, still occurs. observed, and pot fishing is fairly extensive. The latter is especially detrimental as pots which are swept up onto the reef may damage the corals (Hayes and Lawrence, 1982). Goodwin (1984b) concluded that fish dersities were unusually low, possibly because of excessive fishing pressure. Some of the observed changes on the reefs could be due to sedimentation but this needs further study (Goodwin, 1984b). The island suffered damage from Hurricane Allen in 1980 but there were no reports of damage to the reefs (St Lucia National Trust, 1985).

Legal Protection The Maria Islands were vested to the St Lucia National Trust in October 1982 (Maria Islands Vesting Order, Statutory Instruments, 1982, No. 53). The islands were declared a Wildlife Reserve by Order of the Ministry of Agriculture, November 1982, through the Wildlife Protection Ordinance (1980, Section 7). The adjacent marine areas have now been included within the Reserve (Boatman in litt, 24.7.86). Dynamiting of coral reefs is prohibited (Hayes and Lawrence, 1982).

Management A project for the Conservation and Development of the Maria Islands Nature Reserve is currently in progress, funded by WWF-US and executed by the Eastern Caribbean Natural Area Management Program (ECNAMP) in collaboration with the St Lucia National Trust and the Government of St Lucia. A Management Committee has been set up, comprising representatives of the Fisheries Management Unit, the Forestry Division, the Ministry of Tourism, the National Trust, the Naturalists Society and ECNAMP, to provide direction for the project. A management plan has been prepared (Anon, 1985b). A draft information and public awareness programme has been drawn up, and care has been taken to inform the local community and resource users of the need for the Reserve and of the research work being carried out there. An experimental programme of guided tours (initially restricted to boat trips around the islands, and snorkelling) will be undertaken. An interpretation centre has been built on the Anse de Sables beach on the mainland, which houses an exhibition presenting various aspects of the Reserve in an integrated fashion and an interpretive booklet has been published with financial assistance from WWF-US (St Lucia National Trust, 1985; Smith in litt., 20.1.86). The area is included within the South-east coastal zone management project (see Introduction).

Recommendations Spearfishing should be prohibited in the immediate area of Maria Island, especially, in demarcated snorkelling zones, which should at least include reef $\mathrm{C}$ mentioned above. The legislation prohibiting dynamiting must be enforced. Pot fishing should be restricted on and near the reefs (Smith, 1983). Restrictions on tourist use should include strict control of access and prohibiting the removal of anything from the area or the leaving of anything unnecessary behind. A prime concern should be environmental education for students of secondary schools (Hayes and Lawrence, 1982; Goodwin, 1984b). Goodwin. (1984b) gives additional recommendations. Recommendations for the conservation of the terrestrial reptile fauna are given in Corke (1983). 


\section{INTRODUCTION}

\section{General Description}

The Saint Martin Plateau, $75 \times 45$ miles $(120 \times 72 \mathrm{~km})$, supports the islands of St Barthelemy (St Barts), St Martin and Anguilla. St Barts and the northern half of St Martin are part of the French Antilles, forming, with Guadeloupe, an Overseas Department of France. The southern half of St Martin (Sint Maarten) is part of the Netherlands Antilles (see separate section). St Barts and St Martin are separated by depths of 16 fathoms $(29.3 \mathrm{~m})$, St Martin and Anguilla by depths of 14 fathoms $(25.6 \mathrm{~m})$. The shoreline of both St Barts and St Martin is indented with wave-cut cliffs. The waters around St Martin are relatively shallow $(18-27 \mathrm{~m})$ and there is an extensive seagrass bed off the north-west coast, 11600 ha in size. Detailed descriptions of the shoreline are given in Vroman (1968); there are sandy beaches in the north-west and some mangroves. Ile Tintamarre (Flat Island), Ile Pinel and Green Cay, all uninhabited cays, lie off the east coast. St Barts is a small $(25 \mathrm{sq} . \mathrm{km})$ rocky island with several uninhabited off shore cays including Ile Fourche, Ile Bonhomme, Ile Frégate, Ile Toc Vers and La Tortue. There are extensive seagrass beds off much of the coast and several sandy beaches (ECNAMP, 1980 a and b; Vaughan, 1919).

The reefs are poorly developed compared with many other islands in the Lesser Antilles. On - St Martin, several small Acropora palmata - dominated bank reefs have formed on an apparently shallow shelf between the main island and Ile Tintamarre off the north-east coast. The north side of Ile Tintamarre has several small algal ridges or cups. Vaughan (1919) describes well developed reefs on the east side of St Martin, off the north point and on the south-east side of Ile Tintamarre. ECNAMP (1980a) indicates reefs around the north and east coasts of the mainland. These are considered to be among the more important marine habitats of the Lesser Antilles since they extend more or less continuously for $25 \mathrm{~km}$ (ECNAMP,1982).

On St Barts, reefs occur across the entrances of most bays on the north-east and south-east coasts (Vaughan, 1919). High energy coralline - Millepora reefs have formed on spits between the main island and $\mathrm{La}$ Tortue in the north-east, while an uncapped head-coral bank extends to the north-west of the latter island. The north side of St Barts also has several small algal ridges or cups which are probably perched on small shelves cut in the shore (Adey and Burke, 1976; ECNAMP, 1980b).

Major wetland sites are described in Scott and Carbonell (1986). St Martin has up to eleven species of seabirds, including Brown Pelicans Pelecanus occidentalis, Magnificent Frigatebirds Fregata magnificens and Red-billed Tropicbirds Phaeton aetherus, which nest on the islets off the south-east coast. St Barts has up to nine breeding species (Halewyn and Norton, 1984). On St Martin, Hawksbill Eretmochelys imbricata and Green Chelonia mydas Turtles nest on the west point, the east coast and on lle Tintamarre. On St Barts these two species nest at Anse Colombier and Ile Fourche (Meylan,
1983). Loggerhead Caretta caretta and Leatherback Dermochelys coriacea Turtles are present around both islands but are less common.

\section{Reef Resources}

Line and pot fishing are important activities and the commercial fishery is described by Jackson (1980). Tourism is becoming increasingly important (Jackson, 1980; Laborel, 1982). In St Martin, tourism is concentrated on the west point and along the east coast (ECNAMP, 1980a), but almost all the beaches on the island have now been developed (Meylan, 1984). Charter boats take day visitors to St Barts and Anguilla. Many of the reefs are suitable for diving and snorkelling, and popular dive sites include the bay on the east coast opposite Ile Tintamarre (ECNAMP, 1980a). On St Barts, tourism is centred on one of the bays on the north coast where reefs occur. Diving is popular on the south coast (despite the apparent lack of reefs) and off the north-west point (ECNAMP, 1980b).

\section{Disturbances and Deficiencies}

Threats to reefs include increased recreational pressure, pollution, sand extraction (at Anse de Grande Saline on St Barts and several sites on St Martin) and coral mining, but no details are available.

\section{Legislation and Management}

A reserve has been established on the south coast of Ile Tintamarre off St Martin (ECNAMP, 1980a). There are no protected marine areas on St Barts (ECNAMP, 1980b).

\section{Recommendations}

According to Meylan (1983), reserves have been proposed on St Martin for the islets of Molly Beday, Hen and Chicken, Man O'War Shoal, Pelican Cay and Guana Cay, but these will not necessarily include reefs. The reefs are considered to be in urgent need of study, particular in the light of rapid development of tourism in the islands (Laborel, 1982). The Université Antilles-Guyane undertook a survey expedition (ECORECIF) in April 1986 to both St Martin and St Barts (Bouchon et al., 1987) which provides some of the necessary baseline data and recommendations for management of the reefs.

\section{References}

Adey, W.H. and Burke, R. (1976). Holocene bioherms (algal ridges and bank - barrier reefs) of the eastern Caribbean. Geol. Soc. Am. Bull. 87: 95-109.

Bouchon, C. et al. (1987). Etude des biocenoses marines cotières des îles de St Barthélémy, St Martin et Anguilla. Rapport prêliminaire. Mission Ecorécif Université des Antillée et de la Guyane. 


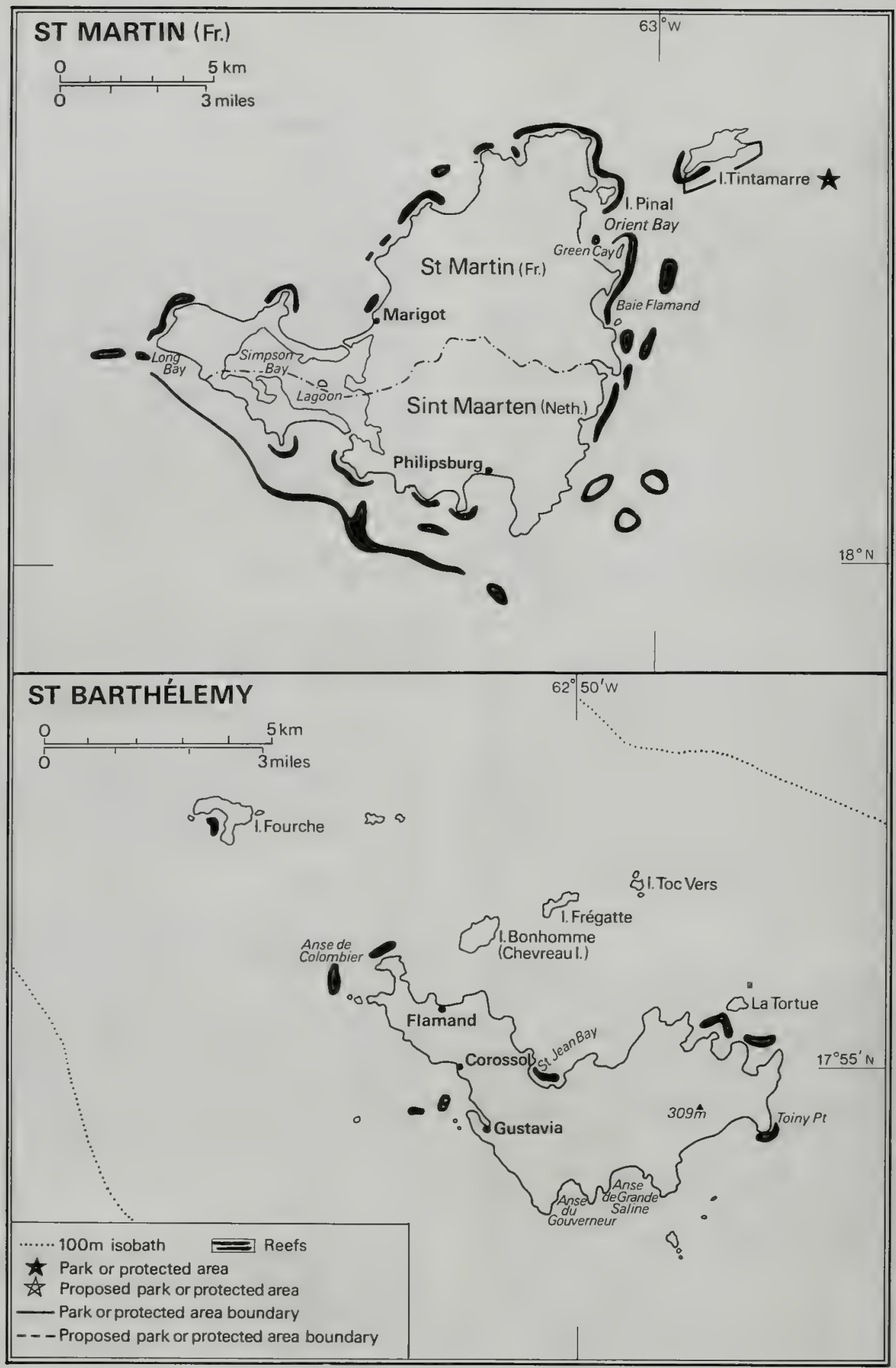


ECNAMP (1980a). Saint Martin/Sint Maarten. Preliminary Data Atlas. Survey of Conservation Priorities in the Lesser Antilles. Eastern Caribbean Natural Area Management Program.

ECNAMP (1980b). Saint Barthélemy. Preliminary Data Allas. Survey of Conservation Priorities in the Lesser Antilles. Eastern Caribbean Natural Area Management Program.

ECNAMP (1982). Final Report. Survey of Conservation Priorities in the Lesser Antilles. Eastern Caribbean Natural Area Management Program.

Halewyn, R, van and Norton, R.L. (1984). The status and conservation of seabirds in the Caribbean. In: Croxall, J.P., Evans, P.G.H. and Schreiber, R.W. (Eds), Status and Conservation of the World's Seabirds. ICBP Technical Publication No. 2, Cambridge.

Jackson, I. (1980). Report on trip to Saint Martin and Sint Maarten, Sept. 29-Oct 1, 1980. Report to ECNAMP.
Laborel, J. (1982). Formations coralliennes des Antilles Françaises. Oceanis 8(4): 339-354.

Meylan, A.B. (1983). Marine turtles of the Leeward Islands, Lesser Antilles. Aroll Res. Bull. 278:24.

Meylan, A.B. (1984). The ecology and conservation of the Caribbean Hawksbill (Eretmochelys imbricata). Final report WWF Project 1499.

Scott, D.A. and Carbonell, M. (1986). Directory of Neotropical Wetlands. IUCN, Gland and Cambridge.

Vaughan, T.W. (1919). Fossil corals from Central America, Cuba and Porto Rico with an account of the American Tertiary, Pleistocene and Recent coral reefs. Bull. U.S. Nat. Mus. 103: 189-524.

Vroman, M. (1968). The marine algal vegetation of St Martin, St Eustatius and Saba (Netherlands Antilles). Stud. Flora Curaçao and other Carib. Is 2:1-120. 



\section{INTRODUCTION}

\section{General Description}

St Vincent, an independent country within the British Commonwealth, is one of the youngest of the major volcanic islands in the Windward Group of the Lesser Antilles and lies between Grenada and St Lucia, due west of Barbados. The northern end of the island is formed by the recently active volcano, the Soufrière $(1219 \mathrm{~m})$, while the southern end is composed of the remains of several extinct volcanoes. The relatively poor development of the St Vincent reefs is considered to be due to continuous volcanic activity throughout the late Pleistocene and Recent. The exposed north and east coasts lack reefs, but on the southern, south-eastern, and western coasts, there are several small fringing reefs (Adams, 1968).

The southern leeward coast has a broad shallow shelf over most of its length, greatest coral growth occurring where there is only one major river, which contributes a limited amount of volcanic sediment to the coast. The development of reefs here is probably helped by wave energy refracted around the south-eastern tip of the island. There are three well-developed reef structures: Indian Bay, the eastern side of Youngs Island and the westward extension of Johnson Point. The Indian Bay and Johnson Point reefs were studied in the early $1960 \mathrm{~s}$ (Adams, 1968) and are described in separate accounts.

The rugged western coast is characterized by a narrow shelf and a moderate (compared to the east coast) influx of volcanic sediment which is trapped in narrow bays or carried out to greater depths off shore. There are localized coral formations. The coast from Chateaubelair to Kingstown appears to support a considerable growth of individual corals but does not have well-developed fringing or patch reefs. Rocky headlands are interspersed with small sandy beaches, and coral growth is concentrated on rubble aprons which flank the headlands, sometimes to $30 \mathrm{~m}$ depth (e.g. Bottles and Glass Point and Grande Baleine (Price in litt., 1985).

Dependencies of St Vincent in the Grenadines comprise about 28 rocky islands extending south to include Bequia, Mustique, Cannouan, Union and Little St Vincent. Three quarters of the Grenadines platform is $36-40 \mathrm{~m}$ deep and has no shallow reef systems but there is a significant, although little studied, submerged reef system on the eastem margin (D'Anglejean and Mountjoy, 1973). Around Mayreau (Mayero), Union, and the associated smaller islands, large bank barrier reef complexes have developed on the windward side. Many of the shallower parts of these reefs, especially the more protected northand south-facing structures, are strongly Acropora palmatadominated and have well developed deeper fore-reef head coral zones. In the more exposed east-facing sections, $A$ palmata tends to be replaced by crustose coralline-Mille pora pavements. Some reef crests and upper fore-reefs, especially at Worlds End Reef $\left(12^{\circ} 37^{\prime} \mathrm{N}, 61^{\circ} 20^{\prime} \mathrm{W}\right.$; east of Tobago Cays) and Prune Island (Palm Island), south-west of Tobago Cays, are characterized by more or less smooth pavements with a thin algal turf. Reefs around the Tobago Cays are described in a separate account.

To the east of the islands, the shelf forms a troad carbonate platform terminating in a steep slope extending into the Tobago Trough. The east Cannouan Reef has large tracts of coralline-dominated spur-and-groove structure with incipient coralline-Millepora mounds and ridge sections. A striking feature of the eastern margin of the Grenadines Shelf is the ridge, presumably of extinct barrier reefs, which extends nearly continuously for over $45 \mathrm{~km}$. It is covered with algal nodules and coral debris, but living forms include Halimeda, some corals, sponges and crustose coralline algae (D'Anglejean and Mountjoy, 1973).

The northernmost and southernmost Grenadines generally lack large bench or shallow bank-barrier reefs, although some small reefs occur in coves or between small islands. The 11-13 $\mathrm{m}$ shelf on which the massive southern reefs are formed is quite narrow or absent, especially at Bequia, Battowia and Baliceaux and Ronde to the south of Carriacou, where the $40 \mathrm{~m}$ contour closely approaches the east sides of the islands. Mustique has a well developed 11-13 $\mathrm{m}$ shelf but still lacks reefs (Adey and Burke, 1976).

There are few coastal wetlands of importance on St Vincent (Scott and Carbonell, 1986). The Green Turtle Chelonia mydas and Loggerhead Caretta caretta are found around St Vincent; the Hawksbill Eretmochelys imbricata is the main nester and the Leatherback Dermochelys coriacea nests occasionally. Green Turtles and Hawksbills nest in the Grenadines; the latter is most abundant although heavily exploited (Bacon et al., 1984; Carr et al., 1982; Groombridge, 1982). There are four species of breeding seabirds on St Vincent and twelve in the Grenadines (Halewyn and Norton, 1984).

\section{Reef Resources}

The low coastal plain of St Vincent is densely populated and tourism is an important part of the economy in the south-east where the beaches and reefs are readily accessible. Snorkelling and diving are popular at Youngs Island and Johnson Point (ECNAMP, 1980a), but Scuba diving operators prefer the quieter locations up the leeward coast. Diving operations exist on Bequia, Mayreau and Palm Islands (Price in litt., 1985). The resources of the Grenadine dependencies are mapped in ECNAMP (1980b); many of the islands are important for tourism. Fisheries are important, providing employment for some 2000 people, but have not been fully developed (Wood, 1984).

\section{Disturbances and Deficiencies}

The conservation status of the reefs is not known. Coral mining occurs on St Vincent near Calliaqua Bay and the south coast is subject to pollution. Several tourist shops 


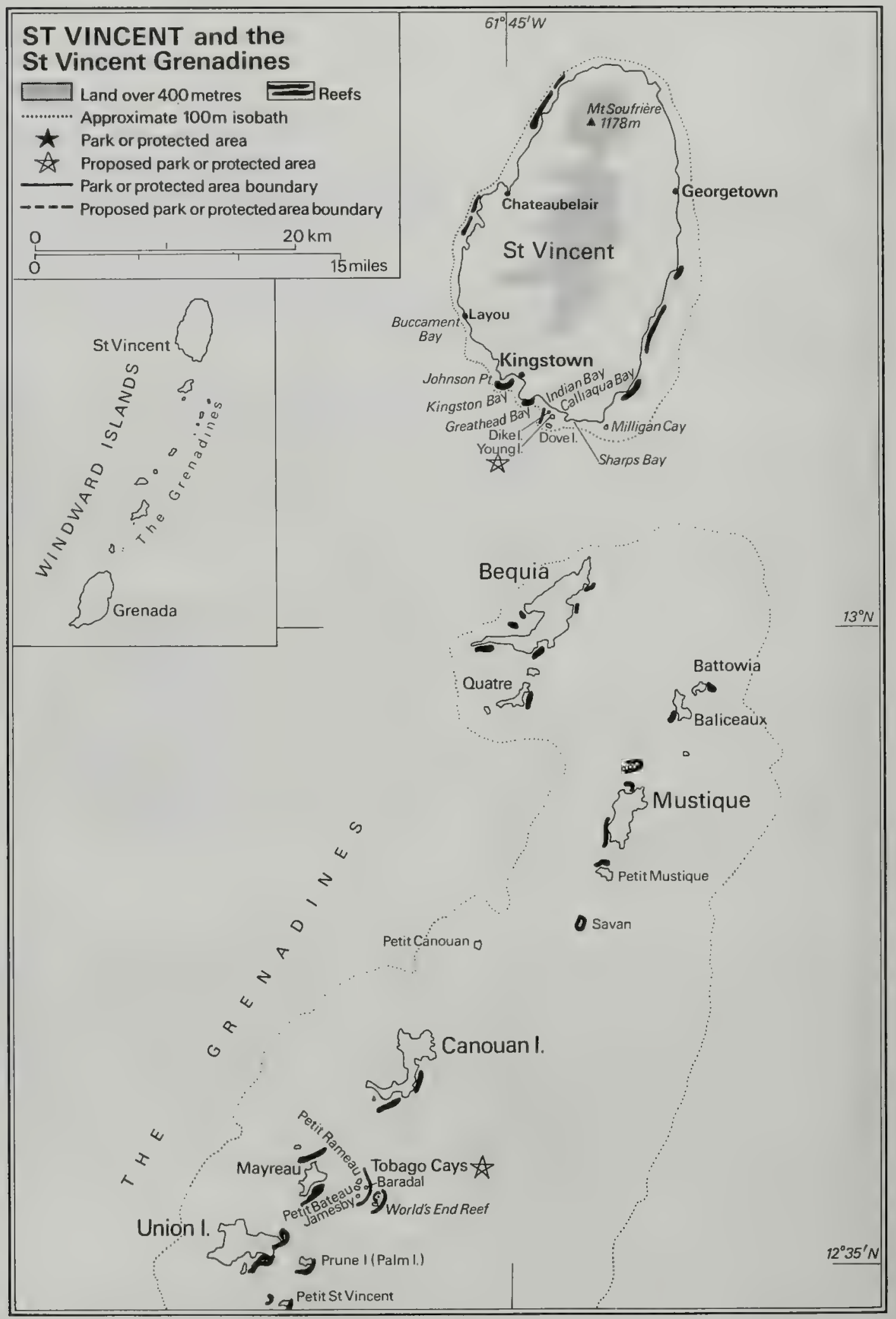


sell coral curios which has had an impact on black corals and other species. Some dynamite fishing still occurs. Conch have been heavily over-exploited and there are now only incidental catches. The recent introduction of tangle nets from Martinique has had a severe impact on marine life. (Price in litt., 1985).

\section{Legislation and Management}

There is a closed season for turtles. Milligan Cay and Buccament Bay are protected areas for seabirds (Meylan, 1984; Scott and Carbonell, 1986) but do not include the marine environment. The Dive St Vincent operation in Calliaqua and Bequia does not permit divers to remove living organisms from the reefs (Price in litt. 1985).

\section{Recommendations}

UNDP (1974) gives some early guidelines for development. WWF-US has recently assisted the Government in drawing up a new wildife law which would provide the basis for the establishment of wildlife refuges, the draft of which lists some sites. Youngs Island has been proposed for reserve/park status (ECNAMP, 1980a). The Tobago Cays have been proposed as a national park and are described in a separate account. St Vincent is included in a preliminary list of potential marine sites for inclusion in a Lesser Antilles Biosphere Reserve, on the basis of the concentration of marine resources in the Grenadine dependencies (Goodwin, 1985).

\section{References}

Adams, R.D. (1968). The leeward reefs of St Vincent, West Indies. J. Geol. 76: 587-595.

Adey, W.H. and Burke, R. (1976). Holocene bioherms (algal ridges and bank-barrier reefs) of the eastern Caribbean. Geol. Soc. Am. Bull. 87: 95-109.

Bacon, P., Berry, F., Bjorndal, K., Hirth, H., Ogren, L., Weber, M. (1984). The National Reports. Proceedings of the Western Atlantic Turtle Symposium, Vol. 3. University of Miami Press, Florida.

Carr, A., Meylan, A., Mortimer, J., Bjorndal, K. and Carr, T. (1982). Surveys of the turtle populations and habitats in the Western Alantic. NOAA Technical Memorandum NMFS-SEFC-91, US Dept of Commerce.

D'Anglejean, B.F. and Mountjoy, E.W. (1973). Submerged reefs of the eastern Grenadines shelf margin. Bull. geol. Soc. Am. 84: 2445-2454.

ECNAMP (1980a). St Vincent Grenadines. Preliminary Data Atlas. A Survey of Conservation Priorities in the Lesser Antilles, Eastern Caribbean Natural Area Management Program.

ECNAMP (1980b). St Vincent. Preliminary Data Atlas. Survey of Conservation Priorities in the Lesser Antilles. Eastern Caribbean Natural Area Management Program.

Goodwin, M. (1985). Characterization of Lesser Antillean Regional Fisheries. Island Resources Foundation, $48 \mathrm{pp}$.

Groombridge, B. (1982). The IUCN Amphibia-Reptilia Red Data Book, Part 1: Testudines, Crocodylia, Rhynchocephalia. IUCN, Gland, Switzerland.

Halewyn, R. van and Norton, R.L. (1984). The status and conservation of seabirds in the Caribbean. In:
Croxall, J.P., Evans, P.G.H. and Schreiber, R.W. (Eds), Status and Conservation of the World's Seabirds. ICBP Technical Publication No. 2, Cambridge.

Lewis, J.B. (1975). A preliminary description of the coral reefs of the Tobago Cays, Grenadines, West Indies. Atoll Res. Bull. 178: 9 pp.

Meylan, A. (1984). The ecology and conservation of the Caribbean Hawksbill (Eretmochelys imbricata). Final Report, WWF Project 1499.

Scott, D.A. and Carbonell, M. (1986). A Directory of Neotropical Wetlands. IUCN, Gland and Cambridge.

- UNDP (1974). Environmental status report and guidelines for development: Antigua, Barbados, British Virgin Islands, Cayman Islands, Dominica, Montserrat, St Kitts and Nevis, St Lucia, St Vincent and Turks and Caicos. Island Resources Foundation.

Wood, J. (Ed.) (1983). Proceedings of the Workshop on Biosphere Reserves and Other Protected Areas for Sustainable Development of Small Caribbean Islands, May 10-12, 1983. Virgin Islands National Park, Caneel Bay, St John, U.S. Virgin Islands. U.S. Dept of the Interior, National Park Service, Atlanta, Georgia. 190 pp.

\section{INDIAN BAY AND DOVE ISLAND}

Geographical Location South coast of St Vincent; $13^{\circ} 08^{\prime} \mathrm{N}, 61^{\circ} 13^{\prime} \mathrm{W}$.

Physical Features The reef at Indian Bay is about $300 \mathrm{~m}$ long and extends $10 \mathrm{~m}$ from the shore to the reef edge at $7 \mathrm{~m}$ depth. Dove Island is an ash remnant on the east side of the Bay, connected to the mainland by an artifical rubble "tombolo" (Adams, 1968).

Reef Structure and Corals Five zones were described by Adams (1968): a) Beach-beachrock, b) Rubble, c) Millepora, d) Porites and e) Alcyonaria-Porifera. The submerged beach and rubble flat had very sparse organic growth, except where outliers of exhumed beachrock were separated from the beach, providing a substrate for coralline algae and a variety of invertebrates. $M$. alcicornis and $P$. astreoides were dominant in the Millepora zone, with small colonies landward and larger structures in deeper water. The substrate was almost completely encrusted by coralline algae and was grazed by the urchin Diadema. The reef crest and fore-slope were a pure stand of $P$. porites, cut only where channels transversed it or where sediment had killed coral branches. At the base of the fore-slope there were a few scattered colonies of Siderastrea siderea and Diploria labyrinthiformis. The deeper Alcyonaria-Porifera zone extended from the base of the reef for $5-10 \mathrm{~m}$ to a barren calcareous sand bottom. At the western end, the reef intersected the flanks of the basalt dike and lost its rigid zonation, the Millepora zone broadening and merging with encrusted rubble. At the eastern, end the Porites zone was broken up into isolated patches with a sand substrate in the intervening areas.

Dove Island had a small reef community similar to the Indian Bay Porites reef, particularly in the Millepora zone, but there was no true reef structure. The submerged flanks of the island were covered with coralline algae, $M$. alcicornis and $P$. astreoides. Small 
colonies of $P$. porites interspersed with a diverse sponge fauna and several heads of Siderastrea, ranging in diameter from 0.5 to $1.5 \mathrm{~m}$, were also present.

Several other rock substrates in the immediate area supported patchy growths of coral and associated marine fauna including the base of Dike Island, the northern flank of Youngs Island and the seaward extension of Rookes Point. A small cavernous beachrock platform just east of Dove Island was covered with calcareous and non-calcareous algae including a particularly good stand of Halimeda. Millepora is the dominant stony form, interspersed with small colonies of Acropora.

Noteworthy Fauna and Flora The Leatherback Dermochelys coriacea, Green Chelonia mydas and Hawksbill Turtles Eretmochelys imbricata may occur (Groombridge, 1982).

Scientific Importance and Research One of the few reef sites on St Vincent to have been described in the scientific literature.

Economic Value and Social Benefits The area is important for tourism and recreation (ECNAMP, 1980b).

Disturbance or Deficiencies

Possibly threatened by pollution (ECNAMP, 1980b).

Legal Protection None.

Management No information.

Recommendations None known.

\section{JOHNSON POINT AND SHARPS BAY}

Geographical Location South coast of St Vincent; $13^{\circ} 09^{\prime} \mathrm{N}, 61^{\circ} 15^{\prime} \mathrm{W}$.

Physical Features A curved basalt dike extending north-west from Johnson Point forms the basis for a reef. The reef crest, on the submerged top of the dike, extends shoreward for $10-20 \mathrm{~m}$. The main portion of the reef is separated from its distal end by a deep channel, artificially constructed through the dike, which connects the lagoon on the westward margin of the bay with the open sea. In front of the reef crest, the dike surface drops off sharply to about $10 \mathrm{~m}$. Strong waves refracted around Johnson Point provide considerable agitation on the reef crest as well as on the bottom (Adams, 1968).

Reef Structure and Corals The reef was described by Adams (1968). Behind the reef crest, the reef flat was composed of coral rubble covered with calcareous and non-calcareous algae, a purple coralline form being dominant. Behind the reef flat there were Thalassia beds which extended back to the beaches along the eastem shore of Johnson Point. The reef crest at about $1 \mathrm{~m}$ depth had flourishing colonies of Acropora palmata, Millepora alcicornis, Diploria labyrinthiformis and Porites porites with a distinct algal ridge. The front slope of the dike was covered by coralline algae and Mille pora with a few, small gorgonians. At $10 \mathrm{~m}$, the bottom consisted of calcareous sand and basalt boulders and was covered by a forest of Gorgonia acerosa and $G$. flabellum reaching heights of $2-3 \mathrm{~m}$.

Sharps Bay is the easternmost occurrence of vigorous coral growth on St Vincent. Adams (1968) found no true reef development but a diverse assemblage of reef-building organisms with a marked zonation. The submerged flanks of the basalt headland and submerged beachrock provided a firm substrate for coral growth, the accumulation and movement of sediment controlling the distribution of coral and algae. A zone of beachrock, $7 \mathrm{~m}$ seaward of the beach, was covered with encrusting algae and coral. Beyond this a broad area of rippled sand was flanked by a dense growth of algae, where several large growths of $A$ palmata had become established. Large heads of Diploria were found in deeper water from the edge of the algal zone to the base of the basalt headland on the western margin of the bay. The submerged basalt was covered with encrusting Millepora and coralline algae.

Noteworthy Fauna and Flora There are mangroves on Johnson Point (ECNAMP, 1980a). The Green Chelonia mydas, Leatherback Dermochelys coriacea and Hawksbill Turtles Eretmochelys imbricata may occur (Groombridge, 1982).

Scientific Importance and Research One of the few reef sites on St Vincent to have been described in the scientific literature.

Economic Value and Social Benefits The area is important for recreation and tourism, particularly for snorkelling and diving. A marina has been constructed near Johnson Point (ECNAMP, 1980b).

Disturbance or Deficiencies Possibly threatened by pollution (ECNAMP, 1980b).

Legal Protection None.

Management No information.

Recommendations None known.

\section{TOBAGO CAYS PROPOSED PROTECTED AREA}

Geographical Location $12^{\circ} 28^{\prime} \mathrm{N}, 61^{\circ} 22^{\prime} \mathrm{W}$; between St Vincent and Grenada, in the Grenadines, including four cays: Petit Rameau, Petit Bateau, Baradal and Jamesby.

Physical Features The Tobago Cays comprise four small islands lying on a long narrow submarine bank which stretches southward to Grenada. All are low lying with narrow beaches and rocky coasts and are covered for the most part by scrub vegetation typical of the Grenadines. The largest island, Petit Bateau, has an elevation of about $45 \mathrm{~m}$; the smallest, Jamesby, is $20 \mathrm{~m}$ in height. The prevailing current flows from east to west, across Horseshoe Reef and past the four cays. Longshore currents flow along the east coasts of each of the cays and are strongest at the northern and southern extremities of the islands. In general, currents are strongest at the eastern entrance to the channel between Petit Bateau and 
Petit Rameau, the north-eastern tip of Petit Rameau, the northern and southern ends of Baradal and along the western side of Jamesby Cay. The cays are protected on the east by a semi-circular reef called Horseshoe Reef. Heavy seas break over this most of the year and strong and variable currents flow across it into the central area. The reef crest has a width of $10-25 \mathrm{~m}$ and a depth of 1-2 $\mathrm{m}$ in the mid-zone. The seaward slope of the reef front drops steeply to $15-20 \mathrm{~m}$ (Lewis, 1975).

Each of the cays is partially surrounded by a narrow reef which, except for Jamesby, is absent on the leeward side. The southern coast of Petit Rameau has a narrow beach with a small patch of Rhizophora mangrove near the eastern end. The middle of the channel between the south coast of Petit Rameau and the north coast of Petit Bateau is composed of calcareous sand at $5-10 \mathrm{~m}$ depth. The west coast of Petit Rameau has low rocky outcrops interspersed with small sandy beaches. The north and east coasts and the four corners of the island are characterized by low rocky cliffs, heavy wave action and strong currents, although currents are weaker at the south-west corner (Lewis, 1975).

On Petit Bateau, the north coast is protected and has a wide beach along most of the coast. On the west side there are steep rocky cliffs with piles of rubble in shallow water at the base. Along the southern and eastern coasts there are sandy beaches. Along the south coast of Baradal, the water is turbulent and there is a sand and rubble bottom in shallow water; at the south-east end there is a long sand spit. On Jamesby, the west coast is rocky with turbid water and strong currents (Lewis, 1975).

Reef Structure and Corals Thirty corals were recorded at Tobago Cays by Lewis (1975). Horseshoe Reef was similar in structure to other Caribbean reefs and three distinct zones were recognized. The back-reef was an area of relatively flat bottom varying in depth between 1 and $2 \mathrm{~m}$ and in width between 50 and $75 \mathrm{~m}$. Between the back-reef and the cays, the bottom was sandy with seagrasses Thalassia testudinum and Syringodium filiforme, broken by clumps of corals, sponges, the sea fan Rhipidogorgia flabellum and other alcyonarians. There were also wide areas of flat reef-rock pavement. Patches of reef on the back-reef were dominated by low clumps of Montastraea annularis, sometimes 3 to $4 \mathrm{~m}$ in diameter at the outer edge of the zone. Large colonies of Siderastrea siderea were also common, together with a variety of other corals. Stunted growths of Acropora palmata occured towards the seaward limit of the zone. Alcyonarians were particularly conspicuous and patches of Millepora were common in the mid-region of the back-reef and towards the reef crest. Other conspicuous invertebrates in this zone included the sea urchins Diadema antillarum and Tripneustes esculentus, the large sedentary polychaete Sabellastarte magnifica and numerous sponges. Near the reef crest extensive areas of flat reef-rock pavement were covered with the yellow zoanthid Palythoa mammillosa.

The reef crest zone was dominated by dense growths of branching $A$ palmata. The bottom consisted either of broken Acropora branches or of bare rock pavement encrusted with Millepora or Palythoa and scattered colonies of Porites astreoides and Favia fragum. Narrow bare channels, a few metres wide, occured at frequent intervals along the reef, but there was no spur and groove system.
The seaward slope of the reef front was dominated by large massive mounds of Montastraea annularis from a depth of about $5 \mathrm{~m}$. At the top, this coral formed tall pillar-like clumps, but colonies became plate-like deeper down. A considerable amount of coral debris lay at the sandy bottom of the slope. A number of corals were found mixed with the Montastraea and the sea fan Rhipidogorgia was abundant near the shallower part of the slope (Lewis, 1975).

The distribution of shallow water communities around each of the cays is related to coastline configuration and current velocities. The narrow reefs consisted for the most part of low clumps of coral on a sandy bottom which sloped gradually down into the channel. Flourishing reef patches were found in areas with strong currents, along with dense stands of Rhipidogorgia and alcyonarians. ThalassiaPorites associations were restricted to the southern coasts of Petit Rameau and Petit Bateau and the eastern coasts of Baradal and Jamesby where the currents were weaker.

At Petit Rameau, the area between the reef and beach on the south coast was densely covered by a mixture of $P$. porites, $P$. furcata, seagrass Thalassia and the algae Halimeda and Amphiroa. A variety of other invertebrates were also found, including other corals, anemones, sea urchins and sponges. On the slope below about $2.3 \mathrm{~m}$, Thalassia disappeared and $P$. porites and $P$. furcata dominated in association with $M$. annularis, $P$. astreoides, Siderastrea radians, S. siderea, $F$. fragum and Millepora. Halimeda was also common and the bottom was thickly covered with debris from calcareous algae and coral rubble. A more diverse coral community was found at the bottom of the slope and on the inner edge of the channel at about $5 \mathrm{~m}$. Moniastraea annularis was dominant but there were a variety of other corals as well. On the west coast, small patches of living $P$. porites and $P$. furcata were found in shallow water. Mancina aereolata and Halimeda were common but the area did not support a diverse fauna. A few scattered corals $F$. fragum, $S$. siderea, $P$. porites, $P$. astreoides and Millepora occured down to the sandy bottom at about $4 \mathrm{~m}$ where isolated patches of Acropora palmata and Montastraea were found. Prolific growths of the sea fan Rhipidogorgia were found on the exposed north and east coasts with massive boulders of $S$. siderea and Diploria spp. in shallow water. At $3-4 \mathrm{~m}$, massive mounds of $M$. annularis were found. A more prolific coral community, dominated by $M$. annularis occurred at the more sheltered south-west corner.

Petit Bateau had similar coral communities. On the sheltered north side, extensive areas of coral rubble with a few patches of Thalassia and small colonies of massive corals were found in shallow water. The bottom sloped down to a sandy channel at $45 \mathrm{~m}$. The north-east promontory supported a dense growth of Rhipidogorgia, $S$. siderea, Diploria spp. and $A$ palmata. On the west side, alcyonarians were abundant on the rubble in shallow water at the base of cliffs, with patches of $A$ palmata, A cervicornis, Millepora, $P$. porites, $P$. astreoides, $F$. fragum and $S$. radians. Along the southern and eastern coasts, the Thalassia-Porites association was found down to $2-3 \mathrm{~m}$. Beyond this there are dense coral communities dominated by Montastraea annularis.

The south coast of Baradal had poorly developed coral communities but important seagrass beds with Thalassia 
and Syringodium. Manicina areolata, Loggerhead Sponges Spheciospongia and the urchin Tripneustes esculentus were common. Along the east coast there were narrow beds of Porites and Thalassia in shallow water. Patches of A palmata, Diploria spp., Siderastrea spp. and Porites spp. occurred in deep water and alcyonarians were abundant. The west coast had a sand and rubble bottom with a heavy growth of algae Ulva and Enteromorpha.

At Jamesby there were flourishing reef communities on the west coast similar to the east coast reefs of Petit Bateau. On the eastern coast there was a poorly developed ThalassiaPorites association (Lewis, 1975).

Noteworthy Fauna and Flora Leatherback Dermochelys coriacea, Green Chelonia mydas and Hawksbill Turtles Eretmochelys imbricata may nest sparsely on the cays (ECNAMP, 1980b).

Scientific Importance and Research No information apart from the preliminary description by Lewis (1975).

Economic Value and Social Benefits The cays are visited by fishermen for conch and lobster (ECNAMP, 1980b; Lewis, 1975) and used by tourists (ECNAMP, 1980b) for snorkelling and diving.
Disturbance or Deficiencies The islands are uninhabited but are visited frequently by fishermen from nearby islands (Lewis, 1975). The cays may suffer from both domestic and seabome pollution (ECNAMP, 1980b) and visiting yachts are reported to dump large volumes of rubbish (Goodwin in litt., 23.3.84). Observations 1980-84 suggest that most large colonies of $A$ palmata have died, e.g. at Catholic Rock, Petit Tabac and Thompson Reef off Union Island. There is uncontrolled exploitation of turtles for their carapaces in Bequia. Visiting yachts cause anchor damage.

\section{Legal Protection None.}

\section{Management None.}

Recommendations The Tobago Cays have been recommended as a protected area (ECNAMP, 1980b). (According to Carr et al. (1982), Tobago Cays are a National Park under the authority of the St Vincent National Trust, with fishing controls and protection for seabirds; this is considered to be an error.) There should be a mooring system for yachts. 


\section{INTRODUCTION}

\section{General Description}

Trinidad and Tobago, with a combined area of $5128 \mathrm{sq} . \mathrm{km}$, are situated on the continental shelf off the north coast of Venezuela and form an independent nation within the British Commonwealth. Trinidad is relatively flat with three mountain ranges, oriented east-west, the highest in the north reaching $940 \mathrm{~m}$. Numerous rivers drain the upland areas and usually end in coastal swamps, marshes or lagoons. The waters around Trinidad are characterized by variable salinity and a low to high sediment load as a result of the island's proximity to the mouth of the Orinoco River and the presence of cold upwellings along the north coast of Venezuela. Tobago, situated 18 miles $(29 \mathrm{~km})$ north-east of Trinidad, is rugged with a mountain ridge running nearly two-thirds of its length and rising to $576 \mathrm{~m}$; there is a small area of coastal plain in the south-west. Annual rainfall is in excess of $2000 \mathrm{~mm}$ and there is a rainy season from May to December interrupted by a short dry season in late September and October, and a longer dry season from January to May. The islands rarely experience hurricane force winds.

The near-estuarine conditions of the Gulf of Paria, separating Trinidad from Venezuela, restrict coral development in this area, in the Columbus Passage and along the east coast where there is a mainly mud bottom. Small patches of coral and drowned coral assemblages are found around the coast however, suggesting that reefs were once more extensive during more favourable environmental conditions (Kenny, 1977; Percharde, 1977).

On Trinidad, the north coast has the greatest coral development. There is a progressive enrichment of community composition from the Bocas Islands in the west, eastwards to Toco in the extreme north-east (see separate account for Salybia Reef), which has the largest number of species, a trend which is consistent with the east-west salinity gradient (Kenny, 1977). Scleractinians are poorly represented, twenty-nine species having been recorded, mainly from the upper $10 \mathrm{~m}$. This is a result of lack of suitable substrata, generally low salinities and high turbidity. Instead, coral communities are dominated by octocorals, including symbiotic species such as Muriceopsis flavida, Muricea elongata, Gorgonia ventalina, Plexaurella dichotoma, Eunicea tourneforti, Pterogorgia citrina, Pseudopterogorgia acerosa and $P$. americana. Non-symbiotic octocorals can occur as shallow as $5 \mathrm{~m}$ but are most abundant in deep channel areas (Ramsaroop, 1976). P. elegans is the only species found all round the Trinidad coast (Ramsaroop, 1977).

The Bocas Islands are separated by deep $(200-300 \mathrm{~m})$ channels forming "the Dragon's Mouth" through which part of the Guyana Current flows into the Caribbean Sea. This current can be swift, creating turbulence and upwelling of cool water. The area has a number of non-symbiotic corals, particularly in passages at depths of $300 \mathrm{~m}$ where there is poor light penetration and marked thermoclines at $15-25 \mathrm{~m}$ depth. Species such as Paracyathas defilippi (Caryophyllidae) and Stylaster duchassaingii, known only from deep dredging in the
Caribbean, are found here (Kenny, 1977). Common species are Lophogorgia punicea, Pacifigorgia elegans, Ellisella elongata, Swiftia exserta and Nicella schmitti (Ramsaroop, 1979). Warner (1981) describes the antipatharian fauna of this area. High densities of gorgonians used to occur in other north coast bays including Macqueripe Bay, La Vache Bay, Cyril's Bay, Balata Bay, Damian Bay, Chupara Bay and Toco Bay but at the beginning of the $1980 \mathrm{~s}$, there was extensive mortality in many of these communities (see below).

Tobago has richer and more diverse coral communities. Buccoo Reef is the largest and best known of the reefs (see separate account) and there are several smaller but important reefs particularly at Kilgwyn, Speyside and Man-O-War Bay (Ramsaroop, 1981) (see accounts for Eastern Tobago proposed National Park, Amos Vale Bay and Culloden Bay).

The Caribbean Manatee Trichechus manatus may travel from the Orinoco delta to estuaries on the east of Trinidad. The Hawksbill Eretmochelys imbricata, Leatherback Dermochelys coriacea, Olive Ridley Lepidochelys olivacea and Green Turtle Chelonia mydas nest sparsely on the north and east coast of Trinidad (Bacon et al., 1984; Groombridge, 1982). The Green Turtle feeds in the Gulf of Paria and the Leatherback occurs on Tobago. Halewyn and Norton (1984) list the thirteen seabird species breeding on Trinidad and Tobago. Major wetland sites are described in Scott and Carbonell (1986). Thelen and Faizool (1980) list threatened birds and reptiles occurring within the national parks.

Early reef work was largely confined to Buccoo Reef (Goreau, 1967; Kenny, 1976; Wood, 1964) although a guide to the corals of Trinidad has been produced (Kenny et al., 1975). The Institute of Marine Affairs, an independent research organization, was set up in 1976 with the assistance of UNDP in order to conduct research on the marise environment and associated watershed areas. Detailed studies of the Charlotteville (Man-O-War Bay) and Speyside reef regions are being carried out (Laydoo, 1983b). A preliminary study of the octocoral fauna at Speyside, Kilgwyn and Buccoo has been carried out (Ramsaroop, 1976).

\section{Reef Resources}

Tourism and, in particular, diving and reef-related activities are being promoted on the islands, particularly on Tobago where there are a number of dive centres (see separate accounts); Sandy Point, to the west of Buccoo Bay is also a popular resort.

\section{Disturbances and Deficiencies}

There was extensive mortality of gorgonians in many of the north coast bays on Trinidad in the early 1980s. The Common Sea Fan Gorgonia ventalina, the Sausage Coral Plexaurella dichotoma and the shallow-water Bottle Brush Coral Muriceopsis flavida used to be quite abundant in the upper $10 \mathrm{~m}$. Dead colonies were first 


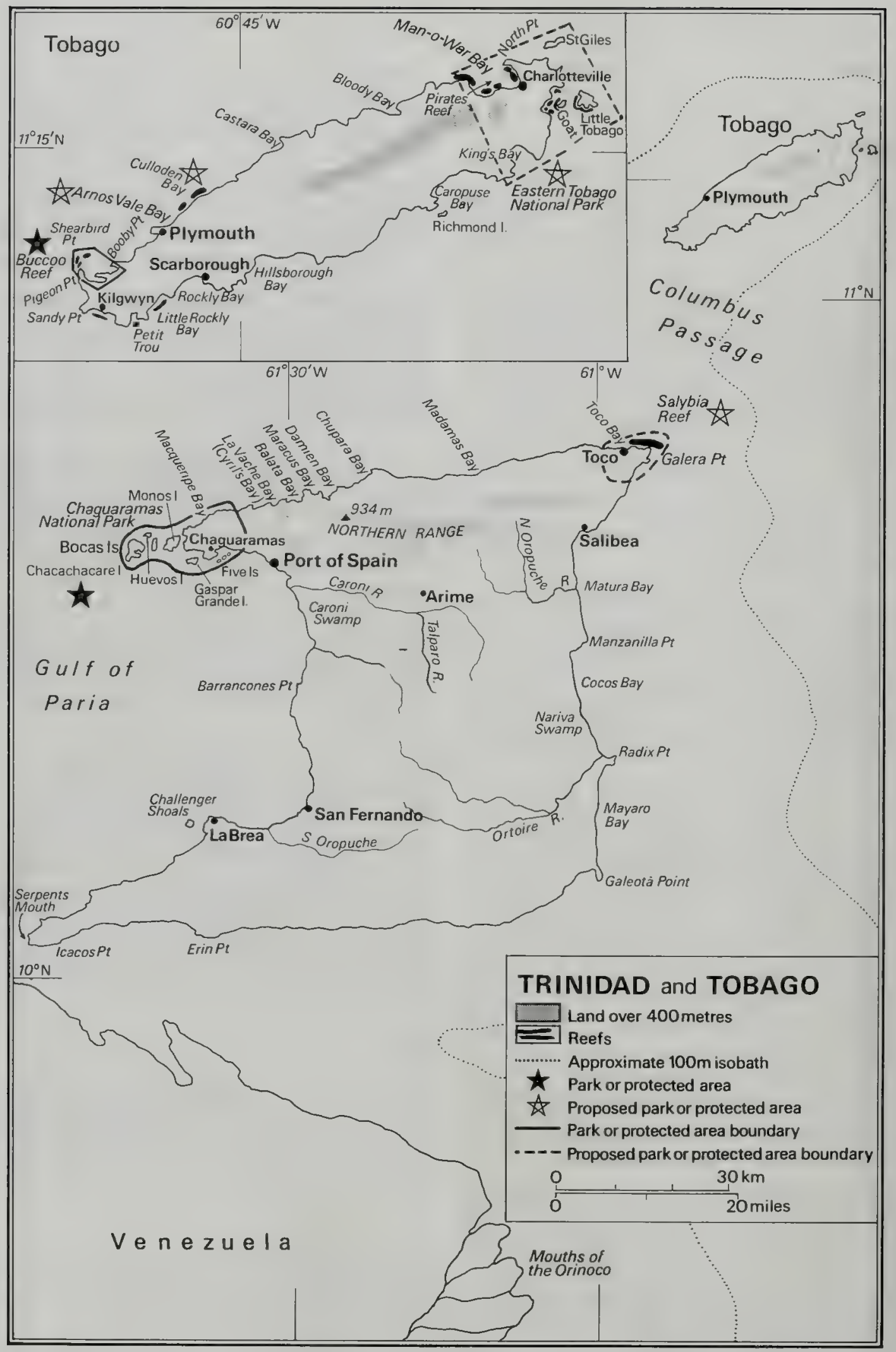


observed in Macqueripe Bay at the end of 1981 and dense stands are now reduced to skeletal stumps encrusted with sponges, barnacles, fire coral and algae. At the end of 1982, healthy colonies occurred at two localities only, near Parasol Rock at Huevos Island in the Bocas and in Toco Bay (Laydoo, 1983b). It is possible that these mortalities were due to a host-specific agent (Laydoo, 1983a). White band disease has been reported (Rogers, 1985).

Siltation may be a potential threat to the reefs of Tobago as the coastal vegetation has been seriously altered and many mangroves are now dead (Thelen and Faizool, 1980). The intensive use of Buccoo Reef for recreational purposes is making it imperative to encourage the use of other areas. Corals are collected for use in construction work (Rogers, 1985).

\section{Legislation and Management}

The Marine Areas (Preservation and Enhancement) Act, 1970 , allows for the setting up of protected marine areas and coral reefs. Legislation covers the exploitation of fish, crustaceans and sea turtles, and the control of oil pollution. Buccoo Reef/Bon Accord Lagoon Restricted Area on Tobago is the only established protected marine area at present. The Chaguaramas National Park, north-west Trinidad, was designated in December 1976 and includes the Bocas Islands, but it is not clear whether marine areas are included. The area comes under the management of the Chaguaramas Development Authority and a park planner is responsible for research on flora and fauna and for advising the local authorities on conservation matters (Scott and Carbonell, 1986).

Reef studies underway by the Institute of Marine Affairs are part of a series being carried out to provide the necessary baseline data for management strategies for other areas (Ramsaroop, 1981; Laydoo, 1985). Leaflets on marine life have been produced for visitors. In January 1986, the Crusoe Reef Society was formed by a group of concerned citizens, with the objectives of monitoring, preserving and protecting the marine and coastal environment and resources in Tobago (Kenny in litt., 1.7.86). The Society will be working in close collaboration with the government authorities and its primary objective will be improved management of the Buccoo Reef area.

\section{Recommendations}

Under a proposed "System of National Parks and other Protected Areas" prepared by the Forestry Division in conjunction with the Organization of American States, recommendations were made to set aside 61 areas in Trinidad and Tobago for nature conservation and preservation. The following areas have been recommended for protection and include reefs; they are described in the following accounts:

Eastern Tobago National Park

Arnos Vale Bay, north coast of Tobago

Salybia Reef, to be included in the proposed Galera

Point National Landmark, north-east Trinidad

Culloden Bay, north Tobago
References

Almy T. and Almy, K. (1974). A snorkeller's guide to the Bay at Arnos Vale. Etna, New Hampshire, U.S.A. (Available through the Amos Vale Hotel).

Bacon, P., Berry, F., Bjorndal, K., Hirth, H., Ogren, L. Weber, M. (1984). The National Reports. Proceedings of the Western Atlantic Turtle Symposium, Vol. 3. University of Miami Press, Florida.

ECNAMP (1979). Draft Plan for the management and development of the proposed Bucco Reef National Park. Report on workshop on Natural Area Management, Forestry Division, Ministry of Agriculture Lands and Fisheries, Tobago.

Environmental Systems Corporation (1972) Remote Sensing Data Analysis for an Ecological and Planning Study for Bon Accord/Buccoo area, Tobago. E.S.C., P.O. Box 2525, Knoxville, Tennessee 37901.

Goreau, T.F. (1967). Buccoo Reef and Bon Accord Lagoon, Tobago. Observations and recommenđations concerning the preservation of the reef and its lagoon in relation to urbanization of the neighbouring coastal islands. Memorandum to Acting Permanent Secretary, Economic Planning Unit, Prime Ministers Office, Government of Trinidad and Tobago.

Groombridge, B. (1982). The IUCN Amphibia-Reprilia Red Data Book. Part 1: Testudines, Crocodylia, Rhynchocephalia. IUCN, Gland, Switzerland.

Halewyn, R. van, and Norton, R.L. (1984). The status and conservation of seabirds in the Caribbean. In: Croxall, J.P., Evans, P.G.H. and Schreiber, R.W. (Eds), Status and Conservation of the World's Seabirds. ICBP Technical Publication No. 2, Cambridge.

Hudson, D.I.G. (1983). Carbonate reef sedimentation, Buccoo Reef complex and Bon Accord lagoon, southwestem Tobago, West Indies. M. Sc. Thesis, McGill University.

Hudson, D.I.G. (1984). Patch reef zonation on Buccoo Reef, Tobago. Abstract. 18th AIMLC.

IUCN (1982). IUCN Directory of Neotropical Protected Areas. Tycooly International Publishing Lid., Dublin.

Kenny, J.S. (1976). A preliminary study of the Buccoo Reef/Bon Accord complex with Special Reference to Development and Management. Univ. West Indies, Dept Biol. Sciences, St Augustine, Trinidad.

Kenny, J.S. (1977). Checklist of the shallow-water corals of Trinidad. Living World (J. Field Nat. Club Trin. and Tob.) 1977: 33-36.

Kenny, J.S., Field, C., Ramsaroop, D., Allick, S. and Alkins, M. (1975). A guide to the shallow water corals of Trinidad. Dept Zoology, Univ. West Indies, St Augustine, Trinidad.

Laydoo, R. (1983a). Mass mortality of corals on the Trinidad north coast. Naturalist Magazine 5(2): 7-9. Laydoo, R. (1983b). Note in Reef Newsletter 9.

Laydon, R. (1985). 1. The coral reefs at Speyside, Tobago. 2. The reefs in Man-of-War Bay, Tobago. 3. The reef at Culloden Bay, Tobago. 4. The reefs at Arnos Vale Bay, Tobago. 5. The fore-reef slopes at the Buccoo Reef complex, Tobago. Natural Resources Division, Institute of Marine Affairs, Trinidad and Tobago.

Percharde, P.L. (1977). A comparison of the Strombus (Mollusca) colonies of Trinidad and Grenada. Living World (J. Field Nat. Club Trin. and Tob.) 1977: 18-20.

Ramsaroop, D. (1976). Studies on the Octocorallia of Trinidad. Ph.D. Thesis, Dept of Biol., Univ. West Indies, St Augustine, Trinidad. 317 pp. 
Ramsaroop, D. (1977). Common shallow water gorgonians of Trinidad. Living World (J. Field Nat. Club Trin. and Tob.) 1977-78: 21-32.

Ramsaroop, D. (1979). Fascinating species of the deep. Trin. Nat. 2(8):28-32.

Ramsaroop, D. (1981). A preliminary survey of the coral reefs in Man-O-War Bay, Tobago. Living World ( $J$. Field Nat. Club Trin. and Tob.) 1981-82: 26-33.

Rogers, C. (1985). Degradation of Caribbean and western Atlantic coral reefs and decline of associated fisheries. Proc. Sth Int. Coral Reef Congress, Tahiti, 6:491-496.

Scott, D.A. and Carbonell, M. (1986). A Directory of Neotropical Wetlands. IUCN, Gland and Cambridge.

Thelen, K.D. and S. Faizool (1980). Plan for a System of National Parks and other Protected Areas in Trinidad and Tobago. Forestry Division, Ministry of Agriculture, Land and Food Production, Port of Spain, Trinidad, May 1980, 106 pp.

Warner, G.F. (1981). Species descriptions and ecological observations of black corals (Antipatharia) from Trinidad. Bull. Mar. Sci. 31(1): 147-163.

Wood, H. (1964). Survey of Buccoo Reef. Fishery Research Dept, Ministry of Tobago Affairs.

Wood, H.E. (1979). Management of Buccoo Reef. In: Proc. Caribb. Cons. Assoc. Workshop - Tobago. April-May, 1979.

\section{ARNOS VALE BAY PROPOSED PROTECTED AREA}

Geographical Location $11^{\circ} 13^{\prime} \mathrm{N}, 60^{\circ} 46^{\prime} \mathrm{W}$; approximately $1.0 \mathrm{~km}$ north-east of Plymouth, Tobago.

Area, Depth, Altitude The mouth of the bay is about $0.25 \mathrm{~km}$ wide and the bay is horseshoe-shaped, extending for about $0.16 \mathrm{~km}$ inland and $0.5-10.0 \mathrm{~m}$ deep.

Land Tenure Public (Government-owned) except for a small, privately owned hotel situated close to the high water mark at the head of the bay.

Physical Features The bay is situated at the foothills of the island's main ridge and has a beach approximately $150 \mathrm{~m}$ long. The floor of the bay is comprised largely of rocks and boulders with a sandy boat channel on the western side. The water is generally calm and clear all year but ground swells and heavy surf tend to occur between November and March.

Reef Structure and Corals Rocks and boulders of Tectonic origin scattered over most of the bay's floor provide substrate for coral growth. Most of the common reef fauna and flora described for other reef localities in Tobago occur here (Almy and Almy, 1974).

Noteworthy Fauna and Flora The major attraction of the bay is the variety of reef fish.

Scientific Importance and Research A survey of the marine community has been completed and a report is in preparation (Laydoo, 1985).

Economic Value and Social Benefits The bay is regarded as one of the top nature spots in the island. The Amos Vale Hotel, which provides the main access to the bay, is a popular tourist resort and makes full use of the adjacent marine ecosystem as a source of recreation and education for its guests.

\section{Disturbance or Deficiencies Minimal.}

Legal Protection None at present.

Management The area is to some extent "managed" by the hotel. Visitors are encouraged to practice conservation in their visits to the bay. Line fishing, spearfishing, trapping and collection of marine organisms in the bay is strongly discouraged. A booklet describing the area is available (Almy and Almy, 1974).

Recommendations In preparation.

We are very grateful to R.S. Laydoo for compiling the preliminary draft of this account.

\section{BUCCOO REEF/BON ACCORD LAGOON RESTRICTED AREA}

Geographical Location $11^{\circ} 10^{\prime} \mathrm{N}, 60^{\circ} 50^{\prime} \mathrm{W}, 12 \mathrm{~km}$ south-west of Scarborough, on a shallow shelf extending off the northern coast of south-western Tobago.

Area, Depth, Altitude 650 ha (terrestrial area $=300 \mathrm{ha}$ ); sea-level to $20 \mathrm{~m}$ depth; Bon Accord Lagoon is 34 ha.

Land Tenure The reef is state owned; land adjacent to Bon Accord Lagoon is privately owned.

Physical Features The reef, consisting of five, distinct platforms separated by sand channels and enclosing a lagoonal area largely devoid of corals, extends in an arc from Sheerbird Point northwards and westwards, to approximately $1.6 \mathrm{~km}$ north of Pigeon Point. There is one channel through the reef. Further details are given in Kenny (1976) and ECNAMP (1979).

Reef Structure and Corals Buccoo Reef is composed of dense Acropora palmata, with large clumps of Millepora complanata. The fore-reef on the windward side has rich and varied populations of Montastraea, Colpophyllia and Siderastrea, together with Porites furcata and extensive $A$ cervicornis. The best stands of living coral occur in the lee of the north-eastem windward reef flat. Four patch reef types, each with distinct coralgal assemblages were identified in the back-reef and lagoonal areas (Hudson, 1984). In the south of Bon Accord Lagoon, Type 1 patch reefs with an algae-Porites assemblage, are dominated by sparse colonies of $P$. porites and Porites coral rubble encrusted with Halimeda opuntia. Type 2 and Type 3 patch reefs are found on the eastern and western flanks of the central reef lagoon. The former, with Acropora assemblages, are dominated by thickets of $A$ cervicornis; the latter, with Acropora-Millepora assemblages, are heavily encrusted with Halimeda and an unidentified fleshy green algae. The Montastraea assemblage of Type 4 patch reefs is dominated by $M$. annularis coral heads, and is confined to the northern portion of the lagoon at the southern entrance of the Blind Passage Channel. 
Noteworthy Fauna and Flora A remarkable forest of red mangrove Rhizophora mangle fringes Bon Accord Lagoon and forms a zone up to $70 \mathrm{~m}$ wide, with some trees up to $15 \mathrm{~m}$ high, perhaps due to the age of the forest or to the optimal conditions. Extensive patches of turtle grass Thalassia spp. and the red alga Acanthophora spp. occur in the lagoon. Halimeda opuntia is an abundant alga on the reef and is an important sand contributor in the Buccoo Reef area.

The avifauna includes the Black-crowned Night Heron Nycticorax nycticorax, the Brown Pelican Pelecanus occidentalis, the Common Gallinule Gallinula chloropus, the Green Heron Butorides virescens, the Little Blue Heron Florida coerulea, the Sandwich Tern Sterna sandvicensis and the Sooty Tern S. fuscata (Thelen and Faizool, 1980; Scott and Carbonell, 1986). The Caribbean Manatee Trichechus manatus and the Hawksbill Turtle Eretmochelys imbricata may occur here; the Green Turtle Chelonia mydas and the Leatherback Dermochelys coriacea have been recorded but are not listed by Thelen and Faizool (1980). The fish fauna is typical of West Indian coral reefs and larval forms of game fish are common. Invertebrates include the Spiny Lobster Palinurus argus and Queen Conch Strombus gigas.

Scientific Importance and Research Scientific facilities are available through the Departments of Zoology and Biological Sciences, University of the West Indies, St Augustine, and the Institute of Marine Affairs, Chaguaramas, Trinidad. Several general surveys have been conducted, such as that of Wood (1964). Studies have been carried out on reef structure, sedimentation (Hudson, 1983) and water movement. Remote sensing data analysis has also been undertaken as part of an ecological planning project (Environmental Systems Corporation, 1972). Studies of Buccoo Reef fore-reef are currently underway (Laydoo, 1983b).

Economic Value and Social Benefits The area is part of an extensive recreation and tourist complex and has considerable numbers of visitors throughout the year. Boats (including glass-bottom boats) take visitors from Buccoo Bay and Store Bay to reef areas at low tide, and snorkelling and diving are popular activities (IUCN, 1982). The area is also used by local people, school parties and fishermen (Wood, 1979).

Disturbance or Deficiencies In 1963, Hurricane Flora damaged corals around Goat Island and the Buccoo Reef area. The reef crest and mangroves were particularly seriously affected (Wood, 1979). A further area has been cleared for development. The reefs have been affected by dragging of anchors by reef guide-boats, trampling and souvenir collecting by visitors, frequent and illegal removal of commercial species and increased sedimentation induced by on-shore developments (Ramsaroop, 1981; Wood, 1979). It has been estimated that about $95 \%$ of the shallow reef area has been destroyed, but there are signs that some of this is regenerating. Most of the coral below two metres depth is still flourishing (Kenny in litt., 1.7.86).

Legal Protection The reef and surrounding waters were proclaimed as a Restricted Area in 1973 and the taking of fish and any species of other marine fauna is regulated under the Marine Areas (Preservation and Enhancement)
Act of 1970 (IUCN, 1982). Land adjacent to Bon Accord Lagoon is not legally protected but the owners prohibit hunting and restrict access (Scott and Carbonell, 1986).

Management The reserve is treated as a strict Nature Reserve and is administered by the Ministry of Agriculture, Lands and Food Production, Trinidad and Tobago (IUCN, 1982). In 1979, there were three patrol officers and a patrol boat. The boundaries were to be marked in 1979. In 1978, the National Training Board and Tourist Board gave lectures to commercial operators using the park to increase their understanding of the marine environment (Wood, 1979).

Recommendations Goreau (1967) drew up a list of recommendations for the management of the area and Kenny (1976) and Wood (1979) discussed development and management of the reserve in the 1970s. Participants of the Eastern Caribbean Workshop on Natural Area Management Planning prepared a master plan for the protection and use of the area (ECNAMP, 1979), which included a zoning plan, suggested boundaries and outlined interpretive and research programmes. The newly established Crusoe Reef Society considers improved management of the area to be its first priority. A number of proposals have been made including the formation of voluntary work parties, the erection of signs, the establishment of permanent moorings and markers for boat lanes, the monitoring of marine life, the implementation of measures to eliminate sewage pollution, the formation of an educational and visitors programme and initiation of policing of the area by local people (Kenny in litt., 1.7.86).

\section{CULLODEN BAY PROPOSED PROTECTED AREA}

Geographical Location $\quad 11^{\circ} 15^{\prime} \mathrm{N}$, $60^{\circ} 45^{\prime} \mathrm{W}$; approximately $4 \mathrm{~km}$ north-east of Plymouth, Tobago.

Area, Depth, Altitude Bay less than $4 \mathrm{~m}$ cieep but reef extends to $25 \mathrm{~m}$.

Land Tenure Public (Government-owned); small privately-owned plantation acreage.

Physical Features The bay is situated at the foothills of the island's main ridge and has a beach approximately $100 \mathrm{~m}$ long. It is shallow (less than $4 \mathrm{~m}$ ) and is characterized by a rocky substrate and sediment patches that merge into a reef crest approximately $100 \mathrm{~m}$ off shore. Owing to the shallowness of the bay and its semi-exposed location, heavy surf and large breakers are common all year round.

Reel Structure and Corals A fringing coral reef extends across the $300 \mathrm{~m}$ wide mouth of the bay. The reef extends to depths below $25 \mathrm{~m}$ and has a fore-reef characterized by a spur and groove formation. The reef flora and fauna are similar to that described for other reef localities in Tobago (Laydoo, 1985).

Noteworthy Fauna and Flora Not known.

Scientific Importance and Research This reef could be important as a future control site in monitoring the 
impacts of development and tourism-related activities at other reef localities in Trinidad and Tobago. A survey of reef extent and flora and fauna has been completed (Laydoo, 1985).

Economic Value and Social Benefits The bay has traditionally been used as a fishing base for a small number of fishermen from adjacent villages. The marine area off the Culloden reef is noted for its rich pelagic fishing grounds.

Disturbance or Deficiencies Storm-related damage is evident. Human activity in the bay is limited to fishing boats crossing the reef crest and back-reef and has had minimal impact on the reef. The shallow, rocky back-reef restricts boat transit even under good sea conditions and has resulted in pleas to the local authority, by fishermen using the bay, for the dredging of a boat channel through the back-reef and reef crest.

Legal Protection None at present.

Management None in effect.

Recommendations In preparation.

We are very grateful to R.S. Laydoo for compiling this account.

\section{EASTERN TOBAGO PROPOSED NATIONAL PARK}

Geographical Location The north-eastern tip of Tobago, including all the land area with the offshore coastal islands and marine communities. Includes Man-O-War Bay at $11^{\circ} 19^{\prime} \mathrm{N}, 60^{\circ} 34^{\prime} \mathrm{W}$, and the Speyside area, $11^{\circ} 18^{\prime} \mathrm{N}$, $60^{\circ} 31^{\prime} \mathrm{W}$, including waters around Goat Island and Little Tobago (Bird of Paradise) Island.

Area, Depth, Altitude Approximately 5700 ha recommended for protection. Man-O-War Bay is $2.5 \mathrm{~km}$ wide at the mouth, extending $2 \mathrm{~km}$ inland; the Speyside area is approximately 130 ha bounded by about $10.8 \mathrm{~km}$ of coastline.

Land Tenure Public (Government-owned) with a small percentage of privately-owned estates.

Physical Features The north-eastern end of Tobago's main ridge formation, adjacent to the Speyside and Man-o-War areas, reaches $576 \mathrm{~m}$. The coastline is characterized by steep slopes, with bays and beaches. In the Speyside area, the principal mainland bays are Bishop's (Indian) Bay, Tyrell's Bay (the largest), Anse Bateau (Blue Waters Bay), Anse Brisant (Belmont Bay) and Anse Gouleme (Starwood Bay), all of which have access roads or tracks. Several rivers on the mainland drain into the marine area, the largest of which is Doctors River which flows out at the northern end of Tyrell's Bay.

Man-O-War Bay, on the north coast, is one of the largest on the island. The coastline is precipitous and dotted with sandy beaches, the longest of which extends for about $0.5 \mathrm{~km}$ between Charlotteville and Cambleton. Smaller ones occur at Pirate's Bay on the east and Hermitage on the west. The bottom is covered with sand and mud, except where there are coral formations in shallow water, and slopes towards the mouth of the bay to depths of $80 \mathrm{~m}$. There is a clockwise eddy and waters are relatively calm, except during November and January when large ground swells are common.

In the Speyside area, Goat Island (5.8 ha) lies about $1.5 \mathrm{~km}$ east of Speyside village with Little Tobago Island (113 ha) about $1.5 \mathrm{~km}$ further east. Deep channels between Tobago and Goat Island and between Goat Island and Little Tobago merge to the south and north of Goat Island. The edge of the continental shelf, at $91 \mathrm{~m}$, is located approximately $600 \mathrm{~m}$ off the south-eastern tip of Little Tobago Island. Little Tobago Bay is on the west coast of Little Tobago Island and is accessible by sea only.

Man-O-War Bay is surrounded by hills which effectively shield it from the prevailing easterly winds. The Speyside area is exposed all year round to the north-east trade winds, Little Tobago Island and Goat Island providing a little shelter. In this area, currents are generally in a northerly direction, and tend to be stronger in shallow areas such as around the Weather Rocks between Bateau and Belmont Bays. Water visibility is generally excellent and averages $15 \mathrm{~m}$. The mean surface and subsurface temperature is $26^{\circ} \mathrm{C}$, and mean salinity is $33 \mathrm{ppt}$. Annual precipitation is approximately $2250 \mathrm{~mm}$ with the driest period from February to April.

Reef Structure and Corals About $45 \%$ of the coastline from the north-eastern end of Anse Gouleme to the south-eastern end of Tyrell's Bay (Lucy Vale Point), including the offshore islands, has fringing reef. Particular sites include Anse Gouleme, Anse Brisant, Anse Bateau, north and south Tyrell's Bay and the west coasts of Goat Island and Little Tobago Island. Little Tobago Reef is the largest, extending for about $2 \mathrm{~km}$, with an extensive back-reef area in Little Tobago Bay. The other reefs range from 0.5 to $1 \mathrm{~km}$ in length. Big Reef is a patch reef in Tyrell's Bay, the seaward edge of which is about $0.3 \mathrm{~km}$ east of Speyside and extends $0.3 \mathrm{~km}$ in a north-south direction. Bateau and Brisant (Belmont) Reefs merge off the headland in a generally turbulent area around the Weather Rocks. Depths of the reef crests range from $1.5 \mathrm{~m}$ to $9 \mathrm{~m}$ and of the reef bases from $10 \mathrm{~m}$ to $35 \mathrm{~m}$. Fore-reef slope angles range from 20 to $40^{\circ}$ in the upper fore-reef to $50-80^{\circ}$ in the deep fore-reef.

In the Speyside area, four zones have been recognized and are described in detail by Laydoo (1985). The back-reef zone extends seaward for $0.05-0.3 \mathrm{~km}$ to depths of $1-6 \mathrm{~m}$ and is characterized by a sandy bottom with occasional rocky outcrops close to shore and coral patches seaward. The latter are dominated by Diploria strigosa and Siderastrea siderea. The reef flat is $50-200 \mathrm{~m}$ wide with an average depth of $2 \mathrm{~m}$, and consists mainly of Acropora palmata and Porites porites rubble encrusted with Lithophyllum spp. The living fauna is dominated by Palythoa mammillosa, Mille pora spp. and includes a variety of octocorals, sponges and stony corals. The reef crest, 1-5 m wide, is emergent at low tide in some areas and is characterized by a coral rubble substrate almost entirely covered by a carpet of $P$. mammillosa and Mille pora spp.

The fore-reef slopes down to $10-35 \mathrm{~m}$ depth where it merges into a sand plain and it has been divided into four sub-zones. The upper fore-reef (to $10 \mathrm{~m}$ depth) consists 
mainly of A palmata and Porites porites rubble with widespread Palythoa mammillosa. A variety of other corals and octocorals are present. The mid fore-reef (10 to $18 \mathrm{~m}$ depth) is characterized by platy colonies of Montastraea annularis, up to $5 \mathrm{~m}$ in height, with abundant foliose gorgonian octocorals and other stony corals. The lower fore-reef (below $18 \mathrm{~m}$ ) has dense populations of octocorals and sponges with a variety of stony corals. Where this subzone extends below $22 \mathrm{~m}$, e.g. between Bateau and Belmont Reefs, and at Goat Island and Little Tobago Reefs, the coral fauna is dominated by arborescent colonies of black coral (Laydoo, 1985).

In Man-O-War Bay, the two largest coral formations are at Booby Island and Pirate's Bay. Smaller formations occur north of Pirate's Bay, opposite the Government Rest House and opposite Charles Turpin's house (Ramsaroop, 1981).

Booby Reef is triangular, the shoreline forming the base of about $150 \mathrm{~m}$ width, and the apex at Booby Island, lying $85-90 \mathrm{~m}$ from shore. The reef top is generally less than $1 \mathrm{~m}$ below the surface near the shore and gradually deepens seaward to depths of $2-3 \mathrm{~m}$ near Booby Island. Acropora palmasa is the dominant coral with occasional small colonies of the octocorals Gorgonia ventalina and Briareum asbestinum and the stony corals Diploria spp., Agaricia spp., Favia fragum, and Montastraea annularis. To the east, the reef extends at its deepest to about $25 \mathrm{~m}$ near Booby Island. On the east slope there are three main zones below the Acropora palmata reef top zone. At 3-7 m, Palythoa mammillosa, Millepora alcicornis and $A$ palmata are predominant. Other common species in this zone are the gorgonians Plexaura flexuosa, Muricea elongata and Eunicea tourneforti and the corals Eusmilia fastigiata, A cervicornis, Porites porites and Millepora complanata. From 7 to $15 \mathrm{~m}$, the Pseudopterogorgia zone has large and numerous colonies of $P$, acerosa and $P$. americana, sometimes up to $2 \mathrm{~m}$ high. This zone has the most diverse coral fauna. From $15 \mathrm{~m}$ to the lower limit of the reef, gorgonians are smaller and more sparsely distributed and there is a variety of stony corals. The west slope is similar and has the same general zonation, the slope ending in a sandy bottom at $20-25 \mathrm{~m}$. On the northern side of Booby Island, the sea floor drops precipitously to $20-25 \mathrm{~m}$ and then more gently to greater depths. Above $20 \mathrm{~m}$, stony corals and gorgonians abound, and include the only ahermatypic corals found on the reef (Ellisella elongata, Lophogorgia punicea, Iciligorgia schrammi, Nicella schmitti and black corals Antipathes spp.).

Pirate's Reef extends southwards from the southern end of Pirate's Bay to the northern limit of Charlotteville. It extends $50-60 \mathrm{~m}$ off shore and has a maximum depth of $12-15 \mathrm{~m}$. The reef fauna has a similar zonation to that at Booby Reef. The reef top $(0.5$ to $2 \mathrm{~m})$ is dominated mainly by Acropora palmata but there are also large patches of Palythoa mammillosa and many colonies of Montastraea complanata, M. annularis and Diploria spp. Between 2 and $5 \mathrm{~m}$, there is a more diverse community with a variety of stony and soft corals.

Rest House Reef, opposite the Government Rest House, extends $25-30 \mathrm{~m}$ offshore and is about $40 \mathrm{~m}$ wide at its widest point. It terminates seawards at $6-7 \mathrm{~m}$ depth.
Only 30 species of corals have been observed compared with $\mathbf{4 8}$ for Booby Reef and $\mathbf{4 2}$ for Pirates Reef. Above $3 \mathrm{~m}, A$ palmata and Madracis asperula predominate; below $3 \mathrm{~m}$ gorgonians, especially Pseudopterogorgia americana, $P$. acerosa, Plexaura spp. and Pseudo plexaura spp. and the stony corals Meandrina meandrites, Diploria spp. and Millepora spp. are abundant. Turpin's Reef, to the west of Rest House Reef is similar in size but has not been studied in detail (Ramsaroop, 1981).

Noteworthy Fauna and Flora The Green Turtle Chelonia mydas, Hawksbill Eretmochelys imbricata and Leatherback Dermochelys coriacea may occur here. Lists of corals, other reef invertebrates and fish are given in Ramsaroop (1981). Fish, lobsters, Panulirus argus and $P$. gurtatus, and conchs, Strombus gigas and $S$. costatus, are found in the area as well as large specimens of the Atlantic Thomy Oyster Spondylus americanus. The area is also important for its avifauna.

Scientific Importance and Research The reefs at Speyside occur at a location least subject to influence by the Orinoco effluent, the major environmental factor influencing marine life in the coastal waters of Trinidad and Tobago. They therefore represent an ecosystem in a relatively healthy environment free from both natural and man-induced sources of damage and provide an ideal locality for scientific monitoring, ecological research and marine recreation. The area was surveyed by Ramsaroop (1981) and Laydoo (1985) as part of a series of surveys of the reefs of Tobago.

Economic Value and Social Benefits The area is important for a subsistence fishery (fin-fish, shellfish), shell and coral collecting, tourism, recreation (bathing, snorkelling, skin and scuba diving), bird watching and education. In Man-O-War Bay, Pirate's Reef, which can be approached from Pirates Bay, and Rest House Reef and Turpin's Reef, which lie next to a beach with road access, are accessible for snorkelling and diving (Ramsaroop, 1981).

Disturbance or Deficiencies The reefs are practically undisturbed by man except for a few shallow areas where corals have been destroyed by boat anchors. The major disturbance appears to be storm-related damage and is most prominent in shallow reef areas. Grazing by the sea urchin Diadema antillarum has had a noticeable impact on corals in the back-reef zone. An increase in diver pressure could cause problems (Ramsaroop, 1981).

Legal Protection None at present.

Management None in effect.

Recommendations Proposed as the Eastem Tobago National Park. Recommendations are in preparation.

We are very grateful to R.S. Laydoo for compiling accounts of the Man-O-War Bay and Speyside reefs which have been used as the basis for this description. 


\section{SALYBIA REEF (INCLUDED IN PROPOSED GALERA POINT NATURAL LANDMARK)}

Geographical Location $10^{\circ} 50^{\prime} \mathrm{N}, 60^{\circ} 56^{\prime} \mathrm{W}$; north coast of Trinidad's north-eastern peninsula, close to the fishing village of Toco and Galera Point.

Area, Depth, Altitude Reef is $1.5 \mathrm{~km}$ long, lagoon depth 0.5-2 m.

\section{Land Tenure Public (Government owned)}

Physical Features The reef runs from east to west about $90 \mathrm{~m}$ from the beach in Salybia Bay, joining the shore at the western end, and consists of a thin veneer of corals lying over large boulders or plates of bedrock (Kenny et al., 1975). The reef crest is cut at several places by fairly deep channels and at most low tides is fully exposed; towards the western comer there is a deep hole on the reef face. The reef shelters a lagoon which is shallower at the eastem end, and has a strong westerly circulation, with a strong current flow at the outflow in the westem end. Lagoonal salinities vary from 5 ppt at the river outfall to $33 \mathrm{ppt}$ in the dry season. Lowest salinities occur in the wet season from July to November. Water temperatures in the Salybia area range from $\mathbf{2 5 . 5}$ to $28^{\circ} \mathrm{C}$, the lagoonal temperature reaching a couple of degrees higher, or as much as $31-32^{\circ} \mathrm{C}$ during very low tides (Kenny et al., 1975). Occasionally, at extremely low tides, parts of the lagoon may be cut off from the sea and at such times water temperatures may rise considerably.

Reef Structure and Corals The fauna of the lagoon varies according to environmental conditions. At the outfall of the river, there are few living organisms but elsewhere Porites spp., Zoanthus spp., the seagrass Thalassia spp. and the alga Bryopsis spp. are common. As the reef crest is approached, the fauna becomes more diverse. The reef flat comprises two zones. The Porites zone nearest the lagoon is dominated by $\boldsymbol{P}$. porites, with $\boldsymbol{P}$. astreoides, Favia fragum and Montastraea annularis in the deeper passages through the crest. There is a rich variety of algae and large numbers of Zoanthus sociatus. On the seaward side there is an almost continuous zone of the soft coral Palythoa mammillosa, $15-30 \mathrm{~m}$ wide in the surf belt. Porites porites and Millepora alcicornis are found in crevices.

The reef front slopes gently seaward to a plain of coral rubble and sand at about $20 \mathrm{~m}$ depth. The upper part has a rich fauna in some areas and towards the eastern end of the reef there are extensive growths of $P$. astreoides. Siderastrea radians, a species tolerant to high temperatures, grows in rock pools and in the splash zone $4-5 \mathrm{~m}$ above MHW. In the central part, fairly extensive colonies of Acropora prolifera occur. The western end is most diverse with brain and star corals, possibly elkhorn coral, and many octocorals. The hole at the western end of the reef is lined with a luxuriant growth of sponges, hydroids and corals. Erratic coral heads may occur off shore, particularly at the western end (Kenny el al., 1975).

Noteworthy Fauna and Flora A variety of fish are abundant in the channels through the reef crest. A diverse invertebrate fauna is found in the reef crest pools, as well as Green Morays Gymnothorax funebris, Spiny Lobster Panulirus argus and, occasionally, small Hawksbill Turtles Eretmochelys imbricata. Cowries, musical volutes and cone shells are found, and occasionally Strombus gigas in the lagoon (Kenny et al, 1975).

Scientific Importance and Research The reef is used as a field site for the final year option in Marine Ecology offered at the Department of Zoology, St Augustine Campus, University of the West Indies. It is the only living fringing coral reef in the coastal waters of Trinidad. Fossil reef formations along the west coast may be related to the opening of the Serpent's Mouth at the south-western tip of Trinidad and the geological events surrounding the formation of the Caroni plain, south of the Northern Range.

Economic Value and Social Benefits A fishing area and public recreation site on weekends and holidays. Sea bathing is safest at low tide when the longshore current in the narrow lagoon separating the reef crest from the mainland, is slowest. This also permits access to the reef crest for educational field trips in marine ecology.

Disturbance or Deficiencies At extreme low tides, elevated lagoonal temperatures sometimes cause high fish mortalities. Damage from human activities is minimal (Kenny et al., 1975).

Legal Protection None at present.

Management None in effect.

Recommendations Proposed as a Natural Landmark (Thelen and Faizool, 1980). Management objectives for the area are to protect the reefs, beaches, landscape, cultural and geological features, and to provide for intensive beach and extensive recreational and tourist activities.

We are very grateful to R.S. Laydoo for compiling the preliminary draft of this account. 


\section{INTRODUCTION}

\section{General Description}

The Turks and Caicos Islands, a British Colony, comprise the south-eastern extension of the Bahamas Platform and lie between $21^{\circ}$ and $22^{\circ} \mathrm{N}$ and $71^{\circ}$ and $72^{\circ} 30^{\prime} \mathrm{W}$. They consist of eight large islands, two of which are currently uninhabited, and approximately 40 small, virtually uninhabited cays, making up a total land area of 505 sq. $\mathrm{km}$ extending over $160 \mathrm{~km}$. The islands rest on deep limestone platforms bisected by deep water passages and the two main banks are separated by the Turks Island Passage, $35.5 \mathrm{~km}$ wide and more than $2200 \mathrm{~m}$ deep. The islands are arid and barren, with cliffs on the windward side and large areas of mangrove swamp on the leeward side. There is a dry season from January to May (average monthly precipitation $31.5 \mathrm{~mm}$ ) and a wet season from June to December (average monthly precipitation $62.8 \mathrm{~mm}$ ). Precipitation gradually increases northwards, although even in the northern islands rainfall never exceeds $760 \mathrm{~mm}$ a year. Temperatures rarely fluctuate beyond a range of $16^{\circ} \mathrm{C}$ to $35^{\circ} \mathrm{C}$, averaging $25^{\circ} \mathrm{C}$ in winter and $29^{\circ} \mathrm{C}$ in summer. The prevailing easterly trade winds make the eastern side choppy but the western side is generally calm. Currents generally run to the north and are stronger around the northern and southern tips of Grand Turk. Water temperatures range from $22^{\circ} \mathrm{C}$ in winter to $28^{\circ} \mathrm{C}$ in summer and underwater visibility is exceptional. Average salinity is $35 \mathrm{ppt}$.

There is comparatively little information on the reefs and surrounding marine environment. The geology of the islands is described by Guppy (1917) and Hopkins et al. (1982) and the sedimentology by Schneider (1964) and Schneider and Heezen (1966). Further general information on the islands is given in Doran (1955a), Smith (undated), Uchupi et al. (1971), Tucker (1974), Hutchings (1977), Mitchell (1983) and Orr and Halaby (1984). Ray and Sprunt (1971) carried out two aerial surveys of the shallow coastal waters and studied selected reefs to a depth of $120 \mathrm{ft}$ ( $36.6 \mathrm{~m}$ ) near Grand Turk, Long Cay, South Caicos and Providenciales. Operation Raleigh surveyed reefs off West Caicos, Providenciales and Grand Turk in 1985.

The Banks are morphogenetically similar to the Bahama Banks, being shallow oolitic sandbanks formed during fluctuations in sea level. The sediments of the Caicos Outer Ridge have been described by Schneider and Heezen (1966). The Caicos Bank, covering $7680 \mathrm{sq} . \mathrm{km}$, is the largest of the two banks, and is approximately triangular in shape with a width of 60 miles $(97 \mathrm{~km})$ at the 100 fathom line $(183 \mathrm{~m})$. The south sides are fringed with patchy boulder coral heads in a matrix of seagrass beds, at least $50 \%$ of this area being less than $2 \mathrm{~m}$ deep.

The Caicos Islands form a crescent around the north and east sides of the Bank, open to the south-west. The islands' windward eastern sides are ridged with hard, rocky, oolitic, limestone cliffs which are pitted and pierced by caves as a result of solution, and blow holes or swallow holes, which are circular depressions formed from collapsed cave ceilings. The islands are relatively fertile with a dense understorey of scrub brush and cacti flourishing below a canopy of low trees. The native lignum vitae Guaiacum of ficinale and the introduced Australian Cedar Casuarina equisetifolia are cominon. The narrow island shelf on the seaward side of the Caicos Islands broadens northwards, permitting the development of richer reefs towards Grassy Creek off East Caicos.

West Caicos is described in a separate account. Providenciales, North Caicos and Middle (Grand) Caicos are oriented east-west and have fine beaches and highlands in the most populated northem area and mangroves, tidal flats and lowlands to the south. Providenciales (96 sq. $\mathrm{km}$ ) is the highest island (max. alt. $85 \mathrm{~m}$ ), with long, low hills in the central and northern regions. North, Middle and East Caicos (109, 124 and $47 \mathrm{sq} . \mathrm{km}$ respectively) constitute a nearly contiguous land mass and are separated by only shallow creeks. Middle Caicos is famous for its numerous caves with stalactites and stalagmites. East Caicos has high hills dominated by Flamingo Hill (163 ft $(50 \mathrm{~m}))$, the highest point in the islands.

Reefs are not extensive on the northerly sides of Providenciales, North Caicos and Middle Caicos, although rich areas with abundant fish and conch are found, especially near Whaley Cut, inshore near the Third Turtle Inn, and in several locations off cuts between Providenciales and North Caicos. From North-west Point on Providenciales to Leeward-going-through Cut, the barrier reef is $2500-3000 \mathrm{~m}$ from the shoreline and is broken only by a few channels. Within this there are many reef patches, predominantly formed by Acropora spp. The Leeward Cays stretch the $15 \mathrm{~km}$ from Providenciales to North Caicos and are a series of a dozen low cays, all less than $5 \mathrm{~km}$ long, of very variable shape, often altered by hurricanes. Several of the cays are separated by high-energy channels, the largest of which is Fort George Cut, off Pine Cay. Differential nutrient flow from the banks creates highly productive marine communities in localized areas. Reefs out from these cays are more gradual in slope than in most other locations. Large Acropora coral communities dominate the shallow margins of the barrier and patches and spurs of plate, brain and starlet corals are interspersed by open sand floors. Gorgonacea and Flamingo Tongue Cyphoma gibbosum are abundant (Lott et al., 1984). In 1985, 35 sites on the reefs from North-west Point to Leeward-going-through Cut, including the Leeward Cays, Pine Cay and Fort George Cut were surveyed during the Operation Raleigh expedition. The reefs were found to be in good condition (Holliday in litt., 10.4.85).

Although the reefs further east are poorly known, there appears to be good coral off the north-easterly tip of North Caicos outside Bottle Creek. The zonation usually changes quickly from Acropora at the reef crest to brain and star coral-dominated spur and groove formations in the deeper waters. The exception to this is off Middle Caicos where a typical fringing reef hugs the shoreline from Highas Cay to Conch Bar (Lott et al., 1984). There is a spectacular ocean hole, over $400 \mathrm{~m}$ in diameter, just east of Vine Point on the southerly side of Middle Caicos, which was visited by the Operation Raleigh expedition. 


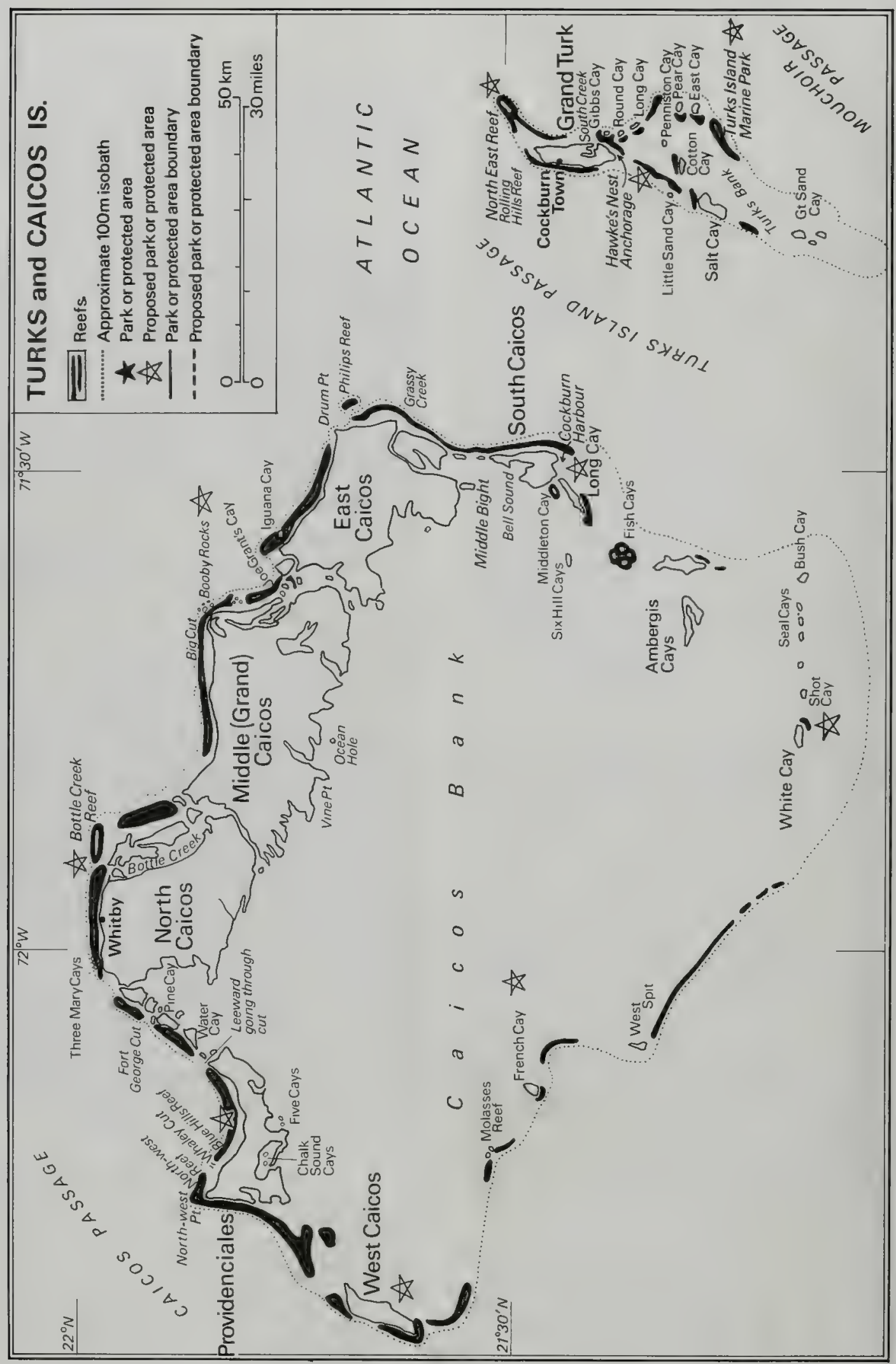


There appear to be good reefs from Booby Rocks and Big Cut off Middle Caicos, south-eastward towards Joe Grant's Cay and Iguana Cay, two unspoilt cays off the north-west coast of East Caicos. There are good beaches on the north-east side of East Caicos from Grassy Creek to Cape Comete (Drum Point) and excellent deep-water reefs are reputed to occur here outwards to Philips Reef. The finger of reef extending out from Drum Point begins in shallow water and drops to about $18 \mathrm{~m}$. Turtle Pond and Flamingo Creek are situated to the south and contribute to the importance of this area for wildlife. Fine reefs, topped with $A$ palmata, are found in Middle Bight between South Caicos and East Caicos and conch are particularly abundant.

South Caicos, the smallest of the major islands (22 sq. km), is "J"-shaped and encloses Bell Sound (an important fishery area) on the west side, with high hills along the eastern shore. Only the southern half of this ridge has a substantial land area in its lee, more than a third of which is composed of salt ponds. Middleton Cay lies approximately $6 \mathrm{~km}$ off Cockburn Harbour and was formed by the accumulation of discarded conch shells in recent times (Lott et al., 1984). An ocean hole, surrounded by black mangroves is found at the confluence of the dikes on the island. The reefs fringing the island and the impressive reef wall $180 \mathrm{~m}$ off Cockburn Harbour, which begins to drop off at about $16 \mathrm{~m}$, are posssibly the most productive in the islands due to upwellings of nutrient-rich water from the Turks Islands Passage. In the south-east, deep water occurs close inshore but the narrow reefs adjacent to the harbour entrance and, to a lesser extent, at the south end appear to be good; there is little information on reef structure in this area. A study of a deep reef off South Caicos was carried out in the course of a survey using Hydro Lab (Bunt et al., 1981).

South of South Caicos there is a group of small islands dominated by Long Cay and including Fish Cays, Ambergris Cays, Bush Cay, Seal Cays, Shot Cay and White Cay. Around these cays, ledges are often capped with coral growth. The seaward coast of Long Cay has cliffs with caves; the western leeward side has long sandy beaches. The island is covered with scrub, has a large blowhole and is popular for hiking and recreational activities. The shallow reef is mainly of $A$ palmata and has a wide variety of fish but few large individuals. The water is exceptionally clear. A smaller but equally rich reef is found beyond the north-west tip of Long Cay, near Dove Cay. Patch reefs, dominated by $A$ palmata, are found off the east coast of Ambergris Cay. Bush Cay is the most scenic of the smaller islands, and is a nesting site for Sooty Terns Sterna fuscata. Nurse Sharks Ginglymostoma cirratum are found in shallow waters around the island. The smaller cays to the west of Bush Cay all have good coral heads around them and are nesting sites for a variety of birds, particularly the Sooty Tern and Brown Noddy Anous stolidus. French Cay to the north-west is covered with vegetation and has a large population of breeding birds particularly Sooty Tems and Brown Noddies, and rich fish and shark populations in surrounding waters. The Institute of Nautical Archaeology (Texas) has excavated the oldest New World wreck ever found, at Molasses Reef, south of West Caicos (Lott et al., 1984).

The Turks Island group, covering an area of $27 \mathrm{~km}$, lies on the Turks Bank which is $59.2 \mathrm{~km}$ long from north to south, between 5 and $24 \mathrm{~km}$ wide and covers an area of $254 \mathrm{sq}$. km. The two largest islands are Grand Turk (19 sq. $\mathrm{km})$ and Salt Cay $(6.5 \mathrm{~km})$. They are fringed by eight smaller, uninhabited cays and numerous large exposed rocks. Grand Turk is elliptical in shape, the main land features being two parallel ridges oriented north-south, separated by a low-lying central valley. The only topsoil is an unproductive fine sandy dust. The porosity of the limestone limits the vegetation to a low scrub which includes tufts of sedge Dichomena colerata, and cacti Melocactus intortus and Cereus millsaughii. It has little relief except on its eastern side which has narrow sand hills reaching a height of $21.3 \mathrm{~m}$ and a rocky coast with beaches. The eastern side of the bank is broad and consists of grassy shoals and shallow fringing reef extending $2.5 \mathrm{~km}$ offshore to depths of $6-15 \mathrm{~m}$ (Lott et al., 1984). There are abundant patch reefs, topped with Acropora palmata, between North-east Reef to a little south of East Cay. These look excellent for diving at $30-40 \mathrm{ft}$ (9-12 m) depth (Ray and Sprunt, 1971). North-east Reef has a spectacular drop-off with a rich coral community in $40-50 \mathrm{ft}(12-15 \mathrm{~m})$ of water and abundant large fish. Grand Turk is bordered by a narrow shelf on the west and north with an abrupt drop-off; the reefs of the west coast are described in a separate account. To the south, the surrounding seas are shallow with offshore reef formations, and there are small rocky islands with good reefs, described in a separate account. Cotton and Salt Cays are the second largest islands in the Turks group. Salt Cay (6.5 sq. $\mathrm{km}$ ) has a bluff $18.3 \mathrm{~m}$ high on the north-west coast. The north side of the cay is fringed by reefs that extend approximately $1 \mathrm{~km}$ northwards. The north-west fringing reef $(1-15 \mathrm{~m}$ deep) is dominated by Acropora spp. The west side has a $0.5 \mathrm{~km}$ wide shore and fringing and patch reefs but there is little coral growth because of ballast stone dumping, although Gorgonacea and sponges are abundant. To the south there are shallow shoals (Lott et al., 1984). The Mouchoir Bank, approximately $65 \mathrm{~km}$ south-east of Salt Cay, and Silver Bank, lying between the Mouchoir Bank and the Dominican Republic, have reefs but no emergent areas.

Scott and Carbonell (1986) provide a list of important wetland sites. The salt pans and salinas of the Caicos Islands attract a variety of birds, particularly flamingos. Good stands of mangrove exist at South Creek on Grand Turk and on the bank sides of all the Caicos Islands, the dominant species being Rhizophora mangle, Laguncularia racemosa and Conocarpus erecta. Sprunt (1984) reviews the status of seabirds. Sea turtles are common, particularly Loggerhead Caretta caretta, Green Chelonia mydas and Hawksbill Eretmochelys imbricata which nest on many of the cays (Bacon et al., 1984; Carr et al., 1982). Adults of all three species are found in deeper water and juvenile Green Turtles inhabit the tidal creeks of North and Middle Caicos. Pilot Whales Globicephala melas are sometimes seen and migrating Humpback Whales Megaptera novaengilae pass through the Turks Island Passage during December to March on their way to breeding and birthing grounds on the Silver Bank. Leeward-going-through Cut and Grand Turk have resident populations of Bottlenose Dolphins Tursiops truncatus that often visit SCUBA divers. Marine fish of the Turks and Caicos are described by Nichols (1921). Manta Rays Manta birostris feed off the west wall of Grand Turk and Green Moray Eels Gymnothorax funebris appear occasionally in spring and summer (Lott et al., 1984). 


\section{Reef Resources}

Most of the population is centred on Grand Turk, South Caicos, Providenciales and North Caicos, with a scattering on Middle Caicos and Salt Cay. The outlying coral reefs, sandy beaches and scenic cuts and creeks are the major attractions of a tourist industry which is developing rapidly on many islands, its growth stimulated by the decline of the salt industry, the over-exploitation of fishery stocks and the closure of U.S. military bases (Stockly, 1984). Pristine reefs and beaches are accessible from all the islands (e.g. the west reef of Grand Turk is less than $1 \mathrm{~km}$ from the shore) and swimming, sailing, water-skiing and windsurfing are popular activities. Tourism is centred on Providenciales, which has a new airport and an extensive road network, and Grand Turk is the second most important area. Ambergris Cay is the only island of the southernmost group which is large enough for limited development although some of the smaller ones would provide good recreational opportunities. There are two SCUBA centres on Grand Turk which can accommodate about 500 divers a year, three on Providenciales and one on Pine Cay (Lott et al., 1984). The number of SCUBA divers visiting the islands is expected to increase considerably in the near future.

The fishing industry is small and potentially rich on a moderate scale, but it will not support large numbers of people (Ray and Sprunt, 1971). South Caicos is the centre of the industry, the salt industry having died out in the 1950 s. The Caicos Bank supports healthy populations of bonefish Albula vulpes, a sportfish of great potential for tourism (Lott et al., 1984). The Mouchoir and Silver Banks and other areas on the Caicos and Turks Banks are important breeding areas for the Queen Conch Strombus gigas and spiny lobster Panulirus argus and there is a major export fishery (Brown, 1983; Doran, 1955b). Brown and Stevely (1981), Dubois (1985), Hamaludin (1982), Kucharski (1980 and 1981) and Nardi (1982) discuss current trends in these fisheries. The Turks and Caicos dominated the conch market in the 1970 s but the spiny lobster fishery is now more important and a source of foreign revenue. The two products make up $95 \%$ of all fish export revenues generated and some 300 fishermen and 2000 individuals work in related support and service sectors.

\section{Disturbances and Deficiencies}

Rapid development, increased tourism and potential population expansion due to immigration of people from the Bahamas could put pressures on the reefs. Many of the leeward cays, such as Little Water Cay, Water Cay and George Cay which are currently wild and pristine, could be threatened by the rapid development of Providenciales, due to their accessibility. The area between Leeward-going-through Cut and Turtle Cove is coming under pressure, with the establishment of a Club Méditerranée on Providenciales and proposals for two hotels. Turtle Cove is showing signs of deterioration due to visitor pressure and could be polluted by effluent discharge from hotels. The proposed park site at Chalk Sound, off Providenciales, has been marked for development for residential purposes and for a hotel (Lott et al., 1984). Stockly (1984) discusses in more detail the conflict between the maintenance of an attractive reef and island environment and the development of hotels.
Littering and oil pollution were observed at Long Cay in 1970 (Ray and Sprunt, 1971) and littering is considered a potential problem on many of the reefs (Lott et al., 1984), but due to the lack of major industry, pollution is minimal. A freighter that had grounded south of Providenciales in 1981, was still a potential threat to the reefs in 1984, as its fuel tanks were still intact. Coral communities on the western side of Salt Cay were damaged by ballast stone dumping from old salting industry sloops but since the 1970s they have been recovering. Until recently the removal of sand for construction was causing serious damage to recreational beaches but this is now carried out at a designated area away from the beaches. A potential danger is a proposal to the Government for the mining of aragonite on the Caicos Bank north of and adjacent to West Caicos, with associated plans to build a road to link all the Caicos Islands from Providenciales to South Caicos (Lott et al., 1984). Slash and burn agriculture is widespread on the islands and could cause erosional siltation.

Large fish, such as groupers (Serranidae), were scarce in accessible areas like North-east Reef, Grand Turk, by the 1970s (Ray and Sprunt, 1971), suggesting that spearfishing was already extensive. Recent reports indicate that reefs are now being damaged by foreign poachers from Dominica, Haiti and Honduras, who exploit fish and lobsters intensively using bleach, spearguns and hooking (which has again been legalized as a fishing method) and who dive deeper than local fishermen. During the last few years several poaching vessels have been confiscated but in general, enforcement of fisheries legislation is inadequate (Gascoigne in litt. 1983 to Sir Peter Scott; Lott et al., 1984). However, local fishing is also not properly monitored and may well be more of a problem than foreign poaching. Conch are still fairly abundant but it is thought that they may be diminishing and spiny lobster numbers are considered to be near their maximum sustainable yield. The use of bleach in lobster fishing used to be a problem but this practice has now ceased among local fishermen.

\section{Legislation and Management}

The Fisheries Protection Regulations (1976) limit the taking of marine products through a licensing system. Fishing or taking of marine organisms with explosives or SCUBA apparatus is prohibited. Spearguns may be used only by residents and not within one nautical mile of the high tide mark; only two fish a day may be taken with a Hawaiian sling. There is a closed season for the spiny lobster Panulins argus from 1 April to 31 July and minimum sizes have been declared for lobster, conch, Hawksbill and Green Turtles. Berried or moulting lobsters may not be taken and methods which would harm them such as hooks and line are prohibited. There are also controls on conch exploitation. Turtles may not be collected on the beach or above low water mark and turtle eggs may not be taken at all. Net and trap fishing is prohibited in Bell Sound, within an area bounded on the north by a line from Horse Cay to Sail Rock Point.

The Foundation for PRIDE (Protection of Reefs and Islands from Degradation and Exploitation) is a non profit-making research and educational organisation, set up in Washington D.C. and operating out of Turks and Caicos, concerned with the management and use of the 
natural resources of the archipelago. Its activities include the development of educational programmes to inform local people of the importance of their marine resources (Brown, 1983) and projects with local diving establishments to improve safety standards and to encourage the rotation of different dive sites. Off Providenciales, dive operators have helped to keep trampling and marine curio collecting to a minimum. There has been little anchor damage and dive operators have recently established mooring buoys on selected sites where safe anchorage on a sand bottom is not available. The Turks and Caicos Islands are being used as a testing ground in the development of teachers guides to environmental education in the Caribbean region in a project being undertaken by RARE, Inc., PRIDE and the Turks and Caicos Development Trust. A conch commercial mariculture facility has been constructed at Leeward-going-through Cut by Trade-Winds Industries (Davis and Hesse, 1982). On Grand Turk, mariculture studies are now under way on the spider crab Mithrax spinosissimus and the West Indian Top Shell Cittarium pica by the Smithsonian Institution and Marine Systems Laboratories.

\section{Recommendations}

The IUCN Strategy for the Conservation of Living Marine Resources in the Caribbean Region recognises that the islands have a high concentration of marine resoures within the Bahamian sub-region, the Caicos Bank providing a relatively self-sustained and isolated ecosystem (IUCN, 1979). The Government through its Department of Planning in the Ministry of Commerce and Development is currently trying to improve management of natural resources but improved awareness of the connection between conservation and the development and maintenance of a healthy tourist industry is still required. Terms of reference are to be established with UN assistance for an ecological and management project to take place once funding becomes available. Efforts should be directed at the designation of parks and reserves with adequate legislation and the development of an enforcement capability (Lott et al., 1984). Holliday (in litt., 10.4.85) recommends that mooring buoys should be established where safe sand anchoring is not available; fishing should not take place in such areas; dive operators should be given Park Ranger status; and the discharge of effluent into Turtle Cove, Providenciales, should be prohibited. A project for continuous monitoring of reef condition is being set up by PRIDE.

Marine Reserves would be controlled via the Fisheries Department under the Fisheries Protection Ordinance of 1976 , but currently there is no agency directly responsible for the management of marine areas and there is little enforcement of fisheries legislation. Over $50 \mathrm{Marine}$ and Land Park areas were designated by the Temporary National Parks Commission under National Parks Ordinance (No. 11 of 1975) with Regulations (1976) but so far none of these have been gazetted. Additional recommendations will be made as a result of the Operation Raleigh expedition (Holliday in litt., 10.4.85). The following areas, including or adjacent to coral reefs, have been particularly recommended for protection $(*=$ marked on map):

\section{West Caicos}

- West Caicos Reserve (Ray and Sprunt, 1971) (see separate account).

\section{Providenciales}

- North-west Point as a Marine Park National Parks Committee, 1976); Whaley Cut and North-west Reef, Blue Hills Reef, and Leeward-GoingThrough Reef as an underwater park (Ray and Sprunt, 1971); North-west Reef to Pine Cay as a marine park with (a) North-west Reef to Little Bay, (b) reefs adjacent to Turtle Cove and towards Leeward-Going-Through and (c) reefs between (b) and Pine Cay as marine reserves (Holliday in litt., 10.4.85).

- Chalk Sound Cays including Silley Cays as a National Park (National Parks Committee, 1976; Ray and Sprunt, 1971): highly scenic recreational area vulnerable to pollution, comprising scattered sand spits; Five Cays as a Recreational Park (Ray and Sprunt, 1971): adjacent to Chalk Sound; this area is currently not considered a high priority for marine park designation because of the lack of coral growth (Holliday in litt., 10.4.85).

\section{North Caicos}

- $\quad$ Bottle Creek Reef as an underwater park (Ray and Sprunt, 1971).

- Three Marys Cays as a Wildlife Sanctuary (Ray and Sprunt, 1971): important for breeding ospreys.

\section{Middle Caicos}

- Booby Rocks as an underwater park (Ray and Sprunt, 1971).

\section{East Caicos}

- Iguana Cay as a Recreational Park (Ray and Sprunt, 1971): to protect iguana populations.

- Joe Grant's Cay as a Recreational Park (Ray and Sprunt, 1971): close to Turtle Pond and Flamingo Creek and therefore important for wading birds.

\section{South Caicos}

* Admiral Cockburn and Long Cay as a marine park and Long Cay as a National Park (National Parks Committee, 1976); Cockburn Harbour Reef as an underwater park (Ray and Sprunt, 1971): good SCUBA diving with cays and canyons; regular picnic area for township of Cockburn Harbour; Six Hill Cays as a Recreational Park (Ray and Sprunt, 1971): close to Long Cay, with breeding populations of terns; coral gardens and reefs in shallow water.

*White Cay, Bush Cay and French Cay as Wildlife Sanctuaries: French Cay is a prime seabird nesting site; abundant coral and reef around all cays (Ray and Sprunt, 1971)

- All other cays less than 0.5 mile $(0.8 \mathrm{~km})$ diameter in the Caicos Islands, including the small cays at south end of Lorimer Creek, Middle Caicos, to be protected (Ray and Sprunt, 1971). 
Grand Turk

*Turks Islands Marine Park and Reserve (Ray and Sprunt, 1971; Holliday in litt., 10.4.85); including Gibb's, Penniston and Round Cays recommended as reserves within the Park (National Parks Committee, 1976) (see separate account). *North-east Reef Park (Ray and Sprunt, 1971)

\section{References}

* = cited but not consulted

Bacon, P., Berry, F., Bjorndal, K., Hirth, H., Ogren, L., Weber, M. (1984). The National Reports. Proceedings of the Western Atlantic Turtle Symposium, Vol. 3. University of Miami Press, Florida.

Brown, J. (1983). The activities of PRIDE - Turks and Caicos Islands. Caribbean Conservation News 7(1): 20-22. Brownell, W.N. and Stevely, J.M. (1981). The biology, fisheries and management of the Queen Conch Strombus gigas. Mar. Fish. Rev. 43(7): 1-12.

Bunt, J.S., Williams, W.T. and Chalker, B.E. (1981). Coral associations at depths of 45 to 125 feet in the Bahamian region. Proc. 4th Int. Coral Reef Symp., Manila, Vol. 1: 707-714.

Carr, A., Meylan, A., Mortimer, J., Bjorndal, K. and Carr, T. (1982). Surveys of sea turtle populations and habitats in the Western Atlantic. NOAA Technical Memorandum NMFS-SEFC-91.

Davis, M. and Hesse, R.C. (1982). Third World level conch mariculture in the Turks and Caicos Islands. 35th Gulf and Carib. Fish. Inst. Conf., Nassau, Bahamas.

*Doran, E. (1955a). Land forms of the south-eastern Bahamas. Dept of Geogr., Univ. of Texas, Publ. 5509. Austin, TX. 38 pp. + maps.

Doran, E.B. (1958). The Caicos Conch trade. Geogr. Rev. 48: 388-401.

Dubois, R. (1985). Coastal fisheries management lessons learned from the Caribbean. Case Study 4. In: Clarke J.R. (Ed.). Coastal Resources Management: development case studies. Coastal Publication 3, Renewable Resources Information Series. Research Planning Institute, Inc., Columbia, South Carolina.

Guppy, H.B. (1917). General characters and geological structures of the Turks Islands. Williams and Norgate, London.

-Hamaludin, M. (1982). Fishing, an industry of potential and problems. The Turks and Caicos Current 1(9); 4-7.

-Hopkins, J. et al. (1982). Univ. of Calgary trip report.

-Hutchings, C.D. (1977). The story of the Turks and Caicos Islands.

IUCN (1979). A strategy for the conservation of living marine resources and processes in the Caribbean region. Final Report.

"Kucharski, K.M. (1980). The spiny lobster fishery in the Turks and Caicos Islands: $\mathbf{A}$ status report and recent landings. South Florida Institute of Marine Sciences, Ft Lauderdale.

-Kucharski, K.M. (1981). The Turks and Caicos Islands spiny lobster fishery: an update. Unpub. ms. South Florida Institute of Marine Sciences, Ft Lauderdale, 4 pp.

Lott, C., Mitchell, B. and Rollings, M. (1984). Coral Reefs of the Turks and Caicos Islands. Report prepared for the IUCN Coral Reef Directory.

Mitchell, B.A. (1983). Our undersea beauty, a hidden world. Turks and Caicos Current 1(1): 10-16.

Nardi, G.C. (1982). An analysis of the Queen Conch fishery of the Turks and Caicos islands, with a review of a new, multi-purpose dock receipt. Unpubl. ms., M.S. thesis. 47 pp. SUNY, Stony Brook, N.Y.

National Parks Committee (1976). Minutes of 4th meeting of the Advisory Committee National Parks, 7th November, 1975.

Nichols, J.T. (1921). A list of Turks Islands fishes, with a description of a new flatfish. Bull. Am. Mus. Nat. Hist. 44:21-24.

-Orr, K, and Halaby, J. (1984). The natural world of the Turks and Caicos Islands. McCollum Press, Rockville, Md., 62 pp.

Ray, G.C. and Sprunt, A. (1971). Parks and Conservation in the Turks and Caicos Islands. The Turks and Caicos Government.

Schneider, E.D. (1964). Sediments of the Caicos Cove, Bahamas (abst.). Amer. Assn. Petrol. Geol. Bull. 48: 546.

Schneider, E.D. and Heezen, B.C. (1966). Sediments of the Caicos Outer Ridge, the Bahamas. Geol. Soc. Am. Bull. 77: 1381-1398.

Scott, D.A. and Carbonell, M. (1986). A Directory of Neotropical Wetlands. IUCN, Gland and Cambridge.

"Smith, H. (undated). A History of the Turks and Caicos Islands. Published privately. Hamilton, Bermuda. Sprunt IV, A. (1984). The status and conservation of seabirds of the Bahama Islands. In: Croxall, J.P., Evans, P.G.H. and Schreiber, R.W. (Eds), Status and Conservation of the World's Seabirds. ICBP Technical Publication No. 2, Cambridge.

Stockly, M. (1984). Tourism and conservation: compatible ideas? Nexus 6(3): 1-7.

Tucker, T. (1974). The Turks and Caicos Islands Group in its relationship to Bermuda. Bermuda Hist. Quarterly 31(4): $78-89$.

-Uchupi, E., Milliman, J.D. and Luyendyle, B.P. et al. (1971). Structure and origin of the South-eastern Bahamas. Amer. Assn. Petrol. Geol. Bull. 55: 687-704.

\section{TURKS ISLANDS PROPOSED MARINE PARK AND RESERVE}

Geographical Location Includes Gibb's, Penniston and Round Cays and all small cays south and south-east of Grand Turk to Great Sand Cay but excluding Salt Cay.

Area, Depth, Altitude Great Sand Cay averages $11 \mathrm{~m}$ in height; depths average $20 \mathrm{ft}(6 \mathrm{~m})$ in many areas.

\section{Land Tenure No information.}

Physical Features From the south coast of Grand Turk, fringing and patch reefs extend $9 \mathrm{~km}$ in a SSE direction; the bank's edge lies $11 \mathrm{~km}$ further east and south-east of the fringing reef. Small rocky islands scattered in the shallow waters provide protection from the prevailing winds. Little Sand Cay, situated directly south of Grand Turk, is a horseshoe-shaped sand cay without vegetation. Great Sand Cay, the southernmost cay, reaches $11 \mathrm{~m}$ in altitude in the north and south, the two extremities being joined by a small neck of low bushy land. The windward side has limestone terraces with tidepools at low tide. The western shore has a long and very wide $(50 \mathrm{~m})$ carbonate sand beach (Lott et al., 1984). There are many caves among the reefs. 
Reef Structure and Corals This is a moderate to high energy wave area dominated by a framework of Acropora palmata and $A$ cervicornis Millepora spp. on an extensive sand bank with Thalassia testudinum. Large knobby Montastraea annularis colonies are also present, rising from the bottom to near the surface. Some of the best patch reefs are found in 20-30 ft $(6-9 \mathrm{~m})$ of water between Penniston, East and Pear Cays (Ray and Sprunt, 1971). Hawke's Nest Reef has good patch reefs with $A$ palmata and $A$ cervicomis. Great Sand Cay's north-west shore zone $(1-10 \mathrm{~m})$ is predominantly an Acropora palmataMillepora spp. framework. The south shore (at $15 \mathrm{~m}$ depth) has Gorgonacea on a sandy bottom (Lott et al., 1984).

Noteworthy Fauna and Flora There is a colony of Magnificent Frigatebirds Fregata magnificens on Penniston; Sooty Terns Stema fuscata and Brown Noddys Anous stolidus nest on Gibb's and Round Cays (Ray and Sprunt, 1971). Queen Conch Strombus gigas is abundant at Great Sand Cay. Marine turtles may nest in the area although there are no definite records (Bacon et al., 1984).

Scientific Importance and Research Briefly surveyed by Ray and Sprunt (1971), Lott et al. (1984) and the Operation Raleigh expedition (Holliday in litt, 10.4.85)

Economic Value and Social Benefits There is considerable potential for recreational activities, such as boating and picnicking, on Gibb's, Penniston and Round Cays. Great Sand Cay is one of the finest recreational sites in the area and the most scenic with fine sandy beaches to the north and west and spectacular arches and cliffs on the east and south. Ray and Sprunt (1971) consider that none of the cays are suitable for development, but they are highly scenic. Hawke's Nest Reef is accessible for swimming and snorkelling and has considerable tourist value, and is the departure point for excursions to other cays.

Disturbance or Deficiencies Spearfishing may have caused the decline of large groupers and other fish (Mitchell in litt., 12.4.85). Hawke's Nest Reef showed signs of damage in 1971; the beach had considerable litter and sand extraction was common (Ray and Sprunt, 1971).

Legal Protection Gibb's, Penniston and Round Cays were designated as a Recreational Park by the National Parks Committee (1976) but have not been gazetted.

Management None at present.

Recommendations Ray and Sprunt (1971) recommended that this area be created the Turks Islands Marine Park and Reserve. Underwater Parks have been suggested for the reefs between Penniston, East and Pear Cays, and for Hawke's Nest Reef. Holliday (in litt., 10.4.85) makes similar recommendations on the basis of the findings of the Operation Raleigh expedition. Some of the cays should perhaps be closed during the nesting season.

\section{WEST CAICOS PROPOSED RESERVE}

Geographical Location $21^{\circ} 41^{\prime} \mathrm{N}, 72^{\circ} 28^{\prime} \mathrm{W}$; westernmost cay in the chain.

Area, Depth, Altitude $18 \mathrm{sq} . \mathrm{km}$.; average altitude $15 \mathrm{~m}$; maximum altitude (South-west Point) $19.8 \mathrm{~m}$; depths begin at about $9 \mathrm{~m}$ on the east of south-west reef, just within the edge of the bank. Plateau depths $12-24 \mathrm{~m}$.

Land Tenure No information.

Physical Features The western shore line is steep, the drop-off beginning approximately $450 \mathrm{~m}$ from shore. There are spectacular submarine vertical clifs and caves in some areas.

Reef Structure and Corals The north-west reef has an Acropora Millepora zone at 1-12 m over a detrital rubble bottom. The mid-west reef consists of patchy head coral communities scattered within a fringing reef at $5-20 \mathrm{~m}$. Montastraea, Siderastrea and Diploria predominate. The south-west ledge $(20 \mathrm{~m})$ to the southern extremity $(12 \mathrm{~m})$ has elongated bars of hard boulder and starlet corals at the top of the drop-off, separated by long sand gulleys tapering to greater depths. The south-west reef is gradually replaced by a seagrass bed with many sponges to the east (Lott et al., 1984).

Noteworthy Fauna and Flora In the south, there is a shallow seagrass bed of Thalassia testudinum scattered with Gorgonacea and numerous large Loggerhead Sponges, Spheciospongia vesparium, Ircinia strobilina and the large $(1.5 \mathrm{~m})$ Vase Sponge Ircinia campana which is dominant. Queen Conch Strombus gigas is abundant (Lott et al., 1984). Hawksbill Eretmochelys imbricata and Green Chelonia mydas Turtles may nest on West and South Beaches (Bacon et al., 1984).

Scientific Importance and Research Briefly surveyed by Ray and Sprunt (1971), Lott et al. (1984) and the Operation Raleigh expedition (Holliday in lit., 10.4.85).

Economic Value and Social Benefits Uninhabited but the island is easily accessible from Providenciales, and the northern beach and adjacent reef are of particular value for recreation (Ray and Sprunt, 1971).

Disturbance or Deficiencies A potential threat to the reefs is a proposal to the Government by a U.S. company for the mining of aragonite on the Caicos Bank north and adjacent to West Caicos. An environmental impact statement has been prepared (Lott et al., 1984; Mitchell in litt., 12.4.85). The proposal would involve dredging, pumping of mined material to land and then piping out of silt and effluent into a lagoon. In addition, there is a proposal by a U.S. company to use West Caicos as a dumping site for processed sewage (Oldfield pers. comm, 1986)

Legal Protection None.

Management None.

Recommendations Recommended by Ray and Sprunt (1971) and Holliday (in litt., 10.4.85) as a reserve. 


\section{WEST REEF SYSTEM, GRAND TURK}

\section{Geographical Location Western coast of Grand Turk.}

Area, Depth, Altitude Depths of fringing reef $5.5-20 \mathrm{~m}$.

\section{Land Tenure No information.}

Physical Features The coast has a low dune ridge formed from deposits of coral debris; a southward drift of sand makes it unstable. The shore is narrow (Lott et al., 1984).

Reef Structure and Corals A fringing reef begins $550 \mathrm{~m}$ from shore and drops from $5.5 \mathrm{~m}$ to $20 \mathrm{~m}$ at the top of the drop-off. The drop-off slopes down with terraces at approximately $24 \mathrm{~m}, 36 \mathrm{~m}$, and $56 \mathrm{~m}$, from which there is a steep drop to the Turks Island Passage. To the north-west, the shallow bottom extends out approximately $1 \mathrm{~km}$ with the fringing reef's ledge in $15 \mathrm{~m}$ of water (Lott et al., 1984).

Lott et al. (1984) describe a number of zones. Close to shore there are isolated patches of head coral scattered over a sandy bottom between the shore and the drop-off fringing reef, from 1 to $18 \mathrm{~m}$ depth. These average $3 \mathrm{~m}$ in diameter and include Montastraea, Siderastrea, Diploria and occasionally Dendrogyra cylindrus. A second zone starts at approximately $20 \mathrm{~m}$ depth with elongated bars of coral extending north to south along the drop-off. Separating these are sand gulleys that taper off into the drop-off. Montastraea and Siderastrea are dominant with clumps of Parites on the plateau. On the vertical wall from 40 to $60 \mathrm{~m}$ depth, Agaricia dominates; purple tube sponges Callyspongia vaginalis and Gorgonacea are abundant.

Rolling Hills Reef on the north-west point has a spur and groove system and is an area of high wave energy (2-10 m deep). Acropora palmata and gorgonians predominate. From 5 to $10 \mathrm{~m}$ depth there is a ridged sandy bottom which slopes down into sand gulleys of irregular depths ranging from 13 to $25 \mathrm{~m}$ depth. At the top of the drop-off of each sand hill there are scattered hard coral heads, pillar coral and gorgonians. On the drop-off of each ridge (from 15 to $40 \mathrm{~m}$ ) there is a long line of deep water Gorgonacea known as the "Gorgonia Walls". The south-west coast has sand flats extending from the beach.

Noteworthy Fauna and Flora Lott et al. (1984) describe the fauna at a number of popular dive sites. At the "Library" (due west of the town pier) there are abundant nocturnal cerianthids, orange ball anemones, nudibranchs and spider crabs Mithrax spinosissimus. Black corals Antipathes spp. (at least five species) and wire corals Cirripathes (?Stichopathes?) lutkeni are abundant at the "Black Forest" dive site, and occur at relatively shallow depths $(20-30 \mathrm{~m})$ beneath a steep overhang. The orange cup coral Tubastrea coccinea is also unusually abundant here. At the dive sites "Amphitheater" and "Chief Minister's" quill fin blennies are numerous, and an occasional large Jewfish $E$ pine phelus ita jara is seen at the former site. Tiki Hut dive site in the south-west has Flying Gunnards Dactylopterus volitans and parrotfish Scarus spp. The shallow $(8-15 \mathrm{~m})$ sand plains found all along the west coast provide habitat for a large population of garden eels Nystactichthys halis.

Scientific Importance and Research One of the few reef areas to have been surveyed recently.

Economic Value and Social Benefits Popular dive sites.

Disturbance or Deficiencies Marina sites are under construction on the north-west and south-west tips of Grand Turk and have caused some silt damage due to dredging. This is more extensive on the north-west site where currents have carried the silt to an area of patch reef that extends out to the main reef (Lott et al., 1984).

Legal Protection None.

Management None.

Recommendations None known. 


\section{INTRODUCTION}

\section{General Description}

The coral reefs of south Florida, the only coral assemblages of significance in the U.S.A, have probably received more attention in terms of research and management than any other reefs in the Caribbean. Jaap (1984) gives a comprehensive overview and the following account is based largely on this.

With the exception of Bermuda and the northern Bahamas, the Florida Keys represent the northernmost limit of coral reefs in the western Atlantic. Coral diversity and abundance falls abruptly north of Miami, although live bottom communities with hermatypic corals and gorgonians can be found as far north as Cape Lookout, North Carolina. From Miami northwards to Palm Beach, tropical coral reef biota become increasingly less important in a south-to-north gradient and there is no true reef building. The area is characterized as an octocoral-dominated hardground community (Goldberg, 1973). Stony coral species which extend north include Oculina, Phyllangia, Solenastrea, Cladocora, Astrangia and Siderastrea. Acropora palmata and Montastraea annularis rarely occur, although the former was an important reef builder 4000 years ago (Lighty 1977; Lighty et al., 1982) (see separate account for John U. Lloyd State Park). Today only a few isolated colonies are found north of Fort Lauderdale.

A transitional community of Oculina bank flora and fauna and hardier elements of the tropical reef biota is found from near Palm Beach to Stuart (St Lucie Inlet see separate account), this region being characterized by the convergence of the temperate and subtropical climate zones. Oculina bank communities are the dominant coral communities in depths of $15-50 \mathrm{~m}$ (see separate accounts for Gray's Reef and Oculina banks) from near Fort Pierce to the Georgia border on the Atlantic coast. An extensive area (1200-1500 sq. mi. (3108-3885 sq. km) of deep-water coral is found near the northern end of Blake Plateau, 165 miles $(265 \mathrm{~km})$ south-east of Charleston, South Carolina (Stetson et al., 1962). Banks of ahermatypic branching corals include Lophelia prolifera and Dendrophyllia profunda.

Temperature is one of the major controls of reef development in Florida (Roberts et al., 1982). The climate of south-east Florida is characterized as subtropical marine in Miami (with a dry season from November to April and annual rainfall of $1500 \mathrm{~mm}$ ) and tropical maritime in Key West (with a dry season from November to May and annual rainfall of $1000 \mathrm{~mm}$ ) (NOAA, 1981a). Prevailing winds are from the east and south-east and produce waves up to $1 \mathrm{~m}$ high which strike parallel to the trend of the reef tract. Severe hurricanes are moderately common, most occurring between June and November. Thirteen major hurricanes have passed across the tract since 1894 . Seawater temperature extremes are from $14^{\circ} \mathrm{C}$ to $38^{\circ} \mathrm{C}$, the annual range usually being $18^{\circ} \mathrm{C}$ to $30^{\circ} \mathrm{C}$, with mean values usually above $18^{\circ} \mathrm{C}$ (Jaap, 1984). Since 1976, winter temperatures have often been variable with polar air masses cooling coastal waters (see below). During the summer, Florida Bay water may become hyperthermal (over $31^{\circ} \mathrm{C}$ ) and communities near tidal passes may be affected. The Florida Current, a subsystem of the Gulf Stream, plays an important role in the existence and maintenance of the reefs by moderating winter temperatures, its waters being significantly warmer than resident shelf water masses. From Miami to Key West there is a semidiumal tidal pattern; the area around Key West is influenced by the Gulf of Mexico which experiences semi-daily or daily tides. Oceanic salinities prevail in the reef tract area although heavy rainfall may cause a temporary reduction, especially in the region adjacent to Biscayne Bay. Water clarity is extremely variable depending on natural conditions and human activities. Jaap (1984) gives further details of the climatological and hydrological parameters of the Florida area affecting reef ecology.

Maximum coral reef development is restricted to south and west of Cape Florida, off the Florida Keys, a narrow 166 mile $(257 \mathrm{~km})$ long band of islands, extending from Soldier Key to Dry Tortugas. At their northern end the keys consist of fossil reefs formed during the Pleistocene when sea-levels were higher. The lower keys, from Big Pine to Key West, are composed of oolitic bryozoan facies overlying fossil reefs and bear some resemblance to the geological structure of the Bahamas (Dustan, 1977a). The geology of south Florida is described by Hoffmeister (1974), Ginsburg (1972) and an overview is provided by Jaap (1984). Enos (1970) gives a detailed account of sediments, facies and bathymetry. The shoreline is dominated by mangrove, rocky intertidal or sedimentary environments. From the intertidal zone seaward to Hawk Channel, which parallels the coast for over a hundred miles 'and is navigable by small vessels, there is a mosaic of environments including sediments, seagrass exposed Pleistocene rock and some patch reefs. These waters are dominated by hardy corals, which can tolerate silt and thermohaline changes, such as Porites porites, Manicina areolata and Cladocora arbuscula, and unconsolidated bottom with alcyonarian beds.

The Florida Reef Tract consists of a chain of reefs, on average $6.5 \mathrm{~km}$ in width, stretching in a curve of some $370 \mathrm{~km}$ from Fowey Rocks, just south of Miami, to the Dry Tortugas, and is separated from the Florida Keys by Hawk Channel. The channel, $4-8 \mathrm{~m}$ deep, is characterized by muddy calcareous sediments and generally very turbid water (Shinn, 1966). The bottom has scattered alcyonarian patches and a few, small corals, particularly Diploria clivosa, Oculina diffusa, $P$. porites, $P$. astreoides and Dichocoenia stokesii. Seaward of Hawk Channel, patch reef abundance and frequency increase and bank reefs begin to occur; seagrass is often abundant and sediment is coarser. The tract exhibits a diverse pattern of hard grounds, patch reefs and bank reefs up to $13 \mathrm{~km}$ off shore. The seaward edge follows the $18-20 \mathrm{~m}$ isobaths and is bounded by the deep waters of the Florida Straits (Voss, 1968 and 1973). Seaward of the bank reefs the sea bottom, where it has been investigated, consists of sediments, sponge habitats and rubble with occasional rocky outcrops that generally parallel the basic reefs (Jaap, 1984). Jones (1963) gives a generalized profile of the tract, and describes environmental conditions and primary productivity in detail. 


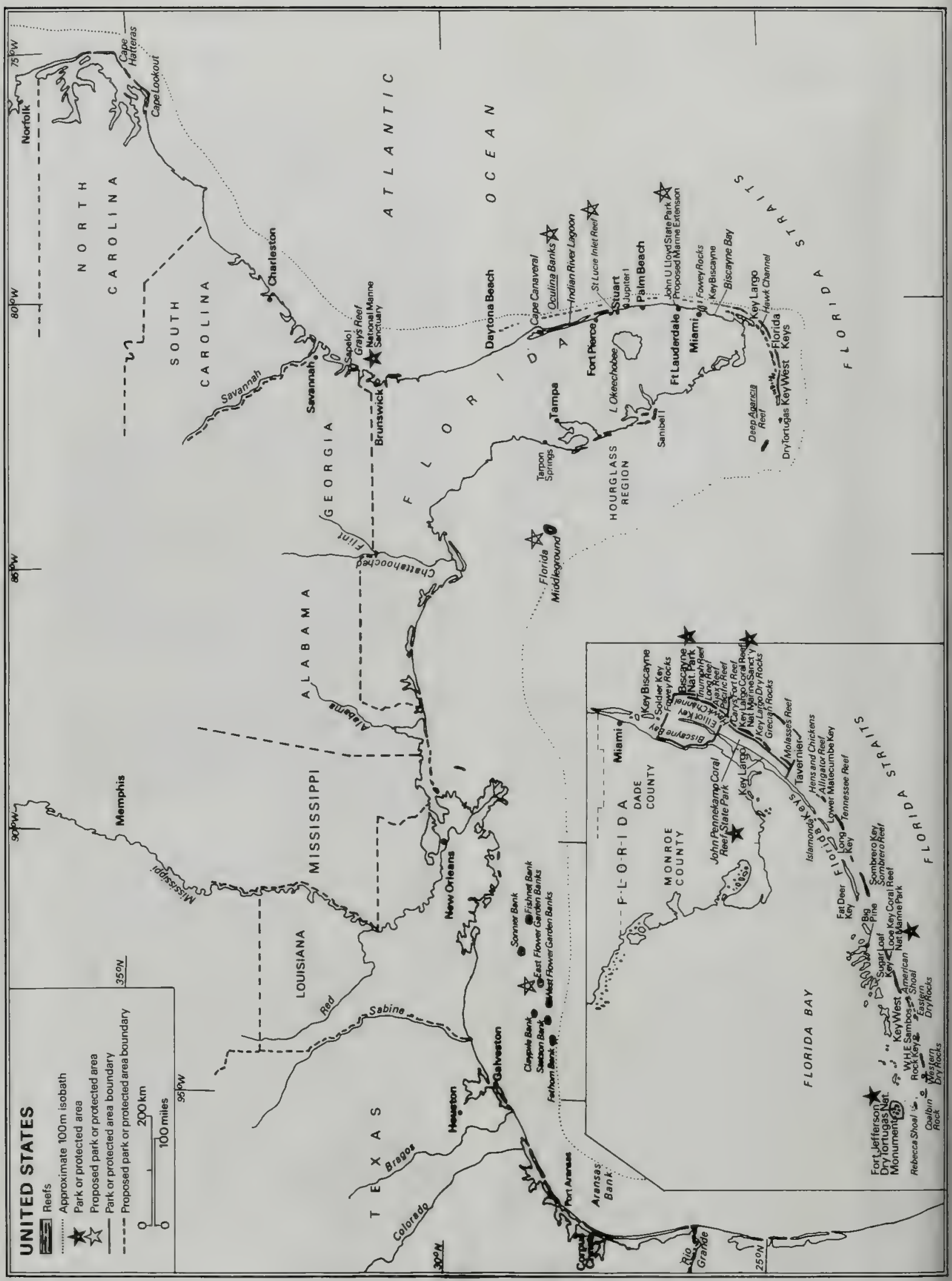


In general, Florida reefs are smaller in area, less biologically diverse and lack the vertical relief of most coral reefs of the Bahamas or Caribbean (Marszalek et al., 1977) but coral diversity is comparable. Jaap (1984) gives an overview of coral reef community types in the tract, distinguishing the following communities: live bottoms, patch reefs, transitional reefs and major bank reefs. Live bottom habitats are scattered from St Lucie Inlet south to Dry Tortugas in depths ranging from less than $1 \mathrm{~m}$ to over $30 \mathrm{~m}$; they support diverse faunas, are visually dominated by octocorals, algae and sponges with small hardy corals, but do not actively form a reef framework. Nearshore and offshore types differ greatly in species composition, and they may be surrounded by seagrasses, sediments or rocky substrates. Throughout the area from the outer reefs shoreward to the Keys, rich Thalassia seagrass beds cover the bottom between coral assemblages (Jones, 1963; Zieman, 1982).

Patch reefs, of which there are over 6000 , are the most conspicuous element in the region and are found mainly between the outer bank reefs and Hawk Channel although a few nearshore patch reefs exist. They are most abundant in the upper keys, seaward of Key Largo and Elliott Key, but also occur off Big Pine Key, Key West and Dry Tortugas. They are generally found $3-7 \mathrm{~km}$ off shore on the inner shelf, are less than $15 \mathrm{~m}$ deep and have a vertical relief of $1-10 \mathrm{~m}$. Most are roughly circular in shape and $10-700 \mathrm{~m}$ in diameter. They support primarily Montastraea annularis, $M$. cavernosa, Porites porites, $P$. astreoides, Siderastrea siderea, Diploria clivosa and $A$ cervicornis. $A$ palmata is usually absent and $A$ cervicornis is never found within $2 \mathrm{~km}$ of the shore (Shinn, 1966). Alcyonarians, Millepora alcicornis and $M$. complanata are abundant between the coral heads (Jones, 1963). They are described in detail in Jaap (1984) and Marszalek et al. (1977).

Transitional reef communities have the rudiments of bank reefs but are not as fully developed, and resemble coalesced patch reefs. They have a well developed reef flat with a tendency towards spur development by $A$ palmata on the seaward fringe. Examples are the reefs found inshore of Pacific Reef and south to the John Pennekamp Coral Reef State Park boundary. Another type of transitional reef develops on artificial substrates such as shipwrecks.

The Tract includes approximately $96 \mathrm{~km}$ of outer bank reefs which are typically elongated and form a narrow, linear discontinuous arc from Miami, south and west along the Keys to the Dry Tortugas. They are located near the abrupt change in bottom slope which marks the seaward edge of the Florida Plateau and are found mostly between 5 and $10 \mathrm{~m}$ depth. Jaap (1984) describes a number of examples including reefs in the Key Largo National Marine Sanctuary (see separate account), Looe Key Reef (see separate account), Eastern and Middle Sambo, Eastem Dry Rocks, Rock Key, Sand Key Reefs and Bird Key Reef (see account for Dry Tortugas National Monument). The bank reefs off Key Largo have also been described by Jaap (1983a) and Shinn (1963).

Bank reef zonation is usually distinct and typically West Indian. The reef flat is usually highly turbulent, with Porites astreoides and Diploria clivosa. The reef crest is usually less than $1 \mathrm{~m}$ deep, dominated by Acropora palmata and Millepora complanata, and the tops of the corals may be exposed at low water. Most bank reefs have well developed, shallow (less than $3 \mathrm{~m}$ ), spur and groove formations which are best developed in the upper and lower Keys and are dominated by $A$ palmata, Porites astreoides and $M$. complanata. Deep habitats are dominated by $A$ palmata, with Agaricia agaricites on the vertical faces. The fore-reef often has low relief spur and groove formations seaward to a depth of $30 \mathrm{~m}$. Montastraea annularis, A. agaricites, $M$. cavernosa and Siderastrea siderea constitute $24-30 \%$ of the coral population. Seaward of the fore-reef, small reef islands are isolated by sediments and Madracis mirabilis and Agaricia lamarcki are common. Acropora reefs may also be found up to $2 \mathrm{~km}$ shoreward of the outer platform margin if there is a large break in the outer reef chain (Shinn, 1963). Behind the outer reef is a depression, $5-10 \mathrm{~m}$ deep and generally about $1.5-2 \mathrm{~km}$ wide.

At least half of the Florida Reef Tract is unsuitable for prolific long-term coral growth, especially the middle part opposite large tidal passes, such as those between Islamorada and Big Pine Key. Reduced coral growth in these areas is related to silt-laden water of variable salinity and temperature which flows on to the reef tract with each low tide. However, the presence of dead reefs indicates that corals flourished in these areas until about $3000-5000$ years ago when the relative rise in sea-level would have created tidal passes and Florida Bay (Ginsburg and Shinn, 1964).

A number of studies have been carried out on reas in the Florida reef tract outside the areas mentioned in the following accounts. Kissling (1965) studied the bottom characteristics and population densities of corals in part of Spanish Harbour, off Big Pine Key. Moe (1984) mentions Coffins Patch, four miles $(6.4 \mathrm{~km})$ off Fat Deer Key, which is a small shallow patch reef almost entirely composed of Dendrogyra cylindrus. Hein and Risk (1975) and Hudson (1981a) have studied Hens and Chickens Reef, a large patch reef complex midway between Snake Creek Channel and Crocker Reef, four n.mi. (7.4 km) south-west of Tavemier. Hudson (1981a) gives brief descriptions of several other sites in this area.

Coral communities are also widely distributed on hard banks in the Gulf of Mexico. Except for the Flower Gardens (see account for "East and West Flower Gardens"), these hard bottoms lack the coral diversity and density of the Florida Reef Tract bank reefs. Ludwick and Walton (1957) describe coral structures at $30 \mathrm{ft}(9 \mathrm{~m})$ in warmer waters in the north-eastern Gulf of Mexico. The "Hourglass Region", bounded by the waters of Tampa Bay on the north and Sanibel Island on the south, consists of a variety of bottom types described by Joyce and Williams (1969), Phillips and Springer (1960) and Smith (1974). A separate account is given for Florida Middleground. There is a considerable diversity of scieractinians and octocorallines, although the distribution is irregular. These "reefs" are subject to wide fluctuations in temperature, turbidity and other physicochemical parameters. The impact of the cold winters of 1977 and 1978 was studied by Bullock and Smith (1979).

Reef communities are found in the north-western Gulf of Mexico (west of the Mississippi River Delta) on hard banks, produced by intrusion of salt plugs from Jurassic 
evaporite deposits $15 \mathrm{~km}$ down (Bright et al., 1984), in deep water $(40-200 \mathrm{~m})$ on the Texas-Louisiana shelf. A brief description of the outer banks is given in CNA (1981) and Bright (1977) describes their general characteristics. Thick neptheloid (turbid water) layers are found at the bases of all banks and there is continuous settling of sediment. Natural gas seeps of biogenic or petrogenic origin have been observed at many of the banks; these are intermittent and usually emit repeated short bursts of bubbles. The South Texas banks experience an alteration between oceanic and coastal water with variation in colour, salinity and turbidity. The faunas of Stetson Bank, Sonnier Bank and Claypile Bank are described by Bright (1977); these are less diverse and abundant than those of the Flower Garden Banks. An antipatharian zone is found on all the South Texas Banks, and at Fishnet and Flower Garden Banks. On Claypile Bank, large pieces of drill-pipe, tyres and other debris jettisoned during offshore drilling operations in the late 1960 s now form excellent artificial reefs around which numerous fish congregate. Moore and Bullis (1960) described a deep water reef of Lophelia prolifera 40 miles $(64 \mathrm{~km})$ east of the Mississippi River.

Another unique reef type in the lower Gulf is the deep Agaricia reef found in depths of $64-77 \mathrm{~m}$. Two sites are known west of Dry Tortugas $\left(24^{\circ} 47^{\prime} \mathrm{N}, 83^{\circ} 51^{\prime} \mathrm{W}\right)$ which include hermatypic and ahermatypic species. Large plates of Agaricia and green algae Andadyomene menziessi dominate remote photographs (Jaap in litt., 1982).

Sixty-eight species of stony corals are known from the Florida region, 62 of which have been recorded from the Florida Keys and Dry Tortugas alone. This is considered a remarkably high number. Oculina robusta, $O$. tenella, Flabellum fragile and Caryophyllia horologium are endemic to the Gulf of Mexico and Florida Keys. Most species are at the limit of their geographical ranges; brief descriptions of their distributions are given in CNA (1981).

Jaap (1984) provides a detailed description of the distribution of plankton, benthos including algae, sponges and cnidarians, fish and other reef-related species. The fish fauna of the Florida Reef Tract, described by Briggs (1958), Starck (1968) and Tilmant (in press), is wholly tropical with only seven species that have not been recorded elsewhere in the West Indies; 389 reef species have been listed but there are probably nearer 450 . The Loggerhead Caretta caretta, Green Chelonia mydas and Leatherback Dermochelys coriacea Turtles nest in the area; details of nesting beaches are given in Bacon et al. (1984). Information on other reef associated flora and fauna are given in the following separate accounts.

Jaap (1984) gives a historical resume of research on the Florida reefs. The establishment of the Tortugas Laboratory on Loggerhead Key by the Carnegie Institution was significant in stimulating research in the first half of the century (the laboratory was destroyed by fire in 1937); publications from this and earlier periods are listed by Jaap (1984). Research since the 1950s has been extensive, and includes that carried out by the Rosenstiel School of Marine and Atmospheric Science at the University of Miami, the Florida Department of Natural Resources and NOAA. A comprehensive bibliography is given by Jaap (1984). Large scale synoptic mapping of the reef tract has been recently completed (Marszalek et al., 1977; Marszalek, 1981/1982). The Oceans Assessment Division has set up a number of databases including a National Coastal Pollutant Discharge Inventory (Basta $e t$ al., in press) and a Living Marine Resource Life History Data Base (Ehler et al., 1982 and 1985) and is also producing the Gulf of Mexico Strategic Assessment Data Atlas which will include maps of the important characteristics of this area. The U.S. Geological Survey has conducted considerable reef research and runs a marine mapping program CONMAP (the Continental Margin Maps) which will result in a series of maps covering the EEZ (Escowitz, 1985).

\section{Reef Resources}

Exploitation of Florida's reef resources began with the Caloosa Indians who fished and collected shells and corals for trade. Subsequently early European settlers on the Keys made a living by luring ships onto the reefs and salvaging the cargos, but eventually such activities were replaced by fishing and the sponge industry. Within the Monroe County region, the reefs, directly and indirectly, generate an estimated $\$ 30$ million to $\$ 50$ million annually from a variety of activities including fishing, diving, education and research (Jaap, 1984).

The Florida reefs and hard banks support major fisheries, including commercial hook-and-line fishing, commercial trapping, sport angling, spearfishing, tropical fish collecting and scientific collecting. The commercial harvest from coral reef areas consists almost entirely of snappers (Lutjanidae) and groupers (Serranidae) although tilefish (Branchiostegidae), jacks (Carangidae) and triggerfish (Balistidae) are also taken. A complete listing of commercially important reef species is given in CNA (1981). The annual commercial catch of reef fish in the Gulf of Mexico was estimated in 1979 at $8482 t$ ( $\$ 932000$ ). Around the outer bank reefs, such as the Florida Middlegrounds, and near Tarpon Springs and Madeira Beach, snapper, grouper and tile fish are also important. Trawling for snappers and groupers are major activities off Georgia and South Carolina; as far north as Cape Hatteras off the coast of Carolina, there is a thriving recreational reef fishery, particularly of Red Porgy Pagrus pagrus and Vermilion Snapper Rhomboplites aurorubens being the species most commonly caught (Grimes et al., 1982). Fishing banks off Corpus Christi support a sizeable sport fishery operating out of Port Aransas and Aransas Pass (Bright, 1977).

The largest commercial fishery in coral reef areas, worth over \$10 million in 1980 , is for the Spiny Lobster Panulins argus. This uses pots and traps and a maximum sustainable yield for the Gulf of Mexico has been estimated at $3259 \mathrm{t}$ (ca $\$ 8636000$ ). Trawling or dredging for scallops occurs off Cape Canaveral in north-west Florida (Leary in litt., 1984). Stone crabs Menippe mercenaria and aquarium fish are also collected in some areas (CNA, 1981; Hopkins et al., 1977; Smith, 1976). Other fisheries, including those for non-reef species, are described in CNA (1981). Live marine specimen collecting is a minor industry and popular hobby, most collecting taking place between Palm Beach and Key West. Specimens are collected by divers for sale in pet shops and aquarium stores. Tilmant (in press) summarises work on the fisheries of the area. 
Besides supporting many fisheries directly, the reefs also play an important role in protecting seagrass beds and mangroves which provide nursery areas for juveniles.

The commercial sale of coral began at Key West around 1830 and became a large-scale activity in the 1950s. Probably no more than 20 individuals have been involved and most of the coral on sale in the Keys at present is imported. The draft Fishery Management Plan Environmental Impact Statement (CNA, 1981) discusses several corals in the Gulf of Mexico which have potential commercial value. At least nine species of actocorals are being collected for use in marine aquaria, some 5800 colonies being taken annually of Leptogoria virgulata, Briareum asbestinum, Telesto riisei, Renilla mulleri, Diodogorgia nodulifera, Nicella schmitti, Swiftia exserta, Lophogorgia cardinalis and $L$ hebes. Approximately $25 \%$ of the current harvest comes from the FCZ (Fishery Conservation Zone) and the rest from state waters. Corals which have had commercial value in the past are Black Sea Rod Plexaura homomalla, the black coral Cirrhipathes lutkeni and Rose Coral Manicina areolata; these species could continue to have value in pharmacological research, jewellery and tropical fish businesses respectively.

Eight deepwater corals (the precious red corals Corallium medea and $C$. niobe, the bamboo corals Acanella eburnea, Keratoisis flexibilis, $K$. ornata and Lepidisis caryophyllia, the black coral Leiopathes glaberrima and the hydrocoral Distichopora foliacea) have been identified as having potential commercial value for jewellery but none have been exploited commercially yet. Corallium and Keratoisis are listed as fishery resources in the Fishery Conservation and Management Act of 1976.

One of the major economic benefits of the Florida Tract Reefs is the revenue generated by recreation and tourism. The area from Ohio Key to Sugarloaf Lodge near Looe Key, generates an estimated 8-10 million dollars annually in marine-related income, much of it coral-related. Diving as a sport and hobby attracts more than a million people annually to the Keys, which are the most popular U.S. diving site, and there are 40 businesses in Monroe County devoted entirely to tourist diving (Jaap, 1984). Income is also generated from reef tours by planes and glass-bottom boats, the sale of souvenirs and educational activities. The rapid escalation in recreational use of the reefs by both residents and visitors is one of the main reasons for the intensive efforts that are currently being put into their management and protection, most recreational diving taking place within marine parks.

\section{Disturbances and Deficiencies}

Natural damage to the Florida reefs occurs on a fairly regular basis as a result of hurricanes, which on average have affected any particular reef once every six years during the past 10000 years (Ball et al., 1967; Jaap, 1984). Studies of the impact of Hurricane Donna in 1960 and Hurricane Betsy in 1965 indicated that reefs can recover within about two years. No hurricanes have come near the reefs since 1965 . Mass mortality of the sea urchin Diadema antillarum occurred in 1983 in the Florida Keys (Lessios et al., 1984) and was considered to be due to a water-borne pathogen. White band disease has been reported (Rogers, 1985).
Bullock and Smith (1979), Roberts et al. (1982) and Walker et al. (1982) document the cooling of shallow bays and the distribution of temperatures below $16^{\circ} \mathrm{C}$ during the passage of severe winter cold fronts in 1977 and 1981 which resulted in fish kills and coral mortalities. During the summer, hyperthermic conditions during low spring tides may cause the expulsion of zooxanthellae from corals (Jaap, 1979b; Hudson, 1981a); in the winter the reef flat water may become hypothermic, again causing thermal stress (Hudson et al., 1976; Davis, 1982; Porter et al., 1982). Communities adjacent to tidal channels suffer most. Areas which have suffered particularly from thermal stress include Loggerhead Key (Dry Tortugas), Hens and Chickens Reef and the Rock, off Plantation Key. Extensive reef coral zooxanthellae expulsion occurred from Key Largo to Dry Tortugas during September 1983. Coral bleaching was intensive between Pelican Shoal and Sand Key Reef off Key Largo and extended to $14 \mathrm{~m}$ or more but was especially severe in shallow spur and groove habitats (Jaap, 1979b and 1985a). This phenomenon was considered to be a result of unusually high seawater temperatures $\left(32.3^{\circ} \mathrm{C}\right)$ but most corals survived.

Damage from human activities is reviewed by Jaap (1984). Dredging, either for deepening and maintaining navigational channels or for beach renourishment, is a major problem particularly north of Miami, as it can cause heavy siltation. A number of investigations of threatened reefs have been carried out (Straughan, 1972; Courtney et al., 1974; Griffin, 1974). In 1981 a beach renourishment project on South Miami Beach threatened a small linear hardground community composed of significant numbers of octocorals and stony corals. Dade County Pollution Control, Dade County Marine Institute, U.S. Geological Survey and Florida Department of Natural Resources personnel transplanted about 200 stony coral colonies that were threatened with burial.

Pollution is a potential serious threat. About 2 million people live in the coastal area $(10 \times 60$ miles $(16.1 \times$ $96.9 \mathrm{~km}$ )) from Palm Beach south to Miami, and the sea has been the main dumping ground for waste. In the six east coast Florida counties between St Lucie and Monroe counties, sewage treatment facilities are so over-burdened that many hotels and other buildings pump their sewage into coastal waters untreated. While most Key Largo houses have septic tanks, many homes in Key West and Dade Co., Florida, also pump sewage directly into the ocean (Bright et al., 1981). One hundred and twenty million gallons of raw sewage were released to sea in 1971 , much of which was carried south to the reefs. In many areas, corals and fish have been found to be unhealthy, particularly on patch reefs. Hens and Chickens Reef, Ajax Reef, and Triumph Reef have all been affected (Voss, 1973) as well as reefs mentioned in the following separate accounts. Chesher (1975) described the biological impact of a desalination plant at Key West. Jaap (1984) briefly reviews a number of pollution sources including heavy metals and waste materials.

Oil and gas exploration on the Gulf of Mexico continental shelf and the Blake Plateau may lead to pollution from drilling platform discharges as drill muds are complex chemical mixtures of coolants, lubricants, biocides and stablizers. High levels of mercury, cadmium, lead, copper and zinc have been found in groupers from Gulf of Mexico coral reefs (Taylor and Bright, 1973). 
Many of the South Texas deep water banks are manifestations of petroleum bearing subsurface geological structures and so are subject to nearby exploratory and production drilling operations (Bright, 1977). Manker (1975) found a heavy metal plume extending off Virginia Key near Miami. A comparison of the corals of south-east Florida and those at Florida Middlegrounds revealed that the former had higher chromium levels than the latter (Bright et al., 1981). Lead and mercury may also be accumulating in sediments at Tavernier Key and the John Pennekamp Reef Marina. Chan (1977) describes the impact of an oil spill in the Florida Keys in 1975.

During the 1960 s and 1970 s, the populations of Dade and Monroe counties grew rapidly, with a concomitant increase in the number of visitors to the reefs. Collection of shells and fish, and dynamiting of wrecks became problems (Voss, 1973). Increased recreational activities are still having a noticeable adverse affect on coral health. Diving for souvenirs and curios appears to be the major problem, but vessel groundings and fuel spillages have also caused problems. Jaap (1984) discusses anchor damage, groundings and shipwrecks.

There is little information on the impact of reef fisheries, although there are some recent studies (Davis, 1977b; Tilmant, 1981; Bohnsack, 1982). Significant conflict has developed between traditional reef fishermen and roller trawl fishing vessels off Daytona Beach and in the eastern Gulf of Mexico, the former claiming that roller trawls destroy the habitat including the Oculina banks. Lobsters have been over-fished in many areas; it is reported that nearly every adult Spiny Lobster Panulirus argus is removed from Florida every year (Beardsley et al., 1975). The size of mature females, compared with that in the now unexploited Dry Tortugas populations, has been reduced (Davis and Dodrill, 1980). Jaap (1984) describes the damage that occurs by misuse of pots and traps, by sports divers and by hook and line methods (loss of tackle). Artificial reefs have caused problems when tyres become unattached (CNA, 1981).

Pillar Coral Dendrogyra cylindrus was heavily collected by commmercial collectors in the 1950s and 1960s (Moe, 1984) and has been recommended for listing on the U.S. Endangered Species Act. No formal action has yet been taken (CNA, 1981) as it is not eligible under the criteria required by this statute. The Florida Committee on Rare and Endangered Plants and Animals has identified a further five species of stony coral as endangered and nine as threatened (Franz, 1982; CNA, 1981), but these are not officially protected. The potential for increased exploitation of corals is examined in CNA (1981). Octocorals are already being harvested on a small scale which has no serious impact at present but they could be threatened if the fishery expands rapidly. Until recently, corals in the Fishery Coastal Zone were protected and managed by the Bureau of Land Management, but this is no longer the case. Although stocks are currently in good condition, their future may be precarious.

\section{Legislation and Management}

A number of agencies are involved directly or indirectly in the management of reefs. The Minerals Management Service has jurisdiction over mineral and petroleum resources on the continental shelf. Management has included specific lease regulations and mitigation of exploration and production activities in areas where coral resources are known to exist. It has helped to fund a coral reef mapping project from Miami and Key West. The U.S. Army Corps of Engineers contracts and regulates coastal engineering projects, particularly harbour dredging and beach renourishment projects, and reviews and issues permits for coastal development projects and artificial reefs. The Environmental Protection Agency is responsible for disposal of hazardous wastes and sewage plant outfall. The Fish and Wildlife Service assists with environmental impact review, develops biological resource evaluations, administers the endangered species program and manages national wildlife refuges.

In 1977 the Fishery Conservation and Management Act was passed which extended jurisdiction over fisheries to 200 miles and called for regional fishery management councils to be established to develop specific long-range management plans for each coast fishery resource within the Fishery Conservation Zone. As a result more attention is being directed to the reef fishery resources. The National Marine Fisheries Service implements approved Fishery Management Plans and, with the Coast Guard and Florida Marine Patrol, enforces reef-related plans. Fishery Management Plans for corals and coral reefs, reef fish, grouper and snapper, and spiny lobster are already in force in some areas and others are being developed. The Gulf of Mexico and South Atlantic Fishery Management Councils have produced a plan (implemented in 1984) for the area from North Carolina to Texas covering all species within Federal jurisdiction (220 miles). The regulations establish unique Habitat Areas of Particular Concern (HAPC) for corals which are currently or potentially threatened (some of which are described in the following accounts), prohibit taking or destruction of certain corals under permit and provide permit systems for the taking of certain corals for scientific and educational purposes and the harvesting of fish or other marine organisms with toxic chemicals in coral habitat.

The taking of tropical fish for aquarium purposes is prohibited in all coral reef protected areas, but spearfishing is permitted in at least one and hook-and-line fishing is permitted in all. Collection, damage or sale of stony corals (Millepora spp. and Scleractinia) and two species of sea fan (Gorgonia ventalina and $G$. flabellum) is prohibited by Florida statute 370.110. Monroe County prohibits use of spearguns for the harvesting of marine protein in and around bridges and piers and in State waters from the Dade County border to Long Key. Shelling is permitted in Florida State Parks but Queen Conchs may not be collected.

In 1972, Congress enacted the Marine Protection, Research and Sanctuaries Act (Public Law 92-532, 16 U.S.C. 1431 et seq, Section 302 [a]). Title III of the Act directs the Secretary of Commerce to designate ocean waters as Marine Sanctuaries for the purpose of preserving or restoring their conservational, recreational, ecological or aesthetic values. The Act is administered by the National Oceanic and Atmospheric Administration (NOAA) through the National Ocean Service (NOS), Office of Ocean and Coastal Resource Management (OCRM) and the Sanctuary Programs Division (SPD). The Marine Sanctuaries Progam is responsible for Key 
Largo and Looe Key Coral Reef Marine Sanctuaries, but on-site management and enforcement are delegated to the Florida Department of Natural Resources which is responsible for management of all marine fisheries and resources in State waters. The Division of Recreation and Parks manages and operates State Parks and Federal Marine Sanctuaries through agreements with NOAA. National parks and monuments, including Biscayne National Park and Fort Jefferson National Monument are under the jurisdiction of the National Park Service. The Coast Guard is the general enforcement agency for all marine activity in the Federal zone including sanctuary and fishery management regulations, vessel salvage and co-ordination of oil spill clean-up operations. The Division of Marine Research conducts scientific research to support management in the areas of coral reef ecology and fisheries. The Department of Environmental Regulation has management powers over environmental change caused by human activity, reviews all major engineering projects, and carries out environmental monitoring and research and reviews permits.

The following sanctuaries and National Parks contain coral reefs and are described in separate accounts:

$\begin{array}{ll}\text { - } & \text { Biscayne National Park } \\ \text { - } & \text { John Pennekamp Coral Reef State Park } \\ \text { - } & \text { Looe Key Coral Reef National Marine Sanctuary } \\ \text { - } & \text { Fort Jefferson Dry Tortugas National Monument } \\ \text { - } & \text { Gray's Reef Marine Sanctuary } \\ \text { - } & \text { John U. Lloyd State Park }\end{array}$

Three preserves (designated under the Florida Aquatic Preserves Act of 1975 and described by Bader (1974)) in the Florida Keys probably include coral habitats, although data are not available: Coupon Bight Aquatic Preserve (adjacent to and south of Big Pine Key), Lignumvitae Key Aquatic Preserve (south of Key Largo) and Biscayne Bay Aquatic Preserve. Three National Wildlife Refuges may also contain coral habitats: National Key Deer Refuge, Great White Heron National Wildlife Refuge and Key West National Wildlife Refuge

\section{Recommendations}

Jaap (1984) makes several recommendations for improved management of the Florida reefs, stressing the need for public education and improved communication between State and Federal agencies. In-depth field surveys should be an integral part of any environmental impact assessment of major coastal engineering projects. Dredging operations close to a coral reef should be required to use turbidity curtains and sediment fall-out should be monitored. Mechanical dredgers should not come into physical contact with the reef and dredged spoils should not be disposed of on or near reef communities. In some areas it might be beneficial to prohibit the harvest of all fish and invertebrates to provide a refuge for those species under intense pressure. Remedial action should only be taken following oil spills when it becomes clear that natural recruitment is not occurring or is very slow. Recommendations are also given for dealing with vessel groundings.

The Draft Fishery Management Plan Environmental Impact Statement for the area (CNA, 1981) stresses that a survey of growth, stress factors and management practices for corals must be carried out over several years before large scale commercial exploitation can start. The difficulties in determining maximum sustainable yields for corals are discussed.

Additional reefs have been recommended for protection or which are considered of conservation concern. These include:

$\begin{array}{ll}\text { - } & \text { Alligator (see separate account) } \\ \text { - } & \text { Tennessee } \\ \text { - } & \text { Ambrero } \\ \text { - } & \text { American Shoal } \\ \text { - } & \text { Eastern, Middle and Western Sambo } \\ \text { - } & \text { Western Dry Rocks } \\ \text { - } & \text { Eastern Dry Rocks } \\ \text { - } \quad \text { Sand Key } \\ \text { - Coalbin Rock } \\ \text { - } \quad \text { Rebecca Shoal } \\ \text { - St Lucie Nearshore Reefs - nominated as National } \\ \text { Marine Sanctuary (see separate account) } \\ \text { - Florida Oculina Banks - nominated as National } \\ \text { Marine Sanctuary (see separate account) } \\ \text { Florida Middleground HAPC (see separate account) } \\ \text { - Deep Agaricia reef } \\ \text { East and West Flower Garden Banks HAPC (see } \\ \text { separate account) }\end{array}$

\section{References}

* cited but not consulted

Agassiz, A. (1852). Florida reefs, keys and coasts. Ann. Rep. Supt Coast Survey, 1851: 107-134.

Agassiz, A. (1883). Explorations of the surface fauna of the Gulf Stream, under the auspices of the United States Coast Survey II. The Tortugas and Florida reefs. Mem. Amer. Acad. Ants Sci. Centenmial II: 107-132.

Alevizon, W.S. and Brooks, M.G. (1975). The comparative structure of two Western Atlantic reef-fish assemblages. Bull. Mar. Sci. 25: 482-490.

Anon. (19??a). Fort Jefferson National Monument. Leaflet for visitors.

Anon. (198?b). Biscayne. Leaflet for visitors.

Anon. (1981). Looe Key National Marine Sanctuary. Leaflet for visitors, U.S. Dept of Commerce, NOAA.

Antonius, A., Weiner, A.H., Halas, J.C. and Davidson, E. (1978). Looe Key reef resource inventory. Final report to NOAA, Office of Coastal Zone Management, Florida Reef Foundation, Homestead, Florida. 63 pp.

Austin, H.W. (1970). Florida Middleground. Mar. Poll. Bull. 1: 171-172.

Avent, R., King, M.E. and Gore, R.H. (1977). Topographic and faunal studies of shelf-edge prominences off the central eastem Florida coast. Int. Rev. ges. Hydrobiol. 62: 185-208.

Bacon, P., Berry, F., Bjorndal, K., Hirth, H., Ogren, L., Weber, M. (1984). The National Reports. Proceedings of the Western Atlantic Turtle Symposium, Vol. 3. University of Miami Press, Florida.

-Bader, R. (1974). The Florida coastal preserve study: a model for coastal state preserve programmes. In: Lynch, M.P. et al. (Eds) Marine and Estuarine Sanctuaries. Spec. Sci. Rep. 70, Virg. Inst. Mar. Sci.

Bagby, M. (1978). The ecology of patch reef gorgonians off the coast of Key Largo, Florida. Unpub. rept, Florida International Univ., Miami., $28 \mathrm{pp}$. 
Bagett, LS. and Bright, TJ. (1985). Coral recruitment at the East Flower Garden reef, Northwestern Gulf of Mexico. Proc. Sth International Coral Reef Congress, Tahiti 4:379-384.

Ball, M.M., Shinn, E.A. and Stockman, K.W. (1967). The geologic effects of Hurricane Donna in South Florida. $J$. Geol. 75: 583-597.

-Barada, B. (1979). Little Looe Key. Skin Diver 28(3): 60-67.

Basta, DJ. $t$ al. (in press). The national coastal pollutant discharge inventory. Proceedings of Coastal Zone '85, 4th Symposium on Coastal and Ocean Management, Baltimore, August 1985.

-Beardsley, G.L., Costello, T.J., Davis, G.E., Jones, A.C. and Simmons, D.C. (1975). The Florida Spiny Lobster fishery, a white paper. Florida Sci. 38(2): 144-149.

-Bohnsack, (1982) (cited in NOAA, 1984 and Jaap, 1984; concerns fish in Looe Key).

Briggs, J.C. (1958). A list of Florida fishes and their distribution. Bull. Fla St. Mus. 2(8): 233-318.

Bright, TJ. (1977). Coral reefs, nepheloid layers, gas seeps and brine flows on hard-banks in the northwestern Gulf of Mexico. Proc. 3rd Int. Coral Reef Symp., Miami: 39-46.

-Bright, TJ. and Abbott, (1978). (reference unknown)

-Bright, T.J. and Pequegnat, L.H. (Eds) (1974). Biota of the West Flower Garden Bank. Gulf Publ. Company, Houston, Texas.

-Bright, T.J. and Rezak, R. (1976). A biological and geological reconnaissance of selected topographical features on the Texas continental shelf. Report submitted to Bureau of Land Management (New Orleans) by College of Geosciences, Texas $\mathrm{A}$ and $\mathbf{M}$ University, College Station, Texas. BLM Contract No. 08550-CT5-4: 377 pp.

Bright, T.J. and Rezak, R. (Eds) (1978). Northwestern Gulf of Mexico topographical features study. Report submitted to Bureau of Land Management (New Orleans) by College of Geosciences, Texas A \& $\mathbf{M}$ University, College Station, Texas. BLM Contact No. AA550-CT7-15.

-Bright, TJ., Jaap, W.C. and Cashman, C. (1981).

Ecology and management of coral reefs and organic banks. Environmental Research Needs in the Gulf of Mexico. Proceedings of meeting, U.S. Dept of Commerce, NOAA, ERC, Miami: 53-160.

Bright, TJ., Kraemer, G.P., Minnery, GA. and Viada, S.T. (1984). Hermatypes of the Flower Garden Banks, Northwestern Gulf of Mexico: a comparison to other Western Atlantic Reefs. Bull. Mar. Sci. 34(3): 461-476.

Britt, D.E. Associates, Inc. (1977). Biological monitoring project of the John U. Lloyd Beach Restoration Project. Final Report to the B.C.E.P.D. Contract No. 6-76-32F.

Brookfield, C.M. (1962). Key Largo Reef: America's first undersea park. Nat. Geo. 121(1): 58-69.

-Brooks, H.K. (1962). Observations on the Florida Middle Grounds, Geol. Soc. Am. Spec. Pap. 68: 65-68.

Brooks, B., Snedaker, M. and Ruskin, E.L. (1983). Reef Preserve Proposal Statement (as an extension of John U. Lloyd State Park). Week of the Ocean.

Bullock, L.H. and Smith, G.B. (1979). Impact of winter cold fronts upon shallow-water reef communities off west-central Florida. Florida Scientist 42(3): 169-172.

Burns, T.P. (1985). Hard coral distribution and cold water disturbances in South Florida: variation with depth and location. Coral Reefs 4: 117-124.

-Chan, E.I. (1977). Oil pollution and tropical littoral communities: biological effects of the 1975 Florida Keys oil spill. In: Proc. 1977 Oil Spill Conf, Amer. Petrol. Inst., Washington D.C.: 539-542.

- Chesher, R.H. (1975). Biological impact of a large-scale desalination plant at Key West, Florida. In: Ferguson Wood, E.J. and Johannes, R.E. (Eds). Tropical Marine Pollution. Elsevier Scientific Publ., Co. N.Y.

CNA (1981). Draft Fishery Management Plan Environmental Impact Statement for Coral and Coral Reefs. Gulf of Mexico and South Atlantic Fishery Management Councils, Center for Natural Areas.

-Courtuey, W.R., Herrema, DJ., Thompson, MJ., Axzinaro, W.P. and Montfrans, J. van (1974). Ecological monitoring of beach erosion control projects, Broward County, Florida, and adjacent areas. U.S. Army Corps of Engineers, Coastal Engineering Research Center, Fort Belvoir. Va Tech. Memo. 41: 88 pp.

Curtis, C. (1985). A plan for investigating the recovery of a coral reef following the grounding of a freighter in the Key Largo National Marine Sanctuary, Florida Keys, U.S.A. Proc. 5th International Coral Reef Congress, Tahiti 6: 471-476.

Davis, G.E. (1977a). Anchor damage to a coral reef on the coast of Florida. Biol. Conserv. 11: 29-34.

Davis, G.E. (1977b). Effects of recreational harvest of a spiny lobster Panulirus argus population. Bull. Mar. Sci. 27(2): 223-236.

Davis, G.E. (1979), Outer continental shelf resource management map, coral distribution Fort Jefferson National Monument, the Dry Tortugas. U.S. Dept Interior, Bureau of Land Management, Outer Continental Shelf Office, 500 Camp St, New Orleans, La, 70130.

Davis, G.E. (1981). The role of underwater parks and sanctuaries in the management of coastal resources in the southeastern United States. Environ. Conserv, 8(1): 67-70.

Davis, G.E. (1982). A century of natural change in coral distribution at the Dry Tortugas: a comparison of reef maps from 1881 and 1976. Bull. Mar. Sci. 32(2): 608-623.

-Davis, G.E. and Dodrill, J.W. (1980). Marine parks and sanctuaries for spiny lobster fisheries management. Proc. Gulf and Caribb. Fish. Inst. 32: 197-207.

Dustan, P. (1977a). Besieged reefs of Florida's keys. Natural History 86(4): 73-76.

-Dustan, P. (1977b). Vitality of coral reef populations off Key Largo, Florida: recruitment and mortality. Env. Geol. 2(1): 51-58.

Edwards, G.S. (1971). Geology of the West Flower Garden Bank. Texas A \& M Sea Grant Publ., 71-215: 199 pp.

Ehler, C.N., Basta, D.J. and La Pointe, T.F. (1982). An automated data system for strategic assessment of living marine resources in the Gulf of Mexico. Proceedings of Auto-Carto 5, Conference on Environmental Assessment and Resource Management. American Society of Photogrammetry and American Congress on Surveying and Mapping: Arlington, VA: 83-91.

Ehler, C.N., Basta, D.J., La Pointe, T.F. and Warren, M.A. (1985). The role of data atlases in a national program of strategic assessments of oceanic resource-use conflicts. Paper prepared for the International Colloquium on Marine Resource Atlases. Challenger Society and Royal Geographical Society, London, October 1985.

Emmery, A.R. (1973). Comparative ecology and functional osteology of fourteen species of damselfish at Alligator Reef, Florida Keys. Bull. Mar. Sci. 23: 649-770.

-Enos, P. (1970). Carbonate sediment accumulations of 
the South Florida shelf margin. Tech. Progress Rept. EPR 29-70-F Shell Development Co., Houston, TX; 114 pp.

Escowitz, E.C. (1985). CONMAP-USGS Marine Mapping Program. Technical Papers. 45th Annual Meeting ACSM, Washington, March 1985.

Franx, R. (1982). Invertebrates. In: Pritchard, P.C.H. (Ed.). Rare and Endangered Biota of Florida. Vol. 6. University Presses of Florida, Gainesville.

-Ginsburg, R.N. (Ed.) (1972). Sedimenta II. Guidebook for field trip 1, Geol. Soc. Am. Ann. Mtg 1964. Comparative Sedimentology Laboratory, University of Miami, Florida. 722 pp.

Ginsburg, R.N. and Shinn, E.A. (1964). Distribution of the reef-building community in Florida and the Bahamas (Abs.). Am. Assoc. Petrol. Geol. Bull. 48: 527.

Goldberg, W. (1973). The ecology of the coral-octocoral communities off the south-east Florida coast: geomorphology, species composition and zonation. Bull. Mar. Sci. 23(3): 465-489.

Goldberg, W.M., McLaughlin, P.L. and Fisher, L.E. (1985). Long term effects of beach restoration in a coralline environment: impact on macrobenthic and infaunal communities. Proc. Sth International Coral Reef Congress, Tahiti 2: 150.

Greenberg, J. (1961). Exploring the worlds first undersea park. Audubon 63(3): 140-141.

Greenberg, J. (1962). Florida's Coral 'City beneath the Sea. Nat. Geo. 121(1): 70-89.

Griffin, G.M. and Antonius, A. (1974). Turbidity and coral health in waters of John Pennekamp Park, Upper Keys. Florida Sci. (abstract) 37: 15.

-Griffin, G.M. (1974). Case history of a typical dredge-fill project in the northern Florida Keys - effects on water clarity, sedimentation rates and biota. Publ. 33, Harbor Branch Foundation. 67 pp.

Grimes, C.B., Manooch, C.S. and Huntsman, G.R. (1982). Reef and rock outcropping fishes of the outer continental shelf of North Carolina and South Carolina and ecological notes on the Red Porgy and Vermilion Snapper. Bull. Mar. Sci. 32(1): 277-289.

Grimm, D.E. and Hopkins, T.S. (1977). Preliminary characterization of the octocorallian and scleractinian density at the Florida Middle Ground. Proc. 3rd Int. Coral Reef Symp., Miami: 135-141.

Groombridge, B. (1982). The IUCN Amphibia-Reptilia Red Data Book Part 1, Testudines, Crocodylia, Rhynchocephalia. IUCN Conservation Monitoring Centre, Cambridge.

Halas, J.C. (1985). A unique mooring system for reef management in the Key Largo National Marine Sanctuary. Proc. Sth International Coral Reef Congress, Tahiti 4: 237-242.

Hein, FJ. and Risk, M.J. (1975). Bioerosion of coral heads: inner patch reefs, Florida Reef Tract. Bull. Mar. Sci. 25(1): 133-138.

Henry, V.J.r. and Van Sant, S.B. (1982). Results of reconnaissance mapping of the Gray's Reef National Marine Sanctuary. A report prepared for the Georgia Department of Natural Resources, Coastal Resources Division, Brunswick, GA, under cooperative agreement with Sanctuary Programs Division of the National Oceanic and Atmospheric Administration (No. NA81AAHCZ098, Amendment 1).

Hoffmeister, J.E. (1974). Land from the sea, the geologic story of south Florida. Univ, of Miami Press, Miami; 143 pp.
Hopkins, T.S., Blizzard, D.R., Brawley, S.A., Earle, S.A., Grimm, D.E., Gilbert, D.K., Johnson, P.G., Livingston, E.H., Lutz, C.H., Shaw, J.K. and Shaw, B.B. (1977). A preliminary characterisation of the biotic components of composite strip transects on the Florida Middlegrounds, northeastern Gulf of Mexico. Proc. 3rd Int. Coral Reef Symp., Miami : 31-37.

Hoskin, C.M., Geier, J.C. and Reed, J.K. (1983). Sediment produced from abrasion of the branching stony coral Oculina varicosa. J. Sed. Petrol. 53(3): 779-786.

Hoskin, C.M., Reed, J.K. and Mook, D.H. (in press). Sediments from a living shelf-edge coral reef and adjacent area of central eastern Florida. Symp. S. Fla Geol., Miami Geol. Soc.

Hudson, J.H. (1981a), Response of Montastraea annularis to environmental change in the Florida Keys. Proc. 4th Int. Coral Reef Symp., Manila 2: 233-240. Hudson, J.H. (1981b). Growth rates in Montastrea annularis: a record of environmental change in Key Largo Coral Reef Marine Sanctuary, Florida. Bull. Mar. Sci. 31(2): 444-459.

Hudson, J.H., Shinn, E., Halley, R. and Lidz, B. (1976).

Sclerochronology: a tool for interpreting past environments. Geology 4:361-364.

Hunt, J.L. (1974). The geology and origin of Gray's Reef, Georgia continental shelf. M.S. Thesis, Univ. of Georgia, Athens. 83 pp.

Jaap, W.C. (1979a). Stony coral community structure and species diversity at selected patch reefs within Biscayne National Monument. Paper presented at Florida Field Biologist Conference, Orlando, Fla.

Jaap, W.C. (1979b). Observations on zooxanthellae expulsion at Middle Sambo Reef, Florida Keys, U.S.A. Bull. Mar. Sci. 29(3): 414-422.

Jaap, W.C. (1983). Population dynamics of stony corals in Biscayne National Park patch reefs, Florida, USA. Biologie et Geologie des Récifs Coralliens. Colloque annuel Int. Soc. for Reef Studies, Université de Nice. December 1983.

Jaap, W.C. (1984). The ecology of the South Florida coral reefs: a community profile. U.S. Fish and Wildlife Service, FWS OBS-82/08.

Jaap, W.C. (1985a). An epidemic zooxanthellae expulsion during 1983 in the lower Florida Keys coral reefs: hyperthermic etiology. Proc. Sth Int. Coral Reef Congr., Tahiti 6: 143-148.

Jaap, W. (1985b). Stony corals, Biscayne National Park. Florida Dept of Natural Resources, Bureau of Marine Research.

-Jaap, W.C. (198?). Stony coral (Scleractinia and Milleporina) community structure of Bird Key Reef, Fort Jefferson National Monument, Dry Tortugas, Florida.

Jones, J.A. (1963). Ecological studies of the southeastern Florida patch reefs. Part I. Diurnal and seasonal changes in the environment. Bull. Mar. Sci. 13(2): 282-307.

Jones, J.A. (1977). Morphology and development of southeastern Florida patch reefs. Proc. 3rd Int. Coral Reef Symp. Miami, 2: 231-235.

Jones, R.S. and Thompson, J.J. (1978). Comparison of Florida reef fish assemblages using a rapid visual technique. Bull. Mar. Sci. 28(1): 159-172.

Jordan, G.F. (1952). Reef formation in the Gulf of Mexico off Apalachicola Bay, Florida. Bull. Geol. Soc. Amer. 63(7): 741-744.

Hoyce, E.A. and Williams, J. (1969). Memoirs of the Hourglass Cruises: rationale and pertinent data. Florida Dept Nat. Resour. Mar. Res. Lab. Vol. 1., Pt 1. 
*Kern, J.A. (1970). Biscayne Bay - the splendour, the endless fight to save it. Audubon 72(5): 36-46.

Kier, P.M. and Grant, R.E. (1965). Echinoid distribution and habits, Key Largo Coral Reef Preserve, Florida. Smithsonian Miscellaneous Contributions 149(6): $68 \mathrm{pp}$.

Kissling, D.L. (1965). Coral distribution on a shoal in Spanish Harbour, Florida Keys. Bull. Mar. Sci. 15: 599-611.

Lessios, H.A., Cubit, J.D., Robertson, D.R., Shulman, M.J., Parker, M.R., Garrity, S.D. and Levings, S.C. (1984). Mass mortality of Diadema antillarum on the Caribbean coast of Panama. Coral Reefs 3: 173-182.

Levert, C.F and Ferguson, H.C. (1969). Geology of the Flower Garden Banks, northwest Gulf of Mexico. Gulf Coast Assoc. Geol. Soc. Trans. 19: 89-100.

-Lighty, R.G. (1977). Relict shelf-edge Holocene coral reef: southeast coast of Florida. Proc. 3rd Int. Coral Reef Symp., Miami 2: 215-222.

- Lighty, R.G., MacIntyre, I.G. and Stuckenrath, R. (1982). Submerged early Holocene barrier reef south-east Florida shelf. Nature (London) 296(5683): 59-60.

Longley, W.H, and Hildebrand, S.F. (1941). Systematic catalogue of the fishes of Tortugas, Florida, with observations on colour habits and local distribution. Pap. Tortugas Lab. 34: 1-331.

Ludwick, J.C. and Walton, W.R. (1957). Shelf-edge calcareous prominences in north-eastem Gulf of Mexico. Bull. Amer. Assoc. Petrol. Geol. 4: 2054-2101.

MacIntyre, I.G. and Milliman, J.D. (1970).

Physiographic features on the outer shelf and upper slope, Atlantic Continental Margin, southeastern United States. Geol. Soc. Am. Bull. 81: 2577-2598.

-Manker, J.P. (1975). Distribution and concentration of mercury, lead, cobalt, zinc and chromium in suspended particles and bottom sediments, Upper Florida Keys, Florida Bay and Biscayne Bay. Ph.D. Rice Univ., Houston, Texas, 114 pp.

-Marszalek, D. (1981/82). Florida reef tract marine habitat and ecosystems. Map series, Florida Dept of Natural Resources, U.S. Dept of the Interior, Bureau of Land Management and Univ. Miami.

Marszalek, D.S., Babashoff, G., Noel, M.R. and Worley, D.R. (1977). Reef distribution in South Florida. Proc. 3rd Int. Coral Reef Symp., Miami 2: 223-229.

Moe, M. (1984). The cathedral at Coffins Patch. Sea Frontiers 30(6): 342-347.

Moore, D.R. and Bullis, H.R. (1960). A deep water coral reef in the Gulf of Mexico. Bull. Mar. Sci. Gulf Caribb. 10: 125-128.

NOAA (1979a). Draft environmental impact statement prepared on the proposed East and West Flower Garden Marine Sanctuary. Office of Coastal Zone Management, U.S. Dept of Commerce, April 1979.

NOAA (1979b). Key Largo Coral Reef Marine Sanctuary Management Plan. Office of Coastal Zone Management, U.S. Dept of Commerce.

NOAA (1979c). National Marine Sanctuaries Program: Key Largo Coral Reef Marine Sanctuary. Brochure produced by NOAA.

NOAA (1980a). Final environmental impact statement prepared for the proposed Looe Key National Marine Sanctuary. Office of Coastal Zone Management, Washington D.C. 144 pp.

-NOAA (1980b). Key Largo Coral Reef Marine Sanctuary Literature Survey and Water Quality Monitoring Program. NOAA.
NOAA (1980c). Flower Garden Bank Brine Seep Biological Assessment. Operations Manual, Office of Coastal Zone Management, U.S. Dept of Commerce.

NOAA (1980d). Final Environmental Impact Statement on the Proposed Gray's Reef Marine Sanctuary. Prepared by Office of Coastal Zone Management, Washington D.C.

-NOAA (1981a). Local climatological data; annual summary (1980) with comparative data. Miami and Key West, Florida, NOAA, National Climatic Center, Asheville, N.C. 4 pp.

-NOAA (1981b). Key Largo Coral Reef National Marine Sanctuary Deepwater Resource Survey. Ed. Jameson, S.C., NOAA Technical Report CZ/SP-1, Washington D.C. 57 pp.

NOAA (1983). Gray's Reef National Marine Sanctuary Management Plan. U.S. Dept of Commerce, Washington D.C.

NOAA (1984). Looe Key National Marine Sanctuary Management Plan. US Dept of Commerce. Prepared by James Dobbin Associates Inc, Washington D.C.

Opresko, D. (1973). Abundance and distribution of shallow-water gorgonians in the area of Miami, Florida. Bull. Mar. Sci. 23(3): 535-558.

Phillips, R.C. and Springer, V.G. (1960). Observations on the offshore benthic flora in the Gulf of Mexico off Pinellas Co., Florida. Amer. Midl. Nat, 64: 362-381.

Porter, J., Battey, J. and Smith, G. (1982). Perturbation and change in coral reef communities. Proc. Natl Acad. Sci. 79: 1678-1681.

Raymond, B. (1972). The marine geology of Broward County, Fla; Final report of investigations to Broward County Erosion Prevention District, Unpubl. M.Sc., Florida State Univ.

Raymond, B. and Antonius, A. (1977). Reef Damage Survey Biological Monitoring Report, John U. Lloyd Beach State Recreation Area. Final Report for Broward County Environmental Quality Control Board and Erosion Prevention Division. Contract 6-76-32-F.

Reed, J.K. (1980). Distribution and structure of deep-water Oculina varicosa coral reefs off central eastern Florida. Bull. Mar. Sci. 30: 667-677.

Reed, J.K. (1981). In situ growth of the scleractinian coral Oculina varicosa occurring with zooxanthellae on $6 \mathrm{~m}$ reefs and without on $80 \mathrm{~m}$ banks. Proc. $4 t h$ Int. Coral Reef Symp., Manila 2: 201-206.

Reed, JK. (1983). Nearshore and shelf-edge Oculina coral reefs: the effects of upwelling on coral growth and on the associated faunal communities. In: Reake, M.L. (Ed.). The Ecology of Deep and Shallow Coral Reefs. Symposia Series for Undersea Research, NOAA's Undersea Research program, U.S. Dept of Commerce, Vol. 1: 149 pp.

Reed, J.K. (undated). Nomination of a Habitat Area of Particular Concern (HAPC).

Reed, J.K. and Hikkelsen, (in press). (reference not known).

Reed, J.K. and Hoskin, C.M. (in press). Biological and geological processes at the shelf edge investigated with submersibles. Undersea Research Symposium, May 1984, Avery Pt, Connecticut.

Reed, J.K., Scotto, L.E. and Wilson, K.A. (1982). Community composition, structure, areal and trophic relationships of decapods associated with shallow and deep water Oculina varicosa coral reefs: studies on decapod crustacea from the Indian River region of Florida. Bull. Mar. Sci. 32(3): 761-786.

Reynolds, J.E. and Steinmetz, J.C. (1983). Dry Tortugas: products of time. Sea Frontiers 29(2): 66-75. 
Rezak, R. (1977). West Flower Garden Bank, Gulf of Mexico. AAPG Studies in Geology 4: 27-36.

Robbin, D.M. (1981). Subaerial $\mathrm{CaCo}_{3}$ crust: a tool for timing reef initiation and defining sea level changes. Proc. 4th Int. Coral Reef Symp., Manila 1: 575-579.

-Roberts, H.H., Rouse, L.J. Jr., Walker, N.D. and Hudson, H. (1982). Cold water stress in Florida Bay and northern Bahamas: a product of winter frontal passages. J. Sed. Petrol. 52(1): 145-155.

Rogers, C.S. (1985). Degradation of Caribbean and Western Atlantic coral reefs and decline of associated fisheries. Proc. 5th Int. Coral Reef Cong., Tahiti 6: 491-496.

Schmahl, G.P. and Tilmant, J.T. (1980). An initial characterization of macroinvertebrate populations associated with patch reefs of Biscayne National Monument. Fla Sci. 43(suppl. 1), Abs.

Searles, R.B. (1981). Seaweeds from Gray's Reef, Georgia. Northeast Gulf Science 5(1): 45-48.

Shinn, E.A. (1963). Spur and groove formation on the Florida Reef Tract. J. Sedim. Petrol. 33(2): 291-303.

Shinn, E.A. (1966). Coral growth rate, an environmental indicator. J. Paleo. 40(2): 233-240.

Shinn, E.A. (1976). Coral reef recovery in Florida and the Persian Gulf. Env. Geol. 1: 241-254.

Shinn, E.A., Hudson, J.H., Robbin, D.M. and Lidz, B. (1981). Spurs and grooves revisited: construction versus erosion, Looe Key Reef, Florida. Proc. 4th Int. Coral Reef Symp., Manila $1: 475-483$.

Skinner, R. and Jaap, W. (1984). Effects of boat traffic and land development on Key Largo's coral reefs and adjacent marine environments. Report to the Governor and Cabinet, Jan 1984.

Smith, F.G. (1943). Littoral fauna of the Miami area. 1. The Madreporaria. Proc. Fla Acad. Sci. 6(1): 41-48.

-Smith, G.B. (1976). Ecology and distribution of eastern Gulf of Mexico reef fishes. Florida Dept of Nat. Res., Florida Mar. Res. Lab., Publ. 19: 78 pp.

-Smith, J.W. (1974). Studies on Eastern Gulf of Mexico corals. Proc. Fla. Keys Coral Reef Workshop. State of Fla Dept of Nat. Res., St Petersburg, Fla, Abstract: 20-21.

Smith, F.G., Williams, R.H. and Davis, C.C. (1950). An ecological survey of the subtropical inshore waters adjacent to Miami. Ecology 31: 119-146.

South Carolina Wildlife and Marine Resources Department, Marine Resources Research Institute, Georgia Department of Natural Resources, Coastal Resources Division and Duke University Marine Laboratory (1981). Final Report on the South Atlantic OCS Area Living Marine Resources Study. Prepared for the Bureau of Land Management, Washington, D.C. under Contract AA551-CT9-27. October, 1981. Vol. I-III. South Carolina Wildlife and Marine Resources Department, Marine Resources Research Institute, Georgia Department of Natural Resources, Coastal Resources Division and Duke University Marine Laboratory (1982). Final Report on the South Atlantic OCS Area Living Marine Resources Study, Year II Prepared for the Minerals Management Service, Washington, D.C. under Contract AA551-CT1-18. December, 1982. Vol. I-III.

South Carolina Wildlife and Marine Resources Department, Marine Resources Research Institute, Georgia Department of Natural Resources, Coastal Resources Division and Duke University Marine Laboratory (1983). Final report on the South Atlantic OCS Area Living Marine Resources Study, Year III.
-Starck, W.A. (1968). A list of fishes of Alligator Reef, Florida, with comments on the nature of the Florida reef fish fauna. Undersea Biol. 1(1): 1-40.

-Starck, W.A. and Davis, W.P. (1966). Night habits of fishes of Alligator Reef, Florida. Ichthyol. Aquar. J. 38: 313-356.

Stetson, T.R., Squires, D.F. and Pratt, R.M. (1962).

Coral banks occurring in deep water on the Blake Plateau. Amer. Mus. Nov. 2114: 1-39.

-Straughan, R.P.L. (1972). Pollution, dredging decimating Florida's reefs. Natl Fisherman, Camden, Maine 52(13): 46-48.

Taggart, K.E. (1983). Announcement of National Marine Sanctuary Program Final Site Evaluation List. Federal Register 48(151): 35568-35577.

*Taylor, D.D. and Bright, T.J. (1973). The distribution of heavy metals in reef-dwelling groupers in the Gulf of Mexico and Bahama Islands. Texas A and M. University Dept Mar. Resources Information Center. Publ. 249 pp.

Thompson, M.J., Gilliland, L.E. and Mendein, J.E. (1978). Bathymetric mapping of three selected areas on the southeastem Florida continental shelf. Harbour Branch Foundation Inc. Tech. Rep. 27: 54 pp.

Thompson, M.J. and Schmidt, T.W. (1977). Validation of the species/time random count technique sampling fish assemblages at Dry Tortugas. Proc. 3rd Int. Coral Reef Symp, Miami : 283-288.

-Tilmant, J.T. (1981). Recreational impacts on coral reef fish populations. In: Cary, R.C., Markovits, P.S. and Kirkwood, J.F. (Eds). Proc. U.S. Fish and Wildlife Service workshop on coastal ecosystems of the south-eastern United States. USDI Publ. FWS/OBS-80/59.

Tilmant, J.T. (in press). (reference not obtained).

Tilmant, J.T. and Schmahl, G.P. (1981). A comparative analysis of coral damage on recreationally used reefs within Biscayne National Park, Florida. Proc. 4th Int. Coral Reef Symp., Manila 1: 187-192.

-Tilmant, J.T., Schmahl, G.P. and Morrison, D. (1980). An ecological assessment of Biscayne National Monument's coral reefs in relation to recreational use. In: Gouge, J. (Ed.). Proc. 2nd Conf. on Sci. Res. in the National Parks, San Francisco 9: 183-224.

Tresslar, R.C. (1974). Corals. In: Bright, T.J. and Pequegnat, L.H. (Eds) (1974): 115-139.

Turmel, R.J. and Swanson, R.G. (1976). The development of Rodriguez Bank, a Holocene mudbank in the Florida reef tract. J. Sed. Petol. 46: 497-518.

Tweedt, P.L. (1984). Initiation of preliminary consultation on Flower Garden Banks as an Active Candidate for possible National Marine Sanctuary designation. Federal Register 49(88): 19094-19096.

*Voss, G.L. (1968). Ecology and dynamics of coral reef populations, Florida. Nat. Geog. Soc. Res. Reports 1963: 225-230.

Voss, G.L. (1973). Sickness and death in Florida's coral reefs. Nat. Hist. $82(7): 40-47$.

Voss, G.L. and Yoss, N.A. (1955). An ecological survey of Soldier Key, Biscayne Bay, Florida. Bull. Mar. Sci. 5: 202-228.

-Voss, G.L., Bayer, F.M., Robins, C.R., Gorman, M. and Laroe, E.T. (1969). Marine ecology of Biscayne National Monument. Report to National Park Service, Dept Interior, Institute of Marine and Atmospheric Science, Univ. of Miami: 128 pp.

Walker, N.D., Roberts, H.H., Rouse, L.J. and Huh, O.K. (1982). Thermal history of reef-associated environments during a record cold-air outbreak event. Coral Reefs 1: 83-87. 
Warman, S. (1984). South Florida Marine Parks. Unpub. rept to Scottish Heritage USA, Inc.

Wells, J.W. (1932). Study of the reef corals of the Tortugas. Yearb. Carnegie Inst. Washington 31: 290-291.

Wheaton, J.Ln and Jaap, J.C. (1984). Looe Key National Marine Sanctuary Resource Survey: corals and other major benthic Cnidaria. Florida Dept of Natural Resources, Bureau of Marine Research, St Petersburg. White, M.W. and Porter, J.W. (1985). The establishment and monitoring of two permanent photograph transects in Looe Key and Key Largo National Marine Sanctuaries (Florida Keys), Proc. Sth Int. Coral Reef Congr., Tahiti 6: 531-537.

-Zieman, J. (1982). The ecology of the seagrasses of south Florida: a community profile. U.S. Fish Wildl. Serv. Biol. Serv. Program FWS/OBS-82/25: 150 pp.

\section{ALLIGATOR REEF}

Geographical Location Florida, $4-6 \mathrm{~km}$ off Lower Matecumbe Key; $24^{\circ} 51^{\prime} \mathrm{N}, 80^{\circ} 42^{\prime} \mathrm{W}$.

Land Tenure State of Florida (to $3 \mathrm{n}$. mi. (5.6 km)); Federal Government beyond.

Physical Features Includes a large area stretching from the island shoreline to a depth of $45 \mathrm{~m}$ off shore. The Alligator Lighthouse is situated in the centre. The reef consists of a deep reef, a reef top, a back-reef and a lagoon. Sand flats with Thalassia beds extend $4 \mathrm{~km}$ from the shoreline, and are dotted with patch reefs. Further from shore, sand cover increases and there is less grass. The back-reef consists of eroded coral rubble resting on a sandy base immediately preceding the ridge of the reef top. There are relatively few caves or overhangs on the reef front which is cut by surge channels. The reef front stops at a sandy plain, $150 \mathrm{~m}$ wide, which separates it from the deep reef, which is also cut by surge channels. At $16-18 \mathrm{~m}$ depth, this shelf falls away to form a deep reef slope, ending at $28-30 \mathrm{~m}$ depth in another sandy plain (Emmery, 1973). Sea level changes on the reef are described by Robbin (1981)

Reef Structure and Corals Although core samples indicate that the reef was built by Acropora palmata and $\boldsymbol{A}$ cervicornis, living examples of these corals are rare and growth is restricted to occasional head corals such as Diploria, Colpophyllia and Dichocoenia (Robbin, 1981). The patch reefs on the sand flats are covered with live corals and extensive hard bottom outcrops with tall alcyonarians and Sargassum mixed with sponges and algae. The tops of the larger patch reefs are often dead and overgrown with algae. The coral on top of the patch reefs is either knobbly or of the large expansive boulder form; on the sides, coral colonies form overhanging sheets. Alcyonarians and small patches of Thalassia are found on the back-reef. The reef top is a Millepora ridge, $1.5-7 \mathrm{~m}$ deep, sloping seawards. The reef front is a pavement of coral rock overgrown with small secondary corals, alcyonarians, sea fans, sponges and low algae. The deep reef has corals, sponges, algae and alcyonarians on both the shelf and reef slope (Emmery, 1973).

Noteworthy Fauna and Flora The fish fauna is described in Starck (1968) and Starck and Davis (1966).
Damselfish (Pomacentridae) have been studied on the reef (Emmery, 1973). The Loggerhead Caretra caretta, Green Turtle Chelonia mydas, Hawksbill Eretmochelys imbricata and Leatherback Dermochelys coriacea may occur in the area and the Caribbean Manatee Trichechus manatus occurs here in summer.

Scientific Importance and Research The reef is used for research work (Emmery, 1973; Robbin, 1981).

Economic Value and Social Benefits Fishing, diving and snorkelling.

Disturbance or Deficiencies No information.

Legal Protection The coral is protected under federal regulations implemented in 1984.

Management No information.

Recommendations No information.

\section{BISCAYNE NATIONAL PARK (FORMERLY NATIONAL MONUMENT)}

Geographical Location Located in the southern part of Dade Co., Florida, $24 \mathrm{~km}$ south of Miami. Includes the waters of Southern Biscayne Bay, Northern Card Sound, the northernmost islands of the Florida Keys and the offshore waters and coral reefs out to the $18 \mathrm{~m}$ depth contour. Bordered by the John Pennekamp State Park-Key Largo National Marine Sanctuary to the south.

Area, Depth, Altitude 70822 ha of which $5 \%$ is emergent land; average depth $1.3 \mathrm{~m}$, maximum depth $18 \mathrm{~m}$.

\section{Land Tenure Federal Government.}

Physical Features The mainland coast is a relatively unspoiled strip of coastal mangroves, broken only by the Park Headquarters at Convoy Point and by artificial drainage canals. Biscayne Bay is a large area of very shallow water crossed by the Intercoastal Waterway from north to south. Twenty-five keys, including Ragged Keys, Sands Key, Elliott Key, Old Rhodes Key, Totten Key, Arsenicker Keys, Swan Key, Rubicon Keys, Reid Key and Adams Key, form an almost continuous north-south chain, separating the bay from the ocean. Caesar's Creek, the tidal pass to the south of Elliott Key, channels the flow of water from Biscayne Bay well out onto the reef tract west of Pacific Reef. North of Elliott Key, the series of small islands, submerged banks and tidal channels allows a more extensive water exchange between the bay and reef tract (Bums, 1985). The offshore marine ecosystem consists of highly varied subaquatic terrain consisting primarily of turtle grass, with sedimentary, live bottom and coral reef communities. Live bottom - hard grounds are found closest to shore.

A discontinuous series of bank reefs is located approximately $7 \mathrm{~km}$ seaward of the keys just inside the Park's eastern boundary, including Triumph, Long, Ajax, Pacific, Dome, Star, Schooner and Elkhom Reefs. 
Between the keys and the outer bank reefs lies a large sheltered lagoonal area with up to 4000 patch reefs, most of which are unamed apart from Margot Fish Shoal and Bache Shoal (Tilmant and Schmahl, 1981). This area is crossed north to south by Hawk Channel, averaging 2.5-3 $\mathrm{m}$ in depth, and shoaling to shallow banks on each side averaging 1-2 $\mathrm{m}$ depth. A general description of the area is given in Voss et al. (1969), including a description of the outer bank reefs.

Reef Structure and Corals Biscayne Bay is dominated by Thalassia seagrass beds with patches of algae, sponges and soft coral. Early studies on the ecology and corals of the area include Smith (1943) and Smith et al. (1950). The most common reef form is the patch reef, described by Jones (1963 and 1977), Hein and Risk (1975), Jaap (1979b and 1983) and Schmahl and Tilmant (1980). Reef zonation is similar to that described for Key Largo (see separate account). Species composition and population dynamics of stony corals have been studied by Jaap (1979a, 1983 and 1985b). The most common stony corals are Porites astreoides, Millepora alcicornis, $P$. porites, Agaricia agaricites and Siderastrea siderea (Jaap, 1983). $P$, astreoides and $M$. alcicornis are dominant numerically but $A$ palmata and Montastraea annularis contribute most of the biomass. Marginal or immature bank reefs with populations of Acropora palmata are limited to the area south of Caesar's Creek and Pacific Light, to the John Pennekamp Coral Reef State Park boundary. North of Pacific Light, offshore reefs are impoverished in the shallower $(0-5 \mathrm{~m})$ depths. Burns (1985) describes the variation, with depth and proximity to tidal passes, of the stony coral community on Triumph, Long, Ajax and Pacific Reefs. Low coral diversity, cover and abundance indicate that this area is suboptimal for reef building corals. 41 taxa of stony corals were identified by Jaap (1985b); Burns (1985) recorded 36 species.

The gorgonian fauna was described by Opresko (1973). Octocoral density was as high as 58 cols/sq. $m$ for eight patch reefs, whereas stony coral density averaged only 8.5 cols/sq. m. The five most abundant octocorals were Plexaura flexuosa, $P$. homomalla, Gorgonia ventalina, Eunicea succinea and Pseudopterogorgia americana (CNA, 1981).

Noteworthy Fauna and Flora Woody vegetation almost completely covers most of the keys. Developed keys, such as Boca Chita, are dominated by exotic vegetation but others, such as Adams and Elliott Keys, still support relatively pristine hardwood vegetation (Warman, 1984). Mangroves are found along much of the shoreline and a surprising variety of tropical hardwoods dominate the higher interior. There are some remnant stands of larger trees including mahoganies (Anon., 19??b). Raccoon, marsh rabbit and the Mexican Red-bellied Squirrel are found on the keys. Arsenicker Keys have nesting sites for many water birds (Anon., 198??b). The Caribbean Manatee Trichechus manatus is found in Biscayne Bay and the American Crocodile Crocodylus acums may still occur although it no longer breeds here. The Leatherback Dermochelys coriacea, Kemp's Ridley Lepidochelys kempii, Loggerhead Caretta caretta and Green Turtle Chelonia mydas may occur; the two latter species may nest (Bacon et al., 1984). A study of fish populations at Margot Fish Shoal, off Elliott Key, has been carried out by the Miami School of Marine and
Atomospheric Science (Voss, 1973). 214 fish species have been reported from the reefs (Tilmant, in press).

Scientific Importance and Research The Park has the northernmost reef development in the Florida Keys. Studies that have focused on reef communities in the area include Smith (1943), Smith et al. (1950), Voss and Voss (1955), Jones (1963 and 1977), Opresko (1973), Hein and Risk (1975), Jaap (1980 and 1985b), Schmahl and Tilmant (1980) and Voss et al. (1969). Voss and Voss (1955) carried out an ecological survey of Soldier Key to the north of the park, on the eastern border of Biscayne Bay between Key Biscayne and Elliott Key. The Park is the only area in the Gulf of Mexico where all the data necessary for calculating Maximum Sustainable Yields for corals has been collected (CNA, 1981). A water quality study is being carried out as a joint project with the John Pennekamp State Park and Key Largo Marine Sanctuary The National Park Service and Florida Department of Natural Resources, Bureau of Marine Resources, are co-operating in a study of the physical, chemical and biotic parameters of the Park.

Economic Value and Social Benefits The Park is readily accessible to recreational visitors from Miami and receives 369000 visitors a year (largely at weekends) of whom about 10000 swim or dive on the reefs (Tilmant and Schmahl, 1981). Water sports are encouraged but there is no public boat transport. Boating and fishing are the main activities but swimming, snorkelling and scuba diving are also popular. There are no commercial diving operations unlike the other Florida parks, but Florida residents dive in the area from their own boats. There is a boat launching ramp, and a small marina. Four patch reefs, $3.5 \mathrm{~km}$ east of Elliott Key and Old Rhodes Key, including one shipwreck, are marked by mooring buoys and can be visited. Camping, picnicking and hiking are permitted on Elliott Key but there is no freshwater. Most services have to be obtained at Homestead (Anon., 198?b). The Park Headquarters at Convoy Point, $14.5 \mathrm{~km}$ east of Homestead, and the visitor centre and ranger station on Elliott Key provide information and maps for visitors but currently few visitors drive to the headquarters. An interpretive trail has been laid on Elliott Key and there are unmarked trails on Adams Key and at Convoy Point. Glass bottom boat trips are available and a tour boat is being prepared. There are a variety of other educational activities.

Commercial fishing for sponge, blue crab, other crustaceans and finfish are carried out in Biscayne Bay which is an important nursery area for spiny lobster Panulirus sp., pink shrimp and several gamefish, and commercial fishing takes place throughout the Park (Warman, 1984). Recreational fishing for spiny lobster and fin fish is also popular. There is some collecting of fish and invertebrates for aquaria (Jaap, 1985b). The National Park Service has recorded over 120 species of reef fish caught within the Park but 10 species comprised over $80 \%$ of the harvest (Jaap, 1984)

Disturbance or Deficiencies Natural events are largely responsible for controlling reef community structure (Jaap, 1985b). Large storm waves have a major influence on shallow reefs in the Park but have a less serious impact north of Caesar's Creek because of the shelter provided by the offshore bank reefs. Cooling of surface waters during severe winter cold fronts is another major 
environmental control, contributing to the lack of acroporids on the shallow fore-reef, the increase in total coral cover with depth and the greater abundance of Montastraea annularis in the deepest zones (Burns, 1985). Water temperatures in Caesar's Creek dropped below $14^{\circ} \mathrm{C}$ in 1977,1978 and 1980 (Tilmant et al.s in prep.). In 1981, another cold water outbreak killed corals at $4 \mathrm{~m}$ depth off Elliott Key (Burns, 1985). Cooled bay water appears to affect the shallow reefs and reefs near tidal passes sooner and more severely than others, and an increase in abundance of Acropora cervicornis and Diploria clivosa and in total coral cover is found with increasing distance from Caesar's Creek.

The National Park was once threatened by the proposed development of an oil refinery and plastics complex with a deepwater shipping channel through Caesars Creek, but these plans were halted. An early account is given in Kern (1970). Manker (1975) described early pollution problems in the area. A nuclear power plant was built at Turkey Point by the Florida Power and Light Company, and a cooling system was subsequently added to stop heated effluent flowing into Biscayne Bay. However, when running on oil, fuel is transported into the plant by barge through Biscayne Bay which poses a threat of pollution. The barges and tugs also leave a large sediment plume behind them which increases turbidity (Warman, 1984). Damage to corals in the Park has been reported as a result of a number of other factors including organic pollution. Patch reefs, being closer to shore, are thought to be more susceptible than bank reefs to pollution from sewage (Voss, 1973).

The Park is exposed to considerable recreational pressure due to its close proximity to Dade County urban areas and its accessibility from Miami (CNA, 1981). An evaluation of human impact on the reef system has been carried out (Tilmant et al., 1980), including a five-year study of eight patch reefs to document the incidence of physical damage to corals. Natural wave action and substrate erosion are believed to account for the vast majority of damage encountered, which masks that caused by swimmers or boaters. Current visitor usage is not however thought to be seriously affecting corals (Jaap, 1985b). Boat groundings cause some serious localized damage, probably due to the high density of small shallow patch reefs within the lagoonal area and the inexperience of many recreational boaters (Tilmant and Schmahl, 1981); damaged corals have been found adjacent to several navigation and mooring buoys (CNA, 1981). A limited assessment of fishing impacts has been carried out (Tilmant, 1981); during a 3-year period, fish catch rates varied inversely with the number of fishermen using the Park waters but reef fish populations remained relatively stable.

Legal Protection The Park was established in 1968. There are no specific regulations but general regulations in Title 36 of the Code of Federal Regulations apply to all units of the National Park System. Fishing is permitted in accordance with Florida Law. Biscayne Bay is closed to lobstering and the possession, removal or disturbance of corals, seafans, seafeathers, tropical fish, shells, historical artifacts or any natural feature is prohibited. Spearfishing is permitted except at localities where it might be dangerous to other park users (Warman, 1984). Those portions of the Park located outside State waters have been designated a Habitat Area of Particular Concern (HAPC) (CNA, 1981). Biscayne
Bay Aquatic Preserve and the Biscayne Bay-Card Sound Lobster Sanctuary lie adjacent to the Park.

Management Administered by the National Park Service, U.S.D.I. Superintendent based at P.O. Box 1369, Homestead, Florida 33030. The Park is designed to facilitate the existing recreational activities in a compatible manner with the physical and biotic environment and to provide mechanisms for detecting areas of existing or potential environmental degradation. Management provisions include: 1) monitoring to detect destruction of an area at early stages, 2) improvement of monument boundary, depth, channel and depth warning markers at critical locations, 3) establishment of activity areas, 4) enforcement of regulations prohibiting tropical fish collecting and removal of archaeological artefacts, 5) establishment of mooring stations near corals to reduce anchor damage, and 6) establishment of monitoring stations to detect natural fluctuations in environmental factors. Special studies are planned in co-operation with the State of Florida to determine what types of commercial and sport fishing will be allowed, in what magnitude and what regulatory actions will be necessary. There are 22 permanent full-time rangers and technicians and an additional 20 part-time staff. The National Park Service is seeking Park Protection zoning status for the mangrove shoreline on the mainland so that activities which might disrupt this area will be restricted (Warman, 1984). Mooring buoys have now been established on four reefs and maps, navigation instructions and guide books are available through the Park Office (Jaap, 1985b).

Recommendations A public education programme may be necessary to prevent further damage due to boat groundings (Tilmant and Schmahl, 1981). Jaap (1985b) recommends continued monitoring and the establishment of additional mooring buoys.

\section{EAST AND WEST FLOWER GARDEN BANKS PROPOSED NATIONAL MARINE SANCTUARY}

Geographical Location North-western Gulf of Mexico; over $200 \mathrm{~km}$ SSW of Galveston, Texas; East Flower Garden Bank $27^{\circ} 55^{\prime} \mathrm{N}$, 93⒊ ${ }^{\prime} \mathrm{W}$; West Flower Garden Bank $27^{\circ} 52^{\prime}, 93^{\circ} 49^{\prime} \mathrm{W}$.

Area, Depth, Altitude West Flower Garden Bank 40 ha; East Flower Garden Bank 28 ha (but according to Bright et al. (1984) WFGB is $74 \mathrm{~km}$ with $0.5 \mathrm{sq}$. km of reef; EFGB is $50 \mathrm{sq}$. $\mathrm{km}$ with $2.7 \mathrm{sq}$. $\mathrm{km}$ of reef); the proposed sanctuary would cover $44 \mathrm{sq}$. mi (114 sq. km), i.e. the area within the $100 \mathrm{~m}$ isobath; surrounding depths are $100-140 \mathrm{~m}$; bank crests are at $20 \mathrm{~m}$.

\section{Land Tenure Federal Government.}

Physical Features These are outer shelf structures originating at depths of $100-200 \mathrm{~m}$ (Bright, 1977) and located in clear oceanic water, $25 \mathrm{~km}$ apart on the edge of the continental shelf. The banks are salt-dome structures, colonized by coralline algae and reef-building corals (Levert and Ferguson, 1969), and have been described as submerged reef-banks with coral prominences cresting at a depth of approximately $20 \mathrm{~m}$ (Bright and Pequegnat, 1974; Bright et al., 1984). The surrounding water is 
exceptionally clear, with visibility of usually more than $30 \mathrm{~m}$, and light penetrating well to $85 \mathrm{~m}$. Salinity averages over $36 \mathrm{ppt}$ but is occasionally as low as $32 \mathrm{ppt}$ at the surface and $34 \mathrm{ppt}$ on the bank tops. Above $24 \mathrm{~m}$, temperatures vary seasonally from $18^{\circ} \mathrm{C}$ to $32^{\circ} \mathrm{C}$. Bathymetric charts have been produced by the Flower Gardens Research Center and by Edwards (1971).

East Flower Garden Bank is a tear-shaped dome roughly $5 \mathrm{~km}$ in diameter rising to within $16 \mathrm{~m}$ of the sea surface (Bright and Rezak, 1976 and 1978). The total area of the coral reef on top of the bank is $0.3 \mathrm{sq} . \mathbf{k m}$. West Flower Garden Bank is roughly oblong $(11 \times 8 \mathrm{~km})$, and lies close to the shelf edge, orientated NE-SW. Live reef occupies $0.4 \mathrm{sq} . \mathrm{km}$ (NOAA, 1979a), including a peak rising to $22 \mathrm{~m}$ depth (Rezak, 1977). The slopes of the reef range from $45^{\circ}$ to vertical and are cut by steep-walled canyons floored with coarse carbonate sands. The sediment apron slopes gradually away from the reef to a depth of $100 \mathrm{~m}$ on the landward side and $136 \mathrm{~m}$ on the seaward side. Dead reefs are found in some places on the sediment apron.

Natural gas seeps of an intermittent nature, usually occurring as repeated short bursts of bubbles, have been found on the banks. These are thought to be biogenic in nature, although the deep seeps at East Flower Garden Bank may be partly or wholly petrogenic. Whatever their origin, they consist of $98.5-99.9 \%$ methane with traces of ethane and propane, and there is no evidence that they particularly influence the biota. Another unusual feature at the East Garden Flower Bank is the presence of a brine pool on the surface of the bank, $0.75 \mathrm{~m}$ deep at the centre, with a salinity of $188 \mathrm{ppt}$. The brine supports a sulfuretum biotic community which apparently produces enough organic matter to enhance infaunal and epibenthic populations in the immediate vicinity. Fish do not enter the pool but groupers Serranidae and the Cottonwick Haemulon melanurum swim freely in the stream emanating from the pool (Bright, 1977; NOAA, 1980c).

Reef Structure and Corals The main species in each zone have been described using transect surveys (Bright, 1977; Bright and Pequegnat, 1974; Bright and Rezak, 1976 and 1978; Bright et al., 1984; Tresslar, 1974). Above 25-29 $\mathrm{m}$ depth, both banks are covered with thriving submerged coral reefs which, except for the total lack of shallow-water alcyonarians, are good examples of the Diploria-Montastraea-Porites community typical of Caribbean reefs (Bright, 1977). Most of the substrate $(85 \%)$ in these areas is hard with live coral coverage exceeding $50 \%$; the rest is coarse carbonate sand or coral gravel. At their shallowest, West Flower Garden Bank has $30-40 \%$ live stony coral cover (Bright and Pequegnat, 1977) and East Flower Garden Bank has $60-65 \%$ cover (Bright and Abbott, 1978). Montastraea annularis is dominant, making up about $30 \%$ of the coral cover, and 15 additional hermatypic coral species and 10 genera of red calcareous algae have been identified between depths of 15 and $36 \mathrm{~m}$ (Bright et al., 1984). D. strigosa, Colpophyllia spp., M. cavernosa, Millepora alcicornis and $P$. astreoides, in that order of abundance, occupy together approximately $20-25 \%$ of the hard bottom. The reefs are platform-like with broad tops and steep sides to the north, east and south, with a tendency to break into small reef patches along the west.
The corals and associated species of East Flower Garden Bank occur in seven distinct zones from the top at a depth of $16 \mathrm{~m}$ to the base of the bank (i.e. onset of soft bottom community) at 110-120 m depth: 1) leafy algae, 2) Madracis, 3) Diploria, Montastraea and Porites, 4) algae-sponge, 5) Stephanocoenia, 6) antipatharians and drowned reefs, 7 ) soft bottom (Bright, 1977). In the leafy algae zone, knolls are completely covered by lush growths of leafy algae (Caulerpa, Chrysymenia, Halymenia, Goniophloea, Lobophora, Microdictyon and others). The Madracis zone is occupied almost entirely by sizeable knolls of the small branching coral $M$. mirabilis. Finger-sized remains of dead Madracis are extremely important components of the sediment on and adjacent to the reefs.

West Flower Garden Bank is composed of large closely spaced coral heads up to $3 \mathrm{~m}$ or more in diameter, resulting in a rough topography with much growth in the form of ledges and overhangs (Bright and Pequegnat, 1974; Rezak, 1977). The zonation is similar to that found on the East Flower Garden bank, but the leafy algae and Madracis zones are absent. The Diploria-Montastraea-Porites zone is found over an area of $40 \mathrm{ha}$, everywhere above depths of $45-49 \mathrm{~m}$, and consists of $M$. annularis, $D$. strigosa, $M$. cavernosa, Colpophyllia natans and $P$. astreoides in that order of abundance.

The deeper portions of both banks contain a coralline algal-sponge zone followed by a deeper $(70 \mathrm{~m})$ antipatharian zone (Bright, 1977). From 36 to $52 \mathrm{~m}$ depth, there are 12 hermatypic species and abundant coralline algae in a StephanocoeniaMillepora zone; dominant corals are $S$. michelini and $M$. alcicornis. From 50 to $85 \mathrm{~m}$ depth, the banks are dominated by crustose coralline algae, forming an algal-sponge zone. The algae may form rhodoliths, reef patches and crusts. Stony corals are absent except for sparse populations of an agaricid, a small species of Madracis and some solitary hermatypic varieties. There are abundant populations of comatulid crinoids, deep-water alcyonarian fans, whips, and distinctive fish. The most conspicuous organism is a bedspring shaped antipatharian sea whip Cirrhipathes (Bright, 1977)

Noteworthy Fauna and Flora About 250 benthic invertebrates and more than $100 \mathrm{fish}$, including several commercially important species have been described from the Flower Garden Banks (Bright, 1977). Further information is available in Bright and Pequegnat (1974). The Loggerhead Carelta caretta and Green Turtle Chelonia mydas may occur in the area.

Scientific Importance and Research The banks bear the most complete and complex coral communities on the northwestern Gulf of Mexico continental shelf and are the northwesternmost reefs in the Gulf of Mexico (CNA, 1981). They are of particular interest in that they are exposed to winter temperatures which are marginal for the development of thriving tropical coral reefs (Bright et al., 1984). Coral diversity is low compared with other reefs in Florida and the Caribbean; in terms of community structure and coral dominance patterns the banks resemble Bermuda more closely than they do the Florida Middlegrounds. The reefs on the banks differ from all other tropical Atlantic reef systems in their lack 
of shallow water alcyonarian populations (Bright et al., 1984). Acroporids are entirely absent, possibly due to the greater depth, wider temperature ranges and distance from other coral gene pools of South Florida and the southern Gulf. Bright et al. (1984) consider that the biota of the Banks represents a northward extension of the communities of the southern Gulf of Mexico such as the Campeche Bank. A number of research studies have been carried out by the Department of Oceanography of Texas A and M University (Rezak, 1977). Baggett and Bright (1985) studied coral recruitment in the area.

Economic Value and Social Benefits Divers pay as much as $\$ 100$ each to visit the Flower Gardens by boat (CNA, 1981) but numbers of recreational visitors are low. Commercial fishing is common along the edges of the banks. Recently the Flower Garden Banks have become popular with sport fishermen as they support rich populations of Red Snappers Lutjanus campechanus, Vermilion Snappers Rhomoboplites aurorubeus and groupers Mycteroperca spp. (Bright, 1977). The Banks are believed to be a major nursery area for brown shrimp and are therefore important to the commercial shellfishing industry (Tweedt, 1984).

Disturbance or Deficiencies The biota supported by the Flower Garden Banks are climatologically stressed and at least partially isolated from their gene pool. As a result they are very susceptible to collapse if existing populations are destroyed (CNA, 1981). Anchor damage is considered to be a major source of mechanical damage, even at depths of $45 \mathrm{~m}$ where mooring buoys have been lost (Bright and Rezak, 1976). Oil tankers are known to anchor on the banks, and increasing use of the area by recreational and commercial vessels, as well as the expanding traffic in deep draft vessels, poses potential threats in the form of groundings and further anchor damage (CNA, 1981). The Flower Garden Banks, like the other Gulf of Mexico deep water banks, are manifestations of petroleum bearing subsurface geological structures and are therefore subject to exploratory oil and gas drilling which is likely to increase. Drilling for petroleum adjacent to the banks began in 1975 and has occurred as close to the reefs as 1.25 naut. mi. (2.3 km) (Bright, 1977; CNA, 1981; Bright et al., 1984).

Legal Protection The portions of each bank above the $100 \mathrm{~m}$ isobath have been designated Habitat Areas of Particular Concern (HAPC) (CNA, 1981). Bottom longlines, traps and pots, and bottom trawls are prohibited and coral collection is permissable only with a permit (Leary in litt., 1984; Tweedt, 1984).

Management Minerals Management Service lease stipulations require that oil and gas drilling operations adjacent to the banks must shunt their drilling discharges directly to the bottom nepheloid layer (a dense water mass of high turbidity) to minimize potential impacts from surface discharges (CNA, 1981).

Recommendations The banks were the subject of an environmental impact statement as a nominated marine sanctuary (NOAA, 1979a) in 1978 but were withdrawn from consideration in 1982 amid controversies over boundaries and drilling effluent disposal. These were subsequently resolved and the Banks are now an active candidate for potential designation as a national marine sanctuary (Taggart, 1983). Traditional, historical fishing methods should be allowed but anchoring should be prohibited in water less than $100 \mathrm{~m}$ in depth except for vessels less than $100 \mathrm{ft}(30 \mathrm{~m})$ in registered length. Oil and gas exploration should also be controlled (CNA, 1981).

\section{FLORIDA MIDDLEGROUND HAPC}

Geographical Location $28^{\circ} 11^{\prime}-28^{\circ} 45^{\prime} \mathrm{N}, 8^{\circ} 00^{\prime}-84^{\circ} 25^{\prime} \mathrm{W}$; $160 \mathrm{~km}$ west-north-west of Tampa Bay, Florida; $150 \mathrm{~km}$ south of the north Florida coast, near the outer edge of the West Florida shelf.

Area, Depth, Altitude $2556 \mathrm{sq} . \mathrm{km} ; 26-48 \mathrm{~m}$ deep.

Land Tenure Federal Government.

Physical Features An area of deep, discontinuous, reef-like limestone escarpments and knolls rising 10-13 m above the surrounding sand and sand shell substrate. The relief is attributed to underlying Pleistocene relic reefs which flourished during the last inter-glacial epoch (Brooks, 1962; Jordan, 1952). The reef tops are covered with living and dead corals typical of deep Caribbean reefs with assaciated invertebrate and fish fauna indicative of an impoverished coral reef fauna (Grimm and Hopkins, 1977; Austin, 1970). The area is of hydrological interest since it is situated between three water masses; the tropical Gulf Loop current, west Florida estuarine waters and Florida Bay waters (Austin, 1970).

Reef Structure and Corals A total of 15 hermatypic and one ahermatypic scleractinian species have been collected, comparable to the diversity of other Gulf of Mexico reefs. The dominant corals include Madracis decactis, Porites divaricala, Dichocoenia stellaris, D. stokesii and Scolymia lacera. Montastraea and Diploria are absent. Octocorals are prominent, including several genera usually considered typical of tropical areas. The main components of the octocorallian fauna (13 species), which is considered diverse and prolific, are Muricea elongata, $M$. laxa, Eunicea calyculata and Plexaura flexuosa. From about 26 to $28 \mathrm{~m}$ depth there is a Muricea-Dichocoenia-Porites zone. From 28 to $30 \mathrm{~m}$ depth, the dominant forms are Dichocoenia and small Madracis heads with scattered gorgonians while at depths of 30 to $31 \mathrm{~m}$ Millepora predominates almost exclusively. $M$. alcicornis forms massive colonies along the rocky margins at about $27 \mathrm{~m}$ depth and may be the main frame builder. $M$. complanata is present to a lesser extent as encrustations on octocorallian skeletons. From 31 to $36 \mathrm{~m}$ depth, Millepora and Madracis are dominant and sponges and algae are abundant (Grimm and Hopkins, 1977 ).

Noteworthy Fauna and Flora Faunal assemblages are described in Hopkins et al. (1977). Seventy five mollusc species, 56 crustaceans, 23 echinoderms, 41 polychaetes, about 40 sponges, 170 fish species and 103 algae, of which $61 \%$ comprise red algae, have been recorded. The Caribbean Manatee Trichechus manatus, the Green Turtle Chelonia mydas and the Loggerhead Caretta caretta may occur in this area. Fish are described by Smith (1976). 
Scientific Importance and Research The Florida Middleground is considered to have unique faunal and floral assemblages, quite dissimilar to the Flower Garden Banks, and with a much higher species richness in some taxonomic groups (Hopkins et al., 1977). The area is of considerable interest to geologists, oceanographers and hydrographers and has been the subject of an interdisciplinary study by Florida State University (Austin, 1970).

Economic Value and Social Benefits The area supports major grouper Serranidae and Red Snapper Lutjanus campechanus fisheries. Recreational activities are limited by the distance from shore but, although a one-day boat trip is required, sport fishermen and recreational divers occasionally visit the area (CNA, 1981).

Disturbance or Deficiencies In 1975 Hurricane Eloise caused serious damage, particularly to algae. Autumn and winter storms also cause damage but it appears that plant populations recover each year in the summer (Grimm and Hopkins, 1977). The damage is probably due to low temperatures and the scouring effect of turbulent water.

Legal Protection Bottom longlines, traps and pots, and bottom trawls are prohibited within the area as well as the taking of all corals unless authorized by permit (Jaap in litt., 1984; Leary in litt., 1984).

Management None at present.

Recommendations Classified as a Habitat Area of Particular Concern (HAPC) by CNA (1981). The HAPC is bounded by latitudes $28^{\circ} 45^{\prime}-28^{\circ} 11^{\prime} \mathrm{N}$, and longitudes $84^{\circ} 00^{\prime}-84^{\circ} 25^{\prime} \mathrm{W}$. The area has been nominated as a marine sanctuary but no further action has been taken (CNA, 1981).

\section{FLORIDA OCULINA BANKS PROPOSED NATIONAL MARINE SANCTUARY}

Geographical Location $27^{\circ} 30^{\prime}-28^{\circ} 59^{\prime} \mathrm{N}, 7^{\circ} 56^{\prime}-80^{\circ} 07^{\prime} \mathrm{W}$; off the central east Florida coast, from Ft Pierce to Daytona Beach, south of Cape Canaveral. A small bank also occurs opposite St Lucie Inlet $\left(27^{\circ} 12^{\prime} \mathrm{N}\right)$.

Area, Depth, Altitude The banks occur discontinuously along a length of $110 \mathrm{~km}$ coastline over a zone $2-6 \mathrm{~km}$ wide at depths of $6 \mathrm{~m}, 27 \mathrm{~m}$ and $70-100 \mathrm{~m}$.

\section{Land Tenure Federal Government.}

Physical Features Oculina "reefs" of $O$. varicosa, the Ivory Tree Coral, are found on the inner shelf at $6 \mathrm{~m}$, the mid-shelf at $27 \mathrm{~m}$ and the shelf-edge from 70 to $100 \mathrm{~m}$ on limestone ledges (1-5 m relief) that parallel the coast and also in the Indian River Lagoon. Oculina colonies are interspersed among a cover of algae, sponge and octocoral. South of $27^{\circ} 30^{\prime} \mathrm{N}$, prominences are less pronounced except for a broad mound off St Lucie Inlet at a depth of $40 \mathrm{~m}$ where numerous sand-covered limestone knolls with less than $1 \mathrm{~m}$ relief support a very dense population of small, stoutly branched colonies (Reed, 1980).
The shelf-edge banks are found on a series of pronounced prominences at the break between the continental shelf and the Florida-Hatteras slope, roughly parallelling the $70-80 \mathrm{~m}$ bathymetric contour. There are dozens and possibly hundreds of isolated, steep-sloped $\left(30-45^{\circ}\right)$ prominences with relief of $25 \mathrm{~m}$ and bases a few $100 \mathrm{~m}$ in diameter, the southern side generally being steeper. There are also numerous knolls with less than $5 \mathrm{~m}$ relief (Reed and Hoskin, in press; Thompson et al., 1978). Oculina caps many of these pinnacles and mounds in the form of banks and thickets which are mapped and described in Reed (1980). Other prominences are covered completely with dead coral rubble or standing dead colonies of Oculina. Jeff's Reef, one of the most southerly banks $\left(27^{\circ} 32 \mathrm{~N}, 79^{\circ} 58^{\prime} \mathrm{W}\right)$ has been studied for several years. It is approximately $1000 \mathrm{~m}$ in circumference at the base, roughly rectangular in shape and consists of three parallel ridges running approximately east-west with a minimum depth of $64 \mathrm{~m}$, and a maximum depth of $80.8 \mathrm{~m}$. Further south the shelf narrows to less than $5 \mathrm{~km}$ off Palm Beach.

All areas on the reef not covered with coral consist of a matrix of greenish silty-sand, limestone pavement and Oculina rubble. The sediments of the area have been described by Hoskin et al. (1983) and Hoskin et al. (in press) and sedimentological studies are reviewed in Reed and Hoskin (1984). Less than 1\% of surface light is found at the $80 \mathrm{~m}$ reef and turbid bottom water, caused by resuspension of shelf sediment and by plankton blooms resulting from the upwelling, often inundates the banks, reducing visibility to less than $1 \mathrm{~m}$. Sedimentation rates average $53 \mathrm{mg} / \mathrm{sq}$. cm/day (Reed, 1981). The nearshore reefs are influenced by strong wave surge which causes sedimentation rates to be ten times greater than those at the shelf-edge. Light transmittance is variable $(0-31 \%)$, depending on surge.

Although surface currents are usually strong and northerly from the Gulf Stream, the bottom currents have strong east-west, north and south components (Hoskin et al., in press); average near-bottom current speed is $8.6 \mathrm{~cm} / \mathrm{sec}$ but occasionally reaches $75 \mathrm{~cm} / \mathrm{sec}$. Salinity is stable ranging from 35.7 to $36.4 \mathrm{ppt}$ (Reed, 1981). Temperature ranges from 7.4 to $26.7^{\circ} \mathrm{C}$ with an average of $16.2^{\circ} \mathrm{C}$ and are significantly warmer at the inner and mid-shelf reefs $\left(24.6^{\circ} \mathrm{C}\right.$ average). The shelf-edge reefs are subject to episodic upwelling of cold and nutrient-rich water throughout the year, whereas the nearshore reefs are affected by upwelling for only a few weeks during the summer (Reed, 1983; Reed and Hoskin, in press). Cold water wells up periodically from the Florida Straits, with each event lasting 1-4 weeks and temperatures dropping rapidly below $10^{\circ} \mathrm{C}$. During upwelling periods, levels of nitrates, phosphates and chlorophyll $a$ increase by nearly an order of magnitude. The effect of upwelling on coral growth and the associated faunal communities of the inner and mid-shelf banks is described by Reed (1983) but its exact influence on the system is still unknown.

Reef Structure and Corals Three different Oculina colony types are found: a) small colonies less than $2 \mathrm{~m}$ in diameter attached to limestone outcrops or lying unattached on the mud; b) a linear form 1-2 $\mathrm{m}$ in height and width and 3-4 m long and c) massive thickets of contiguous colonies up to $2 \mathrm{~m}$ high, found in extensive banks with a steep slope of $30-45^{\circ}$, especially on the south side facing into the Florida Current. The north 
slopes are less steep and have a greater percentage of coral rubble or barren areas. In general the larger linear thickets and banks of Oculina occur near the eastern side of the zone.

At Jeff's Reef, the most studied area, the south face generally has a steep slope of $30-45^{\circ}$ and is covered with massive contiguous Oculina up to $2 \mathrm{~m}$ in height. In places it forms linear east-west orientated rows, $3-4 \mathrm{~m}$ in width, separated by a narrow space, forming a step-like pattern up the slope. The three ridges are capped with live coral 1-2 $\mathrm{m}$ in height. The north slope is generally less steep and has scattered $0.5-2 \mathrm{~m}$ diameter corals and coral rubble. The topography around Jeff's Reef is relatively flat with coarse sediments and some limestone outcrops which afford a substrate for the antipatharian Cirrhipathes desbonii, the hydroid Antennularia sp. and the gorgonian Titanidium frawen feldii (Reed, 1980).

Inshore Oculina colonies have zooxanthellae whereas the deep water $(49-101 \mathrm{~m})$ growth form, with thin highly anastomosed irregular branches, usually lacks zooxanthellae due to the low light levels. Colony size, relative tip length and intercalical distance generally show a progressive increase with depth whereas relative branch diameter decreases, suggesting that inner-shelf colonies are more wave resistant. The community harbours a rich vertebrate and invertebrate fauna including other scleractinians, Astrangia astreiformis, Balanophyllia floridana, Cladocora debilis, Paracyanthus pulchellus and Coenocyanthus sp., and octocorals, Telesto nelleae and Titanidium frauen feldii (Avent et al., 1977).

Noteworthy Fauna and Flora The banks support abundant hydrozoans, actiniarians, ophiuroids, small molluses and dense fish populations (Reed, 1980). The shelf-edge banks ( $80 \mathrm{~m}$ deep) have a greater diversity of both decapods (Reed et al., 1982) and molluscs (Reed, 1983; Reed and Hikkelsen, in press) than the inner and midshelf reefs, possibly due to the supply of nutrients and plankton from the upwelling. Some 230 species of mollusc (Reed, 1983), 50 species of decapod crustaceans (Reed et al. 1982), 50 species of amphipods, 20 species of echinoderms and 23 families of polychaete worms are associated with the Oculina communities. Over 70 species of fish have been identified on the shelf-edge coral banks. The Caribbean Manatee Trichechus manatus may occur nearshore and the Loggerhead Caretta caretta, Green Turtle Chelonia mydas, Kemp's Ridley Lepidochelys kempii, and Leatherback Dermochelys coriacea are found along the East Florida coast and may occur in this area (Bacon et al., 1984; Groombridge, 1982).

Scientific Importance and Research The banks have been studied using dredges (MacIntyre and Milliman, 1970) and manned research submersibles (Avent et al., 1977; Reed, 1980). Reed and Hoskin (in press) and Reed (undated) summarize scientific research in the area and provide references to many of the faunal studies, particularly echinoderm and crustacean, carried out in the area. Reed (1981) has shown that mean growth rate of Oculina is significantly greater at the shelf-edge reef than nearshore.

Economic Value and Social Benefits The shelf-edge Oculina banks are a feeding, breeding and nursery ground for numerous fish. Commercially important species include Scamp Mycteroperca phenax, Gag M. microlepis, Snowy Epinephelus niveatus, Warsaw E. nigritis and Red E. morio Grouper; Black Sea Bass Centropristis striata, Speckled Hind Epinephelus drummondhayi, Red Porgy Pagrus pagrus and Red Snapper Lutjanus campechanus. Recreationally important fish include snapper Lutjanidae, grouper Serranidae, King Mackerel Scomberomorus cavalla, amberjack Seriola sp., Little Tunny Euthynnus alletteratus, Sailfish Istiophorus platypterus, Wahoo Acanthocybium solanderi, Tiger Shark Galeocerdo cuvieri and Hammerhead Shark Sphyrna sp. Grouper and snapper populations appear to travel among the banks and tend to prefer areas with living coral rather than dead coral rubble. Oculina varicosa and the black coral Cirrhipathes lutkeni are of potential commercial importance.

Disturbance or Deficiencies Many of the shelf-edge pinnacles are entirely covered with dead Oculina coral rubble, often in an apparently random way. Many fragments of coral are white, suggesting that coral breakage is recent (Hoskin $e t$ al., 1983) but the cause of death is unknown. Bottom trawling has occurred especially near the northern part of the region and could cause damage; lost nets and long lines have been observed on the reefs.

Legal Protection Bottom longlines, traps and pots, bottom trawls and methods destructive to the coral are prohibited (Leary in litt., 1984) but traditional hook and line fishing is permitted. Corals may be taken for scientific and educational purposes if authorized by permit.

Management A 92 sq. mi. (238 sq. km) portion of the Banks $\left(27^{\circ} 30^{\prime}-27^{\circ} 53^{\prime} \mathrm{N}\right.$, $\left.79^{\circ} 56^{\prime}-80^{\circ} 00^{\prime} \mathrm{W}\right)$ has been established as a Habitat Area of Particular Concern under the Coral and Coral Reef Fishery Management Plan. The area contains four known Oculina banks, several thickets and coral rubble pinnacles, the area off Sebastian having very irregular topography of high relief (Reed, undated)

Recommendations A portion of the banks (the HAPC area) has been nominated as a National Marine Sanctuary and is on the final evaluation list of the sanctuary program (Reed in litt., 17.10.84; Taggart, 1983). The banks have been considered in the Snapper-Grouper Fishery Management Plan of the South Atlantic Fishery Management Council (CNA, 1981). Reed and Hoskin (in press) give recommendations for future studies using submersibles.

\section{FORT JEFFERSON NATIONAL MONUMENT}

Geographical Location Dry Tortugas, Florida, $116 \mathrm{~km}$ west of Key West. Includes the seven keys, Loggerhead Key, Garden Key (with Fort Jefferson), Bush Key, Long Key, East Key, Hospital Key, and Middle Key, of the Dry Tortugas and the surrounding shoals and waters; $24^{\circ} 44^{\prime}-24^{\circ} 33^{\prime} \mathrm{N}, 82^{\circ} 46^{\prime}-82^{\circ} 58^{\prime} \mathrm{W}$.

Area, Depth, Altitude $190 \mathrm{sq} . \mathrm{km}(27 \mathrm{~km} \mathrm{x} 12 \mathrm{~km})$; 2-29 m depth. 
Land Tenure Federal Government, U.S. National Park Service.

Physical Features Although forming a pseudo-atoll, the islands of the Dry Tortugas have a mud bank type formation (Jones and Thompson, 1978). They are isolated from the main body of Florida's reef tract by about $100 \mathrm{~km}$ of open water. There are three major banks, Pulaski (north-east), Loggerhead (west) and Long Key (south), which surround a 12-23 $\mathrm{m}$ deep lagoon and are separated by $10-20 \mathrm{~m}$ deep channels. Mean water depth over the barks is $2-3 \mathrm{~m}$, while depths outside the banks range from 11 to $29 \mathrm{~m}$. The keys are continually above sea-level apart from Middle Key which is frequently awash and Hospital Key which is occasionally submerged during spring tides. Long Key Bank and Pulaski Bank constitute the windward side of the Dry Tortugas during the spring, summer and early autumn with relatively constant south-east winds of $10-15$ knots. During the winter, strong weather fronts sweep down from the north, seasonally reversing the "windward" and "leeward" sides of the reef complex (Davis, 1982). Nine hurricanes have passed through or near Tortugas since 1866, the most recent being in 1966 (Jaap, 198?; Reynolds and Steinmetz, 1983).

Reef Structure and Corals In 1976, living reef occupied less than $4 \%$ of the bottom above the 10 fathom $(18 \mathrm{~m})$ line and was mapped and described by Davis (1979 and 1982). The occurrence of bank reefs on the south-eastern windward side of the reef complex reflects the moderate wave energy generated by mild summer "trade winds", while massive coral buttresses and hard bottom octocoral areas along the northem rim appear to be a result of regular high energy winter storms.

Bank reef accounted for only $0.6 \%$ of the system and was limited to a narrow band on the south-east edges of Long Key Bank and Pulaski Bank. Except for the virtual absence of Acropora palmata and a reduced $A$ cervicornis zone, this reef was a typical West Indian Acropora bank reef with spur and groove systems and buttress zones. The shallower portions (9-15 $\mathrm{m}$ ) were dominated by Montastraea annularis and Siderastrea siderea, but a variety of other corals were common. $M$. cavernosa replaced $M$. annularis below $16 \mathrm{~m}$, and the octocorals Briareum asbestinum and Pseudopterogorgia bipinnata were common on the deep reef.

A. cervicornis reef covered 478 ha in 1976 and accounted for $55 \%$ of scleractinian coral cover. Most of this was concentrated in a single 220 ha reef on the north-west side of Loggerhead Shoal, at 6-14 $\mathrm{m}$ depth in an area of strong tidal currents that run on a north-east/south-west axis perpendicular to east-west oriented ridges, $2-3 \mathrm{~m}$ high and 7-18 $\mathrm{m}$ wide, separated by sand bottomed ravines $3-10 \mathrm{~m}$ wide. In other areas, $A$ cervicornis blanketed slopes on the edges of channels or occupied large patches of hard bottom. Occasionally, large heads of M. annularis, Diploria or Colpophyllia occurred within the expanse of $A$ cervicornis (Davis, 1977a and 1982). These reefs were largely destroyed in 1977 (see below).

Coral head buttresses occupied 251 ha (1\% of the bottom) in 1976 and were well developed on the north-eastern edge of Pulaski Shoal. They consisted of clumps of hermatypic corals (5-100 $\mathrm{m}$ diameter) scattered across the tops of banks, on the steepest slopes and occasionally on the sand plain outside the atoll, invariably rising several metres above the adjacent substrate. They were generally dominated by $M$. annularis and $S$. siderea but $D$. labyrinthiformis and $C$. natans were also frequently conspicuous. The zoanthid Palythoa was common.

On the shallow flats (less than $10 \mathrm{~m}$ depth) between the outer reefs and the lagoonal grass beds, over an area of 3965 ha, there was a hard bottom community of exposed limestone conspicuously dominated by octocorals. The dominant species were Pseudopterogorgia americana, $P$. acerosa and $P$. flexuosa; small patches of $A$ cervicomis were common on the hard bottom of Pulaski Shoal. This octocoral community also dominated numerous shallow patches within the lagoon. Porites porites is a common coral on the shallow grass beds (Davis, 1982).

Jones and Thompson (1978) gave brief descriptions of Long Key Reef, Loggerhead Reef, and White Shoal Reef. The latter is a shallow plateau, dominated on the upper portion by rubble. Thickets of $A$. cervicornis, $M$. annularis and Diploria characterize the sides of the steep plateau at $9-15 \mathrm{~m}$.

Jaap (198?) studied the stony coral community of Bird Key Reef from 1975 to 1976 . The shallow reef crest was emergent at low tide and formed of coral rubble encrusted with coralline algae. A shallow lagoon (less than $2 \mathrm{~m}$ deep) occured inshore, characterized by algae, seagrasses and clusters of $P$. porites. Low stony coral diversity in shallow water is thought to be due to unstable substrate, temperature extremes and turbidity. Greatest abundance, diversity and organic cover occurred seaward of $7-8 \mathrm{~m}$ depth in an antecedent spur and groove formation. $M$. annularis, $M$. cavernosa and $S$. siderea dominated, comprising $43.3 \%$ of all colonies and $56.5 \%$ of all cover. Bird Key Reef differs from the Florida Keys' reefs in the lack of shallow spur and groove formations, possibly due to the paucity of $A$ palmata at Dry Tortugas in recent times.

Wells (1932) described 24 shallow-water corlal species and eight deep-sea species; Jaap (198?) lists 53 species of stony coral. Davis (1982) lists Scleractinia and Millepora recorded between 1971 and 1976 and Octocorallia between 1975 and 1977.

Noteworthy Fauna and Flora Fewer than 50 plant species on the keys are indigenous although many species have been introduced. Native flora is mainly mangrove, bay cedar, seagrape, sea-lavender, purslane and sea-oats. Seagrasses cover 6904 ha, primarily within the lagoon area, and range from barely subtidal on Long Key Bank to $15 \mathrm{~m}$ depth in the north-eastern portion of the lagoon. Turtle grass Thalassia testudinum is dominant, particularly on shallow flats less than $2 \mathrm{~m}$ deep. Deeper seagrass beds are often mixed stands of Thalassia and manatee grass Syringodium filiforme. In deeper parts of the lagoon, south-west of Pulaski Bank, Syringodium gradually replaces Thalassia and in turn is replaced by Halophila. Algal communities cover 114 ha (Davis, 1982). On the shallowest portions of the south-eastern sides of the major banks, particularly on coral rubble in relatively high wave energy zones, the benthic community is dominated by fleshy algae, represented primarily by the genera Laurencia, Dictyota, Sargassum, Padina and Zonaria. A narrow intertidal ridge of coral rubble 
extends south-south-west of Long Key and is dominated by crustose coralline algae Goniolithon.

An estimated 80 000-100 000 Sooty Terns Sterna fuscata nest on Bush Key between April and September (Anon., 19??a; Reynolds and Steinmetz, 1983). Roseate Tems S. dougallii nest on Hospital, Bush and Long Keys. A colony of 2500 Brown Noddies Anous stolidus is said to be increasing and large numbers of frigatebirds congregate at the Dry Tortugas in summer. Blue-faced Sula leucogaster and Brown $S$. dactylatra Boobies are observed occasionally. The islands lie across one of the principal flyways from the U.S.A. to Cuba and South America and gulls, terns and migratory shore birds come from the north to winter at the Tortugas (Anon., 19??a).

The Caribbean Manatee Trichechus manarus may occur. Hawksbill Eretmochelys imbricata, Green Chelonia mydas and Loggerhead Caretta caretta Turtles are found and the Leatherback Dermochelys coriacea may occur; the Loggerhead nests (Bacon et al., 1984). In 1975 and 1976, 192 fish species were recorded (Thompson and Schmidt, 1977). In an earlier study, approximately 440 fish species were recorded, but this included many not specifically associated with coral reefs (Longley and Hildebrand, 1941). A checklist of fish is given in Jones and Thompson (1978), and the fish fauna is discussed in Briggs (1958). The Queen Conch Strombus gigas is found in the seagrass beds.

Scientific Importance and Research The Dry Tortugas are isolated from mainland run-off by their remote location and are one of the most spectacular and least disturbed reef areas in the western Atlantic. Jaap (198?) lists some of the early studies in the area. Extensive coral reef work was carried out at the Carnegie Institute's Dry Tortugas Field Laboratory on Loggerhead Key from 1904 until 1937, when it was destroyed by fire (CNA, 1981; Davis, 1977; Jaap, 198?). Some of the classic publications are listed by Jaap (198?) and Davis (1982). The benthic marine habitats have been mapped and a field guide to the corals produced.

In 1976 the National Park Service initiated an interdisciplinary investigation of the reefs called the Tortugas Reef Atoll Continuing Transect Studies (TRACTS) in order to develop a "bench-mark" description of marine resources which could be used to define and evaluate long-term change. Davis (1982) describes the results of a mapping project which compared the reef communities of the 1970 s with those of the 1880s mapped by Agassiz (1883). The Dry Tortugas reef system is of particular value in demonstrating major natural changes in reef structure and the necessity of establishing and maintaining ecosystem sanctuaries in which such natural phenomena can be documented and studied.

Economic Value and Social Benefits The central feature is Fort Jefferson, the largest of the 19th century American coastal forts, built in the mid-1800s and of considerable historic interest. Public transport to the islands is available from Key West by boat and sea plane but there are no facilities for meals or accommodation. Sport fishing, diving and snorkelling are popular activities; diving is particularly good off the east of Fort Jefferson. The coral head buttresses, with their spectacular concentrations of fish, spiny lobsters and echinoderms, are particularly popular sites for glass bottom boat viewing and diving (Davis, 1982). French Wreck lies in a broad, flat, inshore area of uniform depth, south-west of Loggerhead Key (Thompson and Schmidt, 1977). Traditional recreational hook and line sport fishing is permitted from the pier and shore between the North and South Coaling Docks (Anon., 19??a; Davis, 1977b). In winter and spring, several hundred shrimp trawlers fish the Dry Tortugas grounds for Pink Shrimp Penaeus duoranum (Davis, 1977b). U.S. Coastguard personnel are resident on Loggerhead Key to operate the lighthouse (Reynolds and Steinmetz, 1983).

Disturbance or Deficiencies The influence of temperature on reef development in shallow waters around Tortugas is considerable. Winter cold fronts passing over the region chill the waters to within lethal limits for corals. Furthermore, weak circulation and proximity to the Gulf of Mexico sedimentary environments mean that water quality conditions are less than optimal for reef corals, particularly $A$ palmata (Jaap, 198?).

Davis (1982) describes the natural changes that occurred between 1883 and 1976. Living coral reefs increased in area only slightly, covering $2.8 \%$ in 1881 and $3.8 \%$ in 1976 , but there were major changes in species distribution and reef types. A 220 ha $A$ cervicornis reef north-west of Loggerhead Key developed on what had been octocorals on broken ground in the 1880s. Natural massive mortalities of $A$ cenvicomis were observed in 1878 when nearly all the colonies died, due to a phenomenon known as "black water"; extensive fields of $A$ palmata and $A$ prolifera on the shallow flats were also killed and there were associated massive fish kills. This may have been due to surface run-off of freshwater from the Everglades (Jaap, 198?) during a cold winter front. Similar mortalities of $A$ cenvicomis were observed in $1976 / 1977$ when a winter front killed about $90 \%$ of colonies (Davis, 1981). The only $A$ palmata in 1881 , a 44 ha swath on Long Key reef crest, was reduced to rubble in 1976 with only two small patches of living coral remaining, two-thirds of which was killed in 1977. Some $M$. annularis and $P$. porites colonies were also killed by this cold front. $A$ cenvicornis appears to recover more rapidly than $A$ palmata from thermal impact at Dry Tortugas; the former has repeatedly regained considerable densities within a decade after severe thermal stress whereas the latter seems to have declined further after each major hypothermal event during this century. This may be due to the fact that $A$ palmata is more restricted by depth and unlike $A$ cervicornis requires a stable substrate to settle (Jaap, 198?).

Humicanes have caused serious damage in the past and in some areas $A$ palmata and $A$ cervicomis have not recovered (Reynolds and Steinmetz, 1983). Bird Key disappeared in the 1930 s following denudation by hurricanes in 1910 and 1919 (Davis, 1982); East and Sand Keys also submerged during the 1930s (Jaap, 198?).

The population of spiny lobsters Panulirus argus was being significantly lowered in the $1970 \mathrm{~s}$, due to recreational fishing, even though there was a quota of two individuals per person (Davis, 1977b). During a single eight months long season, divers legally removed 26500 lobsters or about one half of the available population. Spiny lobster collecting is now prohibited. The Queen Conch Strombus gigas was scarce during the 
early 1970 s but, after 1975 , juvenile conchs became quite common particularly on Long Key Bank. No clear explanation of the apparent earlier decline was evident although a "red tide" in the vicinity may have been implicated (Davis, 1982).

The greatest damage to the reefs is probably from boat anchors. Shrimp trawler anchors caused severe damage in the south-west of the atoll when taking shelter for several days from storms (Davis, 1977a) and 20\% of an extensive $A$ cervicornis stand west of Loggerhead Key was damaged in one winter season. Scarring, apparently from 14 anchors unintentionally snagged and imbedded near Pulaski Shoal, was noted (Bright et ab., 1981). Shrimp trawlers also contribute to reef deterioration through the dumping of disused fishing gear and other rubbish on the reef (Jaap, 1984). Turtle populations (mainly Loggerheads) were reduced many years ago through indiscriminate hunting (Reynolds and Steinmetz, 1983). Rats destroy nests and young in the Sooty Tern colony (Reynolds and Steinmetz, 1983).

Legal Protection A bird sanctuary was established in 1918 and the area was proclaimed a National Monument in 1935. All areas within the Monument's administration boundaries (with the exception of Garden Key) are classified as an outstanding natural area under the National Park Service's land classification system. Fort Jefferson National Monument is included within the Everglades Biosphere Reserve.

There is a set of special regulations in addition to the general National Park Service regulations (CNA, 1981). Fishing and molesting of marine life is prohibited within the moat, within $500 \mathrm{ft}(152 \mathrm{~m})$ of the moat wall and in the shallow waters of the harbour encircled by Garden, Bush and Long Keys which are set aside for snorkelling. The dumping or throwing overboard of waste and rubbish is prohibited. Spearfishing is prohibited within the monument boundaries. Shells, corals, seafans, tropical fish, spiny lobsters, turtles and terrapins (and their nests) may not be disturbed (Anon., 19??a). Collection of Panulirus argus and Strombus gigas is prohibited (Davis, 1977a). All keys other than Garden Key and Loggerhead Key are closed during the turtle season (May-Sept. 30). Bush Key, which has a tern colony, is closed during the nesting season from March to September and in summer seaplanes must stay more than 100 yards $(91 \mathrm{~m})$ off the Key (Anon., 19??a). Vessels entering Tortugas Harbour in the vicinity of Garden Key may anchor only in the designated anchor area of Bird Key Harbour, south-west of Garden Key. Mooring and docking is limited to the area within a mile $(1.6 \mathrm{~km})$ of the fort itself. Anchoring by recreational vessels is limited to not more than eight hours between sunrise and sunset by permission of the Monument Superintendent or his/her representative (CNA, 1981).

Management The area is administered by the National Park Service with a superintendent based at the Everglades. Camping is permitted. Brochures and information are available for visitors. A self-guided tour is available at Fort Jefferson, where the rangers live. Green Turtle hatchings have been released to increase population numbers.

Recommendations None known.

\section{GRAY'S REEF MARINE SANCTUARY}

Geographical Location $31^{\circ} 24^{\prime} \mathrm{N}$, 8056' W; approximately $34.2 \mathrm{~km}$ east of Sapelo Island, Georgia.

Area, Depth, Altitude Gray's Reef covers 42.9 sq. km; area of sanctuary $16.68 \mathrm{sq}$. naut. mi. (57 sq. km); depth 18-21 m.

\section{Land Tenure U.S. Federal Government.}

Physical Features The adjacent coastal zone of Georgia is characterized by extensive coastal marshes and waterways, maritime forests and undeveloped islands. The continental shelf in this area is wide, flat, shallow and primarily covered with sand except for occasional areas of emergent hard bottom which form "reefs" supporting rich invertebrate and fish communities. Reefs are less common near shore due to weathering by river channels and deposition. However, although located near shore, Gray's Reef is characteristic of live bottom reefs found off shore in terms of relief and marine life. It has extensive, but patchy and discontinuous, hardbottom of moderate (up to $2 \mathrm{~m}$ ) relief, the rocky outcrops and ledges forming reefs, aligned north-west/south-east, that support rich invertebrate and fish communities. The ledges are subject to weathering, shifting sands and slumping which create a complex habitat with caves, burrows, troughs and overhangs. Gray's Reef was probably formed $20000-40000$ years ago when heavily laden brines percolated through sediments changing the chemical composition and forming rock (Hunt, 1974).

Sea conditions are generally calm from late spring to autumn (seas less than $2 \mathrm{~m}$ with winds variable, less than $10 \mathrm{kts}$ ). From late autumn to winter, conditions are rougher due to frequent storms (north-easters). Water temperatures follow seasonal trends and range from $14^{\circ} \mathrm{C}$ in winter to $28^{\circ} \mathrm{C}$ in summer. Salinity ranges from 34 to $36 \mathrm{ppt}$. Surface water circulation is generally to the south in autumn and winter and to the north in spring and summer. Bottom currents show no consistent patterns but probably respond to indrafts of the northerly flowing Gulf Stream. Turbidity conditions vary with sea condition and tide and underwater horizontal visibilities may range from 1 to $7 \mathrm{~m}$. Further details are given in Henry and Van Sant (1982), NOAA (1980d) and NOAA (1983).

Reef Structure and Corals There are scattered heads of stony corals and a variety of soft corals. Oculina varicosa, Astrangia danae, Phyilangia americana and Cladocora arbuscula are the commonest scleractinians. The octocoral fauna is dominated by Leptogorgia virgulata, L setacea, Lophogorgia hebes, Telesto fructiculosa, Titanideum frauenfeldii and Muricea pendula (NOAA, 1980d).

Noteworthy Fauna and Flora Gray's Reef supports a mixture of temperate and tropical species. Many species are previously unreported for this area, some are "new" species and others represent extensions to previous geographical ranges. Preliminary species lists are given in NOAA (1980d). Fifteen seaweed species were collected in a limited sampling effort which included eight new records for Georgia, two extensions of southern ranges of distribution and one new species (Searles, 1981). A variety of invertebrates grow on exposed rock surfaces, 
with bryozoans, ascidians, sponges, barnacles and hard-tubed worms forming dense encrustations. Other dominant invertebrates include starfish, brittlestars, crabs, lobsters, shrimps and molluscs. Sand bottom areas between rock outcrops are foraging grounds for some fish; although they do not contain the rich marine life associated with hard grounds, these areas play a significant role in the structure and function of live bottom systems, and support a dense fauna of sea pens and sea pansies. Sponges dominate the invertebrate fauna brought up in trawl and dredge tows. Invertebrate diversity at Gray's Reef is generally high during all seasons, but some species occur in very high numbers, such as the tube worms Filograna implexa and Pista palmata. There are also large numbers of rare species which consist of only one or two individuals (NOAA, 1980d).

The demersal shelf fish show large seasonal differences with abundance at its highest in autumn. Recreational and commercially important residents include Black Sea Bass Centropristis striata, Gag Mycteroperca microle psis, Sheepshead Archosargus probatocephalus, Red Porgy Pagrus pagrus, Porgy Stenotomus aculeatus, Red Snapper Lutjanus campechanus and Whitebone Porgy Calamus leucosteus. More seasonal species and pelagics include barracuda Sphyraena barracuda, Greater Amberjack Seriola dumerili, Bluefish Pomatomus saltatrix, Cobia Rachycentron canadum, King Mackerel Scomberomorus cavalla and Spanish Mackerel S. maculatus (NOAA, 1980d). A field guide to the fish of the reef is in preparation.

The endangered Right Whale Eubalaena glacialis uses the Gray's Reef area for its winter calving grounds. The Loggerhead Turtle Caretta caretta has been recorded and Green Chelonia mydas and Kemp's Ridley Lepidochelys kempii Turtles occur within the area but have not been sighted at Gray's Reef. Petrels, shearwaters, gannets, phalaropes, jaegers and terns are seen as they pass from rookeries to off shore feeding grounds (NOAA, 1980d).

Scientific Importance and Research Gray's Reef represents a unique habitat covering approximately the northern limit of many tropical species and the southern limit of many temperate species. The live bottom is important for marine fishery resources of commercial and recreational value, for sea turtles and for tropical biota which are rare in this area.

The reef was discovered in 1961, during a survey by the University of Georgia's Marine Institute, and has received only moderate scientific attention. Research is encouraged in the Sanctuary, although a permit must be obtained from NOAA. Periodic monitoring of the physical environment and assessment of the biological community is carried out. A hydrographic survey has been conducted to determine the reef's areal extent and to provide baseline data for future studies. Other studies underway or planned include water quality monitoring; permanent life history monitoring to study growth, recruitment and other factors; biological inventories; periodic assessment of reef fish populations; surveys of anchor damage; and studies on cryptic reef fish. Community characteristics of both the vertebrate and invertebrate community was described in a 3-year study of live bottom marine resources (South Carolina Marine Resources Research Institute and Georgia Department of Natural Resources-Coastal Resources Division, 1981,
1982 and 1983). The Management Plan gives details of a Resource Studies Plan to identify the information required to assess and manage the Sanctuary (NOAA, 1983).

Economic Value and Social Benefits Sportfishing and diving are major attractions. Access to the Sanctuary is by boat only from a variety of coastal Georgia communities; the majority of visitors use private boats although there are some charters. It has been estimated that 10-20 private boats fish the reef at weekends from April to September, and 1-5 chartered trips visit the reef per month during the fishing season (NOAA, 1980d). The reef is generally not used by commercial fishermen. Small numbers of divers use the reef but, due to its distant offshore location, variable weather and water visibility conditions, and relatively deep waters, diving is recommended for experienced divers only. The reef is also used by students from the University of Georgia system for a variety of studies.

Disturbance or Deficiencies Winter weather conditions and tropical depressions cause the sands to shift, covering and uncovering live bottom areas. Studies are currently underway to determine the extent of sand transport across these valuable reef areas. National recognition as a Marine Sanctuary has intensified public use of the area but exploitation pressure and user impacts, such as anchor damage, remain low. Spearfishing is allowed but its impact on the reef fish population is being closely monitored.

Legal Protection Designated a Marine Sanctuary in January 1981 by the Federal Government. NOAA regulations permit both sport and commercial fishery with hook and line. Spearfishing is permitted but its impact is being monitored. The removal or destruction of any natural reef feature or marine life (other than spiny lobsters) or other materials is prohibited. There is a blanket prohibition on cutting, displacing or breaking of bottom formation or growth. Dredging, filling, excavating, building, and the discharge of refuse and other pollutants are banned. Tropical fish may not be taken.

Management Responsibility for management of the Marine Sanctuary lies with the National Oceanic and Atmospheric Administrations (NOAA) Office of Coastal Zone Management. NOAA sets management objectives for the sanctuary, designs and implements research programmes, issues permits and oversees monitoring and enforcement of the regulations. It provides technical briefing material, designs and implements public information programmes, and provides administrative and emergency on-site support.

The State of Georgia Department of Natural Resources, Coastal Resources Division, provides an on-site manager, responsible for evaluating permit applications, co-ordinating with the U.S. Coast Guard surveillance and enforcement, providing support services and submitting quarterly reports to NOAA. Violators are subject to civil penalties of up to U.S.\$50 000 under Federal Public Law 92-532.

A management plan has been produced to ensure the long-term viability of the area, and covers issues such as public education, environmental monitoring, regulatory enforcement and monitoring needs (NOAA, 1983). The 
University of Georgia's Marine Resource Center on Skidaway Island near Savannah will serve as the primary site for sanctuary interpretive and recreational programmes, and interpretive materials will be available at a variety of other centres in the vicinity. Brochures and pamphlets have been produced for visitors. The Sanctuary is marked by a buoy. CNA (1981) designated the sanctuary a Habitat Area for Particular Concern (HAPC).

Recommendations The Management Plan gives detailed proposals for the development of the Sanctuary (NOAA, 1983). The emphasis is on the provision of interpretive facilities and the need for further research on many aspects of the biology and ecology of the area.

We are very grateful to $\mathrm{N}$. Nicholson for compiling this account.

\section{JOHN PENNEKAMP CORAL REEF STATE PARK}

Geographical Location Monroe County, Florida; from Key Largo seaward to the 3 mile $(4.8 \mathrm{~km})$ State territorial limit; adjacent to and landward of the Key Largo Coral Reef Marine Sanctuary; extends from the southern boundary of Biscayne National Park south to an area near Rodriguez Key.

Area, Depth, Altitude 2290 (927 ha) upland acres; 53722 submerged acres ( 21757 ha).

Land Tenure State of Florida, Department of Natural Resources.

Physical Features The area includes a large sound, mangrove communities, seagrass beds and other bottom types. Upland tropical hardwood forest gives way to coastal marsh, beach or mangrove forest. The mangroves are replaced by limestone fossil reef rock dominated by attached algae and are lined by mudflats. Seaward, a mixture of sand, seagrass and rocky outcrops supports hardy corals, sponges and algae (Skinner and Jaap, 1984). The east end of Rodriguez Bank, an elongated mound (2654 m x $854 \mathrm{~m}$ ) supporting Rodriguez Key, lies within the park (Turmel and Swanson, 1976). Popular descriptions of the park are given by Greenberg (1961 and 1962).

Reef Structure and Corals Live bottom hard grounds are found near shore and small patch reefs, such as Mosquito Bank and Basin Hill Shoals, occur near the seaward boundary. Coral reefs are found to depths of $8 \mathrm{~m}$; like those of Key Largo Coral Reef Marine Sanctuary, these are near the northern limit of coral growth. About 40 species of coral have been recorded (Warman, 1984). The zonatation of Rodriguez Bank, which is not a true reef, is described by Turmel and Swanson (1976). Porites divaricata dominates in a well defined zone, from 0.3 to $1.2 \mathrm{~m}$ deep, on the windward margin; the colonies are not attached to the substrate but are wedged against each other or held by the intergrowth of sponges and green algae. A zone of red algae, Goniolithon is found in shallower water, adjacent to a zone of Thalassia testudinum and the calcareous algae, Halimeda. Descriptions of other reef areas in the Park have not been obtained.

Noteworthy Fauna and Flora North Key Largo is a relatively undeveloped area containing the largest remaining stand of West Indian tropical hardwood hammock in North America. Rodriguez Key supports a dense forest of Rhizophora mangle (Turmel and Swanson, 1976) and mangroves border the coastline. Federally listed endangered animals found in this area are the Key Largo Wood Rat Neotoma floridiana smalli, American Crocodile Crocodylus acutus, Schaus Swallowtail Butterfly Papilio aristodemus ponceanus and the Key Largo Cotton Mouse Peromyscus gossypinus allapaticola. Listed threatened species in the area include the Bald Eagle Haliatus leucocephalus, Caribbean Manatee Trichechus manatus (in summer), Brown Pelican Pelicanus occidentalis, Eastern Indigo Snake Drymarchon corais couperi and Hawksbill Turtle Eretmochelys imbricata. The Leatherback Dermochelys coriacea, Loggerhead Caretta caretta, Green Turtle Chelonia mydas and Kemp's Ridley Lepidochelys kempii may occur in this area (Bacon et al., 1984). The Park provides a valuable habitat for shore birds. About 650 fish species have been recorded in the Park (Warman, 1984).

Scientific Importance and Research The Park includes a wide range of habitat types; research work carried out here and in Key Largo Marine Sanctuary is summarized by Skinner and Jaap (1984). Past and current research activities include evaluation of dredging schemes, coral disease, coral population changes, reef fish community structure, coral growth, coral abundance patterns, systematic accounts of reef plants and animals and resource inventories. The main research in the Park at present is a water quality study, carried out in co-operation with studies in Biscayne National Park and Key Largo Marine Sanctuary.

Economic Value and Social Benefits Reef based tourism is a primary industry in Monroe County (Skinner and Jaap, 1984). The Park is the starting point for diving and boating on Key Largo and receives many visitors. Attendance has increased noticeably over the last ten years and about 500000 visitors enter the Park a year by boat (Warman, 1984; Skinner and Jaap, 1984). Snorkelling, SCUBA diving, picnicking, camping, fishing and boating are all major activities; diving is particularly popular although most of it is carried out in Key Largo Sanctuary (see separate account). It is mainly organized by private dive-shop and dive-boat concerns, at least 20-25 commercial diving charter businesses operating within the Park and Sanctuary. One firm has a concession to operate from facilities at the Park Headquarters, and also runs glass bottom boat trips (Warman, 1984). The mangroves, seagrass communities and intertidal shorelines are important nursery habitats for juvenile fish and lobsters. Spiny lobster are fished commercially (Skinner and Jaap, 1984).

Disturbance or Deficiencies In the early 1970s, the corals within the Park were found to be still healthy although some damage was noted on reefs outside the boundaries. Pollution has caused problems (Voss, 1973) and lead and mercury may be accumulating at the John Pennekamp Reef marina (Bright et al., 1981). The demand for mosquito spraying will rise as the population 
increases and could have an influence on the marine environment. In 1982 the Division of Recreation and Parks began monitoring water quality on a monthly basis. Overall, water quality is good at present but concentrations of plasticizers have increased in surface waters and small amounts of a variety of pesticides have been found.

Turbidity, caused by dredging, land-filling and other sources increased in the 1970s (Griffin and Antonius, 1974). Garden Cove and South Sound Cross Channels which cut through very shallow areas for long distances have continuous boat traffic creating high turbidity. The former will soon be one of the main access routes to the Park and reefs, and may cause siltation and damage to the seagrass beds. Lobster traps cause some damage to corals through tangled lines and traps being abandoned (Skinner and Jaap, 1984).

The Park was listed as one of the world's most threatened protected areas by IUCN in 1984. It is threatened by plans to build 3500 luxury condominiums along the coast of North Key Largo in 16 major developments, to include several marinas. This will result in a significant population increase in the area, and if the proposal is carried through, it will cause significant filling, dredging, pollution and mangrove destruction (Skinner and Jaap, 1984).

Legal Protection Established in 1961 as the first underwater park in the U.S.A. Commercial and recreational fishing with hook and line and lobster and stone crab fishing with nets and traps are permitted (Davis, 1981). Spearfishing and coral collecting are prohibited. Divers may take lobsters provided these are within the permitted size limits. The Park is listed on the National Register of Historic Places.

Management The Park is managed by the Florida Department of Natural Resources, Division of Parks and Recreation with the Key Largo Marine Sanctuary (see separate account) as a single unit although administratively they are separate. The Park is a state-regulated resource, while the Sanctuary is governed by NOAA under Federal Statutes and administrative procedures (Skinner and Jaap, 1984). The Park visitor centre has interpretive facilities. The staff of 22 rangers includes four law enforcement officers and four interpreters (Warman, 1984).

Recommendations Griffin and Antonius (1974) stress the importance of preserving the mangroves and seagrasses to trap sediment and prevent increased turbidity within the Park. Considerable pressure is being exerted by concerned citizens and NGOs to prevent the proposed development plans taking place. A special study initiated at the request of the State Government and cabinet (Skinner and Jaap, 1984) has resulted in detailed recommendations. These include more stringent enforcement; stricter guidelines for shoreline development; improved controls on boats, pollution and the harvesting of marine resources; improved boundary marking; limiting of marina development to natural deep water channels; and improved monitoring and education programmes. It is recommended that there should be greater involvement of the Governor and Cabinet of Florida through the establishment of a Task Force to evaluate resource management and protection needs. It is suggested that a one year moratorium on new development should be enacted while a comprehensive land use plan is prepared. This should include the lowering of the overall population density for North Key Largo; minimizing loss of coastal mangroves and seagrasses; and the acquisition of bufferland including uplands and mangroves such as the 790 ha on north Key Largo (which is already on the Conservation and Recreation Lands List), Rodriguez Key and its surrounding waters, an undeveloped tract on the Atlantic side of North-Key Largo; and the mangrove shore adjacent to the Park.

Additional plans include the creation of a uniform data storage system which will offer personnel at the three parks a larger framework of reference and enhance understanding of water quality along the south eastern Florida Atlantic coast. Used in conjunction with studies of currents, this will serve as a management tool for personnel charged with protecting the marine environment from damaging pollution influx.

\section{JOHN U. LLOYD STATE PARK PROPOSED MARINE EXTENSION}

Geographical Location The area between $26^{\circ} 05^{\prime}-26^{\circ} 03^{\prime} \mathrm{N}$ and $80^{\circ} 04^{\prime} \mathrm{W}$ and the erosion control line, off Fort Lauderdale, Florida.

Physical Features The marine geology of Broward County is described by Raymond (1972).

Reef Structure and Corals The reefs in Broward County are relict remains of Holocene bank reefs, and constitute impoverished communities of Diploria and Montastraea corals covering less than $7 \%$ of the reef substrate (Raymond and Antonius, 1977). The area includes three separate reefs each at a different depth. The first is one of the few living soft coral and sponge reefs which can be reached by walking off the beach (Brooks et al., 1983).

Only corals such as Diploria clivosa, Isophyllia and Siderastra that can survive heavy sedimentation and high wave energy live in the shallow exposed reef areas near shore and at the crest of the sandstone ridge $0.5 \mathrm{mi}$. $(0.8 \mathrm{~km})$ off shore. The oldest, largest coral colonies are in the protected reef areas on high profile reef crests or on hard grounds far from sediment. Lists of corals, octocorals and sponges recorded in the area are given in Raymond and Antonius (1977). The dominant corals (in decreasing order of abundance) are: Montastraea cavernosa, Stephanocoenia intersepta, $M$. annularis, Dichocoenia stellaris and Meandrina meandrites. Pillar Coral Dendrogyra cylindrus is found in some areas.

Noteworthy Fauna and Flora The John U. Lloyd State Park has a mangrove bordered estuary and nesting areas for Loggerhead Caretta caretta, Green Chelonia mydas and Leatherback Dermochelys coriacea Turtles (Bacon et al., 1984; Brooks et al., 1983).

Scientific Importance and Research The reefs off John U. Lloyd Sate park are especially important geologically as they are built on three successive Holocene Acropora palmata reefs, which are deeper and older 
seawards. A palmata is a significant sea level indicator due to its limited growth depth and dating these dead reefs would yield information on Holocene sea level history in a tectonically stable region (Raymond in litt, 18.10.85).

Economic Value and Social Benefits The area is important for commercial fishing, recreation, diving and sport fishing. The reefs form an major breakwater, lessening the impact of coastal storms, and they are a primary source of sand for Florida's beaches.

Disturbance or Deficiencies Coarse grained sand is found on and immediately adjacent to the Broward County reefs which causes stress to the corals when it is suspended by storms. The reefs have also been severely stressed by human activities. Dredging of offshore beach sand to repair the severely eroding shoreline of the John U. Lloyd State Recreation Area from 1976 to 1977 caused damage to the coral community. The County of Broward, through the State Department of Natural Resources, initiated an investigation to assess the damage and evaluate the long term effect of this disturbance. The sheet coral Agaricia lamarcki was the most vulnerable to dredging activities. In general, collision damage on the reef outweighed damage from sedimentation. Dredging took place in the winter months when the waves and bottom currents produced by strong north-easterly storms helped remove the sediments, but also tended to resuspend deposited sediment (Raymond and Antonius, 1977).

Part of the reef in the south of the area has a long history of ship anchor damage due to its proximity to Port Everglades Harbor. Octocorals are reduced in size and number in this area and stony corals are almost entirely lacking. The area is also vulnerable to pollution and siltation emanating from the Harbor. Turtle nesting beaches could be affected by sand dredging (Brooks in litt., 1984).

Legal Protection The John U. Lloyd State Park includes the terrestrial part of the coast, but regulations do not extend to the marine environment.

Management Broward County implemented an extensive coral monitoring programme prior to, during and after the dredging activity. On identifying the disturbances, modification of the dredging operation was requested to reduce the possibility of further damage (Britt, 1977; Courtney et al., 1974). A beach restoration project was carried out in the vicinity of the area in 1983 (Goldberg et al., 1985).

Recommendations The area has been proposed as a reserve on the initiative of "Week of the Ocean", a group of Fort Lauderdale citizens. The designated area is directly east of John U. Lloyd State Park and could be included as part of the park property, under park management. The beach area is already protected (Brooks et al., 1983).

\section{KEY LARGO CORAL REEF MARINE SANCTUARY}

Geographical Location $24^{\circ} 58^{\prime}-25^{\circ} 19^{\prime} \mathrm{N}, 80^{\circ} 8^{\prime}-80^{\circ} 25^{\prime} \mathrm{W}$; Florida, about $90 \mathrm{~km}$ from Miami. Extends from the $4.8 \mathrm{~km}$ offshore boundary of the John Pennekamp Coral Reef State Park, off Key Largo, seaward to the $91 \mathrm{~m}$ isobath, about $13 \mathrm{~km}$ seawards. The northern boundary borders Biscayne National Park.

Area, Depth, Altitude $259 \mathrm{sq} . \mathrm{km}(32.2 \mathrm{~km} \times 5-9 \mathrm{~km})$. About half the sanctuary lies in $30-91 \mathrm{~m}$ of water; depths at its inner limit are $5-7 \mathrm{~m}$.

Land Tenure U.S. Federal Govemment, NOAA, Sanctuaries Office.

Physical Features The Sanctuary consists largely of a shallow submerged shelf of open expanses of sand and Thalassia beds, punctuated with patch reefs. It is uniquely located where the scarcity of tidal passes through the Keys restricts mixing of colder, turbid, less saline Florida Bay water with warm Florida Current water, keeping the environment of the reef stable and healthy (NOAA, 1979c). The Keys continuous land mass provides a natural barrier to pollutants, turbidity and cold freshwater. Visibility in the sanctuary is $15-25 \mathrm{~m}$ unless the sediment is stirred up by wave action (Alevizon and Brooks, 1975). Popular descriptions of the area include Brookfield (1962) and Greenberg (1962).

Reefs within the sanctuary include Molasses Reef (on the south-west seaward boundary, this is one of the most complex and productive reefs in the sanctuary); White Bank Dry Rocks (a shallow patch reef situated about $320 \mathrm{~m}$ north-east of the light at Molasses Reef); French Reef (a bank reef, averaging $7.5 \mathrm{~m}$ depth, north-east of Molasses Reef); Grecian Rocks (a small, shallow (1.8 m deep in places) inner bank reef, $8.9 \mathrm{~km}$ east-north-east of South Channel, Key Largo); Key Largo Dry Rocks; the Elbow (a bank reef) and Carysfort Reef (a highly developed bank reef $8 \mathrm{~km}$ north-north-east of the Elbow) (CNA, 1981).

Hardground communities are found seaward of the reef front and scattered throughout the shallow areas of the sanctuary. Much of the sanctuary is covered by seagrass beds, dominated by Thalassia testudinum. Syringodium filiforme grows in deeper areas, either forming monospecific sparse zones, or mixed with $T$. testudinum. Sand and sediment areas are scattered throughout the area (NOAA, 1979b and c).

Reef Structure and Corals Bank reefs and numerous patch reefs are the predominant forms, the main reef formations occurring at depths of less than $37 \mathrm{~m}$. Patch reefs are found landward of the reef front in areas of sand and rock substrates and occur as single dome-shaped patches or clustered linearly along a submerged topographical trend. They lack Acropora palmata but have small amounts of $A$ cervicornis; many consist entirely of huge colonies of Montastraea annularis. They are seldom higher than $9.1 \mathrm{~m}$, averaging $3-4.5 \mathrm{~m}$ (NOAA, 1979b). Bagby (1978) described the ecology of patch reef gorgonians.

Approximately $22 \mathrm{~km}$ of bank reefs occur in the sanctuary in areas of high energy, including Molasses, French, Elbow and Carysfort Reefs at the seaward edge 
of the shelf margin and Grecian Rocks, Key Largo, Dry Rocks and Turtle Reef landward of the reef front in areas were the water shoals rapidly. Reef height is usually less than $7.6 \mathrm{~m}$ and averages about $3-4.5 \mathrm{~m}$. Coral cover is generally high, reaching $80-90 \%$ (Alevizon and Brooks, 1975) and reef epifauna is abundant with many gorgonians and soft corals. A. palmata is the dominant coral (NOAA, 1979b). In less turbulent areas behind the high energy region, thickets of $A$ cervicornis and Porites porites are found in varying abundance. In some areas massive head corals develop, dominated by $M$. annularis. Other common species are Diploria strigosa, D. labyrinthiformis, Colpophyllia natans, $M$. cavernosa and Siderastrea siderea. Less common species on bank reefs include Agaricia agaricites, $P$. astreoides, Mycetophyllia lamarckiana, Colpophyllia natans, Dichocoenia stokesi, Eusmilia fastigiata, Meandrina meandrites and Mussa angulosa. Millepora complanata is important in shallow zones on some bank reefs.

Reef zonation was described by Shinn (1963) at Key Largo Dry Rocks and Grecian Rocks. Five zones were identified: a back-reef, a reef flat, an Acropora zone, a Millepora zone and a rubble zone. The reef flat occupies approximately a third of the reef and is composed mainly of Acropora shingle and dead colonies in siru. On the leeward side, a narrow band of living $A$ palmata extends the reef flat laterally. Seaward of the reef flat are two terraces. The first terrace is $200 \mathrm{ft}$ $(60 \mathrm{~m})$ wide and slopes downward from the reef flat to a depth of $10 \mathrm{ft}(3 \mathrm{~m})$ at which point it drops almost vertically. The most conspicuous corals are massive colonies of $A$ palmata which, unless protected in crannies, are strongly oriented away from the sea. Almost all Acropora growth stops at the drop-off. The second terrace extends out for $100 \mathrm{ft}(30 \mathrm{~m})$ where it drops down to a maximum depth of $25 \mathrm{~m}$. It is covered mainly by bladed growths of Mille pora complanata, with branches oriented parallel to the waves, and large heads of Montastraea annularis. Since Hurricane Donna in 1960, A cervicornis has overgrown much of the reef previously occupied by other corals (Shinn, 1976). A rubble zone with no slope extends along the face of this terrace in a band $60 \mathrm{ft}(18 \mathrm{~m})$ wide, consisting of cobble sized pieces of Acropora and Millepora. Both terraces are incised by grooves, $10-20 \mathrm{ft}(3-6 \mathrm{~m})$ wide and $10 \mathrm{ft}$ ( $3 \mathrm{~m}$ ) deep, running normal to the trend of the reef and generally lined at the bottom with coarse sand and rubble. The spurs between the grooves vary in width from $100-200 \mathrm{ft}(30-60 \mathrm{~m})$. Several bank reefs within the area exhibit this type of spur and groove formation.

Molasses Reef is a barrier reef with a lagoon community on the shoreward side. As it is situated on the margin of the reef tract, it receives the full force of the waves. Unlike southern Caribbean reefs it has an extensive back-reef rubble zone separated from a poorly defined $A$ palmata reef crest by a slightly deeper barren zone. A well defined spur and groove system is found on the outer face of the reef, the fore-reef slope levelling off at about $14 \mathrm{~m}$ and largely composed of dead Acropora. The buttress zone is quite narrow but has large colonies of Montastraea annularis just seaward of the deep spur and groove zone (Shinn, 1963).

At French Reef, the shallow spur and groove system is less well defined and a deeper zone of better developed spur and grooves with active coral growth extends further seaward. $M$. annularis and $A$ palmata are dominant on the reef, which is undercut by cavernous passages. NOAA (1981b) describes the deeper water communities.

Carysfort Reef has a typical southern Caribbean reef zonation with a well developed back-reef zone; an $A$ palmata reef crest which may be exposed at low tide; a fore-reef slope and terrace; a barren zone; and a deep reef slope ending in a sand terrace at about $21 \mathrm{~m}$ (Jones and Thompson, 1978). The reef flat has an extensive concentration of $A$ palmata on its seaward flank, which grades into a nearly barren area before the buttress zone. The spur and groove formation is in an early stage of development. Haystack-size colonies of $M$. annularis and fields of $A$ cervicornis are common. A broad expanse of rock separates the reef platform proper from hard-substrate deep reef communities which are described by NOAA (1981b).

A deep reef extends to $40 \mathrm{~m}$ seaward of the main reef zone. Beyond it, a Lithothamnion cobble zone is found, extending to $55 \mathrm{~m}$ depth and characterized by an absence of hermatypic corals (NOAA, 1981b).

Noteworthy Fauna and Flora Of the 516 fish species that have been recorded, many are of commercial value. Reef fish assemblages have been studied at Grecian Rocks and Dry Rocks (Alevizon and Brooks, 1975) and at Molasses, French and Carysfort Reef (Jones and Thompson, 1978). Queen Conch Strombus gigas and Horse Conch Pleuroploca gigantea are found occasionally on seagrass and sand areas. The spiny lobster Panulirus argus is of prime commercial interest. $P$. guttatus and Seyllarides aequinoctialis are also found but their small adult size and scarcity make them uneconomical to harvest commercially. The Stone Crab Menippe mercenaria is of commercial importance. The Sanctuary contains 38 species of coral (NOAA, 1979c). The echinoderm fauna is described by Kier and Grant (1965). The American Crocodile Crocodylus acutus and the Caribbean Manatee Trichechus manatus occur in the area, and the Green Turtle Chelonia mydas, Loggerhead Caretta caresta and Leatherback Dermochelys coriacea may also occur.

Scientific Importance and Research The reefs within this area comprise the approximate northern limit of reef growth along the mainland coast of the Western Hemisphere, and are considered an outstanding example of patch and outer bank coral reefs (CNA, 1981). The northern tract reefs have a long history of scientific research which is reviewed in NOAA (1979b) and Skinner and Jaap (1984). Research is encouraged in the sanctuary, although a permit must be obtained from NOAA. NOAA has compiled a bibliography of published scientific research for the area (NOAA, 1980b).

A geological study has been conducted to determine the reef's past growth and to outline its geological history. Periodic monitoring of the physical environment and assessment of the biological community is carried out. Other studies underway or planned include water quality monitoring in conjunction with studies in John Pennekamp State Park and Biscayne Bay National Park; permanent life history monitoring to study growth, recruitment and other factors; biological inventories; periodic assessments of coral mortality, disease and other damage; surveys of lobster and stone crab populations; deepwater surveys using submersibles. A permanent photograph transect has been established on Carysfort 
Reef (White and Porter, 1985). A deep water resource survey has been carried out (NOAA, 1981b). Annual growth rates of Montastraea annularis have been determined (Hudson, 1981b) and transplantation and growth experiments have been carried out on A cervicornis (Shinn, 1966). The recovery of Molasses Reef following the grounding of the freighter Wellwood is the subject of a large-scale multi-disciplinary research program sponsored by NOAA and described by Curtis (1985).

Economic Value and Social Benefits Tourism is crucial to the economy of the Keys and the reefs are a major attraction for the 400000 holiday makers who come sport fishing and diving each year. Total usage may be greater as visitors arriving by boat from elsewhere are not recorded. Access to the sanctuary is by boat only, from a variety of facilities on Key Largo, including boat charterers, dive centres and marinas. Glass bottom boats take non-divers to Molasses Reef. Swimming, snorkelling, scuba and skin diving, photography and recreational boating are encouraged (NOAA, 1979c; CNA, 1981). Most visitors to the reefs concentrate around Dry Rocks, Molasses Reef and a few other locations, such as French Elbow and Carysfort Reefs, at the southern end of the sanctuary, opposite the area of greatest urbanization on Key Largo.

Molasses Reef is one of the most intensively used areas with $20-30$ boats anchoring there at any one time on summer weekends. There is abundant coral and good visibility, making it well suited for diving, and approximately 25 large commercial dive boats operate in the southern half of the Sanctuary. Key Largo Dry Rock is also extremely popular on account of the huge brain coral formations and the $2.7 \mathrm{~m}$ high bronze statue, the Christ of the Deep. This stands in approximately $7.6 \mathrm{~m}$ of water and is a replica of the Christ of the Abysses statue off Genoa in the Mediterranean. French Reef is heavily visited by divers interested in the large pelagic fish found there and the abundant corals in canyons, caves and tunnels. White Bank Dry Rocks and Grecian Rocks are used by snorkellers and novice divers as they are relatively shallow. The Elbow, being some way off shore, is used mainly by local divers. Use of Carysfort Reef has increased due to the development of a marina directly opposite it on Key Largo. Wrecks which provide interesting dive sites include the British frigate HMS Winchester (1695), the Benwood (1942) which is the most popular wreck (7.6-14 m deep, $2.4 \mathrm{~km}$ north of French Reef), the steamer Towanda (1866), the schooner Windlass at Molasses Reef, the schooner Thiorva on Turtle Reef, the Charles $W$. Bird on White Bank and "No Name Wreck" near Elbow Reef. Wrecks of the two Spanish galleons, El Infante and San Jose y los Amenas which sank in 1733, are located outside the southern boundary and are also popular dive sites. Carysfort Reef Lighthouse is an additional attraction for visitors; it is fully automated and maintained by the U.S. Coastguard.

Hook and line fishing serves as a source of food and recreation, and species taken include groupers Serranidae, mackerel Scombridae, dolphin, snappers Lutjanidae, hogfish Lachnolaimus maximus, tarpon Megalops atlanticus, pompano and jacks Carangidae and bonefish Albulidae. Spiny lobsters (the main commercial harvest) and stone crabs are taken in traps and by divers. Annual catch statistics are not available.

Disturbance or Deficiencies Hurricane Donna in 1960 and Hurricane Betsy in 1965 caused considerable damage in some areas, but the reefs recovered in a few years on each occasion (Ball et al, 1967; Shinn, 1976). The bank reefs at Key Largo Dry Rocks and Molasses were extensively damaged during Donna, but patch reefs, such as those at Mosquito Bank (in John Pennekamp Park) were less affected. Continuous coral monitoring initiated in 1981 suggests a $20 \%$ change in coral populations each year at Carysfort, Elbow, French and Molasses reefs (Skinner and Jaap, 1984).

Pollution is a potential threat. In 1975, the greater Miami area pumped 84 million gallons ( 315 million litres) of sewage a day into surrounding marine waters. It was thought that much of this travelled south to the Keys (Dustan, 1977a). The outfall at Plantation Key, just south of Key Largo, pumps 700000 gallons (2.65 million litres) of secondary treated sewage a day, and there are two outfalls that dump sewage into Largo Sound. Studies at Carysfort Reef revealed high mortality rates of corals (Dustan, 1977b). Recent agricultural and industrial growth in south Florida has increased the potential for pollution from insecticides, herbicides and industrial chemicals. Evidence of oil pollution and increased turbidity from vessel traffic through Hawk Channel and off the Marine Sanctuary increases yearly (NOAA, 1979c). The main commercial traffic in Hawk Channel is tugboat oil barge movement between Miami, Marathon and Key West which stirs up silt (Skinner and Jaap, 1984). A major concentration of shipping lanes is situated offshore beyond the Sanctuary which poses a constant threat of accidental grounding or catastrophic cargo spill. Litter is a problem in many areas and vessel groundings may cause damage although recovery can be rapid. A decrease in growth rate of Montastraea annularis was found between 1953 and 1968 which coincided with the increased dredge-and-fill activities in the Florida Keys at that time; the slight increase in growth rates after 1968 can be correlated with a reduction in these activities (Hudson, 1981b).

Groundings at Grecian Rocks in 1964 and 1975 cut swathes in Acropora stands but these have largely regenerated (CNA, 1981). The Maya was wrecked on Key Largo Dry Rocks in 1974 and caused serious damage. The freighter Wellwood grounded on Molasses Reef in 1984 and was salvaged after 12 days; in the course of the grounding and salvage work, the reef suffered substantial damage, particularly the massive corals (Curtis, 1985).

Recognition as a national marine sanctuary has intensified public use of the area; collection pressure is low but impacts such as diver contact and recreational boat anchoring continue. Heavily used areas of reef are in a distinctly poorer condition than more remote regions, probably largely due to anchoring and concentrated diver pressure (CNA, 1981). The trend towards larger charter boats has meant that there are more divers per unit time on the reefs. Private boats violate the statutes more often and are responsible for many of the groundings, pollution and illicit collecting. Commercial dive boat operators are probably more conscientious; professional dive guides police the divers and ensure that conservation regulations 
and diving safety constraints are observed (Skinner and Jaap, 1984). Few reefs in the sanctuary are marked so the use of those with buoys is much intensified. For example, an average of $20-50$ boats visit Molasses Reef (only 2 acres ( $0.81 \mathrm{ha}$ ) in area) a day, and up to 200 may visit it on a busy day. Anchors are dropped on the reef some 15000 times each year; cumulative damage over a year could cover one tenth of an acre (0.04 ha) (Dustan, 1977a).

Spearfishing and collecting of coral, shells and archaeological artifacts still occurs, although illegal. Key Largo was found to have a higher species diversity of fish than a more isolated reef at Las Aves, Venezuela, possibly due to the greater complexity of the reef and the proximity of mangroves and seagrass beds, but a lower number of large individuals, possibly due to the effects of spearfishing on groupers, snappers and barracuda (Alevizon and Brooks, 1975). Explosives were used for fishing at Carysfort Reef from about 1900 to the early 1950s. Damage throughout that period was severe but recovery has been fairly complete (CNA, 1981). The scarcity of the large molluscs Strombus gigas and Pleuroploca gigantea reflects high collecting pressure in past years. During the past decade there has been a trend of more spiny lobster trap deployment per fisherman with reduced catch-per-unit effort; many individuals are now taken before sexual maturity. The law requires fishermen to recover traps at the end of the season but many traps are abandoned each year. There is also some evidence that illicit fish trapping ocurs in the Sanctuary with time-released marker buoys (Skinner and Jaap, 1984).

Legal Protection Designated a Marine Sanctuary on December 18, 1975, by the Federal Government. NOAA regulations permit both sport and commercial fishery with hook and line but spearfishing and the use of wire fish traps are prohibited. Spiny lobster and stone crabs may be taken with woodtraps in accordance with plans outlined by the Regional Fishery Management Council.

The removal or destruction of any natural reef feature or marine life (other than spiny lobsters and stone crabs) or other materials is prohibited. There is a blanket prohibition on cutting, displacing or breaking of bottom formation or growth. Dredging, filling, excavating, building and the discharge of refuse and other pollutants are banned. Tropical fish may not be taken. Divers are forbidden to handle or stand on coral formations. Constraints have been placed on the operation of boats in the area to ensure that neither vessels nor their anchors damage coral (NOAA, 1979c). Regulations are issued under the authorities of section 302 (f), 302 (g) and 303 of the Marine Protection, Research and Sanctuaries Act, 1972. The sanctuary has been designated a Habitat Area of Particular Concern (HAPC) (CNA, 1981).

Management Responsibility for management of the Marine Sanctuary lies with the National Oceanic and Atmospheric Administrations (NOAA) Office of Coastal Zone Management. NOAA sets management objectives for the sanctuary, designs and implements research programmes, issues permits and oversees monitoring and enforcement of the regulations. It provides technical briefing material, designs and implements public information programmes, and provides administrative and emergency on-site support. A management plan has been produced by NOAA to ensure the long-term viability of the area, and covers issues such as public education, environmental monitoring, regulatory enforcement and monitoring needs. Up to $20 \%$ of the Marine Sanctuary area may be closed to the public by NOAA at any time to allow the living resources to recover from overuse or to provide for scientific research.

Mooring buoys have been placed on the most frequently visited reefs and research has been carried out on their effectiveness (Halas, 1985). Brochures and pamphlets have been produced for visitors to the sanctuary. A coral reef resource survey has been co-ordinated by NOAA (1979b) and an environmental assessment and biological inventory is being organized jointly by NOAA and the Florida Department of Natural Resources. The latter provides an onsite manager, responsible for evaluating permit applications, co-ordinating with the U.S. Coastguard surveillance and enforcement, providing case documentation for notices of violation and submitting biannual reports to NOAA. Surveillance is carried out using the same personnel and facilities as for the John Pennekamp Coral Reef State Park. Violators are subject to civil penalties of up to USS 50,000 under Federal Public Law 92-532.

Recommendations Skinner and Jaap (1984) give detailed recommendations (described in the account for the John Pennekamp Coral Reef State Park) for improved management of the Sanctuary and adjacent Parks. The research program following the recovery of Molasses Reef will identify any possible strategies that could enhance or hasten reef recovery following groundings (Curtis, 1985).

\section{LOOE KEY NATIONAL MARINE SANCTUARY}

Geographical Location $12.4 \mathrm{~km}$ south-west of Big Pine Key, Lower Florida Keys; $24^{\circ} 37^{\prime}$ N, $81^{\circ} 24^{\prime} W$.

Area, Depth, Altitude 5.3 sq. naut. mi. (18.2 sq. km), covering a roughly rectangular area; NOAA (1984) gives details of the areas and dimensions of each reef zone; depths vary from $0.0 \mathrm{~m}$ on the reef crest to $41 \mathrm{~m}$ over the deep ridge.

\section{Land Tenure Federal.}

Physical Features The Sanctuary comprises seagrass beds, patch reefs, sand flats, and the bank reef itself. Water clarity is excellent and sea conditions are moderate (Anon., 1981). Two wide channels consisting of sand plains cut across the east-west trending Florida Reef Tract on either side of the reef flat. Numerous inlets and passages through islands to the east of Looe Key allow waters of Florida Bay to flow out, but most of the reef seems to have been protected from the adverse impact of these waters (low salinity, altered temperature and higher turbidity) by local current regimes and the Big Pine Key land mass. In summer, winds are primarily from the south-east; surface water temperatures on the outer reefs average $30-31^{\circ} \mathrm{C}$. From October to April, water temperatures drop to $22^{\circ} \mathrm{C}$ and occasionally lower, and winds are predominantly north-east. Hurricanes 
sometimes occur, usually between June and November, but there have been no severe ones in recent years (NOAA, 1984).

Looe Key exhibits features representing two distinct geological origins. An older deeper reef has developed on a former shoreline and exhibits spurs and grooves that are closely spaced and probably originated through erosion of bedrock. In contrast the shallow active coral reef has formed over $5 \mathrm{~m}$ of carbonate sand which is now no longer accreting due to an extensive die-off of Acropora palmata a few thousand years ago, possibly associated with inflows of Florida Bay waters. A submersible research vessel discovered a narrow deep ridge running parallel to the margin of the continental shelf, separated by about one $\mathrm{km}$ of sand from the deep reef. The deep reef is gradually being smothered by migrating carbonate sand moving in a westerly direction (Shinn et al., 1981). Looe Key Reef appears to be losing the battle with rising sea level as the key was a dry sand island in the 1700s (Wheaton and Jaap, 1984). Agassiz (1852) described Looe Key as a "series of submarine elongate hillocks rising above sea level in the form of islands or boulders". The rubble zone on the east end of the reef, which is emergent during low tide, may be the remains of the island.

Reef Structure and Corals Looe Key reef exhibits only minor differences from other bank barrier reefs in the Florida Reef Tract; distinctive features include vertical zonation of coral off the reef front and the presence of spur and groove formations and Acropora palmata (Wheaton and Jaap, 1984). Five zones were described by Antonius et al. (1978): 1) a patch reef area, 2) a reef-flat, 3) a fore-reef, 4) a deep reef, and 5) a deep ridge further seaward. Shinn et al. (1981) identified the following zones: 1) a grass flat, 2) a reef-flat, 3) spur and groove and 4) deep spur and groove. Wheaton and Jaap (1984) give detailed descriptions of six sites within three major types of community: spur and groove, buttresses and livebottom. The management plan (NOAA, 1984) provides concise summaries of the resource management units which have been identified for the purpose of the plan: back-reef, reef-flat, fore-reef, intermediate and deep reef, deep ridge and sand plain and side channels.

The Thalassia and Syringodium covered sand flat is located landward of the shallow reef-flat and is surrounded by coral rubble "horns". Water depth in this zone ranges from $1-4 \mathrm{~m}$ and the thick turf is broken in places by sand-filled blow outs several metres in diameter which have formed during hurricanes (Ball et al., 1967). $A$ band of rubble separates the seagrass from the rubble-covered reef-flat which breaks water, especially at the east end, during spring low tide. At the east and west ends of the reef-flat, the rubble extends landward in drifts which probably originated during hurricanes (Shinn et al., 1981). Dominant species in this zone include Porites astreoides, (27\%), Diploria clivosa (17\%), Millepora complanata $(14 \%)$ and Siderastrea siderea $(11 \%)$. The gorgonians Gorgonia ventalina and Pterogorgia citrina are conspicuous (Antonius et al., 1978). The back-reef area, which is protected from turbulent water, is covered with loose debris, coral rubble and conch shells. A ring of Thalassia separates the reef top ridge from the back-reef (Emmery, 1973).

The patch reef zone closest to Looe Key contains the same scleractinian species as the reef-flat, but has an increased abundance of $A$ cervicornis. Twenty-six gorgonians have been found, of which Pseudoplexaura flagellosa was the most abundant (Antonius et al., 1978).

The reef crest is dominated by $M$. complanata and Palythoa and is transected by large surge channels (5-6 $\mathrm{m}$ deep), some of which extend forward as a spur and groove system about $800 \mathrm{~m}$ long and $300 \mathrm{~m}$ wide, which slopes sharply from the surface to a sand bottom at a depth of 9-11 m. The spur and groove system is one of the best in the Florida Reef Tract, extending about $1200 \mathrm{~m}$ east to west with individual spurs attaining a length of about $200 \mathrm{~m}$. The spurs deviate slightly from a perpendicular orientation (Shinn et al., 1981) and the shallowest part is emergent at low tide. The spurs are composed of a framework of $A$ palmata, with living corals of Montastraea annularis, $D$. strigosa and Colpophyllia natans. At present, $A$ palmata is scarce in shallow waters but is commoner on deeper parts, occurring on more than $70 \%$ of the spurs. $M$. cavernosa becomes dominant at the deeper ends of the spurs. Montastraea spp. and $A$ palmata comprise $54 \%$ of the scleractinians. The gorgonian fauna is dominated primarily by Pseudopterogorgia americana and Gorgonia ventalina, making up $19 \%$ of the fauna (Antonius et al., 1978; Emmery, 1973; Shinn et al., 1981; Wheaton and Jaap, 1984).

The end of the spur and groove system is marked by a sandy plain at 10-12 m depth which grades into a deeper reef zone, particularly towards the west (NOAA, 1984). A second tier of deep spurs and grooves continues to a depth of $30 \mathrm{~m}$, with much tighter spacing and a more diverse coral community than the shallower spur and groove zone. A spectacular drop-off with slopes as great as $35^{\circ}$ is found between 20 and $30 \mathrm{~m}$. Octocorals, such as the rough sea plume Muriceopsis flavida, are common but are replaced by Pseudopterogorgia bipinnata and Iciligorgia schrammi with increasing depth. The scleractinians of the deep reef are similar in composition to the shallower zones but contain a relatively greater abundance of branching forms such as Eusmilia fastigiata, Porites porites and Madracis spp. The larger scleractinians of the deep reef are Agaricia and Mycetophyllia (Antonius et al., 1978; Shinn et al., 1981).

Wheaton and Jaap (1984) recorded a total of 59 cridarian species, of which 23 were octocorals (including 16 species in the family Plexauridae). The 31 scleractinians were distributed among ten families. The Favidae and Mussidae had most species and $A$ agaricites and $P$. astreoides were most abundant. Combining the results of work of Antonius et al. (1978) and a survey by the Florida Department of Natural Resources in 1980, the total for the area is thought to be 36 octocorals, 39 scleractinians and 2 hydrocorals.

Noteworthy Fauna and Flora Spiny lobsters Panulirus argus, crabs, many fish and the Queen Conch Strombus gigas are present. The damselfish fauna is described by Emmery (1973). The American Crocodile Crocodylus acutus, the Loggerhead Caretta caretta, the Green Turtle Chelonia mydas, the Hawksbill Eretmochelys imbricata and the Leatherback Dermochelys coriacea may occur here and the area is included in the summer range of the Caribbean Manatee Trichechus manatus; Kemp's Ridley Le pidochelys kempii is an occasional visitor. 
Scientific Importance and Research Looe Key Reef is considerd an outstanding example of a submerged coral reef in the Lower Florida Reef Tract and contains a classic example of spur and groove formation. The management plan includes of bibliography of scientific work carried out in the area. Recent research is comparatively scarce; Antonius et al. (1978) conducted a pre-sanctuary resource survey; an environmental impact statement was prepared by NOAA (1980a) and a study by Shinn et al. (1981) provides information on the reef's age and its spur and groove development. Wheaton and Jaap (1984) provide a detailed survey of corals and cnidarians, carried out through the National Marine Fisheries Service South-east Fisheries Center. A permanent photograph transect has been established on the reef (White and Porter, 1985) and detailed site surveys are being undertaken in order to compile a series of large scale resource maps (NOAA, 1984). Looe Key Marine Sanctuary is used for teaching purposes by the Newfound Harbour Marine Institute facility on Big Pine Key (CNA, 1981).

Economic Value and Social Benefits The reef is a popular site for diving and snorkelling, sport fishing and recreational boating by both tourists and local residents, due to its relative accessability from Miami and Key West (Barada, 1979; NOAA, 1984). A variety of boat launches between Marathon and Sugarloaf Key take visitors to the Sanctuary, and twelve dive-boat operators offer daily trips. The most important access point in the Bahia Honda State Recreation Area. The peak season is the summer when diving and snorkelling conditions are optimal. Attractions include the remains of the shipwreck, the H.M.S. Looe, a British frigate sunk in 1744 (Anon., 1981). The shallow reef flat is particularly popular with novice snorkellers and the fore-reef is the best diving area. Sport and commercial fishing throughout the Sanctuary and the commercial harvest of lobsters outside the fore-reef area are traditional uses; hook and line fishing occurs mainly along the fore-reef and in the south-west corner of the Sanctuary.

Disturbance or Deficiencies Reef areas to the east of the Sanctuary have occasionally been damaged by intrusions of Florida Bay waters. Most of the reefs in the Sanctuary seem to be protected from this (NOAA, 1984) although it has been suggested that the disappearance of $A$ palmata in this area may have been due to such intrusions. NOAA (1984) discusses in detail the management issues raised by intensive recreational use and the potential threats that this poses. There is growing pressure on the reefs from souvenir hunters and anchor damage, and broken corals have been reported (Antonius et al., 1978; Bohnsack, 1982). Boat groundings have damaged Diploria strigosa and Montastraea annularis and salvage efforts often cause further damage. The reefs are potentially threatened by fuel and oil seeping from wrecks, particularly since the largest commodity flows of oil in the U.S.A are shipped through the Strait of Florida, two km south of Looe Key (CNA, 1981; NOAA, 1984).

Legal Protection Nominated as a Marine Sanctuary in November 1976 by the Florida Keys Citizens Coalition and designated in 1981 in accordance with Title III of the Marine Protection, Research and Sanctuaries Act. The following activities are prohibited: taking or damaging Sanctuary resources, including tropical fish and invertebrates other than lobsters outside the zone known as the Fore Reef; spearfishing; using wire fish traps, poisons or electric charges; tampering with markers, including those used for lobster pot fishing; removing historic artefacts; littering and discharging of effluents; and anchoring on coral within the Fore Reef. Detailed regulations and specific restrictions are published in the Code of Federal Regulations (Title 15; Part 937). The area is considered a Habitat Area of Particular Concern (HAPC) by CNA (1981).

Management The Sanctuary Programs Division is responsible for regulatory management. The Florida Department of Natural Resources is the main agency involved in the enforcement of regulations. A Core Area of less than 0.5 sq. $\mathrm{n}$. mi (1.7 sq. $\mathrm{km}$ ) has been defined which includes the Fore Reef zone. Visitors are requested to anchor carefully and not to touch coral. Education programmes are being designed to heighten public awareness. Workshops, field trips and guides help visitors to understand the marine environment. A leaflet has been produced for visitors and a number of guidebooks are in preparation (Anon., 1981; NOAA, 1984). The Sanctuary Manager's office is located at Bahia Honda. The Gulf of Mexico and South Allantic Fishery Management Councils have prepared management plans for Spiny Lobster and reef fish, and recreational and commercial fishing is carried out in accordance with these plans.

Recommendations Long term and short term management goals are detailed in the management plan (NOAA, 1984). Two management phases are proposed: the focus during the first phase to be on resolving management issues, improving existing operations and undertaking research and feasibility studies for the second phase; this will entail the development of programs for land and water. In the first phase, mechanisms for continued compatible use of the Fore Reef area will be developed and markers will be installed to delineate the Core Area to help enforce the federal regulations. Mooring buoys will be installed to improve boating and diving safety during peak use periods and to reduce anchor damage. Surveillance and enforcement will be improved. There are plans for the expansion of the Sanctuary headquarters to include an interpretive centre. A permanent biophysical monitoring system is to be implemented.

\section{ST LUCIE NEARSHORE REEFS PROPOSED NATIONAL MARINE SANCTUARY}

Geographical Location Very close to shore near Stuart, Florida, south of St Lucie Inlet, off Jupiter Island; $27^{\circ} 21^{\prime} \mathrm{N}, 80^{\circ} 16^{\prime} \mathrm{W}$.

Area, Depth, Altitude depths 5-27 ft (1.5-8 m); area 4.5 sq. mi (11.65 sq. $\mathrm{km}$.)

\section{Land Tenure State of Florida.}

\section{Physical Features No information.}

Reef Structure and Corals A remnant of coral reef fauna, combined with the marine polychaete Phragmatopoma lapidosa with many tropical 
and temperate organisms. On the south side of the inlet, corals are found on offshore outcroppings of the Anastasia facies and on old Phragmatopoma formations. Tropical scleractinians include Montastraea annularis, M. cavernosa and Diploria strigosa (Jaap, in litt. 1984). A number of temperate octocorals are also found, as well as Eunicea, Pseudopterogorgia and Gorgonia (CNA, 1981). Limestone ledges and spur and groove butresses are covered with sabellarid worms and soft corals (Taggart, 1983).

\section{Noteworthy Fauna and Flora The Caribbean} Manatee Trichechus manatus occurs here and moves along the St Lucie Canal to Lake Okeechobee in the summer. The Loggerhead Caretta caretta, Green Turtle Chelonia mydas, Kemp's Ridley Lepidochelys kempii and Leatherback Dermochelys coriacea may occur here; the Loggerhead nests in the area (Bacon et al., 1984).
Scientific Importance and Research The northernmost assemblage of tropical reef corals on the east coast of Florida (Jaap, in litt., 1984); the area represents the northern limit for several species of hard (D. strigosa and $O$. diffusa) and soft corals (Taggart, 1983).

Economic Value and Social Benefits Spiny lobster and fish are collected from the reef which is a popular area for snorkellers and SCUBA divers (Jaap, in litt, 1984)

Disturbance or Deficiencies There is a potential threat from salinity alterations caused by discharge from Lake Okeechobee (Jaap, in litt., 1984).

Legal Protection None specific to the area although general fishing and conservation legislation applies.

Recommendations Nominated as a National Marine Sanctuary (Jaap, in litt., 1984) and included on the Site Evaluation List (Taggart, 1983). 



\section{INTRODUCTION}

\section{General Description}

The U.S. Virgin Islands (U.S.V.I.), a territory of the U.S.A., comprises three main islands: St Thomas and St John ( $88 \mathrm{~km}$ east of Puerto Rico) in the north and St Croix, $40 \mathrm{n}$. mi. (74 km) to the south, and about 90 small islands and cays. St Thomas (8.3 sq. $\mathrm{km})$ and St John (5.2 sq. km) lie on the same submerged bank as Puerto Rico and the British Virgin Islands and the earliest volcanic deposits of the north-west Caribbean lava flows are visible in many places (Connelly, 1966). St Croix is the largest island ( 22 sq. $\mathrm{km}$ ) and, unlike others in the Lesser Antillean chain, is primarily sedimentary in origin, and lies on a submerged bank separated from the other islands by a $4000 \mathrm{~m}$ deep trench. The geology of St Croix is described by Adey et al. (1977). The islands are hilly with peaks rising to $474 \mathrm{~m}$; the original forest is largely destroyed and existing forest and scrub is secondary.

The major wind and wave patterns affecting the Virgin Islands are related to westerly trade wind circulations to the north. Severe winds occur in the winter and hurricanes in the autumn. Average temperatures vary little between winter $\left(25^{\circ} \mathrm{C}\right)$ and summer $\left(28^{\circ} \mathrm{C}\right)$. The climate of St Croix is described in Adey et al. (1977). Annual rainfall varies between 750 and $1250 \mathrm{~mm}$, with heavy autumn and winter rains having profound effects on local marine sedimentation (Hubbard et al., 1981). Tides on St Croix vary between diurnal and semi-diurnal with a spring-tidal range of $0.24 \mathrm{~m}$. Climatic conditions on St John vary from the drier, windward (eastern) exposures to the moist mountain top.

A general description of the marine environments of the U.S.V.I. is given in Island Resources Foundation (1977a). The marine environments of St Thomas are described in two separate accounts. The ecology of Lindbergh Bay has been described by van Eepoel and Grigg (1970). No other general information has been obtained for St Thomas. The fringing reefs on St John are said to be poorly developed (Randall, 1963); those within the Biosphere Reserve, which covers over two thirds of the island, are described in a separate account. Outside this area, in Coral Bay, a more mature reef profile is found at Lagoon Point. Randall (1963) compared fish populations on an artificial and two natural reefs.

St Croix has the most extensive reefs, with many miles of bank barrier reefs, often with algal ridges, extending in an almost unbroken line from Coakley Bay on the north coast, around the eastern tip to Great Pond Bay on the south coast. There are also numerous fringing and patch reefs (Teytaud, 1980). On the north coast, the eastern shelf is up to several kilometres wide and is rimmed by emergent Holocene reefs, considered to be the best developed on the island (see separate account) (Dahl et al., 1974). The western portion is less than $0.2 \mathrm{~km}$ wide and is traversed by two small submarine canyons; in the Salt River (see separate account) and Cane Bay areas, the edge of the shelf drops precipitously into great depths and the reefs form a vertical wall supporting abundant growths of black coral (Teytaud, 1980). The south shore has a shelf up to $4 \mathrm{~km}$ wide (Hubbard et al., 1981). The reef zonation of the entire island has been mapped from aerial photographs for the Bureau of Land Management.

The status of sea turtles in the U.S.V.I. is described by Groombridge (1982) and Bacon et al. (1984). Green Turtles Chelonia mydas forage in seagrass and coral reefs habitats but rarely nest; Hawksbills Eretmochelys imbricata have sparse nesting but are found on the coral reefs; Leatherbacks Dermochelys coriacea have a population of 50-70 nesting at Sandy Point, St Croix. Halewyn and Norton (1984) review the status of seabird colonies in the U.S.V.I., listing sixteen species which breed on the islands. Important wetland areas are described in Scott and Carbonell (1986).

The marine environments of the U.S.V.I. have been comparatively well studied, including early work such as Britton (1919-1952). Research is carried out by the Caribbean Research Institute and Virgin Islands Ecological Research Station on St John, both connected with the College of the Virgin Islands, and the West Indies Laboratory (W.I.L.) of Fairleigh Dickinson University at Teague Bay on the north-east coast of St Croix. The Department of Conservation and Cultural Affairs has a research laboratory at Benner Bay, St Thomas. The St Croix reefs are the most well known, with many reef research programmes underway at the W.I.L. There are a variety of reef types which are excellent for scientific study, although there is no reef bordering deep oceanic waters. Hydrolab, the scientific saturation diving habitat operated by NOAA's Undersea Research Program, is located at the apex of Salt River Canyon (see separate account) and a wide range of studies are carried out using its facilities (Nyden, 1985). A number of ecological studies and surveys have been carried out at Cane Bay by the W.I.L. (Gladfelter in litt., 9.12.85).

\section{Reef Resources}

Fishing has traditionally been an important activity in the islands and spiny lobsters Pamulirus argus, black coral Antipatharia and Queen Conch Strombus gigas are major resources. A study of the potential of the black coral fishery was carried out by Olsen and Wood (1980). Early studies of fisheries include Randall (1963) and Olsen et al. (1975). More recently, Olsen (1982) estimated a resident fishing community of some 420 full-time and part-time fishermen. Koester (1985) provides an account of the industry on St John where the increasing availability of wage jobs accompanying the tourist boom and the creation of the national park has changed fishing from a primary occupation to an important but part-time and secondary means of livelihood. There are about $25-30$ subsistence fishermen on the island, some of whom fish principally to supply their households and others of whom sell their catch. Fish pots or traps are the most common techniques for reef species including lobster; various hook and line methods are used for pelagic and demersal fish. SCUBA diving for conch and lobster is less common and large 


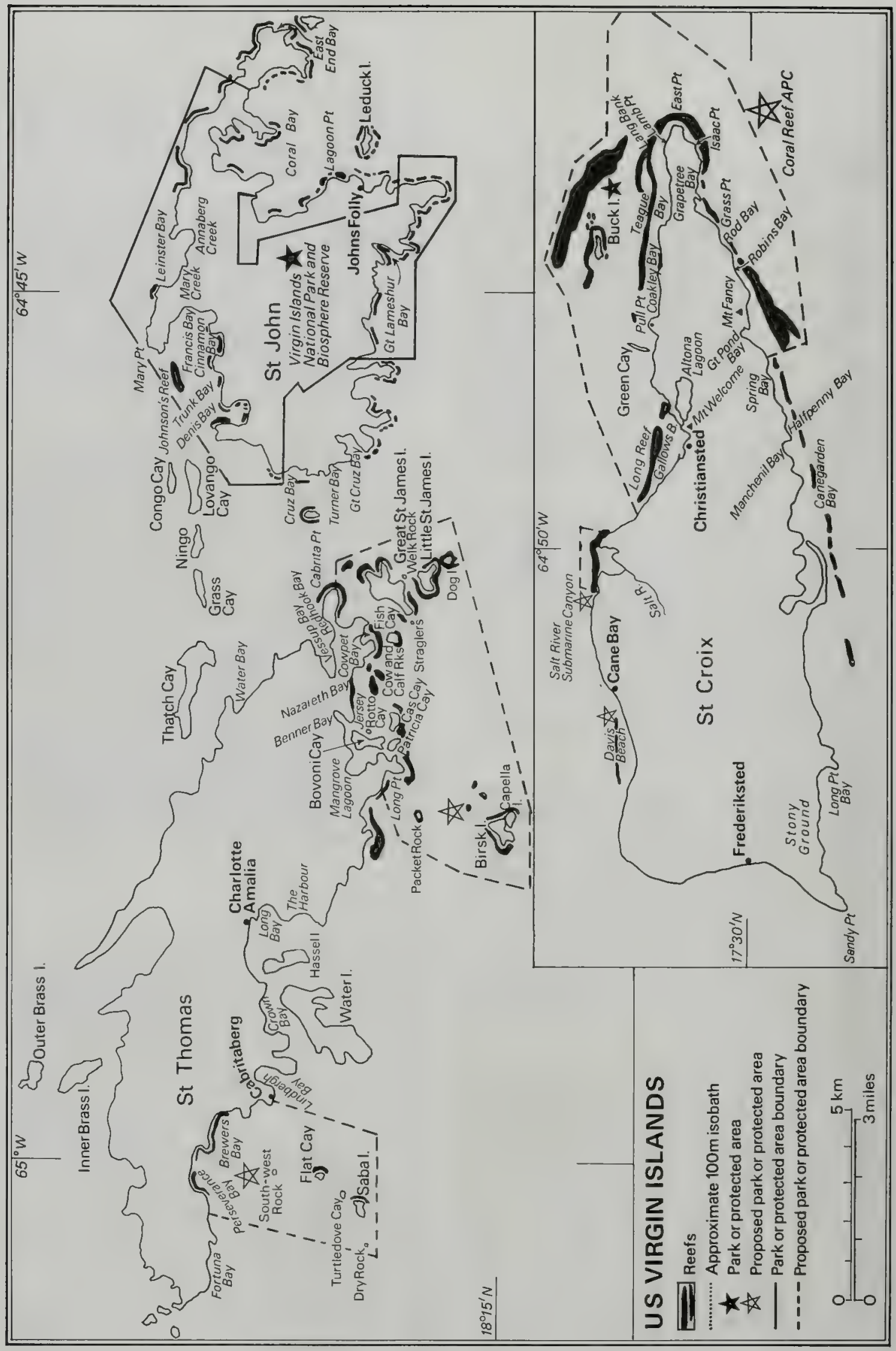


seines and turtle nets are no longer used. Fishing is most intense during the tourist season. There is only one large scale commercial fishing enterprise, operating from Cruz Bay and fishing outside the Biosphere Reserve, but there are several fishing charters operating on St Thomas and St John. Ciguatera fish poisoning has been a problem for some time in the U.S. Virgin Islands and has been studied on St Thomas and St John (Brownell and Rainey, 1971; McMillan et al., 1980). Almost half of the 84 fish species caught on St Thomas could cause poisoning (Olsen et al., 1984).

The tourist industry has been of of major economic importance in the U.S.V.I. for some time and has undergone exponential growth and is now the leading economic activity. For example, there are more than one million visitors a year to St John (Koester, 1985) and a survey in 1977 revealed that $52 \%$ of tourists snorkel and dive, $85 \%$ swim, $31 \%$ sail and $7 \%$ fish. Over $30 \quad 000$ divers visited the cays and islands off St Thomas and St John in 1978 and four dive boat charters now operate from St John (Koester, 1985). A survey of recreational boating and fishing was carried out in 1979 (Olsen, 1979). Lund et al. (1985) describe the growth of the pleasure boat industry, recording 2765 boats of all kinds registered in the U.S.V.I. in 1980, of which 190 were crewed charter boats. The St Croix reefs are also heavily used by sport divers and visitors (see separate accounts)

\section{Disturbances and Deficiencies}

The reefs of the U.S.V.I. have suffered a variety of forms of natural damage. The impact of Hurricanes David and Frederic was studied on Buck Island and the south shore reefs of St Croix by Rogers et al. (1979) and on St Thomas by Rogers et al. (1983). Tropical Storm Klaus caused damage in 1984 (Rogers, 1985). Implications of the Diadema die-off on St Croix are described by Carpenter (1985). High Diadema mortalities were also observed at St Thomas and St John (Lessios et al., 1984), and are probably due to a water-borne pathogen which caused Caribbean-wide mortality of this species. Outbreaks of white band and black band disease have been reported (Rogers, 1985).

Dahl et al. (1974) found the reefs to be healthy and suggested that this was because there was little need to exploit them for food. Adey et al. (1981) also reported that, in spite of the explosive population growth on St Croix since the beginning of the 1960 s, most of the reef system had remained largely unaffected. However, human activities have had an increasingly serious impact. For example, poor management and erosion control practices in many upland watersheds on St Croix have resulted in large quantities of sediments being discharged into coastal waters. During periods of high rainfall, plumes of sediment are often visible in the nearshore waters (Teytaud, 1980). Similar problems occur on St John and St Thomas, where abnormally high rainfall in April 1983 created extensive run-off, and calm seas reduced circulation in the bays, compounding the problem. On St Croix industrial development and pollution has been extensive on the south shore (see separate account) and north shore around Christiansted. The Tereco Corporation (1973), Weston (1974) and Howard et al. (1975) provide environmental impact statements dealing with the reefs in the area off the Hovic oil refinery and the proposed VIRCO oil refinery.
Dubois and Towle (1985) describe problems resulting from dredging and sand removal. There has been a long history of mining for marine sand in the U.S.V.I., over one million $\mathrm{cu}$. yds ( 0.76 million cu. $\mathrm{m}$ ) having been dredged from the bottom of Lindbergh Bay on the south-west of St Thomas for airport construction in 1935. Turbidity is still a problem, compounded by siltation from soil erosion resulting from construction work on hillsides (van Eepoel et al., 1971). Between 1961 and 1981, over 2.2 million $\mathrm{cu}$. yds (1.7 million cu. $\mathrm{m}$ ) of aggregate were extracted for local construction activity from Christiansted Harbor on St Croix (Hubbard et al., 1981); over $200000 \mathrm{cu}$. yds $(152920 \mathrm{cu}$. m) of sand were taken from each of eight other bays (Brewers, Water, Crown, Cruz, Gt Cruz, Vessup, Long and Turns) during the $1960 \mathrm{~s}$ and early 1970 s.

Dubois and Towle (1985) summarize the events which took place at Water Bay on the north-east shore of St Thomas, an area dominated by seagrass flats interspersed with small patch reefs. More detailed accounts of this area are given in van Eepoel (1969), Grigg and van Eepoel (1970 and 1972), Insular Environments (1975) and in an Island Resources resurvey of 1983. Dredging for a resort development project took place until hotel guests complained that swimming and snorkelling conditions had declined. Renewed dredging later on led to the disappearance of the beach at Sugar Bay, reef die-off and a reduction in seagrass density. Grigg and van Eepoel (1970) estimated that approximately $90 \%$ of the undredged corals on the south-east shore and $20-25 \%$ on the north shore were killed through sand extraction. Despite legislation and monitoring programmes, the Bay is still considered to be damaged, the beach has not recovered and the dredge pits act as sources of continuing turbidity. Other studies on the problems of dredging for sand include Anon (1971) and Grigg (1970).

Traditional artisanal fisheries for turtles, conch, baitfish, shellfish and fish potting have drastically declined (Koester, 1985; Damman and Sylvester, 1976; Dubois, 1985). On St John, demand for fish is consistently greater than supply, much of the local demand now being met by fishermen from the British Virgin Isiands and St Thomas. The limited supply is attributed to a variety of possible factors such as adverse environmental change, curtailment of several traditional fishing methods, increasing numbers of tourists and fewer fishermen. Local people generally consider the decline to be due to over-exploitation and environmental misuse associated with tourism. Tourism has certainly increased the demand for conch and lobster. The increase in shipping, pleasure boats and motorboats may also have had an impact (Koester, 1985). Rogers (1985) reports the reefs of the U.S.V.I. to be under stress from a variety of additional factors including visitor impact, boat groundings, coral collection and sewage pollution.

\section{Legislation and Management}

There have been several initiatives to ensure the preservation and sustainable use of the reefs following a report (Anon., 1968) showing that coral reefs, offshore islands and cays were among the most important resources of the U.S.V.I. The Virgin Islands Coastal Zone Management Program was established by the Virgin Islands Coastal Zone Management Act of 1978 under the Virgin Islands Department of Conservation 
and Cultural Affairs (DCCA) with its main office on St Croix. It has jurisdiction over all wetlands and coastal areas and under the Program a number of coastal sites have been identified as being of particular concern. Other organisations involved with reef management include the Island Resources Foundation, a non-governmental organization based on St Thomas and concerned with the improvement of resource management strategies in the islands and the provision of special environmental guidelines for development projects, and the Virgin Islands Resource Management Cooperative (VIRMC) which is composed of about a dozen state and federal agencies, academic institutions and private foundations in both the Virgin Islands and Puerto Rico (Koester, 1985). It is currently involved with the establishment of the Virgin Islands National Park as a Biosphere Reserve.

There is a minimum size limit for lobsters and quotas on their collection within the parks. There are no regulations for conch. Virgin Islands Law No. 4848 prohibits harvesting of all corals from U.S.V.I. waters. Spearfishing is prohibited within parks but is permitted elsewhere (Rogers, 1985). Turtles are protected. Fishermen maximise their fishing effort by using resources throughout the Virgin Island chain, regardless of political distinctions and in 1979, the USA and Great Britain signed a Reciprocal Fisheries Agreement, to formally endorse this tradition by permitting artisanal and commercial fisherman of all the Virgin Islands continued access at their current levels (Koester, 1985).

Following a number of recommendations such as Robinson (1973), the DCCA initiated, in 1978, the development of a Marine Parks and Reserves System under the auspices of the Territorial Park System. The following reef areas are now protected (see separate accounts):

\section{- The Virgin Islands National Park and Biosphere Reserve \\ - Buck Island National Monument (St Croix)}

Four recreation areas on St Croix, administered by the Virgin Islands Government, provide similar activities to those at Buck Island and are mainly used by residents. These include the Stony Ground complex near Frederiksted in the west, with waterfront and beach access at Frederiksted; the Altona Lagoon facility in Christiansted Harbour; and Cramer Park on the east end opposite Buck Island (Anon., 1977).

\section{Recommendations}

The fishery regulations require revision and improvement, and a management strategy for the harvesting of commercial fish, coral and other invertebrates is required (Ogden in litt., 15.4.81). A minimum size has been proposed for yellowtail snapper Ocyurus chrysurus and Nassau grouper Epine phelus striatus (Rogers, 1985).

A number of reef areas have been recommended for protection and are described in the following accounts:

South-eastern St Thomas

Saba Island/Perseverance Bay (St Thomas)

Salt River Submarine Canyon (St Croix)
- St Croix Coral Reef Area of Particular Concern (APC)

Cane Bay, off the north coast of St Croix, towards the west end, is also of conservation interest on account of its popularity with divers and tourists and its scientific interest (Gladfelter in litt., 9.12.85). Lagoon Point on St John has been recommended as a coral reef reserve (Björklund, 1974) but no further details are available.

\section{References}

" cited but not consulted.

Adey, W.H. (1975). The algal ridges and coral reefs of St Croix: their structure and holocene development. Atoll Res. Bull. 187: 67 pp.

Adey, W., Gladfelter, W., Ogden, J., and Dill, R. (1977). Field Guidebook to the reefs and reef communities of St Croix, Virgin Islands. 3rd Int. Coral Reef Symp., Miami.

Adey, W.H., Rogers, C.S., Steneck, R.S. and Salesky, N.H. (1981). The South St Croix Reef: a study of reef metabolism as related to environmental factors and an assessment of environmental management. Report prepared for Dept Conservation and Cultural Affairs, Government of U.S. Virgin Islands. West Indies Laboratory, Fairleigh Dickinson University.

Adey, W.H. and Burke, R. (1976). Holocene bioherms (algal ridges and bank-barrier reefs) of the eastern Caribbean. Geol. Soc. Am. Bull. 87: 95-109.

Anderson, M., Lund, H., Gladfelter, E. and Davis, $M$. (1985). Ecological Community Type-Maps and Biological Community Descriptions for Buck Island Reef National Monument and Proposed Marine Park Sites in the British Virgin Islands. Subtask 1.3 of a report prepared for the Virgin Islands Resource Management Co-operative W.I.L., Fairleigh Dickinson University, St Croix, U.S.V.I.

Anon. (1968). The Islands - selected resources of the United States Virgin Islands. (full reference not known).

-Anon. (1971). The sand crisis. Industry Committee of the St Croix Chamber of Commerce. 7 pp.

Anon. (1977). Statement for Management - Buck Island Reef National Monument, U.S. National Park Service.

Anon. (1982). Marine Sanctuary Site Evaluation List: Request for public comment. Chelsea International Corporation/NOAA, Washington, D.C.

Bacon, P., Berry, F., Bjorndal, K, Hirth, H., Ogren, L. and Weber, M. (1984). The National Reports. Proceedings of the Western Allantic Turtle Symposium, Vol. 3. University of Miami Press, Florida.

Björklund, M.I. (1974). Achievements in marine conservation. I. Marine parks. Env. Cons. 1(3): 205-223.

-Britton, N.L.et al. (1919-1952). Scientific Survey of Puerto Rico and the Virgin Islands. New York Academy of Science. 19 vols.

Brownell, W. and Rainey, W.E. (1971). Research and development of deep water commercial and sport fisheries around the Virgin Islands plateau. Special Report 3, Virgin Island Ecological Research Station, Caribbean Research Institute

Carpenter, R.C. (1985). Sea urchin mass-mortality: effects on reef algal abundance, species composition, and metabolism and other coral reef herbivores. Proc. 5th Int. Coral Reef Congr., Tahiti, 4: 53-60.

Connelly, T.W. (1966). Geology of St Thomas and St John, U.S. Virgin Islands. Geological Society of America Memoirs 98: 85-176. 
Connor, J.L. and Adey, W.H. (1977). The benthic algal composition, standing crop and productivity of a Caribbean algal ridge. Atoll Res. Bull. 211

Dahl, A.L., Macintyre, I.G. and Antonius, A. (1974). A comparative survey of coral reef research sites. Atoll Res. Bull. 172.

-Dammann, A.E. and Sylvester, J.R. (1976). Review of the status of Virgin Island fisheries. In: Juhl, R. and Dammann, A.E. (Eds). Review of the status of fishery resources and fishery management problems of the Caribbean Council Area. NMFS, U.S. Dept Commerce, Miami, FL.

-Dong, M. et al. (1972). The Role of Man-Induced Stresses in the Ecology of Long Reef and Christiansted Harbor, St Croix, U.S. Virgin Islands. Unpub. Rept West Indies Laboratory of Fairleigh Dickinson University.

Downing, N. and EI-Zahr, C.R. (1983). Artificial reef utilisation by three species of groupers in the Salt River Canyon, St Croix (U.S. Virgin Islands). Final Scientific Report 82-9 and 83-9. National Undersea Research Program Hydrolab Project.

Dubois, R. (1985). Coastal fisheries maragement lessons learned from the Caribbean. Case Study 4 . In: Clark, J.R. (Ed.) Coastal Resources Management: development case studies. Coastal Publication 3, Renewable Resources Information Series, U.S. National Park Service.

Dubois, $\mathbf{R}$ and Towle, E.L. (1985). Coral harvesting and sand mining management practices. Case Study 3. In: Clark, J.R. (Ed.) Coastal Resources Management: development case studies. Coastal Publication 3, Renewable Resources Information Series, U.S. National Park Service.

- Gerhard, L.C. (1978). Reconnaissance study of sediment facies of Salt River estuary, St Croix, U.S.V.I.: mixed carbonates and clastics. The Mountain Ecologist 15(4): 109-123.

Gerhard, L.C. (1981). Origin and evolution of the Candlelight Reef Sand Cay system, St Croix. Atoll Res. Bull. 242.

Gladfelter, E.H. (1980a). Aspects of population dynamics and ecological impact of the sea urchin Diadema antillarum. Chap. 5. In: Gladfelter and Gladfelter (1980).

Gladfelter, E.H. and Gladfelter, W.B. (1980).

Environmental studies of Buck Island Reef National Monument III. Report to National Park Service, USDI, West Indies Laboratory, Fairleigh Dickinson University, St Croix.

-Gladfelter, E.H., Gladfelter, W.B., Monahan, R.C., Ogden, J.C. and Dill, R.F. (1977). Environmental studies on Buck Island Reef National Monument. U.S. National Park Service Report. 144 pp.

-Gladfelter, E.H., Gladfelter, W.B., Hubbard, D.K., Carpenter, R.C. and Simpson, G.S. (1979).

Environmental studies of Buck Island Reef National Monument II. U.S. National Park Service Report. 168 pp.

Gladfelter, W.B. (1979). Twilight migrations and foraging of the copper sweeper Pempheris schomburghi (Teleostei: Pempheridae). Mar. Biol. 50: 109-119.

Gladfelter, W.B. (1980b). Fish community structure and dynamics in five reef environments. Chap. 4. In: Gladfelter and Gladfelter (1980).

Gladfelter, W.B. and Gladfelter, E.H. (1978). Fish community structure as a function of habitat structure on West Indian patch reefs. Rev. Biol. Trop. 26 (Suppl.1): 65-84.

Gladfelter, W.B., Ogden, J.C. and Gladfelter, E.H. (1980). Similarity and diversity among coral reef fish communities: a comparison between tropical western
Atlantic (Virgin Islands) and tropical central Pacific (Marshall Islands) patch reefs. Ecology 61(5): 1156-1168.

- Grigg, D.I. (1970). Some effects of dredging on water quality and coral-reef ecology. Carib. Cons. Assac. Newsl. 1: 22-27.

-Grigg, D.I., Van Eepoel, R.P. and Brody, R.W. (1971). Water quality and environmental status of Benner Bay Mangrove Lagoon, St Thomas. Water Pollution Report 10, Caribbean Research Inst., College of the Virgin Islands, St Thomas.

Grigg, D.I. and van Eepoel, R.P. (1970). Status of the marine environment at Water Bay, St Thomas. Caribbean Research Institute, College of the Virgin Islands, St Thomas, 8 pp.

Grigg, D.I. and van Eepoel, R.P. (1972). Status report on bays of St Thomas and St John, Virgin Islands. Water Pollution Report 14. Caribbean Research Inst, College of the Virgin Islands, St Thomas. $30 \mathrm{pp}$.

Groombridge, B. (1982). The IUCN Amphibia-Reptilia Red Data Book, Part 1: Testudines, Crocodylia, Rhynchocephalia. IUCN, Gland Switzerland.

-Haines, and Brownell, (1978). (Reference not known; cited in OCZM (1981)).

Halewyn, R. van and Norton, R.L. (1984). The status and conservation of seabirds in the Caribbean. In: Croxall, J.P., Evans, P.G.H. and Schreiber, R.W. (Eds), Status and Conservation of the World's Seabirds. ICBP Technical Publication No. 2, Cambridge.

Hofrman, S., Robinson, A. and Dolan, R. (1974). Virgin Islands Beach Processes Investigation. Occasional paper., U.S. Dept of Interior, National Park Service, Washington D.C.

-Howard, Needles, Tammen and Bergendorf (1975).

Proposed Offshore Crude Oil Terminal and Submarine Pipeline. Environmental Assessment Report prepared for Hess Oil Virgin Islands Corp.

-Hubbard, DK. (1979). A summary of physical factors affecting sediment transport in the proposed St Thomas Marine Sanctuary. A report to DCCA, Government of the Virgin Islands.

*Hubbard, D.K., Burke, R.P. and Gill, I.P. (in press). Styles of reef accretion along a steep, shelf-edge reef, Salt River submarine canyon, St Croix, U.S. Virgin Islands. J. Sedim. Petrol.

Hubbard, D.K., Sadd, J.L. and Roberts, H.H. (1981). The role of physical processes in controlling sediment transport patterns on the insular shelf of St Croix, U.S. Virgin Islands. Proc. 4th Int. Coral Reef Symp. Vol 1: 399-404.

Hubbard, D.K. et al. (1981). The production, transportation and deposition of carbonate sediments on the insular shelf of St Croix, U.S. Virgin Islands. Tech. Rept. NG-1. Mar. Geol. Group, West Indies Lab, Fairleigh Dickinnson Univ., St Croix, U.S. Virgin Islands, 145 pp.

Hubbard, D.K. and Scaturo, D. (19??). Growth rates of seven species of scleractinian corals from Cane Bay and Salt River, St Croix, U.S. Virgin Islands. W.I.L Contribution 118.

Insular Environmnents, Inc. (1975). Environmental reconnaissance surveys of selected bays. St Thomas, U.S. Virgin Islands.

Islands Resources Foundation (1977a). Marine environments of the Virgin Islands. Technical Supplement 1, Virgin Islands Planning Office, Coastal Zone Management Program.

-Island Resources Foundation (1977b). Circulation, water quality and environmental resources of 
Perseverance Bay, St Thomas. Prep. for Dept of Conservation and Cultural Affairs, Virgin Islands. $102 \mathrm{pp}$. IUCN (1982). IUCN Directory of Neotropical Protected Areas. Tycooly International Publishing Ltd., Dublin.

Koester, S. (1985). Socio-economic and cultural role of fishing and shellfishing in the Virgin Islands Biosphere Reserve area. U.S.V.I. National Park/Biosphere Reserve Program. Research Series, Report 2.5., National Park Service and Virgin Islands Resource Management Cooperative.

Lee, C.C., Lee, E.L. and Bunt, J.S. (1975). Distribution of biomass in a coral reef transect. Results of the Tektite Program. Bull. Nat. His. Mus. Los Angeles Co. 20: 69-75.

Lessios, H.A., Robertson, D.R., and Cubit, J.D. (1984). Spread of Diadema mortality through the Caribbean. Science 226: 335-337.

Lund, $\mathbf{H}_{\text {., Anderson, }} \mathbf{M}_{\text {, }}$ Gladfelter, E. and Davis, $\mathbf{M}$. (1985). Development of a monitoring program for safe anchorages. Subtask 1.4 of a report prepared for the Virgin Islands Resource Management Co-operative W.I.L., Fairleigh Dickinson University, St Croix, U.S.V.I. McMillan, J.P., Granade, H.R. and Hoffmsn, P. (1980). Ciguatera fish poisoning in the United States Virgin Islands: Preliminary Studies. J. Con. Virgin Is, 6: 84-107. -MeNulty, J.K., Robertson, W.B. and Horton, B.F. (1968). Departmental study team report and recommendation on proposed new jet airport, St Thomas U.S. Virgin Islands. Unpub. Rept. 34 pp.

-Nichols, M. et al. (1972). Environment, Water and Sediments of Christiansted Harbor, St. Croix Water Pollution Report 16. Caribbean Research Inst., College of the Virgin Islands, St Thomas.

Nyden, B. (1985). Hydrolab: NOAA's undersea research program at West Indies Laboratory. Proc. Sth Int. Coral Reef Congress, Tahiti, 5: 607-609.

OCZM (Office of Coastal Zone Management) (1981).

Draft Environmental Impact Statement: proposed St Thomas National Marine Sanctuary. U.S. Dept of Commerce, NOAA/CZM, Washington D.C.

Ogden, J.C., Brown, R.A. and Salesky, N. (1973).

Grazing by the echinoid Diadema antillarum philipp: formation of halos around West Indian patch reefs. Science 182: 715-717.

Ogden, J.C. and Ehrlich, P.R. (1977). The behaviour of heterotypic resting schools of juvenile grunts (Pomadasyidae), Mar. Biol: : 273-280.

- Olsen, D.A. (1979). Socio-economic survey of recreational boating and fishing in the U.S. Virgin Islands. National Marine Fisheries Service, 76 pp.

Olsen, D.A. (1982). Fishery statistics of the Virgin Islands. Rept to the Govemor of the U.S. Virgin Islands, DCCA, St Thomas, U.S. Virgin Islands.

-Olsen, D.A., Damman, A.E. and La Place, J.A. (1975). Analysis of catch data for the Virgin Islands (1974-75). Virgin Islands DCCA, PL88-309 Rept. 16 pp.

Olsen, D.A. Damman, A.E. and La Place, J.A. (1978). Portunus spinamanus Latrielle, a portunid crab with resource potential in the U.S. Virgin Islands. Mar. Fish. Rev. 40: 7.

*Olsen, D.A., Nellis, D.G. and Woods, R. (1984).

Fisheries impact of ciguatera fish poisoning in the Eastern Caribbean. Mar. Fish. Rev.

-Olsen, D.A. and Damman, A.E. (1971). (Reference not known).

Olsen, D.A. and Wood, R.S. (1980). Investigations on black coral in Salt River Submarine Canyon, St Croix, U.S. Virgin Islands. Final Scientific Report 80-12, Division of Fish and Wildlife, U.S.V.I.
-Posner, B., Cuthbertson, C., Towle, E. and Reeder, C. (1981). Economic impact analysis for the Virgin Islands National Park. Prep. for U.S. Dept of Interior by the Island Resources Foundation.

Randall, J.E. (1963). An analysis of the fish populations of artificial and natural reefs in the Virgin Islands. Caribbean Journal of Science 3(1): 31-47.

-Randall, (1968), (Reference not known - cited in OCZM (1981)).

Randall, J.E. and Schroeder, R.E. (1962), New Underwater Park. Sea Frontiers 8(1): 8-17.

Risk, MJ. (1972). Fish diversity on a coral reef in the Virgin Islands. Atoll Res. Bull. 153.

-Robinson, A.H. (1973). Natural vs. visitor related damage to shallow water corals: recommendations for visitor management and the design of underwater nature trails in the Virgin Islands. U.S. National Park Service, 1973.

*Robinson, A.H. and Henle, F. (1978). Virgin Islands National Park, The story behind the scenery. K.C. Publications, Nevada.

Rogers, C.S. (1982). The marine environments of Brewers Bay, Perseverance Bay, Flat Cay and Saba Island, St Thomas. U.S. Virgin Islands, with emphasis on coral reefs and sea grass beds. $181 \mathrm{pp}$.

Rogers, C.S. (1985). Degradation of Caribbean and Western Atlantic coral reefs and decline of associated fisheries. Proc. 5th Int. Coral Reef Congress, Tahiti, 6: 491-496.

Rogers, C.S., Fitz, H.C., Gilnack, M., Beets, J. and Hardin, J. (1984). Scleractinian coral recruitment patterns at Salt River Canyon, St Croix, U.S. Virgin Islands. Coral Reefs 3: 69-76.

Rogers, C.S. Gilnack, M., and Fitz, III, H.C. (1983).

Monitoring of coral reefs with linear transects: a study of storm damage. J. Exp. Mar. Biol. Ecol. 66: 285-300.

Rogers, C.S. and Salesky, N.H. (1981). Productivity of Acropora palmata (Lamarck), macroscopic algae and algal turf from Teague Bay reef, St Croix, U.S. Virgin Islands. J. Exp. Mar. Biol. Ecol. 49: 179-187.

Rogers, C.S., Suchanek, T.H. and Pecora, F.A. (1979). Effects of Hurricanes David and Frederic (1979) on shallow Acropora palmata reef communities: St Croix, US Virgin Islands. Bull. Mar. Sci. 32(2): 532-548.

Schell, C. (19??). Resource Management Plan, Buck Island Reef National Monument. Christiansted, St Croix, Virgin Islands.

Scott, D.A. and Carbonell, M. (1986). A Directory of Neotropical Wetlands. IUCN, Gland and Cambridge.

-Sigma Environmental (1979). (Reference not known)

Stanhope, M.J. (1980). Marine benthic algae, with an indication of their distribution, relative abundance and standing crop. Chap. 2. In: Gladfelter, E.H. and Gladfelter, W.B. (1980).

-Tabb, D.C. and Michel, J.F. (1968). A study of the biological and coastal engineering aspects of the proposed jet airport at Jersey Bay, St Thomas U.S. Virgin Islands. Institute of Marine Sciences, Univ. Miami.

-Tereco Corporation (1973). A Bio-environmental Study of the Southern Aspects of St Croix, U.S. Virgin Islands. Report to Brown and Root, Inc.

Teytaud, A.R. (1980). Draft Guidance Plan for the St Croix Coral Reef System Area of Particular Concern. Dept of Conservation and Cultural Affairs.

-Teytaud, A.R. (1981). A Management Plan for the St Thomas Mangrove Lagoon Area of Particular Concern. Government of the U.S. Virgin Islands, Department of Conservation and Cultural Affairs, Division of Coastal Zone Management, St Thomas. 
Towle, E.L. (1985). The island microcosm. Case Study 8 . In: Clark, J.R. (Ed.) Coastal Resources Management: Development Case Studies. Renewable Resources Information Series, Coastal Management Publication 3, U.S. National Park Service.

Towle, E.L., Olsen, D.A. and Teytaud, A.R. (1978).

Report on sea turtle nesting, sighting, eggs and hatching for 1978 in the U.S. Virgin Islands. Island Resources Foundation Report to NOAA/N.M.F.S.

-U.S. National Park Service (1977). Statement for Management - Virgin Islands National Park.

-U.S. National Park Service (1983). Virgin Islands; General Management Plan, Development Concept Plan and Environmental Assessment. U.S. Dept of Interior.

Van Eepoel, R.P. (1969). Effects of dredging in Water Bay, St Thomas. Caribbean Research Institute, College of the Virgin Islands, $12 \mathrm{pp}$.

*Van Eepoel, R.P. and Grigg, D.I. (1970). Survey of the ecology and the water quality of Lindberg Bay, St Thomas. Water Poll. Rep., Caribb. Res. Inst., St Thomas, Virgin Islands.

Van Eepoel, R.P., Grigg, D.I., Brody, D.W. and Raymond, W. (1971). Water quality and sediments of Lindbergh Bay, St Thomas. Water Poll. Rep. 11. Caribbean Research Institute, College of the Virgin Islands: $46 \mathrm{pp}$.

van't Hof, T. (1985). The economic benefits of marine parks and protected areas in the Caribbean region. Paper presented at the 5th International Coral Reef Congress, Tahiti (not published).

Wells, J.M. and Olsen, D.A. (1973). Oxygen balance in tropical benthic communities. Proc. 10th Ann. Conf. Is. Mar. Lab., Caribb. J. Sci.

-Weston, Roy F. (Inc.) (1974). Environmental Assessment Study for a 200000 BPCD Refinery at St Croix, U.S. Virgin Islands. Prepared for the Virgin Islands Refinery Corporation.

\section{BUCK ISLAND REEF NATIONAL MONUMENT}

Geographical Location $17^{\circ} 45^{\prime} \mathrm{N}, 64^{\circ} 45^{\prime} \mathrm{W} ; 6 \mathrm{mi}$. (10 km) north-east of Christiansted, St Croix, $2 \mathrm{~km}$ off the eastem shore.

Area, Depth, Altitude 71 ha terrestrial; 285 ha marine.

Land Tenure $100 \%$ federally owned.

Physical Features Buck Island is a small cay covered with vegetation, with beaches on the south and west shores. A bank barrier reef surrounds the east and north of the island, $12 \mathrm{~m}$ high in places along its outer perimeter. The enclosed lagoon is up to $100 \mathrm{~m}$ wide with an average depth of $3 \mathrm{~m}$ (Anon., 1977). The water is extremely clear, since there is no freshwater run-off (Randall and Schroeder, 1962) and horizontal visibility often exceeds $100 \mathrm{ft}(30 \mathrm{~m})$ (Gladfelter et al., 1977).

Reef Structure and Corals The reef extends from the middle of the southern coast where it joins the shore, around the eastern tip of the island and along the north shore. To the north-east, it breaks up into large patch reefs. It lies approximately $200 \mathrm{ft}(60 \mathrm{~m})$ from the southern shoreline, where the lagoon has clear water, a clean sandy bottom and a patch reef system. At the eastern tip of the island and along the north shore, the lagoon has many patch reefs reaching the surface. There are several small passages through the reef that can be negotiated by boat, the largest of which is near the western end of the reef on the southern shore (Anon., 1977).

The barrier reef in the Underwater Trail area has complex back-reef topography, with $2-3 \mathrm{~m}$ vertical relief of crevices and caves within the reef structure. Although separated from the shore by a narrow sandy belt, it can be considered a form of fringing reef (Dahl et al., 1974). The front of the reef comprises a solid stand of Acropora palmata and $A$ cervicornis, which shelves off steeply from the surface to the bottom at $35 \mathrm{ft}(11 \mathrm{~m})$ where sand alternates with coral patches. On the lagoon side the reef is composed mainly of Millepora and Diploria with some Montastraea, Agaricia and Isophyllia. The reef off the north-west end at West End is different, having a broad area of patch reefs in $10-30 \mathrm{ft}(3-9 \mathrm{~m})$ of water with rich coral growth (Anon., 1977). There is a barren pavement area with scattered eroded dead coral heads with little algal cover. Gladfelter and Gladfelter (1980) provide a map of the principle reef zones.

Noteworthy Fauna and Flora In the 1700s, Buck Island was covered with Lignum vitae Guaiacum spp., locally called Pokholdt trees, which were cut for timber in the 19 th century. The vegetation is now largely xerophytic, dominated by cactus with trees such as Acacia Acacia tortuosa, Tan Tan Leucaena latisquama, Tamarind Tamarindus indica and Turpentine Bursera simaruba. Sea Grape Coccoloba urifera and other prostrate growth are the predominant plants along the beach. The poisonous Manchioneel Hippomane mancinella covers the remaining low beach areas inland to the foot hills (Anon., 1977). The Stinging Bush, Malpighia pallens, which is endemic to Buck Island and St Croix, is found further inland.

The distribution, abundance and standing crop of marine benthic algae are described by Stanhope (1980). Ninety-three of the 250 species known from St Croix waters, were recorded within the Monument. The gorgonian fauna is poor, with only a few colonies and less than half a dozen species. Sea anemones, including Stoichactus, Palythoa and Zoanthus are abundant (Anon., 1977; Adey et al., 1977). Strombus gigas, the whelk Cittarium pica, the spiny lobster Panulirus argus, moray eels and many fish such as the Foureye Butterfly Fish Chaetodon capistratus, Smooth Trunkfish Lactophrys triqueter, Porkfish Anisotremus virginicus, French Angelfish Pomacanthus paru, Queen Angelfish Holancanthus ciliaris and Blue Angelfish $H$. bermudensis are found. Larger fish include sharks, snappers, barracudas and tarpon. Dolphin occur in these waters.

The island has Hawksbill Eretmochelys imbricata, Leatherback Dermochelys coriacea and Green Turtle Chelonia mydas nesting sites (Bacon et al., 1984) and is one of the few remaining Caribbean nesting sites for the Brown Pelican Pelecanus occidentalis. The Magnificent Frigatebird Fregata magnificens also nests (Anon., 1977). The Ground Lizard Amieva polyps is extinct on Buck Island (Schell, 19?).

Scientific Importance and Research The area included within the National Monument was initially surveyed for 
the National Park Service by Randall and Schroeder (1962) and was looked at briefly in the course of preliminary investigations for the CITRE project (Dahl et al., 1974). Since 1976, the staff of the West Indies Laboratory have investigated the structure and dynamics of the ecosystem (Anderson et al., 1985; Gladfelter and Gladfelter, 1980b; Gladfelter et al., 1979; Gladfelter et al., 1977), including studies on plankton, coral growth, population dynamics, ecological impact of Diadema antillarum and fish community structure and dynamics. Research has been carried out on the relationships between human impact, reef growth and regeneration at the underwater trail (Anon., 1977).

Economic Value and Social Benefits Tourism is of major importance and the National Park Service provides simple facilities for visitors. Overnight stays are only permitted on boats. The National Monument plays an important recreational role for visitors which will increase as the marine and terrestrial environments along the St Croix coastline disappear through real estate development. The cultural resources of the Monument are described in Anon. (1977) and Schell (19?). Most visitors to Buck Island are from the U.S. mainland, on tours arranged by commercial charter organizations. The island is not very accessible to local residents. About ten commercial operators (with additional operators in the winter) using 21 boats arrange trips to the Monument and organize snorkelling tours along the underwater trail (Anon., 1977). Recreational activities include snorkelling, skin diving, fishing, swimming, boating, hiking, picnicking, photography and nature observation. Picnic areas are located at West End Beach and Deidrich's Point.

Disturbance or Deficiencies The reefs are subject to storm damage. Hurricane David and Tropical Storm Frederick passed Buck Island in 1979 and Rogers et al. (1979) describe the damage to the reefs from hurricane-generated waves. The effect of these storms on the beaches was monitored at West End (Gladfelter and Gladfelter, 1980). Diadema antillarum used to be a conspicuous member of the fauna, particularly on the flat, barren pavement area off the north-west coast of the island. Sizable populations were found on all parts of the living reef in the 1970s (Gladfelter, 1980a), which appeared to be stable although long term monitoring of this species was recommended. The high densities may have resulted from decades of over-exploitation of reef fish (prior to the establishment of the National Monument), including species which prey on urchins (Gladfelter, 1980a). However, more recently, St Croix has been affected by the mass mortality of Diadema which occurred throughout much of the Caribbean (Carpenter, 1985).

Oil, sludge, litter and debris discharged from tankers, cruise ships and other watercraft, as well as that drifting in from islands further east, deposit pollutants within Monument waters. Oil slicks have caused damage along rocky shores and sandy beaches. Increased visitor use is potentially threatening the underwater trail area and congestion at the moorings has caused problems, with some coral damage from anchors and pollution caused by boat cleaning (Anon, 1977; IUCN, 1982). St Croix fishermen used to take turtles and bird eggs, and the marine resources of the surrounding waters are considerably over-exploited (Schell, 19?).
Introduced rats Rattus rattus and mongoose Herpestes auropunctarus prey on the native fauna taking snakes, lizards, ground-nesting birds and turtle and bird eggs (Anon., 1977; Randall and Schroeder, 1962), but a pest control programme is now underway (Schell, 19?). In the past, the island was extensively grazed by goats, but these have been eliminated. The original forest was felled and repeatedly burned to provide pasture, but vegetation has regenerated.

Legal Protection Buck Island became a Park in 1948 and was administered by the Virgin Islands Government. In 1961, it was transferred to the National Park Service under proclamation $3443(28.12 .61)$ and subsequently under proclamation 4346 (1.2.75) (Anon., 1977). The taking of fish, shellfish and lobsters is regulated by quantity, area of collection and methods of collection. Regulations to minimise damage to and collection of corals are enforced. Sport and commercial fishing are prohibited between the outer fringes of the barrier reef and the shoreline of Buck Island, eastward of the recognizable extremities of the sand beach on the north and south sides of the island but is permitted elsewhere. Diving is prohibited at the underwater trail, adjacent area and swimming beach. Motorized equipment is not permitted on the island (Schell, 19??). Removal of beach sand for any purpose is not permitted.

Management Buck Island is administered by the National Park Service, U.S. Dept Interior. The superintendent of Virgin Island National Park (Box 806, Charlotte Amalie, St Thomas, V.I. 00801) has general supervision of the area and a superintendent for Buck Island is stationed at Fort Christiansvaern (Box 160, Christiansted, St Croix, V.I. 00820). There are six full-time staff.

Management strategies are described in Anon. (1977) and Schell (19??). The park has three subzones: a Natural Environment Subzone, an Environmental Protection Subzone, and an Outstanding Natural Subzone (Anon., 1977). The Natural Environment Subzone (15 ha sea, 2 ha land) applies to the West End beach - Manchioneel ecosystem and its adjoining anchoring area. The area lacks underwater resources of significance but has a sandy bottom providing good anchorage and receives many visitors who use the $500 \mathrm{~m}$ long beach. Overnight camping is not permitted. The picnic area and beach are cleaned twice a week and there are lifeguards. Collecting of shells and drift on the beach is permitted. The Environmental Protection Subzone (50 ha sea, 62 ha land) applies to the island itself, apart from the pelican and frigatebird rookery, and waters outside along the southern boundary of the Monument, outside the barrier reef. This area reaches a depth of $50 \mathrm{ft}(15.2 \mathrm{~m})$ and has primarily a sandy bottom with occasional patch reefs in deeper water. It is a prime feeding ground for turtle, conch and other aquatic fauna. The Outstanding Natural Subzone ( 220 ha sea, 7 ha land) applies to the coral reefs, enclosed lagoon and the rookery. Underwater trail markers, rest floats and boat moorings are provided.

An explanatory leaflet has been produced for visitors and information can also be obtained at the museum in the Steeple Building in Christiansted. A nature trail leads to the summit of the island. Turtle nests have been covered to prevent discovery or damage to the eggs. A pilot study 
on the reintroduction of the lizard Ameiva polyps was carried out and an attempt made to introduce some individuals but this proved unsuccessful.

Recommendations The National Monument lies within the proposed East End, St Croix Marine Sanctuary Site (Anon., 1982) and St Croix Coral Reef Area Of Particular Concern (see separate account). A general development plan was drawn up in 1976 to facilitate increased visitor use while minimising the impact on natural resources. An additional underwater nature trail, and a ferry system to the island are among the proposals (Schell, 19?). Research is required to provide baseline data for long-term management of the beaches and to determine visitor impact on marine resources and habitats. Improvement in interpretive facilities is required, apart from trails which are considered adequate. Schell (19?) lists research requirements, and outlines a series of projects that should be carried out to improve management of the area.

\section{SABA ISLAND AND PERSEVERANCE BAY PROPOSED PROTECTED AREA}

Geographical Location $18^{\circ} 20^{\prime} \mathrm{N}, 64^{\circ} 59^{\prime} \mathrm{W}$; south-west coast of St Thomas, including Perseverance Bay, Brewers Bay, a portion of South-west Road, and waters surrounding Saba Island, Dry Rock Cay, Turledove Cay and Flat Cay.

Area, Depth, Altitude 14 sq. $\mathrm{km}$.

Physical Features Perseverance Bay is the largest bay on the south-west coast of St Thomas and is naturally protected from waves driven by the prevailing north-east trade winds. The mainland shores are primarily sand and cobble pocket beaches situated between rocky promontories. Below $15 \mathrm{~m}$ depth, algal plains predominate. In shallower depths, seagrass beds, sand and coral formations cover the bottom (Anon., 1982). Saba Island and Flat Cay are uninhabited cays 3.6 and 2 km SSW of Truman Airport runway. The area is described in detail by Rogers (1982), and the hydrology by Island Resources Foundation (1977b).

Reef Structure and Corals Extensive fringing reefs are found in western and eastern Perseverance Bay, central and western Brewers Bay and along the eastern shores of Saba Island and Flat Cay (Anon., 1982). Perseverance Bay has a submerged barrier reef. Brewers Bay has submerged barrier reefs in the western and central portions, the smaller western reef being separated from the central one by a distinct sand channel. Porites porites and Montastraea annularis are abundant; Agaricia agaricites is abundant at Perseverance and Brewers West, and Millepora is abundant at Perseverance and Flat Cay (Rogers, 1982; Rogers et al., 1983).

Noteworthy Faung and Flora Seagrass beds intermixed with algae cover much of the sandy substrate of Perseverance and Brewers Bays. Mangroves are found around salt ponds on the mainland shore. Perseverance
Bay Pond is briefly described in Scott and Carbonell (1986). Numerous seabirds including the Brown Pelican Pelecanus occidentalis nest on the offshore cays. Fighting Conch Strombus pugilis are found on the algal plains. 136 fish species have been recorded (Anon., 1982).

Scientific Importance and Research The College of the Virgin Islands, situated on Brewers Bay, is a potential centre for interpretative and research activities. The marine environments have been described by Rogers (1982) as part of the Water Pollution Control Program of the Division of Natural Resources Management, in order to determine the impact of the extension of the airport runway (see below).

Economic Value and Social Benefits The area has high aesthetic value and tourism may become important. The site is a multi-use area adjacent to the recently enlarged Harry S. Truman Airport (Anon., 1982).

Disturbance or Deficiencies Hurricanes occur on average once every 23 years, damaging corals and causing surge water levels $1.5-3.7 \mathrm{~m}$ above normal. Rogers et al. (1983) describe damage at Brewers West, Brewers Middle, Perseverance Bay and Flat Cay due to Hurricanes David and Frederic in 1979 and Allen in 1980. There was a significant decrease in live coral cover and water quality and recovery will not be complete for several years. Water quality within the area is generally good but high concentrations of heavy metals have been recorded in salt ponds near Perseverance Bay and turbidity in Perseverance Bay has been increased by dredging operations in Brewers Bay and following hurricane disturbance of the bottom. The runway of Harry S. Truman Airport was extended into South-west Road, south of Brewers Bay, and appears to have modified the water circulation here although there was no severe damage to reefs and seagrass beds (Rogers, 1982). Sediment plumes moved by wave-generated longshore currents have been observed to transport sediment from Brewers Bay into Perseverance Bay where the net circulation appears to move in a counter-clockwise direction. Convergent littoral currents within Perseverance Bay cause the accumulation of unsightly rofuse and debris along the shore (Anon., 1982).

Legal Protection None.

Management None.

Recommendations The Virgin Islands Coastal Zone Management Program has identified Turtledove and Flat Cays as vital, unique areas important as nesting sites for seabirds. The whole area was identified as a potential marine sanctuary under the 1972 Marine Protection, Research and Sanctuaries Act (Anon., 1982) but was not accepted for the Site Evaluation List of possible future sites (Foster in litt., 21.2.86). Rogers (1982) recommends long term monitoring of Brewers Bay to assess environmental changes resulting from the airport runway extension. 
ST CROIX CORAL REEF AREA OF PARTICULAR CONCERN (APC) AND PROPOSED NATIONAL MARINE SANCTUARY

Geographical Location North-east and south-east coasts of St Croix; $17^{\circ} 45^{\prime} \mathrm{N}, 64^{\circ} 33^{\prime} \mathrm{W}$.

Area, Depth, Altitude About 23 miles (37 km) long; the proposed marine sanctuary site has an area of $102 \mathrm{sq} . \mathrm{km}$.

Physical Features The mainland shore consists largely of segments of sandy beach interspersed with low and steep rocky areas. Coral reef formations are distributed throughout the area with numerous reefs fringing the shore (Anon., 1982). Seagrass beds are found in shallow lagoon areas in association with patch reefs. Sediments of the insular shelf are described by Hubbard et al. (1981).

The east end of St Croix is fairly dry with an annual rainfall of $30 \mathrm{in} .(760 \mathrm{~mm})$, much of this concentrated in the rainy season from June to December. Occasional very heavy rains may reduce salinity below $35 \mathrm{ppt}$ near shore where intermittent streams enter the lagoons. In the vicinity of the reefs and ridges, salinities probably only rarely go below $34 \mathrm{ppt}$. Offshore sea temperatures range from $25^{\circ} \mathrm{C}$ in February to $28^{\circ} \mathrm{C}$ in July; lagoonal temperatures behind the reef are in the range $23-30^{\circ} \mathrm{C}$. Easterly trade winds are very constant. Water clarity is usually largely dependent on wave action and the resulting suspension of fine carbonate sediment. In rough weather visibility is about $4-6 \mathrm{~m}$; in calm weather visibility may reach $15-20 \mathrm{~m}$. Visibility is poorest in the summer when plankton density is at its highest. The tidal pattern is diumal with a range of $30-35 \mathrm{~cm}$ during spring tides and 10-15 cm during neap tides when a semi-diumal pattern may occur (Adey, 1975). Tropical storms or hurricanes occasionally pass to the south during the autumn and tsunamis have been recorded (Anon., 1982; Rogers et al., 1979).

Reef Structure and Corals The shallow coral reef and algal ridge systems on the eastern shelf of St Croix are described and mapped by Adey (1975). Bank barrier reefs on the landward edge of the insular shelf parallel the north-eastern and south-eastern coasts for over $5 \mathrm{~km}$ (Dahl et al., 1974). The insular shelf is relatively shallow $(10-15 \mathrm{~m})$ at its western ends both in the western Buck Island Channel on the north and along the south shore from Krause Lagoon west. Further east on the south coast, around Grassy Point, the shelf lies at about $15-18 \mathrm{~m}$ under the reef and $20 \mathrm{~m}$ outside. To the north, off Boiler Point, a shallow shelf in the bay slopes to about $20 \mathrm{~m}$ just off shore and has given rise to a triple-reef complex. At East Point, outside the reef, the shelf is about $24 \mathrm{~m}$ deep.

The reefs on the inner shelf extending eastward to East Point, from Pull Point in the north and Long Reef in the south, show a general pattern of decreasing maturity. Reef flats are relatively broad to the west, becoming narrower towards the east; they are fragmented off Boiler Bay in the north and Grapetree Bay in the south, and are virtually absent from Isaac Point around East Point to Lamb Point (Adey, 1975; Adey and Burke, 1976). In many places they have become so shallow that coral growth is less prolific now than it used to be. West of the southern ship channels, there are a few reefs which are generally poorly developed with narrow or patchy reef flats. Abundance of live Acropora palmato decreases from east to west; in the east shallow reefs are dominated by impressive living and dead stands (Adey et al., 1981).

The reef flats are generally dominated by $A$ palmata, a large part of the pavement surface being constructed of dead branches coated with crustose coralline algae. The outer edge or crest of the flat tends to have a high proportion of Millepora complanata. The back-flat sections, as they deepen into the lagoon $(2-6 \mathrm{~m})$, frequently have abundant Montastraea annularis, Diploria spp., $P$. porites and the small form of $A$ cervicornis.

The $A$ palmata fore-reef extends to about $13 \mathrm{~m}$ depth at East Point, the lower boundary gradually rising to the west probably because of decreasing light due to turbidity and lessened wave action. Further west on the north shore (on the Teague Bay Reef, on the south side of Buck Island Channel and on the western parts of the South Shore), the lower depth limit is 5-8 m (Adey, 1975). The bank barrier off Teague Bay has about $5 \mathrm{~m}$ relief off the shoreward edge and is approximately $90 \mathrm{~m}$ wide. It is dominated by $A$ palmata but an indistinct zonation is found around the inner edge of the reef where the base is characterized by $M$. annularis, the edge by $A$ palmata and large mounds of $P$. porites (up to $2.5 \mathrm{~m}$ high and $4.5 \mathrm{~m}$ wide) and the top by $A$ palmata, Diploria and Millepora. The seaward slope drops off to $14 \mathrm{~m}$ depth (Dahl et al., 1974). The reef at Teague Bay and Knight Bay is described in several publications including Gladfelter (1979) and Ogden and Ehrlich (1977). Candlelight Reef, at the end of the northern bank reef forming the seaward margin of Coakley Bay, is a large patch reef, slightly separated from the main reef by a boat channel. The reef flat is partly algal turf. The reef, which supports sparsely vegetated Sand Cay, is dominated by $A$ palmata, with small amounts of Porites, Montastraea and Diploria present (Gerhard, 1981). Long Reef, in Christiansted Harbour on the north coast, was surveyed in 1972 (Teytaud, 1980).

Several patch reefs north-east of Buck Island, rising from a sandy shelf at a depth of about $10-12 \mathrm{~m}$, appear to be anastomosing thickets of massive $A$. palmata from top to bottom (Adey, 1975). A deep patch reef directly east of Buck Island consists of mainly $A$ palmata and has a relief of $8-9 \mathrm{~m}$. It is covered with large heads of Montastraea annularis, Diploria sp., $M$. cavernosa and surrounded by a great abundance of alcyonarians (Dahl et al., 1974). Reefs immediately around Buck Island are described in a separate account.

In the relatively quiet Buck Island Channel, an irregular band of $P$. porites often extends from the base of the $A$ palmata fore-reef to the sand channel floor at a depth of 10-12 m. Further east and on the south shore, this zone is usually occupied by $A$ cervicornis. The $A$ cervicornis band can be extensive or may consist only of scattered patches. From the lower end of the A palmata fore-reef to the sandy shelf, the dominant coral is usually $M$, annularis, with interspersed Diploria spp., $A$ cervicornis and $A$ palmata. Occasionally a marked spur and groove pattern occurs in the lower fore-reef. The lower boundary of the deeper fore-reef is sometimes marked by an abrupt drop of 1-2 $\mathrm{m}$ to the sediment interface. A flat sandy shelf is found directly below the MontastraeaDiploria deep fore-reef which generally extends almost to the reef margin (Adey, 1975). 
Between East Point and Lang Bank the sand band is narrow and the shelf beyond is coated with a pavement or hard ground. The dominant coral here is Meandrina meandrites although Montastraea cavernosa, Siderastrea siderea, D. strigosa, Dichocoenia stokesii and Zoanthus spp. also occur. Approximately $75 \%$ of the surface is coral-bare pavement with abundant sponges and gorgonians (Adey, 1975). Lang Bank is the best example of an inactive reef, the prominent reef type of St Croix. It is situated at the eastern shelf edge at $9-18 \mathrm{~m}$ depth and is ideally located for active barrier reef growth. However, an interlocking reef framework is lacking, and the bank is largely a rubble-covered carbonate pavement with abundant alcyonarians, sponges and large sand patches with only scattered coral heads and very little A palmata (Adey et al., 1977; Dahl et al., 1974).

Isaac Reef on the eastern tip, extending from Cudejarre Point to Isaac Point, is a relatively young reef with narrow reef flats. The crest is broken by numerous channels, there is high living $A$ palmata cover and the reef breaks the surface in a discontinuous fashion. Off Robin Bay, on the south-east coast a strongly developed mature reef, with a nearly continuous crest and a moderately deep reef flat, blocks most of the shore from Rod Bay to Great Pond Bay. It has a wide and relatively shallow back-reef. Living $A$ palmata is an important constituent but there is only $20 \%$ cover. Further west off Halfpenny Bay there is a continuous reef with a broad and shallow reef flat, and few living acroporids (Adey et al., 1981).

A reef (known in some publications as Long Reef) forms a barrier between the sea and Krause Lagoon, opposite the Hess Refinery on the south coast. Two channels have been cut across the reef to provide access to the lagoon. The waters is relatively turbid. The reef appears to consist of a rather loose aggregation of coral fragments, although this may be a result of blasting in the channel (Adey, 1975). Further west, Channel Reef is the remains of a reef between the Hess Refinery and the Martin Marietta Bauxite plant channels, and Airport Reef is a patch-like structure lying west of the ship channels (Adey et al., 1981). The back-reef areas of Airport Reef do not correspond to the normal pattern but appear to be a series of relatively young, elongate patches.

Off open shores, the reefs develop algal ridges at the surface (Adey, 1975). Lithophyllum congestum, Porolithon pachydermum and several Neogoniolithon species are the primary algal ridge builders. All of the known algal ridges occur east of Canegarden Bay on the south coast. The westernmost ridge is on the south shore at Vagthus Point but most of the ridges lie east of Great Pond Bay. Small ridges are found on the north side of Buck Island, on the south shore outside Spring Bay and at East End Bay. Algal cup reefs are found around Cottongarden Point. These have pronounced rims and overhangs, with a relief of about $2 \mathrm{~m}$. Their upper surfaces are covered by fleshy algae including Sargassum sp. and a few flat colonies of Porites astreoides (Dahl et al., 1974). The main ridges, however, are found off the South Shore at Fancy Mountain, Robin Point, Isaac Bay, and at Boiler Bay at the eastern end.

The algal ridges at Fancy Mountain are relatively low and are degenerating as a result of wave-blocking by the $A$ palmata ridge forming on the outside. The algal ridge complex off Robin Point lies on a south-westerly projection of the reef system. It is open to the easterly sea and almost perpendicular to the wave direction and is generally the roughest and most active of the ridges. In the outer line, there are small individual boilers or cup reefs, 2-3 $\mathrm{m}$ in diameter, with well-developed raised rims and marked central depressions. Others are up to $30 \mathrm{~m}$ in diameter, with highly raised rims on the seaward margins only. The relatively deep $(1 \mathrm{~m})$ central basins in this case often have large Diploria heads. Such structures are formed by fused individual boilers. Robin Ridge lies landward and north-west of the actively growing $A$ palmata reef. The waters immediately around these high algal ridges are often relatively deep (3-6 m), and in addition to rubble and sand patches in some of the channels, the pavements often support a community of scattered but large Diploria spp., Mille pora and Montastraea annularis.

Beach Algal Ridge, between Grassy and Grapetree Points, is the longest (over $0.5 \mathrm{~km}$ ), straightest, and probably the oldest Holocene ridge. It is being blocked by an off-lying reef system which has already developed a reef flat in the eastern part. Isaac Algal Ridge off Isaac Point is one of the smallest, but being quite exposed it has high rims. The developing $A$ palmata reef here is still relatively deep $(3-4 \mathrm{~m})$. The Boiler Bay Algal Ridge is described in detail by Adey (1975). The surfaces of the boilers are infested with Echinometra, their burrows occupying about $30 \%$. Crustose corallines occupy about $30 \%$ of the remaining surface, interspersed with algal-bored, dead coralline peysonnelid crusts, Homotrema and the crusts or filamentous bases of abundant fleshy-leaf algae. The latter are described by Conner and Adey (1975)

Noteworthy Fauna and Flora Marine algae of this area are described by Adey et al. (1981). Fish communities have been studied at a number of sites by Gladfelter and Gladfelter (1978), Gladfelter et al. (1980) and Ogden and Ehrlich (1977). The halos formed around West Indian patch reefs by the echinoid Diadema antillarum have been studied at Knight Bay (Ogden et al., 1973), $1 \mathrm{~km}$ west of Cottongarden Bay. Hawksbill Eretmochelys imbricata, Green Chelonia mydas and Leatherback Dermochelys coriacea Turtles nest at a number of sites in this area (Bacon et al., 1984). Seabirds include Brown Boobies Sula leucogaster, Frigatebirds Fregata spp., Laughing Gulls Larus atricilla, Terns Sterna spp., Bluefaced Boobies Sula dactylatra, Tropicbirds Phaethon spp. and Brown Pelicans Pelecanus occidentalis (Anon., 1982). Scott and Carbonell (1986) describe several important wetland sites including Altona Lagoon, Southgate Pond (4 km north-east of Christiansted), Coakley Bay Pond and Great Pond.

Scientific Importance and Research The 4000 year old eastern and south-eastern bank barrier reef of St Croix is one of the best developed reef systems in the tropical Atlantic Caribbean area and is the most extensive reef on the Puerto Rican-Virgin Islands shelf (Adey et al., 1981). It has long been of considerable scientific interest, partly because it is relatively untouched but also because the many subtypes of reef which exist in the one complex serve as a baseline for comparison with others throughout the Caribbean. The south shore reefs are particularly interesting as all of the reef geographical and ecological successional stages, young to old, are present. 
The Meandrina hard ground of East Point is in need of extended study because of its possible importance to shelf-building in the Antilles (Adey, 1975).

The area has been studied for many years and is readily accessible from the West Indies Laboratory of the Fairleigh Dickinson University, on the eastern end of St Croix (Adey et al., 1981). Intensive investigations have been carried out on the south St Croix reef off Isaac Bay, Robin Bay, and Halfpenny Bay, and at Channel and Airport reefs (Adey et al., 1981; Rogers and Salesky, 1981). Reef metabolism and community structure relative to environmental factors at these sites have been described and the reefs down current and west of the industrial area have been contrasted with those upstream to the east. A study of the metabolism of living $A$ palmata, macroalgae and turf algae was carried out on Teague Bay Reef (Adey et al., 1981).

Economic Value and Social Benefits Teague Bay Reef and the Boiler Bay reefs and algal ridges are used intensively by the W.I.L as an underwater classroom (Teytaud, 1980). Artisanal fishermen harvest conch, whelk and spiny lobster in the area. Ciguatera poisoning poses a problem for finfishing (Anon., 1982). Long Reef is of importance to Christiansted Harbour in terms of storm protection, waste recycling, aesthetics, recreation and fish production (Teytaud, 1980).

Disturbance or Deficiencies Hurricanes David and Frederick caused considerable damage to shallow $A$ palmata reefs in 1979. Greatest destruction occurred on the more exposed south coast where the structural complexity of $A$ palmata stands was reduced by $50 \%$ and some areas were virtually flattened. Damage at Buck Island and Teague Bay on the north coast and Isaac Bay and Robin Bay on the south-east coast, and recovery rates are described by Rogers et al. (1979).

The Christiansted Harbour ecosystem has deteriorated significantly in terms of water quality and viability of some biological communities in the past $20-25$ years. No overall management plan exists for the area and piecemeal developments, such as the new WAPA thermal effluent, are underway with no adequate analysis of their effect on the entire system. Dong et al. (1972) and Nichols et al. (1972) documented extensive adverse changes due to pollution in the harbour prior to 1972 but there has been no follow-up study to document subsequent changes. Stresses include thermal discharge, sewage from boats and malfunctioning municipal sewer lines, contaminated street surface and other urban run-off, sedimentation from badly constructed and poorly maintained storm drainage structures, residual fines from early harbour dredging, sediment from eroding fill beaches, contaminated run-off from industrial areas, oil spills and turbidity from cargo vessel propeller wash. WAPA has been a major contributor to the damage due to its eroding drainage control ditch, fuel transfer operations and frequent visits by tanker vessels, and sloppy oil separation and handling procedures on site. Proposed "maintenance dredging" of the Gallows Bay area in the $1970 \mathrm{~s}$, considered necessary because of the accumulation of sediment from the Mt Welcome gut, resulting from poor watershed management and erosion control, posed an additional threat. The relocation of the municipal sewage outfall from Christiansted to the South Shore has eliminated one major source of stress (Teytaud, 1980).
Excessive erosion and sedimentation from uplands drainage into the harbour also causes general damage. The northern section of the bank barrier reef is already heavily used for recreational purposes. The high total species diversity and productivity of these shallow water reefs deserve particular attention. Heavy boat and tourist use of the reefs could damage this, as could turbidity and increased nutrient levels from waste disposal and run-off. Fish take needs controlling (Adey et al., 1981). The current impact of human activities in this area js not known.

The reefs in the south-east are still relatively unaffected by human activities, but certain areas now show the effects of increased commercial and recreational use. The 11 mile $(18 \mathrm{~km})$ section from Cottongarden Point in the north-east around to Manchenil Bay in the south-west remains essentially as it has been for the last 1000 years. Most of the St Croix south shore bank barrier reef is well off shore and not affected by normal fresh water run-off. Isaac Reef is relatively near shore but is on the eastern tip of the island, with minimum rainfall, and there has been little disturbance of natural drainage into Isaac Bay. Nutrient data and suspended matter data suggest very minimal effects of run-off on the reefs (Adey et al., 1981).

Research on the south shore showed that the composition of reef sediments depended on local conditions and that sedimentation rates were similar to those at other relatively undisturbed reefs (Adey et al., 1981). The landmass and population of St Croix appears to exert little influence on the dissolved nutrient concentrations in the ocean waters overflowing these reefs. However, a marked increase in nutrient levels could exert a considerable change in reef community structure, particularly if hurricanes, over-fishing or damage of reef structure were to markedly lower the grazing intensity on the reefs. For example, intensive building or clearing of land along the watershed from Halfpenny Bay to East Point, especially of multi-unit dwellings or hotels would potentially threaten the reef system (Adey t $a l ., 1981$ ).

Extensive pollution is occurring off the south-western coast of St Croix, where a garbage dump, bauxite plant and oil refinery are located. A major industrial complex has been built at Krause Lagoon. Effluents from the Hess oil refinery and an aluminium plant have damaged $10-15 \%$ of the south shore bank barrier reef; fortunately this reef was mature and generally the "least desirable" part of the previously existing reef system. The damage involved was local and, considered as a trade-off for industrial needs, construction was undertaken at what was probably the best point (Adey et al., 1981). Further east, the reef is in good condition but is threatened by proposed oil refineries and hotel/marina development (Canoy, in litt., 1981). It was expected that pollution levels would rise if plans to pipe sewage from Christiansted to this side of the island went ahead (Dahl et al., 1974).

Legal Protection Buck Island National Monument lies within the area (see separate account). Green Cay is a U.S. Fish and Wildlife Refuge. Cramer Park is a local park on the east coast of Teague Bay (Anon., 1982).

Management The St Croix Coral Reef Area of Particular Concern (APC) covers the reef complexes extending from Great Pond Bay on the south coast eastward to East Point and then westward on the north 
coast to the western end of Long Reef off Christiansted, as well as those between Cane and Davis Bays on the north coast and the non-federal areas of Buck Island Reef (see separate account). There appears to be no management specific to this designation. Goals, objectives and management mechanisms for the area were drawn up by Teytaud (1980) but have never been implemented.

Recommendations Teytaud (1980) recommended that current water quality standards should be revised to decrease turbidity and further research and analysis be carried out to define critical turbidity limits for the reefs; stringent controls on erosion and sedimentation should be required with development permits in upland areas; permits should not be issued for dredging or filling in reef complexes; discharge of thermal, saline or high nutrient wastes should be prohibited and toxic wastes or heavy metals should not be discharged into the marine environment; in the event of an oil or hazardous material spill, emergent portions of reefs should be given high priority protection, particularly during periods of low tides; development resulting in alteration or blockage of circulation or wave action should not be permitted in, or upcurrent from, reef complexes; anchoring should be prohibited in all reef zones other than pavements and designated mooring areas should be provided in areas of intensive use.

Certain areas within the Coral Reef APC are identified for special protection including Teague Bay and Boiler Bay Reefs and the algal ridges, and Long Reef was proposed for designation as a significant natural area (Teytaud, 1980). It was recommended that the Department of Coastal Zone Management should prepare a study of the entire coastal ecosystem containing Long Reef, Christiansted Harbour and all watersheds draining into the area. Action should be taken to reduce or eliminate sewage and sedimentation inputs into the harbour and the need for maintenance dredging in Gallows Bay should be reviewed. WAPA should take appropriate action to reduce sedimentation and a programme of monitoring sediments in the vicinity of WAPA outfalls should be set up.

Part of the Coral APC is included within the proposed East End, St Croix Marine Sanctuary (Anon., 1982) which would cover approximately $125 \mathrm{sq} . \mathrm{km}$ and include the waters around Green Cay and Buck Island, and the area of Lang Bank out to the $18 \mathrm{~m}$ depth contour. This area is on the Site Evaluation List, but is unlikely to be implemented in the very near future (Foster in litt., 21.2.86). Lang Bank has been identified as a "Critical area of high biological productivity" in the Virgin Islands Coastal Zone Management Program.

Adey et al. (1981) recommended that the south St Croix Reef should be kept in a natural state for essential and basic research as well as for controlled use by local residents and tourists. It is suggested that any further industrial expansion should take place only to the west of Canegarden Bay where the reefs are small and generally more poorly developed than those to the east. If such expansion were to occur it could perhaps be made dependent on the preservation of the remaining south coast and its waters east of Canegarden Bay. Adey et al. (1981) also recommend that two field technicians/wardens should be assigned full-time to patrol the area and carry out the following tasks: a) continuous or monthly examination of community productivity at selected sites; b) enforce regulations and maintain fishing, diving and boating at or near current levels on the reef; c) develop a procedure for monitoring coral cover and spatial heterogeneity that is less time consuming and destructive than chain transects (e.g. low level aerial photography); d) bi-annual nutrient analyses.

\section{SALT RIVER SUBMARINE CANYON PROPOSED PROTECTED AREA}

Geographical Location $17^{\circ} 47 \mathrm{~N}, 64^{\circ} 45^{\prime} \mathrm{W}$; north coast, St Croix. The area includes the Salt River Estuary and shoreward portion of the Salt River Submarine Canyon.

Area, Depth, Altitude $8 \mathrm{sq} . \mathrm{km}$.

Land Tenure The wetland area is mainly privately owned although the Nature Conservancy owns a section of mangrove swamp.

Physical Features There is virtually no shelf outside the mouth of the estuary. The canyon floor shelves gently northward from the apex for about $200 \mathrm{~m}$, at which point it drops precipitously to $3500 \mathrm{~m}$ through cemented, carbonate sand terraces towards the deep Virgin Islands basin which lies between St Croix and St Thomas. The west wall is very steep, with overhanging cliffs cut by sediment-filled tributaries. The east wall is more gradually sloping with a cobble-border substrate (Olsen and Wood, 1980). An algal/coral reef forms a bar across the mouth of the estuary (Anon., 1982). The area is described in Adey et al. (1977); sediments are described by Gerhard (1978). Water within the estuary flows only intermittently seawards and the waters in the inner portions of the estuary are poorly mixed. Salinities in the southern portion may reach $38 \mathrm{ppt}$ during extended periods of low rainfall. The tidal range is about $0.3 \mathrm{~m}$.

Reef Structure and Corals Siderastrea corals occur along the southern shoreline of the estuary (Anon., 1982). Other reefs are briefly described in Acey et al. (1977) and Rogers et al.(1984). The upper lip of the canyon has a dense covering of hard coral and gorgonian fans (Adey et al. 1977). The east wall has a raised flange of $A$ palmata extending along its margin. The west wall is composed of carbonate rocks of coral reef origin, with overhanging cliffs cut by sediment filled tributaries. Dead coral is common at $9 \mathrm{~m}$ depth. Highest living coral cover occurs at a depth of $18 \mathrm{~m}$ and is about $6-24 \%$ on the east wall and 5-24\% on the west wall. At 9 and $18 \mathrm{~m}$ depths, the dominant corals are Agaricia agaricites, Madracis decactis and Montastraea cavernosa. Agaricia lamarcki is the most abundant species at $27 \mathrm{~m}$ and $37 \mathrm{~m}$ depths on both walls (Rogers et al. 1984). There is abundant black coral (Teytaud, 1980).

Noteworthy Fauna and Flora The estuary is lined by white, black and red mangroves and is described in Anon. (1982) and Scott and Carbonell (1986). Seagrasses occur over much of the shallow bottom. Birds using the mangroves include herons, egrets, pelicans, gallinules and ospreys. Juvenile fish are common in the estuary and sharks are reported to occur quite frequently in the central portion (Anon., 1982; Scott and Carbonell, 1986). 
Several sponges in the genus Verongia, and the gorgonian Iciligorgia schrammi occur in the canyon but are unknown or rare elsewhere on St Croix. Hawksbill Eretmochelys imbricata and Green Chelonia mydas Turtles nest at Salt River (Bacon et al., 1984).

Scientific Importance and Research The Hydrolab diving facility, operated by NOAA's Undersea Research Program at the West Indies Laboratory, is located at the apex of the canyon at $15 \mathrm{~m}$ depth and the shore-based support station is located on the Salt River estuary shore (Anon., 1982; Nyden 1985). The area within which scientists usually work is marked by a series of underwater navigation lines and there are 25 small artificial cinder block reefs. Numerous scientific investigations have been carried out since 1977, including Rogers et al. (1984), Hubbard and Scaturo (19??) and Hubbard et al. (in press). The mangroves are one of the two remaining large stands in the U.S.V.I.

Economic Value and Social Benefits The site is becoming increasingly popular for recreational diving and is considered one of the most spectacular underwater areas in St Croix. The most popular sites are the White Horse wrecks and the reefs and caves submerged near the head of the canyon (Anon., 1982). Black coral resources are described by Olsen and Wood (1980). Artificial reef utilization by groupers has been studied by Downing and El-Zahr (1983).

Disturbance or Deficiencies Rogers et al. (1983) found little damage to the coral after Hurricane David. Fishing pressure within the area is low (Anon., 1982). The wetland area is threatened by the development of two marinas and the construction of private houses and hotels (Scott and Carbonell, 1986).

Legal Protection There is a Nature Conservancy wildlife refuge on the east side of the estuary (Anon., 1982; Scott and Carbonell, 1986).

\section{Management None known.}

Recommendations Adey et al. (1977) recommended that the area should become part of the U.S.V.I. marine park system and it was identified as a potential Marine Sanctuary under the 1972 Marine Protection, Research and Sanctuaries Act (Anon., 1982). However, it was not selected for the Site Evaluation List of possible sanctuaries.

\section{SOUTHEASTERN ST THOMAS PROPOSED PROTECTED AREA}

Geographical Location South-east St Thomas, $7 \mathrm{~km}$ south-east of Charlotte Amalie; $68^{\circ} 48^{\prime}-64^{\circ} 54^{\prime} \mathrm{W}$, $18^{\circ} 16^{\prime}-18^{\circ} 19^{\prime} \mathrm{N}$. The area comprises Mangrove Lagoon, Benner, Jersey and Cowpet Bays and the waters surrounding nine offshore islands and cays: Bovoni Cay 50 acres ( 20 ha), Buck Island 42 acres (17 ha), Capella Island 22 acres (9 ha), Cas Cay 14 acres (6 ha), Dog Island 12 acres ( 5 ha), Patricia Cay 33 acres (13 ha), Rotto Cay 2 acres (1 ha), Great St James 157 acres (64 ha) and Little St James 69 acres (28 ha).
Area, Depth, Altitude Mangrove Lagoon with its passages and bays forms a system $2 \times 1.3 \mathrm{~km}$ in size although the average width of the lagoon is only $0.5 \mathrm{~km}$; areas of offshore islands are given above; the area originally proposed as a sanctuary covers $32 \mathrm{sq}$. km.

Land Tenure Buck Island is federally owned; Capella Island and Dog Island are owned by the Virgin Islands Government and the remaining six cays and islands are privately owned although Cas Cay may become Government property (OCZM, 1981). The local Government owns nearly all the land from Long Point to Turpentine Run.

Physical Features The proposed area is typical of the St Thomas bank shelf, representing a former Pleistocene back-reef lagoon environment. The sedimentary geology and oceanography of the area is described by Hubbard (1979). Run-off caused by the steep slope of the island and the erodable nature of the soils causes sedimentary deposition within Benner Bay and Mangrove Lagoon. The latter lies in a north-east/ south-east trending fault zone of sedimentary fill at the mouth of Turpentine Run, the largest perennial stream on St Thomas. Its mangrove-fringed islands and shallow waters contrast with the steep rocky coast of the rest of the south coast (Towle, 1985).

Bovoni, Patricia and Cas Cays, interspersed with reefs, separate Mangrove Lagoon from Jersey Bay. The uninhabited offshore islands are similar to each other in ecology and appearance, being volcanic in origin, arid and covered with thin stony soil. Cas and Patricia Cays have precipitous south and east windward sides but are flatter to leeward, where the headlands are dominated by cedar and mangroves (Anon., 1982; OCZM, 1981). Other islets in Jersey Bay include several groups of rocks such as Cow and Calf, the Stragglers, Welk, Dog and Fish Cay. Salt ponds are found on Great and Little St James, Dog, Patricia and Capella Islands.

The rest of the area is dominated by fine sandy substrate with transitional seagrass beds of Halimeda and turtle grass Thalassia testudinum; 15 different biotic associations of calcareous algal plains, zones of rock and rubble and open ocean waters have been identified, as well as a series of shallow fore-reefs, deep reefs and back-reefs. Seaward of the reef community is the characteristic sand zone which typically separates Caribbean reefs from the deep water algal association (OCZM, 1981). Most of the offshore areas below $15 \mathrm{~m}$ depth are covered by a rich and diverse algal plain which is extremely productive and is frequented by a variety of crustaceans, molluscs and fish (Olsen et al., 1978; Wells and Olsen, 1973). In the extreme eastern portion of Benner Bay there are two well-defined zones of sabellid worms.

Towle (1985) provides a detailed analysis of the area and identifies ten ecological zones or units within the lagoonal complex, all of which are linked by the flow of water. They include the upland Tutu Valley area, the primary drainage basin of Turpentine Run, black mangrove-dominated high tidal flats, and several ponds and inner lagoons.

The climate of the area is subtropical and semi-arid, with a mean annual temperature of $79^{\circ} \mathrm{F}\left(26^{\circ} \mathrm{C}\right)$. Trade winds from the east are predominant from March to October 
and from the north-east from November to February. Periods of strong northerly winds are common from December to February. Annual rainfall averages 40 in. (1020 mm), most falling between August and December. Drainage into Mangrove Lagoon is described in Towle (1985). Tidal range averages $12 \mathrm{~cm}$ with a maximum of $24 \mathrm{~cm}$ at spring tides. Offshore currents are dominated by a branch of the Equatorial Current from the east for most of the year. The inshore area is dominated by tidal currents in the narrow passes and to the east of the St James Islands (OCZM, 1981). Mangrove Lagoon has a salinity of about $42 \mathrm{ppt}$ and is subject to periodic flooding and drying out.

Reef Structure and Corals Acropora palmata dominates the shallow fore-reef along with a variety of other corals including massive formations of Siderastrea, Montastraea and Diploria and some $A$ cervicomis, Agaricia and Millepora. The reef communities surrounding the offshore islands and cays are variable and include several species of sponges and soft coral assemblages in the shallower waters. In deeper waters gorgonian forests are found, characterized by Pterogorgia, Pseudopterogorgia, Eunicea, Plexaurella and sponges. The condition of the reefs within the sanctuary was considered to be good in the 1970 s (OCZM, 1981).

Noteworthy Fauna and Flora The area including Jersey Bay, Mangrove Lagoon and Benner Bay with Bovoni Cay, Cas Cay and Patricia Cay, is the most extensive Red Mangrove Rhizophora mangle system remaining in the Virgin Islands. The cays of Mangrove Lagoon (Rotto Cay, Manglar Cay, Cas Cay, Patricia Cay and Bovoni Cay) support a unique and simple community of red, white and black mangroves. Sea Grape Coccolaba uvifera, cactus Cephalocereus and Opuntia, Saltwort Batis maritima, Bay Bean I pomoea pes-Caprae and Sea Spinach Sesuvium portulacastrum are found along the beaches of the mainland. Further inland White Frangipani Plumeria alba, palms Cocos nucifera and Coccothrinax alta, Agave sp. and Casha Acacia farnesiana are found. The vegetation of the offshore islands is primarily mixed grasses, scrubby thorn woods and cactus, which is often extremely dense. A complete list of plant species found in the proposed sanctuary area is given in OCZM (1981).

Faunal lists for the area are given in OCZM (1981). More than 76 species of algae, 46 mollusc species, 15 sponge species, 58 echinoderm species, numerous cnidarian, annelid and crustacean species, 243 fish species, 5 marine turtle species, 100 shore bird species and three whale species have been recorded within the proposed sanctuary area. The Green Turtle Chelonia mydas, Hawksbill Eretmochelys imbricata, Leatherback Dermochelys coriacea, Olive Ridley Lepidochelys olivacea and Loggerhead Caretta caretta have been recorded (Towle et al., 1978). They are no longer common but there are still two or three nesting sites of Hawksbills on the beaches of Great St James, Dog Island and Great Bay (Bacon et al., 1984). Turtles are often sighted at the precipitous underwater cliffs at Little St James. The waters to the north and east of the sanctuary area serve as one of the many migrational paths for the Humpback Whale Megaptera novaengliae as it enters the Caribbean from the Atlantic.
Over 300 species of fish have been recorded in the area (Randall, 1968), with seventy-nine species reported from Jersey Bay; Mangrove Lagoon is estimated to support more than 50000 fish individuals. Prior to stresses from development, this area supported extensive populations of juvenile lobsters Panulinus argus and crabs. There is an extensive juvenile conch Strombus gigas bed vetween Great and Little St James (Haines and Brownell, 1978; Sigma Environmental, 1979). Colonies of the West Indian Fighting Conch $S$. pugilis are found in Great Bay and in the St James Passage.

Scott and Carbonell (1986) list many of the important breeding, passage and wintering waterfowl. Large Laughing Gull Larus atricilla and Roseate Tern Sterna dougallii colonies occur each year on Dog Island. Mountain Zenaida aurita and Ground Columba passerina Doves and Tropicbirds Phaethon sp. nest on most of the cays and Brown Pelicans Pelecanus occidentalis feed and roost on and around all the islands. The cays and manglars of Jersey Bay are an important habitat for about 20 species of herons, egrets, rails, stilts, gallinules, White-crowned Pigeons Columba leucocephala and Bahama Pintail Ducks Anas bahamensis. Osprey Pandion haliaetus and Redtail Hawks Buteo jamaicensis frequent the lagoon and the Peregrine Falco peregrinus is a spring visitor. Iguanas, ground lizards and a local snake Alsophis sp. are also found (Anon., 1982).

Scientific Importance and Research The area has long been an important research site due to the rich variety of marine resources, their importance to the economy of the Virgin Islands and their proximity to land. Scientific research increased in the late 1960 s when several environmental impact studies were carried out as a result of a proposal to construct an airport in Mangrove Lagoon. Since then the Government of the Virgin Islands has sponsored studies of the dynamics of the Lagoon ecosystem, fisheries, lobsters, wildlife and the flora and fauna of offshore islands and cays. A specially constructed laboratory at Nazareth Bay was used to experiment on dolphin communication. The Caribbean Research Institute carried out work on sharks and turtles from here and also worked from a laboratory at Benner Bay (now used by the Department of Conservation and Cultural Affairs for research and monitoring). Research underway in the early 1980s included a study of whelks and conch; a fishery study; water quality monitoring; a study of whale and turtle movements and an environmental impact assessment for Long Point (OCZM, 1981). Some 20 research reports, monitoring documents and development impact assessment studies were produced between 1968 and 1983.

Economic Value and Social Benefits The cultural and historic resources of the area are described in OCZM (1981). Traditional uses of the lagoon included fishing, crabbing, clamming, cutting mangrove wood for charcoal and boat timbers, and as anchorage especially during hurricanes (Anon., 1982). There was a dramatic change in use between 1960 and 1984 (Towle, 1985). Initially there were only farmers, fishermen and a sprinkling of residents and small commercial establishments. By 1984 there were nearly 500 vessel owners, an active marine industry, thousands of low-income public housing residents, middle-income single family dwellings, apartment-dwellers and owners and hundreds of commercial businessmen. 
The proposed sanctuary area is a major tourist attraction and the centre of about $20 \%$ of all Virgin Islands boating activity, including private and commercial diving tours (Olsen, 1979). The offshore islands are aesthetically spectacular, with windward rocky shorelines, sheer cliffs and massive boulders, and receive about 1000 boats each year. Buck and Capella Islands, 15 minutes by boat from Charlotte Amalie, and Christmas Cove, facing Great St James, are particularly popular, the former receiving about 6000 visitors a year. Large numbers of recreational and charter boats are based in the area and Benner Bay and Mangrove Lagoon are used as hurricane anchorages. The St Thomas Yacht Club is situated in Cowpet Bay and races often take place through the area. The leeward bays, coves and rocky points offer many of the finest dive sites in the Virgin Islands, including the cave formations at Cow and Calf Rocks, the ledges at Little St James and the reefs at Buck Island, Capella Island and Nazareth Bay. There are sixteen dive sites within the proposed sanctuary which are frequented by tour operators, who make over 4000 trips a year to them and several shipwrecks including the Royal Mail steamship HMS $W$ ye on the south shore of Buck Island, a World War I freighter in West Bay, Buck Island, an unidentified wreck at Whelk Rocks and a Caribbean trading schooner.

Commercial fishing within the area involves about $50-60$ fishermen. Inshore from the algal plain, the deep reefs support an important small-scale artisanal local fishery valued at 2.5 million dollars (Olsen, 1979). Landings average 1.7 million pounds $(0.77$ million $\mathrm{kg})$ of fish and 122000 pounds $(55340 \mathrm{~kg}$ ) of lobster. Indian fish traps and boats generally less than $25 \mathrm{ft}(7.6 \mathrm{~m})$ in length are used. There is also a bait fishery for Harengula sp. and Anchoo sp., caught in fish traps and with hand lines. Benner Bay and Mangrove Lagoon are important fish nursery grounds (Olsen, 1979) and over $80 \%$ of the reef fish in the area are juveniles.

Disturbance or Deficiencies Towle (1985) provides a summary of the events which have taken place since the early $1960 \mathrm{~s}$, when development started in earnest. The area was originally threatened by proposals to site a new airport on the southern shore of Mangrove Lagoon. Numerous environmental studies were carried out (e.g. McNulty et. al., 1968; Tabb and Michel, 1968) and the plans were eventually dropped, but an enormous increase in recreational activities created new problems. Upland slopes and floodplains were bulldozed for residential sites, mangroves were cut and buried to create marinas, docks and sewage plants, roads and a race track. By 1980 the population of the drainage basin had reached 15000 .

Current impacts on the lagoon include: sewage pollution from anchored boats, sewage treatment plants, local septic tanks and shore establishments (the problems of sewage treatment are described in more detail in Towle (1985)); release of toxic trace metals from the municipal dump, boat yards, and local debris scattered around the lagoon margins and watershed; discharge of wastes causing high turbidity, low transparency and low oxygen content; an abundance of coliform bacteria posing a health hazard; growth of filamentous algae associated with high nutrient pollution loads; sedimentation associated with storm run-off from the watershed and shoaling of the lagoon floor with formation of a black mud blanket; disturbance of mangrove habitats by bulkheading, dumping and landfill to create dock space, berthing facilities and useable land; loss of productive inshore clam and fishing grounds and reduction in vitality of bottom biota; restriction of drainage with loss of fishing capacity and stagnation of backwaters favorable to mosquito breeding. Shoals in the Benner Bay entrance channel limit boat traffic, marine use and consequently economic viability (OCZM, 1981). Intense development in the upper drainage basin of Turpentine Run has increased the potential for flash flooding into Mangrove Lagoon (Towle, 1985). Most watershed sediment reaching the lagoon is fine-grained silt and clay which remains suspended, degrading water clarity. Changes in the drainage patterns into the bay since 1961 are described by Towle (1985).

Shoreline development is considerable in some areas. Hotels and condominiums are located at Nazareth Bay, Secret Harbour, Cowpet Bay and Cabrite Hill and there are private residences on the western side of Benner Bay and on the cliffs between Compass Point and Cowpet Bay. Commercial docks and a number of privately owned small docks are concentrated east of Mangrove Lagoon between Turpentine Run and Benner Bay. Extensive marina development has occurred in the Benner Bay area (Anon. 1982).

In the late 1960s, turtle grass dominated Jersey and Benner Bays and the Mangrove Lagoon (McNulty et al., 1968; Tabb and Michel, 1968) but by the early 1970s, this had been largely replaced by algae and mud (Olsen and Damman,1971). The benthic jelly fish Cassiopea population had increased dramatically. These changes were probably caused by development in the surrounding watershed and eutrophication. Deteriorating water quality has caused the formation of a loose semi-liquid sediment, covered by the spermatophyte Halophila baillonis, a species characteristic of stressed environments, over $90 \%$ of the inner lagoon, extending through Bovoni Passage into deeper parts of Benner Bay.

A number of dredge and fill activities took place between the 1960s and 1970s. In Mangrove Lagoon, the area between the mainland and Patricia Cay was dredged to make a small beach on the northside of Long Point. Artifical beaches were created at Cowpet using sand from Cowpet Bay, and at Secret Harbour using sand from Nazareth Bay. Some illegal small-scale dredging has taken place in and around Benner Bay.

Houseboats at Cas Cay and in the Lagoon have caused local pollution. The seagrass beds of Cas and Patricia Cays are a maze of drag lines where boats have run aground, and the bottoms of Boyd and Delugo Bays are already littered with trash (Anon., 1982). In the 1960 s the back-reef community of Porites extended through the entrance channels at Patricia Cays into the lagoon (McNulty et al., 1968) but the segment in the Patricia entrance is now dead. Cas Entrance reach was once filled with Porites rubble and living corals (McNulty et al., 1968 ) but subsequent surveys have shown it to be covered with a Halimeda Penicillus community (Grigg et al., 1971), turtle grass (Tabb and Michel, 1968) and a fine calcium carbonate sand (Olsen, 1979).

The carrying capacity of the area for boats and yachts may well have been exceeded. Buck, Capella and the St James Islands have been affected by careless anchoring. Cabrita Point and Packet Rock were popular spearfishing grounds less than a decade ago but are now seldom visited. Spearfishing still occurs occasionally off 
Dog Island, Cow and Calf and Little St James (OCZM, 1981). Increased recreational use may destroy conch and lobster habitat (Anon., 1982); the conch bed between Great and Little St James is under heavy recreational pressures. Triton and helmet shells have been over-collected by tourists and resident shell collectors.

Legal Protection None, although the area is under the jurisdiction of the Coastal Zone Management Programme.

Management There have been numerous, so far unsuccessful, attempts to control pollution in the lagoon and these are discussed by Towle (1985). Current attempts include proposals for a new sewage treatment plant and a solid waste incinerator/energy recovery plant, to be located at the Lagoon head shoreline on the land previously purchased by the government for the aborted jet airport. Dive guides had assumed a substantial degree of responsibility for protecting the reefs by the 1970 s (Anon., 1982).

Recommendations The area was identified as a potential marine sanctuary under the 1972 Marine Protection, Research and Sanctuaries Act (Anon., 1982), and a Draft Environmental Impact Statement was prepared (OCZM, 1981), containing detailed proposals, goals and objectives. A number of options for regulatory measures and boundaries were suggested and are discussed in Anon. (1982) and OCZM (1981). It was suggested that the Virgin Islands should promulgate specific regulations pursuant to the Virgin Islands Coastal Zone Management Act of 1978 (I2VIC \#901) which should apply only within the sanctuary boundary. These should prohibit the taking or damaging of any living natural resource; permit traditional fishing methods except at designated dive areas; prohibit disturbance of cultural resources; prohibit anchoring in a manner damaging to coral; prohibit the discharge of substances except cooling waters from vessels, fish, fish parts or chumming materials and discharges from marine sanitation devices; and limit alteration of the seabed to the area outside Mangrove Lagoon to those in the public interest. The area is still on the Site Evaluation list, but has been removed from the list of Active Candidates.

Much of the Government owned land between Long Point and Turpentine Run was designated an area of particular concern under the Virgin Islands Coastal Zone Program in 1978 but this has had little impact. A management plan for the St Thomas Mangrove Lagoon area of particular concern was produced (Teytaud, 1981) but this was considered too late to have any effect, too complex for efficient application and too removed from prevailing uses and management requirements to be accepted (Towle, 1985). A cleaning-up operation would be necessary to restore the seriously disturbed areas.

\section{VIRGIN ISLANDS NATIONAL PARK AND BIOSPHERE RESERVE}

Geographical Location Covers two thirds of the island and surrounding waters of St John; $18^{\circ} 21^{\prime} \mathrm{N}, 64^{\circ} 44^{\prime} \mathrm{W}$.

Area, Depth, Altitude The reserve includes 3644 ha land and 2286 ha sea; total area: 6127 ha; altitude $0-389 \mathrm{~m}$.
Land Tenure 4953 ha owned by the Park; 1174 ha in private ownership, including less than 20 ha owned by the Territorial Government.

Physical Features The Park includes steep, verdant hillsides, rising from rocky shores which are interspersed with coral sand beaches, numerous bays and cays, and is described by Robinson and Henle (1978). There are clear, warm waters, fringing reefs, seagrass beds, mangroves and natural salt ponds. At Leinster Bay there is a mangrove swamp and reef flat. Along the north shore beaches, west of Mary Point, there are shallow fringing reefs adjacent to the major headlands and deeper, sloping fringing reefs of scattered coral heads. There is also a system of extensive patch reefs rising to within 5-20 ft $(1.5-6 \mathrm{~m})$ of the surface. Cinnamon Bay has a large beach and a small offshore cay; fringing reefs surround the headlands and cay and there are offshore patch reefs. Within Trunk Bay there are several large reefs, mostly fringing the headlands, and an offshore cay. Along much of the southern and eastern shores, water depth increases more rapidly off shore and much of the shallow-water coral growth consists of scattered colonies on hard rock, with few significant offshore patch reefs (Hoffman et al., 1974). Temperatures remain fairly constant around $26^{\circ} \mathrm{C}$, and rainfall averages about $1000 \mathrm{~mm}$ per year (IUCN, 1982).

Reef Structure and Corals The shallowest fringing reefs, at eastern Cinnamon Bay, Windswept Beach and Denis Bay, are typically barren on their upper, wave-washed surfaces, which are occasionally exposed by extreme low tides. The emergent reef crests support encrusting sponges, zooanthids, the sea urchin Echinometra sp., seaweeds and encrusting Millepora sp. Seaward of the reef crest, Acropora palmata stands, oriented in the direction of incoming waves, are interspersed with encrusting Diploria spp. and Mille pora sp. The protected reef face is steep or overhung with Agaricia sp. and Cladocora sp. Montastraea spp. dominate the base of the reef (Robinson and Henle, 1978).

Various stages of reef development are apparent, from eastern Cinramon Bay, where development is minimal, to Annaberg and Mary Creek where the reef extends seaward over $100 \mathrm{~m}$, producing a broad, shallow back-reef supporting a dense growth of the alga Halimeda sp. and isolated patches of Porites porites. Mary Creek has dense growths of seagrass Thalassia sp. Offshore patch reefs, such as Johnson's Reef off Trunk Bay, are similar to the fringing reefs (Robinson and Henle, 1978). A low lying, shallow patch reef in the eastern part of Greater Lameshur Bay was surveyed in the course of a study of fish diversity (Risk, 1972). Corals present included $M$. annularis, Millepora alcicornis, $P$. furcata, and Agaricia agaricites.

Noteworthy Fauna and Flora Hawksbill Turtles Eretmochelys imbricata nest on beaches within the park boundaries (Bacon et al., 1984). The mangrove swamp ecosystem supports breeding populations of many species, including the locally threatened White-crowned Pigeon Columba leucocephala, the Brown Pelican Pelecanus accidentalis, Brown Booby Sula leucogaster, Man-o-war Bird Frega:a magnificens, Bahamian Pintail Anas bahamensis, Zenaida Dove Zenaida aurita and Mustached Quail Dove Geotrygon mystaceae. The main wetland areas 
within the Park are described by Scott and Carbonell (1986). Terrestrial reptiles include anoles Anolis spp.; amphibians are limited to frogs. The only native mammals are several species of bats (IUCN, 1982).

Scientific Importance and Research The Virgin Islands Ecological Research Station (Caribbean Research Institute of the College of the Virgin Islands) is based on St John and an international research station is to be established in the Reserve under the Man and the Biosphere Program. In co-operation with other local institutions and agencies, the Virgin Islands Resource Management Cooperative has recently completed a variety of studies, including characterization of local fisheries, analysis of the cultural role of fishing, mapping of nearshore marine communities, descriptions of the bays and marine communities and lists of organisms found within the reserve area. Other projects emphasise watershed management, including development of long-term monitoring programs for coral reefs and fisheries and determination of the impact of terrigenous run-off on coastal ecosystems. A study of beach erosion within the Park was carried out in the early 1970 s (Hoffman et al., 1974) and the "Tektite" 【 underwater program involved detailed research in Lameshur Bay (Lee et al., 1975).

Economic Value and Social Benefits Posner et al. (1981) carried out an economic impact analysis for the National Park which is discussed by Van't Hof (1985). It was calculated that the Park plays a significant role in the economy of St John, operating on a benefit/cost ratio (including both direct and indirect costs and benefits) of 11.1 to 1. Caribbean cruises make day trips from St Thomas; Trunk Bay and Cinnamon Bay are the main recreational areas. Coral Bay and Hurricane Hotel are important safe anchorages for boats during hurricanes or tropical storms (Boulon, R. pers. comm. to Nash, S., 1983).

The Division of Fish and Wildife have produced a number of reports on the fishing industry within the area. Koester (1985) describes the socio-economic and cultural role of fishing and shellfishing. The majority of the subsistence fishermen who use the resources of the Reserve live on St John but there are an unknown number of users, both subsistence and recreational, from St Thomas and the British Virgin Islands. There is some conflict between the fishermen and park staff but it is considered that local people benefit from the park, despite losing their traditional economy.

Disturbance or Deficiencies IUCN (1982) describes some of the problems occurring within the terrestrial part of the Reserve. Centuries of intensive plantation agriculture stripped St John of its original vegetation although gradual regrowth has brought back some forest. There are road cuts and residential development within the authorized Park boundaries and private development of land is causing heavy soil erosion. The marine environment has remained relatively undisturbed, but there is some visitor impact on the reefs of Trunk Bay, poaching of turtle eggs, coral collecting and boats anchoring on reefs. The underwater trail at Trunk Bay has been badly damaged by tourists, usually collecting coral momentos. There has been noticeable damage in some areas from trampling, diving or swimming (Rogers, 1985). The reefs off Windswept Bay are regularly damaged by charter boats running aground (Boulon, $\mathbf{R}$. pers. comm. to Nash, S., 1983).
Legal Protection Established 2 August 1956 (public law 925 ) as a National Park; there is concurrent jurisdiction with the Virgin Islands Terrestrial Government on those Park lands in federal ownership. Designated in June 1976 as a Biosphere Reserve although formal dedication did not take place until May 1983. The code of Federal Regulations, Title 36, Chapter 1, protects natural resources, and controls visitor safety and commercial activities. The establishing legislation for the Park (added to on 5 October 1962) provides for the taking of certain marine animals by traditional methods to meet the food needs of the local population (IUCN, 1982). There are possession limits on conch, lobster and whelks. Turtles may not be caught under the U.S. Endangered Species Act of 1973 (Koester, 1985). Off-shore rod and reel fishing is the only form of fishing permitted and may not be carried out in the vicinity of public swimming or snorkelling beaches but nets up to $20 \mathrm{ft}(6 \mathrm{~m})$ long may be used (Koester, 1985). The use or possession of any type of spearfishing equipment within the park boundaries is prohibited. All taking of marine life is prohibited in Trunk Bay and the defacing, breaking or removal of natural features, including underwater growth, is prohibited throughout the Park. Water ski-ing is prohibited within the Park.

Management Park lands are classified into four general zones - natural, historic, development and special use. Within these the following areas are recognised: environmental protection zone (Trunk Bay) - 1\%; outstanding natural features zone (coral reef and park waters) - 5\%; natural environmental zone (land area) $85 \%$; historic zone (ruins) - $2 \%$; development zone (developed areas) - 5\%; special use zone (transport) - $2 \%$ (U.S. National Park Service, 1977 and 1983; IUCN, 1982). In 1981 there were 34 full-time and 25 seasonal staff carrying out maintenance, protection, interpretation, and administrative functions. The Park is administered by the Superintendent, Virgin Islands National Park, P.O. Box 806, Charlotte Amalie, St Thomas, Virgin Islands 00801, U.S.A.

The Cruz Bay Visitor Center provides orientation talks, maps, literature, guided snorkel trips, hikes and cultural demonstrations. There is a self-guiding underwater trail at Trunk Bay and snorkel equipment can be rented at Trunk Bay and Cinnamon Bay. Seagrass anchorage sites have been studied at Lameshur and Francis Bays as part of a programme to establish long-term monitoring for existing safe anchorages. A series of reports on marine life and habitats around St John is available. The Park maintains a small reference library, and brochures have been produced for visitors. Following formal designation of the park as a biosphere reserve, the Virgin Islands Resource Management Cooperative (VIRMAC) undertook a detailed descriptive survey (as described above) in 1983 and 1984 and provided guidelines for management of the Reserve and adjacent areas (see also account for British Virgin Islands) (Koester, 1985).

Recommendations There needs to be greater involvement of the local fishermen in the planning and management of the reserve and in research (Koester, 1985). Ultimately, the Reserve will probably become part of a multi-site Lesser Antillean Biosphere Reserve, including both U.S.V.I. and B.V.I. waters (Koester, 1985; Rogers, 1985). 


\section{INTRODUCTION}

\section{General Description}

With $2900 \mathrm{~km}$ bordering the Caribbean Sea, Venezuela has one of the longest coastlines of the countries in this region (Pannier, 1977), but due to the presence of major river estuaries, comparatively few areas are optimal for coral growth. The best reefs in the country are around offshore islands (Weiss and Goddard, 1977; Antonius in prep. a and b), such as Los Roques and Las Aves (see separate accounts).

Reefs are limited in the west by heavy turbid stream input. The most westerly reefs at Cayo Sombrero, off Tucacas to the south of Chichiriviche, are described by Almeida (1977). Those in Parque Nacional de Morrocoy, near Tucacas, are described in a separate account. Urich (1977) describes reefs off Isla La Orchila. Coral abundance and diversity become increasingly poor towards the east (Antonius, in prep. b). Macsotay and Gonzalez-Buto (1979) compare fossil and living reefs in north-eastern Venezuela at Bahia de Bergatin. The Parque Nacional de Mochima area is described in a separate account.

The easternmost reefs, in the Golfo de Cariaco, a habitat of extreme environmental conditions for reef corals, are described by Antonius (1980). The geology of this area is described by Morelock (1982). The littoral areas are comparatively turbid. An upwelling causes exceptionally high plankton production and food supply, and an unusually steep temperature gradient in the coastal regions. These conditions produce a clear vertical zonation, with no coral growth below $15 \mathrm{~m}$. Porites porites and Millepora spp., inhabiting the uppermost layers, constitute $9 \%$ and $21 \%$ respectively of total coral cover. Siderastrea siderea makes up $27 \%$ of the total coral cover and dominates the intermediate zone. Dichocoenia stokesi and Solenastrea hyades grow under very low light and temperature conditions in the deepest zone. Horizontal differences in occurrence and distribution of species are caused by several shallow areas of mobile substrate. Corals in such areas are less healthy than those in more exposed areas. Twenty-one scleractinians and three Millepora species have been recorded (Olivares, 1971). Several important reef building species are absent and no prominent reef structures occur but corals tolerating the special conditions found here are well represented.

Corals are very scarce around Isla Margarita but Rodriguez (1959) and Ramirez-Villaroel (1978) describe a coral assemblage off Isla Cubagua, to the south. Scattered colonies of Acropora cervicornis, A. palmata, Porites and Meandrina are found in a zone consisting mainly of alcyonarians, Pterogorgia acerosa, Plexaurella kunzei, Muricea muricata and Millepora alcicornis. Ramírez-Villaroel and González (1974) describe the octocorals of Isla de Coche, to the east of Isla Cubagua.

Important wetlands along the coast are described in Scott and Carbonell (1986). The Caribbean Manatee Trichechus manatus is recorded from the
Orinoco Delta but not from any reef regions. The American Crocodile Crocodylus acutus is found along the Atlantic coast. The Loggerhead Caretta caretta, the Hawksbill Eretmochelys imbricata and the Green Turtle Chelonia mydas are found on the western coast and offshore islands and occasionally nest; the latter has important feeding areas around the Paraguana Peninsula (Bacon et al., 1984; Groombridge, 1982). Halewyn and Norton (1984) describe the seabird species nesting on the mainland and on nine separate locations off the coast.

A considerable amount of research has been carried out on the reefs, particularly by the Fundación Científica Los Roques, but information is not easily obtainable, being published mainly in theses and technical reports. Much of the marine research has been taxonomically oriented and there is no single review paper on the country's reefs. Recent studies have been carried out at Los Roques, La Orchila, Parque Nacional de Morrocoy, Bahia de Mochima and Isla Larga (Puerto Cabello) by the Fundación de Los Roques and the Universidad Simón Bolivar (Losada in litt., 12.5.86). A major research effort is underway to investigate the ecology of the sea urchin Diadema antillarum (Weil and Losada, 1984). This chapter almost certainly under-represents the work that has been carried out.

\section{Reef Resources}

The marine resources of Venezuela are reportedly well known and the reefs are major fishery resources (Munro, 1983). The results of a FAO/UNDP Fisheries Research and Development Project are documented in an extensive series of publications issued by the project. The reefs are important for tourism; although the latter is still in its infancy, the National Parks are becoming increasingly popular for recreational activities including marine sports. No specific information, apart from the following site-specific accounts, has been obtained on the economic importance of reefs.

\section{Disturbances and Deficiencies}

Mass mortality of Diadema antillarum was reported from some reefs in 1983 and was probably due to the same water-borne pathogen that appeared to affect large numbers of reefs in the Caribbean (Lessios et al., 1984). Small scale coral bleaching was reported in 1983 (Lessios et al., 1983). In the last 30 years, the coastline has seen rapid changes, particularly in the central and western regions, due to the building of port facilities, the presence of chemical complexes and oil refineries and urban and recreational development (Pannier, 1977). Details of threats to particular reefs are given in the following accounts.

\section{Legislation and Management}

The Fundación para la Defensa de la Naturaleza FUDENA is concerned with the conservation of endangered species and habitats and environmental conservation. The capture of turtles is prohibited 


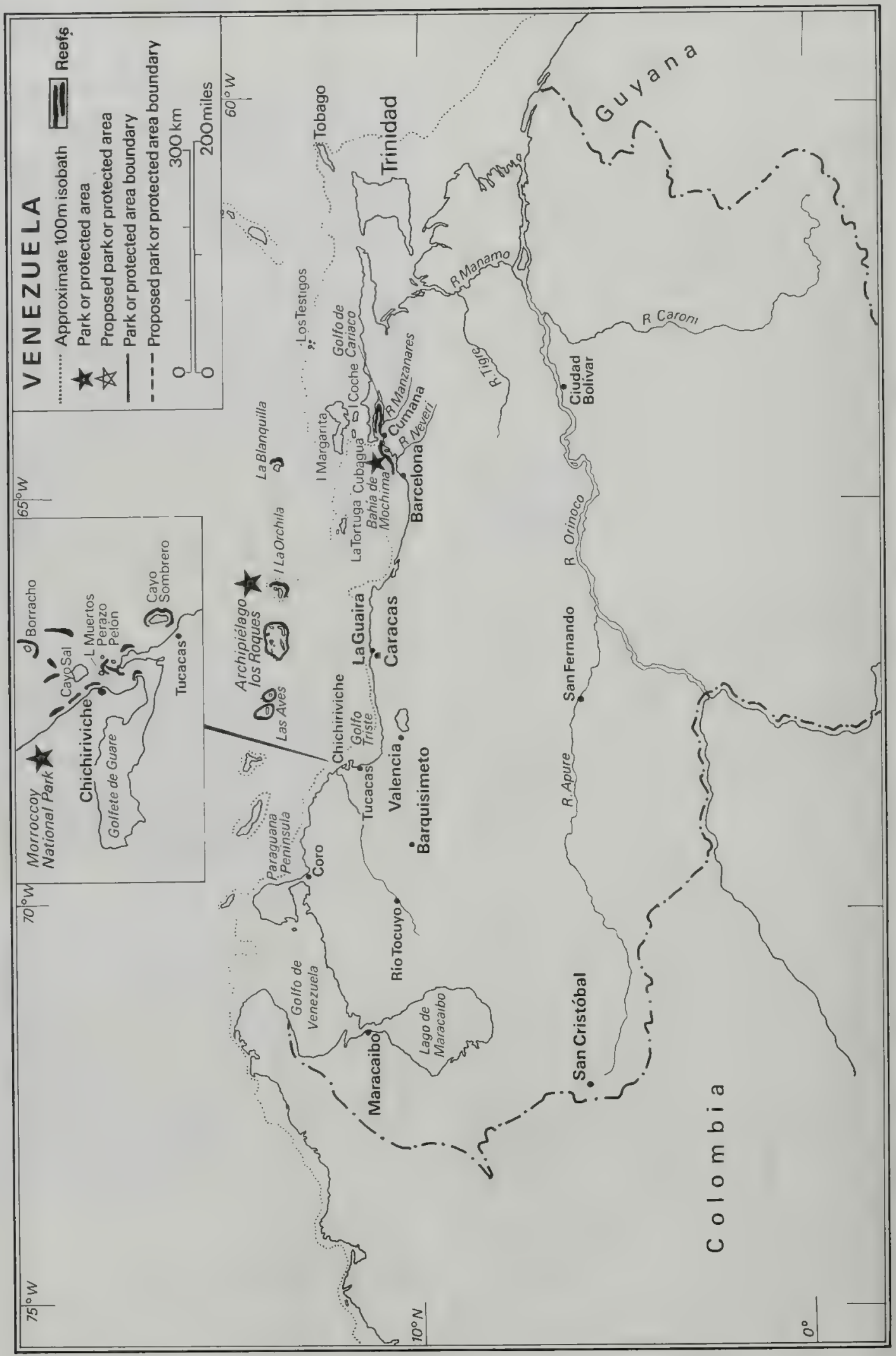


(Bacon et al., 1984); legislation relating to other reef species is not known. A programme for Coastal Zone Management has recently been established (Pannier, 1980) but details are not available. Three National Parks, Parque Nacional Archipiélago Los Roques, Parque Nacional de Mochima and Parque Nacional de Morrocoy include reef habitats and are described in the following accounts. An account is also provided for Las Aves where a reef survey has been carried out.

\section{References}

- cited but not consulted

-Almeida, P. (1977). Biología y ecología de los arrecifes coralinos de Tucacas Cayo Sombrero. Bol. Soc. Venez. Cienc. nat. 32(132-133): 43-70

-Almeida, P. and Goddard, D. (1974). Biología y geología del fondo alrededor de la Isla de Aves hasta $10 \mathrm{~m}$ de profundidad. Bol. Soc. Venez. Cienc. nat. 31:135-162.

Alevizon, W.S. and Brooks, M.G. (1975). The comparative structure of two western Atlantic reef fish assemblages. Bull. Mar. Sci. 25: 482-490.

Antonius, A. (1980). Occurrence and distribution of stony corals in the Gulf of Cariaco, Venezuela. Int. Rev. ges. Hydrobiol. 65(3): 321-338.

Antonius, A. (in prep. a). Occurrence and distribution of stony corals in Los Roques, Venezuela.

Antonius, A. (in prep. b). Occurrence and distribution of stony corals in north eastern Venezuelan waters.

Bacon, P., Berry, F., Bjorndal, K., Hirth, H., Ogren, L. and Weber, M. (1984). The National Reports. Proceedings of the Western Allantic Turle Symposium, Vol. 3. University of Miami Press, Florida.

- Bone, D. (1980). El impacto de las actividades del hombre sobre los arrecifes coralinos del Parque Nacional de Morrocoy, Estado Falcon. Tesis de Grado, Escuela de Biologia, Universidad Central de Venezuela, Caracas. 131 pp.

Campos Villaroel, RA. (1972). Aporte al estudio de los Corales (Coelenterata) de la Bahía de Mochima, Estado Sucre. Bol. Soc. Venez. Cienc, nat. 29(122-123): 545-589.

- Caraballo, L.F. (1968). Sedimentos recientes de la Bahia de Mochima. Bol. Inst. Oceanogr. Univ. Oriente 7:45-64.

- Caraballo, L.F. (1970). Condiciones de sedimentación en las playas de la Bahía de Mochima. Bol. Inst. Oceanogr. Univ. Oriente 9:9-20.

Carr, A., Meylan, A., Mortimer, J., Bjorndal, K. and Carr, T. (1982). Surveys of sea turte populations and habitats in the Western Atlantic. NOAA Technical Memorandum NMFS-SEFC-91.

- Cobe de Berany, T., Edwald, J. and Cadima, E. (1972).

La pesca de la langosta en el Archipiélago "Los

Roques". In forme Técnico 43, Caracas.

Groombridge, B. (1982). The IUCN Amphibia-Reptilia Red Data Book, Part 1: Testudines, Crocodylia, Rhynchocephalia. IUCN, Gland, Switzerland.

Halewyn, R, van and Norton, R.L. (1984). The status and conservation of seabirds in the Caribbean. In: Croxall, J.P., Evans, P.G.H. and Schreiber, R.W. (Eds), Status and Conservation of the World's Seabirds. ICBP Technical Publication No.2, Cambridge.

IUCN (1982). IUCN Directory of Neotropical Protected Areas Tycooly International Publishing Ltd, Dublin.

La Schiazza, J.A. and Losada, FJ. (1985). Octocoral functional morphology in relation to depth in a coral reef at Los Roques Archipelago. Proc. Sth Int. Coral Reef Congress, Tahiti, 2:210.

Lessios, H.A., Glynn, P.W. and Robertson, D.R. (1983). Mass mortalities of coral reef organisms. Science 222:715. Lessios, H.A., Robertson, D.R. and Cubit, J.D. (1984). Spread of Diadema mortality through the Caribbean. Science 226: 335-337.

Losada, FJ. (1983). Importancia del estudio y conservación de los arrecifes coralinos. Natura (Revista de Divulgación Científica Sociedad de Ciencias Naturales la Salle) $74: 4-8$.

-Macsotay, O. and Gonzalez-Brito, P. (1979). Atolones fósiles, epirogenesis y sedimentación en la Bahía de Bergatín, Venezuela Nororiental. Bol. Soc. Venez. Cienc. Nat. 34: 43-71.

-Maloney, NJ. (1965). Geomorphology of central coast of Venezuela. Bol. Inst. Oceanogr. Univ. Oriente 4:246-265.

Morelock, J. (1982). Marine geology of the Gulf of Cariaco. Acta Cient. Venezolana 33: 226-236.

Munro, J.L. (Ed.) (1983). Caribbean Coral Fishery Resources. ICLARM Studies and Reviews 7.

-Okuda, T., Benitez, J., García, A.J. and Fernándex, E. (1968). Condiciones hidrográficas y químicas de la Bahía de Mochima y la Laguna Grande del Obispo desde 1964 a 1966. Bol. Inst. Oceanogr. Univ. Oriente 7:7-37.

Olivares, M.A. (1971). Estudio taxonómico de algunos madreporarios del Golfo de Cariaco, Sucte Venezuela. Bol. Inst. Oceano. Univ. Oriente 10 (2): 73-78. Olivares, M.A. and Leonard, A.B. (1971). Algunos corales pétreos de la Bahía de Mochima, Venezuela. Bol. Inst. Oceanogr. Univ. Oriente 10(1): 49-70.

Pannier, F. (1977). Report of progress achieved in Venezuela on initiatives towards the creation of Marine Parks and Refuges. In: Collected abstracts and papers of the International Conference on Marine Parks and Reserves, 12-14 May, 1975, Tokyo, Japan. The Sabiura Marine Park Research Station, Kushimoto.

Pannier, F. (1980). Mantenimiento de los procesos ecológicos esenciales y los requisitos prioritarios para cumplir este objetivo. Presentación de la Estrategia Mundial para la Conservación, Venezula. Una edición especial de la Fundación para la Defensa de la Naturaleza (FUDENA). 15-17 pp.

Pauls, S.M. (1982). Estructura de las comunidades coralinas de la Bahía de Mochima, Venezuela. M. Sc. thesis. Universidad de Oriente. Cumaná, Venezuela. 124 pp.

Phelps, W.H. and Phelps, W.H. (1950). Las Aves de las Islas los Roques y las Aves y descripción de un nuevo canario de mangle. Bol. Soc. Venez Cienc. Nat. 76: 7-30.

*Ramírez-Villaroels, P.J. and González, P. (1974).

Ecología y distribución de los octocoralios de la Isla de Coche, Venezuela nor-oriental. Bol. Soc. Venez Cienc. nat. 31 (128-129): 33-62.

*Ramirez-Villaroels, P.J. (1978). Fauna coralina de la Isla Cubagua, Venezuela. Trabajo de Ascenso, Depto Ciencias, Universidad de Oriente, Guatamare, Isla de Margarita, Venezuela, 58 pp.

Rodriguez, G. (1959). The marine communities of Margarita Island, Venezuela. Bull. Mar. Sci. 9(3): 237-280.

Saunders, D. (1985). Venezuela. Subaqua Scene 65: $24-25$.

Scott, D.A. and Carbonell, M. (1986). A Directory of Neotropical Wetlands. IUCN, Gland and Cambridge.

-Tamayo, F. (1972). El Atolón de los Roques. Unpub. rept, Caracas. 
-Urich, J.F. (1977). Estudio de la estructura comunitaria de un arrecife coralino al sur-oeste de La Orchila. Tesis de Grado, Escuela de Biologia, Universidad Central de Venezuela, Caracas, Venezuela. $157 \mathrm{pp}$.

Weil, E. and Losada, F. (1984). Spatial variations in density and size of the echinoid Diadema antillarum Philippi on some Venezuelan coral reefs. Bijdragen tot de Dierkunde 54(1): 73-82.

Weiss, M.P. (1973). Carta batimétrica de Chichiriviche. Caracas, Ministerio de Minas e Hidrocarburos, Open File Report.

Weiss, M.P. and Goddard, D.A. (1977). Man's impact on coastal reefs - an example from Venezuela. AAPG Studies in Geol. 4: 111-126.

Weiss, M.P., Goddard, D.A., and Picard, X. (1977?). Geología marina de la región de Chichiriviche, Estado Falcón, Venezuela. Caracas, Biol. Min. Minas e Hidrocarburos.

-Yibirin, C., Jordan, F. and Puzick, P. (1975). Parque Nacional Archipiélago Los Roques. Plan Rector, MAC.

\section{ISLAS LAS AVES}

Geographical Location $12^{\circ} 00^{\prime} \mathrm{N}, 67^{\circ} 30^{\prime} \mathrm{W} ; 120 \mathrm{~km}$ from Venezuelan mainland, in the Lesser Antilles, between Bonaire and Los Roques. Comprises the islands of Barlovento and Sotavento.

Physical Features The Islas las Aves is an atoll-like formation with low cays surrounded by coral reefs. Mound-shaped patch reefs, several thousand square metres in area, rise from a sandy lagoon floor within $0.5 \mathrm{~km}$ of the western lagoon perimeter. Water depth varies from $10 \mathrm{~m}$ to $1 \mathrm{~m}$ at the reef crest. Visibility varies from 10 to $25 \mathrm{~m}$ depending on wind strength (Alevizon and Brooks, 1975). The biology and geology of the seabed down to $10 \mathrm{~m}$ depth are described by Almeida and Goddard (1974).

Reef Structure and Corals Where studied, coral cover was 75 to $85 \%$ and the remaining substrate was sand and coral rubble. Sponges, soft corals and other reef epifauna were low in abundance although stony coral cover was high (Alevizon and Brooks, 1975).

Noteworthy Fauna and Flora The fish are described by Alevizon and Brooks (1975). Phelps and Phelps (1950) recorded 20 bird species from Islas de Aves; Halewyn and Norton (1984) list thirteen species of seabird breeding on the islands. The Green Turtle Chelonia mydas nests in fairly large numbers on the islands (Bacon et al., 1984).

\section{Scientific Importance and Research Not known.}

Economic Value and Social Benefits Not known.

Disturbance or Deficiencies In 1974, a moderate amount of coral damage was evident which was thought to be mainly due to occasional heavy storms, wave action and sedimentation. Human activity is minimal as there are no permanent inhabitants, few fishing boats and the islands are not used for recreational activities such as diving (Alevizon and Brooks, 1975).

Legal Protection None.
Management None.

Recommendations None known.

N.B. This should not be confused with the Isla de Aves Fauna Refuge, $400 \mathrm{~km}$ to the north of Venezuela.

\section{PARQUE NACIONAL DE MOCHIMA}

Geographical Location $10^{\circ} 09^{\prime}-10^{\circ} 26^{\prime} \mathrm{N}, 64^{\circ} 13^{\prime}-64^{\circ} 47 \mathrm{~W}$; includes the eastern coastal hills in the Sucre District of Sucre State and the Sotillo District of Anzoátegui State.

Area, Depth, Altitude 94935 ha; sea-level to 1500 m.

Land Tenure State owned with some private property.

Physical Features The hills are steep with narrow valleys falling abruptly to the coast which is fringed with beaches, bays, creeks and small rocky islands. The main rivers are the Colorado (tributary of the Neveri) and the Guaranch which forms part of the river basin of the Manzanares. Bahía de Mochima, in the east of the Park, is $8 \mathrm{~km}$ long and between 0.3 and $3.5 \mathrm{~km}$ wide (Campos Villaroel, 1972; Pauls, 1982). It is surrounded by mountains and opens to the east through a channel $1.7 \mathrm{~km}$ wide and $60 \mathrm{~m}$ deep which connects to the Fosa de Cariaco (Okuda et al., 1968). The bay appears to be a river valley submerged by rising sea levels in the Pleistocene (Maloney, 1965). Three zones have been described in the bay: a) an interior zone with regular topography and a maximum depth of $20 \mathrm{~m}$, becoming shallower towards the shore; b) a central zone, with marked slopes on both sides and a maximum depth of $27 \mathrm{~m}$ and c) a zone near the mouth of the bay with gentle slopes, few irregularities and a maximum depth of $60 \mathrm{~m}$ (Caravallo, 1968). During the rainy season, freshwater input is by means of small streams that flow into the bay and carry sediments to the small beaches (Caravallo, 1968 and 1970).

Easterly trade winds from January to April create swells and cause low temperature, salinity and oxygen levels and high nutrient levels. From May to December, the waters settle and marked thermoclines develop (Pauls, 1982). Currents in the bay run west to east; salinity varies from 32 to $37 \mathrm{ppt}$. and surface water temperatures from 19 to $28^{\circ} \mathrm{C}$ (Campos Villaroel, 1972; Pauls, 1982). The climate is semi-arid, typical of the Venezuelan coastal zone, but becomes more humid in the mountains. Median annual temperatures are $26.5^{\circ} \mathrm{C}$ in Barcelona and $26.6^{\circ} \mathrm{C}$ in Cumaná (IUCN, 1982). The dry season extends from January to May and the rainy season from June to December. Annual precipitation varies from $150 \mathrm{~mm}$ on the islands to $2100 \mathrm{~mm}$ in the Cordillera which is the watershed of the Río Neveri. Mean monthly values of $3.5 \mathrm{~mm}$ during the dry season and 60 to $70 \mathrm{~mm}$ in the rainy season have been reported for the Bahia de Mochima by Pauls (1982). Humidity is $76 \%$ (IUCN, 1982).

Reef Structure and Corals Forty coral species have been recorded from Bahia de Mochima (Campos Villaroel, 1972; Olivares and Leonard, 1971; Pauls, 1982). Coral communities in the bay are not well developed and 
do not form proper reefs. They occur around the edge of the bay, away from valleys formed during the rainy season, and their distribution is determined by the availability of rocky substratum, wave exposure, sedimentation and light. Communities develop down to $14 \mathrm{~m}$ depth and are dominated by species that can tolerate low temperatures and turbidity. There are basically two types of community, one dominated by Millepora and found in the bay and another found seaward on the rocks around the coast. Communities in the bay have a low diversity ( $8-16$ species) and are dominated by Millepora alcicornis and Porites porites, with branched colonies adapted to calm waters and high sedimentation during the rainy season and calm waters. The seaward communities have a higher diversity (16-22 species) and are dominated by Montastraea cavernosa, Diploria strigosa, Colpophyllia natans, Dichocoenia stokesii and Acropora palmata. They are better developed as a result of greater exposure to waves which provide a continuous supply of nutrients, prevent sedimentation and maintain high oxygen levels. Coral diversity along the bay is determined by Millepora alcicornis cover which it reaches 76 to $90 \%$ inside the bay, decreasing seaward to $5.5 \%$ (Pauls, 1982).

Noteworthy Fauna and Flora The coastal fringe has a rich flora. The bay is bordered almost entirely by mangroves and seagrass beds down to $5-6 \mathrm{~m}$ depth, which decrease towards the central channel and disappear near the mouth of the bay except at Ensenada Matacual (Paul, 1982). Aquatic vegetation includes Thalassia testudinum, Ruppia maritima, Cymodocea manatorum and Halodule wrighti. Wetlands in the area are described in Scott and Carbonell (1986). Along the shoreline there are palms Mauritia flexwosa, ferns Acrostichum aureum and mangroves Rhizophora mangle, Avicennia nitida, Laguncularia racemosa, and Conocarpus erectus. Bowdichia virgiloides, Cork Oak Bocconia frutescens and Dwarf Oak Byrsonima grassifolia are found on the savannahs. Prickly Pear Opuntia caribea, teasels Lemaireocereus deficiens and "guamacho" Peireskia guamacho are found among the thom trees; and Tabebuia chrysantha, Beureria punicifolia, Aspidosperma cuspa, Brosium utile and Terminalia amasonia in wooded habitats (IUCN, 1982).

Loggerhead Caretta caretta and Hawksbill Eretmochelys imbricata Turtles may occur. Iguana iguana and the Black Lizard Gymnodact ylus lemniscatus are found in dry areas. Snakes include a number of pit-vipers including Crotalus durissus cumanensis, Fer-de-Lance Bothrops atrox and Bushmaster Lachesis muta muta. The most common seabirds are the Brown Pelican Pelecanus occidentalis and Magnificent Frigatebird Fregata magnificens. On land, the commonest birds are the Rufous-vented Chachalaca Ortalis ruficauda and the Russet-backed Oropendola Psarocolius angustifrons. In the wetter wooded areas, the commonest mammals are the White-tailed deer Odocoileus virginianus, the Giant Armadillo Priodontes giganteus, the Capuchin Monkey Cebus nigrivittatus and the Jaguar Panthera onca (IUCN, 1982).

Scientific Importance and Research The Universidad del Oriente carries out research in the Park area.

Economic Value and Social Benefits No information.
Disturbance or Deficiencies Dead corals are found in central parts of the Bahia de Mochima, but these are probably the result of natural sedimentation. Cattle grazing, fires and litter on the islands are among the problems in the terrestrial part of the Park. Subsistence fishermen and other local people live in the park and may cause some disturbance (IUCN, 1982)

Legal Protection Established as a Park in December 1973 under Executive Decree 1524, gazetted in 30285.

Management Administered by the Oficina Coordinación Región Nor-Oriental, Avenida Libertador, Quinta Roca, Maturín, Estado Monagas. A management plan has been produced and a zoning system has been proposed (IUCN, 1982).

Recommendations Given in management plan.

\section{PARQUE NACIONAL DE MORROCOY}

Geographical Location east coast of Falcón State, in the Silva district; $10^{\circ} 47^{\prime}-10^{\circ} 59^{\prime} \mathrm{N}, 6^{\circ} 09^{\prime}-68^{\circ} 22^{\prime} \mathrm{W}$; includes Cayo de los Muertos, Cayo Borracho, Cayo Pelón, Cayo Peraza and Cayo Sal, extending from Tucacas north to Cayo Borracho.

\section{Area, Depth, Altitude 32090 ha; sea level to $200 \mathrm{~m}$.}

Land Tenure The majority is State owned; a small area is private property. Cayo de los Muertos is owned by the Venezuelan navy (Weiss and Goddard, 1977).

Physical Features The topography of the area is typical of the coastal plains with low and muddy areas. The Park has four main parts: 1) the Cerro Chichiriviche which is formed from calcareous fossil reefs with numerous caves and cliffs; 2) the cays and coral reefs; 3) the mangrove area surrounding the coastal lagoons, and 4) the salt pans and swamps. Weather conditions vary little during the year. The mean annual rainfall is $1213 \mathrm{~mm}$, and the mean annual temperature is $26.5^{\circ} \mathrm{C}$. Bathymetry is described in Weiss (1973). The Golfete de Guare has virtually no permanent currents and there is a tidal amplitude of $25-30 \mathrm{~cm}$, resulting in limited circulation, high turbidity and slightly elevated salinity (+ $35.6 \mathrm{ppt}$.), leading to marginal coral growth (Weiss and Goddard, 1977).

Reef Structure and Corals Fringing reefs and five coralgal cays have been studied by Weiss et al. (1977) and some of the coralagal reefs have been mapped (Weiss and Goddard, 1977). Although the reefs have been severely damaged their structure is still evident. The patch reef closest to the town of Chichiriviche has a rim of dead Acropora palmata, about $20 \mathrm{~m}$ wide, bordering the east side. The reef edge is $0.5 \mathrm{~m}$ deep, and surrounds a shallow depression about $1 \mathrm{~m}$ deep. The reef front is formed by scattered heads of Siderastrea, Montastraea and Diploria down to muddy sand at $2.7 \mathrm{~m}$. In 1977, the heads were dead above $1.7 \mathrm{~m}$, and were interspersed with branches of living and dead $A$ palmata. A cervicornis, both living and dead, was conspicuous on the lower face of the north-east side. The reef flat consists mainly of muddy sand with a few dead $A$ palmata, the 
seagrass Thalassia and the algae Halimeda opuntia, Penicillus spp. and Udotea spp. A few gorgonians are found on the outer reef face.

On the fringing reef to the south, healthy $A$ palmata gives way westwards to mixed live and dead colonies and eventually thickets of dead and encrusted $A$ cervicornis and Millepora. The lower face of the reef is covered with Siderastrea and Diploria with heads $1-1.5 \mathrm{~m}$ in diameter in water $2-4 \mathrm{~m}$ deep. The Diploria heads are alive only above $2 \mathrm{~m}$. Gorgonians and sponges are common at depths below $4 \mathrm{~m}$. The reef flat facing the open sea is characterized by Porites, some Goniolithon, Halimeda incrassata, $H$. opuntia and some Udotea. In the north-west part of the reef flat, Penicillus is dominant growing over dead $A$ palmata.

The four reefs lying in Bahia Chichiriviche and the mouth of Golfete de Guare are characterized by Siderastrea and Millepora, with scarce and reduced quantities of Acropora, Montastraea and Diploria. The western part of the reef, which nearly encloses Cayo de los Muertos, has dead $A$ palmata; on the southern side, the small and medium coral heads on the reef flat are dead and encrusted with calcareous algae (Weiss and Goddard, 1977). The gorgonian Plexaura homomalla is abundant in the area (Losada, 1983).

Noteworthy Fauna and Flora Deciduous woods cover Cerro Chichiriviche and the coast is fringed with mangroves and seagrass beds of Thalassia testudinum. Wetlands within the park are described in Scott and Carbonell (1986). Portulacids and other plants adapted to high salinity are found on the cays. There are numerous birds including the Scarlet Ibis Eudocimus ruber, the American Flamingo Phoenicopterus ruber and the Magnificent Frigatebird Fregata magnificens. The American Crocodile Crocodylus acutus is found and probably the Green Turtle Chelonia mydas, the Hawskbill Eretmochelys imbricata and Loggerhead Caretta caretta. Mammals inhabiting the Cerro Chichiriviche include the Red Brocket Mazama americana, White-tailed Deer Odocoileus virginianus and Ocelot Felis pardalis (IUCN, 1982).

Scientific Importance and Research Studies in the area have covered vegetation, geomorphology, soil, fauna and coral reefs. The park provides accomodation for scientists (IUCN, 1982). The role of Diadema antillanum in sediment production was studied by Losada (1983) and its density and size structure on three reefs (Pescadores, Playuela and Cayman) are described by Weil and Losada (1984).

Economic Value and Social Benefits The area has long been important for holiday makers, and the creation of a park has increased the potential for tourism. Cayo Borracho has no permanent buildings but is used frequently by campers. Cayo Pelón consists mainly of unstable Halimeda sand, and is less than 1 ha in area, with a single holiday home on it. Cayo Peraza has a few summer residences. Cayo Sal, close to the mainland, has undergone considerable development (Weiss and Goddard, 1977).

Disturbance or Deficiencies Currently the main problems in the Park are pollution and slash and burn agriculture. The low altitude (1-2 $\mathrm{m}$ ) of Chichiriviche and the neighbouring coastline and the high permeability of the alluvial soil has meant that wastes from the town rapidly flow out to sea. High levels of sedimentation caused by erosion on the banks of Río Tocuyo have damaged the reefs (Losada, 1983). The patch reef nearest to Chichiriviche was seriously damaged between 1963 and 1977, when it consisted mainly of dead coral and was covered with sediment and turbid water (Weiss and Goddard, 1977). The fringing reef to the south was healthy where it faced the open sea but its western end was impoverished with an abnormal amount of dead coral. The town developed rapidly in the $1950 \mathrm{~s}$ and $1960 \mathrm{~s}$ and a new public water supply, built in 1963, caused increased human and industrial wastes. A cement company dumps waste and rinse from its kiln into the bay and visiting ships are a further source of pollution. Oil exploration on the coast may be a threat.

There is evidence of increased coral mortality in the reefs in the Golfete de Guare and at Cayo de los Muertos. Development has taken place rapidly on the latter, where holiday homes, built in the 1960 s, now completely cover the island. Although intermittent occupancy and exposure to the open sea has prevented pollution except on some leeward reefs, the island has been eroded as a result of the destruction of the fringing mangroves and the construction of walls and buildings at the waters edge. Litter on the beaches at Cayo Sal was a problem in the 1970s. The construction of a dock on Cayo Peraza damaged some of the reef (Weiss and Goddard, 1977). The four patch reefs in Bahía Chichiriviche have large areas of dead coral. Conditions here are marginal for coral growth since the sluggish circulation of the bay disperses organic pollution to the patch reefs, Cayo de Los Muertos and the damaged western end of the fringing reef. Fish were reported to be scarce on the patch reef close to Chichiriviche in the 1970s (Weiss and Goddard, 1977). Further information on the impact of human activities on the reefs in the Park is given in Bone (1980).

Legal Protection Declared a National Park on 26 May 1974 by Executive Decree 113, Official Gazette 30.408, 27.5.74. Additional legislation is covered by Executive Decree 944, 27.5.75, Official Gazette 30.706, 30.5.75 and the rules of the Park: Res. No. 69; 29.8.79, Official Gazette 2505E, 11.9.79 (IUCN, 1982).

Management Administered by the Oficina Coordinación Región Centro-occidental Parque José Maria Ochoa Pile, Barquisimeto, Edp. Lara. There is a superintendent and five guards. The Park is zoned with different areas for total protection, natural areas, natural regeneration and recreation and services (IUCN, 1982). The Park was designated following a serious outbreak of infectious hepatitis which was traced to polluted oysters harvested in the mangrove thickets bordering the south side of Cerro Chichiriviche. Action was also taken to improve sanitary conditions in the area. A moratorium on further building was posed and some of the temporary holiday buildings were removed (Weiss and Goddard, 1977).

Recommendations There is an urgent need to reconcile tourism in the park with the protection of wildlife. 


\section{PARQUE NACIONAL ARCHIPIELAGO LOS ROQUES}

Geographical Location In the Caribbean, $125 \mathrm{~km}$ north of La Guaira; $11^{\circ} 42^{\prime}-12^{\circ} 04^{\prime} \mathrm{N}, 63^{\circ} 30^{\prime}-67^{\circ} 00^{\prime} \mathrm{W}$.

Area, Depth, Altitude $225153 \mathrm{ha}(25 \mathrm{~km} \mathrm{~N}-\mathrm{S} \times 40 \mathrm{~km}$ $\mathrm{E}-\mathrm{W}$; sea level to $120 \mathrm{~m}$.

Land Tenure State owned.

Physical Features An atoll-like structure with more than 30 islands and 300 smaller coral reef islets, all of which (except for El Gran Roque which reaches $100 \mathrm{~m}$ ), are very low and composed of sand and coral. The islands are surrounded by reef. The climate is dry with occasional rainstorms and a rainy period from September to January. Annual temperature is in the range of 27 to $30^{\circ} \mathrm{C}$ with a maximum of $33.9^{\circ} \mathrm{C}$ in July and a minimum of $23.6^{\circ} \mathrm{C}$ in January.

Reef Structure and Corals Antonius (in prep a) has surveyed the stony corals of the area. The gorgonaceans on a reef south of Los Roques are described by La Schiazza and Losada (1985).

Noteworthy Fauna and Flora The hills of El Gran Roque have a typical xerophytic vegetation, including Sesuvium portulacastrum and the Fishermens Tobacco Tournefortia gnaphalodes. Mangroves are common on all the islands, the genera Rhizophora and Avicennia predominating. There are seagrass beds of Thalassia testudinum. The importance of the area as a wetland site is described in Scott and Carbonell (1986). Green Turtles Chelonia mydas, Loggerhends Caretta caretta and Hawksbills Eretmochelys imbricata nest (Bacon et al., 1984; Carr et al., 1982; Groombridge, 1982). The Caribbean Manatee Trichechus manatus is probably extinct in this area. Few terrestrial species are found in the inhospitable environment of the islands (IUCN, 1982). Reptiles include Iguana iguana, Gymnodactylus lemniscatus, G. antillensis and Phyllodactylus rutteni. There are large numbers of both migratory and nesting birds including the Brown Booby Sula leucogaster, the
Louisiana Heron Hydranassa tricolor, the Magnificent Frigatebird Fregata magnificens and the Reddish Egret Dichromanassa refuscens. Phelps and Phelps (1950) recorded 42 bird species and Halewyn and Norton (1984) list sixteen breeding seabird species.

Scientific Importance and Research The Estación Biologica de la Fundación Científica Los Roques, situated on Cayo Dos Mosquines has carried out studies on zooplankton and on the culture of molluscs and crustaceans, many of which are published in its series of reports. Extensive research on geology has been carried out by the Ministry of Energy and Mines, on biology by the Fundación La Salle de Ciencias Naturales, on ornithology by the Museo Phelps, and on soil by the Ministerio de Agricultura y Cría.

Economic Value and Social Benefits The lobster fishery is described by Cobe de Berany et al. (1972). The annual harvest is $99 \mathrm{t}$. Other forms of fishing are restricted. Diving trips to Los Roques are organized from Caracas and there are numerous wrecks which are attractive to divers (Saunders, 1985).

Disturbance or Deficiencies There are illegally constructed summer houses on some of the larger islands, a village of 900 inhabitants on El Gran Roque and transitory subsistence fishermen (IUCN, 1982).

Legal Protection The Park was established on 9 August 1972 under Executive Decree 1062, Official Gazette 29833, 18 August 1972

Management The park is administered by the Oficina Coordinación Región Nor-Oriental, Avenida Libertador, Quinta Roca, Maturín, Estado Monagas. A preliminary zoning system is proposed in the management plan. There are a superintendent and three guards (IUCN, 1982).

Recommendations These are available in the management plan. 



\section{INTRODUCTION}

\section{General Description}

No true reefs exist along the West African coast or in the archipelagos of the Gulf of Guinea and Cape Verde but there are a number of sites with rich coral communities. These generally form in very shallow, protected coves, the number and size of colonies decreasing abruptly outside such areas. In open waters, hermatypic species are limited to depths of less than $20 \mathrm{~m}$ although there are some exceptions in the archipelagos.

Studies on West African corals include those of Thiel (1928, 1940 and 1941) and Chevalier (1966 a, b and 1970) which are based exclusively on museum material. Other papers include Koch (1886), Gravier (1910), Gardiner (1939), Buchanan (1954), Monod (1954), Allan and Wells (1962) and Forest (1959 and 1964). Laborel (1974) provides an overview and synthesis of these works and discusses the results of field visits to Senegal, the Cape Verde Islands, Sierra Leone, Cape Palmas on the western coast of the Ivory Coast, Accra and Cape Three Points in Ghana, West Cameroon, Gabon and the islands of Principe and Annobon.

A description of the coastal and marine environments of West Africa is given in UNDIESA/UNEP (1984) and Laborel (1974) briefly summarizes the hydrology of the region. High precipitation and numerous rivers result in large masses of warm (above $24^{\circ} \mathrm{C}$ ) and low salinity (less than $35 \mathrm{ppt}$ ) water, known as Guinean waters, circulating in the Gulf of Guinea. These are invariably shallow and rest on colder water, their extent varying greatly throughout the year. They are permanent off the Grain Coast (Sierra Leone and Liberia) and in the Bight of Biafra (Nigeria, Cameroon and Gabon). They are found seasonally from Mauritania to Angola, where they may be replaced by colder and more saline waters from other currents or upwellings, and they are also seasonal around the islands of the Gulf of Guinea and the Cape Verde Archipelago.

A list of West African corals and a detailed analysis of the oculinid corals of the region are given in Laborel (1974). Two oculinid corals, Schizoculina africana and $S$. fissipara, are endemic to the region and are adapted to Guinean waters and very low salinities. They are absent outside these waters, for example at Annobon or the eastern Cape Verde Islands. Colonial shallow water dendrophyllids are among the most abundant corals in West Africa, covering vertical rocky surfaces with brilliantly coloured populations. Their taxonomy is still confused and it is not clear how many species are restricted to the area. The genus Astrangia is well represented. Millepora and hermatypic corals are found mainly around the islands where some of them are endemic, and the more tolerant species also occur in low salinity mainland littoral waters. Madracis pharensis seems to be abundant everywhere in the tropical and subtropical Atlantic and other species of this genus are found in the two archipelagos. The taxonomy of Siderastrea still needs clarification. S. siderea, a form similar to $S$. stellata, and $S$. radians are found in the islands of the Gulf of Guinea; the latter is also found along the mainland and is the only species of the genus found in the Cape Verde Islands. There are three species of Porites: $P$. astreoides, $P$. porites and $P$. berrardi. $P$. bemardi is endemic to West Africa and is found from Liberia to Gabon and in the islands of the Gulf of Guinea, but is absent from Sierra Leone and the islands of Cape Verde. The other two species are found in the Cape Verde Islands. Two faviid populations have been found, one in the Cape Verde Islands and one on the coast of Gabon and in the islands of the Gulf of Guinea. No Diploria species appear to be extant on the West African coast; subfossil specimens have been reported from the Cape Verde Islands (Chevalier, 1966a) but these records are considered dubious (Laborel in litt., 1985). Montastraea cavernosa is found only in the islands of the Gulf of Guinea and Acropora is absent from the region.

The following areas have a noticeable amount of reef construction:

Cape Verde Islands The coral fauna, of one hydrocoral and five hermatypic species, consists of little or unmodified West Indian forms including one Guinean species (Schizoculina africana) and two species ( $P$. porites and Favia fragum) which are found neither in the Gulf of Guinea nor in Brazil. $P$. porites is abundant in tide pools but rare in open waters, and $F$. fragum is common in shallow waters throughout the islands. $P$. astreoides is very abundant, mainly in sheltered areas. At Bahia das Gatas (north coast of Sao Vicente Island), Bahía de Sal-Rei (Boa Vista) and Pedra Lume (Sal), slabs of living Siderastrea radians up to $10 \mathrm{~m}$ wide and small pinnacles of Millepora are present. Branching forms of Madracis are found in deep waters.

Mainland coast The mainland fauna is typified by the two very variable endemic oculinids, Schizoculina fissipara and $S$. africana. On the western side of Cape Three Points, Ghana, in a protected cove there is a dense growth of large encrusting colonies of $S$. fissipara; branching colonies of the same species are found in the region of Cape Esterias, Gabon and even in estuaries and almost landlocked mangrove channels near Libreville. The rocky western coast of Cameroon, Victoria and Buea, has relatively clear water with an unusual but poorly known gorgonian fauna and corals including Schizoculina. Parts of the Gabon coast, such as the Elobey Islands, are similar. Siderastrea radians is very rare on the West African coast where there are periodic cold upwellings; for example on the western Ivory Coast near Cape Palmas, occasional colonies are found in well situated tidal pools but are completely absent in open water. In warmer areas, this species builds larger colonies, sometimes forming small pinnacles. Favia gravida, Porites bernardi and ahermatypic species in the genera Tubastrea, Astrangia and Phyllangia are also common.

Islands of the Gulf of Guinea Apart from the oculinids, there are five hermatypic coral species in the Gulf of Guinea islands, four of which are related to Brazilian species and all but one of which are also found on the mainland (Laborel, 1974), and four ahermatypes. The fauna includes three West African endemics 


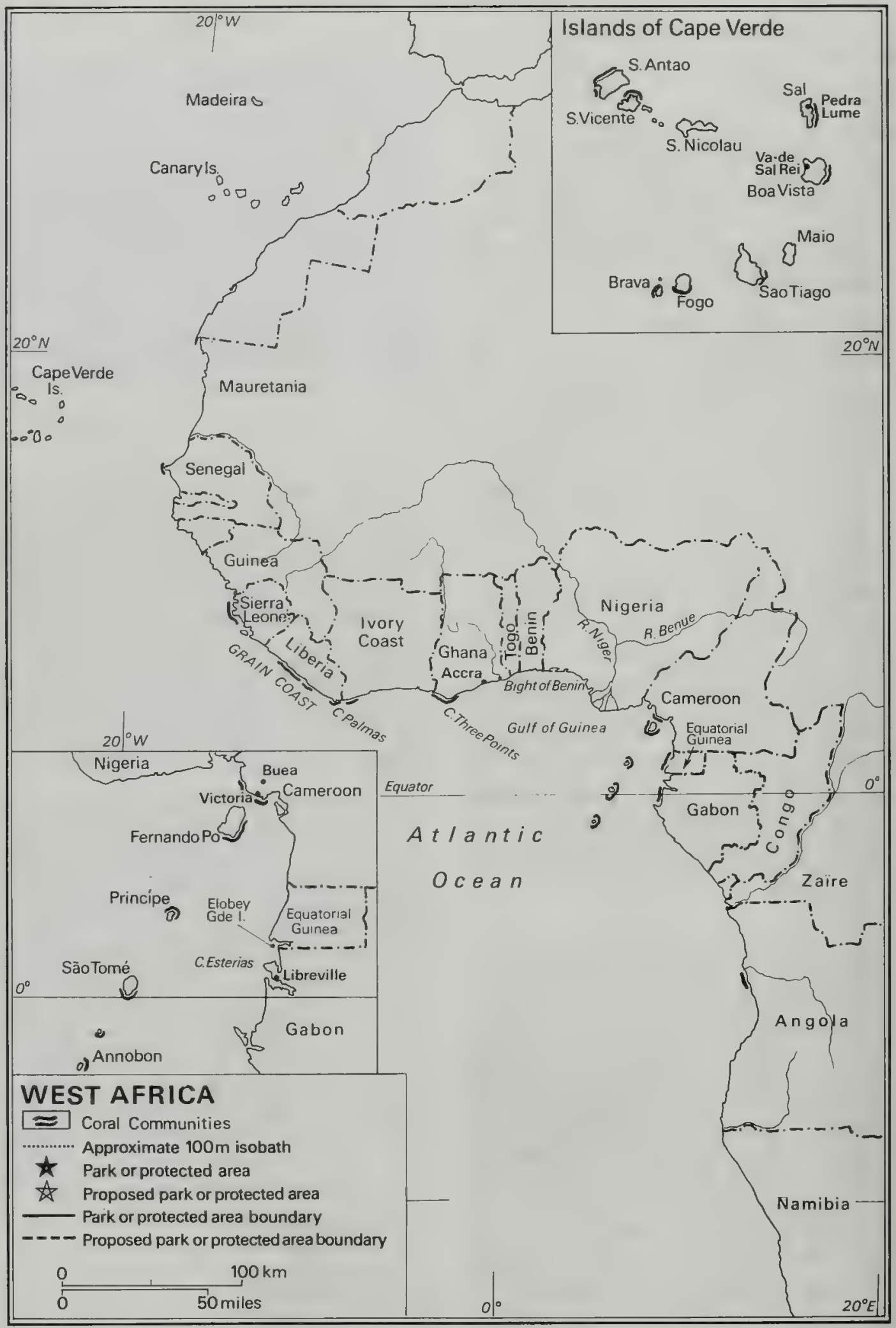


(Laborel in litt, 18.5.84). On Annobon Island, in a cove near the village, colonies of Montastrea cavernosa and Siderastrea up to $2 \mathrm{~m}$ diameter show a certain amount of coalescence. Colonies of Madracis decactis are found at depths of not less than $10 \mathrm{~m}$ and in underwater caves and are very pale, apparently lacking zooxanthellae. The waters of the islands are clear and present ideal diving conditions. There are numerous poorly known and undescribed fish and invertebrates.

\section{Reef Resources}

The small extent of coral communities in this region means that they probably do not play an important role in the fishery industry and are not of particular value to tourism. The Schizoculina communities in northern Gabon and western Cameroon could perhaps be an attraction for tourists if managed appropriately. Such communities are of undoubted scientific interest and may prove to be of economic value if further research is undertaken.

\section{Disturbances and Deficiencies}

Coral communities in this area are potentially threatened through their restricted distribution, as pollution, industrial and urban development and siltation become increasingly major problems in this region (UNDIESA/UNEP, 1984). These are not discussed here as, at present, there is no information on their impact on corals.

\section{Legislation and Management}

The UNEP Regional Seas Programme has initiated extensive work in the region. An "Action Plan for the protection and development of the marine environment and coastal areas of the West and Central African Region" has been drawn up (UNEP, 1983) which will help to implement the "Convention for Co-operation in the Protection and Development of the Marine and Coastal Environment of the West and Central African Region".

A workshop on the coastal ecosystems of West Africa was held in June (1979) to identify the main lines of future research and to prepare pilot projects for ecosystems of priority interest. Greatest emphasis was put on lagoons, estuaries and mangroves and a number of activities were recommended in the field of regional training courses, pollution monitoring and coastal zone management plans (UNESCO, 1981). It would be interesting to consider the more important coral communities in the light of these proposals.

\section{References}

Allen, J.R.L. and Wells, J.W. (1962). Holocene coral banks and subsidence in the Niger delta. Journ. Geol. 70(4): 381-397.

Buchanan, J.B. (1954). The zoogeographical significance of the Madreporaria collected in the Gold Coast, West Africa. Rev. Zool. Bot. Afr. 49: 84-88.

Chevalier, J.P. (1966a). Contribution à l'étude des Madréporaires des côtes occidentales d'Afrique tropicale; Part 1. Bull. I.F.AN. 28 ser. A: 912-975.

Chevalier, J.P. (1966b). Contribution à l'étude des Madréporaires des côtes occidentales d'Afrique tropicale; Part 2. Bull. I.F.A.N. 28 ser. A: 1356-1405.

Chevalier, J.P. (1970). Les Madréporaires du Neogéne et du Quaternaire de l'Angola. Ann. Mus. Roy. Afrique Centrale, Ser. in octavo, Sc. Geol. 68.

Forest, J. (1959). Campagne de la "Calypso" dans le Golfe de Guinée et aux Iles Principe, Sao Tome et Annobon (1956). Result. scientif. camp. Calypso 5: 36 pp. Forest, J. (1964). Campagne de la "Calypso" aux lles du Cap Vert (1959). Result. scientif. camp. Calypso 6: 31-41.

Gardiner, J.S. (1939). Madreporarian corals with an account of the variations of Caryophyllia. Discovery Reports 18: 328-338.

Gravier, C. (1910). Madréporaires des Iles Sao Tome et du Prince. Ann. Instit. Oceanogr. Monaco 1: 1-27.

Koch, W. von (1886). Über die von Herm Prof. Dr. Greef in Gulf von Guinea gesammelten Anthozoen. Bonn, 34 pp.

Laborel, J. (1974). West African reef corals; an hypothesis on their origin. Proc. 2nd Int. Coral Reef Symp. 1: 425-443.

Monod, T. (1954). Sur deux Madréporaires Ouest africains. Ann. Mus. Congo Belge, Zoologie, Nlle Ser. 1: 227-230.

Thiel, M.E. (1928). Madreporaria. In: Michaelsen, (Ed.) Beitrage zur Kenntnis der Meeresfauna Westafrikas 3: 253-350, Hamburg.

Thiel, M.E. (1940). Uber einen fund einer neuen Astrangia Art, Astrangia macrodentala nov. sp. aus des WestkÜste von Afrika. Rev. Zool. Bot. Afr. 33: 195-200.

Thiel, M.E. (1941). Madreporaria. Resultats scientifiques des croisieres du navire ecole belge "Mercator". Mem. Mus. Roy. Hist. Nat. Belgique, series 2, 21: 28pp.

UNDIESA/UNEP (1984). Environmental management problems in resource utilization and survey of resources in the West and Central African Region. UNEP Regional Seas Reports and Studies 37.

UNEP (1983). Action Plan for the protection and development of the marine environment and coastal areas of the West and Central African Region. UNEP Regional Seas Reports and Studies 27.

Unesco (1981). The coastal ecosystems of West Africa: coastal lagoons, estuaries and mangroves. Unesco Reports in Marine Science 17; 59 pp. 

UNEP (1976). Directory of Mediterranean Marine Research Centres, 1st ed. UNEP Regional Seas Directories and Bibliographies. Geneva, UNEP. 280 pp.*

UNEP (1977). Directory of Mediterranean Marine Research Centres, 2nd ed. UNEP Regional Seas Directories and Bibliographies. Geneva, UNEP. 622 pp.*

NIO/UNEP (1978). Directory of Indian Ocean Marine Research Centres. UNEP Regional Seas Directories and Bibliographies. National Institute of Oceanography, Goa, India. 360 pp.*

UNEP/1OC (1980). Directory of Caribbean Marine Research Centres. UNEP Regional Seas Directories and Bibliographies. Geneva, UNEP. 500 pp.

IAEA/UNEP (1981). Directory of Kuwait Action Plan Marine Science Centres. UNEP Regional Seas Directories and Bibliographies. Geneva, UNEP. 100 pp.*

UNEP/CPPS (1981). Directory of the South-East Pacific Marine Science Research Centres. UNEP Regional Seas Directories and Bibliographies. Geneva, UNEP. 120 pp."

UNEP/ FAO/ UNESCO/ WHO/ WMO/ IOC/ IAEA (1981). Selected Bibliography on the Pollution of the Mediterranean Sea. UNEP Regional Seas Directories and Bibliographies. Geneva, UNEP. 135 pp.*

UNEP/UN-ECA/UNESCO (1982). Directory of Marine Research Centres in Africa. UNEP Regional Seas Directories and Bibliographies. Rome, FAO. 254 pp.

UNEP (1984). Bibliography of the Marine Environment in the Kuwait Action Plan Region, 1972-1981. UNEP Regional Seas Directories and Bibliographies. Rome, FAO. 52 pp.

UNEP (1984). Bibliography of the Marine Environment in the South Asian Seas. UNEP Regional Seas Directories and Bibliographies. Rome, FAO. 39 pp.

UNEP/FAO (1984). Bibliography of the Marine Environment in the East Asian Seas Region. UNEP Regional Seas Directories and Bibliographies. Rome, FAO. 68 pp.

UNEP/FAO (1984), Directory of Marine Environmental Centres in East Asian Seas. UNEP Regional Seas Directories and Bibliographies. Rome, FAO. 138 pp.

UNEP/PSA/SPREP/UG (1984), Directory of Coral Reef Researchers in the Pacific. UNEP Regional Seas Directories and Bibliographies. Rome, FAO. 101 pp.

UNEP/FAO (1985). Directory of Marine Environmental Centres in Caribbean, 2nd ed. UNEP Regional Seas Directories and Bibliographies. Rome, FAO. 214 pp.
SPREP/FAO (1985). Directory of Marine Environmental Centres in Mediterranean, 3rd ed. UNEP Regional Seas Directories and Bibliographies. Rome, FAO. 302 pp.

SPREP/UNEP/FAO (1985). Directory of Marine Environmental Centres in South Pacific. UNEP Regional Seas Directories and Bibliographies. Rome, FAO. 147 pp.

UNEP/UNESCO/UN-DIESA (1985). Bibliography on Coastal Erosion in West and Central Africa. UNEP Regional Seas Directories and Bibliographies. Rome, FAO. 92 pp.

UNEP/FAO (1985). Directory of Marine Environmental Centres in Indian Ocean and Antarctic Region. UNEP Regional Seas Directories and Bibliographies. Rome, FAO. 226 pp.

CCA/UNEP (1985). Directory of Environmental Education Institutions, Programmes and Resource People in the Caribbean Region. UNEP Regional Seas Directories and Bibliographies. Rome, FAO. 89 pp.

UNEP/FAO (1985). Bibliography of the Marine Environment in the Mediterranean, 1978-1984, 2nd ed. UNEP Regional Seas Directories and Bibliographies. Rome, FAO. 151 pp.

Eldredge, L.G. (1987). Directory of Coral Reef Researchers in Pacific, 2nd ed. UNEP Regional Seas Directories and Bibliographies. Rome, FAO. 104 pp.

Eldredge, L.G. (1987). Bibliography of Marine Ecosystems in Pacific Islands. UNEP Regional Seas Directories and Bibliographies. Rome, FAO. 72 pp.

UNEP (1987). Directory of Organizations and Organizational Units Co-ordinating or Contributing to the Co-ordination of the Action Plans Related to the Regional Seas Programme. Nairobi, UNEP. 34 pp.

PNUMA/CPPS (1987). Directorio de Centros de Investigacion Marina: Pacifico Sudeste. UNEP Regional Seas Directories and Bibliographies. Rome, FAO. 145 pp.

Obtainable from:

Oceans and Coastal Areas Programme Activity Centre,

United Nations Environment Programme,

P.O. Box 30552, Nairobi, Kenya

"Out of print. 



. 



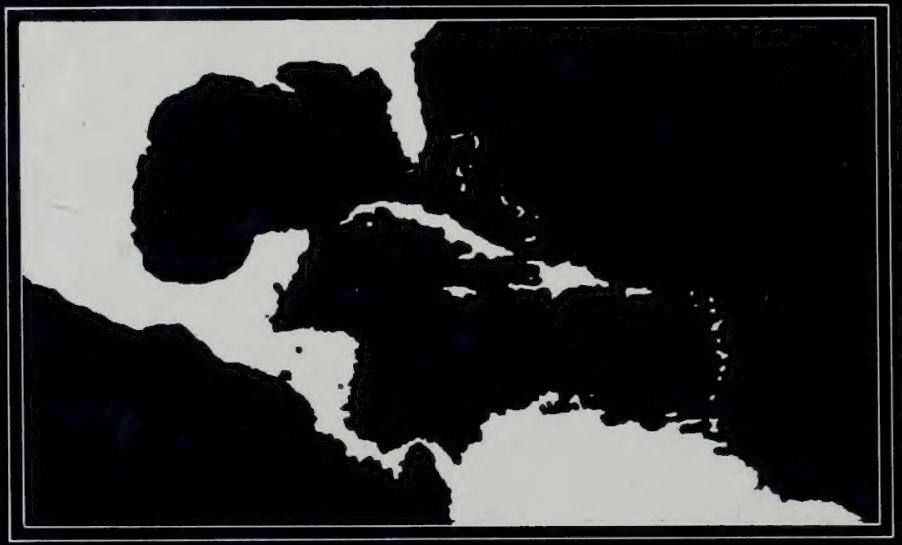

Other volumes in the set

Volume 2: Indian Ocean. Red Sea and Gulf ISBN: $2-88(132-944-2$

Volume 3: Central and Western Pacific ISBN: $2-88(132-945-11$

Coral reefs are one of the most biologically diverse ecosystems in the world. Teeming with life, they are also one of the world's most productive natural communities. Yet they are under increasing threat. Pollution, siltation. illegal trade, and development pressures are generating growing concern amongst conservationists and scientists about the future of coral reefs as a biological and economic resource.

This three volume reference work catalogues for the first time the significant coral reefs of the world, their geographical context, ecology. current condition and status in legislation, together with prescriptions for their conservation and sustainable use.

Recognizing the global threat to coral reefs, the United Nations Environment Programme (UNEP) and the International Union for Conservation of Nature and Natural Resources (IUCN) collaborated on the production of these volumes. The work was commissioned by UNEP's Oceans and Coastal Areas Programme Activity Centre (OCA/PAC), and was compiled by the IUCN Conservation Monitoring Centre (CMC) in Cambridge, U.K.

These three volumes will be an indispensable reference source on the status and conservation of coral reefs. They will he particularly valuable to marine biologists in colleges and universities, marine research and planning institutes, and all citizens' groups or individual enthusiasts concerned with the marine environment, whether through conservation. recreation, tourism, or underwater exploration. 